Universidad Politécnica de Madrid

Escuela Técnica Superior de Arquitectura

\title{
IDENTIDAD Y TRANSFORMACIÓN DEL PAISAJE EL TERRITORIO LAGUNA CARÉN
}

\author{
María del Pilar Barba Buscaglia \\ Arquitecto \\ Director \\ Francisco de Gracia Soria
}

2019

Tesis Doctoral

Departamento De Composición Arquitectónica 
Tribunal nombrado por el Magfco. Y Excmo. Sr. Rector de la Universidad Politécnica de Madrid, el día de de 2020.

Presidenta, Dñ.

Pilar Chías Navarro

Vocal $1^{0}, \mathrm{D}$.

Rodrigo de la O Cabrera

Vocal $2^{\circ}, \mathrm{D}$.

Miguel Ángel Aníbarro Rodríguez

Vocal $3^{\circ}$, Dñ.

María Elia Gutiérrez Mozo

Vocal $4^{\circ}, \mathrm{D}$.

Pablo Martí Ciriquian

Realizado el acto de defensa y lectura de la tesis el día de febrero de 2020 en Madrid.

Calificación:

El Presidente

El Secretario

Los Vocales 
A quienes tendrán el paisaje como un derecho 


\section{AGRADECIMIENTOS}

En estos casi cinco años, han sido muchas las personas que me han brindado su apoyo, sus conocimientos, experiencia y sus libros. Mi reconocimiento especial a Diego Vallejos, Hugo Romero, Pía Montealegre y Felipe Sáez, mi amigo de toda la vida.

Quisiera agradecer a mi director de tesis, Francisco de Gracias Soria por el interés que demostró desde el principio en mi trabajo, por sus palabras de ánimo y constante apoyo, así como por ser fuente de inspiración y conocimientos durante los cursos del doctorado y la realización de esta tesis.

Agradezco especialmente a mi madre Elsa Buscaglia, que ha sido mi compañía y soporte emocional durante estos largos años dedicados a escribir, a investigar, criar y a trabajar. Su voluntad y pensamiento crítico han sido un modelo constante. También agradezco a Eric Goles, por animarme a terminar la tesis, pese a los continuos requerimientos de mi trabajo y de la vida. Su cariño constante ha sido fundamental para llevar esta tarea con optimismo.

Mis hijos tienen un lugar muy importante en este proceso, cada uno me ha acompañado de un modo distinto. Son inolvidables las largas conversaciones nocturnas con Teresa, Sofía y Pedro, sentados en la mesa de la cocina y las con Pablo, mi hijo mayor, que desde lejos me ha apoyado con su visión crítica y culta. Mi filosofa, mi arquitecta, mi matemático y mi artista son el tesoro más grande que me ha dado la vida. Sus ideas y visiones han nutrido mi trabajo, su amor le han dado sentido. Junto a ellos, agradezco a Cristóbal Montecinos por su apoyo y cariño paciente de hijo político, a Patricia Díaz mi nuera y socia en muchas aventuras, a quien agradezco especialmente su apoyo metodológico y por traer al mundo a Aurora y José Pedro, que nacieron en medio de este trabajo, mostrándome que el futuro siempre puede ser mejor.

Mi más sincero agradecimiento a mis colegas y amigos Francisco Allard y Fernando Bravo, a quienes conocí como estudiantes y que con el tiempo se han convertido en grandes arquitectos y los mejores compañeros de trabajo que he tenido. Mis socios en el proyecto de Laguna Carén, son posiblemente quienes más conocen y valoran este trabajo. Junto a ellos mi gran amiga y colaboradora Macarena Alarcón ha desempeñado un papel clave como soporte y ejemplo de una mujer inteligente y trabajadora. También a Claudia Alarcón, Carolina Matheson y Geraldine Díaz.

Quisiera finalmente recordar a mi padre Juan Manuel Barba que me hizo conocer el amor incondicional y el rigor. Estoy segura de que en algún lugar te sientes orgulloso de mi. 


\section{RESUMEN}

El conocimiento ya no está separado de la acción, sino que se encuentra en la propia acción

(Ascher, 2004, p. 33).

Un diagnóstico compartido por numerosos autores, desde diversas disciplinas, viene a señalar lo siguiente: los problemas de la ciudad contemporánea requieren determinados modelos de interpretación de la realidad que nos permitan comprender para después actuar sobre la complejidad de los procesos urbanos, al objeto de recuperar y no tanto conquistar los territorios afectados por el desarrollo urbano y social. Esas mismas miradas proponen, además de lo anterior, una visión crítica acerca de la misión del arquitecto y el urbanista modernos, así como de las jerarquías que éstos han impuesto de manera tópica y profesional en el paisaje urbano.

La evaluación de los procesos de transformación del paisaje urbano a través del estudio de la recuperación del territorio de la periferia, en tanto parte de un sistema ecológico de ámbito mayor, es el ejercicio teórico, con fundamentos prácticos, que se acomete en esta tesis. No sin antes haber tenido la ocasión de observar que estos territorios, los de la periferia, estarían sometidos a una tensión que reclama un abordaje metodológico transdisciplinar y multiescalar a fin de lograr articular aspectos bióticos, ambientales, socio-culturales, económicos, arquitectónicos, normativos e infraestructurales. Haciéndolo de tal modo que tendrían el potencial de convertirse en verdaderos laboratorios de experiencias aplicables luego en la ciudad como macrosistema.

Ante el desafío enunciado en las líneas anteriores, cabe preguntarse si la noción de proyecto aplicada por los arquitectos y urbanistas modernos como ideal materializado en un diseño ${ }^{1}$, con la pretensión de controlar el futuro y reducir la incertidumbre, no debe ser reemplazada por una gestión más reflexiva y empática ${ }^{2}$ , capaz de adaptarse a los cambios de una sociedad más compleja y a un futuro más incierto (Ascher, 2004). La arquitectura del paisaje es presentada en esta investigación como la opción disciplinar capaz de abordar este desafío, ofreciendo sus herramientas de análisis y negociación, y exigiendo al mismo tiempo, nuevas competencias profesionales.

El término paisaje, se ha incorporado en el lenguaje contemporáneo para sintetizar aspectos éticos, estéticos y técnicos vinculados al territorio que, junto a las ciencias asociadas, permiten describir y fundamentar cualitativa y cuantitativamente las acciones de transformación ante los múltiples actores que intervienen y tienen interés económico, político y simbólico en el territorio.

La arquitectura del paisaje, entendida como una disciplina híbrida que conecta la práctica arquitectónica y urbana, entiende el proyecto como un proceso abierto y participativo. Esta condición le exige investigar, teorizar y comunicar a lo largo de todo el proceso de diseño, convirtiendo así al proyecto en una herramienta de mediación entre conflictos territoriales, fronteras administrativas, perspectivas sectoriales y diferentes escalas. Ésta es sin duda una posibilidad, tal vez utópica, que nos permitirá hacer frente a los crecientes fenómenos de fragmentación, segregación, abandono y degradación en el que están sumidas nuestras ciudades.

La presente tesis analiza el plan maestro de un territorio de 1.022 ha desde una perspectiva aplicada. Este se ubica en el límite poniente de la ciudad de Santiago de Chile, signado en los instrumentos de planificación territorial como parque 
metropolitano - no consolidado. Para ello, se analizan las relaciones espaciales de los diversos componentes del sistema territorial en sus múltiples escalas. La aplicación se materializa en una propuesta general que busca poner a prueba los enfoques metodológicos estudiados en proyectos de referencia, para depurar una estrategia de desarrollo del predio a escala local, basado en los procesos ecológicos y la construcción de una identidad paisajística. En este proceso, la caracterización del paisaje actuará como un vector, que cruza las capas de análisis a distintas escalas, permitiendo definir criterios de actuación macro, meso y micro-escalar, como también las alternativas y dificultades que cada una de estas escalas representa. Se integrarán en el análisis las capas del pasado, del presente y del futuro del predio, incorporando las iniciativas futuras tanto a nivel regional como local. Se enfatizan dos temas presentes en el lugar: el agua y los riesgos socio-naturales, ambos temas de relevancia para la práctica actual.

El protagonista de esta investigación es el paisaje, pero otros conceptos de uso frecuente en el discurso disciplinar y político contemporáneo, también serán analizados presentados, auscultados y confrontados como actores, para que operen con claridad en la fundamentación del proyecto y en la reflexión teórica. Este ejercicio crítico es el que inicia esta investigación y acompaña su desarrollo en los capítulos siguientes.

En una suerte de ejercicio autorreferente 0 de auto-reflexión acerca del quehacer del arquitecto, la investigación dedica un capítulo a la investigación en arquitectura: la reflexión acerca de la relación entre teoría y práctica, y la situación del investigador ante el objeto de estudio, que en el fondo es el proyecto. Buscando aportar tanto a la disciplina de la arquitectura, como al oficio y su enseñanza.

La transformación de este predio en parque, un gran parque, implica un desafío que supera la formación actual de los arquitectos y los urbanistas en Chile. Esta tesis es el intento de mejorar las herramientas que necesitamos para actuar en la complejidad de la ciudad actual y para legar un futuro más equitativo, sano y bello a nuestros hijos. 


\section{ABSTRACT}

Knowledge is no longer separate from action, but is found in action itself.

(Ascher, 2004, p. 33)

A diagnosis shared by numerous authors, from different disciplines, points out the following: the problems of the contemporary city require certain models of interpretation of reality that allow us to understand and then act on the complexity of urban processes, in order to recover and not so much conquer the territories affected by urban and social development. These same views propose, in addition to the above, a critical view of the mission of the modern architect and urban planner, as well as of the hierarchies they have imposed in a topical and professional manner on the urban landscape.

The evaluation of the processes of transformation of the urban landscape through the study of the recovery of the peripheral territory, as part of a larger ecological system, is the theoretical exercise, with practical foundations, that is undertaken in this thesis. Not before having had the opportunity to observe that these territories, those of the periphery, would be subject to a tension that demands a transdisciplinary and multi-scale methodological approach in order to articulate biotic, environmental, socio-cultural, economic, architectural, normative and infrastructural aspects. Doing so in such a way that they would have the potential to become real laboratories of experiences applicable later in the city as a macrosystem.

Faced with the challenge enunciated in the previous lines, it is worth asking whether the notion of project applied by modern architects and urban planners as ideal materialized in a design, with the pretension of controlling the future and reducing uncertainty, should not be replaced by a more reflexive and empathetic management, capable of adapting to the changes of a more complex society and to a more uncertain future (Ascher, 2004). Landscape architecture is presented in this research as the disciplinary option capable of tackling this challenge, offering its tools for analysis and negotiation, while at the same time demanding new professional skills.

The term Landscape has been incorporated into contemporary language to synthesize ethical, aesthetic and technical aspects linked to the territory which, together with the associated sciences, make it possible to qualitatively and quantitatively qualify and base transformation actions before the multiple actors who intervene and have an economic and political interest in the territory.

Landscape architecture, understood as a hybrid discipline that connects architectural and urban practice, understands the project as an open and participatory process. This condition requires it to investigate, theorize and communicate throughout the design process, thus turning the project into a mediation tool between territorial conflicts, administrative borders, sectorial perspectives and different scales. This is undoubtedly a possibility, perhaps utopian, that will allow us to face the growing phenomena of fragmentation, segregation, abandonment and degradation in which our cities are plunged.

To enter into this analysis, the present thesis approaches, from an applied perspective, the master plan of a territory of 1,022 hectares, located in the western limit of the city of Santiago de Chile, signed in the instruments of territorial planning as "metropolitan park - not consolidated". To this end, the spatial relationships of the various components of the territorial system in its multiple scales are analyzed. The application is materialized in a general proposal that seeks to test 
the methodological approaches studied in reference projects, to refine a development strategy of the property at a local scale, based on ecological processes and the construction of a landscape identity. In this process, the characterization of the landscape will act as a vector, which crosses the layers of analysis at different scales, allowing to define criteria of macro, meso and microscale performance, as well as the alternatives and difficulties that each of these scales represents. The layers of the past, present and future of the property will be integrated into the analysis, incorporating future initiatives at both regional and local levels. Two themes present at the site are emphasized: water and socio-natural risks, both of which are relevant to current practice.

In this research, the protagonist is the landscape, but other concepts of frequent use in contemporary disciplinary and political discourse will also be analyzed, presented, auscultated and confronted as actors, so that they operate with clarity in the foundation of the project. This critical exercise is what initiates this research and accompanies its development in the following chapters.

In a kind of self-referential exercise or self-reflection on the work of the architect, the research dedicates a chapter to research in architecture: the reflection on the relationship between theory and practice, and the situation of the researcher before the object of study, which in the end is the project. Seeking to contribute to the discipline of architecture, as well as to the profession and its teaching.

The transformation of this property into a park, a large park, implies a challenge that surpasses the current training of architects and urban planners in Chile. This thesis is the attempt to improve the tools we need to act in the complexity of today's city and to bequeath a more equitable, healthy and beautiful future to our children. 


\section{INDICE}

\section{CAPITULO 1: INTRODUCCIÓN}

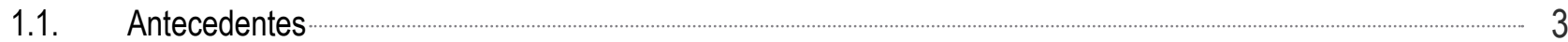

1.1.1. Contexto global

1.1.2. Contexto local.

1.1.3. Contexto de realización de la tesis

1.1.4. primeros referentes teóricos.

1.1.5. Laguna Carén: proyecto, caso de estudio o referente

1.2. Preguntas, Hipótesis y Objetivos de la Investigación.

1.2.1. Preguntas iniciales 14

1.2.2. Hipótesis

1.2.3. Objetivos 15

1.2.4. Estructura del documento 16

\section{CAPITULO 2: APROXIMACIÓN METODOLÓGICA: PROYECTO E INVESTIGACIÓN}

2.1. Introducción - _...… 21

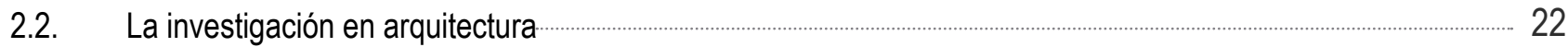

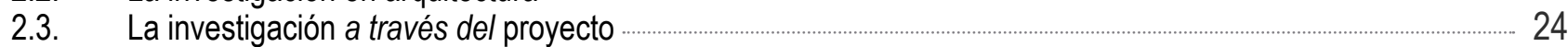

2.4. La paradoja del proyecto

2.5. Contexto local: Situación de la investigación en arquitectura $\ldots \ldots \ldots$

2.6. El objeto de estudio _..._. 26

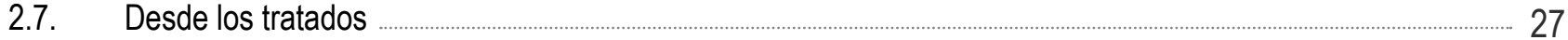

2.8. Proyecto (diseño) y Ciencia ....... 35

2.9. Los Métodos de Diseño o Proyectar con Método _ _ _ _ _ . 36

2.10. Proyecto y Complejidad —__ _ 44

2.11. Proyectar e investigar $\quad 46$

2.12. El eclipse del objeto ….... 47

2.12.1. El proyecto como estética aplicada

2.12.2. El proyecto como proceso lógico 48

2.12.3. El proyecto como razón práctica, ética, [o relacional] 48

2.13. Los Intereses en juego ...........ión

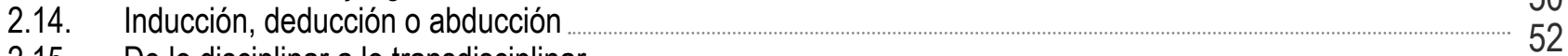

2.15. De lo disciplinar a lo transdisciplinar

\section{CAPITULO 3: PAISAJE E IDENTIDAD}

3.1. Introducción $\ldots \ldots \ldots \ldots$

3.2. El paisaje de Laguna Carén por primera vez $\quad 58$

3.3. La palabra paisaje 61

3.3.1. El francés como punto de partida

3.3.2. Otras lenguas y sus equivalentes

3.3.3. El paisaje en español $\quad 63$

3.3.4. Significado y significante $\quad 65$

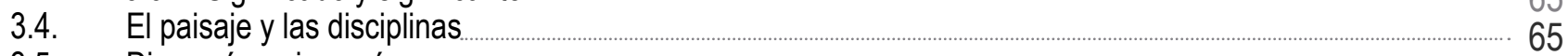

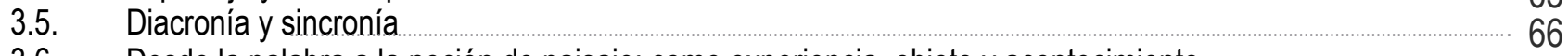

3.6. Desde la palabra a la noción de paisaje: como experiencia, objeto y acontecimiento.

$\begin{array}{ll}\text { 3.6.1. El paisaje narrado } & 67\end{array}$

3.6.2. La tierra como paisaje $\quad 69$

3.6.3. Viaje y paisaje 73

3.6.4. El paisaje como objeto de estudio: entre la historia y el determinismo físico 79

3.6.4.1. Chile descubierto y narrado por la ciencia 81

3.6.5. La experiencia del paisaje, aproximación fenomenológica 84

3.6.6. Paisaje y acontecimiento $\quad 89$

3.7. El paisaje en la legislación chilena _ _ _ _ _ _ $\quad 95$

3.7.1. El paisaje y la protección medio ambiental 95

3.7.2. Legislación y protección inmaterial: el paisaje como aspecto cultural 96

$\begin{array}{ll}\text { 3.7.3. Paisaje, palabra perdida } & 97\end{array}$ 


\section{CAPITULO 4: LA TRANSFORMACIÓN DEL PAISAJE}

4.1. Introdución

4.2. Haciendo algo de historia: el mito, el ritual la alegoría y la razón 102

4.2.1. El paisaje arcaico. $\quad 103$

4.2.2. El paisaje clásico 105

4.2.3. El paisaje monoteísta $\quad 109$

4.2.4. El diseño ilustrado.

4.4.5. La literatura y la pintura como impulso al diseño pintoresco 113

4.2.6. El triángulo higiénico técnico y estético $\quad 115$

4.2.7. El diseño del paisaje en el mundo global. 116

4.3. la Transformación del paisaje en Chile. $\quad 117$

4.3.1. La ciudad (o la función sigue a la forma)

4.4. La ilusión de una nueva arquitectura chilena frente al paisaje $\ldots \ldots \ldots$

4.5. Estrategias de transformación desde el arte

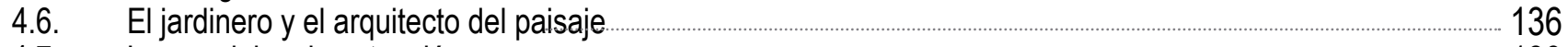

4.7. Los modelos de actuación _. …… 139

4.8. El paisaje y la ciudad _ _ _ _ _ _ 140

4.9. Paisaje y ecología $\quad 141$

4.10. A modo de conclusión - 146

\section{CAPITULO 5: PARQUES, GRANDES PARQUES}

5.1. Introducción - — - 151

5.2. El huerto, el jardín y el parque, lo que nos dice la etimología _.

5.3. El parque como objeto de estudio $\quad 153$

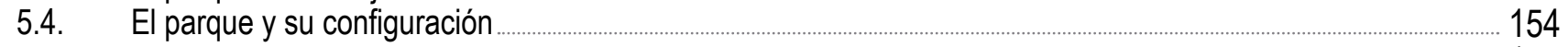

5.5. Desde el jardín a la ciudad …_............. 155

5.6. Artefactos anticipatorios _...___ 157

5.7. Parques Reales y jardines que devienen públicos … - 158

5.8. El Reporte sobre paseos públicos: confort, salud y contento _ _ _

5.9. Les Promenades de Paris: los parques y la modernidad $\ldots \ldots \ldots$

5.10. Central Park _ _ 168

5.11. El Volkspark, el parque popular alemán _ _ 173

5.12. Los Parques en Chile _. 176

5.12.1. La Quinta Normal de Agricultura 176

5.12.2. De Campo de Marte a Parque Cousiño, y a Parque O'Higgins 181

5.12.3. El Parque Metropolitano de Santiago 185

5.13. Los parques como sistemas complejos … 187

5.13.1. La Courneuve (Parc Georges-Valbon) 187

5.13.2. Shelby Farms Park 191

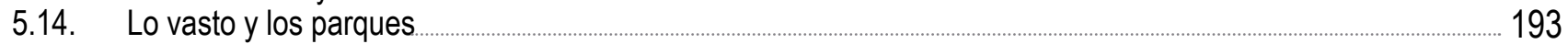

\section{CAPITULO 6: EL TERRITORIO LAGUNA CAREN: DIMENSION SOCIO-CULTURAL}

6.1. Introducción _ 197

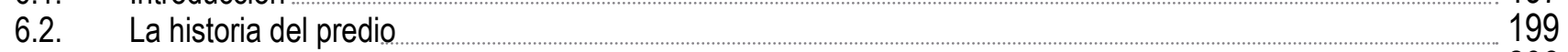

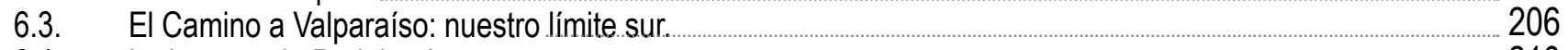

6.4. La Laguna de Pudahuel _ $\quad 210$

6.5. De las haciendas a las comunas de Barrancas y Pudahuel. __. _ 211

6.6. Demografía e identidad comunal __. 213

6.6.1. La Fiesta de Cuasimodo 214

6.6.2. El mito del Culebrón $\quad 215$

6.6.3. Gabriela Mistral 216

6.6.4. Pudahuel y la música de protesta

6.7. La Reforma Agraria 221

6.8. La minería en el valle de Lo Aguirre

6.9. El Centro de Energía Nuclear de Lo Aguirre $\ldots \ldots \ldots$

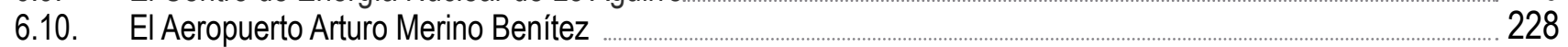


6.11. Volviendo al terreno de Laguna Carén 231

6.12. A modo de síntesis 232

\section{CAPITULO 7: EL TERRITORIO DE LAGUNA CARÉN COMO SISTEMA ECOLOGICO}

7.1. Introducción 237

7.2. Área de estudio $\quad 237$

7.3. Geomorfología - 237

7.4. Geología …. 239

7.4.1. Formación Pumicítica 240

7.4.2. Formación Lacustriana

7.4.3. Formación de Cerros

7.5. Suelos 243

7.5.1. Series de Suelos 243

7.5.1.1. Serie Carén (CR) 243

7.5.1.2. Serie Espinal (ES) 244

7.5.1.3. Serie Pudahuel (PD) 244

7.5.1.4. Serie Amapola (AM) 244

7.5.1.5. Misceláneos de Escarpe (ME) 244

7.5.1.6. Sectores Rocosos (SR) 244

7.5.1.7. Sector Sur (SS) o (SD) 245

7.5.1.8. Sectores de Construcción (SC) 245

7.5.1.9. Estero y Laguna Carén 245

7.5.2. Capacidad de uso del suelo

7.5.3. Erodabilidad y Erosividad 246

7.6. Hidrosfera $\ldots \ldots \ldots \ldots \ldots \ldots$

7.6.1. La Laguna Carén 250

7.6.2. Los acuíferos 250

7.6.3. Riesgos hídricos 252

7.7. Pisos y Formaciones Vegetales 252

7.7.1. Vegetación regional $\quad 252$

7.7.2. Vegetación local

7.7.3. Composición de la Flora 256

7.7.4. Especies amenazadas 256

7.7.5. Reforestación 258

7.8. Fauna 258

7.8.1. Composición de la fauna local

7.9. Atmósfera - 264

7.9.1. Clima y Meteorología

7.9.2. Vientos Predominantes 266

7.10. Áreas protegidas y sitios prioritarios para la conservación $\ldots \ldots \ldots \ldots$

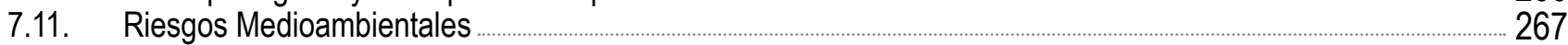

7.11.1. Inundaciones 267

7.11.2. Incendios forestales: $\quad 267$

7.11.3. Ruido: 268

7.11.4. Probables fuentes de contaminación o de riesgos ambientales

7.12. Legislación y disposiciones de relevancia ambiental 269

7.12.1. Sistema de Evaluación Ambiental.

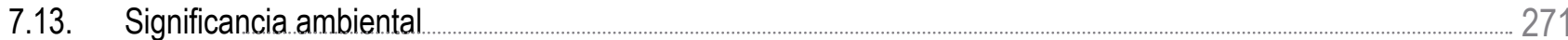

\section{CAPITULO 8: EL PAISAJE DE LAGUNA CARÉN: DIMENSIÓN PERCEPTUAL}

8.1. Introducción: Descubrir 275

8.2. Aspectos visuales de los bordes y el entorno 276

8.2.1. En el límite sur

8.2.2. Entrada principal

8.2.3. Límite oriente 277

8.2.4. El límite norte del predio

8.2.5. Limite Poniente $\quad 279$ 
8.3. Componentes del paisaje dentro del predio _ _ 279

$\begin{array}{ll}\text { 8.3.1. Superficie } & 279\end{array}$

8.3.2. Aguas 279

8.3.3. Vegetación 281

8.3.4. Elementos artificiales 281

8.4. Unidades de paisaje … 287

8.5. Legibilidad: carácter y escalas _...__ 296

8.6. Calidad visual: belleza y significado $\quad 297$

8.7. Importancia y fragilidad ….. 298

8.8. Algunas recomendaciones desde el paisaje _ 299

8.9. A modo de conclusión ……...... 299

\section{CAPITULO 9: MARCO NORMATIVO}

9.1. Introducción: "Puesta A Tierra" …… 305

9.2. Desde el Plan de Transformación de Santiago al PRMS-100 _.............................................. 305

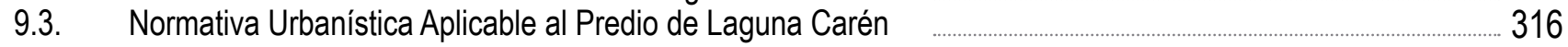

9.4. Normativa Aplicable para el Desarrollo de un Plan Maestro _ ………................................................ 321

9.4.1. Áreas de Interés Silvoagropecuario 321

9.4.2. Proyectos de Desarrollo Urbano Condicionado (PDUC) 322

9.4.3. Desarrollos Industriales y/o Empresariales Condicionados (DIEC) 323

9.4.4. El Artículo 55 de la LGUC permite urbanizar en áreas rurales en casos excepcionales. 324

9.5. Escenarios Normativos _...... 324

9.5.1. Escenario 1: Seguir con Plan Maestro de 2004 (Aplicación Artículo 2.3.31): 324

9.5.2. Escenario 2: Aplicación del Artículo 55 de la Ley General de Urbanismo y Construcciones 325

9.5.3. Escenario 3: Modificación de PRMS.

9.5.4. Complemento a los 3 escenarios: Sistema de Evaluación Ambiental. 328

9.5.5. Síntesis y diagnóstico de los escenarios 330

\section{CAPITULO 10: LAGUNA CARÉN, SUEÑOS Y REALIDAD}

10.1. Introducción _....... 333

10.2. Los sueños: planes maestros anteriores 333

10.2.1. Plan Maestro Parque Metropolitano, Año 1992 - Ilustre Municipalidad de Pudahuel 333

10.2.2. Plan Maestro MECSA, Año 1997

10.2.3. Propuesta Plan Design Workshop, año 2002: 338

10.2.4. Laguna Carén Investment, año 2013

10.2.5. Estadio Club Universidad de Chile, año 2014

10.3. La realidad: estado actual del predio, respecto a los planes maestros 348

10.3.1. Vialidad e infraestructura vial. $\quad 350$

10.3.2. Alcantarillado y tratamiento de aguas servidas y disposición final de aguas tratadas. 350

10.3.3. Agua Potable y sistema de grifos de incendio. 352

10.3.4. Sistema de recolección de aguas lluvias. 353

10.4. Situación de la laguna _..... 353

10.5. Inserción del predio en el desarrollo del Valle de lo Aguirre

\section{CAPITULO 11: EL PROGRAMA: ¿UN PARQUE CIENTÍFICO-TECNOLOGICO?}

11.1. Introducción 361

11.2. La Universidad de Chile $\quad 361$

11.3. La tercera misión de la universidad 363

11.4. La triple hélice - 364

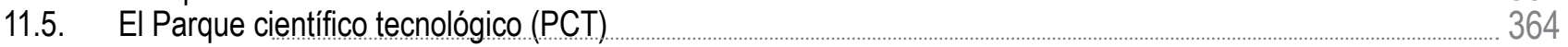

11.6. Los orígenes 366

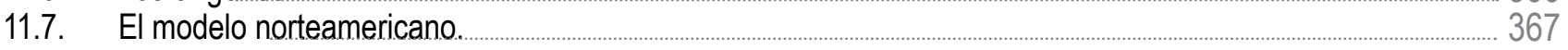

11.7.1. Science Park Park de Stanford 367

11.7.2. Silicon Valley $\quad 367$ 
11.8. El modelo pasa a Europa _ $\quad 370$

11.8.1. Sophia Antipolis $\quad 370$

11.8.2. Cambridge Science Park 373

11.8.3. El caso español.

11.9. Parques y ciudades de la ciencia en Asia $\ldots \ldots \ldots \ldots \ldots$

11.9.1. Tsukuba Science City 378

11.9.2. Hsinchu Science Park. $\quad 379$

11.10. Latinoamérica _ — — _ _ 381

11.10.1. Ciudad del Saber (CDS) 383

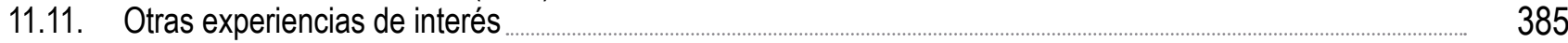

11.11.1. Skolkovo Innovation Center (SkIC)

11.11.2. IC Institute, Austin Texas

11.12. Evaluando el éxito de los parques científicos tecnológicos _..._........................................... 388

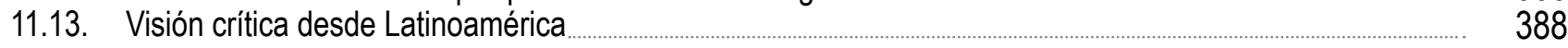

11.14. La situación de Chile. _ _ _ _ _ 389

11.15. ¿Un parque científico y tecnológico en Carén? 390

11.16. El pensamiento de diseño como herramienta en el proceso. . _ _ 391

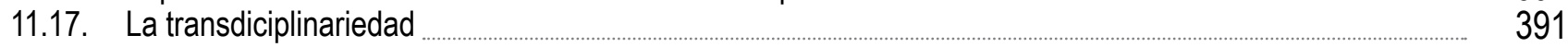

\section{CAPITULO 12: FUNDAR: UN PLAN MAESTRO PARA LAGUNA CARÉN}

12.1. Introducción 397

12.2. Antecedentes $\quad 399$

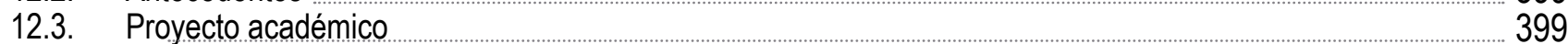

12.4. El Plan Maestro $2015 \quad 403$

12.5. Plan maestro $2016 \quad 406$

12.5.1 Macroescala 406

12.5.1.1. Santiago Cerros Islas 407

12.5.1.2. Mapocho 42K 408

12.5.1.3. Plan Quiero Santiago Verde 410

12.5.1.4. Estrategia Nacional para la Conservación y Uso Racional de los Humedales en Chile 4410

12.5.2. La meso escala, la escala del predio: el parque Laguna Carén 412

12.5.2.1 Conservando el valor del paisaje local para las generaciones futuras 413

12.5.3. La micro-escala y la primera etapa de intervención. $\quad 422$

12.6. Gestión y problemas emergentes 431

12.7. A modo de cierre 431

\section{CAPITULO 13: CONCLUSIONES}

13.1. Sobre la transformación del paisaje _ 444

13.2. Sobre la relación entre proyecto e investigación 446

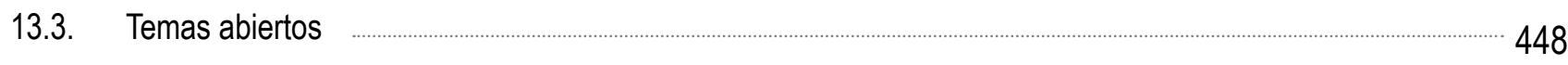

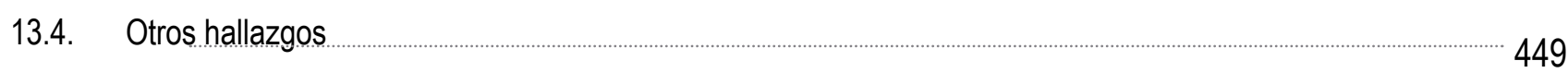

13.5. Sobre la escritura $\quad$ _ n

\section{BIBLIOGRAFIA}

\section{ANEXOS}

Anexo 1:Difusión de los resultados de la Tesis

Anexo 2:Presentaciones

Anexo 3:Documentos reservados 


\section{$5 x=$}

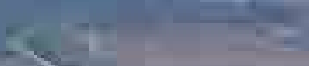

$35=$

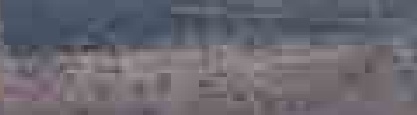

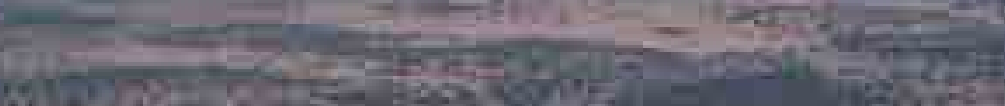

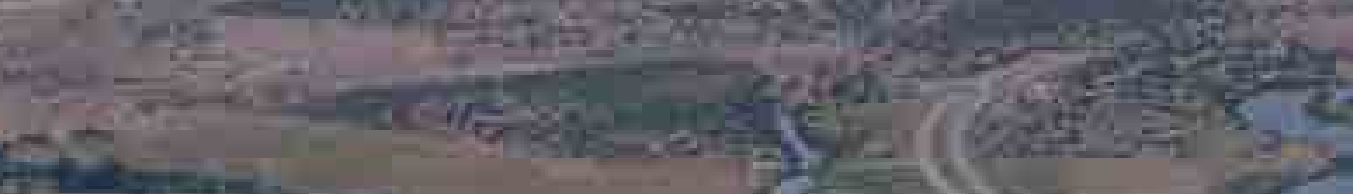

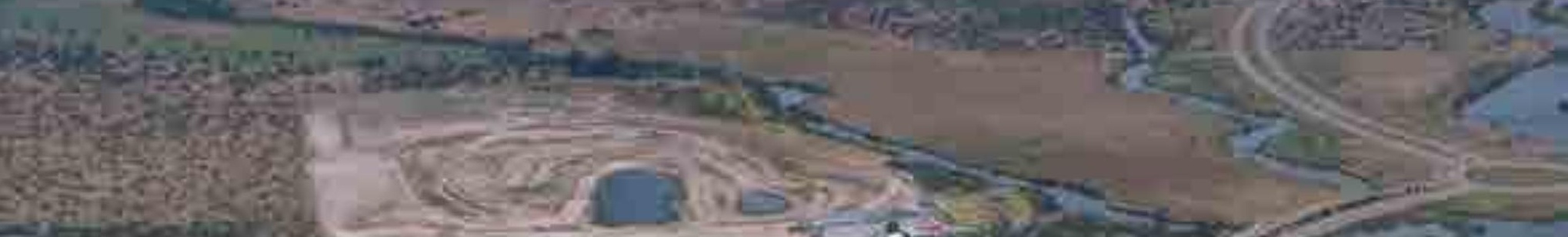

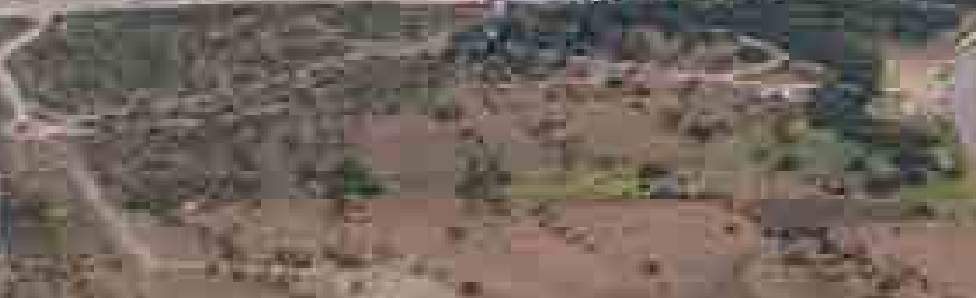

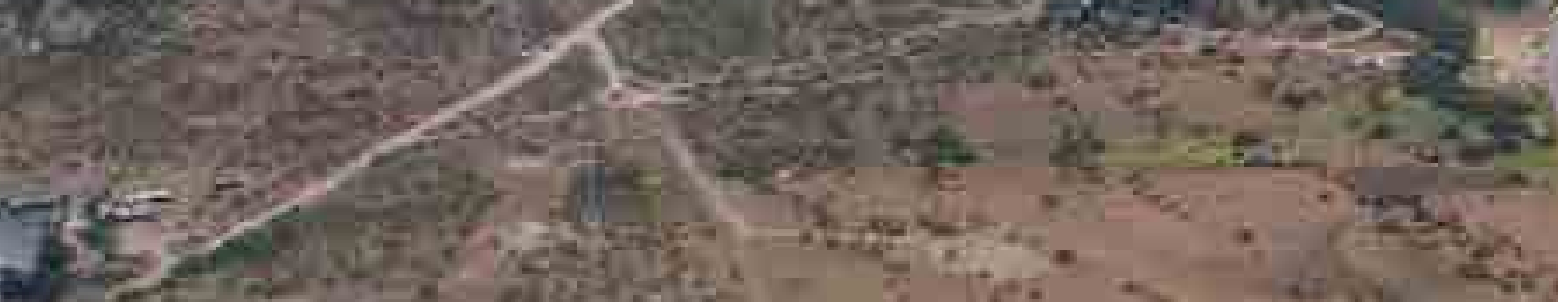

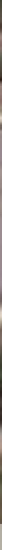

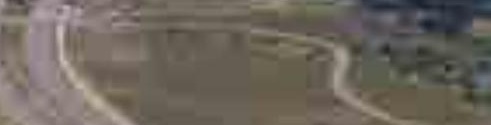

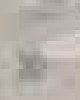

स.

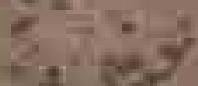

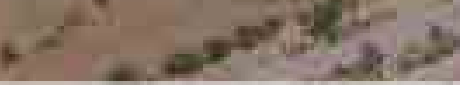




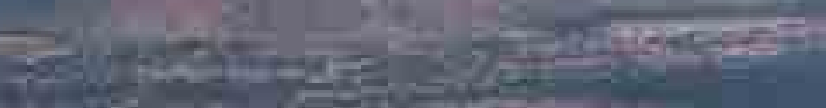

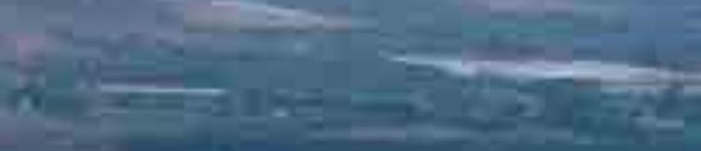

cing- $x=3$

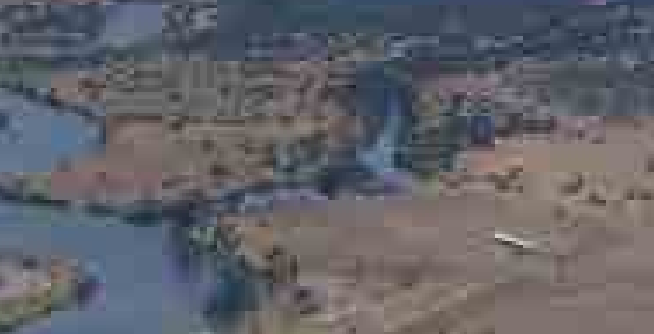

a

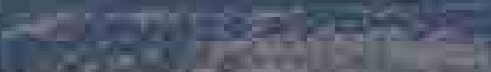

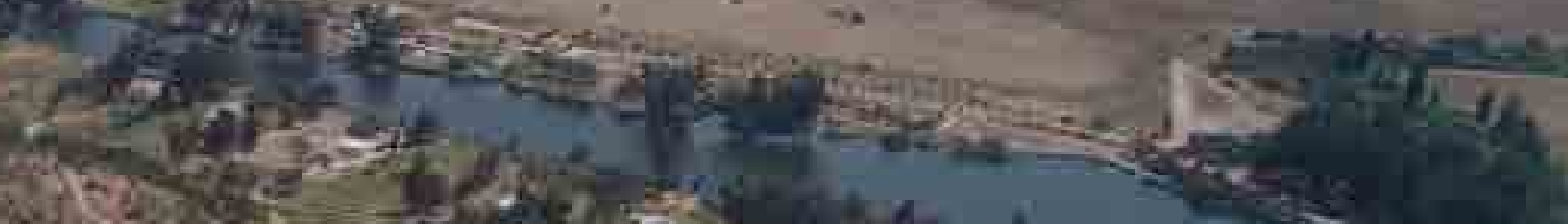

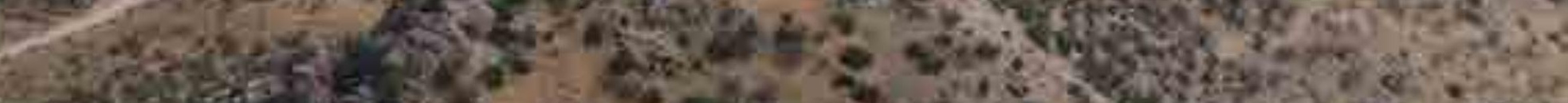

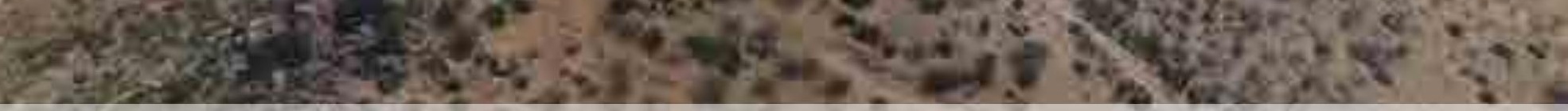

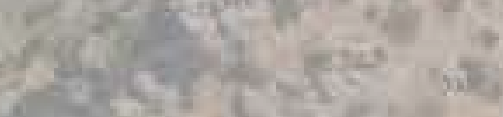

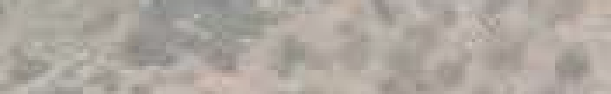

\section{CAPÍTULO 1 INTRODUCCIÓN}

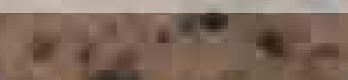

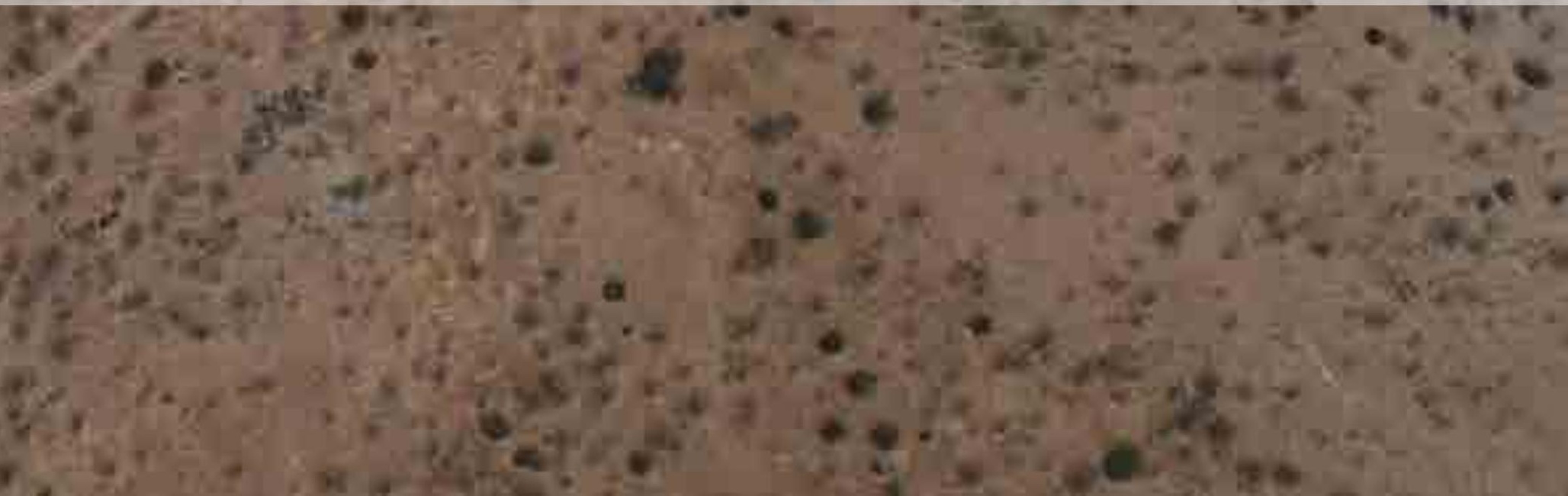




\section{INTRODUCCIÓN}

Hemos adquirido conocimientos sin precedentes sobre el mundo físico, biológico, psicológico, sociológico. La ciencia ha hecho reinar, cada vez más, a los métodos de verificación empírica y lógica. Mitos y tinieblas parecen ser rechazados a los bajos fondos del espíritu por las luces de la Razón. Y, sin embargo, el error, la ignorancia, la ceguera, progresan por todas partes, al mismo tiempo que nuestros conocimientos. (Morin, 1994, p. 28)

\subsection{ANTECEDENTES}

\subsubsection{Contexto global}

El impacto de la modernidad ha dejado profundas huellas en la ciudad y en el territorio que heredamos del siglo XX. Junto al impulso por ampliar el conocimiento del mundo y por dominar sus leyes, propio del pensamiento científico, hemos pretendido, a través de la tecnología, extender este dominio a la naturaleza misma. La ciudad es expresión material de esta determinación, su producto físico más categórico. En ella, el movimiento moderno aplicó los principios del funcionalismo, con la misma pretensión civilizatoria (científica, reduccionista y abstracta), dando como resultado la (buscada) segregación funcional, (y la defectiva) segregación espacial y social de la ciudad que hoy conocemos. Este fenómeno se ha profundizado por la expansión del modelo de mercado sobre el territorio, provocando el crecimiento desregulado de la ciudad sobre los suelos agrícolas, con el consecuente consumo de recursos como territorio, vegetación, agua, suelo y energía. Las ciudades contemporáneas sufren por esta causa, de la contaminación, del incremento de residuos y de una mayor ocurrencia de desastres socio-naturales. Desde el punto de vista social, este modelo económico ha reforzado los procesos de segregación espacial y social, de exclusión y violencia urbana, haciendo patente que la lógica de mercado es insostenible, tal como plantea Esteban de Manuel Jerez (2007).

En efecto, resulta dramático y paradójico constatar que la ciudad, como expresión física y simbólica de la modernidad, es al mismo tiempo la principal fuente de conflictos sociales y ambientales que amenazan la vida del planeta (Moreno, 2006), evidenciado las tensiones y contradicciones del desarrollo (Winchester, 2006).

Esta situación se evidenció en el último cuarto del siglo XX a partir de, entre otras causas, la crisis del petróleo que obligó a los estados a pensar su realidad en términos globales. Para autores como Carlos de Mattos:

los caminos que los distintos países escogieron para salir de la crisis económica, [...] estuvieron fuertemente condicionados por los efectos simultáneos e interrelacionados de la consolidación de un nuevo paradigma científico-técnico y del incontenible avance de la globalización de la economía. (2001, p. 18).

En el caso de Sudamérica, el avance de la globalización de la economía fue incontestable a causa de las dictaduras que se instalaron en ese período.

En este contexto desalentador, surgen en la década de 1970, junto con la crítica al Movimiento Moderno formulada por destacados autores (Alexander, Silverstein, Angel \& Ishikawa, 1978; Jencks, 1977; Lefebvre, 1968 y Mumford, 1968, 2012), diferentes planteamientos teóricos y prácticos sobre el problema socio-ambiental, proponiendo y globalizando conceptos tales como sustentabilidad, ecología urbana, ambiente, patrimonio, participación y paisaje. Dentro de este repertorio, la noción de paisaje ha reaparecido con fuerza en el discurso contemporáneo, o como nos dice James Corner, "se ha vuelto a poner curiosamente de moda" (Corner, 2006, p. 23). 
La arquitectura del paisaje, en tanto disciplina intermedia e integradora de las ciencias naturales y las ciencias sociales, propone un modo de interpretar y de intervenir en el territorio que deja atrás los enfoques sectoriales ${ }^{3}$ que han caracterizado el accionar sobre la ciudad, la sociedad, el medioambiente y sus problemas. Supuestamente se integran así, como señala Osvaldo Moreno (2006), las destrezas de varias disciplinas como la ecología, la geografía, y el urbanismo. A éstas debemos sumar la importante y a veces subvalorada tradición del paisajismo y la jardinería, todas ellas operando a distintas escalas. La noción de paisaje se transforma de este modo en un trascendental instrumento de actuación sobre el ambiente y el territorio.

Según desarrollaremos más ampliamente, el arte del paisaje -en su doble faz, ética y estética (Español, 2010, p. 104), modelada por la historia- se diferencia de la visión preeminentemente científica de ambiente, en la que el ser humano se concibe como parte del medio que habita. El paisaje, en cambio, habla de una distancia que el ser humano "nunca podrá colmar, aunque permanentemente se mueva hacia ese objetivo utópico" (Silvestri y Aliata, 2001, p. 186). El ser humano establece, mediante esta posición distante, una mirada en perspectiva, la cual le permite observar, comprender y actuar sobre el ambiente, del cual también es parte (Moreno, 2007).

Para autores como Christophe Girot, "existe un cisma entre la forma en que el paisaje se entiende científicamente, ya sea como una red normativa funcional o un sistema ecológico, y la forma en que el mismo lugar existe cognitiva, poética y emocionalmente para las personas"4 (Girot, 2013). Esta tensión estará presente a lo largo de este trabajo: aparece continuamente desde el origen etimológico del concepto de paisaje, en las distintas nociones de éste en la historia, en la literatura, la filosofía y en la poesía. Es una tensión que se evidencia también al estudiar las nuevas escuelas de Landscape Urbanism que frecuentemente excluyen consideraciones estéticas y poéticas, centrando su actuar en el ordenamiento del territorio y en los servicios ecosistémicos, sin tener en cuenta las costumbres y tradiciones locales, que son las que sostienen la identidad de un lugar, las que construyen paisaje. En estas escuelas es habitual confundir paisaje y territorio, conviene señalarlo.

Es así como el término paisaje no sólo se hace eco de una creciente toma de conciencia ambiental y ecológica relacionada con la calidad de vida urbana o el crecimiento descontrolado de la ciudad sobre las áreas rurales (Corner, 2006), sino también puede asumir lo que Alberto Magnaghi llama la "conciencia de lugar" (entrevistado por Moran Alonso y Fernández Casadevante, 2013, p. 146), metáfora que utiliza en sustitución de la conciencia de clase. Para este autor, la atomización de la sociedad en individuos consumidores y productores ha trasladado las luchas sociales, antes de clase, al territorio, para la defensa del propio entorno de vida. En palabras de este autor:

Poco a poco, esta población desposeída de su cualidad de habitantes, para convertirse en usuarios, consumidores y residentes en el contexto de la sociedad del consumo de masas, comienzan a reidentificarse, a reencontrarse, y del objetivo singular de estas luchas surge esta "conciencia de lugar", es decir de la propia comunidad, de estar juntos, y del valor del propio territorio olvidado por la ciudad fábrica. (entrevistado por Moran Alonso y Fernández Casadevante, 2013, pp. 146-147).

${ }^{3}$ Nos referimos a enfoques sectoriales como aquellos que aíslan de un modo artificial un problema y los en-frentan con intervenciones aisladas con criterios y trategias divergentes.

4 Traducción propia
El paisaje reaparece como una idea renovada que demanda una postura no sólo técnica, sino también "ética de la gestión de los recursos naturales y del territorio" (Español, 2010, p. 104). Esta nueva fuerza del paisaje ofrece al urbanismo actual nuevos recursos y puntos de vista para analizar, teorizar, planificar y proyectar lo 
vasto; para transformar territorios considerando sus redes, infraestructura, ecosistemas, usos y costumbres, los imaginarios asociados al lugar y aquello que está más allá del sitio.

Con el cambio de siglo, el Convenio Europeo del Paisaje de Florencia (Consejo de Europa, 2000) ratificada por $39^{5}$ de los 45 países de la UE, viene a reforzar el papel de este concepto, incorporándolo como herramienta de análisis y de proyecto bajo tres acciones: protección, gestión y ordenación del paisaje (2000, pp. 2-3). Este marco internacional, ha impactado fuertemente más allá de los Estados Miembros de la UE, impulsando cartas y convenios locales también en América. En todos ellos se establece una nueva manera de leer el territorio, donde ya no es posible hacer tabula rasa, recuperando así, tanto lo visible como lo invisible que existe en un lugar y que se constituye en un patrimonio natural y cultural que debe ser cuidado 0 a menos considerado. Tras estas adhesiones, está la conciencia de que "gestionamos un recurso frágil y dinámico" (Borobio y García, 2012, p. 115).

Cabe observar que en el Convenio Europeo del Paisaje (Consejo de Europa, 2000) no se menciona la palabra escala, cuestión que en esta tesis plantearemos como relevante al momento de pensar y proyectar el territorio desde el paisaje. El pensamiento a múltiples escalas, sería a nuestro juicio una de las características de esta nueva racionalidad paisajística que el mismo convenio promueve.

\subsubsection{Contexto local}

América Latina y el Caribe es hoy la región más urbanizada del mundo en desarrollo. Las cifras regionales ocultan las grandes diferencias existentes entre los países. A un extremo están los países con una avanzada etapa de urbanización como Argentina 92,4\%, Chile 89,6\%, Uruguay 95,9\% y Venezuela 90,2\%, según proyecciones de la CEPAL para el año 2019 (CELADE-CEPAL, 2019); al otro extremo están los países de cultura más rural, principalmente los ubicados en América Central y Paraguay, con una población urbana cercana al 60\% (CELADE-CEPAL, 2019). El deterioro del medioambiente urbano es el problema más grave que enfrenta Latinoamérica, luego de la pérdida de ciertos recursos naturales (Winchester, 2006); a esto se suman los problemas ambientales del hábitat residencial y aquellos derivados de contextos de pobreza, que hacen aún más urgente y complejo el abordaje integrado de los problemas ecológicos, económicos y sociales que caracterizan el actual desarrollo urbano.

Como observan Reyes y Figueroa, una de las consecuencias más claras de la acelerada historia urbana de América Latina durante la segunda mitad del siglo $X X$, es su precariedad, objetivable a partir de la escasez de áreas verdes que presentan las grandes ciudades (2010, p. 90).

Podemos afirmar que la experiencia de desarrollo en América Latina revela una conflictiva relación entre el desarrollo económico y justicia social. En el caso de Chile, la segregación espacial y social, los riesgos naturales y la carencia de áreas verdes son los problemas más críticos que aquejan a sus ciudades (Romero et al, 2009). Las periferias urbanas son los lugares donde más crudamente se expresan los conflictos paisajísticos-ecológicos-socioeconómicos, con un acelerado deterioro de las condiciones y capacidad ambiental, afectando el hábitat y la calidad de vida de una parte importante de los habitantes de las ciudades.

En la ciudad de Santiago es difícil establecer un límite formal claro entre lo urbano y lo rural; los instrumentos de planificación territorial -planes reguladores comunales y el Plan Regulador Metropolitano de Santiago (PRMS)- han demostrado una limitada capacidad para conducir el acelerado crecimiento de la ciudad, cuya dispersión ha arrasado con las calidades ambientales, económicas y sociales del medio rural. El Estado ha sido co-responsable de esta evolución al liberar los límites de la ciudad y dejar al mercado la responsabilidad de su desarrollo.

5 cifra actualizada al 15/5/2019 según el Council of Europe. Disponible en línea en: https://www.coe.int/en/web/conventions/ full-list/-/conventions/treaty/176/signatures?p_auth=Yu6Va2ZG 
También al impulsar la creación (a través de concesiones) de autopistas urbanas, posibilitando la aparición de aglomeraciones en la periferia, que han privilegiado la vivienda en extensión bajo la forma de condominios cerrados. Lewis Mumford seguramente calificaría estas conurbaciones como "anticiudades" (1969, p. 313), formadas por condominios herméticos que, junto a núcleos logísticos y empresariales de grandes dimensiones, producen un territorio discontinuo, desarticulado y segregado, totalmente insensibles a la calidad paisajística de un valle de gran belleza a los pies de la cordillera de Los Andes.

Las periferias de Santiago son un buen ejemplo del error, la ignorancia y la ceguera de la que nos habla Morin en la cita inicial. Una ceguera que progresa pese al desarrollo económico y al avance de las ciencias y la tecnología, destruyendo a su paso aquello que no ve. Podríamos atribuir el error a la falta de reflexión o pensamiento crítico, sin embargo, parece ser un fenómeno más amplio y profundo, que más bien refleja el fracaso de un modelo de pensamiento, inadecuado frente a la complejidad de la realidad urbana, exigiendo una nueva racionalidad, también compleja, y un abordaje transdisciplinar que aún hay que explorar.

En el caso de Chile, resulta especialmente paradójico que un país que se ha dado a conocer globalmente ${ }^{6}$ por su rica geografía y "paisajes remotos", no haya desarrollado en paralelo una arquitectura y un urbanismo orientado por el paisaje, posiblemente su principal patrimonio. Es posiblemente ésta, la más importante tarea de los arquitectos chilenos: contribuir a una real valoración del paisaje en todas las dimensiones de la vida, desde la cotidiana a la política, permitiendo de este modo re-vincular los sistemas naturales y sociales, la cultura y la ecología.

\subsubsection{Contexto de realización de la tesis}

Esta tesis surge en el intento de hacer confluir más de 30 años de experiencia profesional y docente, y el trabajo de investigación acerca de las escalas en la arquitectura y la vinculación entre diseño, arquitectura, urbanismo y paisaje, iniciado en el contexto del Programa de Doctorado en Patrimonio Arquitectónico de la UPM.

Por casi tres años, tuve la responsabilidad de la Dirección de Infraestructura de la Universidad de Chile, labor que me ha permitido constatar el impacto urbano de las intervenciones arquitectónicas a escala de los campus que, en el caso de la universidad, están distribuidos en cinco zonas de la Región Metropolitana de Santiago. Como espejo de los problemas de la ciudad, estos lugares han crecido en general, sin planes maestros y sin considerar que los edificios forman un sistema que requiere ser operado, que debe adaptarse en el tiempo, tanto a nuevas necesidades, como al contexto cambiante de la ciudad que los rodea.

En paralelo, se me encomendó dirigir el Plan Maestro de un predio de 1.022 ha ubicado en la periferia de Santiago. Este gran sitio donado por el Estado de Chile a la Universidad de Chile hace 25 años, comprometía el desarrollo de un parque científico-tecnológico, una ciudad universitaria y un parque público de 200 ha.

La tarea encomendada por la rectoría consistía en viabilizar este proyecto universitario en un contexto normativo que define este predio como rural y como un parque metropolitano-no consolidado, tras dos décadas de planes maestros frustrados y la ejecución de obras de infraestructura que urbanizan 90 ha del predio.

${ }^{6}$ Este fenómeno tiene una historia recien-

La etapa inicial de este proyecto profesional, consistió principalmente en la elaboración colectiva de un proyecto académico que le diera sustento conceptual al plan; la propuesta general lograba concentrar la zona de desarrollo en 422 ha, dejando una reserva ecológica de otras 400 ha y un parque público de 200 ha. Sin embargo, nuevos problemas políticos y administrativos han detenido el actual proyecto. 
Es este paréntesis en el tiempo el que me ha permitido tomar distancia y revisar el proceso, incluyendo el sentido del encargo, y cuestionar los principios que están detrás de una intervención en el territorio tan extensa.

Es así, como mi investigación ha evolucionado desde la búsqueda de fundamentaciones para el proyecto, basadas en la sostenibilidad como un criterio ético de diseño, a una investigación a través el proyecto del paisaje, que, sin compromisos de poder, busca fundamentar la defensa de este predio como Parque Metropolitano.

Desde ese frente, vuelvo a mirar el paisaje de Laguna Carén.

\subsubsection{Primeros referentes teóricos}

A partir de los antecedentes expuestos, podríamos aventurar que esta tesis se enmarcaría dentro del modelo de una investigación aplicada o de investigación-acción.

La mayor dificultad que se vislumbraba originalmente, era, cómo a partir de un problema singular (local) podría lograr conceptualizar un tema de interés general. Así, como en el ejercicio proyectual, es finalmente el diseño (proyecto) el que juega el papel de síntesis, en el proyecto de investigación es el proyecto y el sitio los que se convierten inductivamente, en fuente de las preguntas de investigación. Sin embargo, la hipótesis surge deductivamente a partir del distanciamiento teórico y crítico, al confrontar los problemas enunciados con la historia y la teoría de la arquitectura y del paisaje. La hipótesis se aloja en una temática disciplinar y transdisciplinar: la percepción y representación multiescalar. Si bien, el término multiescalar es recurrentemente mencionado en los textos, requiere ser conceptualizado para ser operativo, bajo la idea de una nueva racionalidad, un modo de pensar del arquitecto frente al paisaje.

Al repasar el proceso de investigación, los temas clave del proyecto se abrían, exigiendo cada uno de ellos una profundización y ofreciendo nuevos enfoques, más allá de los tenidos en consideración en el "proyecto real". La ramificación (a veces poco controlada) de temas se convierte así en una característica del texto, que he decidido no corregir, dejando de ese modo la huella de un proceso intelectual y muy personal, que muestra a través de diversos autores, las ideas y nuevas relaciones que aparecen entre esas ideas y las decisiones de proyecto, siempre presentes.

El proceso de investigación ha hecho ineludible la reflexión sobre la relación entre proyecto e investigación, la que se incluye en el segundo capítulo. En un inicio, este tema tuvo el objetivo de justificar ante el tribunal por qué y cómo un proyecto real puede ser la base de un proyecto de investigación doctoral, para luego transformarse en un tema de reflexión e investigación en sí mismo. En esta materia, han sido cruciales las aportaciones de Jean-Pierre Boutinet (1990/2015), especialmente su libro Anthropologie du projet, donde el autor argumenta que la arquitectura fue la profesión que históricamente impuso la práctica social del proyecto, perfeccionándolo gradualmente desde el renacimiento. Asimismo, fue central el artículo de Alain Findeli \& Anne Coste (2007) De la recherche-création à la recherche-projet, un ensayo donde se analiza la tensión dialéctica entre teoría y práctica, los problemas metodológicos de la investigación empírica, y los temas antropológicos y éticos que plantea la investigación en las disciplinas profesionales, permitiendo trasparentar las alternativas que el investigador tiene y declarar su posición.

Parte del material del capítulo 2 ha sido expuesto en dos instancias: el Congreso Internacional Intersecciones, desarrollando en Chile en diciembre de 2018, con la ponencia Investigación y proyecto y en el simposio Internacional DARA 9, reali- 
zado en Hannover, Alemania, en abril de 2019 con la ponencia Research through Landscape Design. Ambas presentaciones han permitido a la autora verificar la actualidad del tema y ampliar la reflexión acerca de la posibilidad de hacer investigación -una investigación doctoral- a partir de la experiencia de un proyecto real, con el proyecto como referente.

Esta misma necesidad de tomar posición críticamente, es la que motiva el Capítulo 3 de Fundamentos Conceptuales y Teóricos, que más allá de conceptualizar sincrónica y diacrónicamente los términos, pretende trabajar con los conceptos como si estos fueran actores, sujetos de estudio, que evolucionan, mutan y se relacionan para conformar un imaginario y un marco teórico coherente para el análisis y actuación en la realidad. Por ejemplo, desde el inicio, en la propuesta subyace una visión crítica al concepto de sostenibilidad en su interpretación economicista y banalizada, el desarrollo sostenible. En una suerte de psicoanálisis de la sustentabilidad a través de la lectura de distintos autores, en distintos momentos y desde diversas disciplinas, el término muestra lo que de algún modo queda oculto en el discurso común. En este ejercicio, ha sido importante el encuentro con Les Mots Du Développement (Cartier-Bresson, Destremau \& Lautier, 2009) un ensayo que describe la importancia de las palabras en la circulación de ideas y como éstas evolucionan: pasan desde un nacimiento pleno de sentido desde los actores sociales, a la academia, que sugiere traducciones, determina significados -los pone a pie de página-, para finalmente terminar disueltas en el mundo político, naturalizándolas, haciéndolas plásticas y de moda; haciendo también que pierdan sentido y sean usadas para disfrazar otros intereses. El sentido común, el poder, el rigor técnico y la poesía utilizan las mismas palabras: la palabra nunca es neutra.

A través de la palabra y la noción de paisaje, se busca también configurar la relación entre paisaje e Identidad. Este asunto es crucial, por cuanto uno de hallazgos de este trabajo es que la identidad paisajística o el sentido de identidad que las personas establecen con un paisaje, es uno de los factores críticos para su conservación y protección. Por el contrario, un paisaje exento de identidad, no arraigado a ningún grupo, sin mitos o leyendas que cuenten de él, puede desaparecer sin dejar huella.

La sombra de las cosas. Sobre paisaje y geografía de Jean Marc Besse (2010), es un texto que guía la reflexión sobre la noción de paisaje en este capítulo, también las conferencias dadas por Besse en Santiago el año 2018 ${ }^{7}$. A través de este autor, el paisaje aparece como objeto de estudio privilegiado por la geografía, una disciplina rica y muy próxima a la arquitectura, pese a que, en la experiencia de la formación en la Universidad de Chile, donde ambas disciplinas comparten la misma Facultad, prácticamente no tienen contacto. Este trabajo de investigación ha sido también una oportunidad de acercamiento a los y las geógrafos(as), que ha dado como resultado una investigación conjunta expuesta a finales del año 2018 en el Congreso Internacional Intersecciones bajo el título Resiliencia urbana y sustentabilidad ante el cambio climático en Latinoamérica: teoría y práctica, en coautoría con el geógrafo y Premio Nacional de Geografía, Profesor Hugo Romero.

El mundo en un abrir y cerrar de ojos. Representaciones francesas del mundo en el siglo 19, dictada el 20 de junio en el Instituto Chileno Francés de Cultura y Pensar y actuar con el paisaje, dictada el 21 de junio en la Universidad Católica de Chile. La visita de Jean Marc Besse se realizó en el contexto de los 500 años del "des-cubrimiento" del Estrecho de Magallanes.
La Transformación del paisaje es el tema abordado en el Capítulo 4, bajo el supuesto de que la lógica con la que opera el arquitecto es conocer y comprender para transformar. Se hace un recorrido histórico deudor de la historia del paisaje que Elizabeth Barlow (2001) hace en su libro Landscape design: a cultural and Architectural History, desde el mito y el ritual a las ideas filosóficas. Estas ideas, ya sean concepciones filosóficas o creencias religiosas, sólo se configuran en el espacio a partir de condiciones políticas, económicas y tecnológicas particulares, así como en algunos momentos por circunstancias que permiten que la acción individual trascienda su época y su territorio. 
Teniendo como base la historia, se busca establecer modelos de actuación apropiados a una arquitectura a través del paisaje. A la ineludible influencia de la obra de lan McHang, Design with Nature $(1969)^{8}$, que inaugura una metodología de planificación que supera los planes basados en la proyección de la forma urbana a otros centrados en la comprensión ecológica del territorio, se suman los profesionales y teóricos del paisaje, muchos de ellos formados por el propio McHarg en el programa de Landscape Architecture de la Universidad de Pensilvania. Heredero de su método de mapeado y superposición de capas que se ha convertido en una herramienta clave para revelar las potencialidades y limitaciones de los sitios para acoger determinados usos, Richard Forman, amplía el método con su modelo de "mosaicos territoriales" (1995) que pone acento sobre las dinámicas de interacción entre los distintos patrones y escalas presentes en el territorio.

El arquitecto y urbanista Charles Waldheim, puede ser señalado como uno de los pioneros ${ }^{9}$ en la reutilización del concepto del paisaje, como una nueva forma de pensar el ordenamiento urbano y la planificación de las ciudades, en la dura tarea de producir un reino público "significativo" o "habitable" frente a los "desastres ambientales de la industrialización" (Waldheim, 2016, p. 38). Citando al controvertido arquitecto Rem Koolhaas, ${ }^{10}$ Waldheim expresa que "La arquitectura ya no es el elemento primario del orden urbano; cada vez más el orden urbano está dado por un delgado plano horizontal vegetal, cada vez más el paisaje es el elemento primario del orden urbano" (2016, p. 42). Para estos autores, la planificación urbana abdicó por completo, ni la arquitectura ni el urbanismo tienen las herramientas conceptuales ni operativas para organizar la ciudad. La construcción de edificios-objeto y la elaboración de políticas y procedimientos burocráticos son incapaces de hacer frente al dinamismo emergente, abierto e impredecible de las ciudades contemporáneas.

En el libro Landscape Urbanism Reader (2006), Waldheim propone:

...un re-ordenamiento disciplinario, en el que el paisaje reemplaza a la arquitectura como el elemento básico. Para muchos, a través de una variedad de disciplinas, el paisaje se ha convertido en el lente a través del cual se representa la ciudad contemporánea y el medio a través del cual se construye. (Waldheim, 2006, p. 11).

En efecto, los proyectos urbanos contemporáneos demandarían una nueva forma de pensar, una nueva racionalidad y un tipo de "imaginación sintética", como la define James Corner (2004, p. 34). Una imaginación en la que, "la arquitectura, el paisaje, la planificación, la ecología y la ingeniería, las ciencias sociales y los procesos políticos sean comprendidos y coordinados como un campo interrelacionado" (Corner 2004, p. 34), poniendo a disposición de los espacios abiertos y los espacios públicos los conocimientos y aplicaciones de una nueva práctica del paisajismo de carácter estratégico. A veinte años de la publicación del libro Recovering Landscape (1999) podemos reconocer la influencia de James Corner, su editor, y de los 14 autores ${ }^{11}$ que lo acompañan en muchas de las reflexiones actuales, que han sido claves en el desarrollo de esta tesis.

Si bien son dominantes las aproximaciones metodológicas que podríamos denominar de base científica-anglosajona, a ellas que se confrontan las aportaciones de los teóricos del paisaje de la tradición europea, especialmente la francesa, heredera de una visión más estética del paisaje. Al inicio de esta tesis, fue muy importante encontrar y leer al filósofo-paisajista Sébastien Marot. Buscaba nuevos modos de entender qué significaba trabajar en la periferia, en un lugar aparentemente sin orden ni reglas claras. En ese momento fue iluminador entender con Marot que los suburbios son un tercer territorio entre la ciudad y el campo, el lugar ideal para la práctica paisajística -el lugar de la memoria ${ }^{11}-$, donde el sujeto observa la transformación del mundo, que no es otro que el lugar donde
Traducido y publicado al español recién en el año 2000 como Proyectar con la Naturaleza.

9 Podemos señalar como hito la primera exposición Landscape Urbanism organizada por Charles Waldheim en Chicago en 1997. El evento contó con las presentaciones del mítico lan McHarg, James Corner, Mohsen Mostafavi, Linda Pollak, Brigitte Shim, Adriaan Geuze, Joan Roig, Grant jones y Kathy Poole, entre otros, y de la exposición homónima que viajó desde la Fundación Graham a la Storefront for Art and Architecture de Nue-va York antes de embarcarse en una gira por los Estados Unidos durante 1997 y 1998.

10 Traducción propia del inglés: "Architecture is no longer the primary element of urban order; increasingly ur-ban order is given by a thin horizontal vegetal plane, increasingly landscape is the primary element of urban order."

${ }^{11}$ Alan Balfour, Anita Berrizbeitia, James Corner, Denis Cosgrove, Georges Descombes, Stanilaus Fung, Chris-tophe Girot, Steen Høyer, David Leatherbarrow, Bart Lootsma, Sebastien Marot, Anuradha Mathur, Marc Treib, Charles Waldheim y Alex Wall.

${ }^{12}$ Marot en un texto posterior, Suburbanismo y el arte de la memoria (2006) define así la relación con la memoria:

En la arquitectura en la arquitectura entendida como instrumento de memoria, o en la memoria entendida como materia, como dimensión de la arquitectura, el tema de la memoria es un topos, un lugar común especialmente vívido del debate sobre la construcción y la ordenación. Si en la actualidad es necesario entrar en dicho debate es porque la condición suburbana invita a otorgar más relevancia y una mayor profundidad a esta cuestión. (Marot, 2006, p. 11) 
nuestro proyecto real se despliega. Así, este autor, hablando desde la cultura paisajista francesa explica que "Al cavar por debajo de la superficie, coser, injertar y recuperar fenómenos ocultos y latentes de los lugares, los arquitectos paisajistas en Francia están empezando a desarrollar modos cada vez más delicados de interpretar y construir sitios y situaciones locales" (Marot, 1999, p. 56).

En The Reclaiming of Sites (1999), Marot utiliza el término suburbanismo para nombrar una subversión en el urbanismo, que consiste en invertir la jerarquía entre el programa y el sitio, en favor de este último. Esto es una subversión considerando que vivimos en un momento en cual, por el contrario, el superurbanismo prevalece. Vale decir, cuando pensamos el lugar, sometido a una operación de producción del programa y cuyo principal teórico es Rem Koolhaas, que en Delirious New York, A Retroactive Manifesto for Manhattan (1978) ${ }^{13}$, ha planteado que la acción, el programa, modela el sitio.

La hipótesis teórica y crítica de que el lugar puede convertirse en el regulador de la idea del proyecto, será retomada a lo largo de la investigación y en el proyecto mismo.

El paisaje se concibe así, como un espacio para la relación y la negociación ecológica, cultural y social-, un espacio también para la participación, entendida como acción de aprendizaje y puesta en común a lo largo de todo el proceso.

Estas ideas han sido volcadas y puestas a prueba en un curso electivo de pregrado en la Universidad de Chile La Transformación del Paisaje dictado por la autora en el semestre de primavera de 2018. Gran parte del texto del Capítulo 4 ha sido discutido en clases y reelaborado a partir de esa instancia.

A partir de esta confrontación de modelos, el Capítulo 5 propone el estudio un análisis crítico de parques y sus resultados. Preliminarmente se seleccionaron, visitaron y analizaron una veintena de parques, para finalmente incluir aquellos que de algún modo responden algunas de las preguntas que se han formulado en la investigación. Se analizan con más detalle: El Central Park, como referente ineludible; el Parc La Courneuve (Francia); y el Shelby Park (Estados Unidos); en Santiago se incluyen la Quinta Normal, el Parque O'Higgins y el Parque Metropolitano. La pregunta que cruza el tema de los grandes parques, es qué les da identidad y los hace persistentes en el tiempo, vale decir, qué los hace "legibles y resilientes" como se lo plantea Julia Czerniak en el ensayo Legibility and Resilience, uno de los 8 artículos contenidos en el libro Large Parks (Czerniak \& Hargreaves, 2007). Este texto que tiene a Julia Czerniak y George Hargreaves como editores, reúne destacados(as) teóricos(as) y paisajistas ${ }^{14}$ que abordan como tema los grandes parques urbanos, entendidos como espacios culturales complejos en los que se tocan cuestiones clave del discurso sobre el paisaje, los desafíos ecológicos, la historia social, las relaciones urbanas y la creación de espacios e infraestructura. Se incluyen desde parques históricos hasta proyectos contemporáneos con la sola condición de ser grandes, vale decir, de al menos 500 acres (202 ha).

Al problematizarse, los grandes parques pueden ser vistos como verdaderos laboratorios donde experimentar sobre la complejidad y las consideraciones que

${ }^{13}$ Esta es una obra teórica y poética que puede considerarse como el manifiesto del superurbanismo con-temporáneo.

${ }^{14}$ El prólogo es de James Corner y los siete capítulos del libro son escritos por: Julia Czerniak (Introducción y capítulo siete), Nina-Marie Lister, Elizabeth K. Meyer, Linda Pollak, George Hargreaves, Anita Berrizbeitia y John Beardsley se deben tener en cuenta cuando se proyecta lo vasto, tanto en extensión física, como también el sentido de una obra de envergadura cultural. Aquello que es difícilmente abarcable con la imaginación y que requiere ser pensado a distintas escalas, tanto en la definición de problemas como en las soluciones de diseño. 


\subsubsection{Laguna Carén: proyecto, caso de estudio o referente}

Podríamos decir que el marco teórico de esta tesis, está constituida por los primeros cinco capítulos. La segunda parte debe entenderse como una suerte de disección del objeto de estudio que es el vasto predio de Laguna Carén.

El proyecto Laguna Carén es un proyecto territorial desarrollado por la Universidad de Chile, la universidad pública más antigua de la nación, históricamente comprometida con la construcción de la visión republicana del país. Este hecho debiera permitir que, ante el desafío de una gran intervención territorial, su postura fuera emancipada, crítica, ejemplar y no se sometiera irreflexivamente a los principios del mercado, pero ¿cuál es el proyecto adecuado ecológicamente y que pueda ser legitimado socialmente? ¿es una utopía plantear un proyecto con conciencia del límite?

El plan maestro propone, a partir de la caracterización del paisaje, minimizar y compactar los desarrollos en los asentamientos existentes y reconocer al territorio vacío su carácter estructurante. Más allá del hecho ecológico, se trata de articular lo urbano y lo rural, evitando la intervención indiscriminada de este paisaje, singular por su belleza. Es una oportunidad de poner en práctica lo que plantea Roberto Lira (2004) respecto al patrimonio urbano, cuando aconseja que las ciudades debieran definir, con cierta urgencia, cuál es su patrimonio, qué es aquello que quiere que permanezca y consecuentemente educar para valorarlo y cuidarlo $(2004$, p. 1).

Sería una señal elocuente de la Universidad de Chile al país, integrar el paisaje como patrimonio y un derecho.

Los referentes conceptuales antes enunciados, se hacen activos y se complementan con múltiples fuentes, entre ellos: otros estudios, visitas a terrenos, levantamientos, cartografía, fotografía, normativa, etc.

La estrategia para el análisis tiene como referente el ensayo Four Trace Concepts in Lanscape Architecture de Cristophe Girot (1999). En este artículo, contenido en el libro Recovering Landscape (Corner, 1999), Girot propone cuatro conceptos operativos para comprender y actuar en un territorio a partir del paisaje. Cada uno tiene lugar en un momento diferente, y cada uno busca penetrar más profundamente en la comprensión del lugar.

Sabemos que "... un diseñador rara vez pertenece al lugar en el que se le pide que intervenga" (Girot,1999, p. 60), por lo que cualquier estrategia debe ayudarnos a establecer el sentido de lugar, pese a ser normalmente ajenos a él. Por este motivo llama a la primera etapa "aterrizaje" (landing). En ella, es fundamental la percepción inicial del sitio, desprejuiciada y sensible a toda presencia. El aterrizaje es sobre todo una renuncia a la tabula-rasa, un acercamiento intuitivo y experiencial para que los elementos del paisaje puedan manifestar su sentido. Este primer acto en el sitio, es también el primer acto de proyecto y de investigación a través del proyecto, donde nada es neutral. Quien diseña, debe asumir lo subjetividad y afectivo involucrado en el proceso. Girot insta a los diseñadores a aprehender el sitio con "asombro y curiosidad, bajo una mirada subjetiva e interpretativa” (1999, p. 61).

El segundo concepto operativo es la "puesta a tierra" (grounding) que se logra a través de las innumerables "otras" visitas al sitio, como a través de la documentación, el estudio y del análisis.

La puesta a tierra tiene que ver con la orientación y el arraigo, tanto en el sentido literal como figurativo de la palabra [...] es un proceso que implica capas sucesivas, tanto visibles como invisibles. A veces, el aspecto más importante de un sitio determinado es casi intangible. No es necesariamente lo que permanece visible a simple vista lo que más importa, sino las fuerzas y los acontecimientos que sustentan la evolución de un lugar. (1999, pp. 62-63) 
El proceso de aprehender la realidad a través del paisaje nos enfrenta al lugar innumerables veces, con la conciencia de que trabajamos sobre una estructura compleja y estratificada, que se renueva continuamente. Podemos ver ella las fuerzas del tiempo presente, como también los procesos del pasado y los rasgos que anticipan el futuro. Se incluyen en este proceso de "puesta a tierra" el análisis la dimensiones socio-culturales, ecológicas, perceptuales y normativas del sitio.

"Encontrar" (finding), es la etapa siguiente y consiste en descubrir aquellos aspectos del sitio que lo hacen único. Estos pueden ser físicos, como una laguna, un cerro, un árbol o bien intangibles como una leyenda, "son algo único (aunque escondido) que pertenece definitivamente a un lugar y contribuye de forma duradera a su identidad" $(1999$, p. 63). Estos hallazgos pueden asociarse y construir un relato que permite generar ideas, lugares y nuevos temas de investigación. Dentro del proceso, las intuiciones iniciales se transforman en ideas.

Finalmente "fundar" (founding) es el acto de lo perdura, y se basa en tomar lo que se aprendió en los pasos anteriores y formular una reacción basada en esa información. Se trata de crear un proyecto específico para el lugar, basado en la información que se recogió directamente del sitio. Fundar necesariamente implica la transformación del paisaje, haciendo aparecer aquello que estaba latente.

Fundar puede entenderse también como aportar algo nuevo a un lugar, algo que puede transformar y reorientar un sitio en particular. Los ejemplos van desde la colocación de un nuevo objeto, pasando por el encuadre de un nuevo punto de vista, hasta simplemente cambiar el uso de un lugar en particular. Cada acto de fundación corresponde, en la jerga arqueológica, a una época -un período de la historia en el que una relación cultural con el paisaje evoluciona y cambia- (Girot,1999, p. 64).

Cabe destacar que parte del contenido del capítulo final "Fundar, El proyecto Laguna Carén" y de las Conclusiones se han publicado en dos artículos en revistas indexadas: Ciudad y Territorio N0201 de otoño 2019 y Planur-e nº13 del verano 2019 (adjuntos en anexo 1).

Centrada en un lugar específico -Carén- desde una hipótesis de decodificación del paisaje, la tesis se ancla en el tiempo presente en una escala temporal amplia, integrada en un proceso complejo e intrincado de adiciones y sustracciones, construyendo una memoria espacial; expresión de contingencias ecológicas, ideológicas, culturales y económicas que se han desarrollado en el tiempo. Es por eso que en el capítulo 10 se han documentado y analizando los proyectos y planes maestros anteriores realizados para ese sitio. De este modo también se reconoce "el trabajo de otros" que han pensado y soñado con el futuro de este lugar.

Estos conceptos operativos (aterrizaje, puesta a tierra, encontrar y fundar) que articulan los capítulos relacionados directamente con el sitio del proyecto, permiten dar sentido a la data y los análisis que se pueden extraer de ella. Representan una metodología complementaria al usual análisis multicapa, que, integrando los recursos científicos y tecnológicos, permiten entender el lugar como parte de un mosaico territorial, evidenciando las dinámicas de interacción entre los distintos patrones y escalas presentes en el territorio. Sin embargo, tomando distancia de la tradición anglosajona, más científica y ecológica del diseño del paisaje, proponemos una alternativa que se nutre de otras tradiciones culturales, incluyendo la local.

Esta perspectiva ve el proyecto y la investigación en curso como parte de un mismo proceso, donde la intencionalidad del sujeto que diseña (y que investiga 
reflexivamente) debe quedar explicitada, así como la evolución de su postura en el proceso. Esta posición diverge de aquella que ve el paisaje sólo como un componente de la ecología, donde el proyecto, al menos aparentemente, es el resultado analítico de la superposición de capas, donde los datos hacer "emerger" el proyecto como la solución más racional, científicamente fundada.

Podemos reconocer en la postura propuesta un enfoque adaptativo, que, siendo heredero del pensamiento ecológico, nos otorga la posibilidad de una intervención más experimental. Para Andrés García Azuero, el enfoque adaptativo nos permite la observación y reflexión sobre las consecuencias de las acciones, un continuo aprendizaje en el tiempo que permite la "retroalimentación, reajuste de acciones y métodos a la luz del conocimiento adquirido por la acción reflexionada" (2005, p. 38). Esta lógica parece apropiada a situaciones complejas con información incompleta y muchas interacciones de factores y actores, como es el caso de Laguna Carén. Donde, como en todo proyecto vasto, el horizonte de realización se extiende más allá de lo que posiblemente verán los proyectistas.

Incluso, si sólo nos atenemos a las condiciones ecológicas, como plantea Robert G. Bailey, lo que sucede en los procesos a gran escala "es vital para cada ecosistema a pequeña escala y, teniendo en cuenta la amplia escala de tiempo a la que cambian la mayoría de los paisajes a gran escala, son necesarias acciones de monitoreo a largo plazo" (2002, p. 87).

En este trabajo, proyecto e investigación se trenzan continuamente, el proceso es a veces iterativo, autorreferente, avanza y retrocede. Si bien el producto de esta investigación -la tesis- necesariamente es lineal, el proceso real tanto de diseño como de investigación no lo es. Continuamente la indagación de aspectos del problema-proyecto redefine posiciones. Es así como en el capítulo 11, vuelven a aparecer los parques -el parque científico-tecnológico como modelo-. Al analizar el origen y evolución de esta tipología, se busca establecer una posición crítica a la idea de programa. Debemos recordar que el compromiso de la universidad con el estado -un a priori-, era convertir el predio donado en un parque científico-tecnológico, una ciudad universitaria y un parque público, la posibilidad de revisar este mandato exigió entonces, conocer más profundamente el fenómeno de los parques tecnológicos para poder definir si su imposición era pertinente y apropiada.

También en el proceso, se construyen continuamente relaciones: relaciones sociales, relaciones ecológicas, relaciones económicas, relaciones políticas, relaciones urbanas, relaciones de escala, que impactan el modo de pensar el proyecto y que obligan a una acción reflexiva.

En resumen, se trata de un pensamiento temporal y transitorio que incorpora una ética abierta, que permite obrar con prudencia ante condiciones y relaciones cambiantes.

El plan maestro, se convierte así en un experimento real que tiene al sitio como laboratorio; un lugar de experimentación proyectual y al mismo tiempo objeto de una reflexión crítica, que como veremos más adelante, es sobre todo un ejercicio continuo de autorreflexión en busca de emancipación, característica que debiera ser propia de, como diría Donald Schön (1983), un profesional reflexivo.

El despliegue de este proceso en el texto, que incluye ramificaciones y dudas, que deja algunos cabos sueltos, refleja un largo recorrido de trabajo. Se espera a través de esta tesis, aportar tanto a la reflexión arquitectónica como a la urbana desde la perspectiva del diseño del paisaje, aprovechando esa posición privilegiada de la que nos habla Sharon K. Collinge: 
Las tasas proyectadas de crecimiento continuo de la población humana exigirán cada vez más recursos naturales y continuarán alterando la estructura espacial de los hábitats nativos. Los arquitectos y planificadores paisajistas están en una posición única para incorporar este conocimiento de las consecuencias ecológicas de la estructura espacial del paisaje en soluciones creativas de diseño y planificación del paisaje. (Collinge 1996, p. 61).

\subsection{PREGUNTAS, HIPOTESIS Y OBJETIVOS DE LA INVESTIGACIÓN}

\subsubsection{Preguntas iniciales}

A continuación, se transcriben las principales preguntas que surgieron desde el problema particular, vale decir el diseño del Plan Maestro para Laguna Carén. Estas preguntas han servido para cercar el campo de estudio, inductivamente. El registro muestra cierta ingenuidad en el primer acercamiento a la investigación, al ampliar más que enfocar el tema. Sin embargo, las hemos mantenido como registro del proceso, ya que todas ellas expresan la complejidad del problema, ya que no se pueden responder con una afirmación o una negación, sino que requieren del análisis de ideas y fuentes, así como de la síntesis para lograr una respuesta. Son preguntas que abren la reflexión y obligan a no aceptar hechos como dados. Son preguntas que han actuado como pulso de la investigación centrándola continuamente, evitando que se abra a una especulación teórica:

¿A quiénes tenemos que convocar para procurar un proyecto de gran escala?

¿Cuál es el proyecto que los habitantes del territorio apoyarian? ¿Cómo se legitima?

¿Qué herramientas tenemos los arquitectos para fundamentar la protección del paisaje ante las presiones políticas y económicas?

¿Cómo se trabaja en el borde?

¿La parcelación es la única manera de proyectar un desarrollo y una operación en el tiempo de un sitio extenso?

¿A qué escala tenemos que ver el problema, qué escala tiene el Plan Maestro? ¿Cómo puede un parque (y los parques) ayudar a las ciudades a ser ecológicamente equilibradas, sostenibles, seguras e inclusivas?

¿Qué da identidad a un parque y lo hace memorable y persistentes en el tiempo?

¿Cómo pensar en la restauración ambiental del espacio suburbano desde un enfoque que integre las demandas sociales, la problemática ecológica y la viabilidad económica?

\section{¿Cómo sabemos que es lo correcto?}

Sin embargo, al enfrentar la elaboración de una hipótesis nos hemos impuesto reducir estas preguntas a cuatro que serían las siguientes:

¿A qué escala tenemos que ver el problema, qué escala tiene el Plan Maestro?

¿Cómo puede un parque (y los parques) ayudar a las ciudades a ser ecológicamente equilibradas, sostenibles, seguras e inclusivas?

¿Qué da identidad a un parque y lo hace memorable y persistentes en el tiempo?

¿Cómo pensar en la restauración ambiental del espacio suburbano desde un enfoque que integre las demandas sociales, la problemática ecológica y la viabilidad económica? 


\subsubsection{Hipótesis}

Después de presentar los antecedentes que dan forma a la problemática a abordar por esta tesis, así como las preguntas que van a guiar la investigación, proponemos la siguiente hipótesis de trabajo:

La arquitectura del paisaje representa una racionalidad multiescalar, que permite el desarrollo de métodos de análisis y estrategias operativas para la transformación del territorio desde un pensamiento ecológico, que integra los elementos naturales (bióticos y abióticos), sociales, culturales, estéticos y económicos. En esta racionalidad, el proyecto se convierte en un dispositivo dinámico en el tiempo, abierto y flexible, que incorpora la incertidumbre y la participación de múltiples actores.

\subsubsection{Objetivos}

Nuestro objetivo general es contrastar la hipótesis central de la investigación con la experiencia proyectual del plan maestro de Laguna Carén. Es un ejercicio teórico con fundamentos prácticos que consiste en la evaluación de los procesos de transformación del paisaje urbano a través del estudio de la recuperación del territorio de la periferia, en tanto parte de un sistema ecológico de ámbito mayor. Este abordaje, tendría el potencial de convertir el sitio un laboratorio de experiencias aplicables luego en la ciudad como macrosistema. A partir de este objetivo general se definen ocho objetivos específicos que pretenden aportar a la disciplina, la profesión y la enseñanza de la arquitectura:

OBJETIVO 1: Comprender teóricamente el contexto ideológico e histórico del advenimiento del paisaje como objeto, método de estudio y estrategia operativa para el proyecto arquitectónico y urbano.

OBJETIVO 2: Fundamentar la validez científica de la investigación a través del proyecto.

OBJETIVO 3: Definir y fundamentar un método de análisis, representación y de intervención para la interface urbano-rural basada en la arquitectura del paisaje y en una racionalidad multiescalar.

OBJETIVO 4: Identificar y definir la problemática contemporánea de los Grandes Parques.

OBJETIVO 5: Analizar críticamente el origen y evolución de los parques científico-tecnológicos para cuestionar la jerarquía del programa sobre un territorio vasto.

OBJETIV0 6: Aplicar de métodos de análisis y de intervención en el predio Laguna Carén, dejando un registro documental de aspectos históricos, técnicos $\mathrm{y}$ teóricos estudiados en el proceso.

OBJETIVO 7: Fundamentar la protección del paisaje, como patrimonio cultural, ecológico, social y económico; y como un derecho.

OBJETIVO 8: Identificar desde el proyecto particular, la aplicación del modelo estudiado a distintas escalas y a las prácticas de arquitectos y urbanistas.

\subsubsection{Estructura del documento}

La investigación se presenta en un documento dividido en los siguientes doce capítulos, Los primeros cinco capítulos construyen un marco teórico donde se 
define la posición desde donde se problematizan la relación entre proyecto e investigación, la noción de paisaje, los mecanismos de transformación del paisaje y la idea de lo vasto en los grandes parques públicos. La segunda parte aborda el análisis de los aspectos bióticos, ambientales, socio-culturales, económicos, arquitectónicos, normativos e infraestructurales del predio de Laguna Carén para luego, en el capítulo 12 desarrollar la propuesta del plan maestro.

\section{CAPITULO 1: INTRODUCCIÓN}

Incluye un resumen, los antecedentes, el contexto de realización de la Tesis y las principales influencias teóricas; Se presenta el proyecto Laguna Carén como caso de estudio y referente desde donde se formulan las primeras preguntas de investigación, la hipótesis y los objetivos de la investigación.

\section{CAPITULO 2: APROXIMACIÓN METODOLÓGICA}

Incluye una introducción al concepto de proyecto analizando la relación entre investigación y proyecto. Se discute la situación de la investigación en arquitectura, en especial en el contexto de los programas de doctorado. Se analiza la evolución de los métodos de diseño en un contexto de problemas complejos, y los modos de inferencia que serían aplicables al pensamiento proyectual. Se expone la experiencia disciplinar, multidisciplinar y transdisciplinar al interior del proceso de diseño.

\section{CAPITULO 3: PAISAJE E IDENTIDAD}

Análisis diacrónico y sincrónico del concepto paisaje desde la etimología a la poética. Se busca entender como la noción de paisaje está ligada a los modelos de pensamiento de cada época y de cada lugar en particular. Desde un recorrido histórico se esboza la posibilidad de una identidad chilena asociada al paisaje mediada por la poesía. Se incluye un último apartado con un análisis de la normativa chilena como contrapunto.

\section{CAPITULO 4: LA TRANSFORMACIÓN DEL PAISAJE}

Se ensaya una breve historia de la transformación del paisaje en occidente, que se entrelaza con los principales hitos de transformación del paisaje en Chile. Se analiza la influencia del land-art en la acción paisajista contemporánea. Finalmente, proponemos una reflexión acerca de los métodos de actuación, confrontando las escuelas anglosajonas y francesas para ilustrar las tendencias actuales, tensionadas entre intervenciones que consideran el paisaje como bien ecológico y otras que lo ven como un bien cultural.

\section{CAPITULO 5: PARQUES, GRANDES PARQUES}

Se describen y analizan críticamente referentes internacionales y chilenos, desde el punto de vista metodológico y de resultados. Se identifican ventajas y amenazas para proyectos que trabajan en lo vasto. El análisis se centra en los parques públicos de más de 202 hectáreas (500 acres), excluyendo los parques históricos.

\section{CAPITULO 6: EL TERRITORIO LAGUNA CAREN: DIMENSION SOCIO-CULTU-} RAL

En este capítulo se introduce y describe el predio de Laguna Carén desde la experiencia personal de la primera visita. Este acto inaugural del proyecto, luego se nutre con la historia del sitio. Recorremos Carén para encontrar los primeros vestigios de cultura precolombina, leeremos los relatos de los cronistas viajeros, recopilaremos los mitos y costumbres locales y estudiaremos su historia. El sitio 
se convierte así en un palimpsesto donde se encuentra grabado el pasado y presente del sitio.

CAPITULO 7: EL TERRITORIO LAGUNA CARÉN COMO SISTEMA ECOLOGI$\mathrm{CO}$

El estudio de Carén desde el punto de vista ecológico tiene como objetivo descubrir los procesos que han dado forma a este vasto territorio, para a partir de ellos orientar las estrategias de un plan maestro. Se estudiarán la geología, la geomorfología, la aptitud de los suelos, la hidrología, la vegetación, la fauna, la atmósfera, las áreas protegidas o sitios prioritarios, los riesgos y la legislación de relevancia ambiental.

\section{CAPITULO 8: EL PAISAJE DE LAGUNA CARÉN: DIMENSIÓN PERCEPTUAL}

El objetivo de este capítulo es caracterizar el terreno en estudio desde el punto de vista perceptual, esencialmente visual. La clasificación resume y sintetiza, muchas visitas, análisis de imágenes aéreas, planos, fotos, como también la experiencia de recorrer el terreno en diversas estaciones y horas del día. Se establecen las unidades de paisaje desde la experiencia visual.

\section{CAPITULO 9: MARCO NORMATIVO}

A través del análisis e interpretación normativa aplicable al predio en estudio, se plantean distintos escenarios de futuro. Este ejercicio aborda la dimensión ética del paisaje, al intentar responder qué es lo que se puede hacer en el sitio y qué es lo que se debe. Nos permite reconocer las fuerzas que actúan en el lugar y leer a través de normas y planes, lo que el lugar quiere ser.

\section{CAPITULO 10: EL TERRITORIO LAGUNA CARÉN: SUEÑOS Y REALIDAD}

A través del análisis crítico de los planes maestros que se ha realizado en el predio en los últimos 25 años, se busca reconocer bajo qué criterios, otros arquitectos y planificadores han problematizado el encargo de proyecto y cuál ha sido su marco de posibilidades. Se incluye un panorama de la situación actual del predio.

\section{CAPITULO 11: EL PROGRAMA: ¿UN PARQUE CIENTÍFICO-TECNOLOGICO?}

Se estudia el origen y evolución de los parques científicos-tecnológicos para responder acerca de la pertinencia de este programa para Carén. La reflexión se contextualiza en Chile para discutir el rol que le cabe a la Universidad de Chile como mandante. Se discute el modelo triple hélice universidad-empresa-estado y se propone un modelo penta-hélice que incorpora a la ciudadanía como una cuarta aspa y al territorio como una quinta.

\section{CAPITULO 12: FUNDAR: UN PLAN MAESTRO PARA LAGUNA CARÉN}

Este capítulo describe el proceso de proyecto iniciado el año 2014: se analiza críticamente el primer plan de 2015 y la reformulación de 2016. Se definen los criterios de actuación y las estrategias a macro, mezo y microescala que consideran los cambios de uso de suelo a nivel comunal, otros proyectos de interés ambiental y social, la proximidad de otras áreas naturales y las condiciones propias del sitio. 


\section{CONCLUSIONES}

Se fundamenta la validez de la hipótesis en una revisión del proceso de investigación y del resultado de aplicación, proponiendo varios escenarios futuros.

Se analizan y describen aprendizajes aplicables a otros casos y a la práctica actual de arquitectos y urbanista, a distintas escalas, identificando posibles líneas de investigación.

Se sintetiza una suerte de defensa fundada del Parque para Carén.

Se retoma el tema de la investigación a través del proyecto y de la posibilidad de creación, comunicación y aplicación de conocimiento en arquitectura.

ASPECTOS GENERALES: cada capítulo incluye un resumen, que permite introducir los temas a tratar, pero también que el documento pueda ser leído por capas. Una de ellas, la más superficial, sería la de la suma de resúmenes. 


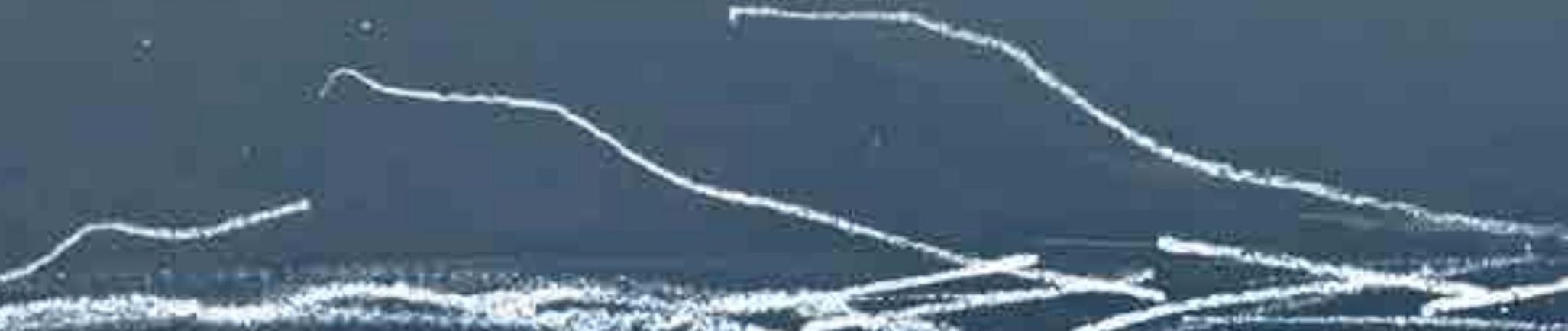

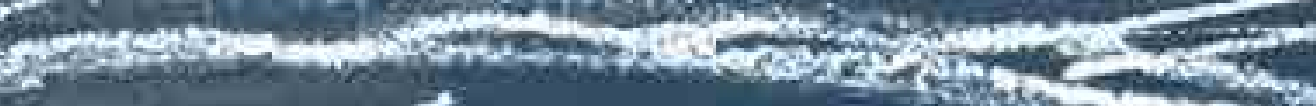

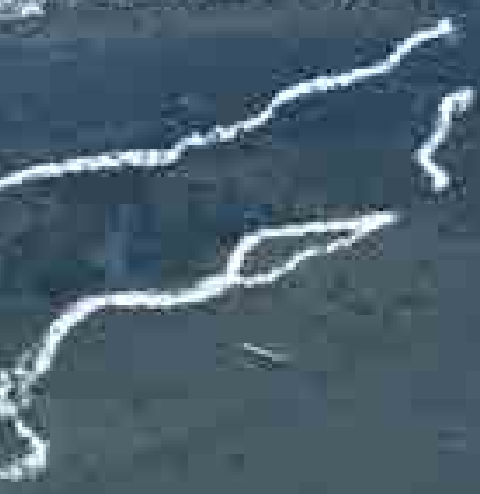




\section{APROXIMACIÓN METODOLÓGICA: PRO- YECTO E INVESTIGACIÓN}

Además, en todo aquello que es resultado de nuestra naturaleza, adquirimos primero la capacidad y después producimos la operación (esto es evidente en el caso de los sentidos: no adquirimos los sentidos por ver muchas veces u oír muchas veces, sino a la inversa: los usamos porque los tenemos, no los tenemos por haberlos usado); en cambio, adquirimos las virtudes mediante el ejercicio previo, como en el caso de las demás artes: pues lo que hay que hacer después de haber aprendido, lo aprendemos haciéndolo; por ejemplo, nos hacemos constructores construyendo casas y citaristas tocando la cítara. Así también practicando la justicia nos hacemos justos, practicando la templanza, templados, y practicando la fortaleza, fuertes. (Aristóteles, 1994, p. 19)

\subsection{INTRODUCCIÓN}

Cuando nos enfrentamos a un proyecto de investigación, especialmente en las tesis de doctorado, una de las primeras tareas es definir y explicitar la posición teórica y las herramientas que guiarán este proceso de búsqueda. Sin embargo, en el empeño de objetivar, de presentar racionalmente un problema, las hipótesis de trabajo y los resultados, el sujeto investigador se neutraliza y desaparece, al menos formalmente. Incluso en el lenguaje, privilegiamos la tercera persona y usamos el plural, que da a nuestras afirmaciones la apariencia de imparcialidad. De este modo se desdibuja el proyecto personal o el lugar del investigador en el proceso de investigación.

En esta tesis, intentaremos hacer comparecer tres proyectos: el proyecto de tesis, el proyecto de arquitectura del paisaje y el proyecto personal.

Sin duda, todo proyecto (académico o profesional) tiene objetivos personales. Realizar una investigación doctoral normalmente está determinada por la necesidad de validación social, especialmente relevante hoy, ya que dentro de los estándares internacionales la posesión del grado de doctor representa una condición para ingresar a la vida académica. Podemos reconocer aquí, como la asimilación a los modelos hegemónicos de Norteamérica y Europa ${ }^{16}$, impulsan la continuidad de estudios de posgrado, tensionando las carreras profesionales para que adopten un modelo de investigación bajo estándares científicos.

En mi caso (primera persona, singular), este proceso hacia el doctorado ocurre después de 30 años de ejercicio profesional. Por ello, el objetivo y el desafío autoimpuesto, ha sido articular - desde la experiencia en el oficio y en la enseñanza de la arquitectura- una investigación con estatus científico, vale decir, con el rigor y la originalidad que la comunidad disciplinar exige, pero también con pertinencia, es decir, utilidad para el ejercicio profesional y su enseñanza.

Si consideramos como virtudes de una investigación: rigor, originalidad y pertinencia, cabría preguntarse cómo lograrlas. En la cita que encabeza nuestro capítulo, Aristóteles plantea que con la práctica; que sólo podremos adquirirlas, como las demás virtudes, con el ejercicio previo. En mi caso, vale decir en esta tesis, el ejercicio previo ha consistido en el oficio de la arquitectura, en el ejercicio de hacer proyectos. Es por esta razón que el proyecto de investigación se inicia con preguntas que surgen de un proyecto real, aquel que me ha ocupado en los últimos 4 años, para luego situar estas preguntas en el contexto de un tema más amplio de interés disciplinar, como es la arquitectura del paisaje y descubrir en esta deriva disciplinar, su potencial de renovar la relación entre arquitectura y ciudad, y de éstas con el territorio y sus habitantes ${ }^{17}$.

El concepto de paisaje, que es el tema del siguiente capítulo, no formó parte
La Ética a Nicómaco es una obra de Aristóteles escrita el año 349 A.C. Este texto,compuesto por diez libros, expone la relación del carácter y la inteligencia con la felicidad. Considerada, junto al mensaje bíblico judeo cristiano, una de las obras que están en la base de la ética occidental. ${ }^{16}$ A partir del Acuerdo de Bolonia (1999), es habitual la continuidad de estudios desde la licenciatura (Bachelor para Europa), el máster y el doctorado.

${ }_{17}$ Pensado así, el proyecto se transforma en una justificación, una coartada para abordar un tema más amplio de interés disciplinar, como es la arquitectura del paisaje. 
18 Los Recontres doctorales en Architecture se realizan cada dos años, con el apoyo del Bureau de la recherche architecturale, urbaine et paysagère y reunen a las 20 escuelas de arquitectura francesas.

${ }^{19}$ Desde el punto de vista práctico podemos citar dos programas de doctorado que tienen este enfoque: en el Reino Unido, el de Bartlett School of Architecture, de University College London, dirigida por Jonathan A. Hill que desde 2006 "fomenta el desarrollo de la investigación arquitectónica a través de la combinación de di-seño y escritura"(The Bartlett School of Architecture, s.f.), donde los estudiantes presentan una tesis que consiste en un proyecto y un texto (de 60.000 palabras) que comparten un tema de investigación y una relación productiva; y en Esta-dos Unidos, el programa DPP, Doctor of Professional Practice de Carnegie Mellon University, que, desde 2014 propone un programa de tres años para profesionales a mitad de carrera "que aspiran a resolver pro-blemas avanzados en los campos de la arquitectura, la ingeniería o la construcción"(CMU, 2019, s.p) , aprove-chando los conocimientos adquiridos en la práctica profesional.

20 Hago la distinción entre "afuera" como requerimiento de proyecto, frente a la alternativa de un problema de investigación que pudiera surgir desde "dentro" del ámbito disciplinar, sin mediar un proyecto concreto.

${ }^{21}$ Ranulph Glanville (1999) propone una posición aún más provocadora, ya que considera que la investigación no es más que un suconjunto del diseño:"(scientific) research is a subset of design"(1999, p.89). de mi educación como arquitecto. Puedo confesar que aprendí poco sobre la complejidad ecológica del entorno natural y construido, menos aún sobre la apreciación estética del paisaje. La idea de paisaje en la década de 1980 no tenía espacio en la discusión sobre la arquitectura y la ciudad. Contexto y área verde, eran los términos usuales, que denotaban una preocupación secundaria frente a la relevancia de otros temas, tales como el lenguaje de la arquitectura y la relación función-materialidad, característica de la formación de la Facultad de Arquitectura de la Universidad de Chile en esos años. El interés por el paisaje, surge más bien por exigencias externas, desde el trabajo profesional y especialmente desde la enseñanza, ya que una nueva sensibilidad ecológica aparece en las recientes generaciones de estudiantes.

Si consideramos que el conocimiento se puede obtener a través de la interacción activa con el mundo. La investigación consistiría en recoger críticamente ese conocimiento que se genera a través del proceso de diseño y a través del diseño mismo. De este modo, estaríamos contribuyendo a una reflexión sobre la arquitectura del paisaje, más arquitectónica, que va más allá de los inventarios y del conocimiento que proporcionan otras disciplinas que lo acompañan (como la historia del sitio y la historia urbana, la sociología o las múltiples especialidades científicas en están involucradas en un sitio) y ofrecer nuevas perspectivas para crear lugares.

Por lo tanto, proyecto personal, proyecto de paisaje y proyecto de tesis fluyen juntos nutriéndose uno al otro. Este trabajo desarrollará principalmente el proyecto de investigación. El proyecto de diseño será, como me ha planteado el profesor de Gracia "un patrón de evaluación, un crisol donde se funden (o no) las referencias teóricas que manejamos. También un termómetro de la transferencia de calor entre teoría y práctica". El tema de este capítulo será entonces, principalmente una reflexión acerca del proyecto, de la relación entre proyecto de investigación y proyecto de arquitectura y de los medios para lograr una relación virtuosa entre ellos. La segunda parte de la tesis abordará el proyecto de paisaje y será posiblemente el espacio de las conclusiones, del capítulo final, donde el proyecto personal se hace visible junto a los otros.

Desde el punto de vista teórico, han sido fundamentales para este trabajo, los aportes de la escuela francesa, que publica los resultados de encuentros doctorales en arquitectura desde $2012^{18}$, como también de autores como Alain Findeli y Jean-Pierre Chupin, desde la Universidad de Montreal; y Anne Coste en Grenoble ${ }^{19}$. Debo mencionar también, mi participación en el encuentro DARA_2019, que me permitió el contacto con Margitta Buchert de la Universidad de Hannover y Jürgen Weidinger de la Universidad de Berlín, ante quienes tuve la posibilidad de exponer parte del contenido de este capítulo, y recibir sus comentarios, los que sin duda han nutrido mi análisis.

\subsection{LA INVESTIGACIÓN EN ARQUITECTURA}

Consideremos un primer escenario, en el que los datos de base de la investigación provienen de arquitecto en su oficio. Las preguntas a las que el proyecto responde, en primera instancia, están formuladas desde afuera ${ }^{20}$. Llamaremos a este tipo de producción teórica, investigación para el proyecto, que como en todo proyecto profesional, busca fundamentar decisiones y hacer viable su realización.

Esta etapa reflexiva, sin duda necesaria, es defendida como investigación por muchos arquitectos (especialmente por los docentes de taller) que sostienen que todo proyecto de arquitectura es un proyecto de investigación ${ }^{21}$, cuestión rebatida en el contexto académico, donde lo que está en juego es la producción de nuevo conocimiento científico. La principal crítica que se hace a esta postura es que el proyecto de arquitectura se apoya, generalmente, en conocimientos ya existentes. Si se producen nuevos conocimientos, son específicos al proyecto en par- 
ticular. Incluso en muchas ocasiones no existe el interés de publicar, ya que los hallazgos de la investigación constituyen el know how del proyectista o bien son considerados información confidencial por los mandantes, especialmente cuando se trata de innovaciones tecnológicas. Lo que es nuevo, por el contrario, son los dispositivos que resultan del proyecto en cuestión. Éstos integran conocimientos, pero no constituyen por sí mismos fuentes de conocimiento, con el riesgo adicional de disolverse en la auto justificación.

En otro extremo Alain Findeli y Anne Coste (2007) relatan cómo en los programas de doctorado se ha llegado a recomendar a sus estudiantes que, para familiarizarse con el oficio de investigador, se olviden de ser arquitectos, de sus habilidades profesionales, del habitus intelectual que adquirieron en su formación profesional, en resumen, que abandonen la cultura del proyecto para entrar en otra, en la cultura científica, animándolos a construir sus problemáticas según la perspectiva de otras disciplinas más establecidas que la arquitectura. Ya no se trataría de realizar investigaciones en arquitectura, sino en el mejor de los casos, asumiendo el trabajo de "ponerse al día", se adoptan las metodologías de otras disciplinas, "resultando trabajos que corresponden más bien a historia, tecnología, semiótica o sociología de la arquitectura, lo que es diferente" (Findeli \& Coste, 2007, p. 143). El inconveniente mayor es que estos trabajos, normalmente, no contribuyen más que de manera indirecta al corpus de la disciplina, vale decir que, en la práctica, su pertinencia no está clara. Llamaremos a éstas, investigaciones sobre el proyecto (sobre la arquitectura). No hay duda de que esta investigación satisface los criterios científicos comúnmente utilizados en las disciplinas de base, y que su rigor no está en tela de juicio. La crítica que podemos hacer a este tipo de investigación, es que no siempre está anclada, ni situada en las preocupaciones de los profesionales y usuarios, vale decir en el campo del proyecto. Adicionalmente encontramos en este tipo de investigaciones algunos fenómenos que aumentan la distancia entre el oficio del proyecto y su teorización, entre ellos podemos mencionar: la crítica arquitectónica, que en su forma más extrema adopta un estilo literario y lenguaje hermético, que sólo entienden los especialistas; $y$ los intentos forzados de someter al diseño a métodos cuantitativos, una tendencia aún muy dominante en las ciencias sociales.

En esta clasificación -para y sobre el proyecto- podemos reconocer algunos criterios importantes que toda investigación en arquitectura debe satisfacer: que debe ser rigurosa y que deber ser relevante. Vale decir, que esté a la altura de los estándares científicos tradicionales y contribuir a la mejora de la práctica del proyecto. Sin embargo, metodológicamente y en la práctica, representan posiciones y escuelas muy distantes.

$\mathrm{Si}$, por ejemplo, buscamos aquel conocimiento que se obtiene a través de la reflexión sobre el proyecto, como forma de hacer algo, tendríamos un enfoque orientado al proceso de diseño o bien a evaluar sus consecuencias (resultados). Podríamos declarar que la investigación está menos interesada en los objetos o productos del proceso que, en el análisis y descripción de esos procesos, sin llegar a los artefactos mismos.

Para ilustrar este dilema, podemos ubicar los dos postulados descritos como situaciones extremas de la recta que contiene la investigación en arquitectura (Figura 2.1.). En un extremo encontraremos el camino profesional de la investigación para el proyecto (el trabajo intelectual preliminar y paralelo a todo proyecto singular) y en el otro extremo, la investigación sobre el proyecto, el de la ortodoxia científica (con las herramientas de otras disciplinas).

Lo que proponemos explorar es la virtud ${ }^{22}$ en la posición equidistante entre estos dos extremos. Siguiendo a autores como Alain Findeli \& Anne Coste (2007), Nigel Cross $(2001,2007)$ y Stéphane Vial $(2015)^{23}$, tomaremos el camino intermedio, el de la investigación en arquitectura a través del proyecto ${ }^{24}$.
${ }^{22}$ Siguiendo a Aristóteles, que nos invita a encontrar la virtud teniéndonos a distancia de dos de los vicios que él considera contrarios, uno que representa el exceso y el otro que destaca por su poca presencia.

${ }^{23}$ Los autores de referencia en este artículo son principalmente francófonos, sin embargo, podemos mencio-nar trabajos que desarrollan la relación proyecto-investigación en el mundo anglosajón, a través de la noción de design research: Richard Buchanan (2001), Murray Fraser (2013), IIpo Koskinen (2011), y en Alemania a Margitta Buchert (2014) y Jürgen Weidinger (2015), entre otros

24 Estas categorías fueron propuestas originalmente por Christopher Frayling en su artículo Research in art and design de 1993 como: Research into art and design; Research through art and design y Research for art and design. Por su parte, Coste, Findeli y Vial, las expresan como Recherche sur le design, Recherche par le de-sign y Recherche pour le design, respectivamente. En español, hablaremos de Investigación sobre el pro-yecto, Investigación a través del proyecto e Investigación para el proyecto. 
Figura 2.1. Esquema de los tipos de investigación en arquitectura. Elaboración propia

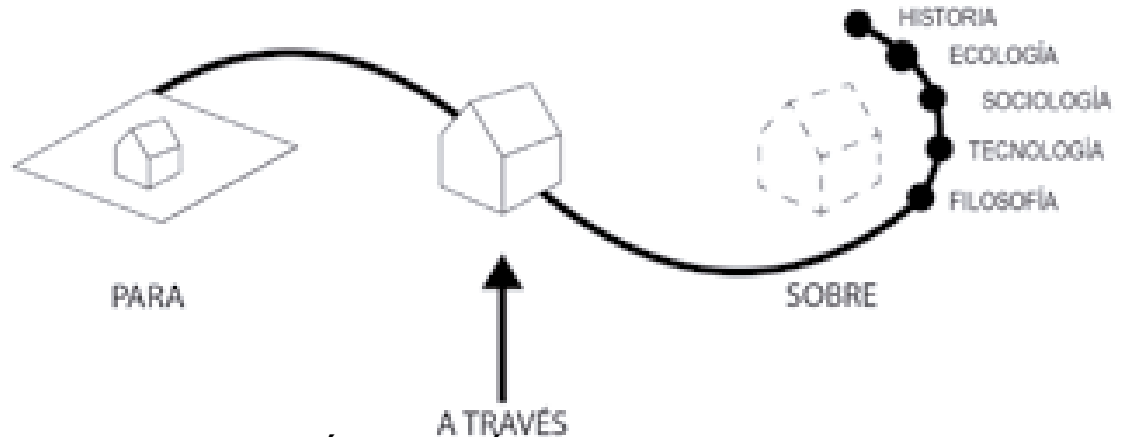

2.3. LA INVESTIGACIÓN A TRAVES DEL PROYECTO

El desafío de una investigación a través del proyecto consistiría en conjugar las virtudes que poseen los otros tipos de investigación (para el proyecto y sobre el proyecto), sin ser excluyente. Esto equivale a definir la investigación a través del proyecto como un tipo de investigación sobre el proyecto -aunque más relevante para el diseño- 0 como una investigación para el proyecto, que produce conocimiento original, con los estándares de rigor que ostenta la investigación sobre el proyecto. Findeli y Coste (2007) llaman a este enfoque "a través del proyecto" como investigación-proyecto (recherche-projet), lo que claramente está influenciado por los modelos de investigación-acción y por una postura filosófica pragmática. Esto equivale a considerar el proyecto, no sólo como una práctica creativa, sino también como una postura ética.

Las condiciones de una investigación a través del proyecto son, según estos autores:

-Que éste esté enraizado en el proyecto, apoyándose por consecuencia sobre una situación particular que busca modificar el curso de las cosas, -Que éste sea empírico y debe permitirse el observar tanto el mundo exterior sobre el cual trata el proyecto como el mundo interior de los actores del proyecto (intenciones, valores, expectativas, etc.),

-Que éste se abra a un trabajo reflexivo "en acción" e interpretativo "fuera de la acción",

-Que conduzca a conclusiones lo más generales posibles, tanto en el plano de la teoría, como de la práctica profesional y de la enseñanza ${ }^{25}$. (Findeli y Coste,2007, p. 153).

Es importante distinguir el proyecto práctico -el proyecto de paisaje (acción práctica)- del proyecto de investigación (acción teórica desde una mirada científica). Ambos proyectos deben insertarse en un marco general desde donde se estructura el proyecto de tesis, sin embargo, los objetivos son diferentes: el objetivo desde la perspectiva científica será contribuir al cuerpo de una teoría general de la arquitectura del paisaje, mientras que el objetivo desde la perspectiva práctica (arquitectónica) es responder a un problema "real", proveniente del mundo exterior. Para Findeli y Coste (2007), la problemática de una tesis que se define a través del proyecto puede tener dos fuentes, una exógena, cuando se trata de un problema que viene de un requerimiento real que normalmente trae consigo el doctorando, como es en este caso, o bien endógena, cuando corresponde a un problema que viene desde el interior de la disciplina, una pregunta científica que ha quedado en suspenso. En este último caso, normalmente se busca cómo llevar esta pregunta de investigación al campo real del un proyecto, a través de un caso.

De acuerdo a este modelo, la investigación se inserta en el proceso de un proyecto profesional real, diferenciándose del modelo de la teoría aplicada o de estudio de caso, para transformarse en un trabajo teórico comprometido, "situado, involucrado en un proyecto" (Findeli, 2003, p. 170). No se trata de "validar una 
teoría en un experimento" (p. 170), como lo hace la física, sino de "involucrar una teoría en el campo [...] de un proyecto" (p. 170). A partir de esto podemos afirmar, siguiendo a Findeli, que la investigación en diseño es "una búsqueda sistemática de conocimiento y adquisición de conocimientos relacionados con la ecología humana, desde el punto de vista de la forma de pensar del diseñador, en una perspectiva de proyecto" (2010, p. 294). Para ello es necesario que el investigador además de ser capaz de definir una posición teórica, vale decir de elaborar un discurso formulado en el lenguaje, posea la experiencia práctica en el proyecto (en nuestro caso en un proyecto de paisaje).

La pregunta que cabría hacer entonces es más específica ¿Cuál es el lugar que debe tener el proyecto de arquitectura en el proyecto de investigación de una tesis de doctorado?

Una posibilidad, es que quede en los anexos como antecedente base de la reflexión, la otra, que adoptaremos en este trabajo, es que forme parte del cuerpo de la investigación, rehaciendo críticamente el proceso de diseño. Al tomar esta última opción, postulamos que se puede crear un tipo específico de conocimiento, a través del diseño de arquitectura del paisaje.

Nos referimos así, al conocimiento que se puede obtener en el curso del desarrollo de un proyecto para un problema y lugar específico. A través de modelar, se adquire conocimiento sobre la morfología del lugar, probar, a través de la conversación con los actores y usuarios del proyecto, se puede obtener conocimiento sobre las variables sociales o sobre las condiciones ecológicas. El objetivo de este tipo de investigación es el conocimiento que se produce a través del proyecto.

Un paso más sería una investigación a través del resultado del proyecto, que se diferencia de la investigación sobre el proyecto en que el foco se desplaza desde el proceso al objeto de diseño o proyecto mismo, en el mismo proceso de la tesis

\subsection{LA PARADOJA DEL PROYECTO}

Partimos desde una paradoja: la arquitectura fue el oficio que históricamente impuso la práctica social del proyecto, perfeccionándolo gradualmente desde el Renacimiento (Boutinet, 1990/2015). Sin embargo, el proyecto de investigación en arquitectura es uno de los más recientes. Nos ha llevado casi 5 siglos pasar del estado de la práctica profesional a su teorización a través de la investigación científica. Esta visión, sin duda simplificada, que pasa por sobre los tratados y textos modernos -que revisaremos más adelante-, pone como referente de la investigación científica en arquitectura a aquella que se realiza en los programas de doctorado. Si consideramos que la investigación doctoral es un indicador de madurez de una disciplina, y que el grado de doctor se otorga desde el siglo XIX ${ }^{25}$, podemos afirmar que la investigación en Arquitectura bajo estos criterios es relativamente nueva.

En Chile, el primer grado de doctor fue otorgado en 1953, mientras que en Arquitectura fue recién en 2008 , situación no muy distante a la francesa, ya que, si bien los primeros programas aparecen después de mayo de 1968, cuando arquitectura pasa de las escuelas de Bellas Artes a las universidades ${ }^{26}$, las primeras tesis se desarrollan en los años 2000.

Por su parte, en Estados Unidos, el primer doctor en arquitectura de la Universidad de Harvard fue Sami Hassid en 1956 (quien después se trasladó a Berkeley y estableció un programa de doctorado en 1968), seguido por Christopher Alexander en 1963. Otros maestros de la arquitectura como Peter Eisenman y Charles Jenks, reciben su grado de doctor en 1964 en Cambridge (UK) y en 1970 en el
${ }^{25}$ Si bien, según Keith Allan Noble (1994), el primer título de doctorado se otorgó en el París medieval alrededor de 1150, la denominación $\mathrm{PhD}$ surge en el siglo XIX en la Universidad de Berlín, extendiéndose luego al mundo anglosajón.

${ }^{26}$ La introducción del diseño y la arquitectura en la universidad estuvo acompañada de la creación de programas de post-grado, incluido el doctorado. 
programa de Historia de la Arquitectura en la University College de Londres, respectivamente. El primer programa de doctorado en Arquitectura, independiente de la historia de la arquitectura (como rama de la historia del arte) se abre en 1964 en la Universidad de Pensilvania, seguido en 1965 por Princeton, Carnegie Mellon en 1967, Berkeley en 1968, Michigan en 1969 y Cornell en 1970, para luego expandirse a Canadá que abrió su primer programa en la universidad francófona de Montreal en 1970 (Moore, 2015, p. 33). En China se abre el programa de doctorado en arquitectura en la Universidad de Hong-Kong en 1969 (Universidad de Hong Kong, 2019). En el caso de España, González de León y Núñez Valdés en su ponencia Mujeres Pioneras en la Arquitectura Española, señalan a $\mathrm{M}^{\mathrm{a}}$ Cristina Gonzalo como una de las primeras doctoras en arquitectura en el país, obteniendo el grado en 1967 (2018, p. 275).

Podemos decir entonces que la investigación en arquitectura bajo los estándares científicos es relativamente nueva en comparación con otras disciplinas y como veremos, con una fuerte tensión entre el proyecto de arquitectura y el proyecto de investigación científica.

\subsection{CONTEXTO LOCAL: SITUACIÓN DE LA INVESTIGACIÓN EN ARQUI- TECTURA}

Si trasladamos la pregunta sobre el lugar del proyecto de arquitectura en las tesis de doctorado, el conjunto de tesis realizadas en Chile se reúne en los tres programas existentes: el de la Universidad Católica abierto en 2004 -con 50 tesis defendidas (2017)-, el de la Universidad del Bío-Bío abierto en 2009 -con 20 tesis defendidas (2017)- y el de la Universidad de Chile abierto recién el 2018. Al estudiar los resúmenes de estas 70 investigaciones, vemos que más del $80 \%$ (58 tesis) se tratan de investigación "sobre" una problemática relacionada con la arquitectura, mientras el $20 \%$ restante se enfoca en investigación tecnológica. Ninguno de los 70 resúmenes da cuenta de una investigación hecha con 0 a través de un proyecto arquitectónico concreto.

Un análisis análogo encontramos en el artículo de Tomasi y Mazel del año 2017 respecto a las 58 tesis defendidas entre los años 2008 y 2014 en la Universidad de Grenoble, de un programa abierto el año $2005^{27}$, con resultados similares. Si bien las categorías utilizadas por estos autores son más numerosas, ellas pueden agruparse en las mismas 3 que hemos propuesto. En las conclusiones del estudio, los autores señalan que "Las tesis que desarrollan enfoques para y a través del proyecto siguen siendo por ahora minoritarias" (p. 12), para luego declarar:

Postulamos que esta fuerza de anticipación, intrínsecamente presente en la noción de proyecto y que necesita un fuerte compromiso del investigador, constituye un campo de exploración vasto y rico, y participa plenamente del debate científico. (p. 12)

Resulta paradójico, entonces, que estando la disciplina arquitectónica íntimamente ligada al proceso del proyecto, no sea éste su principal objeto de estudio. La experiencia proyectual es muy rica, variada y tiene un gran potencial interpretativo, reflexivo y crítico. El proyecto y sus circunstancias ofrecen la posibilidad de penetrar en el fértil proceso entre la idea y la obra, un espacio donde el inves-

${ }^{27}$ El doctorado en arquitectura fue instaurado en la marco de la reforma LMD de la enseñanza de la arquitectura por decreto, el 30 de junio de 2005. Existen de todas maneras otras tesis más antiguas de la disciplina, defendidas como resultado del primer doctorado en arquitectura, creado en 2003 por la Universidad Paris VIII. tigador puede encontrar su lugar.

\subsection{EL OBJETO DE ESTUDIO}

Para hacer el ejercico de definir el objeto de estudio en una investigación en arquitectura, tomaremos el texto de Juhani Pallasmaa Habitar el tiempo. Allí Pallasmaa define la arquitectura como el arte de la permanencia, desde donde po- 
(...) la arquitectura hace doméstico el espacio natural ilimitado y uniforme para el habitar humano. Los edificios, los pueblos y las ciudades dan a ese espacio sin sentido un significado experiencial y existencial al convertirlo en un lugar específico que resuena con nuestras acciones y reacciones mentales y las coreografía. (2016, p. 184)

Si bien en este texto podemos reconocer elementos que también pueden ser problematizados desde la sociología, la semiótica, la historia, la filosofía, la tecnología e incluso la psicología, lo que distingue la arquitectura como disciplina, es que el objeto de estudio no es una parte, si no la conjugación de diversos componentes que contituyen el fenómeno de habitar. Si bien compartimos la mirada descriptiva, analítica, explicativa, interpretativa y crítica con otras disciplinas científicas, la arquitectura va más allá del diagnóstico. Más bien, el diagnóstico que hace de la realidad contiene también el impulso de la transformación, vale decir del proyecto de habitar el mundo con sentido. La mirada analitica busca entonces, encontrar pistas para mejorar o al menos conservar las condiciones de habitabilidad, imaginar la posibilidad de un futuro mejor.

Si situamos el proyecto de habitar el mundo en un paisaje y lo convertimos en nuestro objeto de estudio, sobre él intentaremos teorizar para construir conocimiento a través del proyecto de arquitectura del paisaje.

Sin embargo, no podemos olvidar que la arquitectura constituye también una práctica profesional (un oficio), por lo tanto, la finalidad de una investigación no se satura con la explicación del fenómeno, como lo hacen las disciplinas científicas. En efecto, como nos plantean Findeli y Coste " $¿$ de qué puede servir la investigación si ésta no desemboca en una mejor práctica de la arquitectura, si ésta no permite a la práctica del proyecto dar una mejor respuesta a los diagnósticos que la arquitectura realiza sobre la realidad?" (2007, p. 145) o más radicalmente, en palabras de Cristopher Alexander, "si la teoría no lleva a mejores construcciones, es una perdida de tiempo" (citado por Hanson, 2005, p. 35).

La investigación en arquitectura se encontraría motivada por un doble desafío, aquel de producir conocimientos sobre el acto proyectual y el de contribuir a mejorar sus prestaciones. Findeli y Coste proponen el siguiente enunciado: "una tesis de doctorado en arquitectura tiene por tarea principal conducir a una mejor inteligibilidad del proyecto de arquitectura, y de contribuir así a una teoría general del proyecto o a una 'pragmática del proyecto'" (2007, p. 145). Para ello, es necesario concebir un modo de abordar la investigación que nos ayude a transitar por un camino empírico, en el cual el proyecto de arquitectura del paisaje ocupa un lugar central. La posibilidad de que la investigación aporte a la práctica será el resultado de la "postura pragmática adoptada" (p. 145). Para adoptar esta postura, sin embargo, me parece necesario situar este problema y revisar primero algunos textos teóricos que han enfrentado esta toma de posición, para responder a la pregunta sobre cuál es el modelo o concepto de proyecto que determina, controla y justifica mi punto de vista, tanto en el proyecto de investigación como en el de arquitectura del paisaje.

\subsection{DESDE LOS TRATADOS}

Podríamos decir que desde el primer tratado que ha llegado a nuestros días, Los Diez Libros de la Arquitectura de Marco Lucio Vitruvio Polión ${ }^{28}$, publicada en el siglo I a.C , los tratadistas se han propuesto, junto con la definición de qué es

${ }^{28}$ Escrito probablemente en el año $20 \mathrm{AC}$, es el único tratado que se conserva de la antigüedad, fue redescubierto en el siglo $\mathrm{XV}$. 
arquitectura y qué es ser arquitecto, establecer la relación de teoría y práctica dentro de la disciplina, oscilando entre quienes defienden la autonomía de ésta como arte y quienes intentan someterla a criterios científicos. Ya para Vitruvio, la arquitectura es una ciencia, que hoy llamaríamos multidisciplinaria, que requiere de la contínua práctica para, como en las virtudes, se adquiera su dominio:

La Arquîtectura es una ciencia adornada de otras muchas disciplinas y conocimientos, por el juicio de la qual pasan las obras de las otras artes. Es práctica y teórica. La práctica es una continua y expedita freqúentacion del uso, executada con las manos, sobre la materia correspondiente á lo que se desea formar. La teórica es la que sabe explicar y demostrar con la sutileza y las leyes de la proporción, las obras executadas. (Vitruvio, 1992, p. 2)

Esta definición exige del arquitecto una serie de destrezas y conocimientos, que le permitirán ser "...instruido en buenas letras, diestro en el dibuxo, hábil en la Geometría, Inteligente en la Óptica, instruido en la Aritmética, versado en la Historia, Filósofo, Médico, Jurisconsulto, y Astrólogo"(Vitruvio, 1992, p. 3).

Muchas de estas competencias tenían que ver con la capacidad de llevar a cabo las obras de construcción, según los tres principios enunciados en el capítulo l: firmitas, utilitas y venustas, todas ellas desarrolladas en el tratado como un conjunto de normas y procedimientos.

Vitruvio insistía en la necesidad del dominio del dibujo, que es el instrumento del proyecto y expresión de la capacidad de anticipación, pero también en aquellos conocimientos que permitían la "elección de parages sanos" (Vitruvio, 1992, p. $14)^{29}$. Posiblemente, en una época en la que las pestes diezmaban periódicamente a la población, evitar terrenos pantanosos y preferir los lugares soleados, bien orientados y ventilados, así como saber cómo encontrar y aprovechar las aguas, dotaba al arquitecto de la capacidad de elegir con fundamento un sitio adecuado, sin aún reparar sobre sus condiciones paisajísticas.

Sin embargo, pese a la madurez y reconocimiento que la disciplina alcanza en la cultura clásica occidental, con la caída del imperio romano desaparece también la figura del arquitecto, función que asumirá el jefe de obra, el abad o el financista. En este nuevo orden social, la construcción se realizará a partir de la reproducción y perfeccionamiento de reglas (más cercano al trabajo artesanal). Como observa Jean-Pierre Boutinet en su libro Anthropologie du projet (1990/2015), en esa época se presencia un "arte más realizado que anticipado y pensado" (p. 172), un modo de hacer sin proyecto, proceso que en gran medida utiliza

${ }^{29}$ En el capítulo IV del libro I, titulado "De la elección de parages sanos"(1992, p. 14), se establecen una serie de procedi-mientos empíricos para la adecuada localización de las obras; en el capítulo VII se refiere a la distribución de usos y edificios en la ciudad; en el capítulo V del libro IV a la orientación de los templos; en el capítulo IX del libro V, habla de la situación de los teatros. Es en el capítulo I del libro VI donde trata con más profundidad la "situación de los edificios en orden a las condi-ciones de los parages"(1992, p. 139). Por último, el libro VIII está dedicado al agua (captación y aprovechamientos). Ade-más de estos capítulos específicos, el tratado hace alusiones esporádicas a aspectos contextuales de la arquitectura, sin lle-gar a sistematizarlos.

${ }^{30}$ Traducción propia del francés. otros procedimientos como la prueba-y-error, la improvisación, el bricolaje, el mimetismo y la aplicación situada de reglas, un procedimiento que carece de dos elementos inherentes a todo proyecto arquitectónico: "un creador personalizado llamado arquitecto y un enfoque anticipatorio grabado en dispositivos identificables: [planos], croquis, diagramas, maquetas" ${ }^{30}$ (p. 173).

No será hasta el Quattrocento italiano, con la construcción de la cúpula de la catedral de Florencia que emerge nuevamente la figura del arquitecto. Filippo Brunelleschi rompe una tradición heredada de la Edad Media, asumiendo junto a la construcción de la cúpula la coordinación de un enjambre de especialidades de obra y el arbitrio de conflictos entre oficios rivales. Desafiando las antiguas prácticas, Brunelleschi separa la concepción arquitectónica de su ejecución: el arquitecto se hace único responsable del proyecto y de la estrategia para ejecutarlo, quedando los maestros constructores con una autonomía reducida. El arquitecto introduce en su trabajo una nueva racionalidad y el renacimiento italiano, valorando esta racionalidad en arquitectura, instaura una práctica que durará hasta nuestros días. 
Brunelleschi, al disociar proyecto y construcción, al mismo tiempo que organiza una división técnica y social del trabajo, identifica al proyecto, como primer acto característico de toda creación arquitectónica. Los dibujos a través del juego de perspectivas y las maquetas buscarán asegurar una representación geométrica del edificio pensado. Este momento es el hito señalado por Boutinet, que da origen a la noción de proyecto como la conocemos hoy, donde el proyecto de arquitectura pasa a ser el paradigma del proyecto para todas las otras disciplinas. Podemos afirmar que, si bien la palabra proyecto tuvo hasta el siglo XIX un uso muy vago en el lenguaje cotidiano, desde el Renacimiento italiano hablamos de proyecto en arquitectura (Boutinet, 1990/2015, p. 15).

Es también Desde el Renacimiento que la tratadística constituyó, casi con exclusividad, el soporte teórico del proyecto. Leone Battista Alberti sigue el modelo de Brunelleschi ${ }^{31}$ en su tratado De Re Aedificatoria de 1485, distinguiendo la actividad del arquitecto de la del constructor. Pone acento en su capacidad de actuar de acuerdo a métodos y procedimientos, así como de proyectar en teoría. El arquitecto debe dar cuenta y razón de su quehacer y se enfatiza la capacidad de anticipación, que es propia del proyecto.

(...) el arquitecto será aquel que con un método y un procedimiento determinados y dignos de admiración haya estudiado el modo de proyectar en teoría y también llevar a la práctica cualquier obra que, a partir del desplazamiento de los pesos y la unión y ensamblaje de los cuerpos, se adecúe, de una forma hermosísima, a las necesidades más propias de los seres humanos. Para hacerlo posible, necesita de la intelección y el conocimiento de los temas más excelsos y adecuados (Alberti, 1991, p. 57)

Alberti hace una distinción entre "la voluntad que proporciona la fuerza motriz que permite al hombre realizar lo que desea realizar, y la razón que le permite saber exactamente lo que quiere obtener como lo que debe evitar" (Boutinet, 1990/2015, p. 17).

El apoyo del proyecto es el plan, a diferencia de los procesos tradicionales en los que "el trabajo se concibe como autogeneración, a medida que avanza" (Boutinet,1990/2015, p. 18). El artista -arquitecto- trasciende así su papel de artesano para constituirse en un humanista, viéndose obligado a combinar el aprendizaje del oficio con la adquisición de una sólida formación intelectual.

La lectura crítica de los textos clásicos y la duda metódica se instalan dos siglos más tarde en la academia francesa ${ }^{32}$. Claude Perrault recibe el encargo de traducir y comentar detalladamente De architectura de Vitruvio, entre los años 1665 y 1666. Se trata de una empresa política, fundante. Recordemos que la Academia Francesa de Arquitectura, creada en 1671, tendrá la función de definir una doctrina global de la arquitectura francesa, basada en principios racionales que tendrán su soporte histórico y teórico en las obras de la antigüedad. Se buscaba asegurar que los monumentos del reinado de Luis XIV tuvieran un valor universal, que fueran irrefutables, para así convertir a Francia en el referente cultural europeo. Para ello, debía instaurarse un arte en el que la noción de belleza respondiera a normas debidamente establecidas e indiscutibles, por el prestigio de los escritos (fuentes) y de los edificios de los que procedían (modelos y referentes).

Perrault tenía estudios de medicina, física y astronomía (pertenecía a la Academia de Ciencias desde 1666), lo que explica el rigor taxonómico de la traducción, que se despliega con virtudes que podríamos considerar propias de los textos científicos contemporáneos como la legibilidad escrita y gráfica, y la actualización. Esto se logra a través de un riguroso trabajo hermenéutico sobre el texto original, con numerosas notas que ocupan prácticamente la mitad de las páginas, donde a través de llamadas numeradas se explican conceptos y se relaciona el
${ }^{31}$ A quién dedica su tratado sobre la pintura, pero a quién no nombra explícitamente en su tratado de arquitectura.

32 Recordar que Descartes culmina el Discurso del método en 1637 (Discours de la méthode pour bien conduire la raison et chercher la vérité dans les sciènces).

33 El ministro Colbert no escatimó en los medios, por lo que el formato del libro fue confiado a Jean-Baptiste Coignard, el impresor de la Academia Francesa. Los mejores dibujantes del reino (Edelinck, Pitau, Grignon, Scotin, Tournier) trabajaron en las ilustraciones (grabados en cobre) 
Figura 2.2. Les Dix livres d'architecture de Vitruve corrigez et traduits nouvellement en françois, avec des notes et des figu-res. En Perrault, Claude. (1673, pp. 288 y 289).

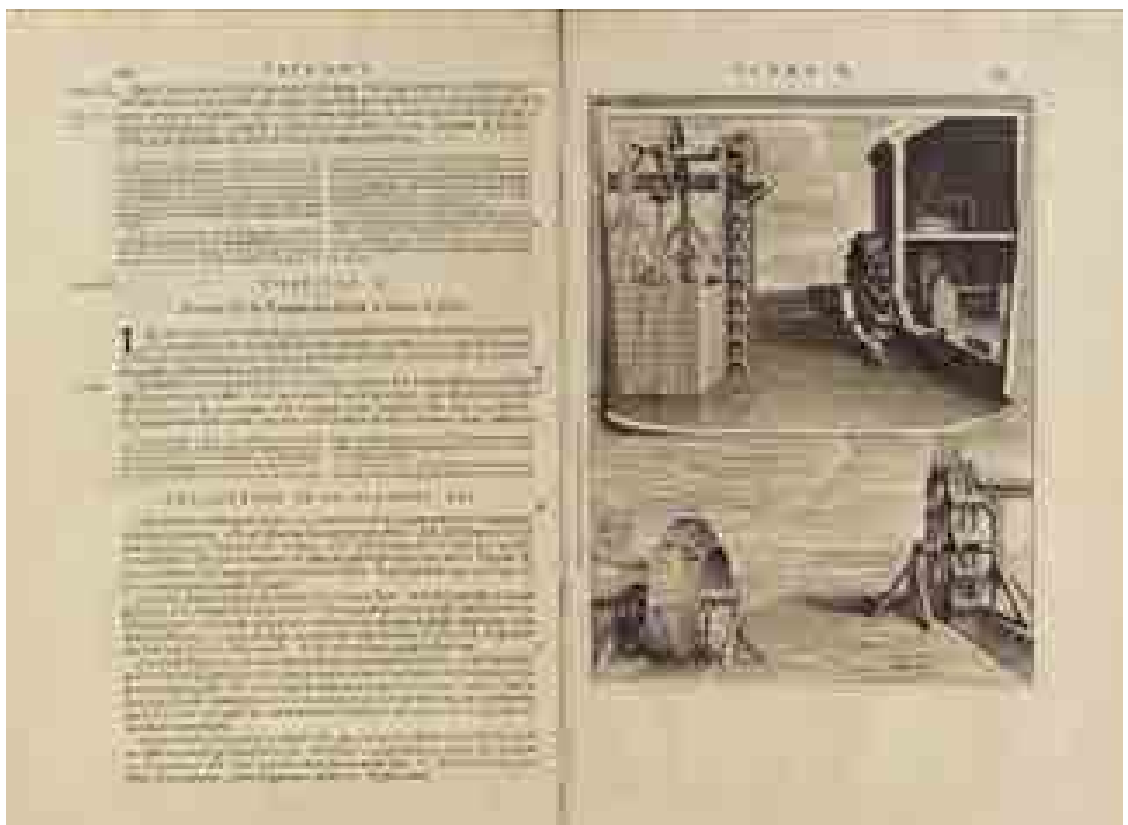

texto con otros libros impresos. La legibilidad gráfica se produce a partir de los 65 grabados $^{33}$, casi todos ellos con una explicación detallada (Figura 2.2.). Uno de los requisitos del encargo era actualizar las ciencias en el campo de la arquitectura y la hidráulica, las técnicas antiguas - todavía aplicables- se ilustran y explican ampliamente en las notas. Perrault también desarrolla aplicaciones modernas e incluso mejoras ingeniosas a partir de las recomendaciones vitruvianas.

Es interesante notar que en el texto de Perrault se puede encontrar una primera versión de investigación en arquitectura desde el método científico, pero también desde la propia arquitectura.

El trabajo de Perrault prepara el terreno para que un siglo después surja la crítica arquitectónica de la pluma de Marc-Antoine Laugier en su Essai surl'Architecture de $1752^{34}$, donde se puede reconocer la afinidad de Laugier con la idea del buen salvaje de Rosseau, que transmuta en la imagen-mito de la cabaña primitiva como origen de la arquitectura. El texto tiene el carácter de un sermón, donde el religioso, anónimamente critica los excesos de arquitectura manierista y barroca que han complejizado irreflexivamente las formas arquitectónicas:

Entiendo que, en las artes que no son puramente mecánicas, no basta con saber trabajar, es importante sobre todo aprender a pensar. Un artista tiene que poder darse a sí mismo razón de todo lo que hace. Para ello necesita principios fijos que determinen su juicio y justifiquen su elección; de modo que pueda decir que una cosa está bien o mal no sólo por instinto, sino por medio de la razón y como hombre instruido en los caminos de lo bello. Sólo la arquitectura se ha abandonado, hasta ahora, al capricho de los artistas, que han establecido sus preceptos sin discernimiento. Han fijado reglas al azar, basándose sólo en el examen de los edificios antiguos [...] Es, pues, de esperar que algún gran arquitecto intente salvar la arquitectura de la excentricidad de las opiniones, descubriendo sus leyes fijas e inmutables. Todo arte, toda ciencia tiene un objetivo determinado. (Laugier, 1999, p. 35-36)

Esta búsqueda de leyes fijas e inmutables, tan característica del pensamiento ilustrado, encuentra en los principios constructivos en la gramática de los elementos, las "reglas fijas de trabajo y medios infalibles para alcanzar la perfección" (Laugier, 1999, p. 38). Sin embargo, a finales del siglo XVIII aparece un impulso por recuperar el sentido poético de la arquitectura.

Etienne Louis Boullée, en su Architecture, Essai sur Lárt, se revela ante el legado de la tradición clásica, desafiando directamente a Vitruvio y polemizando con las teorías de su época: 34. La primera edición fue anónima, siendo
la segunda de 1755 la más conocida. 
¿Qué es la Arquitectura? ¿La definiría yo, con Vitruvio como el arte de construir? No. Hay en esta definición un error grosero. Vitruvio toma el efecto por la causa.

Lo que creo importante distinguir dentro de la arquitectura es la ciencia y el arte propiamente dicho (1985, p. 41)

Boullée considera que, si bien primero deben garantizarse "los medios de construir sólidamente, antes de construir agradablemente" (1985, p. 42), la arquitectura debe recuperar su carácter artístico, liberándola de las exigencias de rigor que son propias del trabajo científico, vale decir, de determinaciones que él considera externas, para recobrar la autonomía que poseen las demás artes.

Tenemos que convenir en que las bellezas del arte no pueden ser demostradas como las verdades matemáticas.; y aunque esas bellezas emanen de la naturaleza, para sentirlas y para aplicarlas certeramente, hay que estar dotados de cualidades que la naturaleza conserva celosamente (Boullée, 1985, p. 41)

Como plantea Fernando Pérez et al. (1999), para Boullée la clave del arte es la imitación de la naturaleza, y ésta "no se alcanzaría mediante la aplicación de principios y leyes racionales (...), sino a través de la observación cuidadosa que reproduzca el efecto de la naturaleza que, entendida como escena y como paisaje, despierta en nosotros" (p. 40) ${ }^{35}$.

Boullée escribe sobre la relación entre la arquitectura entendida como un objeto y la experiencia que ella suscita. Lo explica así: "Consideremos un objeto. Nuestra primera reacción es, por supuesto, el resultado de cómo nos afecta el objeto. Y lo que yo llamo carácter es el efecto del objeto, que nos causa algún tipo de impresión" (1985, p. 89). Para luego explicar en qué consiste la poesía:

(...) radica en el arte de crear perspectivas a través del efecto de los volúmenes. ¿Qué causa los efectos? Es su masa. Y así es la masa de estos volúmenes la que da origen a nuestras sensaciones. Sin duda alguna. $Y$ es el efecto que tienen en nuestros sentidos lo que nos ha permitido darles nombres apropiados y distinguir las formas masivas de las delicadas". (p. 115)

Más aún, Boullée nos revela que el origen de su pensamiento está su propio proceso de estudio:

Cansado de la imagen muda y estéril de los cuerpos irregulares, he pasado a examinar los cuerpos regulares. Aparte de su regularidad, he notado en ellos su simetría y su variedad, y he visto que de ahí se deducía la forma y la figura. Además, he tenido que reconocer que solamente la regularidad habría podido dar a las personas ideas nítidas acerca de la figura de los cuerpos y determinar su denominación, que como se ve ha sido el resultado no solo de su regularidad y de su simetría, sino incluso de su variedad. (1985, p. 54)

Si la arquitectura puede reducirse a la configuración de los volúmenes y su percepción, entonces el orden arquitectónico puede establecerse simplemente mediante las relaciones entre las formas particulares y nuestra experiencia de ellas (Figura 2.3.). La arquitectura se convierte así en una experiencia sublime, creada por el orden de las formas arquitectónicas.

Aunque resulte paradójico, es un discípulo de Boullée, Jean-Nicolas-Louis Durand quien inaugura una posición totalmente opuesta a la de su maestro. Como profesor de la École Polytechnique, fundada en 1794, Durand enseñó por 40 años los principios de la arquitectura moderna a los ingenieros ${ }^{36}$. Además de enseñar y proyectar, produjo un importante legado teórico. Publicó en 1802 y
${ }_{35}$ Para estos autores, La noción fundamental que surge en estas circunstancias es la del carácter. Es a través del carácter que la poesía de la arquitectua alcanza lo sublime

${ }^{36}$ En la introducción a su Discours Préliminaire dice:

Como los ingenieros se encargan más que nunca de la construcción de edificios importantes, es imposible reco-mendar a los estudiantes de la Escuela Politécnica el estudio de la Arquitectura y, al mismo tiempo, facilitarles los medios para llevarla a cabo con éxito. (1802, p. 1).

${ }^{37}$ Compedio de Lecciones de Arquitectura. 
Figura 2.3. Proyecto del Cenotafio Isaac Newton -Vista de la sección transversal- de Etienne-Louis Boullée. En Boullée (1784)
${ }^{38}$ Colección y paralelismo de edificios de todo tipo, antiguos y modernos: notables por su belleza, grandeza o singularidad, y dibujados a la misma escala.

39 Traducción propia del francés: "Ainsi, la convenance et l'économie; voilà les moyens que doit naturellement employer l'architecture, et les sources où elle doit puiser ses principes, les seuls qui puissent nous guider dans l'étude et dans l'exercice de cet art. D'abord, pour qu'un édifice soit convenable; il faut qu'il soit solide, salubre et commode."

${ }^{40}$ El término mathesis universalis (del griego matheseôs, ciencia o aprendizaje y del latín universalis, universal) hace refe-rencia a un hipotético modelo matemático previsto por Leibniz y Descartes, entre otros filósofos y matemáticos del siglo XVI y XVII que buscaban establecer un lenguaje perfecto y universal para dirimir acerca de la verdad.

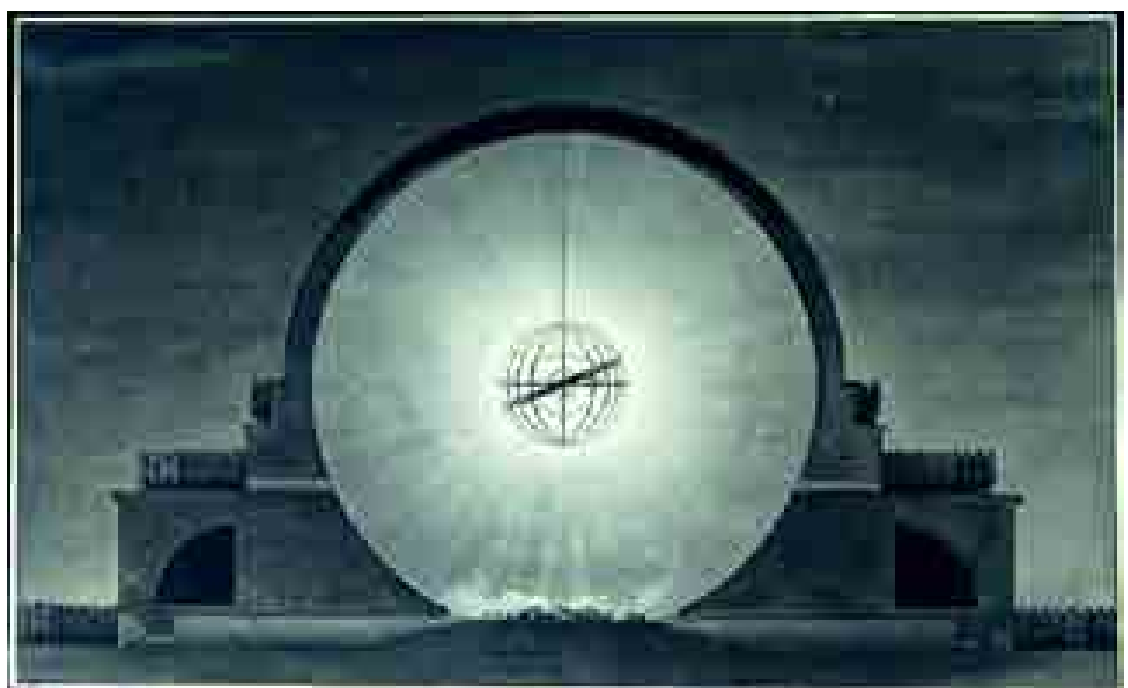

1805 los dos volúmenes de su obra Precis de Leçons d'Architecture ${ }^{37}$ que sirvió como libro de texto en la École Polytechnique; y en 1877 publica Recueil et parallèle des édifices de tout genre, anciens et modernes : remarquables par leur beauté, par leur grandeur, ou par leur singularité, et dessinés sur une même échelle ${ }^{38}$. Cuestiona como su maestro, la tradición clásica desde Vitruvio, pero también el mito de la cabaña primitiva. Durand se pregunta sobre el placer como objetivo principal de la arquitectura y si es la decoración el modo de satisfacerlo. Renuncia a la idea de belleza como mimesis de la naturaleza y a la imitación de las proporciones del cuerpo humano como modelo para deducir las reglas de la arquitectura, ya "que este arte debe su origen únicamente a la necesidad, y que no tiene otro fin que el de la utilidad pública y privada" (Durand, 1805, p. 13)

Por lo tanto, conveniencia y economía; estos son los medios que la arquitectura debe utilizar naturalmente, y las fuentes de las que debe extraer sus principios, los únicos que pueden guiarnos en el estudio y la práctica de este arte.

En primer lugar, para que un edificio sea adecuado, debe que es sólido, limpio y cómodo. (Durand, 1805, p. 16) ${ }^{39}$

El principio de economía es aquí central, ésta se logra a través de recursos formales como la simetría, la regularidad y la simplicidad (Durand, 1805, p. 17). Para esto Durand establece un método de diseño racional en base a una trama ortogonal (cuadrícula), donde se ubican los elementos estructurales, en un juego que le permite comparar obras ejecutadas con una versión eficiente, demostrando empíricamente (través de plantas y elevaciones), su hipótesis de trabajo. Deja así de lado las tradiciones arquitectónicas, los valores simbólicos y las condiciones de emplazamiento; es un sistema abierto y procesal que permite proyectar, analizar y comparar objetivamente, incorporando el uso del módulo.

Sergio Villari (1990) argumenta que este método es sintáctico y lo ha comparado con la estructura del lenguaje. Podemos ver el cumplimiento del sueño ilustrado de representar el mundo como una mathesis universalis ${ }^{40}$, como un lenguaje que no necesita referencia explícita al mundo natural.

Como en las palabras, un edificio puede descomponerse en sus partes irreductibles y reconstruirse de nuevo en otro completamente diferente, llevando al mismo tiempo las huellas de esa parte irreductible. Este proceso, estas series (Figura 2.4.) establecen un vínculo con su precedente y con la historia de los tipos en la arquitectura.

Durand enfatiza la idea del tipo, formulada por Quatremere de Quincy en su Dic- 


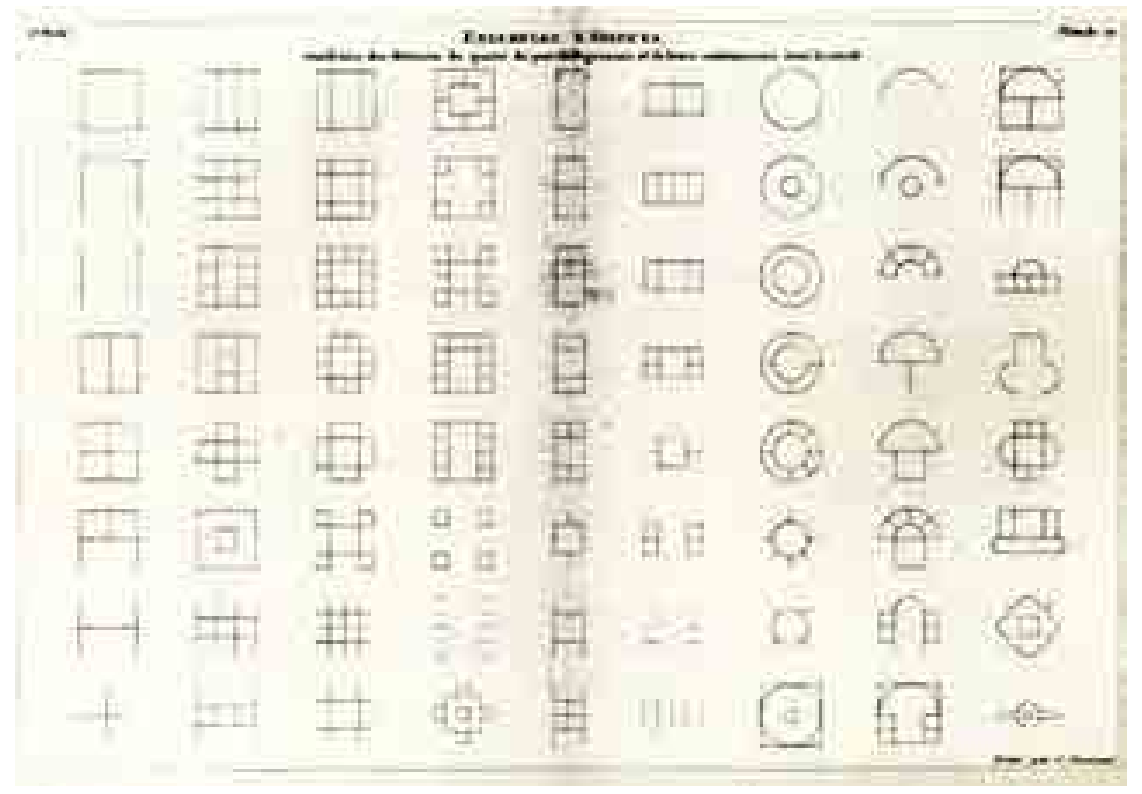

tionnaire Historique de'Architecture (1832). Como objeto de estudio, el tipo representa una forma y función identificable.

La forma construida no es más que la resultante de componer, combinar y/o sumar las partes y elementos que la constituyen. Operaciones que abren la puerta al eclecticismo de fines del siglo XIX en el que las formas heredadas de a antigüedad se ofrecen como partes, como material disponible a para nuevas e infinitas combinaciones.

El intento de Durand de crear un método universal de diseño tuvo gran influencia, pero en la práctica su enfoque fue limitado e ingenuo. La principal debilidad del método de Durand era su creencia de que el tiempo histórico podía ser detenido

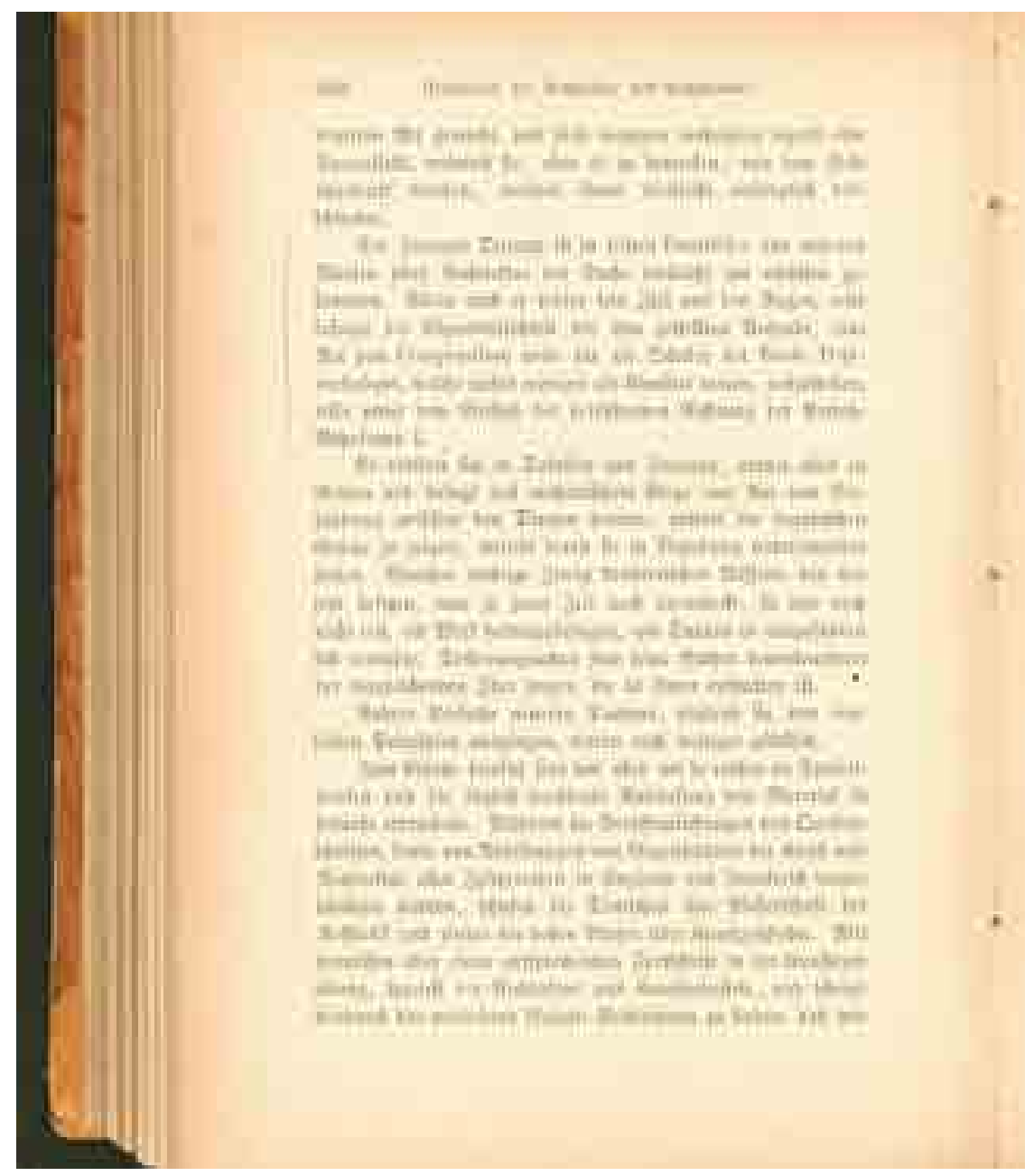

Figura 2.4. Ensambles d' Edifices. Planche 20. En Durand (1802, pp. 248-249).
Figura 2.5. Kleine Schriften, Tratado de Gottfried Semper, donde se encuentra la referencia a Durand. En Semper, G.\&Semper, M.; Semper, H. (1884, p. 262). 
y encapsulado en una teoría que tendría una validez permanente. Estos logros y también sus limitaciones fueron reconocidos en la siguiente generación, en particular por Gottfried Semper, cuyo trabajo tenía una aspiración similar. "El francés Durand", escribe Semper (Figura 2.5.):

(...) en sus trabajos de Parallels y en otros trabajos sobre arquitectura se acercó más que nadie a la tarea, es decir, a la teoría científica de la arquitectura. Pero incluso él perdió la puntería (...) se perdió en tablas y fórmulas, organizó todo en series y reunió los elementos individuales de forma mecánica sin demostrar la ley orgánica que estableció su relación ${ }^{41}$. (1884, p. 262).

Semper parecía ser consciente, a diferencia de Durand, de que su objetivo era nada menos que una compleja ciencia del diseño arquitectónico.

A mediados del siglo XIX la balanza vuelve a inclinarse hacia el dominio del arte. La cultura secular se enfrenta a una cultura idealista con valores cristianos, "Así ocurre con John Ruskin (1819-1900) que junto a Augustus Welby Pugin (18121852) y a William Morris (1834-1896) defienden la causa neomedieval en Inglaterra, con resonancias tanto estéticas, como éticas y sociales" (Pérez et al., 1999, p. 40).

Ruskin en su libro Seven Lamps of Architecture publicado en 1849, adopta una posición completamente opuesta a la de Durand, define la arquitectura como "el arte de levantar y decorar los edificios" que más allá de las condiciones de funcionamiento, "imprime a su forma ciertos caracteres venerables y bellos, aunque inútiles desde otros puntos de vista" (Ruskin, 2015, p. 10), definiendo en otro texto que la arquitectura como arte humano:

(...) depende primero del instinto y, después, de cierta práctica, ciencia e imaginación disciplinada por el pensamiento, que el verdadero poseedor de ella sabe que es incomunicable, y el crítico verdadero sabe que es inexplicable, salvo mediante un largo proceso de años de trabajo. (Ruskin, 1950, p. 193)

Paralelamente reaparece en Francia la idea de que la construcción puede revelar los principios de los que se derivan la calidad y la belleza. E.E. Viollet-le-Duc, restaurador, viajero, constructor, didacta y uno de los teóricos más influyentes y productivos del siglo XIX, también defensor de la arquitectura gótica, plantea en su Dictionnaire raisonné de l'architecture française du XIe au XVle siècle (18541868) que los valores estéticos del gótico representan mejor el espíritu francés que el neoclasicismo. En los edificios medievales lee una racionalidad constructiva, coherente con la "razón, la nación, la religión, el clima y los materiales" (Viollet-le-Duc, 2004, p. 14) reforzando de paso la identidad de la nación y la conciencia colectiva sobre el patrimonio.

Arte de construir. La arquitectura se compone de dos elementos, la teoría y la práctica. La teoría comprende: el arte propiamente dicho, las reglas inspiradas por el gusto, proveniente de las tradiciones, y la ciencia, que puede ser demostrada por medio de fórmulas invariables, absolutas. La práctica es la aplicación de la teoría a las necesidades; es la práctica la que hace que el arte y la ciencia se plieguen a la naturaleza de los materiales, al clima, a las costumbres de la época, a las necesidades del momento. (Viollet-le-Duc, 1854-68, p. 116) ${ }^{42}$.

${ }^{41}$ Traducción propia del alemán

${ }^{42}$ Traducción propia a partir del facsímil (Viollet-le- Duc, 1854-68)
Con el fin de la tratadística, se abre definitivamente el debate teórico acerca del alcance y los límites de la razón, dando paso, desde distintos enfoques a la posibilidad de que la metodología científica participe en la generación de la arquitectura. Para Rafael Pina, en su tesis de doctorado sobre "El proyecto de Arquitectura" (2004), éste es el núcleo central del debate teórico de la arquitectura moderna por venir:

desde mediados del siglo XVIII, el conjunto de transformaciones de toda índo- 
le: sociales, económicas, políticas, científicas, etc., que de forma vertiginosa afectaron a Europa, tuvo su natural repercusión en la Arquitectura. Posiblemente, la repercusión mayor consistió en la aparición, extensión y paulatino fortalecimiento de la idea de que la nueva arquitectura -la buena arquitectura del futuro- debía de estar alentada por una nueva actitud ética, y producida a través del ejercicio inexcusable de la razón. (Pina, 2004, p. 26)

\subsection{PROYECTO (DISEÑO ${ }^{43}$ ) Y CIENCIA}

La arquitectura, el diseño y las artes en general, deben asumir desde el siglo XIX las exigencias que le imponen las sociedades industriales y los avances científico-tecnológicos. Desde este momento histórico, se hace insostenible que el proyecto de arquitectura, entendido como un proceso racional, se escude en la tradición o se base en la combinatoria de elementos para su configuración. Ya no será posible adoptar modelos sin, al mismo tiempo, revisar críticamente la operación que le da lugar. El tratado es reemplazado por el manifiesto y el ensayo, como soportes de un trabajo teórico comprometido socialmente que se hace cargo de la idea de progreso que inunda todo quehacer creativo y en especial, la arquitectura del siglo XX.

Para Miquel Mallol en Diseño y Realidad (2008) "Si el proyecto es un mandato de civilización, no hay ingenio sin proyecto mediador: ya no hay ingenuidad" (p. 75), como bien comprende Theo Van Doesburg (1883-1931) al declarar que "Nuestra época es hostil a toda especulación subjetiva" [para ello] "necesitamos un método, es decir, un sistema objetivo" (citado por Bann, 1974, p. 117), vale decir, un fundamento científico y técnico.

No es extraño entonces que varios autores (Bonsiepe, 2004; Cross, 2001; Vial, 2015) señalen que el impulso por hacer del diseño una actividad "científica" se remonta a las vanguardias artísticas del siglo XX, en especial al movimiento holandés De Stijl, que tuvo como uno de sus fundadores, justamente a Theo Van Doesburg. Por su parte, en la década de 1920, Le Corbusier ya gozaba de reputación que debía esencialmente a sus artículos, publicados en la revista $L$ 'Esprit Nouveau ${ }^{44}$ y compilados en 1923 en el libro Vers une architecture, donde fundamenta su ideal racionalista, que tiene en la máquina (el avión, el barco, el automóvil, incluso la máquina de escribir) como referente, acuñando la idea de la "casa como una máquina de habitar" (Le Corbusier, 1929, p. 73). "La lección del avión", nos dice el mismo Le Corbusier, "está en línea con la lógica que llevó al enunciado del problema y de su realización" (Le Corbusier, 1929, p. IX), vale decir con el mismo rigor científico que utilizan los ingenieros al diseñar objetos tecnológicos.

Van Doesburg y Le Corbusier visitan la Bauhaus de Weimar en 1921-1922 y 1923 , respectivamente. En 1923 se realiza la exposición de la escuela de diseño, una oportunidad para reflexionar sobre la enseñanza de los métodos de diseño y los métodos mismos. La aplicación explícita en la arquitectura se realiza con Hannes Meyer, el segundo director de esta escuela (1928-30), quien propuso remitir los principios figurativos y los procesos de proyecto a bases científico-teóricas, lo que se estableció como la base metodológica para la educación en arquitectura.

Durante ese mismo período, Richard Buckminster Fuller trató de desarrollar una "ciencia del diseño" que maximizaría los beneficios de un uso mínimo de energía y materiales. Llamó a su concepto de diseño "Dymaxion" (dynamic maximum tensión). En estos hitos inaugurales y en gran parte del Movimiento Moderno, vemos el deseo de producir diseños basados en la objetividad y la racionalidad, es decir, sobre los valores de la ciencia.

Después que la Bauhaus fue cerrada (1933), la mayor parte de sus profesores se
${ }^{43}$ la cultura anglófona ha difundido el término design con cierta equivalencia a proyecto, que tanto en alemán como en es-pañol están claramente diferenciados. Gran parte de los textos citados están escritos originalmente en inglés, por lo que se ha mantenido el termino design o diseño. ${ }^{44}$ Fueron 28 números editados entre 1920 y 1925 que sirvieron de trampolín a Le Corbusier para una verdadera estrategia de auto-promoción. Su casa Citrohan, las Casas-Chalets y su Ciudad Contemporánea de tres millones de habitantes fueron exhibidos en París en el Salón de 1922 y la Bauhaus de Weimar en 1923. 
trasladó a los EE.UU., Gran Bretaña, URRSS y Latinoamérica, pudiendo diseminar la tradición de esta escuela en otras instituciones. Moholy-Nagy se trasladó a los Estados Unidos, donde se convirtió en el director de la "Nueva Bauhaus", que luego dio origen al Instituto de Diseño en el Illinois Institute of Technology en 1949. Gropius fue a Harvard, Hannes Meyer a la Unión Soviética y luego a México. Tibor Weiner, alumno de Meyer en la Bauhaus y luego su colaborador en los planes Quinquenales de la Unión Soviética, viajó a Chile en 1939, donde trabajó como arquitecto y tuvo una importante influencia en la Reforma de 1946 en la Escuela de Arquitectura de la Universidad de Chile, marcado muchas generaciones de profesionales formados bajo el modelo del "arquitecto integral". En esa misma época, Walter Gropius publica un artículo en Estados Unidos donde se pregunta: “¿Existe una ciencia del diseño?” (Gropius, 1962, p. 30) ${ }^{45}$.

La Escuela Superior de Diseño de Ulm (Hochschule für Gestaltung, HfG) funda en 1953, en pleno ambiente de reconstrucción post Segunda Guerra, su proyecto en la tentativa de integrar la ciencia en el diseño, abriendo paso al movimiento, que desde los años 1960 abogaría por el desarrollo de los Métodos de Diseño. Allí, El matemático Horst Rittel empezó a aplicar ideas de cibernética e investigación operativa, el sociólogo Hanno Kesting y el diseñador industrial Bruce Archer se manifestaron a favor de una metodología basada estrictamente en las operaciones matemáticas y estudios analíticos. Otros profesores de la HfG como Otl Aicher ${ }^{46}$, Hans Gugelot, Walter Zeischegg y Tomás Maldonado se resistieron a este desarrollo y defendieron en cambio, que el diseño tenía que ser algo más que un "método de análisis".

\subsection{LOS MÉTODOS DE DISEÑO O PROYECTAR CON MÉTODO}

El interés por los métodos de diseño en la década de 1960, está fuertemente determinado por las consecuencias de la Guerra Fría ${ }^{47}$. En esta época, Estados Unidos hace una importante inversión pública en el desarrollo tecnológico de tres áreas: el armamento, la computación y la carrera espacial (recordemos que la Unión Soviética lanza el Sputnik en 1957 y el Apollo 11 llega a la luna en 1969).

${ }^{45}$ Traducción propia del inglés: "Is There a Science of Design?".

46 Para Aicher "El mundo puede contemplarse [...] como proyecto, esto quiere decir, como producto de una civilización, co-mo un mundo hecho y organizado por seres humanos. El mundo visto así es, incluso con una naturaleza preestablecida, un mundo de proyectos, sin exclusión de los proyectos fallidos" (Aicher, 2001, p.171).

47 Horst Rittel en una entrevista de 1972 declara que el impulso a los métodos de diseño vino de:

The reason for the emergence of design methods in the late "50s and early ' 60 s was the idea that the ways in which the large-scale NASA and military-type technological problems had been approached might profitably be transferred into civilian or other design areas. (Bayazit, 2004, p.17)

Estudiando los datos biográficos de algunos de los pioneros, por ejemplo, Simon, creemos que el impulso fue inverso.

El movimiento de los Métodos de Diseño se desarrolla rápidamente, Iniciado en 1962 en Londres por el coloquio Design Methods, con varias fechas clave que Stéphane Vial (2015) ordena así: en 1964, se crea del primer Departamento de Investigación de Diseño en el Royal College of Art (que adquiere el estatus universitario en 1967) y recibe a Archer; en 1966, se forma la Design Research Society (DRS) en el Reino Unido y en 1967, se da inicio al Design Methods Group and journal (DMG) en la Universidad de California en Berkeley que ayudó a formar Rittel desde 1963.

En esa misma década, el matemático y arquitecto Christopher Alexander obtiene el grado de doctor en 1963 (otorgado por Harvard) con una tesis sobre métodos de diseño titulada Notes on The Synthesis of Form (Ensayo sobre la Sintesis de la Forma), publicado en 1964 con el mismo nombre, donde señala:

Lo mismo que las matemáticas, también la lógica es vista con sospechas por muchos diseñadores. En gran parte se funda esto en diversas supersticiones sobre la clase de fuerza que tiene la lógica al decirnos qué hemos de hacer. Ante todo, la palabra "lógica" goza de cierta vigencia entre los diseñadores como referencia a un tipo de formalismo particularmente desagradable y funcionalmente ineficaz. La supuesta lógica de Jacques François Blondel o de Vignola, por ejemplo, se refería a normas según las cuales podrían combinarse los elementos de estilo arquitectónico. (Alexander, 1976, p. 14)

Las ideas de Alexander fueron revolucionarias en el campo de la investigación 
tanto para arquitectos y diseñadores, como para informáticos. Propone un método para racionalizar la resolución de problemas complejos de diseño, que consiste en descomponer la situación-problema en enunciados específicos a los que se puede aplicar la pregunta ¿cumple o no cumple? (0-1). La idea es que, al representar los requisitos por medio de un esquema, pueda obtenerse un diagrama de la forma. Lo que Alexander llama un "diagrama constructivo, es el puente entre los requisitos y la forma" (Alexander, 1976, p. 89), una representación formal, lógica y funcional al mismo tiempo. Parece de este modo cumplirse el sueño de la arquitectura moderna, que aspiraba a acabar con la arbitrariedad en la generación de la forma, pero en una versión sistémica, que abriga la pretensión de obtener la forma casi mecánicamente ${ }^{48}$. El proyecto como un proceso racional (lógico) necesita el correcto enunciado del problema, ya que, como plantea Alexander, "El arma heurística más poderosa con que puede contar el diseñador es enunciar el problema con tanta claridad que la enunciación misma se convierta en su palanca" (Chermayeff \& Alexander, 1968, p. 115).

Es así como la definición del problema pasa a ser una tarea central para el desarrollo de proyectos. El anexo de la tesis de Christopher Alexander, The Determination of Components for a Indian Village, es un ejemplo que ilustra estas primeras investigaciones, describiendo el uso de métodos matemáticos y una computadora IBM 7090 para diseñar un pueblo de 600 personas en la India. A cada necesidad específica de los aldeanos se asignó un número (del 1 a 141), desde los rituales religiosos hasta las divisiones sociales, las estructuras familiares, el ocio, la agricultura, la ganadería, el empleo, el agua, el transporte, la educación, la salud, la economía y la relación con los desarrollos locales y nacionales. Como valores numéricos, las necesidades del aldeano fueron entonces conectadas como un conjunto de interacciones: una descripción estructural completa del ambiente funcional que contiene el pueblo y su contexto. Para Alexander "La gran potencia y belleza de este sistema, como herramienta analítica para los problemas de diseño, es que sus elementos pueden ser tan variados como sea necesario, y no tienen por qué limitarse a requisitos que puedan expresarse en forma cuantificable" (Alexander, 1973, p. 79) ${ }^{49}$.

Entre 1968 y 1969 se publican tres libros claves que caracterizan la aplicación de lo que llamaremos el proyecto como proceso lógico en nuestro análisis posterior: La Teoría general de los Sistemas (General System Theory; Foundations, Development, Application) de Karl Ludwig von Bertalanffy, Las Ciencias de lo Artificial (The Sciences of Artificial) del economista Herbert A. Simon ${ }^{50}$ y Proyectar con la Naturaleza (Design with Nature) del arquitecto y urbanista lan McHarg.

Si bien la teoría de sistemas se inició como una reflexión desde el campo de la Biología, donde se entiende cada organismo como un sistema abierto, en constante intercambio con otros sistemas circundantes por medio de complejas interacciones, ésta se amplía a otros campos a partir del trabajo publicado por Bertalanffy en 1968. La perspectiva sistémica rechaza la idea de que un determinado fenómeno puede ser comprendido cabalmente de manera analítica, especialmente cuando el objeto de estudio consiste en un fenómeno complejo, vale decir, caracterizado por una significativa interacción entre sus componentes.

La ciencia clásica procuraba aislar los elementos del universo observado compuestos químicos, enzimas, células, sensaciones elementales, individuos en libre competencia y tantas cosas más--, con la esperanza de que, volviéndolos a juntar, conceptual o experimentalmente, resultaría el sistema o totalidad célula, mente, sociedad- y sería inteligible. Ahora hemos aprendido que para comprender no se requieren sólo los elementos sino las relaciones entre ellos -digamos, la interacción enzimática en una célula, el juego de muchos procesos mentales conscientes e inconscientes, la estructura y dinámica de los sistemas sociales, etc.- (...) La teoría general de los sistemas es la exploración científica de 'todos' y 'totalidades' que no hace tanto se consideraban nociones metafísicas que salían de las lindes de la ciencia. (Bertalanffy, 1989, p. XVI)
${ }^{48}$ Esta pretensión de obtener una verdad mecánicamente, es la que ha estado tras la revolución cibernética, las ciencias de la computación y la Inteligencia Artificial, que hoy nos impactan fuertemente en la vida cotidiana.

49 Traducción propia del inglés:

The great power and beauty of the set, as an analytical tool for design problems, is that its elements can be as var-ious as they need be, and do not have to be restricted only to requirements which can be expressed in quantifiable form

${ }^{50}$ Premio Nobel de Economía 1978 
Esta visión implica un cambio de foco de la "parte" como unidad de análisis hacia el "todo", lo cual implica percibir la realidad como un todo integrado e interrelacionado donde las características individuales de cada una de las partes se tornan indistintas mientras la relación entre las partes y los eventos que esas relaciones generan, se vuelven más importantes. Vale aclarar que el enfoque de los sistemas no coincide con el enfoque holístico y no es opuesto al enfoque analítico-reduccionista, por el contrario, se trata de una perspectiva que, ubicándose en el medio de un continuo en el cual el reduccionismo y el holismo son sus extremos, propone la reconciliación de ambos enfoques. Así, a partir del análisis de los componentes básicos de un fenómeno es posible entender y explicar el fenómeno en su totalidad (Bertalanffy, 1989), idea que como vemos en la siguiente cita está influenciada por la Gestalt:

Lo mismo pasa hasta con los objetos de nuestro mundo cotidiano, que en modo alguno son sencillamente "datos" como datos sensoriales o simples percepciones, sino que en realidad están construidos con innumerables factores "mentales" que van de la dinámica gestáltica y los procesos de aprendizaje a los factores culturales y lingüísticos que determinan en gran medida lo que de hecho "vemos" o percibimos. (Bertalanffy, 1989, p. XVI)

Helbert A. Simon, de Carnegie Mellon University, fue invitado ese mismo año al MIT (Massachusetts Institute of Technology) para dictar una serie de charlas a ingenieros, diseñadores y arquitectos. En base a su investigación sobre la toma de decisiones, su experiencia en la industria y en investigaciones de Inteligencia artificial, plantea que esta última podría elevar el diseño al estatus de una práctica científica, basada en la investigación, y proporcionar una base pedagógica "intelectualmente dura, analítica, formalizable y enseñable" (Simon, 1996, p. 112).

La publicación en 1968 de su libro Las Ciencias del Artificial -que incluye en el capítulo 5 Las Ciencias del Diseño-, despertó gran entusiasmo en la entonces enorme comunidad de investigación del diseño. El modelo de Simon opera dentro de un marco cerrado, un sistema abstracto que es controlado y manipulado por un profesional "solucionador de problemas" (Simon, 1996, p. 86), libre de juicio y experiencia humana. En esta perspectiva, el modelo requiere definir todos los aspectos del proceso en términos de información cuantificable y codificable. Sin embargo, en un trabajo posterior, sugiere que algunos problemas de diseño pueden ser "mal estructurados", en este caso el "solucionador de problemas" no es adecuado, sin embargo -insiste-, el problema podría ser dividido en sub-problemas bien estructurados, solucionables por un programa. Es el caso del diseño arquitectónico complejo y la planificación ${ }^{51}$.

Para Daniel J. Huppatz (2015), uno de los aportes de Simon, es haber de algún modo legitimado, a través de su modelo, la investigación en diseño en el sistema de investigación académica de la posguerra. Este cambio de práctica difundido hasta hoy en "laboratorios de proyecto" o "laboratorios de diseño" supuso una nueva cultura de prácticas científicas, esquemas conceptuales, metodologías y medios incorporados a las investigación y práctica del "nuevo diseñador", irónicamente modelado bajo un experto científico. Con este cambio, la creación se

51 "La Ciencia de lo artificial" de Simon, ignora la investigación temprana de Alexander, que ya había intentado y abandona-do un enfoque riguroso de resolución de problemas, no es el caso de Rittel, quién había trabajado junto a Alexander en Berkeley.

52 El libro se publicó recién en 1979 en francés y el año 2000 en español, lo que podría explicar su tardío descubrimiento fuera de Estados Unidos.

${ }^{53}$ Salvo más tarde por Christopher Alexan- relega al reino de lo artesanal-artístico, ya que para Simon, "resolver un problema simplemente significa representarlo para hacer la solución transparente" (Simon, 1968, p. 132).

Por otro lado, junto con plantear los problemas de diseño como "complejos"para los cuales es imposible encontrar soluciones exactas, y al mismo tiempo, cada solución propuesta genera nuevos problemas a resolver-, Introdujo la idea de "soluciones satisfactorias" o apropiadas, primero aplicables al ámbito de la economía para luego extender esta teoría al campo de lo artificial, entendido como todo lo hecho por el hombre, desde los modelos económicos a los objetos (Simon, 1968). 
Con pocos meses de diferencia, lan McHarg publica en 1969 Proyectar con la Naturaleza, un texto capital para el desarrollo de la arquitectura del paisaje, especialmente en Estados Unidos ${ }^{52}$, pero que sin embargo es prácticamente obviado en las historias de la investigación y metodología de diseño ${ }^{53}$. El libro que posee un carácter didáctico, proponiendo un modelo para el planeamiento, centrado en el entendimiento ecológico del territorio como alternativa a los planes basados en la composición urbana. Junto a su investigación, McHarg tuvo un importante desempeño en la práctica, la academia y la divulgación. Fue el fundador del Departamento de Arquitectura del Paisaje y Planeamiento regional de la Universidad de Pensilvania, formando la escuela norteamericana del paisaje, donde posteriormente se destacarán Charles Waldheim y James Corner, entre otros.

El método propuesto por McHarg consiste en el levantamiento del terreno, separando en el momento de dibujar los distintos estratos (overlay-mapping) que, al superponerse a una misma escala, forman una torta (layer cake) que permite analizar la correspondencia de elementos que, según McHarg, revelarían las capacidades que están en potencia en el sitio, como también sus restricciones.

Los estratos del layer cake, superponen las características climáticas, la topografía, los tipos de suelo, la hidrografía, la vegetación, la fauna, la geología, la vialidad, los usos, etc.

Normalmente, los mapas de usos del suelo e incluso, las propuestas de ordenación, muestran categorías de uso amplias. Los mapas de este estudio se asemejan más a mosaicos que a carteles... por buenas razones. Son el resultado de pedir al terreno que manifieste aquellos atributos discretos que, al superponerse, revelen una gran complejidad. Pero ésta es la verdadera complejidad de la oportunidad y la limitación. Aun así, nos pueden parecer caóticos, pero es sólo porque estamos acostumbrados a la seca regularidad de la zonificación, porque no estamos acostumbrados a percibir la verdadera diversidad del entorno, ni a responder a ella en nuestros planes. (McHarg, 2000, p. 115)

Esta metodología ha sido la precursora de los sistemas evaluación ambiental, al establecer sobre mapas la capacidad de albergar distintos usos, integrando la escala regional-ecológica a la planificación. La crítica a este método, se funda en la poca valoración de aspectos sociales, culturales y económicos dentro del mapeo. Para García y Borobio, el "método se muestra insuficiente cuando se quiere acometer el análisis no sólo de lo urbanizado, sino de lo que podíamos denominar el territorio humanizado y que, especialmente en el continente europeo, supone grandes extensiones de territorio" (2012, p. 116). De hecho, McHarg establece una relación directa entre los valores sociales y los procesos naturales, pero no jerarquiza lo cultural o lo identitario. El uso social, sería una resultante "emergente" del sistema. Sin embargo, defiende el valor de uso del suelo sobre su valor de cambio, rechazando la concepción del suelo como mercancía:

El determinismo económico como una forma de evaluación imperfecta del mundo biofísico es sólo una de las consecuencias de nuestro legado ${ }^{54}$. Una deficiencia aún más seria es la actitud hacia la naturaleza y hacia el hombre, que emana de la misma fuente, y de la que nuestro modelo económico no es sino una de sus manifestaciones. (McHarg, 2000, p. 25)

Sin duda un logro importante de McHarg es haber podido articular el proyecto y la planificación con la naciente ciencia de ecología, encuentro, que como veremos en el capítulo 4 ha sido difícil de llevar adelante en Europa y Latinoamérica. Es posible, que el ambiente cultural de fines de la década de 1960 en Estados Unidos permitiera un diálogo más libre entre disciplinas y una nueva sensibilidad frente a la naturaleza. A los tres textos antes citados podemos sumar el trabajo de Nicholas Georgescu-Roegen sobre Economía Ecológica (en La ley de la entropía
54 El autor se refiere al legado occidental judeocristiano.

55 Esta posición es desarrollada más tarde, por Herman Daly (1995) en su crítica al desarrollo sustentable. Este autor plantea que los recursos naturales se transforman a través de la mano de obra y los procesos industriales, en productos y en residuos. Los productos son usados y en su consumo, producen más desechos. El capital resultante no puede sustituir los recursos naturales que le dieron origen. Es tan absurdo como pensar que "se puede construir la misma casa con la mitad de la madera, sin importar cuantos serruchos y carpinteros se intente sustituir" (Daly, 1995, p. 51)

56 Este ensayo fue preparado como ponencia del autor para la Conferencia de la Fundación Wenner-Gren sobre Efectos del propósito consciente en la adaptación humana. El autor fue presidente de esta conferencia, que se celebró en Burg Wartenstein, Austria, del 17 al 24 de julio de 1968. Los procedimientos de la conferencia fueron publicados por Knopf \& Co. bajo el título Nuestra propia metáfora, editado por su hija, Mary Catherine Bateson. 
y el proceso económico de 1971), donde se analizan impactos ambientales de la economía humana ${ }^{55}$, y en el campo de la antropología y epistemología, los aportes de Gregory Bateson, quién en Our own methaphor ${ }^{56}$, proporciona un acercamiento a la cuestión básica de si los humanos, con sus tecnologías cada vez más potentes, destruirán en última instancia el entorno del que dependen 0 demuestran la capacidad de un nuevo nivel de adaptación. El discurso de Bateson sugiere que cualquier solución a los innumerables problemas del mundo debe basarse en una comprensión empática de los sistemas, desde la ecología hasta amor en las interrelaciones familiares, por lo tanto, aparece "el papel de la conciencia en el proceso continuo de adaptación humana" (Bateson, 1987, p. 447). En su análisis se considerarán tres sistemas cibernéticos o homeostáticos: el organismo humano individual, la sociedad humana y el ecosistema más grande. La conciencia y el propósito se considerarán componentes esenciales en el acoplamiento de estos sistemas, ya que como sintetiza Guido Lagos:

Bateson buscará siempre generar relaciones nuevas entre los fenómenos y procesos que analiza. No observa "objetos" aislados, su mirada está constantemente dirigida a las relaciones entre ellos para así poder establecer conexiones nuevas entre lo que él observa. Se trata siempre de construir puentes nuevos; esas nuevas relaciones establecidas son sus "pautas (patterns) que conectan", en la nomenclatura que él mismo nos propone. (Lagos, 2004, p. 4).

También reivindica el papel de la poesía, que entiende como un conjunto de relaciones, como un dispositivo capaz de vincular y cartografiar la diversidad de la experiencia humana, a la que de otro modo no tendríamos acceso. Bateson nos dice que "necesitamos la poesía como conocimiento sobre el mundo y sobre nosotros mismos" (Bateson, 1998, p. 288).

La influencia de estos pensadores puede detectarse en Christopher Alexander, quien en términos de arquitectura habla de sociedades autoconscientes y no conscientes de sí mismas, diciendo que una sociedad no consciente toma la vivienda por un procedimiento esencialmente homeostático, que continuamente se prueba como adaptativo en el ambiente. Del mismo modo, en A Pattern Language (Un Lenguaje de Patrones) de 1977, identifica al patrón número 4 -Valles agrícolas- como eco de las ideas fundamentales sobre el territorio expuestas por McHarg. En la versión sintética de Alexander (quien cita a McHarg) señala: "La tierra mejor para la agricultura suele ser también la mejor para la edificación. Pero su cantidad es limitada y, una vez destruida, no puede recuperarse durante siglos", por tanto "preserve todos los valles agrícolas como tierra de cultivo y proteja estos terrenos de cualquier urbanización que destruya o ponga bajo llave la fertilidad única del suelo" (Alexander, 1980, p. 51). Esta frase muestra un cambio radical de enfoque que intentaremos explicar:

En la década de 1970 surgió una reacción contra la metodología del diseño y un rechazo de sus valores subyacentes, especialmente en algunos de los pioneros del movimiento. Los resultados no habían sido satisfactorios, en parte porque la definición de los problemas, los objetivos y la aplicación, habían estado formuladas por los mismos diseñadores y científicos, lo que causó excesiva parcialidad y rigidez en la forma de tomar las decisiones.

Traducción propia del inglés: "I've disassociated myself from the field... There is so little in what is called "design methods" that has anything useful to say about how to design buildings that I never even read the literature anymore... I would say for-get it, forget the whole thing".

58 "In the 1970s I reacted against design methods. I dislike the machine language, the behaviourism, the continual attempt to fix the whole of life into a logical framework". Jones J.C. (1977) How my Thoughts about Design Methods Have Changed during the Years. Design Methods and Theories $N^{0}$ 11(1) pp $48-62$

Christopher Alexander, que había trabajado para conseguir un método racional para la arquitectura y la planificación (1964), declara en 1971: "Me he disociado del campo ... ya no leo nunca sobre cómo diseñar edificios... diría que lo olviden, que se olviden de todo "(Alexander, 1971, p. 5) ${ }^{57}$. Al otro lado del Atlántico, J. Christopher Jones también reniega: "En la década de 1970 reaccioné contra los métodos de diseño. Me disgusta el lenguaje de máquina, el conductismo, el intento continuo de fijar toda la vida en un marco lógico "(1977, p. 49) ${ }^{58}$.

Para poner en contexto las citas de Alexander y Jones, puede ser necesario 
recordar el clima social y cultural de finales de los años sesenta: las revoluciones universitarias de mayo del 68 y la radicalización de los movimientos políticos, el hipismo, el nuevo humanismo liberal, y la Guerra de Vietnam. Pero también tuvo que ver con la falta de éxito en la aplicación de los métodos "científicos" en la práctica cotidiana del proyecto.

Alexander, junto con sus colegas del Center for Environmental Structure de Berkeley, publica en la década siguiente una trilogía de libros: The Timeless Way of Building (1979), A Pattern Language (1977), y The Oregon Experiment (1975) ${ }^{59}$, centrados en la teoría de que las personas pueden y deben retomar el diseño y la construcción de sus ciudades. Al proponer una gramática de patrones comprensible, Alexander piensa que, cuando construimos una cosa, podemos "también reparar ${ }^{60}$ el medio que nos rodea, y ella misma, así el ambiente total de un lugar se volverá más coherente y más completo" (Alexander, 1977, p. xiii).

En la práctica, esta nueva perspectiva ha tenido como consecuencia la progresiva incorporación del usuario en los procesos de diseño, que ha evolucionado desde la estrategia de la "consulta" a la participación activa de los actores sociales en la identificación de los objetivos y la toma de decisiones. Pero la participación sumó nuevos desafíos, ya que el éxito de estos procesos depende de las relaciones entre los participantes y exigió la incorporación de otras disciplinas al proyecto, como la sociología, las ciencias políticas, antropología, geografía, etc. Este ha sido el aspecto más crítico, donde las teorías participativas se encontraron con más dificultades, especialmente en problemas de gran escala. Los procesos de diseño participativo dieron origen al environmental design, que es la comprensión de las correlaciones entre las personas, sus medios construidos y sus medios naturales. Desde este punto de vista, puede explicarse también, por qué el concepto de paisaje y las habilidades desarrolladas paralelamente por los diseñadores paisajistas suscitan hoy interés, especialmente los proyectos de escala territorial donde la definición del problema representa una de las mayores dificultades. Este punto de vista es tomado como central en Dilemmas in a General Theory of Planning, publicado en 1973, por Horst Rittel y Melvin M. Webber, orientando el foco desde el método a la precisión del problema. Detectan que los problemas de planificación social no se prestan a la lógica analítica y lineal de la ingeniería y la ciencia, debido a la naturaleza del problema más que a la lógica de su resolución, caracterizándolos como problemas perversos (wicked problems) en contraposición con los problemas mansos (tame problems).

Estos problemas, que son típicamente (pero no sólo) los del arquitecto o diseñador, tendrían para estos autores las siguientes propiedades: ${ }^{61}$

1. No hay una formulación definitiva de un problema perverso. La información necesaria para comprender el problema depende de la idea que se tenga de la solución.

2. Los problemas perversos no tienen una regla de detención.

3. Las soluciones a los problemas perversos no son verdaderas o falsas, sino buenas o malas.

3. No hay una prueba inmediata y/o definitiva de una solución a un problema perverso.

4. Cada solución a un problema perverso es una "operación de un disparo"; porque no hay oportunidad de aprender por ensayo y error, cada intento cuenta significativamente.

5. Los problemas perversos no tienen un conjunto enumerable (o exhaustivamente descriptible) de soluciones potenciales, ni hay un conjunto bien descrito de operaciones permisibles que puedan ser incorporadas en el plan.

6. Cada problema perverso es esencialmente único.

7. Cada problema perverso puede ser considerado como un síntoma de otro problema.

8. La existencia de una discrepancia que representa un problema perverso se
59 Conocido en español como Urbanismo y Participación.

60 Utilizo aquí la cita traducida del inglés, ya que en la versión en español desaparece la palabra "reparar", que resulta im-portante, pues supone que aunque las cosas no son perfectas, tampoco están desamparadas. Traducción propia del inglés: "also repair the world around it, and within it, so that the larger world at that one place becomes more coherent, and more whole." ${ }^{61}$ Más tarde Jeff Conklin (2005) generalizó el concepto y resumió en seis las características antes señaladas como definito-rias: 1. Usted no entiende el problema hasta que haya desarrollado una solución. Cada solución que se ofrece expone nue-vos aspectos del problema, requiriendo ajustes adicionales a las soluciones potenciales. 2 . No hay una regla de detención. Dado que no existe un problema definitivo, tampoco existe una solución definitiva. El proceso de resolución de problemas termina cuando se agotan los recursos, como el tiempo, el dinero o la energía, no cuando surge una solución óptima. 3. Las soluciones no están bien o mal. Son simplemente "mejor / peor" o "lo suficientemente bueno / no lo suficientemente bueno". La determinación de la solución no es objetiva, y no puede derivarse de seguir una fórmula. 4. Cada uno es esencialmente único y novedoso. Nunca dos problemas perversos son iguales, y las soluciones a ellos serán siempre diseñadas como un caso particular. Con el tiempo podemos adquirir sabiduría y experiencia sobre el enfoque de problemas perversos, pero uno es siempre un principiante en los detalles de un nuevo encargo. 5. Cada solución es una operación de un solo disparo. Ca-da intento tiene consecuencias: no se puede aprender sobre el problema sin tratar de dar soluciones. 6 . No hay ninguna so-lución alternativa dada. Se pueden idear una serie de soluciones potenciales. Por lo tanto, es una cuestión de creatividad encontrar las soluciones potenciales, y una cuestión de juicio para determinar cuál debe ser elegida e implementada 
${ }^{62}$ Reconociendo esto, Rittel y Kunz desarrollaron una técnica llamada Sistema de Información Basada en Problemas (IBIS), que facilita la documentación de la justificación detrás de una decisión de grupo de una manera objetiva.

${ }^{63}$ La Hochschule für Gestaltung ( $\mathrm{HfG}$ ) - Escuela Superior de Diseño de UIm, Alemania, se convertiría hacia los años sesen-ta en un referente en el campo del diseño a nivel mundial y, luego de su disolución en 1968, irradiaría, gracias a la migración de sus docentes, su modelo de trabajo a diversos países y especialmente a Latinoamérica. Su influencia en el Cono Sur se-ría fundamental para el desarrollo del diseño industrial de la mano de los planes de "desarrollo hacia adentro" que buscaban fortalecer la industria nacional.

64 Con fecha 26 de agosto de 1970, se reconoció por decreto oficial de la Universidad de Chile el título profesional de Dise-ñador (Castillo Espinoza, 2010). puede explicar de muchas maneras.

9. La elección de la explicación (o solución) determina la naturaleza de la resolución del problema.

10. El planificador no tiene derecho a equivocarse (es decir, los planificadores son responsables de las consecuencias de las acciones que generan). (Rittel \& Webber, 1973, pp. 161-167)

Si bien estos autores acuñaron el término "problemas perversos" en el contexto de la política social, su conceptualización se aplica a cualquier dominio que involucre a las partes interesadas con diferentes perspectivas ${ }^{62}$. Los problemas de diseño están entre ellos y un muy buen ejemplo son los proyectos territoriales de gran escala. Si repasamos las propiedades de estos problemas perversos, podríamos decir que en el diseño de un parque de 1.000 ha en la periferia de una ciudad (que es el que tenemos entre manos), efectivamente las partes interesadas tienen opiniones de mundo radicalmente diferentes y marcos diferentes para entender el problema; que las limitaciones a las que está sometido el proyecto y los recursos necesarios para resolverlo cambian con el tiempo; que es fundamentalmente único y puede ser explicado y resuelto de muchas maneras distintas; no implican soluciones del tipo verdadero o falso, sino del tipo "mejor o peor"; La solución depende de cómo se encuadre el problema y viceversa (es decir, la definición del problema depende de la solución) y estas soluciones, que no pueden ser descritas exhaustivamente, siempre tienen una serie de consecuencias que alteran el problema y requieren nuevas soluciones.

Por esta razón, Rittel (1972) insistirá en la necesidad de diálogo entre un gran número de actores en un proyecto, con la esperanza de domar estos problemas y desarrollar conocimiento, a través de nuevos investigadores que este mismo autor denomina como segunda generación de investigadores en diseño que harán participar en los proyectos a las partes interesadas, convirtiéndolos en los verdaderos "dueños del problema" como plantea Nigel Cross (2007) o en las "teorías de los actores centrados en el proyecto" de Findeli y Bousbaci (2005).

Posiblemente en este relato faltaría profundizar en otros autores, como también en la relación entre los métodos de diseño y las obras producidas en esta época, sin embargo, recordemos que nuestro objetivo es comprender cómo se han relacionado teoría y práctica, la investigación y el proyecto.

Este recorrido histórico nos permite afirmar que a partir de la década de 1970 los Métodos de Diseño han abolido una ilusión: la idea romántica de que el proceso de diseño es un proceso creativo basado esencialmente en la intuición solitaria de un diseñador-artista inspirado, como el mismo Rittel dice:

Primero, el acto del diseño no es un flujo incesante de acontecimientos creativos; es un trabajo altamente organizado y estructurado, que es ocasionalmente interrumpido por ideas e intuiciones repentinas. En segundo lugar, no se puede suponer que estos raros "eventos creativos" son necesariamente misteriosos y más allá de la comprensión. (Rittel, 1971, p. 1)

Una pérdida de la inocencia que también se vive en Latinoamérica. En el caso de Chile, en la década de 1970, se vive un proceso político y social que dará a la idea del proyecto un impulso singular. Lo que se ha llamado "la planificación de la cultura material" (Palmarola, 2002) del primer gobierno marxista elegido democráticamente (1970), el de Salvador Allende, que plasmaría en numerosos proyectos de diseño industrial una primera aproximación hacia las nuevas relaciones propuestas sobre la producción, consumo y uso de los productos industriales.

Una influencia indiscutible en este proceso está dada por la HfG ${ }^{63}$ de Ulm a través de Gui Bonsiepe, que ya había llegado a Chile en 1968 contratado por la OIT a petición del estado chileno para asesorar a la Corporación de Fomento 
de la Producción (CORFO). Con su arribo se inaugura un cambio determinante en el discurso y la práctica del diseño y la arquitectura nacional. Participa en las reformas universitarias de $1969^{64}$, lo que se verá plasmado en el abordaje multidisciplinario y multiprofesional de dos proyectos: el del edificio para la UNCTAD III y el Parque O'Higgins, éste último bajo el modelo del parque popular y que analizaremos en mayor profundidad en el capítulo 5. Todos ellos fueron un intento de orientar el desarrollo industrial a las demandas sociales, redefiniendo el rol de los arquitectos y diseñadores, como actores de cambio. Parte de esto fue la revolucionaria introducción de la cibernética a través de la contratación de un pionero en esta disciplina, Stafford Beer, quien tenía el objetivo de implementar un sistema de control de todas las empresas del estado, el proyecto SYNCO. E modelo estaba basado en el Enfoque de Sistemas Viables (VSA, sigla en inglés), heredero de la teoría de sistemas de von Bertalanffy. La teoría consistía en que las entidades observadas (organizaciones) y sus entornos eran interpretados desde una perspectiva sistémica, comenzando por el análisis de los elementos fundamentales y finalizando con el análisis de sistemas interrelacionados de mayor complejidad. El modelo estaba basado en la estructura de funcionamiento del sistema nervioso, como sistema de información y toma de decisiones. Dicha aproximación sistémica se vería fuertemente influenciada por la teoría de la autopoiesis, sobre la organización de los seres vivos de Francisco Varela y Humberto Maturana, como aporte a las formas de funcionamiento y viabilidad de los sistemas complejos e incorporada por Beer en su libro Brain of the Firm de 1972.

La teoría de la autopoiesis que había sido enunciada por los biólogos chilenos Varela y Maturana en 1970 y publicada en 1973 en De máquinas y seres vivos, autopoiesis de la organización de lo vivo, sostiene que todo organismo personifica un proceso continuo de auto-organización, autorregulación y manifestación.

De acuerdo a Maturana y Varela, los organismos vivos son auto-producidos, es decir, en contraposición a las teorías que entienden a los organismos como generadores de "algo" diferente a ellos mismos, la autopoiesis propone que los organismos vivos son simultáneamente productores y productos (Maturana y Varela, 1980). Un sistema autopoiético es entonces, un sistema organizado en base a una red de procesos que finalmente producen al sistema en sí mismo.

Para Maturana y Varela, el lenguaje, el pensamiento abstracto, la reflexión o la racionalidad no son características de la fisiología humana o de las funciones exclusivas de un cuerpo, sino fenómenos socio-históricos. Asimismo, en vez de otorgarle importancia a los objetos, ellos proponen enfatizar las relaciones, entendiendo que las relaciones son indivisibles del proceso que constituye un sistema. Si llevamos estas ideas al campo de la arquitectura ${ }^{65}$, podríamos aventurar que los productos del diseño y los procesos de diseño están íntimamente conectados entre sí, y están conectados también al contexto en el cual operan.

El proyecto visto como un proceso autopoiético propone que la relación entre el espacio de la solución y el espacio del problema, se entendería como un fenómeno de autorregulación, como un proceso de continuo "ajuste" entre problema y solución que finalmente posibilita la manifestación temporal de estructuras físicas. Es precisamente de esta manera, que podemos entender el proceso de diseño fundamentalmente como un proceso de transformación y evolución y no simplemente como un proceso de re-aplicación de soluciones. La influencia de esta teoría ha sido reconocida por muchos autores, especialmente sociólogo alemán Niklas Luhmann, sin embargo, en Chile prácticamente se diluyó ${ }^{6}$.

La historia en Chile se vio dramáticamente truncada en 1973 con el golpe militar y la dictadura que se impondría hasta 1990. Junto con la represión que eliminó la oposición política, el régimen militar instituyó una política económica basada en los principios neoliberales. Este modelo sustituyó la insipiente Industrialización
${ }^{65}$ La aplicación de la Autopoiesis fuera del campo de la Biología ha sido controvertida, el mismo Varela no estaba de acuerdo con extenderla indiscriminadamente a niveles superiores, si embargo afirma que "el ligar la autopoiesis como una op-ción epistemológica más allá de la vida celular, al operar del sistema nervioso y de los fundamentos de la comunicación hu-mana, es claramente fructífero" (Maturana y Varela, 2003, p. 52).

66 Su aplicación se ha mantenido en el campo de la biología y extendido a la psicología por Maturana a través de su "terapia conversacional".

67 La dictadura produjo grandes transformaciones culturales que han dado como resultado la desigualdad y la segregación social y espacial, la instalación del consumo como vínculo social y una profundización del individualismo. Fueron años donde el debate intelectual no sólo estuvo inhibido, sino prohibido, y las disciplinas se replegaron a sus nichos estancos. La adop-ción de una posmodernidad "copiada" en los 80, no produjo obras relevantes, salvo pocas excepciones, tampoco investiga-ción en arquitectura. 
por Sustitución de Importaciones (ISI) que había dado impulso al diseño, por uno donde el mercado pasaría a ser determinante, no solo en cuestiones económicas sino, en aspectos sociales y culturales ${ }^{67}$. En la versión radical del neoliberalismo chileno, el Estado deja de ser garante del bienestar colectivo, entregando al mercado la educación, la salud, las pensiones, la vivienda y la planificación territorial, incluida la ciudad. Abarcando todas las escalas de la vida colectiva. En este contexto, los procesos liderados por Bonsiepe y su grupo desaparecen.

Para la investigadora Carmen Cabrera (2016) "la experiencia del Golpe Militar en Chile, había mostrado a Bonsiepe y su equipo, que el diseño social en Latinoamérica tenía una connotación subversiva [...] y que si no había apoyo estatal, era poco lo que había por hacer" (Cabrera, 2016, p. 46). La modernidad pensada desde la periferia ${ }^{68}$, desde Latinoamérica, desde Chile, enfrenta a Bonsiepe con una realidad política y social muy diferente a la de los países desarrollados. La incipiente industrialización y fragilidad de democracia hacen patente que la perspectiva científica en el diseño será un aporte sólo si se pone al servicio de las necesidades sociales y se sitúa en el contexto político, e integra la cultura. El potencial emancipador del racionalismo y de los métodos de diseño se ponen de este modo en jaque. Estas ideas, surgidas desde la experiencia en Chile fueron luego publicadas en Italia, en el libro Teoría y Práctica del Diseño Industrial (1975) y más tarde en Diseño y Crisis (2012). En este último texto, Bonsiepe resitúa el proyecto al afirmar que "las ciencias enfrentan al mundo desde la perspectiva de la cognición, mientras que las disciplinas del diseño lo encaran desde el punto de vista de la proyectualidad" (2012, p. 223), vale decir, desde la pretensión de transformar la realidad.

\subsection{PROYECTO Y COMPLEJIDAD}

Desde Bertalanffy hemos visto aparecer término complejidad, que es una "palabra problema" más que una "palabra solución", como señala Edgar Morin (2005), quien nos relata su propia aproximación a ella:

Desde mis primeros libros he afrontado a la complejidad, que se transformó en el denominador común de tantos trabajos diversos que a muchos le parecieron dispersos. Pero la palabra complejidad no venía a mi mente, hizo falta que lo hiciera, a fines de los años 1960, vehiculizada por la Teoría de la Información, la Cibernética, la Teoría de Sistemas, el concepto de auto-organización, para que emergiera bajo mi pluma o, mejor dicho, en mi máquina de escribir. Se liberó entonces de su sentido banal (complicación, confusión), para reunir en sí orden, desorden y organización y, en el seno de la organización, lo uno y lo diverso; esas nociones han trabajado las unas con las otras, de manera a la vez complementaria y antagonista; se han puesto en interacción y en constelación. El concepto de complejidad se ha formado, agrandado, extendido sus ramificaciones, pasado de la periferia al centro de mi meta, devino un macro-concepto, lugar crucial de interrogantes, ligando en sí mismo, de allí en más, al nudo gordiano del problema de las relaciones entre lo empírico, lo lógico, y lo racional. Ese proceso coincide con la gestación de El Método, que comienza en 1970. (Morin, 2005, pp. 23-24)

Para Morin, la complejidad "aparece allí donde el pensamiento simplificador falla, pero integra en sí misma todo aquello que pone orden, claridad, distinción, precisión en el conocimiento" (2005, p. 22). Vivimos bajo el imperio de los principios de disyunción, reducción y abstracción, cuyo conjunto constituye lo que llama el "paradigma de simplificación". El pensamiento simplificador desintegra la "complejidad de lo real", mientras que el pensamiento complejo se presenta como una alternativa que integra los modos simplificadores, esquivando sus consecuencias

"mutilantes, reduccionistas, unidimensionalizantes" (p. 22) y nos invita a mirar con más atención el "tejido de eventos, acciones, interacciones, retroacciones, determinaciones, azares, que constituyen nuestro mundo fenoménico" (p. 32). 
Propone al mismo tiempo, tres principios que pueden ayudar a pensar la complejidad de lo real: el primero es el principio dialógico que se contrapone al principio dialéctico y nos permite mantener la dualidad en el seno de la unidad, asocia dos términos que a la vez son complementarios y antagonistas. Llevado a nuestro ámbito podemos referirnos a las clásicas tensiones entre lo privado y lo público, lo natural y lo artificial, la razón y la percepción, etc.

El segundo principio es el de recursividad organizacional. "Un proceso recursivo es aquél en el cual los productos y los efectos son, al mismo tiempo, causas y productores de aquello que los produce" (Morin, 2005, p. 106). Excediendo así la rígida simetría entre causa y efecto ${ }^{69}$, lo que ilustra con el ejemplo de la naturaleza que engendra cultura y en contrapartida, la cultura modifica la naturaleza, a la que podríamos sumar la relación entre forma y función: la función puede engendrar la forma y ésta a la vez modificar la función o el uso.

Por último, el tercer principio es el principio hologramático ${ }^{70}$ que trasciende al reduccionismo que no ve más que las partes, y al holismo que no ve más que el todo. Para ilustrarlo cita a Pascal: "No puedo concebir al todo sin concebir a las partes y no puedo concebir a las partes al todo sin concebir al todo" (p. 107). Esta idea aparentemente paradójica, nos arranca del análisis lineal de la realidad y nos obliga a mover nuestro punto de vista, en un ejercicio que podríamos llamar multiescalar. De allí que la idea hologramática esté ligada, a la idea recursiva que está, ella misma, ligada a la idea dialógica. El todo está en la parte que está en el todo. La experiencia de diseño, especialmente palpable en el diseño del paisaje, nos enfrenta continuamente a aplicar este principio hologramático o multiescalar, a ser conscientes que decisiones macro, tienen siempre consecuencias en la meso y micro escala; un detalle puede también alterar la percepción del paisaje. Una decisión local en el tratamiento de las aguas, puede provocar una reconfiguración de los afluentes o bien dramáticamente una inundación.

Morin aconseja pensar complejamente como una acción cotidiana y considerar que cada acción es una apuesta, que tiene que lidiar con elementos aleatorios, azar, iniciativa, decisión, conciencia de las derivas y de las transformaciones. La acción también es estrategia, ya que no siempre podemos actuar bajo un programa predeterminado:

La estrategia permite, a partir de una decisión inicial, imaginar un cierto número de escenarios para la acción, escenarios que podrán ser modificados según las informaciones que nos lleguen en el curso de la acción y según los elementos aleatorios que sobrevendrán y perturbarán la acción. (Morin, 2005, p. 113)

Para las secuencias que se sitúan en un ambiente estable, conviene utilizar programas, la conducción automática es posible, pero cuando aparece lo inesperado o lo incierto, cuando tenemos un problema importante que resolver, la estrategia se impone. La estrategia nos obliga a estar vigilantes y a innovar. De este modo, el pensamiento complejo nos recuerda -es una ayuda de memoria- "No olvides que la realidad es cambiante, no olvides que lo nuevo puede surgir $y$, de todos modos, va a surgir" (Morin, 2005, p. 118). El pensamiento complejo de Morin nos permite así concebir los procesos de planificación como procesos participativos, transdisciplinares y multiescalares ${ }^{71}$.

Al aplicar esta interpretación al proyecto, puede vincularse con investigaciones más recientes de Nigel Cross y Kees Dorst, quienes intentaron integrar los avances en el área del modelamiento computacional al paradigma del "diseño como práctica reflexiva", heredera del trabajo que Donald Schön desarrolla en el libro $E l$ Profesional Reflexivo de 1983. Schön defendía una visión menos positivista, que denomina "practica reflexiva". Con esto quiere representar "una epistemología de la práctica, ya que está implícito en el proceso intuitivo y artístico, donde algunos profesionales se involucran en situaciones de incertidumbre, inestabilidad, singu-
La idea recursiva es, entonces, una idea que rompe con la idea lineal de causalefecto, de producto/productor, de estruc-tura/superestructura, porque todo lo que es producido reentra sobre aquello que lo ha producido en un ciclo en sí mismo autoconstitutivo, auto-organizador, y autoproductor.

70 En un holograma físico, el menor punto de la imagen del holograma contiene la casi totalidad de la información del objeto representado. No solamente la parte está en el todo, sino que el todo está en la parte. 71 Junto a la participación de varias disciplinas, la idea de complejidad hace patente la variedad de elemento involucrados en la realidad y sobre todo la relación entre los elementos de un sistema, sus "interacciones dinámicas" a diferentes escalas. Mientras bajo el microscopio podemos analizar y pensar lo pequeño, a través de las imágenes satelitales (macroscopio) comprendemos lo extenso y múltiple. Este enfoque sistémico complementa las metodologías analíticas tradicionales que tie-nen su foco en la comprensión de los elementos, para ampliarla a la relación entre ellos, permitiendo al mismo tiempo incor-porar la visión de distintas disciplinas. 
laridad y conflicto de valores" (Cross, 2001, pp. 53-54). ya no se trataría entonces de suplantar los métodos de los diseñadores mediante métodos científicos que se consideran superiores en nombre la ciencia ("diseño como ciencia"), sino de confiar en las habilidades específicas y únicas que poseen los profesionales del diseño y tratar de explicarlo científicamente (Vial,2015).

Esta nueva tendencia encarnada por Cross, rechaza el modelo de diseño como ciencia, pero mantiene la idea de que el diseño puede ser objeto de investigación científica. Más bien, defiende el modelo de una ciencia del diseño, considerándolo como un conjunto de disciplinas sobre "el estudio de los principios, prácticas y procesos de diseño" para entender "cómo los diseñadores piensan y trabajan" (2001, p. 53). Este ideal, coincidimos con Cross, es ciertamente desafiante, ya que contempla el diseño como un cruce de artes, ciencias y tecnologías, reuniendo a todos los que estudian el mundo artificial. "Aquí es donde reside el esfuerzo epistemológico y paradójico de la investigación del diseño [nosotros diremos del proyecto]: crear una 'disciplina interdisciplinaria"' (Cross, 2007, p. 96), con una cultura intelectual propia, que puede ser formulada científicamente.

\subsection{PROYECTAR E INVESTIGAR}

Diseñar y producir un artefacto, edificio o parque es un acto de diseño, y no puede confundirse con un acto de investigación. Esto ya ha sido ampliamente destacado y recordado por investigadores como Nigan Bayazit, quien al reflexionar sobre la sobre la práctica artística nos advierte: "Las actividades prácticas de un artista cuando crea una obra de arte 0 artesanía no pueden considerarse como investigaciones [científicas]" (Bayazit, 2004, p. 16), en el mismo sentido, Cross indica que necesitamos hacer una distinción entre el trabajo práctico y el trabajo de investigación:

No veo cómo los trabajos normales de la práctica pueden ser considerados como trabajos de investigación. El objetivo de la investigación es extraer conocimientos fiables del mundo natural o artificial, y ponerlos a disposición de los demás en forma reutilizable. Esto no significa que las obras de la práctica del diseño deban ser totalmente excluidas de la investigación sobre el diseño, pero sí significa que, para ser consideradas como investigación, el profesional debe reflexionar sobre la obra y comunicar algunos resultados reutilizables de esa reflexión ${ }^{72}$. (Cross, 2007, p. 99).

Por lo tanto, para el proyecto de tesis, es necesario ir más allá de la lógica de la "investigación para la creación" y adoptar una lógica de "creación para la investigación". Tal conversión no es evidente por sí misma y habitualmente las competencias necesarias no son adquiridas en la formación profesional, pero pueden y debe ser aprendidas. Este debiera ser un objetivo de la formación doctoral en

72 Traducción propia del inglés:

We also need to draw a distinction between works of practice and works of research. I do not see how normal works of practice can be regarded as works of research. The whole point of doing research is to extract reliable knowledge from either the natural or artificial world, and to make that knowledge available to others in re-usable form. This does not mean that works of design practice must be wholly excluded from design research, but it does mean that, to qualify as research, there must be reflection by the practitioner on the work, and the communication of some re-usable results from that reflection. arquitectura.

Siguiendo a Findeli (2003), a diferencia de otras disciplinas, la investigación en arquitectura, a través del proyecto, al estudiar las interacciones entre los seres humanos y su entorno, no considera estas interacciones como objetos de estudio sino como proyectos de diseño. Este punto es importante ya que introduce la idea de que el entendimiento del arquitecto es esencialmente proyectual:

Lo que distingue al diseño de la geografía o la sociología es que considera al mundo como un proyecto, mientras que las ciencias lo consideran más como un objeto. La relación sujeto-objeto se altera radicalmente porque, para las disciplinas del proyecto, el sujeto está necesariamente comprometido, situado, en su objeto. (Findeli, 2003, p. 169)

\subsection{EL ECLIPSE DEL OBJETO}


Las teorías hasta aquí presentadas, dan cuenta de la diversidad de enfoques que el proyecto a partir de un corpus de textos, tales como tratados, libros y artículos que han abordado la relación del proyecto con la ciencia y han intentado establecer bases metodológicas para su práctica. A partir de este recorrido, podríamos definir, siguiendo el modelo que Alain Findeli y Rabah Bousbaci (2005) proponen en su artículo El eclipse del Objeto, tres grandes categorías, las que enuncian como metáforas del "diseño como..." y que para efectos de nuestro análisis entenderemos como metáforas del "proyecto como operaciones de...."

1. estética aplicada: centrado en el objeto u objetual

2. proceso lógico: centrado en los procesos o procesual

3. razón práctica o ética: centrado en las relaciones o relacional

A grandes rasgos, el primer tipo agrupa las teorías centradas en el objeto o producto del proyecto de diseño: el edificio, el objeto, el parque, etc. El segundo tipo reúne las teorías centradas en el proceso, o estructura lógica (metodológical epistemológica) adoptada durante el proyecto. En el tercer tipo, las teorías se centran en los actores, agentes o partes interesadas en el proyecto de diseño.

Ordenados en la línea del tiempo, como hemos visto en el recorrido hecho desde Vitruvio, los del primer grupo corresponden a los textos más antiguos y abarca más de 20 siglos, incluyendo la primera etapa del Movimiento Moderno; el segundo tiene su momento más alto en 1960, con el Movimiento de los Métodos de Diseño, mientas que el tercero sólo emerge en la última década del siglo XX. La aparición de un nuevo tipo no significa que los precedentes desaparecen totalmente, es la razón por la que Findeli y Bousbaci hablan de un "eclipse" ${ }^{73}$. Por ejemplo, el tipo 1 y 2 aún tienen vigencia en la docencia, mientras que el 2 y 3 tienen presencia en las publicaciones científicas y en la investigación. También, como hemos visto, hay autores que han transitado desde un tipo a otro, como es el caso de Christopher Alexander, entre el tipo 2 y 3.

\subsection{1. "El proyecto como estética aplicada (modelo tipo 1)" (Findeli \&} Bousbaci, 2005, p.6):

Reúne los textos teóricos y tratados desde Vitruvio, que tienen como objeto de interés el producto del proyecto. Todos los tratados de arquitectura clásicos que hemos revisado describen las propiedades (técnica, estructural, formal, de uso, etc.) que deben tener idealmente los edificios y monumentos diseñados por arquitectos. Recordemos también que dentro de estos tratados puede observarse, especialmente después del siglo XVIII, un movimiento pendular entre la fundamentación artística y científica del quehacer, sin dejar por ello de tener un carácter normativo y de establecer principalmente las cualidades y propiedades formales del objeto.

Si consideramos que el objetivo de la primera Bauhaus en Weimar (1919-1924) fue definir una forma más racional de encuadrar el trabajo de diseño, para superar el modelo de "las artes aplicadas" del siglo XIX, podemos incluirla en este grupo también. Lo que se busca en la Bauhaus (también De Stijl en los Países Bajos y el Constructivismo ruso) es una concepción científica del arte suficientemente desarrollada para constituir el marco teórico a partir del cual las propiedades formales del objeto pueden deducirse racionalmente, siguiendo el modelo epistemológico dominante del siglo XIX, vale decir, el de la tecnología o la industria como ciencia aplicada. Este punto de vista libera a la primera Bauhaus de la paternidad del funcionalismo, pese al breve intento de Hannes Meyer en Dessau. El racionalismo funcionalista solo será posible hasta después del progresivo abandono de cualquier referencia artística en las teorías del proyecto.

\subsubsection{El proyecto como proceso lógico ${ }^{74}$ (modelo de tipo 2):}

Como vimos en nuestro breve itinerario, con la excepción de algunos precursores racionalistas como Durand y Viollet-le-Duc, los primeros modelos teóricos que
${ }^{73}$ El eclipse es del objeto, el que dejaría de ser el centro de interés de la investigación en arquitectura y otras áreas del di-seño.

74 Findeli y Bousbaci hablan de "El diseño como proceso racional de tratamiento de la información" (Le design comme pro-cessus rationnel de traitement de l'information) (Findeli \& Bousbaci, 2005, p. 8) 
analizan el proyecto como proceso aparecen con posterioridad a la Segunda Guerra Mundial junto a la investigación operativa. Herederos de la Bauhaus en Chicago y especialmente de la HfG de Ulm buscan liberar el acto de diseño de toda subjetividad, Archer, Rittel, Maldonado y Moles que elaboran los primeros modelos racionales, análogos a los que se estaban desarrollando en cibernética, economía, termodinámica y biología. El protagonista tipo 2 busca hacer el diseño "científico" y al mismo tiempo esforzarse por revelar la estructura lógica del proceso proyectual, cualquiera que sea la lógica (formal deductiva, heurística, cibernética, dialéctica, retórica, compleja, etc.). Es por esto que cualquier reflexión teórica se reduce a menudo a una metodología.

Un punto de inflexión se produce con los modelos de Bertalanffy, Simon y McHarg. De acuerdo con estos modelos podríamos decir que el diseñador, ignorando el objeto final de su búsqueda, construye un proceso de diseño con los datos del entorno del proyecto. Estos datos son reconocidos, procesados y reconfigurados dentro del problema de diseño (Simon habla del espacio del problema). Sabiendo que la información sobre este entorno nunca puede ser exhaustiva, el criterio de fin de proceso sólo puede ser "satisfactorio", pues la solución emerge tras un juicio de adecuación o aceptabilidad y no de integridad o verdad. La integración de los métodos empíricos y experimentales, como también el desarrollo del diseño asistido por computador (CAD) permitieron a la comunidad de investigadores de estas áreas abandonar el modelo normativo de los tratados para adoptar teorías de diseño descriptivo, con el rigor científico de otras disciplinas.

El eclipse de este modelo surge por la acción de varios de sus mismos pioneros, como Alexander y Rittel. Este último, hace ver que el juicio es crucial y es necesaria "la comprensión del diseño como un proceso argumentativo" (Rittel, 184, p. 312), haciendo patente que toda actividad de "planificación es necesariamente política, y no meramente técnica" (p. 326). Bajo el manto, aparentemente neutral, de los "métodos de optimización lógicos" se oculta un medio de control social y político ${ }^{75}$. Esto pone en tela de juicio el modelo, basado en la suposición de que la mente es un procesador de información desinteresado, no afectado por discursos culturales o históricos particulares, sino neutral.

\subsection{3. "El proyecto como razón práctica, ética [o relacional] (modelo tipo} 3)" (Findeli y Bousbaci, 2005, p. 9):

para Findeli y Bousbaci (2005), los modelos teóricos de este tipo, consideran prioritariamente a los actores del proyecto, sus intenciones, su visión del mundo, sus prejuicios, su racionalidad profesional o cultura propia, los valores que los animan, los estándares que los condicionan. Esta visión está fuertemente influenciada por las ciencias sociales y ha desviado el foco del objeto, para orientarlo tanto hacia los valores que el proyecto porta como en el significado para el usuario individual y colectivo, vale decir en su experiencia. A partir de autores que han cuestionado el racionalismo clásico como Schön (1983) con su "Profesional Reflexivo", Morin (2005) y su "Método", también cabría mencionar los trabajos de Merleau-Ponty (1964), Lefebvre (1974) y Harvey (2008). La fenomenología y el existencialismo impulsan el interés por la vida cotidiana, la valorización de la observación participante del investigador, recuperando la experiencia personal frente a la abstracción positivista. Se introducen la psicología y los estudios del comportamiento que hacen evidente la insuficiencia de los métodos cuantitativos. Un ejemplo emblemático es el trabajo de Kevin Lynch $(1998)^{76}$ sobre la imagen de la ciudad, quién a través de encuestas, entrevistas y observando el comportamiento de las personas en la ciudad, nos demuestra que el territorio urbano se puede construir a partir de diversos imaginarios, imágenes que varían significativamente según quien la observa, cuestión que se vuelve clave en cualquier investigación. Especialmente en la investigación sobre paisaje, donde se encarna lo que Merleau Ponty llama la "ontología de lo visible" (Merleau-Ponty, 1964, p. 182), como realidad física y como representación que nos hacemos culturalmente de él. Esta concepción se puede leer en la definición de paisaje que hace Nogué: 
...la fisonomía externa y visible de una determinada porción de la superficie terrestre y la percepción individual y social que genera; un tangible geográfico y su interpretación intangible. Es, a la vez, el significante y el significado, el continente y el contenido, la realidad y la ficción. (Nogué \& San Eugenio , 2009,

p. 32)

Incorporar otros actores al proyecto ha exigido ampliar el alcance del diseño al campo de los valores "evitando al mismo tiempo una trampa a la que nosotros mismos hemos sucumbido en el pasado, la de la ética aplicada considerada como un campo importante pero auxiliar y autónomo" (Findeli y Bousbaci, 2005, p. 9). Pero cuando nos referimos a ética en el proyecto ¿a qué estamos aludiendo? La ética en la arquitectura, como en otras profesiones, se manifiesta como un imperativo que nos obliga a observar los códigos que regulan el ejercicio profesional, a los que se suman las leyes, normas y ordenanzas que abarcan aspectos específicos como la seguridad y la salud de los usuarios, la accesibilidad universal, la protección de la naturaleza, la protección del patrimonio, etc. Sin embargo, estos autores proponen desarrollar una ética dentro del proyecto que más allá de lo imperativo, del deber, encuentre en la "prudencia"77 un modo de actuar.

Esto lleva nuevamente a la idea del Profesional Reflexivo de Donald Schön que vuelve a situar nuestro problema de investigación respecto a la práctica, al proyecto, señalando que

...la investigación es una actividad de los profesionales, desencadenada por los rasgos de la situación práctica, acometida en el acto e inmediatamente vinculada a la acción. El intercambio entre práctica e investigación es inmediato, la reflexión en la acción es su propia implementación. (Schön, 1998, p. 34)

Schön explica este momento como un proceso de reflexión en la acción o como una conversación reflexiva con la situación problemática concreta.

Llevando esto a la práctica, cuando recibimos un encargo de proyecto y traducimos este encargo en términos de diseño, la "problematización" será muy diferente si ésta está abordada desde el punto de vista estético, lógico o ético, y por lo tanto las soluciones de proyecto también serán muy diferentes.

Cada punto de vista cambia la conducta del proyecto de acuerdo con un modo o régimen específico. Por lo tanto, idealmente, todo proyecto debiera considerar la posibilidad de interrumpir el trabajo para preguntarse cuál es el régimen desde el cual problematizar y qué consecuencias tiene.

Esta investigación es esa interrupción. Un momento que permite evaluar la postura pragmática adoptada.

Pero ¿cómo interpretar el modelo? y ¿qué significa para el proyecto de investigación?

La posibilidad de un meta-modelo parece difícil. Analizando mi propio acercamiento a la investigación me veo transitar pasando por cada una de las capas del esquema del "eclipse": desde lo normativo, la definición y la historia, para pasar al análisis de las lógicas que están en juego y llegar a la pregunta que de algún modo contiene las otras dimensiones, que es la pregunta por el sentido del proyecto, tanto para los destinatarios como para quien proyecta. Es así como estética, lógica y ética, estarán presentes en el desarrollo de esta investigación que busca crear conocimiento de proyecto a través el proyecto.(Figura 2.6)

\subsection{LOS INTERESES EN JUEGO}

Dentro de esta reflexión parece pertinente distinguir lo que Jürgen Habermas (1982) señala como los "intereses" que motivan el conocimiento científico, que

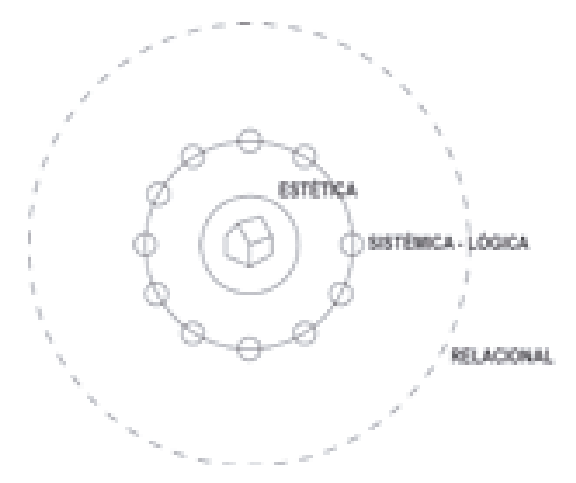

Figura 2.6. Esquema conceptual. Elaboración propia 
77 Recordemos la filosofía de Aristóteles quien reconoce tres categorías en el pensamiento: la práctica, la poética y la teoría. Aristóteles comprende que el bien al que cada actividad del hombre tiende, no es más que la excelencia y el éxito del acto mismo. La virtud es entonces la disposición interna que acompaña y dirige el acto del agente hacia la excelencia. La teoría (theoria) es el acto que apunta al conocimiento intelectual de las cosas por medio del discurso y de la razón, que se concre-tiza en una declaración verdadera sobre el objeto contemplado; La sophia (sabiduría teórica o contemplativa) es la virtud que le corresponde. La poièsis (pensamiento poético) es un pensamiento que apunta a la producción de una obra fuera de ella (un artefacto, un efecto, un poema, un edificio, etc.). En este sentido, poièsis es una actividad transitiva (es como un puente que conduce a algo más fuera de él); Techne es la virtud que le corresponde.

Contrariamente a la poièsis, que es esencialmente la producción de obras o la fabricación de objetos, la prâxis (pensamiento práctico) es una actividad reflexiva, que es en sí misma su propio fin. Por lo tanto, el trabajo de la praxis es inmanente, por-que el objetivo de la acción es actuar bien, es decir, contribuir siempre a hacer del agente un "mejor agente", una buena persona que actúa por el bien; La phronēsis (sabiduría o prudencia práctica) es la virtud que acompaña y dirige la praxis pa-ra hacer del agente un "agente virtuoso". Es esta virtud la que está en el corazón de la ética aristotélica. La praxis virtuosa constituye en este caso el mismo modo de vida del agente virtuoso.

Si volvemos ahora a la concepción imperativa de la ética en el campo del proyecto, es fácil concluir que, en última instancia, se basa en la idea de que el diseño se considera esencialmente como una poièsis (un arte), una poièsis enmarcada por un ciertas obligaciones morales, éticas y metodológicas. El interés de la visión propuesta por Findeli y Bousbaci, radica en que libera el conocimiento profesional de la dominación del pensamiento poético (que se considera a menudo desde un punto de vista instrumental) para hacer que los profesionales prudentes (personas con sabiduría práctica) puedan deliberar bien en situaciones de práctica profesional cada vez más complejas, conscientes de la comunidad a la que sirven.

Figura 2.7. Esquema de los tipos de investigación en arquitectura y los intereses en juego. Elaboración propia. determinarían el marco epistemológico y metodológico de toda investigación. Según este autor, existen tres categorías principales de la investigación: la investigación técnico-instrumental, con fines explicativos y predictivos; la investigación histórico-hermenéutica con objetivo comprensivo e interpretativo; y la auto-reflexión y crítica como búsqueda de la emancipación (1982, p. 284). La investigación a través del proyecto, desde el problema, desde la acción, de algún modo está obligada a abordar estas tres categorías en su desarrollo

También son tres los dominios desde donde un proyecto de investigación en diseño será evaluado (Figura 2.7). El primero es común a cualquier proyecto de investigación, en cualquier disciplina: que el trabajo produzca una contribución original y significativa al conocimiento, en este caso al conocimiento en arquitectura, más específicamente al conocimiento del proyecto, del proyecto de paisaje. El segundo es una contribución al oficio del proyecto, no sólo para los pares sino por sobre todo para la experiencia del usuario del proyecto concreto. Tercero: algún tipo de consecuencia positiva para la enseñanza y la formación en arquitectura. Expresado de otro modo, la comunidad disciplinar está interesada en un conocimiento del tipo fundamental o teórico, los profesionales en conocimiento aplicable $o$ útil, y la comunidad docente (las escuelas) en conocimiento de tipo enseñable o pertinente. Como vemos las categorías de Habermas parecen ineludibles.

Recordemos: en nuestro caso, es el proyecto externo, exógeno, el que ha iniciado el proceso de investigación. Se trata, como hemos enunciado en la introducción, de un mandante, la Universidad de Chile que encarga construir un Parque Científico-Tecnológico en un predio de 1.022 ha en el límite urbano de la ciudad de Santiago. El requerimiento original fue reformular un proyecto, tras más de 20 años de intentos frustrados y ante la amenaza de perder el terreno, debido a que la universidad no había cumplido con los compromisos establacidos en la donación que le hiciera el estado (fundamentalemente edificar algo). Es así como el proyecto se inicia con la tarea de repensar qué es lo apropiado que se desarrolle en ese lugar y cuál es el proyecto que la universidad puede proponerle al país, a la ciudad, a los vecinos y a su propia comunidad, constituida por más de 50.000 personas. La dimensión de este terreno y su ubicación, pero también su abandono, hacen evidente sus valores paisajísticos y ecológicos, lo que permite enunciar el objetivo de investigación desde el territorio.

Nuestro interés por las cuestiones paisajísticas, nos orienta hacia este tema, perteneciente a las disciplinas proyectuales y una de las líneas incluidas en el programa de doctorado de Patrimonio Arquitectonico de la UPM. Entre los asun-

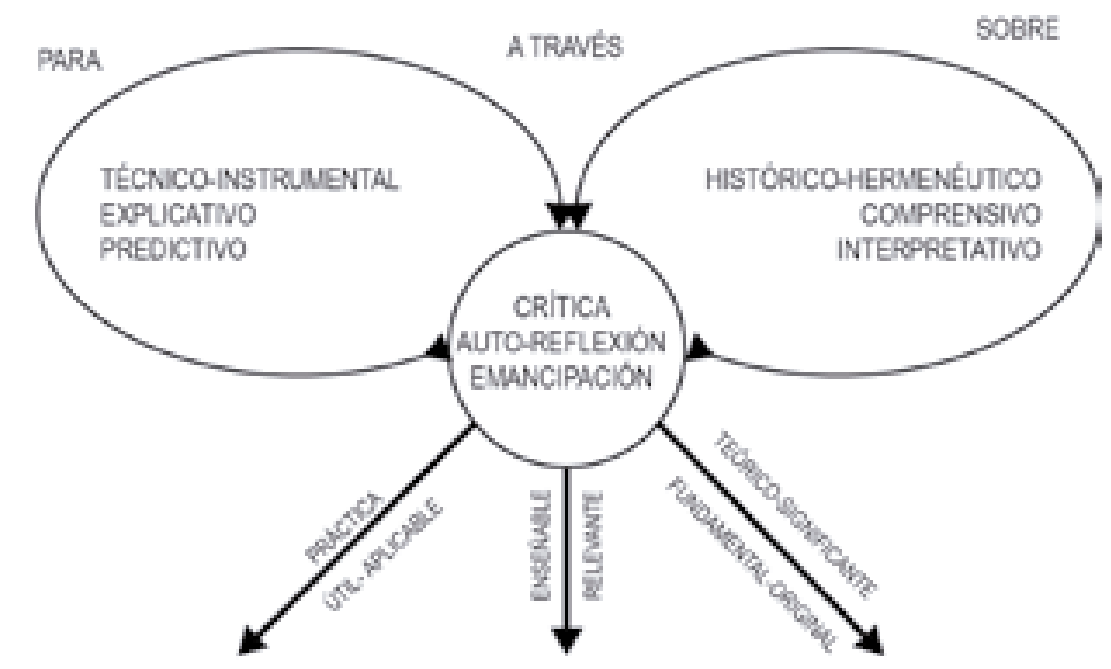

USUAPVIOS-PROFESICNALES
COMUNIDAD DISCIPUNAR 
tos más problemáticos en esta área, están aquellas relacionadas a los criterios de evaluación de las cualidades paisajísticas de un territorio, tanto aquellas relacionadas con su rol medioambiental como las relacionadas con la oposición entre juicios expertos y no expertos, es decir, del lugar que se debe reservar a la opinión de los habitantes (los "no expertos") en los proyectos, cuyos efectos terminan por modificar su paisaje cotidiano u ocasional.

Es en esta dirección que se orientará de ahora en adelante nuestra pregunta de investigación, sabiendo que, hasta el momento, no existe un proyecto integrado en torno al paisaje en este vasto territorio. Por el contrario, el territorio es solicitado y mencionando por múltiples gestores, ya sean públicos o privados, y con intenciones diversas, a veces contradictorias entre sí. También, en este caso, la legislación indica un destino que debe ser interpretado. El trabajo de investigación será entonces, el hacer hablar este conocimiento, y articularlo, manifestando su sentido, para luego introducirlo en el proyecto.

Esta manera de construir la pregunta de investigación requiere de un marco conceptual y teórico particular, una perspectiva que será explicitada en los distintos capítulos de la tesis; no necesariamente de entrada, sino a medida que progrese la investigación, a través de un trabajo paralelo de familiarización con los cuestionamientos epistemológicos, filosóficos y teóricos que se desarrollan en los intersticios propios de la investigación.

En nuestro caso, optamos por una opción híbrida entre ética y ecológica, que considera a los destinatarios de los proyectos de diseño, no como consumidores o como usuarios, sino como actores motivados por un proyecto (el proyecto de habitar el mundo, su mundo con sentido), susceptibles de emitir juicios sobre la cualidad paisajística de su marco de vida, y preocupados por mejorarla. Es por esto que introducimos el tema de la identidad, considerando que sólo lograremos un compromiso con el fututo de este territorio, si los destinatarios sienten como propio el proyecto. Privilegiamos entonces el registro ético del modelo que expusimos anteriormente y nos interesamos primero que nada por los actores, antes que por el proceso o el producto, sin por ello obviarlos. Nuestro marco conceptual requiere, además, elementos de la investigación contemporánea en paisaje y de los aportes que representantes de las otras disciplinas científicas solicitadas para el proyecto.

La pregunta de investigación propuesta es entonces:

¿Cuál es el proyecto de paisaje con el que los destinatarios se pueden identificar? y por lo tanto:

¿Cuál es el proyecto de paisaje que puede ser validado socialmente?

¿Cómo un proyecto puede preservar las condiciones ecológicas y paisajísticas de un territorio en disputa?

¿Qué elementos del proyecto se definen como plan y cuales son una estrategia?, vale decir ¿Cómo un proyecto trabaja con la incertidumbre, con el cambio y con un tiempo que excede el horizonte mismo de quien lo proyecta?

Desde el punto de vista metodológico cabría preguntarse también ¿ómo saber si el método se adapta a nuestras preguntas? Nuestra tesis es que la investigación a través del proyecto es la más apropiada.

Tal vez falte incorporar al título de esta tesis un supra título que podría ser Proyecto integrado de paisaje que anteceda a Identidad y transformación del paisaje. El territorio de Laguna Carén.

Otros asunto, que podría ser formal, pero no por eso menos importante es que lugar le cabe al proyecto en el documento de la tesis. En esta tésis, éste se ubica en los últimos capítulos, recogiendo los diversas temas y puntos de vista desarro- 
llados en la investigación. El proyecto, sus planos y diagramas, son el material de experimentación de las distintas reflexiones que se dan en el proceso de investigación. En este punto me parece importante recordar lo que Marc Besse (2009) plantea sobre la importancia del soporte gráfico en los proyectos de paisaje. Para este autor, el surgimiento de una idea, en cuanto proyecto de paisaje, es ante todo la aparición de una forma o estructura en un intuición mental, perceptual o gráfica, como un "eco de un pensamiento a la vista". Las ideas, como formas, contendrían así un "punto de vista", que más alla de poder capturar directamente la realidad inmediata y medible, establece una estructura intelectual, técnica y perceptual que ordena el material dado.

Esta forma tiene un poder hipotético y exploratorio, en el sentido de que define un eje de investigación, una serie de imágenes y pensamientos; es un marco dentro del cual pueden llevarse a cabo futuras investigaciones. (Besse, 2009, p. 21)

En el horizonte abierto por este punto de vista-que al mismo tiempo es hipótesis, forma o ideaาn- los objetos son fabricados, no son sólo datos, sino productos elaborados y resultados de un proceso que es siempre provisional, una apuesta, como diría Morin. En este sentido el investigador estaría más en la lógica de la prueba que en la lógica de la verdad que es una "lógica del significado" (Besse, 2009, p. 21).

Estos objetos son generalmente (aunque no exclusivamente) fabricados a través de modelado gráfico y figuración, o prácticas de imágenes. Estas "imágenes", y especialmente la secuencia de las figuraciones sucesivas de los objetos, comprenden lo que se puede llamar la trayectoria del objeto, o simplemente su proyecto, que puede reconstituirse en su totalidad. (Besse, 2009, p. 22)

En este proceso es difícil distinguir si se trata de un descubrimiento o una invención, no hay regla de detención (como en un problema perverso), no hay una verdad definitiva, algo que pueda probarse, sino una respuesta satisfactoria 0 adecuada, de ahí su carácter formativo, como señala Luigi Pareyson:

Se dice que una operación es formativa cuando el trabajo resultante está bien hecho, no porque "siguió las reglas", sino porque es un "éxito", es decir, encontró su propia regla en lugar de aplicar una preexistente. (Pareyson, 2007, p. 55)

En los planos, los mapas y diagramas, cualquiera que sea su escala, se propone una forma, una estructura, una idea, un punto de vista. Son el espacio de trabajo en el que el paisaje se construye a través de diversas imágenes. Para Besse, el proyecto de arquitectura en el paisaje es esencialmente una forma mental embebida en y emergiendo del mapa. El mapa juega el papel de una anticipación esquemática de la invención efectiva del paisaje, no porque prefigure, sino porque da a la invención y al proyecto un espacio figurativo, es decir, un significado espacial. Para los arquitectos, dibujar es un modo de pensar y ha sido en esta investigación un modo de ordenar también el cúmulo de lecturas e ideas que giran en torno al proyecto.

\subsection{INDUCCIÓN, DEDUCCIÓN O ABDUCCIÓN}

Uno de los asuntos que queda por dilucidar es cuál es el modo de inferencia propio del proyecto y de este modo gráfico de pensar.

Habermas cita a Peirce, quien distingue tres formas de inferencia: deducción, inducción y abducción.

La deducción prueba que algo debe comportarse de una forma determinada; la inducción que algo se comporta fácticamente así, y la abducción que presumiblemente algo se comporta así. La abducción es la forma de argumentación que 
amplía nuestro saber; es la regla conforme a la cual introducimos nuevas hipótesis. Por consiguiente, sólo el pensamiento abductivo hace avanzar el proceso de investigación.

Por deducción desarrollamos consecuencias a partir de las hipótesis valiéndonos de ciertas condiciones iniciales. Aplicamos estas hipótesis a casos particulares y deducimos así previsiones de acontecimientos que deben producirse si la hipótesis es correcta.

Por inducción verificamos si se confirman los pronósticos y con qué probabilidad. La inducción es, pues, la forma lógica del proceso de la investigación propiamente dicho en la medida en que éste tiene que examinar la validez fáctica de las hipótesis. La forma de inferencia analíticamente vinculante, la deducción, es la menos importante desde el punto de vista de la lógica del progreso científico: pues deductivamente no obtenemos ninguna nueva información. (Peirce citado por Habermas, 1982, p. 118)

Vale decir, son importantes desde el punto de vista de la lógica de la investigación la abducción y la inducción. Para Habermas "Las informaciones que fluyen de la experiencia entran por este camino a formar parte de nuestras interpretaciones" (Habermas, 1982, p. 120).

El trabajo de la investigación a través del proyecto, será principalmente abductivo, vale decir, nuestras teorías sobre la realidad serán ampliadas en la acción en búsqueda de nuevas hipótesis, mientras que "inductivamente controlamos la concordancia de las hipótesis con los hechos" (Habermas, 1982, p. 120).

Pero si entendemos a través de Habermas que "la abducción conduce al estímulo que desencadena la acción, al 'caso', y la inducción conduce a la 'regla' estabilizadora del comportamiento, del mismo modo que la deducción lleva a la reacción comportamental misma, al 'resultado'"(Habermas, 1982, p. 131), la abducción operará principalmente en nuestro contacto propositivo con la realidad, pero haremos uso de la inferencia inductiva cada vez que tratemos de universalizar o encontrar reglas. Del mismo modo, el pensamiento deductivo opera cuando, manipulando la realidad, aislando algunas variables, intentamos concretar un resultado.

\subsection{DE LO DISCIPLINAR A LO TRANSDISCIPLINAR}

Por último, si bien hemos hablado de lo disciplinar, la experiencia de proyectos de arquitectura -especialmente con un proyecto de paisaje- exige del trabajo multidisciplinar. Si somos más rigurosos, habría que distinguir que en el proyecto "real" el trabajo es multiprofesional, ya que en el confluyen varias profesiones (ingenieros, geógrafos, urbanistas, paisajistas, arquitectos, etc.) mientras que el trabajo multidisciplinar ${ }^{78}$, propiamente dicho, es el que de la interacción de varias disciplinas ante un proyecto de investigación o programa académico. En nuestra investigación a través del proyecto, una de las dificultades ha sido el abordar la complejidad del problema territorial que tiene componentes ecológicos, normativos y antropológicos que exceden las competencias de un arquitecto. Incluso si sólo nos centraramos en la experiencia de habitar que esperamos que se desarrolle en nuestro parque, ésta está constituída por una serie de sub experiencias que requieren un analisis cuyas herramientas pertenecen a la psicología de la percepción, a la sociología, a la antropología, a la política, etc. Del mismo modo, las condiciones del terreno nos apremian con su realidad material y con la necesidad de conocer su geomorfología, la hidrología, el clima, la flora, la fauna, las condiciones del suelo, los riesgos, etc. Su condición suburbana también ofrece desafíos disciplinares específicos que están en el campo del urbanismo, la ingeniería de transportes, el derecho, etc. Si a esto sumamos la sustentabilidad y el programa, aparecen también las disciplinas de la gestión, la economía y las que
78 la naturaleza propia de la investigación a través del proyecto implica adoptar un enfoque multidisciplinario. Para esto, la pluridisciplinariedad, la mera yuxtaposición de perspectivas monodisciplinares no es satisfactoria. En la etapa investigativa de problematización y de producción del conocimiento, se necesita de la interdisciplinariedad. Ésta requiere la integración de las perspectivas disciplinares escogidas en torno a las problemáticas comunes. Sólo así es posible el establecer protocolos sus-ceptibles de provechar la produc- 
corresponden a los interesados en establecerse allí con sus propios proyectos de desarrollo y que de algún modo buscan imprimir su mirada en el que será su espacio de trabajo.

El tiempo y el presupuesto son normalmente las variables que definen cuántas y cuáles disciplinas pueden ser convocadas a un proyecto. Luego, el desafío es cómo lograr que esas distintas miradas disciplinares permitan por una lado desarrollar un proyecto "real" y por otra parte, cumplir con los tres objetivos de la investigación, recordemos, que sea relevante para la disciplina, la profesión y la enseñanza.

En la experiencia del proyecto "real", el trabajo multidisciplinar y multiprofesional ha sido fundamental, pudiendo reconocer varias etapas en su evolución. Una primera etapa, donde se ha sintonizado un vocabulario común respecto al lugar y donde hemos recogido lo que cada participante espera del proyecto. La segunda etapa ha sido, a partir de una primera propuesta conceptual, expresada gráficamente, cada disciplina en un trabajo más bien hermenéutico, interpretativo que deductivo, han encontrado aquellas variables que su área de conocimiento puede esclarecer. La mayor dificultad radica en pasar a la siguiente etapa, la tercera, que tiene como desafío lograr que el conocimiento producido por las disciplinas científicas orientadas a lo analítico se transformen, para que puedan participar e integrarse a la acción, a una acción que encuentre su sentido en la satisfacción del usuario final. Findeli et al. llaman a esta operación "pragmatización"(2008, p. 81) de la teoría o del conocimiento y correspondería al momento transdisciplinar. Las etapas siguientes repliegan las disciplinas a su propio quehacer y permiten, por ejemplo, a los investigadores, sistematizar las experiencias en publicaciones específicas, y en el caso de las profesiones, responder con los proyectos de especialidad. Desde el proyecto de paisaje la tarea consiste en articular y jerarquizar las contribuciones de cada especialista para luego en una etapa final evaluarlas en conjunto. Ideamente, el trabajo multidisciplinar podría encontrar otro espacio de investigación al constituirse como equipo de seguimiento del desarrollo del proyecto en el tiempo, pero esta etapa prácticamente nunca es considerada.

Como vemos, el proyecto de diseño provee las condiciones ideales para el trabajo multidisciplinario y el momento transdisciplinar, ya que exige que el conocimiento sea "organizado" hacia la creación de un todo, en nuestro caso, la transformación del territorio de Laguna Carén. La clave está en construir conocimiento para que éste sea relevante desde el punto de vista del usuario final (y no sólo para el de la comunidad científica).

Las competencias del arquitecto son claves en este proceso, sin embargo normalemente no son reconocidas como una característica de su desempeño, Nigel Cross la llama "la manera de conocer, pensar y actuar según el diseño" 79 (Cross, 2011, p. 55) y es tal vez una de las tareas que la disciplina tiene: distinguir y explicitar la capacidad de organizar y sintetizar conocimiento en la forma de un proyecto con sentido para los demás, a la vez que se eleva esto a un nivel más reflexivo. El trabajo transdisciplinario, debería ser nuestro sello.

En el caso de un proyecto de investigación doctoral, el equipo desaparece. Sin embargo la experiencia multidisciplinar del proceso puede recogerse y elaborarse como una actitud transdisciplinar, la de un arquitecto-investigador reflexivo. 


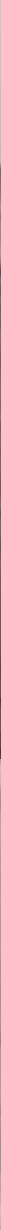

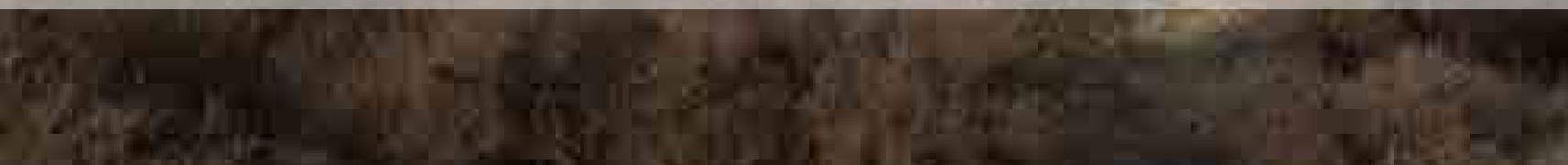

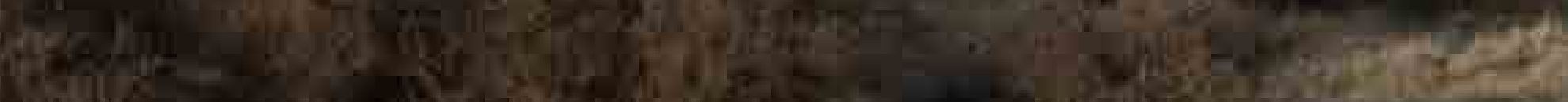

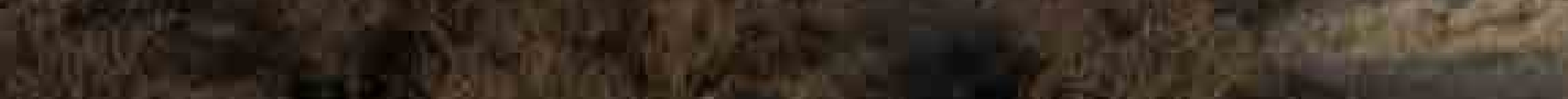

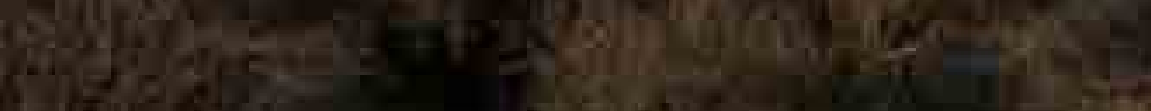

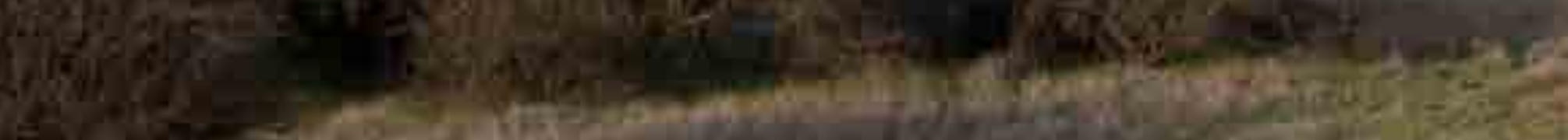

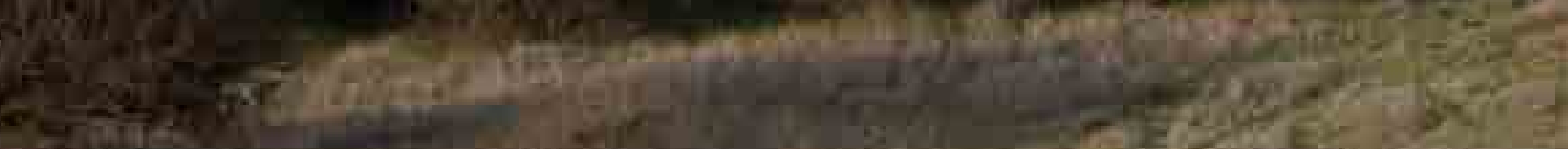

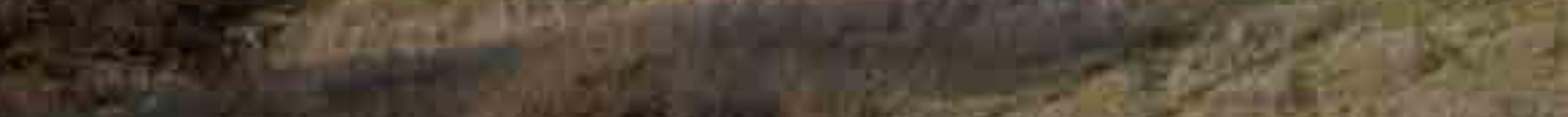

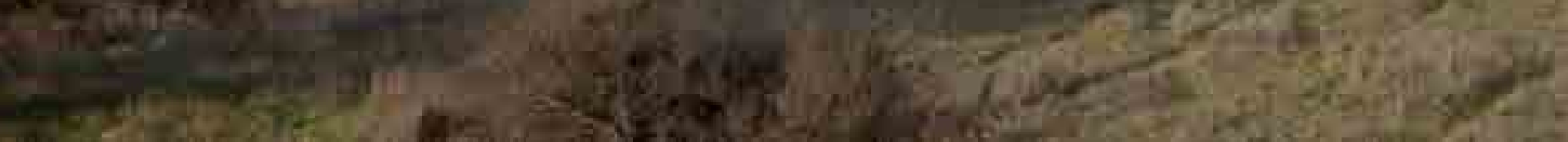




\section{IDENTIDAD TERRITORIO Y PAISAJE}

En los años inaugurales del siglo XXI el término -paisaje- aparentemente anticuado se ha vuelto a poner curiosamente de moda. La reaparición del paisaje en la imaginación cultural más amplia se debe, en parte, al notable aumento de la preocupación por el medioambiente y a una conciencia ecológica global, al crecimiento del turismo y a las necesidades asociadas de las regiones, de transmitir un sentido de identidad propio, así como al impacto del crecimiento urbano masivo sobre las zonas rurales..$^{80}$ (Corner, 2006, p. 23)

\subsection{INTRODUCCIÓN}

Las razones de la reaparición renovada del paisaje en la cultura contemporánea son múltiples, como múltiples las acepciones que se manejan de la palabra paisaje y variadas las disciplinas que lo estudian. Como nos plantea Corner (1999), "el paisaje no es equivalente a - territorio- o medioambiente: el paisaje es menos un objeto cuantificable que una idea, una manera cultural de mirar, y como tal permanece abierta a la interpretación, el diseño y la transformación" ${ }^{81}$ (Corner, 1999, p. X). Porque a diferencia del territorio, que puede ser objetivable, como un área definida y limitada, que incluso puede asociarse a la posesión legal de un individuo, institución, estado o país; y a diferencia del medioambiente, que según la legislación chilena es un:

(...) sistema global constituido por elementos naturales y artificiales, de naturaleza física, química o biológica, socioculturales y sus interacciones, en permanente modificación por la acción humana o natural y que rige y condiciona la existencia y desarrollo de la vida en sus múltiples manifestaciones. (Ley $\mathrm{N}^{\circ}$ $19.300,1994$ actualizada 2019 , p. 2)

El paisaje es un objeto autónomo, cuya realidad es y no es física. Una construcción mental que se estructura integrando percepción, emociones, ideas, experiencias, recuerdos, conductas aprendidas y otros contenidos mentales, que emergen a partir de un territorio. Esto hace que la definición de paisaje dependa de quién, desde dónde y cómo se mire ese territorio. El "cómo" está condicionado, como nos hace ver Luis Álvarez Munárriz (2011), por "las representaciones que comparte [ese sujeto] con los miembros de la cultura a la que pertenece" (2011, p. 59), haciéndose eco de lo que establece la Convención Europea del Paisaje cuando define que "El paisaje es un espacio, tal como lo percibe la gente, cuyo carácter es el resultado de la acción e interacción de factores naturales y/o humanos"82 (Consejo de Europa, 2000). De constructo mental a constructo social, el paisaje será un hecho social que se despliega de manera colectiva, como una representación compartida y cultural de un territorio.

Es por esto, que proponemos entender el paisaje en relación a la identidad; no sólo cuando su composición actúa como reflejo de los rasgos culturales de un grupo humano, sino cuando la propia configuración del paisaje puede determinar la manera en que una cultura se despliega, desarrolla y apropia del espacio que habita.

Identificar y analizar el modo en que las diferentes culturas y sociedad han construido y representado su propio paisaje es una manera de ahondar en "las raíces más profundas de la estructura que la conforma" (Álvarez, 2011, p. 60). Por lo tanto, analizar las representaciones del paisaje en la historia de Chile, son un modo de entender la propia identidad, esa que construye y se construye en $\mathrm{Ca}$ rén.

Para ello, en este capítulo se divide en cuatro momentos: el primero busca encontrar las primeras nociones de paisaje relacionadas con Laguna Carén; el se-
${ }^{80}$ Traducción propia del inglés:

In the opening years of the twenty-first century, that seemingly old-fashioned term landscape has curiously come back into vogue. The reappearance of landscape in the larger cultural imagination is due, in part, to the remarkable rise of environmentalism and a global ecological awareness, to the growth of tourism and the associated needs of regions to retail a sense of unique identity, and to the impacts upon rural areas by massive urban growth.

${ }^{81}$ Traducción propia del inglés:

"Landscape" is not equivalent to "land" or "environment"; landscape is less a quantifiable object then it is an idea, a cultural way of seeing, and as such it remains open to interpretation, design and transformation."

82 Traducción propia del inglés:

"Landscape means an area, as perceived by people, whose character is the result of the action and interaction of natural and/or human factors" (Consejo de Europa, 2000). 
gundo, profundiza en la palabra paisaje para comprender su origen y desentrañar los misterios etimológicos que la hacen tan polisémica; en el tercero, explora la noción de paisaje y su evolución en el tiempo, trenzando hitos de la historia occidental con expresiones de la cultura chilena, recurriendo a la poesía y la pintura para encontrar esa identidad paisajística que buscamos; por último, analizaremos la legislación chilena para descubrir que la palabra paisaje está aún casi ausente.

\subsection{EL PAISAJE DE LAGUNA CARÉN POR PRIMERA VEZ}

Hace 371 años, el jesuita nacido en territorio chileno Alonso de Ovalle ${ }^{83}$ describía por primera vez el dominio de Laguna Carén, el que llamó su atención gracias a la importancia de sus cursos de agua, incluyéndolo así en su obra Histórica Relación del Reyno de Chile, publicada en $1646^{84}$.

[...] allí cerca de su contorno [de Santiago] ay otras muchas [fuentes que nacen en los valles], entre las cuales es digna de particular advertencia la de Caren, que nace en vn prado llano, y hermosissimo, ansi por su vista, como por la que de allí se estiéde [extiende] por mas de cinco, o seis leguas, es el agua de esta fuente notablemente suane [suave], y blanda y porque debe de entrevenarse gran parte de ella por el prado, esta esse tan poroso, que poniéndose de pies sobre el, tiembla todo de manera que muy sensiblemente conoce el temblor el que pisa sobre ella, y mas quien haze esto con mas fuerça, conservase todo el año verde, con la yerva que nace en ella a manera de menudo trébol a quien los naturales llaman caren, y es regalada de comer. (Ovalle, 1646, p. 32).

Su relato nos sitúa sobre la historia de este lugar como parte del territorio chileno que, junto a otras crónicas, pinturas y mapas, intentaremos vincular a la historia del Paisaje en la cultura de occidente. Estos pasajes serán a su vez la excusa para una reflexión acerca de la relación entre territorio, paisaje e identidad, para, a través de su comprensión, encontrar un modo de actuar sobre el territorio de Laguna Carén.

Ante esta tarea, cabe preguntarse cuál es la historia que sirve a los propósitos de la acción, de la transformación, vale decir del proyecto y sus intenciones. $\mathrm{Si}$ recurrimos a Nietzsche, éste identifica tres modos en los que el hombre se relaciona con la historia, llama a este sujeto "hombre de acción" ya que "libra una gran lucha y tiene necesidad de modelos, de maestros, de confortadores, que no puede encontrar en su entorno ni en la época presente" (Nietzsche, 2002, p. 29):

83 Jesuita chileno, considerado el primer historiador de Chile. A los 15 años ingresó a la Compañía de Jesús. Estudió teología, filosofía y humanidades en Argentina por ocho años, para luego regresar a Chile y ser ordenado sacerdote. En 1642 fue enviado a Europa calidad de procurador, y para reclutar religiosos que quisieran venir a Chile, recorriendo Cádiz, Sevilla, Valladolid, Salamanca y Durango, para finalmente llegar a Roma en 1646. Allí escribe y publica su Histórica relación del Reyno de Chile y de las Missiones y Ministerios que exercita la Compañia de Jesús, decidido a remediar el desconocimiento de su país y creyendo que de este modo estimularía en los misioneros el deseo de viajar. ${ }^{84}$ Editada en Roma de manera simultánea en español y en italiano. Incluye 53 grabados con mapas, más de diez fachadas de iglesias a lo largo del país, retratos y escenas costumbristas.

[...] en la medida en que es un ser activo y persigue un objetivo, en la medida en que preserva y venera lo que ha hecho, en la medida en que sufre y tiene necesidad de una liberación. A estos tres aspectos corresponden tres especies de historia, en cuanto se puede distinguir entre una historia monumental, una historia anticuaria y una historia crítica. (Nietzsche, 2002, p. 28)

En el caso de Chile, la "historia monumental" tiene un primer gran capítulo protagonizado por los pueblos originarios que habitaron este territorio, antes de la conquista española, cuya historia, cultura y cosmovisión, así como su relación con la naturaleza y el territorio, serán abordados en el capítulo destinado al territorio de Laguna Carén propiamente tal. En este capítulo, nos ceñiremos al relato documentado de Carén, que intentaremos que transite hacia una historia "crítica". Nuestra historia "anticuaria", para usar el término de Nietzsche, que se inicia con la llegada de los primeros conquistadores europeos. El autor de crónicas corresponde, en efecto, a una figura que nace por orden de la Corona Española a quien se le encargó que, de manera sistemática, registrara por escrito, en forma lo más detallada posible, todo lo que veían el Nuevo Mundo. En sus crónicas debían consignarse no solo los hechos y sucesos ocurridos, sino que también detalles concernientes a la naturaleza, la flora y fauna, los ríos y montañas. 
Durante los primeros siglos desde la conquista y hasta mediados del siglo $\mathrm{XV} \mathrm{l}^{85}$, "la naturaleza chilena fue representada como salvaje e inhóspita" (Peliowski, 2016, p. 99), como un territorio remoto, sacudido por terremotos y defendido por un pueblo belicoso, los mapuches. Desde entonces, y perdurando hasta hoy, la presencia e influencia de las fuerzas naturales en el imaginario nacional han marcado las representaciones externas e internas, así como la identidad chilena. Así, esta tierra se convirtió en una de las más desacreditadas de las Indias, considerada desde su descubrimiento por Diego de Almagro como miserable y hostil, sin oro, y de clima muy frío. Al decir de Valdivia en carta al Emperador Carlos V de fecha 4 de septiembre de 1545 :

No había hombre que quisiera venir a esta tierra, y los que más huian de ella eran los que trajo el Adelantado don Diego de Almagro, que como la desamparó, quedo tan mal infamada, que como de la pestilencia huían de ella; y aún muchas personas que me querían y eran tenidos por cuerdos, no me tuvieron por tal cuando tuve que gastar la hacienda que tenía, en una empresa tan apartada del Perú y donde el Adelantado no había perseverado (Valdivia, 1545/1992, p. 27).

Los primeros cronistas españoles Gerónimo de Bibar ${ }^{86}$ y Pedro Mariño de Lobe$\mathrm{ra}^{87}$ solo confirmaron en sus relatos la imagen de este territorio intimidante.

En el mismo siglo, el poeta y soldado español Alonso de Ercilla y Zúñiga (15331594), regresa a España en 1559 después de pasar 17 meses en Chile; allí escribe su poema épico La Araucana $(1569,1578$ y 1589) donde

junto a relatar la guerra entre los españoles y los mapuches -llamados araucanos por los españoles-, construye la imagen guerrera y valerosa del pueblo originario, reconociendo y exaltando, en consecuencia, el heroísmo español. Si bien la descripción del territorio es aquí secundaria, tomando un rol más bien cartográfico a lo largo del extenso poema, el mérito de ésta radica en poner en valor una mirada, donde por primera vez, son los habitantes los que definen el carácter del territorio. Sus versos son aún enseñados hoy en las escuelas chilenas, reforzando el rasgo histórico, pero sobre todo identitario del relato construido por Ercilla:

Chile, fértil provincia y señalada en la región Antártica famosa, de remotas naciones respetada por fuerte, principal y poderosa; la gente que produce es tan granada, tan soberbia, gallarda y belicosa, que no ha sido por rey jamás regida ni a extranjero dominio sometida.

Es Chile norte sur de gran longura, costa del nuevo mar, del Sur llamado; tendrá del este a oeste de angostura cien millas, por lo más ancho tomado; bajo del polo Antártico en altura de veinte y siete grados, prolongado

hasta do el mar océano y chileno mezclan sus aguas por angosto seno.

(Ercilla, 1569/2006, p. 16)

La Araucana fue ampliamente conocida en su época, celebrada incluso por Miguel de Cervantes como una de las mejores obras épicas en verso castellano que se haya producido en España ${ }^{88}$. Del mismo modo, de acuerdo a Eva María Valero (2010) Marcelino Menéndez Pelayo señaló que:
${ }^{85}$ El período de ocupación española en Chile se expandió durante casi 3 siglos, desde 1536 hasta 1818.

${ }^{86}$ Autor del primer relato en que se describió Santiago de Chile titulado Crónica y relación copiosa y verdadera de los Reinos de Chile, publicado en torno a 1558. En él se describen las cumbres nevadas de la cordillera, los ríos caudalosos, y los paisajes extremos dominados por bosques impenetrables y áridos desiertos, habitados por fantásticos caníbales. El texto fue descubierto en el siglo XX. No se conocen las fechas de nacimiento y muerte del autor.

${ }^{87}$ Soldado que llegó a Chile en 1551, luchando a las órdenes de Pedro de Valdivia, Francisco de Villagra y García Hurtado de Mendoza. En 1562 se trasladó a Lima en donde murió en 1595. En sus últimos años trabó amistad con el jesuita Bartolomé de Escobar, quien también había estado en Chile, entregándole los manuscritos de su Crónica del Reino de Chile para que los corrigiera y editara. Sin embargo, el texto nunca fue impreso en la época, hasta que en 1865 fue publicado en el volumen VI de la Colección de historiadores de Chile y documentos relativos a la historia nacional ${ }^{88}$ La Araucana aparece en la obra de Cervantes como uno de los tres libros que el cura salva cuando quema la biblioteca de Don Quijote (Cervantes, 2012, p. 40). 
No hay literatura en el mundo que tenga tan noble principio como la de Chile, la cual empieza nada menos que con La Araucana, obra de ingenio español, ciertamente, pero tan ligada con el suelo que su autor pisó como conquistador, y con las gentes que allí venció, admiró y compadeció a un tiempo, que sería grave omisión dejar de saludar de paso la grave figura de Ercilla. (Menéndez, 1948, p. 220).

Para el historiador chileno Alfredo Jocelyn-Holt (2004), Ercilla descubrió -o más bien inventó- la figura del araucano, así como Ovalle descubrió el paisaje chileno. Chile figura en los mapas de la conquista desde sus comienzos, pero como "una noticia que se recibe desde lejos" (2004, p. 30), como otro Dorado que no fue. Sólo cuando Ercilla publica sus poemas queda un poco más claras las características de este territorio, y en qué consiste la resistencia mapuche en pos de su defensa.

En cuanto a Alonso de Ovalle, el gran mérito del jesuita es mostrar un Chile asombroso, posible y real. Jocelyn Holt señala que para entender este efecto es necesario recordar que Ovalle escribe y publica el libro en Roma en 1546, donde ha sido enviado por su congregación para conseguir recursos y nuevos misioneros. El libro

tiene un propósito: dar a conocer un país lejano. Curiosamente, la producción de Ovalle se gesta una vez que éste se ausenta de Chile; debe entonces recordarlo y visualizarlo desde afuera, desde lejos: reconstruir en su memoria e imaginación un territorio, que posiblemente sólo pudo producirse a la distancia, en Roma. La misma Roma que los pintores-paisajistas Claude Lorrain y Nicolas Poussin recorrieron en esos años. Desde allí Ovalle aprende a ver.

Uno de los pasajes más logrados es la descripción de la cordillera, cruzando los Andes:

La Cordillera de Chile, que podemos llamar maravilla de la naturaleza, y sin segunda, porque no se que aya en el mundo cosa que se le parezca (...) Vamos por aquellos montes pisando nubes, y los que tal vez andando por la tierra la vemos sin que se atraviese cosa que nos impida su vista, y levantando los ojos al cielo, no le vemos por impedirle las nubes de que esta cubierto; al contrario hallándonos en esta altura, se nos cubre la tierra, sin que podamos divisarla; y se nos muestra el cielo despejado, y hermoso, el Sol claro, y resplandeciente sin estorvo ninguno que nos impida la vista de su luz, y belleza. El arco Iris, que se ve desde la tierra atravesar el cielo; le vemos desde estas cumbres tendido por el suelo, escabelo de nuestros pies, quando los que estan en el, le contemplan sobre sus cabeças; ni es menos de maravillar, que vamos pisando aquellas peñas enjutas y secas, al mesmo tiempo que se desgajan las nubes de agua y inundan la tierra, como lo he visto muchas vezes. (Ovalle, 1646, p. 14)

El Chile de Ovalle pasa a ser concebido "como un confín del mundo conocido, una frontera de la civilización occidental, unos territorios ricos y fértiles donde extender dominios" (Jocelyn-Holt, 2004, p. 27). Podría decirse que, con Ovalle, Chile deviene de territorio a paisaje, pero aún sin nombrarlo, sin la palabra que le permita signarlo como tal.

En este punto, parece imprescindible el abordar el paisaje como palabra y noción, dejando en suspenso la historia y los relatos que dan sustento a la identidad del este país, los que se retoman con la aparición del paisaje nombrado, que en el caso de Chile fue primero Landscape. 


\subsection{LA PALABRA PAISAJE}

Prácticamente todas las tesis y muchos artículos que tratan del tema del paisaje tanto en arquitectura, urbanismo, geografía, sociología, ecología, etc., ponen en relieve la polisemia y vaguedad que acompaña el uso del término paisaje. El trabajo de investigación doctoral obliga a comparar las diferentes definiciones que ofrecen las publicaciones, reteniendo las más adecuadas para abordar la temática o proponiendo una nueva que se suma y que riesgosamente puede aumenta la ambigüedad del término. Para hacer el recorrido desde lo más elemental, podemos referirnos al Diccionario de la Real Academia de la Lengua en su $23^{\mathrm{a}}$ versión de 2014 , donde aparece la siguiente entrada:

\section{paisaje.}

Del fr. paysage, der. de pays 'territorio rural', 'país'.

1. $m$. Parte de un territorio que puede ser observada desde un determinado lugar. 2. m. Espacio natural admirable por su aspecto artístico.

3. m. Pintura o dibujo que representa un paisaje (espacio natural admirable).

En esta definición se reconoce primeramente el origen francés del término, derivado de pays, territorio rural o país. No muestra asociación etimológica en griego ni en latín, y ofrece tres acepciones del término. 1 y 2 se refieren a un territorio físico, la primera como una parte de éste que tiene su existencia en un observador que lo enmarca, la segunda una realidad física, originada a partir de una apreciación estética que cualifica un espacio natural. Por último, la tercera se refiere a la representación como expresión artística.

A continuación, buscaremos profundizar en historia del término desde distintos idiomas, los que ofrecen, a su vez, interpretaciones diferentes al uso de la palabra paisaje.

\subsubsection{El francés como punto de partida}

En el libro Le paysage. Fenêtre ouverte sur le roman. Le cas de I'Italie romantique de 2007, la doctora en Letras Aurélie Gendrat-Claudel hace un interesante análisis de la formación, etimología e historia de la palabra francesa paysage, buscando el modelo sobre el cual se habría formado el concepto italiano paesaggio, el que podría extenderse a la palabra en español paisaje. Para la autora, según las bases formales, paysage puede en primer lugar vincularse a dos conjuntos de palabras: de una parte, las palabras derivadas de pays (campo/tierra), y las palabras con el sufijo -age, cuyo significado, extremadamente amplio, parece determinar la aprehensión global de una realidad.

Desde el punto de vista etimológico, paisaje extrae sus raíces del término latino pays (campo/tierra), que se remonta a una forma del latín pa(g)ensis que nombra al habitante de un pagus. Pagus, se vincula a su vez con el verbo pango (poner pilares, delimitar). Por lo tanto, el pays (campo/tierra) es originariamente un territorio limitado por la intervención del hombre. Por su parte, el sufijo age, usado después de un verbo, indica una acción después del nombre de una persona, un estado, o una colección de cosas (Gendrat-Claudel, 2007, p. 37), como en aterrizaje, arbitraje, 0 un trazo distintivo que indica lo colectivo, observable en palabras como plumaje y follaje.

Los diccionarios franceses actuales, al igual que español, dan dos sentidos principales a paysage (paisaje): el paysage como extensión de pays (campo/tierra) que se presenta a un observador, y el paysage como cuadro que representa la naturaleza. La relación entre paysage y pays parece dar cuenta de una percepción global de la extensión de pays. De este modo, son nombradas con el mismo término una realidad y su representación icónica. Es como si llamáramos a "Pedro" y a "la foto de Pedro" con la misma palabra o lo que sucede en matemática 
con los números, cuando decimos cinco, habitualmente hablamos del signo $5 \mathrm{y}$ de la cantidad 5: numeral y número, donde el numeral es el símbolo o representación visual, y el número como entidad abstracta, que contiene todos los conjuntos de 5 cosas. La matemática también tiene estos problemas.

Desde el punto de vista histórico, la primera utilización de la palabra paysage está documentada en el siglo XV. Jean-Charles Filleron (2008) la encuentra en un texto de 1493 de Jean Molinet, el gran retórico de la Corte de Borgoña, que la utiliza para describir una pintura de paisaje ${ }^{89}$. Es la época cuando se difunden por toda Europa las pinturas flamencas en las cuales se observa una nueva atención por la naturaleza. Joachim Patinir, nacido en Dinant en 1485 y muerto en Amberes en 1524, es el primer paisajista en el sentido que ahora damos a esa palabra. Albert Dürer lo menciona como "der gute Landschaftmaler", el buen pintor de paisajes (Filleron, 2008, p. 2).

En los cuadros de Patinir (Figura 3.1.), la porción del país ya no es un decorado que resalta los personajes representados, ni el fondo de un cuadro, sino que pasa a convertirse en el elemento central. La palabra parece haber determinado originalmente una "innovación" estética, una nueva realidad artística. Desde entonces, incluso si renunciamos a la ilusión de la adecuación perfecta entre las palabras y las cosas, en cierta forma, podemos afirmar que antes de la aparición de la palabra, el paisaje, culturalmente, no existía; no puede haber paisaje (y discurso sobre el paisaje) sino hasta cuando el paisaje se ha ya convertido en una representación artística. 3.3.2. Otras lenguas y sus equivalentes

La geógrafa francesa Catherine Franceschi (1997), en su revisión de la historia de la palabra y sus equivalentes en francés, alemán, holandés, inglés, italiano y español, muestra una partición respecto a su registro semántico. Por una parte, encontramos una serie "territorial" y por otra una serie relacionada con la "imagen". Esta diferenciación no está contenida en la etimología de las palabras, pero sí en su historia. Landschaft, landschap, paese pertenecen a la serie "territorial"; paysage, paesaggio así como el equivalente inglés paisage y landskip, antecesores de landscape, pertenecen a la serie "imagen".

Históricamente, la palabra landschaft es muy anterior a paysage; ésta existe desde fines del siglo VIII para traducir el término regio, patria, mientras que la palabra paese en Italia, a partir de 1481 se usa para designar una representación de pays (Franceschi, 1997, p. 27).

${ }^{89}$ Filleron indica otro hito más tardío en 1556, cuando Jean de Beaugué en su Historia guerra de Escocia utiliza el término "paisaje alrededor" para identificar un territorio controlado por una banda de caballeros.

Figura 3.1 Paisaje con San Jerónimo, Joachim Patinir. Museo del Prado.

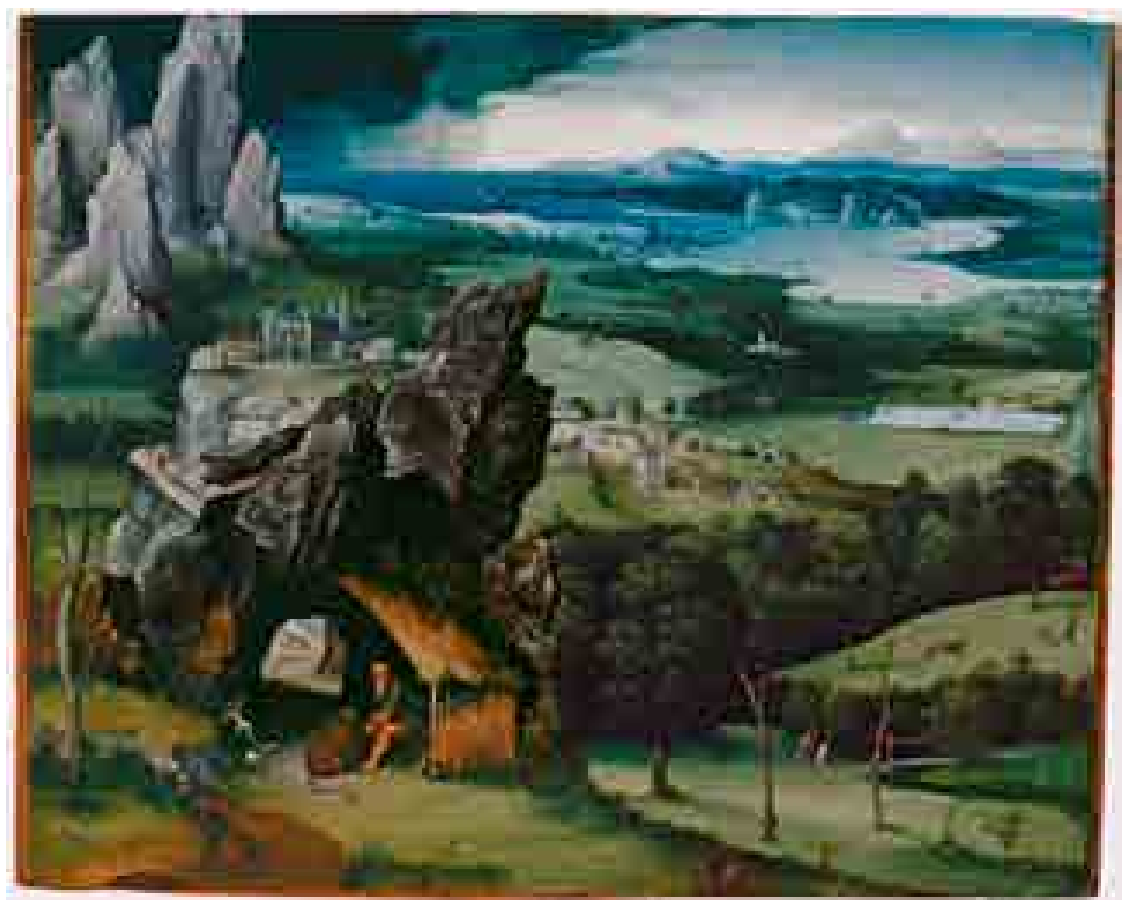


Para Franceschi (1997), al revisar los diccionarios, la referencia europea más antigua se remonta a fines del siglo XV, debutando en el siglo XVI con Landshap en holandés (1481), landschaft en alemán (1508) païsage en francés (1549), paisaje en español (1597), landskip en inglés (1598) que deviene en land-scape en 1603, mientras que la palabra italiana paesaggio que aparece en 1552 no fue registrada en un diccionario hasta 1878. La palabra paesaggio, según algunos diccionarios italianos actuales, es de origen francés y designa una representación pictórica. Thierry Paquot (2016) señala que el Tiziano la emplea en 1552 en una carta a Felipe II de España; en ella, le anuncia que envió un "paesaggio" -cuadro-. El término proviene posiblemente de los pintores que se reunían en el castillo real de Fontainebleau, que dará más tarde origen a la Escuela de Fontainebleau ( $\mathrm{Pa}$ quot, 2016, p. 15).

Una de las observaciones interesantes que hace Franceschi acerca de los seis idiomas estudiados -francés, alemán, inglés, flamenco, italiano, español-, es que sólo el francés ha inventado una palabra nueva para nombrar una cierta forma de representación. En italiano -como en español-, se observa una situación híbrida: una misma palabra, ha largamente nombrado el país y su representación, antes de la introducción de la palabra paesaggio y paisaje, que determinan la representación del país y que luego, con el paso del tiempo, termina por definir la percepción sobre una porción de la naturaleza, a partir de lo que se puede afirmar que "la evolución de las palabras païsage, paesaggio y paisaje va desde el campo de la representación hacia el territorio que se abre a la mirada, es decir, a la inversa de la extensión del sentido de las palabras landschap, landschaft, paese" (Franceschi, 1997, p. 97), que parten de nombrar al territorio, para abarcar luego su representación.

Observando la ausencia de un término que tradujera precisamente la noción de paysage en latín, en griego, y toda una serie de lenguas -japonés, dialectos africanos -entre otros-, Jeanne Martinet (1984) en su artículo Le paysage: signifiant et signifié concluye: "para que la noción de paisaje tome forma y se desarrolle, es necesario reunir ciertas condiciones entre las cuales cuenta, en primer lugar, la existencia de una pintura que tome por tema la naturaleza -dicho de otra manera, un tratamiento semiológico de esta naturaleza" (Martinet, 1984, p. 67). Agreguemos, anticipando ciertas conclusiones, que para que el paisaje exista, hace falta un grupo humano que deje de percibir la naturaleza como un simple hábitat, un lugar de agrado o como el territorio de los dioses. Es en la ruptura de la relación de hábito en el que mirar un paisaje se convierte en el evento que crea las condiciones de la noción.

\subsubsection{El paisaje en español}

En su libro Paisaje, génesis de un concepto, Javier Maderuelo (2006) posterga la aparición del término paisaje en España. Nos plantea que en el Renacimiento se llama "fondos" o "lejos" a aquellos "fragmentos pictóricos, que no necesariamente ejecutaban los maestros, y que han ido cobrando progresivamente más interés plástico hasta reclamar una especificidad y llegar a convertirse en género autónomo" (Maderuelo, 2006, p. 27); se trata de esos espacios intersticiales 0 fragmentos que se observan a través de los vanos. Más tarde Vicente Carducho (1576-1638), no parece querer utilizar el término lexos (lejos) y recurre a formar la frase "bellos pedazos de países" (Maderuelo, 2006, p. 28), fórmula que aplica sin pronunciar aún, el término paisaje.

Un siglo después, en 1737, aparecería según Maderuelo (2006), la palabra paisaje en el Diccionario de Autoridades, definiéndolo como "un pedazo de país en la pintura". Indica más adelante que paisaje en español no está documentado hasta el año 1708, si bien el antropólogo Julio Caro Baroja sostiene que tanto 
Lope de Vega como Cervantes lo habrían utilizado aludiendo a "ámbitos naturales" y a "cuadros y paisajes de Flandes", respectivamente. Esta afirmación es rebatida por Maderuelo a partir de traducciones más fieles que las que han actualizado el léxico original. Sin embargo, en el caso de Cervantes se puede apreciar que ya en 1613 el escritor comprende plenamente el nuevo concepto y conoce el género pictórico, ya que como hemos visto, los cuadros de la época que se pintan en Flandes, se caracterizan por la representación minuciosa de paisajes (Maderuelo, 2006, p. 29).

En los siglos siguientes, se mantiene cierta resistencia al uso de la palabra paisaje, hasta el siglo XIX, fenómeno que queda muy bien graficado en el trabajo de clasificación de cuadros realizada por Pedro de Madrazo en 1843 como director del Museo del Prado. En esta tarea de clasificación, solo uno de los ocho cuadros de Nicolás Poussin es catalogado como paisaje y siete como países.

De aquello, no resulta extraño entonces la ausencia del término Paisaje en las crónicas acerca del Reino de Chile realizada por criollos ilustrados, así como conquistadores, y viajeros españoles ${ }^{90}$, aunque, éstos fueron capaces de describir el territorio y sus paisajes con maestría.

A partir de una de las acepciones de paisaje que lo define como: "Parte de un territorio que puede ser observada desde un determinado lugar" (DRAE, 2014), podemos entender que los que está en juego no es solo una

entidad natural (objeto), sino el recorte (la parte) que puede ser (en condicional) observada por una mirada adiestrada por la pintura y por la confrontación de experiencias. Maderuelo desarrolla así esta idea:

\footnotetext{
...la idea de paisaje no se encuentra tanto en el objeto que se contempla como en la mirada de quien contempla. No es lo que está delante sino lo que se ve... Pero la mirada requiere, a su vez de un adiestramiento para contemplar. La contemplación del paisaje desde el punto de vista del arte debe ser desinteresada, estética. Así el paisaje es el resultado de la contemplación que se ejerce sin ningún fin lucrativo o especulativo, sino por el mero placer de contemplar. Cuando se viaja de un país a otro se perciben las diferencias entre los distintos entornos. De la constatación de estas diferencias procede el término paisaje, que se perfila como el conjunto de aspectos característicos de un país que se detectan al ser comparados con los de otros lugares o países. Lo que se ve requiere de un aprender a mirar para distinguir las diferencias. Requiere una escuela de la mirada en la que poder aprender a distinguir los aspectos característicos y estructurales, prescindiendo de los accesorios. Esta escuela en gran medida, la proporciona la pintura, por eso la palabra paisaje surge en la cultura occidental como un término 'pictórico'. (Maderuelo, 2006, p. 38)
}

Sin embargo, Maderuelo no repara en el potencial de los términos antiguos lejos o fondos, para reinterpretar la arquitectura del paisaje. Figura y fondo han sido uno de los temas centrales en la psicología de la percepción. El arte y en especial la arquitectura han trabajado para ser "figura", a través de recursos como la alteridad y la originalidad. "Figura" significa una entidad reconocible, que emerge como unidad, es a la que dirigimos primero la atención, mientras que fondo es "lo otro", un agente indirecto, la atmósfera. Pese a esta aparente jerarquía, forman una unidad inseparable: sin fondo no hay figura. De este modo podríamos recuperar y dar sentido a la resistencia del lenguaje español respecto a la palabra paisaje. El "lejos" o "fondo", no son necesariamente un escalón más bajo de la evolución del concepto, al contrario, podríamos postular que la arquitectura del

${ }^{90}$ Nos referimos a Pedro de Valdivia, Alonso de Ercilla, Alonso de Ovalle y al Abate Ignacio Molina, cuyas crónicas y cartas se han analizado para esta investigación.

paisaje es fondo, no figura. 


\subsubsection{Significado y significante}

Este rápido paso por el origen -etimológico, pictórico, discursivo- del paisaje era necesario para hacer surgir el vínculo complejo entre el lenguaje, la representación y la realidad, en un paso que dificulta atribuir jerarquías. Jean-François Lyotard (1988), en su ensayo Scapeland (Figura 3.2.), define provocativamente el paisaje como aquello que excede el sentido del orden impuesto por la perspectiva o por cualquier sistema de conocimiento y descripción. A partir de la relación entre las palabras en inglés landscape y scapeland, tierra de la huida, tierra que se escapa, lugar inaprehensible que se oculta y donde el observador y quien comenta pueden ocultarse también (Lyotard, 1988, p. 44). Considera que es en la ambigüedad donde se encuentra toda tentativa de definición y de discurso sobre el paisaje, e insiste en que el encuentro con el paisaje es fundamentalmente desorientador, ya que traspasa los límites tanto espaciales como temporales. El paisaje es entonces una materia que no puede ser cohesionada como forma, como un hecho que va "más allá del reino de la forma", escribe, dejando a la "mente desolada" (1988, p. 44). Aquí podemos detectar una capacidad del paisaje, que podemos aprovechar para desplazar las nociones legibles de espacio y tiempo que apuntalan la subjetividad. El yo, escribe Lyotard, "se queda atrás" (1988, p.43). Podemos considerar que más que un objeto de la naturaleza, el paisaje es una entidad relacional, que se produce en el acto de encuentro entre lo que se conoce y lo que se experimenta, fuera del ámbito del conocimiento.

Una de las primeras dificultades que enfrentamos entonces, es que el paisaje se define tanto por lo que vemos de él, como por lo que no. Es lo que los geógrafos franceses llaman las étendues masquées -extensiones enmascaradas- 0 los espaces défilés -espacios que se suceden-, que participan en la definición de esta comprensión parcial a través de la mirada (Gendrat-Claudel, 2007, p. 49). Según esto, para la geografía, el paisaje es una vista de una porción del espacio terrestre donde "la proporción y la disposición de los étendues masquées dependen, de una parte, de las formas del relieve, de la vegetación y, de otra parte, de la localización (en particular de la altura) del punto de observación. [...] Un mismo espacio puede tener paisajes diferentes según los puntos desde dónde se observe". (Lacoste, 1977, p. 16)

Por lo anterior, si consideramos que el paisaje corresponde "una porción de espacio analizado visualmente", y es "aquello que vemos (accesoriamente aquello que percibimos o sentimos) y aprehendemos esencialmente a través de la mirada; primero se sitúa su lectura, como aval su explicación" (Avocat, 1984, p. 11). Podemos recurrir a la expresión más próxima de Christian Jacob: "el paisaje es un efecto de lectura, aquello que percibimos al término de un proceso de representación: el objeto no prexistía a la imagen que lo construye" (Jacob, 1984, p. 161). Vemos que aquí se suma el problema del lugar del sujeto, y por lo tanto de la subjetividad, en la definición de paisaje. La "delimitación" de un espacio y la "limitación" de la visibilidad ("porción de espacio" es la expresión que sirve de denominador común a todas las definiciones) hacen que el paisaje sea una estructura incompleta, que pide ser completada a través de la intervención activa del sujeto, quien deberá esforzarse para llenar sus lagunas gracias a la imaginación, a la palabra o al movimiento (Collot, 1984, p. 125).

\subsection{EL PAISAJE Y LAS DISCIPLINAS}

Cuando los sujetos son los autores de las definiciones científicas y técnicas del paisaje, trabajan principalmente para legitimar la práctica que éstas implementan o defienden, o incluso para reducir el alcance con el fin de descalificar a las otras prácticas. El discurso lingüístico que orientará el sentido que desarrolla la disciplina, se asocia frecuentemente con esta definición. Eugenio Turri (1998) en II paesaggio come teatro, considera que además de los límites impuestos por lo que la vista puede abarcar, las intenciones del sujeto serán determinantes:

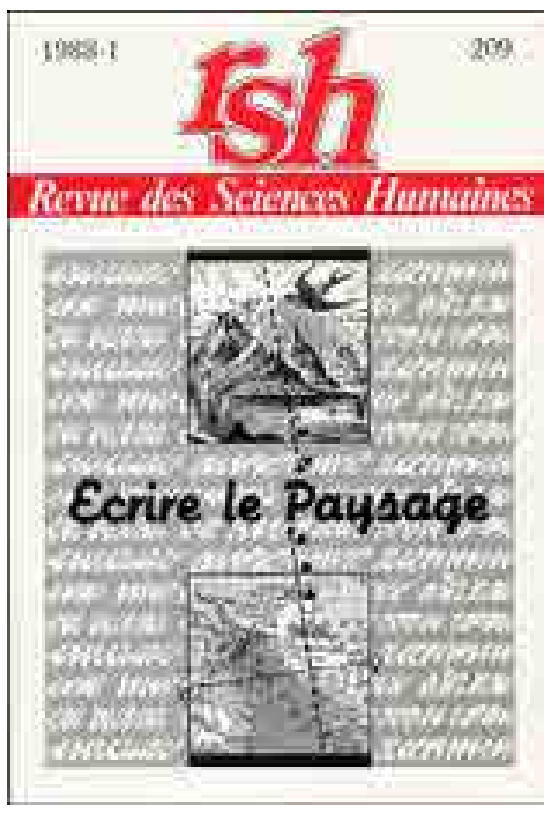

Figura 3.2 Ecrire le Paysage (1988). Portada de la revista. 
Nuestra percepción está vinculada a los espacios limitados que nuestra mirada puede abarcar, y el paisaje representa sólo esto, una parte del mundo [...] el paisaje existe y de ello se puede hablar por el hecho que existe un sujeto -el hombre- que lo percibe, lo vive, lo representa, lo cuenta, lo describe o lo estudia. (Turri, 1998, p. 22) $)^{91}$

Hasta aquí la investigación se ha orientado a partir de referentes centroeuropeos, en una suerte de contrapunto a la hegemonía anglosajona, especialmente norteamericana, que ha ejercido una fuerte influencia en el desarrollo del plan maestro para Laguna Carén. Autores como James Corner desde la Universidad de Pensilvania y Charles Waldheim de Harvard son referentes ineludibles cuando se trata de abordar desafíos en la práctica, especialmente por la capacidad que han demostrado de difundir sus ideas y proyectos, a través de publicaciones que llegan a Chile con más facilidad que las francesas, incluso que las publicadas en España. Otra razón de este fenómeno es el creciente interés de jóvenes arquitectos chilenos de seguir sus estudios de posgrado en las universidades norteamericanas. Si bien estos autores serán incorporados en los capítulos siguientes, podemos anticipar algunas particularidades de este campo disciplinar muestra hoy:

- Existe muy poca conexión entre la arquitectura y el urbanismo del paisaje a ambos lados del Atlántico. Si revisamos las bibliografías, son escasas las citas de autores franceses, italianos o españoles en textos norteamericanos, y lo mismo recíprocamente. Las excepciones son Gilles Clement y Sébastien Marot. Para los europeos, el punto de conexión es el ecólogo del paisaje Richard Forman de Harvard.

- Uno de los padres del Landscape architecture y Landscape urbanism norteamericano es lan McHarg. En su libro más importante, Proyectar con la Naturaleza (2000) no hay bibliografía.

${ }^{91}$ Traducción propia del italiano:

La nostra percezione è vincolata agli spazi limitati che il nostro sguardo può abbracciare, e questo rimanda al paesaggio, che del mondo rappresenta solo una porzione" (...) "Il paesaggio esiste e di esso si può parlare in quanto c'é un soggetto -l'uomo- che lo percepisce, lo vive, lo rappresenta, lo racconta, lo descrive o lo studia.

92 Diacronía es el desarrollo o sucesión de hechos a través del tiempo. El término diacronía se opone a sincronía, dimensión que permite observar cualquier fenómeno -cultural o lingüístico- tal como es en un momento dado de su evolución. En lingüística, diacronía es el estudio de la lengua a lo largo de su evolución, es decir, históricamente, reconstruyendo los momentos del idioma desde su origen hasta el momento actual. En antropología, el término diacronía fue adoptado por la corriente estructuralista francesa. Claude Lévi-Strauss había conocido la obra del lingüista suizo Ferdinand de Saussure, creador de la díada teórica diacronía-sincronía. De ahí la retomó aproximadamente con el mismo sentido que se usa en lingüística. En historiografía, la perspectiva diacrónica es la más habitual, la que presenta la evolución de los hechos o procesos históricos a lo largo del tiempo histórico. (Dyachronic, feb 13, 2011). banistas, por el contrario, los arquitectos y urbanistas referencian a los geógrafos y ecólogos.

- Los filósofos del paisaje han adquirido un importante protagonismo en el desarrollo teórico del paisaje, tanto para geógrafos (Jean Marc Besse) como para los arquitectos (Sébastien Marot).

- Los lingüistas tienen un puesto importante entre los franceses, al igual que los sociólogos. Explorar la historia del término, cosa que es casi obsesiva en los franceses, no se encuentra en los autores norteamericanos. - Los artistas dicen poco hoy. Se cita el land art, pero dentro de la reflexión filosófica e histórica del paisaje.

- La influencia asiática; desde el punto de vista teórico-filosófico, está representada por Fu Tuan-Yi y Tetsuro Watsuji.

Podríamos afirmar que el desarrollo más importante en historia y teoría del paisaje está entre los Geógrafos, con una larga tradición en estudios territoriales y paisaje, y que hoy entienden la Geografía como "la ciencia del paisaje".

\subsection{DIACRONÍA Y SINCRONÍA ${ }^{92}$}

Si bien el análisis sincrónico que hemos expuesto resulta esclarecedor, ya que nos permite entender un término en una época determinada, el estudio diacrónico nos ayudará a comprender la palabra paisaje más como un concepto que se ha ido construyendo y transformando a lo largo del tiempo. Resulta sospechoso que actualmente el discurso político y el de los medios de comunicación parece no presentar ninguna tensión entre el término en inglés, francés o español. Pero cuando se trata de profundizar, de interpretar y sobre todo de intervenir el paisaje, las estrategias, metodologías y principios hacen ver que habitamos en paisajes inconmensurables, muy distintos. Así como las capas de un terreno también el 
lenguaje está entre lo visible y lo invisible, como bien lo capta Foucault:

El lenguaje está a medio camino entre las figuras visibles de la naturaleza y las conveniencias secretas de los discursos esotéricos. Es una naturaleza fragmentada, dividida contra Paisaje sí misma y alterada, que ha perdido su primera transparencia; es un secreto que lleva en sí, pero en la superficie, las marcas descifrables de lo que quiere decir. Es, a la vez, una revelación escondida y una revelación que poco a poco se restituye una claridad ascendente. (Foucault, 1968, p. 43)

\subsection{DESDE LA PALABRA A LA NOCIÓN DE PAISAJE: COMO EXPERIENCIA, OBJETO Y ACONTECIMIENTO.}

Si consideramos que el paisaje es un constructo, una construcción mental que los hombres y mujeres realizamos a través de los fenómenos de la cultura, hacemos nuestra la idea de Maderuelo, de que cuando hablamos de paisaje, nos referimos a "una convención que varía de una cultura en otra, [...] [lo que nos] obliga a hacer un esfuerzo e imaginar cómo es percibido en mundo en otras culturas, en otras épocas y en otros medios sociales diferentes del nuestro" (Maderuelo, 2005, p. 17).

Para reconstruir la evolución del concepto paisaje, tomaremos como referente al filósofo francés Jean-Marc Besse ${ }^{93}$, que en los ensayos reunidos en el libro La sombra de las cosas (2010), se plantea frente a la tensión dialéctica entre el paisaje como "contemplación a distancia del mundo"(2010, p. 17) y como relación del hombre con su medio, con la tierra en su sentido ontológico y perceptual. Siguiendo su texto, proponemos un recorrido por la historia de la noción de paisaje distinguiendo seis momentos que también representan seis aproximaciones al concepto. Siguiendo estos hitos, que se complementará a través de la relectura de los autores citados por Besse y otros que complementan y sitúan las ideas dentro de los objetivos de esta investigación, se busca entender cómo esta noción está profundamente ligada a los modelos de pensamiento de cada época, los que en el texto están trenzados con la aparición de la noción de paisaje en Chile y la construcción de la identidad nacional a partir de él.

La cuestión planteada por Besse, y que nos abre la posibilidad de pensar el paisaje más allá de la historia del concepto, es la emergencia de la experiencia, de la conciencia y del sentimiento de paisaje en la modernidad. Fundamentalmente, es ese proceso en el que se hace posible no sólo pensar en términos de paisaje el mundo y a nosotros mismos, sino de existir como sujetos de paisaje.

\subsubsection{El paisaje narrado}

La primera aproximación propuesta por Besse se encarna en el lírico y humanista Francesco Petrarca, a través de la lectura de la famosa epístola de 1336 dirigida al agustino Dionisii de Borgo San Sepolcro, donde relata la ascensión al Monte Ventoso (La Subida al Monte Ventoso, Figura 3.3). Petrarca, considerado por varios autores como el primer humanista, manifiesta la curiosidad, el deleite estético y el ansia de conocimiento que hoy reconocemos como propio del renacimiento italiano. El texto además tiene un carácter autobiográfico, íntimo, introspectivo, como si se tratase al mismo tiempo de un diario donde se refleja la subjetividad del individuo, anunciando una de las características del discurso moderno.

Petrarca se refiere al ascenso del monte Ventoso y el deseo de contemplar lo que hoy llamamos paisaje: "Impulsado únicamente por el deseo de contemplar un lugar célebre por su altitud, hoy he escalado el monte más alto de esta región, que no sin motivo llaman Ventoso" (Petrarca, 1336/2011, p. 35).

En su ensayo sobre Petrarca y Gracián, Luis Avilés (2000) plantea que:

El espacio de Ventoux se podría definir como una topografía que se impone como barrera física que, de inmediato, se va a transformar en un mapa alegó-
${ }^{3}$ Filósofo, trabaja sobre la historia y la epistemología del paisaje y del ambiente en la cultura contemporánea, en la Universidad de París-I, en la Escuela Superior de Paisaje de Versalles y en el Instituto de Arquitectura de la Universidad de Ginebra.

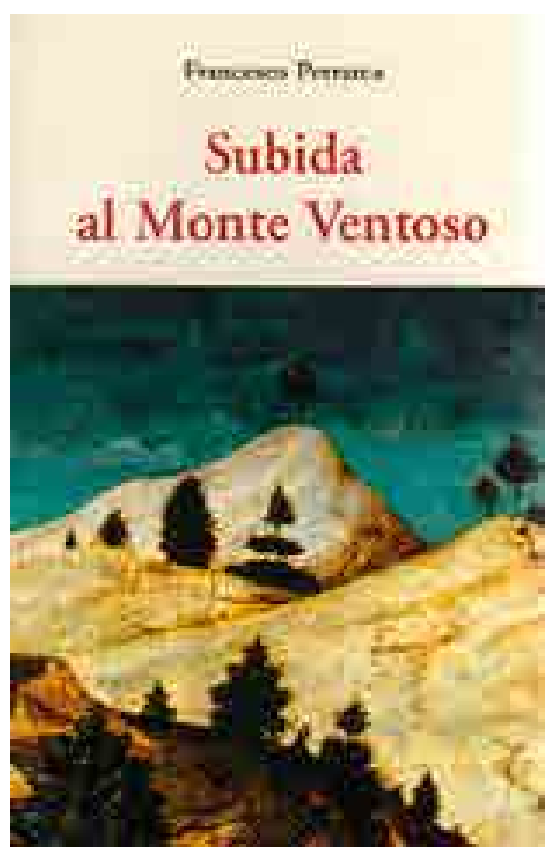

Figura 3.3. Subida al Monte Ventoso, Francesco Petrarca (1336/2011) 
rico por el que transita el yo en su circunstancia. Experimentar el espacio es confrontarse consigo mismo en el contexto de una dificultad corporal que va desde el movimiento y el cansancio hasta el estatismo y descanso que permite el pensamiento. (Avilés, 2000, p. 282).

En su ascensión, Petrarca describe un proceso interior: "dejando volar la mente de lo corpóreo a lo inmaterial" (Petrarca, 2011, p. 43). El viaje es así tanto un movimiento visible como uno invisible que es interno y existencial. La posibilidad de contacto con el espíritu surge así de la experiencia ante un paisaje que lo asombra y lo libera de las ataduras de los pensamientos terrenales. La naturaleza adquiere de este modo, un valor estético que eleva, a ejemplo del cuerpo, el espíritu a regiones superiores:

La frontera entre la Galia e Hispania, los Pirineos, no podía divisarse desde allí, no porque se interponga algún obstáculo, que yo sepa, sino por la sola debilidad de la vista humana; en cambio se veían con toda claridad las montañas de la provincia de Lyon a la derecha, y a la izquierda el mar que baña Marsella y Aigües-Mortes, distante algunos días de camino; el Ródano mismo estaba bajo mis ojos. Mientras contemplaba estas cosas en detalle y me deleitaba en los aspectos terrenales por un momento, para en el siguiente elevar, a ejemplo del cuerpo, mi espíritu a regiones superiores, se me ocurrió consultar el libro de las Confesiones de Agustín,(...) a partir de entonces no siguió más allá, así yo también encontré en el breve pasaje citado la razón y el límite de toda mi lectura, meditando en silencio cuán faltos de juicio están los hombres, pues descuidan la parte más noble de sí mismos, se dispersan en múltiples cosas y se pierden en vanas especulaciones, de modo que lo que podrían hallar en su interior lo buscan fuera de sí (Petrarca, 1336/2011, pp. 52-53)

En El arte del paisaje, Raffaele Milani sostiene que el mérito de Petrarca reside en que posiblemente haya sido el primero en explicitar una visión estética del Paisaje, una "admirable fusión de experiencia estética y reflexión filosófica, considerada el primer documento moderno de la valoración estética del paisaje" (Milani, 2015, pp. 4243).

Del mismo modo, Jean-Marc Besse considera el ascenso de Pretarca al Monte Ventoso como una de las primeras aproximaciones a la experiencia paisajística, a la mirada "desinteresada" sobre la naturaleza, como un proceso -el ascenso- en el que se manifiesta la separación del sujeto y de su entorno. La visión desde un lugar determinado adquiere un nuevo valor estético que se diferencia del mundo clásico y medieval, lo que haría de Petrarca un precursor de la mirada moderna del paisaje.

A través de la experiencia de Petrarca, es posible percibir la situación de tensión y contradicción vivida en la transición hacia la modernidad, en la que el Paisaje se configura como una noción a partir de la cual se establece un distanciamiento en relación al mundo -la naturaleza contemplada por una mirada, la curiosidad, el deseo de saber- y el enfrentamiento de modos de vivir, que se oponen en un sentido más interior o espiritual, descalificando el espacio. y un sentido más exterior, que valora la posición y el desplazamiento en el espacio. Petrarca -sujeto proto-moderno- vive ese dilema. El relato de esta escalada no sólo habla de una experiencia práctica,

que participa de un desplazamiento en el sentido físico y de un desplazamiento de la mirada, haciendo posible la experiencia del paisaje, sino también de un desplazamiento epistemológico, en el modo de interpretar y estar en el mundo.

Petrarca representa así el cambio entre la concepción medieval del mundo que se fundaba sobre la revelación divina, a una otra, revelada ahora por los antiguos que habían conocido la verdad a través del contacto directo con la naturaleza, 
a través de la creación. Giulio Carlo Argán (1909-1992) en su primera Lección en Tucamán de 1961 explica que, si para el hombre del siglo XIV la verdad era revelada por Dios:

(...) la experiencia de la naturaleza no era ya la única fuente de la verdad, sino que, en cierto sentido, era una fuente menos importante y menos directa: si Dios mismo había revelado la verdad, no era necesario buscarla en la naturaleza. (Argán, 1973, p. 15)

Es la voz de San Agustín- esa que escucha Petrarca en el Monte Ventoso. Por otra parte, se presenta el problema de cómo entender el mundo antiguo, el clásico, el de la historia que se admiraba como un mundo casi perfecto, pero que no tenía posibilidad de salvación. Argán en esa misma lección da la respuesta:

(...) que la Divina Providencia antes de la Revelación, había hecho las cosas de manera tal que los hombres pudieran conocer la verdad a través de la naturaleza, a través de la creación, remontándose así desde la cosa creada al Creador. Así, pues, los antiguos eran los más grandes conocedores de la naturaleza, puesto que eran los que en la naturaleza y de la naturaleza debía extraer todos los elementos de su vida espiritual. Por eso, ya desde comienzos del Renacimiento existe el concepto de la verdadera naturaleza, la naturaleza en su sustancia y no solamente en su apariencia, es aquella que nos es revelada por los antiguos, por los poetas. (Argán, 1973, p. 15).

3.6.2. La tierra como paisaje La segunda aproximación propuesta por Jean-Marc Besse (2010) aborda la relación entre la pintura y la geografía que se cruzan para crear una imagen de la tierra como paisaje, intentando representar el espacio con la mayor precisión posible. Se trata de un dilema que queda representado a través de la figura del pintor flamenco Pieter Brueghel, llamado el Viejo (15251569). Aquí, el autor busca demostrar cómo el paisaje flamenco, antes de ser una experiencia ligada a un género pictórico, estuvo primordialmente relacionada con una experiencia territorial y geográfica, con un fuerte sentido pragmático e instrumental, vinculado con la representación cartográfica. Los grandes paisajes y grabados de Brueghel el Viejo permiten analizar la cercana relación entre la cartografía y la representación artística de los paisajes en el siglo XVI. Pintores y cartógrafos desarrollan un modo de observar y representar los espacios, una "lectura de los signos que constituyen la cualidad propia del paisaje" (Besse, 2010, p. 51). Como hemos visto, en esta época, ya existía una tradición de la paisajística en la pintura flamenca; los pintores flamencos descubren casi al mismo tiempo que los italianos, la perspectiva lineal y la aérea, pero de manera empírica y no según un desarrollo geométrico ni teórico. El resultado de este ejercicio práctico es la perspectiva "caballera" o "a vuelo de pájaro", que consiste en representar la escena como si el observador se situara en una posición elevada -como una persona a caballo-, ordenando desde la parte inferior del cuadro, en vertical, desde los objetos más cercanos a los más alejados, escalando hasta la parte más alta, donde, con frecuencia, se encuentra la línea del horizonte. Este fenómeno pictórico puede vincularse con la cartografía, cuyo desarrollo se iniciaba en los Países Bajos por aquel entonces. Un paisaje visto a vuelo de pájaro se extiende más allá del horizonte, hasta donde alcanza la vista, compuesto de varias vistas yuxtapuestas en la misma escena; en ella se ven pequeñas criaturas, animales y hombres, no siempre relacionados con el tema "oficial" del primer plano, y a menudo dedicados a las ocupaciones más humildes (Figura 3.4.).

En el caso de Brueghel el Viejo, éste retoma la tradición inaugurada por El Bosco, abrazando definitivamente temas profanos, describiendo la realidad del mundo, donde todas las acciones son vistas con la misma importancia y escala, y tratadas con la misma atención al detalle ${ }^{94}$, rompiendo con la escala perceptual, como lo hace el mapa -fijando la escala-. Estos hechos revelan una nueva relación entre el hombre y la Tierra, en la que el observador requiere "apartarse de ella para percibirla y pensarla, para comprender mejor lo que también lo vincula a
${ }^{94}$ La pintura flamenca carece de precedentes en gran formato, a excepción de las vidrieras. Pero sí en las miniaturas, sobre las cuales posee una larga tradición de excepcional calidad. Esto determinará algunas características del arte flamenco, como serán el empleo de colores brillantes, que recuerdan a los pigmentos usados para la iluminación de las miniaturas. También el detallismo aplicado a estas pequeñas obras maestras se transmite a la pintura de gran formato. 
Figura 3.4. El triunfo de la Muerte (1562 1563). Óleo sobre tabla de Pieter Bruegel el Viejo. (C) Museo Nacional del Prado

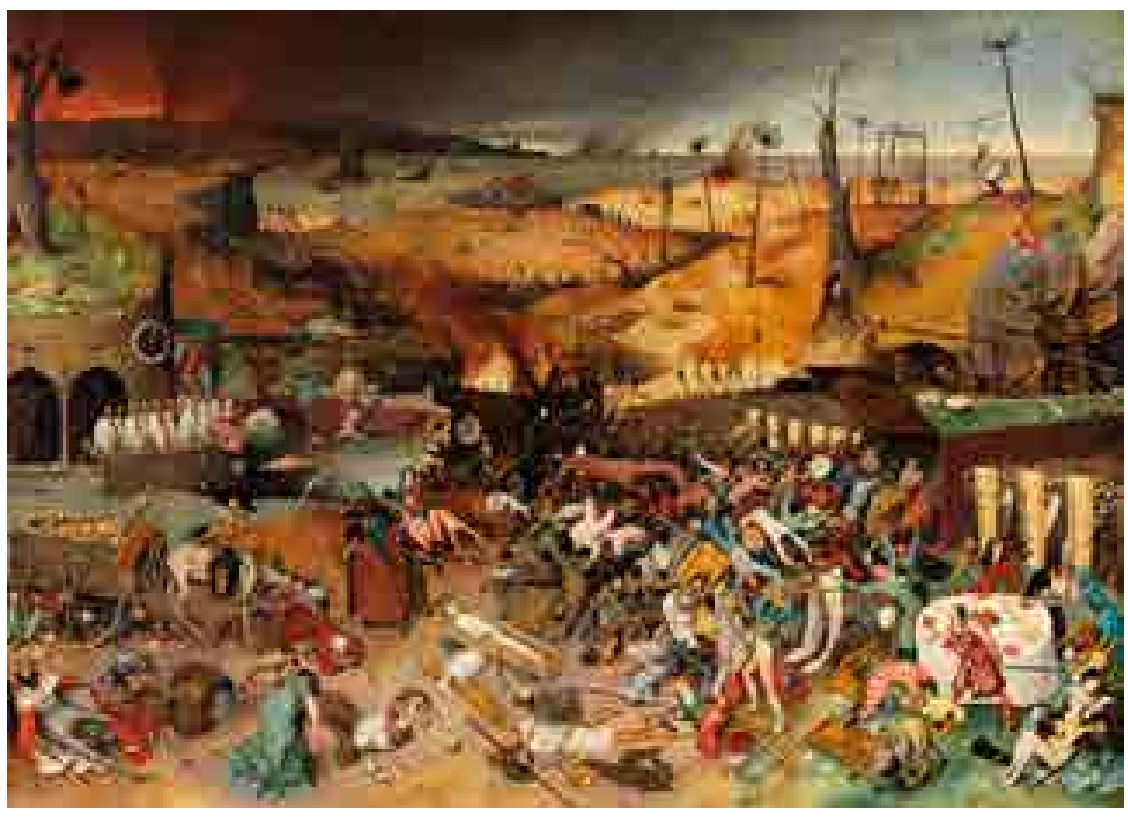

ella" (Besse, 2010, p. 64) y poder entenderla como un todo. El paisaje, como espacio objetivo, permite esta nueva experiencia, donde las propiedades naturales, los objetos y las personas pueden ser descritas.

El mismo autor destaca a dos contemporáneos de Brueghel, Abraham Ortelius y Petrus Albinus. El cartógrafo flamenco Ortelius, es reverenciado como el Ptolomeo del siglo XVl; su principal obra, el Theatrum Orbis Terrarum (1570) se considera el primer atlas moderno. Sus mapas regionales son señalados junto a las descripciones corográficas del Albinus, padre de la historiografía sajona, como ejemplos de minuciosos inventarios de las realidades cercanas. De este modo, el objeto de estudio del corógrafo es el mismo que el del cartógrafo y del pintor de paisaje. En la era de los descubrimientos, se expande el mundo conocido, desarrollándose la idea del "paisaje de mundo" y de una cartografía afín, donde según el autor, "el paisaje traspasará los límites de la región particular y se abre al espacio terrestre y a la relación entre lo que está cerca o lejos del horizonte" (Besse, 2010, p. 57).

En este contexto, la Tierra es vista como un objeto y su representación, sea un mapa o un cuadro, reúne todas sus características y las dispone objetivamente ante el observador.

Es en esta búsqueda de reunir la totalidad de caracteres del mundo, aunque ambas representaciones buscan precisar con detalle todas las áreas definiendo el paisaje por el sitio, por la posición y vecindad, que la idea del Paisaje como "horizonte ampliado" se elabora; hablamos de un momento histórico donde la Tierra es concebida como un "paisaje del mundo", dispuesto por la geografía -cartografía y corografía- y por la pintura.

Este hito, al inicio del siglo XVI, marca un cambio en las condiciones y en la forma de interpretación del mundo, del sentido de la representación de la Tierra. Besse plantea que este cambio es también promovido por las grandes navegaciones y "los descubrimientos" geográficos de la época. La gran pretensión y el desafío del europeo es representar a la Tierra en su totalidad, y participan de ese proyecto tanto la geografía como la pintura. Pero esa representación del mundo no es tan sólo un ideal contemplativo, no tiene solamente un valor filosófico. Podríamos añadir, para ir más allá en la proposición realizada por Besse, que este ánimo presenta, al mismo tiempo, un valor paradigmático, por un lado, está el impulso por el saber, pero también un interés geopolítico: la conquista de territorios por los europeos.

Jean-Marc Besse prefiere explorar el cambio en el modo de ver y ser en el mun- 
do del sujeto europeo que encuentra en la visión del paisaje el medio y la riqueza de la actividad contemplativa, anteriormente imbuida de un sentido religioso y filosófico que valoraba la visión interior. El paisaje, en ese sentido, forma parte de un dispositivo general de percepción y de pensamiento que, en el siglo XVI, estructura la relación mantenida con la superficie de la Tierra. Para el sujeto europeo de la época, este dispositivo está estructurado en la relación sujeto-objeto. Ciertamente, es un nuevo tipo de experiencia de la Tierra, que encuentra en el Paisaje la base de su representación -cartográfica, pictórica, descriptiva- y en el teatro su modelo analógico. Esta concepción de teatralidad del mundo, según Besse, es precisamente ilustrada por el pintor Brueghel. En sus cuadros, el paisaje se hace imagen del mundo, experiencia visual del mundo. Por lo tanto, en la pintura de Brueghel el paisaje es una imagen de mundo dado a un observador desinteresado de sus ocupaciones ordinarias, por una mirada que juzga a la distancia: el paisaje revelado y alcanzado en una fruición estética de la naturaleza.

Pero el Paisaje también posee una densidad cosmológica y ontológica. Por eso, es el orden del mundo el que se hace visible. Lo que Brueghel representa, sin embargo, no es un orden estático y meramente estético; es el movimiento, la circulación, el viaje: el mundo es un espacio que invita al movimiento. Para Besse, la representación pictórica del mundo de Brueghel nos pone ante un nuevo sentimiento de espacio y de un nuevo concepto de la Tierra, pero también de una nueva práctica, de una nueva experiencia geográfica del mundo: como imagen contemplada a distancia y como el "espacio en que se circula, al ser recorrido, una ecúmene ampliada, en que el paisaje gana sentido de mundo para el hombre que lo contempla" (Besse, 2010, p. 67). Lo que vemos en los cuadros de Brueghel no es solo una nueva percepción del espacio, caracterizado por "la transposición de límites" y un aumento de las escalas, sino también un nuevo concepto: el de la Tierra como un espacio universalmente habitable y abierto en todas direcciones; la superficie de la tierra está puesta ahí para contemplar "desde cierta altura y desde la distancia de una mirada extranjera" (Besse, 2010, p. 70). En esa misma época los límites de la Tierra se extienden hasta el extremo austral de América. Chile, en ese entonces, no es más que una noticia que llega desde lejos, sin que dicho rumor distante asegure comprensión alguna. Figura en los mapas desde un comienzo, pero como una costa, un borde que prometía ser más rico que El Cuzco, pero que nunca lo fue. Es Pedro de Valdivia (1497-1553), el conquistador de Chile, quien escribe cuatro años después de la fundación de Santiago una de las primeras descripciones de nuestro territorio, que busca, tras una dura campaña, dar a conocer a su rey, Carlos $\mathrm{V}$, los esfuerzos de la conquista, posiblemente impulsar su nombramiento como gobernador, y atraer a nuevas gentes para avanzar sobre los territorios al sur de Santiago. La carta, fechada el 4 de septiembre de 1545, tiene así en este fragmento el carácter de una de invitación:

(...) y para que haga saber a los mercaderes y gentes que se quisieren venir a avecindar, que vengan, porque esta tierra es tal, que para poder vivir en ella y perpetuarse no la hay mejor en el mundo; dígolo [lo digo] porque es muy llana, sanísima, de mucho contento; tiene cuatro meses de invierno, no más, que en ellos, si no es cuando hace cuarto la luna, que llueve un día o dos, todos los demás hacen tan lindos soles, que no hay para qué llegarse al fuego. El verano es tan templado y corren tan deleitosos aires, que todo el día se puede el hombre andar al sol, que no le es importuno. Es la más abundante de pastos y sementeras, y para darse todo género de ganado y plantas que se puede pintar [énfasis agregado]; mucha y muy linda madera para hacer casas, infinidad otra de leña para el servicio dellas [de ellas], y las minas riquísimas de oro, y toda la tierra está llena dello [de ello], y donde quiera que quisieren sacarlo allí hallarán en que sembrar y con que edeficar [edificar] y agua, leña y yerba para sus ganados, que parece la crió Dios a posta [adrede] para poderlo tener todo a la mano (Valdivia, 1545/1992, p. 43). ${ }^{95}$ 
Chile es descrito por Valdivia como la mejor tierra del mundo, un verdadero paraíso, un mundo que invita al movimiento y a la conquista. Sin aún poder hablar de paisaje -recordemos que el uso de la palabra en español es tardío-, Valdivia lo insinúa, ya que lo que describe "se puede pintar": se trata de un paisaje en potencia. Esta idealización por un observador que toma distancia, como en los cuadros de Brueghel, se convierte en una imagen que puede comunicarse. Pero es Ercilla en su poema épico la Araucana, quien completa este cuadro y pone el territorio de Chile en la historia; el mapuche de Ercilla, "sujeto noble y equiparable a su conquistador español", es a la vez es algo más que el mapuche de carne y hueso (Jocelyn-Holt, 2004, p. 102), transformándose así en un sujeto histórico.

En fin, el hado y clima desta tierra, si su estrella y pronósticos se miran, es contienda, furor, discordia, guerra,

y a sólo esto los ánimos aspiran; todo su bien y mal aquí se encierra: son hombres que de súbito se aíran, de condición feroces, impacientes, amigos de domar extrañas gentes.

Son de gestos robustos, desbarbados, bien formados los cuerpos y crecidos, espaldas grandes, pechos levantados, recios miembros, de nervios bien fornidos; ágiles, desenvueltos, alentados, animosos, valientes, atrevidos duros en el trabajo y sufridores de fríos mortales, hambres y calores.

No ha habido rey jamás que sujetase esta soberbia gente libertada, ni extranjera nación que se jatase de haber dado en sus términos pisada,

ni comarcana tierra que se osase mover en contra y levantar espada: siempre fue exenta, indómita, temida,

de leyes libre y de cerviz erguida.

(Ercilla, 1569/2006, pp. 22-23)

En el Canto III vemos a Ercilla narrando desde una perspectiva "caballera": describe sin que la realidad lo toque, como espectador de una escena teatral. El fondo, la naturaleza, parece inmóvil: es y está siempre, por eso no se menciona,

95 El cronista chileno Joaquín Edwards (1887-1968) cuenta cómo antiguamente se aludía con ironía a esta representación del conquistador, diciendo que " la calefacción en los antiguos inviernos consistía en leer la carta de don Pedro de Valdivia; donde dice que en Chile nunca hace frío". (Edwards Bello, 1973, p. 47).

Figura 3.5. Combate entre españoles e indígenas. En (Bibar, 1558/1966, p. O [493])

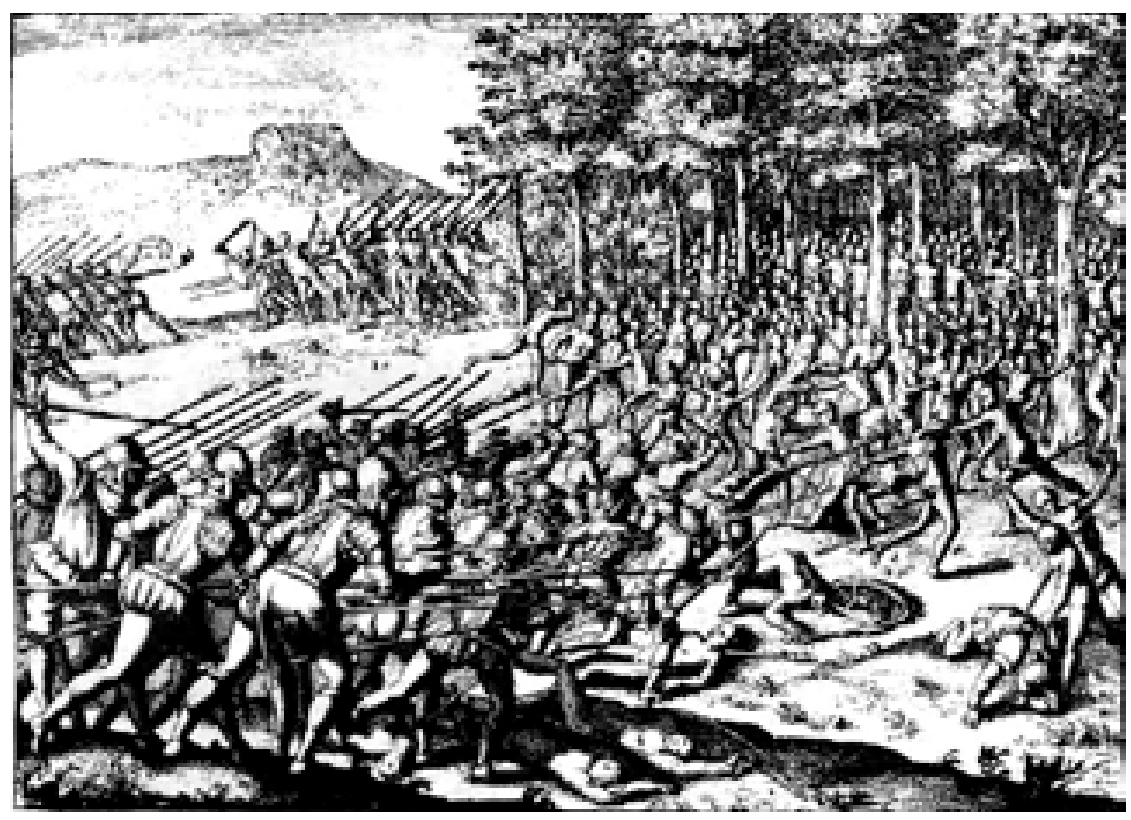


ella es inmensa y remota ${ }^{96}$. El espacio de la acción se llama tierra: medible, en pies, leguas y millas, está en cambio en proceso y se define por la acción de la conquista y de la batalla (Figura 3.5.). El paisaje que no se nombra es espectáculo observado, objeto contemplado:

Dado asiento en la tierra y reformado el campo con ejército pujante, en demanda del reino deseado movieron sus escuadras adelante: no hubieron muchas millas caminado, cuando entendieron que era semejante el valor a la fama que alcanzada tenía el pueblo araucano por la espada.

Al caballo con ánimo hiriendo, sin más les persuadir, rompe la vía; de los miembros el miedo sacudiendo, le sigue la esforzada compañía; y en breve espacio el valle descubriendo de Tucapel, bien lejos parecía el muro antes vistoso levantado, por los anchos cimientos asolado.

Valdivia aquí paró y dijo: " $¡ O h$ constante española nación de confianza!

Por tierra está el castillo tan pujante, que en él sólo estribaba mi esperanza;

el pérfido enemigo veis delante,

ya os amenaza la contraria lanza; en esto no tengo que avisaros pues sólo el pelear puede salvaros."

Estaba, como digo, así hablando, que aún no acababa bien estas razones, cuando por todas partes rodeando los iban con espesos escuadrones, las astas de anchos hierros blandeando, gritando: " Engañadores y ladrones!

\subsubsection{Viaje y paisaje}

La tercera aproximación a la noción de paisaje que propone Jean-Marc Besse, es a través del Viaje a Italia (Figura 3.6.) del poeta, novelista, dramaturgo y científico alemán Johann Wolfgang von Goethe ${ }^{97}$ (1749-1832). Su relato nos permite explorar la experiencia paisajística a partir de una visión particular del romanticismo en el espacio europeo del siglo XVIII. El viajero, ya tiene 37 años y emprende una aventura, confesando: "He aquí como mi viaje es una verdadera huida" (Goethe, 1891, p. 16) al encuentro libre con la naturaleza. Una búsqueda de la verdad a través del contacto con las cosas:

Otra vez he vuelto a sentir que para todo he envejecido, menos para la Verdad. Sus ceremonias y sus danzas, todo se desliza por mí como el agua sobre un impermeable; mientras, al contrario, una acción de la Naturaleza, como ver una puesta de sol desde la Villa madama, una obra de arte como esta Juno venerada, me causan impresión profunda y vivificante. (Goethe, 1891, p. 162).

Ahora busco la impresión de las cosas sobre los sentidos, que ni libros ni estampas pueden dar. Se trata de volver a tomar interés por el mundo, de probar mi espíritu de investigación, de saber a cuánto alcanzan mi sabiduría y conocimiento; si la luz de mis ojos es limpia y clara, cuántos objetos puedo percibir de golpe, si los pliegues que se han impreso en mi alma pueden volver a deshacerse (Goethe, 1891, p. 24).

Para Besse, en este peregrinar el escritor alemán descubre "la unidad profunda
${ }^{96}$ Es la misma crítica que, como veremos más adelante, hace A. Humboldt a Ercilla: "los volcanes cubiertos de perpetua nieve, los valles abrasadores a pesar de la sombra de los bosques, los brazos de mar que penetran a lo lejos en las tierras, no le han inspirado, a Ercilla, casi nada que pueda constituir una imagen". El juicio de Humboldt no le impide reconocer, sin embargo, que La Araucana "es un libro en que se respira un noble sentimiento nacional", entre otras razones, porque "las costumbres de una tribu salvaje que combate por la libertad están en él descritas calurosamente", aludiendo así a uno de los tópicos más corrientes para caracterizar lo chileno, esto es, la larga resistencia araucana -mapuche- a la conquista española (Humboldt, 2011, p. 226)

${ }^{97}$ El viaje de Goethe puede asimilarse al Grand Tour, un itinerario de viaje por Europa, antecesor del turismo moderno, que tuvo su auge entre mediados del siglo XVII y la década de 1820, cuando se impusieron los viajes masivos en ferrocarril, más asequibles. El termino Grand Tour apareció escrito por primera vez en 1670, en la obra El Voyage d' Italie (El viaje a Italia) de Richard Lassels, en la que hace referencia al viaje por Europa que realizaban jóvenes aristócratas -principalmente británicos- como parte de su educación. Goethe realiza su Grand Tour tardíamente, al no haber aceptado este viaje como regalo de su padre 11 años antes y esperar hasta poder costearlo por sus propios medios. El viaje duró dos años, entre 1786 y 1788, lo realizó en carruaje.

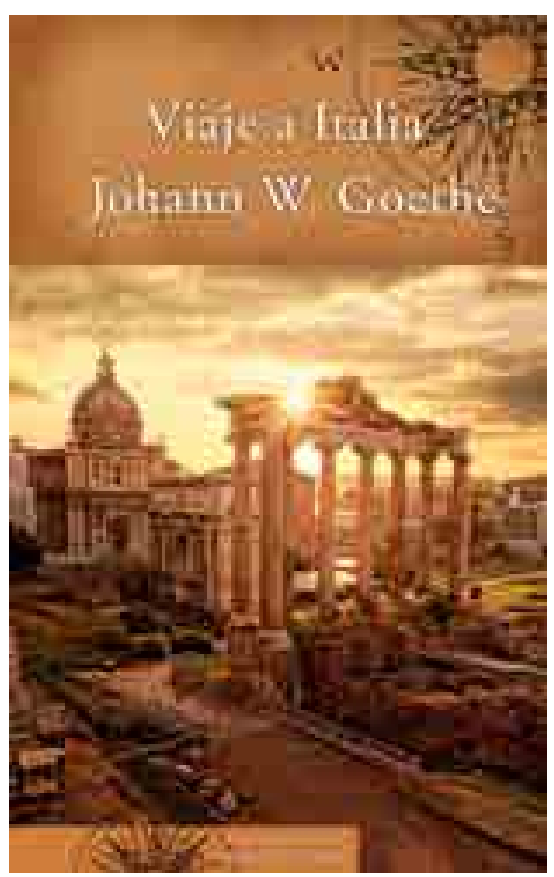

Figura 3.6 Viaje a Italia, Johann W. Goethe (2017). 


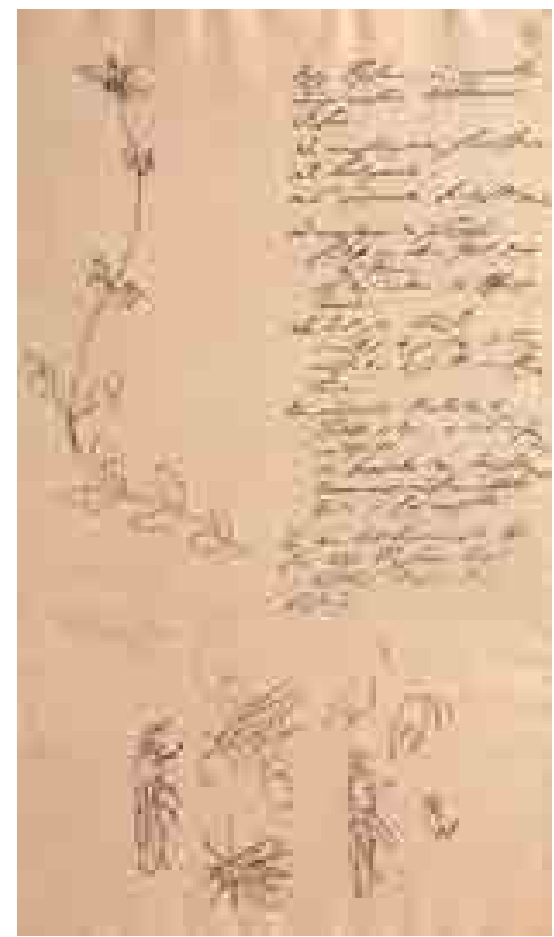

Figura 3.7. Dibujo de Goethe incluido en su libro Zur Morphologie (1790). En Herbarium (26 de diciembre, 2013)

${ }^{98}$ Sus ideas acerca de las plantas y la morfología y homología animal fueron desarrolladas por diversos naturalistas decimonónicos, entre ellos Charles Darwin. El texto citado Goethe se refiere a "mi Linneo", el libro de Carlos Linneo, Species plantarum, obra que da origen a la clasificación biológica moderna. y misteriosa entre el arte y la naturaleza"(Besse, 2010, p. 94). Pero este renacimiento a través del encuentro libre con la naturaleza, este acercamiento a la verdad, está mediado por imágenes pictóricas de la región, que Goethe ha observado antes de su viaje y que constituyen una referencia: "flota sobre la tierra el polvillo del día, que solo conoce uno en los cuadros y dibujos de Claudio Lorena" (Goethe, 1891, p. 183), y antes "como he podido observar en los cuadros del Ticiano (...) producir figuras celestiales pero verdaderas" (Goethe, 1891, p. 63).

Esto muestra la relación entre un mundo ya representado -por los textos y las pinturas, la cultura heredada- y el mundo como objeto visual - el paisaje ahora no sólo como un medio a partir del cual se produce una imagen del mundo, el mundo como imagen dada a un observador distanciado y desplazado, pero también como imagen de una representación.

Pero ¿de qué manera Goethe concibe el paisaje en ese viaje? y ¿cuál es el paisaje que podemos extraer del relato de ese viaje de Goethe? El paisaje es visto como susceptible de reconciliar "interior y exterior, lo visible e invisible [...]: imagen idílica, evocación nostálgica y revelación de la eternidad [...]" (Besse, 2010, p. 86). A su vez, a la diversidad del mundo que se presenta al mirar se impone un recorte selectivo, una cultura de la mirada, que representa el reencuentro de la razón con la emoción.

Pero este reencuentro no sólo se plasma en la narración: Goethe es un paisajista. El año 2008 se montó la exposición Johann Wolfgang Von Goethe | Paisajes en el Círculo de Bellas Artes de Madrid; el comisario de la muestra, Javier Arnaldo, señalaba:

Nunca se había hecho nada sobre el Goethe paisajista. Hizo muchísimos dibujos, de los que mostraremos 75, pero ésta es una selección mínima de su trabajo. En Weimar se conservan alrededor de 2.500, de los que dos tercios de ellos son paisajes. (Luzán, 26 de enero, 2008)

En el catálogo de la exposición se señala que Goethe produjo más de 700 dibujos en su viaje a Italia; en ellos aplicó las enseñanzas recibidas de Jacob Philipp Hackert, explorando diferentes técnicas como la aguada, acuarela, tinta y lápiz (Luzán, 26 de enero, 2008). Logra nuevos elementos de sombreado, de luminosidad y espontaneidad. El Goethe de esa etapa italiana es un precursor de la pintura de paisajes románticos. Italia, Nápoles, le proporcionan inspiración, ruinas y campo, la historia y lo real. Se adelanta en casi treinta años a las grandes obras de Caspar Friedrich, el artista romántico por excelencia.

"Mis ojos se están entrenando de manera increíble, y mi mano no se quedará atrás" (Goethe, 2017, p. 376), escribe desde Italia. Dibujar, como escribió a Humboldt, sacaba en él "lo más real"(Arnaldo, 2008, p. 15).

Junto a este afán por el dibujo, su narración está cargada de observaciones botánicas ${ }^{98}$ (Figura 3.7.), describiendo las diferencias entre las especies que se dan en el valle y en las alturas, advirtiendo:

Cierto que llevo conmigo mi Linneo y que he retenido su terminología en la memoria. Pero ¿de dónde puedo sacar el tiempo y la calma necesarias para la actividad analítica, la cual por otra parte, si me conozco bien, nunca será mi fuerte? De ahí que agudice mi mirada para lo general. Cuando vi en el lago de Walchen la primera genciana, caí en la cuenta de que hasta el momento siempre había sido en el agua donde había descubierto las nuevas plantas. (Goethe, 2017, p. 23)

Para Goethe la pintura de paisajes es una forma en la que se revela la naturale- 
za, de manera que saber ver el Paisaje es escoger los elementos significativos en el espacio para construir una composición; en su visión, el paisaje se concibe como una "trasposición pictórica de la percepción de la naturaleza" (Besse, 2010, p. 88). En este "saber ver", el paisaje no pretende mostrar la naturaleza en su objetividad científica; es más bien la posibilidad de reunir el deleite y la contemplación y de captar la verdadera naturaleza. En aquella época, quienes lograban captar los mejores paisajes eran considerados "alumnos de la naturaleza", ya que tenían la capacidad de captar la armonía de la forma y la exactitud de los colores que daban a sus paisajes ciertas características sensibles como paz 0 reposo.

En esta misma perspectiva de la observación de los paisajes, Goethe desarrolla una discusión sobre los colores ${ }^{99}$, ya que éstos son los que permiten a la pintura dar vida a aquello que la objetividad científica muestra como simples formas geométricas. En su Teoría de los Colores, señala:

el color es un fenómeno elemental de la naturaleza para el sentido de la visión que, como todos los demás, se manifiesta al dividirse y oponerse, mezclarse y fundirse, intensificarse y neutralizarse, ser compartido y repartido, pudiendo ser más bien intuido y concebido en esas fórmulas generales de la naturaleza. (citado por Werle \& Restrepo, 2012, p. 131)

El color en las representaciones pictóricas es un elemento esencial, ya que da armonía y un sentido de totalidad a los conjuntos plasmados, se propone como una reacción frente a lo propuesto por Newton quien aseguraba que los colores son parte de la luz y no que son el devenir de la luz.

El paisaje visto en Italia lleva a Goethe a reconocer la unidad profunda entre arte y naturaleza, un reencuentro con la naturaleza como actividad creadora y unidad viva en la diversidad (Figura 3.8.). Así, tal vez lo fundamental es la forma con que Goethe se contrapone a la concepción científica de mundo que se consolidaba en Europa con Newton y Galileo, revalorizando la experiencia sensible. Constantemente se refiere a la pintura cuando habla de la naturaleza porque en ella "se encuentra lo que la geometría no alcanza, la carne del mundo, que es el lugar mismo de la manifestación de su esencia" (Besse, 2010, p. 88). A partir de esto, podríamos decir, que Goethe recupera el sentido afectivo de la experiencia paisajística como condición de una experiencia integral del mundo.

Como una fuerza invisible, ese sentimiento romántico se hace presente en la descripción del territorio chileno a través de María Graham. Hace casi dos siglos esta viajera, escritora y botánica ${ }^{100}$ inglesa viaja por primera vez desde Valparaíso a Santiago. Pocos meses antes, su marido el Capitán Thomas Graham había

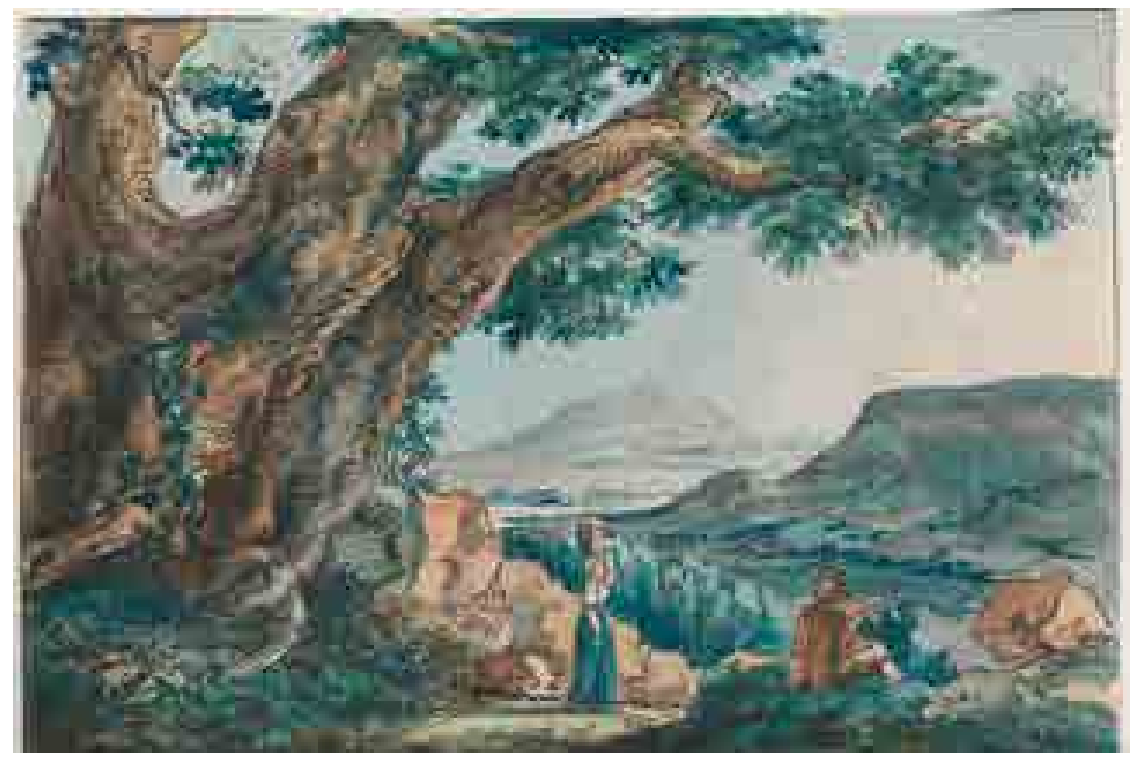

${ }^{99}$ Goethe explica la diferencia de su posición frente a la óptica de Newton: Newton sostiene que en la luz blanca incolora cualquiera, pero particularmente en la luz del sol, están contenidas varias luces de diversos colores, cuya combinación produce la luz blanca (...) la teoría que nosotros establecemos con convicción (...) no pretende desplegar colores a partir de la luz, en lugar de ello busca exponer por medio de innumerables casos que el color es al mismo tiempo producido por la luz y por aquello que se opone a ella" (Werle \& Restrepo,2012, p. 131)

Figura 3.8. Paisaje, Johann Wolfgang von Goethe. En Fundación Martin Bodmer (23 de abril, 2017). 
${ }^{100}$ En Inglaterra, la botánica fue una afición de moda para hombres y mujeres durante el período entre 1760 y 1830 , se convirtió en un tema de novelas y poemas, se difundió en revistas, libros y conferencias dirigidos a un público general, se hicieron naipes botánicos, manuales para el dibujo de flores. Las mujeres adoptaron la cultura botánica con entusiasmo a principios del siglo XIX. Algunas mujeres británicas, en su mayoría esposas de funcionarios coloniales y diplomáticos, cuyas circunstancias particulares les permitieron viajar más lejos, desarrollaron la botánica como parte del proyecto imperial de principios del siglo XIX. María Graham (1785-1842) llegó a la mayoría de edad durante este período y convirtió la botánica en un interés central a lo largo de su vida, es una actividad presente en sus viajes y en su escritura. Contribuyó en la recolección de plantas y tuvo una activa participación en la red internacional de coleccionistas organizada por William Jackson Hooker, profesor de Botánica en la Universidad de Glasgow y posteriormente director de Kew Gardens.

101 María Graham (1785-1842) vivió en Chile entre abril de 1822 y enero de 1823 . Zarpó a Brasil el 18 de enero de 1823, diez días antes de la abdicación del general Bernardo O'Higgins.

${ }^{102}$ La independencia de Chile corresponde al proceso histórico de emancipación de Chile del Imperio español, comprendido entre el establecimiento de la Primera Junta Nacional de Gobierno (18 de septiembre de 1810) y la abdicación de Bernardo O'Higgins al cargo de director supremo (28 de enero de 1823); durante la mayor parte del proceso, se llevó a cabo una guerra entre realistas -partidarios de la monarquía española- y patriotas -partidarios de la independencia. Oficialmente, la emancipación de Chile fue declarada a través del acta de Independencia de Chile, jurada el 12 de febrero de 1818.

${ }^{103}$ Este fue el paisaje que, por más de cien años, entre 1713 y 1832, transitaron los viajeros europeos y norteamericanos que visitaron Chile, describiendo el territorio, el ambiente en que se desenvolvía la sociedad y las vicisitudes políticas. Muchos recorrían el mundo al servicio de sus países, por motivos comerciales, científicos o diplomáticos. Y tal como Chile era paso marítimo obligado para los navegantes en América del Sur, el antiguo Camino Real, entre lo fue para quienes entraban o salían de Santiago.

Figura 3.9. Vista desde la cuesta de Lo Prado. En Graham, 1824, p. 196. muerto mientras cruzaban el Cabo de Hornos. Tras los funerales en Valparaíso, ella decide permanecer en Chile. En su estadía de solo nueve meses ${ }^{101}$, recorrió gran parte de la zona central del país y dedicó su tiempo a observar, escribir y dibujar los paisajes, a la gente, las casas, vestimentas y costumbres locales. Durante el tiempo que vivió en Chile se relacionó con líderes políticos, como el general chileno Bernardo O’Higgins y el general argentino José de San Martín, destacados miembros de la sociedad, y oficiales navales británicos que estaban ayudando al nuevo país a consolidar su independencia ${ }^{102}$ de España, entre ellos el almirante Lord Cochrane.

Las experiencias de María Graham son conocidas hoy gracias a su cuaderno de viajes, Journal of a Residence in Chile during the year 1822, publicado en Londres en 1824 y editado por primera vez en Chile en 1902 como Diario de mi residencia en Chile en 1822. María Graham, además de ser la primera mujer que escribió sobre Chile al comienzo de nuestra vida republicana, es a través de su mirada y su prosa que vemos aparecer por primera vez la palabra paisaje asociada al territorio de la Laguna Carén, cuando describe su paso por Pudahuel, trayecto obligado de los viajeros de la época ${ }^{103}$ desde el puerto hacia la capital:

El panorama que se divisa desde el paso del Pudahuel es bellísimo. Mirando a través del río, cuyas escarpadas orillas adornan grandes árboles, el valle de Santiago se extiende hasta las montañas, a cuyos pies se despliega; y la ciudad, con sus blancas torres, da a todo el conjunto un carácter especial que lo distingue de los demás bellos paisajes de Chile, en que la ausencia de moradas humanas imparte cierto sello de melancolía sobre la naturaleza [...]Aquí Pudahuel desaparece en su belleza solitaria, sin que ningún poeta le cante, sin que se le tribute honor alguno. (Graham, 1916, p. 250)

Si bien son numerosas las descripciones que encontramos de este valle y de la cordillera por parte de los viajeros que transitaban desde el puerto de Valparaíso a Santiago, es María Graham, quien, por primera vez, habla de ellos como un paisaje, "landscape", en el texto original en inglés. Acompaña su relato con dos dibujos, uno de la Cuesta de Lo Prado donde se detalla la vegetación en primer plano (Figura 3.9.) y otro con la vista panorámica que encuadra el valle con la Cordillera de Los Andes como telón de fondo.

La descripción de Graham aborda todos los pliegues de lo visible, desde los elementos geográficos e hidrográficos, la gran escala, el infinito y lo que está más cerca, los trazos que invitan a explorar los detalles, aquello que permanece invisible. Posiblemente su viaje, al ritmo de los caballos, le permitían tomar algu-

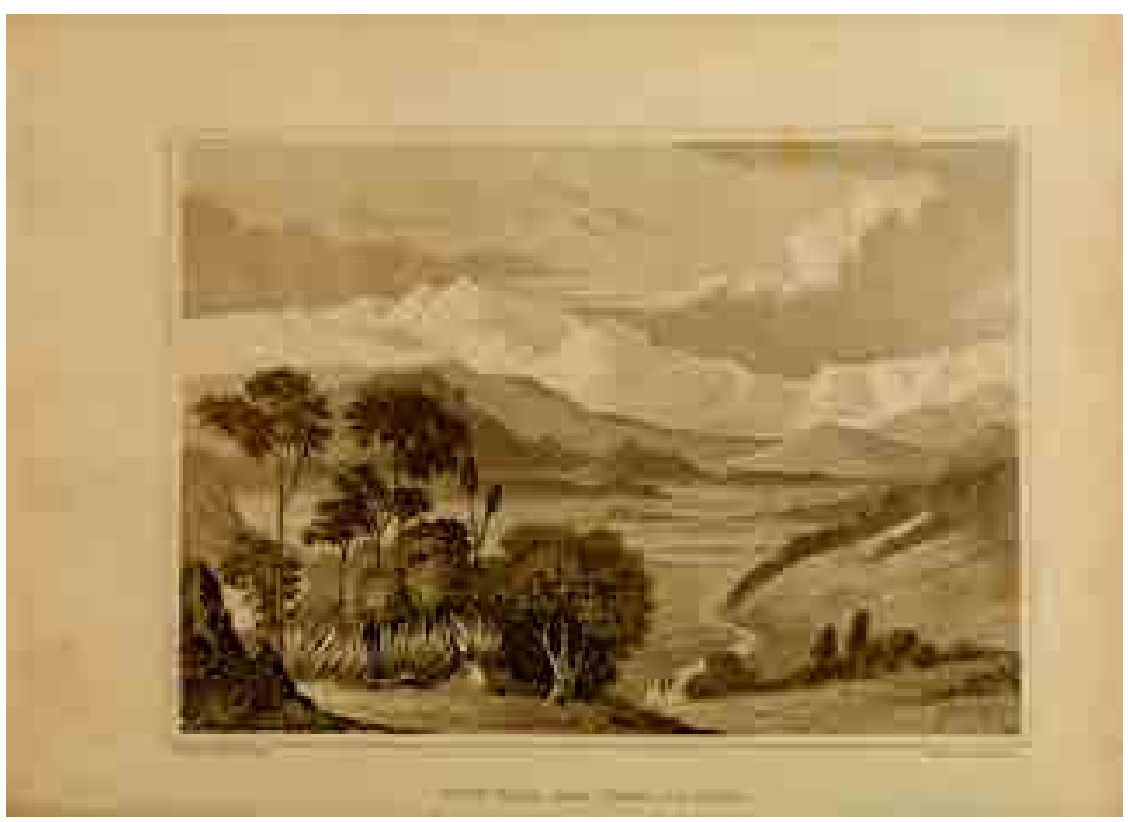


nas notas, recoger algunas especies, hojas, flores y semillas que miraría luego bajo el microscopio y dibujaría con detalle ${ }^{104}$, rotulándolos luego con los nombres científicos -los de su Linneo ${ }^{105}$ - así como los autóctonos (Figura 3.10.). En sus descripciones apela a su conocimiento del mundo -que podríamos llamar científico-, a su intuición y sensibilidad, y a su cultura, a sus referentes culturales. Es su relato no hay un afán teórico, sino más bien vital, solo lo describe:

La flor se da en gruesos y apretados racimos y tiene la apariencia de la cera blanca, con un ligero tiente rosado en el centro; es de seis pétalos, más 0 menos del tamaño de las flores sencillas del lirio del valle, y muy fragante (...). Pronto se agotaron mis conocimientos de botánica, y entonces cogí un gran puñado de toda clase de hojas y de flores para llevarlas donde un vecino que tiene fama de ser muy buen conocedor; mientras caminaba, iba recordando el apóstrofe de Clorinda a las hierbas que ha cogido, y que es uno de los más bellos pasajes del acto II de la Pastora Fiel. (Graham, 1916, p. 199)

María Graham tiene 37 años cuando llega a Chile, la misma edad que Goethe tenía cuando emprende su viaje a Italia (Figuras 3.11 - 3.12.). El libro del Viaje a Italia de Goethe se publica en 1816, cuando ella se encuentra aún en Londres. Si bien se observa una gran sintonía -o influencia- del autor alemán en su observación del paisaje, ella no lo menciona en su Diario, lo que deja la relación entre ambos sin pruebas concretas ${ }^{106}$.

Lo que sí podríamos afirmar como hecho, es que Graham ya había publicado sus diarios de viaje a la India cuando apareció el libro de Goethe, es decir, ya había manifestado un interés concreto en la escritura de viajes. Antes de viajar a Chile publica Journal of a Residence in India (Diario de mi residencia en India) en 1812 y luego su segundo libro Letters on India (Cartas acerca de India). En 1819 María visitó Italia junto a su marido dando como resultado la publicación de Tree Months passed in the Mountains east of Rome (Tres meses en las montañas al este de Roma), de 1820. El mismo año, se publicaron sus Memorias de la vida de Nicolas Poussin, la primera monografía en inglés sobre el artista, también admirado por Goethe. Conocemos además que sabía alemán -leía perfectamente alemán y francés, y antes de viajar a Chile estaba estudiando castellano-, y que su gusto por la literatura se representaba también en su ánimo lector, por lo que concluimos que es probable que haya leído el Viaje a Italia, así como también

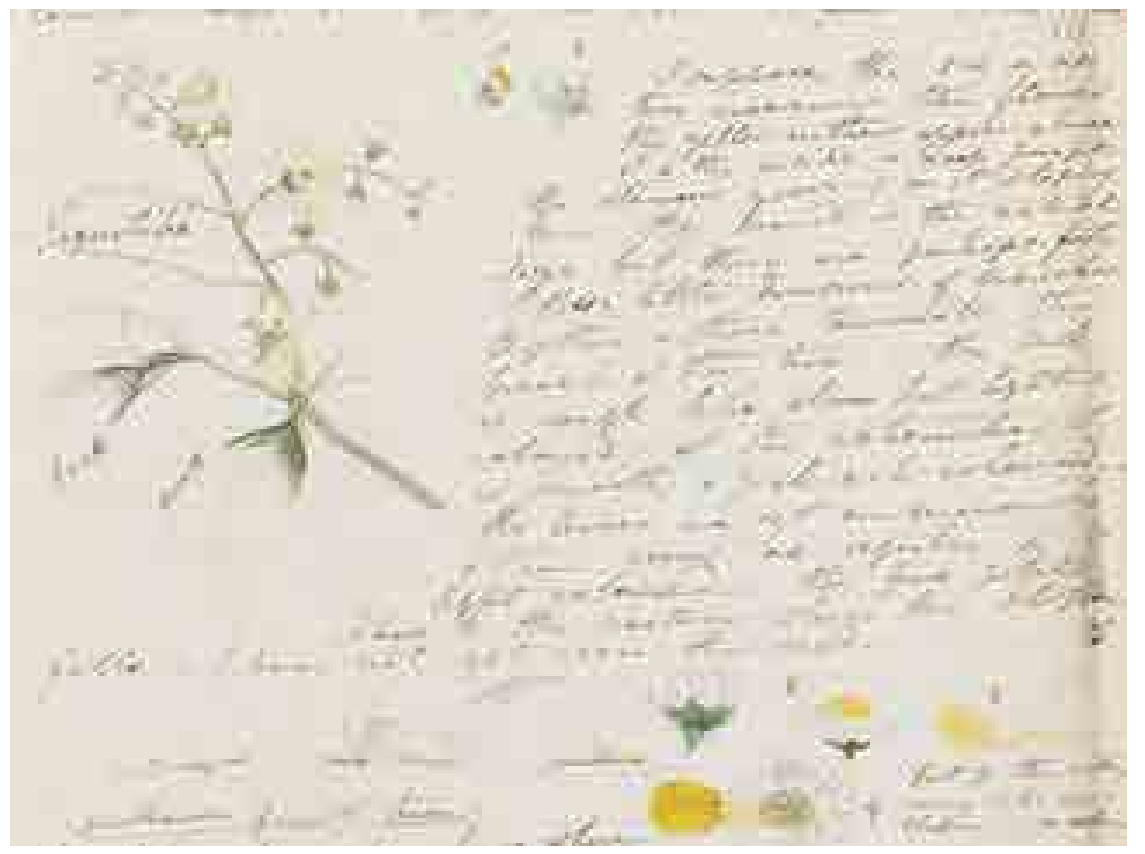

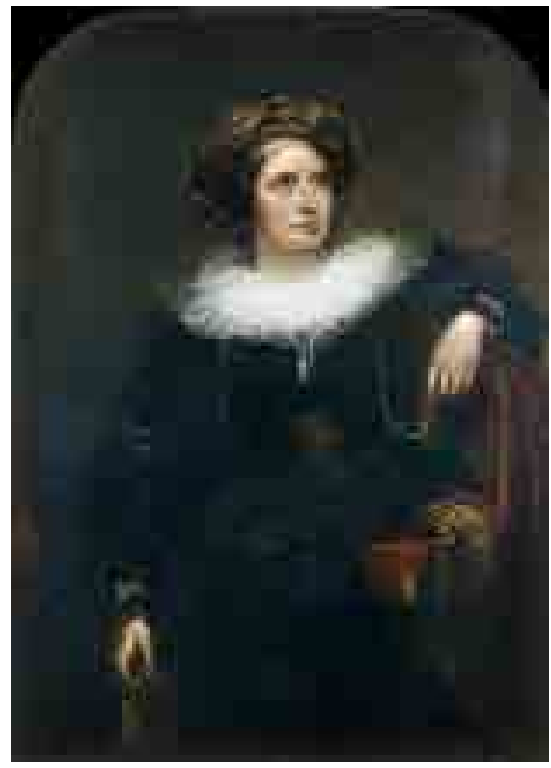

Figura 3.11. Retrato de María Graham, Lady Callcott, pintado por su esposo Augustus W. Callcott (1828). Por Thomas Blomberg (2 de enero 2006).

${ }^{104}$ El botánico Willian Jackson Hooker atrajo a Graham a su proyecto de recolección de plantas, por lo que gran parte del tiempo que paso Graham en Sudamérica se dedicó a recolectar, secar y dibujar semillas y sembrar especímenes para el botánico, a menudo usando un microscopio para retratarlos con más detalle. Hooker proporcionó a Graham libros y equipo y ella respondió con especímenes cuidadosamente secados. Preocupada por el desvanecimiento de los colores cuando las plantas se secaron, le escribió: Podía no ser aconsejable añadir color a los bocetos. - Dígame, sólo un contorno con el color real de un pétalo y una hoja? - No suelo dibujar flores pero podría hacer eso - y también cualquier forma peculiar de semilla. - Sólo dígame cómo puedo ser útil y trataré de serlo. (Graham, 11 de abril, 1824)

${ }^{105}$ Graham (1916) menciona su Linneo en dos ocasiones en las páginas 200 y 204.

${ }^{106}$ A partir de esta investigación, he mantenido contacto con epistolar con la investigadora Regina Akel quién me ha confirmado que en sus escritos no hay mención a Goethe.

Figura 3.10.Extracto de la carta de Maria Graham a William Hooker, 11 de abril de 1824. En Manthorne K. (21 de julio, 2017) 
Figura 3.12. Porträt Goethes in der Campagna, pintado por Johann Heinrich Wilhelm Tischbein (1787). Por Anagoria (18 de diciembre, 2010).

George Gordon Byron, Lord Byron (1788- 1824) aparece citado cuatro veces en el diario que María Graham escribió estando en Chile.

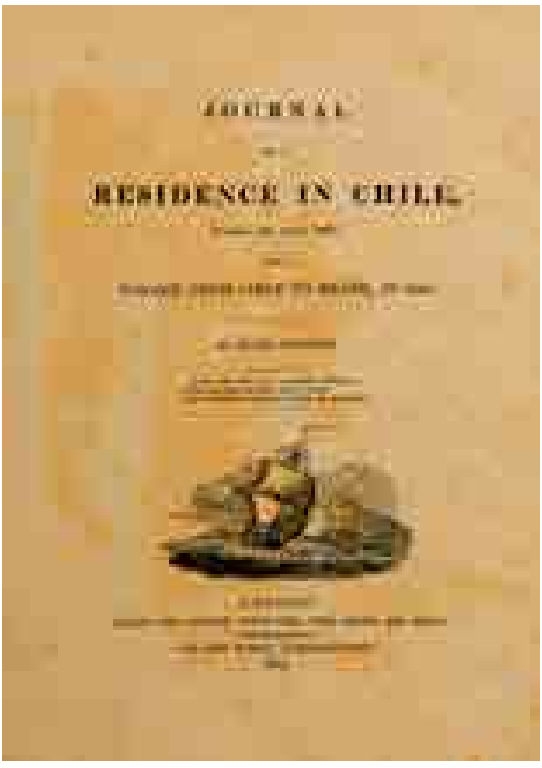

Figura 3.13. Journal of a Residence in Chile during the year 1822. Maria Graham (1824)

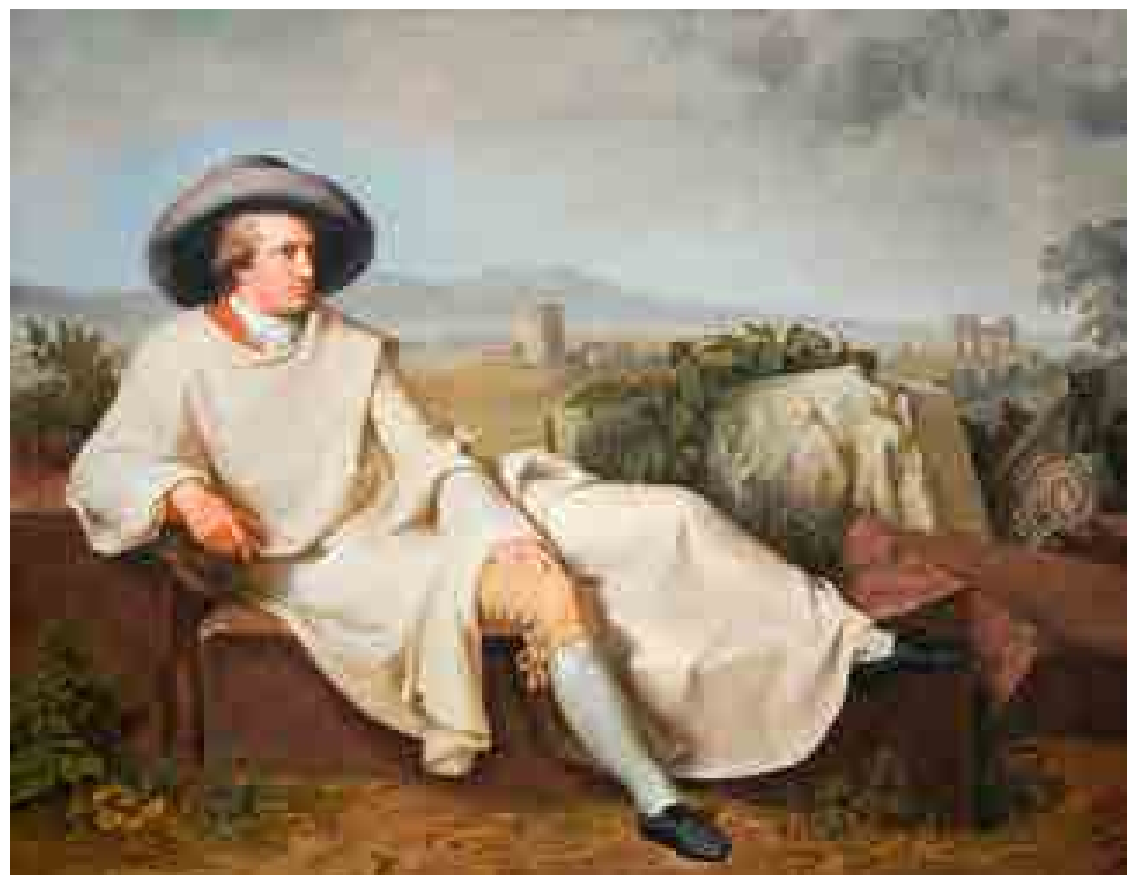

Las peregrinaciones de Childe Harold de Lord Byron ${ }^{107}$, publicado entre 1812 y 1818, y cuyo editor es John Murray, el mismo que trabajó con Goethe, Melville y Darwin, entre otros, también con Graham por cierto.

Según sostiene la investigadora y biógrafa de María Graham, Regina Akel (Akel, comunicación personal, 22 de mayo de 2017), la escritora no tenía problemas en copiar lo escrito por otras personas. Lo hizo con partes de la Historia de Brasil de Robert Southey, así como en su libro sobre la India se observa la copia de un párrafo de Francis Wilford, haciendo aparecer sutilmente algunas de las dudas que expresa el autor como suyas propias. Son estos detalles los que hacen pensar que no sería raro que, para caracterizar su viaje a Chile, María se hubiera "inspirado" en Goethe, con quien comparten la pasión por la botánica, el dibujo, la pintura del Tiziano, de Poussin y de Claude Lorrain, a quien Graham alude así: "El sitio se hallaba al pie de una escarpada colina cubierta de arrayanes; de dosel teníamos, colgada como los cortinajes que Claude introduce á [sic] veces en sus paisajes" (Graham, 1916, pp. 232). Para Regina Akel (2011), la voz narrativa de María Graham representa a "un miembro de una sociedad civilizada observando a otras en un estado más primitivo, con el fin de informar sus conclusiones a sus pares" (2011, p. 139). En el párrafo final del prefacio de su diario, María confía en que su obra llenará una necesidad y será útil tanto para sus compatriotas como para los habitantes del nuevo país. Tras indicar que el clima de Chile es benigno, que el suelo es fértil y la gente tiene gran dignidad, destaca la utilidad de su trabajo:

(...) estas no son las dificultades corrientes que habrá que vencer ni carencias sencillas que satisfacer, y si las siguientes páginas pueden en el grado más mínimo contribuir directa o indirectamente a satisfacerlas o paliarlas, llamando la atención hacia dicho país, ya sea como uno particularmente apto para el intercambio comercial, o uno cuyos recursos naturales y capacidades aún falta por cultivar, la escritora sentirá la más grande de las satisfacciones. (Graham, 1916, pp. 22-23)

El libro de Graham fue publicado Londres en 1824 junto a su diario de Brasil (Figura 3.13.). La primera traducción al castellano, se hizo en Chile, en 1902, a la que siguió la edición española de 1916 (que es, la que hemos utilizado). Tuvo éxito en Europa, incluso en el ámbito científico, debido a su relato del terremoto de 1822. Pero el efecto más importante fue su contribución a la creación del imaginario nacional del Chile republicano. Graham ve lo diverso, lo compara, lo enmarca, y de ese modo lo pone en el mundo; es así como las luchas políticas, las costumbres, las fiestas y la comida son observadas con la misma curiosidad 
de las plantas y las flores. Nuevamente la mirada distanciada, extranjera, desde afuera, cultivada-que puede comparar-, es la capaz de ver paisaje donde otros ven sólo territorio.

\title{
3.6.4. El paisaje como objeto de estudio: entre la historia y el determinismo físico
}

El Paisaje como objeto de estudio es la cuarta perspectiva que desarrolla JeanMarc Besse. Frente al idealismo de Goethe, se levanta la geografía como ciencia, representada por las escuelas del naturalista alemán Alexander von Humboldt (1769-1859), y la que instituye en Francia Paul Vidal de la Blache (1845-1918). Esta postura científica y materialista, si bien no desecha el paisaje como representación, pone a su fisonomía como valor central: el paisaje no es una imagen, es una forma. Humboldt y Goethe se habían conocido en Jena en 1794 y se frecuentaron durante varios años Humboldt tenía 25 años, Goethe era famoso y tenía 45 años. Los unía la pasión por comprender la naturaleza ${ }^{108}$, en especial las ideas sobre la evolución de las formas. Humboldt reconocía la lucidez de Goethe en sus estudios sobre las formas en la botánica, desarrollado en un texto de 1870 titulado Intento de explicar la metamorfosis de las plantas, se trata de aprehender lo dinámico en la vida vegetal, aplicando el concepto de tipo, así lo declara años más tarde en su obra cúlmine, Cosmos:

aquel problema de la metamorfosis que Goethe ha tratado con una sagacidad superior, y que nace de la necesidad que experimentamos de reducir las formas vitales a un pequeño número de fundamentales tipos. En medio de las riquezas de la naturaleza y de esta acumulación creciente de las observaciones, se penetra el hombre de la convicción íntima de que en la superficie y en las entrañas de la tierra, en las profundidades del mar y las de los cielos, aun después de miles de años, "el espacio no faltará á los conquistadores científicos". (Humboldt, 1875, p. 26)

Pese a la admiración de Humboldt por Goethe, su concepción de la naturaleza es distinta. Para Miguel Ángel Miranda, autor de la Introducción a Cosmos, la obra culmine del naturalista alemán, claramente, "frente al idealismo de Goethe se encuentra el materialismo de Humboldt" (Miranda, 1977, p. 11).

\begin{abstract}
Mientras [...] [Humboldt] realizaba sus observaciones y mediciones con instrumentos de medida lo más perfeccionados posible, Goethe consideraba que el ojo humano era suficiente para abarcar la totalidad de los fenómenos. De aquí que mientras Goethe se interesa exclusivamente por las formas, Humboldt profundiza en su contenido material, siguiendo, por consiguiente, con la línea del pensamiento correspondiente al materialismo francés del siglo XVIII. (Miranda, 1977, p. 10)
\end{abstract}

Si bien ambos coinciden en la necesidad de la experiencia en la construcción del conocimiento, la divergencia se produce en el método: Para Humboldt la observación le permite obtener datos, los que analiza por medio de la razón, es lo que llama el "empirismo razonado", término que acuña en Cosmos: "Mi ensayo sobre el Cosmos es la contemplación del Universo, fundada en un empirismo razonado; es decir, sobre el conjunto de hechos registrados por la ciencia y sometidos a las operaciones del entendimiento que compara y combina"(Humboldt, 1875, p. 39).

Para Humboldt, la naturaleza está en constante movimiento, es un organismo vivo en cuyo interior interactúan los elementos y fuerzas diversas. En este contexto, la tarea del naturalista (del científico) será comprender la relación entre los elementos y fuerzas, porque, como el mismo Humboldt describe en Cosmos:

El descubrimiento de cada ley de la naturaleza lleva a otra ley más general, o hace presentir su existencia, al observador inteligente. La naturaleza, como

108 Andrea Wulf nos señala en su libro "que en el fausto de Goethe había algo de Humboldt era evidente para muchos [...] Fausto como Humboldt actuaba impulsado por una sed implacable de conocimiento" (2017, p. 63) 
la ha definido un célebre fisiólogo y como la palabra misma indica entre los Griegos y los Romanos, es «lo que crece y se desarrolla perpetuamente, lo que solo vive por un cambio continuo de forma y de movimiento interior. (Humboldt, 1875, p. 25)

Andrea Wulf en su libro de 2017 sobre Humboldt, La invención de la naturaleza, cita una carta de Humboldt donde declara que su periodo en Jena "ejerció una poderosa influencia". "Estar con Goethe, dijo, le proporcionó 'nuevos órganos' con los que ver y comprender el mundo natural" (2017, p. 64). Serán estos órganos los que, años más tarde, le permitirían comprender profundamente Sudamérica.

Su empirismo razonado le permite relacionar colonialismo, esclavitud, economía y medioambiente en una publicación Ensayo político sobre el Reino de la Nueva España, publicado entre 1808 y 1811, en pleno periodo de la independencia sudamericana. Jefferson y Bolívar ${ }^{109}$ lo conocieron, su contenido fue estratégico, ya que relaciona y compara sus observaciones de las colonias americanas con los datos y su conocimiento de Europa y Estados Unidos (Wulf, 2017, p. 198). En el libro se registraban observaciones sobre la geografía, configuraciones de la costa, la botánica, los conflictos étnicos y las luchas españolas. También se dejaba claro los desastrosos efectos del colonialismo en Latinoamérica y que sus habitantes originarios no eran los salvajes que los cronistas europeos habían descrito por casi tres siglos $(2017$, p. 208). No hizo solo un relato de viajes, ni la descripción de paisajes (que sin duda le maravillaron), Humboldt realiza una investigación que describe hechos, datos y cifras y hace un estudio comparado con ellos. Esto le permite afirmar años después en Cosmos que "el hombre no tiene acción sobre la naturaleza ni puede apropiarse ninguna de sus fuerzas, sino en tanto que aprenda a medirlas con precisión, a conocer las leyes del mundo físico" (Humboldt, 1875, p. 46).

La cuestión que está en juego entonces, es si el paisaje es realmente del orden de la representación, de acuerdo a la noción viene siendo presentada por la modernidad. Ante esto, Besse observa que, como producción cultural, las significaciones del paisaje van más allá de las significaciones estéticas, y relaciona esas múltiples significaciones del paisaje con las particularidades del sujeto que mira: el científico, el arquitecto, el ingeniero, el geógrafo, el religioso, etc. Lo que no es sólo un problema subjetivo, sino antropológico, ya que la mirada de esos sujetos representa saberes instituidos. Por lo tanto, el paisaje no es sólo objeto de una contemplación y evaluación estética, su valor residiría en el hecho de ser representativa de la acción humana y, más aún, del desarrollo de una cultura de la mirada (Besse, 2010, p. 116).

La postura moderna que separa lo subjetivo-estético y lo objetivo-científico en el conocimiento del paisaje rompiendo la relación entre razón y emoción, ciencia y arte, sujeto y objeto, hombre y naturaleza, no fue así desde el principio. La geografía, entre otros campos del saber, mantiene aún en el siglo XIX esa relación profunda de la ciencia y del arte a través del paisaje.

En ese sentido, la geografía, en el s. XIX, teniendo el paisaje como objeto específico, busca aprehenderla, reforzando la tesis de que el paisaje no se reduce a una representación, a un mecanismo de proyección subjetiva y cultural. Pues para el geógrafo, el urbanista y el arquitecto, por ejemplo, se ve desde una intención de conocimiento e intervención, es decir, a partir de una proyección (existencial y política). Esto implica que el paisaje no se limita a la cuestión de visibilidad, sino que depende del estatuto que se atribuye a lo visible, de su función y su significado.

${ }^{109}$ Para Wulf, el interés de Bolívar en este texto se debía a que el libertador, no conocía la mayor parte del continente por el cual luchaba (2017, p. 198).

Para Besse, lo que marca todavía el concepto geográfico de paisaje, a pesar de todas sus transformaciones, es la concepción del paisaje como fisonomía o ex- 
presión, que se va a encontrar en la geografía de Vidal de la Blache a principios del siglo XX. Para el geógrafo, la fisonomía no es una representación forjada por el intelecto del observador, "son realidades objetivas que identifican verdaderamente un territorio, que es necesario reconocer, localizar, delimitar a la vez espacial y cualitativamente, a fin, como dice Vidal de la Blanche, de 'reproducirlos"' (2010, p. 124). Besse defiende que el paisaje, a los ojos del geógrafo, es una impresión de las intervenciones e interacciones humanas, incluso en lo que se toma como "natural"; por lo tanto, el paisaje sería un artefacto. Así, como impresión sobre un sustrato, que posee cierta plasticidad, el hecho geográfico se presenta como una escritura: la superficie de la Tierra es escrita, y esa escritura es el paisaje.

Esta objetividad parte de que el paisaje es lo visible, como una realidad más allá de la representación, y lo que se analiza es el paisaje como conjunto de signos que cuentan una historia, la que debe ser descifrada e interpretada, "la idea es, pues, que habría que leer el paisaje" (2010, p. 119). La realidad geográfica sería compuesta, siguiendo el pensamiento de Vidal de la Blache, por un sustrato plástico, una energía de circulación y un conjunto de formas, el paisaje, la escritura de la Tierra, leída por la geografía como fisonomía. Besse entiende que hablar del paisaje en términos de una fisonomía significa que se atribuye al paisaje una densidad ontológica propia. Por lo tanto, cabría entonces a la geografía realizar una interpretación, una hermenéutica paisajística, así, "el paisaje es el efecto y la expresión evolutiva de un sistema de causas también evolutivas" (Besse, 2010, p. 122). Esta fisonomía del paisaje, este acercamiento a su objetividad desarrolla "un estilo cognitivo que se estructura en lo que se podría llamar una inteligencia paisajística" una "inteligencia geográfica de los lugares" (2010, p. 137), que los paisajistas deberíamos asumir.

\subsubsection{Chile descubierto y narrado por la ciencia}

Humboldt es para Chile mucho más que la fría corriente que baña sus costas ${ }^{110}$ Representa, como veremos, el modelo de esa inteligencia paisajística capaz de revelar el espesor de un territorio ignoto. Un modelo que inspiró a científicos y artistas que trabajaron para descifrar la fisonomía del país, producir y hacer circular ese saber -cuestión estratégica- en la etapa de consolidación de la República durante el siglo XIX.

El territorio americano debe haber significado para Humboldt, la oportunidad de explorar la naturaleza en su estado más prístino. Más que un objeto de estudio, América fue ese organismo vivo y en constante cambio que buscaba, un laboratorio extenso y diverso para comprender la naturaleza. Los treinta tomos de su Viaje a las regiones equinocciales del nuevo continente (publicado originalmente en francés entre 1807 y 1834) incluyen la experiencia en América entre 1799 y 1803 con los resultados de sus observaciones que más que desinteresadas permitirían "juzgar su importancia política" y señalar "las ventajas que pueden ofrecer al comercio de Europa". Sus descripciones y cifras buscaban, según sus palabras, mostrar "los elementos variables de la prosperidad y de la potencialidad nacionales" (Humboldt, 1826, pp. 74, 77 y 118). No recorrió Chile, ya que consideraba que sólo las regiones tropicales merecían ser visitadas. Incluso aconsejó a otros viajeros que no lo hicieran. Son las referencias de otros científicos y viajeros, las principales fuentes de su rica descripción de este territorio, que aparece asociado al Océano Pacífico, el desierto, la cordillera, los volcanes, los terremotos, el cóndor y las coníferas.

Entre las principales referencias de su obra, están el tratado del Abate Juan Ignacio Molina (1749-1829), Compendio de la historia geográfica, natural y civil del Reyno de Chile (Figura 3.14.), publicada originalmente en italiano ${ }^{111}$ en 1787, especialmente cuando se trata de alusiones históricas, catástrofes y cultivos. El jesuita chileno inicia el prefacio de su obra así:

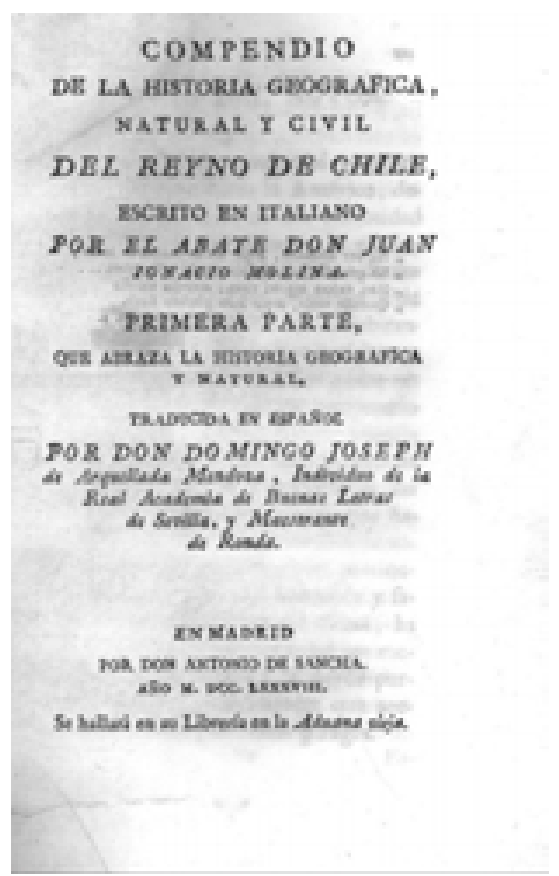

Figura 3.14. Compendio de la historia geográfica, natural y civil del Reyno de Chile. Juan Ignacio Molina (1788).

110 Me refiero a la Corriente de Humboldt que corre por el océano pacífico. A Humboldt nunca le gustó esta designación. En una carta fechada el 21 de febrero de 1840, Humboldt protestó contra el uso de su nombre para denominar la corriente costera diciendo: yo protesto (si necesita ser, públicamente también) contra todo de hablar de corrientes de Humboldt (...) esta corriente era conocida para todos los pescadores de río desde Chile a Payta 300 años antes que yo. Mi única contribución es haber sido la primera persona en haber colectado información sistemáticamente acerca de ésta. (citado por Chirino, 2005). ${ }^{111}$ El abate Molina vive en Roma, desde la expulsión de los jesuitas en 1767. Considera que Italia es el "Jardín de Europa" y que Chile, por ser el país que más se le parece, merece ser llamado la "Italia Antártica". 
112 Darwin estuvo en Chile 3 de los 5 años de su viaje en el Beagle (1831-1836). Esta era la segunda exploración a las costas australes de América del Sur del Beagle comandado por Robert Fitz-Roy, la primera fue entre 1826 a 1830.

${ }^{113}$ En 1830 el gobierno chileno contrató al naturalista francés Claudio Gay para realizar un viaje científico por el país. Su misión: "estudiar la historia natural de Chile y lo que contribuya a conocer la industria del país, su comercio y administración". Su gran obra, la Historia Física y Política de Chile en 29 tomos, que se editó en Francia entre 1844 y 1871, con el apoyo del gobierno chileno. Dos de estos tomos conforman el así llamado Atlas, que contiene mapas y grabados de costumbres, de botánica, de zoología, historia, etc., y que constituye el material iconográfico más completo y sistemático que hasta entonces se hubiera hecho en Chile.

114 Según el historiador chileno Guillermo Feliú Cruz (1900-1973), además de los nombrados, intelectuales chilenos como Miguel Luis Amunátegui y Domingo Amunátegui Solar, Diego Barros Arana y José Victorino Lastarria también fueron influenciados por, o aprovecharon las obras, de Humbodt. Tal como en su momento había ocurrido también con Andrés Bello.

${ }^{115}$ Gay justifica su obra sobre Chile en la necesidad de "penetrar el interior de los vastos continentes, explorándolos en todas direcciones", siendo "de sobrado estímulo los preciosos resultados que el ilustre Humboldt obtuvo" (Gay, 2010, pp. I y 3).
La Europa vuelve al presente toda su atención hacia la América, deseando conocer con erudita curiosidad la diversidad de sus climas, la estructura de sus montes, la naturaleza de sus fósiles, la forma de sus vegetales y de sus animales, las lenguas de sus habitantes; y en suma, todo lo que puede empeñar su atención en aquellas varias regiones. (Molina, 1788, p. III)

Consciente de que habla desde el lugar donde se construye el conocimiento, el abate Molina, llama la atención sobre el territorio chileno, reivindicando la posición y el interés científico del Nuevo Mundo. Aprovecha también de enfrentar las teorías de Paw y Buffon sobre la inferioridad de la naturaleza americana:

En suma, Paw ha escrito de las Américas y de sus habitantes con la misma libertad que pudiera haber escrito de la luna y de los Selenitas: pero quiere su desgracia que la América no diste tanto de nosotros como la luna, y así muchos sabios europeos que han estado en aquellas regiones, y que han visto lo que son con sus propios ojos, afirman lo contrario de lo que afirma Paw. (Molina, 1788, pp. XVI-XVII)

Asimismo, el historiador Rafael Sagredo (2013) en su investigación titulada Chile en el Cosmos de Humboldt, nos detalla las referencias que utilizó Humboldt sobre Chile en su obra, a partir de los relatos, crónicas e investigaciones entre las que destacan: la obra de Charles Darwin ${ }^{112}$ Observaciones geológicas en América del Sur, aparecida en 1846, y el Viaje de un naturalista, de 1839, que resultan vitales para Humboldt cuando se trata de abordar la geología y la actividad sísmica; de Robert Fitz-Roy (1805-1865) utiliza los datos sobre coordenadas y altitudes; y de Claudio Gay ${ }^{113}$, Ignacio Domeyko y Rodulfo Amando Philippi, toma los registros sobre geología, paleontología y la actividad volcánica.

Así como Humboldt cita los textos de los naturalistas, viajeros y estudiosos chilenos y extranjeros que publicaron obras sobre Chile, también muchos de ellos citaron su obra. Tal vez el primero en hacerlo fue el abate Molina en su Ensayo sobre la historia natural de Chile, publicado en Bolonia en 1810; lo hacen también otros autores ${ }^{114}$ como Claudio Gay ${ }^{115}$ y Rodulfo Philippi sugiriendo su influencia, pero sin duda también como argumento que daba autoridad a sus investigaciones.

Se va generando de esta forma, un intercambio de conocimiento que se puede seguir en el tiempo en un diálogo muy interesante entre las obras y los autores. Así ocurre también con la lectura que Humboldt hace de la Araucana, el poema épico de Alonso de Ercilla, que confiesa, haber leído dos veces y que comenta en Cosmos. Si bien reconoce que "es indudablemente un libro en que se respira un noble sentimiento nacional", critica la "figura romántica del guerrero español" que omite la naturaleza al punto de que afirma "nada hace suponer en toda la epopeya de la Araucana que el poeta hubiese observado de cerca la Naturaleza", para luego incorporar su propia imagen de Chile con "los volcanes cubiertos de perpetua nieve, los valles abrasadores a pesar de la sombra de los bosques, los brazos de mar que penetran a lo lejos en las tierras, no le han inspirado casi nada que pueda constituir una imagen" (Humboldt, 1875/2011, p. 226).

Esta queja, más allá del poema y su autor, revela la idea que Humboldt había llegado a formarse de Chile a través de otros relatos, en tanto realidad natural, con sus paisajes sublimes. También se deprende lo que, en su obra Vistas de las cordilleras y monumentos de los pueblos indígenas de América (1810/1995), define con más claridad, la relación entre geografía y sociedad:

Puesto que las costumbres de las naciones, el desarrollo de sus facultades intelectuales, el carácter particular estampado en sus obras, dependen a la vez de un gran número de causas que no son exclusivas de un lugar, no se debería 
dudar de que el clima, las características del suelo, la fisionomía de los vegetales, el aspecto de la naturaleza risueña o salvaje, influyen sobre el progreso de las artes y sobre el estilo que distingue sus productos. (Humboldt, 1995, p. 19).

Esta relación queda plasmada especialmente en la pintura, sobre la cual, Humboldt también ejerce una importante influencia, especialmente en el pintor alemán, contemporáneo suyo Mauricio Rugendas (1802-1858). De acuerdo a lo investigado por la historiadora Viviana Gallardo:

Rugendas conoció a Humboldt en París en 1825 al regresar de su primer viaje a América y entabló con él una gran amistad. Humboldt no sólo le sugirió lugares para visitar en América, sino que se transformó en su verdadero mentor. (Gallardo, 2012, p. 70)

En los cuadros de Rugendas se plasma esta influencia (Figura 3.15.), podemos observar como el paisaje, más que describir aisladamente sus componentes, integra las distintas especies en una escena totalizadora, relacionando elementos (las fuerzas de las que hablaba Humboldt) para crear una atmósfera. Para ello, el artista crea el paisaje incorporando el "empirismo razonado" en base al conocimiento científico y su propia sensibilidad.

Por su parte para el historiador del arte Pablo Diener (2007), no se trataba de convertir la pintura en una mimesis de la realidad observada, sino más bien, de dotar al artista de la libertad de crear un paisaje con aquello que "debería tener", en base al conocimiento científico, especialmente botánico, que el artista pudiera alcanzar. "De este modo, el pintor no se comportaría como un esclavo de lo que existe, sino como un creador de lo que podría ser" (Diener, 2007, p. 294 citado en Gallardo, 2012, p. 71).

Estas ideas humboldtianas tuvieron eco, como hemos visto, no sólo en los científicos de la época, sino, también, en varios artistas que viajaron a América ${ }^{116}$, sin ir más lejos María Graham lo menciona en su Diario y si volvemos a observar su grabado del valle de Santiago, encontraremos la misma fruición botánica que Rugendas desarrollará y ampliará a su llegada a Chile en 1834 (doce años después de la partida de Graham). Rugendas por once años recorrió el país observando sus paisajes, los grupos humanos, las costumbres y personajes típicos que dejó plasmados en innumerables dibujos, grabados y pinturas (Figura 3.16.). Su rigor científico permite que reconozcamos qué zona del país está retratada a través del reconocimiento de las especies dibujadas, que actúan como un dato, una nota a pie de página.

Gallardo (2012) concluye en su artículo que "Rugendas asumió el modelo del 'cuadro' propuesto por Humboldt incorporando los elementos de la geografía y el medio ambiente a la realidad social representada" (Gallardo, 2012, p. 73).

Otra influencia Humboldt que Sagredo advierte, corresponde al político e historiador Benjamín Vicuña Mackenna ${ }^{117}$ (1831-1836), personaje clave en renovación urbana y paisajística de Santiago en el siglo XIX y que volveremos a tratar en el capítulo dedicado a los parques urbanos. Tras un encuentro entre ambos en el año 1855, Vicuña Mackenna escribe en su diario:

La América del Sur fue por supuesto el tema de la conversación de aquel ilustre viajero. Nos dijo que él no había llegado hasta Chile, pero, agregó, vuestro país es bastante conocido en Europa. El distinguido Molina arrojó muchas luces sobre él, y después el inglés Darwin, los alemanes Meyer y Poepping y particularmente Mr. Gay, el hombre mejor instruido sobre Chile que yo haya conocido, nos han dado una noción general de todo el país bastante exacta [...] se informó también del señor Domeyko, cuyas importantes memorias sobre mineralogía había visto publicadas en el Boletín de la Academia de Ciencias de París. (Vicuña Mackenna, 1936, pp. 227-228).

Vicuña Mackenna, contemporáneamente reconoce la contribución de los natura-

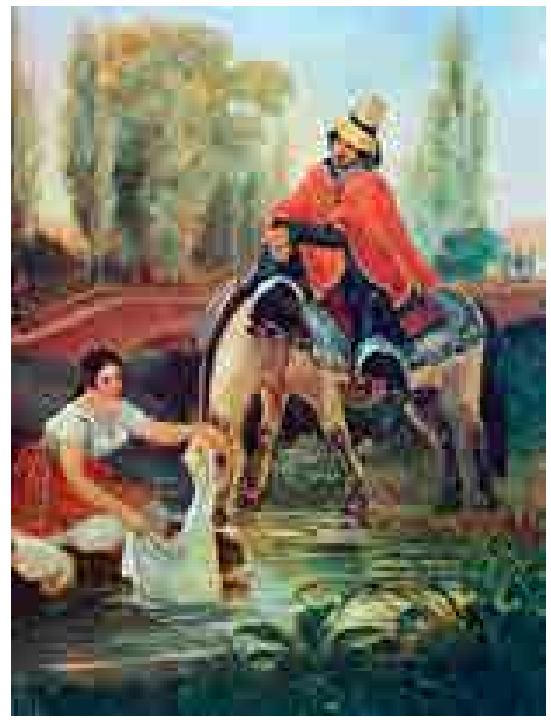

Figura 3. 15. El huaso y la Lavandera, óleo sobre tela de Mauricio Rugendas (1835). Museo Nacional de Bellas Artes (s.f.)

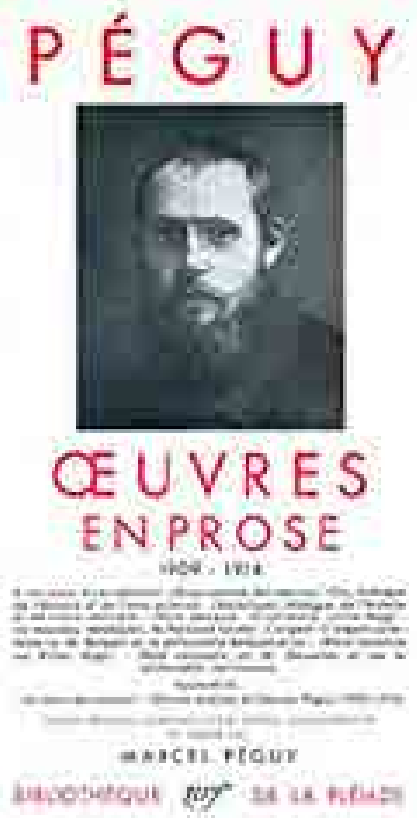

Figura 3.16. OEuvres en Prose 1909 1914. Charles Péguy (1961).

${ }^{116}$ De los dibujos y pinturas de Rugendas emerge una nueva visión de nuestro país, que puede ser hoy completada con los textos o imágenes de otros viajeros: Charles Darwin, María Graham, Samuel Johnston, John F. Coffin, Richard Longeville Vowell y otros. (Véase J.T. Medina, Viajes Relativos a Chile).

117 En 1872 fue designado Intendente de Santiago, cargo en el cual demostró una capacidad de acción sin comparación, al concretar su obra: la transformación de Santiago. La envergadura e impacto social de las obras realizadas -entre las cuales destacan la remodelación del cerro Santa Lucía, la canalización del río Mapocho, la construcción del Camino de Cintura y la arborización de plazas y avenidas- le granjearon una popularidad tan contun- 
dente que su proclamación como candidato a la presidencia para las elecciones de 1875 surgió casi espontáneamente. Sin embargo, las reticencias de algunos de sus propios correligionarios le obligaron a apartarse de los partidos oficiales y a poner en práctica la llamada "Campaña de los pueblos", basada en el contacto directo con la ciudadanía.

118 Geograficidad es un término poco usado (tanto en la lengua francesa, como en inglés o en español) que engloba dos nociones distintas. 1. En una primera acepción, "geograficidad" designa a aquello que en un objeto se relaciona específicamente con la geografía, o incluso a aquello que concierne a la actividad propia del geógrafo. En este sentido fue utilizado el término por el geógrafo belga Paul Michotte (1922), quien, al tratar de la posición de la geografía entre las ciencias, la definió como "disciplina corológica" Una segunda acepción se vincula no sólo con lo cognitivo, sino también con la relación existencial que se establece entre el hombre y su hábitat. Que es el sentido que le da Dardel listas a la construcción de la identidad territorial de Chile bajo preceptos científicos. El país y su paisaje, se convierte en objeto de estudio, y como plantea Sagredo (citado por Saffie, 2014) casi 160 años después, este territorio inexplorado adquiere consistencia.

[Si] Chile era visto por los andinos como "lo más hondo, lo más lejano, lo más profundo de la tierra", para los españoles fue solo una "costa", que se representó "siempre desde el mar". Se detallaron islas y bahías, lo importante para la navegación y la defensa, [ pero hacia adentro, el mapa estaba prácticamente vacío.] "Son los naturalistas y científicos que llegaron a nuestro país en los siglos XVIII y XIX los que dieron "contenido" y "profundidad" a ese territorio insondable. A partir de Humboldt, Chile [...]surge como una frontera geográfica, la cordillera de Los Andes (de gran interés para el científico); como una tierra telúrica, es el lugar donde la tierra se mueve -fenómeno que describiría detalladamente Darwin en su bitácora de viaje-; y también "es piedra, roca, mineral, cobre".

La tarea de adentrarse en las "tierras templadas" [la emprendieron los viajeros, naturalistas y artistas] para iniciar la labor de censar, analizar, investigar y dar cuenta de los recursos con que contaba nuestro país. [...] A caballo y con una libreta en mano, se comienza a "delinear" Chile, a representarlo cartográficamente, a dibujar su flora, su fauna y su gente. Las cosas comienzan a tener nombre y el país, una identidad. (Sagredo citado por Saffie, 2014, s.p.)

Así, Chile entró en el cosmos de Humboldt.

\subsubsection{La experiencia del paisaje, aproximación fenomenológica}

La relación entre experiencia y ciencia bajo la influencia de la fenomenología marcan un quinto momento que nos acerca a la noción contemporánea de paisaje. Besse (2010) la aborda a través del libro El hombre y la tierra (1952/2013) de Eric Dardel. Dardel fue un geógrafo francés cuya obra pasó prácticamente inadvertida en su época, dominada por el paradigma de la Geografía Regional Francesa institucionalizada por la escuela de Paul Vidal de la Blanche, desde inicios del siglo XX. Su reflexión teórica de carácter histórico, filosófico y etnológico ha sido recuperada desde el mundo anglosajón, un fenómeno raro, considerando la poca comunicación que aún existe entre el mundo centroeuropeo y el de habla inglesa. Su noción de la "geograficidad"118 del ser humano, es comprendida desde el mundo de los símbolos, de las significaciones, de las percepciones, de las representaciones y de las emociones (Dardel, 2013, p. 56 y 109).

Conocer lo ignoto, alcanzar lo inaccesible: la inquietud geográfica precede y conduce a la ciencia objetiva. Ya sea por el amor al terruño o por la búsqueda de lo desconocido, una relación concreta se establece entre el hombre y la Tierra, una geograficidad del hombre, propia de su existencia y su destino (Dardel, 2013, p. 55)

La palabra geograficidad es poco usada, por lo que he recurrido a un artículo de la geógrafa Marie-Claire Robic (2004) quién nos precisa que este término remite y juega con otra noción, la de historicidad, extraída de una tradición filosófica representada, principalmente, por Heidegger, Jaspers y Kierkegaard. Dardel explora las dimensiones del saber geográfico como efecto de una interpretación de la presencia originaria, inmediata, del sujeto en la tierra, que aúna su dimensión histórica con la individual. Será el paisaje donde se expresen mito, saber y arte, un paisaje que es también la Tierra.

Eric Dardel, sustentándose en una cita de Karl Jaspers, escribió:

[El hombre] "pertenece a una ciencia que ha hecho del mismo su objeto de estudio", es sujeto, ser libre, capaz de elaborar proyectos nuevos y empresas imprevisibles. La geografía debe comprenderse no como un marco cerrado donde los hombres se dejan observar como si de insectos en un terrario se tratara, sino como el medio a través del cual el hombre realiza su existencia mien- 
tras la Tierra sea una posibilidad esencial de su destino. (Dardel, 2013, p. 161) Para Besse, esta postura surge como respuesta crítica frente a la hegemonía del positivismo. Hace notar como en la década de 1950 el espacio se apoderó de la geografía en su pretensión de ciencia exacta. En este sentido, la fenomenología viene a contribuir a una actitud más abierta y flexible en relación a los objetos y métodos de la geografía, suscitando el interés por la percepción, la representación y el espacio. Cada llanura, montaña u océano adquiere un significado nuevo que no sólo se basa en sus aspectos cuantitativos, "El espacio geográfico tiene horizonte, forma, color, densidad. Es sólido, líquido o aéreo, ancho o estrecho: limita y resiste [...] La Tierra es un mundo por descifrar" (Dardel, 2013, p. 56), Dardel nos entrega los signos para leer la nueva composición del mundo, más cercana a la poesía que a la ciencia.

Si bien es cierto que esta postura no se opone a la configuración material del espacio, sí se hace un intento constante por rescatar elementos que conjuguen la vida del ser humano con la movilidad espacial. Para ello, utiliza la voz de exploradores y navegantes, que narran la experiencia del mundo desde distintos tipos de espacios: los espacios geométricos (Dardel, 2013, p. 56), el espacio material (p. 62), el espacio telúrico (p. 71), el espacio acuático (p. 77), el espacio aéreo (p. 82), el espacio construido (p. 86) y el paisaje (p. 90).

Así, la geografía fenomenológica de Dardel, reflexiona sobre la relación ser humano-naturaleza y considera que el paisaje es un mediador que permite a la naturaleza subsistir como mundo para el ser humano, es el dispositivo que mantiene esta relación viva. El paisaje en este sentido, representa una apertura a lo sensible, pero no busca revelar "el sentido oculto de los lugares" sino mostrar cómo surgen los significados en el encuentro con los lugares (Besse, 2010, p. 161). De este modo, se plantea que la geografía es "una dimensión originaria de la existencia humana" (Besse, 2010, p. 155), ya que su sentido está implícito en la pregunta ontológica del ser humano. Así, "la ciencia geográfica presupone que el mundo sea comprendido geográficamente, que el hombre se sienta y se sepa ligado a la Tierra como ser llamado a realizarse en su condición terrestre" (Dardel, 2013, p. 94).

Esta complicidad con la subjetividad no significa que estemos hablando de algo imaginario, por el contrario, "las experiencias de habitar, construir, cultivar, circular, la tierra se experimenta como base. No solo punto de apoyo espacial y soporte material, sino condición de cualquier 'posición' de la existencia" (Dardel, 2013, p. 102). El paisaje sería entonces el portador de sentido, la traza espacial del encuentro entre la Tierra y la acción humana, su proyecto. Este punto de vista fenomenológico propone entonces, mantener la comunicación entre la experiencia y la ciencia. Es también pensar la ciencia del paisaje más allá de las fronteras disciplinares, en el intervalo entre la ciencia y la filosofía.

Besse introduce el pensamiento de Dardel analizando primero cómo la fenomenología distingue paisaje y geografía. Para ello, toma la obra de Erwin Straus (18911975), psiquiatra y fenomenólogo, que en su obra Du sens des sens (1935/2000) diferencia percepción y sentir. Para este autor, la geografía estaría del lado de la percepción, de la ciencia, es su primer paso, y el paisaje del lado del sentir. Podríamos deslizar esta idea a la diferencia entre territorio y paisaje, dejando el territorio del lado de la geografía, según la conceptualización de Straus, que nos dice: "el mundo de la percepción es un mundo de las cosas con propiedades fijas [...] en un espacio y tiempo objetivos y universales" (Straus, 1935/2000, p. 511), podríamos decir que tiene coordenadas medibles, por lo tanto, objetivables.

Por el contrario, el paisaje precede a la distinción de sujeto y objeto, por lo tanto, nos plantea Besse, "precede también a toda orientación y referencia, es una manera de ser invadido por el mundo" (Besse, 2010, p. 146). Más adelante Straus 
aclara de qué se trata esta desorientación, que a priori aparece como anti-intuitiva, señalando tres aspectos del paisaje:

1. El paisaje está ligado a la idea de un horizonte. La geografía (territorio) no tiene el horizonte como estrategia, por ejemplo, cuando buscamos un lugar y miramos un mapa, el lugar donde nos localizamos es un punto, desde allí nos orientamos, no consideramos el horizonte, sino coordenadas, direcciones, distancias.

2. La presencia de una estructura de horizonte implica la ausencia de una visión totalizadora, de sobrevuelo; ya que, al desplazarnos de un lugar a otro, lo hacemos "en el interior del círculo de la visibilidad" (Straus, 2000, p. 513), por lo tanto, sólo habría paisaje local.

3. Debido a lo anterior, en el paisaje coexisten lo próximo y lo lejano, lo visible y lo oculto, es abierto. A la inversa, el espacio geográfico (territorio) es cerrado, delimitado según los criterios del espacio abstracto, dentro de un sistema de coordenadas. (Besse, 2010)

El paisaje nos devuelve, en esa concepción, un mundo perdido para y por la modernidad. El paisaje permite mantener una relación viva entre el hombre y la naturaleza que lo rodea inmediatamente. Recupera el "mundo de la vida", es la "mediación" que permite a la naturaleza subsistir como mundo para el hombre; Mundo que también fue perdido por la geografía como ciencia positiva, como experiencia de la tierra y también indagación sobre las diferentes maneras posibles de hablar del mundo. En este sentido, Besse dice que la geografía debe ser considerada fundamental para comprender la modernidad. De modo que la geografía no es sólo entendida como un contenido de saber, sino también debe ser tomada como una orientación hacia el mundo. (Besse, 2010).

Dardel pone en cuestión la geografía como saber instituido, su cientificidad, pues la considera como una "dimensión originaria de la existencia humana" (Besse, 2010, p. 155), ya que antes de ser una representación científica es un acto, que se desarrolla y se descubre en la existencia.

¿Cómo queda el paisaje en esa visión fenomenológica de la geografía de Dardel?

Si la existencia humana es por naturaleza geográfica, el paisaje, sería "la cara local de la Tierra en sus distancias y direcciones" (Besse, 2010, p. 165), ilustra ese encuentro de la existencia humana con la Tierra. Una tierra, que en los momentos que escribo ${ }^{119}$ se encuentra amenaza por enormes incendios en la selva amazónica, haciéndonos tomar consciencia de la fragilidad de la existencia humana. Para Besse, el paisaje de Dardel "es esencialmente mundo antes que naturaleza" $(2010$, p. 166).

[...] es portador de un sentido, porque es la traza espacial del encuentro entre la Tierra y el proyecto humano [...], es el mundo humano, la cultura como encuentro entre la libertad humana y el lugar de su desarrollo: la Tierra. [...] más todavía significa que no hay libertad en la historia más que si ésta se sitúa. 0 todavia [más], que la historia humana está fundamentalmente espacializada. (2010, p. 166-167).

Así como no hay hombres sin la Tierra, pues lo humano se realiza en la relación con la Tierra, esa relación es lo que hace paisaje y hace ver el paisaje.

A partir de estas lecturas me parece pertinente relacionar la visión de Dardel con el concepto de topofilia, acuñado originalmente por Gastón Bachelard en su

${ }^{119}$ Mientras realizo la última corrección de este texto, la Amazonía arde, con más de 74.000 incendios registrados desde enero de 2019. libro La poétique de l'espace, publicado en 1957. Hablando de las imágenes del espacio feliz, "que merecería llamar topofilia", nos dice:

Aspiran a determinar el valor humano de los espacios de posesión, de los 
espacios defendidos contra fuerzas adversas, de los espacios amados. Por razones frecuentemente muy diversas y con las diferencias que comprenden los matices poéticos, son espacios ensalzados. A su valor de protección que puede ser positivo, se adhieren también valores imaginados, y dichos valores son muy pronto valores dominantes. El espacio captado por la imaginación no puede seguir siendo el espacio indiferente entregado a la medida y a la reflexión del geómetra. Es vivido. Y es vivido, no en su positividad, sino con todas las parcialidades de la imaginación. (Bachelard, 1957/2000, p. 22)

En la aproximación de Bachelard, la percepción del espacio está mediatizada no solo por la experiencia sensible, sino también por el predominio de la imaginación que le otorga valor, condición que amplía el espacio mensurable de la física, para adoptar el estatus de espacio vivido. La topofilia sería así una categoría poética del espíritu que es trabajada luego por el geógrafo Yi Fu-Tuan, elaborando en su libro Topophilia de 1974, una nueva definición del concepto que describe como un sentimiento de "apego" que vincula a los seres humanos con los lugares, con los cuales establecen relaciones afectivas-emotivas debido a que se sienten identificados con ellos. Esta dimensión simbólica del habitar humano estaría fundada en un instinto de pertenencia y apropiación del mundo.

Esta identidad asociada a los lugares, nos advierte Tuan (1974/2007), no puede ser proyectada mecánicamente ya que surge como sentimiento. No es una condición del lugar sino un modo en que los individuos se relacionan entre sí y con un lugar, estableciendo lazos emotivos con sus atributos o como señala el autor, "manifestaciones específicas del amor humano por el lugar" (Tuan, 2007, p. 129).

Al intentar relacionar la aproximación fenomenológica a la noción de paisaje que Besse propone, con la construcción de una identidad chilena vinculada al paisaje, encontramos con la obra poética de Pablo Neruda. Podríamos afirmar que la poesía ha sido el vehículo a través del cual el paisaje es entendido como una experiencia, como algo vivido emocionalmente 0 como diría Dardel, como "un mundo por descifrar".

Desde sus construcciones metafóricas Neruda construye una visión mítica de la naturaleza. El paisaje del sur de Chile, el de su infancia, se fija en su imaginación como basamento de sus imágenes poéticas. En el poema, Primer Viaje de Memorial de isla Negra lo confiesa:

Las tablas de la casa / olían a bosque / a selva pura. / Desde entonces mi amor / fue maderero / y lo que toco se convierte en bosque. / Que me confunde los ojos y las hojas, / ciertas mujeres con la primavera / del avellano, el hombre con el árbol / como el mundo del viento y del follaje I me distingo entre labios y raíces. (Neruda, 1980, p. 12)

Este contacto directo y emocional con la naturaleza y la fusión de identidades son una clave de interpretación que estudiosos como Saúl Yukievich (2005) hacen notar. Otros autores recalcan su lenguaje telúrico. Para Hugo Montes en Análisis crítico de la obra nerudiana plantea que:

La expresión más evidente de esta dimensión es la identidad entre el yo y la tierra, que ocurre desde el primero hasta el último de los numerosos libros de Neruda. Una y otra vez se insiste en que el territorio donde el hombre habita no es una cosa ajena a éste, sino su esencial elemento constitutivo. La tierra es más que fundamento o contexto: es origen, materia prima, forma y destino. Residir en la tierra es ser y estar en ella y para ella; es ser de ella y para ella, es -más hondo- ser ella. No se puede ser sin ser de tierra, sin ser tierra. (Montes, 1974, p. 119). 
Si volvemos a Dardel en su reflexión sobre el espacio telúrico, parece que nos hablara de Neruda:

Siendo materia, implica una profundidad, un espesor, una solidez o una plasticidad que, en principio, una percepción interpretada por el intelecto no las percibe, sino que las descubrimos a través de una experiencia primitiva: respuesta de la realidad geográfica a una imaginación creadora que, por instinto, busca algo parecido a una substancia terrestre o que, tropezando con ella, la idealiza en símbolos, consecuencias, movimientos, prolongaciones, profundidades. (Dardel, 2013, p. 71)

Otra dimensión de la poesía de Neruda que se relaciona con la identidad es el reconocimiento que hace el poeta a Alonso de Ercilla como "inventor de Chile". En Nosotros los indios escribe:

El inventor de Chile, don Alonso de Ercilla, iluminó con magníficos diamantes no sólo un territorio desconocido. Dio también la luz a los hechos y a los hombres de nuestra Araucanía. Los chilenos, como corresponde, nos hemos encargado de disminuir hasta apagar el fulgor diamantino de la epopeya. La épica grandeza que, como una capa real dejó caer Ercilla sobre los hombros de Chile fue ocultándose y menoscabándose. A nuestros fantásticos héroes les fuimos robando la mitológica vestidura hasta dejarles un poncho indiano raído, zurcido, salpicado por el barro de los malos caminos, empapado por el antártico aguacero. (Neruda, 1979, p. 139).

En el Canto General ${ }^{120}$ recupera poéticamente la figura de Ercilla, confrontando la imagen idealizada de Arauco frente a la realidad histórica.

El poema XXII denuncia la imagen actual de raza vencida, el paisaje de Arauco, vacío de héroes que también se expresa en los versos del poema Los hombres:

Mira el vacío de los guerreros.

No hay nadie. Mira las piedras.

Mira las piedras de Arauco.

No hay nadie, sólo son los árboles.

Sólo son las piedras, Arauco.

(Neruda, 1981, p. 17)

${ }^{120}$ Con esta obra, Neruda consagra su reconocimiento internacional. Canto General fue publicado en México por la editorial Océano en 1950. Se integraron en esta primera edición ilustraciones de David Alfaro Siqueiros y Diego Rivera. Casi simultáneamente, en Chile, "una edición clandestina, con pie de imprenta ficticio (Canto general, Imprenta Juárez, Reforma 75, Ciudad de México) burlaba las censuras y desventuras contingentes de la época" (Quezada, 2004, p. 59). Su publicación -encargada por la dirección del Partido Comunista- estuvo a cargo de un equipo integrado, entre otros, por el técnico gráfico Américo Zorrilla y el artista José Venturelli.

${ }^{121}$ El 15 de septiembre de 1945, dos años después de su visita a la ciudadela incaica, Neruda terminó de escribir Alturas de Macchu Picchu, uno de los poemas más reconocidos del Canto General.
Originalmente el Canto General había sido concebido como un canto nacional, dedicado a explorar poéticamente los episodios históricos chilenos. Sin embargo, como el mismo Neruda reconoció más tarde, sus viajes por América modificaron radicalmente su visión:

Comprendí que, si pisábamos la misma tierra hereditaria, teníamos algo que ver con aquellos altos esfuerzos de la comunidad americana, que no podíamos ignorarlo, que nuestro desconocimiento o silencio era no solo un crimen, sino la continuación de una derrota. (Neruda, 1954, p. 12)

El paisaje de Macchu Picchu fue una inspiración portentosa:

Allí comenzó a germinar mi idea de un Canto General americano. Antes había persistido en mí la idea de un Canto General de Chile, a manera de crónica. Aquella visita cambió la perspectiva. Ahora veía a América entera desde las Alturas de Macchu Picchu. $\left(1954\right.$, p. 12) ${ }^{121}$

Desde el paisaje, en esta extensa obra, se entrelazan la miseria humana, el dolor por la pérdida de la tierra y de su identidad y la guerra:

... Macchu Picchu, pusiste piedra en la piedra, y en la base harapo? 
Carbón sobre carbón, y en el fondo, la lágrima?

Fuego en el oro, y en él, temblando, el rojo goterón de la sangre?

... Es más ancho que el mar y que sus islas,

y hay que caer en él como en un pozo para salir del fondo con un ramo de agua secreta y de verdades sumergidas.

(Neruda, 1981, p. 28)

En la misma obra, hay un poema donde Neruda confiesa que cuando fue perseguido, sus únicas herramientas de trabajo fueron una rama de espino, sus libros de geografía y otro sobre pájaros; objetos que representarían la experiencia directa y reciente (aquello que necesito tocar, sentir para recordar), el saber científico (de la geografía), y el libro de pájaros, la imagen que permite reconocer las aves del territorio.

Cuando salí de ti perseguido, erizado de barbas y de pobreza, sin ropa, sin papel para escribir las letras que son mi vida, sin nada más que un pequeño saco, traje dos libros y una sección de espino recién cortada al árbol. (Los libros: una geografía y el Libro de las Aves de Chile). (Neruda, 1981, p. 295) $)^{122}$

La poesía es quizás en el siglo $X X^{123}$, la máxima expresión del paisaje vivido para Chile. Es la poesía la que ha mantenido, desde Ercilla, esa relación de "mediación" diría Dardel, que permite a la naturaleza subsistir como mundo para el hombre. En la pintura, el paisaje, fue, si no abandonada, relegada a un segundo plano. Según el mismo Neruda:

[...] lo grave para nosotros es que los pintores bien dotados de nuestra América que antes han pintado pueblos, árboles y cielos americanos, vuelven de París pintando circulitos y rayas. El cosmopolitismo los ha aplastado [...] Pero nosotros necesitamos ver pintado lo que conocemos y amamos

Del mismo modo, la arquitectura y el urbanismo moderno dan la espalda al paisaje. Solo queda la poesía. La poesía de Neruda mantiene viva la experiencia de contemplar la cumbre de Los Andes, los bosques espesos, los valles y la inmensidad del mar. Así como para los viajeros románticos, los cuadros de Lorrain y Poussin fueron las imágenes de referencia para poder ver los paisajes en la realidad. Neruda provee de estas imágenes a través de las metáforas, permitiendo, como señala el poeta Raúl Zurita (2016):

[...] más que la creación de un autor se parece a un destino en cuya inexorabilidad están expresados todas las muertes, esperanzas, tragedias, sueños y despertares, de millones y millones de hombres y mujeres que han requerido de los poemas para completar sus existencias. (Zurita, 2016, p. 1)

Así se llega a comprender el territorio que habitan.

\subsubsection{Paisaje y acontecimiento}

El sexto autor que Besse nos presenta es el filósofo y poeta francés Charles Péguy (1873-1914) y su concepción del paisaje. Su obra poética y narrativa están fuertemente influidas por la filosofía de Henri Bergson (quién fuera su profesor desde la secundaria) a la que se suman la militancia socialista y luego su conversión al catolicismo. Una de las preocupaciones principales de Péguy es el "ser del tiempo" y es, a partir del presente, de la inmediatez que examinará el paisaje. Para este filósofo "el paisaje es una promesa con respecto al presente" (Besse, 2010, p. 190), una unión específica, propia, que invita a un pensamiento del acontecimiento. Porque el paisaje es enclave biográfico y ontológico, en la

122 Del poema "Saludo" de 1949.

${ }^{123}$ El poeta Raúl Zurita en discurso de agradecimiento por el Premio Pablo Neruda (2016) nos dice: Chile, mucho antes de ser un país fue un poema. Es el 'Chile fértil provincia señalada/ en la región antártica famosa/ de remotas naciones respetada/ por fuerte, principal y poderosa', de La Araucana de Alonso de Ercilla, ese soldado español que participó en la conquista y que después de declarar que no venía a cantarle al amor sino a la espada, vio en un territorio absolutamente desconocido, en el lugar más remoto del mundo, los bordes aún imaginarios de un país, uniendo para siempre nuestro destino con el destino de la poesía, de los grandes sueños y de sus encarnaciones concretas, pero también con las trazas de una violencia extrema anidada en el centro de nuestra historia. (Zurita, 2016, p. 3). 
conjunción de la experiencia personal y el mundo, que "da la experiencia local e instantánea, totalmente efímera" (Besse, 2010, p. 190). Biográfico, referido a lo que está en proceso, lo que tiene un origen conocido, pero cuyo final es pura incerteza. Ontológico, porque todas nuestras acciones y nuestras opciones tienen una trascendencia filosófica. El pensamiento creador es un fenómeno localizado, instantáneo y provisional. El paisaje para Péguy es la experiencia de esa precariedad. Así, el paisaje es evento y está en incesante cambio, ya que para Péguy la dimensión verdadera está en lo más cercano, en lo próximo, nos propone que "hay que quedarse abajo" para empezar a comprender el paisaje. Además, si toda experiencia permite el encuentro con lo real y para pensar es necesario mantenerse en la proximidad de las cosas, "en su zona de contacto", el "pensar es este poder llegar a ser sensible" (Besse, 2010, p. 186).

Así es que "todo paisaje es una zona de contacto donde se da a una velocidad infinita el cruce del mundo y el de la conciencia" (2010, p. 183). Esta es la coincidencia y la analogía que Péguy presenta entre el pensamiento y el paisaje.

A través de su filosofía se refuerza la idea de la mirada y del movimiento en la relación del ser-pensar-actuar con el paisaje. El pensamiento -como el paisaje- exige tomar una posición opuesta al intelectualismo, que necesariamente se convierte en lugar de lucha, que debe ser conquistado, y de una actitud comprometida con la acción. Este lugar, es un punto sensible, punto de una ruptura y de una liberación de los mecanismos y de las instituciones de todo orden.

Su concepción filosófica lo conduce así, a una concepción del paisaje no como "acumulación de memorias, depósito de signos, patrimonio construido, nostálgicamente consultado" (Besse, 2010, p.178). El paisaje ante todo es un acontecimiento, es pasajero, efímero e incompleto como la vida. El "paisaje-acontecimiento" de Péguy es movimiento que articula lo interior y el exterior como anunciación, presente del futuro, punto de tránsito, múltiple y repetido, del presente de las posibilidades.

El paisaje habla del sentido y de la responsabilidad ética de habitar la Tierra. Podríamos entonces decir que, en la lectura que Besse hace de Péguy, el paisaje está en el camino de la acción, en cuanto pensamiento filosófico y proyecto de existencia. Acción como pensamiento, como acto fundante de un comienzo siempre nuevo, que parte de la experiencia de una precariedad (de las cosas), del origen. Pero esa no es la experiencia moderna del paisaje. La experiencia moderna del paisaje constituye una visión de sobrevuelo, sintética, que plantea sólo ubicaciones a recorrer, problemas de orientación, salidas y llegadas, instrucciones a seguir. Dominado por el deseo de mirar y de dominar el mundo a la distancia. Péguy recupera el paisaje también por el sentido y la experiencia de la proximidad, ya que no hay paisaje de sobrevuelo, vista desde lo alto el paisaje es un plano. Esta experiencia de proximidad, para Péguy, tiene un sentido topológico, pero sobre todo un sentido moral (cristiano). Nos advierte que no hay que mezclar la filosofía con problemas materiales y condena el trabajo hecho por la gloria, que restringe la libertad del pensador. Desde este punto de vista Péguy, en su obra póstuma Clio (1961), plantea su oposición a la teoría del progreso. Para él la teoría del progreso supone que la humanidad es como un gran banco en el que se van acumulando los ahorros. Pero desgraciadamente, en el correr de los tiempos hay un desgaste necesario. La teoría del progreso es lógica pero inorgánica. Supone que cada paso es un paso hacia arriba en una escalera que sube. Que cada esfuerzo es un capital de inteligencia ahorrado, pero:

(H)ay un desperdicio, una pérdida perpetua, un desgaste, un roce, algo irreversible que está en la naturaleza misma, en la esencia y en el acontecimiento, en el corazón mismo del acontecimiento. En una palabra, hay envejecimiento. (Péguy, 1961, pp. 129-130). 
Basándose en Bergson, Péguy reconoce que lo orgánico tiene una duración real, un ritmo de duración. El envejecimiento es orgánico. "El envejecimiento está incorporado en el corazón mismo del organismo. Nacer, envejecer, devenir y morir; crecer y decrecer, es todo uno" (Péguy, 1961, p. 132). El mecanismo de la historia, de lo temporal, consiste en esa pérdida constante. Pero también explica cómo sin esta idea de progreso, puede emerger el pensamiento creador:

Una raza recibe su carácter del clima, del suelo, de los alimentos y de los grandes acontecimientos que ha sufrido desde su origen. Este carácter apropiado y reducido a la cultura implica un cierto espíritu como también una cierta concepción de belleza. El terreno de lo nacional está allí, es bueno para ciertas plantas, pero malo para otras, incapaz de hacer germinar las semillas del país vecino, pero capaz de darle al suyo una savia exquisita y una floración perfecta, cuando el curso de los siglos trae la temperatura que ellas necesitan. Así nacieron La Fontaine en Francia, Shakespeare en Inglaterra y Goethe en Alemania, cada uno en su época. (Péguy, 1900-04, p. LXX) ${ }^{124}$.

Si bien es llamativo el uso de la palabra raza ${ }^{125}$, vale decir personas caracterizadas por factores biológicos, entendemos que el autor se refiere a etnia, vale decir, sujetos caracterizados por factores culturales comunes. Releva de este modo, los aspectos identitarios asociados a un lugar, vale decir, la conciencia de que los valores culturales, las conductas colectivas y también las individuales, incluso el genio creador, estarían condicionadas por el territorio, por sus condiciones materiales, sean estos el clima, el suelo, los alimentos, como también los eventos que han marcado su devenir.

Hay un pasaje en el texto Zangwill (Péguy, 1961), que Besse no recoge, y que para efectos de esta tesis es importante: en su reflexión sobre la tendencia a artificializar el mundo, Péguy plantea:

La naturaleza no es viable en las condiciones generales; la ciencia podrá extender los límites de la sostenibilidad [énfasis agregado]. La naturaleza hasta aquí hizo lo que pudo; las fuerzas espontáneas no sobrepasarán la cota que alcanzaron. Que aquí donde la ciencia toma la obra en el punto donde la naturaleza la dejó. La botánica hace vivir de manera artificial de los productos vegetales que desaparecerían si la mano del hombre no los sostuviera sin cesar. [esto tiene un precio] esta producción [el lugar natural] será evaluada en un cierto capital, volviéndonos dependientes de aparatos caros, acciones más lentas, selección laboriosa, educación complicada y la conservación penosa de un modo de ser contra la naturaleza. (Péguy, 1961, p. 226) ${ }^{126}$.

La (viabilité) -que he traducido como sostenibilidad-, a través de mecanismos científicos, se advierte aquí como un peligro. De algún modo se lee en este autor (sin que lo explicite en ninguno de los textos citados), la aparición de una mirada ecológica del paisaje, pero concebida como la comprensión un mundo precario, que sólo puede ser captado como contingencia, algo distanciado de consideraciones estéticas. Hay que recordar que Péguy muere en 1914, en la primera Guerra Mundial y recién en 1886 Haecke acuña el término ecología. El dualismo hombre-naturaleza está presente aún en Péguy; el vitalismo heredado de Bergson aún no deja paso a la mirada relacional.

Esta concepción se desarrollaría más tarde, el paisaje como sistema, en el que todos los elementos interactúan, lo que significa que el paisaje es ante todo una totalidad dinámica, evolutiva, recorrida por flujos cuya naturaleza intensidad y dirección son muy variables, atribuyéndole por ello una temporalidad propia. Flujos de materia y energía. Hoy agregaríamos también, flujos e intercambios de información.

Péguy representa en nuestro trabajo ese punto de quiebre, que puede ser entendido también como articulación entre la concepción cultural del paisaje, que da paso a otra holística y jerárquica, también más naturalista, representada por la escuela anglosajona del Landscape, que ve en el espacio del paisaje, un espacio poroso y común donde se encuentran hombre y naturaleza.
${ }^{124}$ Traducción propia del francés: Une race se rencontre ayant reçu son caractère $d u$ climat, du sol, des aliments, et des grands événements qu'elle a subis à son origine. Ce caractère l'approprie et la réduit à la culture d'un certain esprit comme à la conception d'une certaine beauté. C'est là le terrain national, très-bon pour certaines plantes, mais trèsmauvais pour d'autres, incapable de mener à bien les graines du pays voisin, mais capable de donner aux siennes une sève exquise et une floraison parfaite, lorsque le cours des siècles amène la température dont elles ont besoin. Ainsi sont nés La Fontaine en France au dix-septième siècle, Shakespeare en Angleterre pendant la Renaissance, Gœthe en Allemagne de nos jours.

${ }^{125}$ Como forma de referirse a los grupos humanos asociados a un territorio, es posible que esto corresponda a una apreciación ideológica e histórica, ya que en el lenguaje contemporáneo practicamente no se habla de raza sino más bien de etnia

126 Traducción propia del francés: La nature ne fait rien que de viable dans les conditions générales ; mais la science pourra étendre les limites de la viabilité. La nature jusqu'ici a fait ce qu'elle a pu ; les forces spontanées ne dépasseront pas l'étiage qu'elles ont atteint. C'est à la science à prendre l'œuvre au point où la nature l'a laissée. La botanique fait vivre artificiellement des produits végétaux qui disparaîtraient si la main de l'homme ne les soutenait incessamment. Un âge se conçoit où la production d'un déva serait évaluée à un certain capital, représentant les appareils chers, les actions lentes, les sélections laborieuses, l'éducation compliquée et la conservation pénible d'un pareil être contre nature. 
La concepción cultural del paisaje, la que conforma identidad, ha sido el hilo conductor de la segunda parte de este capítulo. Todo paisaje, de una manera que le es propia, está relacionado con un proyecto social, incluso aunque no seamos conscientes, el paisaje es un espacio político, sobre el que Péguy nos invita a "trabajar modestamente", pero también a renunciar a que seremos capaces de cambiar los grandes eventos. Cabe preguntarse aquí si existe una posición análoga en la cultura chilena, ya que claramente, la noción de paisaje excepcional que se transmite a través de la poesía de Neruda responde a otro carácter, uno trascendente, donde el poeta es también un distinto, no un trabajador modesto entre otros.

El poeta Nicanor Parra ${ }^{127}$ nos permite ilustrar una nueva actitud frente a la realidad y hacia el paisaje. Parra se burla de la solemnidad y grandilocuencia, pone al poeta en la calle, usando el lenguaje de todos. En su poema Frases recurre a los lugares comunes:

No nos echemos tierra a los ojos

El automóvil es una silla de ruedas

El león está hecho de corderos

Los poetas no tienen biografía

La muerte es un hábito colectivo

Los niños nacen para ser felices

La realidad tiende a desaparecer

Fornicar es un acto diabólico

Dios es un buen amigo de los pobres. (Parra, 1969, p. 168).

Sus antipoemas se construyen haciendo referencia a lo cotidiano, al lugar común, a la ironía y a la aparente falta de orden. "La poesía", afirma, "es para mí como el habla. Debemos escribir como hablamos; por eso, en mis recitales, me gusta entonar, hacer gestos, guiños" (García Santa Cecilia,23 de enero, 1987). Antipoemas, artefactos, garabatos reemplazan a los poemas. "La poesía no es magia, ni divinidad, ni voz salvadora", capaz de modificar los acontecimientos. "Se destruye el mito. Nicanor Parra, como niño juguetón, tira piedras contra todo estiramiento, contra la importancia" (Montes, 1974, p. 118), también contra el paisaje:

PAISAJE

¡Veis esa pierna humana que cuelga de la luna Como un árbol que crece para abajo Esa pierna temible que flota en el vacío lluminada apenas por el rayo De la luna y el aire del olvido! (Parra, 1969, p. 39)

${ }^{127}$ Nicanor Parra Sandoval (1914-2018), poeta, matemático y físico chileno cuya obra ha tenido una profunda influencia en la literatura hispanoamericana. Considerado el creador de la antipoesía, Parra fue, en palabras de Harold Bloom, "incuestionablemente, uno de los mejores poetas de Occidente". El mayor de la familia Parra cantera de connotados artistas y músicos de la cultura chilena-, recibió el Premio Nacional de Literatura 1969 y el Premio Cervantes 2011, entre otros galardones. 

por razones de orden político por razones de orden sexual por razones de orden religioso

dando por descontada la existencia

de la ciudad y de sus habitantes: aunque está demostrado que los habitantes aún no han nacido ni nacerán antes de sucumbir

y Santiago de Chile es un desierto. Creemos ser país y la verdad es que somos apenas paisaje.

(Parra, 1969, p. 241)

Los últimos versos son demoledores y no tienen inocencia, más aún, viniendo del poeta que en sus últimos años se declaró ecologista (García Santa Cecilia, 23 de enero, 1987) ${ }^{128}$. El análisis de este poema nos permite desentrañar las relaciones entre el paisaje y la cultura chilena y desde una mirada crítica comprender hasta qué punto la identidad de este país se encuentra vinculada al paisaje, asunto que ha acompañado la revisión diacrónica de su noción. Para ello, tomo las preguntas con las que el pintor y teórico del arte, Pablo Chiuminatto inicia su conferencia "Paisajes, materia y olvido", partiendo de estos mismos versos de Parra, se pregunta:

¿Por qué esa valoración peyorativa entre país y paisaje pareciera dar con la sensación exacta y compartida de un inalcanzable destino nacional precario? ¿Por qué esta percepción de ser una comunidad marcada por la mirada sobre el territorio, aparece como una versión menor de las dinámicas propias de una nación, del orgullo de una pertenencia a un país? (Chiuminatto, 2016, p. 1).

Es tal vez porque el paisaje no ha logrado alcanzar la valoración que, por ejemplo, tiene el patrimonio construido. Si bien el tema del paisaje en los últimos 25 años ha logrado penetrar lentamente en el discurso público y existe una larga tradición de creación de Parques Nacionales y reservas naturales en Chile, no obstante "hoy no consideramos la naturaleza como parte de la cultura" (Chiuminatto, 2016, p. 2), como un bien común que debe protegerse para asegurar las condiciones de relación medioambiental y un horizonte cultural futuro, que recuerde en algo que fuimos "la copia feliz del edén", imagen presente en nuestra Canción Nacional.

Esta es una paradoja que Augustin Berque ha expresado a través de la oposición entre un "pensamiento paisajero" y un "pensamiento del paisaje":

Un pensamiento de tipo paisajero, sin embargo, no exige necesariamente de palabras. Prueba de ello es que, en Europa, desde los primeros poblamientos llegados de África hasta el Renacimiento, se vivió de una manera tan paisajera que nos ha dejado paisajes admirables, y ello en ausencia de todo pensamiento del paisaje. Las personas actuaban sobre los paisajes con acertado gusto [...] de tal manera que hacían paisajes hermosos. [...] En resumen, daban indiscutibles muestras de un pensamiento paisajero. Por el contrario, no está nada claro que nosotros seamos capaces de ello. Jamás se ha hablado tanto de paisaje como en nuestra época [...] y jamás hemos asolado tanto los paisajes. Somos unos charlatanes, grandes habladores del paisaje en total contradicción con nuestros discursos; pues nuestros actos van en sentido opuesto. Cuanto más pensamos el paisaje más lo masacramos. (Berque, 2009, p. 20)

Por lo tanto, si quisiéramos extender el concepto patrimonio para incorporar la

128 En esta entrevista indica: La actividad poética de Nicanor Parra se centra en la actualidad en sus ecopoemas: "Me interesan estos versos breves y explosivos, pero me considero fundamentalmente un alfabetizador ecologista. Los ecologistas [...] creemos en la finitud de la naturaleza. No hay bienestar si no se respeta la naturaleza. No hay que dominar a la naturaleza, sino convivir con ella". 
noción de paisaje, necesitaríamos sintonizar nuestros discursos y nuestros actos cotidianos. También, repensar la cultura como un sistema de relaciones más amplio, donde el paisaje, sea justamente ese "fondo" relacional que vincula la comunidad y su territorio, incluyendo los factores culturales, económicos y medioambientales. Esto significa considerar los atributos estéticos, éticos y sistémicos de su conformación.

Como señala uno de los textos de la convocatoria a los Coloquios Patrimoniales del Consejo Nacional de la Cultura y las Artes:

El patrimonio es el producto de un proceso de valoración, conservación y promoción de determinadas entidades materiales e inmateriales, que en otro momento poseían un valor diferente. Esas entidades patrimonializadas se transforman en un bien común para una comunidad, cuya identidad gira en torno a ellas. Sin embargo, en el contexto actual el patrimonio no solo se articula como un bien común para una comunidad, sino también como un nicho económico apto para ser explotado por el turismo y objetualizado por el mercado. (Consejo Nacional de la Cultura y las Artes, 2017, p. 4)

En esta definición, encontramos términos que son comunes al discurso medioambiental, como la valoración y conservación, así como la advertencia sobre el riesgo de entrar en el juego del mercado, que usa la identidad asociada a un territorio y la singularidad de su paisaje, como un bien de consumo. Un "nicho económico apto para ser explotado y objetualizado por el mercado", disociándolo definitivamente de su relación con la identidad de la comunidad que lo habita.

Una de las razones que arguye Chiuminatto para comprender por qué esta discusión sobre la patrimonialización del paisaje se ha descuidado en Chile, es la dificultad de levantar un debate sobre patrimonio de forma transversal durante la dictadura militar (1973-1989), en una situación política donde los derechos fundamentales no estaban asegurados. La interpretación es que, en ese período, "para los grupos opositores al régimen, prácticamente cualquier propuesta 0 acción que no estuviera dirigida directamente a la recuperación de la democracia, podía ser entendida como una forma distractora de colaboración con el poder"129(Chiuminatto, 2016, p. 5).

A más de doscientos años de la fundación de la República, preguntarnos si Chile es país o paisaje, sigue siendo complejo. La poetisa Gabriela Mistral lo decía en una conferencia dictada en Uruguay en 1938:

El hombre nuestro parece tan flotante, es una especie de alga que corre por encima, por la superficie de la nación. Muy rara vez yo me encuentro a esos americanos que dice el europeo, apoyados hasta el pecho en su geografía y en su historia. (Mistral, 2013, p. 4)

Pensar en el paisaje como patrimonio desde el extremo sur del mundo, es asumir la precariedad de la que nos habla Péguy. No es fácil encontrar un modelo propio. No podemos aplicar irreflexivamente las imágenes ni los métodos que corresponden a otros paisajes, a otras culturas, a otros países. Nuestra historia reciente ha desdibujado el país y su paisaje, en palabras del cineasta Raúl Ruiz "El hecho de que sea el país de América Latina de mayor eficacia capitalista, implica que

${ }^{129}$ Fue así también, como las etnias presentes aún en Chile (aimaras, atacameños, quechuas, colla, diaguitas, rapa-nui, mapuches, kawésqar y yagán) fueron totalmente postergadas en el debate por años. es el país más abstracto y, por lo tanto, el más inexistente, si cabe emplear ese término" (Naranjo, 1998, p. 1).

Recuperar patrimonialmente la categoría paisaje sería, uno de los desafíos de nuestra propia cultura, superando así, la paradoja que nos muestra Nicanor Parra. Solo así lograremos religar nuestra identidad al paisaje. Ya que, sin paisaje, no hay país. 


\subsection{EL PAISAJE EN LA LEGISLACIÓN CHILENA 3.7.1. El paisaje y la protección medio ambiental}

En el ámbito institucional internacional, el uso de la palabra "paisaje" está generalmente asociado a la noción de la protección y la conservación del patrimonio natural y cultural, y a la necesidad de identificar, valorizar y preservar sus elementos distintivos, así como la serie de valores culturales, identitarios, incluso económicos asociados a éste.

En el caso de Chile, esta discusión también ha permeado el quehacer legislativo, de manera incipiente a partir de los años 1970, y luego fuertemente en la primera década del siglo XXI, poniendo las nociones de conservación y protección del patrimonio cultural y natural al centro de la acción institucional. Podemos señalar, incluso, que ambas dimensiones (aquella relacionada con la protección del patrimonio natural, y aquella relacionada con la protección del patrimonio cultural) han ido avanzando de manera paralela, por vías diferentes, y no siempre al mismo ritmo, como si ambas concepciones fuesen diferentes o disociadas.

La entrada al tema de la conservación y la protección del patrimonio natural, a nivel de la legislación nacional, se ha hecho de manera reciente, centrándose en la biodiversidad local, es decir, en la valoración y el interés de la diversidad de ecosistemas y de los hábitats naturales de determinadas poblaciones de especies, asociadas a determinados entornos naturales, y su particularidad. Desde ese punto de vista, y desde los años 2000 principalmente, la legislación chilena ha apuntado, por ejemplo, a definir geográfica y jurídicamente ciertas zonas del país, considerándolas como áreas protegidas, detentoras de un patrimonio ambiental de valor nacional e internacional.

En este contexto, sin embargo, la noción de "paisaje" aparece como poco utilizada, siendo convocada sólo para describir, por ejemplo, por el Ministerio del Medio Ambiente, los entornos atravesados por expresiones socioculturales (como los paisajes rurales) donde también pueden crecer 0 ubicarse ciertas especies domesticadas y que necesitan ser protegidas, a pesar de no estar en su ambiente "natural". La ley № 18.362 de 2014 que crea el Sistema Nacional de áreas silvestres protegidas del Estado, vuelve a utilizar el concepto de "paisaje" para identificar y enumerar las "áreas de carácter único o representativas de la diversidad ecológica natural del país", a pesar de que esta definición asocia rápida y someramente el concepto de "paisaje" al mundo antrópico y en oposición a las manifestaciones, los espacios y las especies naturales, el marco legislativo, en particular. En esta Ley, uno de los pocos documentos legislativos que considera el vocablo "paisaje", éste aparece como parte del conjunto de elementos naturales, al lado de las comunidades animales o vegetales, o las formaciones geológicas naturales.

El proyecto El Hombre y la Biosfera (MAB, Man and Biosphere) de la Organización de las Naciones Unidas para la Educación, la Ciencia y la Cultura (UNESCO), y que ha servido de marco para el desarrollo institucional chileno en materia de conservación de la biodiversidad , ratifica también la inclusión del "paisaje" dentro de los elementos fundamentales a considerar en los proyectos destinados a la protección y conservación de la biosferas locales (las reservas de la biosfera); el documento, sin embargo, incluye también otros elementos de carácter antrópico, como las nociones de desarrollo económico y humano, o la investigación y la educación, sin hacer una división estricta entre aspectos naturales y culturales y, por lo tanto, sin encasillar la noción de "paisaje" en ningún registro en particular, ni del costado "naturaleza" ni del costado "sociocultural"; define, en cambio, las reservas de la biosfera desde un punto de vista integrador, como zonas de "de preservación, y zonas de amortiguación y transición, en las cuales se permite la existencia de población humana y la realización de actividades económicas 
aplicando criterios de conservación y protección de la biodiversidad" (Rovira J., Ortega D., Álvarez D. \& Molt K. 2006).

Como destaca el propio Ministerio del Medio Ambiente (creado recientemente, en 2012), las discusiones mundiales y los acuerdos internacionales de los últimos años en materia de conservación medio ambiental, han sido fundamentales para el actual establecimiento de áreas protegidas en Chile; otros elementos fundamentales para estos han sido, de igual manera, las razones geopolíticas, la importancia de la protección de recursos económicos específicos, y la disponibilidad de terrenos fiscales o de baja plusvalía . Sin embargo, y a pesar de que en varios de estos documentos observamos una concepción acerca de la protección del medio ambiente desde una perspectiva ecosistémica, donde los aspectos naturales y culturales interactúan y donde el "paisaje" aparece a la interfaz entre ambos, esta acepción parece no haber permeado necesariamente hacia el vocabulario legislativo nacional en temas de medio ambiente, donde la utilización de la palabra "paisaje" propiamente tal aparece notoriamente reducida.

\subsubsection{Legislación y protección inmaterial: el paisaje como aspecto cultural}

La segunda línea legislativa donde emerge la noción de la protección y la conservación en la legislación chilena, tiene que ver con la identificación y el cuidado del patrimonio material e inmaterial del país. Retrocediendo un poco en la historia institucional, es importante señalar que ya desde los años 1970, este tema comenzó a ocupar la acción legislativa y normativa, tanto a nivel internacional como nacional. Es en 1972 cuando se aprueba la Convención para la Protección del Patrimonio Mundial Cultural y Natural de la UNESCO, erigiéndose como documento clave en la identificación y la protección en materia de cuidado de los bienes reconocidos como patrimoniales, debido a su valor material, histórico o cultural- estético, etnológico y antropológico; este documento, además, será fundamental para legitimar el rol del patrimonio en el desarrollo cultural de las diferentes naciones, estableciendo acciones estatales y supranacionales para cuidarlo.

Aunque este marco normativo, que sigue vigente hasta hoy (con ciertas modificaciones, de manera periódica), expande las nociones acerca del patrimonio hacia lo intangible, la noción de "paisaje" no alcanza a ser considerada, más que como un soporte casi material, susceptible de integrar diferentes conjuntos o elementos materiales de valor histórico, artístico o científico.

Una situación similar se vivía en Chile, también en 1970, año en que se promulga la Ley de Monumentos Nacionales (Ley N ${ }^{\circ} 17.288$ ). Asumiendo el rol que le cabía al Estado en la protección y cuidado de los bienes u objetos de carácter histórico 0 artístico que interesen a la historia, al arte o a la ciencia, esta ley buscaba velar por su identificación, protección y conservación, aunque concentrándose principalmente (hasta el día de hoy) en aquellos bienes de tipo material y destacando principalmente su valor arquitectónico o monumental. La noción de "paisaje" es, una vez más, inexistente. En la década de 1990, la UNESCO profundiza su discurso acerca de la importancia del patrimonio inmaterial o intangible, en oposición a aquel de carácter material, monumental, arquitectónico 0 natural, y que hasta ahora había ocupado un lugar central. Se comienza a hablar de incluso de "paisajes culturales", entendido como los bienes culturales que representan "obras conjuntas del hombre y la naturaleza" y que:

[...] ilustran la evolución de la sociedad humana y sus asentamientos a lo largo del tiempo, condicionados por las limitaciones y/o oportunidades físicas que presenta su entorno natural y por las sucesivas fuerzas sociales, económicas y culturales, tanto externas como internas. (UNESCO, 2005, p. 48). 
Esta definición, que hace referencia a las dimensiones no sólo materiales sino también históricas, políticas y económicas del patrimonio cultural, adquirirá rápidamente una fuerza particular, al ser considerada dentro de los criterios que determinan que un lugar, monumento o práctica cultural pueda incluirse en la lista Patrimonio de la Humanidad de dicha institución.

En el caso chileno, los años venideros también verán una incorporación de la noción de patrimonio en la legislación nacional, a través de la creación de normativas que dinamizarán su cuidado y protección. La Ley general de urbanismo y construcciones (Decreto 458/1976) cumplirá un rol importante en este trabajo, al momento de entregar la responsabilidad a los municipios del país de identificar y conservar los elementos patrimoniales a nivel urbano. Según lo establece la ordenanza general de esta ley, los planos reguladores comunales, y luego la categoría de Inmueble y de Zonas de Conservación Histórica, serán las herramientas a través de las cuales las municipalidades podrán (o no) identificar y proteger ciertas áreas, en función de su valor natural o patrimonial, estableciendo ciertas restricciones o disposiciones urbanísticas especiales que preserven sus características arquitectónicas e históricas.

Si bien ambos documentos prevén la protección del patrimonio local, ampliando su noción y considerando ya no sólo los bienes o inmuebles de manera individual sino también en su conjunto, esta normativa seguirá estando restringida hacia lo material o histórico, obviando la dimensión simbólica del patrimonio y, por su puesto, su vínculo con la idea de paisaje. Éste, someramente mencionado en el concepto "paisajístico" será evocado sólo desde una concepción operativa dentro de la gestión práctica del territorio, como cuando se habla de las disposiciones municipales en relación, por ejemplo, a la creación y mantenimiento de las áreas verdes locales:

La Municipalidad podrá autorizar determinadas construcciones en las áreas verdes y parques a que se refiere el inciso anterior, entendiéndose que éstas mantienen su carácter de tales, siempre y cuando [...] Se ejecuten o garanticen las obras paisajísticas que establezca la respectiva Municipalidad, incluyendo la mantención de las mismas. (MINVU, 1992, Artículo 2.1.31).

No será hasta fines de la década de 1990 y comienzos de los 2000 que la idea de "paisaje cultural" adquirirá un interés particular para el caso chileno, luego de la inscripción de seis sitios nacionales en la lista de Patrimonio de la Humanidad, como lo son el Parque Nacional de Rapa-Nui (1995), el conjunto de iglesias de Chiloé (2000), el área histórica de la ciudad-puerto de Valparaíso (2003), las oficinas salitreras de Humberstone y Santa Laura (2006), el campamento de Sewell (2006), y el Sistema Vial Andino Qhapaq Ñan (2014). Actualmente, sin embargo, el concepto como tal tampoco está incorporado en la legislación chilena, lo que mostraría que, a pesar de la popularidad de la que éste goza actualmente a nivel internacional y el uso que se le da como manera de relacionar naturaleza y cultura, reflejando el "medio en el que viven las personas, formando parte de su calidad de vida", la noción de "paisaje", pasa aún casi desapercibida en el lenguaje de la legislación proteccionista de Chile.

\subsubsection{Paisaje, palabra perdida}

En efecto, a nivel de la legislación nacional, es sorpresivo el hecho de encontrarse con una práctica inexistencia del concepto "paisaje", particularmente a nivel de las leyes o normativas generales que estructuran el corpus legislativo chileno; estamos hablando de leyes que, debido a su relación con temáticas estructurales para el funcionamiento del país, y que determinan un uso particular del territorio nacional, podrían ser susceptibles de considerar la noción de paisaje en sus determinaciones, como el Código de Minería, la Ley de transportes, la Ley general 
de pesca, las normativas correspondientes a los pueblos indígenas, el Código de Aguas, las leyes relacionadas con el borde costero nacional o las concesiones marítimas, el Código de Energía, la ley que crea el Consejo Nacional de la Cultura y las Artes, y aquellas referidas a la protección y explotación de los bosques nativos del país.

Al igual que lo hemos señalado anteriormente, es nuevamente en el escenario medio ambiental donde encontramos la mayoría de los pocos documentos jurídicos nacionales que consideran la noción de "paisaje", tal como lo hace la propia ley que crea el Ministerio del Medio Ambiente (Ley No 20.417, 2012), el decreto que aprueba el Reglamento del sistema de evaluación de impacto ambiental (Decreto 40, 2014), la Ley de Bosques (Decreto 4363, 2013) y las normativas ya citadas, relacionadas con la creación de zonas silvestres y marinas de protección y conservación (Decreto 238 de 2006 y Ley № 18.362 de 2014). En todas éstas, el "paisaje" es considerado como sinónimo o como subconjunto de los elementos que componen el medio ambiente; recurso asimilable a la flora, la fauna, los ecosistemas y los espacios naturales en general, el "paisaje" es considerado en prácticamente la totalidad de estos documentos como parte de la "biodiversidad" a conservar y proteger.

De esta forma, asistimos no sólo a una invisibilización del concepto a nivel jurídico, sino que a una falta de determinación acerca de sus acepciones culturales, lejos de los lineamientos que han marcado el escenario internacional, principalmente el europeo, donde el Convenio Europeo del Paisaje (2000) ha sido fundamental para la instauración regional de una noción cultural y compleja acerca del paisaje, que lo convierte no sólo en una categoría interpretativa, que nace de la observación humana de una porción de territorio determinada, sino simbólica, donde se conjugan, entre otros, elementos de valoración social, cultural, identitaria, económica e histórica. De allí nace entonces la importancia y el interés compartido por identificar, proteger y valorizar los diferentes paisajes del país, como exponentes del patrimonio y la diversidad cultural de las distintas sociedades humanas, y que aseguran y proyectan su valor hacia afuera, como fuente de turismo y desarrollo económico, pero sobre todo hacia adentro, como fuente de identidad local, regional y nacional. 


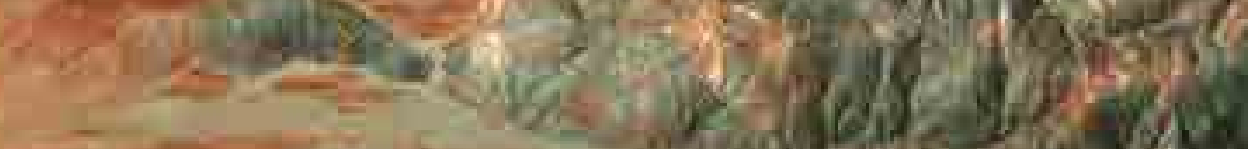

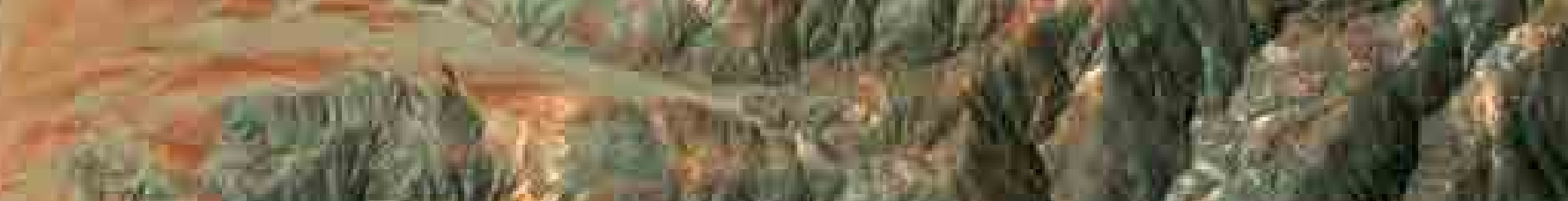

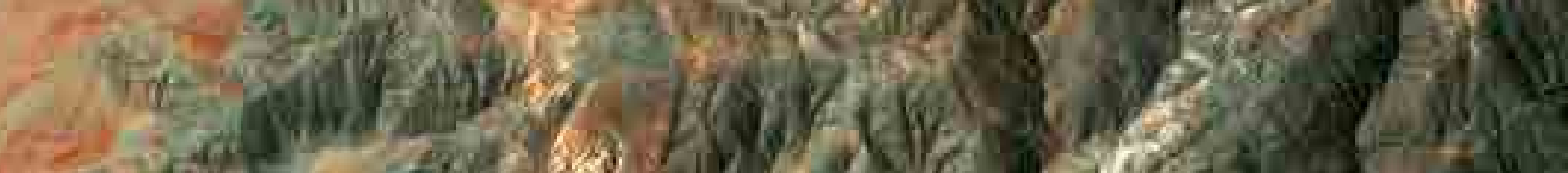
(15) What

3
$=64$
36

$$
\text { (20) }
$$

(6)

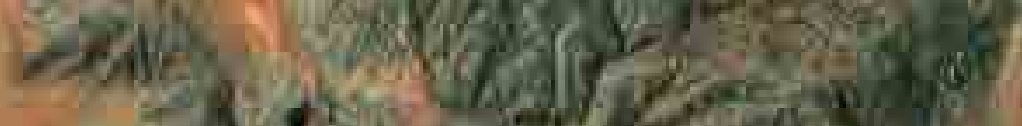

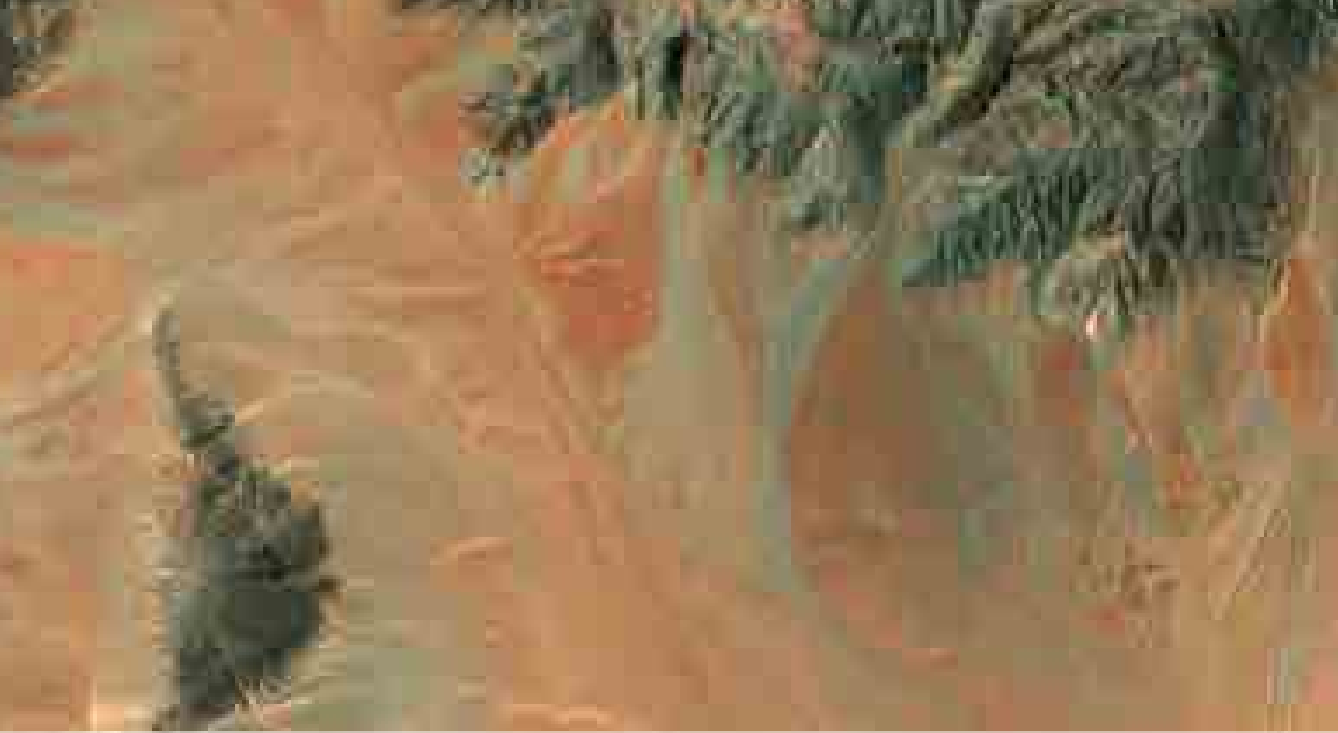

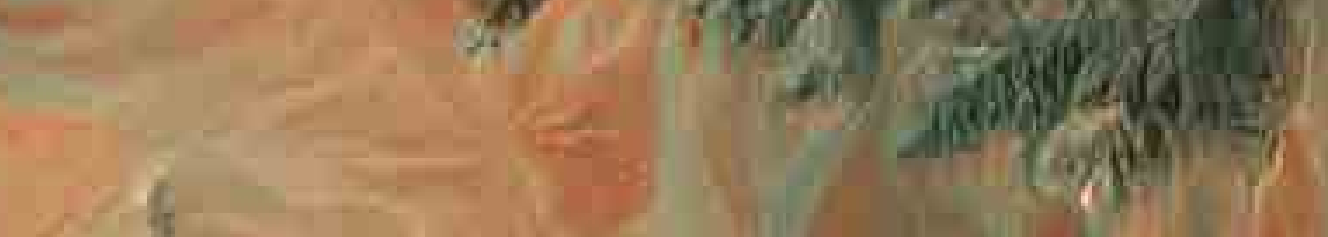

he

$\operatorname{tin} 2$
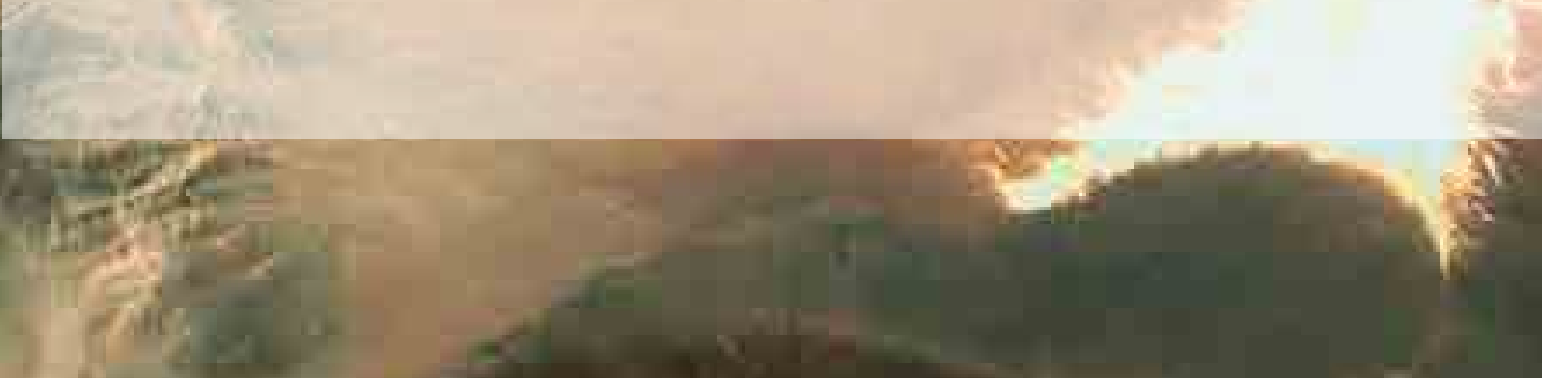

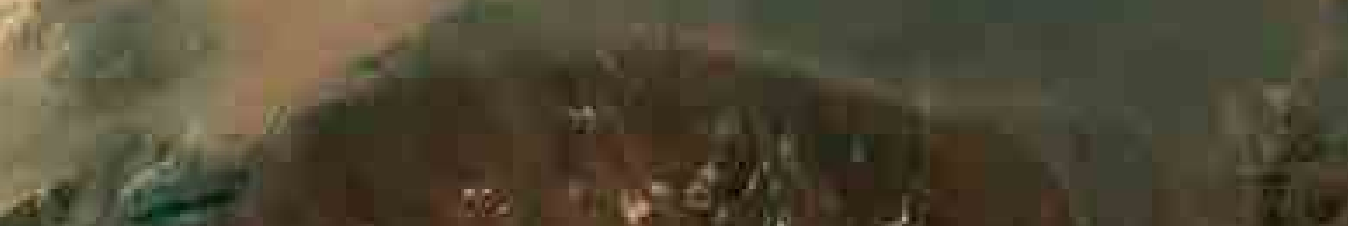

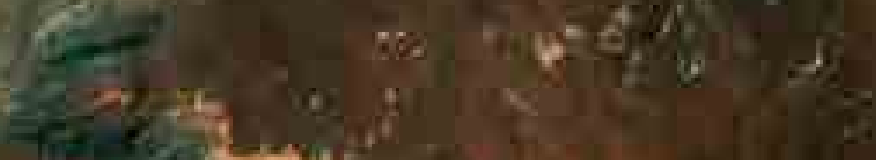
Pen

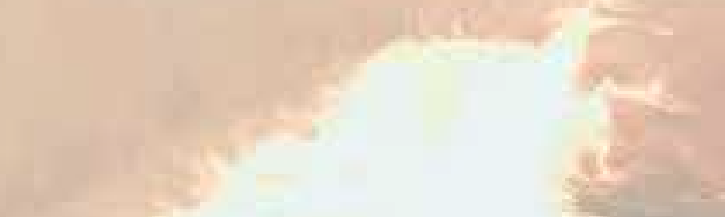




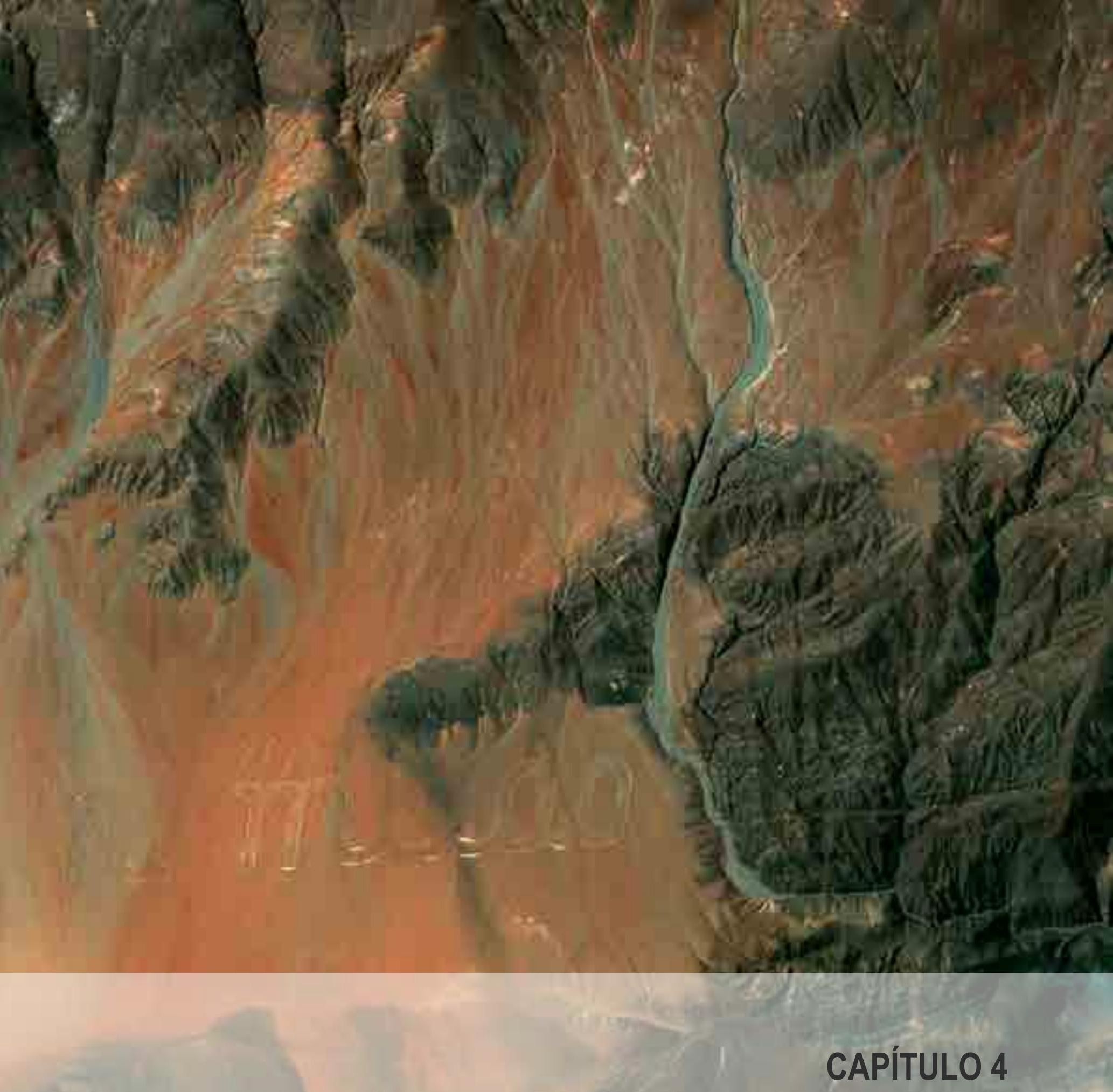

\section{LA TRANSFORMACION DEL PAISAJE}

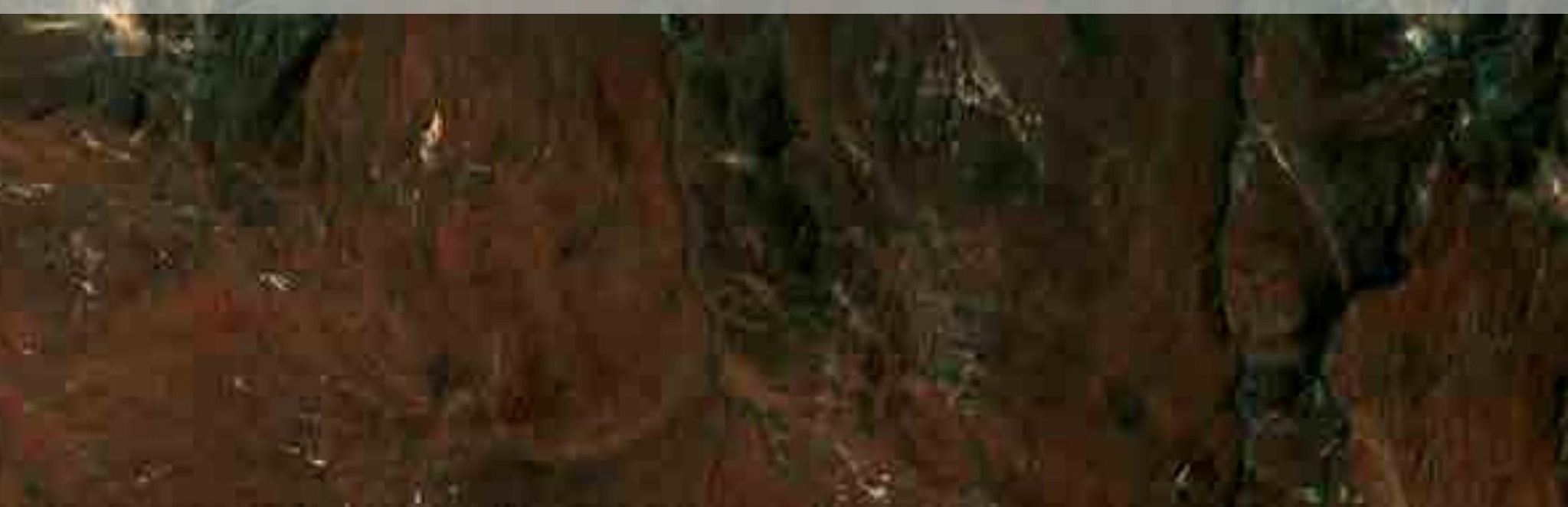




\section{LA TRANSFORMACION DEL PAISAJE}

Creating is a processing of ideas during the gesture of making

(Flusser, 2014, p. 42).

\section{1. INTRODUCIÓN}

En el capítulo anterior hemos estudiado como surge la noción de paisaje y se desarrolla como concepto a lo largo de la historia. Para ello, hemos tomando referentes desde la geografía, la filosofía, la literatura y las ciencias, todas ellas disciplinas que lo han estudiado y lo describen posiblemente mejor que nosotros los arquitectos. Sin embargo, hay un aspecto peculiar en la concepción de paisaje que tienen las disciplinas proyectuales: en nuestra comprensión del paisaje se anida la idea de transformación. A la visión puramente científica de conocimiento, se confronta otra, que busca conocer para transformar. La idea de transformación que ponemos en relieve, incluye la "protección, gestión y ordenación", tal como lo ha descrito el convenio de Florencia (2000).

Para ello, es necesario estudiar la relación que, en diferentes momentos históricos, han establecido los hombres y mujeres con el paisaje. Cómo la cultura ha dejado su huella en ellos, para desde allí poder entender nuestro presente y saber cómo actuar en él.

Este capítulo parte con un breve recorrido por la historia de la transformación, tomando algunos momentos que revelan un cambio, o bien ilustran un modo de actuar en el territorio con sentido paisajístico, intercalando en la "historia occidental" lo que sucede en América precolombina, cuestión prácticamente obviada en los textos sobre el tema.

Luego, se esbozan las primeras intervenciones del paisaje en Chile, caracterizadas por la importación de modelos europeos a este lejano territorio, y se analiza el surgimiento de una cultura arquitectónica-paisajística después de los años 1990 en el país.

A partir de este fenómeno reciente y sincrónico con el que se produce en Europa y Estados Unidos, se estudia la influencia del Landart en esta nueva sensibilidad hacia el paisaje. El arte de la tierra, para la autora, sería ese impulso que, desde el arte, contribuye al cambio de paradigma que observamos hoy: junto a la conciencia ecológica, el paisaje no es sólo la huella dejada por el hombre y la mujer en el territorio, sino también debemos considerar que el paisaje deja una marca, una capa, en la memoria individual y colectiva, que fija una representación de la propia identidad.

De este modo, no es posible estudiar el paisaje sin entender la cultura que le da forma, ni entender la cultura, sin analizar las intervenciones en el paisaje.

Finalmente, se propone una reflexión acerca de los métodos, vale decir los modos contemporáneos de abordar el proyecto-paisaje, ilustrados gruesamente por la escuela norteamericana y la escuela francesa de paisaje, la primera con un claro énfasis en el paisaje como sistema ecológico y la segunda, como bien cultural.

Buscamos de este modo, encontrar aquellas estrategias que nos permitan transformar y al mismo tiempo poner en valor el paisaje como bien patrimonial, sostenible en el tiempo. Una propuesta contemporánea que vea el paisaje como un sistema y también como bien cultural debieran considerar como plantea el geógrafo cubano José Rodríguez al menos tres niveles: el geo-sistema, el socio-sistema y el sistema cultural, vale decir el medioambiente y la ecología, los sistemas de poder y producción al interior de una sociedad y la identidad colectiva asociada a este paisaje (Rodríguez, 1998, citado por Ciseli, 2011, p. 13), como también las escalas de intervención, que revelan la relación humana con el infinito, su idea de la tierra y de su posición en ella.

De este modo, al hablar de transformación del paisaje no podemos esquivar la historia de la cultura, situándonos en un sentido amplio, en relación con los valores de un tiempo y un territorio determinado, para desentrañar cómo conceptos filosóficos y no sólo ideales de belleza se expresan a través de este arte, un arte que modifica y da forma a la naturaleza a distintas escalas.

Al señalar lugares específicos, se busca representar éstos como producto de 
actitudes humanas respecto al cosmos, la naturaleza y la humanidad misma, relacionándolos con expresiones de la arquitectura, las artes decorativas, la literatura y la filosofía, todos ellos medios de expresión ideológica que se imprimen en el territorio con un orden y significado intencionados y transcendentes para constituirse como paisaje.

Como veremos, las costumbres humanas en cada época y región geográfica se manifiestan en mitos, rituales, estructuras sociales y actividades productivas, gestos que modifican el espacio, y a su vez condicionan e institucionalizan patrones de comportamiento cultural.

Podemos observar también, como históricamente el paisaje y el poder se entrelazan. Las grandes intervenciones son mayoritariamente decisiones de los gobernantes y de las élites, a quienes han servido y bajo quienes se han formado los planificadores, ingenieros, arquitectos y paisajistas; mientras que las expresiones vernáculas con fines prácticos, concebidas a menor escala (como suma de gestos individuales, pero con impacto a mayor escala), cuando han podido perdurar, solo son reconocidas e interpretadas con posterioridad.

Así, a veces tenemos una brecha entre las ideas filosóficas de una época y su expresión en el territorio, en algunos casos anticipando una idea por venir, y en otros actuando como representación o imaginario de una utopía.

Estas ideas, ya sean concepciones filosóficas o creencias religiosas, sólo se configuran en el espacio a partir de condiciones políticas, económicas y tecnológicas particulares, así como en algunos momentos por circunstancias que permiten que la acción individual trascienda su época y su territorio (pienso en Olmsted, en Estados Unidos, Paxton en Inglaterra o Vicuña Mackenna en Chile). El talento de diseñadores sólo se puede expresar bajo ciertas condiciones de gobernanza, disponibilidad de recursos, tecnología y un concepto de mundo.

Elizabeth Barlow Rogers (2001) ilustra esta misma idea, poniendo como ejemplo el trabajo del gran paisajista francés André Le Nôtre del siglo XVII, que expresa tanto el régimen absolutista de Luis XIV, como la prosperidad de la economía francesa bajo la dirección del ministro de finanzas Jean-Baptiste Colbert, el desarrollo de los nuevos medios de construcción usados en los movimiento de tierras por el ingeniero militar Sébastien Le Prestre de Vauban y la aplicación del racionalismo cartesiano al arte del diseño paisajístico. Decir esto no disminuye nuestra estimación del genio de Le Nôtre, "simplemente proporciona las condiciones y parámetros de su originalidad” (Barlow Rogers, 2001, p. 20).

Si bien muchos paisajes han sido destruidos y olvidados, otros muestran una sorprendente capacidad de permanecer a través del tiempo. Esa dimensión temporal, lo inevitablemente alterado por el tiempo, hace que los paisajes puedan ser leídos como palimpsestos, como vestigio de la propia dinámica poderosa de la naturaleza y las cambiantes intenciones humanas a lo largo de la historia, donde "la superficie de la tierra en la que se registra la memoria de sus transformaciones, se convierte en el mapa y la crónica del lugar" (Marot, 2006, p. 126).

Para comprender los paisajes diseñados tanto como la actitud humana de protección hacia los paisajes naturales, debemos ir más allá de la historia, la política, la economía y la tecnología, incluyendo la cosmovisión de una época, ya que el paisaje, como nos recuerda Rogers, actuará como el "teatro del mito, del ritual, de la alegoría y de la razón" (Barlow Rogers, 2001, p. 25). Las páginas siguientes describen este flujo de ideas a través del tiempo y el espacio, en varios períodos y lugares donde podemos ver como distintas culturas han modelado su territorio. La creación de la que nos habla Flusser en la cita que inicia este capítulo, sería entonces, aquel proceso de ideas que surgen del gesto de transformación, ya que la creación en términos de paisaje, siempre es un acto de transformación.

\subsection{HACIENDO ALGO DE HISTORIA: EL MITO, EL RITUAL LA ALEGORÍA Y LARAZÓN}

Todas las civilizaciones han transformado su territorio siguiendo pautas que conjugan la dimensión natural, su medioambiente, con sus creencias religiosas y cultura. 
Sin embargo, siguiendo a Alain Roger (2007), para que exista un acto de paisaje, debemos encontrar una "doble operación de artealización", "in situ" e "in visu", la primera es directa sobre el objeto natural, la segunda, indirecta, por mediación de la mirada. (Roger, 2007, p. 21). Según este criterio, se han escogido ejemplos que dan cuenta de esta doble operación, como evidencia de una transformación consciente del paisaje, a veces aún sin que la palabra lo nombre.

\subsubsection{El paisaje arcaico.}

Podemos inferir a través de los vestigios prehistóricos, que el paisaje y la religión tuvieron una relación particularmente estrecha, los pueblos nómades deben haber percibido que el cosmos y la naturaleza estaban cargadas de fuerzas espirituales, las que a través del mito personificaron como dioses que gobernaban la caza, y más tarde la fertilidad del suelo y las cosechas. El errar primitivo, como plantea Francesco Careri (2014), sería el primer acto de "arquitectura del paisaje, entendiendo por 'paisaje' el acto de transformación simbólica, y no sólo física, del espacio antrópico" (Careri, 2014, p. 16). Para este autor, fue más bien el nomadismo y no la vida sedentaria "lo que dio vida a la arquitectura, al hacer emerger la necesidad de una construcción simbólica del paisaje" (Careri, 2014. p. 28), ya que una vez satisfechas las necesidades primarias, andar y su huella se transformaron en la primera acción estética que transformó el territorio y el caos circundante, instituyendo un orden, una orientación y una memoria para luego situar o reubicar los objetos en él.

Junto a los dioses, los muertos ocuparon un lugar privilegiado en los primeros paisajes, como nos recuerda Lewis Mumford:

El respeto del hombre primitivo ante los muertos, en sí mismo muestra de fascinación por sus vigorosas imágenes de la fantasía diurna y del sueño nocturno, desempeña tal vez un papel más importante que otras necesidades más prácticas a la hora de impulsarlo a buscar un lugar fijo de reunión y, más adelante, un asentamiento estable. En el penoso vagabundeo del hombre paleolítico, los muertos fueron los primeros que contaron con morada permanente: en una caverna, en un montículo señalado por unas cuantas piedras o bien en un túmulo colectivo. (Mumford, 2012 [1961], p. 14-15)

Así, conscientes del grado en que sus vidas estaban sujetas a las fuerzas de la naturaleza, las sociedades prehistóricas y antiguas desarrollaron ritos propiciatorios ante dioses y antepasados, para asegurar los beneficios estacionales, tales como la caza generosa, las lluvias adecuadas y el calor del sol, así como la continuación de la vida humana, a través de la reproducción exitosa. Los ritos funerarios fijaron lugares para la conmemoración -la memoria-y dieron una escala al lugar, aplacando el terror al infinito: el de la tierra y el de los cielos.
Figura 4.1. Cerros Pintados, Pampa del Tamarugal, Chile. Por Diego Delso, 11 de febrero, 2016.

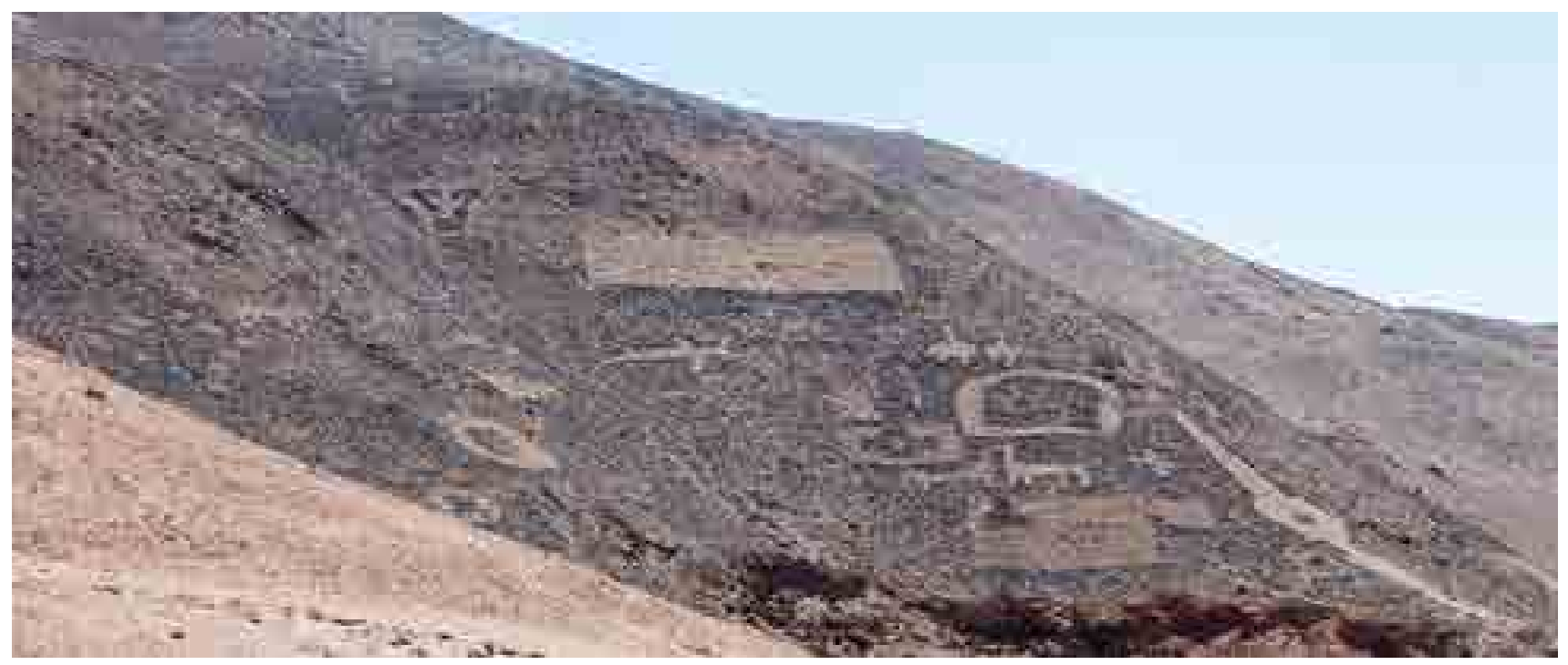


Figura 4.2. Mono con cola de espiral, Líneas de Nazca, Perú. Por Gtres, 1 de agosto, 2016

\footnotetext{
${ }^{130}$ El menhir o benben, significó para los egipcios "la piedra que surgió del caos" (Careri, 2014, p. 15).

${ }^{131}$ Monumento Histórico según Decreto N ${ }^{\circ}$ 5591 de 1969. En http://www.monumentos.cl/monumentos/monumentos-historicos/geoglifos-pintados

132 Patrimonio de la Humanidad Unesco, 1994. En http://whc.unesco.org/en/list/700/ documents/\%23ABevaluation
}

Figura 4.3. Rehue. En Mapuche [blog], 9 de agosto, 2017

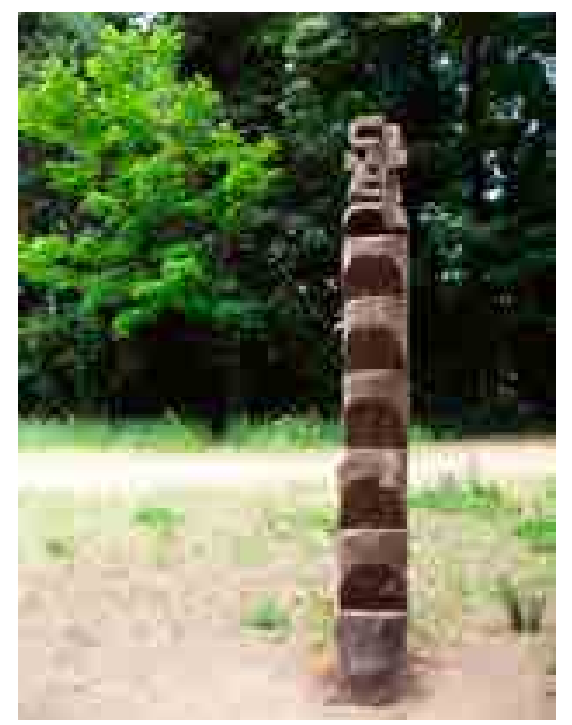

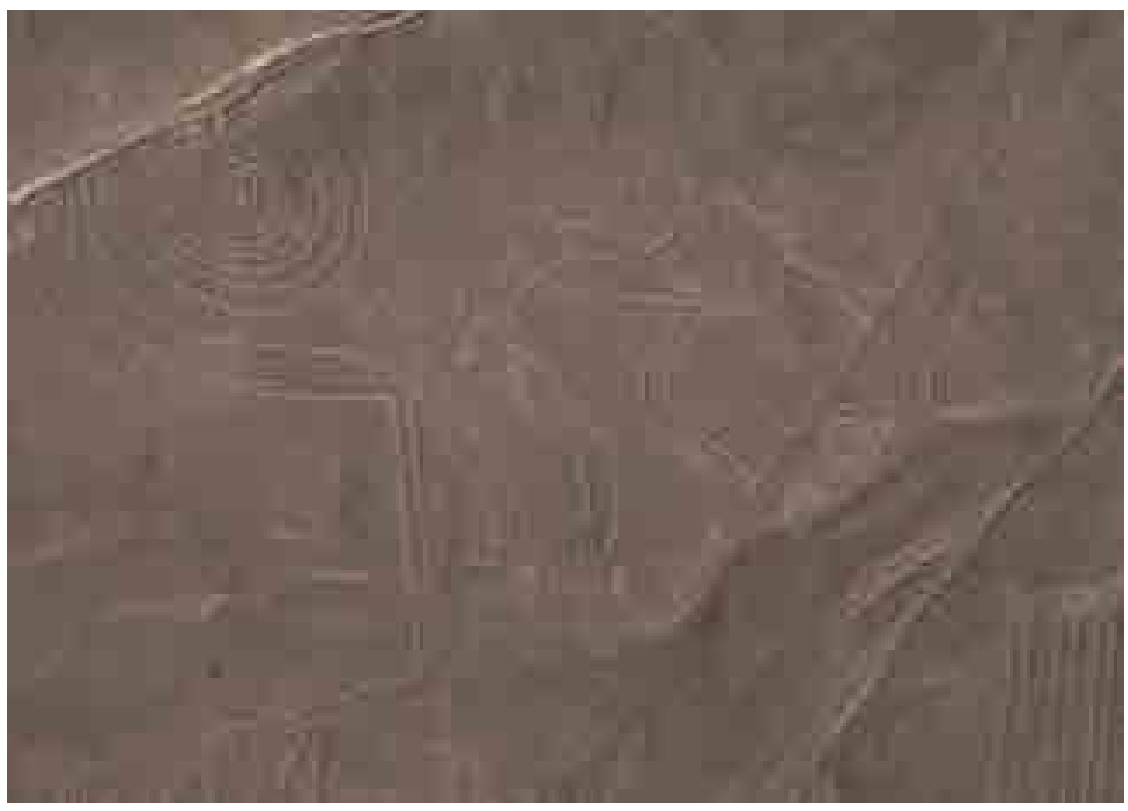

Estos espacios ceremoniales, actuaron como teatros para la expresión religiosa dentro de un paisaje más amplio. Los gestos rituales se expresaron materialmente en el arte rupestre, en el benben ${ }^{130}$ o menhir y en círculos megalíticos como el de Stonehenge. Todos ellos debieron relacionar ritos con los modelos cosmológicos, lo que puede deducirse de su alineación con los solsticios, situación similar a la encontrada en plataformas y pirámides en Egipto, India y América. En todas ellas existe también la doble artealización: in situ, como transformación material e in visu, como representación, ya que su presencia enfocaba una imagen, enmarcaba un paisaje, antes infinito. Esta alianza entre paisaje y fuerzas cósmicas reconoce una condición divina para lo humano y lo natural, cuestión que ha sido estudiada en los pueblos originarios del actual territorio chileno, que compartían en sus distintas religiones, características cósmicas, animistas, y chamánicas.

Los sitios sagrados - montañas, lagos y manantiales, fueron también bautizados. Los topónimos complementan así los signos visuales para comunicar y recordar el lugar donde se está, o aquel que se ha dejado atrás. Aparecen primero los geoglifos, luego vendrán el montículo, el zigurat, la pirámide, la kiva y el templo. En el territorio chileno se conservan aún innumerables geoglifos, especialmente en la zona norte. Entre ellos, los cerros Pintados ${ }^{131}$ (Figura 4.1), ubicados en la Pampa del Tamarugal a unos 1.035 metros sobre el nivel del mar, en las laderas de los cerros en una extensión de más de 3 kilómetros, donde se han identificado cerca de 450 figuras. Según el registro del Consejo de Monumentos Nacionales, fueron construidos entre los siglos VIII y XIV d.C., extrayendo material superficial, y representan figuras zoomórficas, geométricas y antropomórficas, que se supone servían como guía para las caravanas que recorrían pampas, valles, quebradas y zonas costeras, señalando flujos de agua y acompañando ritos en el camino (CMN, 2018). A una escala mayor, se encuentras las Líneas de Nazca ${ }^{132}$ en el desierto peruano (Figura 4.2), también con figuras antropomórficas, geométricas y zoomórficas, algunas de las cuales tienen casi 3 kilómetros, y cuyo significado tiene variadas interpretaciones: como camino sagrado (Mejía, 1940), rutas de peregrinaje (Silverman, 1990), marcas contables o calendarios astronómicos (Reiche, 1968). Son cerca de 800 figuras en una superficie de 800 $\mathrm{km}^{2}$, que sólo pueden ser vistas desde el cielo, lo que implica una operación de imaginación y necesariamente una representación previa (in visu) para organizar el trazado (in situ).

En Chile, junto a la pintura rupestre y los geoglifos, la cultura mapuche y rapa-nui desarrollan estatuaria monumental. En la cosmogonía mapuche, encontramos el Rewe (lugar cósmico en mapudungun), que materialmente es un tronco de unos 3-4 metros de altura, cuya extremidad superior tiene tallada una cabeza humana, y en el frente 7 peldaños. Este árbol cósmico representa el eje del mundo, donde se conectan el cielo y la tierra, recreando en sus peldaños las plataformas del 


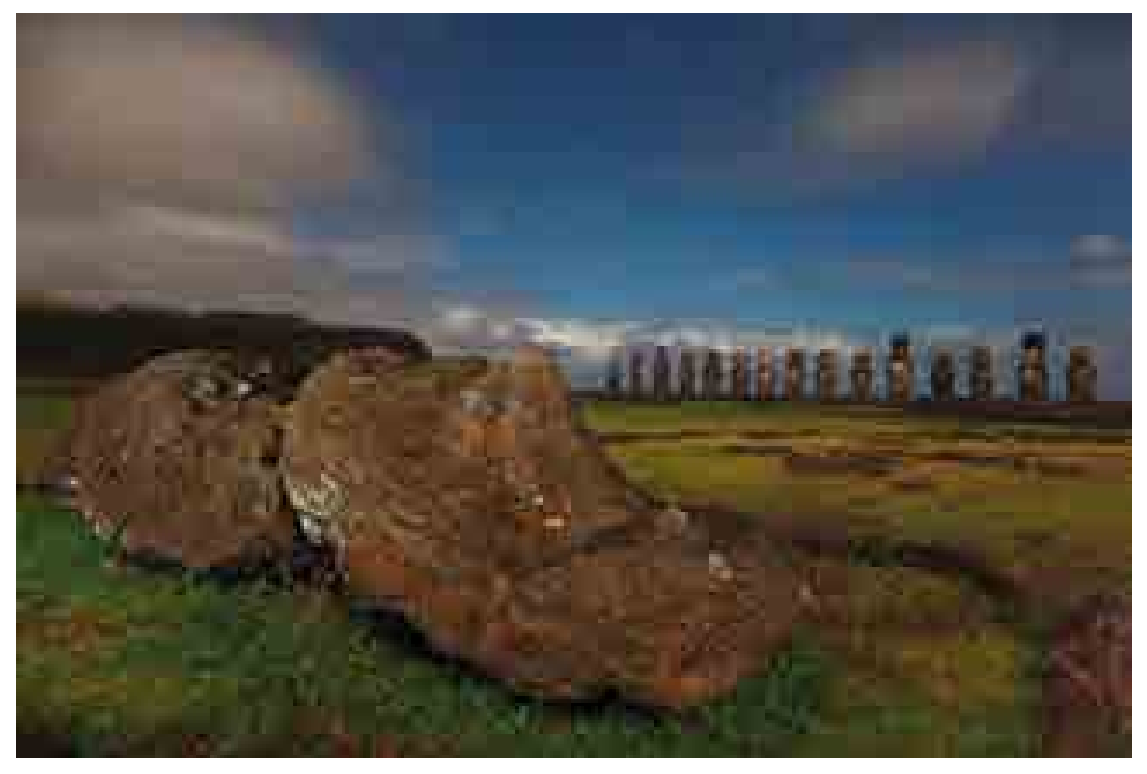

universo (Figura 4.3). La figura se yergue levemente inclinada al este, el lugar por donde sale el sol. (Moulian, 2009).

El Rewe configura un espacio, el Kemukemu, el lugar sagrado donde se encuentran los espíritus invocados, alrededor del cual se realizan los ritos en forma circular, en sentido levógiro.

En la zona cultural polinésica, los moáis (Figura 4.4.), las antiguas estatuas de piedra que erigieron los rapa-nui en la Isla de Pascua ${ }^{133}$ entre el año 1000 y 1.500 d.C., siguen siendo un misterio. Son más de 900 megalitos en distintas etapas de producción, que representaban a los ancestros que cada familia alzaba para la protección del clan. Las que están erguidas, se encuentran de espaldas al océano pacífico. Más allá de la proeza técnica de su construcción, traslado e izamiento, cabe preguntarse el por qué su repetición y su mirada fija sobre la isla. Jacob Bronowski en su libro El Ascenso del Hombre, interpreta esta disposición como símbolo de un fracaso, el de no poder salir de la isla, ya que esta cultura no conocía el movimiento de las estrellas. Al no ser visible la estrella polar, la navegación exigía un dominio de la astronomía que este pueblo no logró desarrollar (Bronowski, 1987, p. 192). Se representa así el terror al infinito y la contención de las estatuas del espacio interior de la isla.

\subsubsection{El paisaje clásico}

La transición desde las religiones que veneraban a los antepasados, al sol y la Madre tierra a un sistema de creencias donde el mito da paso a la filosofía, se refleja en un nuevo tipo de paisaje sagrado. Los antiguos templos griegos y su emplazamiento en el paisaje revelan como la lógica, la geometría y la matemática produjeron un cambio en el modo en el que este pueblo, entendió el vínculo humano con la naturaleza. Poco a poco desaparecieron los sacrificios de sangre,

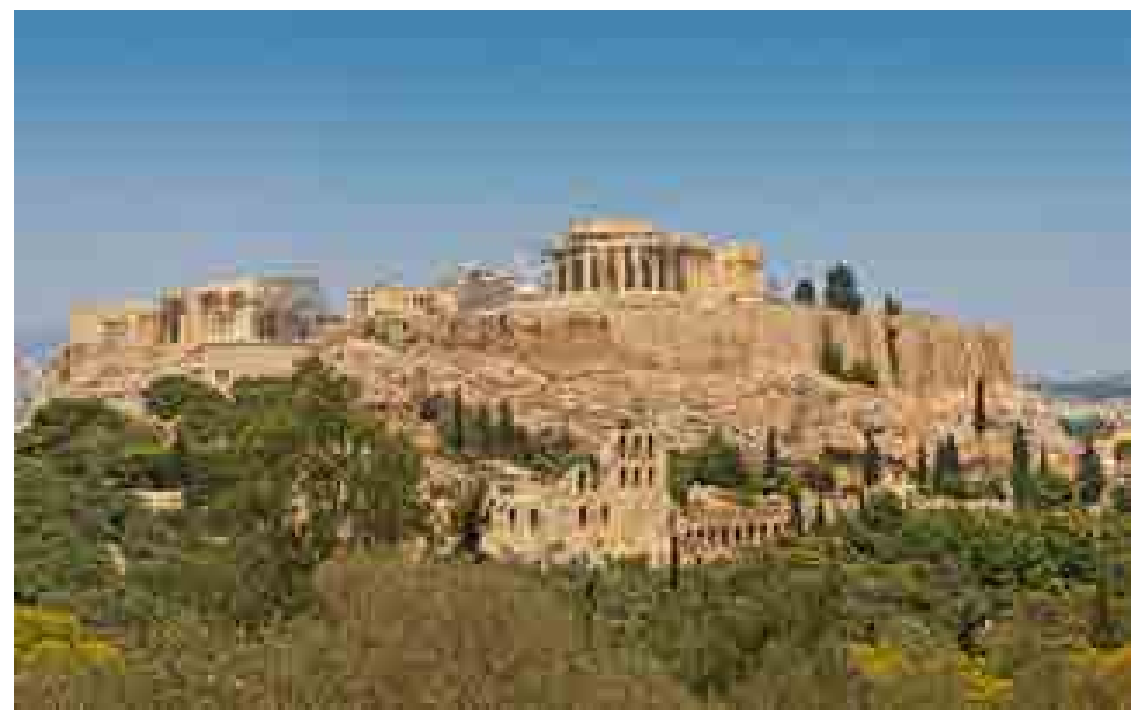

Figura 4.4. Moai, en segundo plano Ahu Tongariki. Isla de Pascua, Chile. Por Randy Olson, 21 de septiembre, 2018.
${ }^{133}$ Isla de Pascua es un territorio insular de Chile a $3.500 \mathrm{~km}$ de la costa y a $2.000 \mathrm{~km}$ de la isla más cercana.

Figura 4.5. Acrópolis de Atenas, Grecia. Vista desde monte Philopappos. Por a. Savin, 2 de julio, 2013. 
Figura 4.6. Acrópolis de Atenas, planta esquemática. Elaboración propia.

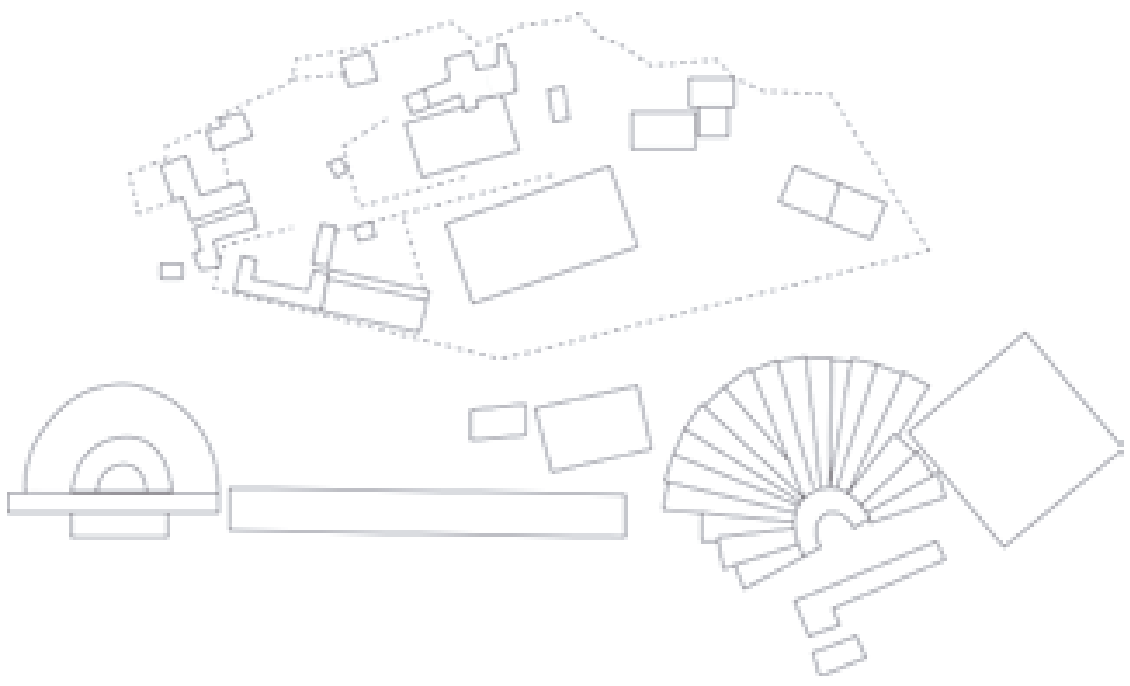

la consulta al oráculo y el baile ritual, estas prácticas fueron reemplazadas por otros medios para dar forma al destino a través del intelecto. Si bien el paisaje sigue siendo país, su transformación sugiere un nuevo sentido de confianza en la razón, más allá de los dioses del Olimpo.

La acrópolis de Atenas (Figura 4.5.), el sitio reconstruido después del ataque por los persas, se levanta desde el siglo $V$ a.C. a $91,5 \mathrm{~m}$ de la ciudad para "satisfacer a los dioses y honrar a la polis" (Roth, 1993, p. 222). Sus edificios de exquisitas proporciones, expresan el dominio de la geometría y de la escala, sin embargo, la disposición en planta del conjunto parece aleatoria (Figura 4.6.). Este contraste obedece a que está diseñado desde el recorrido, para ver los edificios en escorzo y en un juego con las distintas vistas del paisaje circundante, donde se destacan la montaña sagrada de Mileto y la Bahía de Salamina a través de los propileos. Para Ronald Harris (2011) "el templo que nace producto de idealizaciones matemáticas abstractas se concretiza cuando encuentra su lugar en la naturaleza; es en medio de ese paisaje que se hace acotable y adquiere las proporciones que lo singularizan" (Harris, 2011, p. 69). El mundo griego se aleja así del movimiento de las estrellas y se centrara en la tierra, encontrando su lugar en la naturaleza.

Un fenómeno análogo, pero anclado aún al movimiento de las estrellas, es el que se puede observar en Machu Picchu, (Figura 4.7.) donde la perfección del trabajo de la piedra emerge de la montaña en Los Andes peruanos, una proeza construida a $2.430 \mathrm{~m}$ sobre el nivel del mar, poco antes de la llegada de los españoles a América. Si bien la construcción en terrazas con fines productivos es una de las características más singulares, en la ciudadela, se encuentran varios elementos que indican que los incas transformaron conscientemente el paisaje

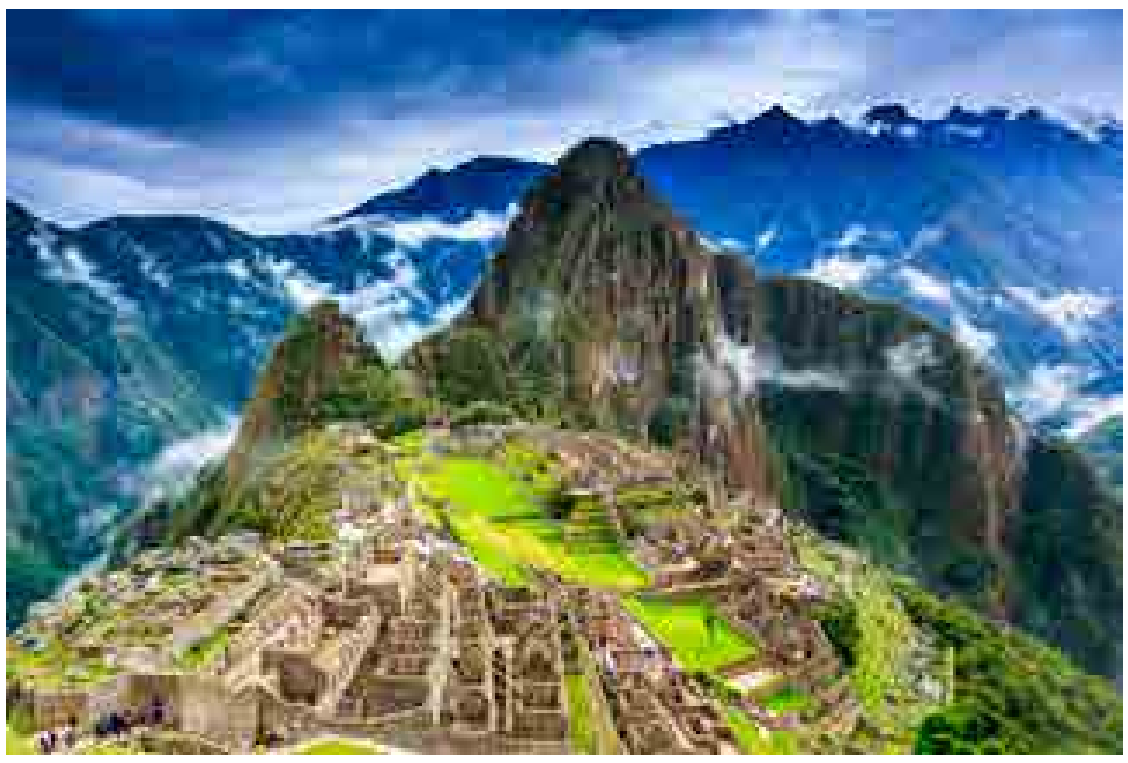




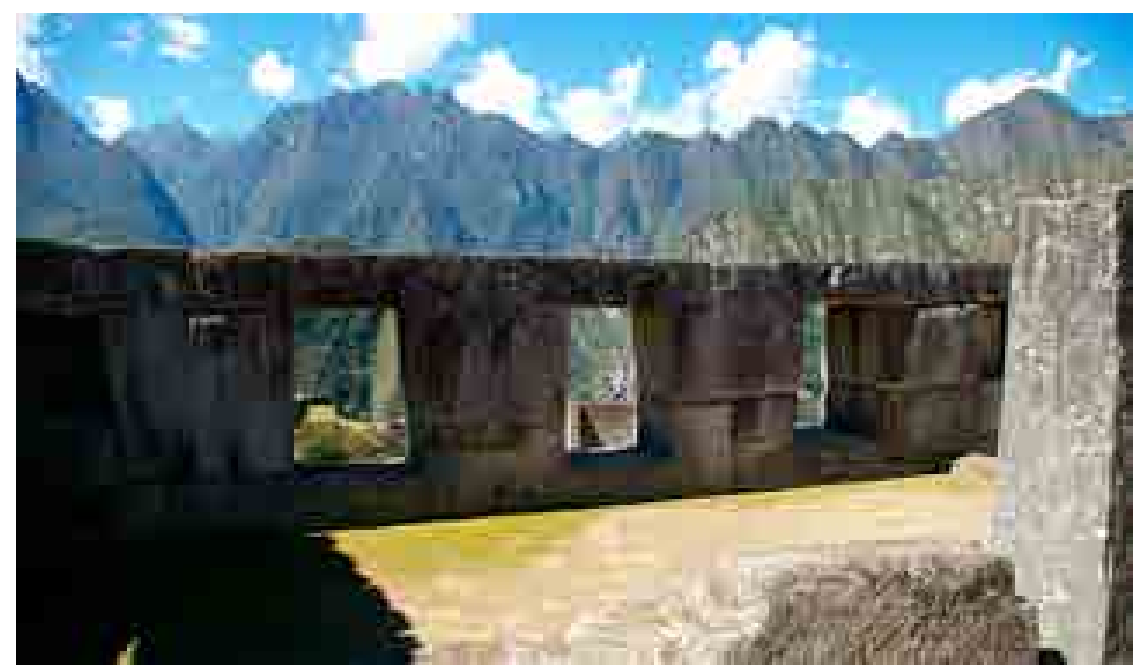

(aunque se desconoce si existía una palabra para nombrarlo). En la Figura 4.8 podemos observar el templo de las tres ventanas, cuyos vanos trapezoidales enmarcan los cerros circundantes y la Roca Sagrada, una pieza de granito tallada de $7 \mathrm{~m}$ de largo y $3 \mathrm{~m}$ de altura, con la cara hacia la plaza interior, plana, que imita el perfil de Apu Yanantin, la montaña que se encuentra justo al frente, tal como si fuera una gran maqueta (Figura 4.9.). El agua es otro elemento central en el diseño del conjunto. Según estudios de Wright \& Valencia (2009), la ciudad fue cuidadosamente planificada a partir de la disponibilidad de agua en las cumbres vecinas, desde donde se condujo recorriendo $750 \mathrm{~m}$ con una pendiente del $3 \%$ para abastecer una ciudad, que llegó a tener casi 1.000 habitantes, en un trayecto aun visible a través de los volúmenes de piedra. El terreno fue preparado para drenar ${ }^{134}$, con un sustrato de piedra fracturada, tanto para el sector agrícola como para el urbano, el que incluía un jardín botánico con una colección de diversas especies ornamentales, entre las que se destacaban la orquídea. Lo anterior es evidencia no solo de capacidad técnica sino también una disposición a la contemplación y cuidado de la naturaleza.

En el caso de la antigua Grecia, sin embargo, el desarrollo del jardín sin fines productivos parece ser tardío. Aparentemente, como sugiere Marie Luise Gothein (2014[1913-1928]) el sistema democrático, no favoreció la concentración de riqueza necesaria para la aparición de espacios de deleite, vale decir del lujo (2014, p. 40).

Pese a que existen pocas alusiones literarias al jardín, o a una naturaleza más domesticada, la expansión colonial y el contacto con otras culturas ${ }^{135}$ incorporó el diseño del paisaje a pequeña escala, adecuado a la accidentada topografía griega y la poca disponibilidad de agua. Plutarco relata que fue Cimón (510-450)

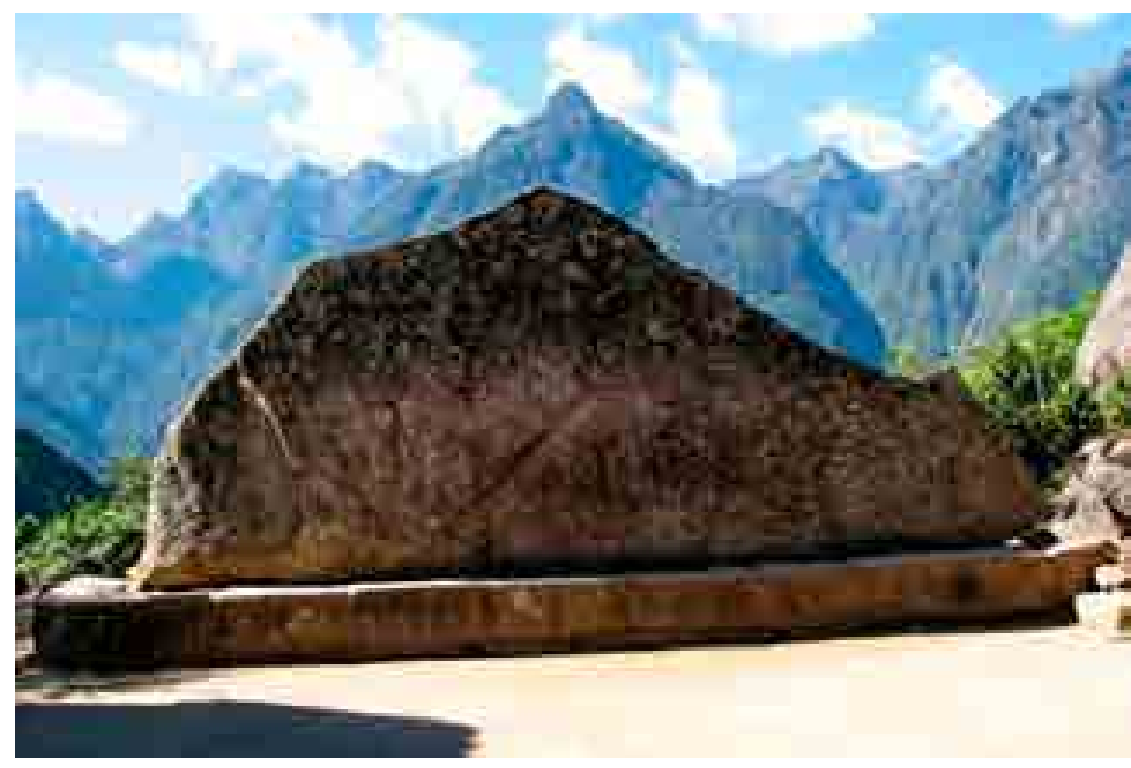

Figura 4.8. Templo Tres Ventanas, Machu Picchu, Perú. Machupicchu Travel (s.f.).
${ }^{134}$ Un aspecto muchas veces olvidado en el diseño contemporáneo.

135 Podemos suponer que la expansión colonial y contacto con otros pueblos permitió a los antiguos griegos conocer otras culturas en las que los jardines eran un bien preciado y habitual, como la egipcia y la mesopotámica. Cabe recordar que Alejando Magno llegó hasta Babilonia, donde aún existían sus famosos jardines.

Figura 4.9. Roca Sagrada. Machu Picchu, Perú. Por Luis Henríquez, 7 de septiembre 2016. 
${ }^{136}$ En griego peripatêín significa pasear.

${ }^{137}$ En esta época las polis griegas o ciudades estado, pierden su independencia y los lazos que vinculaban al hombre con su ciudad se debilitan.

Figura 4.10. Pintura mural de la Villa Livia, siglo I d.C. Por John-Roe Luna, 22 de octubre, 2017 quien dotó al Ágora y la ciudad de árboles. Sabemos Platón (427-347 aC) instaló su Academia filosófica, en las afueras de Atenas en un bosque sagrado (Platón, 1872 , p. 276), y que la escuela peripatética ${ }^{136}$ de Aristóteles (384-322 aC) toma su nombre de la costumbre del maestro y sus discípulos de pasear por los jardines que estaban próximos al templo de Apolo.

Junto con estas experiencias paisajísticas, en Las Leyes de Platón podemos encontrar los primeros vestigios de urbanismo del paisaje, cuando el filósofo define que los agrónomos garantizarán que el país esté bien limitado y fortificado, teniendo cuidado de que los "caminos sean suaves y cómodos" y que la lluvia en vez de causar daño, den fertilidad a la tierra. Indica que "junto a las aguas corrientes se levantarán calzadas plantadas con árboles" (Platón, 1872, p. 276). Su ciudad ideal, Magnesia, una entidad acotada de 5.040 habitantes ( $1 \times 2 \times 3 \times 4 \times 5 \times 6 \times 7)$ es expresión de la idea de lo finito, la matemática y la geometría serán un medio de control del intelecto sobre las cosas.

Más tardíamente, en el período helenístico, surge Epicuro (341-270 aC), que crea la Escuela del Jardín, a la que podían entrar hombres y mujeres, sin distinción de clases sociales. En una época ${ }^{137}$ de ruina, pobreza y desconcierto se desarrolla una ética y filosofía de la naturaleza que promovía los placeres moderados. Recluido en su jardín, Epicuro piensa que "el sabio ha de buscar placeres espirituales y gozar, moderadamente, de los que la naturaleza le proporciona" (Chazarra, 2017, s.p.). Estas ideas tienen una importante influencia en la cultura romana a través de autores como Plutarco, Diógenes Laercio, Séneca y Cicerón; son desacreditadas durante el medioevo; retomadas en el Renacimiento y estudiadas más recientemente por el mundo anglosajón. Podemos aventurar que la filosofía de Epicuro sería la bisagra que da paso al desarrollo del jardín de la villa romana, un sistema de casa y jardín, el oikia kai kepos con magníficos ejemplos, como el de la Villa Livia, sus vestigios se conservan en la pintura mural donde se observan los árboles poblados de pájaros (Figura 4.10).

Roma fue la metrópoli del mundo clásico y también el centro de un imperio constructor, que tiene su origen en el mito fundacional de la ciudad. La Lex, el latín y el ladrillo fueron los instrumentos civilizatorios, de los que surge una arquitectura "de este mundo" que no pretendía desentrañar los misterios del más allá, sino solucionar los problemas del presente.

El poder del imperio y la soberbia del César se irradiaron sobre el paisaje de la campiña con obras de infraestructura con un sentido práctico y más profano, lo que dotó a los territorios conquistados de vías, acueductos, puentes y una profusión de tipologías edilicias como baños, teatros, basílicas, templos y arenas.

Las nuevas ciudades fueron trazadas racionalmente según los planos de damero, donde se conjugaban las fuerzas centrífugas de sus ejes, con las centrípetas que concentraban sus energías en los grandes espacios cerrados. El peristilo es uno de esos vacíos, un jardín cuadrado o rectangular, rodeado por columnas que

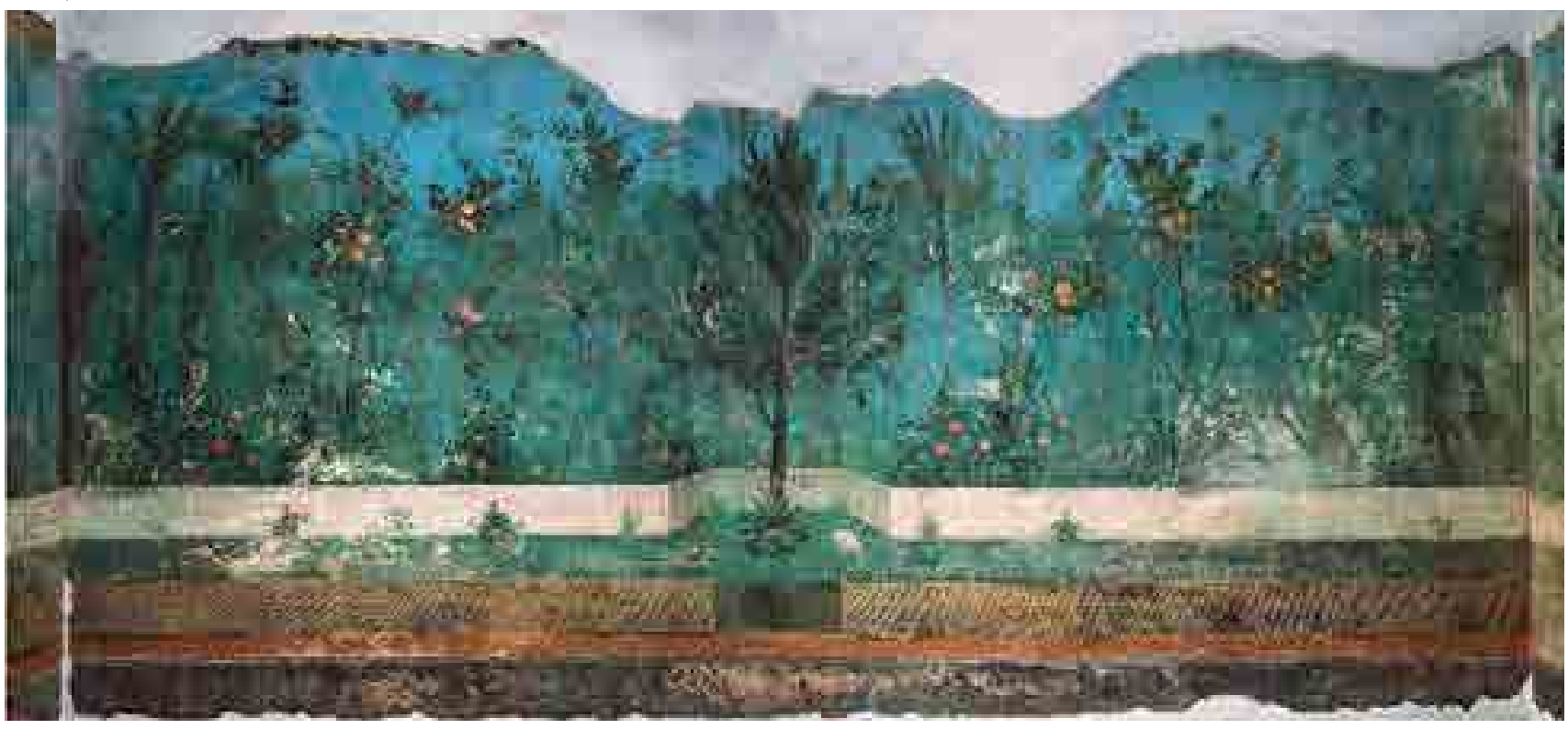


sustentan un pórtico al que se abren las habitaciones.

Serán estos elementos: la grilla, el campamento y la casa hermética abierta al patio interior, los que servirán de modelo siglos más tarde en la conquista y creación de ciudades en América.

El deseo de rus in urbe, de un poco de paisaje en la ciudad, surge en Roma, a partir de su crecimiento y densificación, también como un modo de recordar el origen campesino de los romanos. Tras el incendio del Foro, Trajano ordenó que la reconstrucción dejara libre un área de tierra e hizo plantar un olivo, una parra y una higuera (Kluckert, 2000, p. 16) lo que dio origen a la creación de más de 80 jardines, entre jardines domésticos y otros mayores.

El descubrimiento de las ruinas de Pompeya ha permitido conocer que los jardines romanos no solo estaban configurados arquitectónicamente y poblados de grupos florales, arbustos y árboles, sino también de fuentes, grupos escultóricos, pavimentos de mosaico y pinturas murales.

Fuera de la ciudad las grandes villas desplegaron complejos jardines anexos, donde los mitos y rituales se transmutaron como alegoría. En la Villa Adriana de Tivoli (118 dC) el Serapeion remite al culto egipcio a los dioses a través de una gruta artificial ${ }^{138}$, una fuente alargada y una cornisa, donde se yerguen estatuas griegas, mientras que del agua emerge un cocodrilo. En el parque se representan también, los distintos territorios que el emperador había recorrido y que comparecen en un vasto programa decorativo de escultura, pintura mural y mosaico, ofreciéndose como "ejemplo temprano del jardín asociativo o el tratamiento temático del paisaje en el que la alegoría juega un papel central" (Barlow Rogers, 2001, p. 10).

\subsubsection{El paisaje monoteísta}

Las principales religiones occidentales surgidas del monoteísmo, han modelado nuestra actitud frente a la naturaleza. Paradojalmente, como señala lan McHarg (1969) en su Libro Design with Nature, "la misma raíz semítica, el mismo contexto árido y hostil y la misma fuente bíblica, remitida al Génesis, produjo dos visiones muy distintas de la naturaleza del hombre" (McHarg, 1969, p. 76). El islam, interpretó que el hombre podía hacer el paraíso en la tierra, hacer florecer el desierto, que era el creador y el guardián: "Yavé tomó al hombre y lo puso en el jardín del edén para que lo cultivara y lo cuidara" (Génesis 2:15), los judíos y el luego el cristianismo interpretaron que estaban llamados a la dominación de la naturaleza: "Dios los bendijo diciéndoles: sean fecundos y multiplíquense. Llenen la tierra y sométanla" (Génesis 1:28). Ambas visiones se entrelazan en el jardín medieval evocando el paraíso perdido, desarrollando la relación simbólica del paisaje como recompensa celestial. Los cuatro cursos de agua de los jardines islámicos y las cuatro sendas del jardín cristiano, en ambos casos desde una fuente central, representaron los cuatro ríos de la Biblia y el Corán.

El agua es en el mundo islámico, es el elemento principal, un auténtico tesoro para los pueblos de la península arábiga, que el Corán recuerda "¿No ves cómo hace Alá bajar agua del cielo y la tierra verdea?" (Corán,2005, p. 147, sura 22, aleya 63).

El dominio de las técnicas de captación, conducción, drenaje y regadío desarrolladas durante la expansión del imperio musulmán, permitieron el aprovechamiento y el diseño a través del agua con efectos sobre la frescura del ambiente, la vista, el oído y el tacto. El reflejo sobre el agua es uno de los recursos empleados en combinación con la arquitectura, por ejemplo, en en Taj Mahal, cuyo estanque reproduce la mezquita y el cielo (Figura 4.11.).

Si bien el jardín islámico abarca territorios tan diversos, como lrak, la india 0 Andalucía en España, todos ellos tienen en común un muro como límite radical entre el interior y el exterior (ya sea el desierto más árido o la serranía) un plano de árboles altos, plantas ornamentales, yerbas aromáticas o medicinales a nivel medio y agua en un plano más bajo. Junto a la función estética, se encuentra el jardín-huerto con frutales y hortalizas. De este modo la experiencia del jardín activa los cinco sentidos y constriñe la escala a lo próximo.
${ }^{38}$ La gruta es un elemento recurrente en los jardines, que simboliza el encuentro entre el mundo de la diosa tierra y los espíritus de la naturaleza, en una cámara que actúa como eco psicológico. 


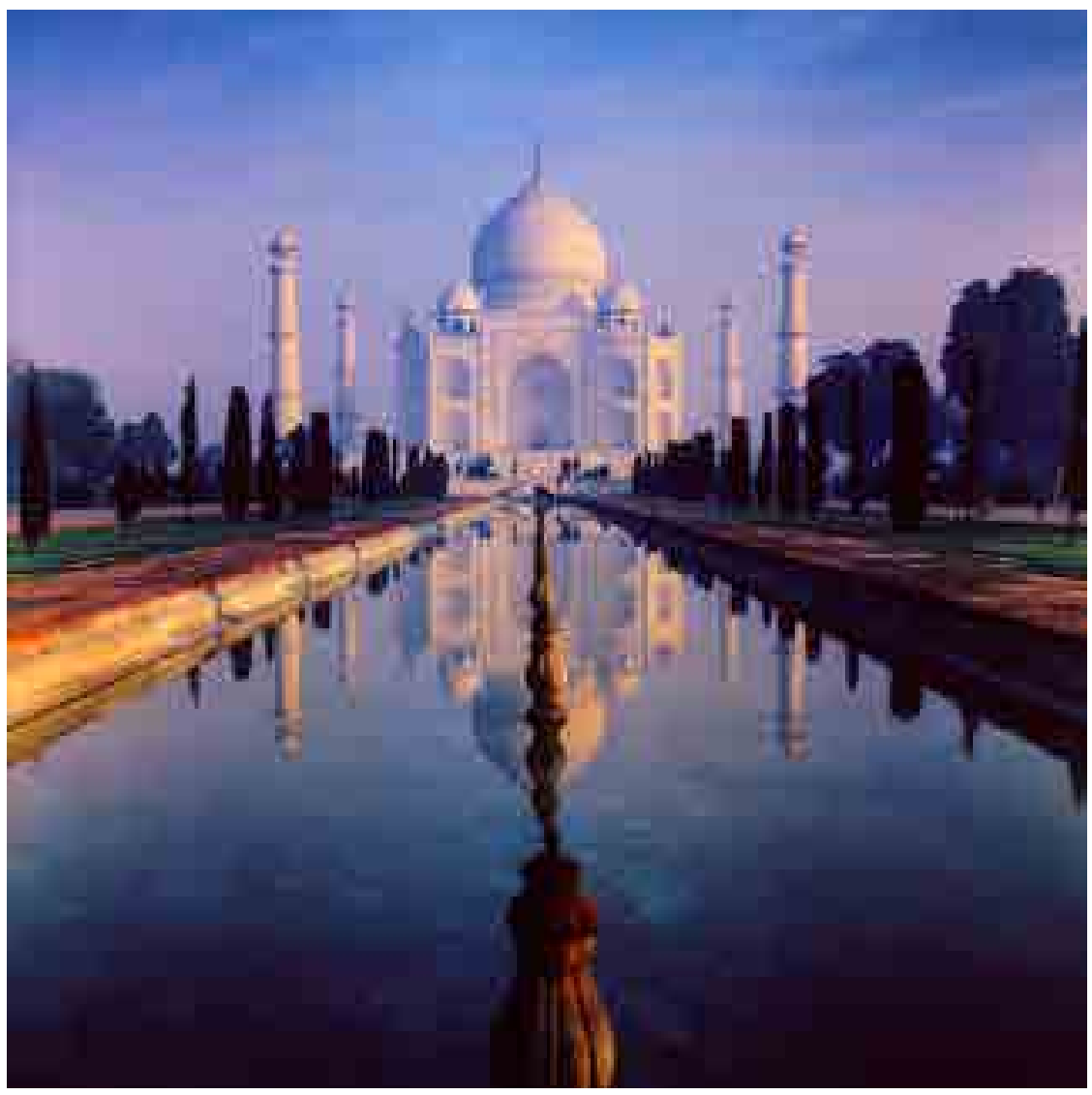

El árbol es otro de los elementos esenciales del diseño del paisaje, que aparece en distintas culturas, asociado a mitos y supersticiones: hogar de poderes sobrenaturales, pilar del cielo o centro del universo. Los Maya imaginaban un árbol en el centro del universo (Marion Singer, 2000, p.46), los mapuches consideran el Canelo (Drymis winteri) su árbol sagrado, símbolo la intersección entre el axis mundis y la tierra (mapu, en mapudungun). También posee propiedades medicinales y se usa para construir la base del kultrún, instrumento de percusión de carácter ceremonial.

Ya a finales de la Edad Media, el jardín se ha convertido en un tema literario, sin embargo, aún no aparece la palabra paisaje. Como hemos planteado en el Capítulo 3, Petrarca (1336/2011) cristalizaría una de las primeras nociones de este concepto, en el relato de su experiencia de ascenso al Monte Ventoso. También, que harán falta aún, las imágenes de los viajeros para que la idea de paisaje aparezca.

En el Renacimiento italiano la alegoría se recupera como operación para evocar los mitos de la antigüedad, revivirlos y reinterpretarlos. Desde el siglo XV los principios clásicos fueron revisados y sistematizados por los tratadistas, incorporando elementos que caracterizarán el paisajismo renacentista. Es el caso de Alberti (1404-1472), que en el libro noveno de De Re Aedificatoria (1991), habla del diseño de jardines en relación a las edificaciones privadas inspirado en las villas clásicas. Considera que el jardín debe estar al servicio de la salud y del placer individual. Recomienda algunas especies como "el ciprés, el alerce, el boj" (1991, p. 372) y la disposición de árboles con arreglo a la geometría: "las hileras de árboles se colocan en línea, a igual distancia entre sí y con los ángulos en correspondencia [en los ángulos rectos]" (1991, p. 381), como también las formas decorativas logradas a través de la poda de arbustos y otras hierbas. A partir de este recurso, Francesco Colonna (1499) incorporará la idea del laberinto como tipología en su detallado Hypnerotomachia Poliphili y Sebastiano Serlio (1551) el uso del parterre, dibujados en el libro cuarto de su Regole generali di architettura. Junto a la alegoría, el poder de los propietarios se imprimió en el paisaje toscano. Un claro y citado ejemplo es la Villa d'Este (i:1550). Esta obra de Pirro Ligorio fue encomendada por el cardenal Ippolito II d'Este, quien, tras su decepción por no asumir como papa, quiso superar en Tivoli la pompa de Roma, Ferrara y Fontainebleau y revivir la grandiosidad de la Villa Adriana. 


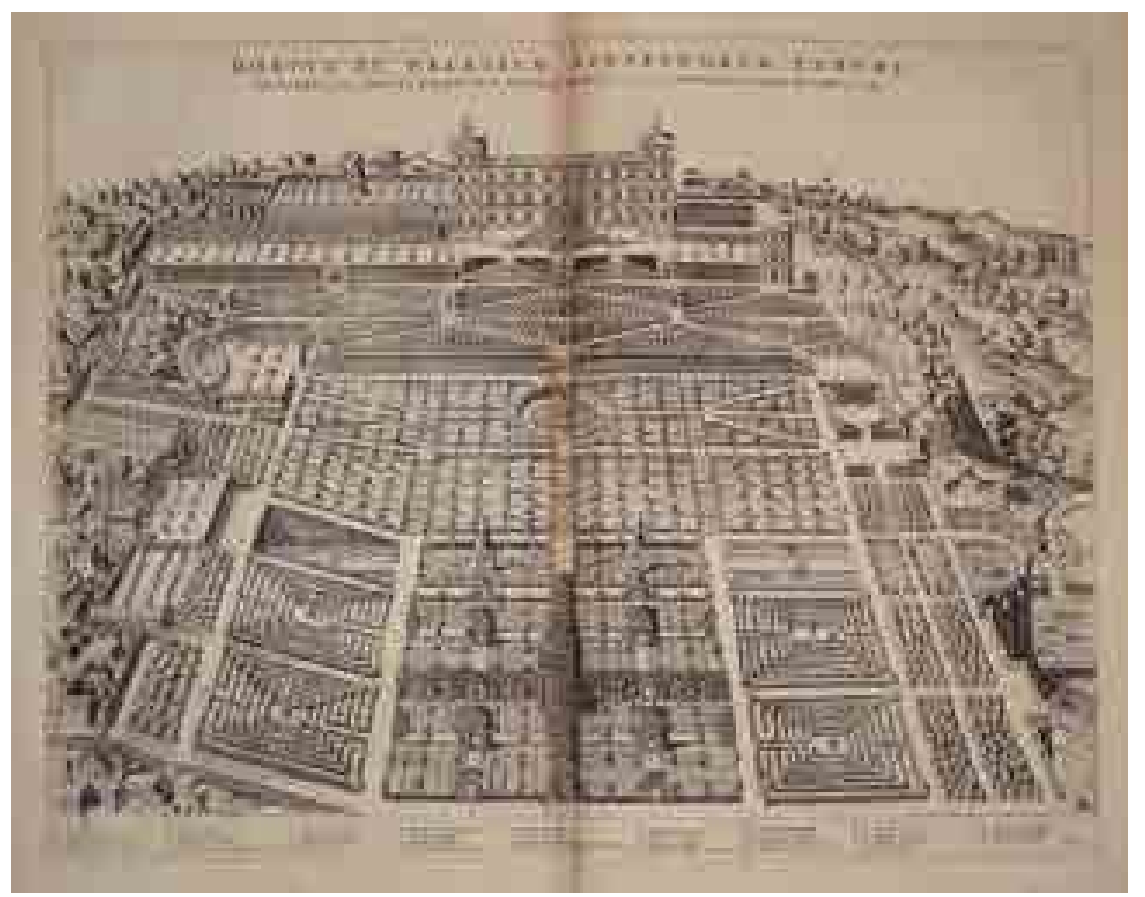

El jardín está estructurado en dos zonas (Figura 4.12.): una llana en la parte inferior y otra inclinada dispuesta en varias terrazas. Un eje axial, que parte de las terrazas del palacio, discurre por el centro de los jardines y unifica los distintos elementos. El trazado está estructurado visualmente desde abajo hacia arriba, ofreciendo múltiples vistas sobre la ladera del jardín, los caminos, las rampas, las puertas y por último sobre la fachada de la villa.

Así como en la Villa d'Este, en la Villa Lante, el parque del Cardenal Gambara, se encuentran símbolos que celebran la capacidad de cada propietario para transformar la tierra a través de una combinación de arte y naturaleza. El uso de la alegoría para glorificar a los papas y príncipes también puede ser reconocido en muchos jardines de los siglos XVII y XVIII, como en Versalles, donde la presencia recurrente de Apolo, el dios sol, alude a Luis XIV, al rey sol.

Junto al uso tardío de la alegoría que hace el Barroco, surge un nuevo desafío, que Leonardo Benevolo llama el "desafío de la realidad" que consiste en "ampliar concretamente, de un modo visualmente perceptible, los límites posibles de la perspectiva" (Benevolo, 1994, p. 83), consistente con la ampliación de los límites del conocimiento que acompañan el nacimiento de la ciencia sistemática y el uso de la razón en todos los planos de la vida.

El paisaje como palabra surge en medio de este cambio, expresando también el paso entre la imagen de un universo cerrado, finito y centrado en la tierra a

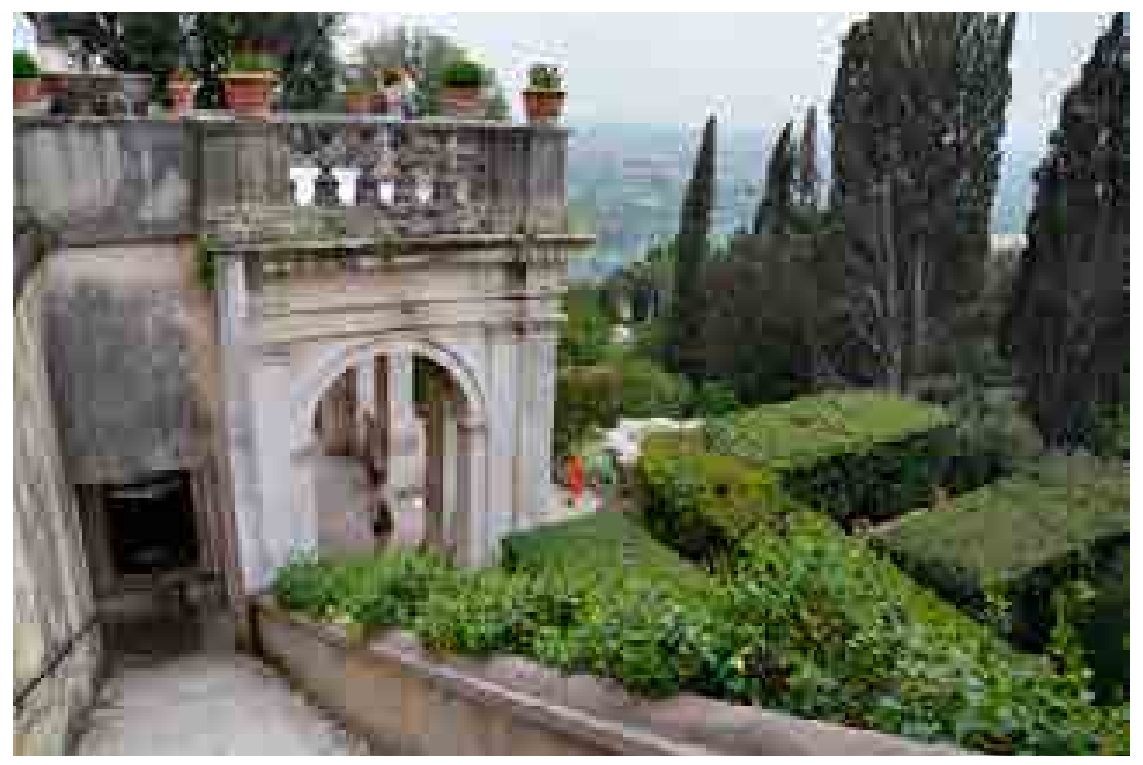

Figura 4.12b. Vista del jardín desde la Villa d'Este. Por la autora.
Figura 4.12a. Vista a vuelo de pájaro de la Villa d'Este, Tivoli, Italia. Por J. Blaeu 1704. 
uno ilimitado, que deja de temer a lo infinito. Si hasta ese momento el jardín se había caracterizado como tercera naturaleza, en contraposición con la segunda naturaleza del paisaje agrario y la tercera del desierto o "naturaleza salvaje", el concepto de paisaje permitió abrir el espacio y concebir diseños que consideraran el horizonte real.

El proyecto de Le Nôtre para los jardines del Rey Sol en Versalles, representa entonces esta apertura a una nueva interpretación del universo, influenciada por el racionalismo de Descartes y las ideas de Newton, materializadas en el control racional y geométrico del diseño. También representa el poder absoluto de Luis XIV, que busca mostrar "la confianza, el optimismo y orgullo de Francia" (Barlow Rogers, 2001, p. 173).

La extensión del plano horizontal y el uso de ejes ordenadores, tuvo fuertes repercusiones en la ciudad, convirtiéndose en un modelo para la planificación, que tuvo difusión internacional y aplicación, tanto en ciudades nuevas como aquellas que emprendieron procesos de modernización. Como en Versalles, los nuevos planes consideraron amplias avenidas que partían desde un punto central vacío o edificio singular, para extenderse en algunos casos hasta más allá de la zona urbana. Los nuevos trazados se impusieron sobre la ciudad existente desde el siglo XVIII hasta inicios del siglo XX impulsados por el poder y autoridad de los gobiernos que implementaron planes de renovación abriendo grandes avenidas, acompañada del desarrollo de una fastuosa arquitectura y escultura. La transformación tuvo implicancias políticas, ya que las grandes calles facilitaron el control policial (hoy diríamos la seguridad ciudadana), pero también la acción militar frente a las masas rebeldes. Estas calles permitieron además el paseo, que se convirtió en un pasatiempo habitual de las élites, que podían circular en los nuevos carros ligeros.

Con el nacimiento del estado-nación moderno, primero en Francia, la ciudad fortificada quedó obsoleta, se derribaron así los muros de la ciudad antigua, dando paso al surgimiento de extensos bulevares perimetrales.

Si bien podemos reconocer que detrás de esta conquista conceptual y perceptual del infinito están la filosofía de Newton (1643-1727) y Leibnitz (1646-1716), el absolutismo y la noción judeo-cristiana de dominio de la naturaleza, también es cierto que las condiciones geográficas de Europa central, especialmente de Francia, fueron especialmente propicias, ya que, en su territorio, más bien plano, efectivamente la mirada puede perderse en el infinito, o recuperarse, si pensamos desde la ciudad.

\subsubsection{El diseño ilustrado.}

La consolidación del pensamiento ilustrado, supuso una crítica al antiguo régimen y una concepción liberal y tolerante en todos los órdenes, que tiene su correlato en el diseño del paisaje del siglo XVIII que es donde mejor se plasma una de las características de esta época, la concepción utópica de la realidad.

En el mismo territorio (Inglaterra) y prácticamente en la misma época, mientras Newton establecía las bases de la mecánica clásica y el cálculo infinitesimal, John Locke (1632-1704) afirmó que el fundamento de todo conocimiento que pretende desentrañar las leyes de la naturaleza, "se debe a lo que percibimos" que se extraen de "la materia, del movimiento y de la estructura del mundo visible y de su organización..." (Locke, 1664/1986, p. 33).

Siguiendo una evolución similar a la de Epicuro, concibió la mente como un instrumento inductivo, donde la experiencia personal y sensible son fuentes de conocimiento. La verdad revelada y las leyes inmutables dejan paso a una concepción naturalista y experiencial de la realidad. Podemos afirmar que el empirismo filosófico estaría en la base de una nueva sensibilidad frente a la naturaleza que los diseñadores de jardines materializaron en nuevos paisajes, capaces de producir sensaciones mentales a través de asociaciones poéticas y pictóricas, evocando el pasado a través de motivos pastorales y bucólicos. Los parques y jardines dejaron de ser diseñados para ostentar el poder o como lugar para grandes fiestas, privilegiando la creación de ambientes diseñados "como naturales" para la reflexión y la contemplación. Para el pensamiento ilustrado, el arte de pasear, como 
recreación de un mundo idílico, se complementa con el conocimiento científico de la botánica que a partir del siglo XVII se desarrolla y difunde ampliamente ${ }^{139}$, así como los libros que relatan las expediciones de Humboldt a América, y el Diario que Darwin escribió a bordo del Beagle entre los años 1831 y 1836.

\subsubsection{La literatura y la pintura como impulso al diseño pintoresco}

El surgimiento del paisajísmo inglés sólo puede comprenderse si consideramos el debate teórico sobre la belleza, el gusto y la valoración de la naturaleza en la literatura. Autores como Alexander Pope, Edmund Burke, William Gilpin, Uvedale Price y Richard Payne Knight, inspiraron importantes operaciones paisajísticas en los grandes predios que poseía la aristocracia inglesa, con ejemplos tempranos como Castle Howard (Figura 4.13.), de John Vanbrugh (Yorkshire, 1712), donde el diseño va más allá de la jardinería enlazando naturaleza y artificio. Jardinería y pensamiento se asocian, como en el poema de Richard Payne Knight, The Landscape (1794), donde la observación estética y cultural del paisaje se mezclan con objetivos moralizantes y recomendaciones prácticas sobre el cultivo de especies.

En su tratado A Philosophical Enquiry into the Origin of Our Ideas of the Sublime and Beautiful (1757), Edmund Burke se aventura a trazar la diferencia entre lo bello, que define como aquello que nos da placer y reafirma nuestra existencia, y lo sublime, como aquello que nos tensiona para enfrentarnos con el límite de nuestra existencia, especialmente, las fuerzas de la naturaleza. Por su parte, William Gilpin, en sus Observations on the River Wye and several parts of South Wales, \&c.: relative chiefly to Picturesque Beauty; made in the summer of the year 1770 (1789) establece las reglas para el género pintoresco, donde la variedad, la aversión a la línea recta, el uso de texturas, son algunas de las reglas que el artista debe seguir para imitar la imperfección de la naturaleza. Inspirado en el poema The Landscape, Gilpin establece que lo pintoresco se encuentra en un punto intermedio entre lo bello y lo sublime, consciente de que la jardinería no es capaz de reproducir las fuerzas de lo sublime. Según la definición de Price, autor de Essay on the Picturesque, As Compared with the Sublime and The Beautful (1794), la jardinería pintoresca toma lo existente del lugar y lo moldea, por lo que se muestra especialmente crítico de las grandes intervenciones a tabula rasa de Lancelot "Capability" Brown y Humphry Repton. La literatura es parte de un proceso que a fines de siglo ya ha producido los principales referentes del estilo pintoresco: Stowe Park (1731-50) entre Kent y Brown; Prior Park (Bath, 1734-64) en un trabajo conjunto entre Brown y el poeta romántico Alexander Pope; los jardines del palacio Blenheim (Oxfordshire,1764) y Sheffield Park (East Sussex, 1789).

Pese a las polémicas y críticas que se dan al interior de este movimiento, lo pintoresco se yergue con éxito. En su aceptación concurren la búsqueda de una

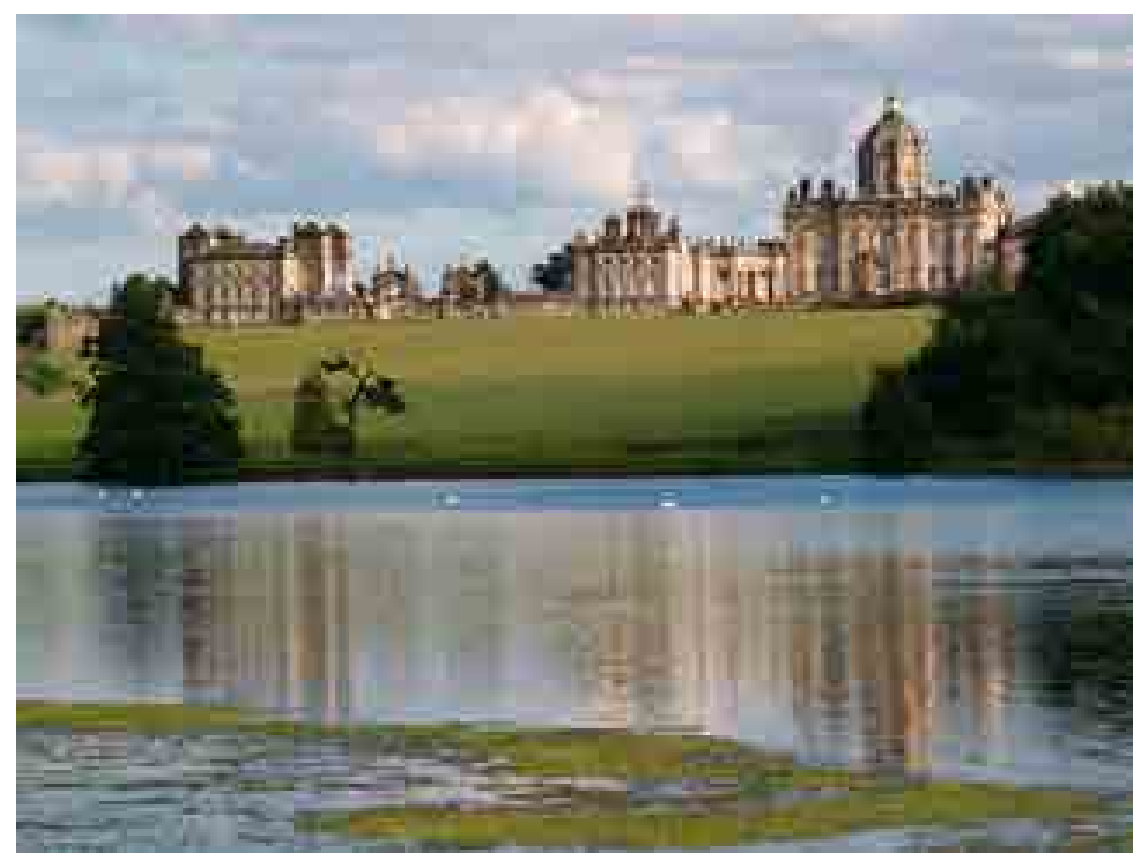

Figura 4.13. Castle Howard. Yorkshire, Inglaterra. Por John Nicholson, 29 de julio, 2007 
estética alternativa a la belleza clásica, a la simetría y a la idea de proporciones ideales, junto a razones políticas. La crítica a la "academia" será también una reacción contra el racionalismo francés desde los ideales románticos.

La subjetividad encuentra en la jardinería un campo de expresión para la burguesía emergente. El pintoresco será conocido como "jardín inglés" fuera de la isla -híbrido de naturaleza y artificio-, que consumará las tensiones que cruzan la filosofía moderna y el naciente concepto de espacio.

El conflictivo ethos del jardín pintoresco, es resuelto a través del concepto de scenery o puesta en escena. Se trata de superar la dicotomía entre naturaleza y artificio, al plantear que el paisajista sólo traza las grandes líneas para que lo natural destelle. En ese sentido, la jardinería no determina la forma, sino la naturaleza. Si bien esto reconcilia el espacio objetivo del jardín (artificio) con la experiencia estética subjetiva, hace aparecer otro conflicto: si el pensamiento romántico cree en la figura del genio, ¿de qué genio estamos hablando? ¿del genio humano 0 del genio de la naturaleza?

Alexander Pope, en una carta fechada en 1731, resuelve el conflicto con la figura del jardinero, que ha de invocar al genio del lugar (genius loci).

Consulta el genio del lugar en todo: le dice a las aguas si subir o caer; 0 ayuda a la ambiciosa colina escalar el cielo, o excavar el valle en anfiteatros circulares; llama al campo, captura abiertas llanuras, junta bosques dispuestos y varía sombras de sombras; ahora quiebra ahora dirige las directrices; pinta mientras tú plantas y mientras trabajas, dibuja ${ }^{140}$ (Pope, 1731, p. 7).

De este modo se define el carácter del genio romántico que actúa sobre el paisaje: debe ser especialmente modesto y ceder la palabra a la naturaleza.

En este espíritu de respeto encuentra también su inspiración en la literatura sobre el lejano oriente. Ya en 1685, el diplomático y escritor inglés Sir William Temple publicó el ensayo Upon the gardens of Epicurus, with other XVIIth century garden essays, que confrontaba las teorías europeas de jardines simétricos con las composiciones asimétricas de los jardines de China, introduciendo el término sharawadgi ${ }^{141}$ (Temple, 1908 [1685], p. 54). Pese a que no había estado en oriente, sus descripciones recogían las impresiones de viajeros y comerciantes que habían estado allí. En el ensayo señaló que en los jardines chinos se evitaban las hileras de árboles y los macizos de flores, y en cambio componían árboles, plantas y otros elementos de manera irregular para crear escenas hermosas de carácter naturalista (Temple, 1908 [1685], p. 53). Sus impresiones fueron luego citadas por el ensayista Joseph Addison en 1712, como fundamento de su crítica a los jardineros ingleses, que, en vez de imitar a la naturaleza, imitaban los jar-

140 Traducción propia del inglés:

Consult the Genius of the Place in all,

That tells the Water or the rife, or fall,

Or scoops in circling Theatres the Vale,

Calls in the Country, catches opening Glades,

Joins willing Woods, and varies Shades from Shades,

Now breaks, or now directs, th' intending Linea;

Paints as you plant, and as you work, Designs

${ }^{141}$ Sharawadgi o sharawaggi es un estilo de jardinería paisajística o arquitectura en el que se evitan las líneas rígidas y la simetría para dar a la escena un aspecto orgánico y naturalista.

142 En Chile, el año 1962 se construye el primer jardín chino dentro del ese entonces Parque Cousiño, hoy Parque O'Higgins. dines franceses.

La novedad y el exotismo del arte, especialmente la pintura y la arquitectura china condujeron en 1738 a la construcción de la primera Casa China en un jardín inglés, el jardín de la Villa Stowe. El estilo se hizo más popular gracias a William Chambers (1723-1796), que sí vivió en China por algunos años y publicó $A$ dissertation on oriental gardening (1772).

En 1761 construyó una pagoda china, una casa y un jardín en Kew, Londres, como parte de Kew Gardens, un parque con jardines y arquitectura que representa todas las partes del mundo y todos los estilos arquitectónicos. A partir de entonces, las pagodas chinas comenzaron a aparecer en otros jardines ingleses, luego en Francia y en otras partes del mundo ${ }^{142}$.

A finales del siglo XVIII, el pensamiento de Jean-Jacques Rousseau tuvo consecuencias importantes para el diseño del paisaje al radicalizar el naturalismo y otorgar un valor moral y podríamos decir educativo, a la experiencia personal de la naturaleza. En Emilio o la Educación, un texto de 1762, este autor confronta la naturaleza y el mundo técnico: 
Todo es perfecto cuando sale de las manos de Dios, pero todo degenera en las manos del hombre. Obliga a una tierra a que dé lo que debe producir otra, a que un árbol dé un fruto distinto; mezcla y confunde los climas, los elementos y las estaciones, mutila su perro, su caballo y su esclavo; lo turba y desfigura todo; ama la deformidad, lo monstruoso; no quiere nada tal como ha salido de la naturaleza, ni al mismo hombre, a quien doma a su capricho, como a los árboles de su huerto. (Rousseau, 1762/2019, p. 19)

En su novela Julie ou la Nouvelle Hélö̈se (1761), imaginó un paisaje perfecto, donde las personas podían ser fieles a sí mismas. Este jardín imaginario se convirtió en un modelo para los jardines paisajísticos franceses e ingleses, logrando transferir lo que hasta ese momento podría considerarse parte de un movimiento literario o pictórico a lo político, promoviendo un tipo de sociedad que respetara la subjetividad: "Observad la naturaleza y seguid el camino trazado por ella" (Rousseau, 1762/2019, p. 33).

Lo personal, lo político y lo patriótico integran al paisaje la función de honrar a los héroes y dar reposo a los muertos. El carácter melancólico y afectivo de este estilo hizo que se transformara en el lenguaje de diseño adoptado por los cementerios del siglo XIX. La popularidad de la filosofía de Rousseau acompañó la formación de los movimientos revolucionarios de emancipación en una época turbulenta de grandes cambios sociales y políticos. Podemos encontrar aquí los orígenes del movimiento de parques públicos, un tema que desarrollaremos en el próximo capítulo.

Junto a las fuerzas revolucionarias que desembocaron en la creación de los estados-nación, la Revolución industrial introdujo una dinámica cultural que puso a la ciencia y la tecnología como saberes privilegiados. Las democracias capitalistas desarrolladas en los últimos doscientos años han reforzado también la consciencia en los derechos individuales y de la propiedad privada, que, como plantea Rogers "ha promovido el placer personal como un poderoso principio en el campo del diseño paisajístico [...y], han provocado la continua transformación del jardín de recreo, antes dominio exclusivo de la aristocracia, en una reserva recreativa para las masas" (Barlow Rogers, 2001, p. 25).

\subsubsection{El triángulo higiénico técnico y estético}

El desarrollo de los medios de transporte introdujo una nueva movilidad al interior y entre las ciudades, alterando las nociones de tiempo y distancia, y consecuentemente, la percepción y naturaleza de la vida urbana. La transformación de Paris del siglo XIX expresa bien los nuevos requerimientos del diseño que podríamos sintetizar en la triada técnica, estética e higiénica que inspiró la obra del Barón Haussmann y que incluyó la creación de paseos, parques, jardines y calles arboladas, ejecutadas por Jean-Charles Alphand. La renovación de París animó a cambios urbanísticos en otras ciudades e inspiró el movimiento City Beautiful y el desarrollo de los suburbios residenciales en Norteamérica, expresión también, de una identidad agraria enfrentada al desarrollo industrial y al crecimiento acelerado de las ciudades.

Desde esta época, la ausencia de una visión común ha promovido el carácter ecléctico del diseño del paisaje en Occidente. El diseño ha sido cada vez más visto como una mercancía, una mera cuestión de gusto del consumidor, tal como se expresa en la mezcla casual de varios estilos pasados.

Si bien el movimiento moderno intentó una reinvención radical del diseño arquitectónico, los resultados en términos de paisaje han sido comúnmente desastrosos. La segregación urbana, la ampliación descontrolada de los límites de la ciudad y la pobreza, especialmente en Sudamérica, relegaron los temas concernientes al paisaje como un aspecto superfluo en la planificación del territorio, dejando la forma tanto del ambiente natural como del ambiente construido bajo los designios de la especulación inmobiliaria y de la infraestructura de transporte. 
4.2.7. El diseño del paisaje en el mundo global.

Como producto de una concepción neoliberal y globalizadora de la cultura, que abarca también el paisaje, han surgido nuevas tipologías que deben ser observadas críticamente. Me refiero a los recintos feriales, parques temáticos y centros comerciales (mall en la jerga global) que operan transformando las exiguas periferias a través de grandes intervenciones apoyadas por el marketing y la TICs ${ }^{143}$ para producir un relato que haga olvidar el lugar donde se está y lo que se ha perdido. El desarrollo de la industria turística, es otro fenómeno de transformación "modernizadora" de las ciudades y pueblos que, si no se consideran como partes de un paisaje cultural, tienen el riesgo de transformar los lugares en un simulacro, donde tiempo y espacio se dislocan. Si bien la fotografía, el cine y el acceso universal a las imágenes por internet nos permiten conocer y anticipar la experiencia de lugares lejanos, esta facilidad también convierte las imágenes en medios de comercialización de unos "originales" que luego están obligados a permanecer fijos e inalterados, vale decir sin la vida real. Sin embargo, pensar el territorio desde el paisaje, permite que se consideren tanto los valores naturales como los históricos y culturales, también los económicos y los relacionados con el poder, de manera que las intervenciones logren aumentar el vínculo espiritual entre las personas, y de éstas con el ambiente construido y el natural.

Este recorrido por la historia de la transformación, que, si bien es parcial, permite trazar patrones de influencia a través del tiempo y de distintas latitudes, evidenciando una paradoja: que, así como la forma sigue a la cultura, una vez que un modelo de actuación se ha consolidado, la forma sigue a la forma, incluso a veces, la cultura puede seguir a la forma.

Así, el vasto imperio aqueménida adoptó las formas griegas y el Romano, llevó las suyas hasta la isla de Bretaña. En un impulso inverso, el Renacimiento italiano recuperó las formas de la antigüedad esparcidas sobre su territorio, para adoptarlas y convertirlas en imagen del espíritu humanista.

Los procesos de conquista, como en el caso de América, permitieron imponer formas y con ellas una cultura, pero también llevar de regreso a Europa algo, que, si bien se parece al modelo original, es distinto. Las rutas comerciales trenzan influencias, como es el caso del jardín inglés se inspiró en el jardín chino y luego el jardín chino, adoptó la estética del jardín inglés.

Para Rogers (2001) La imitación estilística de formas pasadas, no sólo representan nostalgia o una actitud tradicionalista, ya que como hemos visto, puede explicarse como un modo de resistencia a los cambios (es el caso de la resistencia a la Revolución Industrial) o como fuente de nuevas asociaciones con un presente optimista (como fue el Renacimiento).

Un mismo modelo de actuación puede tener significados contrapuestos: es el caso del plan para fundar Washington DC, capital de la nueva nación democrática, que paradojalmente fue una adaptación de los planes que surgieron de la experiencia de Versalles, máxima expresión de un régimen absoluto. También podemos seguir la evolución del parque público desde la pintura de la campiña italiana, al jardín inglés, cuyas villas fueron desarrolladas por y para la aristocracia en el siglo XVIII, para transformarse luego en el modelo de un espacio democrático.

Hemos caracterizado cada época en relación a su sistema de creencias, desde el mito, la religión, la filosofía y la ciencia, para asociarlas al tipo de transformación del paisaje que cada cultura produjo, integrando en ella todo propósito social -religioso, económico, arquitectónico- que desde el tiempo presente percibimos como un sistema de creencias compartido. Es lo que permite hablar de las sociedades prehistórica, antiguas, o de aquellas que se desarrollaron bajo concepciones como el cristianismo, el islam, el racionalismo o el humanismo. Siguiendo a Rogers (2001), la dificultad de nuestra época sería justamente, la falta de esa visión compartida y la falta de unidad en nuestra propia concepción de lo humano, compartimentando la existencia en dimensiones que son luego mación y las comunicaciones. estudiadas por distintas ciencias. 
Así cuando se trata de subjetividad y experiencia individual, recurrimos a la psicología, cuando se trata de comportamiento colectivo, nos sometemos a la mirada de la sociología, la economía o el marketing. Una excepción que sin duda influencia a Rogers y a través de ella nuestro punto de vista, es "la teoría y práctica propuesta por Carl Jung que aporta una visión más compleja sobre el inconsciente colectivo y el papel del mito y de los arquetipos como portadores de significado" (Barlow Rogers, 2001, p. 26).

Cabe preguntarnos qué es aquello que hoy compartimos. Tal vez uno de los elementos comunes es la emoción ante los beneficios de la tecnología, las infinitas posibilidades de comunicación y del acceso a la información en la que participamos, incluyendo incluso a pueblos remotos, que posiblemente se sienten fuera de la historia que hemos trazado ${ }^{144}$. Sin embargo, junto a la emoción también experimentamos la angustia de un modo de vida, que como plantea Gilles Lipovetsky es cada día más ligero. Para este autor, la ligereza, sería la tendencia dominante en el espíritu de nuestra época: "Lo ligero nutre cada vez más nuestro mundo material y cultural, ha invadido nuestras prácticas cotidianas y remodelado nuestro imaginario" (Lipovetsky, 2016, p. 7). Hemos creado un nuevo tipo de ciudad sin forma y sin fundamentos míticos, religiosos e incluso políticos, que intentan parecerse cada vez más unas a otras, favoreciendo la movilidad rápida sobre otras formas de uso del espacio. Cada vez más desarraigados del lugar, el hombre y la mujer contemporáneos han devenido en viajeros, "un consumidor estético que busca sin cesar emociones, diseño, música, imágenes, paisajes" (Lipovetsky, 2016, p. 43), habitantes de un mundo que ha explotado sin medida sus recursos naturales, comprometiendo el futuro de la vida como la conocemos. No es primera vez que el cambio climático se transforma en consciencia paisajística, debemos recordar que entre el siglo XIV y mediados del siglo XIX hubo una pequeña Edad del Hielo, que consistentemente coincide con el surgimiento y desarrollo de lo que hoy entendemos por paisaje, posiblemente inducido por la necesidad de dominar técnicamente el crecimiento de las plantas con fines productivos, pero por sobre todo porque impulsó la creación de imaginarios idílicos relacionados con la naturaleza, vale decir con la construcción de utopías.

Seguimos siendo dicotómicos: frente a la globalización vuelve a surgir el aprecio de lo local, frente al individualismo, el impulso que valora la comunidad, y ante la crisis ambiental y energética producida por la industrialización, aparece una consciencia ecológica, que vuelve a mirar el territorio, ya no para explotarlo, sino para cuidarlo y preservarlo. Estos tres elementos estarían presentes en el contemporáneo interés por el paisaje.

La pregunta que buscamos responder es cuál es la estética, entendida como proyección de la cultura, que corresponde a nuestro tiempo, cuál es la vida que deseamos para el futuro, la utopía que plasmaremos en el paisaje.

\subsection{LA TRANSFORMACIÓN DEL PAISAJE EN CHILE.}

Retomando lo desarrollado en el capítulo 3, podemos afirmar que la identidad chilena está fuertemente asociada a su geografía, a su historia de catástrofes naturales y de colonización tanto física como ideológica, la que prácticamente ha borrado las nociones culturales precolombinas, que, como hemos visto en el apartado anterior, establecieron una relación mítica con el paisaje.

El paisaje sólo vuelve a aparecer, a través de una mirada hegemónica, la contemplación ilustrada de los viajeros que visitaron el país, atraídos por interés comercial o científico a finales del siglo XVIII y durante gran parte del siglo XIX. De este modo, parece cumplirse la máxima acuñada por Beatriz Sarlo, cuando plantea que "el campo nunca es paisaje antes de la llegada de un observador ocioso que puede permitirse una distancia en relación con la naturaleza" (Sarlo, 2001 [1973], p. 19)

Esta mirada hegemónica del paisaje, que por cierto exaltó su belleza, ha hecho del territorio chileno un laboratorio de experiencias urbanas, especialmente

144 Pienso en las fotografías donde en ambientes muy diversos, como en áfrica central, el altiplano americano donde las personas aparecen hablando por su teléfono celular. 


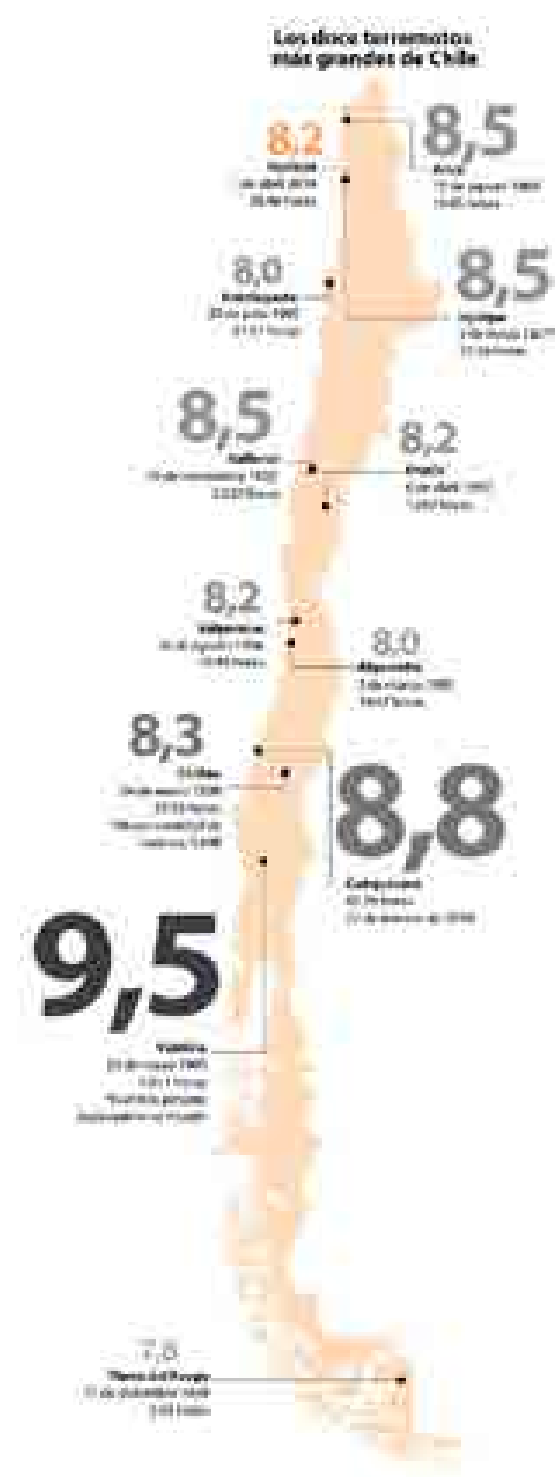

Figura 4.15. Doce terremotos más grandes de Chile. Infografía. Por INFOGRAMAX, 10 de abril, 2014

${ }^{145}$ Aludo a Chile, o, una loca geografía, el título del libro de Benjamín Subercaseaux (1940).

${ }^{146}$ Estudiada por Mauricio Onetto recientemente en su libro Temblores de tierra en el Jardín del Edén (2017).

Figura 4.14. Tamaño comparativo de Chile. The True Size Of [web] (20 de noviembre, 2019). desde el inicio de su vida republicana donde lo natural, lo político y social se recombinaron.

Podríamos definir tres fenómenos que han modelado el paisaje chileno: una variada y "loca geografía"145 y el conflictivo infinito; las catástrofes naturales; y la idea de la ciudad como un laboratorio.

La conformación del territorio chileno, descubierto por Magallanes en 1520, desde su extremo más austral al surcar la tierra del Fuego a través del inhóspito estrecho, marcó su imagen remota y peligrosa. La difícil y accidentada conquista emprendida posteriormente desde el norte por Diego de Almagro (1536) y luego por Pedro de Valdivia (1540), reforzaron una visión negativa de un territorio continuamente azotado por terremotos y por la resistencia indígena replegada después del siglo XVI al extremo sur del país, en lo que se llamó La Frontera, al sur del río Malleco.

El territorio chileno se estructura a lo largo de la cordillera de Los Andes, un gigantesco macizo geológico, que aísla del resto del continente una angosta faja de tierra de 4.270 kilómetros de longitud, lo que hace a Chile el país más largo del mundo (Figura 4.14.). Esta fisonomía engendra una inmensa diversidad de climas que van desde el desierto más árido (el desierto de Atacama) a la fría $\mathrm{Pa}$ tagonia, y transversalmente desde las altas cumbres de la cordillera al mar, frente al océano Pacífico. El espacio llano intermedio, está limitado por la cordillera de los Andes y la cordillera de la costa. La fertilidad de los valles transversales y el clima templado de la zona central, fueron el contrapeso de la imagen negativa y ayudaron a configurar una segunda imagen del país como "copia feliz del edén", alegoría que quedó grabada en el Himno Nacional hasta nuestros días. Esta doble figuración de catástrofe y paraís ${ }^{146}$, de siniestro y sublime, ha hecho que el territorio se perciba como algo vivo, en continuo movimiento y transformación a través de los grandes desastres que llamamos naturales. Los desastres, especialmente los terremotos, recorren la historia de Chile (Figura 4.15), y han destruido y transformado las ciudades, determinando en gran medida nuestra relación con el paisaje, imprimiendo un sello identitario. También han modelado las costumbres y hecho evolucionar las normas, las técnicas constructivas y los criterios de planificación. Contemporáneamente, han configurado dentro

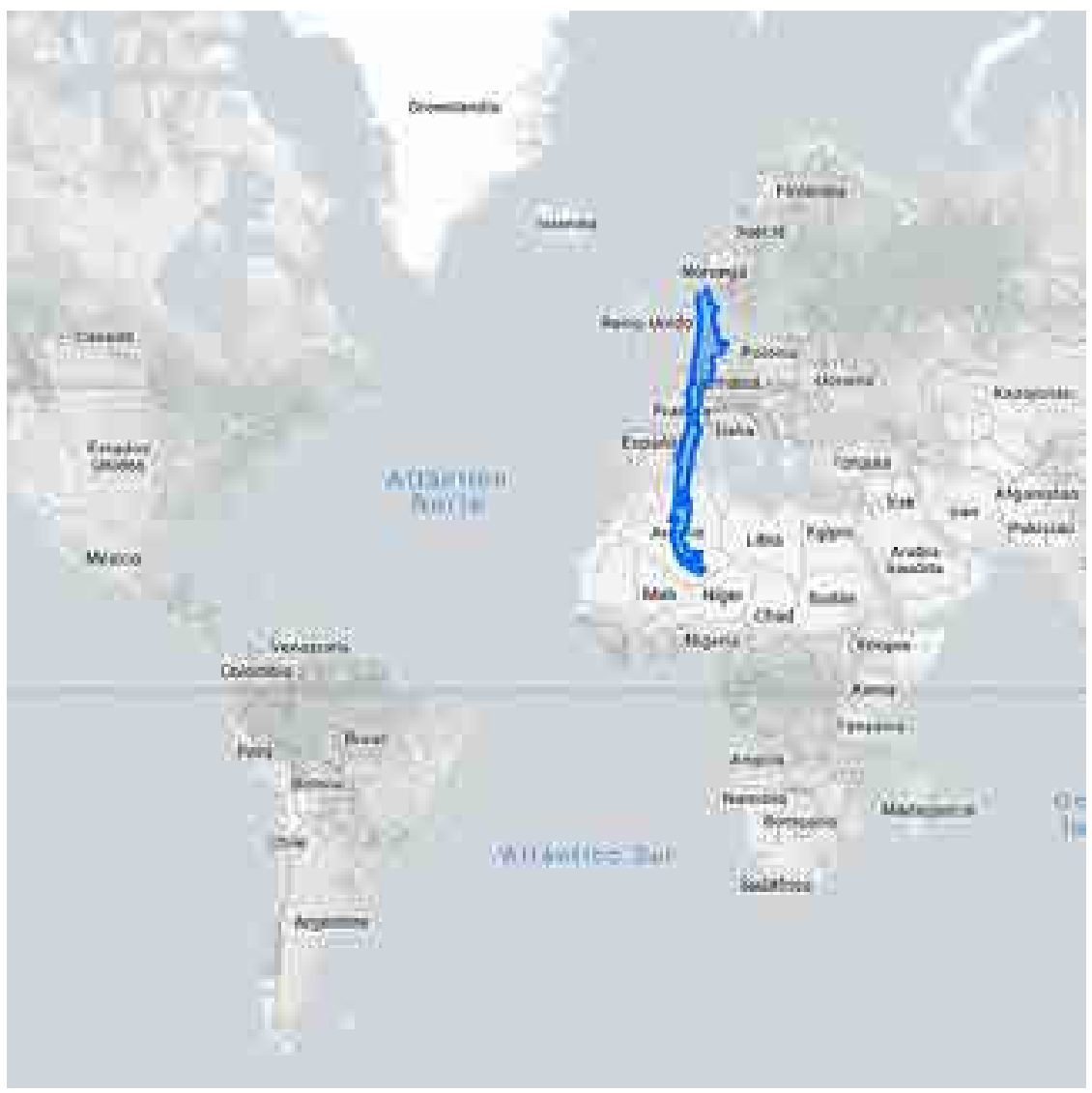


del lenguaje común de los habitantes, términos como riesgo, resiliencia, telúrico, catástrofe, etc. Estéticamente, por casi cinco siglos, los terremotos han impreso en la arquitectura chilena un carácter telúrico y gravitacional, una característica que poco a poco se disuelve en lo ligero, a partir de los avances en la ingeniería sísmica, el uso avanzado del hormigón y las estructuras de acero, ocultas tras el muro-cortina.

Si bien temporalmente, la fundación de ciudades en Chile como en el resto de América del sur, coincide con el Renacimiento europeo, la transferencia de los principios de la perspectiva a una geografía abrupta, hizo que la articulación entre las escalas geográficas y arquitectónica se entorpeciera. El "ensamble" del que habla Leonardo Benevolo, capaz de "abarcar y dominar el cuadro geográfico extenso" (Benevolo, 1994, p. 83) a través de la perspectiva, al enfrentarse, en su despliegue a la escala gigantesca de la cordillera, siempre presente, impidieron definir un punto de vista estático y de dominio. Este efecto nos permite comprender por qué las cosmovisiones de los pueblos originarios interpretaron la naturaleza en movimiento, regida por ciclos y constreñida a una geografía de escala inabarcable. Sofía Letelier nos recuerda que "en América Latina la concepción de la ciudad como reflejo de mundo no era un sistema expansivo y radial hasta el infinito como los ideales europeos de ese momento, sino que estaba atenida a la medida de la geografía" (Letelier, 2008, p. 11), lo que nos acerca más a la aplicación del damero jónico de Mileto (también condicionado a una topografía accidentada), que a la imposición del sistema de cuadrícula y ejes que se desarrollaron a partir del racionalismo humanista. El diseño a mezo escala, será el entonces el desafío para una arquitectura del paisaje que recién se empieza a configurar en Chile en el siglo XIX.

La imagen del jardín del edén atrajo principalmente en el siglo XIX, a naturalistas y cartógrafos, muchos de los cuales llegaron contratados por la nueva República con la tarea de catalogar y cartografiar el territorio. Los conocimientos botánicos de la época, se aplicaron al aclimatamiento de diversas especies vegetales a lo largo de todo el país.

La botánica Adriana Hoffmann en su libro El árbol urbano en Chile (1983) además de la descripción detallada de distintas especies, entrega una relación de la vegetación arraigada en las distintas regiones: En el extremo norte, la desértica ciudad de Arica se aclimataron ejemplares de jacarandá, gomeros e hibiscos de brillantes colores, hacia el interior, en el valle de Azapa, crece un oasis, regado por acequias con antiguos olivos, junto a mangos y bananeros. En los últimos 30 años se ha desarrollado también el cultivo de hortalizas, convirtiendo Arica en el principal proveedor del país, lo que ha transformado el paisaje desértico en un

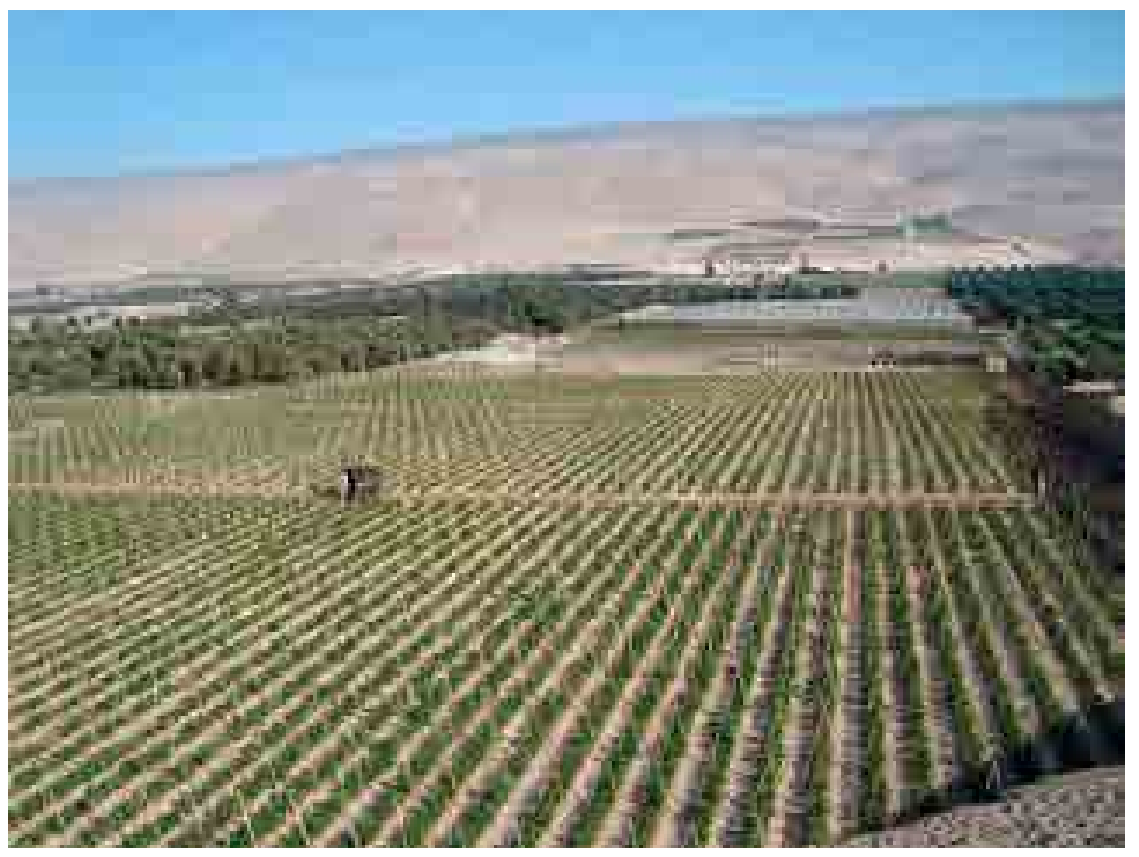


Figura 4.17. Roces a fuego en Coyhaique, Chile. AQUIAYSEN [web], 3 febrero, 2017. achurado vergel. (Figura 4.16.). El Pimiento (Schinus molle), introducido en Chile por los incas, es una de las especies más frecuentes en el norte del país. Sus raíces profundas lo hacen resistente a los climas áridos ofreciendo la sombra de una amplia copa y ramaje colgante. Esta especie está presente en las principales plazas nortinas y también en los poblados del altiplano. Es actualmente un árbol muy usado junto a las obras viales, debido a su rápido crecimiento y a que su follaje actúa como pantalla aislante del ruido y la luz de los vehículos.

Desde la Serena al sur, comienza a aparecer el álamo (Populus nigra), especie introducida a Chile en 1810 por el cura franciscano Javier Guzmán (Serra et al, 2002 , p. 1). En la alameda de La Serena, junto a los álamos se encuentran plátanos orientales (Platanus orientalis) y Jacarandá (Jacaranda mimosifoli). En los valles interiores de esta región se encuentran plantaciones de Lúcumo, Papayo y viñas (que han crecido en número y extensión en los últimos 20 años).

El campo del valle central aparece "geométricamente ordenado por plantaciones de frutales e hileras de álamos, sauces y eucaliptos que limitan los potreros sembrados de cereales y hortalizas" (Hoffmann, 1983, p. 30).

El desarrollo de la industria vitivinícola (si bien los vinos se producen desde la colonia), ha alcanzado gran valoración internacional con un fuerte y positivo impacto sobre el paisaje rural, ya que en los últimos 15 años se han organizado en cada valle, las viñas, municipios y otras agrupaciones para ofrecer rutas turísticas bajo el concepto de paisaje cultural. Entre las rutas más preciadas están los valles de Colchagua, Casablanca, Elqui y El Maipo.

El paisaje rural de la zona ubicada al sur del río Malleco, adopta una fisonomía más libre, adaptada a una topografía de suaves lomajes que, gracias a las lluvias frecuentes, mantiene una cubierta siempre verde sobre el que se componen grupos arbóreos que alcanzan gran tamaño con especies como el roble, laurel, castaño, encina y tilo. En la medida que se avanza hacia el sur y hacia la cordillera se pueden encontrar bosques nativos con quillayes, pataguas, bellotos, raulí y las milenarias araucarias araucanas. El paisaje sureño, que puede asimilarse a un gran parque, es el resultado de una ocupación más tardía por colonos alemanes e italianos en el siglo XIX, que encontraron selvas impenetrables a su llegada. EI bosque esclerófilo fue devastado por roces a fuego. Especialmente dramático es el camino a la ciudad de Coyhaique que aún exhibe los efectos de los incendios producidos intencionalmente hace más de cien años (Figura 4.17.). El estado había entregado concesiones para la explotación ganadera y la solución para su asentamiento, fue destruir el bosque nativo para producir las praderas. "Hasta mediados del siglo XX se habían quemado en Aysén un total de 2 millones 800 mil hectáreas, que corresponden a más del $50 \%$ de los bosques de lenga, los que originalmente cubrían unas 5 millones de hectáreas" (aquiaysén, 2017, s.n.). En la misma región de Aysén, Caleta Tortel puede considerarse un buen ejemplo de adecuación al paisaje. Se trata de una aldea costera ubicada en la desembocadura del río Baker, el río más grande de Chile, circundado por una escarpada geografía, regada de fiordos y canales. El pueblo fue fundado en 1955 para ex-

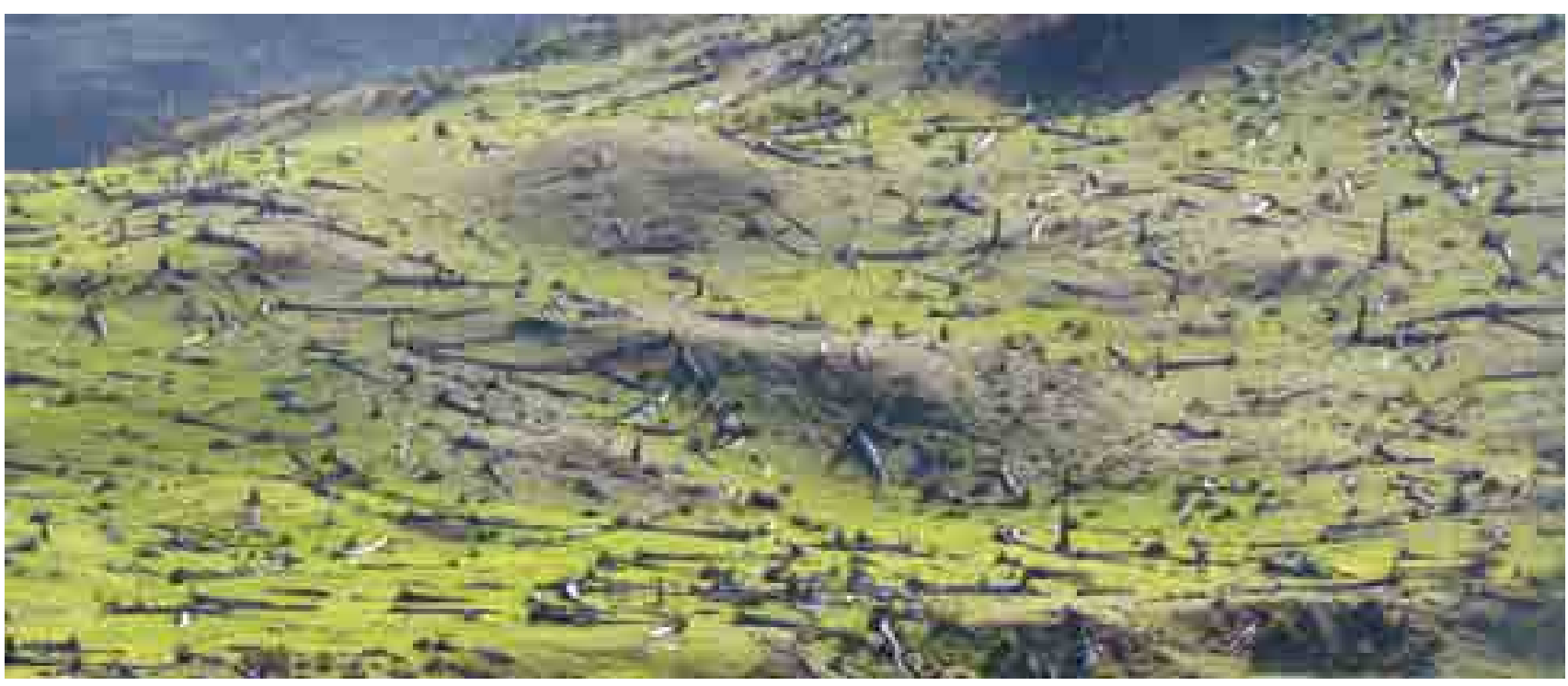


plotar la madera de ciprés de las guaytecas (Pilgerodendron uviferum) y permaneció aislado hasta el año 2003, cuando se conectó al resto del territorio a través de la Carretera Austral. Sus casas sobre pilotes, herederas de la arquitectura de Chiloé, se distribuyen a lo largo de la costa por varios kilómetros, comunicadas a través de un sistema de pasarelas de madera (Figura 4.18.). Esta solución que casi no toca el terreno, y que parece ser la extensión de la tipología del muelle sobre tierra firme, serán un referente de proyectos contemporáneos, tales como Termas Geométricas y Termas de Puritama, ambos de German del Sol (Figura 4.19.).

La experimentación en el territorio, como si se tratara de un laboratorio botánico, ha dado como resultado que, en Santiago, el $86 \%$ de sus más de 6 millones de árboles corresponda a especies exóticas (La Tercera, 20 de marzo de 2018), como se muestra en la Figura 4.20., predominan los ciruelos en flor (Prunus cerasifera), la robinia (Robinia pseudoacacia), el acer (Acer negundo) y el liquidámbar (Liquidambar styraciflua). "Entre las especies nativas más frecuentes están el espino (Acacia caven), el quillay (Quillaja saponaria), maitén (Maytenus boaria) y peumo (Cryptocarya alba)." (La Tercera, 20 de marzo de 2018). Las especies foráneas en general, consumen más agua, exigen mayor mantenimiento y desarticulan los sistemas ecológicos. Hoffmann (1983) es especialmente crítica respecto a la plantación indiscriminada de bosques de pino insigne (pinus radiata) por la industria forestal, ya que pone en evidencia una visión puramente económica, con metas a corto plazo, que "ha ido cambiando la fisonomía del paisaje al introducir la monótona trama del bosque de pino insigne, con sus nefastas secuelas ecológicas" (Hoffmann, 1983, p. 31 ), entre las que se encuentran sus características pirófilas y el efecto sobre los suelos por la lenta descomposición de su humus, que son causantes de un medio más ácido, disminuyendo tanto la flora como la fauna autóctona.

\subsubsection{La ciudad (o la función sigue a la forma)}

Los conquistadores provenientes de Castilla, replicaron su imaginario ocupando el plano y desestimando la construcción en los cerros. En Chile prácticamente no existe arquitectura de montaña, ya que las ciudades fueron levantadas sobre valles fértiles, con rica vegetación arbórea que fue eliminada para dar paso a las calles y precarios espacios públicos donde predominaron polvorientos suelos de tierra en los veranos y barriales durante los inviernos. La vegetación urbana se concentró en los huertos y patios de las casas, que herméticas hacia el exterior, dejaban asomar lo verde por sobre los muros. Observa Benavides (1961) que ya en las primeras casas santiaguinas del siglo XVI el jardín se funde con el huerto, a razón de ser Santiago una ciudad asediada, que obligaba a una agricultura de subsistencia puertas adentro. Del mismo modo, señala el autor, hasta el siglo $\mathrm{XVIII} \mathrm{los} \mathrm{temblores} \mathrm{provocaron} \mathrm{la} \mathrm{resistencia} \mathrm{de} \mathrm{los} \mathrm{santiaguinos} \mathrm{a} \mathrm{edificar} \mathrm{sus}$ viviendas en dos pisos, por lo que las construcciones tendían a extenderse y ocupar mayor superficie.

Pérez Rosales señala que a principios del XIX todas las casas de Santiago eran "casas quinta", y que gozaban de "patios, de corrales i de jardines" (1886, p. 4), manteniendo esa impresión hasta mediados de siglo, cuando señala que "casi todas tienen dos otros grandes patios, donde se mantienen inmensos jardines $\mathrm{i}$ árboles exóticos" (Pérez Rosales, 1859, p. 376). Los registros fotográficos y pinturas permiten distinguir variadas especies, sobre todo en los predios de mayor tamaño, tales como los conventos y hospitales (Figura 4.21.).

Por su parte, las catástrofes impulsaron las primeras obras de infraestructura pública. Las estacionales crecidas del río Mapocho, que inundaban la ciudad dieron origen al paseo público arbolado más antiguo que conocemos, el de Los Tajamares (muro que protegía a la ciudad de los desbordes del río Mapocho). Samuel B. Johnston en Cartas de un tipógrafo Yanqui registra sus impresiones del paseo en 1814:

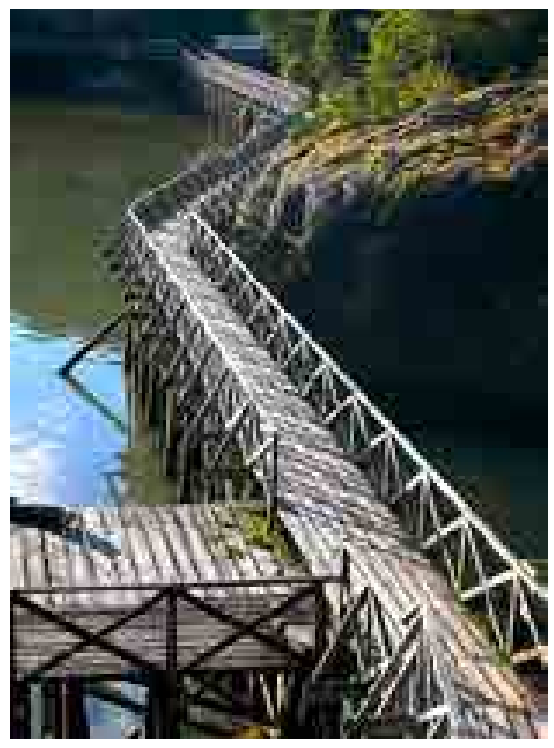

Figura 4.18. Pasarelas en Caleta Tortel, Chile. Por Douglas Fernandes en Plataforma arquitectura [web] 25 de febrero, 2018.

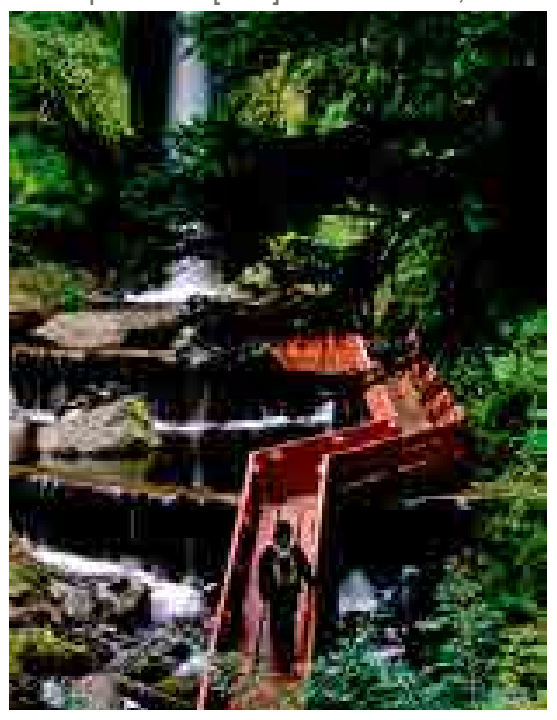

Figura 4.19. Termas Geométricas, Coñaripe, Chile. Obra del arquitecto Germán del Sol (2009). Por Guy Wenborne en Plataforma Arquitectura [web], 24 de diciembre, 2014

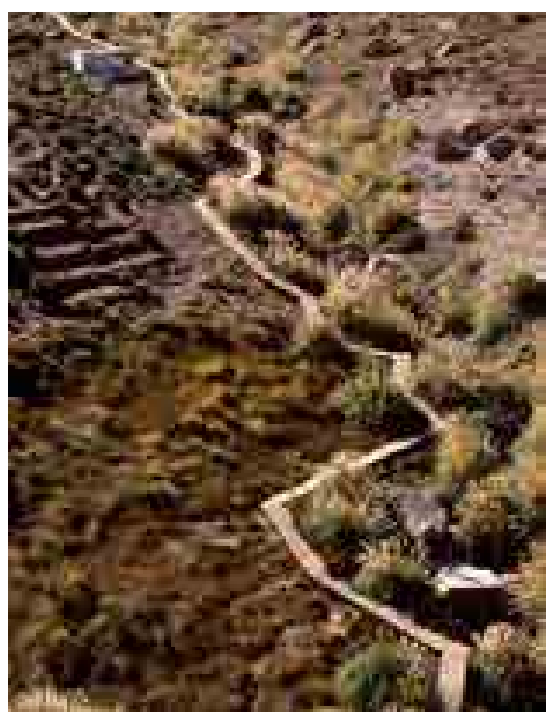

Figura 4.19. Termas de Puritama, del arquitecto Germán del Sol (2000). Por Guy Wenborne en Plataforma Arquitectura [web], 29 de octubre, 2014. 


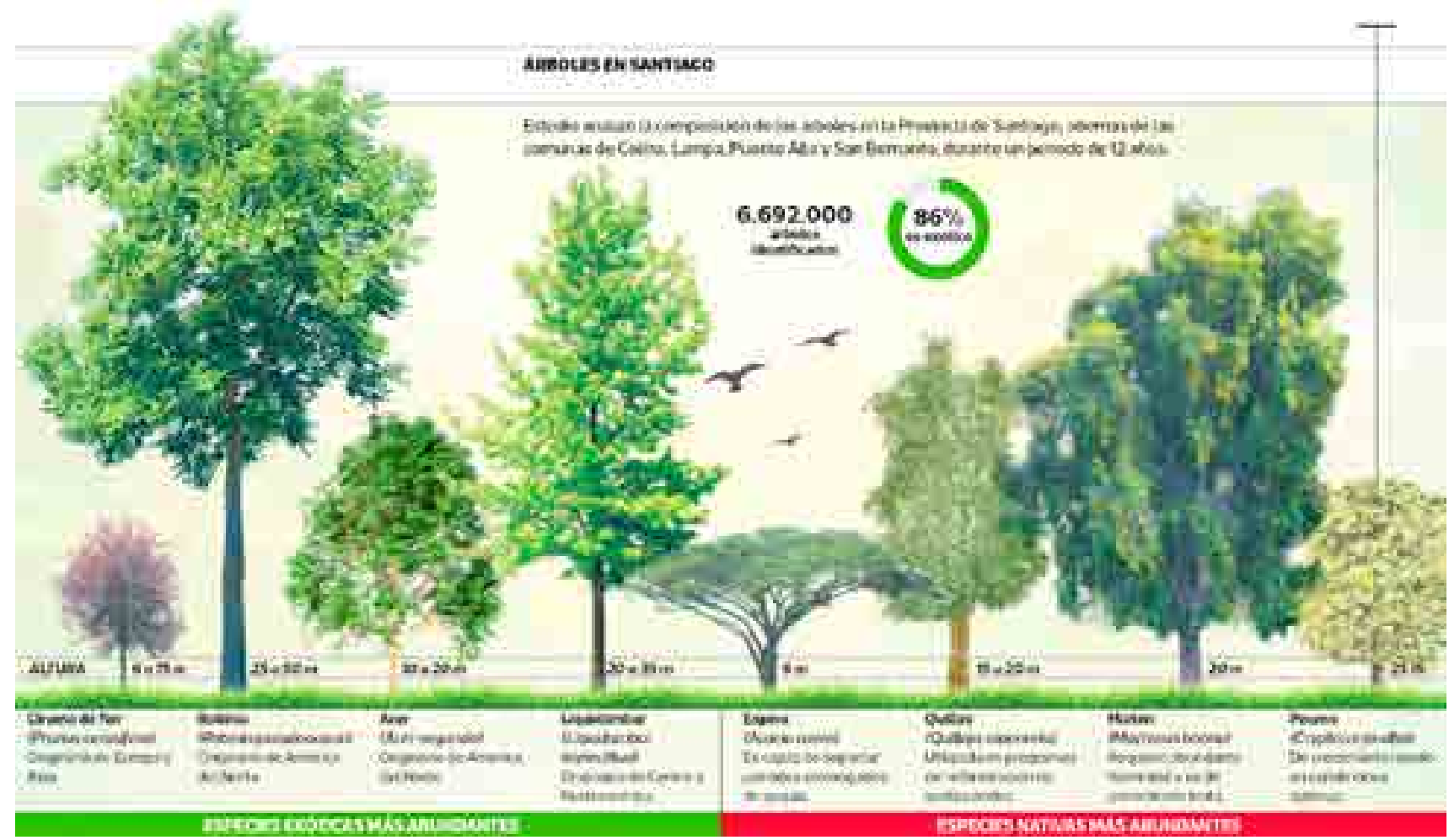

Figura 4. 20. Árboles de Santiago. Infografía. En La Tercera, 20 de marzo, 2018.
El paseo público está atestado ese día con gentes de todas las clases sociales, algunos en carruajes, otros a caballo y otros a pie. El río corre por la parte norte de la ciudad y por el lado sur se extiende una muralla de piedra, de seis pies de espesor y ocho pies de alto, para impedir que el desborde de las aguas inunde la ciudad. Este muro se prolonga por unas dos millas y está en su parte superior pavimentado de ladrillos, y forma un paseo hermoso y fresco, sombresado por árboles. Hacia la parte media de esta muralla existe una fuente, a cuyos costados, en las tardes de los domingos, se ve a las señoras en sus carruajes, formados en líneas, frente a frente, dejando un espacio suficiente para que los elegantes pasen y vuelvan a pasar a caballo. La hora de reunión en este sitio es desde las cinco de la tarde hasta la puesta de sol, mirándose unos a otros y saludando con inclinaciones de cabeza a sus amistades al pasar (Johnston, 1919, p. 206-207).

La vegetación demoró en llegar a la plaza de Armas (fundacional), que fue una explanada de tierra hasta 1856, año en el que el intendente Bascuñán Guerrero ordenó las primeras plantaciones, que fueron reordenadas en 1872 en el Plan de Transformación de Santiago del Intendente Vicuña Mackenna, quien "logró que se plantaran 52 árboles en la plaza" (Hoffmann, 1983, p. 22)

Figura 4.21. Vista de Santiago en 1890. En Archivo Francisco Vidal.

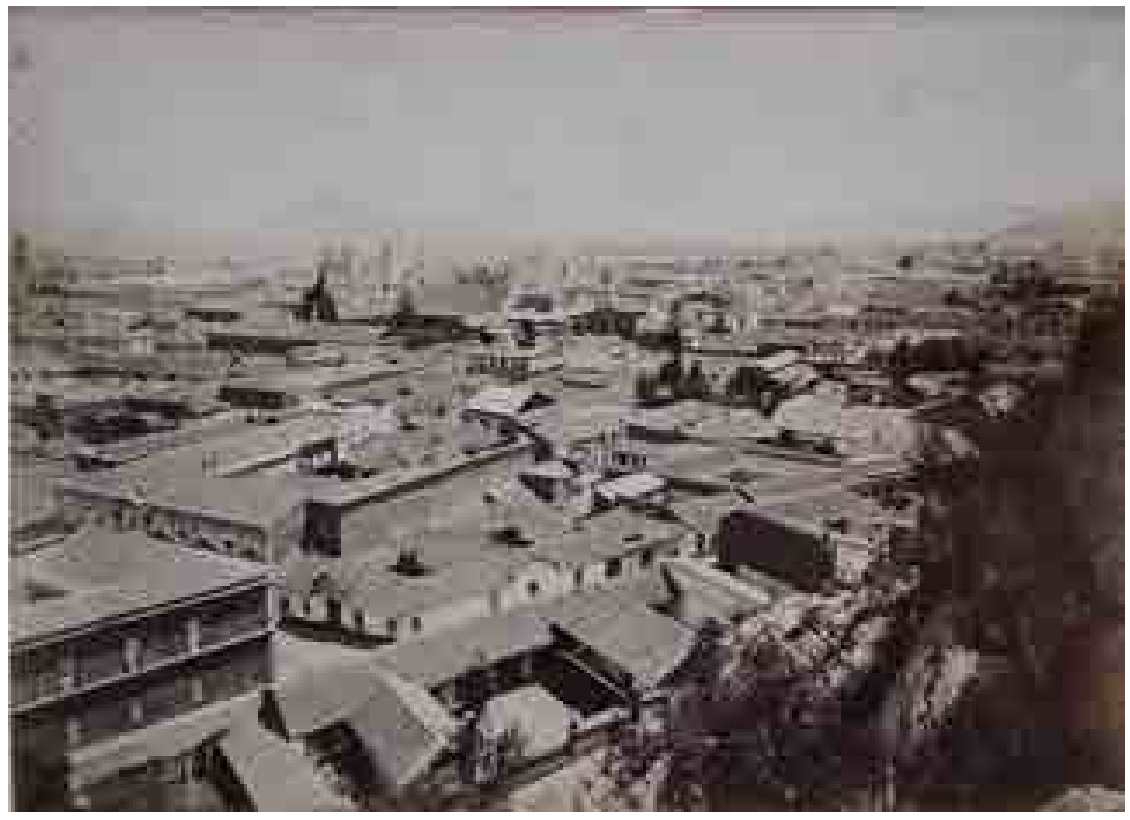


Lo mismo sucedió con la avenida principal de la ciudad (actual Avenida del Libertador Bernardo O'Higgins que corre de oriente a poniente), que recién en 1746 recibió un trazado regular. Su fisonomía definitiva fue obra directa de Bernardo O'Higgins en 1820 que la convirtió en un paseo, como nos describe Carlos Bladh en 1837:

Consiste en tres avenidas paralelas, derechas y anchas, separada una de la otra y de los terrenos colindantes, por cuatro canales pavimentados, a cuyas orillas fueron plantados álamos erectos [...] estas alamedas se cortan en una gran rotonda, rodeada por álamos y juegos de agua" con "Bancos de piedra [...] diseminados por ahí y por allá [...], y caminos cubiertos de arena fina pero duramente apisonada eran regados al anochecer (Bladh, 1951[1837], p. 42-43)

El Plan de Vicuña Mackenna también actuó sobre este eje, extendiendo la avenida hacia el oriente. Hacia 1900 "La Alameda de las Delicias" estaba conformada por cuatro hileras de encinas, olmos y plátanos orientales que reemplazaron los álamos, por "pasados de moda". Esta costumbre "transformadora" llevó a reemplazar constantemente las especies anteriores, arruinando una y otra vez, el escaso verdor de la ciudad.

Hugo Segawa (2004) en su estudio sobre los paseos públicos en Latinoamérica, considera que las colonias americanas fueron un "Laboratorio para el urbanismo europeo" (Segawa, 2004, p. 1), al observar que tipologías como la alameda no se especificaron en las leyes de Indias.

Si bien los motivos ilustrados parecen ya estar presentes, el trance desde paseo arbolado al parque urbano -que será el tema del capítulo siguiente- tardará. Serán los ideales republicanos lo que en definitiva permitirán que la naturaleza domesticada entre a Santiago.

Con el nacimiento de la República se crea el primer parque público en Chile, la Quinta Normal 1841, seis años antes que Birkenhead (1847), el primer parque público que la literatura reconoce. La Quinta Normal de Agricultura, revela en su nombre las motivaciones de su creación como lugar de aclimatamiento de plantas, escuela agrícola y parque público, emplazado en el límite poniente de la ciudad.

Pero el Santiago del inicio de la República dista mucho de la ciudad industrial y de los problemas que dieron origen a los primeros parques públicos del hemisferio norte. Su apariencia general correspondía en esa época, a la de un poblado colonial, sin edificios especulares, sino más bien formada por un conjunto de casonas herméticas hacia el centro y ranchos hacia la periferia que se diluían en la informalidad rural. Las huellas "del desarrollo económico se podían observar -y aún de una forma elemental e incipiente- en los puertos y en las ciudades mineras, pero no en la capital, principalmente ocupada con comercios y manufacturas artesanales" (Montealegre, 2017, p. 18).

Según Gorelik (2003) el parque en la ciudad latinoamericana decimonónica aparece como "ámbito de reproducción de la figuración social como espectáculo de la ciudad burguesa, pero también ámbito de producción de sociedades figuradas" (2003, p. 17). Este efecto es especialmente patente en las últimas décadas del siglo XIX, cuando los paseos públicos empiezan a ser usados por las élites como como espacio de exposición social y como la materialización de imaginarios europeos, especialmente, los parisinos. El afrancesamiento de la cultura chilena se ve reforzada por la literatura de la época, que destaca la experiencia del parque como el ámbito que concentra y ayuda a construir el imaginario urbano de modernidad.

Benjamín Vicuña Mackenna (1831-1886), será el artífice de la Transformación de Santiago, un plan que desarrolló como Intendente entre 1872 y 1875 y contempló la arborización de espacios públicos, la pavimentación de las calles, la creación del camino de cintura, el hermoseamiento del cerro Santa Lucía y la creación del Parque Cousiño (1873), el mismo año que el Central Central Park alcanzó su 
tamaño final.

Los parques se concretan, así como la materialización de los ideales, una "puesta en escena" como señala Jocelyn-Holt (2013) a propósito del cerro Santa Lucía ${ }^{147}$; una suerte de imaginario habitable. Construida su experiencia a partir de representaciones, se vuelven heredero más del plano simbólico y fantasioso que del utilitario. El ritual del paseo por el Parque Cousiño, será para las élites locales, una experiencia europeizante. Una práctica que el escritor Luis Orrego Luco recoge cuando escribe "A veces, creía encontrarme en París" (Orrego Luco, 1984, p. 166).

Al igual que otras ciudades latinoamericanas, Entre mediados de siglo XIX y principios del XX, el tejido urbano se convierte en una mancha metropolitana $y$, de cierta forma, se forja una concepción de la ciudad como fenómeno más que como una entidad finita. En el caso de Santiago, inicia el ciclo con una forma prácticamente aldeana y el crecimiento se ve acelerado con el fin de siglo. De Ramón (1985) señala que la superficie de la ciudad pasa de unas 1.500 hectáreas en 1872 a 2.000 en 1895 y a 3.000 hectáreas en 1915 (Ramón,1985, p. 209). Si bien es cierto, hay un crecimiento vegetativo que puede ser medido objetivamente, esta extensión es ante todo un fenómeno cultural, una ampliación del concepto de lo urbano que comienza a incorporar en la administración, registro y representación de la ciudad, una serie de tejidos existentes. Según el autor, la ciudad absorbe principalmente a poblados y caseríos que se ubican a la orilla de los callejones que sobrepasan el Camino de Cintura.

Para la investigadora Pía Montealegre (2016), el estado actuó en el siglo XIX en Santiago "como agente de la expansión del suelo urbano" a través de la creación de los parques. Tanto la Quinta Normal como el Parque Cousiño, trazados fuera de la zona urbana, definieron la dirección del crecimiento de la ciudad y con ello la disponibilidad de áreas urbanizables. En la Figura 4.22. teniendo como referencia el plano de Herbage de 1841 que muestra el tamaño de la ciudad (de $370 \mathrm{ha}$ ), al dibujar los parques, se suman más de 530 ha de crecimiento. De este

147 Llamado Huelén por los mapuches y "Hillock of rock" por Darwin, fue el lugar de fundación de Santiago por Pedro de Valdivia. Por iniciativa de Vicuña Mackenna, los árboles y la vegetación cambiaron la fisonomía del inhóspito peñón de 69 metros de altura, en uno de los más bellos paseos de Santiago. Más de 1.000 especies cubrieron las desiertas rocas que habían servido de depósito de basura, cementerio de disidentes, a veces patíbulo. Fue necesario trasladar 18000 carretas de tierra vegetal y dotarlo de agua, edificios y esculturas.

Figura 4.22. Plano esquemático de la expansión de Santiago. Elaboración propia a partir del plano de Herbage (1841) y Montealegre (2016).

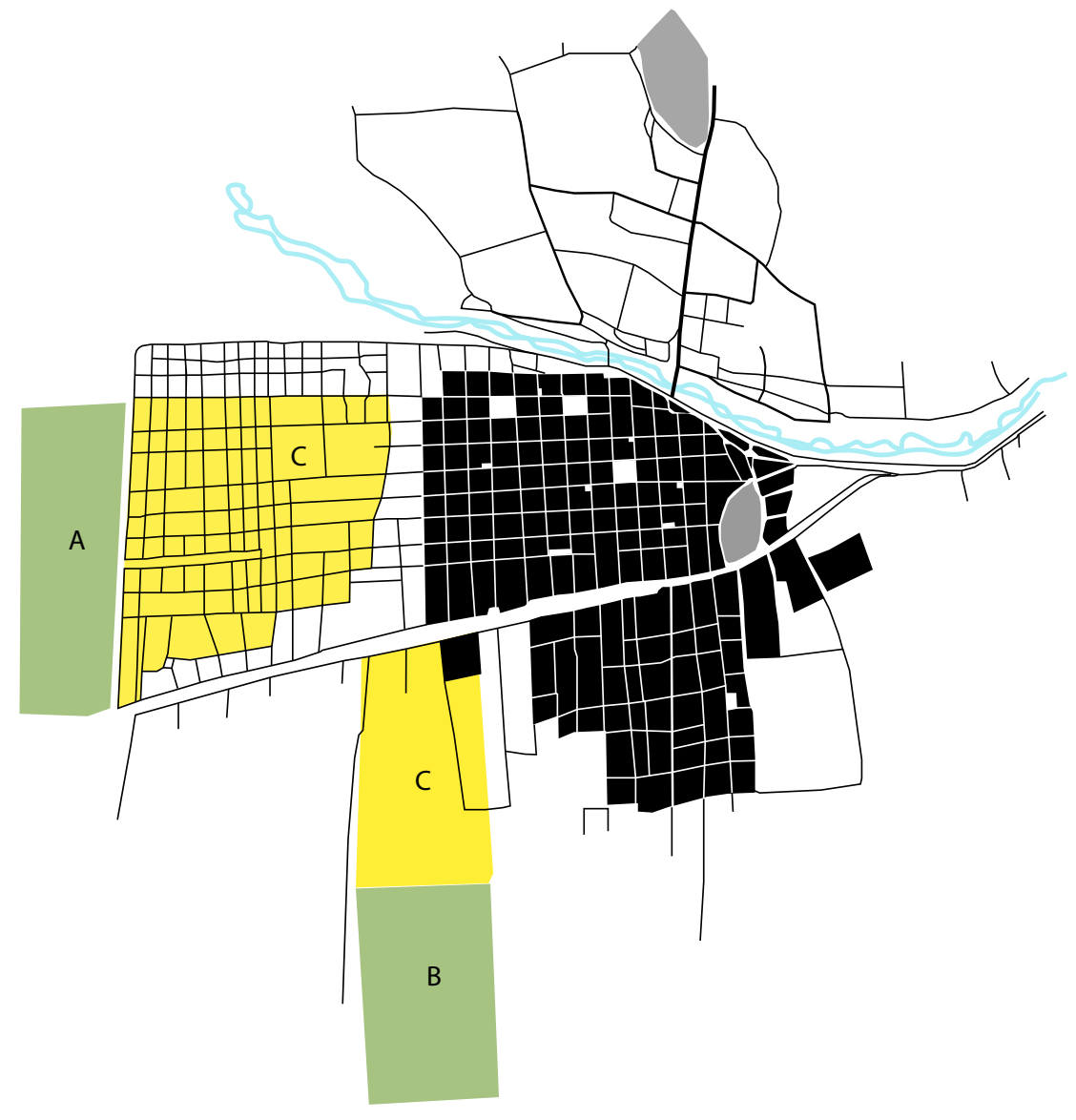


modo, como señala Montealegre, "el espacio públicos, que teóricamente es un freno a la expansión urbana al reservar terrenos para áreas verdes, resultó ser un impulso para el desarrollo inmobiliario en Santiago." (Montealegre, 2016, p. 53).

El inicio del siglo XX se inicia con la creación de otro parque, el Parque Forestal, proyectado por el paisajista francés George Dubois que inicia las obras en 1900 sobre terrenos ganados al río Mapocho y que junto al Palacio del Bellas Artes (obra del centenario de la República) configuran un nuevo barrio de artistas e intelectuales. Este parque inicia una serie de intervenciones urbanas que tienen como centro la Plaza Baquedano, desde donde se irradian unos parques lineales: el parque Bustamante hacia el sur, el parque Providencia hacia el oriente, el mismo Parque Forestal al poniente, que a corta distancia y a través de calles arboladas se comunica con el actual Parque Metropolitano sobre la cadena de cerros que desciende de la cordillera. Este último se consolida en las primeras décadas del siglo XX, ya que hasta entonces había sido explotado como cantera y fuente de leña. En su cumbre se inaugura la imagen de la Virgen (1908) consagrándose definitivamente la cima como santuario.

Como hemos señalado, hasta inicios del siglo XX el diseño de parques y jardines hizo uso de especies foráneas. Solo en 1930 los árboles nativos se integran de la mano del paisajista austriaco Oscar Prager, al Parque Providencia, hoy Balmaceda. Su diseño hace una reinterpretación del paisaje del valle de Santiago, definiendo una explanada central que se fuga en la cordillera y está flanqueada en ambos lados por arboles altos formando bosquecillos, y un sotobosque que producía escenas más íntimas para el paseante. "Se usaron por primera vez pataguas, bellotos, peumos maitenes y quillayes, con arbustos como el chilco, corcolenes, arrayanes, escallonias y una rica cubierta herbácea de cubresuelo." (Hoffmann, 1983, p. 26).

Prager hizo muchos parques privados donde experimentó con el coigüe, el mañío y el canelo. El quillay, el maitén y las pataguas ocupan un lugar destacado en sus proyectos.

El movimiento moderno en Chile relegó el paisaje a edificios notables o bien a nuevos barrios para las élites, desarrollados al oriente de la capital, tales como Jardín del Este ${ }^{148}$. El edificio de la Cepal ${ }^{149}$ (una de las obras más importantes de la arquitectura moderna en Chile), en una versión singularmente paisajística de la arquitectura movimiento moderno, se levanta "[...] en consonancia con el espacio de Santiago, con su valle y sus cordilleras, con su tierra, su clima y sus flores, con el temperamento de sus gentes. Un palacio expresado geométricamente frente a la complejidad cósmica de Los Andes [...]" (CEPAL, 1966, p. 14), incorporando las distintas escalas al espacio habitable "para el trabajo tranquilo en contacto con la geografía grande de Santiago en donde se percibe lo continental, y con la pequeña geografía de las piedras, el agua y las plantas" (p. 14). El edificio (Figura 4.23.), concebido como una unidad autónoma responde también a lo telúrico, al adoptar una estructura "semejante a la de los puentes cuya buena resistencia los terremotos ha sido comprobada" (CEPAL, 1966, p. 13). Si bien, en la memoria del proyecto, la mención a los jardines es breve, se señala que "se han previsto en función del clima de Santiago, a base de la flora autóctona, cuyas especies serán una valiosa demostración de las características botánicas de Chile" (CEPAL,1966, p. 14). Esta intención, materializada por la paisajista Paz Echeverría
${ }^{148}$ Esta tendencia con el correr de los años transformó a la comuna de Vitacura en la más verde de Santiago con 21,8 m2 de vegetación por habitante, versus 4,5 m2 de promedio para la ciudad, y el vergonzoso $1,9 \mathrm{~m} 2$ de la comuna de Pudahuel (Atisba, 2011, p. 7), el territorio donde se emplaza el proyecto de Laguna Carén.

${ }^{149}$ El edificio de la Cepal y la urbanización del barrio Jardín del Este son obra del arquitecto chileno Emilio Duhart (19172006).

Figura 4.23. Emilio Duhart (1966). Edificio sede de la CEPAL, Santiago, Chile. Por Sin Salud [flickr] 15 de octubre, 2009.

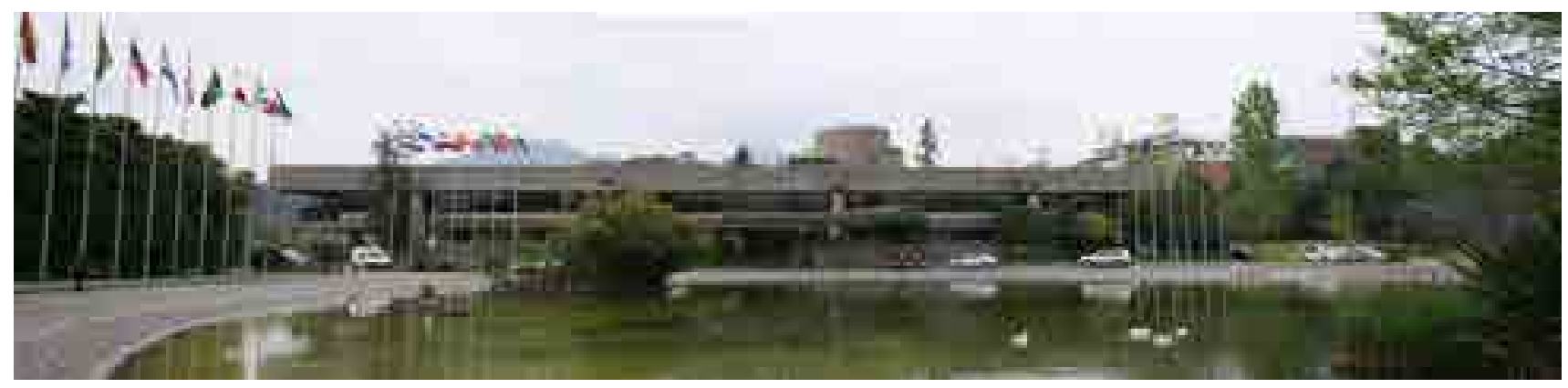


el año 1964, se ha mantenido hasta la actualidad.

Junto a este proyecto se pueden destacar las piscinas Tupahue y Antilén (1971) en el cerro San Cristóbal (Figura 4.24.), obras de Carlos Martner, y la intervención durante el gobierno de Salvador Allende del Parque Cousiño que se convertiría en Parque O'Higgins bajo el modelo de un parque popular.

Martner es equiparable a Burle Marx en Brasil o a Barragán en México. Con intervenciones más austeras, que reinterpretan las culturas prehispánicas y su espíritu constructor de paisajes. En el caso de Chile, como plantean Humberto Eliash y Miguel Laborde (2003) Martner opera con una doble estrategia que "naturaliza la arquitectura y arquitecturiza el paisaje" (2003, p. 3), al incorporar las variables del clima, la geografía y los recursos materiales del lugar, con intervenciones que señalan la presencia humana intentando delimitar el vasto territorio donde se emplaza, a través de elementos que enmarcan el paisaje xerófilo y rememoran el arte rupestre.

En las últimas décadas del siglo $X X$, el desarrollo del paisajismo se redujo al diseño de jardines y parque privados, donde se destacaron especialmente paisajistas mujeres, dentro de las que se destacan María Santa Cruz, Myriam Beach y Virginia Plubins.

\subsection{LA ILUSIÓN DE UNA NUEVA ARQUITECTURA CHILENA FRENTE AL PAISAJE.}

La condición telúrica del territorio chileno, su aislamiento geográfico, el subdesarrollo y casi dos décadas de dictadura ayudan a entender una producción arquitectónica precaria tanto en lo formal como conceptual de los años 1970 y 1980. Este panorama parece tener un vuelco en los noventa. Junto con el retorno a la democracia, la apertura de Chile al exterior y el aumento del número de arquitectos -producto de la proliferación de universidades privadas que ofrecen la carrera- la arquitectura chilena parece visibilizarse, por una parte, por razones políticas, por otra, para ampliar el campo laboral del creciente número de profesionales de un país cuya población tiende a estancarse ${ }^{150}$.

Es así como hoy encontramos obras de arquitectos chilenos en numerosas publicaciones internacionales como revistas SUMMA, Architectural Review, Arquitectura Viva, etc., y en publicaciones chilenas con difusión internacional, tales como los libros Blanca Montaña y PULSO: Nueva Arquitectura en Chile, y las revista $A R Q$, de Arquitectura y 180 grados. Un rol muy importante cumple también, la publicación de los blogs chilenos Plataforma Arquitectura y Plataforma Urbana. Estas publicaciones a través de Internet han tenido la capacidad de fusionar la actividad profesional chilena con otras del resto del mundo contribuyendo a generar en los lectores y visitantes de la web el efecto de una "conexión" de relevancias equivalentes. Este efecto, principalmente en las generaciones más jóvenes

150 "Chile, un país que -según su último Censo- tiene un arquitecto por cada 667 [habitantes]" (Quirk, abril 30, 2014). Anualmente se titulan 1.213 arquitectos (MINEDUC, 2016) y la tasa de natalidad es de 1,77 hijos por mujer (Banco Mundial, 2016).

Figura 4.24. Carlos Martner (1971). Piscina Antilén. Santiago, Chile. Por Instituto chileno de arquitectos paisajistas (ICHAP), 15 de enero, 2019.

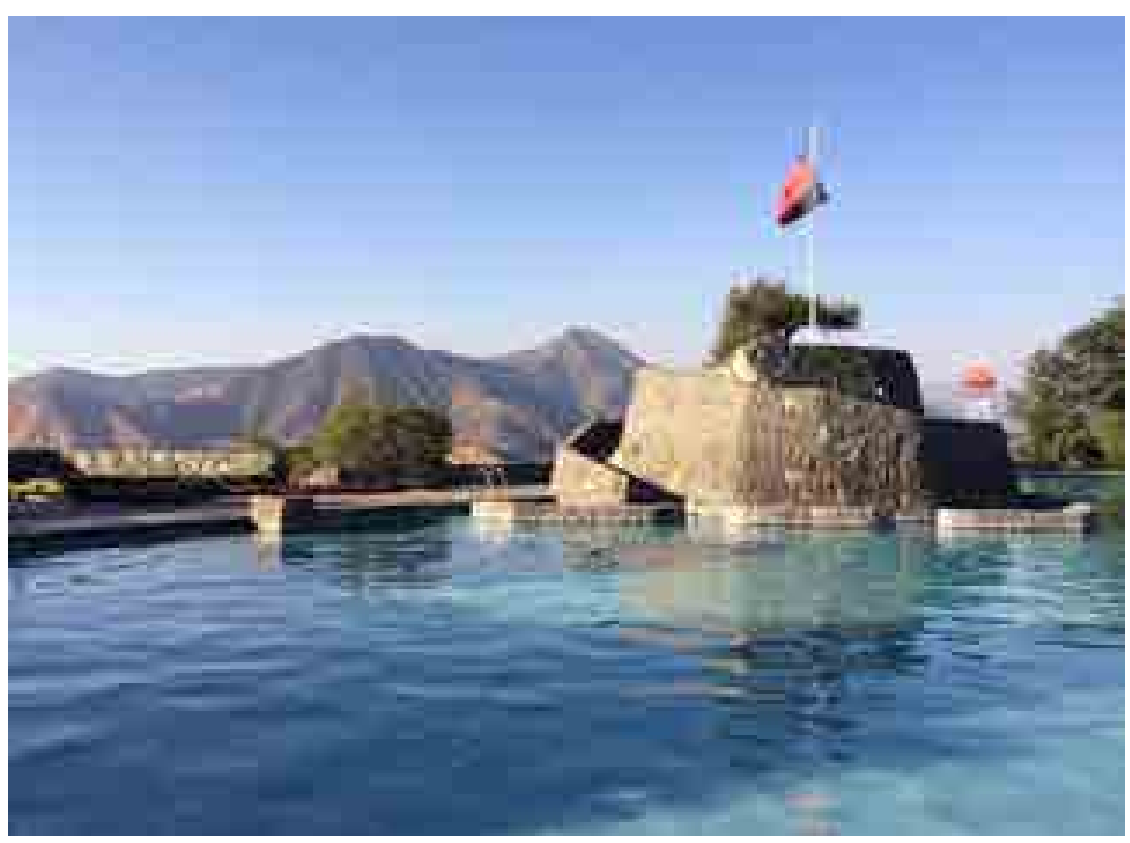


de arquitectos chilenos, ha contribuido psicológicamente a anular el efecto del aislamiento cultural chileno. A esto se suma la participación cada vez más frecuente y destacada de arquitectos en muestras y bienales internacionales.

Este fenómeno de apertura somete entonces a los arquitectos a las tensiones propias de la globalización, con la obligación de cuestionarse acerca de la identidad propia e, incluso, acerca de cuál es el aporte que la arquitectura chilena puede hacer al resto del mundo. Hasta aquí, la respuesta, ha sido la construcción de un discurso que caracteriza lo chileno con "lo remoto", y lo remoto con el paisaje. Hasta aquí, también, ese discurso ha cumplido bien su papel en el ámbito del turismo y de la promoción comercial de una imagen de la arquitectura chilena en el paisaje.

En la publicación Blanca Montaña, Miquel Adrià, curador de la muestra y editor del libro expresa:

La arquitectura chilena nace y se desarrolla en el paisaje. Esta exposición da cuenta al mundo de la riqueza de la cultura arquitectónica chilena, donde lo extraordinario forma parte de lo cotidiano. Es una retrospectiva de un período sumamente prolífico, donde Chile, después de una constante existencia marginal, irrumpe con la arquitectura más interesante de todo el continente americano (Adrià, 2013, p. 24).

Salvo algunos casos como Alejandro Aravena ${ }^{151}$, con ELEMENTAL, que incursiona en la vivienda social, la arquitectura chilena de exportación muestra principalmente obras singulares en parajes remotos en la inigualable diversidad de paisajes chilenos que van desde el desierto de Atacama a la Patagonia, y desde la cordillera al mar. La arquitectura de la ciudad, sin embargo, no aparece. Cabe preguntarse si esto se debe a que no hay elementos que la caractericen y se ofrezcan como un aporte o bien, que los edificios en contextos urbanos no recogen los valores de una arquitectura situada, que sí están presentes en la arquitectura no-urbana, esa que se publica, esa que se valora internacionalmente.

Si bien esta estrategia ha resultado más o menos verosímil en el ámbito de la "exportación" de una imagen publicitaria, las bases de ese discurso de venta contienen algo digno de ser desarrollado en mayor profundidad.

Entre los arquitectos más citados internacionalmente, está el arquitecto chileno Germán del Sol cuya obra inaugura esta nueva visión, pudiendo establecer un hito inaugural con el pabellón de Chile para la Exposición Internacional de Sevilla en 1992.

Sus obras se emplazan en diversos paisajes, integrando aspectos físicos, culturales, históricos y estéticos, caracterizándose por ser intervenciones mínimas que sin embargo son capaces de funcionar a múltiples escalas; desde los objetos que acompañan la experiencia del propio cuerpo, las texturas y los colores; las pasarelas y recorridos y la escala geográfica que se manifiesta en lo pequeño y en lo grande.

El proyecto turístico Explora, desarrollado desde el año 1988, es muestra de que el trabajo de este arquitecto va más allá que el diseño de edificios. El sitio web de Germán del Sol describe el alcance de su acción profesional:

Creación, dirección y realización del proyecto 'explora', empresa dedicada a promover viajes a lo remoto y a mantener vivas sus culturas, que incluyó proyecto de viajes a 5 destinos de Chile, búsqueda y compra de terrenos, proyecto de arquitectura, diseño interior, paisajismo, diseño de muebles, tapices, telas, mejora de artesanías, diseño y dirección de los paseos, marketing y administración de los hoteles. (Sol, s.f., germandelsol).

El año 2002 se monta una gran exposición en la Sala de Arte de Fundación Telefónica en Santiago con el título Explora: las 7 tesis. La instalación del artista Guillermo Tejeda sintetiza lo que esta iniciativa propone:

Explora ha propuesto al mundo un nuevo concepto de viajar a partir de Chile y lo remoto [...] bajo 7 preceptos: nostalgia de lo remoto, empiece por los deta- 
Iles, Chile tiene valor, sólo lo esencial es el verdadero lujo, la aventura es cualquier día, la libertad del viaje, explora. Una experiencia vital (Tejeda, 2002, p. 2).

Pero, ¿a qué se refieren con remoto? Como adjetivo en español, el término remoto, cuya raíz etimológica viene del latín remōtus, participio pasado de removēre (retirar, apartar), significa distante, apartado en el tiempo y el espacio. Lo remoto alude a lo solitario, a la falta de referentes antropizados y al deseo de encontrar una naturaleza virgen.

El paisaje remoto se encuentra entonces entre ese deseo de naturaleza virgen y la arquitectura como punto de llegada-refugio y como punto de partida, como lugar. La arquitectura de este modo hace posible habitar ese paisaje, no sólo contemplarlo.

Lo remoto exige una definición de la escala, un criterio de medida y un "respecto a qué". Cabe preguntarse aquí, quién es el sujeto de lo remoto. Sin duda, no es el sujeto del lugar, sino aquel que viene de "afuera", más aún, para el que viene de lejos, muy lejos. Lo remoto contiene entonces también la escala del viaje, de las grandes distancias, la de las naves. Escalas que afectan la percepción del tiempo y del espacio, una experiencia existencial ya que como plantea Careri:

En la base del viaje hay a menudo un deseo de mutación existencial. Viajar es la expiación de una culpa, una iniciación, un acrecentamiento cultural, una experiencia: "la raíz indoeuropea de la palabra "experiencia" es per, que ha sido interpretada como "intentar", "poner a prueba", "arriesgar", unas connotaciones que persisten en la palabra "peligro". (Careri, 2014, p. 34).

Un ejemplo muy difundido y que puede ilustrar esta idea es el proyecto de Las Termas Geométricas (Figura 4.25.). Este proyecto del año 2009, está ubicado en el camino de Coñaripe a Palguín dentro de un parque nacional, en la Región de los Lagos. El año 2014 recibió el premio del público asistente en la $8^{\circ}$ Bienal Europea de Paisaje en Barcelona, valorado a través de la fotografía. Su autor, el arquitecto chileno Germán del Sol lo describe así en la memoria:

Bañarse en una terma, tal vez sea la mejor actividad que se puede hacer al aire libre con gusto todos los días del año, porque está en su plenitud en el frescor del bosque si es verano, o si amanece, llueve, nieva, o empieza a oscurecer; las Termas Geométricas aprovechan sesenta y tantas fuentes de pura agua caliente termal, que suman más de 15 litros por segundo y que brotan naturalmente a $80^{\circ}$ de temperatura, en una quebrada antes inaccesible, en medio de los bosques nativos del Parque Nacional Villarrica, en el kilómetro 13,5 del camino que cruza el parque entre Coñaripe y Pucón.

Para bañarse a gusto, se tallaron 20 pozones a lo largo de 450 metros de quebrada, en medio de la naturaleza brutal, a los que se llega por una pasarela de madera de coigüe teñido de rojo; una rampa continua sin peldaños, que permite recorrer la quebrada con confianza, y dispersarse entre los pozones, para elegir un rincón más o menos privado para bañarse, sin tropezar de noche gracias a

Figura 4.25. Termas Geométricas. Coñaripe, Chile. Obra del arquitecto Germán del Sol (2009). Por Guy Wenborne en Plataforma Arquitectura [web], 24 de diciembre, 2014.

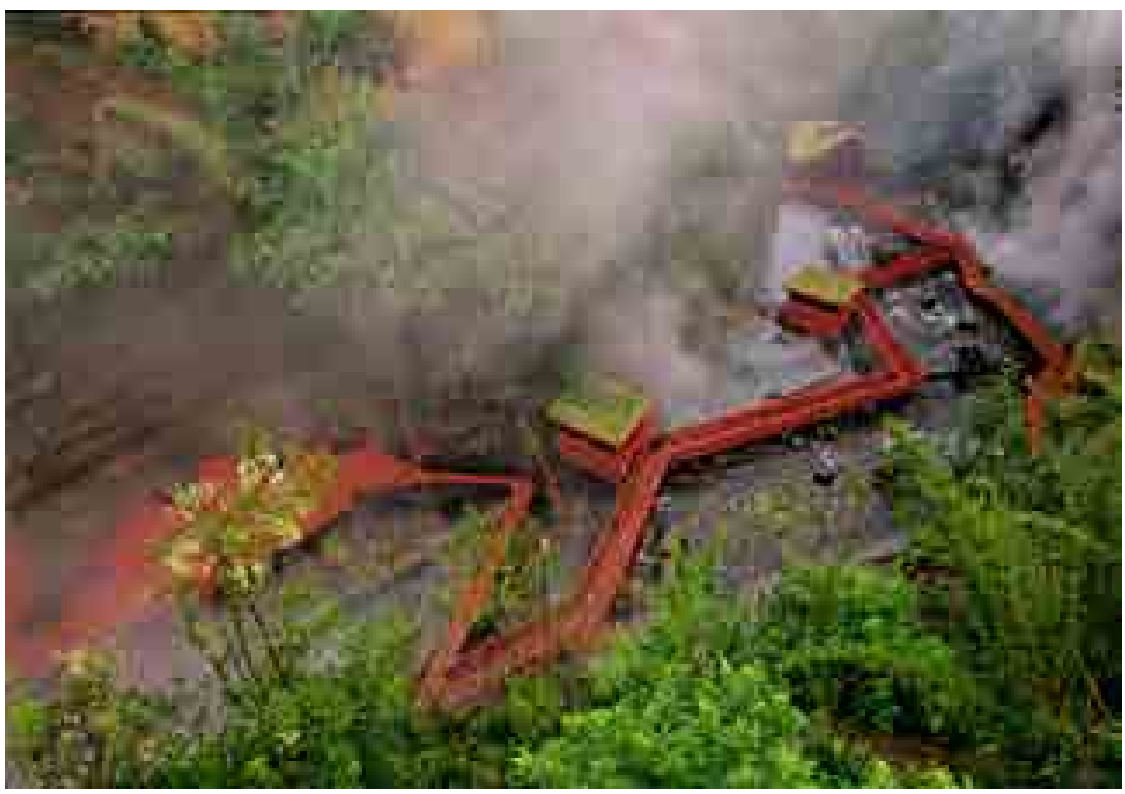


la luz de las velas, ni resbalar en el hielo o la nieve que se derriten con el agua termal que entibia la pasarela corriendo por debajo en unas canoas de madera que la distribuyen a todos los pozones.

Hay un quincho construido con pura madera de coigüe ensamblada, sin clavos, invita a sentarse a conversar después de bañarse, en un espacio cubierto y tibio, alrededor de un gran fuego abierto.

Esta experiencia quizá llega a su esplendor, porque la arquitectura de lo construido, tosca y precisa, permite despreocuparse, y gozar el placer de bañarse o mirar.

La geometría destaca lo que es natural, y lo separa de lo construido.

Esta arquitectura distingue al lugar, y quizá lo hace irrepetible (Sol, s.f., memtg)

Tanto en el relato, como en la obra, podemos reconocer tres puntos de vista que vinculan las diferentes escalas del proyecto: Desde afuera, desde el paisaje y sus preexistencias ecológicas y culturales; Desde adentro, desde la arquitectura y desde el sujeto que recorre.

Podríamos decir que la experiencia desde afuera en la obra de Germán del Sol se inicia con la fotografía de Guy Wenborne, que la anticipa. Las imágenes de las termas, de la rampa zigzagueante entre los árboles y el vapor. Capturan una secuencia de imágenes, sin intentar dar una vista sintética del total. El bosque nativo y el fluir del agua prevalecen sobre la estructura de las pasarelas rojas próximas al Land-Art. Como el Land-Art, la obra deja su traza en la naturaleza, estructurando un nuevo paisaje que surge de la capacidad de interpretación de la misma. El trazado de las pasarelas obedece al curso de agua y la posibilidad de formar las piscinas manteniendo al menos una de las caras en roca viva, elevada para dejar que el suelo y su biodiversidad se mantengan.

Desde la arquitectura, se altera la clásica tensión entre la forma construida y el contexto, que implanta (o impone) un objeto arquitectónico en el paisaje, para ser sustituida por una estructura que es el resultado de las reglas que impone el lugar, dando más importancia a las relaciones que a las formas preconcebidas, 0 aquellas cuya génesis es una interpretación metafórica del programa. Este modo de entender la generación de la forma, propone una relación dialógica entre arquitectura y paisaje, donde la tensión es reemplazada por la concurrencia de esta dualidad arquitectura-paisaje. Surgen así configuraciones espaciales y formales abiertas, que atraviesan un espacio unido a un continuo ilimitado, lo que da por resultado una obra singular pero simbiótica. Única, en un paisaje único, irrepetible.

La arquitectura encuentra su forma en el paisaje y al construirse, transforma el paisaje. Un proceso abierto, que Del Sol explora conscientemente: "por eso busco lo que se presenta de manera inacabada. Repetir, si fuera posible, la gracia de las cosas que todavía están en potencia" (Sol, 2009, párr. 4).

Entender así la relación entre arquitectura y paisaje, como causa y efecto, donde este efecto es causa también de una nueva realidad, significa concebir la obra dentro de un proceso y no sólo como un resultado. Diseñar sería entonces dar forma a un proceso, lo que se presenta de una manera inacabada, haciendo palpable que se trata de una "operación en curso".

En este contexto, el programa se entendería como un guion de las experiencias de habitar un lugar en particular. Una arquitectura sin centro que se desarrolla en el recorrido, como soporte de la sucesión de perspectivas y percepciones sensoriales en el tiempo. Un tiempo que, como señala Pallasmaa nos suspende en dos escalas ya que "como seres biológicos, estamos genéticamente apegados al lento ritmo de la evolución, pero al mismo tiempo, vivimos en el tiempo cada vez más acelerado de la cultura."152 (Pallasmaa, 2005, p. 311).

La experiencia de este recorrido, apela al hombre biológico que aún reside en nuestro cuerpo, que demanda la libertad de andar, también de detención y silencio.

Lo anterior, trastoca lo que habitualmente entendemos por programa, la declaración (o "demanda escrita" para Germán del Sol, 2009, párr. 15) de aquellas partes 0 actividades que conformarán un proyecto, que se representa normalmente
152 Traducción propia del texto en inglés: "as biological beings, we are genetically attached to the slow time of evolution, but at the same time, we live in the ever-accelerating time of culture." 
en un listado de necesidades y que finalmente encuentra su manifestación más elocuente en la planta de arquitectura. Se amplía de este modo, la idea del programa como expresión de la función (utilitas) de la arquitectura, que ha definido el límite entre la arquitectura y otras disciplinas como el arte o la ingeniería que también intervienen materialmente en un lugar.

Cabe preguntarse si en este caso, podemos hablar de función a secas, o bien este término debe, en este caso, adjetivarse como lo hiciera Alvar Aalto con su idea de un funcionalismo psicológico, aventurándonos a la posibilidad de un funcionalismo existencial, que dé cuenta de la experiencia (la calidad) de esas funciones en un lugar determinado. En este, como en otros proyectos de Germán del Sol podríamos identificar la función de recorrer, como la estructurante de las demás experiencias, que contiene al mismo tiempo, como sugiere Careri ${ }^{153}$ "al acto de atravesar (el recorrido como acción de andar), la línea que atraviesa el espacio (el recorrido como objeto arquitectónico) y el relato del espacio atravesado (el recorrido como estructura narrativa)" (2014, p. 19), a lo que podríamos agregar su capacidad de articular las diversas escalas.

Una arquitectura multiescalar sería aquella que aborda la realidad material diluyendo los límites establecidos en la mirada clásica de las disciplinas como compartimientos estancos, donde las escalas se presentan "sin aglutinante". En ella, el diseño de detalles, y del espacio arquitectónico remitiría al lugar donde está emplazado, daría sentido a "estar ahí", superando la relación de "soporte" que se atribuye habitualmente al contexto donde se desarrolla, para ser parte de esa construcción que sería el paisaje, como un todo mayor, que a su vez es parte de lo que llamamos naturaleza, extensa e infinita.

El diseño multiescalar implicaría entender el paisaje como una entidad que contiene las partes y al mismo tiempo es contenido del diseño de los objetos, los detalles y el espacio arquitectónico.

El diseño en un paisaje haría de éste el contenedor activo de las partes y a la inversa, el diseño de los objetos y el espacio contendrían también algo de la lógica que distingue a ese paisaje, ya sea en su realidad material como social o simbólica, permitiéndonos comprender el lugar donde estamos, en toda su complejidad. Esta complejidad hace necesario también ampliar, expandir la mirada disciplinar de la arquitectura y concebirla necesariamente en un contacto más cercano e íntimo con disciplinas que actúan en el mismo territorio.

El análisis de una obra, entendida como la trasformación de un paisaje aportaría una perspectiva, que entiende a la arquitectura dentro de un proceso más amplio. La arquitectura del paisaje tiene la capacidad de convertirse en algo más que una respuesta construida a un sitio; puede abrir una ventana de posibilidades e interpretaciones que van más allá de las fronteras físicas y provocan estímulos estéticos y emocionales. La pregunta que surge es entonces es, ¿cómo los arquitectos somos capaces de abordar esta perspectiva en nuestros proyectos? Las ideas planteadas por Georges Descombes (1999) en su ensayo Shifting Sites pueden darnos algunas pistas, cuando nos propone transformar, quitar cosas, encontrar o revelar lo que está latente:

${ }^{153}$ Careri nos recuerda, además, que "Solo en el siglo XX, al desvincularse de la religión y de la literatura, el recorrido ha adquirido el estatuto de puro acto estético" (2014, p. 15)

${ }^{154}$ Traducción propia del inglés:

My work is essentially about achieving such shifts in complexity with minimum means. I aim to discover all that is possible to accomplish when an occasion is offered or created-discovering, in the process, all that I did not know before. Thus, I aim for a precision of disposition, articulation, arrangement- architecture- so that a preexisting place can be found, disturbed, awakened, and brought to presence.

\begin{abstract}
Mi trabajo consiste esencialmente en lograr tales cambios en la complejidad con un mínimo de medios. Mi objetivo es descubrir todo lo que es posible lograr cuando se ofrece o se crea una ocasión -descubriendo, en el proceso, todo lo que antes no conocía. Por lo tanto, busco una disposición precisa, articulación, arreglo -arquitectura- para que un lugar preexistente pueda ser encontrado, perturbado, despertado, y llevado a la presencia. ${ }^{154}$ (Descombes, 1999, p. 79)
\end{abstract}

Esta forma de diseño experiencial y experimental requiere una gran capacidad de observación, modestia y delicadeza. Más cercana al trabajo de tallar sobre la madera, donde necesariamente debemos conocer y seguir a la materia, el sentido de sus fibras y sus nudos para darle forma. Por otro parte, este modo de abordar un diseño considera la condición humana de un proyecto, entendiendo los recuerdos y rastros colectivos de un terreno, y también la forma en que establecemos un diálogo con un lugar, recuperando la relevancia del movimiento, textura, color, olor y puntos de vista que están dispuestos en un territorio. En 
otras palabras, el diseño de la experiencia, sugerido por la relación entre el sitio y los usuarios.

En una época que exige el control y el orden de cada esfuerzo, este modo experiencial de proyectar parece ir en sentido contrario, incorporando la incertidumbre. El enfoque de diseño a través computador, donde todo se mide, controla y define, ha eliminado algunas de las prácticas de diseño más sensatas y táctiles. Hay un potencial en el diseño impulsado desde el sitio y no desde la pantalla. La importancia de dibujar a mano en el sitio como una herramienta de observación, análisis y filtro para las decisiones tiene la posibilidad de reposicionarnos como sujetos en el diseño y distanciarnos prudentemente de las metodologías que sólo recurren a las técnicas de mapeo basadas en la información instrumental (objetiva). Proponemos así, un método alternativo de diseño que concilie la experiencia subjetiva del arquitecto y las herramientas tecnológicas que capturan la información del sitio.

Otro ejemplo local de esta aproximación, es el proyecto de Punta Pite (2005), un sendero en la zona costera de Chile realizado por la arquitecta Teresa Moller y que se muestra en la Figura 4.26. Este diseño se realizó completamente in situ, iniciándose con una estadía de la arquitecta en el lugar. Los primeros meses solo estudió y experimentó la costa y los roquedales, para luego con un grupo de artesanos, construir un sendero sin planos, sólo a través de las instrucciones verbales dadas en terreno. Todo el material provenía de allí, utilizando sólo la costa rocosa y cambiando sus condiciones, intensificando sus materiales.

El proyecto esculpe la piedra para llevar a la gente a través de un paisaje indómito, abriendo nuevos horizontes a sus habitantes, reconectándolos al mar y su inmensidad.

Ambos proyectos mencionados nos sugieren un modo de abordar el sitio y sutilmente cambiar sus condiciones. Se presentan en su simplicidad y límites, en los que subyacen la complejidad y la intensidad de las relaciones. Podríamos hacer una analogía con el poema haiku, donde la estructura de palabras simples abre un mundo poderoso y complejo de significado e interpretaciones, la observación cuidadosa en el sitio y el cambio preciso de lo allí está latente, pueden servir como una forma de liberar al diseño para un nuevo espectro de experiencias y lecturas.

Cabe recordar que, en Chile la Escuela de Arquitectura de la Universidad Católica de Valparaíso, desde su fundación en los años sesenta, convirtió el tema de la experiencia del viaje por el territorio en un factor clave de la formación de los y las arquitectos(as). Su travesía inconclusa llamada Amereida explora la identidad sudamericana a través de un itinerario de experiencias y huellas desencadenadas por intervenciones poéticas, como un testimonio de los descubrimientos que los estudiantes hacen durante su viaje. La exploración se entiende como un proceso consciente, de reconocimiento espacial y temporal del aprendizaje que imprime la condición americana en el paisaje.

\subsection{ESTRATEGIAS DE TRANSFORMACIÓN DESDE EL ARTE}

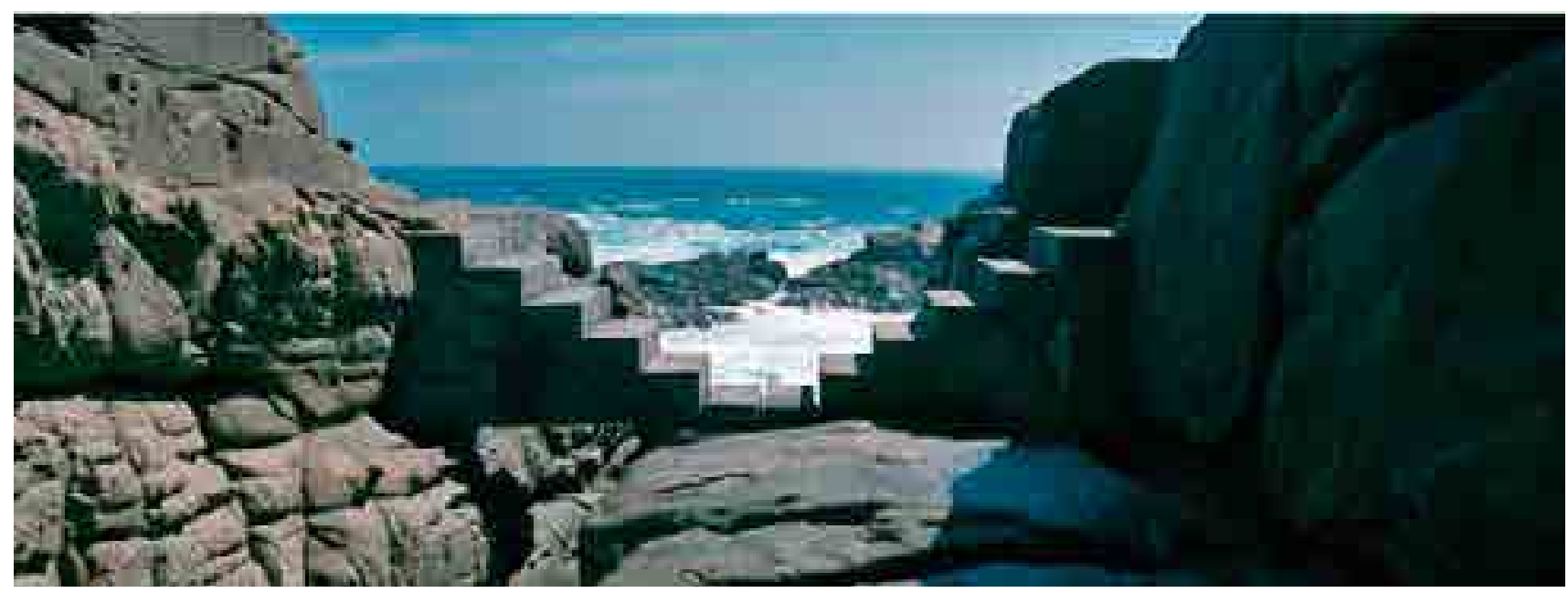

Figura 4.26. Teresa Moller (2005). Punta Pite, Chile. Fotografía de Francisco Allard (2009). 
El fenómeno cultural que hemos analizado en Chile a través de la obra de Germán del Sol y Teresa Moller, es sincrónico con el surgimiento de un nuevo interés en el mundo occidental por el paisaje a partir de los años 1990. Sin embargo, podemos reconocer que esta sensibilidad aparece mucho antes en el arte, en la década de los 60, en lo que A. Bonito Oliva denomina la transvanguardia:

una tendencia capaz de recuperar el genius logi -las raíces del territorio cultural del artista- y de proyectar las citas del pasado en el presente", superando el "puro experimentalismo de técnicas y materiales [para devolver al proceso creativo] un intenso erotismo y el espesor de una imagen que no se prive del placer de la representación y de la narración". (Bonito Oliva, citado por Guasch, 2000, p. 276).

Así como la geografía entregó nuevas herramientas interpretativas, para comprender el paisaje, los artistas mostraron las estrategias para su transformación. Si bien la arquitectura y la escultura han compartido el paisaje a lo largo de la historia, la escultura toma un derrotero propio a partir de los años 1960, especialmente en Inglaterra y Estados Unido, donde se confunden y cruzan los artistas povera, minimalistas, pop, land art y earth art.

El artista abandona su taller y se aventura al campo 0 a la ciudad, situando sus obras en los paisajes naturales y periurbanos, en los bellos y también en los degradados. Renuncian así a la galería y al museo, a su dependencia de la arquitectura y también del mercado del arte. Los artistas del Land-art ${ }^{155} 0$ arte de la tierra, recuperan la antigua relación humana con el paisaje, traen las formas del pasado al presente, que recuerdan las líneas de Nazca, los grandes dibujos de los Cerros Pintados en el norte de Chile también las alineaciones de Stonehenge, con obras permanentes y muchas de ellas efímeras. Otras, sin embargo, invocan

155 Land art fue un término creado por Walter De Maria para definir sus primeras intervenciones en espacios naturales, luego fue usada para la exposición Land Art (1969) que agrupaba la obra de diversos artistas como Long, Oppenheim o Smithson (en 1968 se había realizado una exposición en Nueva York titulada Earthworks). Richard Long y Michael Heizer, rechazaron encasillarse bajo este nombre, sin embargo, la historia del arte contemporáneo los incluye dentro del mismo movimiento.

${ }^{156}$ Entrevista a Richard Long realizada por Carolina Castro Jorquera

${ }^{157}$ Circle of Sticks 1973 (Tate T01783) es un círculo compuesto de setenta y seis ramitas de Leigh Woods, ubicado cerca de Bristol (casa de Long), colocadas de punta a punta en el piso de la galería, delineando el contorno de un círculo. Small White Pebble Circles 1987 (Tate T07160) comprende cinco círculos concéntricos de guijarros de mármol blanco. Slate Circle 1979 (Tate T03027) y Norfolk Flint Circle 1990 (Tate T06483), al igual que South Bank Circle, son círculos sólidos hechos en el suelo utilizando piedras más grandes adquiridas en canteras.

${ }^{158}$ Traducción propia del inglés:

I think circles have belonged in some way or other to all people at all times. They are universal and timeless, like the image of a human hand. For me, that is part of their emotional power, although there is nothing symbolic or mystical in my work. (citado por Brettell y Friis-Hansen, 1996, p.30). el poder del hombre de destruir su medioambiente.

La fotografía y la cartografía se convierten en herramientas que extienden la espacialidad de la obra en el espacio real, mientras que el cuerpo en movimiento permite capturar la escala geográfica. Es el caso del artista británico Richard Long que describe así la interacción entre la presencia de su propio cuerpo en el paisaje:

[...] ese es el centro de mi trabajo. Estar en ese lugar, en ese tiempo, en ese momento. Así que, si hago una escultura en un hermoso lugar en un paisaje remoto, es la celebración de estar en ese lugar. Se trata del aqui y el ahora"156 (Castro Jorquera, 18 de agosto, 2014)

Long desarrolla su trabajo en caminatas al aire libre en la naturaleza, a menudo en lugares remotos. La manifestación visible de la obra de arte toma variados formatos. Además de organizar los objetos encontrados en su paseo a lo largo del camino, tal como lo hicieron los hombres prehistóricos, desde finales de los años sesenta, Long ha introducido elementos orgánicos en los espacios de las galerías y los museos ${ }^{157}$. Allí como en sus paseos, los compone en configuraciones geométricas tales como círculos, líneas rectas y cuadrados en espiral. Intenta de este modo traspasar fronteras culturales y generacionales al conectar estructuras geométricas, especialmente círculos con elementos naturales, lo que explica del siguiente modo:

Pienso que los círculos han pertenecido de una manera u otra a todas las personas en todo momento. Son universales e intemporales, como la imagen de una mano humana. Para mí, eso es parte de su poder emocional, aunque no hay nada simbólico o místico en mi trabajo ${ }^{158}$ (Long, citado por, Brettell \& Friis-Hansen, 1996, p. 30).

Es en Estados Unidos donde más claramente estas vanguardias funden el arte y el activismo ecológico, poniendo en evidencia los logros y fracasos de la modernidad, es por esto un arte con claro compromiso político y social, que denuncia la precariedad de un mundo y su degradación. Usan máquinas para hacer grandes movimientos de tierra, modelando la topografía, cavan zanjas, graban surcos o levantan nuevas cimas. Todas ellas son una mezcla de puesta en escena y 
representación, teoría y práctica, estética y activismo.

Un elocuente ejemplo es la obra Anillos Anuales (Annual Rings, 1968) de Dennis Oppenheim (1938-2011) quien amplió y trazó paleando sobre la nieve, los patrones de crecimiento del árbol sobre las dos riberas congeladas del río que divide Estados Unidos y Canadá, y que pasa por el meridiano que divide sus zonas horarias. Yuxtapone de este modo, las fronteras temporales y nacionales creadas por el hombre, cuestionando los valores y los sistemas de ordenación que nosotros mismos nos hemos impuesto. Establece un juego entre el muy lento tiempo de crecimiento de las plantas, transpuesto gráficamente en un material fugaz: la nieve. Esta lógica de transferencia se ve reforzada por la elección de un lugar que simboliza el tiempo convencional de las zonas horarias y se caracteriza por el rápido ritmo del agua del río (Figura 4.27.). Esta tendencia a enfatizar los límites, ya sean temporales, espaciales o de comportamiento, es una característica constante del arte de Oppenheim ${ }^{159}$.

Como esta, muchas producciones de Land Art poseen una existencia temporal, ya que la obra es efímera y sólo perdura a través de rastros fotográficos complementados por elementos relacionados con el sitio a través de la cartografía. De este modo, como señala Jean-Marc Besse (2009), las obras del land art ponen de manifiesto las dimensiones reflexivas y creativas de la cartografía; revelando, además, cómo "el mapa transmite mucho más que una mera intención de representación, y cómo es también un proyecto de interpretación y transformación del territorio." (Besse, 2009, p. 150).

La idea de que el mapa permite reconstruir mentalmente el territorio, está presente también en la obra de Robert Smithson, a través de su operación dialéctica site y no-site. Sus intervenciones fueron emplazadas en una naturaleza postindustrial, denominándolas ruinas en reversa (ruins in reverse). En sus palabras: "Esto es lo contrario de la "ruina romántica" porque los edificios no caen en ruina después de haber sido construidos, sino que se levantan como ruinas antes de haber sido construidos"160 (Smithson, 1967, p. 55). El "no-sitio" puede ser un mapa, un texto, una instalación, que se refiere al sitio. El sitio y el no sitio no son dos entidades distintas, sino estados diferentes del mismo fenómeno. Si llevamos esta idea a la arquitectura y consideramos al mapa como un recurso procesal y no solo instrumental, podemos encontrar que no es tan ajena esta dimensión de similitud y diferenciación revelada por la dialéctica del sitio y el no-sitio. La cartografía cada vez más usada arquitectura actual, como instrumento de exploración de nuevos territorios tanto físicos como digitales, también ofrece la posibilidad de revivir la antigua noción de periégesis ${ }^{161}$, como proceso que, al describir y recoger una realidad geográfica, humanizada y subjetivada, también la transforma.

La arquitectura del paisaje encuentra en las vanguardias artísticas de esta época una serie de recursos estéticos difíciles de clasificar: caminar como arte y el movimiento, presentes en la obra de Long y Fulton; El empleo de la tierra como material que hacen Smithson y Heizer o el sutil cambio de posición de piedras en los trayectos de Long; los vastos artificios en contraste con la naturaleza que despliegan Christo Jovachev y Jean Claude de Guillebon con sus telas, o el bosque de pararrayos de Walter María; la alusión al orden cósmico, con la orientación respecto a solsticios de Nancy Holt, o el uso del viento, el fuego y el agua; las citas a formas arcaicas presentes especialmente en Long (círculos) Smithson (espirales) Alice Aycock (laberintos); El tiempo y los límites en las obras de Oppenheim o el contraste con las formas puras bajo los principios de la Gestalt que están tras las obras minimalistas de Robert Morris y Richard Serra. Podemos reconocer la influencia del arte de la tierra en la obra Tadao Ando, Eric Miralles, Carmen Pinós, Charles Jencks, Maya Lin ${ }^{162}$ o Germán del Sol, entre muchos otros.

En una versión más prosaica, el arte se ha incorporado en las operaciones de recuperación de paisajes degradados y en los nuevos proyectos de obras públicas, que exigen llamar a concurso para dotar a los territorios afectados, de obras que resignifiquen los lugares e incorporen "valores estéticos". En Chile La Dirección de Arquitectura como organismo técnico asesor de la Comisión Nemesio Antúnez, convoca a concursos de Arte Público, para intervenir edificios y otras obras de infraestructura a lo largo del país. (Figura 4.28.)

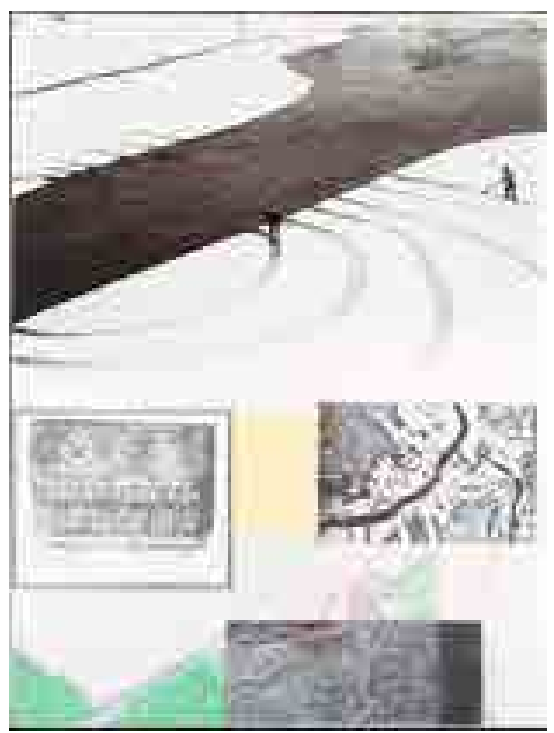

Figura 4.27. Annual Rings. Por Dennis Oppenheim (1968). En The MET Collection. (C) Dennis Oppenheim Estate

${ }^{159}$ Es en Annual Rings que el artista pone por primera vez las formas del círculo o la espiral, los mismos que expresan la idea primordial de la trayectoria y la circulación.

${ }^{160}$ Traducción propia del inglés: "This is the opposite of the "romantic ruin" because the buildings don't fall into ruin after they are built but rather rise as ruins before they are built."

161 Es un término de origen griego que consiste en una descripción en la cual, a lo largo de un itinerario geográfico, se "conduce" y recoge información sobre la historia, los pueblos, los individuos, las costumbres e incluso la mitología de los lugares que se atraviesan. En lo posible se transmite la experiencia directa del autor. Es un antecesor de la literatura de viajes. Se diferencia de los periplos, fundamentalmente, porque en estos últimos el fin es estrictamente utilitario (guía de los barcos en su navegación) y el itinerario, exclusivamente marítimo y unidireccional. (Pariégesis, s.f.).

162 Destacamos especialmente Confluence Project (2011) una instalación que explora la relación entre ecología, historia y cultura en el sistema del río Columbia y Storm King Wavefield (2007-2008), que trabaja la topografía, convirtiendo el terreno natural en un plano ondulante que tematiza la idea de naturaleza, como entidad en constante movimiento. 


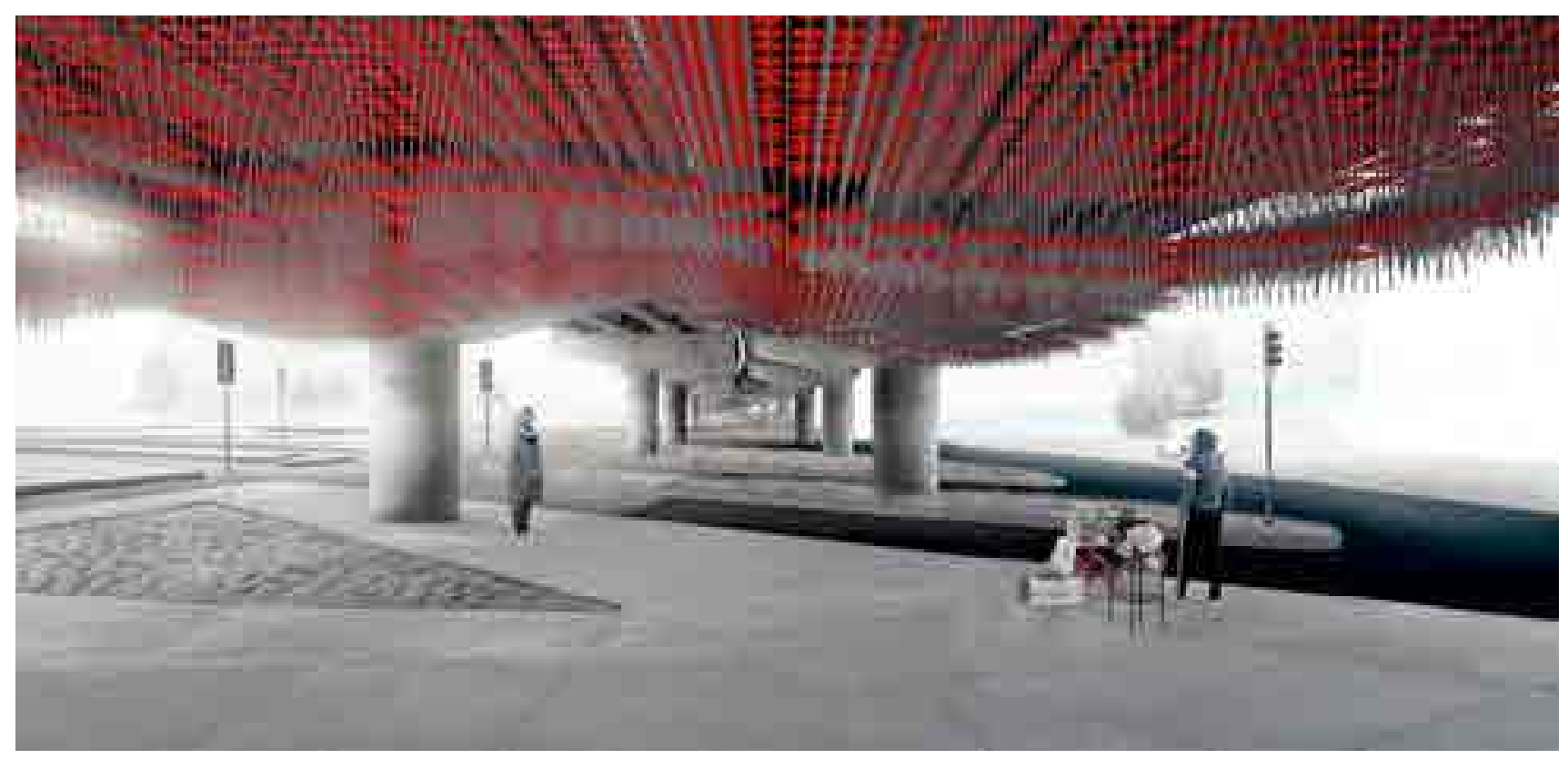

Figura 4.28. Benjamín Ossa (2016) intervención visual y sonora en el paso bajo nivel de General Velásquez en la Comuna de Renca, Chile. En ARTISHOCK, 27 de enero, 2016.

${ }^{163}$ La vida nueva, es un guiño a la primera obra conocida de Dante Alighieri (12651321) La vita nuova.

Figura 4.29. Raúl Zurita (1982). La vida nueva. En Gatopardo [web], 1 de marzo, 2019.
La singular obra del poeta chileno Raúl Zurita, que ya hemos presentado en el capítulo 3, recoge elementos del Land art, y nos recuerda que el arte de la tierra es político y que la poesía en Chile es también paisaje. Una poesía que cambia su soporte, primero es el cielo, luego la tierra. El año 1982, en plena dictadura, escribe quince versos sobre el cielo de Nueva York (Figura 4.29.). Usando la estela de humo de cinco aviones, obliga al espectador a levantar la mirada para leer su poema La vida nueva ${ }^{163}$ :

MI DIOS ES HAMBRE/ MI DIOS ES NIEVE/ MI DIOS ES PAMPA/ MI DIOS ES NO/ MI DIOS ES DESENGAÑO/ MI DIOS ES CARROÑA/ MI DIOS ES PARAÍSO/ MI DIOS ES CHICANO/ MI DIOS ES CÁNCER/ MI DIOS ES VACÍO/ MI DIOS ES HERIDA/ MI DIOS ES GHETTO/ MI DIOS ES DOLOR/ MI DIOS ES/ MI AMOR DE DIOS. (Zurita, 1982, p. 13-20).

Once años después interviene sobre el Desierto de Atacama, con una obra que sólo puede leerse desde el cielo (Figura 4.30.). Con la misma fascinación que Richard Long sintió por las líneas de Nazca, Zurita reedita los geoglifos del norte de Chile trazando sobre el desierto su poema Ni pena ni miedo (1993) aproximándose a las lógicas del Land Art.

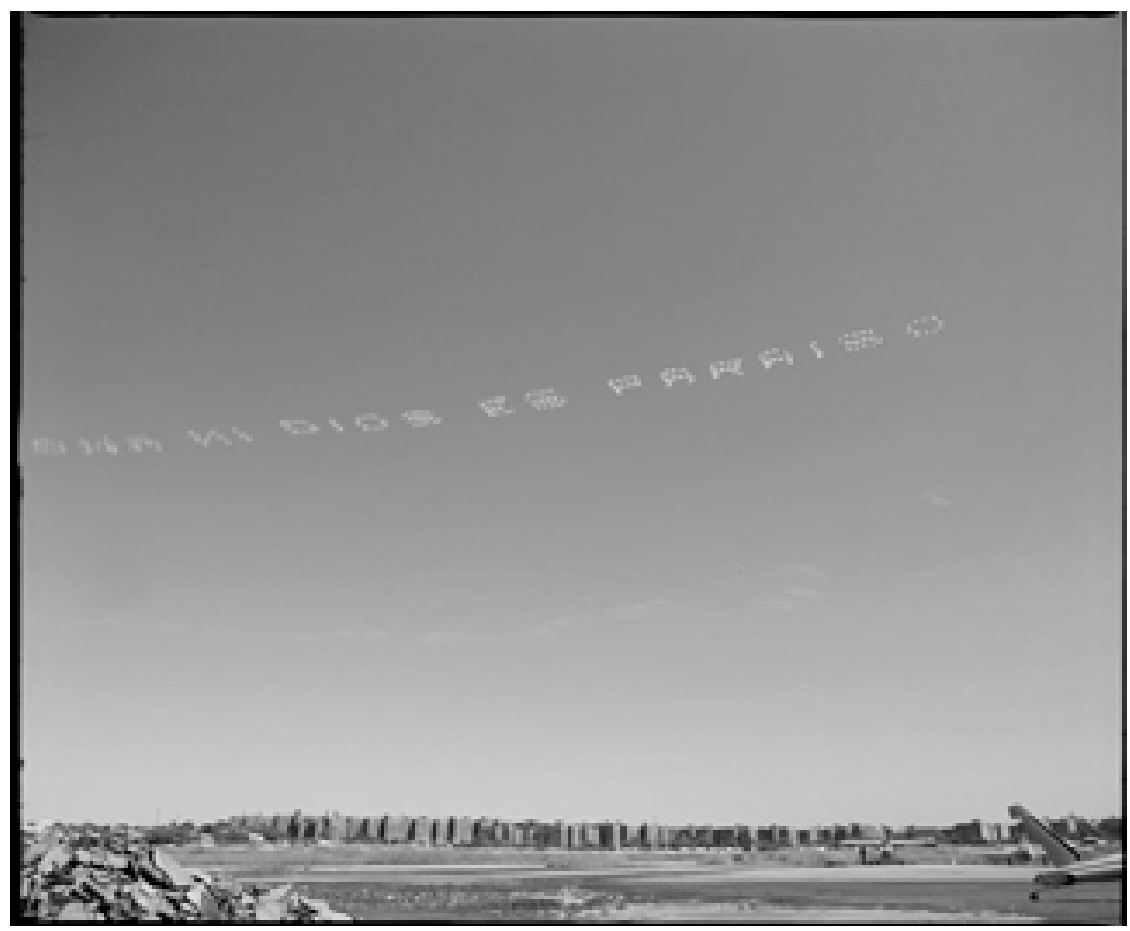




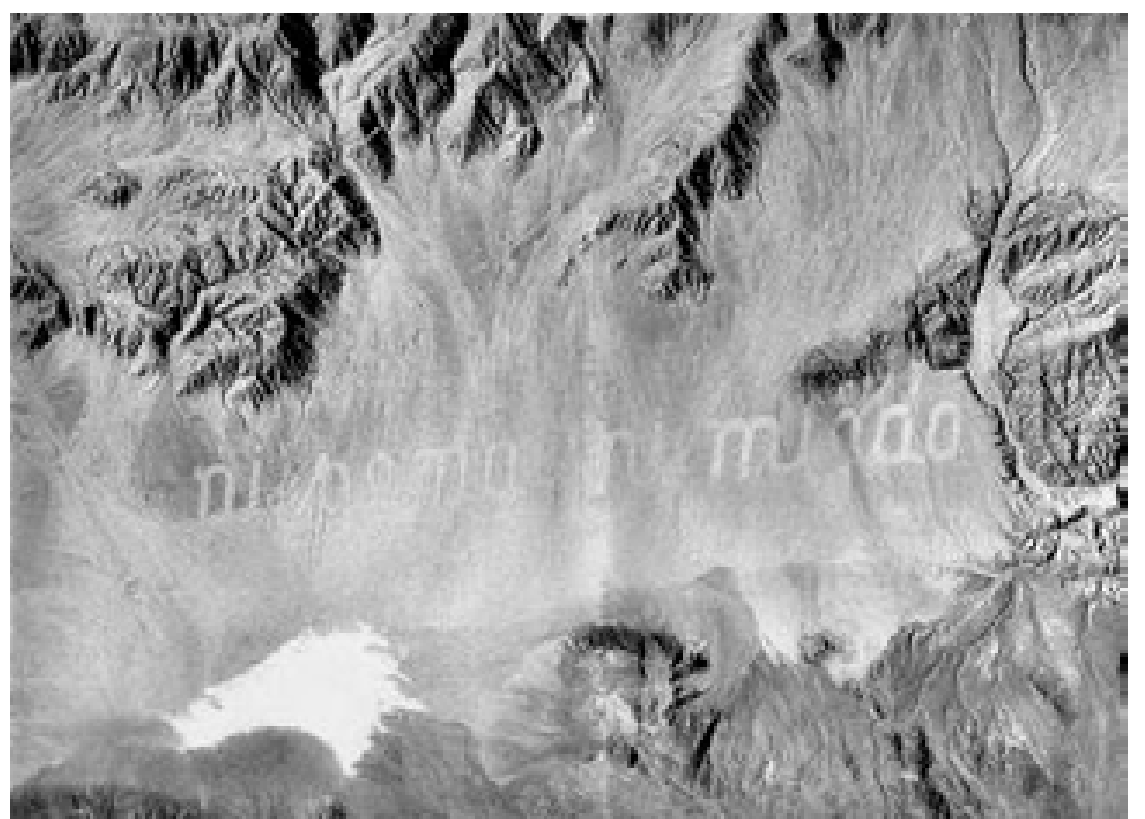

Para comprender esta acción de arte, debemos recordar que Zurita fue uno de los poetas chilenos más radicales y comprometidos con la resistencia a la dictadura de Pinochet y esta obra, realizada ya en democracia, propone una nueva "épica para un país éticamente destruido, incapaz de asumir su pasado inmediato" (Rojas, 2015, s.p.), resonando como un grito solitario en el desierto que habla de pasado y porvenir: del dolor de un país lastimado y la esperanza de que el amor repare las heridas, como expresa el mismo Zurita en el poema Pastoral:

\author{
Chile entero es un desierto \\ Sus llanuras se han mudado y sus ríos \\ están más secos que las piedras \\ No hay un alma que camine por sus calles \\ y sólo los malos \\ parecieran estar en todas partes \\ ¡Ah si tan sólo tú me tendieras tus brazos \\ las rocas se derretirían al verte! (Zurita, 1982, p. 95).
}

Han pasado 25 años, el paso del tiempo ha ido borrando parte de este poema-geoglifo, como podemos observar introduciendo las coordenadas $24^{\circ} 2^{\prime} 49^{\prime \prime} \mathrm{S}$ $70^{\circ} 26^{\prime} 43^{\prime \prime} \mathrm{W}$ en el buscador de Google Earth. Raúl Zurita también lo advierte:

En un mundo donde lo más presente es la pena y el miedo, esa frase creo, es el único deseo vigente. En todo caso es increíble, el desierto donde está escrita se encargó de borrar todas las palabras salvo la palabra miedo. Es para mí demasiado elocuente. (Zurita, entrevistado por Lavquen, 24 octubre, 2003).

Pero el paisaje no es sólo un palipsesto, su obra poética, especialmente, la trilogía Purgatorio (1979), Anteparaíso (1982) y La vida nueva (1994), habla del "amor de Chile" recorriendo sus paisajes desde los desiertos, playas, las cumbres de los Andes; le canta a las piedras, los pastizales, los valles, los torrentes y los glaciales, ya que como el mismo Zurita confiesa: "Mi obra transita desde lo íntimo hasta la gran escala del paisaje, que para mí también es una dimensión íntima" (Gabler, 8 de octubre, 2017).

El arte en el paisaje revela así su potencial asociativo desde la experiencia íntima a la épica, desde el cuerpo a la geografía, despertando sentimientos de amor, dolor y resistencia, que en otro momento se representaron a través de alegorías. La transformación del paisaje tiene esa capacidad de evocar el pasado, pero también proyectarse al futuro; de proyectar los deseos, también los temores.

Sin intenciones artísticas, hemos creado paisajes desoladores, que sin embargo 
Figura 4.31. Hospital Roy H. Glover de Chuquicamata sepultado por los desechos mineros. En Hospital Chuquicamata [weblog de wordpress], 28 de julio, 2003.
164 Publicado póstumamente un año después del Jardin de plaisir de su hijo más famoso, André Mollet.

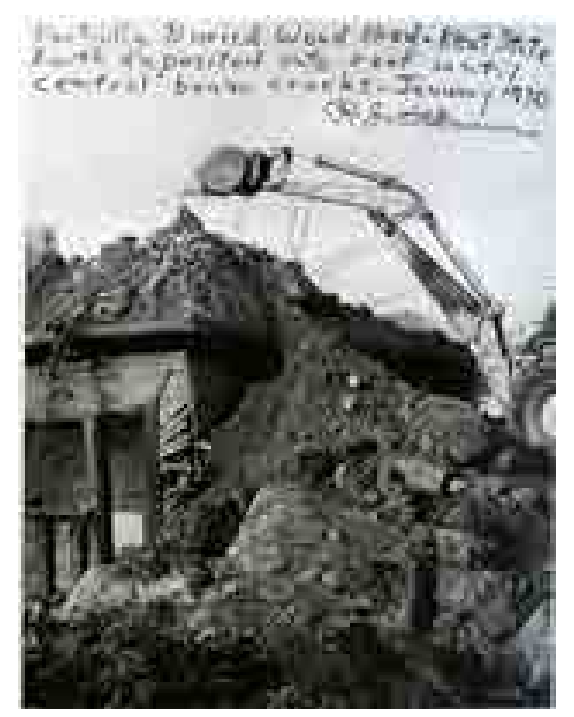

Figura 4.32. Richard Smithson (1970) Partially Buried Wood Shed-Kent State. Earth deposited onto roof until central beam cracks - January 1970. En Becher, B.; Becher, H. \& Smithson, R. (2002, p. 107)

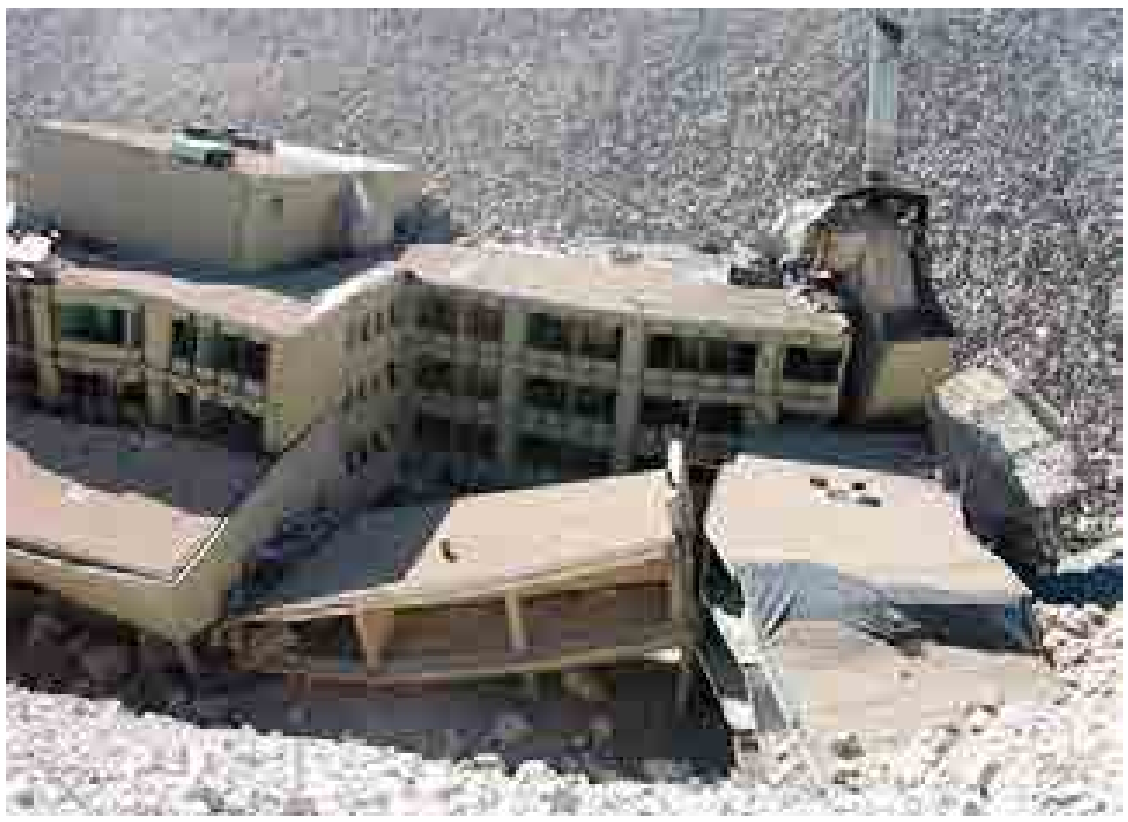

parecen obras de land art, que denuncian la destrucción del medioambiente y el olvido de la historia. Reconocemos los paisajes muertos por roces a fuego en la Patagonia o la desaparición de la ciudad de Chuquicamata bajo millones de toneladas de material minero (Figura 4.31), cuyas fotografías bien podrían ser obra de Smithson: una versión ampliada de Partially Buried Woodshed (Figura 4.32), como una periégesis apocalíptica, revelada a través del arte.

Desde el arte también se ponen de manifiesto aquellos aspectos básicos, que nos permitirán más adelante analizar los modelos de actuación sobre el paisaje, como son: la consideración del tiempo y los procesos; la superposición de superficies que contienen lo visible y lo invisible, lo objetivo y lo subjetivo, lo físico y lo histórico; Las múltiples escalas articuladas a través de las intervenciones, desde lo geográfico al cuerpo; y el problema de la representación, la tensión dialéctica entre mapa y territorio.

\subsection{EL JARDINERO Y EL ARQUITECTO DEL PAISAJE}

Así como la historia nos muestra que cada cultura tuvo un modo particular de comprender y transformar el paisaje, también podemos reconocer la evolución que ha tenido el oficio de diseñar con la naturaleza. En culturas como la china, el jardinero fue considerado artista y filósofo; en la tradición francesa el jardinero tuvo un reconocimiento importante, pero en rivalidad con el arquitecto, incubando una tensión que aún persiste. De hecho, los arquitectos franceses no reconocen el título de arquitecto paisajista. Como veremos también, en la cultura anglosajona la convergencia entre arquitectos y paisajistas se configura a partir del siglo XVIII.

Las primeras evidencias de una definición disciplinar las podemos encontrar en Francia, en un edicto emitido por el rey Enrique IV en 1599 que permitió al gremio de los jardineros agruparse en 5 ramas, según habilidades particulares: el «maraîchen» especialista en el cultivo de hortalizas, el «floresse» que correspondería al horticultor-florista, el «treillageur» especialista en árboles frutales, el «préolier» encargado de viveros y árboledas.y el "courtillier» que reunía todas las competencias anteriores, las que podríamos asimilar a las que poseen los actuales paisajístas. (Le Dantec, 1996).

Tuvo esta categoría Claude Mollet (1560-1649), el primer jardinero del rey, parte de una dinastía de jardineros de la corte, bajo los reinados de Enrique IV y Luis XIII. Mollet compartió la responsabilidad de las Tullerías con Jean Le Nôtre, padre de André Le Nôtre, también trabajó en Fontainebleau y en 1639, Luis XIII le encarga el rediseño del jardín de Versalles. Más allá de sus habilidades prácticas, este jardinero es autor del tratado Theatre des plans et iardinages, contenant des 
secrets et des inventions incognuës à tous ceux qui jusqu'à present se sont meslez d'escrire sur cette matiere (1652), ${ }^{164}$ que si bien dedica gran parte de su texto a cuestiones relativas a la horticultura, introduce el concepto del "jardín de placer" y desarrolla cuestiones que hoy entenderíamos como elementos de un proyecto de paisaje, ya que revela cómo imaginar el orden, es decir, la disposición, de este "jardín de recreo"(apartado 29-33); muestra a los jardineros los elementos de la naturaleza, el clima ${ }^{165}$ (del 40 al 43 ) y en las regiones, la morada del sol y la "extensión de su luz"(1652, p.235).

A esta misma tradición pertenece André Le Nôtre, considerado uno de los paisajistas más importantes de la historia moderna. También hijo y nieto de jardineros, tuvo antes de asumir sus labores en los jardines reales, formación de pintor con Simon Vouet, de escultor con Louis Lerambert y de arquitectura y perspectiva con François Mansart. A los 30 años asume como "dessinateur des plants et parterres de tous les jardins du roi" (1643) y catorce años más tarde, en 1657, el cargo de asesor y controlador general de los edificios del rey. Su obra más emblemática, los jardines de Versalles, lo ocuparían entre 1661-1687.

Si bien Le Nôtre, no escribió sobre su trabajo, sus enseñanzas fueron recopiladas y presentadas en el tratado de Dezallier d'Argenville (1680-1765) La théorie et la practique du jardinage de 1709 , donde sin embrago, no se reconoce la vinculación que buscamos entre arquitecto y jardinero.

Joseph Disponzio (2002) en su artículo Jean-Marie Morel and the Invention of Landscape Architecture, señala que el arquitecto, ingeniero y diseñador de jardines francés Jean-Marie Morel (1728-1810) sería el primero en fundir en una, las dos identidades profesionales, la del jardinero y del arquitecto. Morel se presentaba como architecte et paysagiste, para luego cambiar el "et" por un guion. Tras su muerte en 1810, su obituario lo reconocían como uno de los diseñadores más notables de su época en Francia y décadas más tarde, será referido como architecte paysagiste, sin guion. (Disponzio, 2002, p. 151-152).

Por lo tanto, la designación de arquitecto paisajista, derivado del término inglés "landscape architect" tendría su origen en la alusión póstuma a Morel. Pese a esto, el neologismo tardaría en hacerse común en Francia, asumiéndose con más decisión en el mundo anglosajón, donde el primero que habló sobre la posibilidad de hacer un paisaje fue Joseph Addison en su famoso ensayo de 1712, titulado "The Pleasures of the Imagination" donde señala que "a man might make a pretty landscape of his own possessions" (Addison, 1712, p. 74). Esta sutil asociación de revela la concepción de Addison de la facultad de formación de imágenes de la mente, bajo la influencia de la filosofía de John Locke sobre las "ideas"(Myers, 2013, p. 3), que como hemos visto influenciará fuertemente la teoría y la práctica de la jardinería en el Reino Unido.

Lancelot (Capability) Brown (1716-1783) es posiblemente el mejor exponente de este espíritu, transformando en su vida, una superficie de terreno mayor que cualquier otro paisajista en la historia ${ }^{166}$. Se inició como ayudante de jardinería desde niño y luego a las órdenes de William Kent para, a su muerte, convertirse en el artífice de más de 200 parques y jardines, dominando la técnica de la arquitectura y del paisajismo. Sin embargo, se llamaba a si mismo "hacedor de lugares" (place-maker), consciente de su capacidad de detectar las potencialidades ("capabilitie" como las denominaba) de un terreno en particular, lo que le valió su conocido apodo.

Nuevamente, teniendo como referencia la pintura italiana de paisajes, Gilbert Meason utilizará por primera vez en inglés el término "Landscape Architecture" [arquitectura del paisaje] en On the Landscape Architecture of the Great Painters of Italy publicado en 1828. El neologismo se aplicará en el título del libro de John Claudius Loudon sobre la obra de Repton, The Landscape Gardening and Landscape Architecture of the Late Humphry Repton, Esq. (1840) para referirse a la arquitectura situada dentro del paisaje, pero no precisamente para describir la práctica de Repton (Disponzio, 2002, p.153).

Las publicaciones de Meason y Loudon, como la literatura que hemos descrito anteriormente, prepararon el terreno para la apropiación del gusto paisajista inglés al otro lado del Atlántico. Andrew Jackson Downing, sería el primer repre-
${ }^{165}$ En el capítulo XLIII. Se pregunta "Quién le enseña al jardinero qué nubes, lluvia, nieve, granizo, niebla, niebla, arco iris y truenos" (Le Nôtre, 152, p. 236). https:// gallica.bnf.fr/ark:/12148/bpt6k85672b.pdf

${ }^{166}$ Brown creó más de 200 "landscapes", muchos de los cuales sobreviven intactos en la actualidad. Sus proyectos a gran escala incluyen el paisajismo en Stowe, Petworth Park, Croome Court, Sherborne Castle, Burghley House, Longleat, Wrest Park, Chatsworth, Bowood House, Blenheim Palace, Highclere, Audley End, Syon Park, Warwick Castle, Holkham Hall, Temple Newsam y Harewood House. https://archiveshub.jisc.ac.uk/search/ archives/4a8b94c0-efee-355d-855fb7d7e4365147 
sentante de este nuevo arte en Estados Unidos, sin embargo, mantiene hasta su prematura muerte en 1852 el uso de "landscape gardening" tanto en sus artículos como en el libro A Treatise on the Theory and Practice of Landscape Gardening (1841).

El sucesor de Downing, Frederick Law Olmsted, nombrado en 1857 "Superintendente del Central Park", y luego con Calver Vaux (1824-1895) ganador del concurso para el Central Park de Nueva York, registra la primera evidencia del título profesional de paisajista en Estados Unidos. Charles Waldheim en el artículo "Landscape as Architecture" (2014), señala que la prueba se encuentra en la correspondencia personal de Olmsted a su padre, John Olmsted, en julio de 1860. Esta carta, y la documentación sucesiva, se refiere al encargo de abril de 1860 de Olmsted y Vaux como "Landscape Architects" por los "Commissioners for lay out the upper part of New York island" (Waldheim, 2014, p. 189). Esta designación es consolidada en 1862 con el nombramiento oficial de Olmsted y Vaux como "Landscape Architects to the Board" del Central Park y confirmada tras la interrupción del proyecto debida a la Guerra Civil en 1865 (Schuyler\&Turner, 1992, p. 11). Los proyectos siguientes, como el Prospect Park serán definitivamente encargados a Landscape Architecs, fundando así una profesión y un campo disciplinar para los profesionales de este nuevo arte en Norteamérica. Un arte que iba más allá del diseño de un parque, expandiendo el campo de la jardinería, lo que supone un profesional con la capacidad de intervenir en la ciudad y anticipar su desarrollo usando el potencial del paisaje "como medio para remediar las condiciones sociales, ambientales y culturales de la ciudad contemporánea" (Waldheim, 2013, p. 1).

Si bien Olmsted era consciente de los peligros de esta composición de arquitecto y paisajista, defendió la formula francesa de Morel de architect paysagiste, landscape architect en inglés, frente a la opción británica de landscape gardener, ya que consideraba que la primera reivindicaba el papel del nuevo profesional en las prácticas de orden urbano, incluyendo la infraestructura ${ }^{167}$. Sobre esta base se crea en 1899 la American Society of Landscape Architects (Simo, 1999).

Tras la constitución de la asociación profesional, se fundó en 1900 el primer programa académico de arquitectura del paisaje en la Universidad de Harvard, junto a la escuela de Arquitectura, y la primera revista -Landscape Architecture-, en 1910. La consolidación definitiva de la disciplina se produce después de la Segunda Guerra Mundial, con la creación de la "International Federation of Landscape Architects" (IFLA) en 1948, que actualmente agrupa a más de 35.000 arquitectos paisajistas de 73 países (IFLA, 2016, p. 3).

En Francia, la École Nationale Supérieure du Paysage de Versailles-Marseille, es el establecimiento de referencia de los paisajistas franceses. Heredera de la cátedra de "El arte de los parques y jardines" creada en Versalles en 1874, en el sitio histórico de Huerto del Rey.

Junto a la escuela, la profesión de paisajismo, en sus dimensiones actuales, despegó durante las grandes reconstrucciones de posguerra. El diploma de paisajista (DPLG 2), creado en 1946, fue redefinido en 1992, año en el que se abrió una nueva escuela en Marsella. Ambas sedes actualmente titulan a 70 paisajistas al año.

Con alrededor de 2.500 diseñadores de paisajes, este sector profesional se encuentra en la interfaz de profesiones como el urbanismo, la arquitectura, la planificación, ingeniería hortícola y geografía. A diferencia de Estados Unidos, el

167 Los escritos de Olmsted revelan una tensión entre la identidad disciplinaria y el alcance del trabajo del arquitecto paisajista. Los fundadores del nuevo campo incluyeron una amplia gama de posiciones, desde aquellos que encarnan una tradición de jardinería paisajística y mejoramiento rural hasta aquellos que abogan por el paisaje como arte arquitectónico y urbano. titulo de arquitecto paisajista ha sido negado por el gremio de los arquitectos. Sin embargo, su prestigio internacional e identidad histórica, hacen de esta escuela un referente, asociada a nombres como Gilles Clément, Alexandre Chemetoff, Michel Corajoud, Michel Desvigne, Monique Mosser, Jacques Sgard, Jacques Simon, Gilles A. Tiberghien, Pierre Donadieu y Christophe Girot, entre otros.

Su posicionamiento tiene su núcleo en el proyecto de paisaje, declarándose como una "escuela de proyecto" donde se forma al paisajista que es a la vez "jardinero, artista e ingeniero" (AERES, 2014, p. 9). En el informe de autoevaluación 
de 2014 se explica este enfoque como un "proceso iterativo entre conocimiento multidisciplinario, experimentación e intuición" (2014, p. 9). Esta identidad profesional hibrida, junto a la dependencia múltiple de los ministerios de agricultura y educación, han dificultado la adscripción de la disciplina a los estándares internacionales de investigación científica y consecuentemente, a la creación de programas de doctorado en paisaje. Sin embargo, la escuela edita una revista en francés, Les carnets y participa en otras dos revistas científicas, Projets de paysage con otras escuelas francesas, y Journal of Landscape Architecture (JoLA) con otras escuelas europeas. La ENSP cuenta con un laboratorio de investigación y un programa de Máster en Arquitectura del paisaje (Emila) en asociación con otra cuatro escuelas europeas (Ámsterdam, Barcelona, Edimburgo y Hannover). A nivel latinoamericano, la formación en Arquitectura del Paisaje existe en la UNAM de México, la UBA en Argentina, la Universidad de la República en Uruguay y en la Universidad Central en Chile, donde se otorgan el grado de Licenciado en Paisaje y Medio Ambiente, y el título Profesional de Arquitecto del Paisaje (UCENTRAL, s.f).

Este breve paso por la evolución de la profesión, revela una tensión permanente entre la identidad disciplinaria y el alcance del trabajo del arquitecto paisajista. Desde la fundación de este nuevo campo, se han incluido una amplia gama de posiciones, desde aquellos que encarnan una tradición de jardinería paisajística y mejoramiento rural hasta aquellos que abogan por el paisaje como arte arquitectónico y urbano; desde posiciones más próximas a la ecología a otras más comprometidas con las ciencias sociales y el arte, generando diversos modelos de actuación.

\subsection{LOS MODELOS DE ACTUACIÓN}

Recordando lo desarrollado en el capítulo 3, los modelos de actuación en arquitectura se pueden leer en la historia en forma de metáforas 0 analogías que consideran en diseño como un acto estético, lógico o ético, que a veces tiene la forma de una estrategia racional y en otras la de un acto artístico. Los modelos que se han transmitido a través de los Tratados fueron prescriptivos y normativos, configurando bases doctrinarias que dictaban cómo entender y transformar la realidad. Los modelos más empíricos y de carácter descriptivo, sólo aparecen en el siglo XX. Bajo este criterio se analizaron los textos teóricos de la arquitectura, identificando, de acuerdo al modelo del eclipse del objeto de Findeli, tres categorías que aparecen históricamente en diferentes momentos. Los primeros modelos se centran en el objeto, en el producto del proyecto, es decir, en el edificio, la ciudad, el parque, el objeto de diseño. En este modelo que se extiende hasta mediados del siglo XX, los criterios de evaluación apuntarán a la forma para determinar la calidad del acto arquitectónico. A partir de la Segunda Guerra Mundial, los modelos de actuación se centran más en el proceso de proyecto, para desde allí generar la teoría, con la hegemonía de la función y la fascinación por los métodos de diseño, en la búsqueda de elementos racionales que convirtieran este proceso en uno de carácter científico (en el sentido más reduccionista del término). Como tercera fase, en los últimos años, el foco se ha trasladado a los actores y a una conciencia sobre el medioambiente que orientaría los métodos desde "el proceso" a la dimensión ética de la práctica. En el modelo de Findeli y Bousbaci (2005) el objeto se eclipsa, dando paso al proceso primero, y luego a los actores involucrados en el proyecto, a los que en esta tesis entendemos como parte de un sistema ecológico.

Concebido así, un modelo para actuación en arquitectura - y especialmente una arquitectura entendida como transformación del paisaje-, no puede volver al sentido platónico del término modelo, entendido como una forma ideal, ajena al cambio.

$\mathrm{Si}$, por otra parte, observamos la idea del "modelo" en las ciencias, incluso allí, éste funciona fijando leyes sobre un objeto bien estructurado; pero en el mismo acto de modelar, promueve la concepción y la experimentación. Así los dos significados principales del término modelo, como figuración y al mismo tiempo 
arquetipo o plan maestro, se superponen y se nutren mutuamente. Visto de este modo el modelo tiene un rol intermediario y un papel que debiera ser modesto, como su etimología nos recuerda ${ }^{168}$.

Para Francois Choay, el concepto de modelo en urbanismo, deriva de la Utopía de Tomás Moro quien, basado en la crítica de una sociedad existente, propuso un marco para un mundo mejor. Lo interesante de esta alusión, es que el salto entre crítica y proyecto se materializa a través de un modelo espacial, cuyos valores ofrecerían una función transformadora (Choay, 2000).

El término modelo incluye así, figura, referencia, analogía, también transformación, que se anclan a la noción de paradigma, por lo tanto, forman parte de la construcción de una doctrina. Lo observamos en distintos sentidos en el Central Park, donde el objeto adquiere el valor de un modelo teórico cuando encarna todas las cualidades que lo convierten en una fuente inagotable de inspiración; lo que podemos observar también en A pattern language de Christopher Alexander.

Pese a la riqueza que plantea la idea de modelo en arquitectura, como plantea Jean-Pierre Chupin, "tomamos prestados objetos y métodos de las distintas disciplinas científicas, pero no contribuimos al debate epistemológico sobre el papel de la analogía, el modelo, o incluso la metáfora, en la construcción del conocimiento arquitectónico"(Chupin, citado por Coste 2008, p. 82) Los problemas que la arquitectura del paisaje afronta requiere de modelos que operen en registros diferentes, a diversas escalas y en distintos niveles, desde el cuerpo al objeto, el paisaje, la geografía, pero también la sociedad y la cultura. Lo anterior exige no sólo la capacidad de modelar, sino, como plantea Antoine Picon, una "imaginación social", que este autor define de la siguiente manera:

Por imaginación social me refiero a lo que los historiadores franceses llaman "imaginario", es decir, un sistema de imágenes y representaciones del orden natural y social que está muy extendido entre los miembros de una determinada sociedad y cultura. Estas imágenes y representaciones reflejan los ideales que emergen en esta sociedad. La imaginación social es inseparablemente el orden extendido de las cosas y del ser, y de los cambios que se le deben aportar. En otras palabras, la imaginación social es portadora tanto de una interpretación del mundo como del proyecto de transformarlo. (Picon, 2002, p. 27)

Si repasamos la primera parte de este capítulo, descubriremos cómo la historia de la arquitectura también es la historia de estos modelos, de su desarrollo, transmisión, su eclipse y reedición. Podemos interpretarlos a la luz de las diversas cosmovisiones, pero muchas veces, los patrones de actuación son inconscientes o no declarados por la "escuela" que los comparte, o por el diseñador que en forma autónoma encuentra un camino.

\footnotetext{
${ }^{168}$ La palabra latina modus es raíz de muchas palabras como moda, moderno, módulo, moderar, modesto y modificar. http:/l etimologias.dechile.net/?modelo ${ }^{169}$ Traducción propia del inglés:

By social imagination, I mean what French historians call "imaginaire", namely a system of images and representations of the natural and social order that is widespread among the members of a given society and culture. These images and representations shape the ideals that emerge in this society. Social imagination is inseparably the extend order of things and being, and about the changes that should be brought to it. In other words, social imagination is the bearer of both an interpretation of the world and the project to transform it.
}

No obstante, los modelos no son ajenos a las condiciones generales de su época (como por ejemplo la revolución industrial y sus consecuencias sobre la ciudad, los estilos de vida y la vivienda). Cabría preguntarse aquí, cuáles son esas condiciones de nuestra época que han detonado el interés de los arquitectos y urbanistas por el paisaje como modelo. James Corner interpreta así nuestro momento:

En los primeros años del siglo XXI, el paisaje, aparentemente anticuado, ha vuelto a estar de moda. La reaparición del paisaje en la imaginación cultural más amplia se debe, en parte, al notable aumento del ambientalismo y de la conciencia ecológica mundial, al crecimiento del turismo y a las necesidades conexas de las regiones de conservar un sentido de identidad única, y a los efectos del crecimiento urbano masivo sobre las zonas rurales. Pero el paisaje también ofrece una gama de asociaciones imaginativas y metafóricas, especialmente para muchos arquitectos y urbanistas contemporáneos. (Corner, 2006, p. 23) 


\subsection{EL PAISAJE Y LA CIUDAD}

Sin duda la ciudad es uno de los grandes problemas de nuestro tiempo. El largo proceso de más de 100.000 años que llevó a la humanidad a asentarse en ciudades, ha adquirido una velocidad sin precedentes en los últimos cien años tanto en número como en tamaño. A principios del siglo XX, sólo 16 ciudades tenían más de un millón de habitantes o más, para el año 2000 , esa cifra creció a 417. Si en 1950, sólo una ciudad tenía más de diez millones de habitantes, hoy son más de 31 (ONU, 2016). Porcentualmente, el siglo XXI se inaugura como el primer siglo urbano $0^{170}$, al concentrar más de la mitad de la humanidad en las ciudades (ONU-Habitat, 2018:4). La urbanización más rápida se está produciendo en sociedades que están pasando aceleradamente de economías agrarias de pequeña escala a economías industriales o de servicios, lo que da lugar a una profunda polarización económica, segregación social y cambios culturales. Desde el punto de vista ambiental, este acelerado proceso de urbanización ha sometido a los ecosistemas a la influencia de las ciudades y los entornos construidos, comprometiendo la calidad de vida de los habitantes. También la vida misma ya que, de acuerdo a cifras de 2014, 944 ciudades con más de 300.000 habitantes, que corresponde al $56 \%$ del total, están expuestas a algún tipo de desastre natural (terremotos, tsunamis, huracanes, inundaciones y sequías). "En conjunto, las ciudades que se enfrentan a un alto riesgo de exposición a un desastre natural albergaban a 1.400 millones de personas en 2014" (ONU-Habitat, 2018, p. 8).

Si bien la segunda mitad del siglo XX ha registrado también un crecimiento económico sin precedentes, los avances sociales se han concentrado en las regiones más desarrolladas. Desde el punto de vista ambiental los efectos han sido proporcionalmente negativos, debidos a la depredación de recursos naturales y la contaminación ambiental con graves consecuencias para la biodiversidad y la propia vida de las personas, tendencia que, en los años venideros, sólo tiende a amplificarse.

Un hito en la toma de conciencia sobre sobre la situación global se produce con el Informe Brundtland (1987) que introdujo la noción de desarrollo sostenible como "un desarrollo que satisface las necesidades del presente sin comprometer la capacidad de las generaciones futuras para satisfacer sus propias necesidades"(OCDE, ONU, 1997). Si bien el concepto ha sido controvertido, supone una contrapartida a la idea de un crecimiento económico infinito en un planeta finito, y una alerta respecto al futuro.

Esta situación ha puesto en crisis los principios de la planificación urbana, que han resultado inapropiados para conciliar los procesos de urbanización con el cuidado del medioambiente y obligado a profesionales y políticos a pensar estratégicamente el territorio. Es allí donde las competencias de los arquitectos paisajistas adquieren relevancia, ya que su campo de acción está justamente en la interfaz entre la arquitectura, las ciencias naturales y las sociales. Desde el punto de vista teórico, este proceso se ve reflejado en el advenimiento del discurso sobre el paisaje de las últimas décadas, como fue adelantado por el paisajista inglés Tom Turner en 1996:

La ciudad del futuro será una serie infinita de paisajes: psicológicos y físicos, urbanos y rurales, que fluyen separados y juntos. Serán cartografiados y planificados para fines especiales, con los resultados registrados en sistemas de información geográfica (SIG), que tienen el poder de construir y recuperar innumerables planos, imágenes y otros registros. Christopher Alexander tenía razón: una ciudad no es un árbol. Es un paisaje.(Turner, 1996, p. v).

En este contexto, el concepto Landscape Urbanism o urbanismo paisajista se formula como un recurso operativo para abordar los problemas de la ciudad. Gunilla Lindholm (2012) confirma esta idea al afirmar que "el concepto de paisaje se adapta a los modos de pensamiento interdisciplinarios y dialógicos del desarrollo sostenible" (2012, p. 5).
170 Para una visión crítica del concepto de urbanización como fenómeno planetario, ver Brenner (2016), que señala:

La urbanización planetaria significa que incluso las disposiciones socioespaciales, y redes de infraestructura que se encuentran más allá de los núcleos tradicionales de la ciudad, las regiones metropolitanas, las periferias urbanas y zonas periurbanas, se han convertido en parte integrante de la condición urbana en todo el mundo. (2016, p. 333)

${ }^{71}$ El término ökologie fue acuñado en 1869 por el naturalista y filósofo alemán Ernst Haeckel a partir de las palabras griegas oikos (casa, vivienda, hogar) y logos (estudio o tratado); por ello ecología significa "el estudio del hogar". 


\subsection{PAISAJE Y ECOLOGÍA}

En la escuela norteamericana, la ecología ${ }^{171}$ se integró al pensamiento y las prácticas del paisaje en la segunda mitad del siglo XIX, particularmente con Frederick Law Olmsted. Su "sistema de parques" consagró un nuevo tipo de artefacto urbano, que actuaría junto y en oposición a la naturaleza remota y salvaje del wilderness.

Cien años más tarde, este modelo de articulación entre paisaje y ecología se enfrentó a los problemas ambientales producidos por los acelerados procesos de urbanización ya descritos, y después de la década de 1960 a la "revolución verde", que paradójicamente consistió en el desarrollo de la industria agroalimentaria sustentada en el uso de fertilizantes, plaguicidas y riego tecnificado.

En esta coyuntura, lan McHarg publica en 1969 su libro Design with Nature, donde desarrolla más que un enfoque, un método con enfoque ecológico, desafiando los principios estéticos del diseño del paisaje. Esta obra, gracias a su amplia divulgación en el mundo anglosajón, y la personalidad del autor, impulsaron el desarrollo de la escuela norteamericana del paisaje, la valoración profesional de los landscape architects y los principios de un modelo que concilia las prácticas de la ecología y el diseño urbano y paisajístico, que tiene como fundamento el análisis multicapas de las condiciones del terreno.

Eugene P. Odum complementará el modelo, integrando más explícitamente las actividades humanas, compensando la visión biocéntrica de los ecologistas. Por lo tanto, como el mismo autor plantea, "para muchas personas, ecología ahora significa el estudio de la "totalidad del hombre y su ambiente" (Odum, 1972, p. ix). En 1973 el ecologista canadiense Crawford Holling, en su artículo Resilience and Stability of Ecological Systems, vinculó los conceptos de resiliencia, adaptabilidad y transformabilidad y las compensaciones entre la estabilidad y el cambio, así como entre la previsibilidad y la no previsibilidad. Desde entonces reconocemos que, en la naturaleza, los ecosistemas normalmente no alcanzan un estado de equilibrio óptimo y estable, sino que fluctúan y desarrollan múltiples condiciones de estabilidad como resultado de patrones no lineales de ciclos adaptativos (Holling, 1986, p. 21).

En la década siguiente, la relación entre ecología y paisaje se desarrolla también desde la ecología a través de Richard T.T. Forman y Michel Godron, que en su libro Landscape Ecology (1986) introducen la dimensión espacial de los procesos ecológicos a la escala del paisaje, fortaleciendo el diálogo interdisciplinar entre ecólogos y planificadores. Esta primera síntesis es seguida en 1995 por Land Mosaics: The Ecology of Landscapes and Regions, donde se amplió la escala para incluir a las regiones. En estos textos, además de una base teórica para los estudios de paisaje, se hace operativa la ecología como herramienta para la planificación urbana y regional. En el modelo, se establecen elementos básicos como "mosaicos, parches y corredores ", donde el paisaje es definido como una "serie de ecosistemas que interaccionan bajo un mismo clima, geomorfología y régimen de disturbios" (Forman y Godron 1986). El paisaje como mosaico, consiste en una matriz de parches (unidades básicas que evolucionan y fluctúan) y corredores que forman redes (Forman, 1995).

La escuela norteamericana se consolida con el fin de siglo con la publicación en 1999 de Recovering Landscape con James Corner como editor. Este texto recoge una serie de ensayos que tratan de explicar el advenimiento del paisaje y explorar sus aplicaciones no solo en Estado Unidos, sino también en Francia, India, Sudeste asiático y los países Bajos, convocando a importantes pensadores sobre el paisaje como Charles Waldheim, Alan Balfour, Denis Cosgrove, Georges Descombes, Christophe Girot, Steen Hoyer, David Leatherbarrow, Bart Lootsma, Sebastien Marot, Anuradha Mathur, Stanistaus Fung, Anita Berrizbeitia (la única mujer del grupo), Marc Treib y Alex Wall.

Este rescate del paisaje, para Corner, promueve una nueva disciplina que se ocupa de la recuperación urbana, que puede "ser medida de tres maneras: primero, en términos de recuperación de la memoria y enriquecimiento cultural del lugar y 
el tiempo; segundo, en términos de programa social y utilidad [...]; y tercero, en términos de diversificación ecológica y sucesión" (Corner, 1999, p.13).

A principios de los años 2000 , se extiende la reflexión sobre los emplazamientos postindustriales a las zonas urbanas abandonadas en general, donde el urbanismo paisajístico se ofrece como un nuevo método de planificación, basado en el enfoque ecológico. ¿cómo nos ayuda el paisaje a concebir nuevas condiciones para el urbanismo?, se pregunta Mohsen Mostafavi, en Landscape Urbanism: A manual for Machinic Landscape (2003). Allí postula que la variabilidad y el carácter inacabado, serían las características principales del paisaje, y podrían considerarse como "un antídoto contra la finitud implícita de la zonificación" (Mostafavi, 2003, p. 7), que ha demostrado ser inadecuada para tratar con la ciudad contemporánea, que es dinámica, sometida a constantes cambios y también a grandes desastres. Idea que Corner, en el mismo libro, reafirma al plantear que el éxito de esta nueva disciplina híbrida se debe a que trabaja justamente con la "indeterminación, la apertura, la mezcla y la interdisciplinariedad", opuesta a la "composición estática del urbanismo" (Corner, 2003, p. 62).

La teoría del Urbanismo Paisajístico (Landscape Urbanism) ${ }^{172}$ se formula definitivamente en Landscape Urbanism Reader ${ }^{173}$ (2006) como "un realineamiento disciplinario en el que el paisaje prevalezca sobre el papel tradicional de la arquitectura como unidad constructiva del proyecto urbano" (Waldheim, 2006, p. 11), para luego en el ensayo de James Corner "Terra Fluxus", considerado uno de los textos fundamentales de esta escuela, plantear una de las preguntas que el proyecto en Carén debe responder:

"¿Cómo se conceptualizan geografías urbanas que funcionan con una gran variedad de escalas e implican una multitud de actores?"174 (Corner, 2006, p. 31). Por cierto, a través de un uso de múltiples medios de representación para captar las distintas escalas espaciales como temporales, pero también a través del trabajo con las diversas disciplinas y actores involucrados en el proyecto.

Así como James Corner su equipo Field Operations ponen en práctica los principios del Urbanismo Paisajístico, especialmente en los parque que estudiaremos en el próximo capítulo, Richard T.T. Forman aplica los de la ecología urbana en el proyecto de planificación. En el libro Mosaico Territorial para la región metropolitana de Barcelona ${ }^{175}(2004)$, el análisis a gran escala identifica los elementos del mosaico territorial, a través del cual Forman realiza un diagnóstico de distintos ámbitos de estudio destacando los sistemas naturales y sus usos, desarrollando además un conjunto de recomendaciones y soluciones para la región de BarceIona en particular -sobre las que volveremos en el capitulo 8-. En este autor se observa una evolución desde un modelo con base ecológica, a uno que considera otras dimensiones que podríamos llamar culturales ${ }^{176}$.

Sin embargo, el desafío sigue siendo cómo relacionar de mejor forma aquellas dimensiones que hemos develado desde la etimología y la noción de paisaje. Si bien la ecología ha puesto el conocimiento cientíico a disposición del diseño y el diseño por su parte ha hecho más operativa la ecología, la evolución del modelo con base ecológica presenta al diseño como un resultado "emergente" de las múltiples capas e interacciones en el sitio, donde en apariencia, las o los arquitectos tendrían el rol de conducir estos flujos de información, sin dejar claro si hay espacio para la imaginación o la creación (individual o colectiva), ni cómo se pueden conectar los procesos ambientales con la experiencia estética del paisaje.

Los distintos significados del paisaje como medio y como representación (o imaginario), parecen destinados a permanecer en tensión. Un enfoque reduccionista hacia cualquiera de los dos extremos, corre el peligro de descuidar los valores estéticos o bien los medioambientales, si bajo el "logo del paisaje" se actúa como si fuera un modelo automáticamente unificador e indiscutible.

Justamente esta distinción entre país y paisaje, es la que pone en relieve la escuela francesa del paisaje, con Descola (2005) que la hace análoga a la oposición entre naturaleza y cultura, y con Berque (2000), que propone el concepto de médiance ${ }^{177}$, la interfaz entre el medioambiente en su dimensión física y el paisaje en su dimensión sensible, portadora a la vez, de la percepción objetiva y subjetiva del entorno para una sociedad determinada (Berque, 2000, p. 128).
El término "Landscape Urbanism" se usó por primera vez en 1994. Peter Connolly, un estudiante de Maestría en Diseño Urbano de RMIT Melbourne lo usó en el título de su tesis. Aquí, sugirió que'un lenguaje de "urbanismo paisajístico" apenas existe y necesita ser articulado', y que'los urbanismos existentes... están limitados en la exploración del paisaje'. También utilizó el Landscape as Urbanism' en su ensayo de 1994, 101 Ideas sobre grandes parques.

${ }^{173}$ Cabe destacar que en esta publicación 6 de los 14 autores son mujeres.

${ }^{174}$ En el texto original en inglés: "How does one conceptualize urban geographies that function across a range of scales and implicate a host of players?"

175 Seleccionado como uno de los mejores proyectos de Design with Nature Now por el Centro lan McHarg de la Universidad de Pensilvania

176 Estos fundamentos condujeron a un análisis espacial y ambiental de 38 regiones urbanas grandes y pequeñas en Urban Regions: Ecology and Planning Beyond the City, de 2008, y luego, en el año 2014, una síntesis relativamente completa del estado de la ciencia en, Urban Ecology: Science of Cities, vinculando organismos, estructuras construidas y el entorno físico en el que se concentran las personas.

177 Médiance es una traducción del concepto japonés fûdosei, del filósofo Tetsurō Watsuji (1889-1960), desarrollado por el geógrafo y orientalista Augustin Berque.

178 Por ejemplo, tras la publicación de Landscape Urbanism Reader en 2006, aparecieron artículos en Journal of Landscape Architecture JoLA (Donadieu, 2006), Landscape Research (Thompson, 2012), así como números especiales de las revistas Topos (numéro 71) y Anthos (mayo de 2013). 
Como lo revelan diversas publicaciones ${ }^{178}$ en Francia, Landscape Urbanism es uno de los discursos reinantes que abordan la relación entre ecología y paisaje, con prácticas bastante similares, pero con una teoría distanciada del proyecto. Dominan el campo teórico geógrafos (Pierre Donadieu, Marc Antrop), sociólogos (Michel Conan) y filósofos (Sébastien Marot, Jean-Marc Besse, Augustin Berque, Alain Roger), mientras que en la práctica, a partir de los años 1970, destacan Allain Provost, Bernard Lassus, Alexandre Chemetoff, Guilles Clement, Michel Corajoud y más recientemente Michel Desvigne. La estrecha relación entre profesionales y académicos que se observa en Estados Unidos, no tiene la misma magnitud en Francia. El caso más elocuente es James Corner que ha logrado reunir en el mismo, la herencia de McHarg, la producción teórica y material de libros y conferencias, la docencia, donde recluta a los mejores estudiantes como colaboradores de su firma, Field Operations, y finalmente, su capacidad profesional puesta continuamente a prueba a través de concursos públicos (y publicados). La idea de un linaje también está presente. Se remonta a Olmsted a quien todos reconocen como padre (en este caso sería más bien abuelo), al gran padre McHarg que crea el programa de Landscape en la Universidad de Pensilvania y que expande su influencia a través de sus discípulos Waldheim (que dirige un programa en Harvard) y Corner (que dirigió el programa en UPEN), hasta Weller, Mathur, Reed (profesores en UPEN).

Si bien ninguna de las dos escuelas reconoce la influencia de la otra, ambas coinciden en fijar su origen en los años 1970 y una evolución similar -en paralelo- a ambos lados del Atlántico, en la que podemos identificar cuatro ideas clave compartidas:

La primera, sería la de procesos temporales. El enfoque dinámico de los procesos ecológicos, incorporan la idea de sistemas abiertos, impredecibles, evolutivos, emergentes, en movimiento, todos ellos conceptos de origen ecológico. Aplicado al Urbanismo Paisajístico, implica un reconocimiento de la naturaleza como un entorno dinámico y relacional y considera las escalas de tiempo en el proceso de diseño como la combinación de todos los agentes del campo urbano en una red continua de interrelaciones (Corner, 2006). Como plantea Thompson, "Landscape Urbanism busca menos estudiar objetos que procesos" (Thompson, 2012, p. 12). Los paisajistas franceses como Michel Desvigne convergen en la misma dirección. Desvigne (2009), frente a los peligros incontrolables de los elementos naturales, defiende la idea de un proyecto que actúa sobre los mecanismos de transformación del paisaje, favoreciendo procesos dinámicos en lugar de planes que fijan la realidad. En su obra enfatiza la dimensión temporal, "el juego con el tiempo: el realce de las fases sucesivas, el énfasis en las fases tempranas, la coexistencia de diferentes etapas de desarrollo que concentran y condensan, en un corto período, los procesos con ritmos históricos"179 (Desvigne, 2009, p. 12). La ciudad, por lo tanto, como la naturaleza: cambia gradualmente, en una "lentitud obligada", como un organismo vivo. Para este creador de paisajes, la ecología interviene el marco de surgimiento de una idea, un concepto poético capaz de organizar el proyecto, más que como una experiencia rigurosa y definitiva. Finalmente, Gilles Clément, jardinero paisajista, Ilama tercer paisaje al "fragmento irresoluto del jardín planetario [que] está constituido por el conjunto de los espacios residuales del hombre." (Clément, 2018, p. 11), para los que propone "seguir el flujo natural de las plantas, adscribirse a la corriente biológica que anima el lugar, y orientarla" (Clément, 2017, p. 10). En el enfoque teórico de Clément, el aforismo del "jardín en movimiento", plantea que el diseño del paisaje debe estar está sujeto a la transformación, resultante de la interacción de los seres vivos en el tiempo, reivindicando al mismo tiempo, el papel del jardinero:

79 Traducción propia del inglés: "the play with time: the highlighting of successive phases, the emphasis on early phases, the coexistence of different stages of development that concentrate and condense, in a short period, processes with historical rhythms"
Un arquitecto puede hacer un paisaje de hormigón y metal, el jardinero trabaja con seres vivos. Incluso hay diseñadores del paisaje que no conocen las plantas, son más bien escultores, constructores. A diferencia de un arquitecto, el jardinero tiene por aliado al tiempo, que reinventa el paisaje. Todo lo que edificamos y que está hecho de materia inerte está destinado a desaparecer. Mientras que el destino de la materia viva, de lo viviente, es la transformación[...] Un jardín jamás se convierte en ruinas, se transforma y se complejiza. La naturaleza inventa sin cesar, el paisajista comparte con ella la autoría del diseño. (Clément, 
A partir de este aspecto se produce una de las críticas más delicadas al Urbanismo Paisajístico, la de Douglas Spencer (2011). Este autor afirma que el urbanismo paisajístico comparte inadvertidamente el mismo paradigma que el empresariado urbano neoliberal, los mismos adjetivos que hemos usado son característicos del libre mercado. Lo que se advierte es que la indeterminación y la imprevisibilidad disminuyen el potencial del urbanismo paisajístico como fuerza de equidad social, ecológica y política (Spencer, 2011, p. 21).

La segunda idea es la "superposición de superficies". La analogía del palimpsesto usada por Corboz (1998) y Marot (2006), entre otros, para representar las múltiples capas de memoria de un sitio, se hace operativa a la escala de la ciudad bajo un enfoque sistémico de continuidades y redes. Para considerar varios sistemas, interrelaciones y redes existentes, se propone una superposición de superficies como un medio para que los paisajistas consideren el espacio de intervención. Esta superposición se hereda del enfoque de McHarg, que utilizó esta técnica para seccionar el sitio y su contexto en las capas de análisis del proyecto. Sin embargo, el Urbanismo paisajístico propone un paso metodológico: adapta este enfoque y lo aplica a un equipo multidisciplinar y al conocimiento científico más operativo para el proyecto de paisaje. El proceso permite comparar la información, y entender las redes ecológicas existentes en el sitio y más allá de los límites del sitio. Este tema también es tratado por los geógrafos franceses y filósofos que trabajan en prácticas de paisaje (Cauquelin 2000, Lussault 2007 y Marot, 2006). Al describir la "superficie de la tierra como una matriz activa, el filósofo Sébastien Marot aboga por subversión de la planificación urbana, capaz de articular "la memoria estratificada de los sitios" (Marot, 2006, p. 130), que el paisajista francés Corajoud (2010) define como la "memoria de los lugares". Marot llama "suburbanismo" a este enfoque particular del urbanismo que trabaja a partir de la estratificación de las superficies para dar un anclaje a la forma urbana contemporánea.

La tercera idea se relaciona con las múltiples escalas que intervienen en el proyecto de paisaje. Relacionada con las ideas anteriores, un proyecto de paisaje si bien se aplica a un sitio, debe tener en cuenta las escalas que lo superan.

En Landscape Urbanism Reader, Julia Czerniak (2006) analiza el impacto significativo del proyecto "en el sitio y más allá del sitio", mientras que Linda Pollak (2006) habla de "tratar áreas mucho más grandes" que el sitio. Lo que está en la base de esta idea, son los principios ecológicos, que hacen imprescindible estudiar las continuidades más allá del terreno en el que se actúa. Para Clément las fronteras del Tercer Paisaje son las fronteras del jardín Planetario, vale decir, los límites de la biósfera. El paisajista que mejor encarnan esta idea es Michel Desvigne, quién en sus proyectos articula las diferentes escalas y recompone territorios urbanos a través de lo que él llama una "geografía amplificada" (Desvigne, 2009).

A la escala del sitio, las estrategias procesuales se materializan, incorporando soluciones como la bio y fitorremediación, sistemas activos para retener y tratar las escorrentías, el tratamiento de aguas y superficies vivas incorporadas a la arquitectura. También, el uso de la agricultura urbana, que expresa cómo los procesos productivos del paisaje, pueden estar disponibles para la experiencia sensible en parques y grandes intervenciones urbanas.

A escala del cuerpo, el acto de caminar -como land art demostró- permite explorar las relaciones entre el tiempo y espacio; el clima y la geografía; también permiten estimar distancia, definir lejanía y cercanía. Lo que da paso a la cuarta idea, que está relacionada con la representación y la estética.

Como observamos respecto al Land art, las formas de representación son parte de la existencia y memoria de la obra. Toda técnica es válida en la medida que alimenten la imaginación, ya sean mapas, planos, fotografías, esquemas, relatos 0 videos. Corner señala además que "las técnicas de representación son fundamentales para cualquier acto crítico en el diseño", recordando que "no 
puede haber paisaje sin una imagen previa" (Corner, 1999, p. 8). Analizado así, prácticamente todos los ensayos de Recovering Landscape tocan el tema de la representación: Denis Cosgrove habla sobre la relación entre "construcción y representación de paisajes" (1999, p. 103), Charles Waldheim sobre la representación aérea ( $p .121)$, Stanislaus Fung sobre los aportes de la concepción oriental del paisaje ( p. 141), David Leatherbarrow sobre la topografía(p. 171), Cristophe Girot sobre las huellas en el paisaje, Bart Loosma sobre la cartografía y el mismo Corner sobre la "imagen eidética"( $p .153)$; todas ellas orientadas a resolver como construir una imagen del lugar.

Entre estos ensayos, Four Trace Concepts in Lanscape Architecture de Cristophe Girot servirá de guía para la comprensión del territorio de Laguna Carén. Tomaremos sus cuatro conceptos para penetrar en el sitio, reconociendo, como plantea este autor que "un diseñador rara vez pertenece al lugar en el que se le pide que intervenga"(Girot, 1999, p. 60). Siguiendo las huellas en el paisaje, primero se propone el "aterrizaje" que describe el primer encuentro con el lugar, luego "la puesta a tierra" que consiste en el estudio de los distintos aspectos del sitio, para "encontrar" aquello que está latente y que lo hace único. Finalmente "fundar" es el rastro resultante, de los pasos anteriores. Una respuesta basada en la experiencia y el estudio del sitio, que implica la transformación del paisaje.

\subsection{A MODO DE CONCLUSIÓN}

La idea de transformación ha sido en este capítulo, la estrategia para revisar la historia de la relación humana con el paisaje, señalando momentos que son al mismo tiempo un punto de inflexión en el pensamiento y un modo de apropiación física del territorio. En este sentido, la transformación del paisaje es causa y efecto de una huella (in situ) y de una imagen (in visu), pero también de una narración. Esta narración que puede ser mítica, científica o poética, configura la idea de paisaje en un proceso de construcción de significados colectivos, cuyo origen encontramos en el acto de caminar. Caminar produce una huella que ordena y establece orientaciones físicas y de sentido, genera relatos y se plasma en mapas y otras imágenes. Errar dejó huellas insondables en el territorio americano prehispánico, otras fueron borradas o subsumidas en un nuevo orden que se impuso con la fundación de ciudades por los españoles, que también caminaron, recorrieron este territorio indómito que se bate entre la imagen de copia feliz del edén y de tierra de desastres, a partir de los relatos de la mirada extranjera.

Paradójicamente, el advenimiento contemporáneo del paisaje en Chile, mantiene esa mirada ajena, desde fuera, para configurar la idea del "paisaje remoto", aquel que sólo puede ser aprehendido a través del viaje, y en el que la arquitectura se transforma en el soporte de un recorrido que actúa en múltiples escalas para descubrir aquello que está latente en el sitio con intervenciones mínimas, herederas de las travesías poéticas de "Amereida", ese viaje inconcluso que busca descubrir la identidad sudamericana a través de un viaje de experiencias y huellas desencadenadas por intervenciones poéticas. Así, la poesía es en Chile ese impulso que desde el arte hace que la arquitectura retorne al paisaje, tal como el Land Art de los años sesenta anticipa los principios de la arquitectura del paisaje de los noventa

La transformación del paisaje también es la transformación del sujeto que actúa en el territorio, desde el jardinero, al arquitecto paisajista y al urbanista del paisaje, abarcando las distintas escalas de un arte que trabaja con la naturaleza. Más que la evolución de una disciplina, postulamos que este sujeto debe ensamblar a los antiguos jardineros, arquitectos y urbanistas, para superar la oposición entre paisaje y ciudad, o considerar la arquitectura del paisaje como un mero paliativo de la vida urbana o como complemento de los edificios y la infraestructura, para, por el contrario, constituirse en una respuesta, un modelo de actuación. Si bien, como hemos visto, los modelos contemporáneos están fuertemente influenciados por una sensibilidad creciente por el medioambiente y por las ciencias ecológicas, el paisaje como constructo, más allá de su existencia física, nos recuerda que lo que está en juego no es sólo la condición ecológica, sino también la conti- 
En este sentido, el proyecto de paisaje concebido como un proceso de transformación, es también un proceso de construcción de significados colectivos, que hemos llamado imaginación social o imaginario en el texto. Este es el mayor desafío, compatibilizar la dimensión ecológica del paisaje -su persistencia material-y el sistema de imágenes y representaciones del orden natural y social que la comunidad tiene sobre ese sitio, "que porta tanto la interpretación del mundo como del proyecto de transformarlo" (Picon, 2002, p. 27).

La investigación a través del proyecto, como el proceso de proyecto mismo, trabaja esta relación entre la experiencia, la narración y la imagen. Transitando continuamente desde un ejercicio descriptivo (que puede ser histórico, científico y también poético) del paisaje al horizonte de su transformación. La idea que subyace es que la descripción ya contiene la intuición del cambio. Ya que como hemos visto en el capítulo 2, más que una hipótesis que se prueba, el proyecto del paisaje y la investigación asociada, anticipa intuitivamente (creativamente) un resultado a través de un razonamiento abductivo, que en la práctica es un proceso abierto de apuestas, errores, correcciones y reformulaciones que buscan definir las reglas particulares de organización espacial, una organización espacial que tiene como instrumento la percepción del paisaje.

Si consideramos el proyecto Carén como un gran laboratorio, ${ }^{180}$ nos enfrentamos a un sitio singular, sin reglas generales ni formas predeterminadas, lo que impide el razonamiento deductivo. La investigación en este contexto, a través del proyecto, actuaría según las reglas de la abducción, para configurar paso a paso el sentido de lugar en múltiples escalas. Esta operación "creativa" tiene como punto de partida la exploración del terreno, múltiples idas y vueltas a pie, para determinar situaciones locales, para medir, graduar el tamaño, definir orientaciones, referencias; percepciones que serán narraciones, mapas de travesía que darán sentido a otros, levantados técnicamente como los de geomorfología, topografía, hidrografía, la arqueología de los distintos usos que ha tenido el sitio, y los otros relatos a través de documentos históricos, reuniones y entrevistas. La escala mayor del valle, la cuenca hidrográfica y del territorio (como entidad política) será experimentada comúnmente en automóvil, también en el caso de Carén desde el avión (por su cercanía al aeropuerto).

La representación del "paisaje" mediante el mapa y la narración del itinerario por lugares, inicialmente intuitiva construye un modo de ver, también una postura, que es el punto de partida para la puesta en común y la construcción de sentido colectivo. Para "descubrir" como diría Girot (1999), aquello que está latente y que el diseño puede hacer visible y donde necesariamente el arquitecto debe tomar decisiones y no solo hacer emerger de los datos una forma. El transcurso del mapa al plan exige así un sujeto ético, capaz de sintetizar y organizar el conocimiento de un sitio, en la forma de un proyecto con sentido para los demás.

Caminar y su huella aparecen a lo largo de este capítulo de muchos modos: como origen de la arquitectura del paisaje, como fuerza centrífuga sobre el territorio y centrípeta en la clausura del jardín. En la aparición del horizonte y la idea del infinito. También en el arte de la tierra y en los modelos que distintas escuelas han utilizado para sistematizar su modo de actuar sobre el paisaje, que presuponen la experiencia de recorrer el sitio: la idea de proceso, de capas y huellas; las múltiples escalas, desde el cuerpo a la geografía y el mapa como constructo. Caminar ha sido también el ejercicio que está en la base del análisis de los grandes parques públicos que se desarrollará en el capítulo siguiente, que profundiza en este "artefacto urbano" para comprender aquellas estrategias de fundación, y las que les han permitido perdurar en el tiempo y en la memoria de las personas. 



\section{CAPITULO 5: PARQUES, GRANDES PARQUES}

\subsection{INTRODUCCIÓN}

En los capítulos precedentes hemos abordado el concepto de paisaje, su evolución y sus representaciones culturales, para luego examinar hasta qué punto el paisaje constituye un elemento identitario dentro de la cultura chilena, y comprender de qué manera los procesos que suceden en otras latitudes nos tocan y transforman.

En el capítulo acerca de la transformación del paisaje hemos descrito sucintamente los diversos modos en que, a través de la historia, el hombre se ha relacionado con la naturaleza y ha dejado su huella en ella. Estos modos de actuación han configurado un ámbito disciplinar desde donde hoy se teorizan y ejecutan las acciones territoriales de gran magnitud. La arquitectura del paisaje es ese ámbito disciplinar, que desde el siglo XIX responde a los problemas del crecimiento urbano, creando un dispositivo, un nuevo artefacto: el parque público.

El capítulo que se inicia, profundiza en la tipología del parque, del parque público, del gran parque.

Cabe recordar que el caso de estudio e intervención que recorre esta tesis es el proyecto en el sitio de Laguna Carén, un terreno de 1.022 hectáreas ubicado en el límite poniente de la ciudad de Santiago, definido normativamente como Parque Metropolitano, un parque no-consolidado, por lo tanto, sujeto al peligro de perder dicha condición.

El desarrollo de este capítulo abordará entonces la tipología del parque público, el problema del tamaño, vale decir qué significa "lo grande" o como propondremos más adelante "lo vasto". Para ello, se han visitado y estudiado en profundidad más de cuarenta parques ubicados en Europa, Norteamérica y en la ciudad de Santiago. Los ejemplos seleccionados corresponden a parques públicos que se han materializado y de uno u otro modo han sobrevivido, adaptándose, a veces sufriendo abandono, y resistiéndose a la constante presión de la ciudad sobre ellos. Se han estudiado sus orígenes, vale decir las condiciones materiales, sociales y políticas que impulsaron sus proyectos, como también el rol que sus proyectistas asumieron más allá del diseño. Lo anterior con la intensión de develar la racionalidad que les permitió llevar adelante estas empresas. A través de los proyectos se analizarán aquellas decisiones de diseño que, como señala Julia Czerniak (2007) hacen legibles y resilientes estos parques.

Proponemos, de acuerdo con la hipótesis, que serían el tratamiento multiescalar y la construcción de una identidad asociada al paisaje, lo que permitirian su adaptación y resistencia a la fragmentación. Observaremos algunos casos, en que estas características son más débiles, lo que hace de estos parques, lugares susceptibles al abandono y decadencia.

Los parques aquí mencionados abarcan distintos lugares y siglos. Más allá del tamaño, el criterio para su elección ha sido la relevancia para la vida urbana. Son ejemplos de problemas y soluciones, por lo que nos permiten un análisis crítico. En esta selección se han descartado los parques nacionales y también los parques históricos. Trataremos parques públicos con compromiso urbano, concebidos como tales. Por lo tanto, no se no se profundiza sobre interesantes ejemplos de parques reales tales como, el Regent Park y Hide Park de Londres, o el parque del Retiro de Madrid. Por último, la tipología del parque científico o sus variaciones, en científico-tecnológico, o tecnológicos a secas, tampoco se incluye, ya que será especialmente abordada en el Capítulo 11.

\subsection{EL HUERTO EL JARDÍN Y EL PARQUE, LO QUE NOS DICE LA ETIMO- LOGÍA}

En 401 a.C., formando parte del ejército de diez mil mercenarios griegos que Ciro enlistó, el historiador griego Jenofonte descubre, en el corazón del desierto, espléndidos jardines persas. En la crónica de esta aventura fracasada, llamada Anábasis, Jenofonte llama a estos jardines paradeisos, $\pi \alpha \rho \alpha \delta \varepsilon 1 \sigma o \varsigma$ en griego, que luego derivaría en paradisus en latín eclesiástico. 
La palabra, de origen persa, combina pairi (alrededor) y daiza (muro), ya que estos jardines de delicias estaban rodeados de muros. En las versiones contemporáneas de este texto en español, el término en griego es traducido como parque:

Alli Ciro tenía un palacio real y un gran parque lleno de animales salvajes, que cazaba a caballo cada vez que quería que los caballos y él mismo hicieran ejercicio. Por el medio del parque fluye el río Meandro... Y allí Ciro pasó revista e hizo recuento de los griegos en el parque; en total, resultaron ser once mil hoplitas y alrededor de dos mil peltastas. (Jenofonte, 1999, p. 31)

Allá estaba el palacio de Belesis, que fue gobernador de Siria, y un parque muy grande y hermoso, con todos cuantos productos hacen brotar las estaciones. Ciro lo dejó yermo y quemó por completo el palacio. (p. 44)

Así pues, los griegos montaron sus tiendas junto a esta ciudad, cerca de un grande y hermoso parque poblado de toda clase de árboles, mientras que los bárbaros lo hicieron tras haber cruzado el Tigris, sin que los griegos alcanzaran a verlos. (p. 88)

El término empleado por Jenofonte será de donde procede el paraíso del Nuevo Testamento, donde Dios promete "Al que venciere, le daré a comer del árbol de la vida, el cual está en medio del paraíso de Dios" (Ap 2:7 Reina Valera 1960). En el Génesis no se habla de paraíso, sino del jardín o del huerto, que es lugar donde son colocados Adán y Eva. Desde allí "oyeron la voz de Jehová Dios que se paseaba en el huerto" (Gn 3:8).

La palabra Edén, utilizada comúnmente como sinónimo de paraíso, procede del hebreo 'ēden, que quiere decir "delicia" (Nelson, 2007, p. 178). En la Biblia, edén nombra el territorio en el que se encontraba el paraíso: un huerto o jardín (paraíso) ubicado al oriente de la región (edén).

Y Jehová Dios plantó un huerto en Edén, al oriente; y puso allí al hombre que había formado.

Y Jehová Dios hizo nacer de la tierra todo árbol delicioso a la vista, y bueno para comer; también el árbol de vida en medio del huerto, y el árbol de la ciencia del bien y del mal. (Gn 2: 8-9).

Dios toma al hombre y lo pone en "el huerto de Edén, para que lo labrara y lo guardase" (Gn 2:15), su castigo es la expulsión de este jardín. Adán no es el único, en el libro de Ezequiel se cuenta la historia de un rey que trató de ser como Dios y fue expulsado del Jardín del Edén, del "huerto de Dios" (Ez 28:13), sin embargo, para consolar a Sión, Dios "cambiará su desierto en paraíso, y su soledad en huerto de Jehová" (Is 51:3), asociando así, al menos en español, paraíso, huerto de Jehová y Jardín del Edén.

Si el desierto cubrió gradualmente el paraíso persa, que admiró Jenofonte, su imagen ha sobrevivido por más de mil años en sus alfombras (Figura 5.1), referencia esencial para comprender los jardines tanto del islam como de la India.

181 Traducción propia del francés:

[...] accompagnée de quatre nobles Sarrasins et de dix belles pucelles, était descendue dans le parc planté de pins et d'olivers, et se promenait le long du ruisseau qui serpentain à l' obre des arbres. II s'y trouvait des herbes d'une rare vertu, car si blessé qu' eût été un homme, dès que ses plaies étaient frottées du suc de ces plantes, il était guéri et en aussi bonne santé qu' un poisson dans l'eau.
Otro concepto relacionado es huerto, considerando que en la Edad Media se usaba la palabra huerto en lugar de jardín. Este término deriva del latín hortus, mientras que jardín proviene del antiguo francés jart (huerto), derivado a su vez del fráncico gard, que es entendido como cercado o seto.

La aparición de la palabra parque, en su acepción en francés parc aparece en la primera mitad del siglo XIII en el texto Anónimo Le Charroi de Nîmes, del Cycle de Guillaume d'Orange, un cantar de gesta que narra la conquista de Nîmes por los francos:

acompañado por cuatro nobles sarracenos y diez hermosas doncellas, había descendido al parque plantado de pinos y olivos, y caminaba por el serpentino arroyo a la sombra de los árboles. Había hierbas de virtudes raras, pues si hubiera sido herido un hombre, tan pronto como le frotaran las heridas con el jugo de estas plantas, estaba curado y tan sano como un pez en el agua. ${ }^{181}$ (Jonckbloet, 1867[sobre el original del s. XIII], p. 36) 


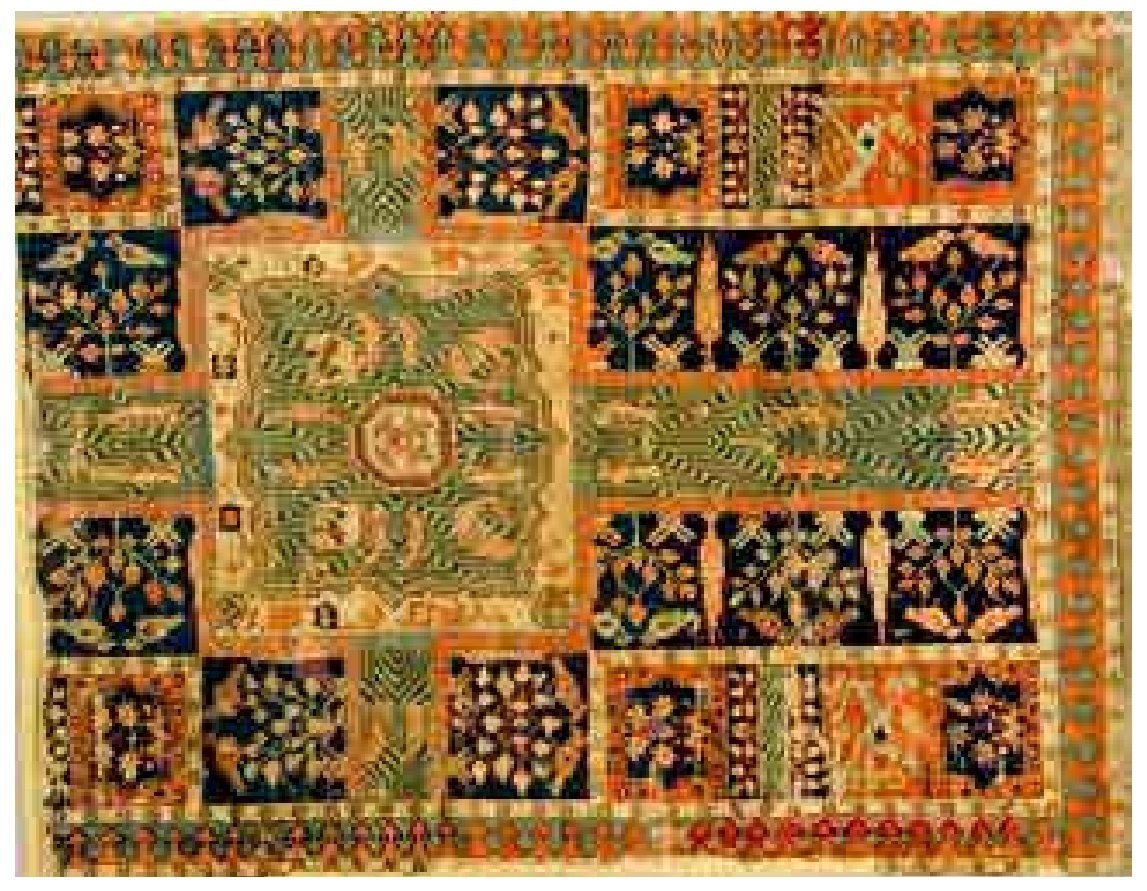

Guerreros y cazadores admiran las vastas extensiones para la lucha y caza, sin embargo, también conocen y cuidan las plantas curativas y aromáticas. Estas últimas viajarán con ellos como esencias que comercializarán y esparciendo los perfumes de violetas, lirios, jazmines y naranjos por el oriente medio y la cuenca mediterránea.

Así, si al principio del medioevo la palabra parque (como parc) nombra tanto una majada de ganado, como el sitio cercado destinado a conservar en él animales salvajes, luego llega a entenderse genéricamente como terreno cerrado y con plantas para recreo. Etimológicamente procede de Parřcusatt, término usado en las Leyes Ripuarias (Grimal, 2019). En español el término aparece en el siglo XVII, como traducción de la palabra italiana parco (para el italiano también es un galicismo que se introduce hacia el siglo XVI). La palabra pre-latina parra, que quiere decir espaldar, guarda el origen etimológico de empalizada.

Park entró en la lengua inglesa alrededor de 1300. Es de origen germánico y está relacionado con el alemán Pferch que significa pluma, pliegue, espacio cerrado. Palabra era originalmente un término legal para la tierra poseída por la concesión real para el mantenimiento de animales de caza (Grimal, 2019). Una zona cerrada y, por lo tanto, distinta a un bosque ya que no tenía leyes especiales u oficiales.

A finales del siglo XVII, "parque" también se convirtió en una palabra en el ejército para un espacio ocupado por artillería, vagones y tiendas en un campamento. El uso verbal del parque para colocar un vehículo empezó a surgir a principios del siglo XIX y se basó en la idea de poner vehículos militares y artillería en este recinto o corral. El siglo XIX, se refería principalmente a estacionamiento de trenes $y$, finalmente, a principios del siglo XX tomó el significado que todos conocemos: un lugar para estacionar un automóvil.

\subsection{EL PARQUE COMO OBJETO DE ESTUDIO}

Para convertir el parque en objeto de estudio, es preciso diferenciarlo de otras configuraciones presentes en el espacio público y en la arquitectura del paisaje. La reflexión teórica que se desarrolla a continuación, los ejemplos y la cronología de su desarrollo, nos permiten relevar la importancia
Figura 5.1. Alfombra-jardín Chahar Bagh del siglo XVII. Fotografía. Por Isfahan (5 de diciembre, 2010). 
del parque en la historia de la ciudad, también enriquecer y actualizar el concepto, teniendo a la vista sus variaciones y evolución. Podemos ver en la historia del parque público como se superponen objetivos políticos, asociaciones simbólicas y prácticas sociales, muchas veces coexistiendo en una suerte de reescritura de su propia conformación en un territorio, que es al mismo tiempo inclusión y exclusión del espacio de la ciudad.

Si bien el parque es un objeto que se produce como extensión del arte de la jardinería, se diferencia del jardín en su escala urbana y carácter público. El jardín es una construcción propia del cultivo, de origen rural, pero de adaptación y desarrollo en el ambiente doméstico, en donde son características la intimidad de una cercanía y una perspectiva proporcionales a la propiedad a la que sirven y a los fines de un propietario particular. A pesar de que el término parque será utilizado en operatorias de jardinería privada -como en los parques pintorescos de las mansiones británicas- el concepto aparecerá cuando la extensión de las mismas rompa la relación de dependencia con la obra de arquitectura como pieza central. En ese sentido, el parque -público o privado- es un artificio ajardinado que se ha emancipado del edificio o que incluso lo ha vuelto funcional a su propia escenificación espacial.

En segundo lugar, el parque urbano es una infraestructura de la ciudad que ha sido construida o habilitada para cumplir con fines públicos. Se diferencia de otros dispositivos como plazas, paseos arbolados y jardines botánicos tanto en su morfología como en su función, pero, sobre todo, en los discursos y las apropiaciones sociales que los identifican como tales. En ese sentido, puede decirse que el parque es una construcción cultural que incluye objetos, ya sea naturales 0 artificiales, que son identificados en una época determinada con las funciones que le son pertinentes. Es así como, por ejemplo, la consideración decimonónica de parque puede diferir radicalmente de las connotaciones ecológicas que en la ciudad contemporánea. Del mismo modo, las funciones que justifican su creación responden a necesidades urbanas que son propias de un momento específico, sean estas el paseo, el deleite estético, la salud, el culto al cuerpo, la recreación, la restauración de un enclave natural, entre muchas. Así también, la definición de lo público será un asunto que cada época y lugar comprenderá de forma diferente.

${ }^{82}$ Gorelik (1998) utiliza frecuentemente el término figuración, especialmente para ampliar los alcances conceptuales de los proyectos de espacio público en la Buenos Aires de cambio de siglo. El libro La Grilla y el Parque es un texto que tiene gran influencia en el punto de vista que expondremos

183 La "solidez" es un término que se toma prestado de Bauman (2003) quien, sin referirse explícitamente a los parques, distingue la modernidad sólida de la líquida, en la producción de utopías tópicas versus las atópicas propias de la globalización.

\subsection{EL PARQUE Y SU CONFIGURACIÓN}

El parque se entiende tradicionalmente como una construcción material, un artefacto urbano delimitado, como hemos visto, un concepto que porta en su etimología latina, parricus o envallado, su encerramiento. Aquí será entendido principalmente en su dimensión de idea: una construcción social y cultural, una figuración ${ }^{182}$ en prácticamente todas las acepciones que encontramos del término. Es una figuración en su sentido de figura o forma, ya que se organiza según un proyecto determinado, una arquitectura definida, una producción estética. Es también una figuración en el sentido de la aparición: en él se representan partes de la cultura, la sociedad y la política, tanto en sus realidades como en sus anhelos. También en sus proyectos -especialmente en el caso de la ciudad latinoamericana-, el parque es una figuración en el sentido que aparenta: en ocasiones, pretende ser un trozo de ciudad foránea y contagiar en su afán cosmopolita al resto del tejido urbano. Es finalmente figuración en el sentido de una construcción imaginada. Una imaginación propiamente moderna, que busca en el porvenir la resolución de sus conflictos presentes y una imaginación sólida ${ }^{183}$, una utopía que se resuelve de manera colectiva en un lugar concreto.

Buscaremos entonces, estudiar el parque tanto en su calidad de idea como de construcción material, aunque el acento no se pondrá en los artefactos como producciones autónomas. Buscamos más bien fijar la atención en las huellas que 
esta figuración deja en el espacio. La idea de parque como receptora de aspiraciones sociales, proyectos políticos y visiones estéticas, libera al proyecto arquitectónico de su condición protagónica. En cambio, se incorporan los imaginarios como la clave de interpretación del lugar, y las prácticas sociales, que completan su sentido e identidad.

Por una parte, los parques son materializaciones de un imaginario político. Como plantea Nicolin (1981), el parque surge como un dispositivo reformista capaz de aliviar una serie de problemas sociales y materiales de la ciudad (Nicolin, 1981, p. 3). Especialmente en el caso norteamericano, donde es utilizado como herramienta proyectual de la planificación urbana, las funciones que asume el parque no son sólo prácticas, sino que también políticas: el parque vendría a constituirse en un bálsamo social, un alimento moral y una plataforma niveladora del presente sobre la cual podría construirse un mejor futuro (Olmsted, 1870; Public Walks, 1834). Para precisar esta idea, resulta inevitable citar la definición de Adrián Gorelik que interpreta los parques como "artefactos históricos en los que aparecen grabadas ideas en pugna sobre cómo debe ser la esfera pública ciudadana, precisos proyectos culturales y políticos" (Gorelik, 1998, p. 19).

Pero, por otra parte, los parques son también escenario de las prácticas sociales, son representaciones no sólo políticas sino del imaginario social. Gran parte del significado de estos lugares es interpretado por lo que los distintos grupos han imaginado y proyectado sobre ellos, no siempre en común acuerdo.

Finalmente, y en un sentido simbólico, resulta complementaria la sugestiva metáfora con la que George Teyssot (1981) se refiere al verde urbano como las "Grandi macchine pensanti" (p. 2). En la concepción de los jardines públicos como producciones estéticas, las formas de los espacios materializan las interpretaciones simbólicas de una época en que la ciudad y especialmente el espacio público, se convierten en espejo de la condición humana. El deambular individual -no ya la recreación grupal ni la imaginación política- ofrecerá una tercera lectura del jardín público como depositario de un imaginario intelectual que reconoce en el parque urbano una figura retórica de la modernidad. Al respecto, resulta expresiva la cita de Nietzsche que reclama en la ciudad, parques como los nuevos templos laicos:

[...]lugares para reflexionar silenciosos y amplios, ampliamente extendidos, lugares con largos y altos pórticos para el mal tiempo, o para el tiempo demasiado soleado, en los que no penetre ruido alguno de coches y de pregoneros y en los que una delicada decencia prohibiría incluso al sacerdote rezar en voz alta: obras arquitectónicas y parques que como un todo expresen la sublimidad del recapacitar y hacerse a un lado. [...] para que nosotros los $\sin$ Dios pudiésemos pensar en ell[o]s nuestros pensamientos. Queremos habernos transmutado nosotros en piedra y planta, queremos pasear por dentro de nosotros mismos, cuando caminemos por esos pórticos y jardines. (Nietzsche, 1882/2002, p. 270271).

\subsection{DESDE EL JARDÍN A LA CIUDAD}

El parque como parricus hereda del jardín la condición de clausura, la idea de un espacio controlado, delimitado y bello. La representación del paraíso tejido en las alfombras islámicas, las pinturas medievales del hortus conclusus y del jardín secreto, nos recuerdan este requisito.

La relación antagónica de la ciudad con la naturaleza refuerza la idea de límites precisos, que el lenguaje también guarda: la palabra latina silva proviene del vocablo griego que designa materia (y que derivaría en madera) y que alude a lo silvestre. De allí, el vocablo inglés forest, proviene del latín forestem silvam que designa aquel bosque que está fuera de los límites urbanos (con la misma raíz se forma el vocablo foreing, que puede traducirse como afuera). El término latino urbs proviene a su vez de orbis, y se refiere al trazado del círculo, que delimita y define la ciudad. Aunque luego orbis sería el orbe, o el mundo en su acepción conceptual más amplia, originalmente urbs hará referencia a aquella cintura que contiene a la ciudad como unidad definida. Los vocablos town (inglés) y Zaun (alemán) tienen también asociados la valla circundante, utilizados originalmente 
incluso para señalar un predio agrícola o propiamente un jardín. Algunos de estos aspectos etimológicos son recogidos en el texto de Silvestri y Aliata (2001) para destacar que las ideas de ciudad y naturaleza se presentan claramente delimitadas.

Sin embargo, esta condición de clausura se tensa y entra en conflicto con la idea de parque como espacio público, con la complejidad de lo público, también con lo difuso de sus límites.

El carácter informe del espacio público se vincula al concepto de civitas-como expresión de la vida social y política- más que al de urbs -como forma construida- ya que como nos señala Gorelik, es más que un espacio que la ciudad ha dejado abierto:

En efecto, espacio público no es, en nuestra acepción, el mero espacio abierto de la ciudad, a la manera en que tradicionalmente lo ha pensado la teoría urbana. Como se sabe, espacio público es una categoría que carga con una radical ambigüedad: nombra lugares materiales y remite a esferas de la acción humana en el mismo concepto; habla de la forma y habla de la política, de un modo análogo al que quedó matizado en la palabra polis. (Gorelik, 1998, p. 19)

Pero al hablar de polis, fijamos el parque dentro de la ciudad, como un lugar urbano, mientras que el jardín en su origen y desarrollo, remite a lo doméstico, a un dispositivo de origen rural que se adapta y somete en un interior formalizado. La extensión y la masividad propias de lo público contrasta con la intimidad del jardín, de una cercanía y perspectiva próxima. Así, las formas del poder político al materializarse en el parque urbano, deberán expresarse dentro de los límites precisos y contenidos del verde ajardinado.

Como ya se ha señalado, el origen de la utilización del término parque se sitúa en jardinería pintoresca inglesa, donde quien opera sobre el paisaje es un particular. A diferencia de Francia en donde el Estado transforma el territorio mediante caminos y puentes, en Inglaterra la transformación del paisaje es total, capilar y múltiple, concebida desde individualidad del jardinero burgués. El gusto inglés por lo irregular, la sensación de libertad, y la aversión por la estética de la línea recta clásica y barroca, caracterizarán esta morfología del jardín, que articulará también una continuidad entre lo salvaje y lo cultivado.

El parque, en su doble condición de jardín y espacio público, se perfila en el contacto con la ciudad como un artefacto político y cultural. Para Elizabeth Rosenzweig y Roy Blackmar en su libro sobre el Central Park el parque siempre es público, ya que, como espacios abiertos e inclusivos, adquieren su carácter a través de su uso por la ciudadanía y no necesariamente a través del ejercicio del poder y control político sobre un territorio (Rosenzweig \& Blackmar, 1992, p. 6).

Sin embargo, el uso público, en el caso de los parques europeos es parte de un proceso de evolución, "deviene público", mientras que, desde el Central Park, el parque norteamericano se crea público, lo público está en sus orígenes (Gorelik, 1998). El caso latinoamericano, según lo planteado por Pía Montealegre en su tesis (2010), tiene una condición ambigua: "el parque deviene público en toda la amplitud del término en la medida que la sociedad también amplía su definición de público. A la vez el espacio abierto también deviene parque, en una evolución paralela a la de la sociedad" (Montealegre, 2010, p. 22).

Encontraremos así, diversas justificaciones para la creación de parques, como también distintas funciones resultantes. Será considerado como infraestructura verde, con funciones ecológicas y de beneficio medioambiental, especialmente en los parques norteamericanos contemporáneos; como parte de un proyecto inmobiliario desde Birkenhead, el primer parque público inglés; como agente de expansión de la ciudad, en el caso de la Quinta Normal de Santiago (Montealegre, 2016); como herramienta de reestructuración urbana y vehículo de integración social, en el caso de la transformación de París; como espacio de sanidad y recreación para las masas, especialmente en los parques alemanes; contrapeso de la vida urbana y hoy pieza clave en cualquier proyecto urbano, donde convergen todas las funciones anteriores, que, como señala Montealegre, son "funcio- 
nes asociadas al parque como instrumento político"(Montealegre, 2010, p. 24).

El parque como instrumento político, será también un espacio utópico, en cuanto promesa de una vida mejor, materializada en un territorio: un proyecto que se asienta sobre la idea de un estado benefactor. Si bien autores como Bauman no asocian explícitamente parque y utopía, su definición de utopía resuena en la idea del parque que desarrollaremos:

...buena vida, significa una vida vivida en una buena sociedad, mientras que una 'buena sociedad' es traducida a su vez, como la población que habita en un territorio trazado y cartografiado, y que luego son proyectados sobre el espacio físico, por los sabios y benevolentes poderes de un buen Estado (Bauman, 2004, p. 276).

Una precisión de la relevancia del concepto de lugar y territorialidad en el concepto de utopía se lee en el mismo texto de Bauman:

La imaginación utópica era esencialmente arquitectónica y urbanística. La principal atención de los constructores de modelos estaba dirigida a trazar y cartografiar, dejando el trabajo de proyección del mapa sobre el territorio (o más, hasta el punto del trabajo de rehacer la realidad a partir de la semejanza del mapa) a los gobernantes del topos. El propósito era diseñar una distribución espacial en la cual existiera un correcto y justo lugar para todos aquellos para los que el correcto y justo lugar había sido diseñado. En el proceso de bosquejo de los mapas anticipatorios de Utopía ambos bordes (inseparables, como eran) de la espada de poder, eran ensombrecidos. La construcción del buen orden era, invariablemente, un ejercicio de inclusión y exclusión: en incondicionalidad de la ley e incondicionalidad de sus exoneraciones (Bauman, 2004, p. 276).

Como veremos más adelante, la cita anterior no sólo sugiere el tipo de operaciones de diseño presentes en un parque, como materializaciones de una naturaleza preconcebida y utópica, sino también a las acciones menos evidentes que resultan de ella, como son las regulaciones que acompañan al jardín público, que condicionan comportamientos adecuados (civilizados), como sucederá en los parques reformistas.

El parque puede considerarse doblemente utópico hoy, si consideramos que el bienestar individual prevalece sobre lo colectivo, y donde el Estado ha abandonado su rol benefactor. Cabe preguntarse entonces si los parques no son una tipología obsoleta, o como sentencia Adriaan Geuze, en el contexto del paisaje holandés, que "ya no hay necesidad de parques, porque todos los problemas del siglo XIX han sido resueltos y se ha creado un nuevo tipo de ciudad"(Geuze, 1995, p. 38), donde el parque y el paisaje se han convertido en clichés desgastados.

Esta tesis por el contrario insiste en la idea del parque como lugar utópico, colectivo y anclado a un territorio asumiendo el desafío que plantea Galen Cranz en su libro The Politics of park design: A History of urban Parks in America, al instar a "aquellos con un interés en el carácter de la vida urbana deben aprovechar los parques como uno de los vehículos para la realización de su visión particular y el debate alrededor de esas visiones". Más específicamente, que "los parques pueden ser un mundo perfecto en miniatura, uno que proporcione normas para el mundo más amplio" (Cranz, 1882, p. 246).

\subsection{ARTEFACTOS ANTICIPATORIOS}

La idea del jardín público aparece en manifestaciones tan extendidas como distantes, muchas de ellas tipológicamente similares al parque urbano. Una cuestión fundamental en esta indagación es la consideración del concepto de "público" que variará entre distintas culturas y épocas. Del mismo modo, sus objetivos resultan tan diversos como ambiguos.

Si nos remontamos a los primeros relatos sobre América, podemos encontrar indicios de una jardinería azteca. En los relatos de Hernán Cortés (en Martínez, 1990) se describe el Templo Mayor de Tenochtitlan, que incluía un trabajo paisajístico que evocaba a Mixcóatl, patrono de la cacería. Los cronistas también 
mencionan avenidas arboladas en Teotihuacán, y los jardines de Chapultepec, que podría ser considerado el primer parque urbano de América. Aprovechando los manantiales y el viaducto que dotaban de agua a Tenochtitlan, Moctezuma Ihuicamina manda a construir estanques para peces e introduce especies de la flora y fauna de todo el imperio en sus dominios. Esta suerte de jardín botánico dataría aproximadamente del año 1400, y deslumbra los relatos de Hernán Cortés. El conquistador describe el zoológico que le muestra Moctezuma Xocoyotzin, que contaba con aviarios (la Casa de las Aves) y animales carnívoros retenidos en jaulas de madera (La Casa de las Fieras). Corté ${ }^{184}$ se impresiona al observar que las bestias son atendidas por personal especializado y constatar que el jardín también contaba con una colección de rarezas humanas. Estos jardines tenían una cierta finalidad científica, lo que refleja el desarrollo de una herbolaria, una botánica y una zoología mexicana. En el jardín, se estudiaban las propiedades alimenticias y medicinales de las plantas y se reproducian los animales adorados por la religión. A la vez, el jardín de Moctezuma era una manera de conocer y representar el imperio. Es de suponer que el acceso al lugar era restringido, pero, aun así, la admiración que despierta en los colonizadores sienta bases para el desarrollo de un zoológico y jardín moderno que en la actualidad ocupan el mismo lugar (Matos Moctezuma, 2014).

En la misma ciudad, pero en el año 1592 surge Alameda Central, creada como paseo público por el virrey don Luis de Velasco. Sobre un sitio rectangular hasta entonces ocupado por un mercado azteca, se plantan árboles y se diseñan jardines. Rodeado por una acequia, el lugar contaba al menos con un acceso controlado. La definición de público de la sociedad mexicana de entonces, seguramente excluía importantes porciones de la población.

Un poco más cercano al momento inaugural del parque inglés, en Norteamérica se originan los primeros paseos verdes sobre las dehesas de uso común. En 1830, se decide retirar los animales del Boston Common, para destinarlo definitivamente al uso humano en 1836. Ya desde 1808 la calle contigua se llama park street, quizás acusando la vocación del terreno o quizás aludiendo a Tremont Mall, una avenida arbolada que ya estaba establecida desde 1728. Esta sería la primera asociación con el término espacio público.

La constelación de casos podría dilatarse e incluir ejemplos tan curiosos como influyentes como los Vauxhall Gardens en la Inglaterra del siglo XVIII, surgido bajo la categoría de pleasure garden. El lugar era tarifado y presentaba más atractivos construidos que expresiones paisajísticas, por lo que se asemeja más a la tipología del parque de diversiones. La música ocupaba un papel fundamental en un monumental odeón y algunos fosos disimulados que sorprendían a los paseantes con sus melodías de procedencia mágica. Aunque distantes a la concepción contemporánea de espacio público, podemos reconocer elementos que son comunes con los parques urbanos modernos. Si bien su publicidad es discutible, al menos son invenciones que son concebidas como infraestructura producida para y, en muchos casos, por la ciudadanía. En varios de ellos, el sustrato de preexistencias hace que tampoco sea posible calificarlos como espacios producidos desde la nada. Al igual que las dehesas que devienen jardines, los cementerios, bosques y grandes praderas integrarán un conjunto de lugares urbanos en donde se conformarán los hábitos de esparcimiento al aire libre. Greenwood Cemetery en Brooklyn, Elysian Fields en New Jersey, las alamedas de Lima y Santiago, el Prater y el Glacís de Viena, el Grünewald y los Bois de Boulogne y Vincennes son ejemplos de complejas evoluciones de usos de los espacios abiertos que anticipan la aparición del parque.

${ }^{184}$ Pese a su admiración, Cortés fue el que puso fin a este zoológico el 13 de agosto de 1521, al mismo tiempo que destruyó la ciudad de Tenochtitlan.

\subsection{PARQUES REALES Y JARDINES QUE DEVIENEN PÚBLICOS}

Como observa Gorelik (1998), existe una importante diferencia entre el fenómeno del parque europeo, que "deviene público", en contraste con lo que sucede en la ciudad americana, donde, en general, el parque nace como espacio abierto para el uso ciudadano. Este devenir público agrupa fenómenos diversos, que incluyen tanto la apertura de los jardines aristocráticos como la transformación de los bosques y cotos de caza. 
En el caso inglés, como señala Richard Sennett en Carne y Piedra, antes de ser abiertos al público de manera masiva, los jardines reales son simplemente cercados con el fin de conservar las plantas en su interior. El beneficio público es indirecto, al permitir que "la gente que circulaba por las calles-arterias de la ciudad podía pasar alrededor de estos parques cerrados, respirando su aire fresco igual que la sangre se renueva en los pulmones" (Sennett, 1997, p. 346).

El bien común no fue siempre el motor principal de la apertura pública. Como observaremos, las operaciones inmobiliarias que buscaban rentabilizar el patrimonio hereditario de la monarquía, tuvieron un papel importante. Es el caso de St. James, el más antiguo de los Royal Parks, un terreno pantanoso que sirvió de para la caza y cría de ciervos de Enrique VII desde 1532. Las inundaciones del lugar hacen que en 1603 James I lo drene y posteriormente en 1661 Carlos II encargue a André Mollet un diseño con un canal central propio del paisajismo francés. El parque es abierto entonces al público y utilizado para el contacto entre el monarca y algunos selectos súbditos. En uno de sus flancos se instala un terreno para la práctica de otra costumbre francesa, el juego Paille Maille, una especie de croquet, que se practica bajo la avenida arbolada que luego deriva en Pall Mall. Abandonada la costumbre del juego y convertido definitivamente en paseo (abierto al público en 1887), el espacio es bautizado como mall, una pieza que se replicará en muchos ejemplos como Hyde Park y el Central Park de Nueva York. Además de selectivo en su acceso, el proyecto de Mollet es bastante esencial y a pesar de la geometría francesa, el parque presenta un cierto aspecto descampado, que lo relaciona más a las dehesas o commons que con los jardines públicos modernos.

No será hasta entrado el siglo XIX que St. James adquiera su imagen actual (23 ha), cuando junto al Regent's Park (166 ha) formen parte de una ambiciosa operación inmobiliaria. Regent's, originalmente terreno de caza de Enrique VIII, sirve como coto hasta 1646, cuando se empieza a utilizar como terreno agrícola. En 1811, el Príncipe Regente, posteriormente conocido como el Rey Jorge IV, ve una posibilidad de desarrollo inmobiliario en los terrenos, aprovechando de incluir también un palacio de verano. John Nash, arquitecto de la Corona, propone un proyecto de parque que incluía un importante programa inmobiliario. En el extremo Norte del predio se construye un canal, y se rodea el flanco sur con una serie de viviendas palaciegas denominadas terreces, que, por su forma semicircular, fueron conocidos como los Crescents. Los terraces fueron una tipología que se reprodujo en distintos sectores de la ciudad para recibir la residencia de las familias aristocráticas. Su aspecto uniforme y la prohibición de exhibir en las fachadas las insignias de las familias, remarcan el origen real de la iniciativa inmobiliaria: en un periodo de crecientes fortunas particulares la Corona cuida destacarse por sobre todas. Como señala Sennett (1997), los Crescents construyen una barrera social que desplaza a la clase popular que hasta entonces habitaba el lugar, y hacen que el parque se encuentre en sus inicios, bastante solitario.

Adicionalmente Nash propone al interior del parque un programa de 56 villas -de las cuales solo se construyen ocho- que se sumaban al palacio de verano que nunca fue construido. Se unía este conjunto al Palacio de St. James mediante una avenida: Regent's Street. Como señala Sennett (1997), con esto se pretendía traer visitantes desde el centro más pudiente de la ciudad y no así de los alrededores. El parque privado es, en este caso, entendido como la antítesis de la provisión social que posteriormente se pretendería en el reformismo. En Regent's, Nash inaugura también una nueva tipología en Londres: la disposición lineal de tiendas con vitrinas que configuran el bulevar o calle comercial. Según el autor, se inaugura también así el concepto del suelo monofuncional, y su consecuente configuración como límite: "el movimiento de masas en una calle con una sola función era el primer paso que había que dar para privilegiar a individuos persiguiendo sus propios intereses en una multitud" (Sennet, 1997, p. 350).

El argumento de Sennett es ya planteado en el Reporte de 1834 que se refiere a Regent's Park en los siguientes términos: 
Llamarlo, en su estado actual, parque de uso y recreación del público es un absurdo. De hecho, hay un buen paseo para aquellos que pueden permitirse el lujo de mantener o alquilar carruajes; y a los lados de este paseo hay caminos de grava, por los que el público puede caminar, y que, en una extensión de tres millas, están provistos de unos cuatro o cinco asientos; pero llamar a un lugar así un parque público es una burla descarada. No es un parque público, sino un lugar apartado para el uso exclusivo de los ricos, y a la gente se le permite moler sus zapatos sobre la grava, simplemente porque no pueden impedírselo ${ }^{185}$ (Public Walks, 1834, p. 502).

El mismo artículo denuncia y reclama la venta de llaves a los vecinos acaudalados para acceder al parque de manera exclusiva, lo que confirma la concepción de que el parque era un artefacto que suministraba ventilación a los pulmones de quienes lo rodeaban.

Finalmente, el Rey se decide por la remodelación de Buckingham y el proyecto de Nash se desarrolla sólo de manera parcial. Entre 1827 y 1828 John Nash reforma entonces St. James Park, un diseño naturalista que considera la transformación del canal central en una laguna. Adicionalmente, se remodelan los jardines y se construye un acceso al palacio de Buckingham. A estas intervenciones acompaña el desarrollo del Carlton House Terrace en el flanco norte del parque. Nash había concebido Regent's Park como una enorme pradera. La gran pradera podría haber sido un gesto de aceptación de grandes grupos, sin embargo, como apunta Sennett (1997), al rodearlo de un anillo de arterias para el desplazamiento veloz y masivo de carruajes, los "individuos [quedan] protegidos por el movimiento de la muchedumbre" (Sennett, 1997, p. 346). Sólo en 1835 Regent's es abierto al público de manera parcial y apenas dos días a la semana. Una vez que las villas son abandonadas, los espacios vacantes alojan a la sociedad zoológica, botánica y toxofilita. Estas sociedades terminan de alhajar el parque, plantándose más árboles que los originalmente proyectados por Nash.

El caso de Hyde Park y los Kensington Gardens son ejemplo de transformación pública sin operaciones inmobiliarias de por medio. Las más de 250 hectáreas que componen en conjunto, también tienen su origen en cotos de caza, en este caso de Enrique VIII. Mientras los Kensington corresponden a la porción de jardines del palacio que estuvo habitado por la reina Victoria hasta 1837, Hyde es una pradera un tanto informe que ya en 1637 es abierta al público por orden del monarca. Al mismo tiempo, se habilita el Ring o camino de borde, para el paseo a carruaje de la aristocracia. En el siglo XVIII, Guillermo III se muda a Kensington y construye la calle del Rey (Rotten Row), una amplia avenida iluminada con faroles a gas que le servía para trasladarse con celeridad a St. James. Kensington y Hyde son separados por uno de los primeros ha-has y en la porción de los jardines, Charles Bridgeman crea en 1730 la Serpentine, el primer lago naturalista que luego sería profusamente imitado.

Con su carácter de vaste land, Hyde Park se constituye tempranamente como lugar de manifestaciones multitudinarias y celebraciones. Ya en 1665, muchos habitantes de Londres acampan en el parque buscando escapar de la Gran Plaga. Del mismo modo, en la esquina noreste del parque se encontraba el árbol Tyburn, en donde se colgaba a los condenados desde el siglo XII. Con el tiempo,

185 Traducción propia del inglés:

To call it, in its existing condition, a park for the use and recreation of the public is an absurdity. There is indeed a fine drive round for those who can afford to keep or hire carriages; and by the sides of this drive are gravel walks, on which the public may walk, and which, in an extent of three miles, are provided with some four or five seats; but to call such a spot a public park is an impudent mockery. It is not a public park, but a place set apart for the use of the wealthy only, and the people are permitted to grind out their shoes upon the gravel, merely because they cannot be prevented. el árbol fue reemplazado por una estructura que servía para colgar hasta 24 personas a la vez. Se dice que la costumbre de dejar decir al ejecutado sus últimas palabras deriva en la tradición de los Speaker's Corners, ya que por ley se permitía a los condenados hablar de cualquier tema. Aunque en la cultura británica estos puntos de libre expresión son muy cuestionados por evidenciar la falta de libertad en otros lugares, contribuyeron a formar una cultura política en los parques como centros de reunión ciudadana. Del mismo modo, las grandes praderas de uso múltiple permitieron que Hyde Park continuara siendo el epicentro de las actividades masivas. En 1930 en la Serpentine es habilitado el Lido, un popular balneario público. Hasta hoy, Hyde presenta una notable diversidad social en los usos, desde lo recreativo popular hasta la equitación aristócrata. Paulatinamente la Corona abrió al público una serie de ocho jardines, que a los cuatro ya mencionados se agregan Bushy Park, The Green Park, Greenwich Park y Richmond Park. Inicialmente se discriminó según la vestimenta para con- 
trolar el acceso. En la actualidad los Royal Parks son una fundación dependiente del Departamento de Cultura, Medios y Deporte, pero el libre acceso a ellos no es un derecho civil, sino que es una gracia y favor que concede la Corona. Estos parques que se muestran en la Figura 5.2. en total suman 5.000 acres (2.023 ha) de espacios verdes públicos. (The Royal Parks, 2019).

\subsection{EL REPORTE SOBRE PASEOS PÚBLICOS: CONFORT, SALUD Y CON- TENTO.}

En 1833 en el parlamento inglés se presenta el Report of the Select Committee on Public Walks considerado como un hito fundacional en la historia del parque, al incorporarlo al debate público y político. El texto original, muchas veces citado, es rudo:

No puede ser necesario el señalar cuánto se requiere de algunos paseos públicos 0 espacios abiertos en la vecindad de las grandes ciudades, para aquellos que tienen consideración por la clase trabajadora que allí habita; confinados como están durante la semana como mecánicos y obreros, y frecuentemente encerrados en recalentadas fábricas: Debe ser evidente que es de primera importancia para su salud, el disfrutar en sus días de descanso, el aire fresco y tener la posibilidad [...] de pasear con digna comodidad junto a su familia; si son privados de un recurso así, es probable que el único escape que puedan tener de sus angostos patios y callejones [...] sean aquellas cantinas en donde [...] despilfarran el sustento de su familia y destruyen regularmente su salud. (Public Walks, 1834, p. 507).

La relevancia de este texto para la historia de la planificación urbana, radica en que tiene la particularidad de establecer una conexión directa entre espacio y política, al unir beneficio social con la mejora de la ciudad. En esta visión reformista, el parque se sitúa en un papel protagónico. Cabe recordar aquí que este reporte se adelanta medio siglo a la discusión sobre las políticas habitacionales, ya que recién en 1884 se formará la "Royal Commission on the Housing of the Working Classes" (London County Council, 1913, p.7), para tratar el problema de vivienda de la clase trabajadora.

La prioridad que tiene el parque en desmedro de la vivienda, tiene una serie de explicaciones en el pensamiento reformista. Por una parte, las urgencias sociales se estructuran principalmente en torno a la masiva mortandad producto de epidemias. Por entonces, se creía que las enfermedades eran contraídas debido a la corrupción del medio y no al contagio. Desde ese punto de vista, los factores ambientales tales como la calidad del aire y asoleamiento resultaban determinantes, en contraste con los espacios encerrados y la falta de luz. Al efecto preventivo de un entorno sano, se sumaba la creencia en la capacidad curativa de la naturaleza, por lo que los parques son vistos como herramientas efectivas de salud pública. William Farr, epidemiólogo y seguidor de la teoría miasmática, declara en 1839 que el aire fresco se necesitaba en Londres con más urgencia que un alcantarillado, y que "un parque evitaría miles de muertes y sumaría años de vida a la población"(Farr, 1839, p. 113)

Por su parte, el pensamiento ilustrado, la confianza en la razón y el desarrollo tecnológico, figurado en la máquina, configuran la fe en la capacidad humana de resolver los problemas a través de la inventiva, de nuevos dispositivos y arte-
${ }^{186}$ No será hasta 1883 que Robert Koch descubra el vibrión del cólera y se comiencen a definir mejor el modelo de virus y bacterias y el papel del agua en su propagación.

Figura 5.2. The Royal Parks de Londres. Por The Royal Parks (2019)
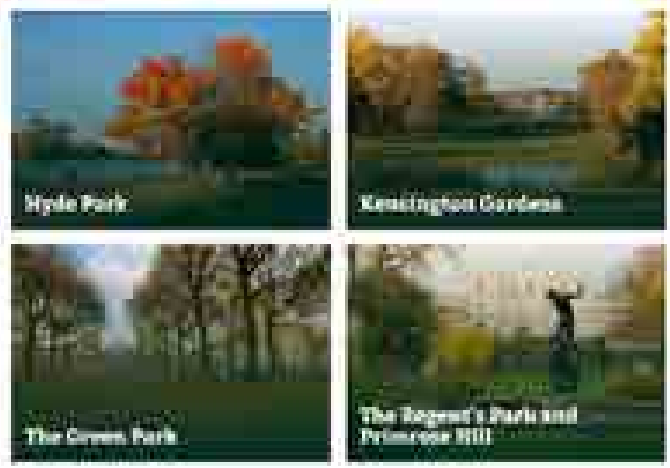
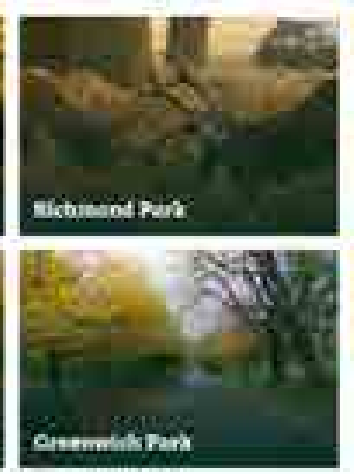
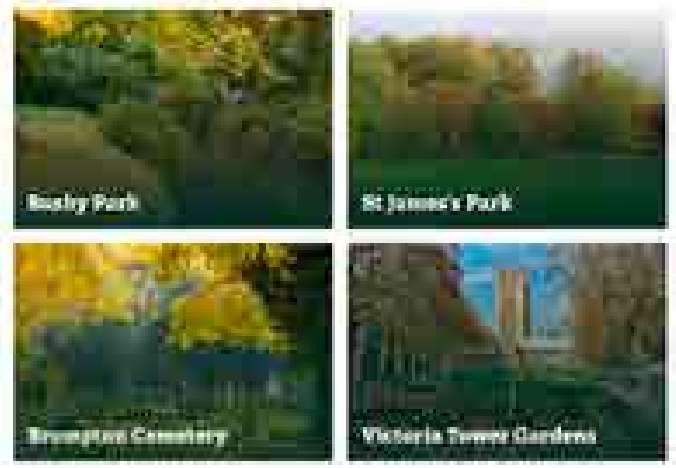
factos, entre ellos, el parque. Los problemas más urgentes se personifican en la pobreza urbana, que pasa a ser la preocupación de los movimientos reformistas y el naciente socialismo. El parque aparece en este contexto, como un antídoto a la insalubridad, pero también a las malas costumbres del proletario, ya que como se deduce de la cita anterior, se ofrece como una alternativa a la cantina.

Finalmente, aún sigue en boga en la filosofía romántica, por lo que el contacto con la naturaleza sigue siendo una prioridad existencial. En la realidad urbana, los viajes al campo y el contacto con la naturaleza se han vuelto cada vez más difíciles de conseguir: la ciudad es cada vez más extensa y las jornadas de trabajo dejan menos tiempo libre. Pero la causa inmediata de la creación de un comité de paseos públicos responde a las consecuencias de las Actas de Clausura (Enclosure $A c{ }^{187}$ ), y la urgencia de asegurar espacios abiertos en las grandes ciudades, como lo declara el Report of the Select Comitee de 1833:

A medida que la población ha aumentado; a medida que los ricos y los más ricos de la clase media se han vuelto más egoístas, y a medida que los edificios se han levantado "como una exhalación", hasta que las aldeas se han convertido en pueblos, y los pueblos en ciudades abarrotadas; las tierras no cerradas han sido arrebatadas a los pobres en el campo; el verde de la aldea, los campos y los espacios abiertos en los que los jóvenes de los pueblos y ciudades estaban acostumbrados a hacer deporte y ejercicio, han sido construidos, o les han sido prohibidos, hasta que la salud y los espíritus de cientos de miles -por no decir millones- han sido sacrificados, y su moral corrompida por las perniciosas diversiones a las que, bajo la privación de la relajación natural y saludable, se han visto obligados. (Public Walks, 1834, p. 499).

Uno de los aspectos más revolucionarios del reporte y que acompaña la instrumentalización del parque como herramienta de reforma, es la orientación hacia un nuevo sujeto-clase. Se busca dejar de legislar a favor de los "zánganos" aristocráticos para favorecer a las "abejas" obreras. Como señala el reporte, al regular el acceso del público a las áreas verdes, se actuaría en función de los pobres:

${ }^{187}$ Los Enclousure Acts, corresponden a las normas que dictaminan el cambio de régimen de los campos abiertos y tierras comunes en Inglaterra y Gales, creando derechos legales de propiedad, clausurando y poniendo precio a las tierras que antes eran comunes. "Entre 1604 y 1914, se aprobaron más de 5.200 leyes individuales de clausura, que afectaron a 2.800.000 ha" (Enclousure Acts, 2019).

188 Traducción propia del inglés:

The rich are those who live in luxury and splendour, and produce nothing; the poor are those who live in mean abodes, and on meagre food, and produce everything. Which class is of the greater importance? Who prefers the drone that eats, to the bee that makes the honey? Yet law has been for the drone, and against the bee; it has given to the former all the honey, and to the latter all the toil.

189 Traducción propia del inglés:

[...] not to a consideration of the cheapest means for preventing them from expiring of cold and hunger, a sort of regard which is well known to have been consistent with the utmost contempt and ill-will towards the unhappy objects of it, but to a benevolent and wise consideration of at least one method of promoting their health, their morals, their comfort, and happiness.
Los ricos son los que viven en el lujo y el esplendor, y no producen nada; los pobres son los que viven en moradas mezquinas, y en comida escasa, y lo producen todo. ¿Qué clase es la más importante? ¿Quién prefiere el zángano que come, a la abeja que hace la miel? Pero la ley ha sido para el zángano y contra la abeja; ha dado a los primeros toda la miel, y a los segundos todo el trabajo. ${ }^{188}$ (Public Walks, p. 498).

Para ello, llama a que el Parlamento no opte por la solución más barata:

[...] no en búsqueda de los medios más baratos para evitar que mueran de frío y de hambre, una especie de indiferencia que es bien conocida por haber sido consistente con el máximo desprecio y la mala voluntad hacia los infelices objetos de ella, sino a una consideración benévola y sabia de al menos un método para promover su salud, su moral, su comodidad y su felicidad. ${ }^{189}$ (Public Walks, 1834, p. 499).

En ese sentido, dentro del repertorio de componentes urbanos, el parque público se constituye en un instrumento político ex profeso.

Desde sus primeras líneas, el Reporte tiene un carácter inquisitivo, planteando preguntas como "¿Qué es un gobierno?" (p. 496) y levantando ideas como la de "proteger al pobre del rico" (p. 498). La figura del "el buen padre" (p. 498) se utiliza para despertar la responsabilidad de la sociedad aristocrática sobre sus hijos pobres, para "volverlos morales, prudentes e industriosos; promover su confort, salud, felicidad y prosperidad al máximo". Se supone también que al proveer a los trabajadores de un medio de relajación natural y saludable no se verán forzados a las diversiones perniciosas que corrompen su moral. Al mismo tiempo, se busca prevenir el surgimiento de las ideas socialistas, "al insistir fuertemente en el peligro de cualquier conocimiento, que no llega a ellos a través de la iglesia esta- 
blecida" (p. 498). De este modo, el parque cumple con la triada funcional, al entregar "confort, salud y contento" para las clases.

El Reporte vincula su acción al espacio urbano. Se señala la necesidad de proveer espacios abiertos en la "vecindad de ciudades populosas" (p. 500), orientando esta política a la escala metropolitana. Efectúa inicialmente un diagnóstico de las condiciones de vida y hacinamiento producto del crecimiento de la población, el cierre de los espacios abiertos y el consecuente aumento de las restricciones para los habitantes de la ciudad. Se destaca también el sesgo de clase en el acceso a los parques reales de St. James, Kensington y Regent's, y se señala que los más democráticos Green y Hyde Park proveen de esparcimiento a un sólo sector de la ciudad. Se busca mantener abierto y sin edificar Pimrose Hill, amenazado entonces, y se levanta la voz de alarma sobre la carencia de espacios públicos en el sector norte de la ciudad, un lugar donde son particularmente necesarios. Del mismo modo, observa el potencial de los Kennington Commons en la ribera sur y se lamenta en general de la falta de planificación de las riveras del Támesis como paseos públicos. Fuera de Londres, el reporte señala que como política general se deben reservar espacios para paseos públicos en las cercanías de las ciudades populosas 0 accesibles por un camino públicos. Del mismo modo, toda ejecución de camino o canal se propone acompañar de la ejecución de un "ancho y sencillo paseo, con dos hileras de árboles y espacio para asientos" (p. 509). Así mismo, en ríos y canales debieran también siempre proveerse balnearios públicos.

Desde el punto de vista de la gestión, el Reporte también señala que el esparcimiento es una necesidad transversal a toda clase social, y que su provisión puede acompañarse de un módico pago por su acceso. Para la obtención de terrenos, se señala la necesidad de una ley general que permita adquirir lotes privados para uso público (p .512).

La función reformista del parque, sintetizada por Gorelik, confía en que puede actuar como un artefacto de transformación social:

[un] dispositivo químico capaz de amalgamar nuevos lazos sociales y culturales, como máquina educativa para la vida ciudadana moderna, como principal dinamizador, en fin, del gran crisol en el que pudieran abandonarse como viejos ropajes las múltiples identidades nacionales, las persistentes tradiciones rurales, las atávicas prácticas productivas y políticas, para dar lugar a una síntesis nueva, nacional, social y cultural (Gorelik, 1998, p. 59).

Desde el paternalismo aristocrático, la función educativa se inicia con el acto de confianza que acompaña a la apertura del parque: "El método apropiado de entrenarlos en un comportamiento más correcto es otorgarles mejores privilegios" (Public Walks, 1834, p. 503). Pero también, el contacto con las otras clases sociales y la asimilación de la urbanidad serían formativos, como lo plantea George Alston en una carta publicada en The Times:

Muchos de los hombres a los que estaba acostumbrado a ver pasar el domingo en completa ociosidad, fumando en su puerta en mangas de su camisa, sin lavar y sin afeitar, ahora se visten tan limpia y ordenadamente como pueden, y con su esposas e hijos se le ve caminando por el parque las tardes de domingo. (The Times, 7 de septiembre, 1847) ${ }^{190}$.

El parque sería el detonador de un círculo virtuoso que empujaría a las clases más pobres a mejorar sus hábitos, su apariencia, y con ello se levantaría también la civilización y la industria de la nación. Como también señala el Reporte, "qué incentivo puede ser más poderoso para cualquiera que el deseo de mejorar la condición y comodidad de su familia" (Public Walks, 1834, p. 507).

Birkenhead fue la primera ciudad en reaccionar ante el nuevo ambiente que promovía espacios abiertos al público, así, el mismo año del Reporte se crea la
190 El motivo de la carta es la reciente inauguración del Victoria Park en Londres. Traducción propia de la carta en inglés:

There is, I believe, a very general opinion entertained, though I think a very erroneous one, that the poorer classes in this country cannot be trusted, unless under the surveillance of the police, in any place of public amusement, from a wanton disposition to injury or destroy whatever is beautiful in nature or curious in art, and that a custom which so generally prevails on the continent, of throwing open all places of amusement, cannot with safety be adopted in this country. Now, when it is known that there have been planted in various parts of the park roses and other flowers of various kinds entirely unprotected, and that in only one solitary instance throughout the summer has a rose or flower of any kind been either plucked or injured, this fact alone is sufficient to refute the unjust aspersions that the poorer classes are not to be trusted in public places without the dread of the police before their eyes. the principal good, however, which the formation of the park has effected is in the inducement it holds out to the artisan and labourer to benefit their own health and that of their families by inhaling the fresh air at least once in the week, at a distance from their own confined and wretched habitations. And that much good has been produced in this way I can most confidently state. Many a man whom I was accustomed to see passing the Sunday in utter idleness, smoking at his door in his shirt sleeves, unwashed and unshaven, now dresses himself as neatly and cleanly as he is able, and with his wife or children is seen walking in the park on the Sunday evening. 
Birkenhead Improvement Comission, organización que levantará la necesidad de crear un parque para la ciudad, para luego pedir al parlamento los fondos para su creación. Sólo 10 años después, Joseph Paxton comienza el innovador proyecto que considera el loteo del perímetro del predio para desarrollar casas cuyos patios traseros se relacionan directamente con el parque. El plan original supone que la venta de estas propiedades financiará la sección pública del proyecto. El 5 de abril de 1847, el Birkenhead Park abre por primera vez sus 90 hectáreas a más de diez mil visitantes, pasando a ser considerado como el primer parque urbano financiado con fondos públicos en el mundo. (Tate, 2015, p. 141).

El parque se inscribe en un rectángulo de 1.000 por 400 metros, con su lado más largo orientado aproximadamente del noroeste al sureste (Figura 5.3). Tiene la forma de un "ocho": La parte más pequeña del parque - el Upper Park - termina en un punto en el extremo oeste con una elevación de 23 metros. Este es la ubicación más alta del parque y ofrece vistas a Liverpool. En la sección inferior del plano se encuentran las principales "notas" de arquitectura, tales como el Swiss Bridge y The Boathouse que pueden observarse desde el lago (Figura 5.4.).

Marcando una diferencia con el Regent's Park, Paxton proyectó que el acceso a las casas estuviera fuera del parque, desde las calles exteriores al predio, dejando el parque libre de carruajes, "se determinó que el parque no debería ser, ni parecer ser, propiedad de las casas que lo rodeaban" (Smith 1983, p. 50). Fue concebido como un Parque del Pueblo y "Paxton era claramente consciente de que estaba diseñando para un nuevo tipo de cliente, que exigía un nuevo tipo de uso" (Smith, 1983, p. 51).

Pero el Victoria Park de Londres aventaja la invención de Paxton y se ajusta más a los ideales del Reporte, al instalarse en un contexto metropolitano con la explícita función de sanear las condiciones de un entorno de barrios conflictivos: Hackney estaba habitado por clases burguesas, pero con grupos reformistas religiosos, y Tower Hamlets era un barrio obrero de tradición socialista y mucha agitación social. Los terrenos sobre los que se instala el parque eran en el siglo

Figura 5.3. Plano de Birkenhead Park con la ubicación de los principales puntos de interés.Por Alexandre Gravis (7 de abril, 2016).

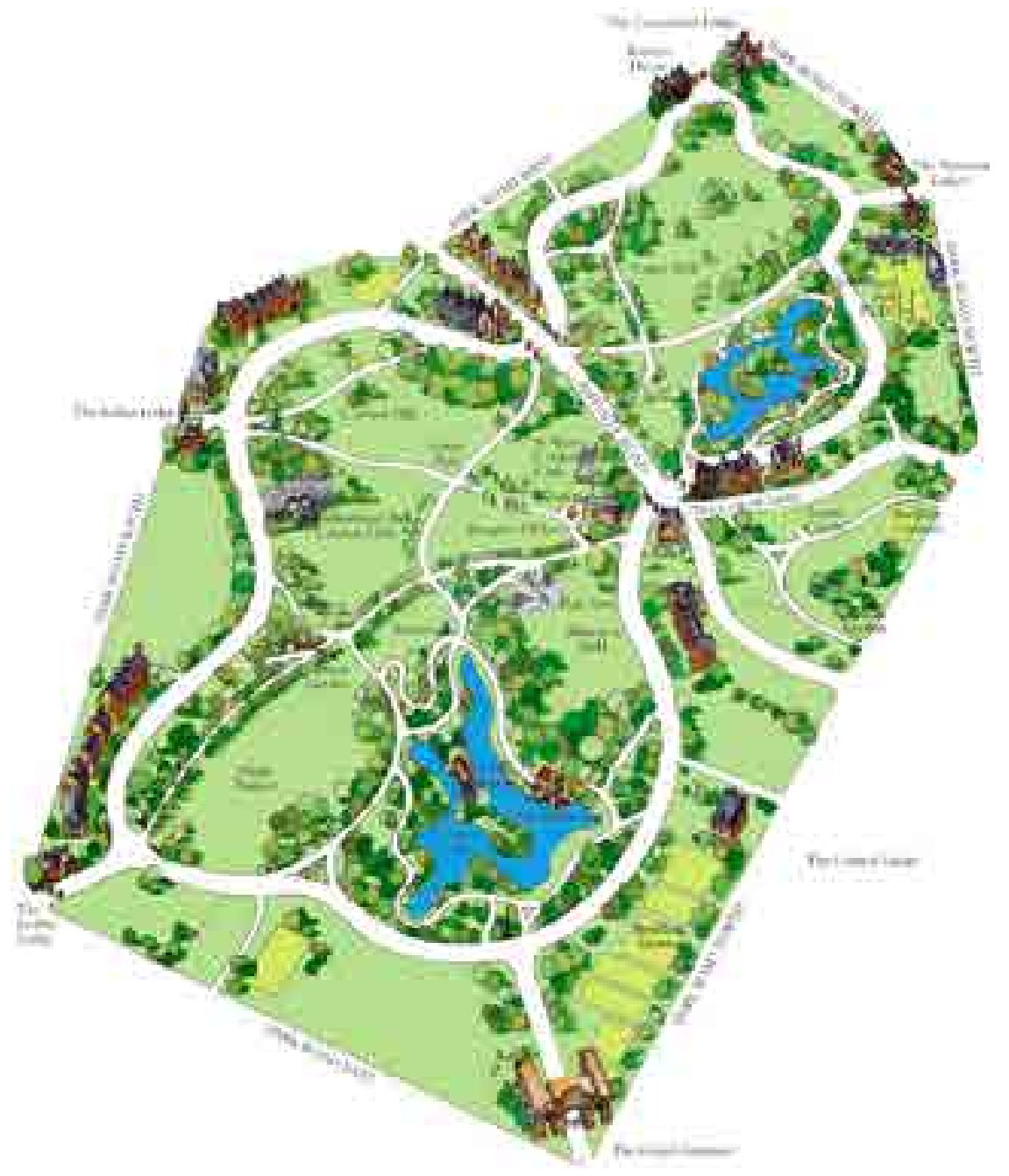




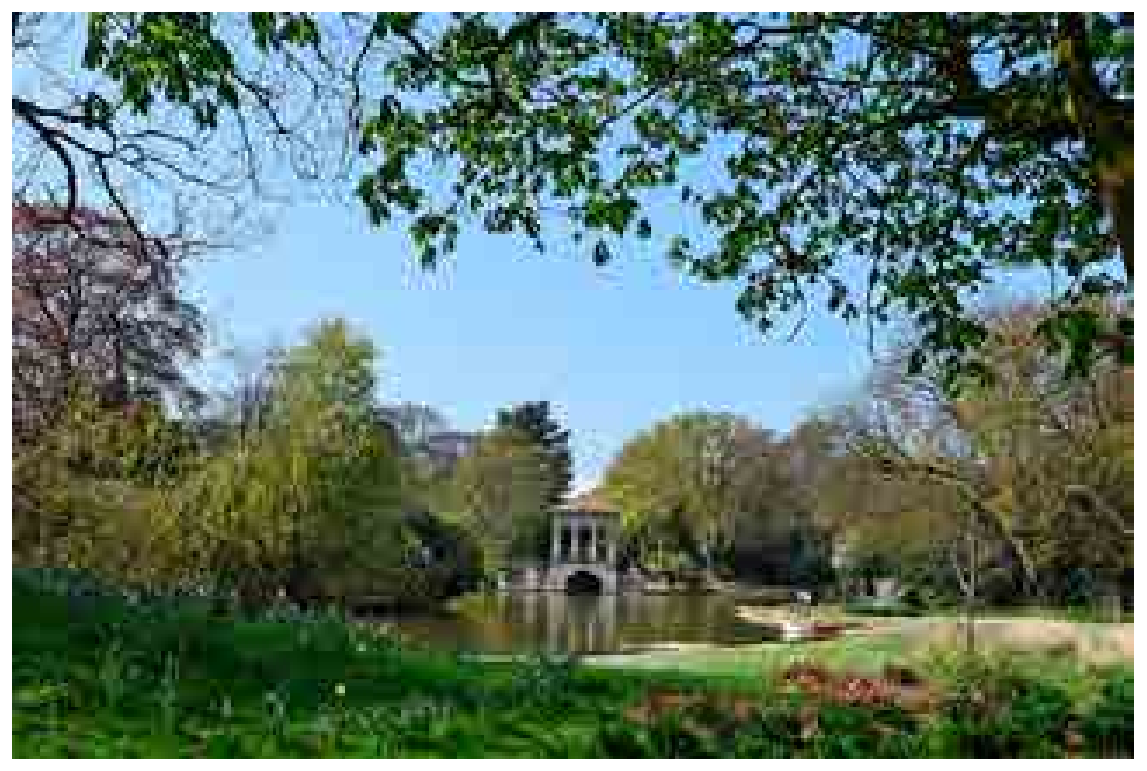

XVI los jardines del palacio del obispo de Londres, Edmund Bonner; aunque para el siglo XIX la explotación de una cantera de áridos y arcilla había arruinado el paisajismo original, sin dejar mucho por recuperar. Una intensa discusión pública, animada por William Farr, logra juntar treinta mil firmas para convencer a la reina Victoria de consolidar este paño de terreno como un parque. En 1842, James Pennethorne, arquitecto de la Corona y discípulo de Nash, inicia el proyecto para las 88 hectáreas. En estilo naturalista, Pennethorne despeja grandes praderas para el uso masivo, incorpora una laguna que hace de balneario, pozos de arena para el juego de los niños y actividades de gimnasia al aire libre. El Victoria Park es el primer parque diseñado y pensado para la recreación popular y abre sus puertas al públicos en 1845.

En la ribera sur, sobre los Battersea Common Fields, se instala otro paseo reformista. Con el jardín como espada, se consigue reemplazar un campo para batirse a duelo y hacer competencia a la vecina Red House, una célebre taberna ${ }^{191}$ que se había convertido en el símbolo de la decadencia londinense. Las 81 hectáreas del Battersea Park (Figura 5.5.) son también diseñadas por Pennethorne en 1846, y abiertas al públicos en 1858.

Utilizó 750.000 toneladas de material excavado en los muelles de Surrey para elevar el nivel del sitio, proeza que queda al descubierto cuando baja la marea, ya que todavía es posible ver en sección, cuánto se ha levantado el terraplén sobre el río para crear el parque.

En la segunda guerra mundial, el parque fue utilizado para proteger Londres de los ataques aéreos enemigos. Se cavaron refugios y gran parte de la superficie se destinó a huertos para hortalizas, y se estableció una granja de cerdos.

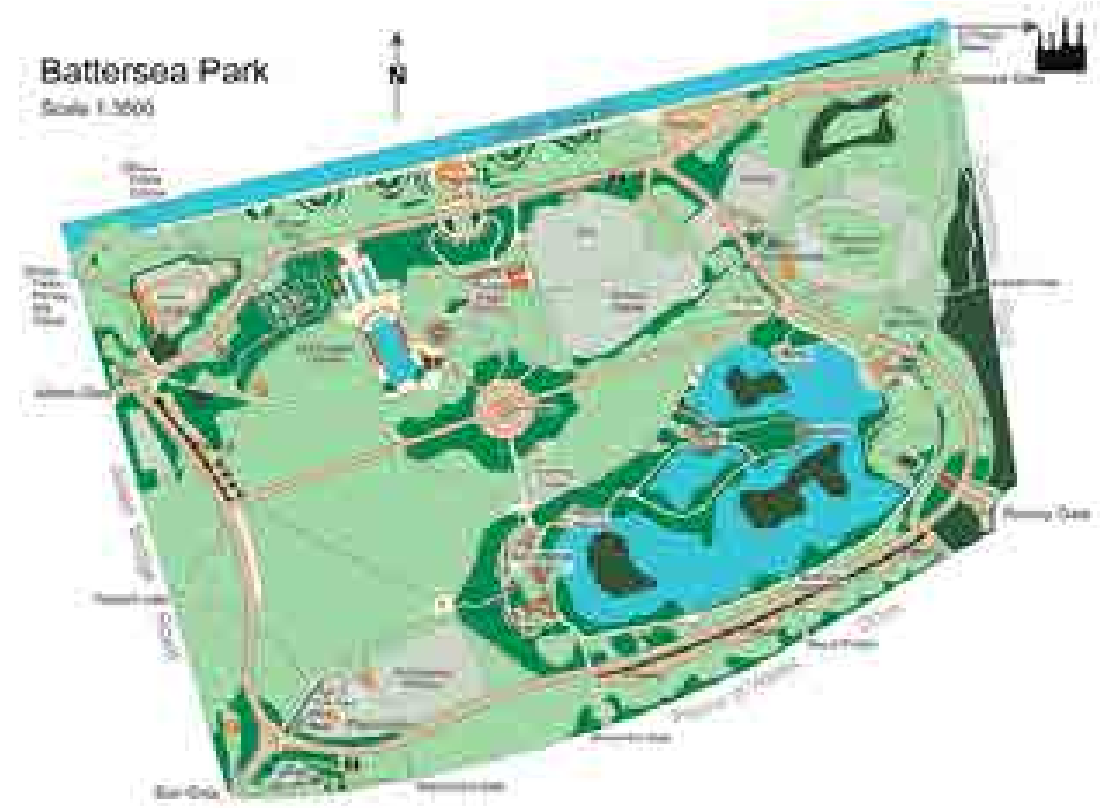

Figura 5.4. Birkenhead Park, Wirral, Inglaterra. Fotografía desde el lago, en el fondo, la Boathouse. Por Colin Lane, 3 de julio, 2019.

\author{
191 La taberna Red House estaba situada \\ en el lugar donde ahora existe la central \\ eléctrica Battersea, un estridente bar fre- \\ cuentado por autores de la talla de Charles \\ Dickens. \\ 192 Proceso de construcción de caminos
}

Figura 5.5. Plano de Battersea Park con la ubicación de los principales puntos de interés. Por Friends of Battersea Park (s.f.) 
Actualmente, Battersea es conocido por su lago para botes, el zoológico para niños y por ser el lugar que alberga distintos eventos temporales, tales como The Decorative Antiques \& Textiles Fair que se instala allí tres veces al año.

\subsection{LES PROMENADES DE PARIS: LOS PARQUES Y LA MODERNIDAD}

Napoleón III inició en 1852 su programa de remodelación con la donación del Bois de Boulogne (845 ha) a la ciudad, para que pudiera ser diseñado para el uso público al estilo de los Royal Parks de Londres, en particular Hyde Park. Para ello, el emperador formó una comisión encabezada por el conde Simeon, para luego pedir a Haussmann en 1853 que dirigiera la obra (Harvey, 2008b, p. 15). Además de sus famosos bulevares, la Transformación de París (Figura 5.6.), ejecutada entre 1852 y 1870 , produce y se soporta en cinco grandes intervenciones paisajísticas: la recuperación de los bosques (Bois) de Vincennes y Boulogne y la creación de los parques Monceau, Montsouris y Buttes-Chaumont (Figura 5.7.). La tarea es asumida por el ingeniero de puentes y caminos, Jean Charles Adolphe Alphand que publicará con detalle el proyecto en el libro Les Promenades de Paris (1867). El álbum es profusamente distribuido en todo el mundo, en una de las primeras iniciativas de promoción de una ciudad: París, como símbolo de la modernidad. La nueva visión que busca la unión de tecnología y naturaleza, inaugura una estética que incorpora la expresión de las posibilidades que ofrece la industria. El acero en productos de catálogo como bancos, faroles, kioscos y barandas; las curvas topográficas para la precisión de los movimientos de tierra, y "el [nuevo] pavimento macadam ${ }^{192}$, fuente de orgullo especial para el emperador" (Berman, 1989, p. 158), que permitirá incorporar los flujos de la ciudad al interior del jardín.

La primera gran intervención es la recuperación de la 845 ha del Bois de Bulogne. El proyecto queda a cargo de un arquitecto, Jacques Hirtoff, y un paisajista, Louis-Sulpice Varé (Gothein, 2002). Para efectuar el canal, Varé no considera la topografía del lugar, excavando con una profundidad uniforme "el río proyectado por el Emperador entre el Royal Round y el Mortemart Round, como el Serpentine of Hyde Park, en Londres" (Haussmann, 1893, p. 122). Al momento de llenarlo, la pendiente hace que se vacíe la parte sur y se inunde la norte. Haussmann llama a Alphand para resolver el problema. El ingeniero separa el río en dos enormes lagos que son conectados por una famosa cascada. A partir de este hito, Alphand se incorpora e inicia el programa de parques del IIIer Imperio. Al gran estanque se agrega una importante empresa de reforestación, la dotación de una red de circulaciones serpenteantes, un jardín de aclimatación y un parque temático infantil con un zoológico.

Rodeado de un desarrollo habitacional aristocrático, el Bois de Boulogne se transforma en la sinopsis y modelo del salón verde. Pero no todos los parques alphandianos resultaron tan elitistas. En 1857 se inicia la remodelación del Bois de Vincennes, allí el entorno obrero motiva una operación reformista. Aunque en Vincennes se reproducen gran parte de las operaciones del Bois de Boulog-

inventado por John Loudon McAdam, que consiste en un conjunto de áridos, de granulometría variable compactado en capas. Marshall Berman en Todo lo sólido se desvanece en el aire, dedica el capítulo 4 al "Fango de macadam".

193 Traducción propia del inglés.

Figura 5.6. Les Promenades de Paris, Plan General, de Adolphe Alphand. Por Alphand (1867-1873, s.p.).

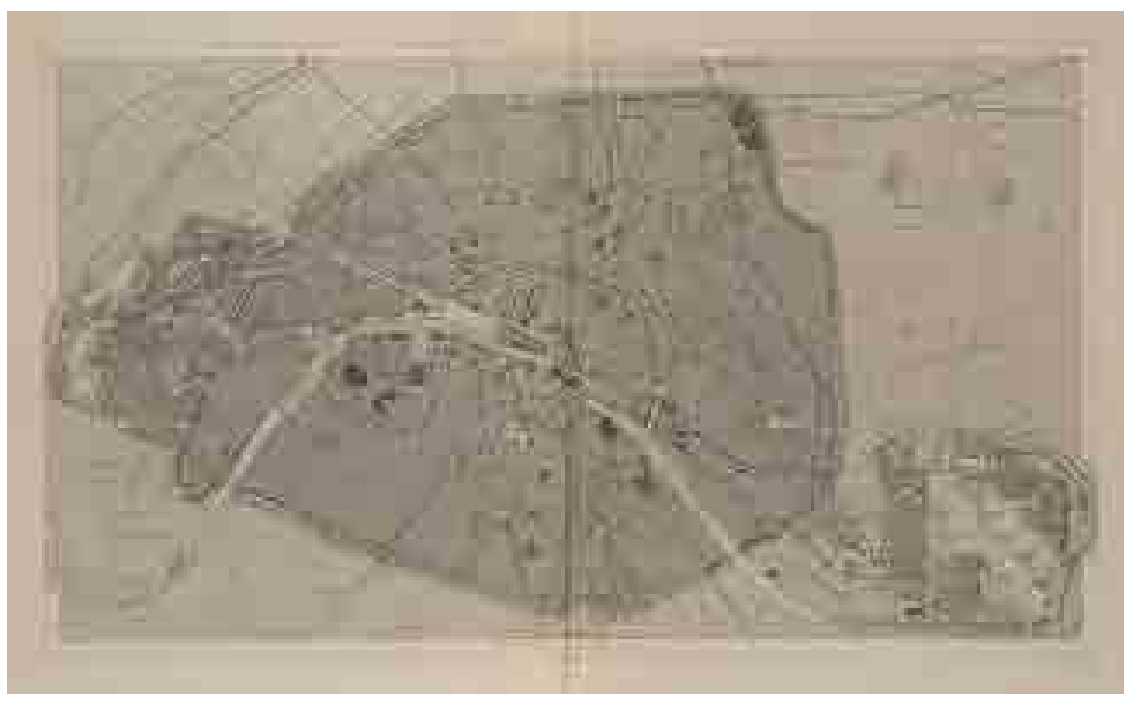




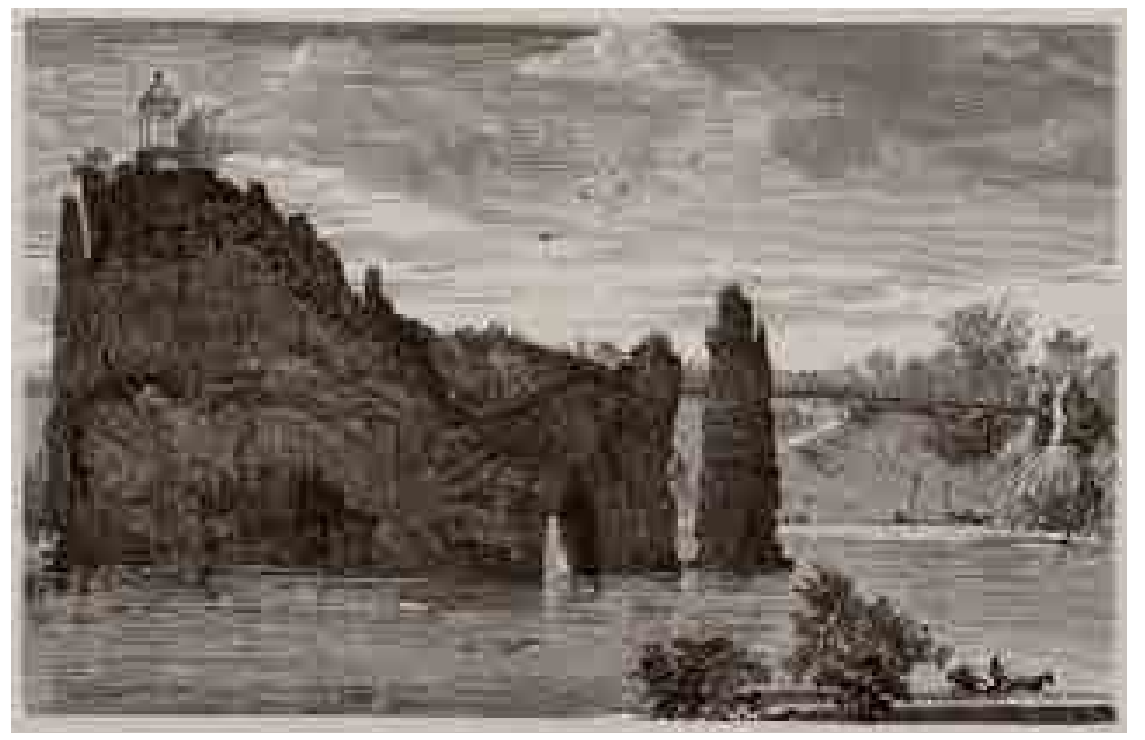

Figura 5.7. Parc des Buttes Chaumont Vista desde el lago. Grabado de E. Morin. En A. Alphand (1867-1873, s.p.).

ne, nunca logró la elegancia y reputación del bosque gemelo. El Parc de Buttes-Chaumont, ejecutado entre 1864 y 1867 fue un proyecto de corte popular, deliberadamente instalado para recuperar un baldío poblado de vagabundos y mejorar las condiciones de vida de los vecinos de Belleville y La Villette. Aunque después de su inauguración gozó de una breve ocupación de las élites, la vecindad de las villas obreras terminó por espantar a la aristocracia.

Por el contrario, las operaciones realizadas sobre el Parc Monceau, entre 1860 y 1861, reconvirtieron para la clase alta, un terreno originalmente conquistado por la Revolución. Las 20 hectáreas de los jardines a la inglesa, que habían pertenecido al duque de Chartres, Phillipe d'Orleans (Alphand, 1867-1873, p. 191), son reducidas a la mitad en una operación inmobiliaria, que deja en manos de un banquero el desarrollo de un perímetro de edificios de 15 metros de altura.

El equipo de trabajo contaba con la presencia de un arquitecto, Gabriel Davioud, cuyo papel expresa bien la subordinación de la arquitectura a la ingeniería en los paseos públicos, tras la crisis del academicismo. Davioud proyecta el pabellón del emperador en el Bois de Boulogne, la rotonda en la isla del Bois de Vincennes, el templo de la Sybila en la cima del peñón del Buttes-Chaumont, la portada del Parc Monceau, kioscos, entre muchos mencionados por el Barón Haussmann en sus memorias (Haussmann, 1893, p. 203-204). Mientras la ciudad se planificaba in extenso, Davioud diseñaba el detalle.

Por su parte, y como ya se ha insinuado con la anécdota de Varé, la ingeniería logró salvar los importantes desafíos técnicos que imponían los grandes paseos. Los enormes estanques resultaron difíciles empresas también en Montsouris, donde según la leyenda, el vaciado del lago el día de la inauguración arrastró al suicidio a al ingeniero a cargo. En el caso del Bois de Vincennes se experimentó con piedra marga para el sellado del fondo. Del mismo modo, los terrenos baldíos en medio del tejido parisino no eran precisamente dóciles. Bajo Buttes-Chaumont yace un pasado como vertedero, drenaje de alcantarillas, matadero y cantera de yeso y piedra caliza. Como si no fuera suficiente, el sustrato arcilloso resulta muy difícil para la plantación de especies por lo que debió construirse un ferrocarril ligero para el traslado de la tierra necesaria para convertirlo en vergel. Dificultades similares se encuentran en Montsouris, donde al relleno de otra cantera, se suma la topografía artificial que modela la pasada de una línea de ferrocarril y la presencia de catacumbas (Haussman, 1893), que hizo necesaria la exhumación de más de 800 esqueletos.

Desde la ingeniería, Alphand sistematiza un interesante sincretismo que reconcilia el naturalismo del parque inglés con la geometría francesa, al organizar los trazados sinuosos de los recorridos pavimentados, que se destacan como los nuevos protagonistas del espacio. Del mismo modo y distanciándose de la tradición bucólica, el paisaje urbano enmarca los jardines. Los ferrocarriles del Parc Montsouris y de Buttes-Chaumont se integran en el diseño y la trama urbana se proyecta al interior del Parc Monceau para incorporar la velocidad del carruaje al jardín. Como plantea María Luisa Marceca (1981), el diseño alphandiano es 
"metáfora y celebración de la máquina", del ciclo biológico y el tecnológico, mientras que la construcción de cimas o points de vue son un impulso "para mirar la ciudad, que se ofrece como paisaje moderno con sus avenidas, ferrocarriles y chimeneas" (Marceca, 1981, p. 61). La propuesta estética de Alphand podría definirse como Ann Komara (2004) llama un "pintoresco industrial" (p. 5): un paisaje artificial, donde lagos, grutas, colinas, pabellones, puentes y escalinatas son moldeadas gracias a la ductilidad del hormigón y el acero. El gran quiebre de la propuesta alphandiana se encuentra precisamente en aquella integración entre jardín y ciudad, es allí donde el parricus pierde su carácter de oasis para transformarse en un artefacto eminentemente urbano.

Gideon Shapiro en su tesis The Promenades of Paris (2015) sintetiza los méritos de la obra de la obra de Alphand y su intrigante ambigüedad en la definición del bien público como salud colectiva y/o placer colectivo, reconociendo como este paisajista y sus colaboradores forjaron un enfoque sistémico que se adaptaba a las necesidades prácticas, los sitios difíciles y una amplia gama de escalas.

Su trabajo estaba limitado por una ética de determinación y respeto por los límites de una situación dada. No obstante, persiguieron una agenda artística y decorativa, lo que refleja un deseo de ennoblecer la esfera pública. Los paisajes que diseñaron están marcados por una frecuente divergencia entre elementos visibles e invisibles, estos últimos abarcan infraestructuras enterradas y metáforas intangibles. Categorías de verdaderas y falsas naturalezas dieron lugar a preguntas sobre qué hacen los paisajes urbanos, en relación con su entorno y qué hace la gente en ellos (Shapiro, 2015, p. vii) ${ }^{193}$.

\subsection{CENTRAL PARK}

Al otro lado del Atlántico, un nuevo fenómeno urbano se desarrolla en la isla de Manhattan. Fundada por los holandeses como Nueva Amsterdam, y renombrada luego Nueva York ${ }^{194}$, la ciudad fue capital de Estados Unidos hasta 1790. Su posición estratégica en la costa este de Norteamérica, entre dos ríos navegables y la fuerza de trabajo de miles de inmigrantes impulsa un acelerado desarrollo económico y un explosivo aumento de la población, que hace insostenible el ordenamiento informal sobre el territorio. El Commissioners' Plan de 1811 remedia esta situación poniendo orden. Los principios democráticos de igualdad y libertad se expresan físicamente en la rígida grilla trazada sobre la isla, una cuadrícula regular de $200 \times 60$ metros, que define 2.028 manzanas rectangulares. De oriente a poniente corren las calles, numeradas, más angostas uniendo los muelles de ambos ríos; de norte a sur las avenidas, más amplias, también numeradas. El trazado a diferencia del hispano, no considera un centro, un punto de inicio. Al no tener centro, parece homogéneo e indiferente a los accidentes naturales, la topografía o la hidrografía. Termina en los ríos y parece extenderse en sus muelles. La estructura urbana del plan de 1811, además del orden, pretende simplificar los trazados, evitar la plusvalía diferenciada de los lotes y por lo tanto mostrarse como una solución democrática e igualitaria (la tierra como algo a lo que todos por igual tendrían acceso). Mientras Nueva York marchaba implementando su plan uniforme, su heterogénea población se multiplicaría varias veces. Si en 1811 había 120 mil habitantes, ya en 1850 casi llegaba a las 700 mil personas, de los cuales la mitad había nacido fuera de Estados Unidos, recibiendo cada año más de 20 mil inmigrantes (Rosenzweig \& Blackmar, 1992, p. 22). Su carácter originario de ciudad puerto, se complejizaba rápidamente con la industria y la actividad financiera ${ }^{195}$.

El orgullo postrevolucionario y los valores de Jefferson ${ }^{196}$ de sencillez rústica e inocencia nativa se debilitaron dando paso a un sinnúmero de necesidades que incluían las aspiraciones de elegancia y sofisticación europeas. Los habitantes de la ciudad deseaban salas de teatro, paseos, museos y parques.

que "para ser independiente de las comodidades de la vida ... debemos ahora colocar al fabricante al lado del agricultor". En otras palabras, América debe tener ciudades de mala gana, por necesidad, pero su auto-imagen debía ser agraria, pastoral.

${ }^{197}$ Downing no fue el primero, cinco años

Para Albert Fein (1972), la sociedad estadounidense experimentaba entonces una triple crisis en las tradiciones: El fundamentalismo protestante es amenazado por la ciencia; la homogeneidad anglosajona es amenazada por la inmigración; y la base agrícola se siente amenazada por la industrialización (Fein, 1972, p. 3). 
El parque público parecía ser una solución que calzaba bien con los principios de una nueva sociedad democrática, "aglutinando diversos principios como el socialismo, la iglesia unitaria, el cristianismo liberal y el trascendentalismo" (Rosenzweig \& Blackmar, 1992, p. 23). Este proyecto sólo se materializará cuando las clases emergentes ven la oportunidad de replicar en el territorio americano el imaginario europeo en su ciudad que se había vuelto invivible.

En las elecciones de 1850, los candidatos en contienda ofrecían un parque. La idea había sido amasada por Andrew Jackson Downing ${ }^{197}$, considerado el primer paisajista de Norteamérica. Entre 1849 y 1850 Downing había escrito una serie de cartas desde Londres instando a "la necesidad de un gran parque" para la ciudad de Nueva York y en uno de sus artículos en la revista The Horticulturist, fustigaba el complejo de inferioridad cultural de sus lectores norteamericanos con frases como "Lo que en Nueva York se llaman parques no son ni siquiera una apología del hecho; son sólo plazas o potreros" (citado por Roger, 1972, p. $17)^{198}$. Había visitado Inglaterra el mismo año que Olmsted hizo el viaje junto a su hermano, quedando igualmente impresionado con los parques de Londres. La primera alternativa que se barajó fue Jones Wood, un hermoso tramo a lo largo de la orilla del East River entre las calles 68 y 77, que era usado habitualmente por pescadores, personas que hacían pic-nic y paseantes. Su superficie desigual, con afloramientos rocosos y arroyos sonoros, se prestaba admirablemente a un tratamiento paisajístico pintoresco. La compra de 154 acres fue aprobada el 11 de julio de 1851, sin embargo, tuvo una gran oposición tanto de los empresarios de la ciudad, que veían con espanto la pérdida de un waterfrontage comercial potencialmente valioso, como del propio Downing, que pensaba que un parque de 154 acres (62 ha) era "ridículamente pequeño" para satisfacer las futuras necesidades de la ciudad. "¡Es sólo un parque infantil!" exclamó, "quinientos acres es el área más pequeña que debe reservarse para las futuras necesidades de una ciudad como esta, mientras pueda obtenerse"199(Downing, 1869, p. 149-150), frase que fijó la superficie de 500 acres (202 ha) como sinónimo de "gran parque". El atolladero político se supera con la compra de un gran paño central de tierras pantanosas no desarrolladas, que estaba cubierto de basura, de lodo e invadido por cabras. Hubo que desalojar también a alrededor de 1.600 habitantes, incluidos los que vivían en la aldea de Seneca, que estaba situada en el lado oeste del parque (The New York Times, 31 de enero, 1997).

El terreno ocupaba las manzanas entre la Quinta y Octava avenida y las calles 59 y 106 que más tarde se extendería hasta la calle 110, alcanzando las actuales 341 hectáreas. Serán 51 por 3 manzanas (153 manzanas en total) eximidas de la extrusión, que quedarán como único registro de la historia geológica de la isla. La trágica muerte de Downing en 1852, obligó a llamar a un concurso público, ya que debido a su prestigio posiblemente hubiera recibido el encargo directo para el diseño del parque. Se presentaron 35 proyectos al concurso, que cerró del 1 de abril de 1858. El ganador fue el número 33, identificado como Greensward (Figura 5.8.). Sus autores eran, Frederick Law Olmsted, que había sido nombrado superintendente del parque, junto a Calvert Vaux, un joven arquitecto inglés que había trabajado con Downing hasta su muerte.

Olmsted y Vaux en su propuesta imaginaron el parque como un gran vacío que a futuro estaría en el centro de una población grande y densa, cuando todo el antes, en 1844, el poeta William Cullen Bryant, ya había publicado una editorial que pedía "un nuevo parque".

198 Traducción propia del inglés: "What are called parks in New York are not even apologies for the thing; they are only squares or paddocks."

199 Traducción propia del inglés: "Five hundred acres is the smalles área that should be reserved for the future wants of such a city, now, while it may be obtained."

200 Traducción propia del inglés:

Figura 5.8. Central Park, Planta General. Calvert Vaux y Frederick L. Olmstead (1968).

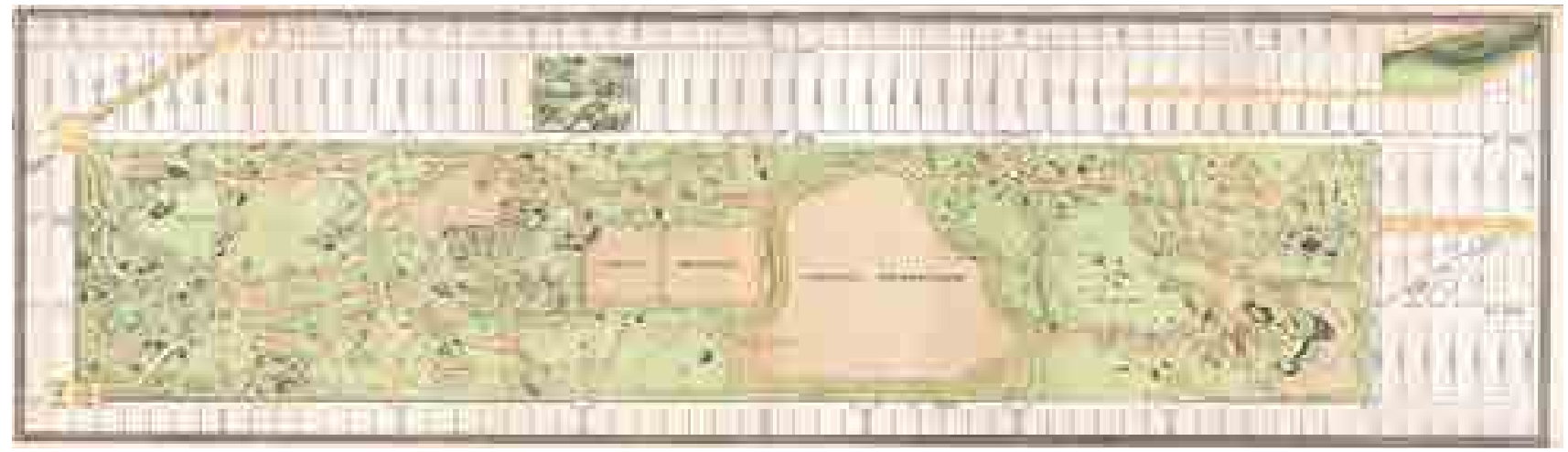


Figura 5.9. Calle 66 transversal, hundida parcialmente para darle continuidad al parque. Central Park, Nueva York. Por Jim Henderson (7 de abril, 2013).
York will be built up, when all the grading and filling will be done, and when the picturesquely varied, rocky formations of the Island will have been converted into formations for rows of monotonous straight streets, and piles of erect buildings. There will be no suggestion left of its present varied surface, with the single exception of the few acres contained in the Park. Then the priceless value of the present picturesque outlines of the ground will be perceived, and its adaptability for its purpose more fully recognized.

${ }^{201}$ Me refiero al paso que se encuentra al lado del Zoológico.

202 El esquisto de Manhattan que recorre la columna vertebral de la isla comenzó hace unos 450 millones de años como un lodo suave en un antiguo fondo marino, Los sedimentos, comprimidos en roca metamórfica, fueron plegados y llevados a la superficie por colisiones continentales, obteniendo su característica inclinación hacia el sur durante estas acumulaciones de placas o cuando el Océano Atlántico se abrió hace 100 millones de años. En la última glaciación los hielos rasparon el lecho de roca de Manhattan, dejando surcos y estrías en las superficies lisas que hoy observamos en el parque. A medida que esas vastas capas de hielo surcaban el paisaje, también arrastraban y soltaban grandes bloques de rocas, hoy conocidas como erráticos glaciales. (Gannon, 2013).

${ }^{203}$ Carvert Vaux diseño treita y seis puentes, todos diferentes, combinando un amplio repertorio que iba desde piezas neogóticas, art nouveau hasta estilizadas formas en acero, siempre eludiendo la ostentación y el academicismo neoclásico.

${ }^{204}$ El parque, encerrado en su perímetro,

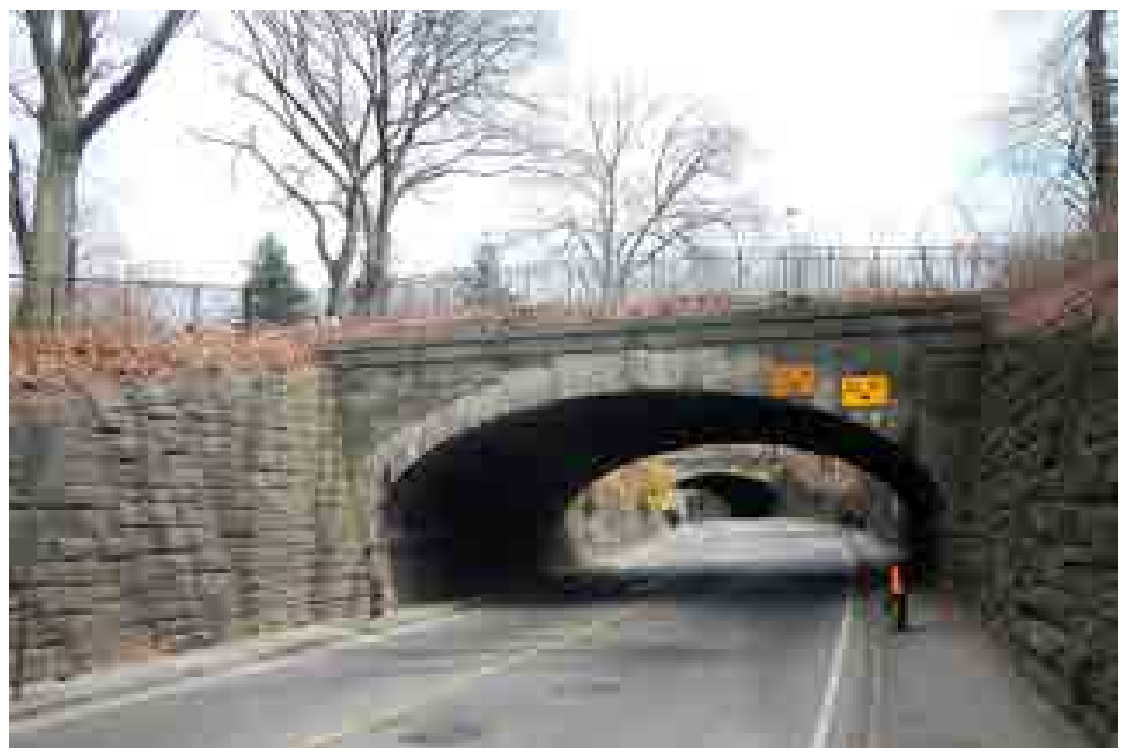

paisaje natural existente fuera del parque se hubiera borrado. Pensaron en el parque como una experiencia de la naturaleza para la mayoría de los residentes de una enorme metrópoli. Proféticamente Olmsted escribió:

Llegará el momento en que Nueva York será construida, cuando toda la nivelación y el relleno estén hechos, y cuando las pintorescas y variadas formaciones rocosas de la isla se hayan convertido en una serie de hileras de monótonas calles rectas, y en montones de edificios erguidos. No quedará ninguna sugerencia de su variada superficie actual, con la única excepción de los pocos acres contenidos en el Parque. Entonces se percibirá el valor inestimable de los actuales trazos pintorescos del terreno, y se reconocerá más plenamente la adaptabilidad para su propósito ${ }^{200}$. (Olmsted, 1858, p. 6).

Greensward actuaba en contraste con el trazado ortogonales de la ciudad. Como plantea Martínez,

Olmsted y Vaux habían huido de caminos lineales intencionadamente, en su memoria del concurso dejaban claro que la idea de un parque como un hermoso espacio abierto no era compatible con caminos en los que fuera posible circular a gran velocidad (Martínez, 2009, p. 101).

El proyecto propone construir un nuevo horizonte con la intención de aislar lo natural de la ciudad. La forma rectangular atentaba contra esta idea, por lo que fue necesario definir, fuera del límite del parque, entre el murete de borde y la acera una doble hilera de árboles. Un primer límite que evita que sea el borde del parque el que cierre.

Otra de las dificultades asociadas a la forma del sitio era la necesidad de los cruces en el sentido transversal, que eran una condición establecida en el concurso. Los cuatro cruces que dan carácter a cuatro zonas a cada lado del parque. Como se observa en la Figura 5.9., hundir las calles, sin hacerlas subterráneas, fue un recurso magistral para conservar la continuidad del parque (que sigue por puentes) y dotar a los atraviesos de un entorno verde y de luz. De esa luz del sol y la visión del cielo que se pierde al entrar en las calles de la ciudad. Olmsted toma esta idea de segregar circulaciones del paso subterráneo del Regent's Park ${ }^{201}$ que visitó en 1856 (Olmsted, 2015, p. 694).

El escenario bucólico del parque se abre democráticamente hacia la calle a través de un murete con las proporciones de un antepecho, que permite múltiples perspectivas hacia el interior. Las operaciones de diseño que llevan adelante Olmsted y Vaux tienen como elementos principales la topografía (donde las rocas son elementos singulares ${ }^{202}$ ), los árboles (y grupos de árboles), los cuerpos de agua y unas "notas de arquitectura" de piedra en los puentes ${ }^{203}$, algunos edificios y esculturas. Cabe recordar que de las más de cincuenta esculturas que actual- 


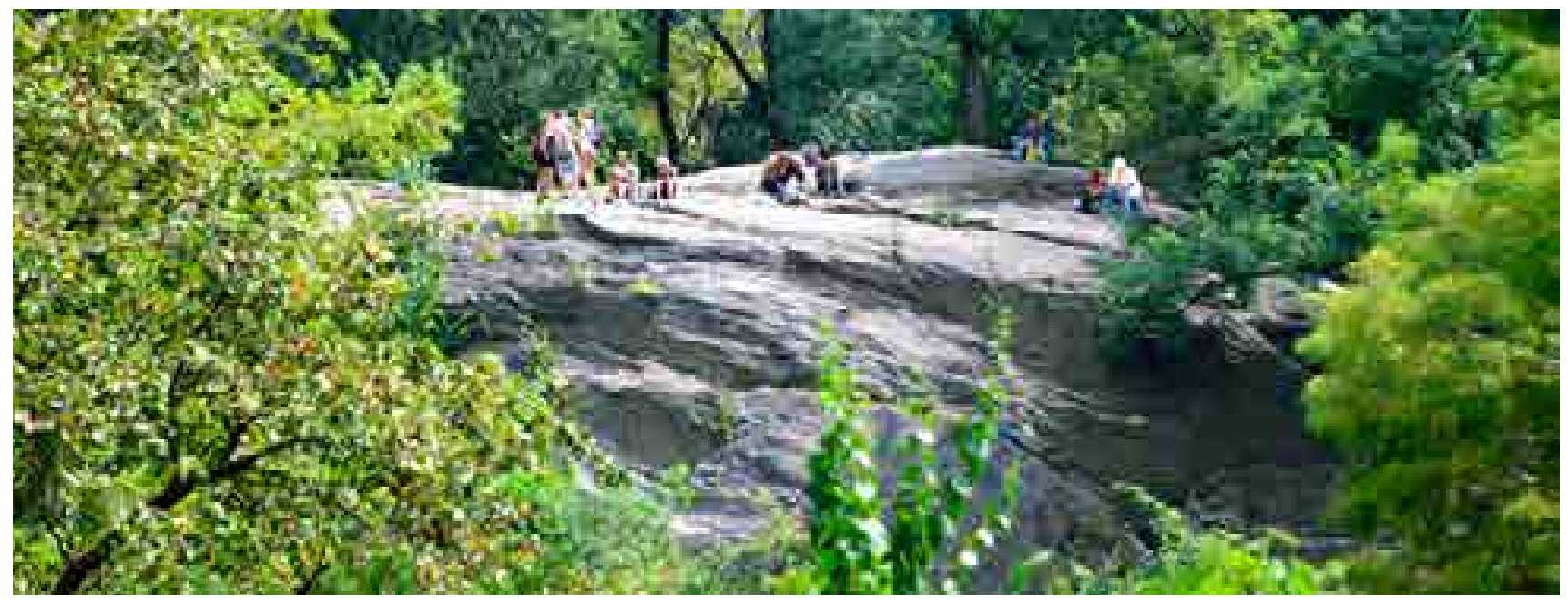

mente ostenta el parque, solo una era parte del proyecto original.

El diseño recoge las condiciones naturales del sitio: cuerpos de agua como el Lago y el Embalse (y más tarde, el Harlem Meer) ocuparon las cinco cuencas de drenaje natural, el terreno más rocoso y más alto se adaptó para crear áreas como la Rambla y lugares de interés como el Belvedere en Vista Rock, y se rellenaron las áreas intermedias para crear praderas. El diseño aprovechó las formaciones rocosas sobresalientes. Algunos afloramientos fueron coronados con refugios rústicos u otras estructuras para enfatizar su presencia en el paisaje, convirtiéndolos en puntos focales y plataformas de observación (Figura 5.10.). Los afloramientos más impresionantes recibieron nombres como Summit Rock y Vista Rock. Muchos fueron esculpidos como escaleras y otros perforados como el túnel que da continuidad a la calle 79.

Si bien Olmsted concibió el parque como una obra de arte, inyectando a la cultura la saludable influencia de la naturaleza, también acudió a múltiples recursos tecnológicos usados de tal forma que quedan ocultos bajo la forma naturalista proyectada. Como se observa en la Figura 5.11., bajo el tejido de prados, rocas y árboles, se extiende una densa trama de ductos, túneles y drenajes ${ }^{204}$, lo que significó el traslado de $46.000 \mathrm{~m}^{3}$ de tierra desde Nueva Jersey, la excavación manual y con el uso de explosivos para generar una nueva topografía, y el uso de exorbitantes cantidades de agua de la red urbana para alimentar las seis lagunas originales del proyecto. En superficie, los faroles están marcados, cada uno referencia la calle, con las coordenadas de su ubicación, recordando que cada lugar está estrictamente ubicado, diseñado, dispuesto.

Hoy podemos percibir la ciudad como una máquina, un ruido de fondo que persiste incluso dentro del parque, especialmente en el invierno, sin que el follaje

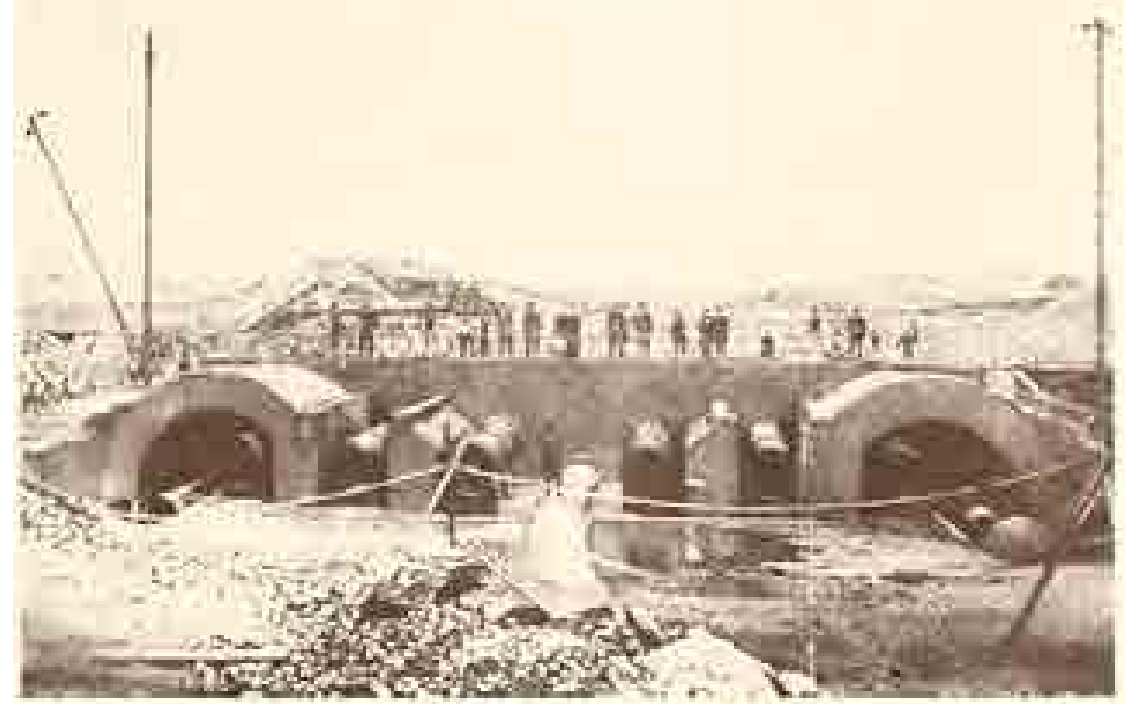

Figura 5.10. Los afloramientos rocosos más importantes en Central Park fueron incorporados en el diseño. En la imagen se muestran bloques erráticos que recuerdan la historia geológica de este territorio que estuvo bajo 305 metros de espesor de hielo desde el pleistoceno (1,5 millones de años) hasta hace unos 18.000 años. Son los restos de una era glacial se extendían desde Canadá. Las rocas emergen sobre el parque y se hunden, aparecen contra los bordes y como elementos exentos. En Central Park Conservancy [web] (7 de septiembre, 2017).

después de la construcción de las manzanas a su alrededor, el drenaje natural del terreno hacia el río quedó interrumpido, lo que solucionó con un sistema de drenaje autónomo y artificial.

${ }^{205}$ El plan de Hobrecht a menudo se com-

Figura 5.11. Construcción del sistema para el drenaje y llenado del lago. Central Park, Nueva York. [Fotografía tomada en 1862]. En Elizabeth Barlow Rogers (1972, p. 77). 
ayude a amortiguar el ruido de la urbe y la vibración del tren subterráneo. En cierto modo, el parque es también una máquina, un gran artificio que produce naturaleza y pone un límite a la ciudad.

Desde el punto de vista social, es un espacio de encuentro multirracial y multicultural. Lo suficientemente grande y reglado para que sea posible convivir armónicamente, con respeto y con cuidado. Para Álvaro Sevilla-Buitrago (2014) el Central Park da respuesta a los profundos cambios sociales producidos por la inmigración, "permitiendo a las élites y las clases populares coexistir bajo códigos de conductas regulados, previsibles, ordenados y libres de conflictos" (2014, p. 57). El parque actuaría como un espacio educador, donde el diseño se refuerza con la creación de un cuerpo de guardias-educadores. Con una orientación menos idealista del movimiento reformista, sus objetivos son mucho más amplios que su versión inglesa. No se trataba sólo de crear espacios de reserva naturales para contrarrestar las tensiones de la vida urbana, el parque se pone al servicio de un proyecto gubernamental más amplio, que aspiraba a reeducar al ciudadano a través de la creación de nuevos espacios públicos y controlar el caos reinante en las calles (el único espacio público que contemplaba Nueva York) y suprimir la apropiación espontánea. Olmsted y Vaux consideran en su diseño también la administración y la gestión, al proyectar enclaves especializados, tales como, la pradera de los niños, el estanque de las damas o la rambla. Una segregación de públicos que Álvaro Sevilla-Buitrago (2014) se pregunta si corresponden a una práctica urbana emancipadora o más bien, a una que busca domesticar la acción en el espacio público.

La cualidad más destacable del Central Park como obra es su triunfo a múltiples escalas. A escala urbana proyecta el gran vacío, el irreversible espacio dentro de la grilla del Commissioners' Plan de 1811, que claramente se observa en la vista aérea (Figura 5.12.). El parque, que se pensó como dispositivo igualador, montado sobre la democrática grilla, paradójicamente terminará por romper la equidad que buscaba, al valorizar excesivamente sus bordes.

A la escala del sitio la decisión de mantener la continuidad del parque y hundir parcialmente las calles que lo atraviesan y crear rutas para que peatones, carruajes, hoy bicicletas y automóviles, permite que todos disfruten el parque sin molestarse. Y a microescala, la cuidadosa escenificación permite la introspección frente al detalle de los elementos de la naturaleza.

Una posterior historia de decadencia, acompañaron la historia del parque, hasta las intervenciones de Robert Moses en los años 1950. Se cumple así la máxima bucólica, Et in arcadia ego: en el Central Park también habitó la ruina.

para con la Transformación de París del barón Haussmann, ya que también dio lugar a amplias avenidas metropolitanas, plazas urbanas, alcantarillas y otros proyectos de modernización de la infraestructura. Pero Hobrecht era geomensor e ingeniero de transportes, lo que explica las consecuencias indeseadas del plan.

${ }^{206}$ Autor del Manifiesto Verde (Das Grüne Figura 5.12. Vista aérea del Central Park. [Fotografía]. Por getamericas (10 de mayo, 2017).

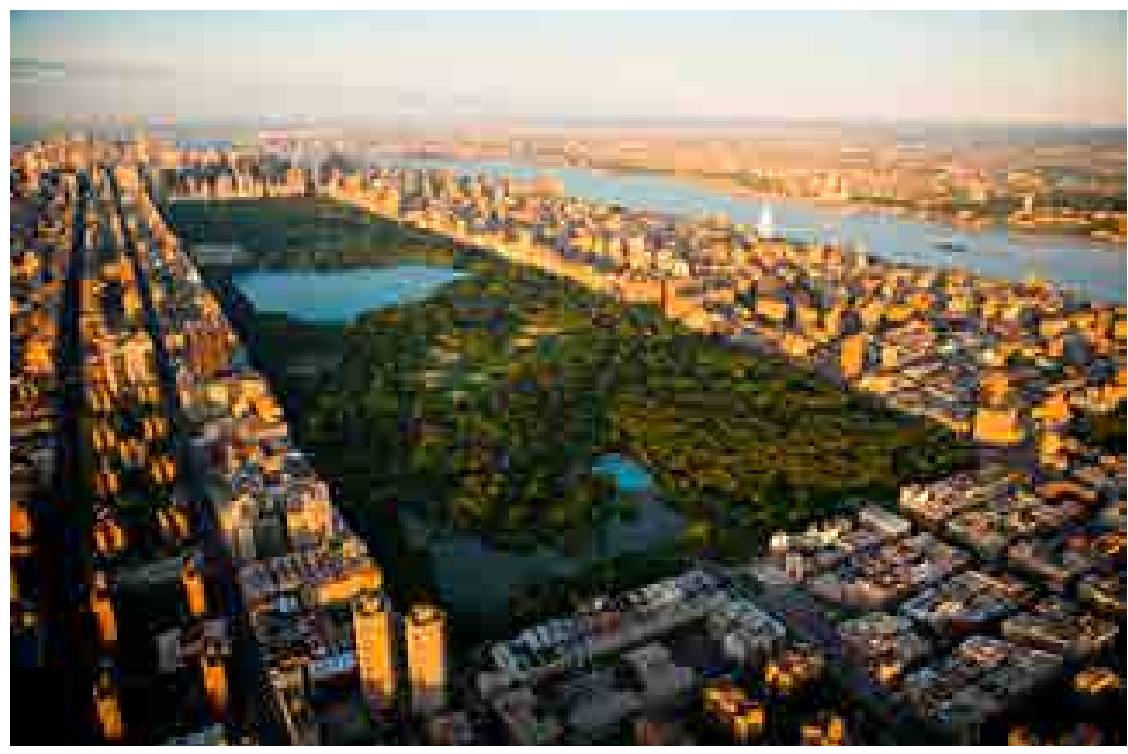




\subsection{EL VOLKSPARK, EL PARQUE POPULAR ALEMÁN.}

En Alemania, la revolución industrial surge con cierto retraso. El Plan de Hobrecht $^{205}$ (Bebauungsplan der Umgebungen Berlins) de 1862 se multiplica en el territorio alemán con un tejido denso, manzanas estructuradas en bloques continuos de uso mixto con un patio central común. El modelo acarrea condiciones de hacinamiento, que Inge Maass (1981) describe como una primera fase de crecimiento, donde "las ciudades se vieron afectadas cada año por epidemias de cólera y hacia finales de siglo por altos niveles de tuberculosis y mortalidad infantil" (Maass 1981, p. 124). Durante el Segundo Reich (1871-1918) las ciudades se vuelven definitivamente industriales, pero no es hasta inmediatamente antes y después de la Segunda Guerra Mundial que las necesidades sociales, impulsan un explosivo aumento de áreas verdes.

La situación social no es abordable a través de la caridad y se vuelve un problema económico que preocupa a las clases acomodadas: Alemania requiere un contingente humano de obreros sanos y fuerzas militares. En este contexto, aparece la figura del volkspark o Parque Popular, con un fuerte carácter político y práctico.

Los primeros parques son un fracaso, ya que se diseñan según las necesidades y gustos de la oligarquía, recurriendo a recursos formalistas más cercanos a la apariencia de un jardín de palacio que al de un lugar de esparcimiento masivo. Junto con grutas, cascadas y escalinatas, aparecieron las normas y las políticas prohibitivas. A medida que las posibilidades de desplazamiento mejoran, y los sindicatos consiguen por primera vez un feriado legal a la semana (entre 1891 y 1900) las familias acuden masivamente a las praderas fuera de la ciudad, en desmedro de los lugares diseñados como espacio público. Es en el espacio abierto, donde el esparcimiento y los deportes encuentran su lugar.

Para Alan Tate (2001) el volkspark supuso una ruptura con el paisaje pastoral que se había convertido en la norma en el resto de Europa y Norteamérica, ya que su usuario ha abandonado la actitud pasiva (bucólica) y exige un espacio destinado a la recreación activa y que al mismo tiempo exprese "la unidad espiritual y la identidad cultural alemana" (Tate, 2001, p. 105). Marco di Michelis (1991) define algunas de sus características:

[...] deben proporcionar grandes espacios para juegos de todo tipo, que deben estar disponibles para todos [...] las avenidas bordeadas de árboles deben rodear estos campos de deportes y conducir a grandes áreas de agua [...] La gente de todas las clases sociales podrá reunirse para disfrutar de las delicias de un lugar diseñado para compensar las extensiones de campo devoradas por la vivienda y la industria, y para proporcionar un oasis de paz en el que escapar de las presiones de la semana laboral (Michelis, 1991, p. 409).

El Stadtpark de Hamburgo expresa bien este cambio. Con 151 hectáreas, es aún hoy, el parque público más grande y más utilizado de la ciudad, la segunda más grande de Alemania. El diseño del Stadtpark fue encargado por el municipio a

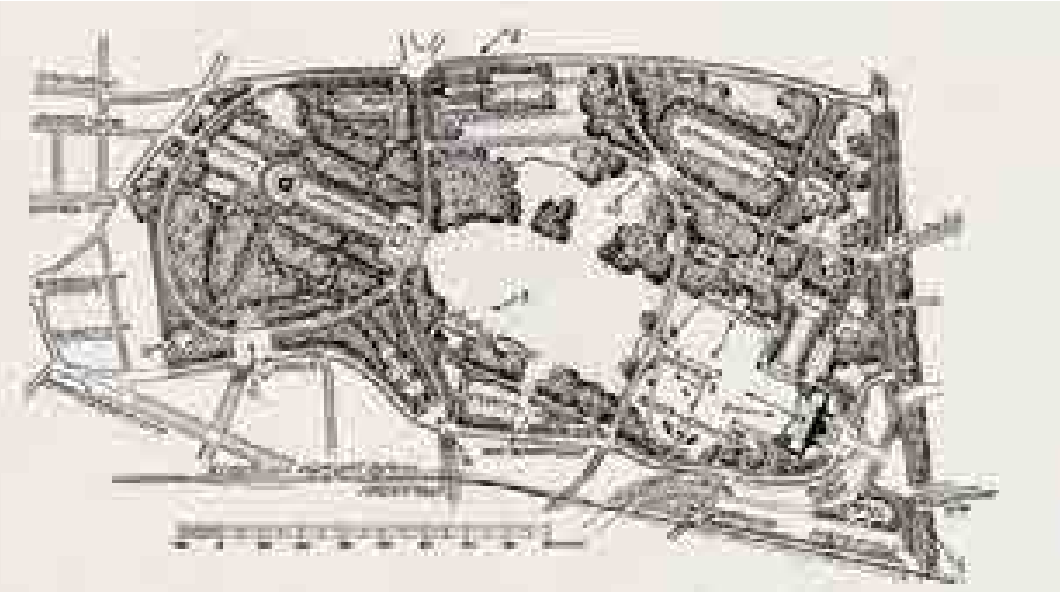


Figura 5.14. Vista aérea Stadtpark, Hamburgo. Por Michael Zapf (2014, p. 76-contraportada)

Manifest) de 1919

${ }^{207}$ El periódico, ha sido fuente de rica in-

Figura 5.15. Stadtpark, Hamburgo. Vista desde el lago, al fondo el planetario. Por Ajepbah (24 de mayo, 2015).

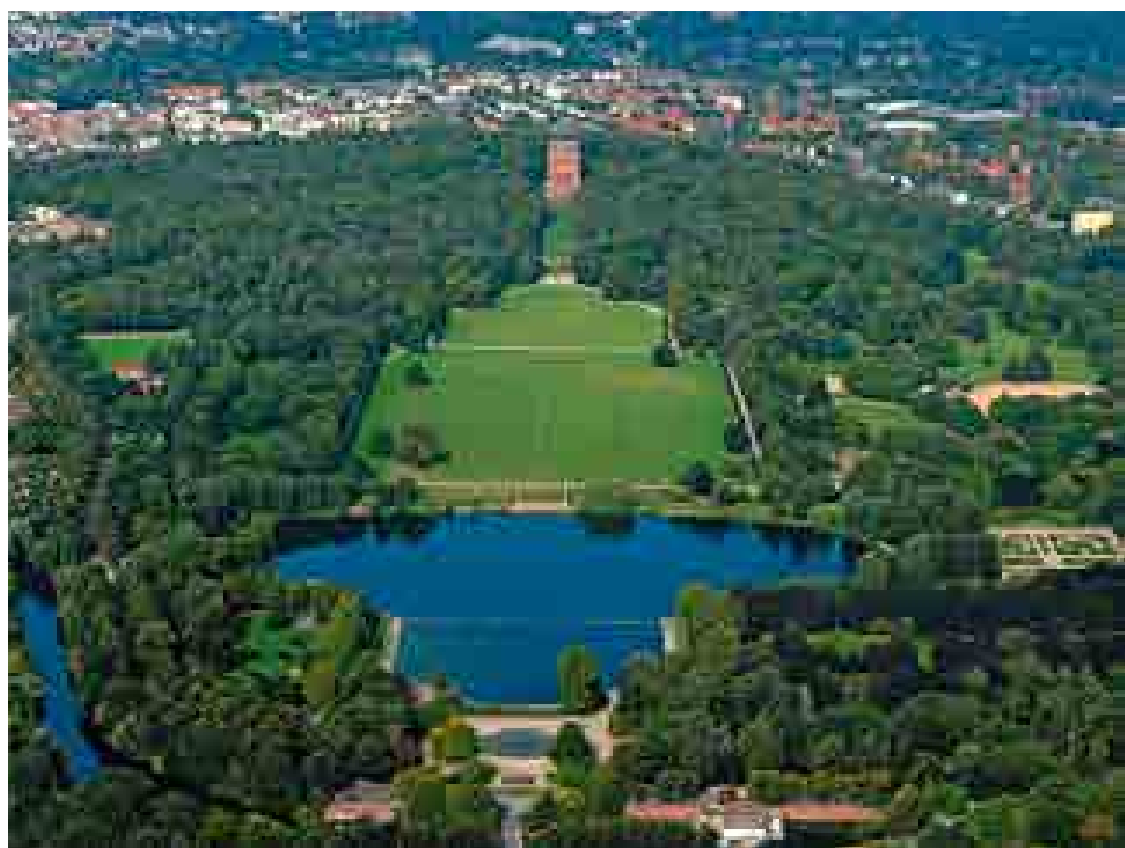

Fritz Schumacher (1869-1947) -Arquitecto de la Ciudad entre 1909 y 1933-y al Ingeniero municipal Fritz Sperber, en 1910.

El proyecto se estructura a partir de un eje de más de 1.500 metros en la diagonal más larga del parque (Figura 5.13.) que une la entrada principal con una torre de agua de 38 metros de altura. El diseño axial articula una zona de prado abierta de 12 hectáreas y un lago en forma ovalada de 8 hectáreas.

El fuerte diseño axial, claro y pragmático, recuerdan los jardines de Le Nôtre (Figura 5.14.). Además de su función de eje de circulación, es un recurso que amplía la naturaleza por medio de la geometría, estructurando una gramática del espacio, donde el horizonte se construye a partir de los cambios de nivel y la posición del observador en el espacio, intercalando elementos clásicos (lago, fuentes, estatuas) con una racionalidad funcional moderna, que permite entender y recorrer claramente el parque. Junto a los elementos clásicos, aparecen una serie de canchas y pistas, uniendo el deporte y el desarrollo físico a los espectáculos culturales. La gran pradera masiva está dispuesta de manera axial, remplazando el gran canal versallesco (Figura 5.15.).

A partir del modelo del volkspark, aparece otra tipología: el jugendpark, el parque para los jóvenes, "promovido por Leberecht Migge ${ }^{206}$ y otros, durante el período de la República de Weimar (1918-1933)" (Tate, 2001, p. 185). En estos nuevos parques, la máxima moderna de la "forma sigue a la función" parece materializarse en el paisaje, liberando a la actividad recreativa y deportiva de las constricciones de una forma preconcebida. Junto al principio higienista de vida al aire libre y la práctica de los deportes, aparece un significado patriótico y nacionalista, que los jóvenes adoptan en honor a los caídos en el frente. Este nuevo sentimiento,

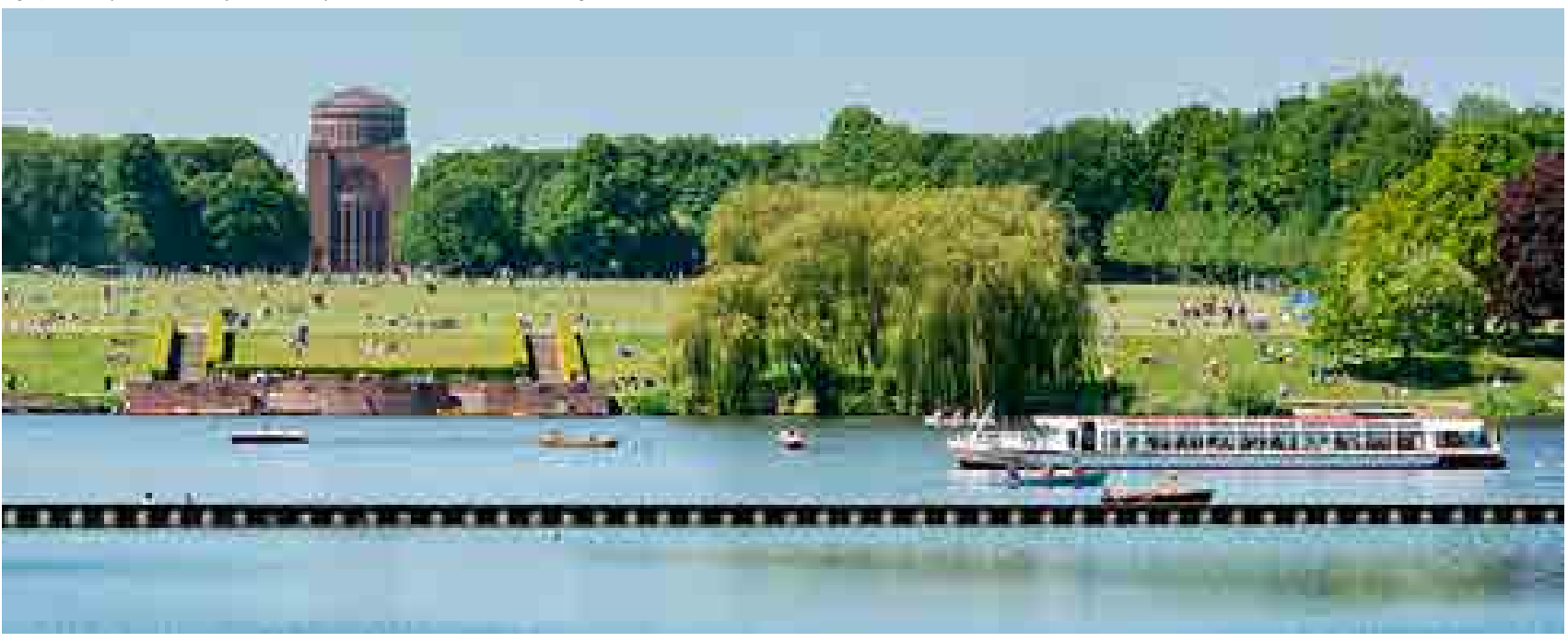


hará surgir un nuevo espacio: "[el] gran eje central para la marcha y los desfiles" (Cárdenas, 2009, p. 120-122).

El Stadtpark sigue siendo una instalación muy popular y muy utilizada. Maass atribuye su éxito a dos características comunes a los volksparks y que están vigentes: "una concepción amplia de la cultura al aire libre y de los espacios abiertos funcionales" (Maass, 1981, p. 127). En el recorrido por el parque predominan las líneas horizontales, en una secuencia, sin que se superpongan elementos, permitiendo una orientación inequívoca, que se enriquece con la cuidadosa plantación de especies autóctonas.

Podemos decir que el volkspark centra su preocupación en el programa, entendiendo las funciones como actividades y costumbres domésticas trasladadas al espacio colectivo. Podemos reconocer actividades que hoy nos parecen normales como los cajones de arena para los niños, las piletas de agua para refrescarse, los lugares para tomar sol, las canchas, las pistas de trote, etc. También el carácter educativo de los parques, principalmente con la enseñanza de la botánica; y el cultural, con la inclusión de museos, salas de teatro y de baile al aire libre.

Ludovica Scarpa en un artículo de 1981, presenta el hallazgo de un primer ejemplo de regulación de los estándares mínimos para los parques de las grandes ciudades que data de 1915, y que está escrito en el trabajo de tesis de Martin Wagner, quien sería luego Stadtbaurat (director urbano) de Berlín. Wagner busca establecer indicadores de áreas verdes como necesidad por habitante, segregando los distintos usos: paseo, juego, deporte, baños de sol. El estudio muestra un cambio respecto al rol del parque, como un artefacto urbano funcional, una pieza clave en la planificación. Wagner busca estándares que le permitan atender los problemas de la ciudad, piensa que los sectores más densamente poblados requerirán de vías de transporte masivo para acceder a las áreas verdes periféricas, cuyo tamaño será proporcional a la población que sirven. Concibe las áreas verdes como un bien público, asociado a la salud, por lo tanto, responsabilidad del Estado. El parque es entendido como un artefacto que provee felicidad. Wagner participa junto a Bruno Taut en el diseño una urbanización moderna, la Hufeisensiedlung (1925-27). Como podemos apreciar en la Figura 5.16., el edificio de viviendas en forma de herradura de tres pisos, deja en el centro un borde de huertos privados y un jardín común, en un marco residencial de cuidada uniformidad: la vida privada es normalizada, la vivienda estandarizada y el descanso organizado.

Como señala Maass (1981, p. 125), con la Revolución de Noviembre (1918) el estado burgués se ve amenazado y luego del fin de la primera guerra se produce una explosión en la construcción de parques. Los parques populares se construyeron en gran cantidad y de importantes dimensiones. Colonia, por ejemplo,

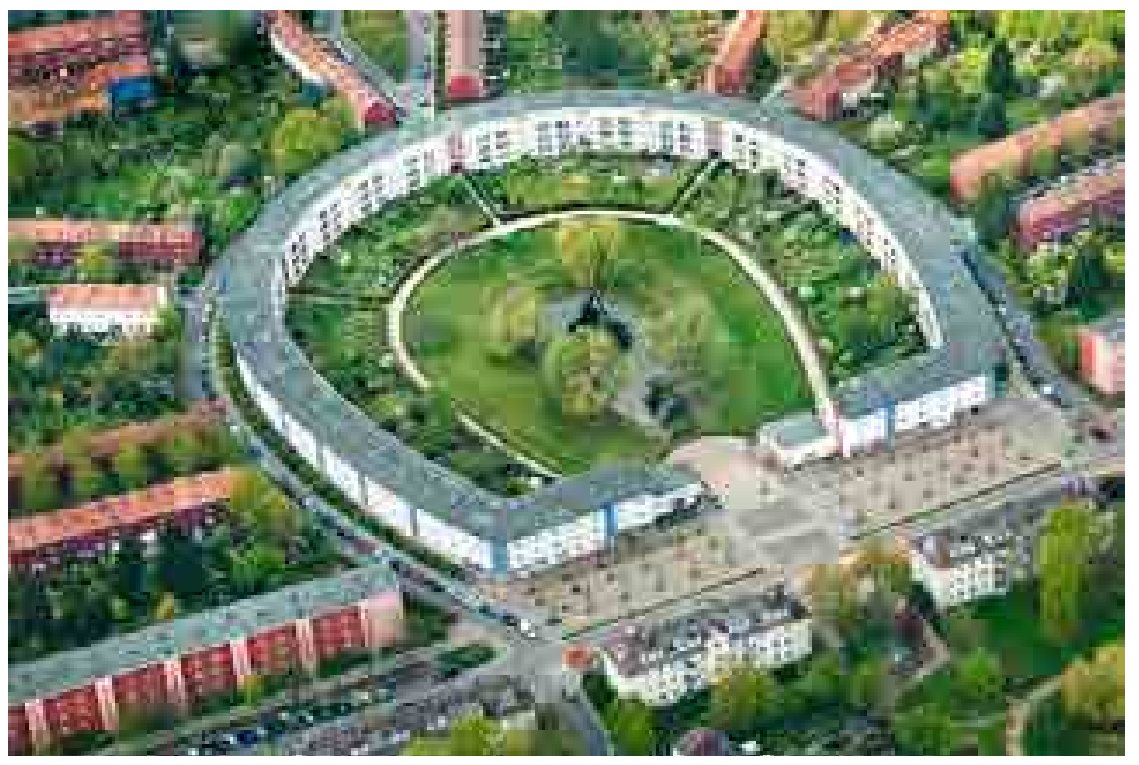


pasa de tener 150 hectáreas a más de 1.000 entre 1900 y 1927 . El fenómeno se da especialmente en ciudades industriales como Colonia, Frankfurt y Berlín, no así en asentamientos residenciales y con jardines de palacios como Dresde y Múnich. El masivo desempleo de los soldados retornados, la disponibilidad de terrenos militares, la falta de mano de obra calificada y de materiales y la facilidad de la construcción, fueron el escenario ideal para que se construyeran grandes proyectos como el Parque de Rehberge (1926-1929), con 90 hectáreas y la mano de obra de más de 1500 obreros que dieron forma al volkspark a lo largo de espacios naturales existentes. Lo elemental del nuevo estilo, facilitó aún más las cosas.

\subsection{LOS PARQUES EN CHILE}

\subsubsection{La Quinta Normal de Agricultura}

A pocos años de la independencia Nacional (1811) la sociedad civil se organiza para contribuir al desarrollo del país. Junto a los ideales republicanos, laicos e ilustrados, está presente la necesidad de autonomía económica, especialmente la alimentaria que impulsa la creación de la Sociedad Chilena de Agricultura y Colonización fundada en 1838, con el apoyo del estado. Para Montealegre (2017), la agricultura en el pensamiento ilustrado se nutre de "principios fisiocráticos", lo que ayuda a entender la importancia del proyecto para sucesivos gobiernos:

[...]que confían en que el progreso y la riqueza se encuentran en la conjunción virtuosa de lo que provee la tierra y la capacidad de trabajo, por sobre la acumulación de capital; oponiéndose, en ese sentido, al pensamiento mercantilista. Para la ética fisiocrática el comercio implica un desgaste y una cierta falsedad en el precio, mientras que la agricultura es la única práctica que produce naturalmente un excedente limpio. Como discurso político, con sus virtuosos poderes alquímicos que transforman el esfuerzo en sustento, la agricultura es la figura de la independencia republicana. (Montealegre, 2017, p. 389)

Esta agrupación gremial, la segunda de su tipo en el mundo, después de la británica, emprendió como una de sus principales tareas, la publicación de una revista ${ }^{207}$ que tuvo gran relevancia para el desarrollo de la agricultura y, como veremos, también de los parques. La otra tarea fue el proyecto de la Quinta Normal, que respondía a los objetivos planteados en los estatutos de la sociedad, que incluían el estudio y la mejora de la práctica agrícola, la aclimatación de nuevas especies, la atracción de profesionales extranjeros, un lugar para que los socios pudieran capacitarse en los alrededores de la capital, así como un espacio para albergar exposiciones (Montealegre, 2017, p. 43).

formación para este apartado. Tuvo cuatro nombres: "El Agricultor" entre 1838 y 1849; "El Mensajero de la Agricultura", entre 1856 y 1857); "El Boletín de la Sociedad Nacional de Agricultura", desde 1869-; y "El Campesino" desde 1933 en adelante. (Montealegre, 2017:40).

${ }^{208}$ Como hemos visto en el capítulo 3, Gay había llegado a Chile en 1828, para luego ser contratado en 1830, por el gobierno, para cartografiar e investigar los recursos naturales del país.

${ }^{209}$ En los textos de la época es habitual el uso de la palabra jardín y no la de parque, posiblemente por la influencia francesa en Chile republicano. Los franceses aún hoy privilegian el término jardín.

${ }^{210}$ El término proviene de la costumbre colonial de pagar con un quinto de la producción de un campo, el arriendo al dueño de la tierra.

${ }^{211}$ Manuel Bulnes Prieto fue presidente de

El historiador Armando de Ramón (2000) en Historia de una sociedad urbana, señala que la adquisición de terrenos para materializar el proyecto de la Quinta se inicia en 1841, completando las 136 hectáreas a finales en 1850. El estado compra los terrenos y encomienda el proyecto al naturalista francés Claudio Gay ${ }^{208}$. La propuesta de Gay se publica en El Agricultor No 15, de febrero de 1841 con el título "Proyecto de un jardín de aclimatación para Santiago". En el documento declara el espíritu de esta empresa:

Uno de los primeros deberes que me he propuesto, ha sido la formación de un jardín modelo, en que se pudiesen cultivar y aclimatar la mayor parte de aquellas plantas útiles con que se enriquecen diariamente los países agrícolas, para propagarlas después en toda la extensión de esta República [...]La hermosa chacra que acaba de comprar y que ha destinado inmediatamente para la formación de este jardín, llenará sin duda los deseos y las miras de la Sociedad, y hará desaparecer en Santiago un vacío que los progresos de su civilización harían más sensible cada día.(Gay, 1841, p. 1)

El nombre del jardín ${ }^{209}$ condensará la complejidad de este cometido, Quinta Normal de Agricultura: Quinta, ${ }^{210}$ aludirá a su condición de finca, Normal será un 
guiño a las escuelas normales francesas, para otros autores, señala su misión de formar a los preceptores de las escuelas normales; y, por último, la Agricultura su objetivo de desarrollo principal. Sin embargo, en el mismo documento esta misión se extiende al ámbito público, comprometiendo un parque para la ciudad:

[...] he creído un deber unir lo útil a lo agradable, y sin alejarme de su objeto, hacer de él un jardín público, un paseo de gusto [...] para despertar de este modo en los hacendados aquel gusto por el adorno y por la grandeza campestre que contribuye tanto a la felicidad de la vida del campo. Este modo de hablarles así a la vista y al corazón, es el único que podría hacerles olvidar que las grandes haciendas no son puras máquinas de productos, sino también manantiales de placeres y felicidad, y capaces además de moralizar a los campesinos acostumbrándolos a la comodidad de la vida, y a aquel bienestar que ignora (Gay, 1841, p. 1-2)

Se unen así los objetivos educativos, políticos, económicos y de progreso social, propios de un parque público. La Quinta es inaugurada el año 1841 por el presidente Manuel Bulnes ${ }^{211}(\mathrm{CMN}, 2019)$ y definida administrativamente el 12 de diciembre de 1842 a través del decreto 106 del Ministerio del Interior, que en su Artículo 18 establece: "La Quinta Normal, como cosa pública, podrá ser visitada por el que quisiere hacerlo" (MI, 1842).

Estas fechas señalan la Quinta Normal como el primer parque público chileno, creado cinco años antes que Birkenhead, que es considerado por varios autores el primer parque público en el mundo, vale decir, financiado con fondos públicos para el uso ciudadano. Pese a esto, la Quinta Normal no está en ningún libro de historia del paisajismo.

El terreno comprado por el estado, será administrado por la Sociedad Chilena de Agricultura y Colonización. La superficie original, Según lo que describe Gay, tiene unas 27 hectáreas (De 16 a 17 cuadras, según Gay) con 877 metros de fondo por 313 de frente (Gay, 1841, p. 8).

En junio del año siguiente (1842), Claudio Gay regresa a Francia, dejando, como lo describe el boletín, "un curioso depósito de árboles, arbustos y plantas, así indíjenas como extranjeras" (El Agricultor, 1842, p. 237), lo que es consistente con la referencia que hace Gay en su carta de despedida, cuando alude a la Quinta como "jardín de aclimatación".

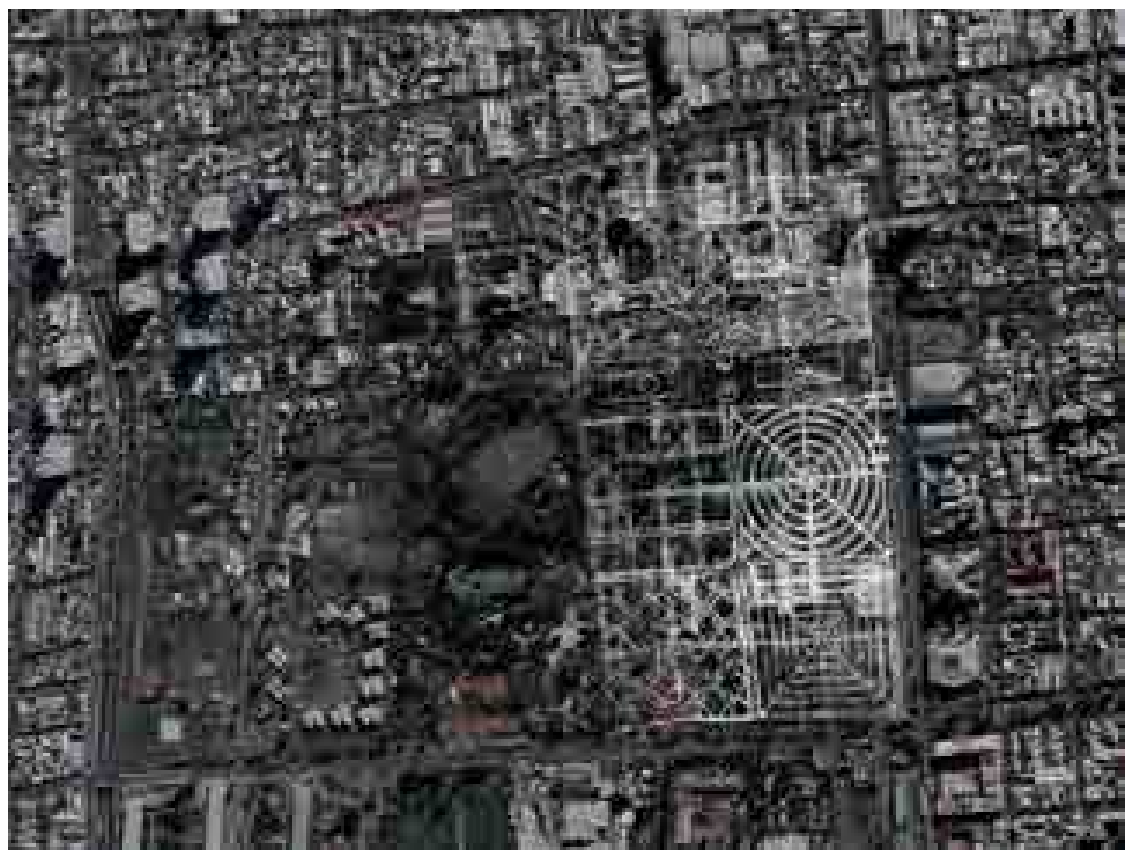

la República por dos períodos entre 1841 y 1846 , y entre 1846 y 1851 . Su gobierno es considerado uno de los más importantes del siglo XIX. Durante su primer período presidencial crea la Universidad de Chile (1842)

212 Vicuña Mackenna representa un per-

Figura 5.18. Superposición del Plano esquemático de Gay (1841) sobre la imagen actual de la Quinta Normal. Elaboración propia sobre imagen satelital capturada de Google maps. 
El plano de Gay para la quinta Normal (Figura 5.17.) corresponde a un esquema de organización más que a una planta a escala. En la Figura 5.18, se propone una posibilidad de calce entre el plan de Gay y el parque actual. La superficie en 1841, era aproximadamente la misma que la actual, a la que serán adicionadas distintas hijuelas hasta completar su superficie final (136 hectáreas) diez años después de su fundación. El dibujo original es acompañado de una descripción que nos permite imaginar las distintas secciones del parque. El acceso, se encuentra por el lado más corto del rectángulo, hacia el norte desde donde se accedería a través de una gran reja (que nunca se ejecutó) que franqueaba una semi-rotonda. En 1841, la única vía de conexión de este sitio con la ciudad se producía a través del camino a Valparaíso. La sección norte consistía en un jardín inglés, que se componía en un arboretum, con distintas especies de árboles extranjeros, como también algunas especies nativas que le interesaban porque eran perennes, de hoja pequeña y bella floración. Su trazado orgánico dejaba unos claros entre el bosque donde imaginaba pequeñas construcciones "caprichosas" que albergarían a los distintos animales de la escuela veterinaria y una laguna.

Articulando esta franja con la sección sur, se proyectaba un edificio con un anfiteatro para dictar clases, sobre él un mirador y a cada lado una extensión donde operarían un invernadero y un naranjal. Este edificio-umbral daba paso a una sección de unos 70 metro de fondo por los 300 metros de ancho del sitio. Este espacio se cerraba a su vez con un muro bajo hacia la zona agrícola y con un muro alto hacia el norte (arriba en la imagen) donde se encontrarían las especies xerófilas en contraposición con el frente que exhibiría un jardín de flores y una doble hilera de naranjos. Los rectángulos exentos corresponderían a macizos de gramíneas (pasto) cada uno con un circulo de flores y fuentes de agua. Los pequeños cuadrados de cada extremo, serían edificios para albergar una cafetería para el público y la vivienda del director de la escuela.

Finalmente, en el punto central, se abría una larga alameda de norte a Sur de 300 metros que era interceptada por otra alameda transversal a mitad de camino, allí se producía una rotonda, donde sugería se instalara un monumento a la batalla de Yungay. Estos ejes, formaban cuatro cuadrantes que albergaban las distintas temáticas de la escuela agrícola: frutales, cereales, hortalizas, y un jardín botánico. El diseño, distinto para cada cuadro, se formaría con arbustos podados como el boj o la murtilla (para los principales): configuraba así una escuela-jardín.

Además de la partida de Gay, que dejó la Quinta sin su gestor, podemos reconocer varias razones que hacen difíciles los primeros años del parque:

- $\quad$ El carácter híbrido de su concepción entre granja modelo, jardín modelo, lugar de aclimatación, jardín botánico, escuela agrícola y parque o paseo público, todos ellos con referentes diversos y lejanos.

La fragilidad de la Sociedad Chilena de Agricultura y Colonización, como administradora, cuyos socios, personajes de la élite criolla no poseian formación en agricultura, ni ejemplos locales de buena gestión. El latifundio chileno fue reconocidamente retrogrado e ineficiente hasta el siglo XX.

- $\quad$ La demora en la formación de la escuela agrícola, lo que condicionaba los fondos del estado

- $\quad$ La falta de recursos, o más bien el gran costo que significaba esta empresa y que no fue previsto.

El plano de Gay no se materializó y la Quinta recibió el año 1843 a un nuevo director científico, el también francés Leopold Aquiles Perrot, que venía de la escuela de Grignon. El profesor Perrot encuentra "Un terreno en decadente estado 
de conservación, pero plantado con generosidad". Sin la capacidad de superar la crisis, el gobierno lo despide tres años después. Sin embargo, bajo su dirección se invierte el sentido del proyecto. A raíz de la apertura de la calle Catedral, al centro del predio, se hace necesario trasladar el acceso principal al límite oriente.

La Sociedad de Agricultura busca y propone un nuevo director, el profesor Luis Sada de Carlos que asume, no sin contratiempos la dirección de la Quinta en mayo de 1848. Su origen italiano es visto como una virtud, que él mismo realza al describir las similitudes que existen entre el clima de Italia y el de Chile. Tras la crisis de la Sociedad de Agricultura, será el gobierno, que directamente lo contrata, no sin antes solicitarle un detallado informe y un plan de trabajo, que luego debe implementar:

Sada de Carlos debe implementar un plan que satisfaga las aspiraciones del Gobierno y justifique los gastos realizados en el predio. Pero el ingeniero le imprime al lugar un contenido simbólico aún más complejo que el de Gay: El paisaje de la Quinta ya no sólo sería el olvido de la máquina, sino el antídoto de la modernización urbana, y, a la vez, la enseñanza de la ciencia. Para ello, Sada confía en la pedagogía de los jardines, los que se vuelven su prioridad. (Montealegre, 2017, p. 65).

El nuevo proyecto de Sada, supone un nuevo diseño (Figura 5.19.) que se desarrolla sobre un sitio más extenso. Uno de los diagnósticos que realiza este especialista es que la operación de una escuela agrícola exige una superficie mucho mayor, "que comprenda todas las especies de cultivo mencionadas, i en que éstas estén dispuestas de tal modo que parezca un jardín" (Sada, 1948, p. 382).

El propio presidente de la República en su Discurso de 1849, lo menciona:

Está concluido en gran parte el edificio de la Quinta Normal de agricultura; un hábil agrónomo dirigirá el establecimiento según el plano presentado, y abrirá una escuela de agricultura práctica, compuesta de doce alumnos, nombrados por el gobierno. (Bulnes, 1849, s.p.)

Como vemos, la Quinta Normal es un problema de Estado. Que aparece nuevamente en la Exposición que el General Don Manuel Bulnes dirige a la nación en 1851, junto al salvataje de la Sociedad de Agricultura y el anuncio de la creación de la Escuela de Artes y Oficios, próxima al parque:

La Sociedad de agricultura y beneficencia ha recibido algunos auxilios pecuniarios para conservar de algún modo su vitalidad, amenazada como estaba de una extinción completa.
Figura 5.19. Proyecto de la Quinta Normal de Luis Sada de Carlos, publicado en El Mensajero de la Agricultura (1856, s.p.)

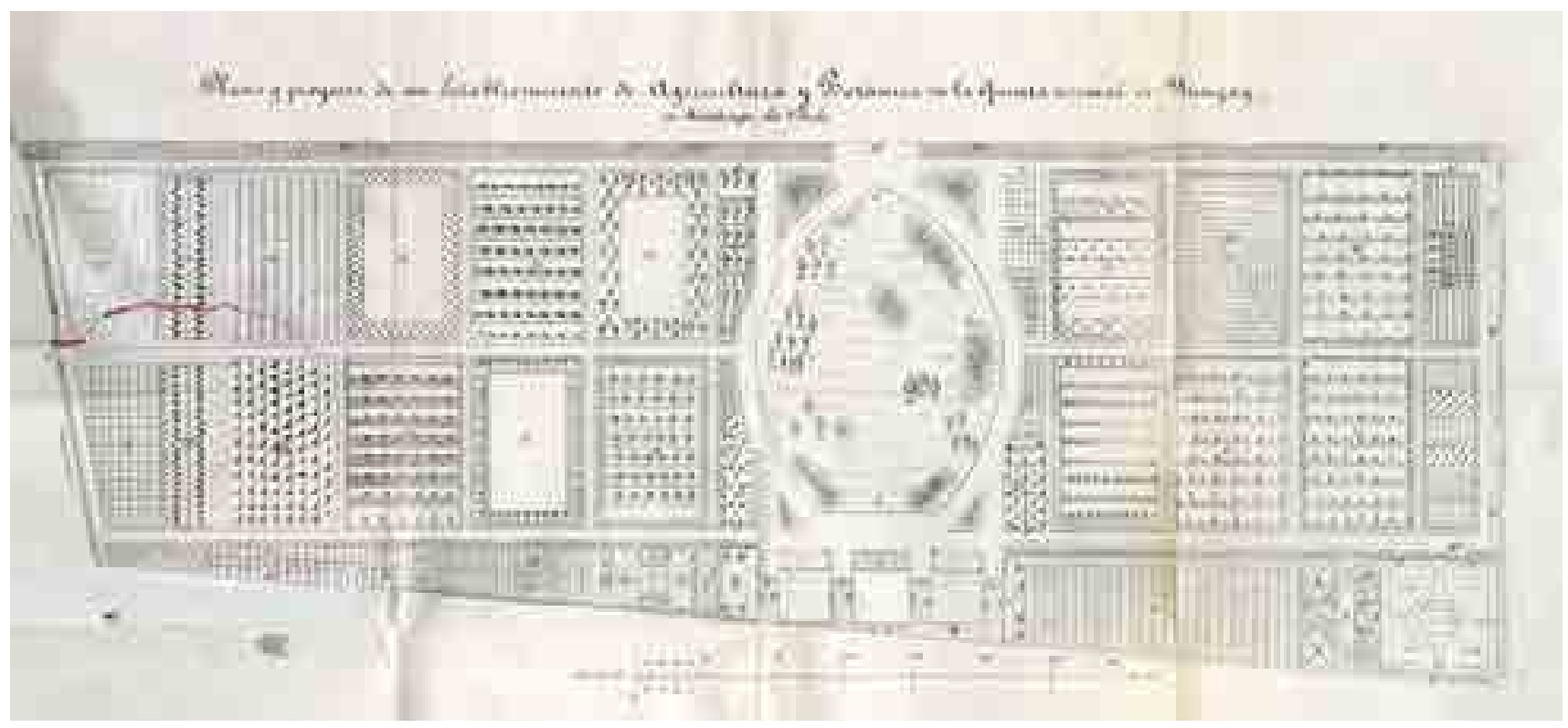


fil es distinto al de sus antecesores, es un viajero y político, pero también posee instrucción formal en el colegio Real en Inglaterra y del Jardín de Plantas de Paris, es miembro de la sociedad Zoológica y de aclimatación Francia y de la Sociedad Botánica de París.

213 Junto a la muestra internacional, una exposición de animales exóticos, a partir de la cual surge la idea de crear un zoológico para los habitantes de Santiago.

${ }^{214}$ El Museo de Historia Natural fue fundado en 1830. Es uno de los primeros de su especie en América (el Museo Americano de Historia Natural de Nueva York se fundó en 1869).

215 El terremoto del 23 de febrero de 1965 , dañó seriamente las instalaciones de la Quinta Normal obligando a buscar una nueva localización para las Facultades de Agronomía y Veterinaria, adquiriendo la Universidad para estos fines, los terrenos ubicados en la actual comuna de La Pintana, inaugurando en 1969 su nueva sede.

Figura 5.20. Vista del Museo de Historia Natural desde la laguna. Parque Quinta Normal. Santiago, Chile. Por Félix Leblanc, (1898) Colección Biblioteca Nacional.
La Quinta Normal, establecimiento del mayor interés para un país esencialmente agrícola, empezó a existir por el reglamento de 17 de diciembre de 1842. Pero en los últimos años es cuando se la ha visto desenvolverse en dimensiones, edificios, plantíos y ensayos, que justifican las esperanzas que se concibieron al crearlo, y le pronostican un porvenir brillante. Se ha naturalizado multitud de vegetales exóticos, de que se han distribuido no pocos a la agricultura y jardinería del país, cuyas demandas han proporcionado ya y seguirán proporcionando crecientes ingresos, que sufragarán a una parte considerable de los gastos. A la aclimatación y criadero de plantas se agrega el estudio de la industria sericícola, de la agricultura, de la mejora de crías y de la veterinaria, a cuyo fin se ha mandado fundar una escuela teórico-práctica, que va a ser inmediatamente abierta, y en la que el Estado costeará doce becas para otros tantos individuos de las diferentes provincias.

No anuncia resultados menos lisonjeros la escuela de artes y oficios, que, creada en el interés de la industria popular, e instalada el 18 de septiembre de 1849. (Bulnes, 1851, s.p.)

El año 1851, es importante: la Quinta Normal exhibía cuatro "jardines": el botánico y sus conservatorios; el de horticultura y sus bastidores; el dendrológico y el dendrocárpico. En este año se comienza al fin, con la instrucción formal en la Escuela Práctica de Agricultura, y también se revitaliza la sociedad, que cambia su nombre a Sociedad Nacional de Agricultura (SNA) asumiendo Vicuña Mackenna ${ }^{212}$ como Secretario General. La idea del museo de herramientas, instrumentos, modelos y productos agrícolas se explicita en el nuevo reglamento que rige a la institución.

Esta función, sólo tomará fuerza la Exposición Internacional de Santiago que se realizó entre el 16 de septiembre de $1875^{213}$ y enero de 1876 con sede en la Quinta, para lo cual se construyen dos líneas de trenes, tres lagunas (de las que sólo persiste una) y un edificio de $1.000 \mathrm{~m}^{2}$, al que luego se trasladará el Museo de Historia Natural214(Figura 5.20.). En 1882, se realizó el primer proyecto de zoológico, el que fue inaugurado en 1863 con animales, principalmente nativos y un acuario con peces de las costas chilenas.

Ya se habían instalado con anterioridad un observatorio Astronómico (1856) y se había construido un nuevo edificio para estos fines en 1862.

Con el tiempo se han sumado el Museo Ferroviario (1984); el Museo de Ciencia y Tecnología (1985) que antes fue la primera sede Museo de Bellas Artes; El Museo Artequín, y desde el año 2005 el Museo de Arte Contemporáneo en el Palacio Versalles, originalmente creado para albergar el Instituto de la Sociedad de Agricultura.

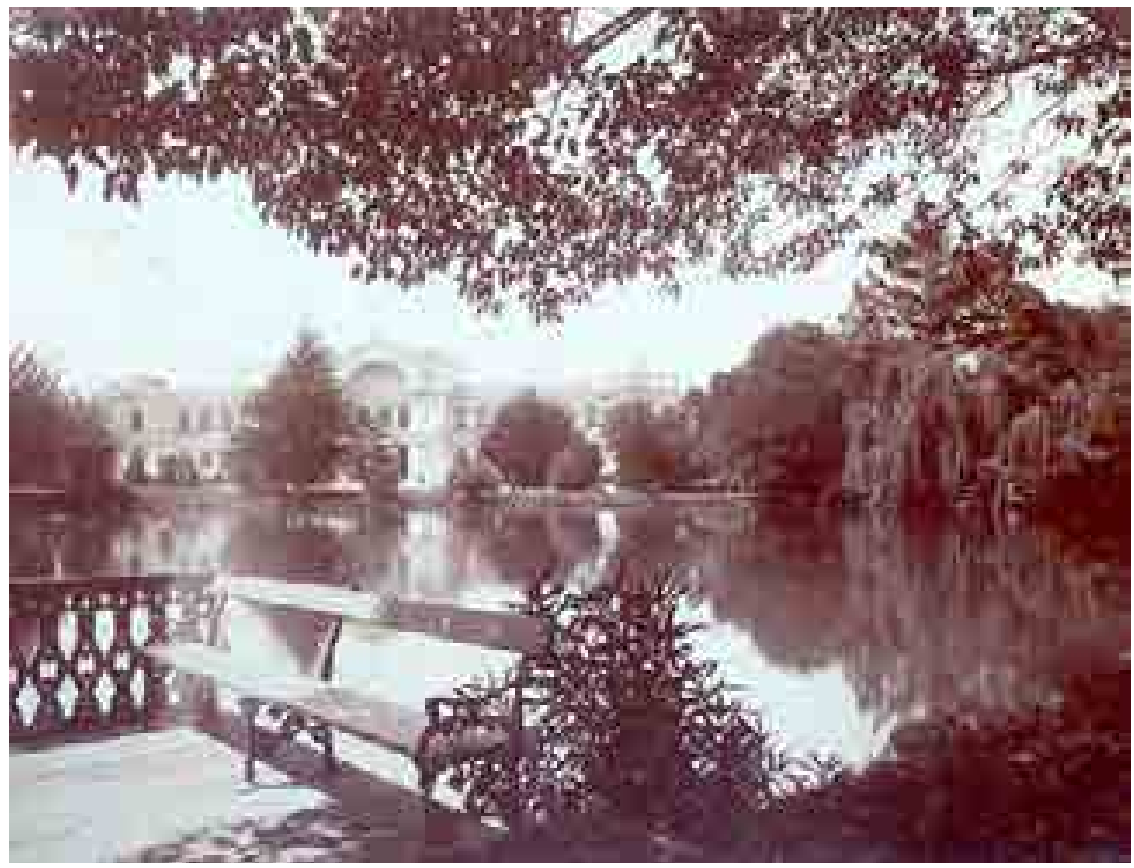


Siguiendo el espíritu inicial del proyecto de Claudio Gay, se mantiene la referencia al Jardín de Plantas parisino, donde los edificios destinados a los museos y a la enseñanza se despliegan en el parque.

La evolución de la ciudad termina definiendo su carácter de paseo, y de parque público. La ciudad rodea y subsume el jardín, especialmente los terrenos destinados a la producción agrícola. La formación en agricultura es traspasada en 1927 a la Universidad de Chile, que traslada primero las actividades prácticas a una hacienda en la actual comuna de Maipú, manteniendo la actividad docente en la Quinta hasta su cambio definitivo en $1965^{215}$ al Campus Antumapu, ubicado en la periferia sur de la ciudad. En los años 1950 el estado expropia 31 hectáreas de terreno para la Unidad Vecinal Portales (construida entre 1954-66), uno de los proyectos modernos más emblemáticos del país, a las que se suman otras expropiaciones para la Universidad Técnica del Estado. Se reduce así su superficie a las 35 hectáreas actuales, las que fueron remodeladas el año 2010 por el arquitecto Teodoro Fernández (Figura 5.21.).

El año 2013, la Quinta Normal fue nominada por travelandleisure.com como uno de los 30 parques más bellos del mundo (Figura 5.22.). Lo que nos hace recordar un pensamiento de Vicuña Mackenna en el devenir de la Quinta: "si la jardinería es la perfección del cultivo, la agricultura solo será verdaderamente perfecta cuando toda el área de la tierra habitada se cultive como un jardín" (Vicuña Mackenna, 1856, p. 102).

\subsubsection{De Campo de Marte, a Parque Cousiño y a Parque O'Higgins}

Pese a las dificultades que rodearon la implementación de la Quinta Normal, el mismo año de su creación, el estado emprende otro proyecto de gran envergadura. El ministerio de Guerra solicita al Congreso la compra de un terreno en la zona sur, fuera de los límites urbanos para la creación de un Campo de Marte. Con la resistencia del ministro de Hacienda Mariano Egaña, finalmente la compra se aprobó, materializándose entre 1842 y 1843 (Montealegre, 2016, p. 58). La función que sustentaba esta operación eran las prácticas militares, sin embargo, el tamaño del sitio era más grande de lo necesario, una condición que los parlamentarios consideraron ventajosa, por la posibilidad de valorizar y luego enajenar los terrenos no utilizados.

La zona sur de la ciudad ha sido históricamente poco valorizada, vastas áreas planas y polvorientas, que recién se conectaban a las obras de canalización del río Maipo (de 1830). Era un sitio yermo y, sin embargo, muy concurrido en las fiestas populares. Por su parte, el ejército hacía uso de ella desde 1830, cuando por primera vez, se realizó una revista de tropas para conmemorar la Independencia, hecho que se convertiría en un rito anual. De este modo las fiestas populares, con instalación de ramadas, bailes, juegos y chinganas, se unían a los desfiles militares cada septiembre. Coincidiendo con el inicio de la primavera, el

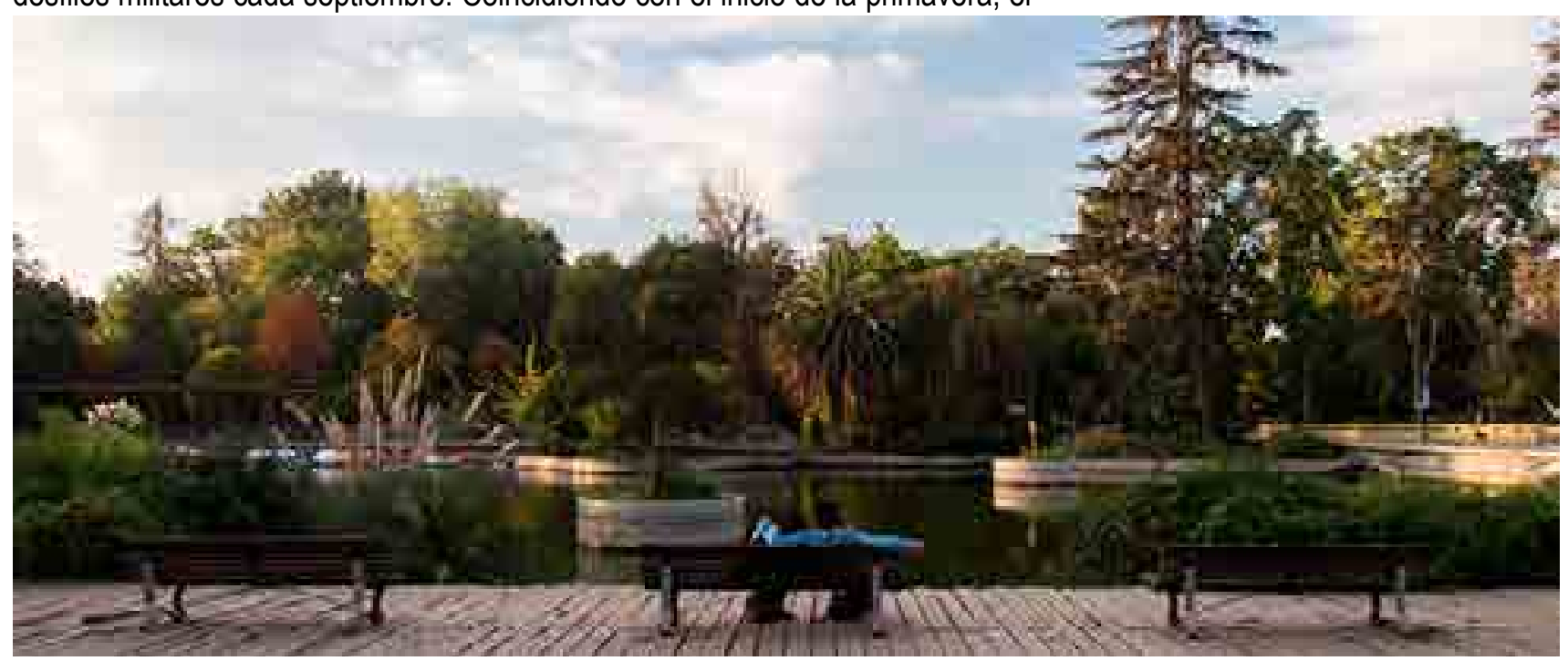

Figura 5.21. Parque Quinta Normal. Santiago, Chile. En SANTIAGOOFF (2019). 
Figura 5.22. Nominación del Parque Quinta Normal entre los 30 parques más bellos del mundo. Travel+Leisure (2 de mayo, 2013).

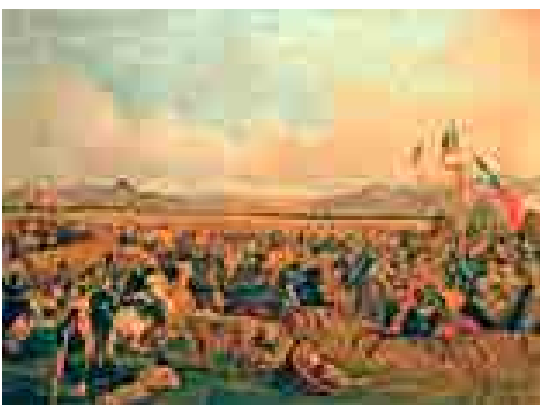

Figura 5.23. El Presidente Prieto Ilegando a La Pampilla. Óleo sobre tela de Mauricio Rugendas (1837). En Wikimedia Commons.

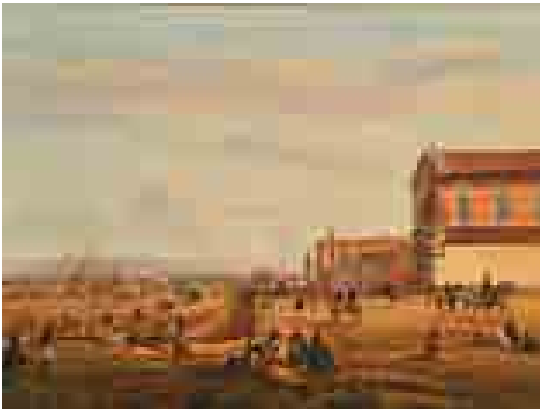

Figura 5.24. El Campo de Marte. Óleo sobre tela de Giovatto Molinelli (1859). Colección Museo Nacional de Bellas Artes. Artistas Visuales Chilenos [web].

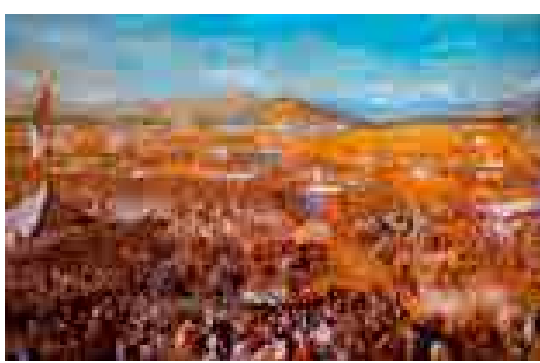

Figura 5.25. 18 de septiembre en el Cam po de Marte. Acuarela y pastel sobre papel de Ernest Charton de Treville (1845). En Wikimedia Commons.

\section{World's Most Beautiful City Parks}

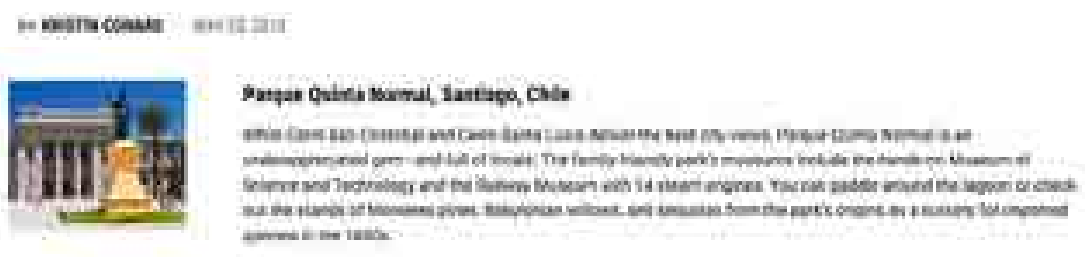

buen tiempo y la brisa que permitía encumbrar los volantines, las distintas clases sociales se encontrarán, como lo relata María Graham en su diario de 1822:

Reúnense en este lugar todos los días festivos, y parecen gozar extraordinariamente en haraganear, comer buñuelos fritos en aceite y beber diversas clases de licores, especialmente chicha, al son de una música bastante agradable de arpa, guitarra, tamboril y triángulo, que acompañan las mujeres con cantos amorosos y patrióticos. Los músicos se instalan en carros, techados generalmente de caña ó de paja, en los cuales tocan sus instrumentos para atraer parroquianos las mesas cubiertas de tortas, licores, flores, etc., que éstos compran para su propio consumo o para las mozas á quienes desean agradar.

Algunas de las flores, como los claveles y los ranúnculos, se venden á precios exorbitantes: suelen pedir hasta medio peso por cada una, y un peso por un ranúnculo amarillo con pétalos matizados de rojo y verde. El pueblo, hombres, mujeres y niños, tiene verdadera pasión por las chinganas. El llano se cubre enteramente de paseantes á pie, á caballo, en calesas y carretas; y aunque la aristocracia prefiere la Alameda, no deja de concurrir también \& las chinganas, donde todos parecen sentirse igualmente contentos en medio de una tranquila y ordenada alegría,

En Inglaterra estoy cierta de que en una concurrencia tan grande de gente no dejaría de haber desórdenes y riñas; pero nada de esto ocurrió aquí, á pesar de que se jugó mucho y se bebió no poco. (Graham, 1916 [1822], p. 255).

Este ambiente es también retratado por pintores de la época como Mauricio Rugendas (Figura 5.23.), Giovatto Molinelli (Figura 5.24.), y Ernest Charton de Treville (Figura 5.25.).

Pero no será hasta que Benjamín Vicuña Mackenna asuma como Intendente de Santiago (1872-1875) que el proyecto de un parque para la ciudad se concrete. Una obra que completa el plan llamado la Transformación de Santiago, del que ya hemos hablado en el capítulo 4 . El antecedente de este proyecto de modernización urbana está en el Plan Haussmann implementado en París dos décadas antes. Un plan que Vicuña Mackenna conoce bien, tras su exilio (1852-56), el destierro (1858-63) en Europa y sus viajes como corresponsal a Estados Unidos (1864-66).

Podemos afirmar que en la segunda mitad del siglo XIX lo francés se consolida como sinónimo y modelo de modernización. Las transferencias estéticas desde el paisajismo francés son concretas y deliberadas. Como consta en una carta de Claudio Gay (citada en González, 2003), él mismo le traerá a Vicuña Mackenna un ejemplar del álbum de Alphand, Les Promenades de Paris, para que la inspiración del Intendente encuentre resonancia en la empresa haussmanniana. Los trazados del Cerro Santa Lucía y posteriormente del Parque Cousiño tendrán bastante parentesco con los parques parisinos, pero, por, sobre todo, el alhajamiento de los jardines, efectuado con artefactos de catálogo, les dará una uniformidad afrancesada. La fundición Val d'Osne fue uno de los proveedores de esculturas, papeleros, rejas y escaños de hierro para los distintos espacios públicos proyectados (Saavedra, 2005). La inclusión de esculturas en paseos y jardines fue otra de las características del plan.

Esta sensibilidad es compartida con la élite intelectual que viaja, y es testigo de la Transformación de Paris, por ejemplo, Vicente Pérez Rosales (1886) recuerda en 
sus relatos cuando los Bois de Boulogne y Vincennes no eran más que cotos de caza y campos de duelo, como también la transformación de las calles tortuosas en avenidas.

En palabras de Vicuña Mackenna (1872, p. 50), "son los espacios abiertos los que harán que Santiago no tenga nada que envidiar a ninguna ciudad europea". Confía en que la intervención paisajística es capaz de nivelar y producir un ambiente cosmopolita. El imaginario francés sirve a este fin, pese a que su reflexión sobre un estilo que podríamos llamar chileno, incluido en su ensayo sobre "La jardinería en Santiago" de 1856, da indicaciones que orientan a una estética más naturalista:

Existe entre nosotros, en verdad, un estilo particular que pudiéramos llamar chileno. Siendo basado mas en la naturaleza que en el arte, parece por consiguiente acercarse mas al gusto ingles, pero tiene, sin embargo, ciertas peculiaridades que lo constituyen como aparte. Son éstas el tamaño colosal de los árboles, la estension (sic) de las eras plantadas, el ancho cauce de sus canales de irrigación siempre abundantemente provistos, la pro fusión de ciertas plantas como los rosales i enredaderas, i sobre todo, estos tres rasgos eminentemente característicos del paisaje i del jardín chileno; a saber: el fondo verde oscuro de la alfalfa en toda la estension (sic) del recinto, las hileras de álamos limitando la vista, i particularmente el infalible parrón sirviendo de sendero principal en todas direcciones (Vicuña Mackenna, 1856, p. 90).

A partir del reconocimiento de las características del paisaje, entrega ocho reglas, útiles tanto para arquitectos como para paisajistas, a pesar que fueron pensadas hace 163 años:

He aquí algunas de nuestras principales conclusiones sobre la organización de los jardines de recreo a que nos hemos referido i que parecerán aplicables relativamente a nuestra topografía, nuestro clima i nuestros gustos propios mas pronunciados.

$1^{\circ} \mathrm{La}$ arquitectura de las mansiones de campo debe tener de preferencia un estilo lijero, abierto con balcones i corredores espaciosos levantados sobre un terraplén.

$2^{\circ}$ Los edificios de las Quintas de recreo deben construirse siempre a alguna distancia de los caminos públicos, teniendo en el patio esterior (que será en lo posible de forma elíptica) una área de jardín i avenidas de árboles por los estremos.

$3^{\circ}$ Los edificios destinados a objetos de labranza como graneros, bodegas, etc. deben estar completamente separados i aun distantes de una mansión de recreo.

$4^{\circ} \mathrm{El}$ terreno elejido para formar un jardín de perspectiva, será tanto mas hermoso cuanto sea mas accidentado, tanto por la naturaleza, como por los trabajos que en él se hayan emprendido tales cuales estanques, colinas i valles artificiales, etc.

$5^{\circ}$ En un clima como el de Chile, la sombra de grandes árboles como higueras, nogales, castaños, etc. es esencial no solo a la perspectiva, sino a la vejetacion de plantas mas delicadas, i de las flores que agostarían los rigores de nuestro estío. La abundancia de agua ; el curso caprichoso de las acequias son ademas, no solo un recurso para el buen cultivo, sino una de las facciones mas pintorescas de nuestra horticultura.

$6^{\circ} \mathrm{Si} \mathrm{se} \mathrm{tratara} \mathrm{de} \mathrm{elejir} \mathrm{entre} \mathrm{el} \mathrm{estilo} \mathrm{inglés,} \mathrm{imitativo} \mathrm{de} \mathrm{la} \mathrm{naturaleza,} \mathrm{i} \mathrm{el} \mathrm{estilo}$ francés, basado sobre el arte, daríamos la preferencia al primero por estar mas en harmonía con nuestra vejetacion que es caprichosa i lozana, i poique siendo nuestros llanos de un aspecto uniforme, se necesita alterar sin monotonía con un agrupamiento bien calculado de los diferentes objetos que entran en la composición de un jardín.

7.Los accesorios i ornamentos de un jardín chileno deben ser de un carácter sencillo i rústico para que guarden proporción con el estilo jeneral de nuestra naturaleza, que tiene en sí misma este carácter que es lo que constituye su belleza. Por esto los bosquecillos i pabellones suizos del jardín de la Quinta Normal, agradan tan particularmente nuestra vista, mientras que las obras artificiales de cal i ladrillo de Peñalolen no parecen hoi día sino baños vacíos 0 lagares de vendimia cubierto de malezas. En la naturaleza nada hai hermoso 


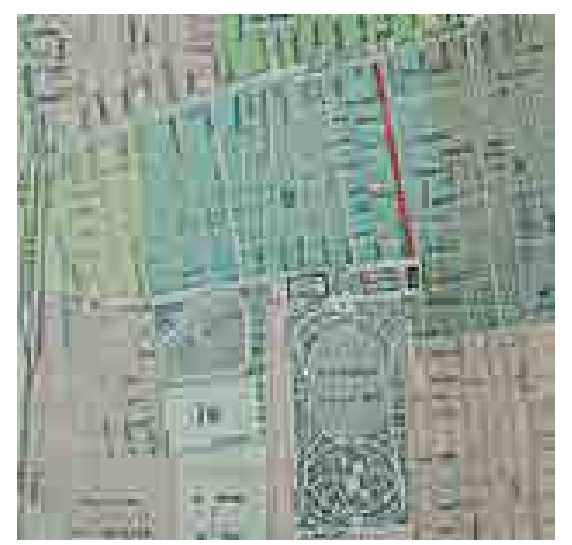

Figura 5.26. Sección del mapa de Santiago de Genaro Barbosa (1908) donde se aprecia el Parque Cousiño, hoy Parque O’Higgins. Colección Mapoteca de la Biblioteca Nacional de Chile.
Figura 5.27. Plano para Exposición Universal de 1867 en París. En A. Alphand (18671873, s.p.)

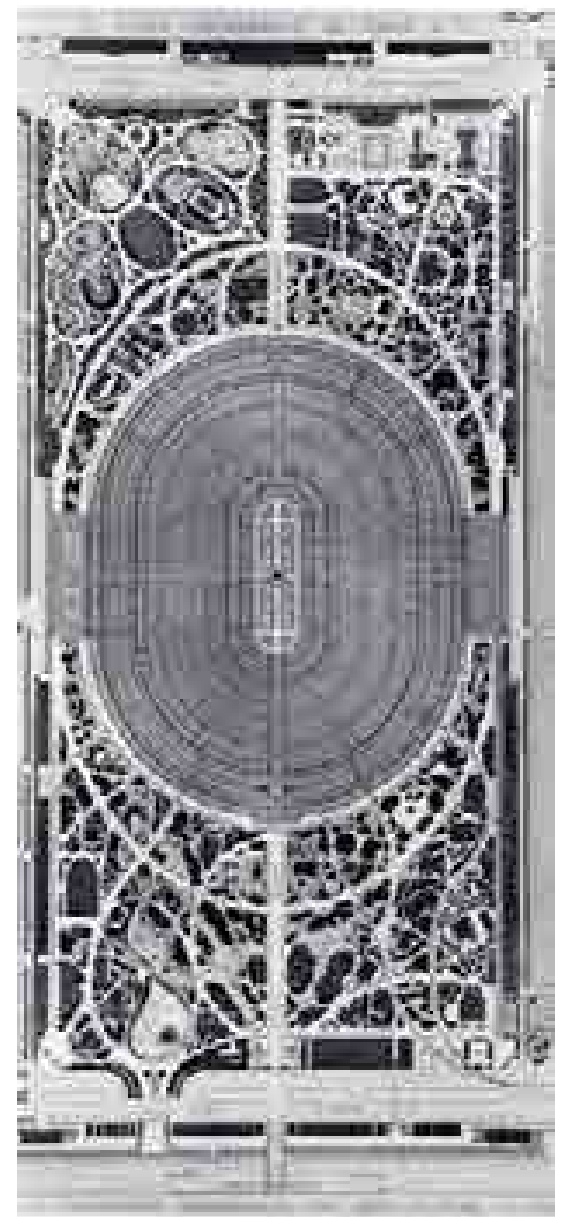

sino lo que imita la naturaleza misma, i este principio es tanto mas esencial en un jardín que está desuñado a ser como un compendio de bellezas naturales.

8. Los adornos artificiales, como estatuas, columnas, jarrones, puentes, cementerios figurados, jaulas de aves exóticas, conservatorios, casas de jardinero, etc., deben ser en este país de una gran simplicidad desde que el arte nos es desconocido i cualquier trabajo de esta clase es por consiguiente demasiado costoso i apenas podrá apreciarse por falta de gusto.

La gran regla del estilo ornamental que podemos llamar chileno, es copiar nuestra naturaleza. Si esta es tan espléndida, qué mejor modelo podemos proponernos? (Vicuña Mackenna, 1856, p. 99-100).

Como plantea Montealegre, si bien no está explícitamente nombrado entre de los veinte proyectos que Vicuña Mackenna incluye en la Transformación de Santiago, "el Parque Cousiño, junto con el Camino de Cintura y los paseos del cerro Santa Lucía, serían las tres piezas fundamentales del programa urbano que pretendía insertar a Santiago en la modernidad" (Montealegre, 2011, p. 43).

Desde su rol como editor del Mensajero de la Agricultura (1856), Vicuña Mackenna ha impulsado por casi veinte años la forestación del Campo de Marte, para transformarlo en un bosque urbano, declarando: "Sería un espléndido regalo para el ornamento de nuestra ciudad y completar los atractivos de ese paseo de La Pampa, que con el tiempo tendrá pocos rivales aún entre las más opulentas capitales" (citado por Montealegre, 2011, p. 43).

El proyecto que habilitaba el sitio como Campo de Marte, vale decir los planos de la primera intervención, atribuido al agrimensor Manuel de Arana Bórica, no ha sido encontrado en los archivos nacionales. Sin embargo, René Martínez (1973), afirma que habrían sido dibujados en 1858, bajo el encargo directo del gobierno del entonces presidente Manuel Montt, mientras Vicuña Mackenna estaba en el destierro (Martínez, 1973, p. 34).

Como observa Montealegre (2011), la gran elipse en el centro del predio, que observamos en la Figura 5.26., tendría un referente, impresionantemente parecido en proporciones, al vacío que proyecta Alphand para la Exposición Universal de 1867 (Figura 5.27.).

El Proyecto del parque se ejecuta con el financiamiento de Luis Cousiño Squella, heredero de una de las fortunas más grandes del momento en Chile, que condiciona su participación a que el sitio le sea entregado con sus deslindes, comprometiéndose el municipio a proporcionar el agua necesaria para las lagunas y el regadío y el costo de los árboles. El compromiso es sellado a través de un decreto del 12 de enero de 1870 que señala:

\begin{abstract}
El Comandante del Cuerpo de Ingenieros Militares entregará a don Luis Cousiño los terrenos del Campo de Marte, incluso sus alamedas, para que ejecute en ellos los trabajos indicados en el plano de don Manuel de Arana reservándose para el Campo de Marte un espacio elíptico de 690 metros de Norte a Sur y 440 metros de Este a Oeste. [...] El expresado Comandante de Ingenieros se encargará del cierre de dicho espacio con los postes y cadenas que actualmente existen. Desde la fecha de la entrega queda de la cuenta de don Luis Cousiño la conservación y riego de las alamedas y de los planteles que existen en dicho campo. (citado por Baeza, 1959, 39.).
\end{abstract}

En el trazado de la elipse, los centros se acercan para lograr una figura menos alargada que la indicada en el documento. Se crean circuitos amplios que rodean el vacío central y permiten el paseo en carruaje por el interior del parque, acompañados por una red de senderos en forma de venas que irrigaban las distintas zonas. De acuerdo a los registros recogidos por Montealegre, "La laguna, origi- 
nalmente era muy extensa, con una superficie de tres hectáreas, $300 \mathrm{~m}$ de largo y $1,75 \mathrm{~m}$ de profundidad. Tenía dos islas: una larga en sentido norte-sur y otra pequeña cercana al quiosco de los músicos" (Montealegre, 2011, p. 48).

Aunque algunos textos insisten en considerar el nombre del parque como un honor póstumo al magnate, en realidad fue un homenaje en vida que Vicuña Mackenna da forma en un decreto en mayo de 1872, un año antes que sucediera la muerte de su amigo y siete meses antes de que se inaugurara el parque. Mientras "otros autores lo siguen denominando Campo de Marte" (Vicuña Mackenna, 1872, p. 73), el Intendente ya lo llama en el mismo documento Parque Cousiño. La obra se finaliza y entrega a la Municipalidad de Santiago en 1873, tres años antes que fuera oficialmente abierto el Central Park de Nueva York" ${ }^{216}$. Tanto las obras de la Quinta Normal, las del plan de Transformación de Santiago, como las del Parque Cousiño, ponen en evidencia fenómenos modernizadores locales que se desarrollan desde mucho antes de la década de 1870, momento especialmente destacado por la historiografía urbana.

A partir de 1912, una serie de parcelaciones rompen la unidad del parque. Las primeras se producen con la instalación de dos clubes de tenis, uno al norte y otro al sur del parque, le siguen la Escuela de Jardinería el mismo año; el estadio techado, a finales de los años setenta con la concesión de un parque de diversiones en la esquina nor-poniente y en los ochenta con la Universidad Bernardo O’Higgins en una sección del límite oriente, que se suma a la expropiación que produce en 1962 la construcción de la carretera Norte-Sur.

La transformación del Parque Cousiño en el actual Parque O'Higgins, se remonta a los años 1970, durante el gobierno de la Unidad Popular, que lo resignifica como un parque del pueblo. El emblemático proyecto (Figura 5.28.), interviene la elipse, incorporando una franja pavimentada de $65 \times 620 \mathrm{~m}$, se construyen graderías y un talud sembrado con pasto, considerando una capacidad de 25.000 personas, que recuerdan los jugendpark y sus espacios para el desfile. Pese al discurso del "parque abierto al pueblo", una de las operaciones de diseño, consiste en enrejar todo el perímetro. El plan contempla la creación de un "pueblito" (señalado con el $n^{01}$ ) que alcanzó a construirse y que hace desaparecer todo afrancesamiento, en una versión pintoresca de la arquitectura chilena, con tejas, portales y estucos rugosos. La intervención paisajística no alcanza a consolidarse, quedando limitada a dos plazas de juegos infantiles, que son los elementos más logrados del proyecto.

El vacío elíptico central sigue siendo su característica más pregnante y contradictoria, como plantea Montealegre,

la condición de baldío con que carga el lugar desde ser Pampilla, persiste aún después del proyecto de Arana Bórica, hecho que se demuestra en la constante superposición de actividades diversas, como si el parque fuera una mera extensión de terreno abierto que permite recibir todo aquello que no tiene otro lugar en la ciudad. (Montealegre, 2011, p. 64).

\subsubsection{El Parque Metropolitano de Santiago}

El Parque Metropolitano de Santiago, es el área verde más importante de la ciudad. Con sus actuales 736,9 hectáreas, es considerado el cuarto parque urbano, más grande del mundo, alcanzando, además, 6 millones de visitas al año (2018). Un gran parque, que cubre y unifica una cadena de cerros que se descuelga de la precordillera Andina y se inserta en la ciudad (Figura 5.29.). "El San Cristobal" (como se le llama vulgarmente) es visible desde muchos puntos de la ciudad, por lo tanto, junto al río Mapocho se constituyen como los principales referentes espaciales y piezas estructurantes del paisaje urbano.

El cordón montañoso está formado por seis cerros, que visualmente se leen como uno solo. Los cerros que lo componen son el San Cristóbal, Chacarillas, La Pirámide, Los Gemelos, El Carbón y Polanco; que solo pierden continuidad por el cruce de la avenida Américo Vespucio (circunvalación) a la altura de La Pirámide.

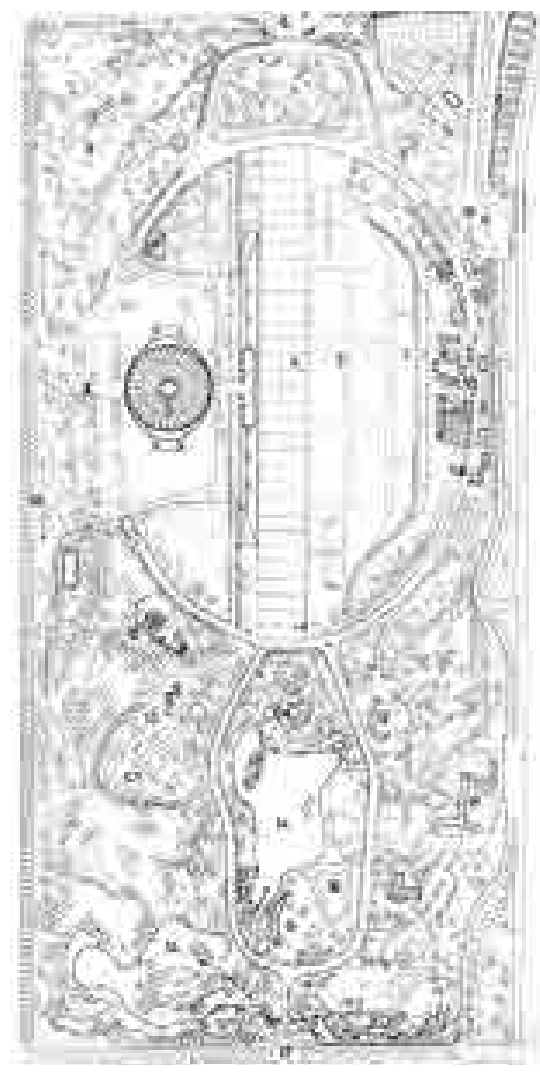

Figura 5.28. Parque O'Higgins, planta general. En Pía Montealegre (2010, p. 125)

${ }^{216}$ La Enciclopedia Británica establece el año 1876 como el año oficial de apertura del Central Park. https://www.britannica. com/place/Central-Park-New-York-City

217 Alberto Mackenna Subercaseaux

Figura 5.29. Vista aérea del Parque Metropolitano de Santiago. En ParqueMet (2016, p. 16)

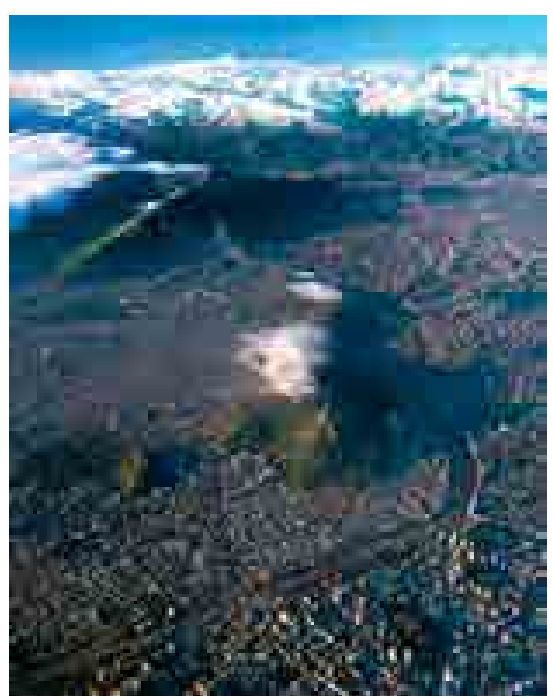




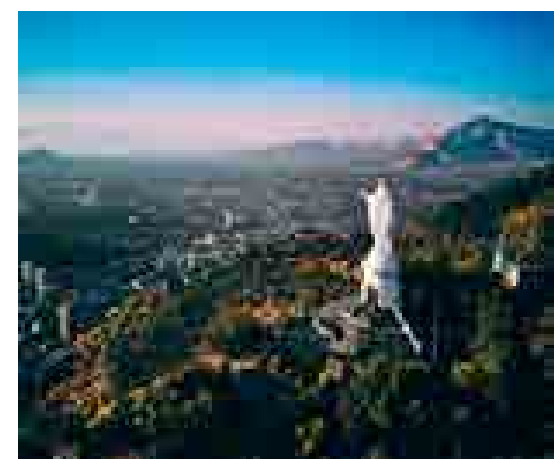

Figura 5.30. Santuario de la Inmaculada Concepción, Cerro San Cristóbal. Vista de la cumbre. Parque Metropolitano de Santiago, Chile. Por Deensel (23 de enero, 2018)
(1875-1952) fue Periodista y político chileno, comisionado por el Gobierno para elegir y traer a Chile, los modelos de escultura y arte industrial que sirvieron para la creación del Museo de Bellas Artes. En 1910, fue nombrado Comisario General de la Exposición Internacional de Bellas Artes. Desde 1921 - 1927, fue Intendente de Santiago y, entre 1933 -1939, sirvió el cargo de director del Museo Nacional de Bellas Artes.

https://www.mnba.gob.cl/617/w3-article-29832.html?_noredirect=1

${ }^{218}$ El patio de recreo es uno de los primeros

Figura 5.31. Plaza Mirador Pablo Neruda realizada por Carlos Martner, Humberto Eliash, Sebastián Lambiasi, Tomás Westenenk. En Plataforma Arquitectura (18 de octubre, 2016)
La imagen del Parque Metropolitano ha ido evolucionando en el tiempo. Originalmente sus laderas estaban cubiertas por vegetación autóctona, especialmente espinos (acacia caven), bosques que fueron expoliados para usar su madera como combustible. El sustrato rocoso también fue explotado para obtener materiales, especialmente piedra rosada, que serviría de basamento para importantes edificios como el Palacio de la Moneda, La Iglesia de San Francisco, el puente de Cal y Canto, como también para el adoquinamiento de calles que se realizó a partir del plan de Transformación de Santiago. Ya a finales del siglo XIX, los cerros del parque eran una suma de canteras. La gigantesca imagen de la Virgen de la Inmaculada Concepción corona el cerro desde 1908, reemplazando una cruz de madera, que desde la colonia marcaba el punto más alto de la ciudad a $502 \mathrm{~m}$ del plano (Figura 5.30.).

En 1915 el periodista y parlamentario Alberto Mackenna Subercaseaux ${ }^{217}$ impulsó la idea de que el parque quedaría inmerso en la ciudad. Con el fin de tener un plan urbanístico integral y que el cerro se conviertiera en un gran parque para los ciudadanos (PARQUEMET, 2016).

Mackenna no descanso hasta conseguir su objetivo, para lo cual emprendió acciones como crear una comisión únicamente para este propósito, difundió la idea en la prensa y logró convocar una protesta simbólica con los Boys Scouts de Santiago. En esta manifestación hizo el siguiente llamado:

Vosotros sois las primeras avanzadas que envía la ciudad a estas alturas para conquistarlas en nombre de la salud y la belleza. (...) Tras de vuestros pasos vendrán otros a darle forma práctica a vuestras aspiraciones Lo que los niños han soñado los hombres han de realizar. (PARQUEMET, 2016, p. 32).

Finalmente, el 28 de septiembre de 1917 se publicaría la Ley 3.295, que autoriza al presidente de la República a aceptar donaciones, comprar o expropiar los terrenos que hoy componen el parque. En 1921, asume Alberto Mackenna como intendente de Santiago. Con los terrenos del parque ya en manos del Estado, pudo desarrollar un proyecto para construir caminos, miradores y el funicular, además de una primera reforestación de 400 árboles. "Se propuso conservar la flora nativa del cerro, aunque también plantó árboles de follajes coloridos y rápido crecimiento, como acacias, aromos y coníferas, para cautivar a los santiaguinos." (PARQUEMET, 2016, p. 66). Desde 1908 ya existía el observatorio astronómico Foster (originalmente observatorio Lick) instalado por la Universidad de California para observar los cielos del hemisferio sur (FCl, 2017, p. 211). El Plan maestro original fue desarrollado por el paisajista Carlos Thays, y contemplaba toda la extensión del cerro San Cristóbal, en el que luego se instala el zoológico en una superficie de 5 hectáreas. En la década de 1960 se desarrollan una serie de proyectos que buscan atraer al público, entre los que se encuentran, la Plaza México, la Casa de la Cultura Anahuac, la piscina Antilén y la piscina Tupahue, obra del arquitecto y paisajista Carlos Martner, quien aprovecha una antigua cantera-basural para encastrar la pileta. ( $\mathrm{FCl}, 2017$, p. 211).

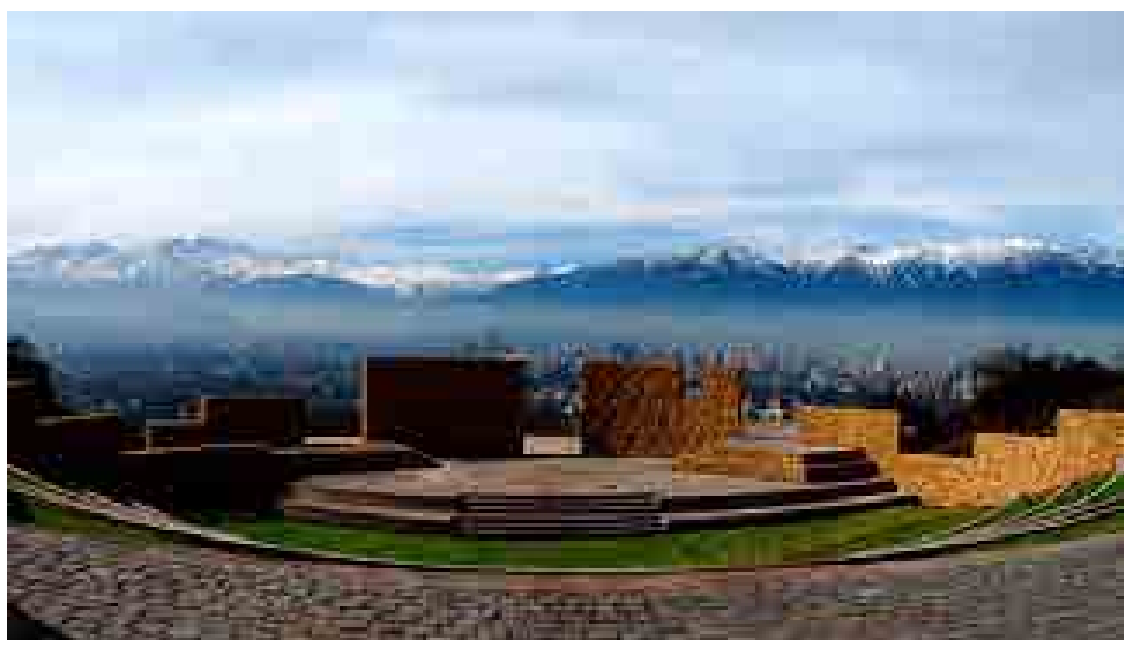


El carácter del parque se ha consolidado en el tiempo, como un mirador excepcional del paisaje urbano (Figura 5.31.), lugar de peregrinaje y espacio de recreación de la ciudadanía en un entorno natural. Hoy estas funciones se han ampliado a la cultura, el deporte y la educación ambiental. Estos servicios se pueden ver materializados en el santuario, el funicular, el zoológico, senderos y miradores en sus inicios, y al día de hoy se aprecia en los anfiteatros, las piscinas, zonas de picnic, el teleférico, el centro cultural, restaurantes, jardines temáticos, espacios educativos del medioambiente y la ampliación constante de senderos y miradores.

Su extensión abarca cuatro comunas: Recoleta, Providencia, Vitacura y Huechuraba, cuestión que administrativamente fue resuelta en 1966 a través de la Ley 16.464 que creó oficialmente el "Parque Metropolitano de Santiago", uniendo los servicios del Cerro San Cristóbal y el Jardín Zoológico Nacional, a las que se han ido sumando nuevas áreas hasta completar la superficie actual de 736, 9 hectáreas ( $\mathrm{FCl}, 2017$, p. 210), cuya administración está bajo la dependencia del Ministerio de Vivienda y Urbanismo.

Este caso estudiado revela que un gran parque no es sólo un laboratorio natural y social, un mundo controlado donde se pretende que las personas vuelvan a encontrarse con la naturaleza. Es también una empresa que requiere una gestión adecuada. El Parque Metropolitano tuvo que organizarse y crecer en personal profesional y técnico. Esta estructura ha permitido extender su modelo a 20 parques de Santiago, que hoy son administrados centralmente por el Parque Metropolitano, sumando más de 250 hectáreas a su gestión que contempla una estructura de alrededor de 400 personas.

\subsection{LOS PARQUES COMO SISTEMAS COMPLEJOS}

El recorrido propuesto para comprender este artefacto urbano que es el parque, es una mezcla de análisis histórico y taxonómico. La cantidad y variedad de casos es inmensa, por lo que se han seleccionado sólo aquellos que han podido ser visitados, dejando muchos e importantes ejemplos fuera. Los dos parques siguientes se presentan brevemente para ilustrar la complejidad de algunas operaciones, que han sido importantes a la hora de tomar decisiones en el Plan Maestro o bien suponemos que lo serán.

\subsubsection{La Courneuve (Parc Georges-Valbon)}

El parque de La Courneuve es el espacio verde más grande del noreste de la ciudad de París, ubicado la intersección de 5 municipios (La Courneuve, Saint-Denis, Stains, Dugny y Garges-lès-Gonesse) con una extensión de 420 hectáreas, sobre antiguas tierras de cultivo que se encuentran prácticamente en la cota del río Sena, vale decir en tierras bajas.

La historia de la construcción del parque de La Courneuve se extiende por más de 80 años, a lo largo del siglo XX. Refleja los cambios en las representaciones del paisaje que han dado forma a la historia de los jardines a lo largo del siglo. Es a partir de 1925 que el departamento del Sena adquiere 410 hectáreas en un área comunal que cubría parte de 5 municipios. El objetivo del Consejo General era adquirir un área más grande, de 710 hectáreas, para instalar una ciudad satélite que incluía viviendas e industrias. La política de adquisición de propiedades se extendió hasta 1967, pero los predios, principalmente agrícolas, se presentaban aún dispersos y fragmentados. En 1934, la prefectura del Sena sugirió crear un gran paseo público que no se concreta. De hecho, no se realizarán obras en los terrenos del futuro parque hasta 1951, debido a la falta de fondos y de un proyecto sólido. (Provost, 2005, p. 7). La idea de construir un parque, mencionada por primera vez en 1934, no será definitiva hasta 1954. El arquitecto Albert Audias, funcionario de la prefectura, presenta un proyecto que contemplaba la reforestación del sitio con la intensión de recrear o preservar la naturaleza en un entorno industrial que se volvía cada vez más opresivo. Sin trabajos de nivelación, ni modificaciones en la topografía, traza senderos y caminos siguiendo curvas naturales. Se incluyen obras de infraestructura, solo en los cruces de ríos y de la vía férrea. Las primeras plantaciones se llevarán a cabo en 1960 bajo la dirección del mismo arquitecto que se había convertido en 1955, en el paisajista 
de la Prefectura del Sena. Entre 1961 y 1964, se intervino una superficie de 30 hectáreas con la plantación de 130.000 árboles caducifolios y 6.000 coníferas; $4.000 \mathrm{~m}$ de senderos, y la siembra de 70 hectáreas de pastizales (Provost, 2005). En 1970, el departamento de Seine-Saint-Denis llamó a concurso, para el desarrollo del segundo tramo de 256 hectáreas. Las bases definen el futuro parque como un espacio de paisaje y relajación, cuyo diseño debe armonizar con las obras realizadas antes por Albert Audias. Los paisajistas Allain Provost y Georges Samel ganan el certamen y se asocian con el arquitecto Dereck Lovejoy y el escultor Pierre Zvenigorodsky para ejecutarlo.

El parque tiene dos secciones principales que permiten leer la historia del parque y al mismo tiempo, la evolución en el diseño del paisaje (Figura 5.32.). La parte más antigua, ubicada al sureste, diseñada por Albert Audias, consiste en una Gran Rotonda (Grand Rond) circundada por una arboleda. Este primer tramo, que requirió 20 años de trabajo, abarca 156 ha. Fue concebido en el espíritu del Bois de Vincennes y del Bois de Boulogne, según los modelos de los parques Napoleón III. A diferencia de los parques del Segundo Imperio, el programa obligó al diseñador a no crear movimientos de tierra, es decir, a mantener la planitud del sitio y a jugar sólo con los espacios llenos y vacíos a través de las masas arbóreas. La gran Rotonda encierra un enorme claro de césped orientado en la extensión de una perspectiva verde bordeada de tilos. La parte más reciente, ubicada al norte del parque, llevada a cabo por el equipo de Provost / Samel presenta, por el contrario, grandes movimientos de tierra asociados con cuerpos de agua que constituyen el marco del proyecto. Este segundo tramo incluye el gran valle. Este es verdaderamente el espacio central del parque. En su centro está el gran lago, de 14 hectáreas, enmarcado por múltiples patrones con curvas y contra curvas, muy trabajadas, formando valles, colinas y un mirador de $65 \mathrm{~m}$ de altitud, desde donde se puede observar todo el sitio. Un espacio más animado se encuentra a un lado del acceso a la Gran Rotonda con la casa del parque y la cafetería. Una Plataforma de madera sobre el lago "Les Dièdres" forma una piscina infantil en la zona sur del cuerpo de agua. Las orillas del lago están alternativamente desnudas, adornadas con rocas o plantadas con plantas acuáticas. Desde este sitio se puede ver el puente Iris hacia el norte, que, con sus colores brillantes, atrae la atención para acceder al extremo norte del parque y cruzar la línea férrea. El valle continúa al norte del ferrocarril por la presencia de una cadena de lagos que conducen a la fuente del flujo de agua: las cascadas (Figura 5.33.). En la última parte, se encuentra otro valle, al noreste del parque, los paisajistas han tenido que hacer frente a importantes problemas como las aguas residuales. Esta es la parte más natural del parque (ZNIEF clasificado, área natural de interés ecológico de fauna y flora y Natura 2000 , red europea sobre la conservación de hábitats naturales de fauna y flora silvestres instituida en 1992). Con el tiempo, el parque

Figura 5.33. Vista aérea Parque La Courneuve (parc Georges-Valbon) zona norte desde la cascada a los lagos superiores. Obra del paisajista Allain Provost. Por Jean-Baptiste Leroux (s.f.).

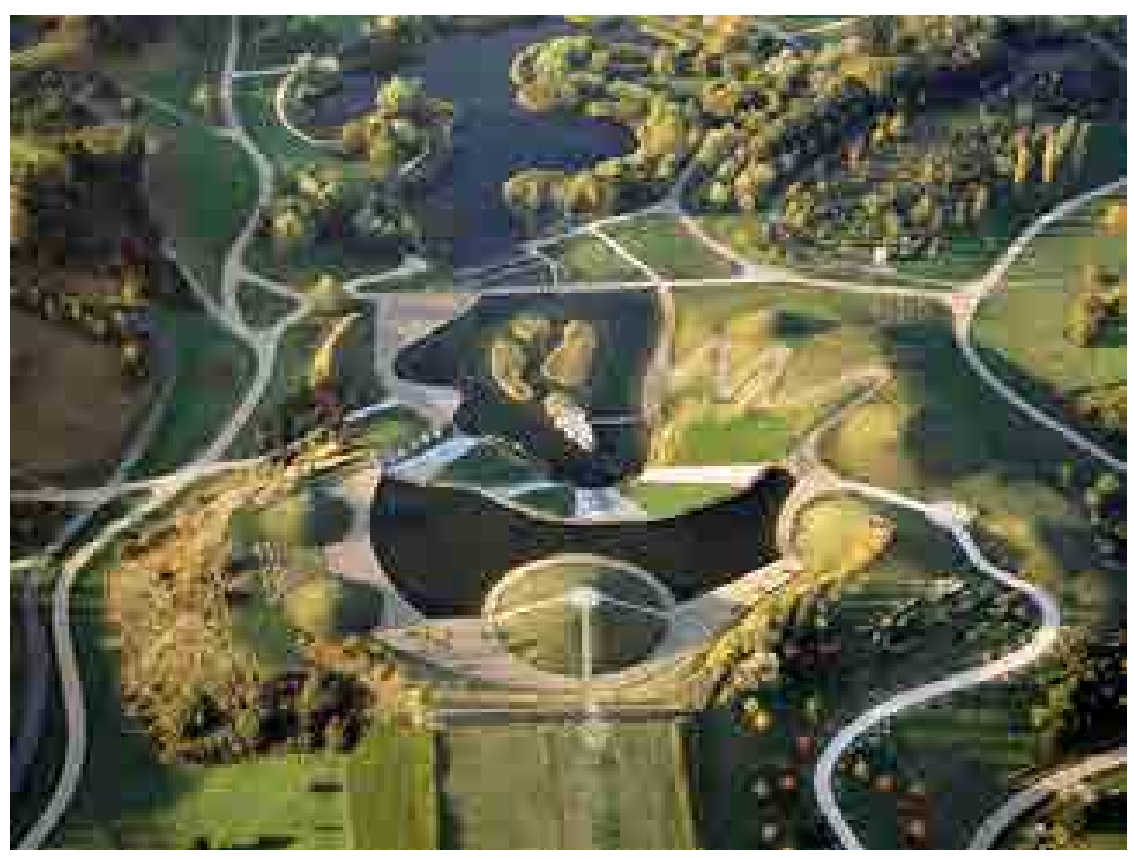


ha generado una serie de lugares con connotaciones ecológicas. Así, se abrió a esta perspectiva ecológica y mantuvo estos equilibrios naturales mediante el uso de un enfoque desarrollado por G. Samel llamado "manejo de armónicos". Es un proceso innovador de paisajismo y mantenimiento de espacios verdes vinculados a la mejora y preservación de la biodiversidad. Se han identificado 156 especies de aves. Se acaba de crear un observatorio de la biodiversidad. Este parque es, por lo tanto, una ilustración típica de la evolución de un parque público en el siglo $X X$.

La legibilidad exterior del parque no es clara debido a su forma irregular y a que se encuentra rodeado y cortado por muchas redes de transporte: la línea SNCF lo cruza en el medio, limita al sur con la Carretera Norte, al suroeste, al sureste y al noroeste por carreteras departamentales con mucho tráfico. Este verdadero yugo alrededor del sitio crea una suerte de enclaustramiento del parque con respecto a su entorno urbano.

Pese a una imagen algo difusa exterior, la experiencia interior es continua. En el recorrido se concilian las dos fases del proyecto. La nueva fase del parque armoniza con la antigua y da cuenta de la evolución del concepto de parque, en una sucesión de experiencias cuya inspiración parecen provenir más de la tradición alemana que de la francesa. El trabajo de la topografía resultante, permite la sucesión de espacios abiertos a gran escala asociados con espacios laterales más íntimos. La propuesta de Provost es muy simple: un valle central ocupado por una cadena de lagos que constituye un "esqueleto de agua". Los movimientos de tierra, en gran parte boscosos, con volúmenes generosos, absorben el ferrocarril, el ruido y borran la carretera. El parque es un interior amplio y legible, que acoge a una gran diversidad de visitantes, principalmente locales (con pocos turistas), niños y niñas, ancianos, personas de todos colores y razas, lectores, equitadores y personas que van en un grupo de pic-nic.

Son estas personas, principalmente vecinos de los populosos barrios aledaños, quienes han defendido férreamente la integridad del parque, ante la amenaza de un proyecto inmobiliario publicitado como "Central Park de París" (Figura 5.34). El plan propone el desarrollo de viviendas y oficinas en el perímetro del parque, que avanzan hacia el interior ofreciendo "vitalizar" y sacar más provecho de este enclave de naturaleza artificial.

El triunfo de la comunidad frente a la presión inmobiliaria es un ejemplo, de un
Figura 5.32. Parque La Courneuve (parc Georges Valbon) - Plano General. Por Conseil départemental de la Seine-Saint-Denis (2016).

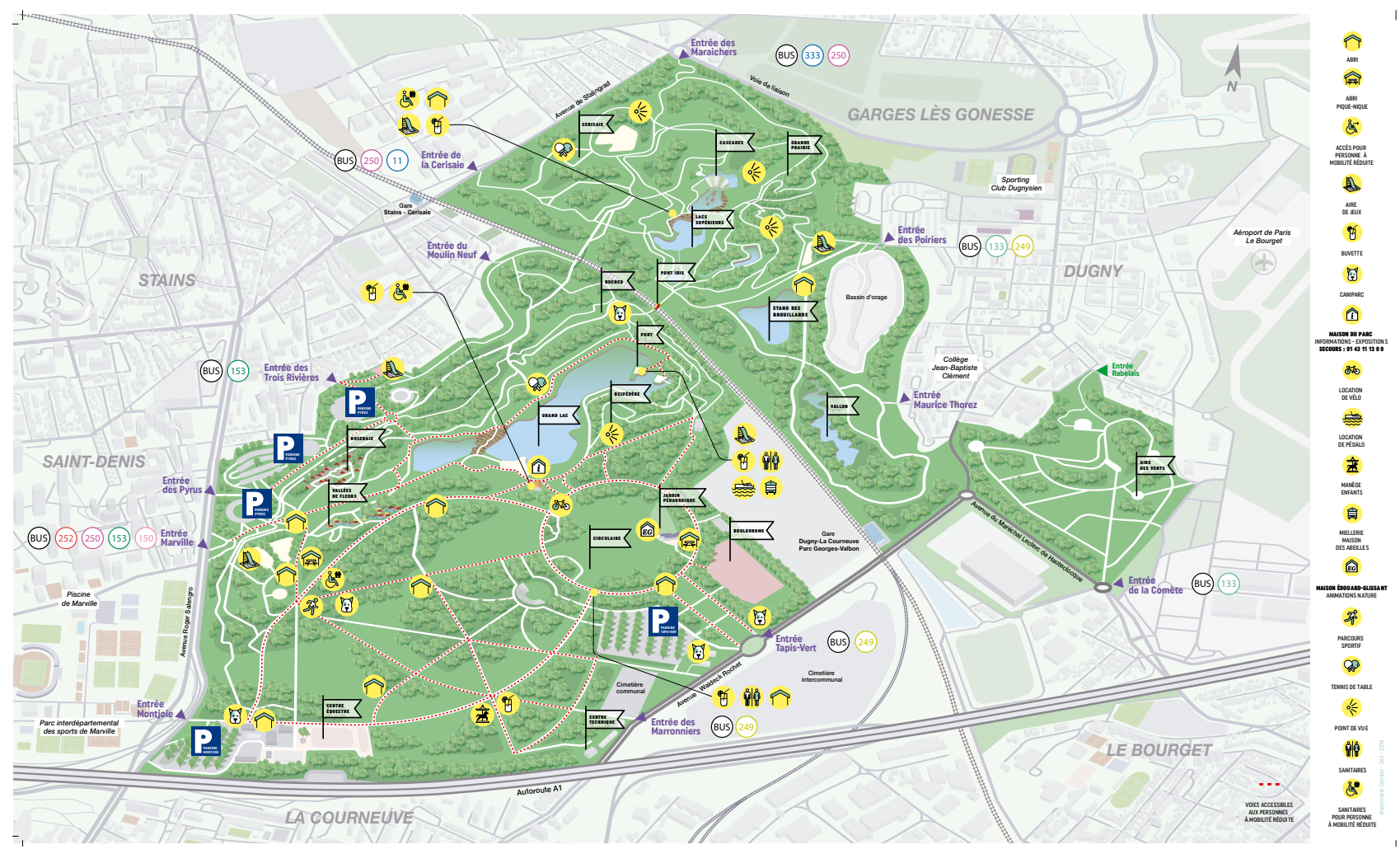


Figura 5.34. El proyecto Central Park du Grand Paris sobre el Parque La Courneuve (parc Georges Valbon). Por Plano General. Por Atelier Castro Denissof \& Associés (c) (10 de octubre, 2014).

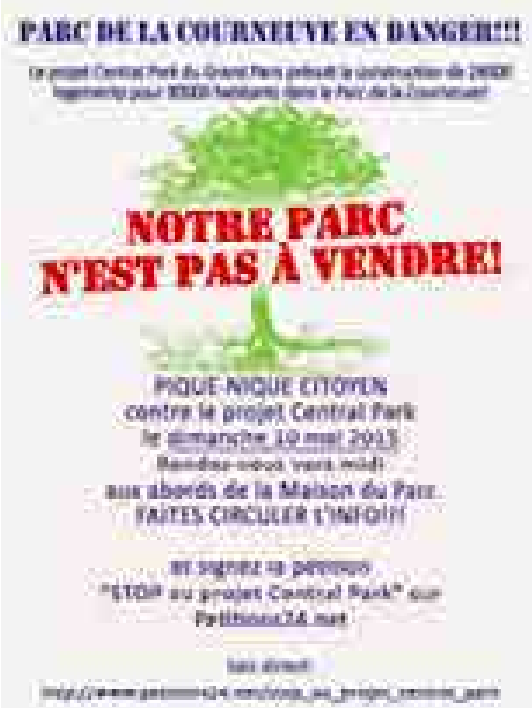

Figura 5.35. Afiches en defensa del parque La Courneuve. En Bondy Ecologie [blog] publicado el 20 de mayo, 2015.

Figura 5.36. Mapa de ubicación de Shelby Farms Park respecto a la ciudad de Memphis. Por Fiel Operations (2008, p. 19).

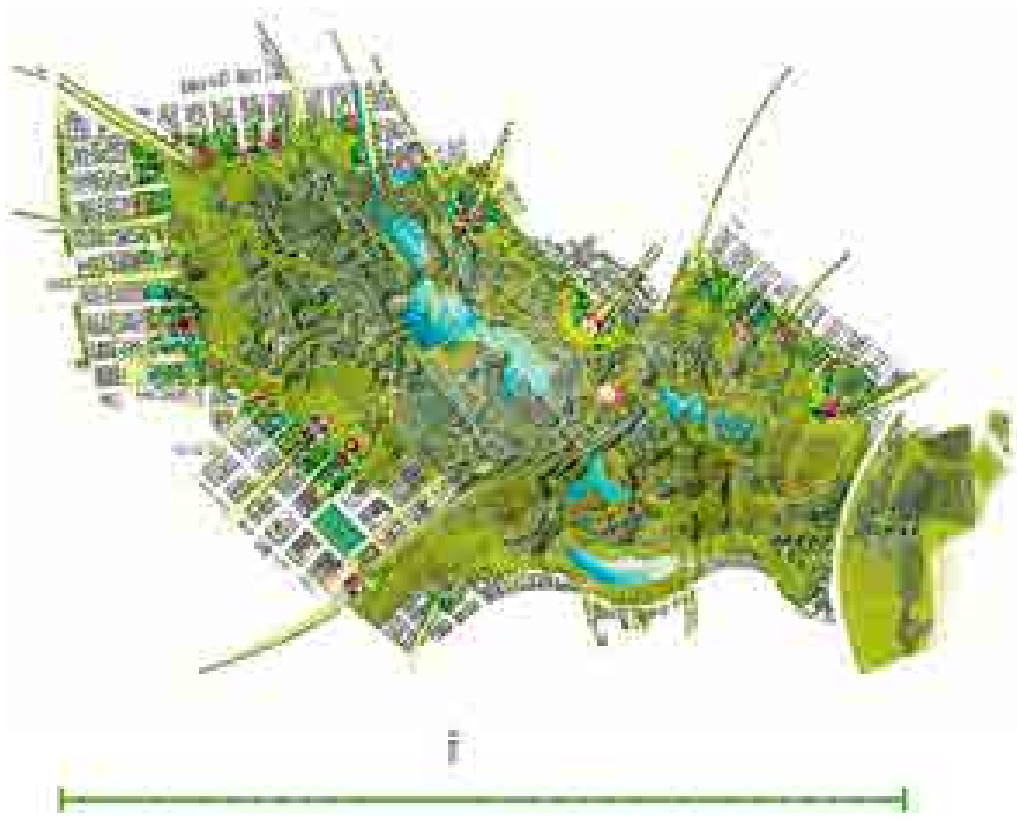

PARC DE LA COUIREUVE BN DANGBI!!!

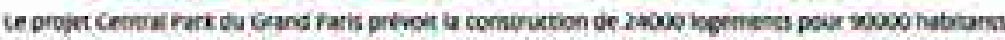

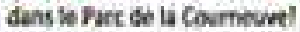

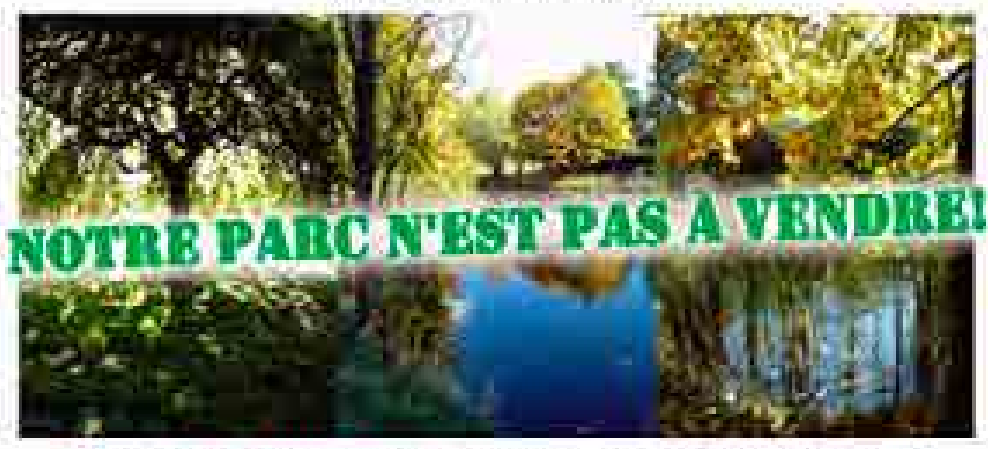

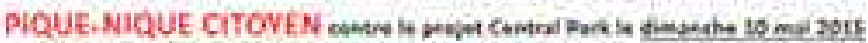

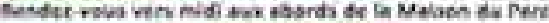

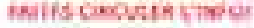

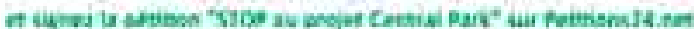

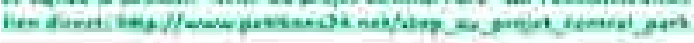

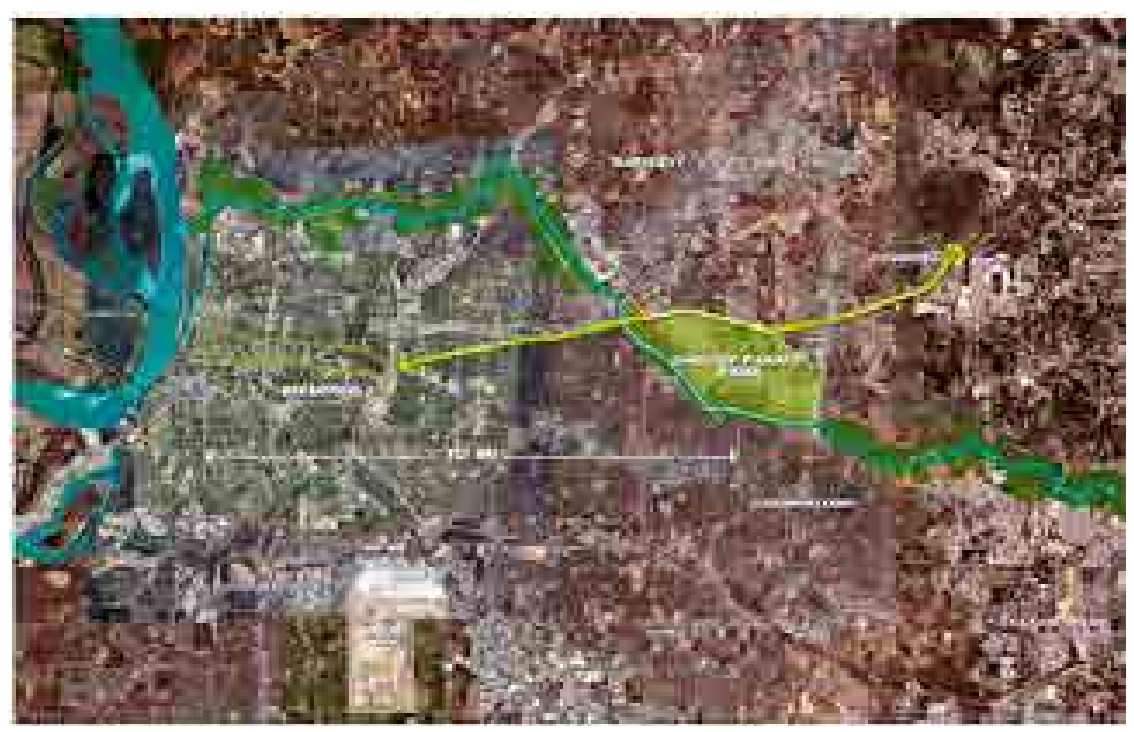




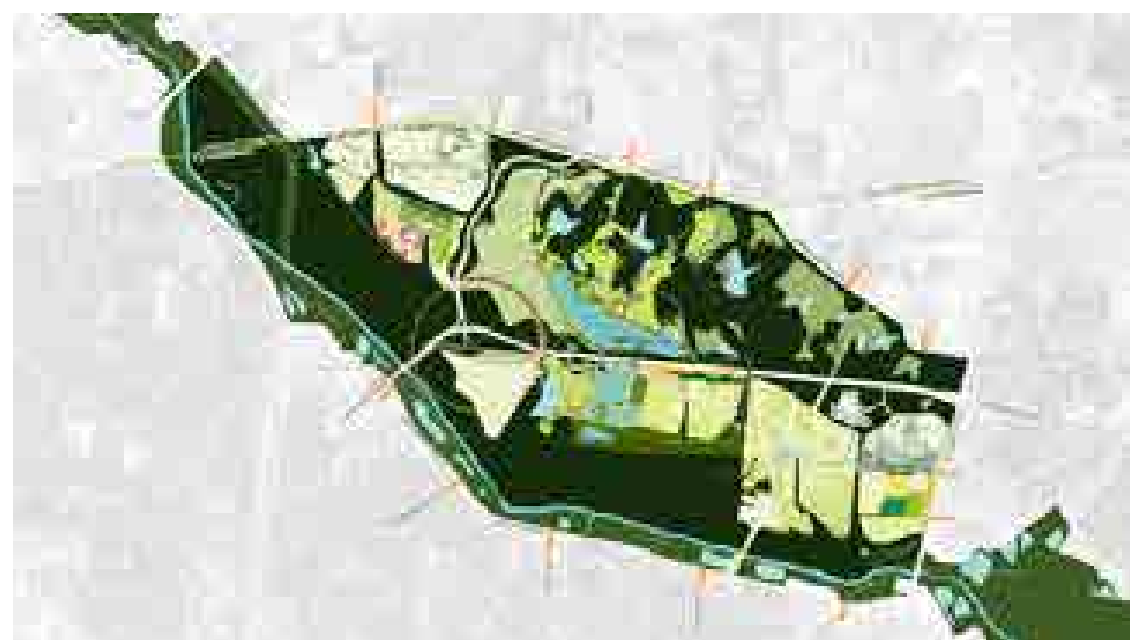

grupo humano que más que usuario es responsable de la vida y el futuro del parque (Figura 5.35.).

\subsubsection{Shelby Farms Park}

Es un parque aún en desarrollo, está ubicado en Memphis, Estados Unidos (Figura 5.36.). La oficina James Corner Field Operation (JCFO) se adjudicó el proyecto a través de un concurso realizado en 2003, cuya primera fase de implementación se inició el 2010. El lapso entre ambas fechas, corresponde al desarrollo del proyecto y al proceso de aprobación del mismo por la Comisión del Condado que contempló un amplio proceso de consulta ciudadana.

Se trata de la transformación de una antigua granja penal de 1.821 hectáreas (4.500 acres, 9 veces más grande de lo que recomendaba Downing) en un parque urbano para Memphis.

La documentación del proyecto está ampliamente desplegada en una página web y en múltiples dispositivos de marketing, que buscan la participación de la ciudad en el proyecto, pero por, sobre todo, construir una identidad rápidamente, en forma simultánea a su implementación.

La propuesta (Figura 5.37.) se ancla en un "concepto estratégico" con tres ideas-slogan: Un parque, Un millón de árboles, Doce Paisajes (Field Operations, 2008, p. 10).

"Un parque" aborda los objetivos de unidad, conectividad, sentido de lugar, ecosistema, identidad e inclusión. Esto significa que las nuevas vías de circulación, la plantación de árboles, pasarelas, señalización y elementos de diseño deben propender a una lectura unitaria, para dar forma al parque como una sola entidad. La dificultad de abarcar lo vasto, es justamente, que la percepción tiende a separar y entender partes, perdiendo la noción de un "todo" que está más allá de la experiencia.

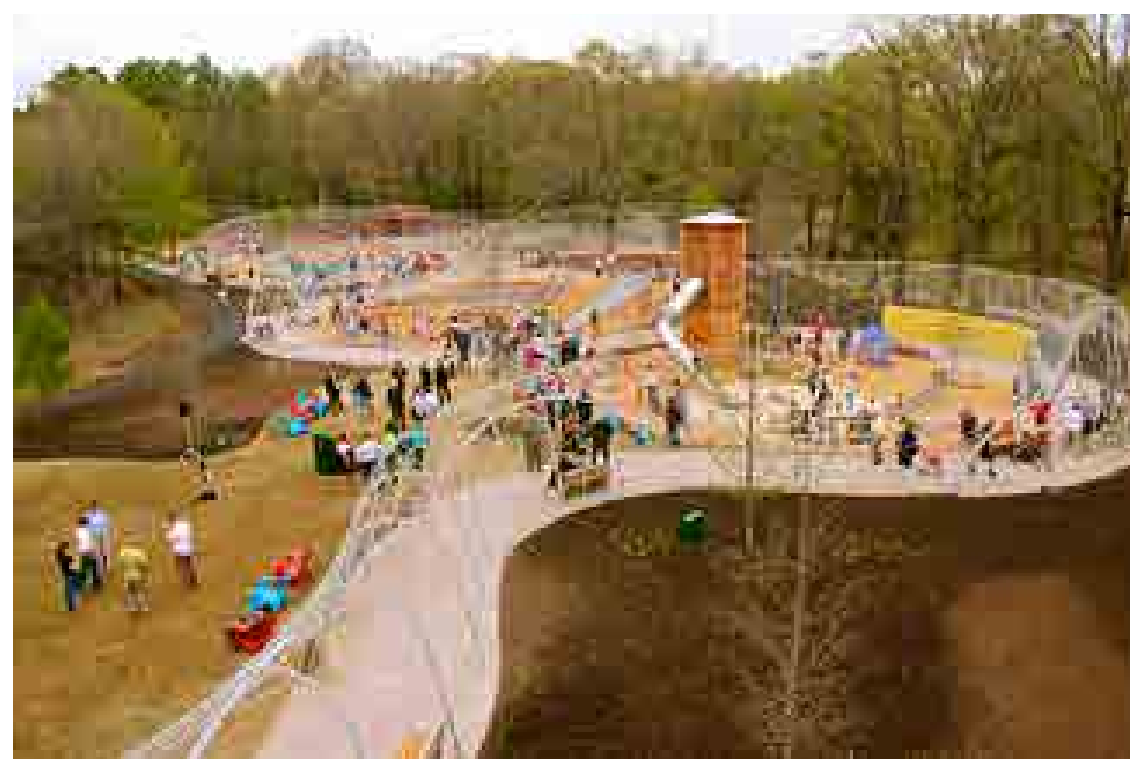

Figura 5.37. Shelby Farms Park Master Plan. Field Operations (2008, p. 15). proyectos en cumplir con los ambiciosos puntos que exige SITES para el bienestar ecológico y humano. La iniciativa Sustainable Sites Initiative tiene como objetivo cambiar el mundo del paisaje mediante la creación e un sistema de acreditación voluntaria similar al modelo de LEED para edificios ecológicos.

${ }^{219}$ F.L. Olmsted Jr. \& Theodora Kimball ci-

Figura 5.38. Woodland Discovery Playground. Por James Corner Field Operations (s.f.). 
"Un millón de árboles nuevos" aborda los objetivos de mejora ecológica y biodiversidad, conectando áreas de hábitat, definiendo bordes, dando forma a las habitaciones y eliminando vistas indeseables.

"Doce paisajes" aborda la diversidad y riqueza de las diferentes áreas del sitio, las diversas demandas de los grupos de usuarios y la definición de futuras zonas de administración. En el centro del parque se encuentra un inmenso lago, que apoya el hábitat de los peces y una amplia gama de actividades de deportes acuáticos no motorizados.

Una de las primeras piezas del parque es el Woodland Discovery Playground..$^{218}$ Figura 5.38.). Un espacio está "destinado a fomentar el juego y el descubrimiento, abrazando la diversión y el placer, al mismo tiempo que fomenta el desarrollo saludable del bienestar físico y social de los niños" (Field Operations, 2008, p.142). Ubicado en un contexto de bosque natural, el patio de recreo ofrece un entorno que promueve la interacción: los niños deben ingresar, moverse y buscar oportunidades para deslizarse, trepar, correr, trepar, balancearse, construir, encontrar y descubrir bajo una visión del desarrollo infantil cercano a la escuela Montessori.

Un elemento preexistente en el parque es el Agricenter. Se trata de un conjunto instalado en 1981 por la Legislatura del Estado de Tennessee para promover la educación, la investigación y el agro-negocio con la intención explícita de estimular el desarrollo económico. El Agricenter administra 404 hectáreas en la parte sureste de Shelby Farms Park para estos propósitos. Este territorio incluye un Centro de Convenciones, un parque productivo y un área de 18 hectáreas para el Showplace Arena. Si bien en el proyecto se incluye este sector, actualmente funcional y estéticamente, está separado.

Si bien se puede considerar que Shelby Farms Park es actualmente un parque público exitoso, persisten algunos problemas que parecen ser estructurales y que también podemos reconocer en el predio de Laguna Carén. Los cuatros puntos críticos deben ser considerados en el Plan Maestro para guiar la transformación del parque a largo plazo:

- Una identidad débil: en el caso de Shelby Park el parque compite con la Granja Agrícola preexistente y con el recuerdo oscuro de la granja penal. Como en el caso de La Courneuve y el de Carén, los límites del parque son difusos, especialmente hacia la Carretera.

- $\quad$ Segmentación por la vialidad, Walnut Grove Road ya divide el Parque en mitades norte y sur, aislando los programas y actividades en cada uno de ellos. La implementación de la nueva Shelby Farms Parkway requiere un diseño que refuerce física y perceptualmente las secciones de cada lado del camino, para leer el parque como uno. Carén tiene un camino interior que será a futuro una vía de acceso a los conjuntos de vivienda vecinos, con, posiblemente, los mismos problemas de segregación espacial.

- $\quad$ Ecosistema Fragmentado - A pesar de que el Parque es a menudo considerado como "natural", es en realidad un ambiente altamente antropizado y continuamente modificado. En Shelby como en Carén, la vegetación de tierras altas está sana, pero ecológicamente limitada al permanecer sin conexión y aislada. Además, el hábitat en esta área está desconectado del corredor más ecológicamente productivo de Wolf River, que es un aspecto crítico para el movimiento de la fauna dentro de la región. Conectar los diversos componentes ecológicos del parque en un mosaico interconectado serviría para mejorar la salud general y el valor ecológico de la tierra.

- Deficiente Acceso / Conectividad / Circulación: Si bien, Shelby Farms Park está bien posicionado para el acceso por tráfico de vehículos, su ubicación respecto al centro de Memphis hace difícil el acceso por otros medios que un automóvil. Ningún medio de transporte público llega al interior o al Parque, y las pocas paradas en su perímetro están demasiado lejos de cualquier destino importante del Parque para ser de 
alguna utilidad real. Proporcionar conexiones a la recreación y vínculos de transporte alternativo, tales como vías públicas o ciclovías, así como modificar y expandir el servicio de tránsito existente al Parque, ayudará a que sea realmente accesible y utilizable por toda la Región de Memphis.

Una vez dentro del Parque, aprovechar los diferentes lugares es difícil debido al sistema de circulación existente es insuficiente y las distancias demasiado largas. Muchas de las rutas de circulación dentro del Parque son caminos de campo re-apropiados o caminos definidos por el usuario. De hecho, el gran tráfico de Camino de Granja no es en realidad una vía pública, sino una carretera interna de "granja". La definición de una jerarquía clara de tipos de circulación; la aplicación de elementos de búsqueda de la vía; y la creación de conexiones redundantes entre las áreas del Parque en lugar de uniones únicas ayudará a mejorar el movimiento dentro y el disfrute del Parque. La implementación de un tren liviano que cruce longitudinalmente sería una solución que los arquitectos sugieren.

En la memoria del proyecto $(J C F O, 2006)$ se describe que durante la etapa de diseño el equipo mantuvo las siguientes preguntas, que pudieran servir de para recordar algunos principios a la hora de tomar decisiones:

- ¿Promueve lo verde y abierto?

- ¿Es flexible y adaptativo?

- ¿Es accesible y atractivo?

- ¿Es sustentable desde el punto de vista medioambiental y financiero?

- ¿Es excepcional y distintivo?

- ¿Aprovecha el tamaño del parque?

- ¿Respeta las limitaciones de la servidumbre?

- ¿Aprovecha nuestros recursos naturales?

- ¿Refleja los estándares más altos posibles?

- ¿Alienta un sentido de comunidad?

- ¿Es seguro? (JCFO, 2006, p. 13)

A las preguntas de del equipo de JCFO podemos agregar aquellos principios que se esbozaron en el capítulo 4, que nos han permitido analizar distintos parques y que podrían ser formuladas como preguntas que deben permanecer a la vista mientras diseñamos:

¿Cómo la historia del sitio, la historia personal, nos ayudan a entender el proyecto como un proceso?

¿Qué capas materiales e inmateriales están impresas en el sitio?

¿De qué manera el diseño aborda las distintas escalas de la realidad?

¿De qué modo el "mapa", el diagrama, los planos nos ayudan a construir una realidad, un territorio en transformación, un paisaje?

\subsection{LO VASTO Y LOS PARQUES}

Los parques antiguos fueron grandes, muchos de ellos, los históricos, evolucionaron a partir de cotos de caza de la realeza que se abrieron al público, otros, nacieron como artefactos urbanos para remediar el hacinamiento y las condiciones insalubres de la ciudad industrial, una ciudad donde todavía el suelo era un bien abundante y de bajo costo, que permitía, capturar algo de esa naturaleza perdida dentro de la urbe.

En la ciudad actual, el terreno es un bien escaso y un "atractor" de intereses diversos, irremediablemente sometido a la presión de los agentes inmobiliarios. Actuar hoy sobre lo vasto e intentar destinar una gran porción del territorio al bien público exige nuevas competencias profesionales que nos permitan comprender, conciliar y coordinar un enjambre de intereses divergentes, divisiones administrativas (y políticas), condiciones ambientales, regulaciones, gobernanza y variables económicas.
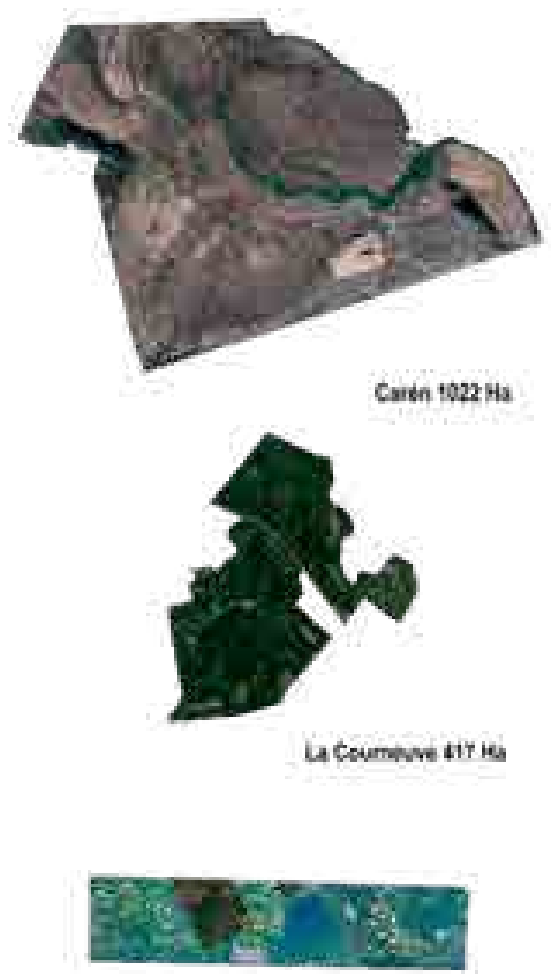

Central Park $345 \mathrm{Ha}$

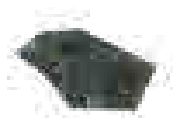

Birktnhead Park $315 \mathrm{Ms}$

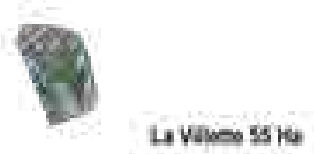


El tamaño, es un "problema perverso", y tiene consecuencias prácticas y disciplinares, pero incluso antes de eso, es un desafío para la imaginación. Pensar en 1.022 hectáreas ( 2.525 acres), o decir más de 10 millones de metros cuadrados es difícil de representar en la mente. Podemos hacerlo comparando los parques que hemos estudiando (Figura 5.39.). Grandes parques como el Central Park (341 ha), el Birkenhead (91,5 ha), La Villette (55 ha), El Parque de La Courneuve (417 ha), o el primer parque público chileno, la Quinta Normal (de 135 ha originalmente, reducidas a 35 en la actualidad) caben varias veces en el terreno.

El tamaño también estuvo en la mente de Olmsted cuando usó la palabra "parque" para el diseño del Central Park en 1870, al señalar que se trataba de una gran porción de tierra diferente de la ciudad "para que el público disfrutara del paisaje rural, diferenciándolo de una plaza pública, un jardín público o una rambla, adecuados sólo para los placeres más urbanizados" ${ }^{219}$ (citado por Olmsted \& Kimball, 1928, p. 3). Su idea estaba influenciada por Andrew Jackson Downing, quien sugirió que 500 acres (202 ha) era el área mínima que debía reservarse para los futuros parques (Downing, 1851, p. 346).

Cien años más tarde, Jane Jacob consideraría que justamente el tamaño, lo grande, como un problema. En Vida y Muerte de las grandes ciudades nos advierte que los grandes parques son especialmente vulnerables y llama a los diseñadores a hacerse responsables de sus consecuencias.

En la introducción del libro Large Parks, Especulando sobre el tamaño (Speculating on size), Julia Czerniak (2007) no se resiste a la asociación de lo grande con el manifiesto de Rem Koolhaas, Bigness or the problem of Large (1995) que, si bien se refiere a lo grande en la arquitectura, podemos hacer el ejercicio de trasladar sus polémicos enunciados a nuestro problema en el ámbito del paisaje. Koolhaas piensa que la grandeza "instiga el régimen de complejidad que moviliza toda la inteligencia de la arquitectura y sus campos relacionados" (1995, p. 497). Acusa de que no tenemos una teoría de lo grande, que no sabemos qué hacer con lo vasto, no sabemos cómo ni cuándo usarlo, no sabemos cómo planearlo. Por lo mismo, lo grande es un dominio teórico que tiene el "potencial de resucitar lo real, reinventar lo real colectivamente" $(1995$, p. 510). Podemos imaginar a Koolhaas preguntándonos ¿cuál es el programa ideológico que se oculta tras la idea, aparentemente inocente de un parque? o si ¿puede el parque resolverse y controlarse con un solo gesto de diseño e incluir una multitud de posibles acontecimientos en un solo receptáculo [en un gran objeto]? con el riesgo, siempre presente, de actuar como el "creador de Frankenstein" (1995, p. 509), juntando piezas sobre el territorio. Lo vasto deroga las certezas y anula las fórmulas que nos han dado seguridad en el actuar, incluyendo la incertidumbre como materia de proyecto.

La certeza que sí tenemos, es que grandes cantidades de terreno son necesarias para producir los efectos ecológicos, recuperar el horizonte, organizar distintas escenas, comprometer la gestión adaptativa, diseñar un sistema natural y ser económicamente sustentable, es decir, ser "lo suficientemente grande como para incluir los recursos y actividades que permitan la construcción y mantención del parque" (Czerniak, 2007, p. 23).

Tras lo que hemos expuesto, podemos preguntarnos ¿qué son hoy los grandes parques? Integradores sociales, agentes ecológicos, lugares para las utopías, lugares donde podemos experimentar y entender nuevas posibilidades para el futuro ¿o todas las alternativas anteriores?

Podemos dar fe de que lo vasto implica una cantidad considerable de energía, visión, compromiso e innovación no solo de parte de los arquitectos, sino también, de políticos, gestores, científicos y del público al que sirven; solo el esfuerzo

tan en su libro a F.L. Olmsted:

He considered that he was entitled to restrict the meaning to a large tract of land set apart by the public for the enjoyment of rural landscape, as distinguished from a public square, a public garden, or a promenade, fit only for more urbanized pleasures.

${ }^{220}$ El Predio de Laguna Carén tiene 1.022 

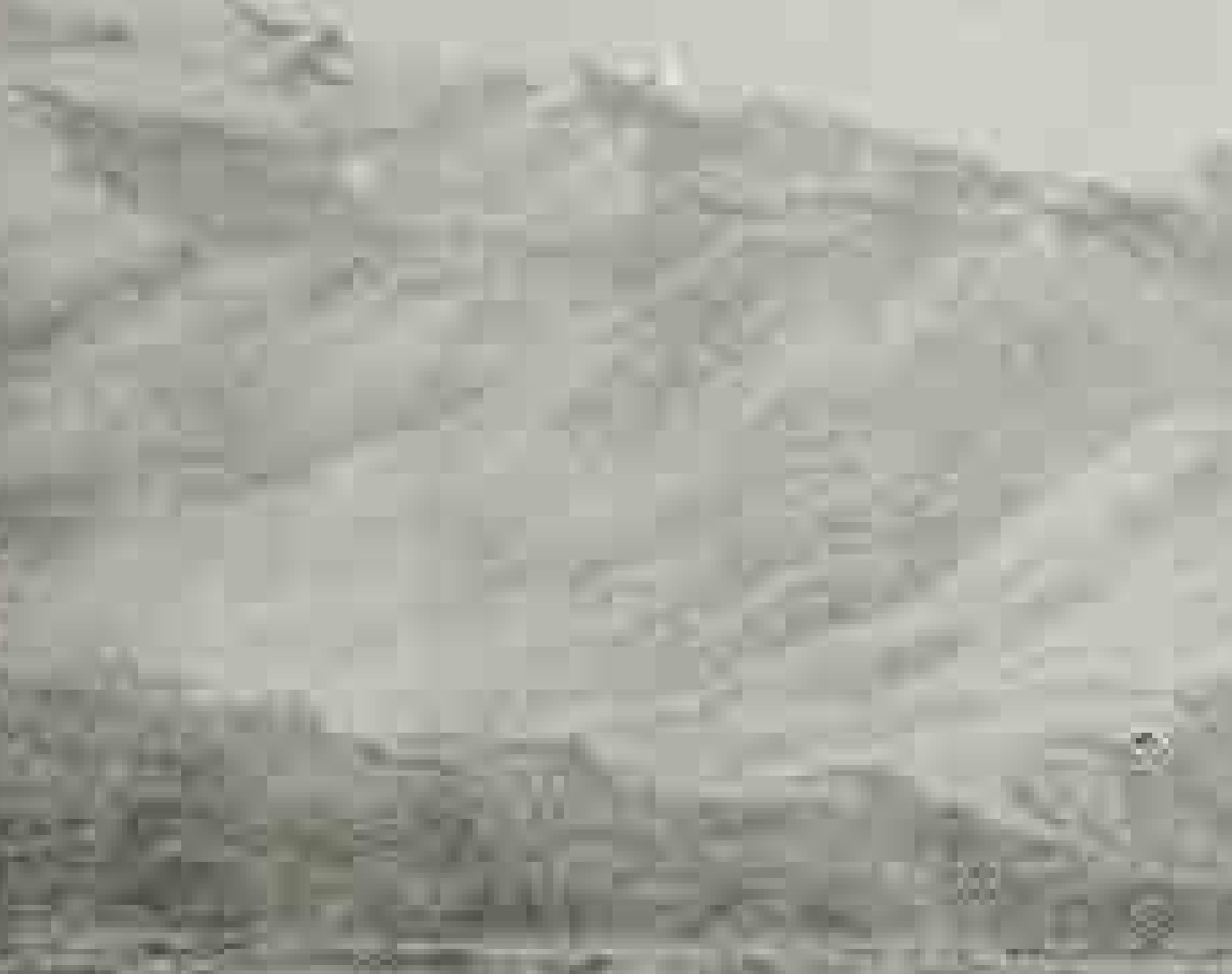

tris

7a,

Heis

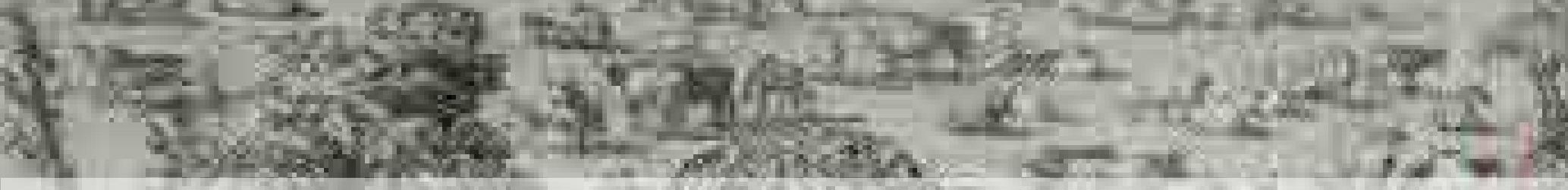

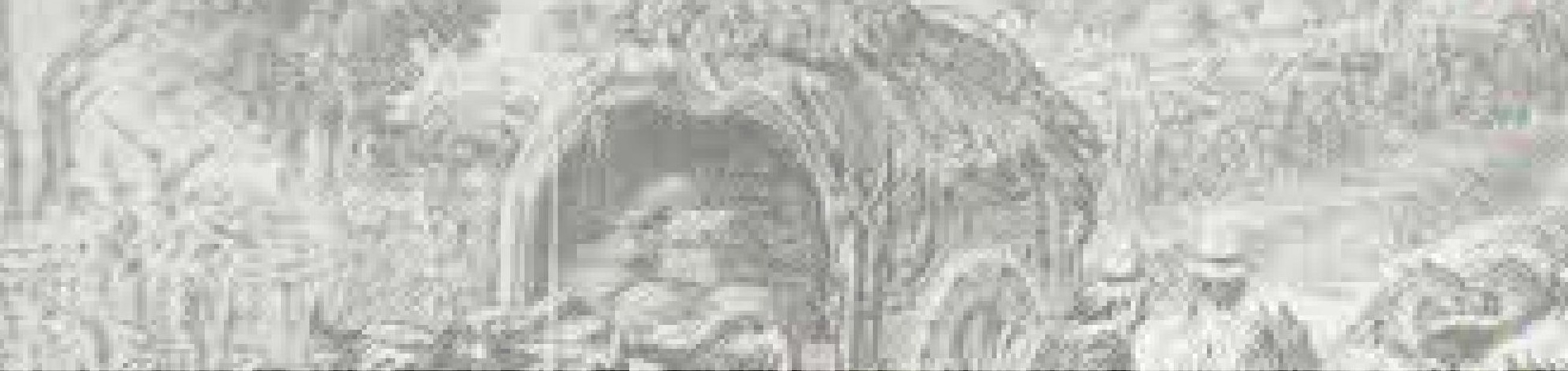

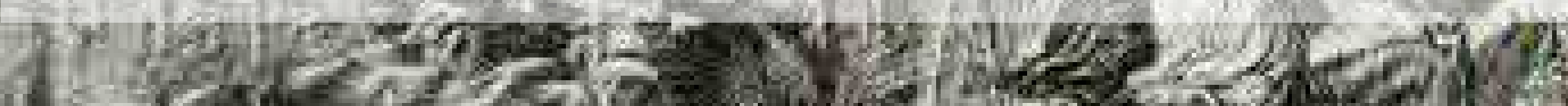

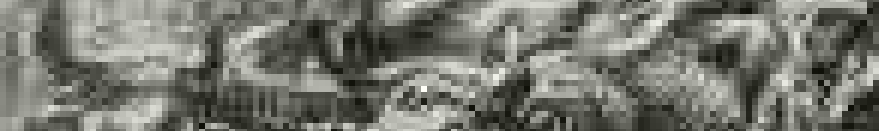

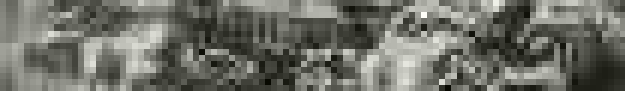

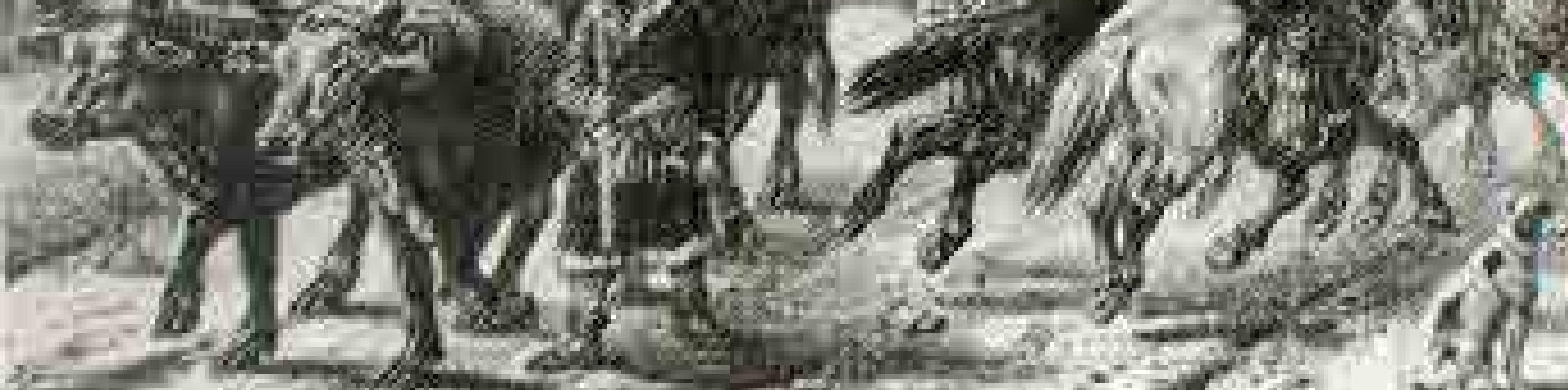



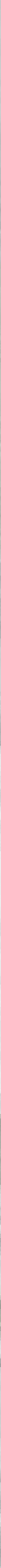


\section{EL TERRITORIO LAGUNA CAREN: DIMEN- SION SOCIO-CULTURAL}

Ligeros de equipaje, podemos partir un día de lluvia y caminar con nuestra soledad a cuestas hasta alcanzar las cumbres que están tan cerca. Porque nunca, en ningún lugar del mundo, las cumbres estuvieron tan cerca. Y nosotros, tan lejos de ellas. (Warnken, 2010, p. 10).

\subsection{INTRODUCCIÓN}

Visité Carén por primera vez la primavera de 2014. Ya habíamos estudiado el sitio a través de planos antiguos e innumerables otros documentos. Casi todos ellos lo describían como un objeto jurídico. También habíamos conocido los planes y proyectos pasados. Sin duda el terreno era extenso, difícil de representar en la mente, había hecho el ejercicio de compararlo con la superficie de algunas comunas de la ciudad ${ }^{220}$, también con estados pequeños como el Principado de Mónaco (202 ha), que cabe 5 veces en Carén, o el Distrito Centro de Madrid ${ }^{221}$ (523 ha) que tiene casi la mitad del tamaño de Carén. Como se observa en la Figura 1 , también el sitio es un poco más pequeño que la ciudad Universitaria de Madrid (1.425 ha); más extenso que el Campus Universitario de la UNAM (de 730 ha), y casi nueve veces más grande que el campus de la Universidad de Oregón (de 119 ha), el mismo que inspira a Christopher Alexander en Urbanismo y Participación (1978). Si se confronta con utopías, la Ville Radieuse de Le Corbusier222 triplica el área que estudiamos con sus tres millones de habitantes. Este ejercicio lo hemos repetido y aumentado varias veces a lo largo de esta investigación, especialmente cuando estudiamos grandes parques como el Central Park (341 ha.), el Birkenhead ( 91,5 ha), La Villette ( 55 ha), El Parque de la Courneuve (417 ha), o nuestra Quinta Normal (de 135 ha originalmente, reducidas a 35 ha en la actualidad).

Habíamos estudiado también la idea, que aún nos parecía algo lejana, de un parque tecnológico y del traslado de toda la universidad a ese predio, que aún era para nosotros como una gran página en blanco.

Con el anuncio de que el tiempo mejoraría, salimos finalmente a conocer "el terreno". En el centro de la ciudad aún se mantenían los chubascos que fueron aumentando en la medida que nos dirigíamos al poniente desde el centro de la ciudad, hasta que abruptamente la lluvia se detuvo al cruzar el puente sobre el río Mapocho y el umbral que separa al área urbana de la ruta 68 (el camino a Valparaíso), formado por el cordón de cerros que entra al sitio y se eleva en el cerro Amapola. En 20 minutos ya estábamos en el lugar, que desde hace más de 25 años se encuentra parcialmente cercado y cerrado, y sin embargo "urbanizado" en un primer tramo, con calzadas de alto estándar que no conducen a ninguna parte. Las abundantes lluvias de las últimas semanas hacian que el verde, en todos sus tonos, predominara por doquier, dejando entrever entre los matorrales la laguna. La primera decisión fue subir al cerro Amapolas para reconocer el lugar desde lo alto. Habíamos viajado de espaldas a la cordillera y subimos mirando al oriente.

En el ascenso, vimos emerger al oriente la cordillera, asomándose tras la pendiente, cortando el cielo ya despejado. La contemplamos en una visión casi irreal, blanca, imponente, inaccesible y, sin embargo, como nunca antes la vi: tan nítida y majestuosa. Comentamos esta experiencia, tan distinta a otras, como cuando en invierno las nubes sólo permiten presentirla, cuando el smog definitivamente la oculta o bien esas imágenes que en el crepúsculo la convierten en un muro rosado y fresco a través de la atmósfera granulosa del verano. hectáreas, equivalentes a 10,22 km2; Cerro Navia tiene $11 \mathrm{~km} 2$; Conchalí $10,7 \mathrm{~km} 2$ y La Cisterna $10 \mathrm{~km} 2$ (con una población de 80.910 habitantes).

221 Considerando los siguientes barrios: Palacio, Embajadores, Cortes de Justicia, Universidad y Sol.

222 Pensando en París, Le Corbusier dice: "3 millones [de habitantes] (ya es enorme, quizás demasiado), la ciudad no cubrirá más de 3000 hectáreas, es decir, un rectángulo de 5 × 6 km de lado." (Le Corbusier, 1933, p. 110). Según esto, en Carén podríamos acoger 1 millón de habitantes, lo que no parece razonable.

${ }^{223}$ Se trata de Proyectos de Desarrollo Ur- 

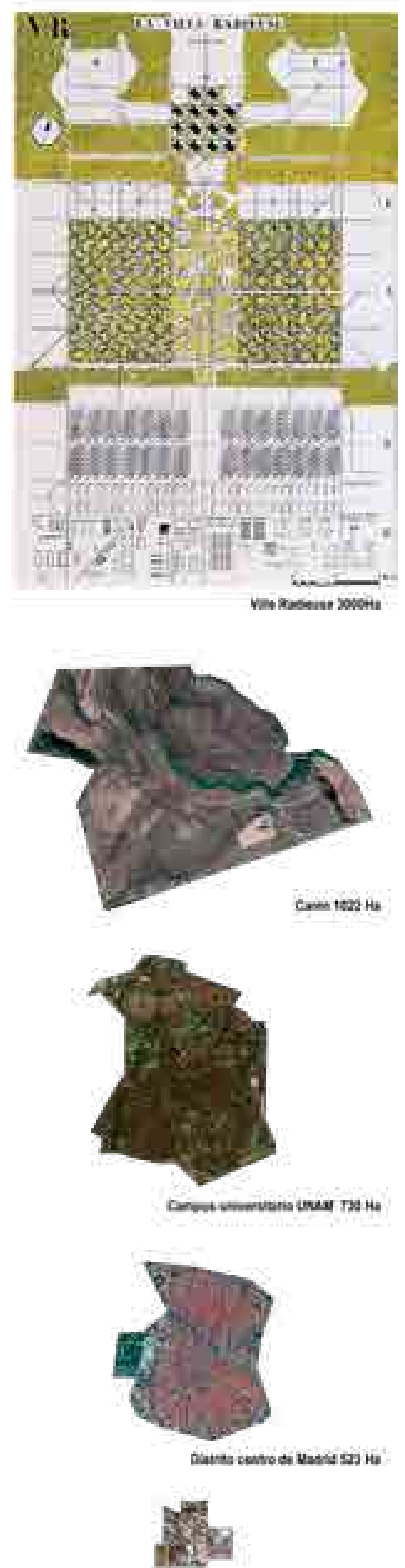

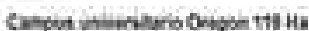

Hacia el poniente se elevaba más desnuda la cordillera de la costa, definiendo claramente los tres elementos que componen el Valle Central de Chile: la cordillera de Los Andes, la cordillera de la costa y la depresión llana intermedia que se extiende de norte a sur. Los límites del predio nos fueron señalados por don José, el antiguo administrador: al sur en un límite endentado, en parte con la carretera y en parte con predios que tendrán un destino logístico, que podemos imaginar análogo a lo que ya se ha desarrollado al otro lado de la ruta, vale decir, grandes volúmenes de bodegas. Al poniente el límite es difuso, pero tiene como referencia el cerro Puntilla de lo Vásquez que baja al valle en un denso bosque de espinos. A futuro se proyecta allí un gran proyecto inmobiliario bajo el nuevo modelo de las PDUC ${ }^{223}$. El deslinde norte es también difuso, definido por el cambio de textura entre los terrenos agrícolas vecinos de la localidad de Noviciado, que están limitados por una hilera de árboles que deja a nuestro lado un llano de vegetación más dispersa. Casi al borde del cerro, dejando una franja que hoy es ocupada por "picapedreros" y viviendas informales, el sitio limita al oriente con el Estero de Lampa que lleva sus aguas al río Mapocho. El río baja desde la cordillera, recorriendo la ciudad, -que como una gran mancha se extiende a lo lejos-, para, en esta zona, desviarse hacia el sur hasta perderse en el río Maipo distante a 40 kilómetros.

En el centro de esta gran planicie que tenemos a nuestros pies, se forma la laguna, que extiende sus tentáculos en diagonal hacia el nor-poniente, recogiendo las aguas de las decenas de quebradas de la cordillera de la costa, que emergen en múltiples afluentes que corren en sentido inverso al que tienen los ríos en nuestro país (de los Andes al océano Pacífico).

Pasamos horas reconociendo las diversas especies vegetales que allí encontramos: guayacanes, Algarrobos, soldaditos y salvia florecidos, los espinosos Quiscos.

Bajamos a la laguna bordeando una serie de precarias construcciones que albergan a los clubes deportivos, que desde antaño usan sus aguas para practicar diferentes deportes náuticos, para luego en su borde oriental abrirse en una extensión que hace olvidar dónde estamos. La Laguna nutre el estero de lampa y controla su caudal a través de una exclusa artificial, ubicada bajo un puente de madera, desde donde podemos escuchar el flujo incesante de agua, que se confunde con el sonido de los pájaros que habitan este paisaje. La ribera norte, está muy erosionado, ya que está habilitada como zona de picnic, la sur, por el contrario, es muy agreste. Al internarse en el terreno, encontramos principalmente espinos (acacia caven) en densidades que en sectores nos permiten hablar de bosques, en otros de llanuras salpicadas por vegetación, algunas de ellas protagonizadas por grandes arrayanes. Imaginamos que, en el verano, cuando la hierba se seca, este paisaje debe transformarse en algo muy parecido a la sabana africana.

Desde la laguna recorrimos hasta la cima la Puntilla Lo Vásquez, en el límite poniente, donde se ubica el depósito de agua potable diseñado y construido para abastecer el proyecto futuro. En ese recorrido nos encontramos con una formación rocosa que el deslinde de nuestro vecino inmobiliario esquiva, y que en esta serie de experiencias sensuales de contacto con la naturaleza nos conecta con el pasado lejano de este vasto territorio. Se trata de una piedra tacita, vestigio de los primeros habitantes de este valle. Recordando este episodio, es a partir de esta impresión, desde donde nacen nuestras primeras intuiciones de cómo habitar este lugar, tratando de entender cómo lo vieron aquellos que lo eligieron por primera vez. Para ello, exploraremos los sucesos históricos, los mitos, los distintos usos e imaginarios asociados a este vasto y aún silencioso territorio. 


\subsection{LA HISTORIA DEL PREDIO.}

Cuando se narra la historia de Santiago, incluso la iconografía asociada a ella, habitualmente se remonta al acto fundacional de Pedro de Valdivia en 1541. Con un poco de esfuerzo, también podemos recordar las teorías de poblamiento prehistórico de América, cuyas evidencias más antiguas de presencia humana en el territorio chileno se remontan a unos 14 mil años. Sin embargo, poco se conoce fuera de los medios especializados acerca de quienes poblaron el Valle Central de Chile. Estos primeros conquistadores según varios autores (Lautaro Núñez, 1983; Fernanda Falabella, 2016; Luis Cornejo y Lorena Sanhueza 2003) fueron nómades que transitaron hace 12 mil años entre la Cordillera de Los Andes y el Océano Pacífico, sobreviviendo gracias a la recolección de frutos silvestres, la caza de los mamíferos de gran tamaño del Pleistoceno -hoy extintos- y de la pesca en la costa. Las tierras pantanosas de esta zona deben haber sido lugares privilegiados para la caza del Stegomastodon (Alberti \& Prado, 2008). De hecho, en los bordes de la antigua laguna de Batuco a $31 \mathrm{~km}$ distancia, hacia el norte de Carén, se han encontrado restos fósiles ${ }^{224}$ de estos animales, que eran similares a los actuales elefantes.

Nuestras "piedras tacitas" son un poco más cercanas temporalmente. Los trabajos de Ampuero y Rivera (1971) -autores de una cronología de piedras tacitas para los valles de Elqui y Limarí- ${ }^{225}$, las ubican en el período Arcaico Tardío (2.000 a.C. a 0). Jackson y Thomas, a partir de hallazgos en la localidad de Lampa (a $20 \mathrm{~km}$ al norte de Carén), sugieren que, en esta zona, estas piedras podrían ser aún más antiguas (Arcaico Temprano). Éstas estarían vinculadas a la ocupación de zonas lacustres en los valles intermedios de la zona central, lo que permitía que los cazadores-recolectores se movilizaran entre la cordillera y la costa, marcando estos lugares de más abrigo cerca de fuentes de agua (Jackson y Thomas, 1994). Este fenómeno estaría asociado a un aumento de la recolección y consumo de vegetales en detrimento de las prácticas de cacería.

Desde el punto de vista físico, estos restos arqueológicos según explican las arqueólogas Teresa Planella, Gabriela Santander y Virginia McRostie (2010), "corresponden a afloramientos de la roca fundamental, o a bloques que se han desprendido de cerros colindantes o rodados arrastrados por cursos de agua, y en cuya superficie expuesta, a veces horizontal, otras inclinada, se han labrado u horadado intencionalmente un cierto número de concavidades" (Planella et al, 2010, p. 2).

En el caso del bloque encontrado en el límite de la propiedad, éste tiene 1,3 $\mathrm{m}$ por $1,8 \mathrm{~m}$ inclinado al SE en aproximadamente 7 grados, con 8 tacitas labradas sobre la roca de grano grueso del tipo porfírico, clasificado como andesita, que es una roca ígnea, de origen volcánico (Figura 6.3.). bano Condicionado, modelo que estudiaremos en el capítulo 9.

224 El fósil de Batuco se denomina SGO. PV.691. Se trata de un fragmento de defensa recta, de $28 \mathrm{~cm}$ de longitud. (Frassinetti y Alberdi, 2005, p. 103)

${ }^{225}$ Ubicado a $400 \mathrm{~km}$ al norte de Santiago en la Región de Coquimbo (IV).

${ }^{226}$ La interpretación de su funcionalidad y datación histórica ha sido especialmente difícil en la zona central debido a la antropización del territorio y a que, en él, no hay poblaciones originarias que puedan aportar datos etnográficos.

${ }^{227}$ En el estudio de Planella et al, 2017, el

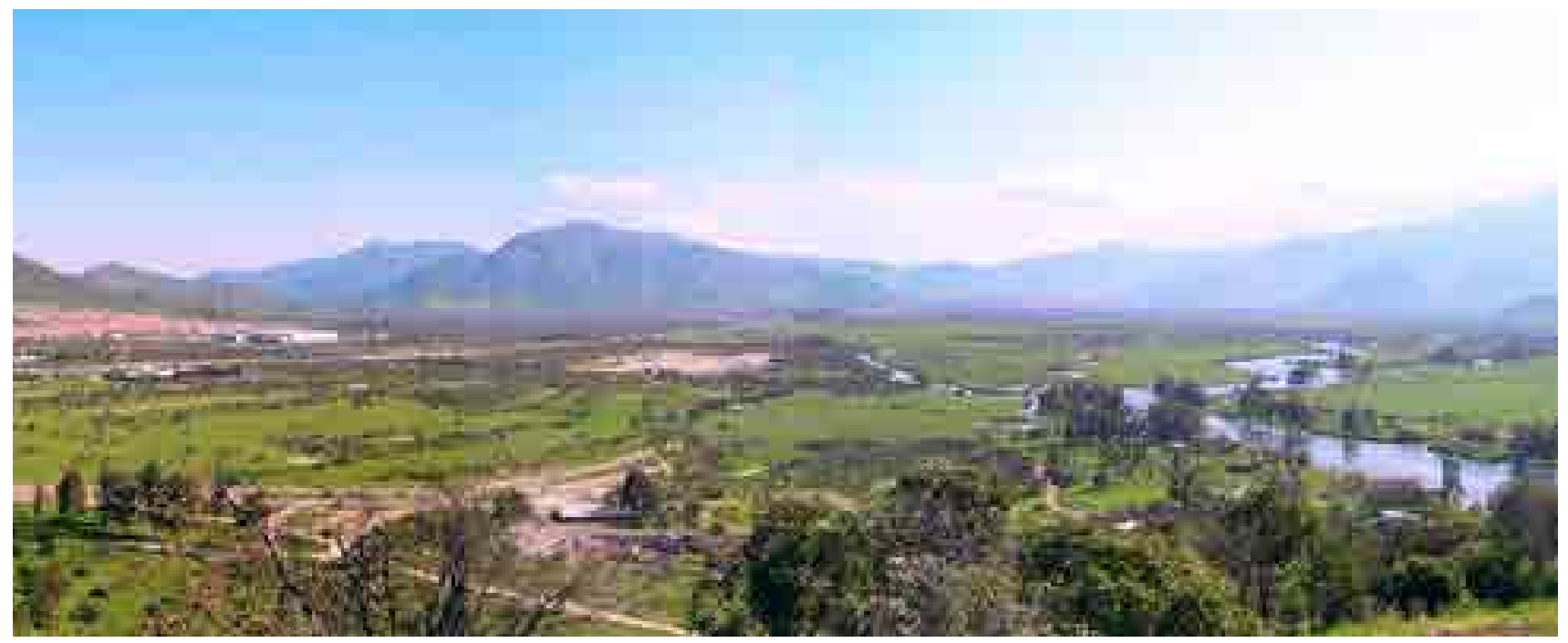

Figura 6.2. Panorámica de laguna Carén desde el cerro Amapola. 
La razón por la que fueron hechas constituye un misterio ${ }^{226}$, si bien se han estudiado desde el siglo XIX. Planella cita los primeros estudios de J. T. Medina 1882 como pionero.

Algunas teorías suponen que eran morteros para semillas silvestres (p.e. Jackson y Thomas, 1994), otras, les otorgan una connotación ceremonial (p.e. Massone, 1978; Hermosilla y Ramírez 1982) suponiendo que en torno a ellas se desarrollaban rituales y ceremonias. También se postula que constituían marcas que señalaban la calidad de los suelos y lugares de "paradero" (p.e. Gajardo-Tobar 1958-59), coincidiendo muchos de ellos en que la aparición de las piedras tacita coincide con la disponibilidad de fuentes de aguas. Si buscamos correspondencia de esta práctica lítica en la cultura mapuche, nos encontramos también con la existencia de piedras sagradas (ngütruntúe), las que según la investigadora María Ester Grebe se relaciona con el espíritu de la naturaleza (ngen-kurra), dueño de la piedra, sujeto de ofrendas y rogativas. Siguiendo esta interpretación etnográfica, Planella et al. (2017) plantean que el uso ritual de las piedras tacitas estaría relacionado con el agua ${ }^{227}$, dado el emplazamiento de estas piezas:

[...] con respecto a otros rasgos geográficos, la superposición de ocupaciones de distintos grupos y períodos culturales y las características excepcionales de algunos de estos bloques rocosos, que muestran una particular y elaborada complejidad.

La relación espacial con el agua está demostrada por la cercanía recurrente de estos sitios con cursos hídricos estacionales, frecuentes en la orografía de la zona (Planella et al, 2017, p. 11).

La piedra tacita emplazada en este terreno, caracterizado por sus posones, materializa no sólo una función productiva, sino también un conjunto de prácticas humanas en el espacio geográfico y en la historia. El arqueólogo Andrés Troncoso et al. (2017) plantea que estas piezas arqueológicas pueden ser pensadas como "un monumento relacional" (2017, p. 67) lo que, en el contexto de esta tesis, podríamos considerar el primer acto paisajístico en Laguna Carén.

Podemos imaginar que la piedra tacita vinculó la actividad humana con rasgos selectivos del paisaje, un elemento que puede ser leído en múltiples escalas: Desde la escala geográfica, marcando un lugar en la trama de los desplazamientos entre la cordillera y la costa, conectando la piedra con el "espíritu de la naturaleza" y, posiblemente con otras piedras tacitas esparcidas en el territorio; desde el sitio, anunciando la existencia del agua que, simbólicamente contendrían sus concavidades después de la lluvia, también desde allí se abre la vista sobre el valle desde lo alto, sobre el cerro Amapola al frente y más atrás el Plomo en el plano de la cordillera. A la micro escala, sería la mesa ceremonial, el lugar de reunión, de molienda y también de rogativas, donde estas prácticas congregarían a este grupo trashumante. Es la escala de la mano, de las semillas y de la textura de la piedra, del contacto personal. Las piedras tacita pueden así considerarse un fenómeno multiescalar tanto en el espacio como en el tiempo, en lo físico y en lo social. Un monumento (objeto) que construye y semantiza el paisaje, lo demarca

$88 \%$ de las piedras tacitas se encuentren relacionadas con cursos de agua y/o confluencias de esteros estacionales

${ }^{228}$ Es al inicio de la era cristiana se popularizan las piedras tacita y se inician las prácticas alfareras

Figura 6.3. Piedra tacita ubicada en el límite poniente del predio de Laguna Carén. Sus grandes proporciones y superficie superior casi plana, permiten imaginar su uso ceremonial. Además de las oquedades en el plano horizontal, muestra otras en el plano vertical.

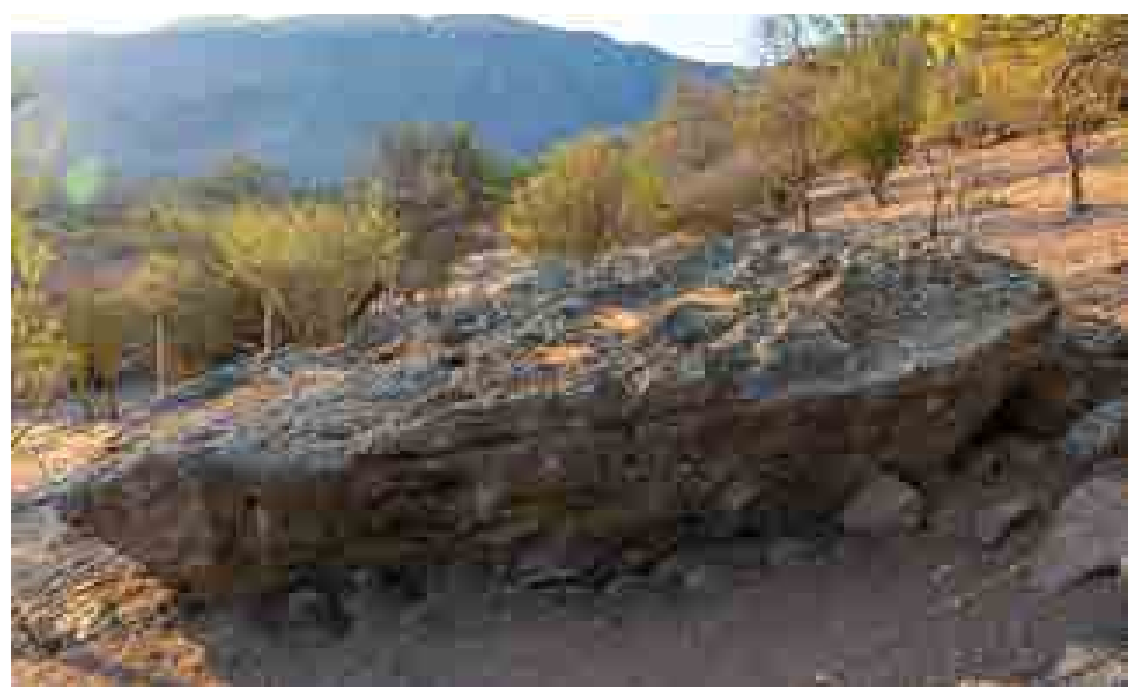


y anticipa la ocupación de este valle.

Si bien la reducción de movilidad ha dejado vestigios desde el Arcaico Tardío228, no es hasta el siglo IX d.C. que estos pueblos nómades se asientan en el territorio. Picunches fueron llamados, hombres del norte, por los mapuches que dominaban desde el río Itata al sur. Cultura Aconcagua ${ }^{229}$ por los arqueólogos que encontraron patrones comunes en los vestigios de estos pueblos que se emplazaron en los valles de los ríos Aconcagua, Mapocho y Maipo, como señalan los investigadores Rodrigo Sánchez y Mauricio Massone:

La población Aconcagua utilizaba el fértil Valle Central para cultivar, domesticar animales y volcar sus inquietudes artísticas en una cerámica decorada de manera singular. También crearon un espacio particular para la muerte, con grandes cementerios en forma de túmulos que hasta hoy señalizan, en un extenso tramado, sus espacios territoriales. Eran personas que valorizaban los recursos marinos de la pesca y recolección en la costa central, practicaban la caza del guanaco y otras especies, e incursionaban en los valles cordilleranos, durante diferentes periodos del año. El diseño del trinacrio, formado por tres aspas divergentes que salen de un círculo central pintado en negro sobre la superficie anaranjada de los tiestos alfareros, parece ser el símbolo de esta cultura, encerrando, en su simplicidad aparente, complejas concepciones que se proyectan a las esferas de la organización social y la cosmovisión (Massone y Sánchez, 1995, p. 10).

El dominio de ciertas técnicas de regadío les permitió irrigar tierras más alejadas de los cursos de agua y aprovechar mejor las numerosas vertientes. Esto produjo una ocupación mucho más amplia del valle, con pequeños caseríos de 10 a 12 chozas, habitados por familias extendidas. Las viviendas eran de materiales ligeros, con bases de piedra y muros de ramas con barro (quincha).

Estas poblaciones subsistían fundamentalmente sobre la base de la agricultura, cultivando productos tales como el zapallo, porotos, ají, quinua y maíz. Coexistiendo con cazadores recolectores que siguieron ocupando los sectores más altos de la cordillera, hasta la colonia.

Es probable que entre los pueblos nómades y los recolectores se produjera intercambio de especies, proveyendo estos últimos, las rocas silíceas de la cordillera. Estas mismas piedras fueron las que los Aconcagua usaron para fabricar sus puntas de flecha, como las encontradas el año 2016 al borde de la laguna Carén, que presentan la característica forma triangular con aletas.

De acuerdo a investigaciones documentales ${ }^{230}$ y hallazgos arqueológicos recientes en la cuenca del Mapocho realizados por el historiador Gonzalo Sotomayor y el arqueólogo Rubén Stehberg, y publicados en 2012, en el siglo XV, este territorio es anexado al Tawantinsuyu ${ }^{231}$, nombre dado por los incas a su imperio, pasando a formar parte del Kollasuyu, una de las 4 provincias de este vasto poderío. Estos autores han demostrado que el centro real era la ciudad inca de Mapocho ${ }^{232}$.

Este proceso, según el investigador Luis Cornejo (2010) fue rápido y relativamente pacífico, resultando un sincretismo de las culturas y cosmovisiones inca, diaguita y aconcagua. La influencia inca en el campo simbólico y religioso incorporó la construcción de wakas o lugares de culto ubicados en los cerros. Ritualmente emplazaron un santuario andino. Lo establecieron en el cerro el Plomo, que domina el valle del Mapocho y es donde se originan las aguas del río. El altar exterior se hizo orientado al Sol naciente, en el solsticio de verano, hacia el 21 de diciembre. En el cerro Chena (al sur de Carén), levantaron un fuerte, con vista al valle y cuyos vanos están alineados con el santuario del cerro el Plomo. También construyeron no un camino, sino dos, que unían este territorio con el Cuzco. Las evidencias arqueológicas parecen demostrar que los conquistadores incas no estaban tan interesados en la propiedad ni el sometimiento total, sino más bien, buscaban ampliar sus territorios, recibir el reconocimiento formal del imperio y recibir el tributo por ello, lo que explica por qué las creencias locales y el lenguaje (mapudungun) se mantuvieron ${ }^{233}$.
${ }^{29}$ Si bien las primeras referencias a los túmulos funerarios de esta cultura se publicaron en 1882 por José Toribio Medina, no es hasta el VII Congreso de Arqueología Chilena en 1977, que Eliana Duran y Mauricio Massone se dan cuenta de que están frente a una unidad cultural regional y no sólo a una manifestación cerámica 0 fúnebre y proponen englobar el total de manifestaciones bajo el nombre de Complejo Cultural Aconcagua.

${ }^{230}$ Especialmente los documentos de Gerónimo de Bibar (1558/1966) cronista del Capitán Pedro de Valdivia, que informan del conocimiento que habría tenido éste, al momento de organizar su expedición a Chile, de la existencia de un centro urbano principal a orillas del río Mapocho

${ }^{231}$ El Tawantisuyu (el imperio de las cuatro regiones) era un estado teocrático y militar que necesitaba de la colonización de nuevas tierras, por eso se extendió desde el Ecuador hasta el centro sur de Chile. Los ejércitos incásicos fueron resistidos por el pueblo mapuche por lo que el imperio nunca pudo sobrepasar el Río Cachapoal. La dominación de los Incas no fue en todo caso violenta, los Curacas y Yaconas del imperio convivieron con los naturales de Chile.

${ }^{232}$ Cabe destacar, que este centro urbano fue la urbe más austral del Tawantinsuyu y la última en desaparecer, ya que, como señalan Stehberg y Sotomayor, "siguió funcionando como tal, hasta 1540, en momentos que la mayoría de los otros centros administrativos incaicos habían colapsado" (2012, p. 144) tras la conquista española. 233 Bustamante y Rojas (2015) consideran que el Tawantinsuyu habría sido, más bien, "una organización multicultural, multiétnica, comercial, técnica, religiosa, a la cual, en la mayoría de los casos, los diversos pueblos ingresaban por razones de conveniencia. Lo cual no implica que estuviera libre de conflictos" (p. 17). 
La filosofía andina por su parte, había aportado a esta cultura, un aspecto que Efrén Ariza destaca: la importancia de las facultades no-visuales en su acercamiento a la realidad. El tacto es un sentido privilegiado, pero también el olfato y el oído (Ariza, 2013, p. 104). Cabe recordar las diversas estrategias mnemotécnicas de la tradición oral, las lenguas arcaicas son sumamente onomatopéyicos y los relatos usan la imagen recurrente de escuchar la tierra, el paisaje y el cielo.

Es así como muchos de los nombres de lugares y cerros del valle de Santiago, conservan hasta hoy los nombres en mapudungun (Manquehue, Pudahuel, Mapocho ${ }^{234}$, etc.). Sin ir más lejos, la palabra Carén, del mapudungún Karün significa "ser verde" (Augusta, 1906, p. 76), que es más que una descripción, evocando una condición ontológica del lugar.

Como hemos visto en el capítulo 4 sobre la Transformación del Paisaje, los mapuches como los demás pueblos originarios de Latinoamérica tuvieron una concepción animista de los elementos de la naturaleza, con los que mantuvieron una relación de reciprocidad. En esta cosmovisión se conciben al hombre y a la mujer como parte constitutiva de la naturaleza. Así mismo, los espacios ecológicos que identifican son nombrados no sólo destacando sus características físicas, sino, además, las significaciones culturales, sociales, o ceremoniales relacionadas con ellos. Podríamos decir en el lenguaje de hoy, que constituyen una unidad ecológica y cultural para los habitantes de ese territorio, un espacio que debe resguardarse y cuidarse, un wallme o wallantu mapu, aquello que puede verse desde lo alto de un cerro, y que contiene todo lo que en él habita en un círculo imaginario trazado por la vista al girar siguiendo el transcurso del sol (Marileo,1995). Karün (ser verde) se nombró seguramente este paisaje desde el cerro Amapolas, observando los posones de agua y los esteros que nutrían la hierba y los arboles hace más de 500 años. Interpretarían también los cursos de agua como una réplica natural del mundo sobrenatural.

La Vía Lactea, wika ka leufü (leufü = río angosto o estero), "era visto por los sabios como un gran río aplastado por un guerrero ancestral quien venció a las fuerzas negativas que habían logrado trascender al principio del todo, el origen del universo" (Pinaud, 2009). Es por eso que son tan importantes los cursos de agua, no sólo para la subsistencia, sino también por el sentido simbólico que portan.

Entre los mitos, encontramos también uno análogo al Diluvio Universal, que narra, según Armando Marileo, el origen de la cultura mapuche:

234 'Desde un pequeño lago a $32^{\circ} 40^{\prime}$ de latitud sur, inician su curso las aguas del río Mapocho (del mapudungun mapu-chun-ko, ('agua que se pierde en la tierra'). Desde allí sigue una dirección nor-este a sur-oeste y, a los cincuenta kilómetros de su curso, luego de ser incrementado con diversos caudales, atraviesa la ciudad de Santiago. Luego acentúa su rumbo sur-oeste y se filtra en la tierra, desapareciendo totalmente. '¿Chuchun-ko?' , decían allí los indios (mapudungn chuchun-ko, '¿qué se hizo el agua?') y un lugar de los contornos recibe ese nombre de Chuchunco hasta nosotros. El agua ha sido absorbida por la tierra y continuará como corriente subterránea para reaparecer más al poniente" (León Echaíz, 2017, p. 58) en tierras de otros indios que las verán emerger cerca de sus campos de cultivo en forma de pozones o dawiles (en mapudungun pu dawil, significa 'muchos pozones'), voz que originaría el nombre Pudahuel.

Se dice que hubo una gran inundación provocada por una fuerza negativa, es decir, se produjo una disputa entre el MAL representado por Kay Kay, quien deseaba matar a todos los seres vivientes y Treng-Treng que era una culebra del BIEN que trataba de salvar a la gente. Kay-Kay hizo subir el agua y TrengTreng, hizo subir el cerro para que la gente se salvara... Así estuvieron muchas lunas peleando, hasta que un día Kay-Kay se dio por vencido...Al bajar el agua quedaron solamente cuatro sobrevivientes, dos ancianos, una mujer y un hombre, (kuse y fücha) y dos jóvenes, una mujer y un hombre (üllcha y weche) [...] Sólo los dos jóvenes fueron autorizados para ser el principio de la gente y los ancianos para alimentar en conocimiento y sabiduría a los jóvenes...Así surgió la cultura mapuche. (Marileo, 1995, p. 93).

En las mañanas de invierno, en la zona poniente de Santiago se produce una neblina baja que hace ver el valle como un gran lago del que parecen emerger los cerros como islas (Figura 6.4). Esta imagen vuelve a nuestra mente cuando estudiamos los estratos geológicos del sitio de Laguna Carén, y encontramos no sólo los sedimentos de una gran erupción volcánica que cubrió el valle, sino también su pasado lacustre. Algún día Carén estuvo cubierto de agua.

Sobre este estrato cultural se incorpora el Tawantinsuyu, que además del camino del inca, introdujo los animales domésticos (llamas) en Chile central y, aportó un 
avanzado sistema de regadío mediante acequias que se alimentaban por las aguas del río Mapocho. Una de las tres acequias importantes, según el investigador Armando de Ramón, "se encontraba en el sector de Pudahuel y era conocida como la acequia de Incagorongo, Principal de Apo chame" (Ramón, 2007, p. 10).

En 1535, poco más de cien años después de que el Tawantinsuyu incorporara al valle del Mapocho a sus dominios, el Cusco, el centro de su Imperio, fue sometido por los conquistadores españoles. Desde esa ciudad, En 1936, Diego de Almagro avanza hacia el valle Central de Chile en una frustrado intento de dominación. Por esto, no es hasta 1540 que Pedro de Valdivia toma posesión de la cuenca de Santiago, y aunque habían pasado seis años desde la caída del Tawantinsuyu, aún sobrevivía la estructura política y económica impuesta por los Inca ${ }^{235}$.

La expedición de Valdivia siguió el camino del Inca (Qhapaq Ñan), cruzó el desierto hasta llegar a los valles poblados por los diaguitas, se detuvo en el valle de Aconcagua y a pesar de la fertilidad agrícola y la actividad minera que encontró allí, siguió adelante, más allá de los cerros de Batuco desde donde se abría el valle formado por los ríos Mapocho y Maipo. Según el cronista Bibar, Valdivia descubrió un enorme y verde territorio cultivado, limitado al oriente por la Cordillera de los Andes, aún cubierta de nieve en el mes de diciembre de 1540, al poniente enmarcado por las cumbres de Pudahuel que se continuaban ininterumpidamente hacia el sur. El arquitecto e historiador Hernán Rodríguez imagina así este encuentro:

La comarca estaba en plenitud, todavía en primavera, el suelo cubierto de pasto tierno y floridos árboles y arbustos, con agua abundante cantando en cauces y acequias que regaban generosas chacras de maíz y quínoa. Por sobre el tupido follaje de quillayes y peumos, debieron verse numerosas columnas de humo, delatando hogares de los indígenas locales y yanaconas, hasta ese momento súbditos del Tawantinsuyu. Valdivia consideró que éste era el lugar para fundar. ( Aldunate \& Rodríguez, 2010, p. 36).

Según las crónicas de la época, Valdivia originalmente pensó hacer un fuerte y fundar la ciudad en la ribera norte del Mapocho, en el sector que luego se llamó la Chimba ("de la otra orilla" en lengua quechua). Según el cronista Diego de Rosales (1877) ${ }^{236}$, habría sido el cacique Loncomilla, quien le sugirió que fundara la ciudad al otro lado del río, más al sur, donde los incas se habían asentado ${ }^{237}$ :

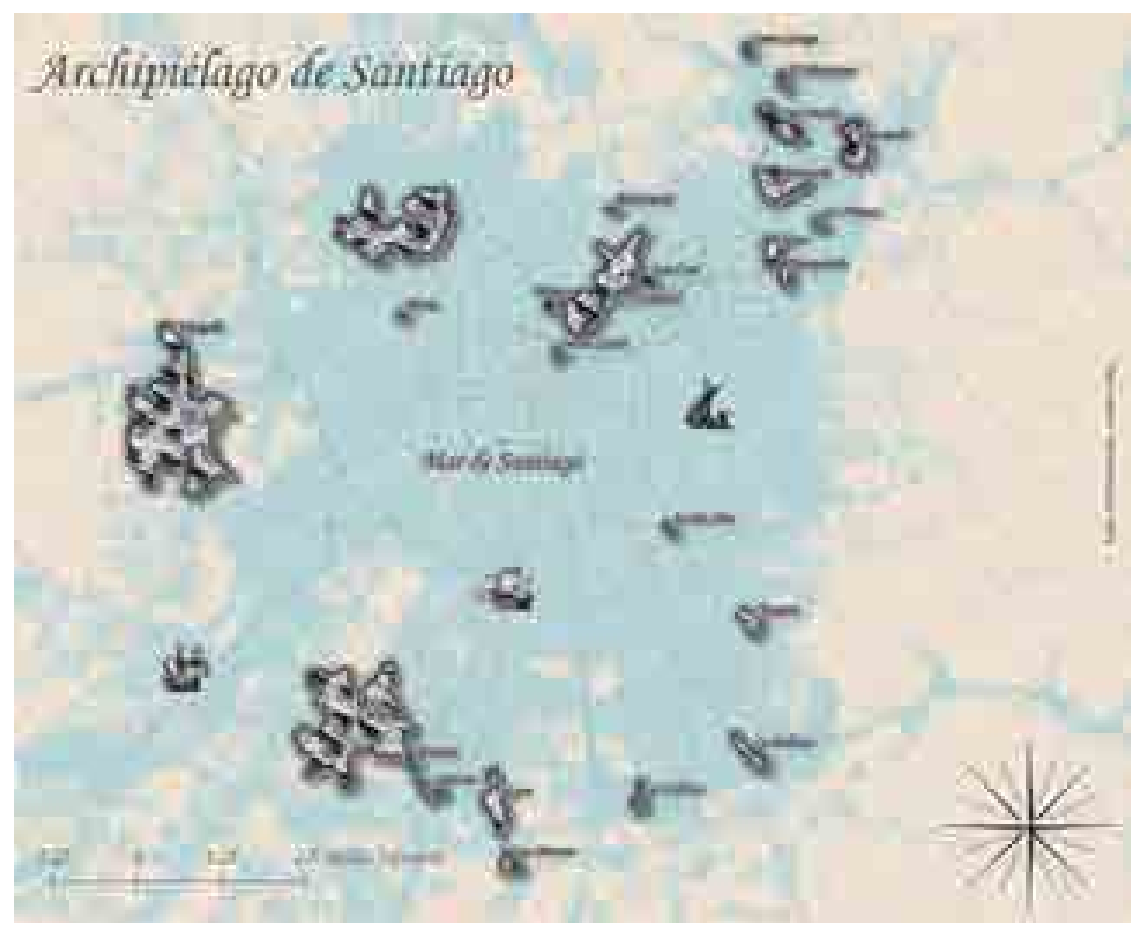

${ }^{235}$ Toda la estructura política que existía en el valle del Mapocho se puso a las órdenes de los españoles.

${ }^{236}$ El sacerdote jesuita Diego de Rosales aporta otra de las más interesantes crónicas coloniales chilenas: Historia general del Reino de Chile, Flandes Indiano, que, si bien es escrito hacia el 1650 , fue rescatado y publicado recién en 1877 por don Benjamín Vicuña Mackenna, luego de encontrar un ejemplar en Londres, en manos privadas.

237 Para Hernán Rodríguez, el español intentó reemplazar el poder de los incas por su propio poder; logro inicialmente un cierto apoyo, en lo que quedaba de dominación quechua: así Quilicanta ayudó a Pedro de Valdivia en la definición del emplazamiento y la construcción de la ciudad de Santiago, pero cuando le fue posible, él mismo se levantó contra los españoles y apoyó la rebelión de Michimalonco.

Figura 6.4. Ilustración Archipiélago de Santiago. Por Cris Hernández, 2016. 
[...] le salió el cacique Loncomilla, que quiere decir Cabeza de Oro, señor del Valle de Maipo, a dar la paz, y le dijo que no poblase en la Chimba, que otro mejor sitio había de la otra randa del río, a la parte del sur, donde los ingas habían hecho una población, que es el lugar donde hoy está la ciudad de Santiago. (Rosales, 1877, p. 383).

Posiblemente esta indicación se sumó a una condición geográfica que permitía replicar el trazado y disposición de la ciudad de los Reyes, Lima, fundada en 1535.

Según indican los documentos del Cabildo, el 12 de febrero de 1541 -o el 24 como señala Valdivia en sus cartas- se procedió $a$ a fundar la ciudad y nombrarla Santiago de la Nueva Extremadura, en honor del santo apóstol patrono de España. El cerro Huelén, próximo al lugar donde se hizo la fundación, se bautizó $\square$ con el nombre de Santa Lucía, por ser el día de la mártir. Se llamó San Cristóbal al alto cerro que dominaba la ciudad desde la otra ribera del río, el mismo santo protector que se dio al cerro en Perú. (Aldunate \& Rodríguez, 2010:38) Nada quedaba al azar en la fundación de una ciudad americana bajo las normas que dispuso el emperador Carlos V en 1523. Una nueva forma urbana ${ }^{238}$ se superpuso al trazado existente, partiendo desde el tambo inca ${ }^{239}$ que se convertiría en la plaza mayor, se trazó la cuadrícula con manzanas de 138 varas y calles de 12 varas quedando a una distancia del Río Mapocho análoga a la que encontramos en Lima con el Río Rímac.

En septiembre de 1541, pocos meses después de fundada la ciudad, mientras Valdivia se encontraba con parte de sus hombres en el sur, el cacique Michimalonco cayó sobre Santiago. Destruyó e incendió todo lo que se había construi$\mathrm{do}^{240}$.

La conquista fue difícil, la Guerra de Arauco, que duró casi de 300 años, se concentró a partir del siglo XVII en los territorios que hoy conocemos como La Frontera. A este desafío permanente, se sumaron otros, los terremotos y los desbordes del Río Mapocho, que, aunque habitualmente tranquilo, arrasaba con la ciudad en la época de los deshielos (primavera) o con las grandes lluvias de invierno.

Junto con la fundación de Santiago se encuentran los primeros documentos que acreditan la entrega de concesiones de tierra que hizo Valdivia a sus hombres en calidad de "Encomienda". Uno de ellos, Bartolomé Blumenthal, castellanizado como Bartolomé Flores, recibe los terrenos del poniente de Santiago hasta Talagante, dominio del cacique inca Tala Canta llabe (León Echaiz, 2017, p. 96). Flores se enamora de la hija del cacique, y de esta unión nace una hija, Águeda. El libro del historiador Benjamín Vicuña Mackenna Los Lisperguer y La Quintrala (personaje mítico de la colonia, famosa por su belleza y maldad) proporciona la genealogía de la mujer, que resulta ser descendiente de Bartolomé Flores. Flores habría heredo su patrimonio a Águeda, y ésta a su hijo Juan Rodulfo Lisperguer, tío de la Quintrala. Entre los bienes estaba la hacienda de Pudagüel (Rosales,1877, p. 32). El mismo hecho es refrendado en el libro Pudahuel: En el camino de la memoria de Héctor Zúñiga (2007), donde se señala que "Doña Águeda heredó vastos territorios. En Pudahuel fue dueña de las haciendas de Lo Aguirre y El Noviciado, propiedades que en 1595 deja a su hijo primogénito, Juan Rodulfo Lisperguer Flores" (Zuñiga, 2007, p. 17). Siendo el predio de Laguna Carén emplazado en el valle Lo Aguirre, de la comuna de Pudahuel, estos serían los primeros documentos que acreditan su propiedad. Cabe señalar que la denominación Lo Aguirre está vinculada a un propietario muy posterior, don Juan Nicolás de Aguirre quién la adquiere en 1741 y la vincula a su Mayorazgo ${ }^{241}$ en 1744.

Según el historiador Diego Amunátegui, este mayorazgo se extendía desde la laguna de Pudahuel hasta la cima de la cuesta Lo Prado. Tras la muerte de Juan Nicolás de Aguirre, el mayorazgo fue heredado consecutivamente por José Santos de Aguirre (1729-1816), Joaquín Fermín Aguirre, Josefa de Aguirre (Amunátegui, 1903, pp. 51-52), José Joaquín Larraín Aguirre, José Ignacio Larraín y Landa, para extinguirse en 1883 en posesión de José Ignacio Larraín Zañartu (Zúñiga, 2007, p. 53). 
El mismo texto de Zúñiga, da pistas acerca del uso que tenía el valle de Pudahuel: registra al menos dos solicitudes de merced hechas al cabildo en 1566 y 1568 con el objeto de dar asiento al ganado, para reforzar esta idea, cita la descripción que hace de este paraje el capitán Ginés de Lillo en 1604:

Vi en un cerrillo de las dichas estancias mucha cantidad de ganado cabruno y algunos ranchos [...] Una estancia de vacas y ciertos ganados de cabras y ovejas [...]donde al presente así mismo parecen tener población, con sus casas, ciertos yanaconas, una casa de tapias y adobes... (Ginés de Lillo, 1604, p. 209 citado por Zúñiga, 2007, p. 18).

Este relato junto a un grabado de Claudio Gay de 1854 (Figura 6.5) que muestra el camino a Valparaíso rodeado por extensas zonas con ganado, explicaría la vegetación que existe hoy en el terreno que estudiamos, consistente principalmente en espinos (acacia caven), una especie resistente al pastoreo intensivo, como también, la exigua presencia de otras especies propias de este clima, que no soportaron esta explotación de la tierra.

La historia colonial de Carén, se liga por vecindad con un actor clave de este periodo: la Compañía de Jesús. Los padres jesuitas llegaron a Chile en 1593 y dos años después, en 1595 reciben, según registra el historiador René León Echaiz, la donación de las haciendas La Punta y Pudahuel de don Andrés de Torquemada, colindantes la una de la otra (León Echaiz, 2017, p. 219). Asimismo, Paz Bascuñán en su libro $A 400$ años de la llegada de los Jesuitas a Chile, señala que en 1602 los misioneros "adquirieron en Carén, mil doscientas cuadras para ampliar la Estancia de La Punta" (Bascuñán, 1993, p. 25). Posteriormente, entre 1616 y 1619, se expandió hacia Lampa (al norte) y, en 1735 hacia El Noviciado (León Echaiz, 2017) ${ }^{242}$, llamado así por servir de abastecimiento al noviciado de San Borja, ubicado en la ciudad. La hacienda El Noviciado, que ha mantenido su nombre como localidad, corresponde a la zona agrícola que cierra el predio de laguna Carén hacia el norte.

La hacienda la Punta, perteneció luego de la expulsión de los jesuitas a Lorenzo Gutiérrez (León Echaiz, 2017)243, y más tarde a la familia del presidente José Manuel Balmaceda (1840-1891). Hoy en día, este predio corresponde al emplazamiento del actual Aeropuerto Internacional Arturo Merino Benítez y de sus alrededores. De este modo, las propiedades de esta zona en manos de los jesuitas llegaron a sumar más de 22.000 hectáreas, las que se mantendrían hasta la expulsión de la Compañía del país, en 1767 (Zúñiga 2007, p. 25). En la Figura 6.6. se presenta un plano de Santiago de 1746, en el que se grafican las propie-

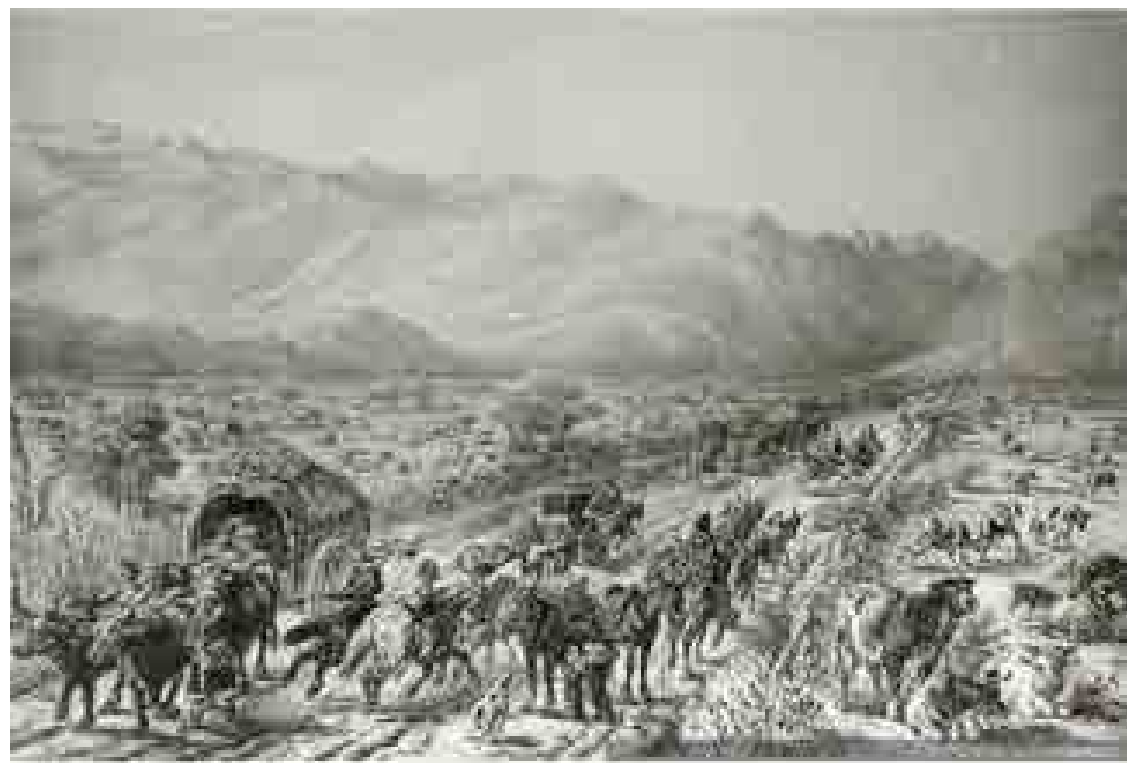

242 "La hacienda El Noviciado [fue] donada en 1735 por don José Lazo" (León Echaiz, 2017, p. 220).

${ }^{243}$ León Echaiz registra las propiedades de los jesuitas que fueron trasferidas a particulares por subasta pública, entre las que se encuentra la "Hacienda de Pudahuel (1771): Lorenzo Gutiérrez, en 14.622 pesos." (2017, p. 228).

Figura 6.5. Camino de Valparaíso a Santiago. Grabado. En Claudio Gay (1854, lámina 20). 
dades de la Compañía de Jesús.

En este período, los misioneros produjeron una intensa actividad productiva, trayendo prosperidad económica y cultural a la zona. Cada hacienda operaba como un centro productivo independiente económicamente, organizado en red tanto para proveer de productos a las distintas obras de la orden, como para abastecer a la ciudad e incluso, exportar. En este mismo sector, también incursionaron en la minería, en la extracción y fundición de cobre de la mina de Lo Aguirre, próxima al terreno de estudio.

Según relata Vicuña Mackenna, "los jesuitas poseían una verdadera cintura de ricas posesiones rurales, casi tantas como regaba a la sazón el agua empobrecida del Mapocho, lo que les constituía en los abastecedores diarios y más grandes del mercado local. Era el anillo de esa colosal cintura Chacabuco, Quilicura, La Punta, Pudahuel [énfasis añadido], La Calera, El Peral y Ñuñoa" (Vicuña Mackenna, 1926, p. 172.). Por su parte, Gustavo Valdés (1985) estima que "un tercio de los suelos agrícolas aprovechables en el Chile colonial estaba en manos de la Compañía de Jesús al momento de la expulsión" (p. 81). Podemos decir entonces que, junto con la misión evangelizadora, se puede considerar que los jesuitas fueron los primeros empresarios de la colonia ${ }^{244}$ y que su expulsión tuvo consecuencias negativas tanto económicas como sociales y culturales, especialmente para las haciendas de la zona poniente que no lograron sustentarse sin el rigor de los administradores ignacianos.

\subsection{EL CAMINO A VALPARAISO: NUESTRO LÍMITE SUR.}

El declive económico de esta zona, producido por la expulsión de los jesuitas, tuvo un vuelco con la construcción del nuevo camino de Santiago a Valparaíso, en un trayecto similar al que hoy sigue la Ruta 68, límite sur del predio de Laguna Carén.

La salida de Santiago al Pacífico siempre tuvo un carácter estratégico. Valparaíso fue el puerto de Santiago, su punto de conexión marítima con el mundo. La ruta más antigua conocida utilizaba el trazado incaico del "Camino de Chile", que avanzaba hacia el norte pasando por los actuales Tiltil, Caleu y la Cuesta la Dormida (Figura 6.7. en azul). Como este camino sólo era transitable por mulas y

\footnotetext{
${ }^{244}$ Varios autores se refieren a la buena administración de los jesuitas, entre los que se encuentra Diego Barros Arana (1932) en Riqueza de los antiguos jesuitas en Chile; Guillermo Bravo Acevedo (1989) en La empresa agrícola jesuita en Chile colonial: administración económica de haciendas y estancias y más recientemente, José Bengoa (2015) en Historia rural de Chile central.
}

Figura 6. 6. Plano de Nicolás Abos Padilla que proyecta el curso del canal del Maipo en febrero de 1746, donde se grafican las propiedades de la Compañía de Jesús en Santiago. En Víctor Zúñiga (2007, p.23).

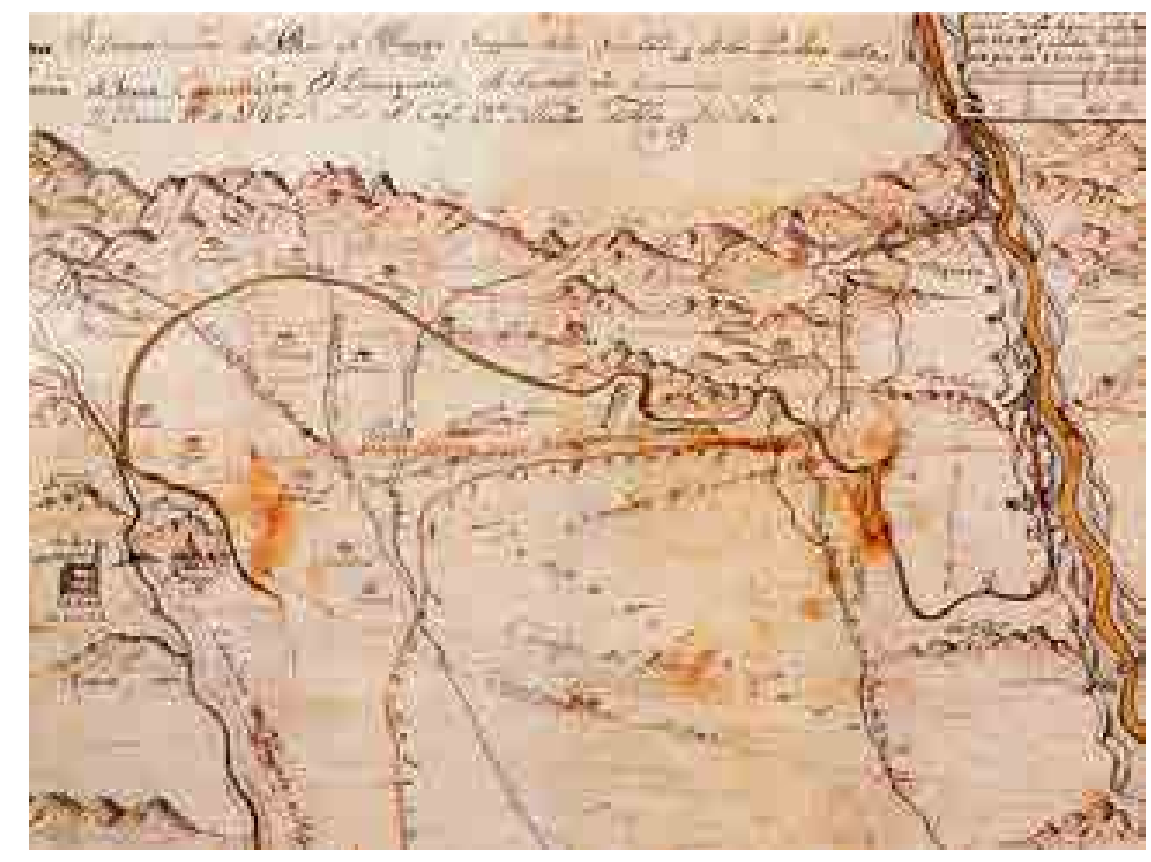


caballos, en el siglo XVII se habilitó el "Camino de Las Carretas" (Figura 6.7. en rojo) que partía en Santiago a la altura de Chuchunco (actual Estación Central), pasando por Melipilla, la Cuesta Ibacache, Casablanca y llegando a Valparaíso después de un recorrido de $185 \mathrm{Km}$.

Las carretas tiradas por bueyes demoraban entre 7 y 8 días en realizar el viaje, mientras que los coches arrastrados por caballos hacían el viaje en dos o tres días. Estas dificultades motivaron al Gobernador Ambrosio O'Higgins a emprender la construcción de un nuevo camino (Figura 6.7. en amarillo):

Utilizó para ello un viejo sendero de mulas y caballos que era llamado "sendero de cuestas" $y$, aprovechando la mayor parte de su recorrido, logró construir un camino que partía de la calle San Pablo, y que pasaba luego por Pudahuel, Lo Aguirre, la Cuesta de lo Prado, Curacaví y la Cuesta de Zapata. (León Echaíz, 2017, p. 301)

Los trabajos iniciados en 1791 permitirian, seis años después, que los carruajes transitaran entre el puerto y la capital en sólo dos días ${ }^{245}$. La obra estuvo a cargo sucesivamente de los ingenieros Pedro Rico, Joaquín Toesca y Agustín Cavallero (León Echaíz, 2017, p. 301). Antes de la inauguración de esta ruta, en los caminos antiguos, el acceso al valle de Santiago se hacía "de lado", entrando de costado al valle, sin la espectacular vista frontal de la cordillera y que comenzó a destacarse gracias al nuevo trazado del "camino de O'Higgins". Tal como lo ilustran los cronistas viajeros, la primera imagen del valle de Santiago será con la cordillera de Los Andes como telón de fondo; esto determinará la emergencia de un nuevo paisaje. El camino, acción racional, de ordenamiento y con fines de eficiencia, se convertirá también en relato, que selecciona y enmarca la naturaleza convirtiéndola en un paisaje que podrá ser contado. Este relato, este nuevo paisaje, será también memoria, expectativas y proyección de una experiencia visual, estética, pero también sensorial, representacional y cultural.

Casi sin excepción, los cronistas reconocen el mérito del gobernador O'Higgins, al origen de este ambicioso proyecto de infraestructura y que resultó fundamental para la época. La mirada de George Vancouver es inaugural. Lo recorre en 1795, cuando aún está en construcción:

Habiéndose puesto en mal estado i peligroso el antiguo camino entre Valparaiso i Santiago, el gobernador general actual ordenó que se abriera uno nuevo mas preferible, de cerca de dieziseis varas de ancho, el cual, para mutua comodidad de los habitantes de las dos ciudades había sido comenzado en los dos estremos i suministraba ya una comunicación mas cómoda i agradable con las tierras de los alrededores. Supimos por nuestros guias que el nuevo camino no estaba aun terminado, pero que avanzaba mucho i encontraríamos en él trabajadores. (Vancouver, 1902, pp. 33-34).

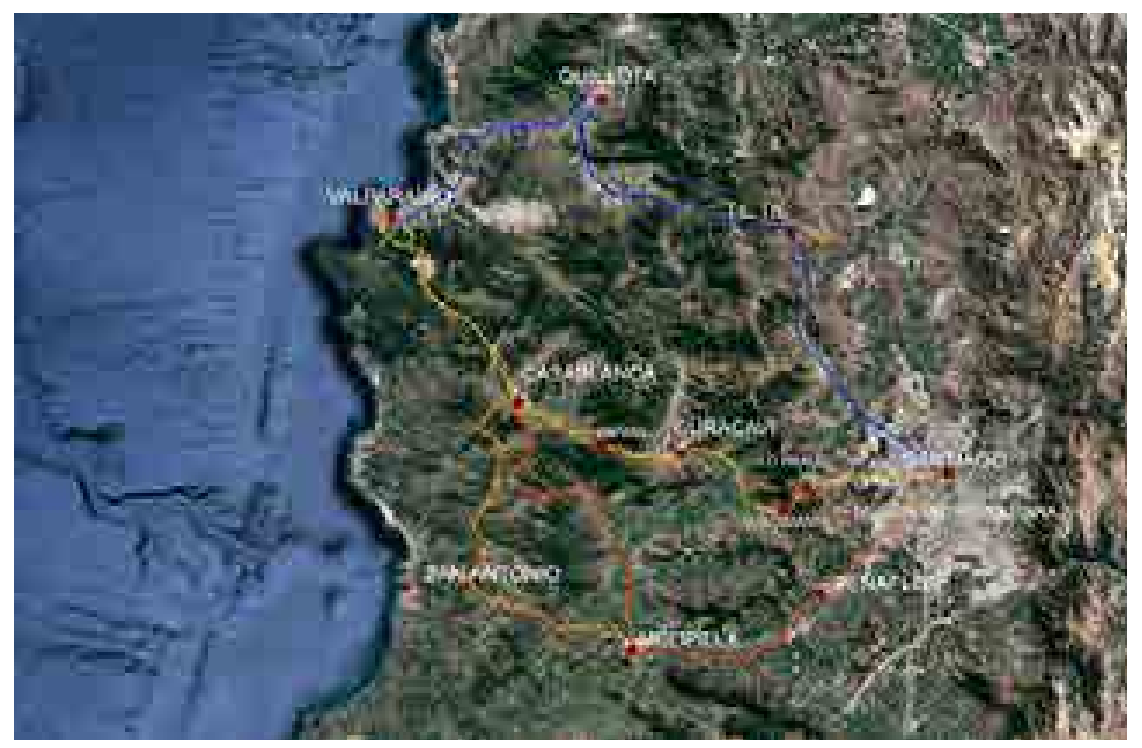

245 Importantes viajeros transitarán esta ruta en los años venideros: George Vancouver lo hará en 1795, Samuel Johnston en 1811, Samuel Haig en 1818, John Miers y Alejandro Caldeleugh en 1819, Peter Schmidtmeyer en 1821, María Graham y el francés Gabriel Lafont de Lurcy en 1822, Roberto Proctor en 1824, Eduard Poeppig en 1827, William Ruschenberger en 1832, Domingo Sarmiento e Ignacio Domeyko en 1841, y Claudio Gay en 1854. Este último, dejará plasmada la imagen de esta zona en el grabado que ya hemos mostrado en la Figura 6.5.

Figura 6.7. Trazado de rutas históricas entre Santiago y Valparaíso. Elaboración propia en base a imagen GoogleMaps y mapa de (Arteche,2012) 
Después de cruzar la Cuesta Lo Prado, Vancouver enfrenta al valle de Santiago, y llama su atención lo "salvaje del terreno", dedicado al pastoreo.

El camino sigue siempre en dirección al Este, i en esta parte está tan bien construida i es tan ancha como los caminos de Inglaterra. Hai a cada lado pequeños verjeles i granjas con pasto de mala calidad, donde se vé a los animales pastar a la sombra de un corto número de árboles; pero la falta jeneral de cultivo da al terreno un aspecto salvaje i estéril i no da señales que indiquen la vecindad de una ciudad tan grande i tan poblada como Santiago. No encontramos mas que dos o tres viajeros i algunos arrieros. Nos detuvimos para almorzar a cerca de quince millas de la capital, de donde distinguíamos ya con claridad, los altos campanarios que dominaban las numerosas casas que la ciudad parecía poseer. (Vancouver,1902, pp. 47-48)

En 1821, Peter Schmidtmeyer realiza el mismo camino, pero en sentido Santiago-Valparaíso, caracterizando en su relato a los usuarios de esta ruta, así como la naturaleza que cubre estas "tierras salvajes" (Schmidtmeyer,1824, p. 242), destacando también otras obras públicas del gobernador.

Al día siguiente de mi llegada a Santiago, partí a Valparaíso. La distancia es de unas ciento cinco millas y el viaje se realiza a veces el mismo día, en trece o catorce horas, con un buen caballo. Los comerciantes, oficiales navales y capitanes de barco, son los viajeros principales de este camino, y varios de los primeros mantienen caballos en campos de alfalfa más o menos a la mitad de camino, para obtener más rapidez.

Durante el virreinato de don Ambrosio O'Higgins, un irlandés, padre del actual Director Supremo de Chile, tuvieron lugar varias de las obras públicas útiles que se ven aquí: el canal desde el Maypo [sic]; el parapeto y paseo público a lo largo del Mapocho; y, entre otras, un camino ancho y bueno para coches, entre Santiago y Valparaíso. El transporte de mercaderías por este camino se hace tanto en carros como con mulas, de acuerdo a la naturaleza de los artículos (Schmidtmeyer,1824, p. 241).

Por su parte, Samuel Haigh hace una observación aguda. Su viaje también parte en Santiago (1917), y en esta dirección, el paisaje no le parece tan impresionante, aunque considera que nadie que contemple este panorama desde el poniente puede dejar de admirarlo. Esta percepción se condice con otros relatos de la época, que describen el viaje desde Santiago a Valparaíso más seca y críticamente, mientras que los que describen la llegada al valle desde el puerto reparan sobre la belleza y los detalles del lugar, pese a la fatiga del trayecto 0 , como diría Sarmiento en 1841, de las "dos tremebundas y fangosas jornadas" (Sarmiento, 1887, p. 142) de viaje.

Haigh también observa las condiciones ambientales que harían posible el desarrollo de la agricultura, reparando que "Chile no está suficientemente dotado de agua, pero la atmósfera es tan deliciosa y favorable a toda clase de cultivo, que, si estuviera bien regado todo el país, se convertiría él solo en el granero de toda Sud América" (Haigh, 1917[1829], p. 56).

En esta época, los hitos del camino ya eran conocidos: había que cruzar la primera línea de cerros, para llegar al valle de Peñuelas, desde ahí bajar al poblado de Casablanca donde les alcanzaba la noche. Al día siguiente el camino tenía subidas y bajadas, pero el hito principal era la cuesta de Zapata, luego Curacaví y desde allí, al segundo albergue en el poblado de Bustamante. Al tercer día había que remontar la Cuesta de Lo Prado (Lago, 2000), para luego bajar y en ese trayecto divisar la ciudad de Santiago. Ese fue el camino que hizo María Graham, desde donde describe:

El panorama que se divisa desde el paso del Pudahuel es bellísimo. Mirando a través del río, cuyas escarpadas orillas adornan grandes árboles, el valle de Santiago se extiende hasta las montañas, a cuyos pies se despliega; y la ciudad, con sus blancas torres, da a todo el

Figura 6.8. Señalización vial que anuncia Carén en el camino desde Santiago a Valparaíso por la ruta 68. Por Frases Suicidas (9 de septiembre, 2018) 
conjunto un carácter especial que lo distingue de los demás bellos paisajes de Chile, en que la ausencia de moradas humanas imparte cierto sello de melancolía sobre la naturaleza [...] Aquí Pudahuel desaparece en su belleza solitaria, sin que ningún poeta le cante, sin que se le tribute honor alguno (Graham,1824, p. 198).

El botánico alemán Eduard Poeppig, por su parte, se queja al ver la escasa variedad de especies que encuentra en el camino, y nos entrega un dato interesante acerca de la explotación del espino como combustible.

[...] el botánico ni siquiera tiene el agrado de observar plantas de especies aún no vistas, pues o se cruza planicies secas, en que los rebaños apenas encuentran un miserable talaje, u hondonadas bajas, en que prospera casi únicamente el espino, cuya posesión tiene para el agricultor, sin embargo, una importancia mucho mayor de lo que podría suponer a primera vista. Hay haciendas que tienen una entrada anual de miles de pesos por la venta del excelente carbón que suministra aquella acacia del país, consumido sobre todo en las ciudades en grandes cantidades, pero también muy bien pagado (Poeppig, 1960, p. 179).

Esta mirada científica cambia radicalmente en el momento de enfrentar desde lo alto el valle de Santiago en 1827:

El camino se había extendido durante mucho tiempo en un terreno rocoso y cubierto por un denso matorral, pero repentinamente se abrieron las rocas, y se presentó en la lejanía, hacia el sur, todo el amplio valle de Santiago, llenando la mirada de maravilloso asombro. Contemplando desde este alto mirador, se asemejaba a un jardín verdeante, pues la población más densa ha obligado a introducir cultivos más cuidadosos de la tierra, y dos caudalosos ríos repartidos sobre todo el territorio por un enjambre de canales, lo han hecho posible y rentable (Poeppig, 1960, p. 180).

...pero todo esto sólo representaba un sector del panorama completo, pues la cadena andina estaba oculta detrás de densos vapores. Un viento favorable los cortó poco después, e inesperadamente se presentó la cordillera en engañadora cercanía, como un encadenamiento continuo de cumbres nevadas. Cuando se creyó haberla contemplado en su integridad, una mirada casual al firmamento que se extiende sobre ella demostró pronto el error. A través de nieblas en dispersión, se veían cerros gigantescos, todavía a una altitud a la que el ojo sólo está acostumbrado a buscar "los presurosos navegantes del aire", las fugitivas nubes. (Poeppig, 1960, p. 181).

Con la inauguración del tren entre Santiago y Valparaíso, el 14 en septiembre de 1863, la ruta perdió importancia, "el ferrocarril despobló el camino e hizo desaparecer las postas, corrales y ventas" (Bunster citado por Calderón, 2001, p. 253). Nuevamente, una obra de infraestructura modificó el territorio y su percepción. El trazado del ferrocarril retomaba la salida norte del valle, dispersando en su trayecto 37 estaciones que activaron las comunidades a su alrededor, creando nuevos polos de intercambio, nuevas visiones y experiencias del territorio, y al mismo tiempo nuevos paisajes. La ruta férrea ahorraba las fatigosas cuestas en un medio de transporte más seguro y moderno.

A mediados del siglo XX, un nuevo adelanto tecnológico, la creación y masificación del automóvil, volvió a cambiar la experiencia del trayecto entre la capital y el puerto. La introducción del automóvil fue muy temprana en Chile. Santiago ya tenía en 1917 un total de 2.354 vehículos (De Ramón, 2011, p. 204). Su rápida masificación impulsó también la pavimentación de las vías urbanas, en especial la de los caminos interurbanos. En 1925 se creó el Departamento de Caminos, emprendiendo como tarea la pavimentación de la ruta entre Santiago y Valparaí-

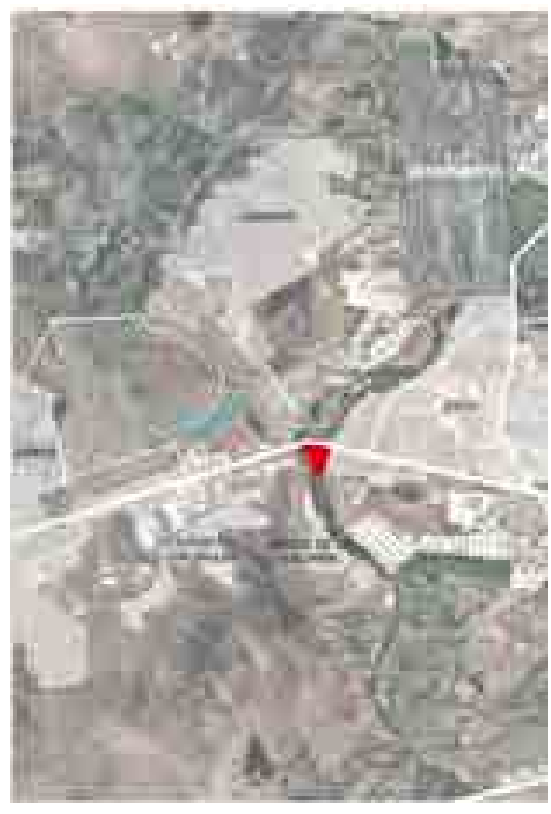

Figura 6.9. Mapa de ubicación de antigua Laguna Pudahuel (señalada en rojo). Elaboración propia sobre Google Maps. 
so. Este trabajo se complementó en 1955 con la construcción del túnel Zapata, y en 1970 con el túnel Lo Prado (Vialidad, 2017). Esta última obra vial cambiará definitivamente los hábitos de viaje entre la costa y el valle, convirtiendo esta ruta, hoy conocida como Ruta 68, en uno de los principales ejes de transporte del país, después de la carretera Panamericana que lo recorre de norte a sur. Como consecuencia, y junto al cese definitivo del ferrocarril en 1986, se vivencia un cambio de uso y percepción del territorio exterior de la ciudad. Se cierran estaciones, se eclipsan los pueblos a su alrededor, y se sellan y olvidan estos paisajes.

La nueva Ruta 68, de doble vía desde los años 1980, "corrige" el trazado del camino de O'Higgins, sepultando también las huellas de la calzada original. Desde 1999, esta carretera funcionará de manera concesionada, con un plazo que expira en agosto de 2024. Entre enero y diciembre de 2018 transitaron por ella 47.258.964 vehículos (MOP, 2019, p. 2), a una velocidad promedio de $100 \mathrm{~km} / \mathrm{h}$. Los ritmos de viaje han cambiado, acortando distancias, aproximando ciudades, $y$ transformando la experiencia de la ruta radicalmente.

En este nuevo camino, ya no existe la visión desde lo alto de la cuesta de Lo Prado, el encuadre que tanto fascinó a los antiguos cronistas, salvo que renunciemos a la facilidad del túnel. Sin embargo, al emerger a través del paso que cruza el cordón de Lo Prado, podemos experimentar una sensación distinta, parecida a la impresión que el botánico alemán Eduard Poeppig plasmó en sus relatos. Entremedio de la bruma mañanera que cubre el valle y se fuga en la autopista, aparecen algunos edificios altos -las antiguas torres de los campanarios, hoy gigantescas torres de oficinas- y más atrás "a través de nieblas en dispersión", aparecen aún los "cerros gigantescos, todavía a una altitud a la que el ojo sólo está acostumbrado a buscar 'los presurosos navegantes del aire', las fugitivas nubes" (Poeppig, 1960, p. 181).

En esta nueva experiencia, emergen también nuevas infraestructuras, producto de una renovada relación con este paisaje. La aproximación a las plazas de peajes, hace disminuir la velocidad, recuperar la visión lateral recortada por torres de alta tensión a un lado y los grandes volúmenes de los centros de distribución, bodegas y containers, al otro. Los avisos publicitarios, son otros elementos que se han apropiado del espacio de la ruta, transformándose en hitos del camino, que imponen un ritmo determinado al trayecto. Un trayecto donde la vegetación es ya accidental, sin intención; donde los bordes y escarpes muestran la erosión de los suelos. Para el viajero habitual, Carén es una señalización vial, solo un letrero ubicado en el kilómetro 11 (Figura 6.8).

\subsection{LA LAGUNA DE PUDAHUEL}

Varias de las crónicas estudiadas, en busca de referencias y descripciones de la zona del proyecto, mencionan la Laguna de Pudahuel, la que un primer momento interpretamos como la Laguna Carén, no existiendo actualmente ningún otro cuerpo de agua en los alrededores. Sin embargo, recurriendo a un texto más antiguo (1646), del sacerdote jesuita Alonso de Ovalle, encontramos una descripción con pistas geográficas: "entran también en Maypo otros dos ríos, que llaman de Colina y Lampa, los cuales juntándose entre sí a diez o doce leguas de su nacimiento, forman la famosa laguna, que se dice de Pudagüell', destacando características que difieren de la actual laguna:

[...]tan profunda, que tiene sobrado fondo para navíos. Corre esta laguna una
o dos leguas a lo largo, margenada toda de hermosos sauces y maitenes, que
son a manera de laureles y se conservan lozanos y verdes todo el año, y para
que no le falte nada de recreo, cría dentro de su seno las más regaladas tru-
chas y bagres que se conocen, y algunas veces en tanta abundancia, que se
pescan con gran facilidad y suele ser este uno de los mayores recreos de la
ciudad de Santiago (Ovalle, 1646, p. 22).

Con estos datos, la observación en terreno y Google Maps, podemos afirmar que Laguna Carén no es la Laguna Pudahuel, ubicando la extinta Laguna de Pudahuel a $1 \mathrm{~km}$ del terreno, como se indica en el siguiente mapa (Figura 6.9): 
Si bien no se tienen antecedentes acerca de su desaparición, la existencia de este cuerpo de agua, al poniente de "Chuchunco", en el cruce de la actual Ruta 68 con el río Mapocho, sí sabemos que esta laguna constituyó un importante lugar de esparcimiento al menos desde el siglo XVII hasta principios del siglo XX. Lo que nos permite entender, como veremos más adelante, el valor que le dan los habitantes de Pudahuel a laguna Carén como balneario, como un lugar de recreación, esparcimiento y de contacto con la naturaleza.

\subsection{DE LAS HACIENDAS A LAS COMUNAS DE BARRANCAS Y PUDAHUEL}

El territorio en el que se emplaza Laguna Carén fue por mucho tiempo esencialmente un lugar de tránsito para todo viajero que emprendía su marcha por el camino a Valparaíso. Un lugar remoto y agreste, circundado por inmensas haciendas, viñas y chacras. El nombre de Barrancas correspondía a un caserío rural en este trayecto más hacia el oriente.

Los cronistas viajeros junto a la descripción de las rutas, retrataron la pobreza, especialmente de la vivienda, un problema que se arrastra desde la colonia. $\mathrm{Pa}-$ tricio García (1994), refiriéndose al Chile del periodo colonial, opina que la ruca indígena era menos precaria que el rancho colonial campesino de los mestizos, y afirma que hubo una "decadencia habitacional desde la ruca originaria, en manos del mestizo", por una pérdida del sentido de arraigo al suelo de origen (García, 1994, p. 150). Esta condición es la que aún pesa. La precariedad será una característica de este territorio hasta nuestros días, que el estado ha buscado remediar por medio de la autonomía administrativa.

Si observamos la evolución de esta pretérita comuna hasta el trazado actual, podemos reconocer aún sus capas históricas. Allí se superponen la antigua estructura predial de grandes haciendas y la vialidad urbana más moderna, con calles que ocuparon los antiguos deslindes prediales y los canales de regadío que construyeron los jesuitas. Así, la comuna se fue desarrollando lentamente a medida que la ciudad se extiende, incorporando sectores rurales cuyos propietarios pueden subdividir sus tierras sin mayores exigencias, sólo extendiendo los servicios públicos y abriendo calles. Esto es posible, ya que la Ley de caminos de 1842 permite la apertura de calles en los suburbios sin la autorización expresa de la Dirección Provincial y, por otra parte, la Ley de Comuna Autónoma de 1891, entrega la atribución a los municipios para determinar los límites urbanos dentro de su jurisdicción. Es así, como amparada en la ley, la ciudad inicia un proceso de crecimiento desordenado con la pérdida de su estructura tradicional, dejando aún fuera de sus límites el Valle de Lo Aguirre.

El 25 de febrero de 1897, tomando el nombre Barrancas es fundada oficialmente la comuna, por orden del gobierno de Federico Errázuriz Echaurren (Zúñiga, 2007 , p. 88). Barriga y Marín (2005) señalan que hacia 1897, la nueva comuna se extendía desde la actual calle Matucana hasta la cuesta de Lo Prado. En el año 1875 el territorio que conforma la comuna de Barrancas contaba con alrededor de 6.600 habitantes, población que permanece relativamente estable hasta fines del siglo XIX, cuando empieza a crecer, poblando los intersticios de sus inmensas haciendas. Es así como en el año 1907, ya contaba con 8.500 habitantes, cantidad similar a la de otras comunas periféricas del entonces Departamento de Santiago (Zúñiga, 2007, p. 12). En 1915 el sector de Quinta Normal se transformó en una comuna autónoma. En ese mismo año, se realizó la parcelación exacta entre la comuna de Barrancas y la de Maipú, decretando el municipio los siguientes límites: 
[...] el límite sur de la subdelegación 13, Pudahuel, del departamento de Santiago, es una línea que parte de la cuesta de Prado en dirección al Naciente, siguiendo el cordón que divide las haciendas "Rinconada de Espejo" de "Lo Aguirre" hasta cortar el río Mapocho, pasando por el cerro Lo Aguirre y terminando en el cerro Chico. (citado por Rojas, 2012, p. 16).

Es en el año 1975 que este distrito pasa a llamarse "Pudahuel", en virtud del Decreto Ley $N^{\circ} 1.208$ del 13 de octubre de 1975, momento en el cual se divide el territorio original en tres comunas: Lo Prado, Cerro Navia y Pudahuel (Barriga y Marín, 2005, p. 2). Pudahuel se expande a lo largo del eje de la ruta 68 (carretera a Valparaíso) con los siguientes límites (Figura 6.10):

[...] al norte con las comunas de Quilicura entre A. Vespucio y el Estero Colina mediante límites prediales y parte del camino Lo Echevers, la comuna de Lampa mediante el Estero Colina, y la línea de cumbres que bordean la localidad de El Noviciado; al oeste con la cadena montañosa de la cordillera de la Costa que la separa de la comuna de Curacaví; al sur con la comuna de Maipú mediante líneas de cumbres del Valle de lo Aguirre, límites prediales y el canal Ortuzano; y al este con las comunas de Estación Central por Avda. Pajaritos y Avda. Las Torres, Lo Prado por Avda. Teniente Cruz, Cerro Navia mediante Tte. Cruz y J.J. Pérez, y Renca mediante A. Vespucio desde el Río Mapocho hasta Quilicura. (Barriga\&Marín, 2005, p. 2).

Pese a esta subdivisión, Pudahuel sigue siendo una de las comunas más extensas de la provincia de Santiago, desplegándose en una superficie de $196,8 \mathrm{~km}^{2}$ (19.680 ha), de las cuales, el $85 \%$ es rural (IMP, 2012, p. 22). Si bien, actualmente la población total de Pudahuel es de 230.293 habitantes ${ }^{246}$ y sólo 4.000 personas habitan fuera del límite urbano, buena parte de la población considera su comuna como rural (IMP, 2017, p. 31).

En la actualidad, la zona rural es considerada como "Área Excluida del Desarrollo Urbano" (IMP, 2017, p. 31), fuera del ámbito de acción del Plano Regulador Metropolitano de Santiago, lo que ha impedido, que el municipio realice inversiones en esta área, dejando su desarrollo en manos de la "planificación de nivel central e inversionistas privados atraídos por las ventajas comparativas que ofrece la red vial intercomunal" (IMP, 2017, p. 31). Esta situación que analizaremos más en profundidad en el Capítulo 9, pone al predio de laguna Carén en medio de las tensiones de este territorio, que, siendo mayoritariamente rural, está fuertemente afectado por la expansión de la ciudad de Santiago.

${ }^{246}$ Según datos del censo de 2017. De éstos, 117.881 son mujeres y 112.412 son hombres. En el Censo de 2002 la población total era de 195.653 habitantes, por lo tanto, la variación en 15 años es de 17,7\%.

Figura 6.10. Plano de Pudahuel dentro de la Región Metropolitana de Santiago. Por llustre Municipalidad de Pudahuel, 2017, p. 9.

Lamentablemente, como veremos, estos procesos han considerado muy poco la opinión de los habitantes de Pudahuel, menos aún el valor de los recursos naturales que están en juego. El paisaje rural, el del borde de la ciudad, sigue siendo visto como el espacio disponible, un terreno plano donde depositar las grandes

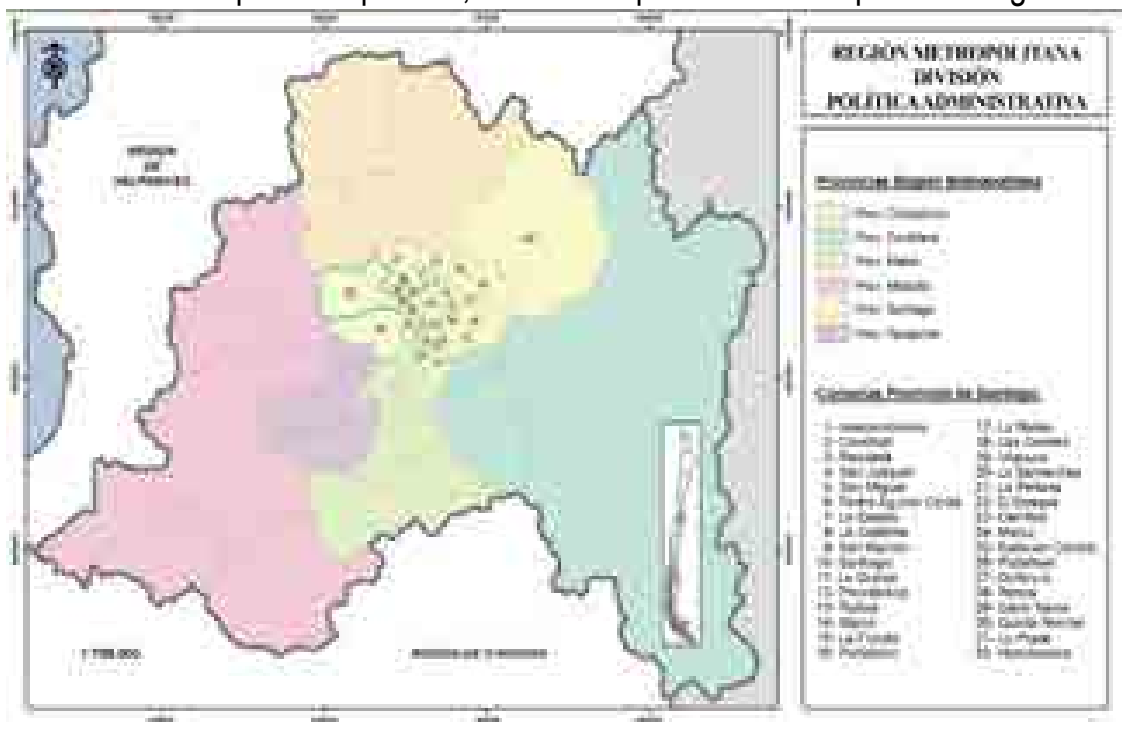


infraestructuras urbanas y también aquel reservado a especulación inmobiliaria, donde se recomponen los grandes predios hacendales para dar paso a estas intervenciones que la ciudad "necesita". Este fenómeno se puede leer también a través del fuerte impulso dado desde el estado a la creación de redes viales (casi todas concesionadas) que refuerzan el carácter logístico de esta zona. Están aquí en tensión las distintas escalas: la escala regional-nacional con el aeropuerto y ruta 68 , a escala de la región metropolitana, la instalación de centros de distribución, plantas de tratamiento de residuos peligrosos y nuevos condominios que aprovechan las autopistas urbanas (costanera norte y ruta del Sol). A la escala de la comuna, sin embargo, parece no haber un proyecto propio que vaya más allá de facilitar la instalación de lo que las demás escalas necesitan, con la esperanza de que esto traiga trabajo y progreso.

Por lo tanto, más allá del proceso administrativo de la creación de una comuna, cabe preguntarse por las consecuencias que tiene el crecimiento explosivo ${ }^{247}$ producido entre 1907 (8.500 hab.) y 2017 (230.292 hab.), e identificar qué historias y referentes arman la identidad de este lugar. Entender por qué el habitante de Pudahuel sigue viendo su territorio como rural, pese a que mayoritariamente habita zonas urbanas, para proponer un proyecto apropiado para y apropiable por los vecinos de la comuna, de manera que este no sea otra de las innumerables iniciativas impulsados con una visión "desde afuera". Pero para ello necesitamos saber quiénes son.

\subsection{DEMOGRAFÍA E IDENTIDAD COMUNAL}

Según cifras del último censo, la Comuna de Pudahuel presenta un 8,2 \% de su población en situación de pobreza ${ }^{248}$ (CASEN, 2017), lo que significa que hay 24.889 personas en situación de vulnerabilidad, población que crece a 64.870 $(22,5 \%)$ si se aplica el concepto de pobreza multidimensional (que considera además de la variable de ingresos, el acceso a la educación, salud, trabajo, seguridad social, vivienda, calidad del entorno y las redes). En esta última cifra incide la carencia de áreas verdes, que para la comuna alcanzan sólo 1,9 m² por habitante (Atisba, 2011), lo que resulta sorprende al considerar la existencia de Carén y su Laguna, que es el mayor cuerpo de agua de la región.

En la investigación de Johann García (2011) sobre las comunidades rurales de Pudahuel, observa que más del $87 \%$ de las familias viven allegadas. Para estas familias, el ingreso promedio mensual es menor a $\$ 120.000$ (US\$200). En base a entrevistas que realiza la autora a la comunidad, se detectan características sociales que permiten a las personas sobreponerse a la adversidad, que García llama "resiliencia comunitaria" (García, 2011, p. 177). Entre los aspectos detectados están la "historicidad" (p. 193), expresada como nostalgia de un pasado campesino; el sentimiento de topofília, como apego a la naturaleza; la "topofobia o la geografía del miedo" (p. 193) (al aeropuerto, las inundaciones y la contaminación); la pertenencia, reflejada en cuentos y mitos, como historia compartida; la localización: la idea de un espacio interno que protege y otro planificado desde fuera, donde aparecen el aeropuerto y los proyectos inmobiliarios. Las estrategias de superación están estructuradas por el espacio vivido, del que surge el orgullo por habitar en el campo (García, 2011, p. 193).

Estos rasgos tienen su origen justamente en aquellas grandes propiedades que estructuraron el Valle Central en la periferia de la ciudad, en la relación de inquilinos $^{249}$, peones y señores.

Para José Bengoa (2015), ya desde el siglo XVIII se estructura el sistema de inquilinaje en el país, que alcanzará, en el siglo XIX, su mayor desarrollo. Se
${ }^{247}$ El censo de 1960 registró 78.402 habitantes en Las Barrancas, cifra que en 1970 llegó a 182.612. A este explosivo aumento contribuyó el impacto de la llamada "Operación Sitio", pues Barrancas fue la comuna con mayor número de poblaciones formadas a través de la política gubernamental impulsada en la Región Metropolitana. Dicha operación consistía en "la entrega de sitios urbanizados, una instalación sanitaria mínima y mediaguas u otro tipo de viviendas económicas a familias de escasos recursos y en extrema necesidad de habitación" (Garcés, 2002, p. 301).

248 El concepto utilizado por la encuesta CASEN es pobreza de ingresos: "se entiende que el hogar está en situación de pobreza si sus ingresos totales per cápita mensuales no le permiten cubrir sus necesidades básicas alimentarias y no alimentarias (el valor de la canasta básica alimentaria y no alimentaria es la línea de pobreza)." (Casen, 2013, p. 5).

${ }^{249} \mathrm{El}$ inquilinaje era compuesto principal- 
mente por mestizos y españoles pobres. Éstos vivían y trabajaban con su familia al interior de la Hacienda. El trabajo que realizarán al interior de esta estructura no es remunerado, por el contrario, su derecho a ocupar una pequeña propiedad al interior de la hacienda y a trabajar ese terreno, es pagado al Señor (hacendado) a través de la prestación de servicios y entrega de un porcentaje del producto de su trabajo.

${ }^{250}$ Acontecimientos externos tienen fuer-

te impacto en la zona central de Chile:

el descubrimiento del oro en California a partir de 1848 inicia el ciclo exportador de trigo, que se amplía en 1865 a Inglaterra. Cayendo estrepitosamente en 1876 al no poder competir con los costos y volumen de producción de Argentina y Estados Unidos. La conquista de los territorios indígenas de la Araucanía incorpora nuevas zonas agrícolas (productora de cereales) que compiten con las de la zona central. En 1883 con la anexión de territorios del Norte Grande tras la Guerra del Pacífico, se producen nuevas demandas internas desde las regiones salitreras. Los empresarios salitreros son también los grandes latifundistas. trata de un complejo sistema de obligaciones de patronazgo, de dominación y de lealtad entre campesinos y terratenientes (latifundistas) que se ha instalado en la base de la sociedad rural, sobre la que se funda a su vez, la sociedad chilena. Para un observador actual, en ella podrían reconocerse los mismos elementos de la Europa feudal, ya que el inquilinaje, además de un sistema de trabajo, operó como un sistema de relaciones entre personas desiguales. Si los indios no se dejaron someter, los inquilinos, después de un siglo y medio de colonización, permitieron el surgimiento del señorío (Bengoa, 2015, p. 95) y fueron estos señores, los dueños de las haciendas, quienes más tarde dirigieron la independencia de Chile y se transformaron en los Padres de la Patria. Así, los orígenes de la dominación social se confunden con los orígenes de la agricultura del Valle Central.

Por otra parte, estaba el peonaje, aquellos que el naturalista Claudio Gay define como "obreros al día, los verdaderos proletarios harto[sic] escasamente alimentados" (Gay, 1862, p. 198). Fueron los temporeros de las haciendas, los obreros que trabajaron en el ferrocarril, en las minas del norte, los que se fueron a buscar fortuna con la fiebre del oro a California, los que luego se fueron a las salitreras. Para el historiador Gabriel Salazar fue una clase sin estructura establecida de comunicación e integración con la sociedad dominante (Salazar, 2000), en ellos "no existía la lealtad de siervo" (Bengoa, 2015, p.102). Para este personaje andariego, pendenciero y vividor, su goma social estaba constituida por las fiestas y las chinganas.

Cuando no había trabajo, se transformaron en vagabundos y cuatreros. Recordemos que el bandolerismo rural fue uno de los problemas que sufrió el país en el siglo XIX, posiblemente debido a la incapacidad de las haciendas de absorber mano de obra debido a los vaivenes de la demanda agrícola. ${ }^{250}$ Los cronistas viajeros estudiados, frecuentemente comentan los peligros del camino a Valparaíso en la zona de Pudahuel. artificial

Pese a todo esto, el "roto chileno", una imagen construida desde la oligarquía en los albores de la República, es ese peón libre. Libre y pobre. También valiente y feroz soldado, carne de cañón en la primera guerra con Perú, hecho que refuerza esta identidad un tanto ficticia que perdura hasta hoy como un arquetipo de la chilenidad (Cid, 2009). De esta figura ambivalente surgirá la conciencia social en dos sentidos: como conciencia nacional y como conciencia obrera, amalgamando elementos de la cultura campesina y urbana, católica y pagana. Esta mixtura resiliente se expresará en costumbres populares, leyendas y personajes que conforman la identidad de Pudahuel, entre ellos: la Fiesta de Cuasimodo, el Mito del Culebrón, la poesía y el canto de protesta.

\subsubsection{La Fiesta de Cuasimodo}

Esta festividad religiosa data en Las Barrancas de 1875 y es la tradición religiosa más popular e importante de Pudahuel hasta hoy. Cuasimodo se celebra el domingo siguiente a la pascua de Resurrección y consiste en un ritual, en el que los sacerdotes llevan la eucaristía a los enfermos, ancianos y postrados que no pueden acudir a la iglesia en Semana Santa. Quienes acompañan al cura por los solitarios caminos rurales, son los cuasimodistas, un grupo de huasos a caballo que cubren su cabeza con un pañuelo blanco y portan banderas (Figura 6.11.). El origen de esta tradición se relaciona justamente con los peligros que asolaban los caminos rurales (Zúñiga, 2001, p. 101).

La fiesta de cuasimodo sigue celebrándose hoy, aún a caballo, también con bicicletas, cruzando los campos y deteniéndose frente a los altares o señales que se instalan fuera de la casa del enfermo. La gente los celebra cuando pasan. La procesión se detiene en cada casa, el sacerdote entra y da la comunión al postrado mientras los feligreses cantan y rezan. La zona agrícola ubicada al norte de Carén, Noviciado, es uno de los lugares donde aún se encuentra esta tradición 
que refuerza la identidad rural que aún persiste en el valle de Lo Aguirre. Un valle que también tiene una leyenda, que surge en esta zona a inicios del siglo $X X, y$ que ilustra los distintos grupos sociales y su relación con el paisaje.

\subsubsection{El mito del Culebrón}

La leyenda del Culebrón es una de las más extendidas en las zonas rurales chilenas y tiene como protagonista a una extraña criatura con aspecto de serpiente gigante y monstruosa, asociada a presencias malignas como la de Mandinga, el diablo. Mandinga es una de esas representaciones del demonio en Sudamérica, personificada en un hombre extraño que seduce con su apariencia.

Una de las versiones más divulgadas de este mito, es aquella que se transmite de forma oral en Pudahuel desde inicios del siglo XX. Según la versión de Carlos Martínez, que he sintetizado a continuación, se revela el origen de Laguna Carén:

Se trata de una historia de amor no correspondido del capataz de una hacienda, enamorado de Carolina, la hija del patrón. La muchacha está comprometida y su padre manda a construir una capilla para celebrar la boda. El capataz, a pesar suyo, es el responsable de la obra. En su congoja, conoce a un personaje extraño, vestido de negro, quien le promete el amor de Carolina, si acude a una cita en el cerro Amapolas tres días después. Cumpliendo la cita, mientras espera, el capataz observa la figura de una serpiente que baja de la luna y se entierra en el valle. La tarea encomendada por el hombre, consiste en excavar un túnel entre la capilla del pueblo y el cerro. La otra condición es que le entregue el fruto de su amor con Carolina para terminar el túnel. La noche de bodas esto se cumple, el capataz suplanta al novio. El hecho se descubre con escándalo y de la unión nace un niño que poco a poco se transforma en un monstruo. Después de ser expulsado y vagar por muchos años, el capataz regresa y le confiesa a Corina, la madre de Carolina, la historia. Corina, que ha perdido a su marido y a su hija, enclaustra a su nieto para protegerlo, sin embargo, al cumplir la mayoría de edad, éste huye atemorizando a la comunidad. Los miembros de cuasimodo se convierten en sus persecutores. La abuela lo encuentra y se encierra con él en la capilla, desde donde este ser, que ya tiene su cuerpo cubierto de escamas y ha perdido sus brazos, cava incesantemente un túnel. Algunos meses después, el cuerpo de doña Corina aparece sin vida en la laguna de Pudahuel. El cura párroco alarmado por esta situación visita una noche el cerro Amapolas, donde el hombre de negro se le presenta como Mandinga y le dice que en el valle que tiene delante dormirá uno de sus hijos y despertará cada invierno levantando las aguas que vienen de la cordillera. A los pocos minutos, mirando hacia el poniente, observa la figura de una gran serpiente que sale de la tierra y se eleva hacia la luna provocando un fuerte temblor. La tierra del valle se resquebraja, levantándose la figura inmensa del Culebrón, para luego recostarse en la gran grieta que había formado. Una intensa lluvia cubre de agua esta grieta, formando una laguna, que con el tiempo fue conocida como Laguna Carén.

Reconocemos aquí las relaciones entre el patrón y el inquilino, también la influen-

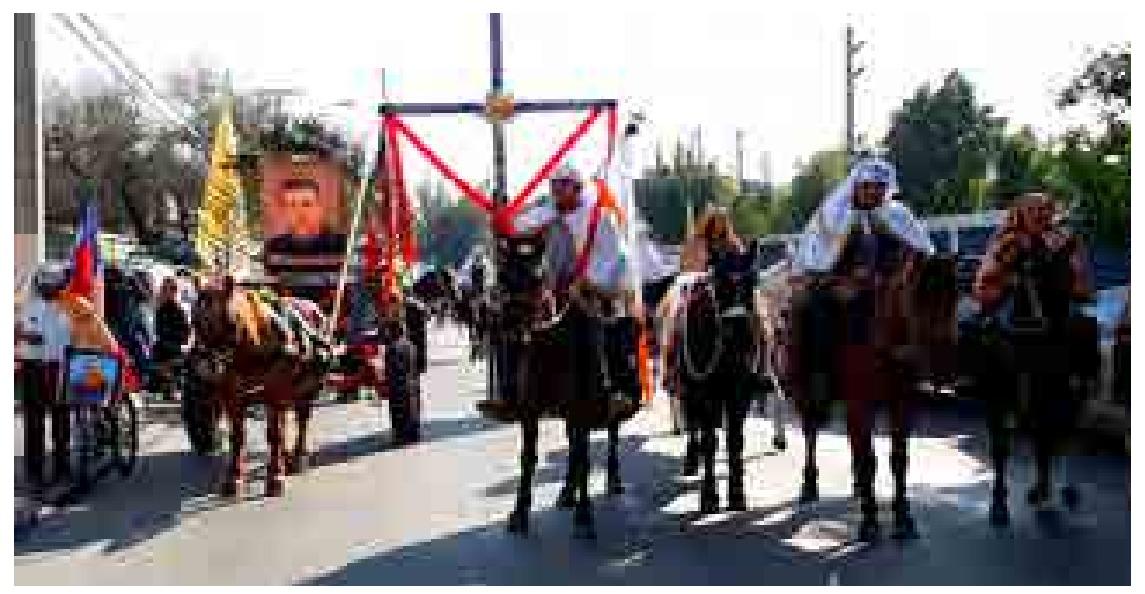




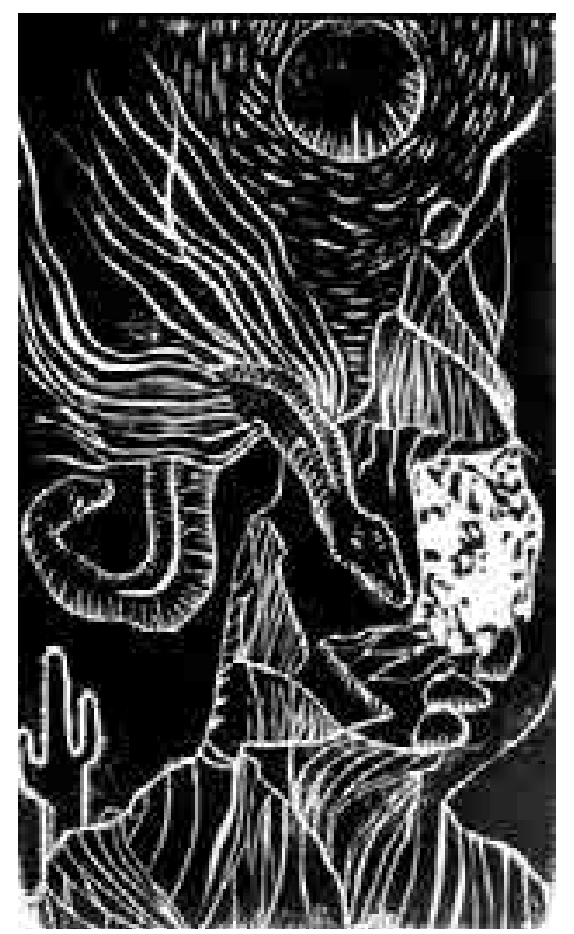

Figura 6.12. El Culebrón. Xilografía. Por Marcelo Lira, 2008. cia de la mitología mapuche, que como recordaremos, posee seres relacionados con el bien y el mal, el cielo y la tierra, con la forma de serpientes, que, si bien no existen como especies de gran tamaño en Chile, su representación es común en las leyendas de América precolombina. Es así como Laguna Carén es también un escenario mítico.

\subsubsection{Gabriela Mistral}

\author{
Es verdad, no es un cuento: \\ hay un Ángel Guardián \\ que te toma y te lleva como el viento \\ y con los niños va por donde van. (Mistral,1992)
}

Se dice que Chile es país de poetas. Desde la ritualidad mapuche y su tradición oral, a los grandes líricos y líricas, la geografía, las personas y su tradición se ha hecho verso. Que, como hemos visto en el tercer capítulo, han ayudado construir una identidad asociada al paisaje.

El primer gran reconocimiento internacional en este género, se otorgó a Gabriela Mistral (1889-1957), la poetisa maestra, quién fue el primer autor latinoamericano en recibir el Premio Novel de Literatura en 1945. Lucila Godoy, llegó desde el norte a Santiago en los primeros años del siglo XX con 21 años, y, después de rendir las pruebas que la habilitaron como profesora normalista, se fue a trabajar a Pudahuel, en ese entonces las Barrancas, en la Escuela Elemental Mixta $\mathrm{N}^{\circ}$ 184. El hecho es señalado en el diario El Comercio, con fecha 15 de mayo de 1910 (Figura 6.13.). Este es uno de los medios que aparecen en torno al centenario y revelan la evolución de una comunidad desde un ordenamiento rural a uno urbano.

Para Fernando Alegría, "ella fue enseñando toda clase de cosas a niños y niñas tan pobres como ella, cultivando en sí misma la imagen de 'maestra rural"” (Alegría, 1990, p. 47), para luego, más madura, abogar con fervor por la educación primaria obligatoria y la instrucción de la mujer. Dos grandes problemas que aquejaban a la sociedad chilena de principios del siglo XX y que se sumarán a la pobreza emplazada en la periferia de la ciudad, que ella conoció muy bien en Barrancas; así como los espinos y otras especies que inspiraron su poesía:

\section{EL ESPINO}

El espino prende a una roca su enloquecida contorsión, y es el espíritu del yermo,

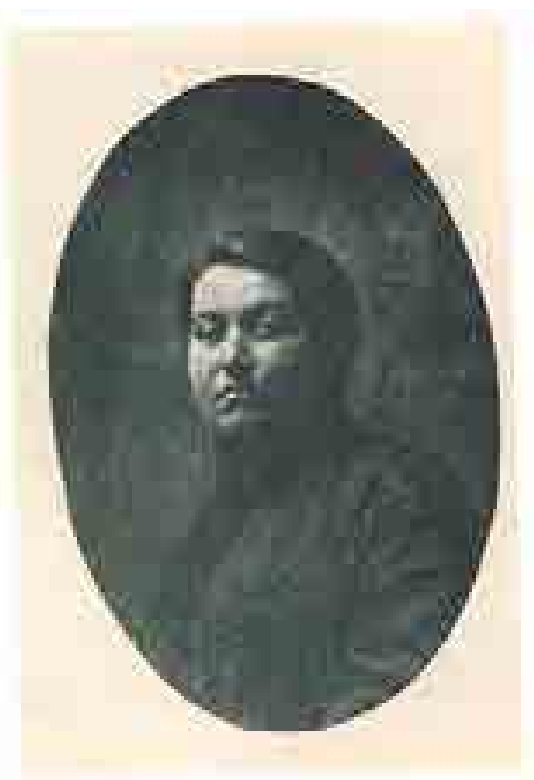

\section{EL COMEBCIO}

Una nucva msertra

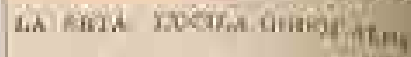

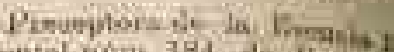

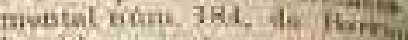

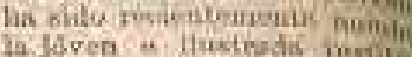

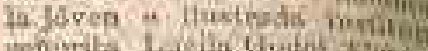

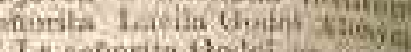

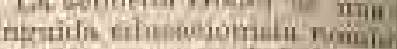

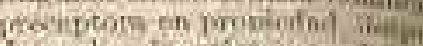

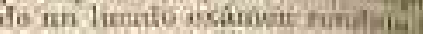
oe joos mi ta Remple 8 in

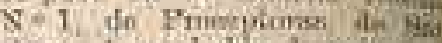

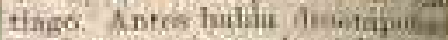

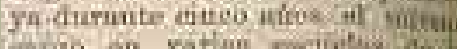

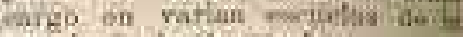

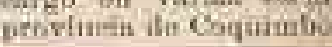


Mistral les cantó a los árboles, a la cordillera, a los campesinos, y especialmente a los niños y niñas de su patria. Su poesía denuncia la precaria situación de la niñez en Chile a principios del siglo XX y protesta ante el terrible desamparo de la infancia, especialmente en las periferias.

\author{
PIECECITOS (fragmento) \\ Piececitos de niño, \\ azulosos de frío, \\ icómo os ven y no os cubren, \\ Dios mío!
}

La cuestión social se instalará definitivamente en los años 30 , debido a factores externos, pero también a una estructura social y productiva incapaz de modernizarse. Gabriela Mistral escribirá en el diario el Mercurio, el 14 de mayo de 1933 su crítica posición: "Una hectárea por cabeza de familia resolvería el problema económico del campesinado de Elqui si el horrible y deshonesto latifundio no estuviese devorándonos y hambreándonos allí como a lo largo del país entero" (citado por José Bengoa, 1990, p. 12)

Con la aparición del salitre sintético, cae estrepitosamente la economía nacional, lo que se agrava con la depresión internacional y el terremoto de Chillán de 1939. Es así como a esta tranquila zona rural llegan oleadas de mineros desempleados, gente del sur que ha perdido sus casas en el terremoto y mapuches, que, al perder sus tierras, buscan en la capital nuevas oportunidades. En este ambiente, surgen los primeros movimientos campesinos. Uno de los líderes de estos movimientos fue Emilio Zapata, un obrero que llegó a ser Diputado por este distrito. Los inquilinos que hasta ese momento habían tenido una actitud pasiva, se unen al movimiento y en 1934 renuncian a la llamada "ración de tierra"251. Son los inquilinos de "los fundos de Noviciado, Lo Aguirre, Peralillo, Las Lilas, Cuartizuela, la Punta, Santa Elvira, Lo Prado Abajo y muchos otros" (Zúñiga, 2007 , p. 113), quienes inician este proceso que culminara 30 años después con la Reforma Agraria y que tiene como uno de sus logros la creación de una de las primeras colonias agrícolas en el fundo El Noviciado. Los campesinos adquirieron en subasta pública este terreno de más de 4.000 hectáreas, dando origen a la localidad agrícola que conforma el límite norte del predio de Laguna Carén. Si bien estos procesos no tienen efectos físicos importantes en el predio de estudio, podemos afirmar que el orden social que caracterizó esta zona por más de 300 años, se alteró. Poco a poco la cultura agrícola dio paso a una mezcla heterogénea de campesinos y pobladores que se convierten en fuente de inspiración para dos grandes cantautores chilenos. Violeta Parra en los años cincuenta y Víctor Jara en los sesenta.

\subsubsection{Pudahuel y la música de protesta}

Violeta Parra (1917-1967), considerada hoy una de las mayores folcloristas sudamericanas, llega a la comuna de Barrancas a fines de los años cuarenta. Su madre se ha instalado en la quinta de recreo 252 "Los Sauces" a un par de cuadras de la calle San Pablo. Violeta había aprendido de su madre la interpretación de tonadas y cuecas ${ }^{253}$, pero hasta ese momento, se ganaba la vida cantando rancheras en bares y restoranes. Su hermano Nicanor ${ }^{254}$ la anima a que investigue y recopile las fuentes del folclore chileno en cada rincón del campo. Allí, en Barrancas, Violeta conoce a Juan de Dios Leiva y a su vecina, Rosa Lorca a quién recuerda así:

Gracias a doña Rosa Lorca y a otras ancianas de la región recopilé quinientas canciones de los alrededores de Santiago y volví donde Nicanor con tonadas,
${ }^{251}$ La ración de tierra, consistía en un potrero entregado a los inquilinos para la producción propia.

252 Las Quintas de Recreo, así como los clubes sociales, fueron escenario característico de la convivencia popular propia de la primera mitad del siglo 20. Generalmente eran galpones amplios y abiertos, con paseos circundantes al aire libre, adornados de guirnaldas, ramas y con gran pista de baile. Los parroquianos se reunían alrededor de la música y cantores, quienes estaban a cargo del despliegue de la fiesta y que por lo general se extendía durante largas horas. Las quintas barranquinas más célebres de la época, eran la Quinta Garay, Los Robles y Los Sauces, circundadas por amplias parras, lagunas y paseos. ${ }^{253}$ Baile Nacional de Chile.

${ }^{254}$ Nicanor Parra, de quién ya hemos hablado en el capítulo 3, fue un físico y poeta chileno, reconocido como creador de la antipoesía. Recibió el premio Nacional de Literatura (1969) y el Premio Miguel de Cervantes (2011), entre otras distinciones, además de haber sido candidato al Premio Nobel de Literatura en diversas ocasiones. ${ }^{255}$ La canción El Rin del Angelito interpretada por Violeta Parra en: https://www.youtube.com/watch?v=vhHXsOPW_1A. 


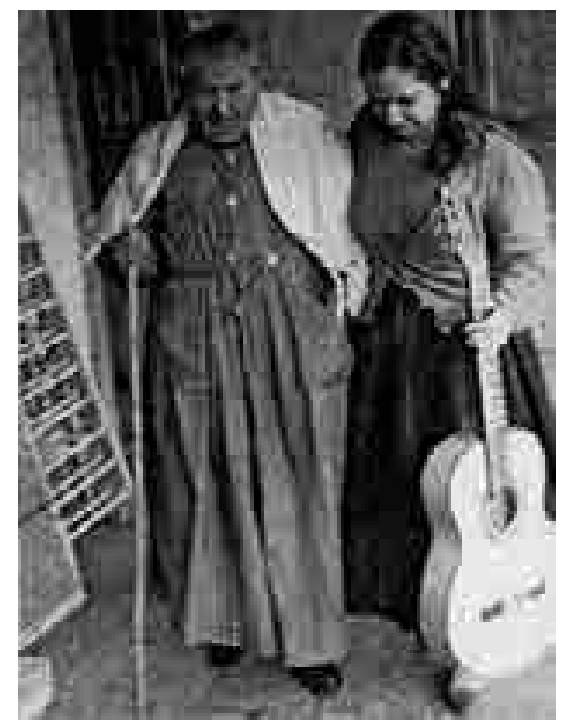

Figura 6.14. Fotografía de Violeta Parra y Rosa Lorca. En Los Parra en Barrancas [blog], 30 de octubre, 2012. parabienes, villancicos, además del canto a lo divino y a lo humano, y con las danzas campesinas el pequén, la refalosa y la cueca. (Violeta Parra citada en Reyes, 2017, p. 30)

Cuando me iba a imaginar yo que, al salir a recoger mi primera canción, un día del año 53, en la comuna de Barrancas, iba a aprender que Chile es el mejor libro de folklore que se haya escrito. Cuando aparecí en la comuna de Barrancas a conversar con doña Rosa Lorca, me pareció abrir ese libro. (Violeta Parra citada en Reyes, 2017, p. 35)

Violeta buscaba canciones y encontró la sabiduría popular encarnada en doña Rosa, que era partera, curandera, sacaba el mal de ojo y era "arregladora angelitos", una tradición campesina que consiste en velar los niños muertos, vestidos como un ángel y sentados sobre una mesa (Figura 6.15.). El velorio del angelito se transforma en una canción, también en una suerte de clave de su canto a lo Divino y lo Humano: "encontré folclor en todas partes, aunque las viejas de Barrancas fueron mi primera fuente" (citada por Reyes, 2017, p. 27).

\section{Ya se va para los cielos ese querido angelito a rogar por sus abuelos, por sus padres y hermanitos. Cuando se muere la carne, el alma busca su sitio adentro de una amapola $o$ dentro de un pajarito.}

La tierra lo está esperando con su corazón abierto, por eso es que el angelito parece que está despierto. Cuando se muere la carne, el alma busca su centro en el brillo de una rosa o de un pececito nuevo.

En una cuna de tierra lo arrullará una campana, mientras la lluvia le limpia su carita en la mañana. Cuando se muere la carne, el alma busca su diana en los misterios del mundo que le ha abierto su ventana.

Las mariposas alegres,

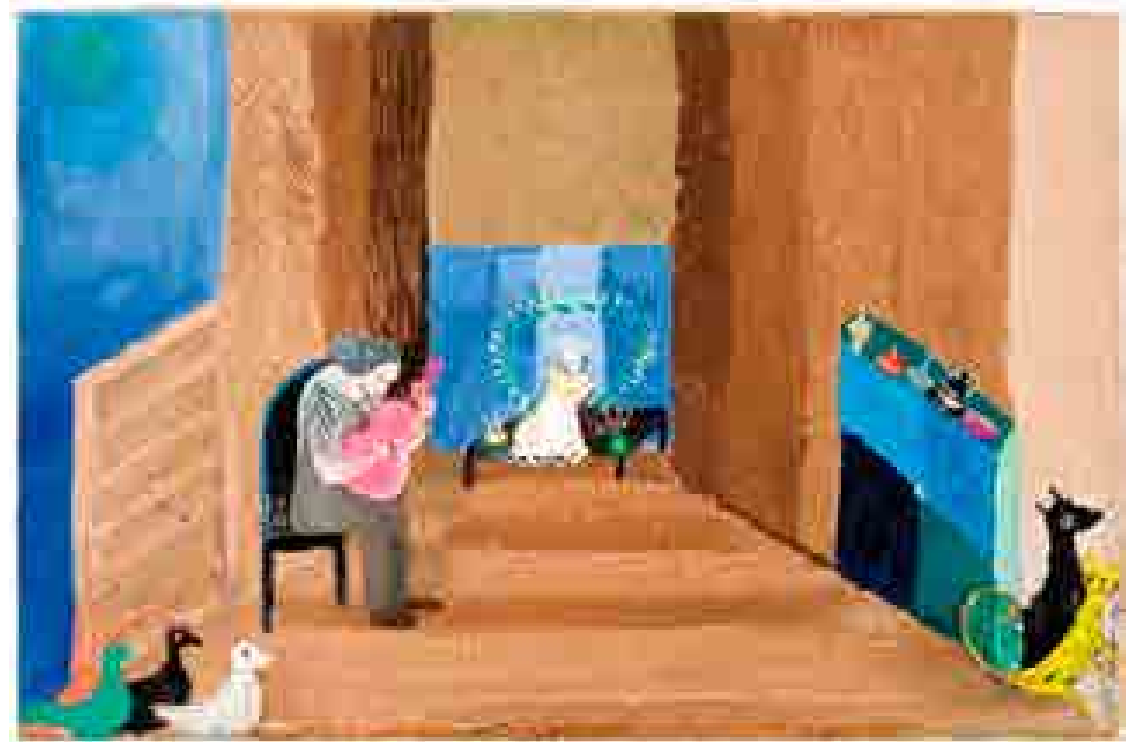

Figura 6.15. Velorio del angelito. Óleo sobre tela. Por Violeta Parra (1964). Fundación Violeta Parra. 
de ver el bello angelito alrededor de su cuna, le caminan despacito.

Cuando se muere la carne,

el alma va derechito

a saludar a la Luna

y de paso al lucerito.

¿Adónde se fue su gracia?

¿Dónde fue su dulzura?

¿Por qué se cae su cuerpo

como la fruta madura?

Cuando se muere la carne,

el alma busca en la altura

la explicación de su vida

cortada con tal premura,

la explicación de su muerte

prisionera en una tumba.

Cuando se muere la carne,

el alma se queda oscura. (Parra, 2016, p. 59) ${ }^{255}$

De su intensa labor de recopilación, reelaboración y difusión de la cultura popular, surge gran parte de lo que hoy entendemos como folclor nacional y también lo que internacionalmente se conoce como canción chilena. Temas como "Gracias a la Vida" lograron cruzar las fronteras, pero Violeta Parra no sólo plasmó este conocimiento en canciones sino también en pintura, bordados sobre arpillera, poesía, escultura y cerámica, expresiones que fueron valoradas en otras latitudes antes que en Chile.

Violeta Parra, a los 47 años de edad, se convirtió en la primera artista latinoamericana -y la primera mujer- en realizar una exposición individual en el "Museo de Artes Decorativas del Palacio del Louvre", en París, donde mostró arpilleras, óleos y esculturas en alambre. (EMOL,5 de febrero, 2005)

La gente de Pudahuel considera suya a Violeta Parra, y como ella, "conserva ese particular atractivo de quien se enorgullece de ser quién es y de vivir donde vive" (Valadez,2 de enero, 2013, p.1).

En 1967, el mismo año de la muerte ${ }^{256}$ de Violeta Parra, 400 familias ${ }^{257}$ se instalan informalmente en un sitio de calle San Pablo. La toma de terrenos representa la única solución para las familias "sin techo". Es la primera toma en la comuna de Barrancas, un atentado a la "propiedad privada", que es reprimido por la policía, dejando como víctima a una pequeña niña, llamada Herminda ${ }^{258}$ que luego se convierte en el símbolo del triunfo de los pobladores, al conseguir ser trasladados a un asentamiento definitivo, que llamaron Población Herminda de la Victoria. Víctor Jara joven cantautor, fue uno de los muchos que acudieron a ayudar a los pobladores, visitó la toma muchas veces, compartió con las familias y entretuvo a los niños. Conmovido por la situación, compuso los temas que más tarde se convertirían en su disco "La Población" (1972) con canciones como "La Herminada de la Victoria":

\footnotetext{
Herminda de la Victoria murió sin haber luchado, derecho se fue a la gloria con el pecho atravesado. Las balas de los mandados mataron a la inocente. Lloraban padres y hermanos en el medio de la gente.
}

${ }^{256}$ Violeta parra se suicida el 5 de febrero de 1967 en su carpa de La Reina. Había invertido mucho esfuerzo en ese proyecto, pero no tuvo apoyo, estaba sola.

${ }^{257}$ Según un empadronamiento municipal, fueron 4.700 adultos y 3.655 niños.

${ }^{258}$ Herminda tenía 9 días de vida y sus padres habían llegado a Santiago, damnificados del terremoto de 1965.

${ }^{259}$ Luis Iribarren Arrieta, hijo de Raúl Jara y Rosa Martínez 
Hermanos se hicieron todos,

hermanos en la desgracia,

peleando contra los lobos,

peleando por una casa.

Herminda de la Victoria

nació en el medio del barro,

creció como mariposa

en un terreno tomado.

Hicimos la población

y han llovido tres inviernos.

Herminda en el corazón

La relación de Víctor Jara con Barrancas se mantuvo en el tiempo, es así como en 1970 acude junto a otros estudiantes de la Universidad de Chile a trabajos voluntarios, para ayudar a las personas damnificadas por un desborde del río Mapocho (Figura 6.16). Allí conoce a Luchín ${ }^{259}$ y sus padres, que con 10 hijos más, le piden que se haga cargo del niño, ya que la pobreza de la familia no permitía mantenerlo. Víctor Jara, no sólo consiguió sacarlo de la pobreza y que fuera adoptado, sino también lo cuidó hasta su muerte ${ }^{260}$, inmortalizando a Luchín en su canción ${ }^{261}$ :
LUCHÍN
Frágil como un volantín
en los techos de Barrancas
jugaba el niño Luchín
con sus manitos moradas
con la pelota de trapo
con el gato y con el perro
el caballo lo miraba.
En el agua de sus ojos se bañaba el verde claro gateaba a su corta edad con el potito embarrado con la pelota de trapo con el gato y con el perro el caballo lo miraba.
El caballo era otro juego en aquel pequeño espacio y al animal parecía le gustaba ese trabajo

${ }^{260}$ Víctor Jara fue detenido en la Universidad Técnica del Estado el mismo día del Golpe Militar, el 11 de septiembre de 1973, fue torturado y muerto de 44 balazos.

${ }^{261}$ La canción Luchín interpretada por Víctor Jara en: https://www.youtube.com/wat$\mathrm{ch} ? \mathrm{v}=\mid \mathrm{ZPx} P \mathrm{~s} 1 \mathrm{vXO \textrm {w }}$

Figura 6.16. Fotografía de Víctor Jara en Barrancas, 1970. Por El Desconcierto, 3 de agosto, 2018.

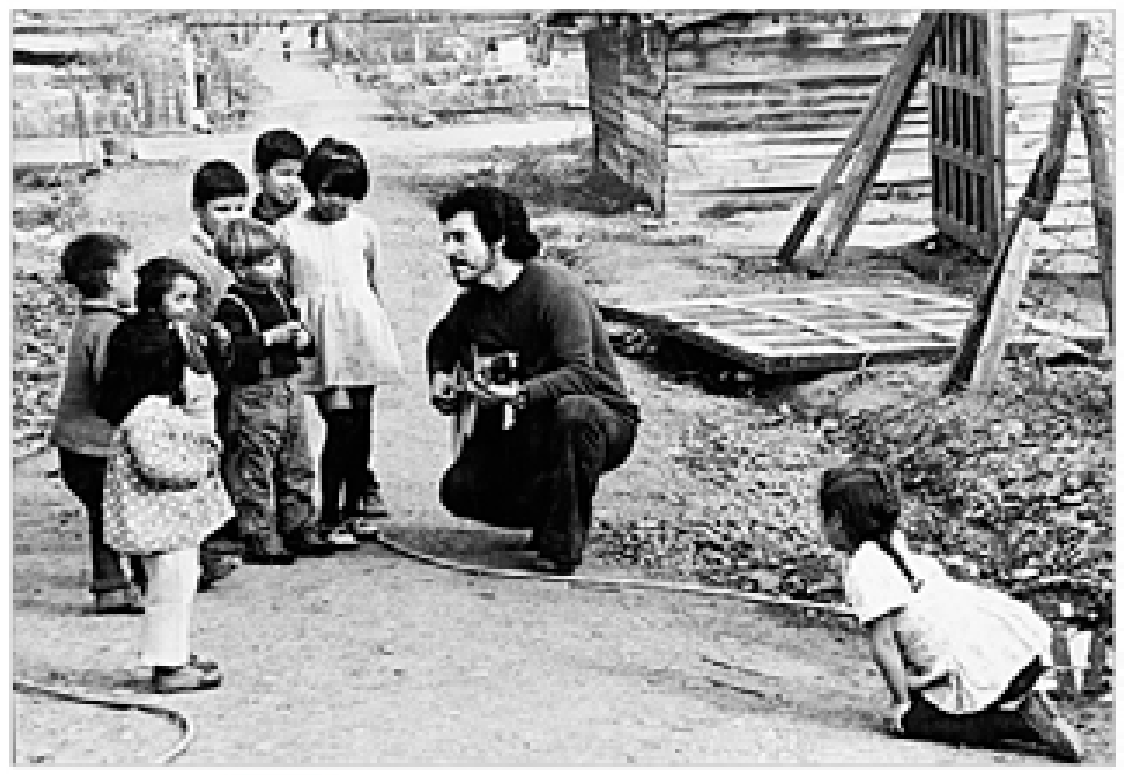


con la pelota de trapo

con el gato y con el perro

y con Luchito mojado.

\begin{abstract}
Si hay niños como Luchín que comen tierra y gusanos abramos todas las jaulas pa' que vuelen como pájaros con la pelota de trapo con el gato y con el perro y también con el caballo.
\end{abstract}

Es así como la canción de protesta tiene su cuna en Barrancas y refuerza la solidaridad e identidad de sus habitantes. Los desbordes del río Mapocho, la falta de vivienda y la pobreza, serían así rasgos característicos del área urbana de la comuna y marcarían la fisonomía de este espacio, que originariamente rural y campesino fue también poblado por obreros de toda índole, mineros del salitre desempleados y sureños cuyo hogar fue destruido tras los terremotos de 1939 y 1960. De manera silenciosa, también la migración mapuche dio a la comuna una riqueza cultural particular, expresada en sus conocimientos medicinales, su lenguaje y la práctica del palín o chueca ${ }^{262}$ en sus plazas.

Paralelamente, la zona rural también experimentaría fuertes cambios. Las luchas campesinas desembocan finalmente, el año 1967, en la Reforma Agraria.

\subsection{LA REFORMA AGRARIA}

Como hemos visto, la hacienda fue la institución que estructuró tanto el orden espacial como social de Chile Central. Desde la temprana entrega de mercedes de tierra y encomiendas otorgadas a los conquistadores, grandes territorios se organizaron con el primer auge triguero del siglo XVIII y se consolidaron en el siglo XIX tras la Independencia. Los latifundios fueron un factor de acumulación y concentración de riquezas que perduró inalterablemente por más de tres siglos.

Como señala Iván Radovic (2005), el movimiento campesino, no tuvo en Chile, ni la intensidad ni el alcance que logró en otros países americanos como, Perú, Bolivia, Colombia o México. Entre una de sus causas está el hecho de que, en Chile "las luchas campesinas estuvieron separadas de las luchas indígenas debido a la composición de su población (fuertemente mestiza) y su distribución regional a lo largo del territorio" (Radovic, 2005, p. 3)

En la tardía industrialización de Chile de los años 30, el estado decidió privilegiar la modernización en el mundo urbano, postergando al rural. Como consecuencia, cientos de miles de campesinos emigraron a las ciudades en busca de un mejor futuro, mientras que la economía agraria comenzó a experimentar una crisis profunda caracterizada por su incapacidad productiva, siendo necesario, en los años cincuenta, llegar a la importación de alimentos.

En el caso de Chile, es la Iglesia Católica, la que inicia el proceso. En 1962, el cardenal Raúl Silva Henríquez anuncia que la Iglesia entregará tierras en el proceso de Reforma Agraria, dando a conocer también el documento pastoral "la Iglesia y el problema del campesinado chileno" (Obispos de la CECH, 1962). El mismo año se dicta la primera Ley ${ }^{263}$, sin que tenga el impacto esperado.

En 1964 asume el gobierno democratacristiano de Eduardo Frei, en cuyo mandato el estado expropia 1.408 predios con 3.564 .580 hectáreas (un tercio de la que sería el total de la reforma). La presión campesina se concentra en la zona central, donde se logra una mayor sindicalización ${ }^{264}$. Aumentan las huelgas y las tomas de predios, las 13 primeras son en 1965, y llegarán a 456 en 1970.

En 1967 se promulga la nueva ley ${ }^{265}$ que establece la necesidad de limitar la acumulación de tierras en el país, de acuerdo a los siguientes criterios descritos en el sitio web de la Cámara de Diputados:
262 El palín es un deporte mapuche similar al hockey. Se juega con una bola (pali) y un bastón de madera (weño). Los conquistadores españoles llamaron al juego con el nombre de Chueca, por la similitud con un juego peninsular (López von Vriessen, 2005). El año 2004 fue reconocido como deporte nacional en Chile.

${ }^{263}$ En agosto de 1962 el Congreso Nacional aprobó la Ley de Reforma Agraria $N^{\circ}$ 15.020. Ésta autorizó al Estado a adquirir tierras con pago en efectivo del $20 \%$ y el resto en bonos. Además, permitió la creación de la Corporación de Reforma Agraria (CORA), para supervisar el proceso de expropiación; el Consejo Superior de Fomento Agropecuario (CONFSA) para garantizar el aprovechamiento eficaz de la tierra; y el Instituto de Desarrollo Agropecuario (INDAP) para proporcionar asistencia técnica y crediticia a los campesinos. 
La principal causa de la expropiación de la tierra era el tamaño. Es así como esta causa podía aplicarse a todas las propiedades de más de 80 hectáreas de riego básico del Valle del Maipo, medida elaborada por la Corporación de Reforma Agraria (CORA) para expropiar tierras de diferentes capacidades a través del país. La disposición era un concepto de productividad y se elaboró una escala segmentada para regiones. Otro criterio de expropiación fue el abandono o la mala explotación de las tierras. Además del no cumplimiento de leyes sociales.

La ley contemplaba que las tierras expropiadas darían origen a los asentamientos, que eran unidades que debían durar al menos tres años para capacitar a las asociaciones campesinas en el manejo y la administración de los predios. Se reconoció el derecho a ser asentados sólo a los inquilinos residentes en el predio expropiado. (Cámara de Diputados de Chile, 2018, sp).

Con el Gobierno de la Unidad Popular (1970-1973), este proceso se acelera, expropiándose en este período 4.401 predios con casi siete millones de hectáreas. La Corporación de Reforma Agraria (CORA) expropió trece haciendas de la Comuna de Barrancas en este período, entre las que se encontraba el fundo de Lo Aguirre, del que es parte el terreno de Laguna Carén.

El golpe de Estado de 1973 puso término al avance del proceso de Reforma Agraria y desde ese momento se inició la Contrarreforma Agraria procediendo a la devolución de las tierras a sus antiguos propietarios o su remate a terceros, lo que fue acompañado de la represión a los campesinos y sus dirigentes. Como resultado, el $60 \%$ de las tierras expropiadas, no llegaron a manos de los campesinos. (Radovic, 2005, p.18)

La creación de "Reservas CORA" surgió como un recurso para redestinar tierras expropiadas que se calificaban como "inaptas para la Reforma Agraria", pudiendo el Fisco rematarlas o bien hacer destinación de ellas a organismos del Estado. Se trataba de terrenos como los de Laguna Carén, que fueron destinados al Ministerio de Defensa Nacional para las ramas de la Fuerzas Armadas o traspasadas al SAG (Servicio Agrícola y Ganadero) como sucesor legal de la CORA.

Como veremos más adelante, el predio de Laguna Carén, fue nominado Reserva CORA № 6 y traspasado al Ministerio de Defensa Nacional en 1981, para destinarlo a la Dirección General de Deportes y Recreación (DIGEDER), organismo dependiente de ese ministerio en dictadura.

En las décadas siguientes, el modelo neoliberal irrumpe en el mundo rural, produciéndose el traspaso de la tierra a nuevos capitalistas. Estas tierras serán destinadas a proyectos de modernización de la producción agrícola, o a proyectos inmobiliarios como es el caso de gran parte de lo que fue el Fundo Lo Aguirre.

Si bien este proceso pareciera ser invisible actualmente, en el acuerdo de límites con la Inmobiliaria El Bosque (Praderas), el deslinde poniente, fue definido respecto al antiguo camino CORA dado que éste se referencia en las escrituras del predio vecino, como un trazo indeleble del proceso de Reforma Agraria en Carén. Por otra parte, a partir de antecedentes aportados por la Fundación Defendamos la Ciudad, se ha hecho presente que:

${ }^{264}$ El impulso dado a las organizaciones comunitarias generó un fuerte cambio en la participación social de los habitantes de Barrancas.

${ }^{265}$ En 1967 fueron promulgadas la Nueva Ley de Reforma Agraria N 16.640 y la Ley $\mathrm{N}^{\circ} 16.625$, que permitió la sindicalización campesina. ...a las autoridades que le transfirieron gratuitamente este predio a la Universidad de Chile se les olvidó conservar en las escrituras públicas los derechos de los ex asentados, amnesia voluntaria que, lógicamente, favoreció al nuevo dueño. Por los apremios ejercidos por la Fundación Valle Lo Aguirre, algunas de esas familias han postulado a los subsidios habitacionales en otras comunas y ya han abandonado sus casas de madera construidas por ellos en esa zona rural (Herman, 2010, sp).

Según antecedentes actualizados, en el sitio viven aún 74 personas en situación irregular, las que constituyen 34 familias. De ellas 21 familias son ex inquilinos del fundo Lo Aguirre, que aún esperan tener su propia tierra. 
De algún modo y pese a que sistemáticamente se ha considerado a sus pobladores como "habitantes ilegales", ellos son una muestra viva de que la Reforma Agraria no está aún terminada. La incorporación de estos pobladores al Proyecto laguna Carén, parece un desafío ineludible. La posibilidad de identificar aquellas familias con quienes el Estado tiene una deuda, organizarlas y asentarlas adecuadamente en el predio, permitiría incorporar el tema agrícola en el parque con toda la complejidad que tiene. Esta podría ser una experiencia modelo de reparación, pero también de futuro ya que la universidad podría apoyar este proceso elaborando programas dirigidos a la agricultura familiar campesina, como ejemplo de soberanía alimentaria dentro de una política medioambiental y paisajística coherente.

Junto a la Reforma Agraria, otros procesos han modificado este valle en el período previo a la transferencia del predio de Laguna Carén a la Universidad. Se trata de tres polos de actividad cercanos al terreno de estudio y que, a la escala de la comuna, impactan en él: la ex Mina Lo Aguirre, el Centro de Energía Nuclear de Lo Aguirre y el Aeropuerto Internacional Arturo Merino Benítez (ex Pudahuel). Luego de estudiarlos, volveremos a Carén, para exponer las condiciones que hicieron posible la transferencia de este vasto territorio a la Universidad de Chile, su actual propietario.

\subsection{La minería en el valle de Lo Aguirre}

Chile tiene bajo sus pies un rico filón mineral, un área geológica que se extiende por el subsuelo y que convierte al país en un importante productor de cobre ${ }^{266}$, siendo la actividad minera su principal industria ${ }^{267}$.

La mina de Lo Aguirre, ubicada a menos de un kilómetro al poniente del predio, se conoce antes de 1800, cuando los jesuitas explotaban cobre de alta ley que luego fundían. Los investigadores Saric, Kreft y Huete (2003) señalan que entre 1865 y 1875 se procesaron allí minerales de baja ley (10-20\% de Cu) y su exportación se detuvo debido a la caída del precio del cobre en 1881. Más tarde, en 1914 el ingeniero norteamericano Willian Braden, el mismo que en 1902 había comprado la mina de El Teniente, inició los trabajos de prospección en el valle de Lo Aguirre, en las minas de Lo Aguirre y La Africana (a 2 kilómetros al sur de Carén). El potencial de estos yacimientos, llevó a que la empresa Anaconda Cooper Company a través de su subsidiaria Santiago Mining Company tomara el control de las propiedades y realizara un intenso programa de sondajes, los que se extendieron hasta 1924 (Saric, Kreft y Huete, 2003, p. 318). La mina de Lo Aguirre se mantuvo sin actividad hasta 1969. En el caso de La Africana, ésta se explotó en forma subterránea hasta el agotamiento del mineral en 1978.

Según relata Esteban Domic en el libro Crónicas Mineras de medio siglo (19502000), para Anaconda Co, dueña también de las minas de Chuquicamata y El Salvador, estos yacimientos eran menores y ante la eminente "chilenización del cobre" podían transformarse en un estorbo a las negociaciones con el estado. Fue así como ambas minas se vendieron al grupo de inversionistas chilenos Vial y Cruzat, conocidos popularmente como los piraña ${ }^{268}$. Pese a que, en el período de gobierno de la Unidad Popular, entre 1971 y 1973, las pertenencias mineras fueron intervenidas (Danus, 2014, p.247), tras el golpe de estado, las faenas se reiniciaron en La Africana y se evaluó comenzar el proyecto de Lo Aguirre.

Es así como la Vial y Cruzat, que habían creado la Sociedad Minera Pudahuel Ltda. (SMP) ${ }^{269}$ en 1969, ponen en marcha el proyecto 1975, considerando su explotación a "tajo abierto". En 1978 comienza la construcción de la planta, en 1979 la preparación de la mina y finalmente en noviembre de 1980 se inicia la producción de cátodos (Saric, Kreft y Huete, 2003, p. 318). El inicio de las operaciones marcó un hito en la industria minera chilena, ya que fue la primera faena minera en el mundo en aplicar a escala comercial la tecnología de lixiviación en pilas,
${ }^{266}$ En el año 2000 Chile producía el 34,7\% del cobre a nivel mundial, esta cifra baja a $31,1 \%$ en el año 2014. (Gentina y Acevedo, 2016).

${ }^{267}$ La gran minería del cobre se inició en 1902, cuando el ingeniero norteamericano William Braden reconoció el mineral de El Teniente y compró las pertenencias mineras, organizando dos años después en Nueva York la Braden Copper Company.

${ }^{268}$ Calificativo que el empresariado chileno le otorgó a un nuevo grupo de poder surgido en la década de 1970. Para Leopoldo Muñoz en su artículo sobre La invasión neoliberal en Chile (2002), uno de los cuatro pilares de este proceso está representado por "los piraña":

.un grupo de empresarios jóvenes asesorado por un visionario profesor de la universidad Católica, Manuel Cruzat, que ha estudiado en Chicago y en Harvard, logran sorpresivamente el control de Banco Hipotecario[...]el grupo formado por Manuel Cruzat, Fernando Larraín, Javier Vial y Ricardo Claro entre otros, emplearon en sus compañías a los mejores egresados. El golpe militar los encuentra preparados [en 1973]. Desde entonces y hasta la crisis del 81-83 serán el motor de la economía. (Muñoz, 2002, p.16). 


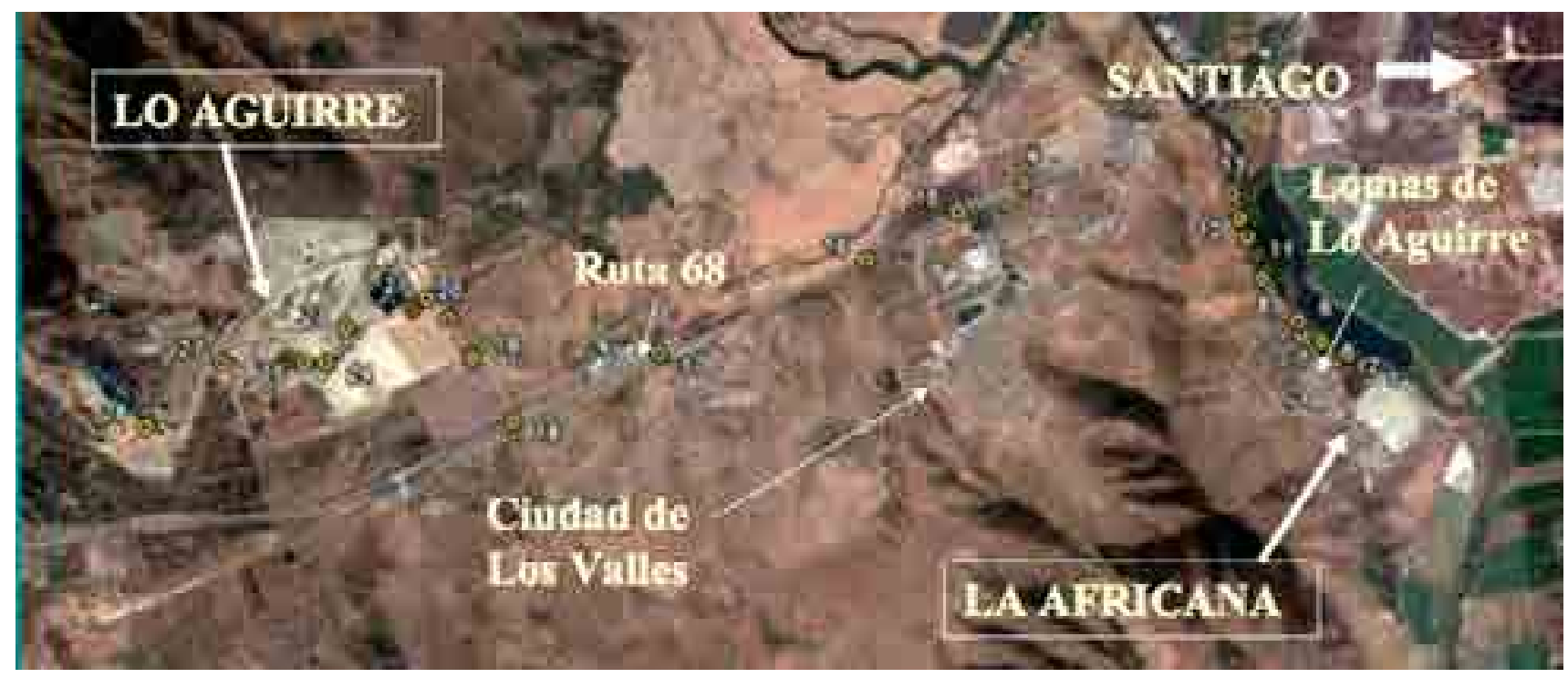

Figura 6.17. Ubicación de las minas de Lo Aguirre y La Africana, respecto a Laguna Carén. Por Nueva Pudahuel S.A. (NPSA, 2010, p.32) para óxidos de cobre y el procesamiento de minerales sulfurados con la ayuda de bacterias ${ }^{270}$. También fueron los primeros en producir cátodos de cobre mediante electro-recuperación, una innovación que revolucionó la industria minera en el país al aplicarla en yacimientos mayores y sobre materiales ya removidos de faenas pasadas. Localmente, estas aplicaciones permitieron que la mina produjera anualmente 17.500 toneladas de cobre fino en cátodos hasta la fecha de cierre, en el año 2000, con una producción total de 19 millones de toneladas de mineral (Saric, Kreft y Huete, 2003).

El cierre voluntario ${ }^{271}$ de la mina Lo Aguirre ha tenido una amplia difusión, siendo citado como un modelo al "asegurar la estabilidad física y química de los materiales removidos, propendiendo con ello a proteger la integridad y salud de la población, los recursos naturales y/o el medio ambiente" (NPSA, 2010, p. 1).

Como se muestra en la siguiente imagen (Figura 6.18.), el área de intervención de la mina es de 43 hectáreas con seis zonas de botaderos. Los trabajos de recuperación del sitio se extendieron por casi 9 años y se autofinanció a partir de la recuperación, traslado y venta de materiales resultantes.

Sin embargo, según una presentación de la propia empresa Nueva Pudahuel S.A.(NPSA) "El desafío principal de remediación para NPSA, ha sido la existencia de una línea base de medio ambiente físico de alta pluviosidad estacional y un canal de aguas lluvia que pasa por medio de las pilas hasta la Laguna Carén" (NPSA, 2010, p. 11), como se muestra en la siguiente imagen (Figura 6.19.):

Este canal, una conexión física con la antigua mina, es un elemento que debe ser permanentemente observado, por cuanto representaría una fuente de contaminación de la laguna especialmente ante lluvias intensas. Vale decir, se deben evitar filtraciones para que las aguas lluvias no se mezclen con los residuos que aún permanecen debajo de las obras de remediación ambiental y drenen hacia la Laguna Carén. Ésta es otra de las huellas que la historia ha dejado impresa en el territorio. Reconocerla, permitiría integrar en el "guion" del proyecto una visión crítica a la historia de la minería en Chile, entender que ese filón que Chile tiene a sus pies, que genera tanta riqueza, puede al mismo tiempo provocar graves daños medioambientales. El tema minero permite también profundizar sobre la condición geológica ${ }^{272}$ del sitio, reforzando así el potencial didáctico del parque.

Por otra parte, estudiar la historia de la mina Lo Aguirre, nos ha permitido comprender cómo los grupos económicos han operado en los últimos 40 años en este territorio. 


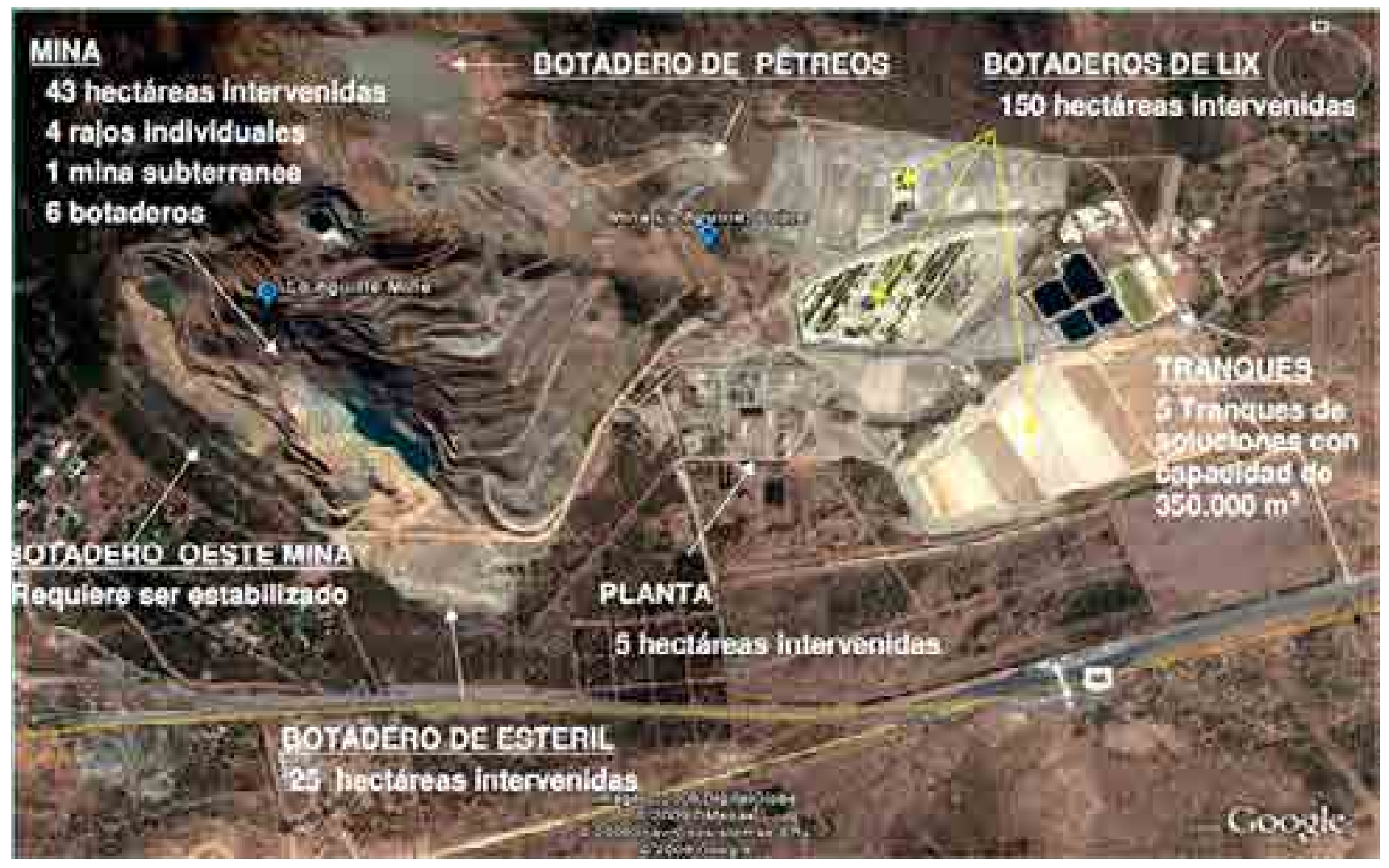

En una publicación del Diario Financiero del 29 de junio de $2010^{273}$ titulada "Grupo Cruzat apura cierre de mina para dar paso a proyecto inmobiliario" relaciona el interés por el cierre de la mina con el proyecto Praderas, vecino al sitio de Laguna Carén. Praderas, del que también es socio Cruzat junto a Hurtado-Vicuña, es un proyecto que consiste en la construcción de 20 mil viviendas para albergar a unas 80.000 personas bajo el modelo de los Proyectos de Desarrollo Urbano Condicionado (PDUC) que el Ministerio de la Vivienda y Urbanismo ha impulsado para el desarrollo de predios de más de 300 ha que se ubican fuera del límite urbano, modelo que estudiaremos en conjunto a las condicionantes normativas que rigen nuestro caso de estudio. Por su parte, en otro medio, The Clinic.cl el 5 de abril de 2015 parece sentenciar que, pese a que los proyectos han tenido un largo proceso de aprobación, la especulación inmobiliaria seguirá extendiendo los límites de la ciudad de la mano de "una clase empresarial bien conectada y un Estado que lejos de fiscalizar, ha pavimentado un camino sin retorno", sugiriendo que, como Curauma, ${ }^{274}$ que ya está en desarroIlo, ciudad de Lo Aguirre (Praderas) logrará convertir el suelo rural en urbano.

Cruzat fue uno de los primeros empresarios del país en descubrir el rentable negocio de la especulación con el suelo. Antes de los 80 ya poseía terrenos en La Dehesa, La Florida y San Carlos de Apoquindo, todos de uso rural. Pero con la crisis económica del 82 los perdió todos, menos sus regalones: Minera Lo Aguirre y Forestal Valparaíso. Del primero salió el proyecto inmobiliario Lo Aguirre, ubicado en Pudahuel, y del segundo, Curauma (Yáñez,5 de abril, 2015).

En este contexto, cabe preguntarse qué responsabilidad y rol tiene el sitio de Laguna Carén en una zona que sigue siendo rural, pero que probablemente se convierta en una extensión de la ciudad de Santiago en los próximos años.

\subsection{EL CENTRO DE ENERGÍA NUCLEAR DE LO AGUIRRE}

La energía atómica sigue siendo de algún modo un tema tabú en Chile. Esto se

${ }^{272}$ La que profundizaremos en el capítulo 7.

273 http://www.enernews.com/nota/159236/ cruzar-acelera-el-cierre-de-su-mina-loaguirre

274 The Clinic señala más adelante respecto a Curauma:

En abril del 2012 y luego de largos años de negociación, se aprobó la modificación del Plan Regulador Metropolitano, logrando que el fundo Las Cenizas, que tenía inscripción agrícola, por fin se transformara en urbano. El fundo La Luz había conseguido lo mismo unos años atrás, aumentando su plusvalía más de diez veces y actualmente alberga a más de 27 mil personas. Los vecinos de los alrededores se opusieron a la medida y aseguraron que no estaban las condiciones viales para la densidad de habitantes. En diarios como La Estrella de Valparaíso, enviaron cartas para expresar su preocupación. Sin embargo, la tramitación del Plan Regulador siguió adelante. Yáñez, 5 de abril, 2015) 


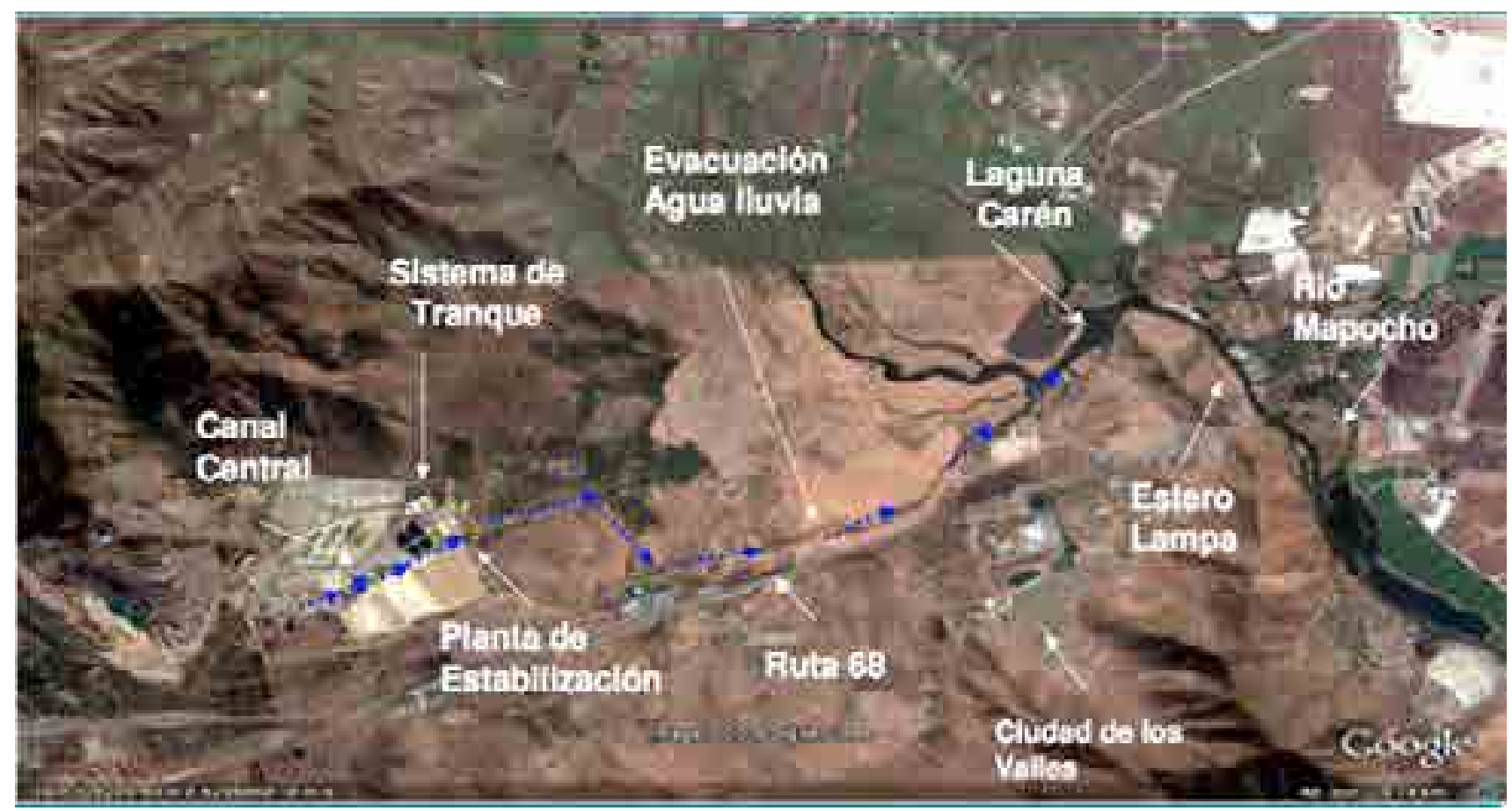

Figura 6.19. Plan de Cierre Mina Lo Aguirre. Mapa con el trazado del canal de aguas lluvias que desemboca en la laguna Carén. Por Nueva Pudahuel S.A. (NPSA, 2010, p. 11)

\footnotetext{
275 Terremotos, Tsunamis, erupciones volcánicas, inundaciones y aluviones. Chile es el país más sísmico del mundo y registra el mayor terremoto de la historia, con 9,5 Richter en el año 1960

${ }^{276}$ En 1954, llegó a la Facultad de Ciencias Físicas y Matemáticas un acelerador de partículas Cockroft-Walton, con el que comenzó la investigación en energía nuclear en Chile. La intensa actividad en torno al acelerador de partículas generó discusiones sobre cómo debía ser la formación de los profesionales del área, así en 1960 fue creada la Licenciatura en Física de la FCFM.
}

debe principalmente al desconocimiento del tema y al impacto que tuvo el accidente nuclear de Fukushima provocado por un terremoto de $8,8^{\circ}$ y su posterior tsunami; hechos acaecidos poco más de un año después del gran terremoto y tsunami que azotó a Chile el 27 de febrero de 2010. La condición telúrica del territorio, es sin duda una marca importante en la cultura nacional. La conciencia del riesgo y de que la "tierra firme" no es tal para Chile, ha hecho que la idea de incorporar la energía atómica no sea aceptada, por constituirse en un riesgo más, que se sumaría a la larga lista que la geografía del país nos ha legado ${ }^{275}$. Este a priori, provoca también un desconocimiento del tema en la ciudadanía, incluso en las elites. En una encuesta realizada en 2017 a 49 líderes de opinión, se detectó que éstos tienen una apreciación que no difiere del ciudadano común, tampoco su nivel de conocimiento del tema. El estudio titulado ¿Qué piensa la élite de la energía nuclear? muestra que esta energía "es vista principalmente como una amenaza, evaluándola con un alto riesgo económico, social, político y geográfico". Además, existe "gran desconfianza de la capacidad del Estado [...] y de los profesionales chilenos. Incluso, los más favorables a la energía nuclear, dicen que faltaría la formación de una generación de profesionales, antes de pensar en la instalación de una planta" (González,17 de mayo, 2017).

Poco se conoce también de la evolución de la energía nuclear en Chile y de las aplicaciones tanto médicas como de control medioambiental que desde esta área se realizan.

La historiadora Adela Cubillos en su artículo "El desarrollo de la Energía nuclear en Chile" señala que el país inició su desarrollo en el campo de la energía nuclear más tardíamente que otros países de la región, especialmente respecto a Argentina y Brasil (Cubillos, 2011, p. 150), países que, cabe señalar, no tienen actividad sísmica. El principal impulso a la introducción de estas tecnologías se produjo por la iniciativa del senador Eduardo Cruz Coke en el año 1955 y por la Universidad de Chile que introdujo cursos de especialidad en la Facultad de Ciencias Físicas y Matemáticas a partir de $1954^{276}$. Sin embargo, la acción del estado tardaría diez años en manifestarse, creando en 1965 la Comisión Chilena de Energía Nuclear (CCHEN), para más tarde, en los años setenta, gracias a la cooperación internacional, instalar dos centros de estudios nucleares, el de La Reina y Lo Aguirre (Cubillos, 2011, p. 164). La ubicación del primero fue gestionado por los alcaldes de tres comunas de la zona oriente de la ciudad y, en el caso de Lo Aguirre, el terreno fue donado por la empresa Anaconda Cooper Company al Ejército ante la inminente expropiación por parte del gobierno de Allende de la mina. Este sitio, vecino a la mina Lo Aguirre, era utilizado como un lugar de recreación y descanso para los operarios faena, y se encuentra próximo al acceso al túnel Lo Prado, visible desde la Ruta 68, a 6 km del predio de Laguna Carén. La elección del terreno 
en Lo Aguirre respondía a los requisitos establecidos por el OIEA (Organismo Internacional de Energía Atómica) y los comprometidos en el acuerdo firmado en 1972 entre España y Chile sobre Energía Atómica para fines pacíficos. Ese mismo año se inician los trabajos en el Centro de Estudios Nucleares de Lo Aguirre, con el apoyo de la Junta de Energía Nuclear de España.

Con posterioridad, el 29 de mayo de 1973 por Decreto Supremo No 170 del Ministerio de Defensa, se creó oficialmente el Centro de Estudios Nucleares del Ejército CENE, como organismo destinado a ejecutar la política de participación de las Fuerzas Armadas en el desarrollo nuclear nacional. En sus instalaciones cuenta con un reactor de investigación de 10MW, una planta de irradiación gamma multipropósito, con laboratorios, talleres y biblioteca. El Centro Nuclear de Lo Aguirre agrupaba todas las actividades del ciclo del combustible nuclear, desde la prospección de materiales de interés nuclear hasta el tratamiento y disposición de desechos radiactivos (CCHEN, 1989, p.14). El reactor RCH2 fue puesto en marcha por primera vez en 1977, para luego ser sometido a múltiples innovaciones y, recién en 1989 iniciar su funcionamiento definitivo.

Según información de la Comisión Chilena de Energía Nuclear, en la actualidad, este reactor se encuentra en parada permanente, como respaldo del Centro de la Reina, que está en funcionamiento, destinado a aplicaciones médicas, mineras y agrícolas. En febrero de 2010, se retiró la totalidad del combustible radiactivo de su núcleo, el que fue enviado a los EE.UU. Hoy el reactor se encuentra sólo con agua desmineralizada, no radiactiva, en una piscina sellada y sometido a un estricto programa de mantenimiento anual (CCHEN, 2018, p. 101). Pese a que el reactor no está en funcionamiento, el Centro está operativo y recibe visitas ciudadanas y de estudiantes universitarios de carreras afines a las investigaciones que allí se realizan. El año 2018, se registraron 2.267 visitas a la planta (CCHEN, 2018, p. 129).
Figura 6.20. Área de exclusión (sección de círculo) del Centro de Energía Nuclear de Lo Aguirre, respecto al predio de Laguna Carén (delimitado en rojo). En Plan Regulador Metropolitano de Santiago (PRMS), Seremi Minvu,1994.

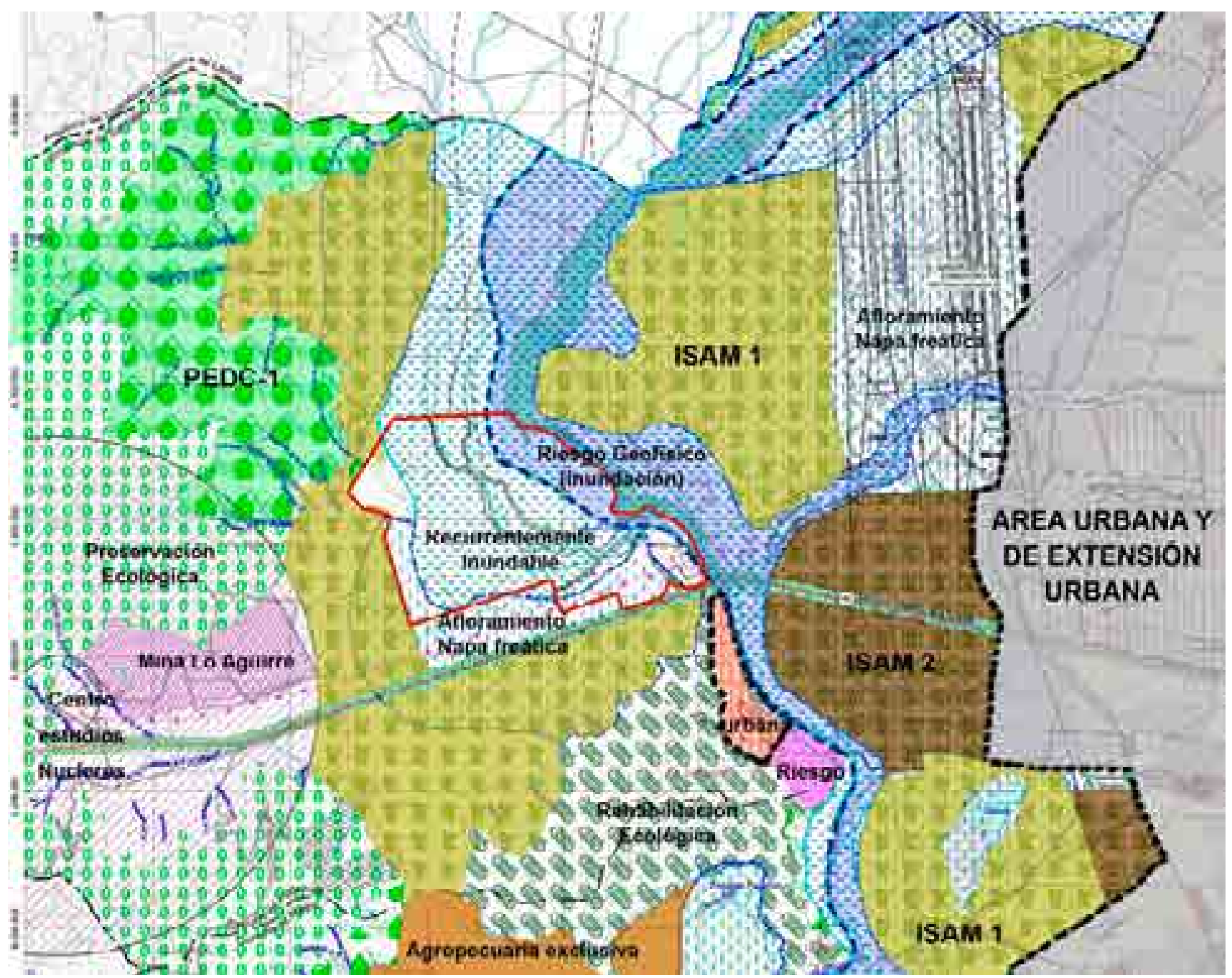


Desde el punto de vista territorial, estas instalaciones están clasificadas como "Áreas de Riesgo por Actividades Peligrosas" (Artículo 8.2.2.) en el Plano Regulador Metropolitano de Santiago definiendo las condiciones específicas en el Artículo 8.2.2.1. "De Protección de Centros Nucleares". Para Lo Aguirre particularmente, se define un área de protección limitada por una circunferencia de $3.800 \mathrm{~m}$. de radio, con centro en la chimenea del reactor, la que afecta a territorios de las comunas de Pudahuel y Curacaví, quedando el terreno de Laguna Carén fuera de su borde exterior como se observa en la Figura 6.20. Dentro de la franja de exclusión, entre los $600 \mathrm{~m}$ y el borde de la circunferencia, se permite la instalación de equipamiento que no implique la permanencia prolongada de personas o concentración masiva de ellas.

Un aspecto que llama la atención de esta norma, es que deja bajo la tuición de la Secretaría Ministerial Metropolitana de Vivienda y Urbanismo, y de la Comisión Chilena de Energía Nuclear, "La delimitación, precisión de su radio de acción, como asimismo las normas específicas en relación a la intensidad de ocupación del área de protección y usos de suelo permitidos" (PRMS, 1990, p.125), sin considerar la opinión del gobierno comunal ni de los ciudadanos.

Sin embargo, en el marco del instructivo Presidencial del 2008 para la participación Ciudadana en la gestión Pública, la Comisión Chilena de Energía Nuclear creó en el año 2009 el Consejo de Sociedad Civil de la CCHEN. Este órgano de carácter autónomo e independiente de ministerios y servicios del Estado, es consultivo, y en esa calidad participa en el proceso de toma de decisiones de la autoridad ${ }^{277}$. El consejo actual está compuesto por 15 miembros representantes de la sociedad civil del sector, "sin exclusiones y respetando el equilibrio de género y diferentes corrientes de opinión" (CCHEN, 2018, p. 130).

De este modo, estas instalaciones que, en una primera instancia representarían un riesgo, dada las condiciones actuales de operación y su apertura a la comunidad, pueden ser vistas como un componente de la trama territorial en la que se inserta el proyecto. La inclusión del Centro de Energía Nuclear en el relato de este territorio, también abre la posibilidad de ser parte de la discusión acerca de la energía nuclear en Chile y desde "fuera del radio de protección" promover el conocimiento de ésta, para que la sociedad civil pueda actuar con fundamento ante decisiones que le atañen.

\subsection{EL AEROPUERTO ARTURO MERINO BENÍTEZ}

El aeropuerto, durante el período de desarrollo de esta tesis ha estado en plena faena de ampliación. Las obras iniciadas en 2016 y que concluyen el año 2020, permitirán recibir 30 millones de pasajeros anuales, ubicándolo entre los 100 mejores aeropuertos del mundo. La realización de esta gigantesca obra de más de 200 mil metros cuadrados y 900 millones de dólares de inversión se ejecuta a través del sistema de concesiones, modalidad implementada por el estado para las obras públicas desde los años 90.

Si bien el aeropuerto está a 6 kilómetros del terreno de estudio (Figura 6.21.), su impacto no sólo se relaciona con la fácil accesibilidad a través de autopistas, sino que también en la relación entre el espacio aéreo y el territorio de Laguna Carén, ya que éste es paralelo a la franja de aproximación de los aviones. Vale decir, el terreno se ve nítidamente desde las aeronaves, en las maniobras de despegue y aterrizaje, factor de legibilidad que no es habitual en los grandes proyectos. La visión "desde arriba", ofrece la posibilidad de que el parque pueda ser leído por millones de personas.

277 En la composición del CSC de la CCHEN se considera integrar, principalmente, a representantes de las organizaciones vecinales de las comunas aledañas a los Centros de Estudios Nucleares. Además, considera a los usuarios del programa de visitas guiadas, esto es, representantes del área académica y, finalmente, a clientes de los productos y servicios que provee la CCHEN.

El aeropuerto internacional, en el actual emplazamiento fue inaugurado en 1967 con el nombre de aeropuerto de Pudahue ${ }^{278}$. En 50 años de operaciones, el tráfico se ha multiplicado casi 31 veces. Según los primeros registros de 1973, ese año viajaron 681.033 pasajeros, llegando a más de 21 millones el año 2017.

El primer aeropuerto internacional estaba ubicado en Cerrillos, una comuna al 
sur de la capital, que como hemos visto en el capítulo anterior, se convirtió en un parque público luego de su cierre. El cambio de emplazamiento se debió a que el crecimiento de la ciudad dejó sin posibilidades de extender la única pista que Cerrillos tenía. La zona de Pudahuel ofrecía la posibilidad de expansión y condiciones geográficas mejores para la operación de las naves. Sin embargo, este emplazamiento también presentaba algunos problemas derivados de la neblina matinal, que, como hemos relatado, caracteriza a la zona poniente de Santiago, y del suelo de fundación que en este valle es de origen fluvio-glacial de material pumicítico. La elección de esta zona nos revela también cuan "disponible" se presentaba desde el punto de vista de la ciudad. Cuando se instaló el aeropuerto, el sitio estaba totalmente fuera de los límites urbanos y se suponía que esta zona permanecería rural, entendiendo lo rural como un vacío disponible.

Los terrenos en los que se construyó el aeropuerto eran hasta el año 1950 propiedad de la familia Marlo Marticoreno (García, 2011, p. 188) y estaban dedicados a la ganadería y producción de leche. Correspondía a parte de las antiguas haciendas La Punta y el Peral (que fueron de los jesuitas). La parcelación de estos fundos fue parte del proceso de la Reforma Agraria realizada por la CORA (Corporación de la Reforma Agraria), dando como resultado los asentamientos de dos cooperativas agrícolas: Pudahuel y Manuel Rodríguez. Si bien este proceso se consolidó en 1976, el crecimiento de la actividad aeroportuaria ha ido desplazando a las comunidades campesinas. El proceso de erradicación de estos habitantes, ha sido estudiado por Johann García (2011), como ejemplo de comunidades resilientes a los cambios producidos por este tipo de infraestructura. Este estudio ha sido especialmente importante en mi reflexión, ya que en los años 1990 participé tanto en el concurso como en el desarrollo del proyecto para la nueva terminal aérea de Pudahuel y, puedo dar fe, de que estas comunidades fueron totalmente invisibles para el proyecto. Ni los mandantes (el Ministerio de Obras Públicas), ni los asesores internacionales (Aeroport de París con Paul Andreu a la cabeza), ni los arquitectos locales (la oficina Montealegre \& Beach Arquitectos, junto a Emilio Duhart), reparamos sobre aquellos habitantes ni sobre el impacto que esta obra producía sobre el campo, la meso y macroescala. En el estudio de García, se demuestra como "para los pobladores el aeropuerto ha significado una situación de empobrecimiento" (García, 2011, p. 179). Si bien desde el punto de vista formal, el nuevo edificio terminal recoge y se inspira en la geografía del valle, en el paisaje. El concepto de paisaje que opera en el proyecto, corresponde más al de escenario de aquello que se observa desde lejos y se incorpora en la forma. Incluso, el diseño paisajístico del proyecto se restringe al área del edificio, especialmente en el interior, creando un micro clima vegetal (que luego se eliminaría para reemplazarlo por locales comerciales). Las capas históricas inscritas sobre el territorio, la comprensión del relieve, los cursos

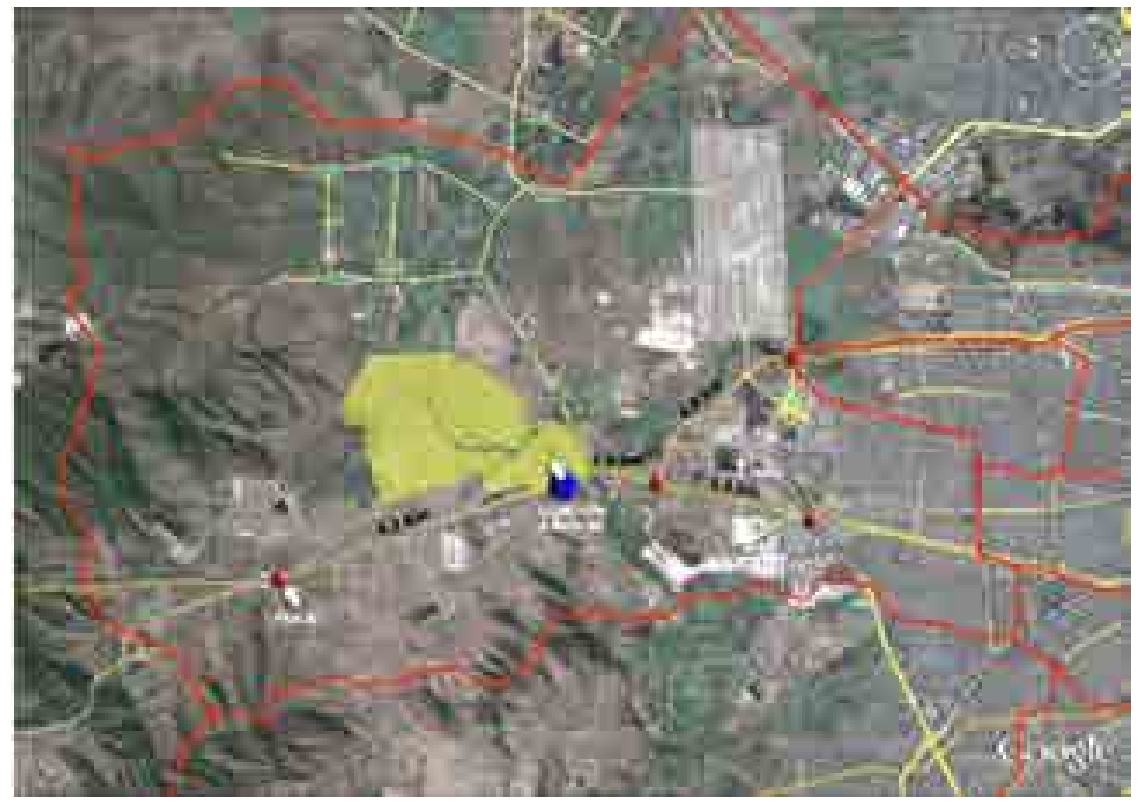

278 El nombre de Pudahuel buscaba homologar este aeropuerto con el territorio que lo acogía, luego el cambio de nombre de la comuna de Barrancas a Pudahuel en 1975, refuerza la relación. (Boettinger, 2001)

Figura 6.21. Emplazamiento del Aeropuerto Internacional Arturo Merino Benítez (AMB). Elaboración propia a partir de imagen obtenida de Google Maps 
de agua y la vegetación, no fueron variables, salvo la dificultad que conllevó la fundación sobre pumicita (toba pumicítica) 279. Tampoco el contexto humano que habitaba este lugar y sus alrededores. Sólo después del año 2000, en una etapa de ampliación, las comunidades de Peralillo, Campo Alegre y Soberanía Urbana lograron que las nuevas obras se sometieran al Sistema de Evaluación Ambiental, asunto que no había sido considerada por la autoridad. Esta evaluación, puso de manifiesto los efectos que no habían sido estimados, como el reasentamiento de las comunidades agrícolas, aislamiento territorial debido a que la única vía de acceso fue concesionada, los desvíos de cursos de agua para el regadío y el ruido producido por el despegue y aterrizaje de aviones (Garcia, 2011, p. 192). Para estos habitantes (2.396 personas, según el estudio), la ciudad es lo externo, una fuerza que los expulsa de su espacio cotidiano, un espacio que ahora es "expansión urbana". Vale decir, planificado por visiones hegemónicas, intereses nacionales y regionales que instalan allí sus infraestructuras y proyectos inmobiliarios. Lo interesante es que adoptando discursos globales, como es "la defensa del medioambiente", han logrado que los "expertos" y políticos consideren dentro de los proyectos la realidad de los asentamientos preexistentes y, al mismo tiempo, ha significado que las propias comunidades se organicen y establezcan relaciones de solidaridad para no desaparecer, reforzando su identidad.

Desde el punto de vista físico, Pudahuel progresivamente se convierte en una comuna logística aeroportuaria. Esto ha implicado la aparición de grandes zonas destinadas a bodegaje, perdiéndose de este modo la granulometría de la zona, hoy subdividida en grandes paños con bodegas inmensas y herméticas, como se observa en la Figura 6.22. Éstas median entre el área urbana de la comuna de Pudahuel y el terreno de estudio, prácticamente rodeándola hacia el oriente y hacia el sur. Este contexto convierte las vías de aproximación al terreno de Carén en zonas inhóspitas, con largas cuadras sin actividad, sin sombra, ni árboles. La conexión peatonal desde la zona urbana de la comuna es así dificultosa. Por el contrario, la aproximación desde la zona rural de Noviciado (al norte) puede ser habilitada, integrando el estero Carén al recorrido y vinculando el límite norte a los predios agrícolas de esta localidad.

279 El nuevo terminal proyectado en 1993 se fundó sobre un sistema de pilotes de hormigón hincados a $18 \mathrm{~m}$ de profundidad.

Figura 6.22. . Fotografía de zona vecina al predio (ENEA) con instalaciones logísticas. Al fondo cerro Amapola. Imagen capturada de Google Maps - Street View (abril, 2012).

\subsection{VOLVIENDO AL TERRENO DE LAGUNA CARÉN}

El fundo de lo Aguirre, hasta inicios del siglo XX tuvo gran estabilidad, debido a que, entre otras cosas, constituyo un mayorazgo que al diluirse pasó a la familia Larraín que lo vendió a la empresa norteamericana Santiago Mining Company,

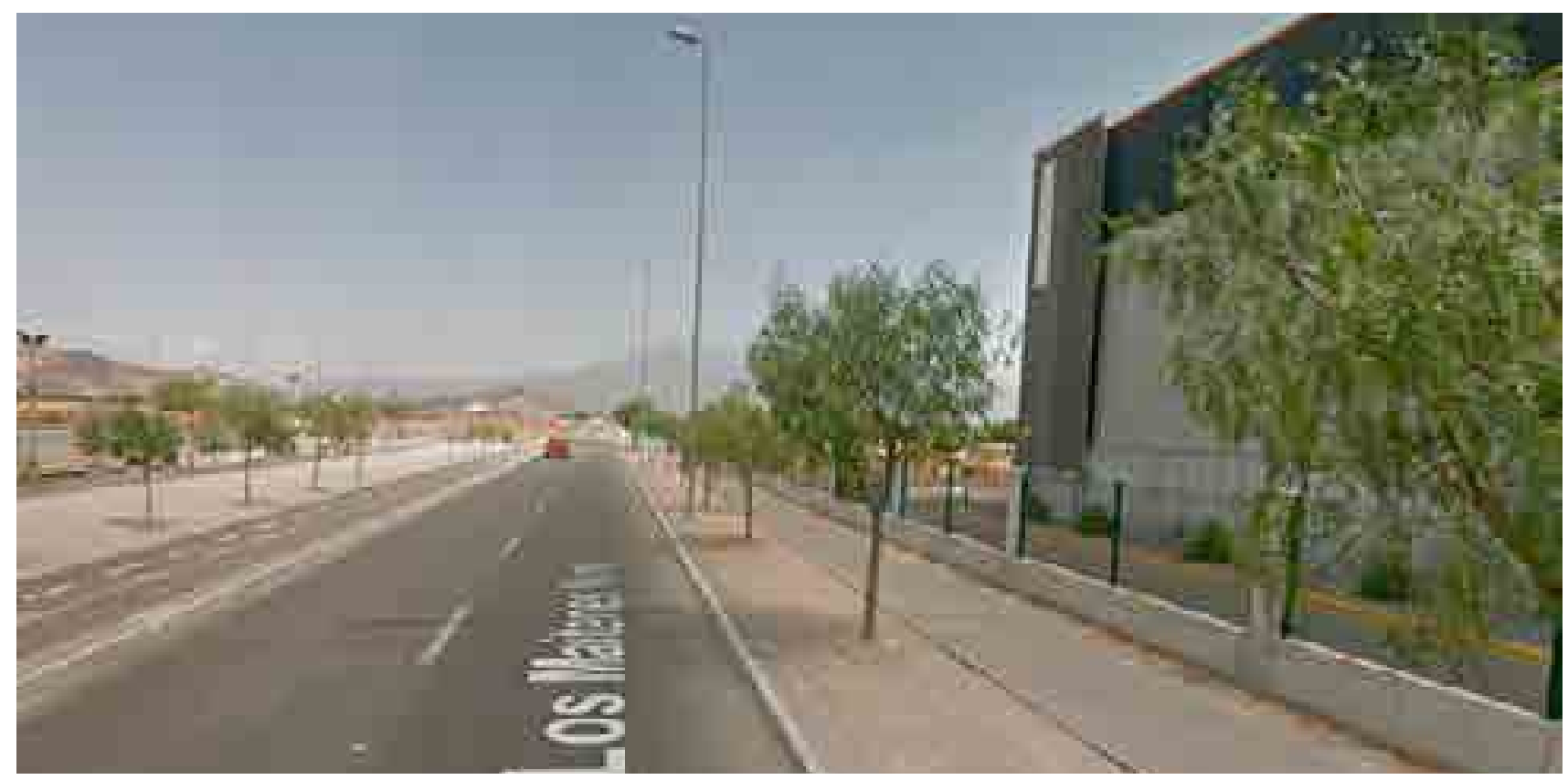


quién posteriormente lo subdivide. Como hemos visto, uno de los retazos fue donado al Ejército de Chile, para construir el Centro de Energía Nuclear de Lo Aguirre. La zona restante, pasó en 1969, a manos de la Sociedad Minera de Pudahuel. El proceso de Reforma Agraria parceló el paño que no estaba ocupado por la mina en 1972, sin llegar a hacer efectiva la entrega de terrenos a los campesinos.

Como hemos visto, la dictadura militar, revirtió el proceso de Reforma Agraria, definiendo este paño como Reserva CORA N ${ }^{\circ} 6$ (sin aptitud agrícola) limitado al poniente por otras reservas de tamaño menor, a través del "Camino Cora", una franja que por ley aún existe.

Como otros sitios calificados como Reserva CORA, éste pasó a manos del SAG (Servicio Agrícola y Ganadero) en $1972^{280}$.

El Fisco adquirió el predio por donación gratuita que le hizo el Servicio Agrícola y Ganadero (SAG) por escritura de fecha 17 de agosto de $1981^{281}$, otorgada en la Notaría de Santiago de don Martín Fuentes Hurtado. Todo ello dado que la Reserva CORA N ${ }^{\circ} 6$, formaba parte de su patrimonio y provenía del proceso de Reforma Agraria. Así se dio cumplimiento a lo dispuesto en el acuerdo de Consejo № 6046 del 20 de octubre de 1978, por la Corporación de Reforma Agraria, que había dispuesto transferir a título gratuito al Ministerio de Defensa Nacional, para su uso por la Dirección General de Deportes y Recreación. Por ello, posteriormente, por Resolución Exenta N051, la Secretaría Regional Ministerial de Bienes Nacionales de la Región Metropolitana, hizo destinación del predio en favor del Ministerio de Defensa Nacional-Dirección General de Deportes y Recreación. Durante el régimen militar se instalaron en el predio varias asociaciones deportivas, algunas de ellas formalizando el uso que hacían de la laguna desde épocas anteriores. Se construyó una "medialuna" de rodeo, deporte que fue estimulado en este período como expresión de "chilenidad". También aparece una zona de golf en tierra, próxima a la ruta 68 , a la derecha del acceso, la que, según relatos orales, fue encargada por uno de los miembros de la Junta de Gobierno, el Almirante José Toribio Medida, quién practicaba allí este deporte.

Con el fin de la dictadura, en los años 1990, el predio se mantuvo en manos de la DIGEDER con intervenciones mínimas, manteniéndose el uso recreativo.

Al finalizar el primer gobierno democrático post dictadura, 11 días antes del cambio de mando, el Presidente Patricio Aylwin firmó el decreto ${ }^{282}$ de transferencia

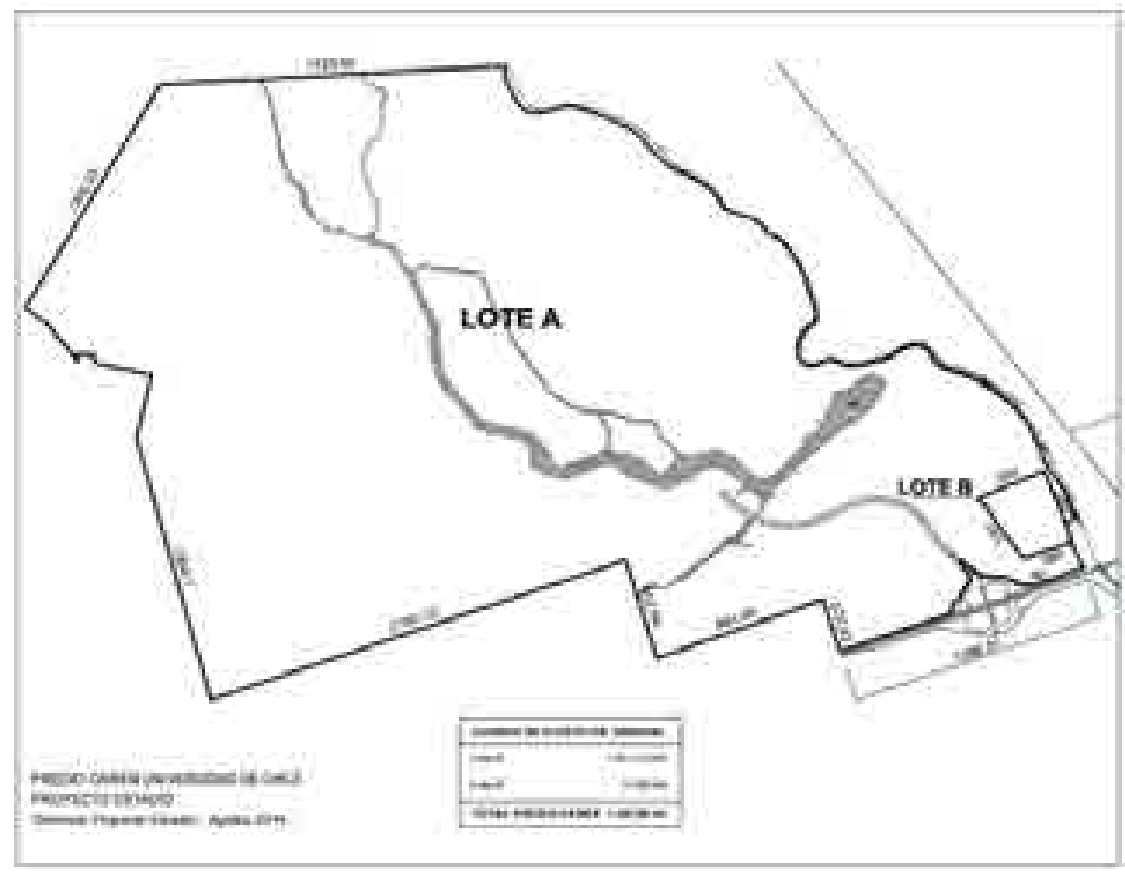

280 Inscrito en el Conservador de Bienes raíces de Santiago del año 1972 a Fojas 2915 № 3910

${ }^{281}$ Otorgada en la Notaría de Santiago de don Martín Fuentes Hurtado, inscrito en el Conservador de Bienes raíces de Santiago del año 1972 a Fojas 2915 № 3910

Figura 6.23. Plano del predio Laguna Carén, donde se individualizan el lote $\mathrm{A}$ y $\mathrm{B}$. En Gerencia Proyecto Estadio (Agosto, 2014). 
${ }^{282}$ Decreto 350 de 28 de febrero de 1994, del Ministerio de Bienes Nacionales

${ }^{283}$ El título respectivo figura inscrito a Fs. 53.967 No 38.199 del Registro de propiedad del Conservador de Bienes Raíces de Santiago, correspondiente al año 1994.

${ }^{284}$ El profesor Iñigo Díaz Cuevas es Ingeniero Forestal. Fue Vicerrector Académico de la Universidad de Chile y también Decano de la Facultad de Ciencias Forestales.

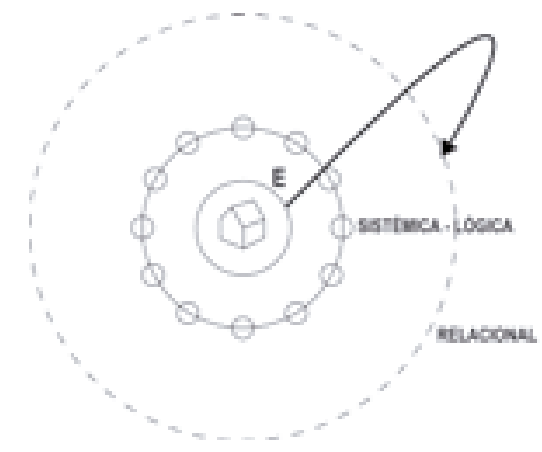

Figura 6.24. Esquema conceptual del capítulo. Elaboración propia. gratuita a la Universidad de Chile del "inmueble signado como Lote A, que corresponde a parte del predio denominado Reserva CORA № 6 del Proyecto de parcelación "Lo Aguirre", Comuna de Pudahuel, Región Metropolitana, de una superficie de 1.011,10 hectáreas", donación que se materializó mediante escritura de fecha 25 de marzo de $1994^{283}$. Del mismo modo, a través del decreto supremo $N^{0} 202$, de fecha 25 de mayo de 1999, se dispuso la transferencia gratuita del inmueble signado como lote "B" que también forma parte de la Reserva CORA N ${ }^{\circ} 6$ de una superficie de 11,8 hectáreas, con el fin de anexarlo al lote "A", completando así la superficie actual (1.022 hectáreas), según se muestra en el siguiente plano (Figura 6.23).

La donación por parte del Estado a la Universidad de Chile de este vasto terreno, tenía el objeto de desarrollar un proyecto denominado "Parque Científico Tecnológico" y una "Ciudad Universitaria", comprometiendo también la creación de un "Parque Público de 200 hectáreas". El citado decreto definía también un plazo de cinco años para iniciar el proyecto, de lo contrario, el Fisco recuperaría el dominio de la propiedad.

Para concretar esta tarea, la universidad creó un año más tarde, en 1995, la Fundación Valle Lo Aguirre (FVLA), entregándole el usufructo del terreno por 30 años, con el mandato de llevar a cabo el proyecto. Al mismo tiempo, nombra a Patricio Rojas como vicepresidente Ejecutivo de la Fundación, quien un año antes siendo Ministro de Defensa Nacional, había impulsado la transferencia del predio a la universidad. Este asunto ha sido motivo de controversia pública, como también de resistencias al interior de la propia universidad frente al proyecto y su administración. Sin embargo, no es hasta el año 2009 que Patricio Rojas abandona el cargo, asumiendo la vicepresidencia ejecutiva de la Fundación el profesor Iñigo Díaz ${ }^{284}$. Cabe aclarar que según los estatutos de la Fundación Valle Lo Aguirre, el presidente de ésta, por derecho propio, es siempre el Rector de la Universidad de Chile.

Transcurridos 25 años desde que la Universidad de Chile adquiriera el dominio de Laguna Carén, y pese al esfuerzo de varias rectorias, la inversión de más de 15 millones de dólares, la presión de innumerables auditorías e investigaciones de la Contraloría General de la República, aún no se concreta un proyecto. Como veremos en el capítulo 10, el proyecto de Laguna Carén ha sido pensado, soñado y criticado durante más dos décadas. Estas ideas se han plasmado en diversos Planes Maestros y propuestas particulares o sectoriales, las que expresan diversas visiones tanto sobre el territorio y el paisaje, como sobre la relación entre el territorio y la ciudad. Una ciudad que ha cambiado y junto a ella sus instrumentos de planificación, los que serán analizados en el capítulo 9, donde estudiaremos el marco normativo que regula el futuro de esta zona. La situación actual se incorpora también como antecedente para este análisis, como una capa más de este palimpsesto.

\subsection{A MODO DE SÍNTESIS}

En este capitulo se desarrolla un primer acercamiento al territorio del proyecto. Se inicia con lo que Christophe Girot llamaría el "aterrizaje", vale decir, el primer acto de reconocimiento del sitio, que marca necesariamente el comienzo del proyecto como aventura. Es el momento en el cual se confrontan la idea preconcebida del lugar y la realidad que aparece durante los primeros pasos de una visita. Llegamos al sitio con ideas y prejuicios, y es justamente el derrumbe de éstas, frente a la experiencia subjetiva, la curiosidad y el asombro, lo que impide considerar de ahí en adelante el sitio como tabula-rasa y dan una guía para iniciar el estudio del lugar, que contempla nuevas visitas y la consulta a diversas fuentes. El énfasis de la segunda parte de este capítulo ha estado inspirado por lo 
que Girot (1999) llama "puesta a tierra", vale decir, por la búsqueda de evidencias que nos permitan descifrar las fuerzas y eventos que explican la evolución del lugar, las que, sin ser necesariamente visibles, contribuyen a definir su carácter y rol a distintas escalas. Este proceso podría ser ubicado en el esquema siguiente (Figura 6.24) como un salto desde la esfera estética (primer encuentro) a la antropológica (investigación sobre la historia del sitio y su contexto), con el objetivo de identificar rasgos identitarios presentes a distintas escalas: la del Valle Central, la de la ciudad de Santiago, la de la Comuna de Pudahuel (ex Barrancas) y comunidades aledañas, y de las que habitan en el sitio, para de este modo, recuperar algo de la amnesia cultural que nos aqueja.

Por lo tanto, postergando el inventario ecológico ${ }^{285}$, la investigación del sitio ha incluido una serie de preocupaciones que van más allá de los límites de propiedad, tales como intereses económicos y políticos, cuestiones demográficas, migraciones, coyunturas políticas, mitos y poesía. La investigación del sitio también explora cómo los sistemas han evolucionado y han operado a través del tiempo, cuestionando cómo y porqué llegó el paisaje al estado actual, para luego registrar lo que ya está allí.

Lo anterior está fuertemente influido por las consideraciones que la arquitecta Anita Berrizbeitia (2007) recomienda para la investigación del sitio. Para la autora, la investigación sobre un lugar debe incluir un conjunto amplio de preocupaciones que pueden extenderse mucho más allá de los límites físicos del predio. Por ejemplo, cómo se ha observado el sitio en el tiempo, o cómo los intereses económicos han jugado un papel en su configuración. En otras palabras, entender cómo el pasado hizo lo que está allí hoy. Coincidiendo con varios autores contemporáneos (Berrizbeitia, 2007; Corner,2006; Marot, 2006; Girot, 1999), la historia se entiende como un proceso inscrito en el sitio, capas de sucesos acumulados que deben conocerse. Podríamos llamarla la geología cultural del sitio, que en este trabajo de investigación antecede a esa otra geología, la tangible 0 natural que es la que abordaremos en el siguiente capítulo.

Esto es la periferia, ese tercer mundo, que es tan vasto y está experimentando cambios tan profundos que uno se olvida de que posee su propia historia, una historia que no pertenece ni a la ciudad ni al campo $^{286}$ [ni a lo urbano ni a lo rural]. (Marot, 1999, p. 53).
285 Considerando que habitualmente el análisis del contexto físico precede a los demás (cultural, social, económico, normativo, etc.)

${ }^{286}$ Traducción propia del texto en inglés:

This is suburbia, that third world, which is so vast and experiencing such profound changes that one forgets it possesses its own history, a history that leads back neither to the city nor the countryside. 


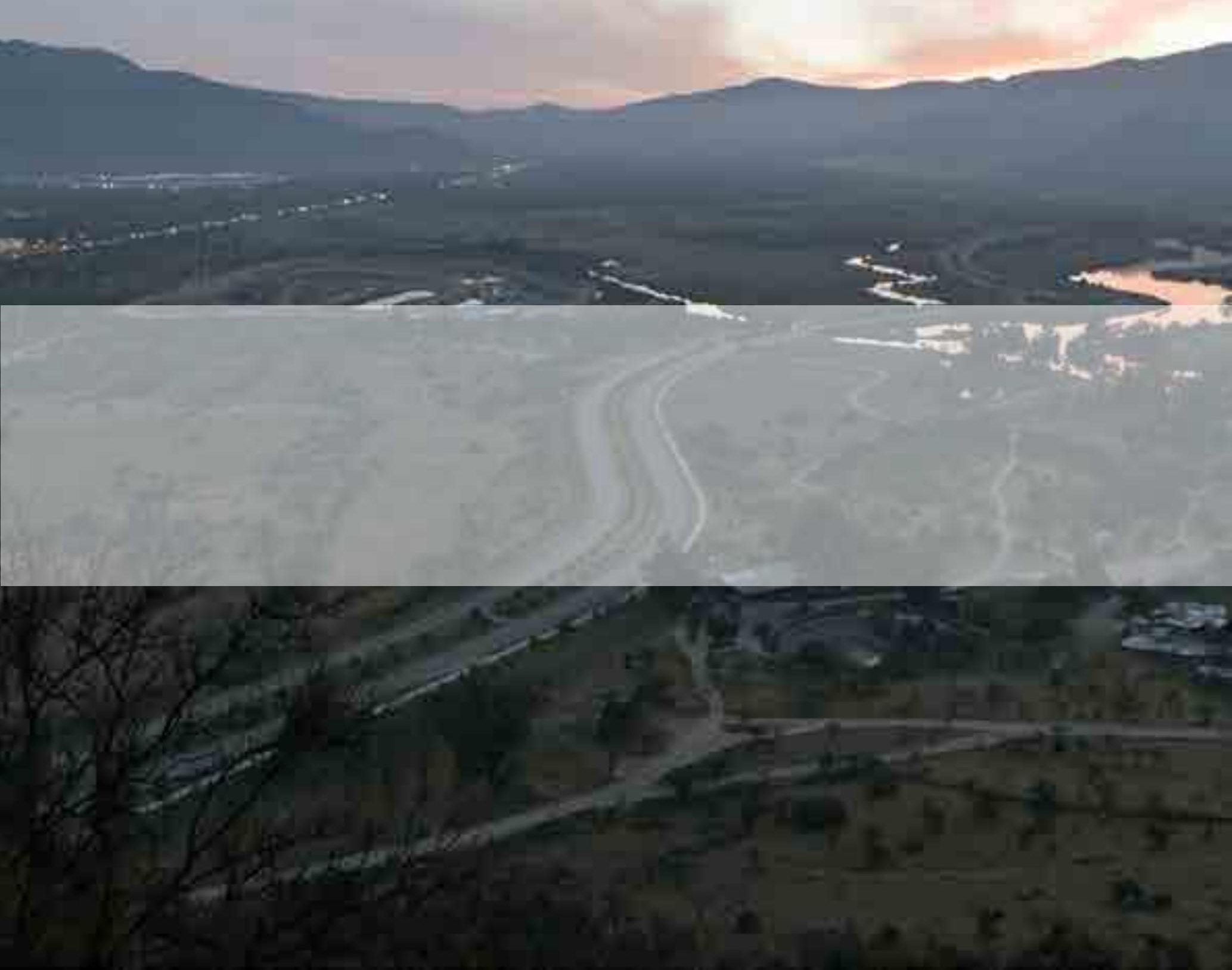




\section{CAPÍTULO 7 \\ EL TERRITORIO DE LAGUNA CAREN COMO SISTEMA ECOLOGICO $33^{\circ} 25^{\prime} 50^{\prime \prime} \mathrm{S} 70^{\circ} 50^{\prime} 29^{\prime \prime} 0$}




\section{EL TERRITORIO DE LAGUNA CAREN COMO SISTEMA ECOLOGICO $33^{\circ} 25^{\prime} 50^{\prime \prime S} 70^{\circ} 50^{\prime} 29^{\prime \prime} 0$}

\subsection{INTRODUCCIÓN}

El estudio de Carén desde el punto de vista ecológico tiene como objetivo descubrir los procesos que han dado forma a este vasto territorio, para a partir de ellos orientar las estrategias de un Plan Maestro y lograr, que nuestros diseños sean más "adaptables, legibles, persuasivos y resilientes" (Reed \& Lister, 2014; Czerniak, 2007). Se estudiarán la geología, la geomorfología, la aptitud de los suelos, la hidrología, la vegetación, la fauna, la atmósfera, las áreas protegidas 0 sitios prioritarios, los riesgos y la legislación de relevancia ambiental. Esto hace evidente una característica de la investigación en paisaje, que como ha señalado Jantsch (1970) es una tarea transdisciplinar. Cuando ésta se realiza en el ámbito profesional, son convocados una gran cantidad de especialistas ${ }^{287}$. La dificultad de esta investigación en el contexto de una tesis, es que estas tareas deben ser asumidas por una única persona, asunto que hemos comentado en el capítulo 2. El orden propuesto "desde abajo hacia arriba" contraviene el orden usual de análisis, que en los informes profesionales se inicia con la atmósfera y el clima. De este modo, esta segunda etapa de la "puesta a tierra" como diría Christophe Girot (1999), parte desde la geología, estudiando desde las capas más profundas y antiguas. Una conexión con la tierra que se relaciona con la orientación y el arraigo, tanto en el sentido literal como figurado de la palabra.

Estas capas o layers ${ }^{288}$, son las mismas que en 1969 propusiera lan McHarg en su libro pionero "Design with Nature"289 y que años más tarde, el ecólogo Richard T.T. Forman amplía, para llegar comprender la ecología de un paisaje como la interacción entre los procesos ecológicos y los patrones espaciales, conciliando el enfoque científico de la ecología, con el espacial, propio del arquitecto (Forman \& Godron, 1986).

Si volvemos a mirar nuestro esquema (Figura 7.1.), lo que proponemos es un nuevo salto, uno que va desde la esfera antropológica (investigación sobre la historia del sitio) a la sistémica-lógica (investigación sobre los procesos ecológicos y usos de suelo de este territorio).

\section{2. ÁREA DE ESTUDIO}

El área de estudio corresponde a un predio de 1.022 hectáreas de superficie, emplazado en la Comuna de Pudahuel, Provincia de Santiago, Región Metropolitana de Santiago, capital de Chile. Desde el punto de vista geométrico, el sitio puede definirse según un gran número de coordenadas como las que vemos en el plano de emplazamiento (Figura 7.2.) y en la Tabla 7.1., que definen la peculiar forma del predio. La tarea de comprender su condición ecológica exige que la escala de estudio se amplíe a la escala geográfica, para luego descender a la meso y micro escala. Hay procesos que solo se comprenden si se estudia la región, otros requieren de la observación detallada, de la toma de muestras y del microscopio. En este nuevo recorrido por Carén se pone a prueba este análisis multiescalar de los elementos, que se desarrollan tanto en el espacio, como en el tiempo. Esta aquí presente la idea del proceso ecológico donde más allá de sus características formales, nos interesa comprender cómo funciona este territorio que da como resultado un paisaje característico.

\subsection{GEOMORFOLOGÍA}

A nivel regional, la caracterización geomorfológica de la Región Metropolitana se encuentra determinada por las dinámicas existentes entre las principales estructuras que recorren el territorio de manera longitudinal. Estas son la Cordillera

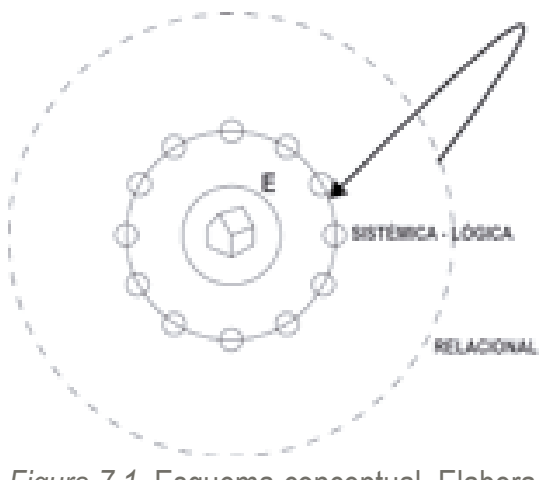

Figura 7.1. Esquema conceptual. Elaboración propia.
287 En el caso de la evaluación ecológica, convergen ecólogos, geólogos, ingenieros hidráulicos, geógrafos y biólogos, también, en muchos casos abogados especialistas en medioambiente.

288 Este método de la superposición de layers fue el precursor la aplicación de Análisis Multicriterio en la Evaluación de Impacto Ambiental basado en herramientas SIG (Sistema de Información Geográfica), una vez que se desarrolló la informática.

289 Recordemos que el cambio paradigmático que propone McHarg consiste en incorporar el enfoque ecológico en la planificación, proporcionando además un método para evaluar y aplicar estos criterios en el diseño. Hasta ese momento la idea dominante que suponía el "equilibrio de la naturaleza", entendía a los sistemas ecológicos como entidades cerradas frente a los factores externos, siendo las interacciones humanas y culturales vistas como externas al sistema y causantes de perturbaciones ponían en riesgo este equilibrio. 
Figura 7.2. Emplazamiento general. Elaboración propia en base a informe de la Consultora Andalué (2016)

${ }^{290}$ Graben o fosa tectónica, es el conjunto de dos fallas normales paralelas con inclinación opuesta en un ambiente tectónico expansivo.

Tabla 7.1. Coordenadas de los vértices del predio Laguna Carén.

WGS 84 / UTM huso 19 Sur

\begin{tabular}{|c|c|c|}
\hline WमEसE & Walle & ISTE \\
\hline A & 6298010 & 325632 \\
\hline$B$ & 6299330 & 325255 \\
\hline c & 6299645 & 325332 \\
\hline D & 6299991 & 324725 \\
\hline E & 6301111 & 325355 \\
\hline$F$ & 6301206 & 327107 \\
\hline G. & 6295924 & 329972 \\
\hline B & 6298691 & 329995 \\
\hline I & 6298269 & 328776 \\
\hline 1 & 6295228 & 327879 \\
\hline$x$ & 6298712 & 32779 \\
\hline
\end{tabular}

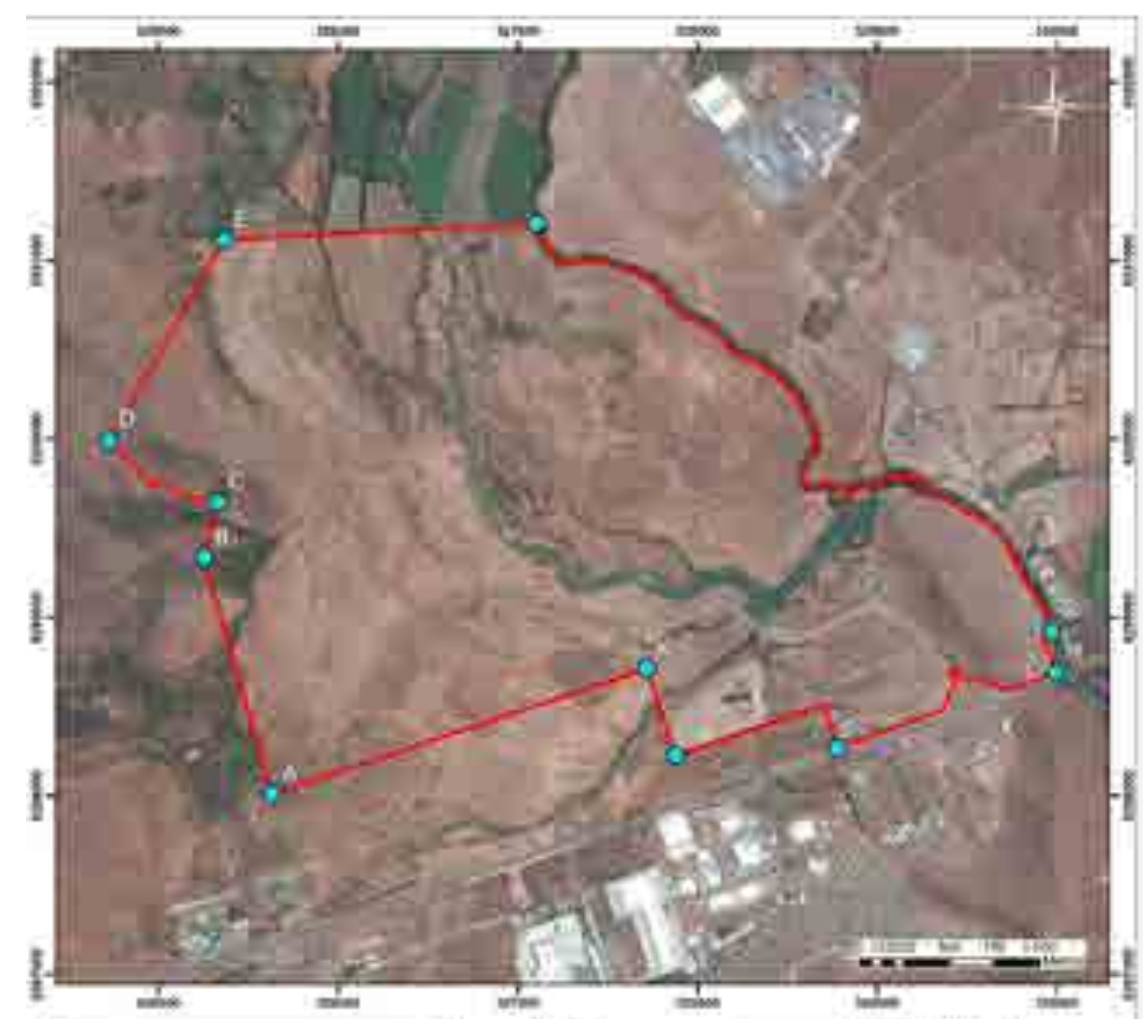

de la Costa, la depresión intermedia y la Cordillera de Los Andes. Estos rasgos morfológicos de superficie son muy distintivos.

La Cordillera de la Costa, es un cordón rocoso más bajo que el andino y que al Norte del río Maipo está conformado a su vez, por dos cordones montañosos de orientación aproximada N-S.

Estos encierran, en un tramo de longitud de $60 \mathrm{~km}$, una amplia depresión por la que corre el Estero Puangue, que la divide en dos cordones de similares disposiciones. (Gana et. al.,1996).

La Depresión Intermedia, corresponde a una gran unidad morfoestructural que se desarrolla desde el valle de Santiago hasta Puerto Montt, que se interpreta como un posible graben ${ }^{200}$, limitado por fallas N-S que se ubican en ambos bordes (Hervé \& Thiele, 1987).

Al Norte de la Angostura de Paine, la Depresión Intermedia se conoce con el nombre de Cuenca de Santiago, (Figura 7.3.), que limita con la Cordillera de La Costa por la Zona de Fallas Los Ángeles (Carter \& Aguirre, 1965). En esta extensión alcanza a cubrir una superficie total de $2.640 \mathrm{~km}^{2}$ de sedimentos. Al Norte de los cerros de Polpaico, desaparece esta depresión como tal, distinguiéndose otras superficies deprimidas, escalonadas, topográficamente cada vez más altas hacia el Norte. De éstas, la más meridional (Peldehue-Lampa) es la más importante y cubre una superficie de $340 \mathrm{~km}^{2}$. Posteriormente hacia el Norte siguen las de Rungue y la de Montenegro sucesivamente, siendo esta última la más alta, por lo que el drenaje tiene un sentido general de Norte a Sur.

Otra característica importante de la Cuenca de Santiago es la existencia de numerosos "cerros isla", tales como: Cerros de Lonquén $\left(36 \mathrm{~km}^{2}\right)$, Cerros de Chena $\left(11 \mathrm{~km}^{2}\right)$, Cerros de Lo Aguirre $\left(11 \mathrm{~km}^{2}\right)$, Cerros de Renca $\left(8 \mathrm{~km}^{2}\right)$, y otros menores tales como: Cerro Santa Lucía, Cerro Blanco, etc. Estos cerros son los representantes superficiales de cordones topográficos parcialmente sepultados por el actual relleno sedimentario. 


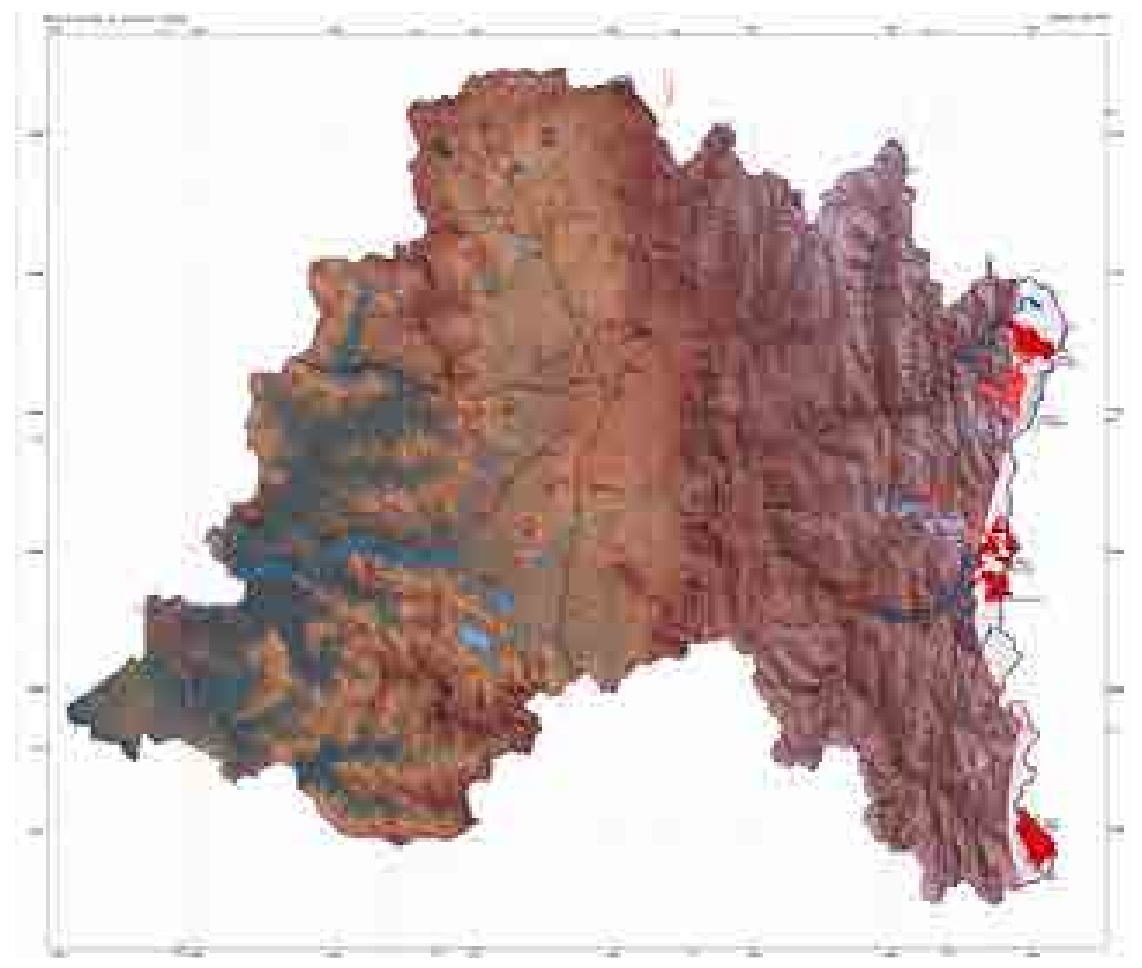

La Cordillera de Los Andes, es la unidad más grande, morfológicamente corresponde a un cordón montañoso rocoso con características de relieve joven. Tiene cotas que aumentan progresivamente de Oeste a Este, con alturas sobre los 6.000 m.s.n.m. (cerro Marmolejo, volcán Tupungato). Numerosos ríos y esteros de orientación N-S y NE-SO cortan su relieve, dividiéndola en cordones de similares disposiciones. Sus aguas son drenadas por los ríos Maipo $\left(5.138 \mathrm{~km}^{2}\right)$, Mapocho $\left(1.095 \mathrm{~km}^{2}\right)$, Colina $\left(370 \mathrm{~km}^{2}\right)$ y esteros Clarillo, El Escorial y Angostura (afluentes andinos) $\left(890 \mathrm{~km}^{2}\right)$. El Cordón de Chacabuco (cierre norte) puede considerarse como una prolongación de la cordillera andina, y cubre una superficie de $531 \mathrm{~km}^{2}$ cuyas aguas alimentan a los esteros Chacabuco, Peldehue y en parte al estero Til-Til. De esta mega estructura proceden la mayor parte de los materiales sedimentarios que rellenan la Depresión Intermedia.

El área de estudio está ubicada en el sector poniente de la ciudad de Santiago, Comuna de Pudahuel. En la Figura 7.4. se visualiza que el área de estudio se ubica en la unidad morfológica denominada Depresión Intermedia, que cubre en gran parte la Cuenca de Santiago y que cuenta con cinco unidades geomorfológicas principales: la cuenca Santiago con depósitos fluvio-lacustres; la cuenca con depósitos pumicíticos; los cerros islas; la cordillera costera volcánica y valle medio del río Maipo.

La mayor superficie corresponde a la cuenca de Santiago con depósitos fluvio-lacustres y depósitos pumicíticos, que corresponde al área de estudio:

\subsection{GEOLOGÍA}

El área de estudio, situada en el valle Lo Aguirre, puede adscribirse a las características geológicas que se presentan en la cuenca de Santiago.

En cuanto al material geológico en superficie, como se puede observar en el mapa de Geología local (1:100.000, ver Figura 7.5.), la cuenca de Santiago y el área de estudio, se caracteriza principalmente por estar compuesta de depósitos no consolidados del tipo aluviales, coaluviales y de remoción en masa, asociados a la presencia de importantes cuencas.

En el predio aparecen tres formaciones principales que se relacionan directamente con el origen y desarrollo de los suelos, la formación pumicítica, la lacustrina y los cerros isla.
Figura 7.3. Geomorfología de la cuenca de Santiago. Peligro volcánico y fallas geológicas de la Región Metropolitana de Santiago. Por Servicio Nacional de Geología y Minería (2004). Informe IR-04-24. Mapa Escala 1:250.000. 


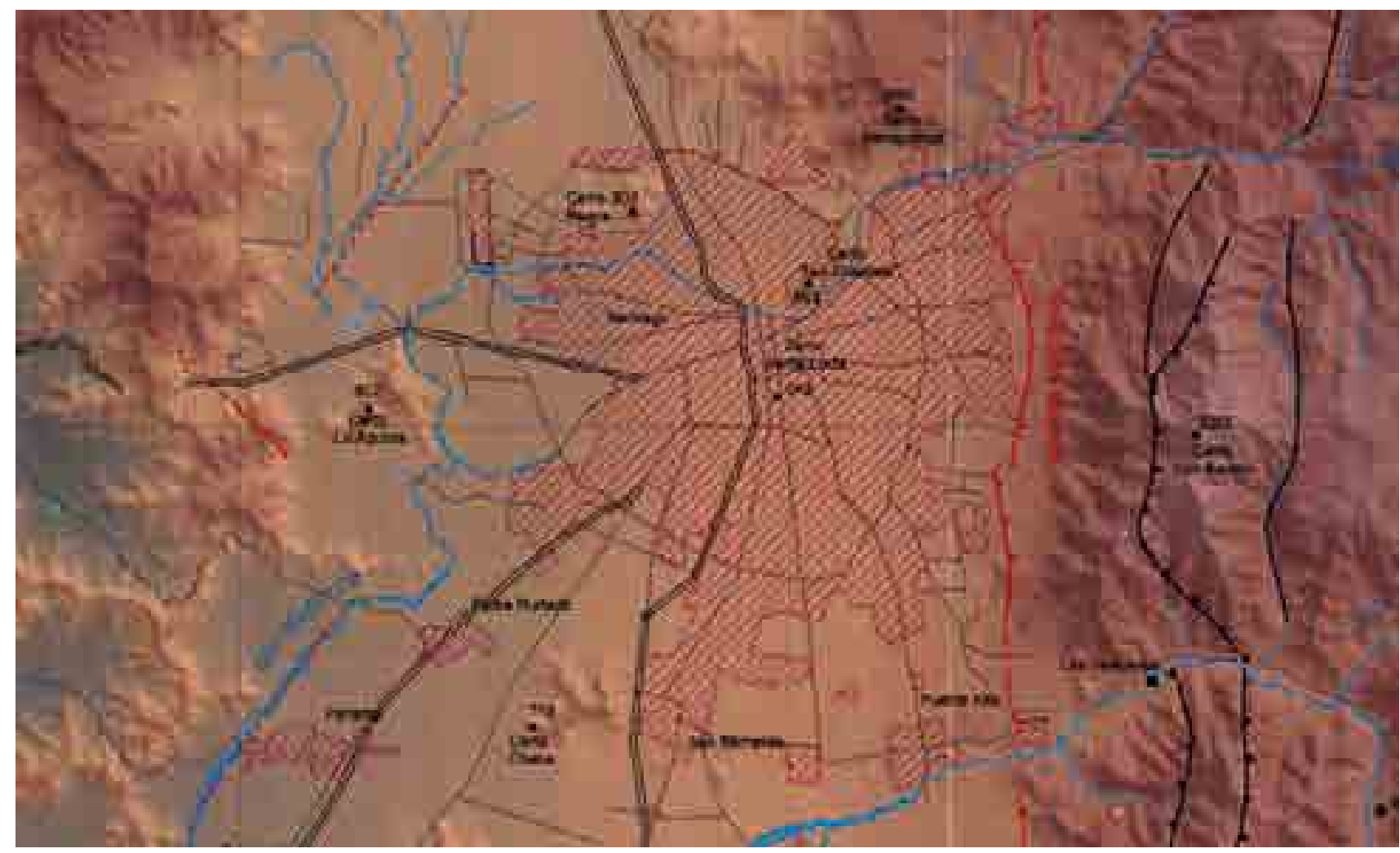

Figura 7.4. Ampliación del mapa anterior, que muestra la ubicación de Carén respecto al valle, donde también se indican otros hitos geográficos. Por el Servicio Nacional de Geología y Minería (SERNAGEOMIN, 2004).

\subsubsection{Formación Pumicítica}

Esta formación está originada por depósitos de cenizas volcánicas pumicíticas mezcladas con fragmentos líticos. Estos fragmentos que encuentran en el área de Pudahuel son similares a los depósitos que se hallan en el valle del Río Maipo y Río Puangue, en las vecindades de Rancagua y en valles del Río Cachapoal y Rapel y dentro del frente principal de la Cordillera de Los Andes en los valles de los ríos Maipo, Codegua y Cachapoal, así como en Argentina en los valles de los ríos Papagayos y Yaucha. Esta amplia distribución y el análisis de las muestras estudiadas por Camila Troncoso et al. (2015), sugieren que su formación se produjo a raíz de una sola y gran explosión del volcán Maipo, hace aproximadamente 450 mil años. Esta edad corresponde al Pleistoceno Superior, como fue propuesto en 1962 por Jorge Polanski, aunque datos posteriores sugieren una data de 150 mil años (Lara et al., 2008). En la Figura 7.6. se grafica la extensión de este fenómeno, que nos revela la macro-escala que involucra el análisis geológico.

Por mucho tiempo se pensó que estos flujos piroclásticos se habían transportado a través del paisaje montañoso a través de corrientes de barro (p.e. Karzulovic, 1960). Sin embargo, en 1984, Charles R. Stern et al. elaboran una nueva teoría según la cual el origen de estos depósitos serían nubes ardientes originadas por erupciones del volcán Maipo, tratándose así de "ignimbritas riolíticas pumacíticas" (Stern et al.,1984, p. 39), que cayeron sobre los glaciales que cubrían la región. De esta manera los flujos piroclásticos pudieron viajar sobre la superficie del hielo hacia los diferentes valles de drenaje, lo que explicaría la falta casi total de depósitos dentro de la cordillera, al oeste del volcán Maipo, y su presencia en los valles bajos de los ríos Maipo y Cachapoal. El contacto entre las rocas ardientes y el hielo, debe haber contribuido en el proceso de fluidificación de los flujos y explican su gran movilidad, que se evidencia en la distancia existente entre los depósitos y la fuente de origen (el volcán Maipo).

En el predio, la formación pumacítica es la más extendida, encontrándose en toda su superficie a profundidades variables, salvo en las formaciones de los cerros Amapolas y Puntilla de Lo Vásquez.

Cuando aparece superficialmente, se caracteriza por producir una topografía de lomajes ondulados. En el resto del área plana, se encuentra en el sustrato basal, sobre el que se depositaron sedimentos finos y es posible observarla en los 


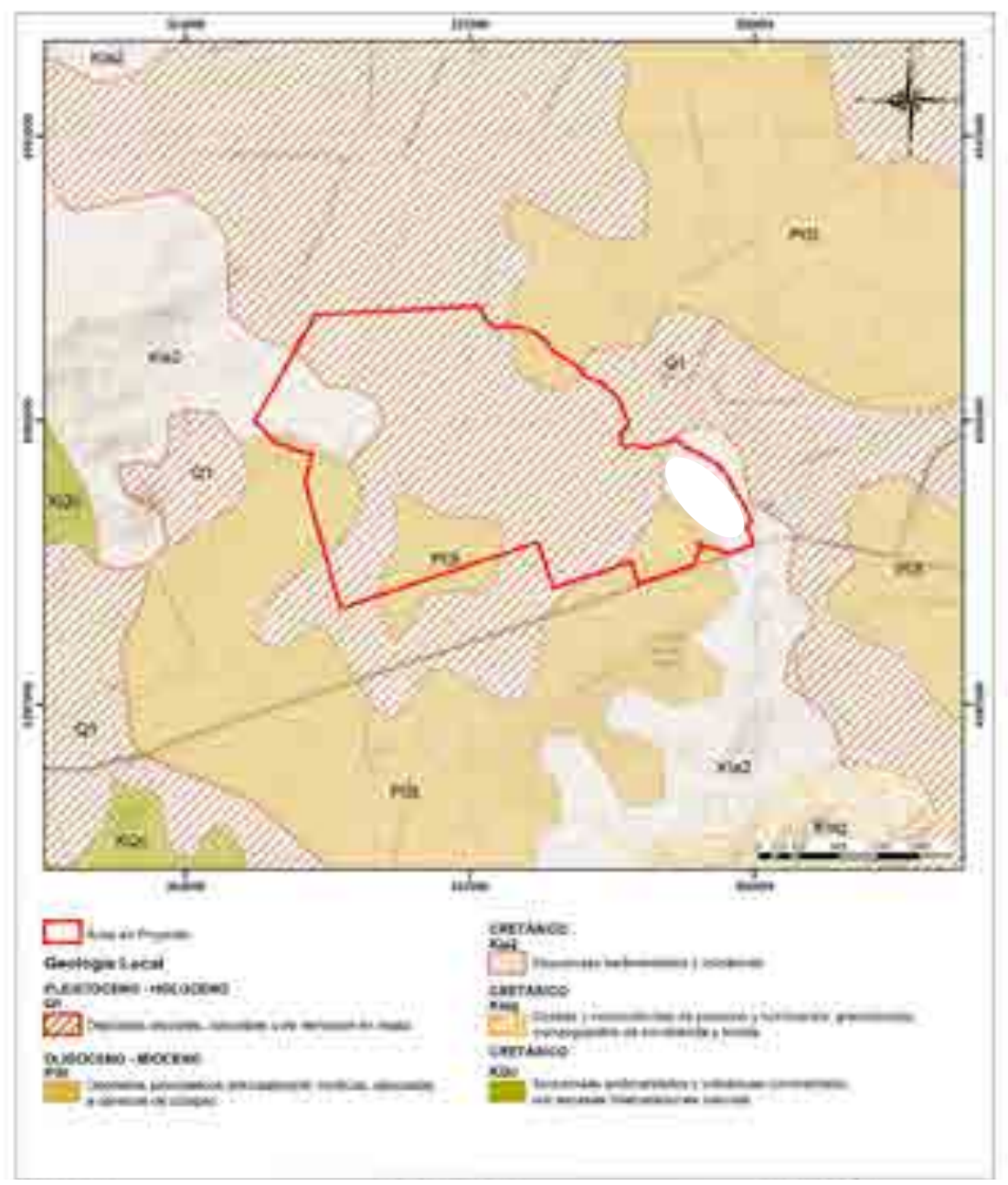

Figura 7.5. Mapa de geología local. Elaboración propia en base a informe de la Consultora Andalué (2016)

cortes a orillas del estero Carén, a dos o más metros de profundidad y con un espesor de 20 a $40 \mathrm{~m}$, la que, por su baja permeabilidad, confinan el agua en napas más profundas.

En cuanto a la roca basal, en la zona, ésta se ubica a gran profundidad, no detectándose en los pozos de 430 metros de profundidad (MECSA, 1997). Hacia el poniente, al acercarse a la cadena de cerros del contorno poniente y sur-poniente, la profundidad de la roca va decreciendo.

\subsubsection{Formación Lacustriana}

Dentro del paisaje general del predio, aparece con una topografía muy plana y definida, principalmente en el sector sur-poniente.

Los suelos que se encuentran en esta formación son de texturas arcillosas, formados por sedimentos finos depositados en ambiente de aguas tranquilas sobre la formación pumacítica.

El drenaje natural está dado por el estero Carén y sus brazos, que antes de desaguar en el estero lampa, forman la Laguna Carén, que no es natural, sino un embalse que regula el drenaje del área.

El sector sur-poniente, constituye la parte más deprimida y con dificultades de drenaje, por la elevación de la formación pumacítica hacia el camino Santiago-Valparaíso (Ruta 68). Debido a esto, se presentan acumulaciones de sales que afectan el desarrollo de la vegetación, dando origen al sector denominado tradicionalmente Tierras Muertas.

\subsubsection{Formación de Cerros}

Corresponde a los cerros Amapola y Puntilla de lo Vásquez, pertenecientes a los cordones cordilleranos intermedios de Lo Prado y Lo Aguirre, y situados en los límites sur-oriente y nor-poniente del predio. Poseen topografía escarpada con afloramiento de rocas andesíticas en sus partes más altas. Debido a su escasa superficie, ubicación y condiciones de pendiente, constituyen elementos paisajís- 
Figura 7.6. Mapa que muestra la distribución original de depósitos de la ignimbrita de Pudahuel. El volcán Maipo se ubica a la derecha. Las líneas indican el recorrido del material hasta los valles. Elaboración propia sobre mapa de Troncoso et al. (2015, p. 105).

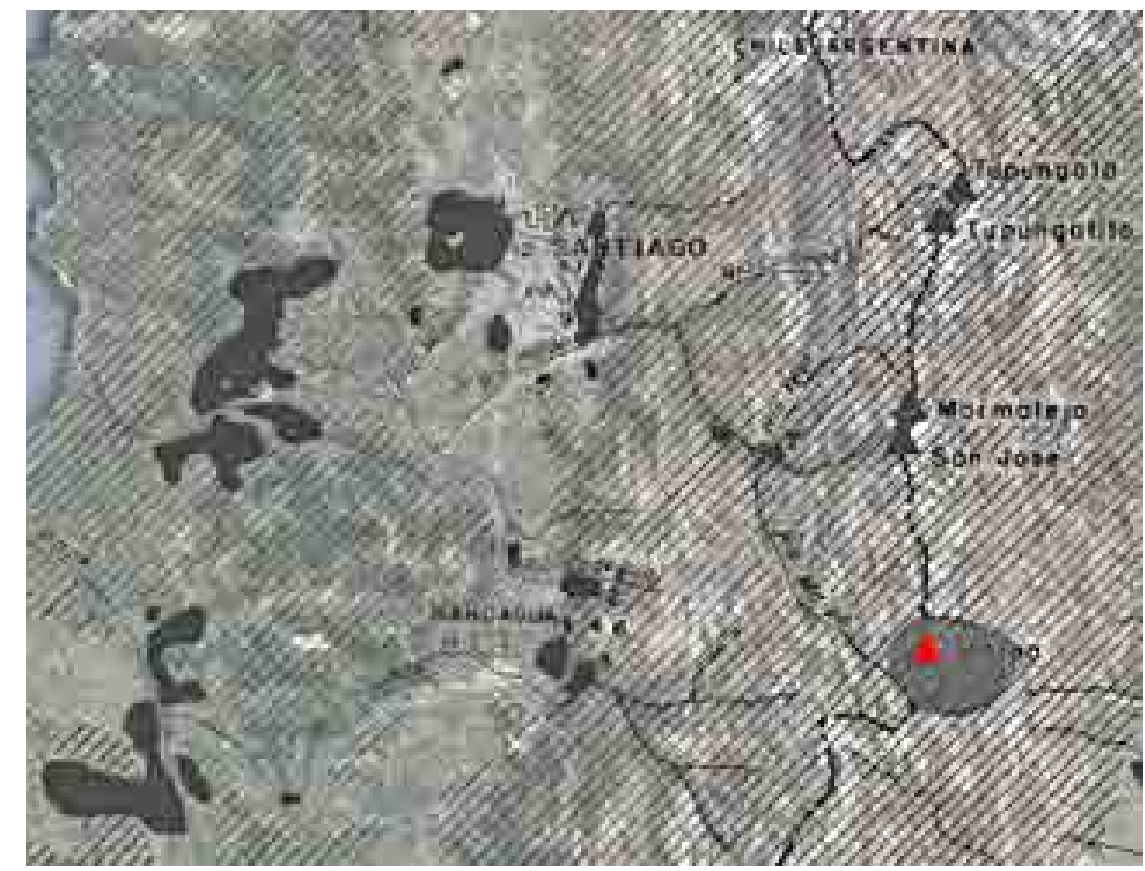

ticos importantes dentro del conjunto plano general del predio.

Si volvemos a la Figura 7.3., podemos deducir que el valle Lo Aguirre no correspondería a un área de particular riesgo volcánico. Sin embargo, podemos observar también que existen dos fallas geológicas cercanas, pero menores. Las mayores se encontrarías hacia la cordillera (falla de San Ramón), al oriente de la capital. Adicionalmente, de acuerdo a información obtenida del Mapa de "Respuesta sísmica de la Región Metropolitana de Santiago (2004) de SERNAGEOMIN (Figura 7.7.) el terreno estaría clasificado como E2, vale decir como una unidad "con muy mala respuesta sísmica" por corresponder a "zona de cauces fluviales actuales o recientes, compuesto por materiales sin cohesión, con granu-

Figura 7.7. Mapa de respuesta sísmica de la Región Metropolitana de Santiago. Por el Servicio Nacional de Geología y Minería (SERNAGEOMIN, 2004).

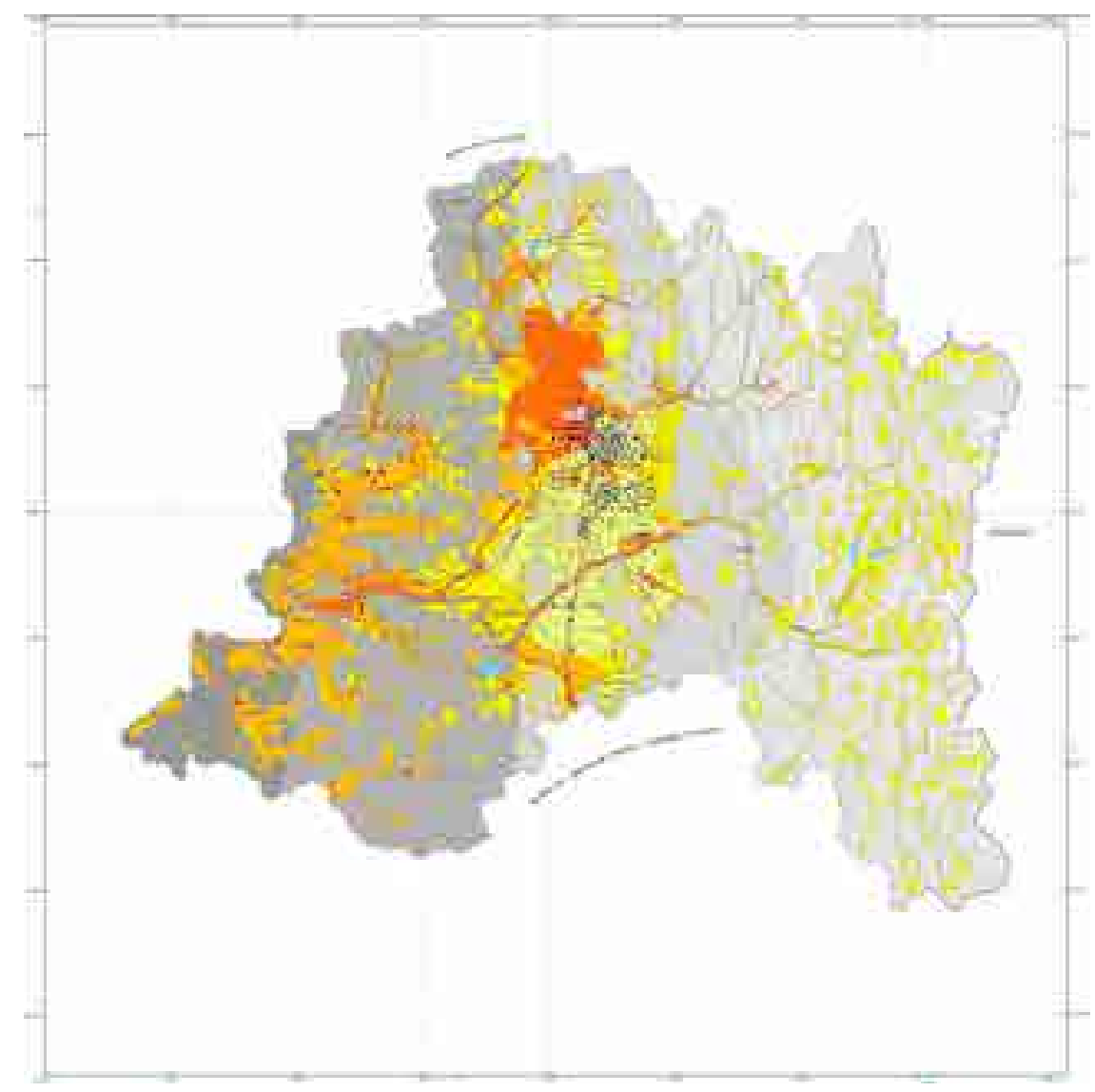




\subsection{SUELOS}

La distribución y tipo de suelos en el terreno, está determinada por la geomorfología que hemos descrito, así como por la forma e intensidad de factores naturales y antrópicos.

A nivel macro, en el país y en la región, el componente suelo está severamente afectado por la desertificación, la sequía y la degradación de las tierras. El Ministerio del Medioambiente en su reporte de 2018 declara:

La desertificación ha sido catalogada como uno de los problemas socio-ambientales más agudos de Chile. Durante la evaluación de la desertificación en Chile de 2016 se estimó que el $21,7 \%$ de la superficie del país presenta algún grado de riesgo de desertificación (CONAF, 2016). Los territorios, áridos y semiáridos afectados por estos procesos superan el $60 \%$ del territorio nacional y alli se concentran los mayores impactos a los suelos, a la biodiversidad y a la productividad silvoagropecuaria en general. Así mismo, la contaminación del suelo implica la alteración de su funcionamiento, pudiendo disminuir o perder su capacidad de soporte, de retención de minerales (alterando el ciclo de nutrientes), de purificación y regulador del ciclo del agua, de suministrar alimentos, biomasa y ser hábitat de diversos organismos, entre otras. En ciertos casos, la contaminación es tal que, además supone un riesgo a la salud humana y/o al medio ambiente. (SINIA, 2018, p. 192).

Para estudiar los suelos a meso escala, hemos trabajado sobre cartografía a escala 1:20.000, los antecedentes recogidos en terreno y los resultados de calicatas ejecutadas en 1997 (MECSA, 1997).

\subsubsection{Series de Suelos}

En la descripción que se hace de las series de suelos, se han empleado los términos de uso corriente en el texto de referencia nacional Manual para el reconocimiento de suelos (Schlatter et al., 2003), que a su vez son tomados, en su generalidad, del Soil Survey Manual del Departamento de Agricultura de Estados Unidos.

En la Figura 7.8. se muestra el plano con las diferentes series identificadas, señalando la superficie que abarcan.

\subsubsection{Serie Carén (CR): Arcillosa}

Suelo formado a partir de sedimentos finos depositados en aguas tranquilas (lacustrino), muy profundo, de textura superficial arcillosa de color negro y textura de arcilla. Descansa sobre un sustrato constituído por cenizas volcánicas riolíticas muy compactadas (pumicita) con acumulación de carbonato de calcio sobre ella. El último horizonte presenta filamentos y manchas de carbonato de calcio hasta $75 \mathrm{~cm}$, que desaparece en profundidad. Estos suelos presentan una topo-

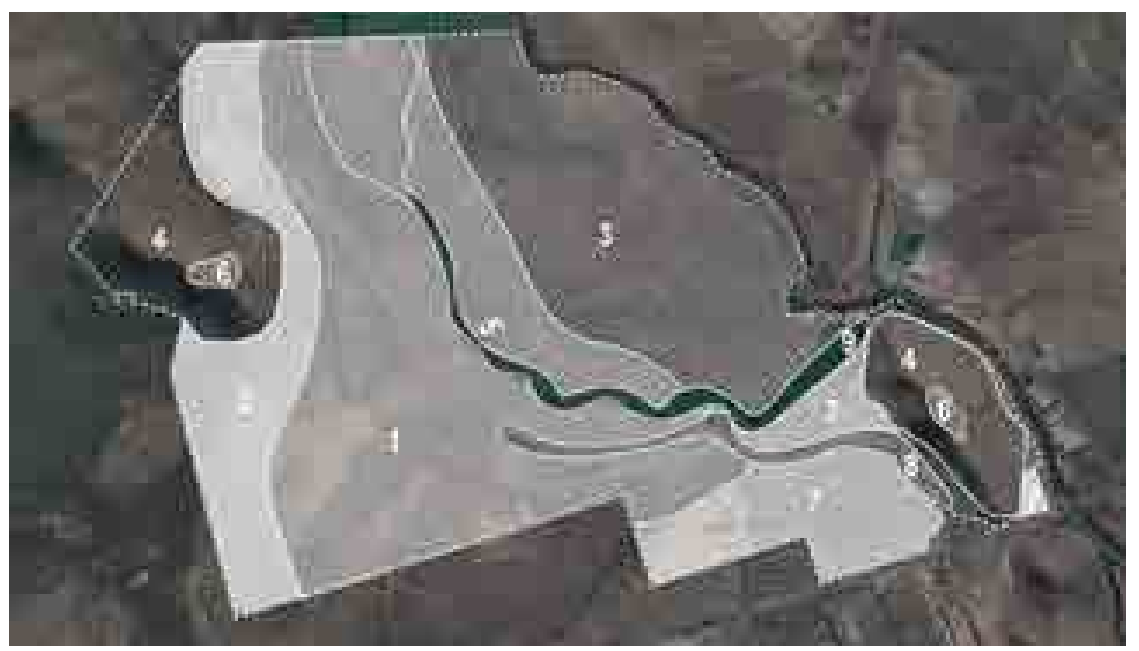


grafía plana de pendientes de 0 a $1 \%$ con grietas desde la superficie y estructura de bloques angulares finos en los primeros centímetros. Son suelos de drenaje moderado y de permeabilidad muy lenta a lenta. La vegetación asociada corresponde a renovales de acacia caven (espino) de diferentes grados de densidad. La cubierta herbácea es estacional.

Superficie: 496 hectáreas aprox.

\subsubsection{Serie Espinal (ES): Arcillosa}

Suelo sedimentario, originado a partir de depósitos en un ambiente de aguas tranquilas (lacustrino), muy profundo, de textura superficial arcillosa de color pardo rojizo oscuro y textura de arcilla densa de colores pardo oscuro y pardo rojizo. Descansa sobre un sustrato constituido por pumicita muy compactada que constituye el piso de la mayor parte de los suelos planos del área de estudio. Esta pumicita se encuentra a profundidades variables entre 130 y $200 \mathrm{~cm}$. La topografía es plana, en pendientes de 0 a $1 \%$, de permeabilidad lenta y buen drenaje.

La vegetación asociada corresponde a renovales de acacia caven (espino) de diferentes grados de densidad. La cubierta herbácea es estacional.

Superficie: 150 hectáreas aprox.

\subsubsection{Serie Pudahuel (PD): Franco arenosa Fina}

Suelo formado a partir de cenizas volcánicas riolíticas (pumicita), delgados a ligeramente profundos, de textura superficial arenosa fina; de color pardo a pardo oscuro y textura arenosa. Suelo de topografía de lomajes de pendientes de 3 a $8 \%$ formando cerrillos dentro del paisaje lacustrino. La profundidad a la que se encuentra la pumicita es variable, entre 20 y $50 \mathrm{~cm}$., en muchos casos, especialmente en los quiebres de pendientes, aflora en la superficie.

La vegetación natural corresponde a renoval abundante de acacia caven (espinos) y pastos estacionales.

Superficie: 120 hectáreas aprox.

\subsubsection{Serie Amapola (AM): Franco Arcillo arenosa}

Suelo formado a partir de rocas andesíticas, moderadamente profundos, de textura superficial franco arcillo arenosa de color pardo oscuro y textura de arcilla densa y color rojizo en profundidad. Descansa sobre rocas andesíticas, parcialmente meteorizadas, con acumulaciones de carbonato de calcio en las fisuras. Ocupa una porción de cerros en pendientes abruptas superiores a 40\%. Presenta bolones y afloramientos rocosas, especialmente en la vertiente nor-poniente del Cerro Amapolas.

Superficie: 110 hectáreas aprox.

\subsubsection{Misceláneos de Escarpe (ME)}

Corresponde a terrenos de pendientes abruptas que se ubican en ambas riberas de los cursos de agua.

Superficie: 10 hectáreas aprox.

\subsubsection{Sectores Rocosos (SR)}

Corresponde a las formaciones en las cumbres de los cerros Amapolas y Puntilla Lo Vásquez. Petrográficamente, corresponden a rocas andesíticas y basálticas.

Superficie: 6 héctareas aprox. 


\subsubsection{Sector Sur (SS) o (SD)}

Corresponde a áreas donde los suelos han sido alterados por el uso como pista de automovilismo y motociclismo; la cancha de golf, estacionamiento de camiones y trabajo de canteros. Originalmente los suelos que ocupan pertenecian: a la serie Amapola (AM) en el sector entre el cerro y el estero Lampa; a la Serie Pudahuel (PD), en el límite sur; y a la Serie Carén (CR) vecina y al norte de ésta última.

Superficie: 60 hectáreas aprox.

\subsubsection{Sectores de Construcción (SC)}

Corresponde a áreas donde los suelos han sido alterados por construcciones de diversa índole, tales como: pavimentación calle de acceso, portal de acceso, salas de bombas, clubes deportivos, medialuna, casas y sitios de recreación. Los suelos sobre los que se ha construido, corresponden casi en su totalidad a la serie Pudahuel y un pequeño sector, en la orilla sur de la laguna Carén, a la Serie Carén.

Superficie: 40 hectáreas aprox.

\subsubsection{Estero y Laguna Carén}

Corresponde a las áreas ocupadas por el estero Carén y la laguna del mismo nombre.

Superficie: 30 hectáreas aprox.

\subsubsection{Capacidad de uso del suelo}

La agrupación de los suelos en Clases de Capacidad de uso, es una ordenación de los suelos existentes, para señalar su relativa adaptabilidad a ciertos cultivos; además, indica las dificultades y riesgos que se pueden presentar al usarlos. Está basada en la capacidad productiva de la tierra, señalando las limitaciones naturales del suelo.

Convencionalmente, las clases se dividen en ocho, que se designan con números romanos, ordenados según sus crecientes limitaciones y riesgos de uso.

En el área de estudio, se detectaron suelos Clase III, IV, VI, VII y VIII. Por lo tanto, no existen suelos clase I, ni II, vale decir, suelos con mayor capacidad agrícola, tampoco clase $\mathrm{V}$.

Los suelos clase III presentan moderadas limitaciones en el uso y cultivos restringidos. Los suelos clase IV presentan severas limitaciones de uso, son la última categoría que permite suelos arables. Los Clase VI corresponden a suelos inadecuados para los cultivos; Los de clase VII son suelos con limitaciones severas, con posibilidades de uso forestal y pastos resistentes, asimilables a la Serie Amapolas y Misceáneo Escarpe (AM y ME). Por último, la clase VIII corresponde a suelos sin valor agrícola, ganadero o forestal. Su uso está limitado a la vida silvestre, recreación o protección de hoyas hidrográficas. Pertenecen a esta Clase los sectores rocosos de los cerros Amapola y Puntilla de Lo Vásquez (SR)

Cabe destacar, que una de las condiciones que hacen que la aptitud de los suelos sea baja se relaciona con la dureza del sustrato constituido por rocas pumicíticas, que impide el desarrollo radicular en profundidad.

La capacidad de uso ha sido definida según información disponible en el portal en línea del Ministerio de Agricultura, donde se presentan los datos del Centro de Información de Recursos Naturales (CIREN, 1996) ${ }^{291}$. De acuerdo a éste, el área de estudio se encuentra mayoritariamente en una zona con capacidad de uso no conocida (N.C.), junto con pequeñas zonas presentes en el límite del área con capacidad III hacia el poniente, IV, VI y VII hacia el sur poniente, III y VII hacia el suroriente, I hacia el oriente y III, IV y VI hacia el norte (Figura 7.9.).

291 Para la región Metropolitana, el último informe de actualización corresponde al año 1996. Es el más antiguo del país. Ver https://www.ciren.cl/actualidad/suelos-agrologicos/ 
Tabla 7.2. Cuadro resumen de clases y series de suelos presentes en Carén y su superficie aproximada. Elaboración pro-pia.

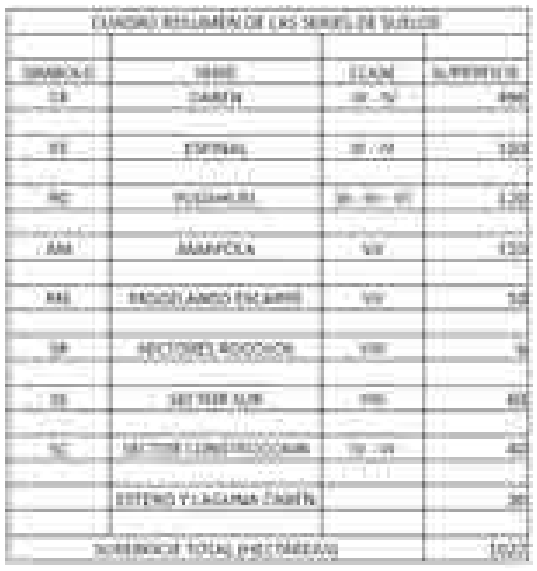

Esta información se ha cruzado con el análisis de las series, a partir del cual se construyó la Tabla 7.2., donde se indican las superficies y el plano resultante con las Clases de Suelo:

\subsubsection{Erodabilidad y Erosividad}

La Erodabilidad del suelo es una descripción cuantitativa que indica la susceptibilidad del suelo a ser erosionado, es considerado como el factor más importante para la predicción de la erosión y refleja el hecho de que diferentes suelos se erosionan a diferente tasacuando los demás factores que afectan la erosión son los mismos (Ramírez-Ortiz et al, 2009). Según datos del Sistema Nacional de Información Ambiental (SINIA), el área de estudio se ubica en un rango de Erodabilidad muy bajo.

La Erosividad en cambio, hace referencia a la capacidad erosiva de los distingos agentes geológicos, no dependiendo de las características del suelo, sino de las características climáticas de la zona. En el área de estudio, al igual que en la Erodabilidad se aprecia un rango muy bajo.

\subsection{HIDROSFERA}

Desde el punto de vista hidrográfico, la Región Metropolitana está estructurada por dos grandes cuencas que configuran las principales características morfológicas de la región. Las aguas de la cordillera y de las lluvias, convergen en dos cauces: el río Mapocho y el río Maipo, los cuales se han encargado de dotar al valle del material depositario, que las aguas han ido arrastrando a lo largo del tiempo.

Estos grandes ríos se desplazan en sentido de oriente a poniente, de manera que las aguas provenientes de lluvias y deshielos cordilleranos cruzan el valle de Santiago para luego atravesar la cordillera de la costa y finalmente llegar al litoral, para desembocar en el mar.

El cauce del río Maipo tiene una extensión de 15.380 km² (Biblioteca del Congre-

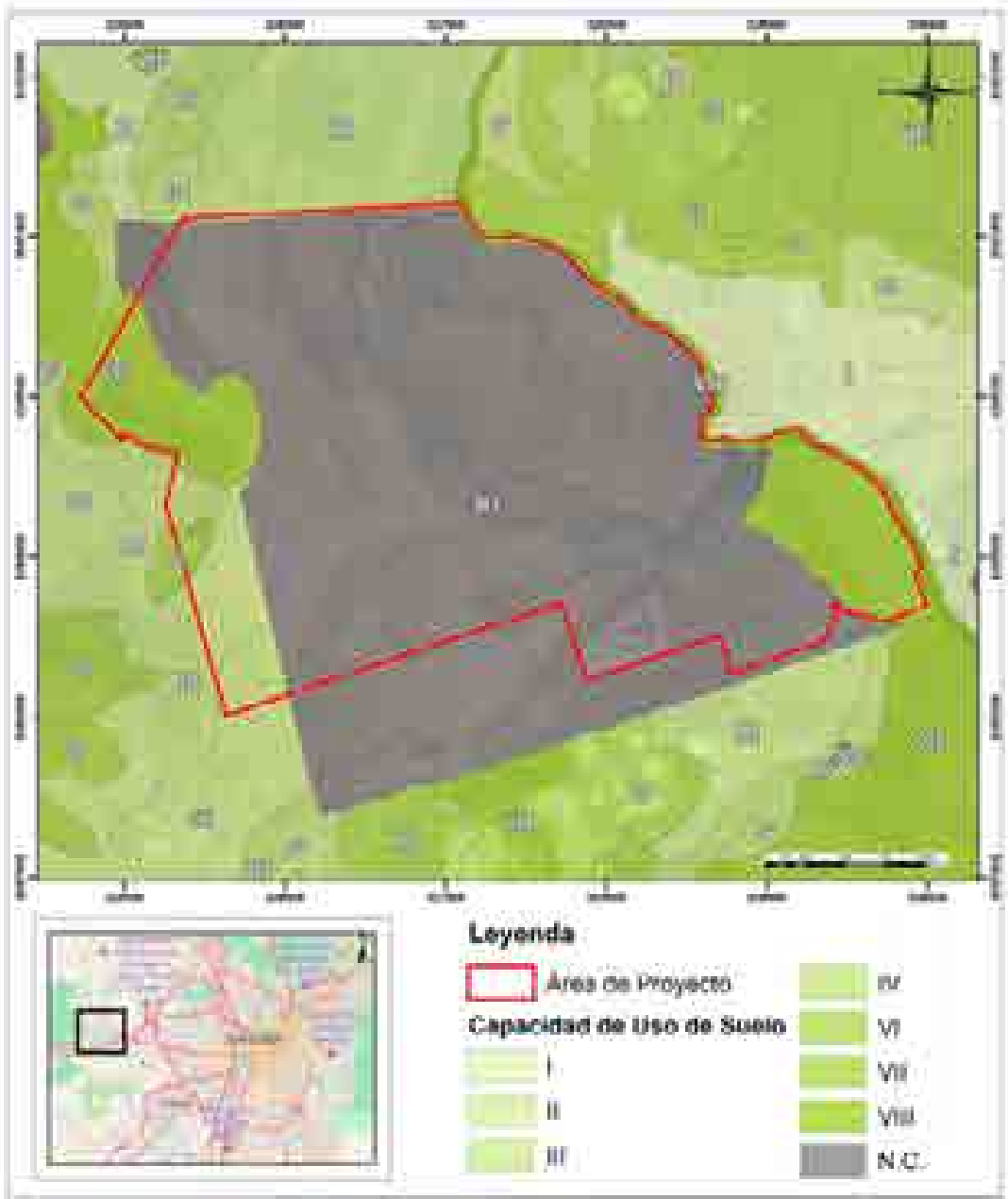

292 https://www.bcn.cl/siit/nuestropais/region13/hidrografia.htm

Figura 7.9. Capacidad de uso de suelos. Elaboración propia a partir de información disponible en línea de CIREN (1996) y al informe de la Consultora Andalué (2016). 
so Nacional, s.f. $)^{292}$, que se origina en la falda del volcán del mismo nombre, hacia el poniente. El régimen fluvial de este río es mixto, ya que presenta máximos estacionales en primavera, debido a los deshielos de la cordillera de Los Andes; y en invierno, a causa de las lluvias, con un caudal medio anual de $92,3 \mathrm{~m}^{3}$ por segundo. El Río Maipo tiene una función vital para la Región Metropolitana, ya que "de él se abastece alrededor del $70 \%$ de la demanda actual de agua potable, y cerca de un $90 \%$ de las demandas de regadío" (García, 2008, p. 6). Adicionalmente, su torrente alimenta centrales de producción hidroeléctrica, que han hecho más crítico el caudal ecológico.

La fertilidad de cuenca, ha generado que, a lo largo del recorrido del río Maipo se desarrollen asentamientos agrícolas e industriales, que en los últimos años han afectado las condiciones medioambientales, con frecuentes episodios de contaminación y crecidas. Estos efectos adversos se suman a los producidos por el cambio climático, que de acuerdo al estudio Actualización del Balance Hídrico Nacional (2017), "han significado una disminución del 23\% del caudal en el período 2005-2015, para un porcentaje de disminución en las precipitaciones de un 19\% en el mismo período" (Universidad de Chile \& Universidad Católica de Chile, 2017, p. 161).

Ahora bien, la comuna de Pudahuel, en el área de estudio, se encuentra la cuenca del río Mapocho, que de acuerdo con la información entregada en el Estudio de previsión de crecidas: Río Mapocho (Peña, 1983), el primer tramo del río se desarrolla en los cordones montañosos de la precordillera de Santiago. En el centro de Santiago la cuenca aportante al río Mapocho alcanza a unos $1.100 \mathrm{~km}^{2}$. Producto de las condiciones climáticas de la zona, lluvias invernales y una estación seca prolongada de 8 a 7 meses, la precipitación media en Santiago sólo alcanza a $300 \mathrm{~mm}$. Sin embargo, por el efecto de la orografía sobre las precipitaciones, en las zonas más altas de la cuenca superan los $1.000 \mathrm{~mm}$. Producto de las lluvias, el manto de nieve que normalmente se encuentra sobre los 2.500 m.s.n.m. podría variar entre los 1.500 y los $2.500 \mathrm{~mm}$. Este hecho es de gran importancia, ya que afecta notablemente el tamaño de la cuenca aportante.

El régimen hidrológico de la zona es principalmente nival, con los mayores caudales durante el mes de noviembre, producto del derretimiento de la nieve en primavera. No obstante, lo anterior, en forma aislada se producen crecidas violentas durante el período de invierno.

El terreno de estudio, se ubica al poniente del valle de Santiago, está próximo a la confluencia de los cauces naturales del río Mapocho y el estero Lampa- Este último representa el límite natural del predio hacia el nor-oriente, en una extensión aproximada de $4.200 \mathrm{~m}$.

A macro escala, este territorio se encuentra en la confluencia de dos subcuencas hidrográficas que descargan hacia la laguna Carén, cuerpo de agua que caracteriza el predio y que posee numerosos causes afluentes. Dichas sub-cuencas aportan recursos provenientes de la escorrentía natural producida por las precipitaciones.

Las sub-cuencas hidrográficas tributarias de laguna Carén son las siguientes tres, de acuerdo a la descripción contenida en la Declaración de Impacto Ambiental de la primera etapa del proyecto (FVLA, 2003, p. 8): Cuenca Lo Aguirre, Cuenca Noviciado y Cuenca Lipangue. Conocer el origen de las aguas es importante, ya que la calidad de ésta, depende de lo que ocurre aguas arriba en las distintas cuencas, las que brevemente se describen:

Cuenca de Lo Aguirre

La cuenca de Lo Aguirre aporta la escorrentía superficial del sector ubicado al poniente de Laguna Carén y lo incorpora a ésta a través de un afluente que atraviesa el camino de acceso al interior del predio. La cuenca posee una extensión total cercana a las 6.800 hectáreas y se inicia al poniente, en el cerro San Francisco (altitud: $1.068 \mathrm{~m}$ ), bajo el cual se encuentra el túnel Lo Prado (una referencia que ayuda a imaginar la escala y la relación del predio con su contexto). El recorrido desde el punto más lejano hasta la laguna Carén es de aproximadamente 11 kilómetros. La laguna Carén es la receptora del total de 
los caudales de aguas lluvias generados por la cuenca en su estado natural, el que ha ido aumentado en los últimos años por las urbanizaciones que se ubican al otro lado de la carretera y que descargan sus aguas tratadas a través de este afluente.

\section{Cuenca de Noviciado}

La cuenca de Noviciado se ubica al norte del terreno en estudio y aporta la escorrentía superficial a través de los dos brazos en los que se separa la laguna Carén en su extremo nor-poniente (el brazo principal se llama Estero Carén) La cuenca posee una extensión total cercana a las 4.300 hectáreas y se inicia al poniente en el cerro Bustamante (Altitud: $1.877 \mathrm{~m}$ ) con un recorrido de aproximadamente 10 kilómetros desde el punto más lejano hasta la laguna.

La laguna Carén es receptora del total de los caudales de aguas lluvias generados por la cuenca en su estado actual, por lo que el estero Carén intercepta el escurrimiento que proviene del poniente, antes de llegar al estero lampa.

[...]El Plano Regulador Comunal no contempla el cambio de uso de suelos de rural a urbano en este sector, por lo que no se espera un aumento relevante del coeficiente de escorrentía de la cuenca

\section{Cuenca Lipangue}

La cuenca Lipangue se ubica al norte de la cuenca Noviciado y si bien existe una continuidad natural entre una y otra, se han presentado por separado debido a una singularidad que tiene influencia determinante en los caudales de aguas lluvias que gravitan sobre laguna Carén.

Si bien el punto de descarga natural de esta cuenca es el estero Carén, éste se encuentra fuertemente regulado por el estrangulamiento que sufre dicho estero debido a las obras de la canoa del canal La Punta en su paso sobre el estero

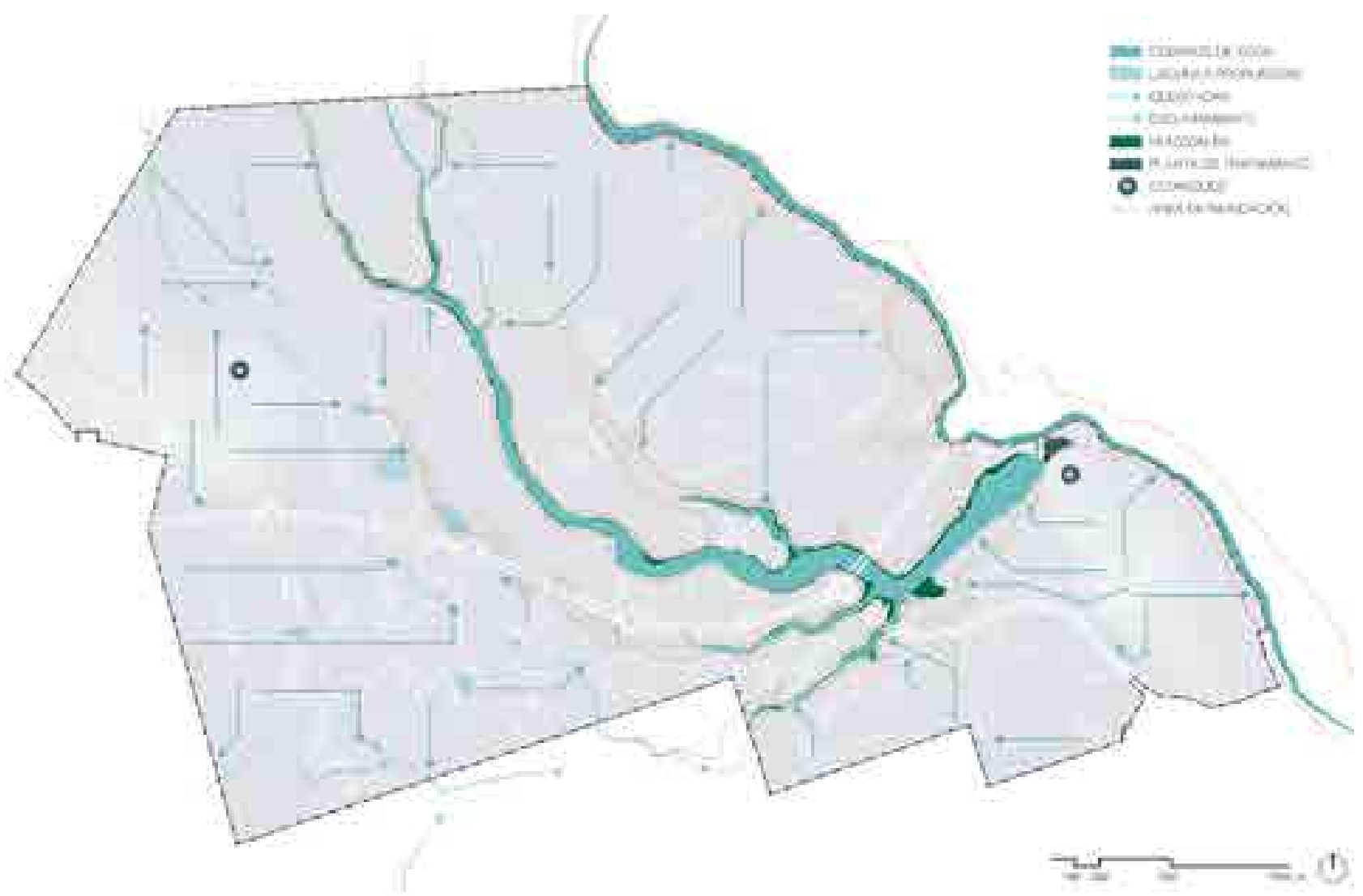


El canal La Punta está dotado de un pretil de gran estabilidad hidráulica y estructural, lo que le ha permitido resistir los embates de numerosas crecidas. Representa la mayor obra de amortiguación de crecidas naturales sobre el estero Carén.

La cuenca del estero Lipangue está cerrada al poniente por un anfiteatro montañoso donde destaca nítidamente el cerro Alto de Lipangue (Altitud: 2.014 m.). El escurrimiento de las aguas hacia el oriente da origen al estero Carén, llegando el área de influencia de esta cuenca hasta el acceso sur del área urbana de Lampa (FVLA, 2003, p. 9-10).

Al interior del predio, como se observa en la Figura 7.10., el sistema hidrográfico atraviesa la propiedad desde el norte por la parte central, para desviarse en el tercio sur hacia el oriente y hacer su evacuación en el estero Lampa, el que a su vez y no muy distante $(1.200 \mathrm{~m})$ evacua en el río Mapocho. El curso principal de este sistema hidrográfico corresponde al estero Carén, que tiene alrededor de 10 $\mathrm{km}$ de extensión hacia el norte y otros 5 hacia el poniente. El estero recoge el escurrimiento de las precipitaciones que caen en la vertiente oriental de los cerros de la Cordillera de la Costa en una extensión de alrededor de $10 \mathrm{~km}$. Los cerros de esta vertiente presentan un desnivel con el plano del predio de alrededor de $1.400 \mathrm{~m}$ de altura.

El estero Carén recibe el aporte de aguas utilizadas en el riego de predios existentes hacia el norte del área de estudio. Dichas aguas tienen su origen en el canal La Punta, que a su vez las extrae del río Mapocho. En parte, el aspecto turbio que presentan las aguas de la laguna Carén se debe, al aporte de fertilizantes y algunos otros contaminantes derivados de estas aguas.

En la porción final del estero Carén, donde se ha formado la laguna del mismo nombre, recibe un afluente menor desde el sector poniente donde se encuentra la mina Lo Aguirre. Esta mina posee algunas captaciones de aguas desde el estero Lampa que cruzan el predio por un ducto subterráneo de este a oeste (situación que hemos descrito en el capítulo 6).
Figura 7.11. Distribución de humedales macro región, con ubicación de Laguna Carén. En visor web CONAMA (s.f.)

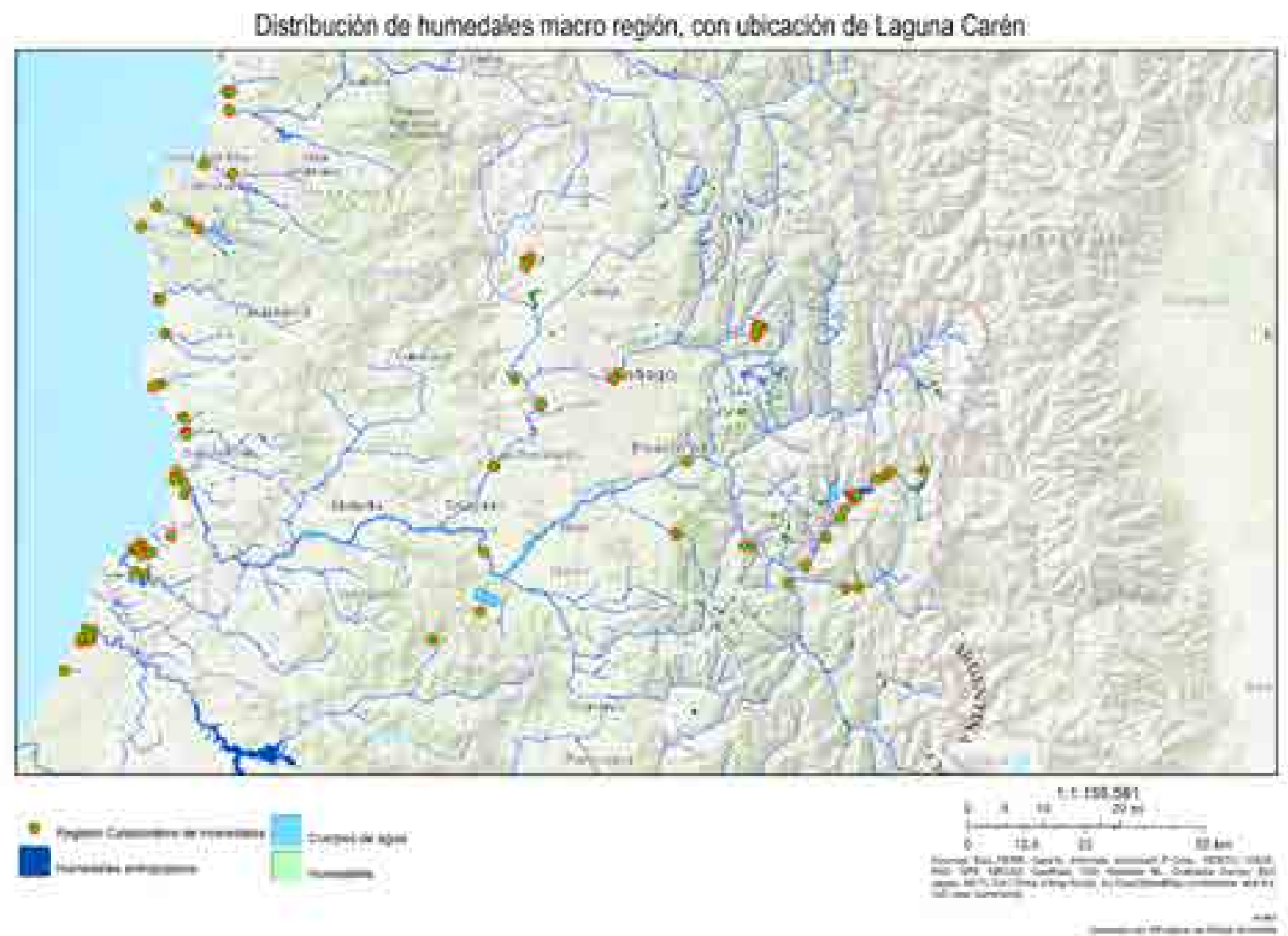




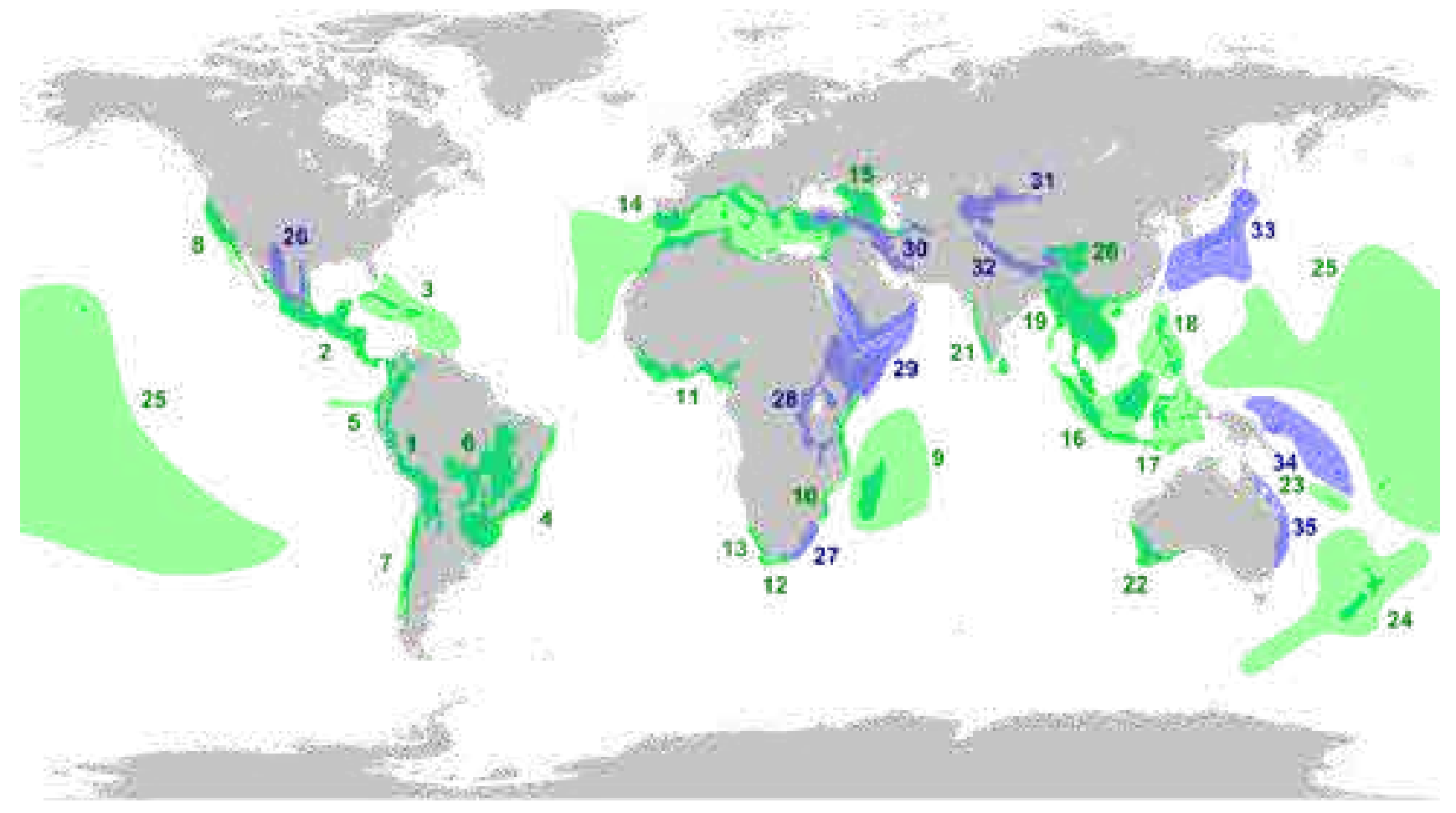

Figura 7.12. Hotspots de la Biodiversidad. Para Chile (número 7 en la imagen) "el hotspot se extiende desde la costa del $\mathrm{Pa}$ clífico hasta las cumbres andinas entre los $25^{\circ}$ y $47^{\circ} \mathrm{S}$ " (Arroyo et al., 2008, p. 90). En Biodiversity Hotspots (13 de sep-tiembre, 2019).

${ }^{293}$ Se consideran ambientes acuáticos tanto a los sistemas de aguas continentales (inland water systems) que abarcan hábitats tales como lagos y ríos, pantanos, embalses y llanuras aluviales, pequeños arroyos y estanques; como a los humedales costeros que incluyen estuarios, manglares, marismas y arrecifes; con la consiguiente variedad de características biológicas, físicas y químicas.

${ }^{294}$ Se especula que el $50 \%$ de los hábitats de aguas continentales se perdieron durante el siglo XX

${ }^{295}$ Myers et al. (2000) define los hotspots o "puntos calientes" de biodiversidad con prioridad de conservación como regiones que concentran un mínimo de 1.500 especies de plantas vasculares endémicas -equivalente al 0,5 por ciento del total de plantas vasculares en el mundo-, una alta proporción de vertebrados endémicos, y en donde el hábitat original ha sido fuertemente impactado por las acciones del hombre.

${ }^{296}$ La diversidad bioclimática de Chile genera una gran variedad de ambientes acuáticos. Los lagos y lagunas de la zona central son espacios ecológicos que se caracterizan por ser altamente productivos, de escasa profundidad, con vegetación ribereña alta casi en todo su perímetro y abundante vegetación sumergida.

\subsubsection{La Laguna Carén}

La laguna formada principalmente por el estero Carén, representa hoy el cuerpo de agua más extenso de la Región Metropolitana. Si bien su origen es artificial, a nivel local (meso escala) tiene gran importancia como ecosistema acuático, y por formar parte de la red de lagunas y humedales que vincula los ecosistemas costeros con los ecosistemas acuáticos de los valles transversales, y éstos con sus semejantes hacia la zona sur, el Atlántico y el hemisferio norte (Vilina \& Cofré, 2006). En la Figura 7.11. se indica la posición de los principales humedales, lagunas y embalses. Se puede observar la importancia de la laguna Carén en la conformación de la red en la macrozona (incluyendo el litoral).

Si bien, gran parte de las campañas por la conservación de la biodiversidad y los esfuerzos por la restauración ecológica han estado orientados a la recuperación de los suelos erosionados y la cubierta vegetal (Nicolau et al., 2007), en la última década se ha reconocido la importancia de los ambientes acuáticos ${ }^{293}$, cuya fragilidad hace peligrar el hábitat de muchas especies, teniendo como agravante, que los procesos en ellos se producen con mayor celeridad ${ }^{294}$. La biodiversidad de especies de aguas continentales es entre los más amenazados de todos los ecosistemas, y en muchas partes del mundo está en continua y acelerada decadencia. Se espera que el cambio climático mundial agrave la pérdida y degradación de muchos sistemas de aguas continentales y la pérdida o disminución de sus especies (Millennium Ecosystem Assessment, 2005, p. 554).

Cabe recordar que la zona de estudio, se ubica dentro del hotspot ${ }^{295}$ mundial con prioridad de conservación, denominado Chilean winter rainfall-Valdivian forests ${ }^{296}$ (Figura 7.12.), uno de las 35 zonas que concentran un alto endemismo de flora y fauna, "y en donde el hábitat original ha sido fuertemente impactado por las acciones del hombre" (Arroyo et al., 2008, p. 90).

\subsubsection{Los acuíferos}

Sabemos que en la Tierra existe más cantidad de aguas subterráneas que en la superficie ya sea en ríos, lagos o presas, por ello, parece importante incluir el concepto de vulnerabilidad de los acuíferos ${ }^{297}$.

El concepto "vulnerabilidad de los acuíferos a la contaminación" fue introducido por primera vez por J. Margat en 1968 y se definió como la sensibilidad de estos 
elementos a la contaminación. Jaroslav Vrba y Alexander Zaporozec definieron en 1994, que la vulnerabilidad intrínseca es una función de la vulnerabilidad natural que incluye factores como el sustrato geológico, los suelos, el clima, la topografía y los efectos humanos.

Entender como escurren las aguas bajo la topografía visible, nos permite incorporar este criterio (con la calidad del agua y fuentes contaminantes) a la planificación y al diseño. Los mapas de vulnerabilidad deben ser analizados junto a las variables habituales para determinar los distintos usos de la tierra.

La vulnerabilidad de los acuíferos fue evaluada considerando el espesor que alcanza la zona no saturada y composición de esta en relación con la facilidad de propagación de sustancias contaminantes a través de ella. El espesor de la zona no saturada se refiere a la distancia vertical entre la superficie y el nivel freático. La facilidad de propagación, depende de la capacidad de la zona no saturada para transportar contaminantes y de atenuarlos química, orgánica y mecánicamente.

La vulnerabilidad simplificada para efectos de este apartado, se evaluó considerando las características de los sedimentos o roca (granulometría y/o grado de fracturamiento) de la zona no saturada y el espesor de ésta. De acuerdo a los datos de pozos y calicatas existentes la línea de isoprofundidad (distancia promedio desde la superficie a la napa freática) se tiene entre 5 y $10 \mathrm{~m}$. Los antecedentes anteriores, se superponen sobre el mapa de Vulnerabilidad a la contaminación de los acuíferos en la cuenca de Santiago, Carta Geológica de Chile 2003, 1:100.000298, que muestra una vulnerabilidad moderada y alta para el área de estudio, por lo que el agua subterránea es altamente susceptible a ser afectada adversamente por una carga contaminante. El mapa resultante (muy simplificado), muestra que el sentido general de escurrimiento de la formación acuífera superficial tiene una dirección predominante norte sur, mientras que el área ubicada al sur-poniente, posee dirección oeste-este (Figura 7.13).

Desde el punto de vista del riesgo de contaminación de los acuíferos, la ubicación

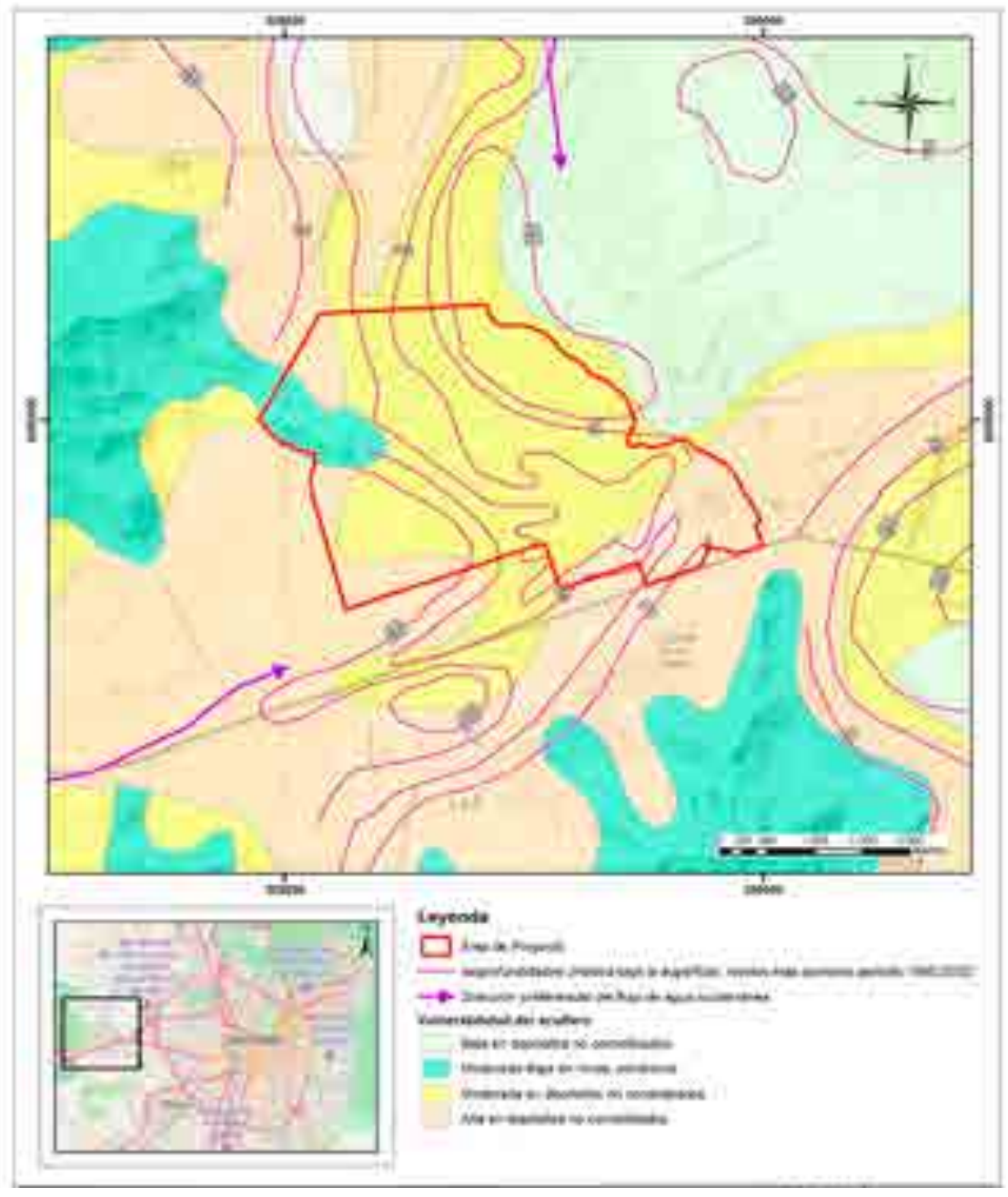

297 Un acuífero es el conjunto de rocas que permiten la permeabilidad del agua y la pueden acumular en sus poros o grietas. A esta agua retenida en las estructuras rocosas se la conoce como agua subterránea ${ }^{298}$ El mapa de vulnerabilidad del acuífero de la Región Metropolitana muestra que las zonas de mayor vulnerabilidad se ubica principalmente en la zona de desembocadura de la cuenca, aguas abajo de la confluencia de los ríos Mapocho y Maipo, en la zona de influencia del estero Lampa y del río Clarillo, y en las zonas de Quilicura, Renca, Cerro Navia, Quinta Normal, Pudahuel, Maipú, Peñaflor, Talagante, Isla de Maipo y Paine.
Figura 7.13. Mapa simplificado de vulnerabilidad del acuífero. Las flechas en morado indican la dirección de escurrimiento.

Elaboración propia en base a informe de la Consultora Andalué (2016) 
de Estaciones de Servicio (que expenden gasolina y tienen estanques subterráneos) serían un foco muy común de contaminación debido a fugas o escapes.

A la escala del terreno, ya habíamos descrito en el capítulo 6, dos posibles focos de contaminación: El Centro nacional de Energía Nuclear, a 9 kilómetros al poniente y el ex Mina Lo Aguirre, a 5,5 kilómetros (ambos medidos desde la laguna). A estos deben sumarse, la estación de servicio ubicada dentro del terreno, hacia la Ruta 68 (comodato) y el desagüe de la planta de tratamiento de aguas servidas de los extensos conjuntos de vivienda que están al otro lado de la carretera y que desaguan en el estero lampa a través de Carén.

\subsubsection{Riesgos hídricos}

El predio es vulnerable a inundaciones en una extensión de aproximadamente 185 hectáreas, especialmente en los episodios de altas e intensas precipitaciones característica del valle de Santiago (Espinoza y Hajek, 1988, p. 49). A esto suma una vulnerabilidad local, cuyas probables causas son: la escasa pendiente del terreno y la existencia de un pretil que se encuentra cercano a la confluencia con el estero lampa, que regula el nivel del agua de la laguna Carén, y que además permite el acceso en vehículo hacia el interior del predio por el lado oriente del estero. Se ha observado también un fenómeno hidráulico que ocurre frente a episodios de aumento brusco del caudal del río Mapocho. En estos eventos, la fuerza de la corriente del río, actúa como barrera a la escorrentía del estero lampa. Esta suerte de dique, provoca inundaciones aguas arriba. La solución a este problema pasa por la ejecución de una obra civil de menor envergadura en el punto de llegada del estero lampa al Río Mapocho

Los riesgos de inundación provocados por el desbordamiento del Estero de Lampa, de acuerdo a la memoria de los habitantes del predio, se producen cada veinte años, sin embargo, en la Declaración de Impacto Ambiental de $2003^{299}$, se anexa una carta de la Ingeniera jefa del Departamento de Obras Fluviales de la Dirección de Vialidad Metropolitana Sra. Marcia Aburto Cabona, con fecha 14/11/2000, donde se expresa su pronunciamiento, que en su último párrafo señala: "...En virtud de lo anterior, considerando los resultados del estudio hidráulico presentado, el área donde se proyecta emplazar el Parque Tecnológico no es inundable en crecidas del estero Lampa, con período de retorno igual o menor a 100 años"(DIA, 2003). Lo anterior es corroborado por la nueva versión del plano Modificación MPRMS/PDUC3 de 2006 que se muestra a continuación (Figura 7.14.):

\subsection{PISOS Y FORMACIONES VEGETALES}

\subsubsection{Vegetación regional}

El clima mediterráneo con inviernos fríos y lluviosos y veranos cálidos y secos, que impera en la zona central de Chile, sumado al relieve montañoso con dos cadenas de cerros que corren paralelos a la costa, valles que atraviesan en sentido transversal y una extensa depresión central longitudinal, determinan fuertemente la fisonomía del paisaje de la zona central. Existe un marcado gradiente norte-sur en las precipitaciones, con ambientes áridos en el norte y exuberante vegetación en el sur.

La vegetación de Chile ha sido descrita por Rodolfo Gajardo (1994) delimitando regiones, sub-regiones, formaciones y comunidades tipo. Se entiende como comunidad tipo o asociación a la agrupación local de especies resultado de condiciones ambientales específicas, criterio que hemos acogido en el estudio en terreno.

Como hemos visto, la zona central del país concentra la mayor parte de la población (73\% la zona central y 40,5\% la región Metropolitana, según el censo 2017), lo que implica una fuerte intervención antrópica sobre el territorio desde tiempos de la colonia. La intervención en forma de cultivos, ganadería, extracción de árboles y arbustos para leña o carbón, prolongada en el tiempo, hacen que $d=a 5 / 6 e / 00$ eb8fda9597bc089f5aef91ecb$4 d 9 f e c b b 8$ 


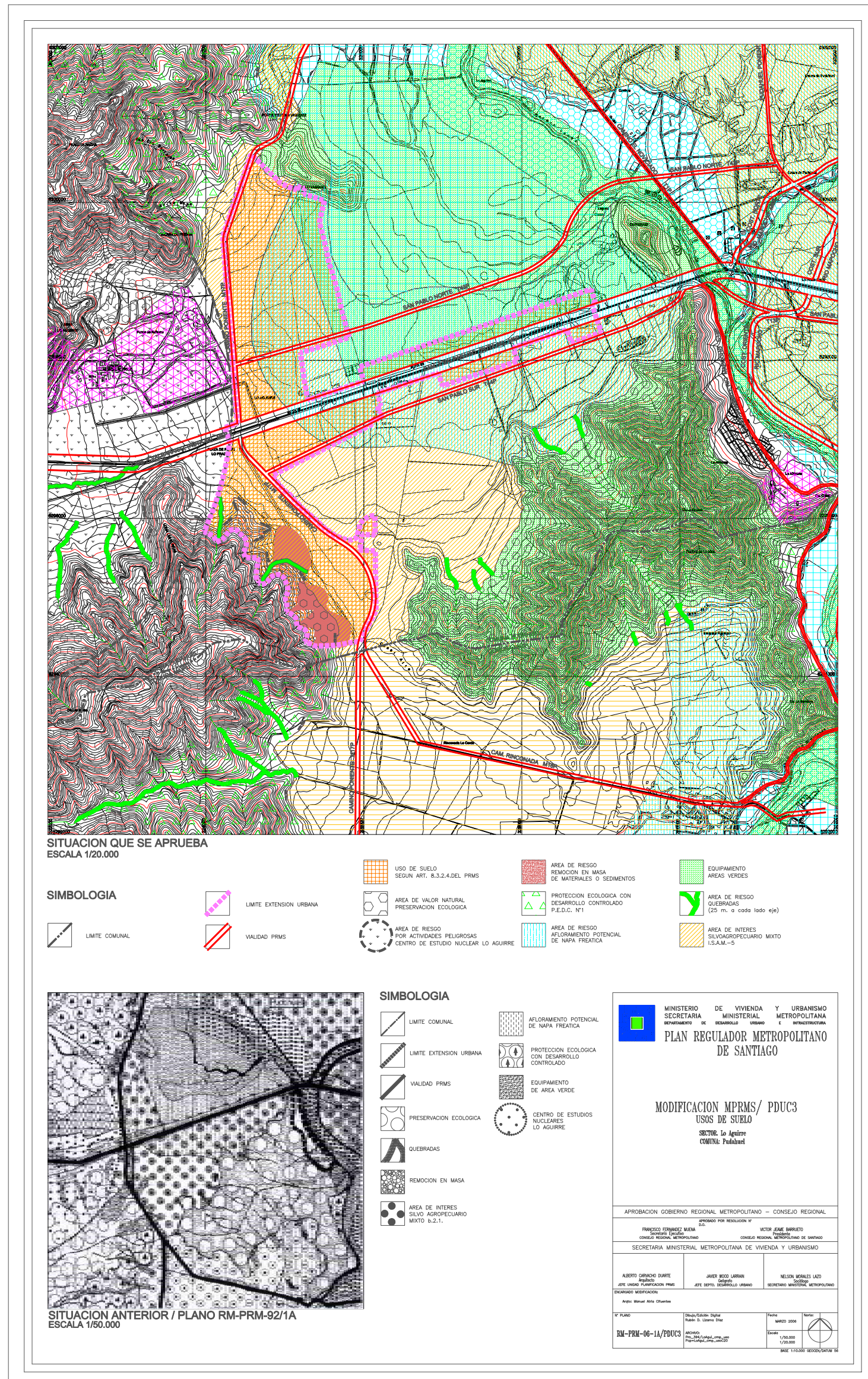

Figura 7.14. Plano de Modificación del Plan Regulador Metropolitano de Santiago (MPRMS/PDUC3), de 2006, donde se observa que el sitio de Carén no está marcado como área de riesgo por afloramiento de napas subterráneas

Por Ministerio de la Vivienda y Urbanismo, 2006. 
Tabla 7.3. Vegetación según regiones, sub-regiones, formaciones y comunidades vegetacionales.

Elaboración propia a partir de la clasificación de Gajardo (1994).

\begin{tabular}{|c|c|c|}
\hline \multicolumn{3}{|c|}{ REGION DEL MATORRAL Y BOSQUE ESCLERÓFILO } \\
\hline \multicolumn{3}{|c|}{ SUB-REGION DEL MATORRAL Y DEL BOSQUE ESPINOSO } \\
\hline \multicolumn{3}{|c|}{ FORMACION BOSQUE ESPINOSO ABIERTO } \\
\hline \multicolumn{3}{|c|}{ COMUNIDAD DE ALGARROBO-ESPINO (PROSOPIS CHILENSIS-ACACIA CAVEN) } \\
\hline \multirow{2}{*}{ ESPECIES REPRESENTATIVAS } & ALGARROBO & PROSOPIS CHILENSIS \\
\hline & ESPINO & ACACIA CAVEN \\
\hline \multirow{6}{*}{ ESPECIES ACOMPAN̂ANTES } & TEATINA & AVENA BARBATA \\
\hline & RONERILLO & BACCHARIS PANICULATA \\
\hline & PASTO LARGO & BROMUS BERTERIANUS \\
\hline & CARDO PENQUERO & CYMARA CARDUNCULUS \\
\hline & GUAYACAN & PORLIERIA CHILENSIS \\
\hline & HUAQIL. & PROUSTMA CUNEFFOLLA \\
\hline \multirow{2}{*}{ ESPECIES COMUNES } & Qullo & MUEHLENBECKLA HASTULATA \\
\hline & COLIGUAY & COLLIGUAJA ODORIFERA \\
\hline \multicolumn{3}{|c|}{ COMUNIDAD DE ESPINO-HUANIL (ACACIA CAVEN-PROUSTIA CUNEIFOLIA) } \\
\hline \multirow{2}{*}{ ESPECES REPRESENTATINAS } & ESPINO & ACACIA CAVEN \\
\hline & HUANIL & PROUSTIA CUNEIFOLLA \\
\hline \multirow{2}{*}{ ESPECIES ACOMPANAANTES } & RONERILLO & BACCHARIS PANICULATA \\
\hline & TOMATILO & SOLANUM TOUATULO \\
\hline \multirow{4}{*}{ ESPECIES COMUNES } & TEATINA & AVENA BARBATA \\
\hline & ALFILERLLO & ERODNM CICUTARUUM \\
\hline & PASTO SEDILLA & KOELERIA PHLEOIDES \\
\hline & PASTO FINO & VULPIA MEGALURA \\
\hline \multicolumn{3}{|c|}{ FORMACIÓN MATORRAL ESPINOSO DE LA CORDLLLERA DE LA COSTA } \\
\hline \multicolumn{3}{|c|}{ COMUNIDAD ESPINO-UTRE (ACACIA CAVEN-LITHREA CAUSTICA) } \\
\hline \multirow{5}{*}{ ESPECES REPRESENTATIVAS } & ESPINO & ACACIA CAVEN \\
\hline & LITRE & UTHREA CAUSTICA \\
\hline & LEUCHERLA ROSADA & LAUCHERIA ROSEA \\
\hline & AZULILLO & PASITHAEA CAERULEA \\
\hline & ESPICUILLA & TRISETUM CHROMOSTACHYUM \\
\hline \multirow{5}{*}{ ESPECIES ACOMPAN̂ANTES } & QUILAY & QULLALA SAPONARIA \\
\hline & COLLIGUAY & COLLGUAMA ODORIFERA \\
\hline & QulLo & MUEHLENBECKUA HASTULATA \\
\hline & MITIQUE & PODANTHUS MITIQUI \\
\hline & HUANIL & PROUSTIA CUNEIFOLIA \\
\hline
\end{tabular}


Pese a esto la región central presenta una gran diversidad vegetacional, con predominio de formas de vida como arbustos (altos y bajos) de hoja dura, arbustos espinosos, suculentas y árboles esclerófilos. El predominio de especies de uno u otro tipo, permite distinguir tres subregiones: la sub-región de Matorral estepario, donde predominan los arbustos bajos esclerófilos, la sub-región del matorral y el Bosque espinoso, y la sub-región del Bosque esclerófilo (Gajardo, 1983)

Para describir los pisos vegetacionales presentes en el área de estudio, se consultó información de Pliscoff (2006). A partir de este se puede apreciar que el área se compone por un bosque espinoso mediterráneo interior de Acacia caven (espino) y Prosopis chilensis (algarrobo).

En cuanto a las formaciones vegetacionales, a partir de la clasificación realizada por Gajardo (1994), se puede apreciar que el área de estudio se compone de un bosque espinoso abierto, lo que coincide con los pisos vegetacionales recién expuestos.

\subsubsection{Vegetación local}

En el área del predio se encuentran las formaciones "Bosque Espinoso Abierto" y "Matorral Espinoso" de la Cordillera de la Costa, las que son parte de la Sub-región del Matorral y del Bosque espinoso (Tabla 7.3.). Cada comunidad-tipo se describe en términos de las especies representativas (presentes entre un $100 \mathrm{y}$ $75 \%$ de los casos), especies acompañantes (presentes entre el 75 y $50 \%$ de los casos), y especies comunes (presentes en el 50 a $25 \%$ de los casos).

Como se mencionó anteriormente, la Sub-región del matorral y del bosque esclerófilo ha sido modificado por actividades humanas (cultivos y ganadería), al punto que sus formaciones vegetacionales son heterogéneas, persistiendo sólo en algunos ambientes los elementos de la condición original. Las formas de vida predominantes (llamados tipo en la Tabla 7.3.) son los arbustos espinosos suculentos o caducifolios de verano. Esta Sub-región está delimitada por la distribución del espino, el algarrobo y suculentas como bromeliáceas y cactáceas.

La comunidad más típica del predio es la de Algarrobo-Espino (Prosopis chilensis-Acacia caven), que se encuentra en las zonas planas, y ocupa, por tanto, la mayor parte de la superficie. Sin embargo, esta área está muy alterada por el pastoreo y la extracción de leña. En el estrato arbóreo, el espino es la especie dominante y subsisten sólo escasos ejemplares de algarrobo. El estrato herbáceo está dominado por el cardo penquero (Cynara cardunculus).

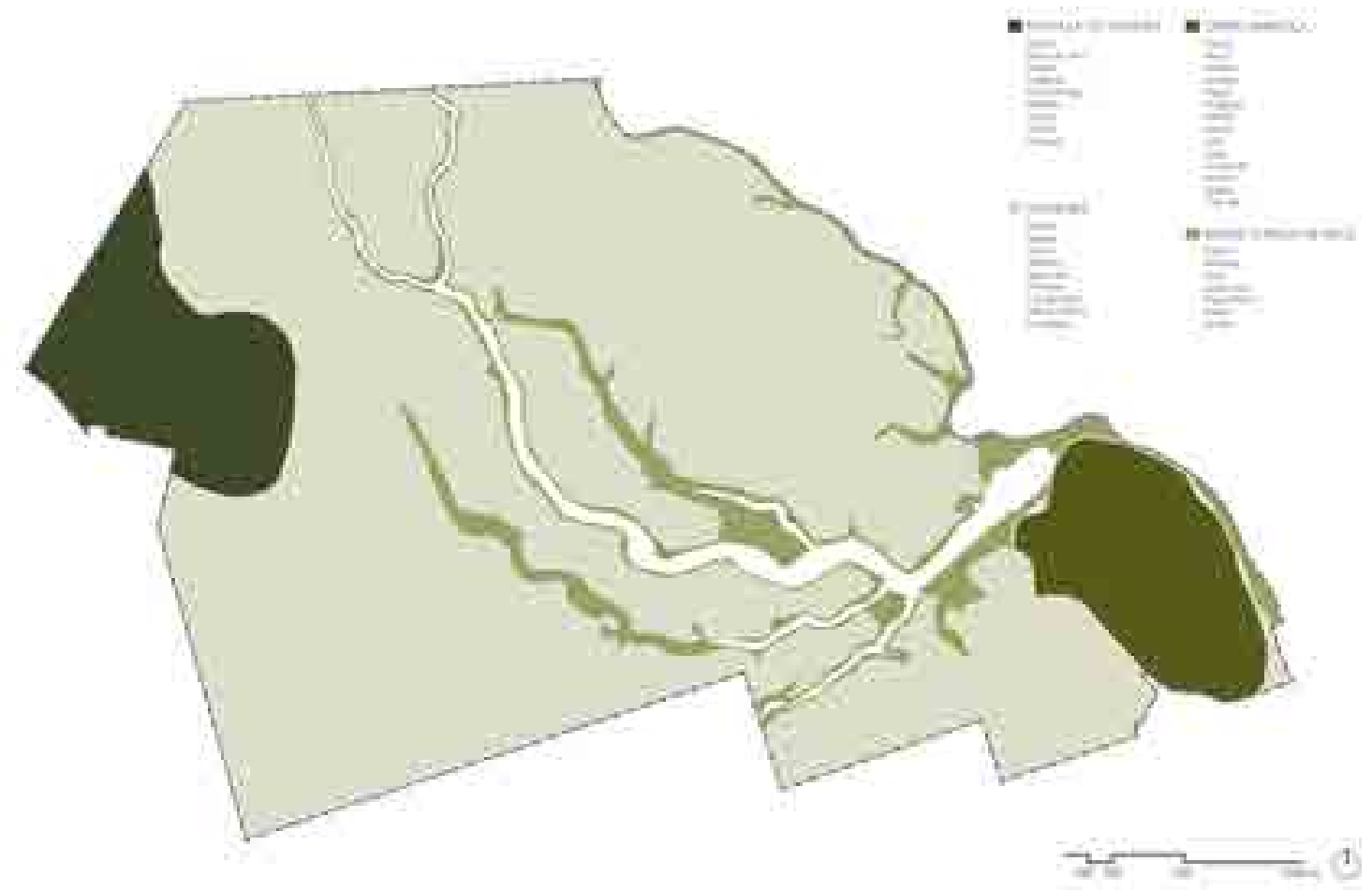


La comunidad de Espino-Huañil (Acacia caven-Proustia cuneifolia) es propia de las laderas bajas con pendientes suaves, y ocupa una pequeña parte del predio en la zona de la puntilla Lo Vásquez (sector nor-oeste). También en este caso, la zona está intervenida y por ello, el estrato arbustivo es de poco desarrollo.

El matorral Espinoso de la Cordillera de la Costa es una formación de probable origen secundario, ya que se ha originado en el territorio de un bosque esclerófilo más complejo. En ella predominan los matorrales espinosos y densos, entre los que se encuentran algunos árboles de mayor desarrollo, creciendo en laderas de exposición sur.

En el cerro Amapola, sector pedregoso e intervenido por acción antrópica, se desarrolla la comunidad de Espino-Litre (Acacia caven-Lithrea caustica), con un estrato arbóreo compuesto por espino, litre y quillay (Quillaja saponaria); en las partes más altas se encuentran dispersos ejemplares de Guayacán (Porlieria chilensis), de crecimiento arbustivo. En la ladera de exposición norte, esta comunidad se ve enriquecida por la presencia de suculentas como quisco (Equinopsis chilensis) y Chagual (Puya chilensis).

En la Figura 7.15. se muestra la distribución de la vegetación, diferenciando las zonas planas e intervenidas, donde se desarrolla la comunidad Espino-Algarrobo, los cerros donde aparece la comunidad Espino-Huañil y Espino-Litre, y los bordes de los cursos de agua donde crecen ocasionalmente algunas especies como sauces o chilcas.

\subsubsection{Composición de la Flora}

En el levantamiento, se detectaron un total de 27 especies en las diferentes áreas visitadas, de ellas, 18 corresponden a flora silvestre. De ellas se muestran las nueve principales en la Figura 7.17. A la flora silvestre hay que agregar especies que han sido plantadas con fines ornamentales, como eucaliptus (Eucalyptus globulus); el pimiento (Schinus molle), que es una especie que crece silvestre, también ha sido plantado en la zona a orilla de algunos caminos; el aromo (Acacia dealbata), plantado cerca de la laguna; la Palma chilena en la banda central del camino de acceso y Liquidámbar (Liquidambar styraciflua) en ambos bordes del mismo camino. En la Tabla 7.4., se presentan las especies levantadas y la información taxonómica y biológica de ellas. Puede observarse que 9 especies (33\%) son introducidas, sin bien menores en número de ejemplares y el resto es nativa. De las 27 especies en total trece especies son leñosas, siete son semileñosas, cinco herbáceas y dos son suculentas. Debido a que la época de muestreo se realizó a inicios del invierno (2017), la cubierta vegetacional está conformada mayoritariamente por especies perennes (leñosas, semileñosas y suculentas) y estrato herbáceo está creciendo, por lo tanto, estas especies (herbáceas) están subrepresentadas en la tabla.

En la Tabla 7.4. también se indica la distribución de las especies en los diferentes sectores. Los cerros son las zonas con mayor diversidad, con catorce especies en el cerro Amapola y nueve en Puntilla Lo Vásquez, en tanto, en los bordes de los cuerpos de agua (laguna y esteros) se desarrollan seis especies; las planicies que ocupan la mayor parte de la superficie, constituyen el sector más pobre con sólo cinco especies nativas. El espino es la especie más ubicua y se encuentra en todos los sectores. Por otra parte, las especies introducidas se ubican principalmente en planicies y cerca de cursos de agua.

Por otra parte, un aspecto ecosistémico a destacar del sitio, propio de las áreas con presencia de matorrales donde el estrato superior es una leguminosa, dice relación con la fijación biológica de nitrógeno por las bacterias asociadas a las raíces de acacia caven que determina en gran medida la productividad de la pradera asociada (Ovalle y Avendaño, 1984), posibilitando la permanencia y magnitud de las otras interacciones biológicas del ecosistema terrestre.

\subsubsection{Especies amenazadas}

De acuerdo a lo descrito en el Libro Rojo de la Flora Terrestre de Chile (CONAF, 1988), donde se define el estatus de cada especie, el área de estudio posee los siguientes casos que deben ser considerados en el proyecto: el Guayacán 


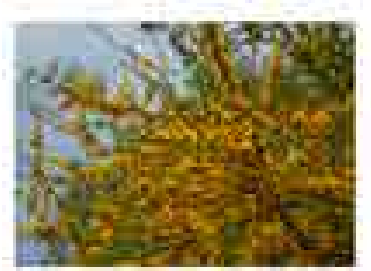

Ksome

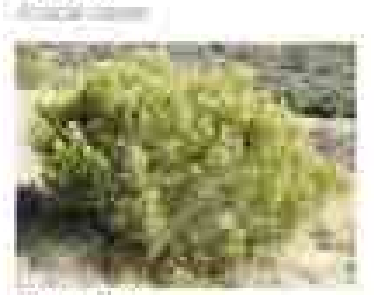

Ponerilito

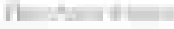

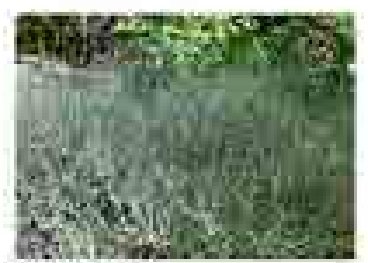

pingo:Pingo

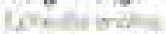

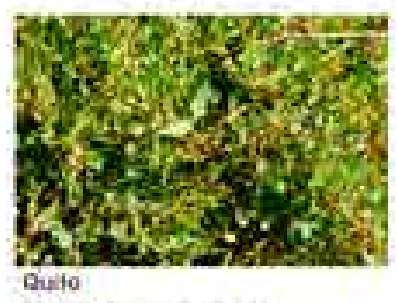

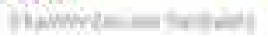
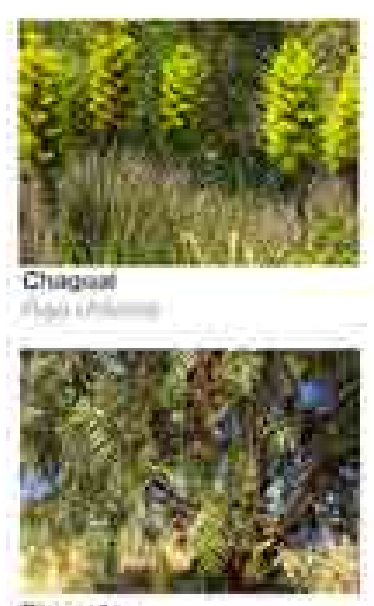

Firsiento

pront

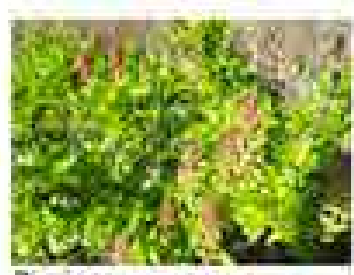

Pinsin

Misomen kne

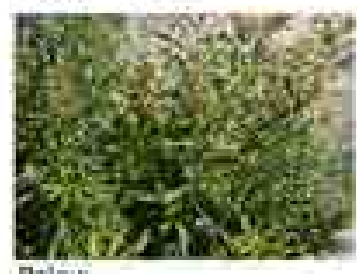

Palqui

comsuritum

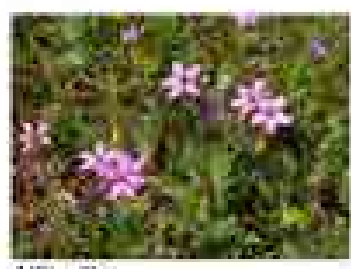

Alfierilo

Downtrate

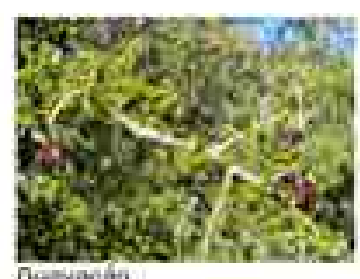

actyacan

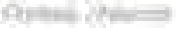
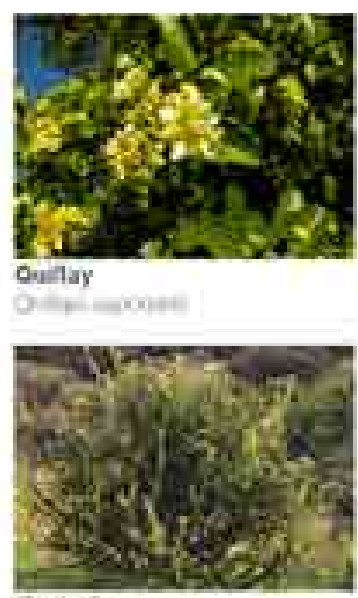

Trathuoùn

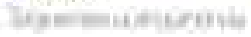

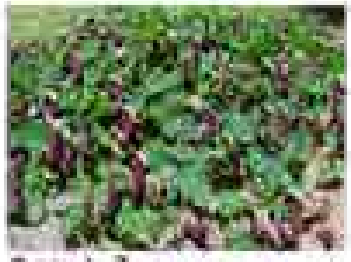

Oreja de Zorro

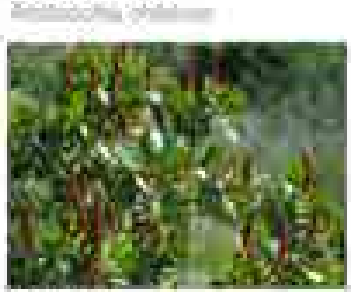

Colliguey

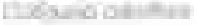

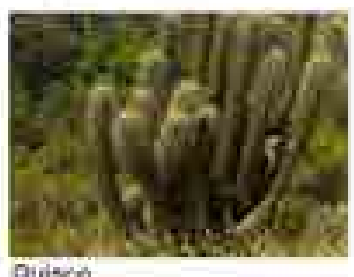

Quised

Eivare ine

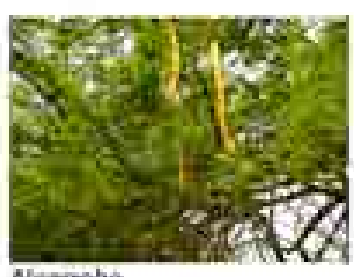

Nemerobo

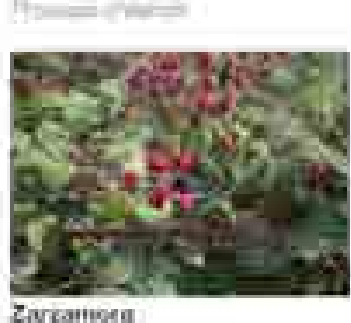

Zaviamoed

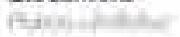

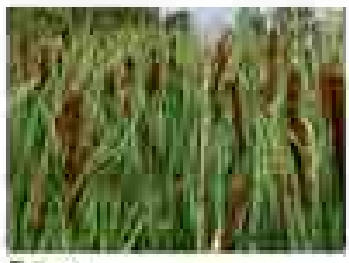

Toton

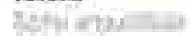

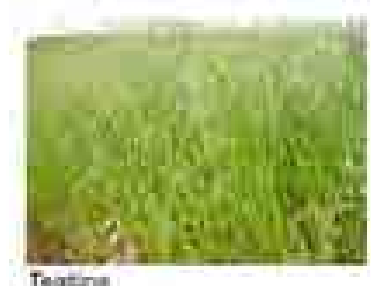

Teotina

Alemian:

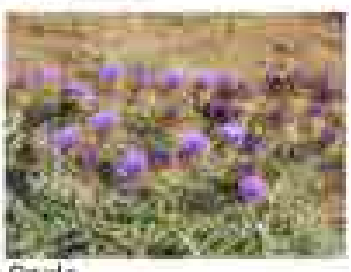

Cardo

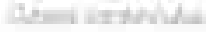

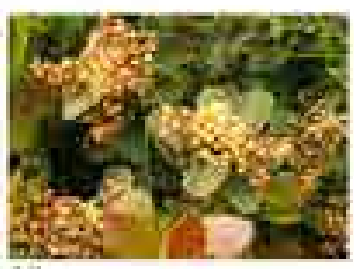

Lit.

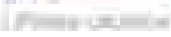

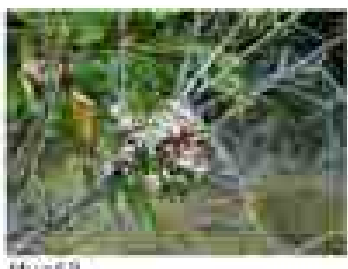

|fuacil

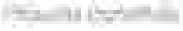
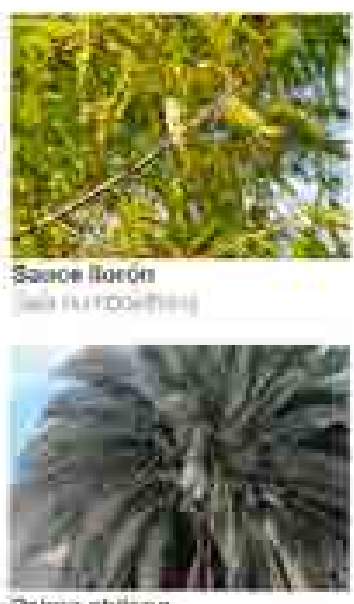

Pabma chileng

Linewingate

Figura 7.16. Flora del predio Carén. Principales especies. Elaboración propia. 
Tabla 7.4. Flora del predio Carén. Información taxonómica y distribución espacial. Elaboración propia.
${ }^{300}$ Capacidad de los organismos para diseminarse

301 Según el censo 2017 la población de la región metropolitana alcanza a 7.036.792 habitantes y la del país a 17.373.831. En www.censo2017.cl

\begin{tabular}{|c|c|c|c|c|c|c|c|c|}
\hline \multirow[b]{2}{*}{ Wovener cCuUn } & \multirow[b]{2}{*}{ Ispaot } & \multirow[b]{2}{*}{ senesh } & \multirow[b]{2}{*}{$\pi+0$} & \multirow[b]{2}{*}{ NTFO } & \multicolumn{4}{|c|}{ costessocod } \\
\hline & & & & & F & 2 & 1 & 4 \\
\hline 1 Exwa & ACANA CANTA. & outraztar & Irse & & $\varepsilon$ & \% & $y$ & $x$ \\
\hline Pancos & Nasone tha ilTorais & AITINANATE: & $5 \mathrm{~N}$ & & $\mathrm{t}$ & & - & \\
\hline 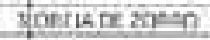 & 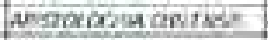 & Lisfre abistiat & int & & & 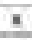 & & \\
\hline atrabsh & Akru awhard & cownowey & Mint & $x$ & $\boldsymbol{E}$ & $*$ & & $\pi$ \\
\hline sposeng. & Mrobussiavear & Cowerne & 45 & & $x$ & & A & \\
\hline Epregy & Qstequnary: & beranacest & $3+3 y$ & & $\mathrm{E}$ & & & \\
\hline Tcousisung: & 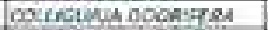 & FAMOSALCON & 1180 & & E & $x$ & & \\
\hline Detacos & chula castivetus & courcoditat & $+12=$ & 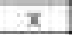 & & & & $x$ \\
\hline Povinomigran & rourtias unnika & rawrokeras & Q 25 & & & $x$ & & \\
\hline 10 fontsiaso. & coosumecutatun & Eotuaviarlat & $14 \mathrm{sh}$ & $\mathbf{x}$ & $x$ & 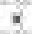 & & $\mathrm{x}$ \\
\hline 19 puser & roinuress on ruves & CACCAXA & (2) NE & & 8 & $\pi$ & & \\
\hline $12 t$ & 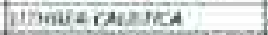 & Averapocis & axw & & 1 & & & \\
\hline 130010 & 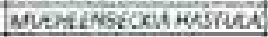 & focroaviose & 390 & & $x$ & & $x$ & \\
\hline 14 couvacen & 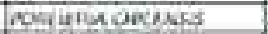 & 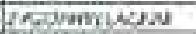 & IE & & 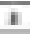 & & & \\
\hline 19) kishtiroso & hodopts onirsst & ratoreciot & $x$ & & & & & $\underline{x}$ \\
\hline acherafa. & 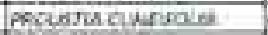 & courcisar. & $45 \mathrm{~V}$ & & t. & 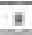 & & \\
\hline ITे ChNouA! & Rra onthes. & enowereactas & (s) & & & 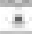 & & \\
\hline 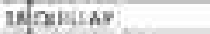 & 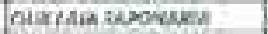 & $\cos a \cos$ & 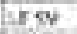 & & $\boldsymbol{E}$ & & & \\
\hline 15) JAETAWCE: : & 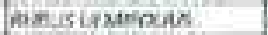 & caseital & $8 \%$ & & & & $x$ & \\
\hline zosvicr unaon & Ses & suchorar & IIS & & & & $x$ & \\
\hline FIINTNID & genvus ANefS & 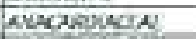 & Ifs & & & & & $\bar{x}$ \\
\hline 22. TW WHES & 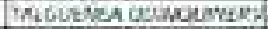 & Fuservaces & 430 & & 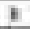 & & & \\
\hline If tomgra: & imer anichisoks & rrvaluses & $M A N$ & & & & $x$ & \\
\hline 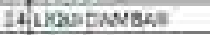 & ciocrosudese & 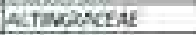 & $\& \leq \mathrm{AH}$ & $\mathrm{x}$ & & & & $x$ \\
\hline 1425050 & ACESA DKLLEATA & Napocarrar & ifse & $\bar{x}$ & & & $x$ & \\
\hline 26. pulva colinis & celodoribers & descrias & 145 & $x$ & & & & $\mathbf{x}$ \\
\hline infrucailonix & rerevon,s findusin & Nosteru & ireh & $x$ & & & & $x$ \\
\hline
\end{tabular}

(Porlieria chilensis) y el Algarrobo (Prosopis chilensis) son especies endémicas y están en categoría "Vulnerable" a nivel regional y nacional. En el caso de las suculentas, el chagual (Puya chilensis) es "Vulnerable", y el Quisco (Equinopsis chilensis) está considerado "Fuera de Peligro".

El Guayacán se presenta en la zona en forma de pequeños arbustos, aislados unos de otros y muy ramoneados por el ganado. El Algarrobo no forma rodales, es muy escaso y se presenta sólo como renovales aislados. El chagual es abundante en los cerros rocosos y la principal amenaza de la especie, según Hoffman y Flores (en CONAF, 1988) es la utilización que la gente hace de sus hojas como fibra.

\subsubsection{Reforestación}

Como parte de las obras de remediación de la primera etapa, vale decir de la construcción de la calle de acceso, rotondas y portal de acceso, se ejecutó la reforestación en el año 2007, de 33 hectáreas en la zona nor-oriente del predio, a un costado del estero Lampa (indicada en Figura 7.16. Las especies incorporadas corresponden especies esclerófilas como: Quillay, Espino, Algarrobo, Guayacán y Colliguay en una densidad de 1.250 plantas/hectárea.

\subsection{FAUNA}

Como hemos señalado, Chile central se encuentra ubicado dentro de los 35 hotspot de biodiversidad con prioridad de conservación a nivel mundial. Lo particular de esta zona es su carácter de isla biogeográfica, vale decir, la vida se desarrolla con cierto aislamiento, debido a los límites naturales (cordillera, océano, desierto) que la confinan, generando una composición taxonómica continental única, observable en la evolución de plantas y animales. En el caso de la fauna, peces, reptiles y anfibios presentan tamaños corporales pequeños, son poco diversos y poseen un alto endemismo (sobre el $50 \%$ ). En contraste, las aves registran un bajo endemismo $(2 \%)$, debido a su alta vagilidad ${ }^{300}$, con especies que presentan patrones de migración intercontinentales. Por su parte, los mamíferos registran también pequeños tamaños corporales y un endemismo moderado (10\%). (Carrasco et al.,2016, p. 7).

La Región Metropolitana de Santiago, dentro de la cual, se encuentra el terreno de estudio, es la más poblada del país, concentrando el $40,5 \%$ de la población ${ }^{301}$, 
hecho que pone en riesgo la conservación de esta biodiversidad, al alterar el hábitat de las especies por el cambio de uso de suelo, el reemplazo del bosque nativos por especies exóticas, la contaminación y la modificación de cursos de aguas, entre otras razones. En este contexto, la intervención en este vasto territorio se constituye en una amenaza, que debe ser aplacada a través de la comprensión del ecosistema para poder luego conciliar transformación y conservación.

Como la presencia de agua en la zona mediterránea semiárida es escasa, los humedales y cuerpos de agua tienen especial relevancia para la mantención de la biodiversidad regional y global, por cuanto estos sitios son hábitat y fuente de alimento de numerosas especies de aves y fauna en general. Por ello, cabe considerar como central que el sitio de emplazamiento del proyecto es un ecosistema dulceacuícola, que como hemos visto, se relaciona con un sistema mayor de embalses y humedales presentes en la región.

Junto a la laguna y el humedal, cabe destacar el ecosistema de espinales de acacia caven, especie que, organizadas en parches, determina en gran parte la productividad de la pradera asociada, posibilitando la permanencia y magnitud de otras interacciones biológicas del ecosistema terrestre. Como han planteado Ovalle y Avendaño (1984), esta especie, mejora los suelos aumentando el contenido de materia orgánica y de nitrógeno, característica particular de esta leguminosa fijadora de nitrógeno atmosférico a través de bacterias asociadas a sus raíces.

La alta variación estacional del matorral abierto de Acacia caven, junto con una cubierta herbácea restringida a los meses de primavera genera cambios en la disponibilidad de alimento para aves y mamíferos lo que provoca, en condiciones normales, cambios cíclicos en la fauna, pues la comunidad de espinal se sustenta estructuralmente en la productividad de las especies anuales. Las hierbas y sus semillas constituyen la fuente de alimentación de insectos, aves y micromamíferos. Esta interacción herbívora/granívora posibilita la generación de nuevas interacciones como depredación de los insectos por vertebrados que alimentan a su vez predadores de mayor tamaño, como las rapaces. Dicha situación, en el contexto de fauna descrita más adelante, en la cual no se encontraron mamíferos de gran tamaño, a excepción de Conejo (Oryctolagus cuniculus), y la mayor parte de la fauna corresponde a micromamíferos (roedores), de amplia distribución en la zona mediterránea de Chile. Otro aspecto a considerar es que los mamíferos introducidos detectados, como conejo, lauchas (Mus domesticus) y ratas (Rattus rattus), son considerados como plagas.

Conforme a lo observado en terreno, por la baja movilidad de los micromamíferos nativos, el sitio del espinal es permanentemente ocupado para actividades de alimentación y reproducción, considerando que, en relación a los roedores exóticos, tienen una tasa de reproducción menor, habitan en madrigueras y su dieta consiste básicamente en granos, pequeños frutos e insectos (Mann 1978, Miller et al, 1975). Los reptiles presentan un rango aún menor que el de los micromamíferos, y requieren habitualmente acceso a vegetación donde cazar insectos (lagartija) 0 vertebrados pequeños (culebra). Los matorrales sirven a ambas especies para protegerse de sus predadores, especialmente de las aves rapaces. En cuanto a las aves detectadas, presentan una gran movilidad. En el muestreo efectuado marzo de 2017 se detectó presencia de nidos. Hecho que mejora observaciones realizadas en 1995 en la zona, cuando se observó ausencia de éstos, lo cual no es habitual en espinales, ya que reflejaría el alto grado de perturbación del área, principalmente por el fuego, que disminuye la cobertura vegetal herbácea, hecho fundamental pues la mayor parte de las especies de aves detectadas se alimentan de insectos y granos. Las aves rapaces observadas fueron especies generalistas y de pequeña talla. La ausencia de rapaces mayores también podría haber sido un signo de alto grado de perturbación del área. Es importante destacar el rol de control, sobre todo tipo de ratones e insectos, que ejercen las rapaces, por lo que el cuidado de los matorrales es clave para la contención de plagas. 
Tabla 7.5. Vertebrado del predio Laguna Carén (2017). Las imágenes de la derecha, corresponden a algunas de las espe-cies endémicas. Elaboración propia en base a clasificación del Libro Rojo de los vertebrados (CONAF, 1989).

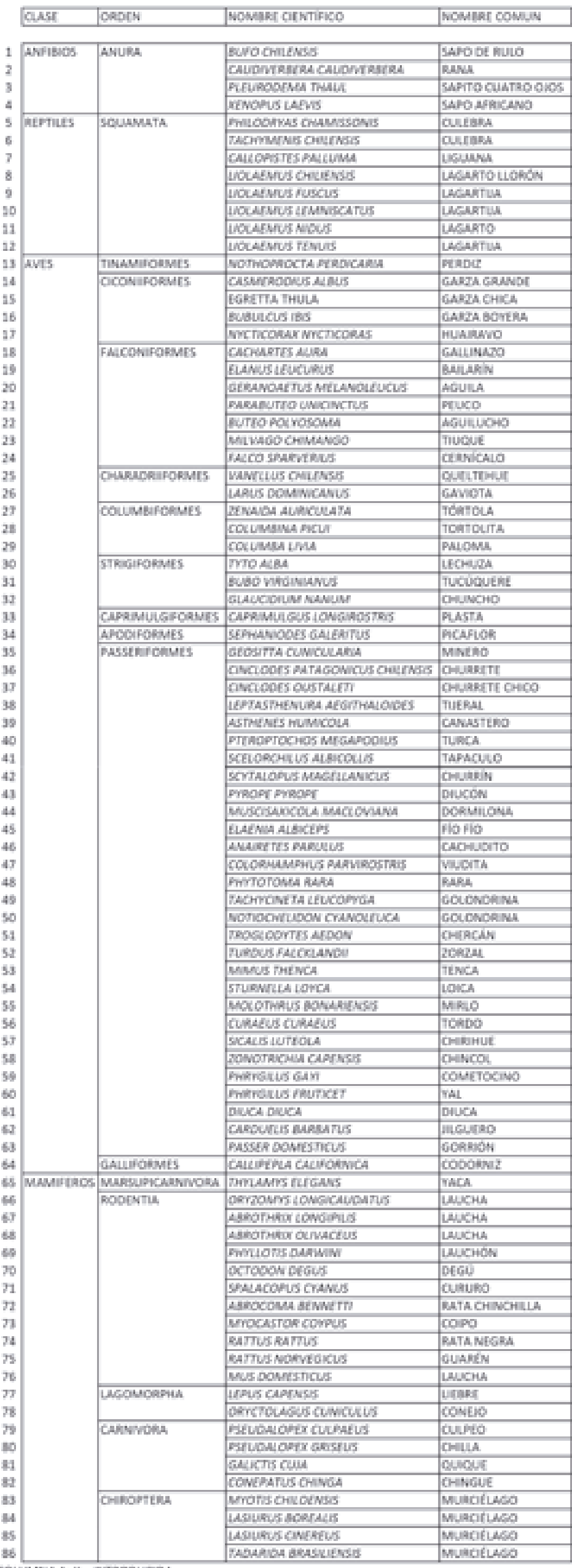

colUUNA A: $X=$ NTTADOUODA

COLUUNA a: $E$ - ENDEMICA

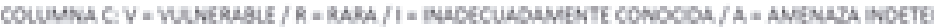

fuente: Ubro hajo de los Vertebrados (CCONA, 195s) 

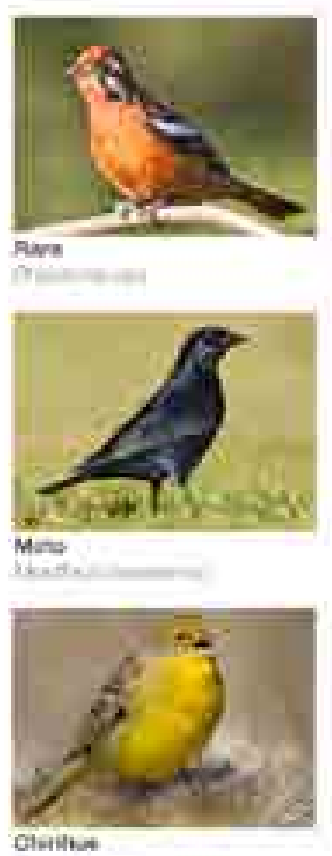

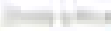
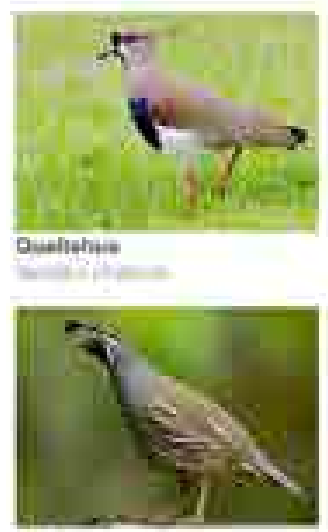

Converir

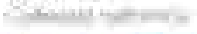

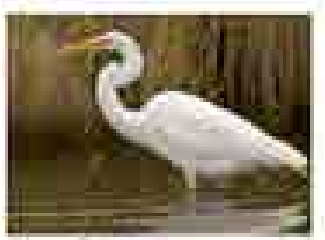

Oerrie Gmons?

Oavo Omoser

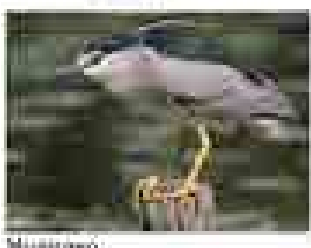

Nuavaso

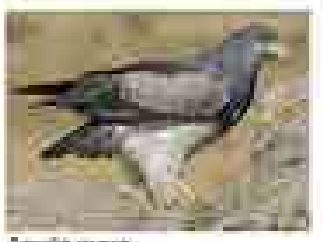

Aprata mora:
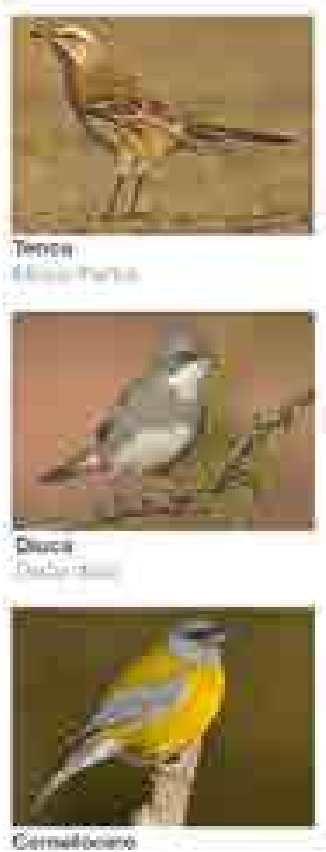

Cenedoseno

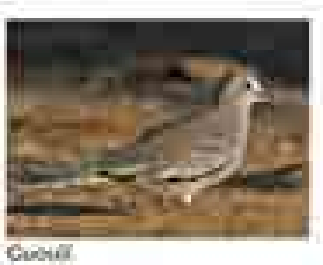

Covere

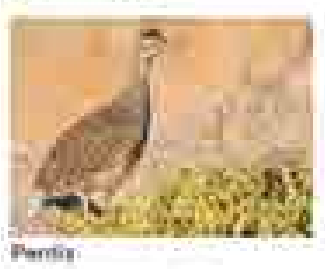

Whith

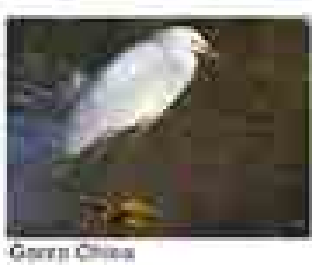

anrmolen

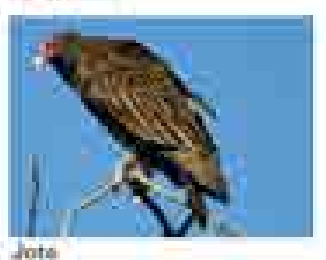

trat

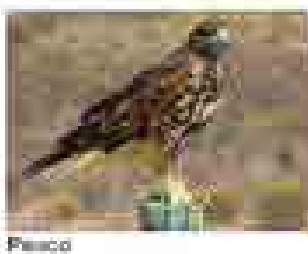

Penco

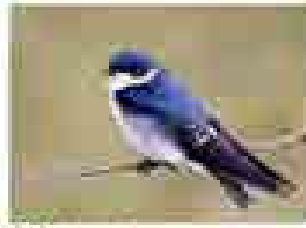

Eckontria
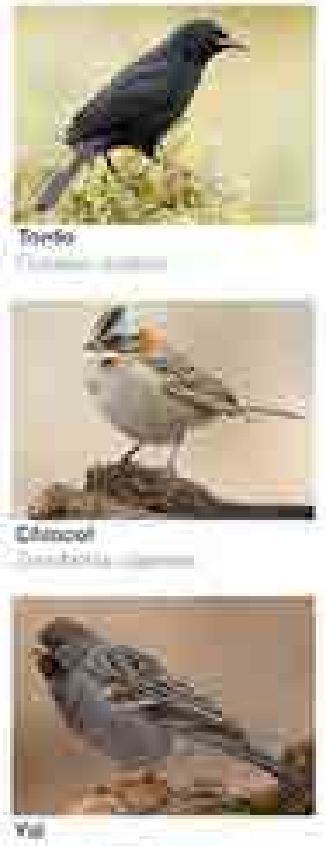

Vinian nas

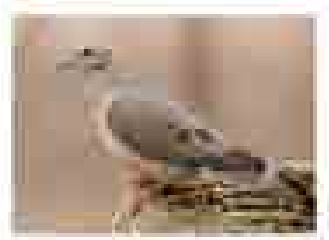

Thatela
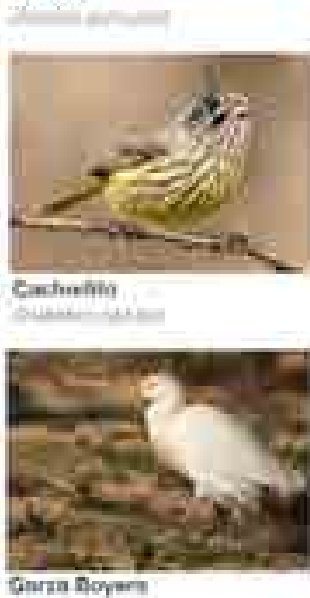

Garra Doyer:

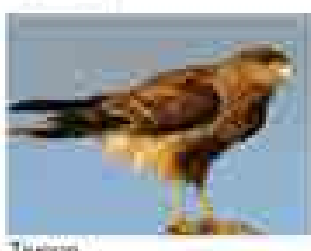

14000

111

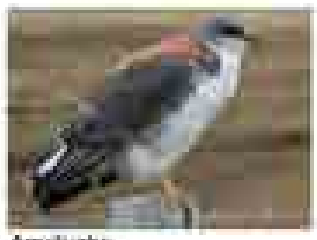

Apulichs

Anition?

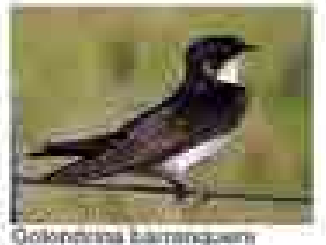

Oobnetina barangamen

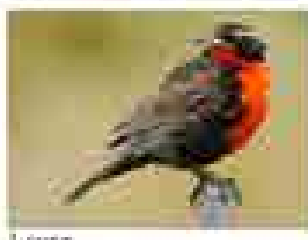

Levea

Woranu:

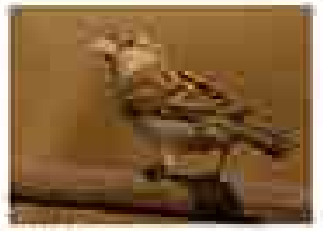

anmon

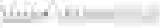

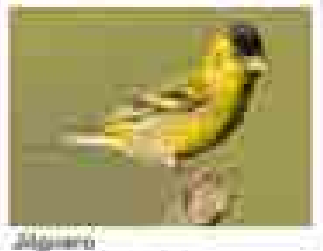

Meide
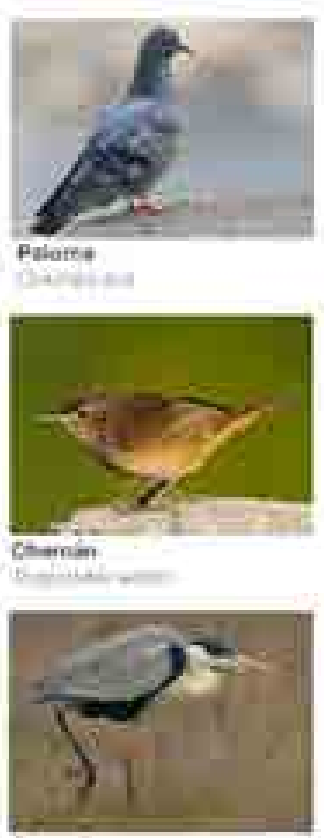

Gerna Gose

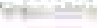

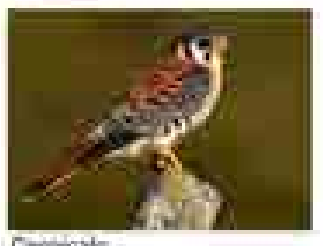

Cencicale

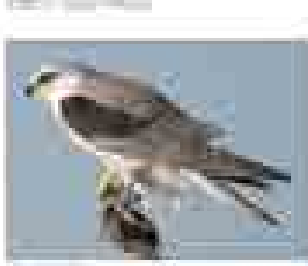

undarn, 

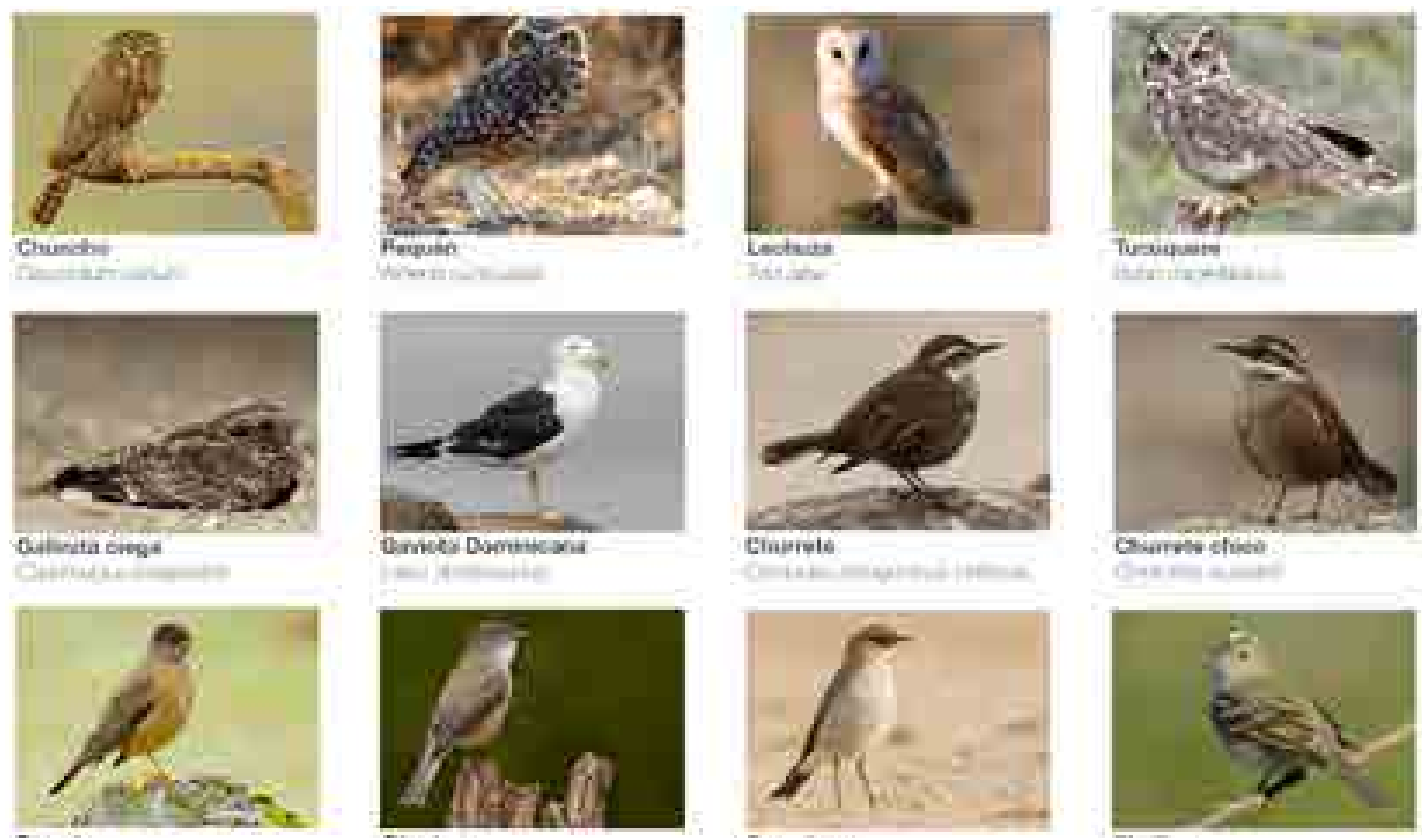

whil in an

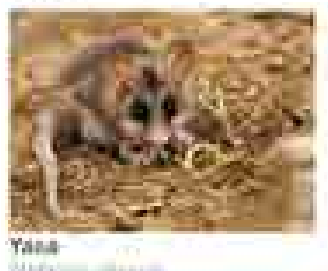

Qumes

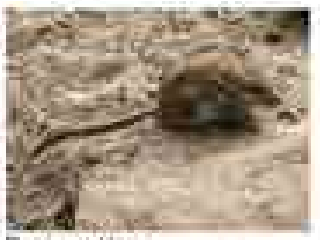

Ya:4

Aroin soltary

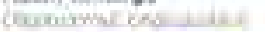
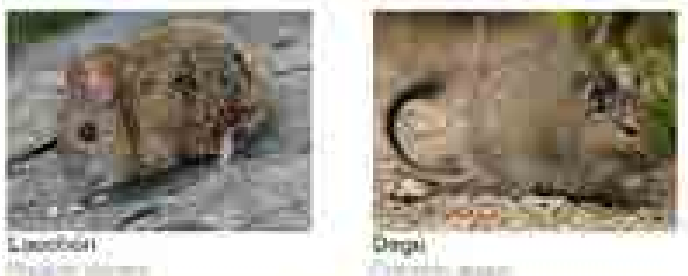

Drimitose nas
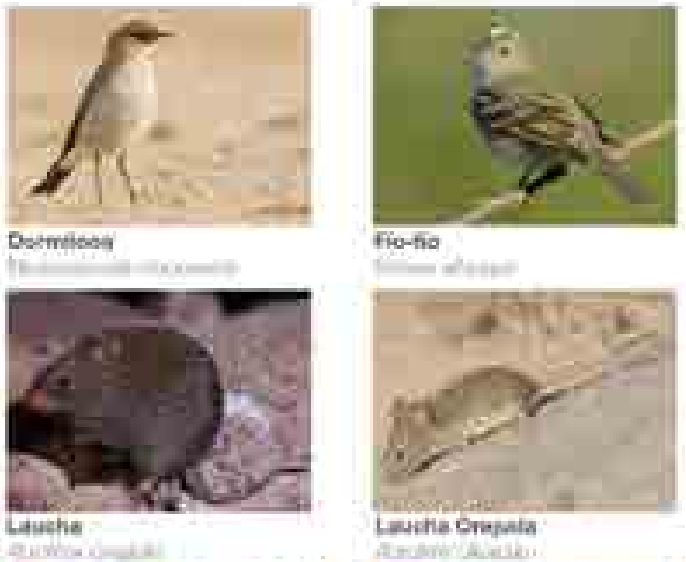

Fio-6o
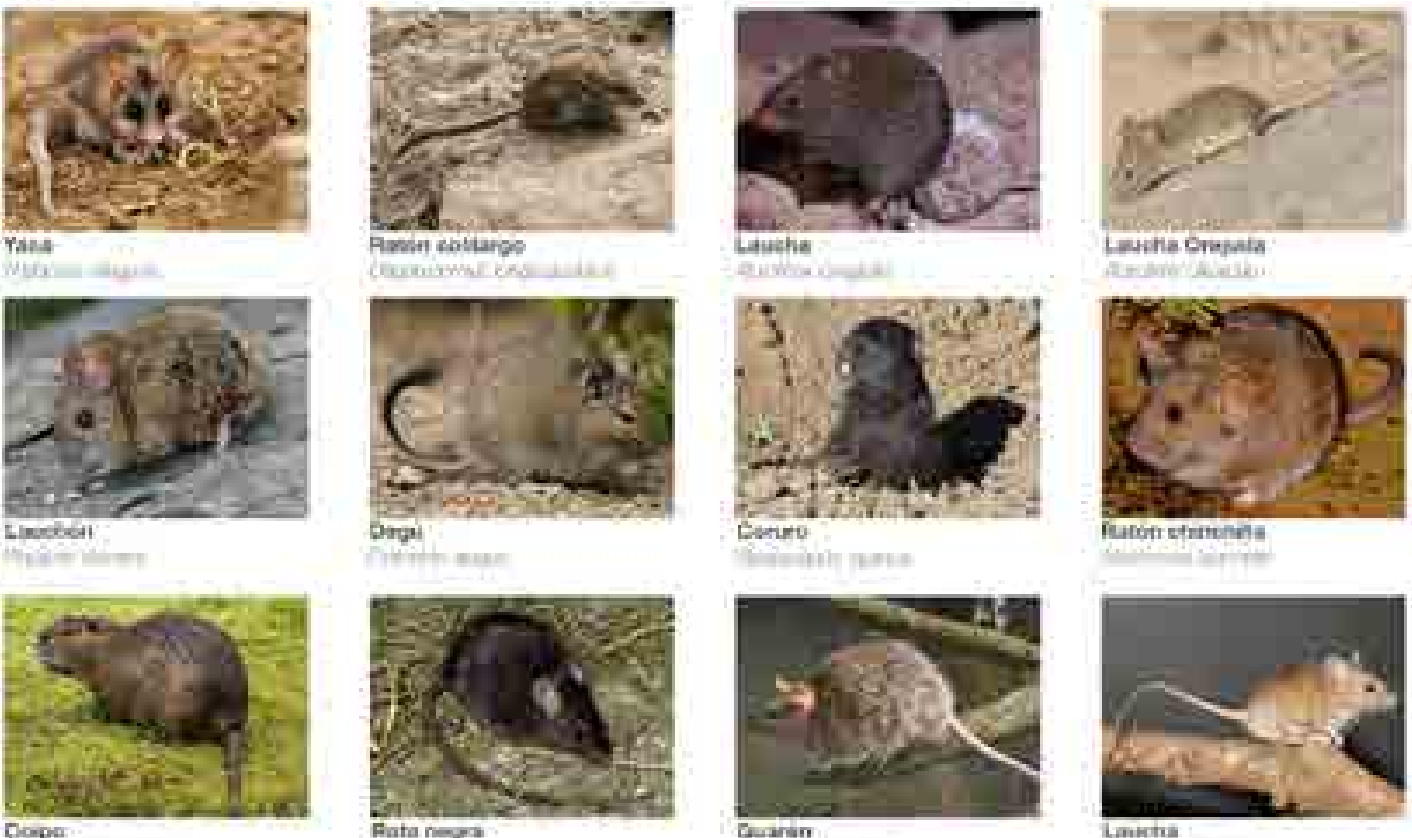

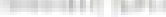

whentsinger
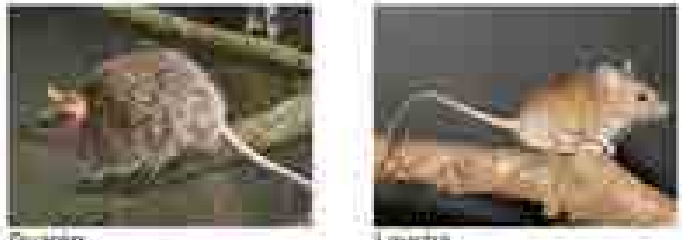

Cuaran

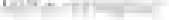
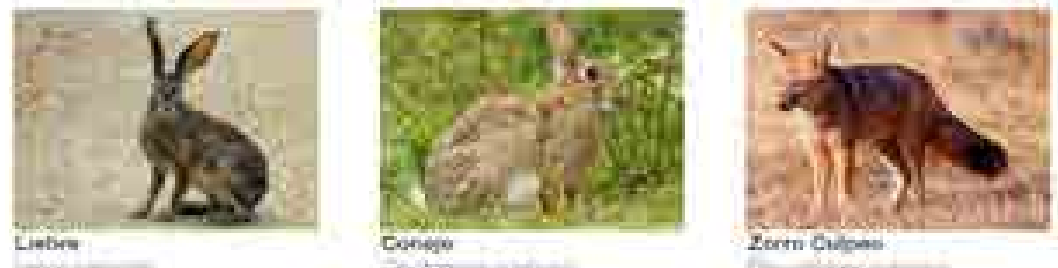

Lankrta

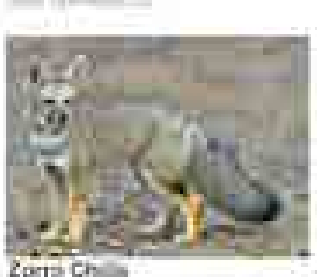

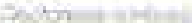
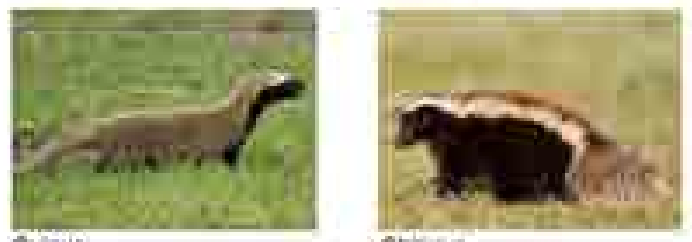

Chrigia

Oinour
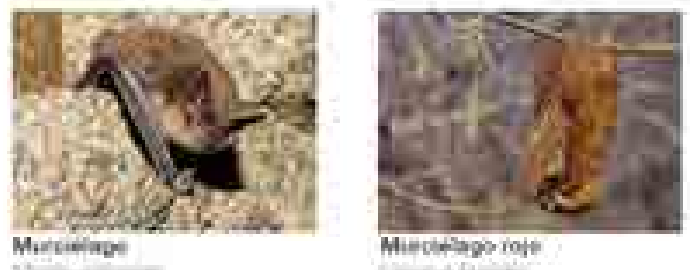

Miedotsporioje
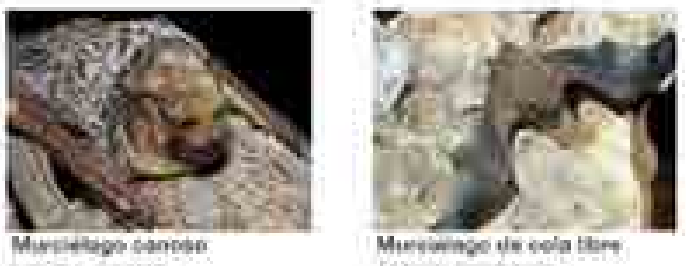


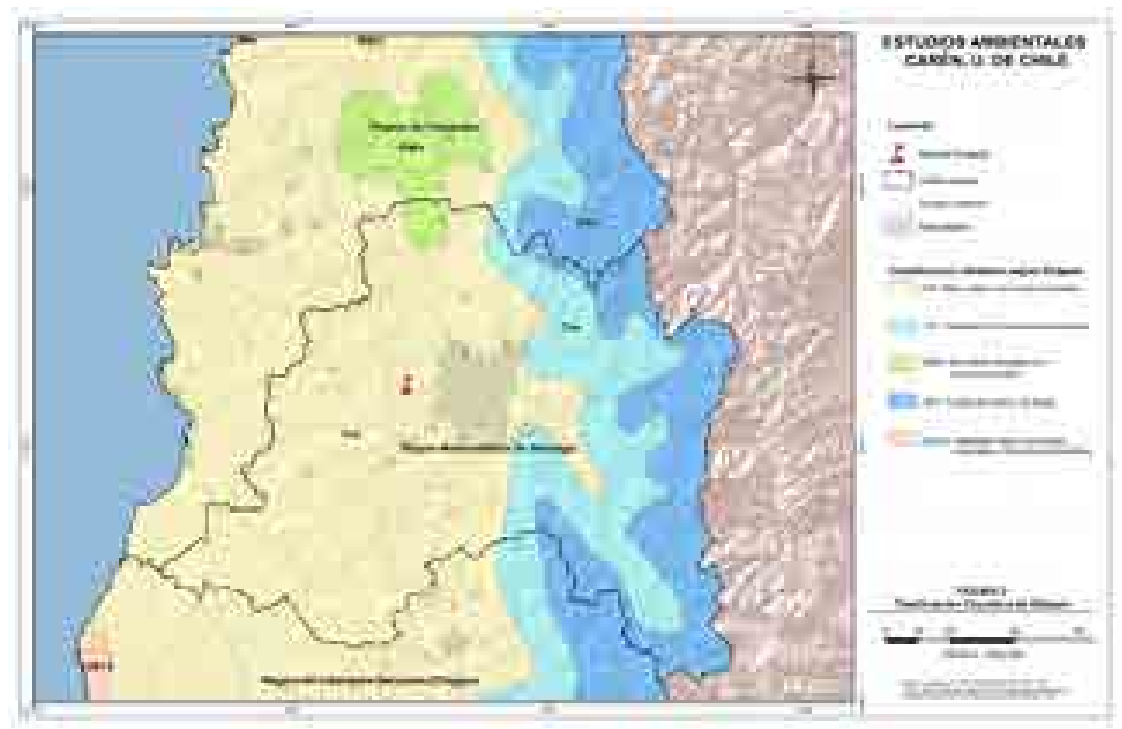

7.8.1. Composición de la fauna local

El catálogo de la fauna presente en la zona de influencia del predio Carén se presenta en la Tabla 7.5. con un total de 86 especies (77 nativas y 9 introducidas) y está compuesta por cuatro especies de anfibios (tres nativos y uno introducido), ocho reptiles (dos culebras y seis lagartos), cincuenta y dos aves (con cuarenta y nueve especies nativas y tres introducidas), y veintidós especies de mamíferos (diecisiete nativas y cinco introducidas).

Dieciséis de las 77 especies nativas presentes en el predio están mencionadas en el Libro Rojo de los vertebrados Terrestres de Chile (CONAF, 1988), resumidas en la columna A de la tabla. De los tres anfibios nativos, el "sapo de rulo" es "Vulnerable" a nivel nacional y la rana es clasificada como "Rara". Los reptiles son el grupo que presenta mayor número de especies amenazadas, sólo dos de las ocho especies no están en alguna categoría del Libro Rojo. Las dos culebras, la liguana y otros cuatro lagartos son "Vulnerables". Las aves son el grupo más diverso y también el menos amenazado: ninguna de las especies observadas en la zona, se encuentra citada en el mencionado libro. Siete de los diecinueve mamíferos nativos están categorizados: el coipo y el quique son "Vulnerables", el chingue es una especie "Rara", los zorros y una laucha son "Inadecuadamente conocidos" y en el caso del ratón chinchilla, su categoría es de "Amenaza Indeterminada" (CONAF, 1988).

Por otra parte, dieciocho de las 77 especies nativas (23\%) son endémicas en nuestro país. El mayor nivel de endemismo lo presentan los herpetozoos $\mathrm{s}^{302}$ y el menor las aves, que como hemos dicho, se debe a su movilidad. En la columna $B$ de la Tabla 7.5., se señala con letra $E$ a las especies endémicas: dos anfibios, seis reptiles, cuatro aves y seis mamíferos).
Figura 7.16. Clasificación climática de Köppen. En Universidad de Chile (2016)
${ }^{302}$ Anfibios y reptiles.

Tabla 7.6. Datos meteorológicos de la estación Pudahuel: Temperatura, humedad relativa y horas de sol. En Dirección General de Aeronáutica Civil (2018, p. 24).

\begin{tabular}{|c|c|c|c|c|c|c|c|c|c|c|c|c|c|c|}
\hline \multirow{3}{*}{ MES } & \multicolumn{10}{|c|}{ TEMPERATURAS ("C) } & \multirow{2}{*}{\multicolumn{3}{|c|}{$\begin{array}{l}\text { HUMEDAD } \\
\text { RELATVA(\%) }\end{array}$}} & \multirow{3}{*}{$\begin{array}{l}\text { HORAS } \\
\text { DE SOL } \\
\text { TOTAL }\end{array}$} \\
\hline & \multicolumn{6}{|c|}{ MEDUA } & \multicolumn{4}{|c|}{ EXTREMAS } & & & & \\
\hline & $\begin{array}{l}12 \\
\mathrm{hrs}\end{array}$ & $\begin{array}{r}18 \\
h r s\end{array}$ & $\begin{array}{l}00 \\
h r s\end{array}$ & Max & Mh & Mensual & Max & Focha & Mn & Fecha & $\begin{array}{l}12 \\
\mathrm{hrs}\end{array}$ & $\begin{array}{l}18 \\
h r s\end{array}$ & $\begin{array}{l}\infty 0 \\
\text { hrs }\end{array}$ & \\
\hline ENERO & 17.5 & 28.4 & 23.5 & 30.3 & 139 & 21.3 & 35.5 & 28 & 10.6 & 30 & 65 & 33 & 44 & . \\
\hline FEBRERO & 16.3 & 290 & 23.4 & 30.6 & 135 & 21.0 & 35.5 & 12 & 11.0 & 28 & 70 & 31 & 45 & \\
\hline MARZO & 130 & 27.3 & 21.7 & 20.1 & 10.7 & 18.6 & 33.0 & 5 & 7.5 & 17 & 70 & 25 & 41 & \\
\hline ABRLL & 9.6 & 23.4 & 18.0 & 25.0 & 8.5 & 15.3 & 28.5 & 15 & 4.5 & 27 & 81 & 36 & 54 & . \\
\hline MAYO & 7.0 & 19.3 & 14.9 & 20.9 & 5.8 & 122 & 26.4 & 4 & -0.7 & 27 & 78 & 39 & 54 & . \\
\hline JNIO & 36 & 142 & 10.5 & 16.3 & 24 & 82 & 26.0 & 18 & -2.8 & 5 & 86 & 48 & 65 & \\
\hline Mo & 4.1 & 13.4 & 10.0 & 15.3 & 3.2 & 8.1 & 22.7 & 13 & -23 & 23 & 89 & 57 & 70 & . \\
\hline AGOSTO & 42 & 16.7 & 12.1 & 18.5 & 3.0 & 9.5 & 27.3 & 26 & -2.5 & 4 & 88 & 41 & 61 & . \\
\hline SEPTEMBRE & 8.4 & 190 & 14.9 & 20.5 & 6.7 & 126 & 30.3 & 4 & 27 & 6 & 82 & 42 & 58 & \\
\hline OCTUBRE & 11.6 & 21.8 & 16.4 & 23.3 & 8.5 & 149 & 28.8 & 4 & 3.5 & 3 & 71 & 36 & 52 & \\
\hline NONEMBRE & 16.7 & 27.0 & 21,1 & 28.5 & 11.3 & 19.4 & 34.4 & 7 & 5.4 & 14 & 51 & 24 & 38 & . \\
\hline DICEMBRE & 16.8 & 27.8 & 21.9 & 29.6 & 12.4 & 202 & 30.3 & 24 & 8.7 & 14 & 63 & 31 & 44 & . \\
\hline ANUAL & 107 & 223 & 17.4 & 24.0 & 151 & 83 & 35.5 & Ene & 2.8 & $\ln$ & 74 & 37 & 52 & \\
\hline
\end{tabular}




\begin{tabular}{|c|c|c|c|c|c|c|c|c|c|c|c|c|c|c|}
\hline \multirow{2}{*}{ MES } & \multicolumn{2}{|c|}{$\begin{array}{l}\text { PRESION } \\
\text { MEDLA(hpa) AL. } \\
\text { NNEL DE }\end{array}$} & \multicolumn{6}{|c|}{$\begin{array}{c}\text { VENTO } \\
\text { DRECCION DOMINANTE } \\
\text { Y VELOCIOAD MEDIA }\end{array}$} & \multicolumn{3}{|c|}{$\begin{array}{l}\text { NUBOSIDAD } \\
\text { MEDLA } \\
\text { (octavos) }\end{array}$} & \multicolumn{3}{|c|}{$\begin{array}{l}\text { PRECPITACIÓN } \\
((\mathrm{mm})\end{array}$} \\
\hline & Estación & Mar & 12 & hrs & 18 & hrs & $\overline{O C}$ & hrs & $\begin{array}{l}12 \\
h r s\end{array}$ & $\begin{array}{r}18 \\
\text { hrs }\end{array}$ & $\begin{array}{l}00 \\
\text { hrs }\end{array}$ & TOTAL & $\begin{array}{r}\text { MAX } \\
24 \text { hrs }\end{array}$ & FECHA \\
\hline ENERO & 958.1 & $1,011.7$ & $\mathrm{~V}$ & 2 & $s$ & 12 & $\mathbf{S}$ & 13 & 2 & 2 & 2 & $s / p$ & s/p & * \\
\hline FEBRERO & 958.7 & $1,012.4$ & V & 1 & s & 11 & s & 12 & 2 & 1 & 1 & $s / p$ & $s / p$ & - \\
\hline MARZOO & 958.8 & $1,012.9$ & $\mathrm{~V}$ & 2 & s & 10 & s & 9 & 1 & 0 & 0 & $s / p$ & $s / p$ & - \\
\hline ABRIL & 960.6 & $1,015.5$ & $\mathrm{~V}$ & 2 & s & 8 & s & 7 & 3 & 2 & 2 & $s / p$ & s/p & - \\
\hline MAYO & 962.3 & $1,017.9$ & $\mathrm{~V}$ & 2 & $s$ & 7 & $\mathrm{~s}$ & 8 & 4 & 4 & 4 & 9.4 & 9.4 & 29 \\
\hline JUNIO & 963.7 & $1,020.2$ & $\mathrm{v}$ & 2 & V & 2 & S & 5 & 4 & 4 & 4 & 37.4 & 18.6 & 9 \\
\hline JULIO & 963.0 & $1,019.5$ & $\mathrm{v}$ & 2 & V & 2 & v & 2 & 5 & 4 & 4 & 47.8 & 34.4 & 5 \\
\hline AGOSTO & 963.4 & $1,019.6$ & $\mathrm{~V}$ & 2 & $s$ & 7 & s & 7 & 4 & 4 & 4 & 3.8 & 3.6 & 6 \\
\hline SEPTIEMBRE & 961.8 & $1,017,3$ & $\mathrm{~V}$ & 2 & s & 7 & s & 7 & 5 & 4 & 3 & 15.2 & 11,4 & 17 \\
\hline OCTUBRE & 961.7 & $1,016.7$ & $\mathrm{v}$ & 2 & $\mathbf{s}$ & 10 & s & 9 & 5 & 4 & 3 & 3.0 & 3.0 & 29 \\
\hline NOVIEMBRE & 959.8 & $1,013,8$ & $\mathrm{~V}$ & 2 & sW & 13 & s & 12 & 2 & 2 & 2 & 0.0 & 0.0 & 12 \\
\hline DICIEMBRE & 959.1 & $1,012.9$ & $\mathrm{~s}$ & 7 & sW & 13 & $\mathrm{~s}$ & 13 & 1 & 1 & 2 & 0.6 & 0.5 & 4 \\
\hline ANUAL & 960.9 & 1.015 .9 & $\mathrm{~V}$ & 2 & $s$ & 9 & $s$ & 9 & 3 & 3 & 3 & 117.2 & 34.4 & Jul \\
\hline
\end{tabular}

Tabla 7.7. Datos meteorológicos de la estación Pudahuel: presión atmosférica, viento, nubosidad y precipitaciones.

En Dirección General de Aeronáutica Civil (2018, p. 24)
${ }^{303}$ Biombo climático es el nombre que reciben las zonas que dividen diferentes climas. En algunos casos, no permiten que las nubes entren al territorio tras ella, dejando terrenos secos, como la cordillera de la costa en el territorio chileno. Un biombo climático en el caso de las montañas o cordilleras genera microclimas en las laderas de las montañas. Debido a este fenómeno, como recordaremos, en la primera visita al predio, en un día de lluvia, al entrar al Valle Lo Aguirre, las precipitaciones se detuvieron abruptamente.

Figura 7.17. Diagrama ombrotérmico de la zona semiárida de Santiago. En Biodiversidad de Chile, Patrimonio y Desafíos (CONAMA 2008, p. 27).

\subsection{ATMOSFÉRA}

\subsubsection{Clima y Meteorología}

De acuerdo a la Dirección Meteorológica de Chile, la Región Metropolitana posee un clima templado cálido con lluvias invernales (Figura 7.16.). El área, según la Clasificación Climática de Köppen (1966) se ubica en la zona con clima templado cálido con lluvias invernales (Csb), entre mayo y agosto, concentrando en estos meses alrededor del $80 \%$ de las precipitaciones que caen en todo el año. Como se aprecia en las Tablas 7.6 y 7.7., la época seca se prolonga por 7 u 8 meses, período en el que llueve menos de $40 \mathrm{~mm}$ en cada mes. Existe una ausencia de períodos fríos, predominando los meses cálidos. La actividad biológica es mayor durante los meses de invierno y primavera.

El patrón genérico para la zona mediterránea semiárida presenta al mismo tiempo una alta variabilidad a lo largo del año, especialmente respecto a las precipitaciones (Figura 7.17.), como también diferencias locales producto del variado relieve topográfico que incide fuertemente sobre el movimiento de masa de aire.

Ambas cordilleras tienen importantes efectos climáticos: la de la Costa, con algunas cumbres superiores a $2.000 \mathrm{~m}$ impide una mayor influencia marítima, a excepción de cuando el nivel de inversión térmica asciende sobre $1.000 \mathrm{~m}$ y asociado a vientos del oeste en los niveles más bajos, permite el ingreso de nubosidad baja costera a través de las cuencas de los ríos. Otro efecto es el de disminuir la cantidad de precipitación en los sectores aledaños a su ladera oriental, lo que se conoce como biombo o sombra climática ${ }^{303 ;}$ la cordillera de Los Andes produce

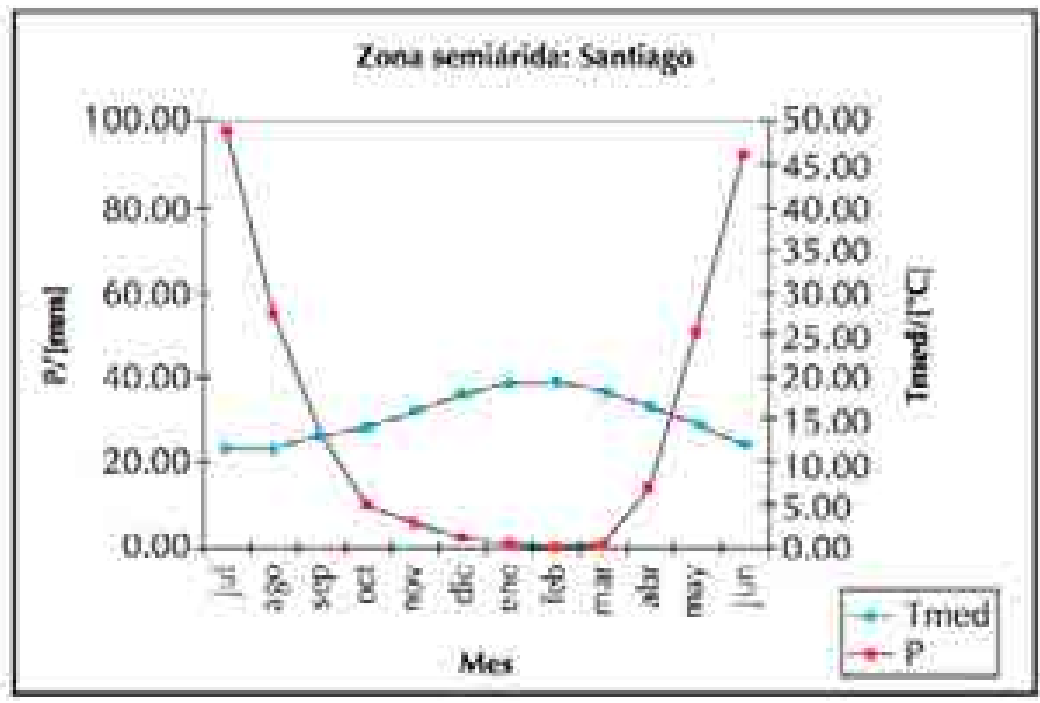




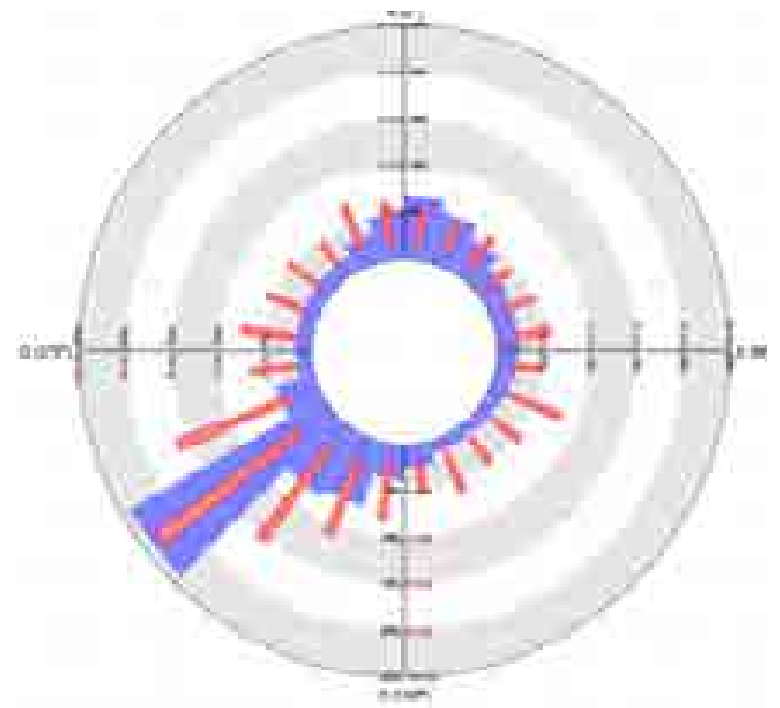

un efecto contrario, aumentando las precipitaciones a medida que se asciende. La situación de mediterraneidad de la Región hace que la humedad relativa sea baja, ligeramente superior al $70 \%$ como promedio anual. Además, las amplitudes térmicas son altas: existen casi $13^{\circ} \mathrm{C}$ de diferencia entre el mes más cálido (enero) y el más frío (julio) y la diferencia media entre las máximas y mínimas diarias es de $14^{\circ} \mathrm{C}$ a $16^{\circ} \mathrm{C}$. La temperatura media anual es de $14^{\circ} \mathrm{C}$; el mes más frío es julio con una media de $10^{\circ} \mathrm{C}$ y el más caluroso enero con una media de $18^{\circ} \mathrm{C}$, registrándose en ese mes temperaturas máximas superiores a $30^{\circ} \mathrm{C}$.

El predio se encuentra en el distrito agroclimático de Santiago y, debido a que se ubica en el borde de la Depresión Intermedia, cercano y relativamente encerrado por altos cerros de la vertiente oriental de la cordillera de La Costa, este es relativamente poco ventilado, con temperaturas más extremas que localidades ubicadas en espacios más abiertos del mismo valle (DGAC, 2013, p. 24).

Las características térmicas invernales indican que el período de receso vegetativo dura tres meses, que existen 12,6 heladas anuales y que la temperatura media mínima del mes más frío es de $3,5^{\circ} \mathrm{C}$ durante julio.

El período libre de heladas es de 9 meses, y la temperatura media máxima en el mes más cálido, que es enero es de $29,3^{\circ} \mathrm{C}$.

La precipitación es la característica climática más variable y el factor determinante principal de la intensidad del período de actividad biológica (Gutiérrez et al., 1993). Cuando las precipitaciones son abundantes, éstas se concentran en algún momento del año, provocando intensa erosión hídrica en terrenos con pendientes, más intensos aún si ellos se han visto desprovistos de vegetación, y al mis-

\begin{tabular}{|c|c|c|c|}
\hline Ne & CATEGORIA & NOMBRE & DISTANCLA AL SITIO \\
\hline & & & $\mathrm{Km}$ aprox. \\
\hline 1 & \multirow{3}{*}{$\begin{array}{c}\text { Sitio Prioritario para la } \\
\text { Conservación de la } \\
\text { Biodiversidad }\end{array}$} & El Roble & 0,231 \\
\hline 2 & & Rínconada de Maipú UCH & 6,5 \\
\hline 3 & & Humedal de Batuco & 23 \\
\hline 4 & \multirow{3}{*}{ Monumentos Históricos } & $\begin{array}{l}\text { Casa y Parque Quinta de } \\
\text { Las Rosas de Maipú }\end{array}$ & 9 \\
\hline 5 & & Cerro Primo de Rivera & 9,4 \\
\hline 6 & & $\begin{array}{c}\text { Templo Votivo Nacional } \\
\text { de Maipú }\end{array}$ & 10 \\
\hline
\end{tabular}

Figura 7.18. Vientos: velocidad y dirección (Rosa de los vientos): las barras azules indican el porcentaje de los valores hora-rios según la dirección del viento. Las barras rojas indican el rango inter-quartíl de velocidad de viento para cada intervalo de dirección. En Explorador de Energía Eólica. Ministerio de Energía. 
Figura 7.19. Áreas Protegidas y Sitios Prioritarios más cercanos a Laguna Carén. Elaboración propia a partir de informe Andalué (2016).

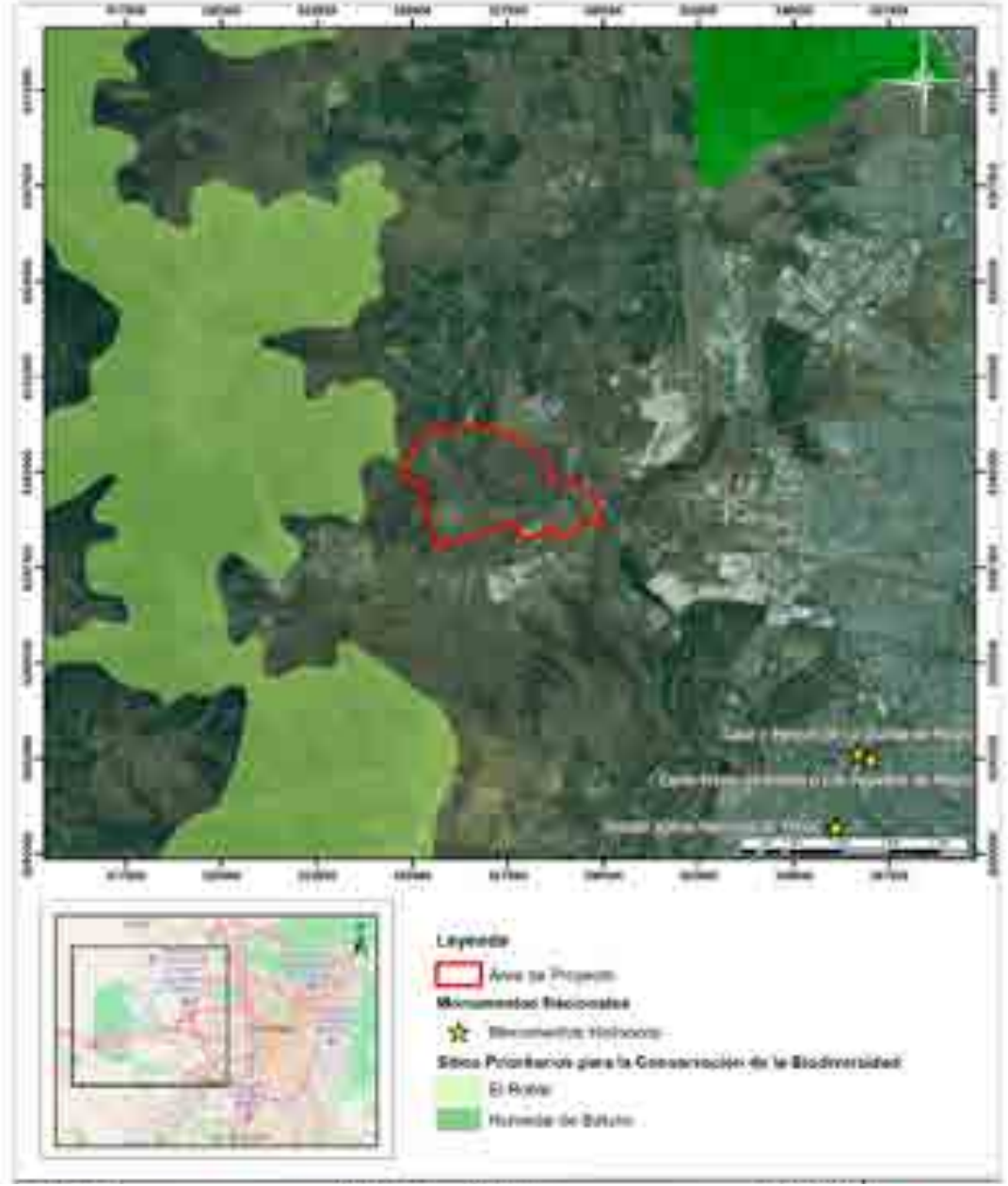

mo tiempo produciendo inundaciones, más o menos temporales, en los terrenos bajos. Por el contrario, cuando las precipitaciones son escasas, especialmente durante años consecutivos, la vegetación arbustiva puede verse muy afectada y el terreno expuesto a erosión eólica (Peralta, 1994).

\subsubsection{Vientos Predominantes}

Según datos de la Dirección General de Aeronáutica Civil, en la Región Metropolitana la dirección del viento predominante es del suroeste, siendo más persistente en el verano, con una intensidad media de $15 \mathrm{~km} / \mathrm{hr}(8,1$ nudos $04,2 \mathrm{~m} / \mathrm{s})$. De acuerdo a los datos climatológicos del año 2013 (DGAC, 2013, p. 24), para la estación de Quinta Normal, se tiene que una velocidad media anual de 7,4 km/h (4 nudos $02,1 \mathrm{~m} / \mathrm{s}$ ) con vientos dirección suroeste a las 14 horas y prácticamente sin viento en las primeras horas del día, salvo en enero. Esto explica por qué los clubes de remo practican en las mañanas, cuando no hay viento, y los de vela en la tarde, cuando sí lo hay.

Según Los datos del Ministerio de Energía (2015), el ciclo anual de viento tiene una velocidad media mínima de $1,8 \mathrm{~m} / \mathrm{s}$ en mayo, y un máximo de $4,5 \mathrm{~m} / \mathrm{s}$ en los meses de diciembre y enero, con un viento medio de $3,2 \mathrm{~m} / \mathrm{s}$.

Respecto a la dirección del viento en el área estudio (Ministerio de Energía, 2015), se tiene como dirección predominante el suroeste (Figura 7.20).

\subsection{0. ÁREAS PROTEGIDAS Y SITIOS PRIORITARIOS PARA LA CONSERVA- CIÓN}

El siguiente análisis consiste en localizar el área de estudio respecto a las áreas protegidas o sitios prioritarios para la conservación, considerando el ORD. $\mathrm{N}^{\circ}$ 130844 de fecha 22.05.2013 que "Uniforma criterios y exigencias técnicas sobre áreas colocadas bajo protección oficial y áreas protegidas para efectos del sistema de evaluación de impacto ambiental, e instruye sobre la materia". De la revi- 
sión efectuada, en la zona de influencia cercana, no se encuentran emplazadas áreas colocadas bajo protección oficial.

La más próxima, se encuentra ubicada a tan solo 231 metros hacia el poniente desde el límite oeste del terreno, la que corresponde al Sitio Prioritario para la Conservación de la Biodiversidad, identificado como El Roble.

Cabe señalar que recientemente, el 13 de octubre de 2017 un total de 1.100 hectáreas de los terrenos de la Estación Experimental Germán Greve Silva de la Facultad de Ciencias Agronómicas, de la Universidad de Chile (llamado Rinconada De Maipú) se transformaron en el undécimo Santuario de la Naturaleza de la Región Metropolitana. ${ }^{304}$ Este lugar, está ubicado a 6,5 km al sur poniente de Laguna Carén en la comuna de Maipú

A continuación, se presentan las áreas protegidas y los sitios prioritarios más cercanos al

área, con la indicación de la categoría, nombre y distancia al límite del predio:

\subsection{RIESGOS MEDIOAMBIENTALES}

Chile es un país de catástrofes, lo que exige que el territorio debe ser pensado y ordenado considerando estos fenómenos. Si bien la actividad sísmica está incorporada cultural y técnicamente, otros riesgos son normalmente ignorados en el diseño. En las investigaciones realizadas por el Centro de Estudios Urbanos y Ambientales, URBAM, se "propone entender y ordenar el territorio desde su coeficiente de riesgo", vale decir, la suma entre amenazas y vulnerabilidades (Magrini \& López, 2015, p. 19). A continuación, se señalan los principales riesgos naturales que este territorio tiene:

\subsubsection{Inundaciones:}

El predio es vulnerable a inundaciones en una extensión de aproximadamente 185 hectáreas, especialmente en los episodios de altas e intensas precipitaciones (Espinoza y Hajek, 1988). Las probables causas son: la escasa pendiente del terreno y la existencia de un pretil que se encuentra cercano a la confluencia con el estero lampa, que regula el nivel del agua de la laguna Carén, y que además permite el acceso en vehículo hacia el interior del predio por el lado oriente del estero Carén.

Existe también un fenómeno hidráulico que ocurre frente a episodios de aumento brusco del caudal del río Mapocho. En estos eventos, la fuerza de la corriente del río, actúa como barrera a la escorrentía del estero lampa, esta suerte de dique, provoca inundaciones aguas arriba. La solución a este problema pasa por la ejecución de una obra civil de menor envergadura en el punto de llegada del estero Lampa al Río Mapocho.

\subsubsection{Incendios forestales:}

En los últimos años se han producido en Chile los más grandes incendios de su historia. En 2014 se produjo el mayor incendio urbano, en la ciudad de Valparaíso y en el año 2017 se registraron los incendios forestales más grandes en una amplia zona que abarcó desde la región de Coquimbo hasta la región de Los Lagos. Según datos de la Corporación Nacional Forestal (CONAF), en el período 20132014 se consumieron 5.914 hectáreas y en el 2014-2015, 4.333 hectáreas por el fuego, alcanzando un promedio 6.000 incendios por temporada, cuyo origen es casi exclusivamente provocado por la acción humana.

En la investigación realizada por Claudio Magrini y Susana López sobre el incendio de Valparaíso, se establece una hipótesis que explica el escenario de vulnerabilidad natural, que permite la ocurrencia de incendios. Según lo observado en Valparaíso, se alinearon tres factores: $30^{\circ} \mathrm{C}$ de temperatura, 30 nudos de viento y una disminución drástica de la humedad ambiente hasta valores del $30 \%$. La combinación 30/30/30 permite que cualquier descuido, accidente 0 acto premeditado genere una catástrofe (Magrini \& López, 2015, p. 19). Si bien la temperatura y el viento son factores sobre los cuales difícilmente se puede incidir, la humedad relativa puede controlarse si se actúa de manera estratégica en el sistema natural. 
Cuidar y aumentar los cuerpos de agua para incrementar la evaporación y contar con aprovisionamiento para, en el caso de ocurrir un incendio, poder controlar el fuego con recursos del propio predio, son medidas que estos investigadores proponen junto a la restitución ecológica y reforzamiento de especies endógenas. Por ejemplo, la plantación de eucalipto (Eucalyptus globulus) y pino (Pinus radiata), especies exógenas tan extendida en Chile, agravan el riesgo, por corresponder a especies pirófilas. Entre las dos especies, es justamente el eucalipto el que presenta más características negativas ya que no sólo es pirófilo, sino también pirógeno, además, consume 20 veces más de agua que un árbol nativo y acidifica el suelo, impidiendo así cualquier otra asociación vegetal. Por el contrario, las especies nativas, tienen una resistencia mayor al fuego, consumen menos agua y se asocia a otras formaciones vegetales a nivel de suelo, lo que fomenta la evapotranspiración, aumentando la humedad ambiente. Lo anterior refuerza, la idea de privilegiar la plantación de especies nativas, ya que constituye una herramienta idónea para mejorar las condiciones ambientales y ecológicas del territorio

\subsubsection{Ruido:}

Los ruidos dentro del predio se pueden separar entre aquellos generados fuera del él y los generados dentro de sus límites. Entre los ruidos de origen externo, los principales derivan de:

- $\quad$ El tránsito de vehículos por la Ruta 68 Santiago-Valparaíso que se encuentra inmediatamente al sur de la propiedad en el sector oriente, y de la cual se encuentra un poco más retirada en el sector medio y poniente. Para aminorar este ruido en el predio y al mismo tiempo aminorar el impacto visual de la carretera, se recomienda crear una cortina vegetacional a lo largo del borde sur. Las especies posibles de utilizar dependerán de la disponibilidad de agua y de la adopción de criterios de conservación de la vegetación nativa en el proyecto.

- $\quad$ El polígono de tiro de las Fuerzas armadas, emplazado al lado sur de la Ruta 68, hacia el poniente, genera contaminación acústica con sus prácticas. En este caso aplican las mismas medidas de mitigación del punto anterior.

- $\quad$ Los aviones que aterrizan y despegan desde el aeropuerto Internacional Arturo merino Benítez, pasan a 1.000 de altitud y a una distancia de $3,5 \mathrm{~km}$ de la franja de aproximación, en sentido norte-sur. Si bien las aeronaves producen ruido, éste es mucho más atenuado que los anteriores, ya que no surcan el espacio aéreo del predio. En este caso las medidas de mitigación que la literatura especializada en este tema consulta, se refieren al control de la fuente. Una experiencia reciente en el aeropuerto de Amsterdam ${ }^{305}$, muestra cómo a través de la creación de parques en torno al aeropuerto mejoran el impacto acústico. El diseño propuesto en esta experiencia consiste en la creación de un relieve artificial de 150 olas o crestas de tres metros de altura y 150 de largo que surcan el terreno, disminuyendo en 5 decibeles el ruido.

- $\quad$ Entre las fuentes internas de ruido, destacan las actividades esporádicas de Moto Cross y Jeep Fun Race, las que se practican en el sector sur-poniente del predio. Antes de definir medidas de mitigación, el proyecto debe evaluar si permitir o no a futuro, estas actividades en el parque.

7.11.4. Probables fuentes de contaminación o de riesgos ambientales Actualmente existen algunas instalaciones en las cercanías del predio Carén que podrían representar algún riesgo ambiental en la medida que se produzcan accidentes ya que, en concordancia con las normas vigentes, en operación normal, el emplazamiento y construcción prevén estos riesgos. Esto se debe al hecho que, en el establecimiento de tales normas, se han considerado los factores de probabilidad de ocurrencia y de severidad una vez ocurridos los accidentes, fijándose ésta a niveles 
tales que los riesgos implicados sean aceptables. Desde el punto de vista del proyecto, su operación debiera contemplar el monitoreo de estos riesgos. En esta situación se encuentran:

a. Los depósitos de relave de la ex Mina Lo Aguirre que se encuentra al poniente del predio. Estos podrían producir contaminación en las aguas superficiales y/o subterráneas.

b. Las actividades del Centro de Energía Nuclear de Lo Aguirre, que si bien como hemos visto en el capítulo 6 se encuentra actualmente "en parada permanente" y "sin combustible nuclear en su núcleo", podrían a futuro reactivarse. Estas instalaciones se encuentran al fondo del valle lo Aguirre, al poniente del predio, más allá de la mina Lo Aguirre. Las actuales disposiciones establecen la prohibición de realizar emplazamientos en un radio de 400 metros del reactor y establecen una zona de baja densidad en un radio de 800 metros.

c. La estación de cuarentena del servicio agrícola y ganadero (SAG) se encuentra frente al límite sur del predio. No ofrece riesgos humanos, aunque puede constituirse en posible fuente de dispersión de organismos patógenos que afecten, principalmente a la agricultura del país y localmente a la flora y la fauna del predio.

d. El Centro de Recuperación, Valorización y Neutralización de Subproductos Industriales ${ }^{306}$ perteneciente a la empresa Hidronor, se encuentra instalada a 2,5 kilómetros al nor-este de la laguna Carén. Debido a que la dirección de los acuíferos que llegan al terreno son norte-sur y oeste-este, es poco probable que derrames de la planta Hidronor afecten las aguas de la laguna. Sin embargo, en el Plan Regulador Comunal (llustre Municipalidad de Pudahuel, 2004) propone clasificarlo como una instalación de Riesgo medio (RM) en consideración a que ante un incendio se podrían producir explosiones en depósitos de elementos combustibles.

e. Líneas de Transmisión de Alta Tensión. Son dos líneas eléctricas que cruzan el valle de este a oeste, atravesando el predio en una franja paralela a la Ruta 68. Según del Plan Regulador Comunal, esta infraestructura está calificada como de riesgo bajo (RB), atendiendo al fiel cumplimiento de la normativa y al correcto mantenimiento de éstas. La postación se emplaza sobre una franja de exclusión de 54 metros de ancho. Al estar a la vista, el riesgo mayor está relacionado con la ocurrencia de hechos vandálicos.

f. Planta de Almacenamiento Subterráneo de Gas Licuado GAS$\mathrm{CO}$, este proyecto, aún en evaluación, se emplazaría en uno de los dos terrenos que tiene la empresa al lado sur de la Ruta 68. Las normas de construcción exigen que estos depósitos sean instalados a $200 \mathrm{~m}$ de profundidad, con una gran piscina sobre él y un parque en la superficie. El Plan Regulador Comunal de Pudahuel (2004) califica esta instalación como Riesgo medio (RM) debido al gran volumen de almacenamiento (100.000 $\mathrm{m}^{3}$ equivale aproximadamente a un millón cien mil cilindros de gas licuado de $45 \mathrm{~kg}$ ) (llustre Municipalidad de Pudahuel, 2017).

\subsection{LEGISLACIÓN Y DISPOSICIONES DE RELEVANCIA AMBIENTAL}

Uno de los principales instrumentos para prevenir el deterioro ambiental es el Sistema de Evaluación de Impacto Ambiental (SEIA). Este instrumento permite introducir la dimensión ambiental en el diseño y la ejecución de los proyectos y actividades que se realizan en el país; a través de él se evalúa y certifica que las iniciativas, tanto del sector público como del sector privado, se encuentran en condiciones de cumplir con los requisitos ambientales que les son aplicables. El SEIA entró en vigencia el 03 de abril de 1997.

\subsubsection{Sistema de Evaluación Ambiental.}

Ley 19.300: Bases Generales del Medio Ambiente (Ley N 19300, 1994/2019) estipula en su artículo 10 , letra $h$, que los proyectos inmobiliarios de este tipo debiesen someterse al Sistema de Evaluación de Impacto Ambiental:

${ }^{306}$ Calificado favorablemente mediante la Resolución No 482/1995 de la COREMA Región Metropolitana 
h) Planes regionales de desarrollo urbano, planes intercomunales, planes reguladores

comunales, planes seccionales, proyectos industriales 0 inmobiliarios que los

modifiquen o que se ejecuten en zonas declaradas latentes o saturadas (Ley n¹9300, 1994/2019).

Por su parte el Decreto Supremo 40, que Aprueba el Reglamento del Sistema de Evaluación de Impacto Ambiental promulgado el 2012, y que entró en vigencia el año 2014, detalla:

Artículo 3.- Tipos de proyectos o actividades.

Los proyectos 0 actividades susceptibles de causar impacto ambiental, en cualesquiera de sus fases, que deberán someterse al Sistema de Evaluación de Impacto Ambiental, son los siguientes:

h) Proyectos industriales o inmobiliarios que se ejecuten en zonas declaradas latentes 0 saturadas.

h.1. Se entenderáa por proyectos inmobiliarios aquellos loteos o conjuntos de viviendas que contemplen obras de edificación y/o urbanización, asín como los proyectos destinados a equipamiento, $y$ que presenten alguna de las siguientes características:

h.1.1. Que se emplacen en áreas de extensión urbana 0 en área rural, de acuerdo al instrumento de planificación correspondiente y requieran de sistemas propios de producción y distribución de agua potable y/o de recolección, tratamiento y disposición de aguas servidas;

h.1.2. Que den lugar a la incorporación al dominio nacional de uso público de vías expresas o troncales;

h.1.3. Que se emplacen en una superficie igual o superior a siete hectáreas $(7$ ha)

o consulten la construcción de trescientas (300) o más viviendas; 0

h.1.4. Que consulten la construcción de edificios de uso público con una capacidad

para cinco mil (5.000) o más personas o con mil (1.000) o más estacionamientos (DS 40, 2012).

Se exceptuarán dichos proyectos de su ingreso al Sistema de Evaluación de Impacto Ambiental en aquellas zonas declaradas latentes o saturadas, que cuenten con un Plan de Prevención o Descontaminación vigente, dictado de acuerdo al artículo 44 de la Ley y se permita el desarrollo de proyectos inmobiliarios en un Instrumento de Planificación Territorial aprobado ambientalmente conforme a la Ley.

\section{D.S. N 131 declara a la Región Metropolitana Zona Saturada y Latente}

Decreto Supremo del Ministerio Secretaria General de la Presidencia, publicado en el Diario Oficial del $1^{\circ}$ de agosto de 1996. Declara a la Región Metropolitana Zona Saturada por ozono (O3), material particulado respirable (PM10), partículas en suspensión (PTS), monóxido de carbono (CO) y Zona Latente por dióxido de nitrógeno (NO2).

De acuerdo a lo señalado en la Ley 19.300 en su artículo 43, el primer paso para el desarrollo de planes de descontaminación o de prevención es la declaración y delimitación de zonas saturadas y/o latentes.

Ahora bien, según el mismo cuerpo legal, es Zona Saturada aquella en que una o más normas de calidad ambiental se encuentran sobrepasadas y Zona Latente aquella en que la medición de la concentración de contaminantes en el aire, agua o suelo, se sitúa entre el $80 \%$ y el $100 \%$ de la respectiva norma de calidad ambiental.

En el año 1978 (Resolución No 1215/78 del Ministerio de Salud) se establecieron las normas primarias de calidad del aire para Partículas Totales en Suspensión (PTS), Dióxido de Azufre (SO2), Monóxido de Carbono (CO), Ozono (O2) y Dióxido de Nitrógeno (NO2), y en el año 1992 se publicó la norma primaria de calidad del aire para PM 10 (D.S. No 185/92 del Ministerio de Minería). A partir de estas normas y sobre la base de los datos recopilados entre los años 1993 y 1995, en 

10, PTS y CO, y Zona Latente por NO2.

La Ley 19.300 establece también dos modalidades para presentación de proyectos ante el Sistema de Evaluación de Impacto Ambiental, la Declaración de Impacto Ambiental (DIA) y el Estudio de Impacto Ambiental. La pertinencia de una alternativa u otra depende de la significancia de los impactos del proyecto de acuerdo a lo establecido en el mencionado Reglamento. En cualquier caso, el primer paso para someter un proyecto al Sistema de Evaluación Ambiental es la realización de una Línea Base Ambiental, la cual en el caso en estudio no ha sido realizada por falta de financiamiento.

\subsection{SIGNIFICANCIA AMBIENTAL}

En términos generales, el predio evidencia una situación ambiental desmejorada en relación a su probable estado original. La actual situación se debe a las malas 0 ausentes prácticas de manejo del predio en el pasado, principalmente, sobre pastoreo, corte de árboles para leña o carbón, caza de animales silvestres, alteración de cursos de agua, contaminación de aguas y diversas construcciones y usos de origen antrópico que han alterado el paisaje natural, tales como galpones, torres de alta tensión y telefonía celular, pistas de jeep Fun Race, entre otros.

Esta evaluación se evidencia principalmente en el estado de la vegetación, como también en la composición florística del predio. Así la extensa cobertura de espinos en forma arbustiva, la común presencia de cardos y los grandes paños desprovistos de vegetación, son indicadores de un alto grado de intervención (Gajardo, 1994). Este patrón cambia levemente hacia la cima de los dos cerros del predio (Amapola y Puntilla Lo Vásquez) en los cuales aún es posible encontrar algunos ejemplares de guayacán, litre y algunos cactos. Concordantemente, la fauna presente es poco diversa, escasa y bastante común, salvo las aves.

El elemento ambiental más relevante respecto a la flora y la fauna está dado por la laguna Carén que, aun siendo artificial, permite la existencia de flora y fauna, que de otra manera no estaría presente en el predio, aumentando así la diversidad y abundancia de especies.

Algunos de los aspectos ambientales a considerar en el diseño de un proyecto en el predio, son:

a. Las marcadas fluctuaciones temporales en la disponibilidad de agua, desde situaciones que conllevan a inundaciones del terreno hasta episodios de sequía, las que deben compatibilizarse con la posible demanda de este elemento derivadas de la naturaleza y tamaño del proyecto. Esto es especialmente crítico al definir la reforestación, proceso que tiene una fuerte exigencia de agua en los primeros cinco años desde la siembra, incluso para especies autóctonas.

b. El impacto visual que puedan tener las instalaciones, especialmente en las cumbres y laderas de los cerros.

c. El estado trófico y ecológico de la laguna. Es necesario desarrollar una evaluación que siga una estrategia multiescalar, vale decir, que combine diversas técnicas de análisis de tipo geográfico, químico, físico y biológico, para definir los indicadores de estado que permitirán su gestión ambiental futura, orientada a mejorar la calidad del agua y a hacer un seguimiento de las variables que definen el estado de la laguna. Este aspecto es especialmente relevante considerando que este sector sufrirá un aumento de población debido a los Proyectos de Desarrollo Condicionado en trámite y en años pasados ya se han presentado eventos de aumento de contaminación a causa de las aguas provenientes del condominio Lomas de Lo Aguirre.

d. El patrón de vientos del sector, especialmente en cuanto a la probabilidad de que se dispersen eventuales emisiones al aire. En forma preliminar, se podría indicar que no es conveniente disponer de instalaciones que impliquen emisiones al aire al lado nor-este de la Pun- 
tilla Lo Vásquez, dado que el viento fluye en esa dirección y la puntilla, probablemente genere turbulencias al lado nor-oriente que dificultarían la dispersión de emisiones.

e. Los riesgos de inundación del predio, estableciendo criterios para la zonificación de actividades e instalaciones, como también de tratamiento superficial, de modo de mantener e incluso aumentar la permeabilidad de éste.

f. El riego de incendio, especialmente en la estación estival, que han sido descrito y cuyas acciones de mitigación consisten, esencialmente, en mantener la humedad relativa del aire en niveles sobre el $30 \%$ a través de la mantención de los cursos de agua, del reemplazo de especies exóticas, especialmente el eucalipto y la incorporación de vegetación nativa como herramienta para mejorar las condiciones ambientales y ecológicas del territorio

\section{Nota sobre el Material cartográfico y la Metodología}

Se utilizó como base del estudio el plano del predio a escala 1:5.000, elaborado por MECSA en 1994. Esta información fue complementada con el plano a escala 1: 10.000 del Proyecto Maipo, de la Comisión Nacional de Riego, elaborado en 1980. Estos datos han sido confrontados y complementados con los estudios de Línea de Base Ambiental de dos proyectos vecinos, el proyecto Praderas, colindante al poniente e Hidronor, a 3 kilómetros al nor-oriente.

Se han utilizado también fotografias aéreas infrarrojas a escala aproximada $1: 20.000$.

El estudio se inició con el análisis del material existente, incluyendo otras tesis e informes. Para los aspectos geológicos y geomorfológicos se revisó, especialmente, la bibliografía relacionada con las formaciones de pumicita de la región, debido a su importancia para el predio y por el origen y desarrollo de los suelos que en él aparecen.

En relación a los aspectos agrológicos, en 1981, la Comisión Nacional de Riego realizó el Estudio de Suelos del proyecto Maipo en escala 1: 50.000, si bien dicho estudio contiene los antecedentes agrológicos de la cuenca del Río Maipo y el predio de laguna Carén se encuentra dentro del área, quedó sin información.

El trabajo incluye el análisis de imágenes satelitales disponibles en Google Earth, en las cuales se separaron los elementos más significativos del pattern. A este valioso recurso tecnológico se han sumado numerosas visitas a terreno, la asesoría de especialistas de la Universidad de Chile, y la información aportada por las personas que trabajan en el sitio.

La interpretación final sintetiza lo que hemos estudiado, ayuda al lector a imaginar el sitio, sin embargo, sabemos que es provisoria, abierta a la incertidumbre que depara el futuro. 


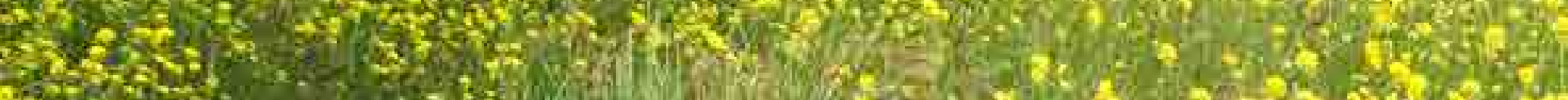
7.

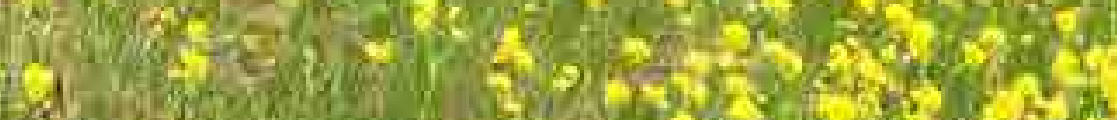

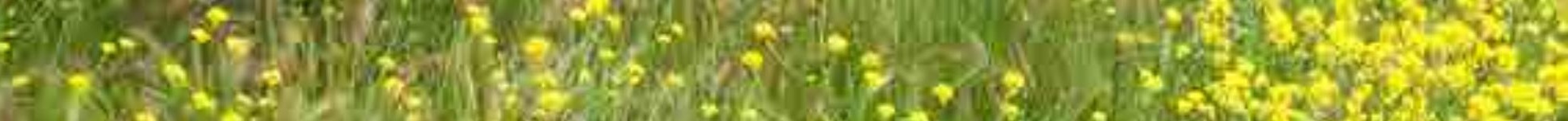
4.

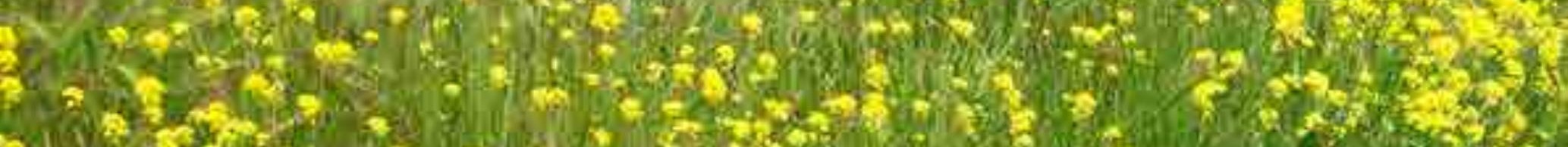

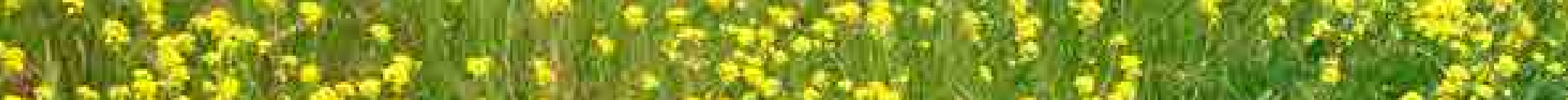

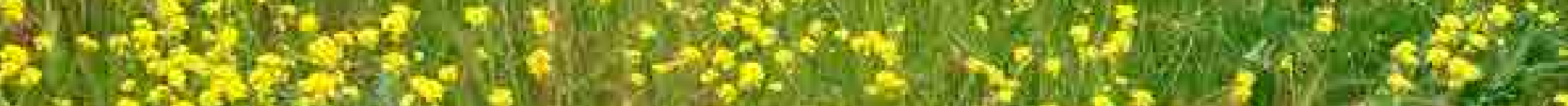

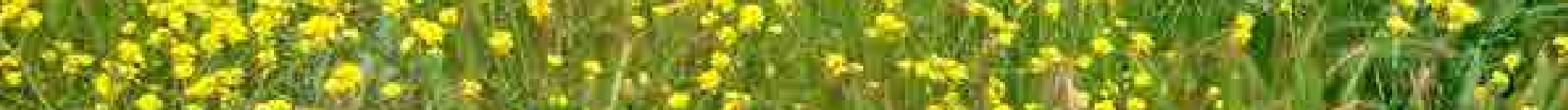

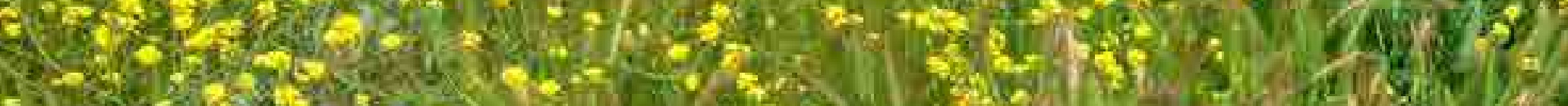

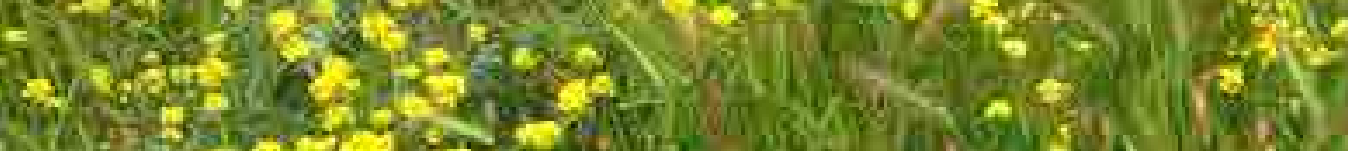

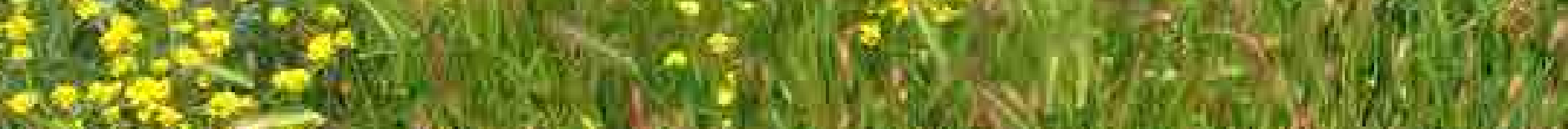

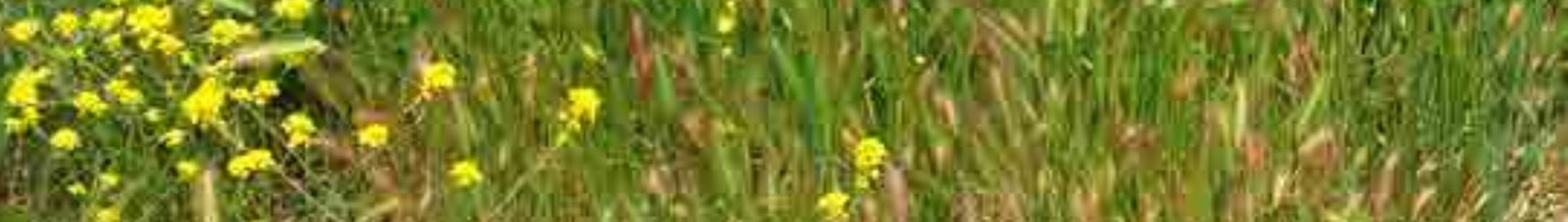
2. 127. det 20.7. (3) (3)

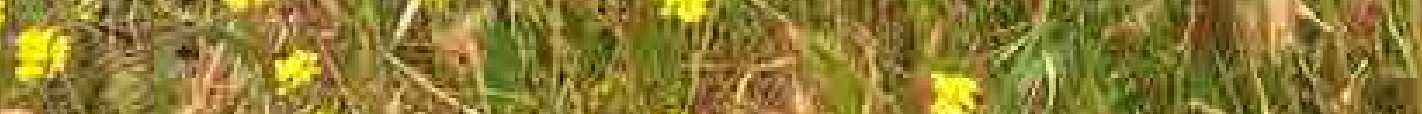

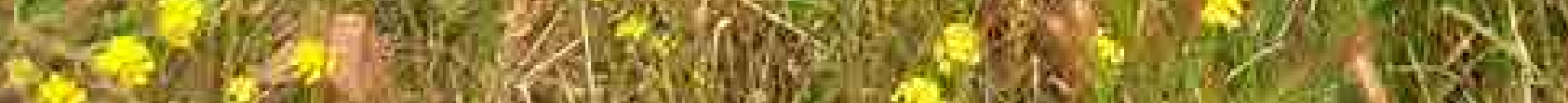

Nit

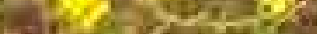




\section{EL PAISAJE DE LAGUNA CARÉN: DIMEN- SIÓN PERCEPTUAL}

\begin{abstract}
J'ai cherché à faire revivre, dans la partie descriptive de ce travail, une physionomie qui m'est apparue variée, aimable, accueillante. Je voudrais avoir réussi à fixer quelque chose des impressions que j'ai éprouvées en parcourant en tous sens cette contrée profondément humanisée, mais non abâtardie par les œuvres de la civilisation. L'esprit y est sollicité par la réflexion, mais c'est au spectacle tantôt riant, tantôt imposant de ces campagnes, de ces monts et de ces mers qu'il est sans cesse ramené comme à une source de causes.
\end{abstract}

Vidal de La Blanche (2008, p. 2)

\subsection{INTRODUCCIÓN: DESCUBRIR}

El objetivo de este capítulo es caracterizar el territorio de Laguna Carén desde el punto de vista perceptual, especialmente visual ${ }^{307}$. El texto que sigue, resume y sintetiza, muchas visitas, análisis de imágenes aéreas, planos, fotos, como también la experiencia de recorrer el terreno en diversas estaciones y horas del día. Las primeras visitas fueron guiadas por las personas que trabajan en el sitio desde hace más de 20 años, de este modo, las unidades de paisaje propuestas, le deben mucho a esa experiencia, que se trasladó a nosotros, "los de afuera" - los proyectistas- en las primeras visitas. En esas ocasiones, nuestros guías tenían el dominio de qué nos mostraban, los puntos de vista, los tiempos de espera y recorrido, las sendas elegidas, la alusión a nombres o a calificativos del terreno, como son la zona del fondo, atrás, el área deportiva, las tierras muertas, la isla, la laguna, etc. Del mismo modo, en estos cinco años, hemos acompañado y guiado la visita de autoridades, científicos, académicos, invitados extranjeros, repitiendo algunas de estas escenas, eligiendo otras nuevas e incorporando la información que surgía de la investigación del predio y de los primeros esbozos del plan maestro. Nos acompañaron muchos especialistas, que han visto en Carén un lugar de interés ya sea desde el punto de vista científico o didáctico; un espacio para hacer "terreno" próximo al centro de Santiago. Es justo recordar al profesor José Araya, geógrafo, quién fue el primero, que al conocer que nos haríamos cargo del proyecto el año 2015, nos ofreció su ayuda, nos entregó su artículo inédito "Importancia científica y cultural del terreno Laguna Carén: Pudahuel, depresión de Santiago de Chile" (incluido en los anexos), e insistentemente nos pidió que "no olvidáramos la geología". Nos enseñó que en el terreno estaba inscrita la historia geológica del valle central, agregando ese filtro a nuestro modo de mirar el paisaje.

La descripción que sigue, define los elementos principales del predio y las unidades de paisaje que corresponderían al mismo tiempo a "manchas" del mosaico territorial ${ }^{308}$ de Forman \& Godron (1986) a meso-escala (a la escala del terreno), inserta en una trama mayor constituida por el valle Lo Aguirre, donde el terreno mismo aparece como una mancha bastante homogénea. A una escala mayor, el valle Lo Aguirre se lee como una mancha con importantes corredores viales que tejen la trama de la Región Metropolitana de Santiago.

Si bien este análisis enfatiza los "efectos de los objetos físicos y perceptibles", también considera la influencia de otros objetos inmateriales, que actúan sobre la "imaginabilidad" del paisaje, como son el significado social de una zona, su función, su historia e incluso sus apelativos. (Lynch, 1998, p. 19). Lo anterior busca definir los elementos principales y unidades de paisaje para desde allí, pensar el proyecto.

En estos términos, el paisaje abarcaría la experiencia naturalista y fenomenológica, pero su orientación se extiende a una acción sintética y estratégica, que, como plantea James Corner, "alinea diversas y competitivas fuerzas (condiciones sociales, deseos políticos, procesos ecológicos, demandas de programas,
307 Para Yi Fu Tuan, "entre los sentidos humanos, la visión es el que tiene mayor capacidad de discernimiento espacial: el uso habitual de los ojos nos lleva a apreciar el mundo como una entidad espacial de líneas, superficies y sólidos bien definidos. Los otros sentidos nos hacen percibir el mundo como un ambiente rico pero desenfocado. Ni los jardines formales del siglo $\mathrm{XVI}$ ni los paisajes «naturales» del siglo XVIII atraen mucho a los sentidos del oído, olor y tacto. Para comunicar efectos sutiles de sonido, perfume y textura se requieren espacios restringidos: en tales espacios, la única vista que no tiene impedimentos es la que se dirige hacia arriba, hacia el cielo" (Tuan, 2007, p. 192).

${ }^{308}$ El mosaico territorial o modelo estructural propuesto por Richard TT Forman se compone de tres tipos de elementos, "manchas", "corredores" y una "trama". Esos elementos son las herramientas que permiten desarrollar unos principios básicos y comparar distintos paisajes. Este modelo mancha-corredor-trama, también es una herramienta para la planificación de usos del suelo, dado que considera los movimientos, flujos y cambios de los sistemas naturales y de la población. En un lenguaje espacial y grafico simple, puede estudiarse cómo se combinan las manchas, los corredores y las tramas, para formar la variedad de mosaicos territoriales, tanto los existentes como los planificados. 


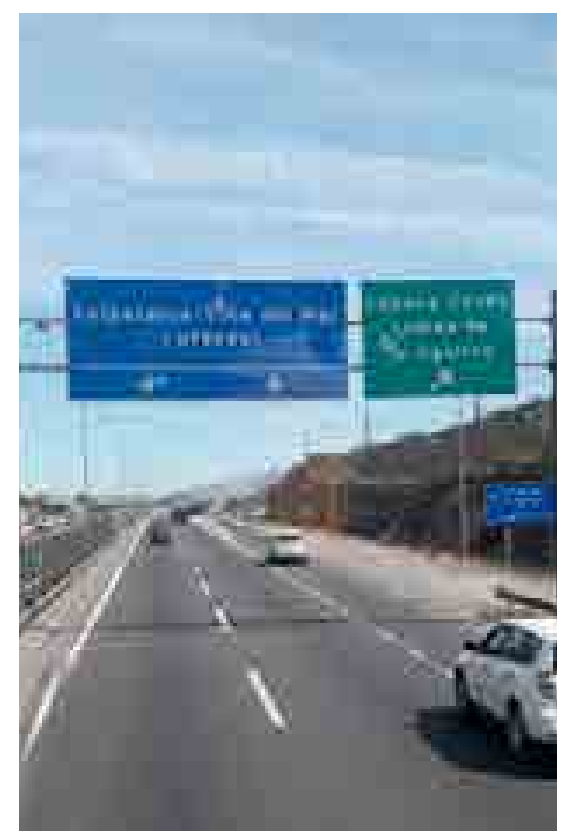

Figura 8.1.Foto desde un bus. A la derecha el cerro Amapola. Por Frases Suicidas (9 de septiembre, 2018) etc.) en alianzas liberadoras e interactivas" (Corner 1999: 2), que buscan que el sitio se convierta en la idea reguladora del proyecto, invirtiendo la jerarquía usual que da hegemonía al programa.

Esta es la etapa que Christophe Girot llamaría "Descubrimiento" (Finding), entendida como un acto y proceso de búsqueda, donde encontrar, -la cosa descubierta-, requiere de un trabajo metódico y meticuloso y de una visión. Si bien, Girot no propone un método preciso, nos sugiere que este proceso no tiene que ver con la invención, sino más bien con encontrar aquello que pertenece al lugar y contribuye a su identidad. Lo que se encuentra puede ser parte de la estructura del paisaje. No se trata necesariamente del descubrimiento de objetos, sino más bien, de formalizar la experiencia de relacionar y asociar ideas. El descubrimiento por lo general, revela las evidencias para apoyar las intuiciones iniciales que tenemos sobre un lugar (Girot, 1999, p. 64).

\subsection{ASPECTOS VISUALES DE LOS BORDES Y EL ENTORNO}

El terreno, tiene una superficie de 1.022 hectáreas y se ubica en el sector poniente de Santiago a 20 kilómetros de la Plaza de Armas, a 5,2 km del anillo de circunvalación Américo Vespucio y, a 5,5 kilómetro del aeropuerto Internacional de Santiago. Se llega al sitio a través de la autopista (Ruta 68), a una velocidad promedio de $80 \mathrm{~km} / \mathrm{h}$. El lugar se anuncia en la carretera como "Carén" (Figura 8.1.).

El predio es parte del Valle Lo Aguirre que es cruzado longitudinalmente con dirección este-oeste por la Ruta 68. Los Límites del valle están claramente definidos, el terreno, las aguas y la vegetación existente en él, conforman compartimientos visuales posibles de observar desde los numerosos puntos en altura existentes en los bordes del valle como también desde la cima de los dos cerros existentes al interior del predio.

8.2.1. En el límite sur (Figura 8.2.), la Ruta 68 , la autopista que une Santiago y Valparaíso, conforma una barrera visual en 4.400 metros, reforzada por señalética de la carretera y por la barrera de división entre las pistas. En el lado sur de la autopista se encuentra una estación del Servicio Agrícola y Ganadero (SAG), un
Figura 8.2. Vista desde el límite sur (carretera) hacia el frente. En el plano del fondo se despliega el conjunto de Lomas de Lo Aguirre. Elaboración propia

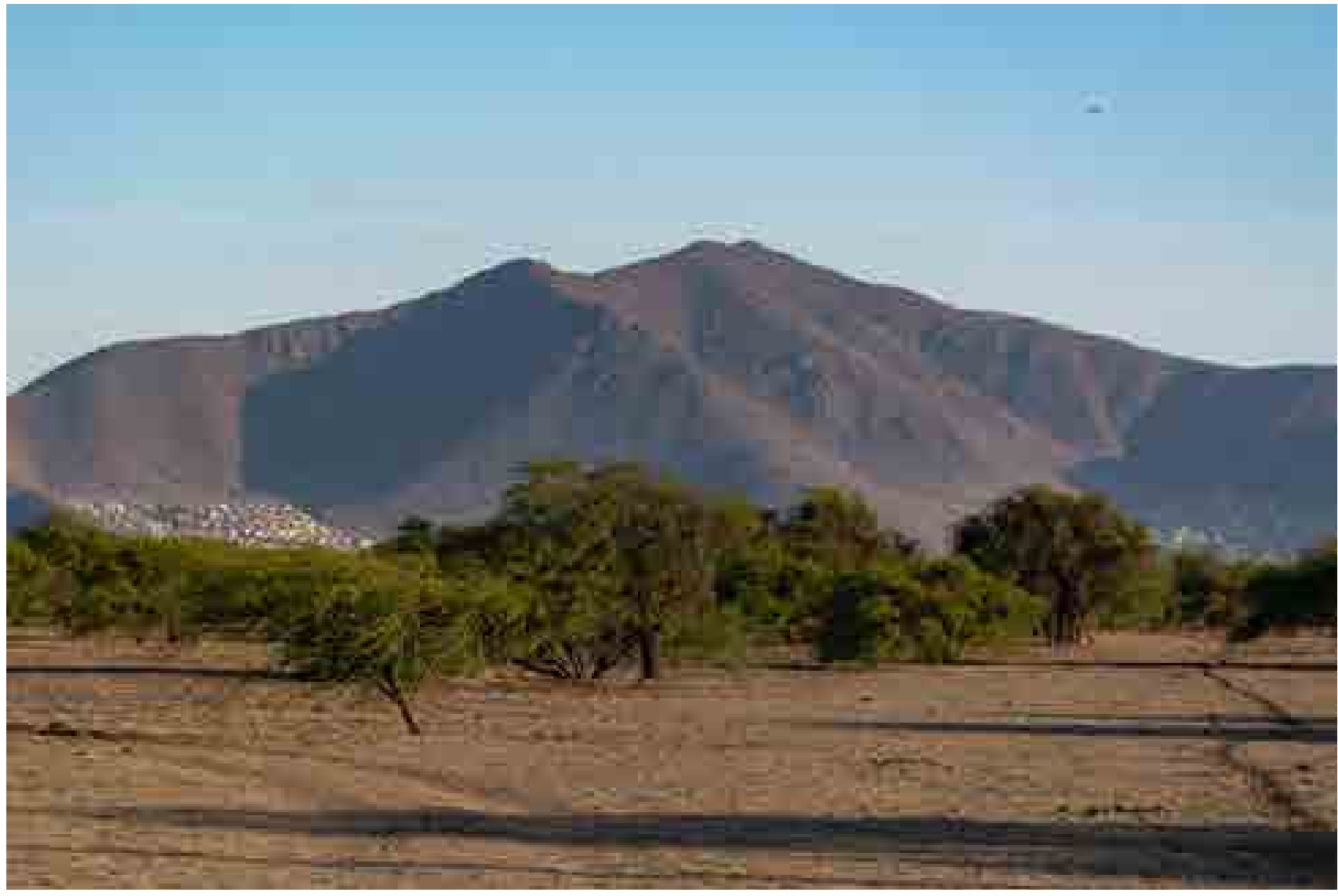


volumen de gran envergadura que opera como centro de almacenamiento y distribución. Todo este primer plano que se desarrolla al otro lado del camino tiene un grano grueso, sin detalle, sin vegetación ni valor visual. En el plano de fondo aparece una extensa y densa franja $(4.000 \mathrm{~m})$ de viviendas que ocupan los faldeos de las Lomas de Lo Aguirre, con una grano fino y homogéneo de color ocre rojizo. Se trata del condominio de más de 3.000 viviendas de Lomas de Lo Aguirre. Si se cruza hasta este condominio, desde la parte alta, se obtiene una vista del terreno de estudio, pudiendo apreciar claramente algunos elementos como: la rotonda de acceso, las calles interiores del predio, la estación de servicios (bencinera) en un primer plano junto a construcciones y vehículos estacionados en el límite hacia la autopista, la cancha de golf (como tierral) el cerro Amapola, la medialuna y el cuerpo de agua tras los matorrales

8.2.2. Entrada principal. Ubicada en la "fachada sur del predio", está claramente señalizada como "Carén" desde la autopista. El acceso desde la Ruta 68 se produce a través de un nudo vial donde una rotonda obliga la reducción de la velocidad, hasta llegar después de $370 \mathrm{~m}$ por una calle pavimentada al cierre de acceso que se interrumpe con un pequeño puesto de guardia (Figura 8.3.). A la derecha, se encuentra la Plaza de Acceso. Esta es la primera obra realizada según el nuevo plan maestro.

8.2.3. Límite oriente (Figura 8.4.): este límite está definido por el Estero Lampa, en una línea sinuosa de 4.200 metros. El curso del estero ha permitido la proliferación de árboles, matorrales y arbustos que dan lugar a una intensa vida de fauna local. Esta vegetación ocluye la visión del predio desde el exterior de este. Paralelo a este límite se encuentra el camino a la localidad de Noviciado. Este camino diverge hacia el norte, después del cerro Amapola, dejando predios que aumentan en tamaño, lo que aleja el Estero Lampa y el deslinde, por tanto, de la visión desde este camino.

8.2.4. El límite norte del predio (Figura 8.5.) está conformado por una serie de hijuelas en $520 \mathrm{~m}$ en total, en línea quebrada. Los predios vecinos están dedicados a la producción de hortalizas. Desde los cerros del sitio, se observa claramente el cambio de propiedad, ya que los terrenos vecinos presentan visual-

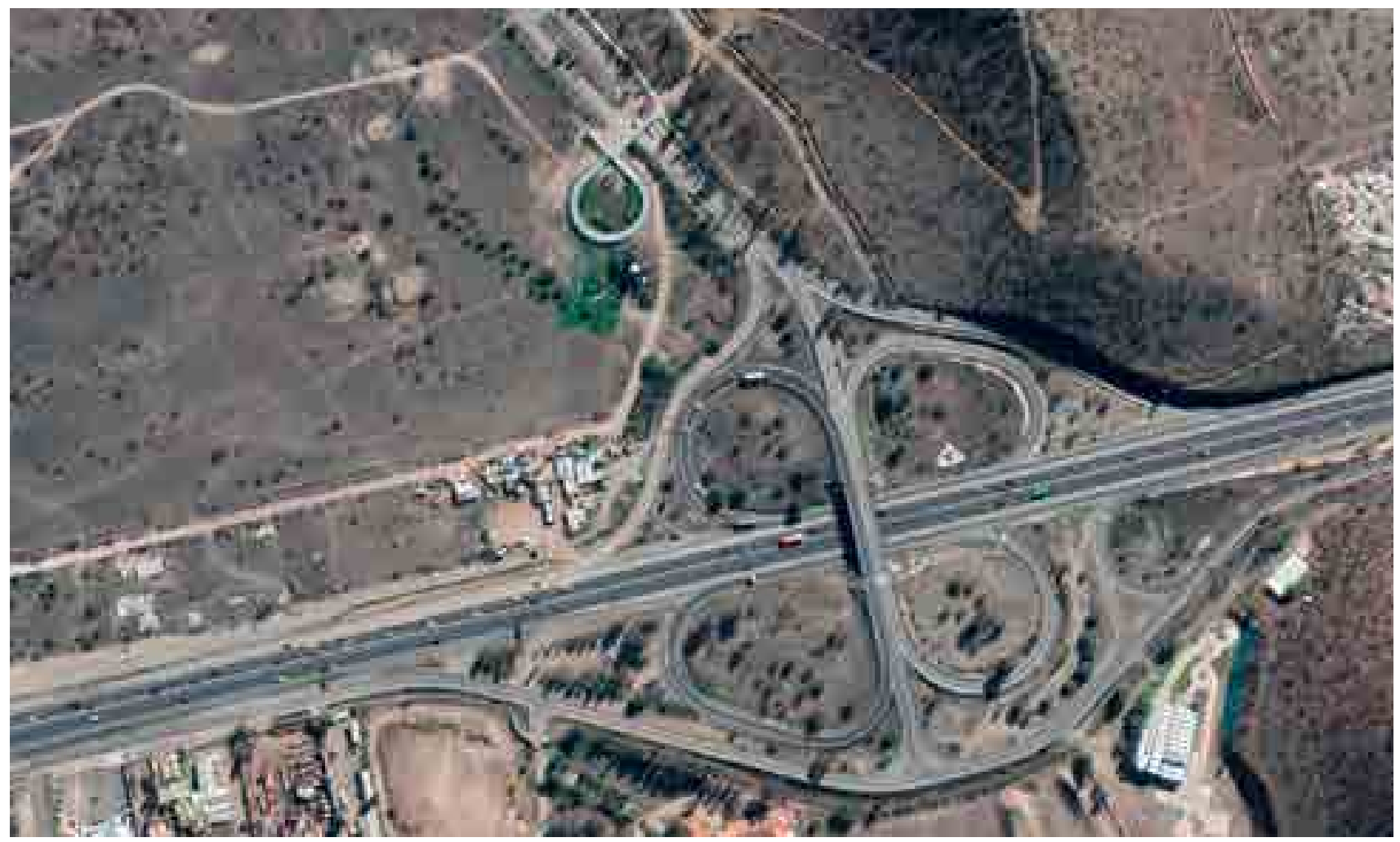

Figura 8.3. Vista satelital de la zona de acceso. Imagen capturada de Google Maps 

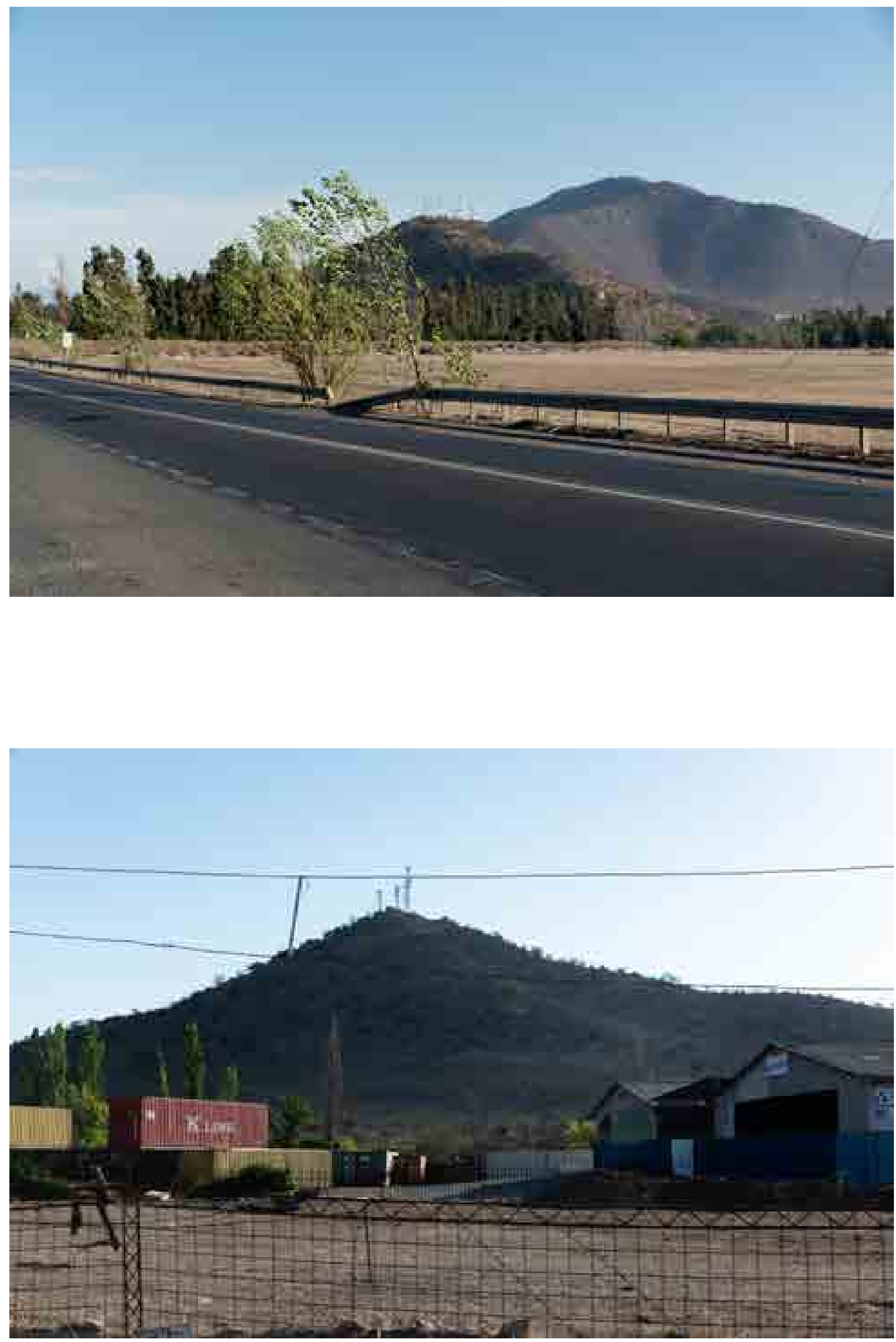

Figura 8.4. Vista del límite oriente, desde el camino a Noviciado. Elaboración propia 
mente un mosaico cuadrangular de tonos verde que contrasta con el predio en estudio, de patrones más aleatorios, redondeados y con predominio de color ocre en verano y otoño, y verde-ocre en invierno y primavera.

El deslinde está definido por un cierre con postes de madera y alambre de púas en precario estado. Este límite esta reforzado visual y perceptualmente por una línea de eucaliptos, que actúa como referencia visual a la distancia y como un borde sombreado y más fresco para quien camina por el fondo del terreno. Debido al uso histórico, este límite se considera el de "atrás" incluso en el lenguaje coloquial de quienes ahí trabajan, este es el "fondo del sitio".

8.2.5. Limite Poniente (Figura 8.6.): este límite está formalizado por un cierre de postes de madera y alambre, en buen estado y construido hace 3 años, que separa el predio de la universidad de su vecino, Praderas (Inmobiliaria el Bosque). Recordemos que el límite está definido por el "Ex camino CORA" (ver sección 6.10), que, si bien hoy es casi imperceptible, existe como objeto legal. En esta línea divisoria también se encuentra "la piedra tacita", descrita en la sección 6.1. El deslinde se encuentra en una planicie con poca pendiente, que baja hacia la Ruta 68 con matorrales de espino que se hacen más densos hacia el poniente, percibiéndose como un bosque en el predio del vecino. En esa misma dirección, hacia el oeste, se encuentran la mina Lo Aguirre, luego el Centro de Energía Nuclear de Lo Aguirre (ninguno de los dos perceptibles), y en el campo visual lejano se aprecian los cerros de Lo Prado (Cordillera de la Costa), punteados por vegetación.

Tras este límite, a fututo, se contempla la construcción de la Ciudad de Lo Aguirre $^{309}$, un Proyectos de Desarrollo Urbano Condicionado (PDUC), que en su etapa final albergará 28 mil viviendas, con un total de 120 mil habitantes. Este deslinde, por tanto, si bien hoy es el menos caracterizable, será en los próximos años, una de las más importantes fachadas para el proyecto, ya que los habitantes de esta verdadera "pequeña ciudad", serán posiblemente los principales usuarios del Parque.

También se prevé, que este conjunto habitacional podrá acoger a los funcionarios de las instalaciones que la universidad emplace allí, ya que el desarrollo inmobiliario contempla una oferta variada de viviendas (desde vivienda social, hasta casas para estratos medios y medios altos), colegios y servicios. La normativa que rige para predio Carén, como veremos más adelante, no permite la función habitacional, limitación que puede ser subsanada a través de la relación con Ciudad de Lo Aguirre.

\subsection{COMPONENTES DEL PAISAJE DENTRO DEL PREDIO}

Las cualidades del paisaje están determinadas por los elementos naturales y artificiales -factores físicos y bióticos-, estudiados en el capítulo 7 y los histórico-culturales, contenidos en el capítulo 6; Los elementos percibidos, pueden agruparse en los siguientes componentes del paisaje:

\subsubsection{Superficie}

La mayor parte del predio corresponde a una superficie topográfica relativamente plana, con poca pendiente, con algunos lomajes ondulados suaves, principalmente en el sector sur-poniente, cercano a la Ruta 68 , y en el sector nor-oriente. En los extremos sur-oriente y nor- poniente, se encuentran cerros con una altura de alrededor de $80 \mathrm{~m}$ respecto al plano predominante, correspondientes a los cerros Amapola y Puntilla Lo Vásquez, respectivamente. En la parte alta de ambos cerros afloran algunas formaciones rocosas.

\subsubsection{Aguas}

El predio es penetrado en su límite norte por dos brazos de agua que posteriormente confluyen y drenan hacia la laguna Carén. De ellos, el mayor, ubicado más al poniente, corresponde al estero Carén. Ambos reciben aportes de aguas de
${ }^{309}$ El Proyecto Praderas Ilamado también "Ciudad de Lo Aguirre", fue concebido como una "Comunidad Urbana Planificada (CUP) que acogería unos 120 mil habitantes en aproximadamente 28 mil viviendas en un horizonte de entre 25 y 30 años. El proyecto aprobado en 2018 considera un total de 19.692 viviendas para 78.769 habitantes. 


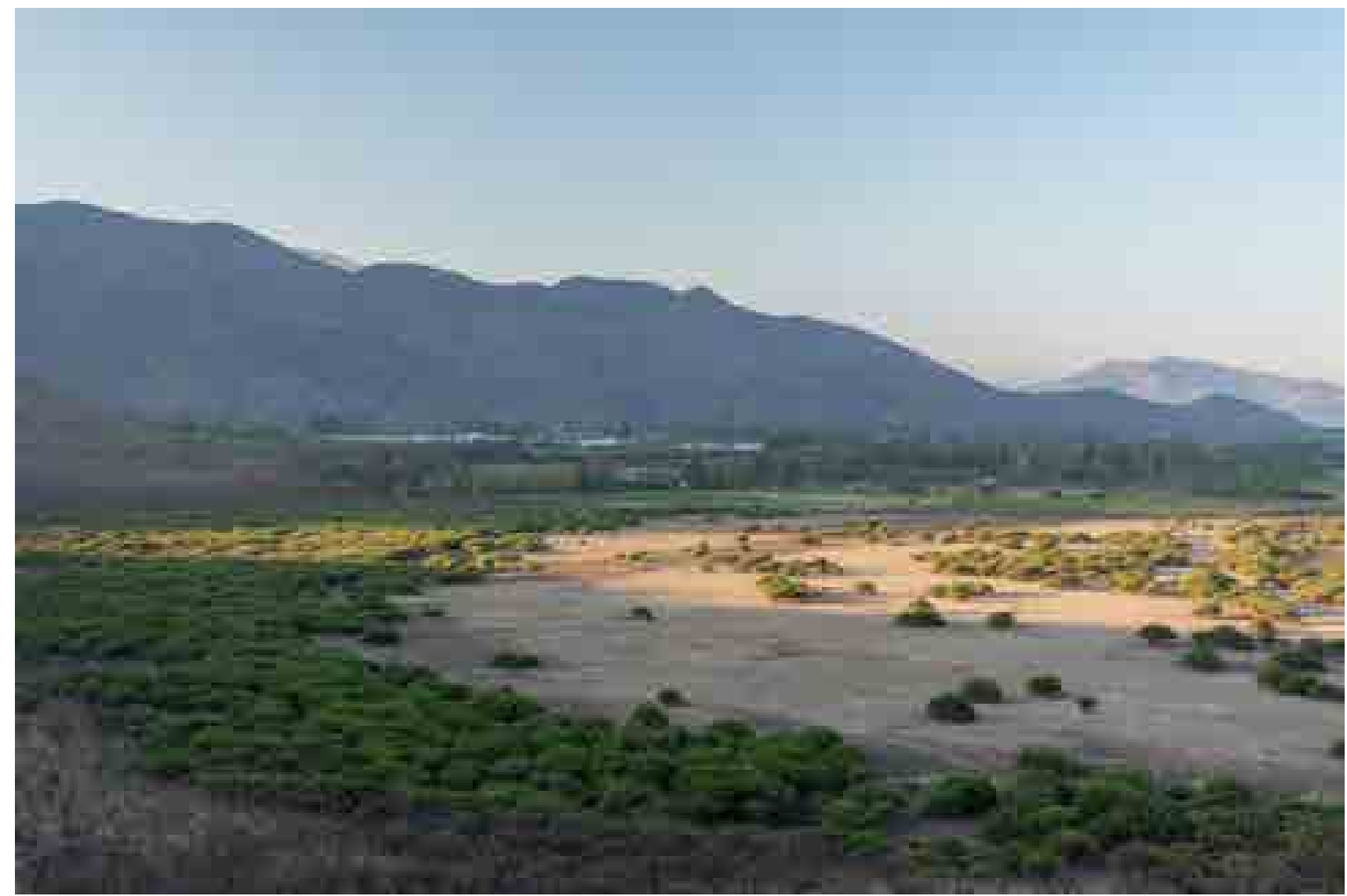

Figura 8.5. Vista límite norte, desde el cerro puntilla de Lo Vásquez, se distingue una línea de árboles más alta al centro de la imagen, que sirve de límite con la localidad de Noviciado. Elaboración propia.

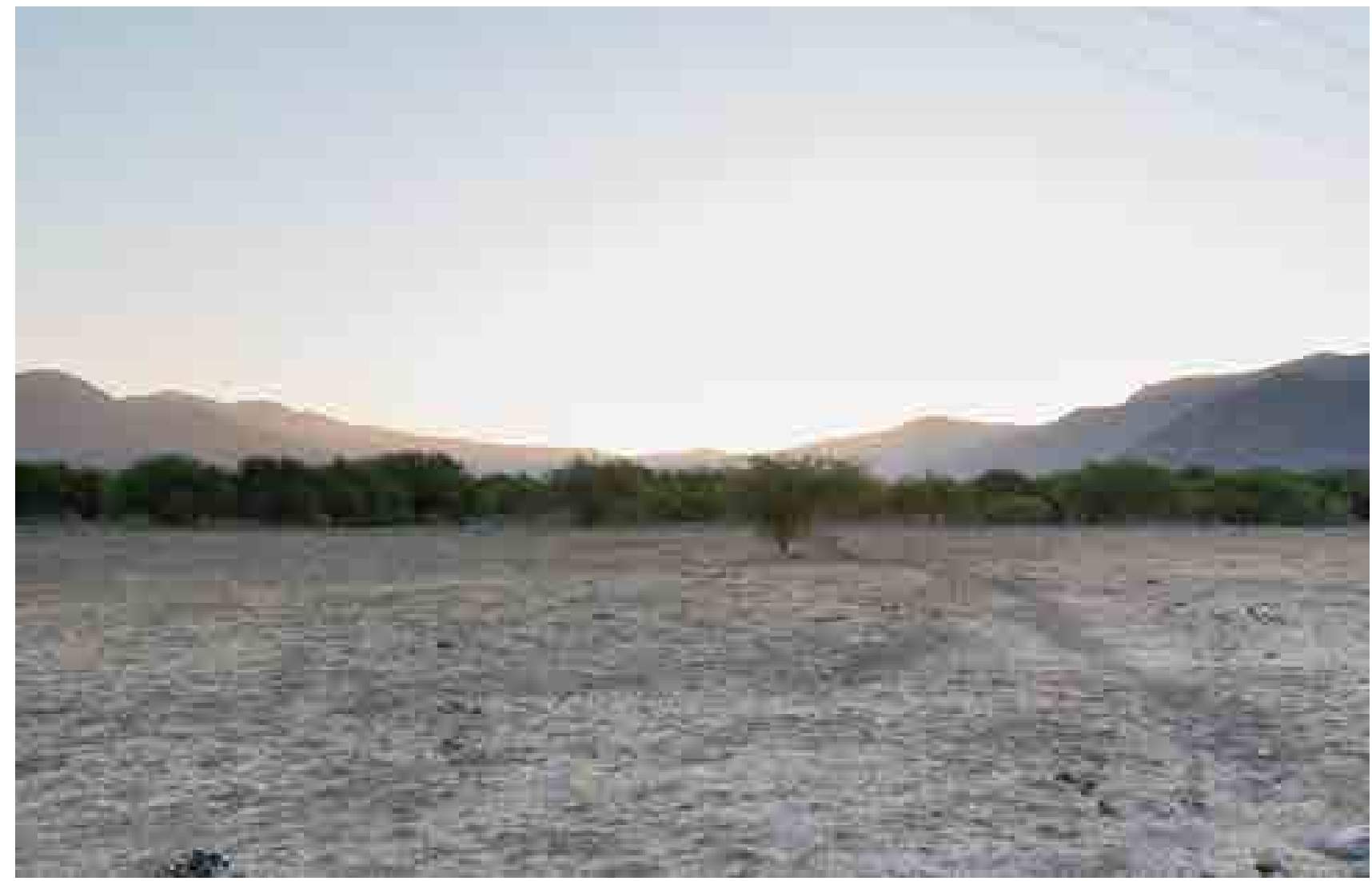

Figura 8.6. Vista del límite poniente. Al fondo se aprecia el predio donde se desarrollará Ciudad de Lo Aguirre. Elaboración propia 
regadío que derivan del canal La Punta. Existen además otros cursos de agua esporádicos que recogen las aguas lluvias en épocas de precipitaciones, y que en la época de estudio se encontraban secos, pero claramente delineados en el terreno y distinguibles en las vistas satelitales de Google Maps (Figura 8.7.). Asociada a la presencia de agua, se observa gran variedad y cantidad de aves (Figura 8.8.). El nivel del agua de la laguna, es regulado mecánicamente por una compuerta en su extremo oriente, desembocando a corta distancia en el estero Lampa (Figura 8.9.).

Esta placa de agua quieta serpentea por el centro del terreno y visualmente zonifica la superficie del predio

\subsubsection{Vegetación}

Las formaciones vegetacionales que se aprecian en la mayor parte de la planicie del terreno tienen visualmente una textura de "grano fino", vale decir, los elementos que componen la vegetación, principalmente espinos, presentan un tamaño relativamente pequeño (Figura 8.10.) y se encuentran distribuidos en forma irregular.

La densidad de los espinales en la planicie es en general baja, y distribuida en forma azarosa. Es decir, su disposición espacial no presenta ordenamiento evidente y por lo tanto no se observan superficies homogéneas, a excepción de paños desnudos de vegetación.

La vegetación natural de algunos sectores de las riberas de los brazos de agua y la laguna está compuesta por totorales y cañaverales que han sido explotados sin un manejo adecuado y controlado. Este mal manejo, en conjunto con la baja calidad de las aguas, influye negativamente en el desarrollo de una fauna acuática más interesante (Figura 8.11.).

\subsubsection{Elementos artificiales}

En los elementos artificiales de este paisaje (señalados en la Figura 8.12.), se pueden reconocer dos grandes períodos de intervención: antes de 2006 y después de esta fecha. Las construcciones más antiguas corresponden a galpones y casas, ubicadas en el borde sur al costado de la Ruta 68 (A), y en el sector ubicado entre el cerro Amapola y el estero Lampa (B). En la cima de este cerro se encuentran 4 antenas de telefonía celular(I) que se observan con facilidad desde la mayor parte del predio y también desde fuera de éste (Figura 8.13.). Cercano a la laguna, existen una serie de instalaciones tipo galpón relacionadas con las actividades de canotaje y remo $(C)$. Aparece también entre la entrada y el área norte de la laguna, una medialuna de rodeo (D) y sus instalaciones anexas. A la entrada del predio, a mano derecha se encuentra una cancha de golf de tierra $(E)$. En la ribera norte de la laguna existe una zona de picnic (G). Esta es una zona muy deteriorada, sus suelos no tiene capa vegetal y la vegetación es exógena.

Las intervenciones más nuevas corresponden a la avenida de acceso, de doble pista, con un bandejón central. Corresponde a $2.600 \mathrm{~m}$ en un trazado curvo, que intercepta dos rotondas de 50 de diámetro $(\mathrm{H})$ y es enmarcada a los $1.000 \mathrm{~m}$ de la entrada $(0)$ por un portal de acceso ( $Q$ ). Un edificio-umbral que contiene un pequeño sector de oficinas, portería y servicios higiénicos. Esta construcción, pertenece a una tipología muy común en los condominios privados, por lo tanto, su presencia es discordante en un contexto natural, con muy poca presencia humana, marcando un antes y un después que no se diferencian. En el cerro Puntilla Lo Vásquez, se encuentra emplazado un estanque de agua $(F)$, que se destaca como punto de referencia desde el interior del terreno. A partir de este volumen cilíndrico, bajan por la ladera oriente, 3 matrices que conducen el agua potable. Todo el tramo en pendiente está a la vista (Figura 8.14.).

Atraviesan la propiedad en dirección este-oeste dos líneas de alta tensión (T), dispuestas en forma paralela entre ellas y a la Ruta 68, a unos $200 \mathrm{~m}$ de la carretera. Además, existe otra línea de conducción eléctrica de alta tensión que pasa en la misma dirección cercana al predio, fuera de él, en el extremo nor- poniente con torres metálicas de gran escala.

También existen en la propiedad algunos trazados de postes con servidumbre de 


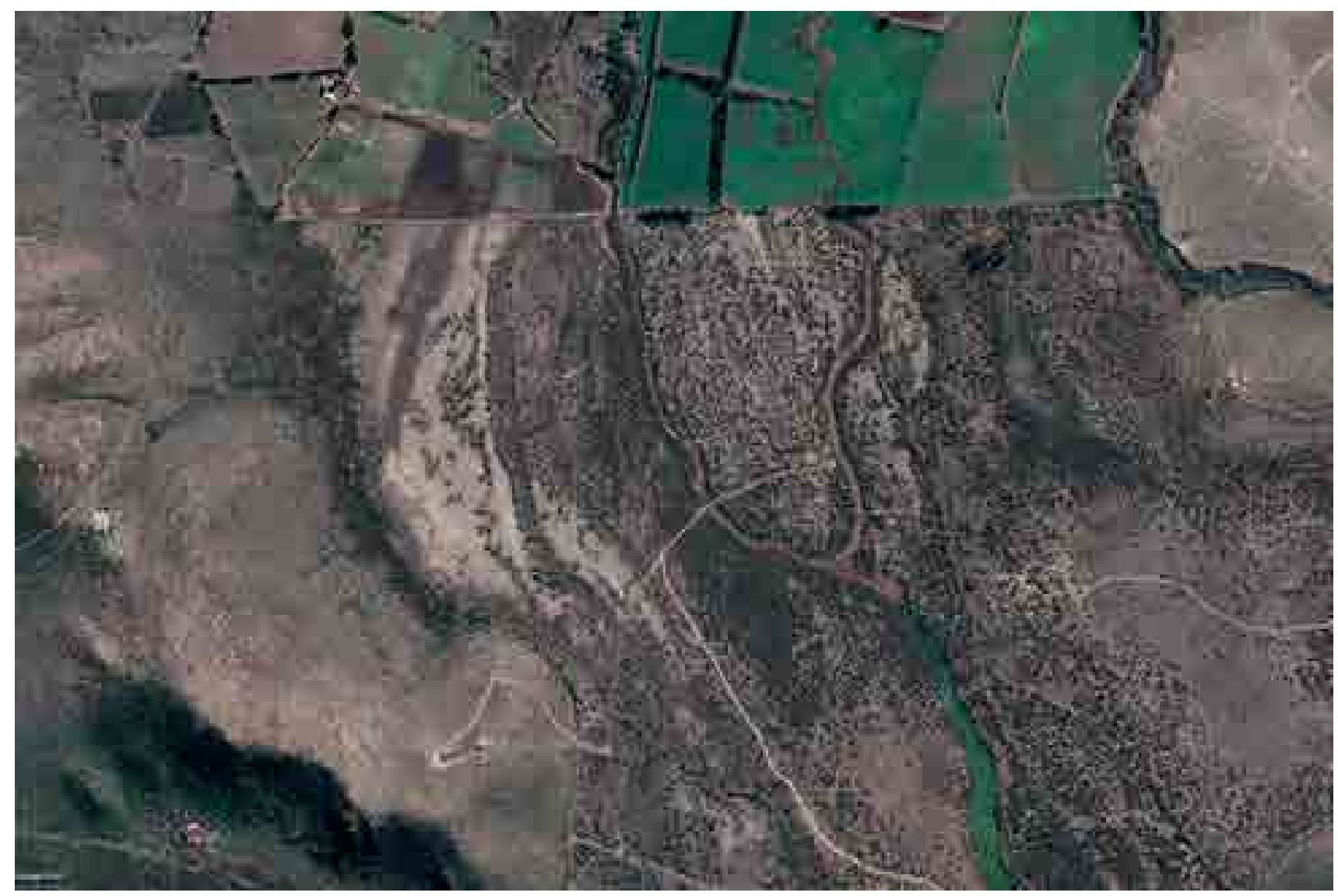

Figura 8.7. Vista satelital de los afluentes del estero Carén. Se observan (a la izquierda), las huellas de los cauces secos.

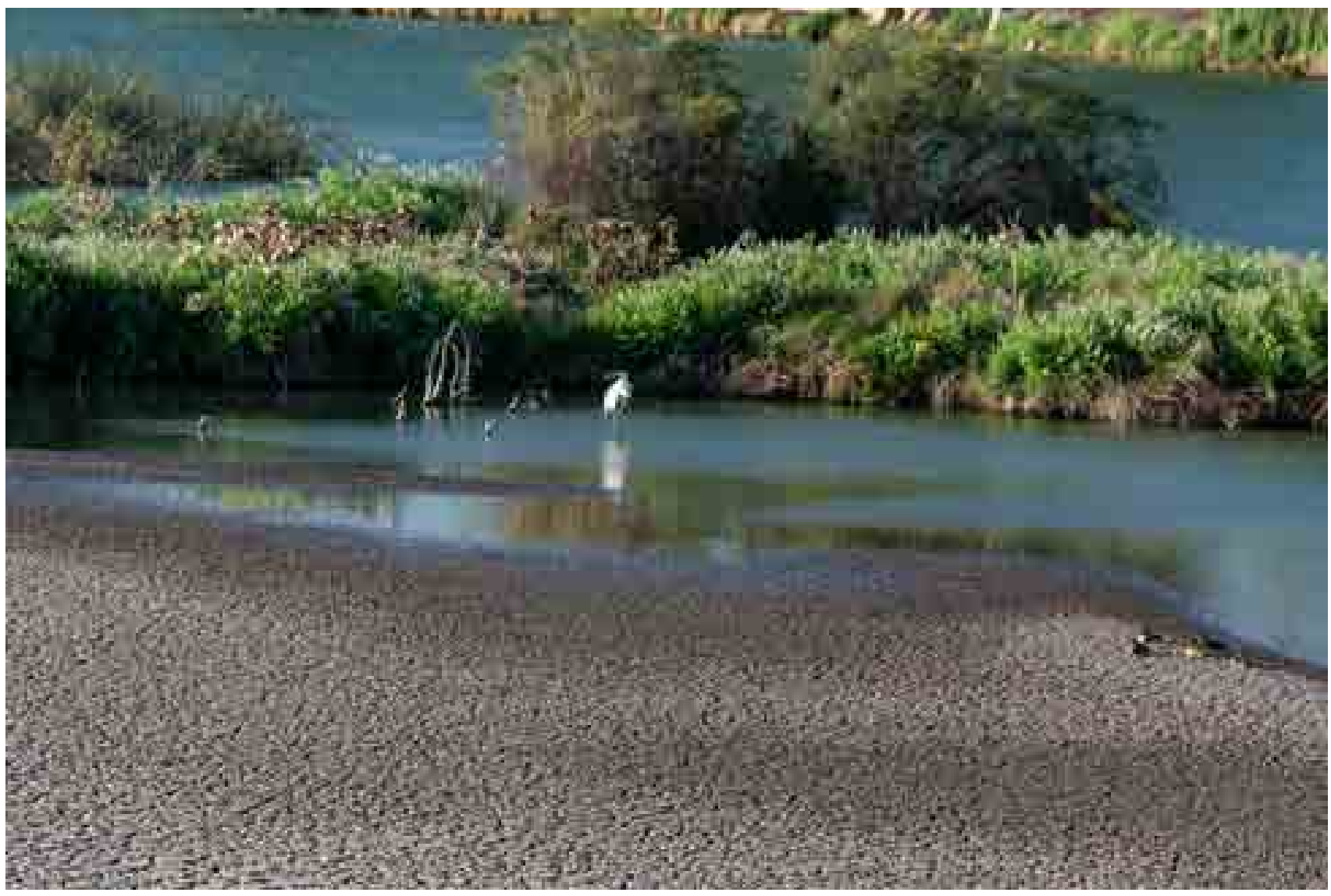

Figura 8.8. Vista de la laguna, hábitat de aves. al centro, una garza cuca (Ardea cocoi). Elaboración propia. 


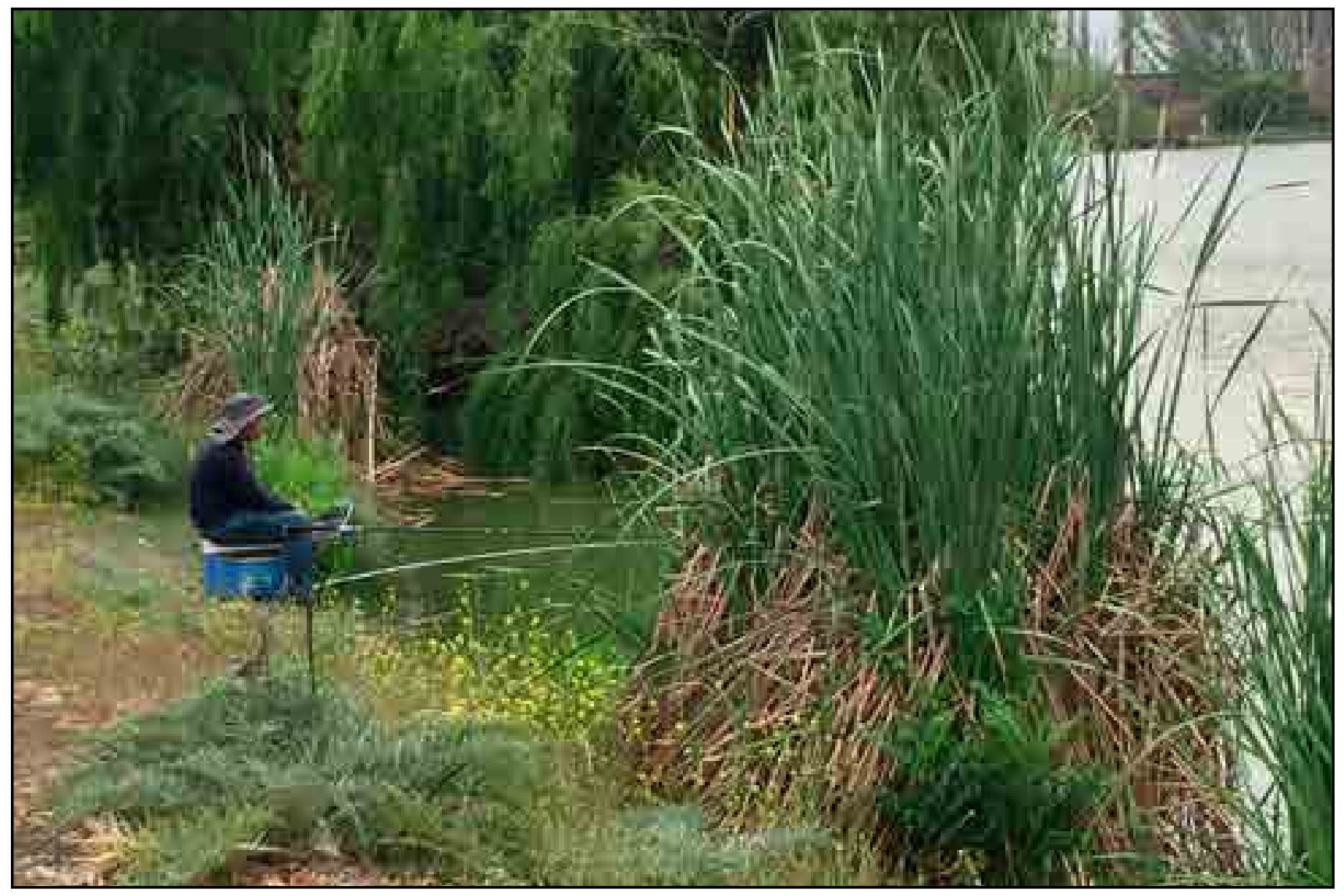

Figura 8.9. Vista de la exclusa que regula el nivel del agua en la laguna.

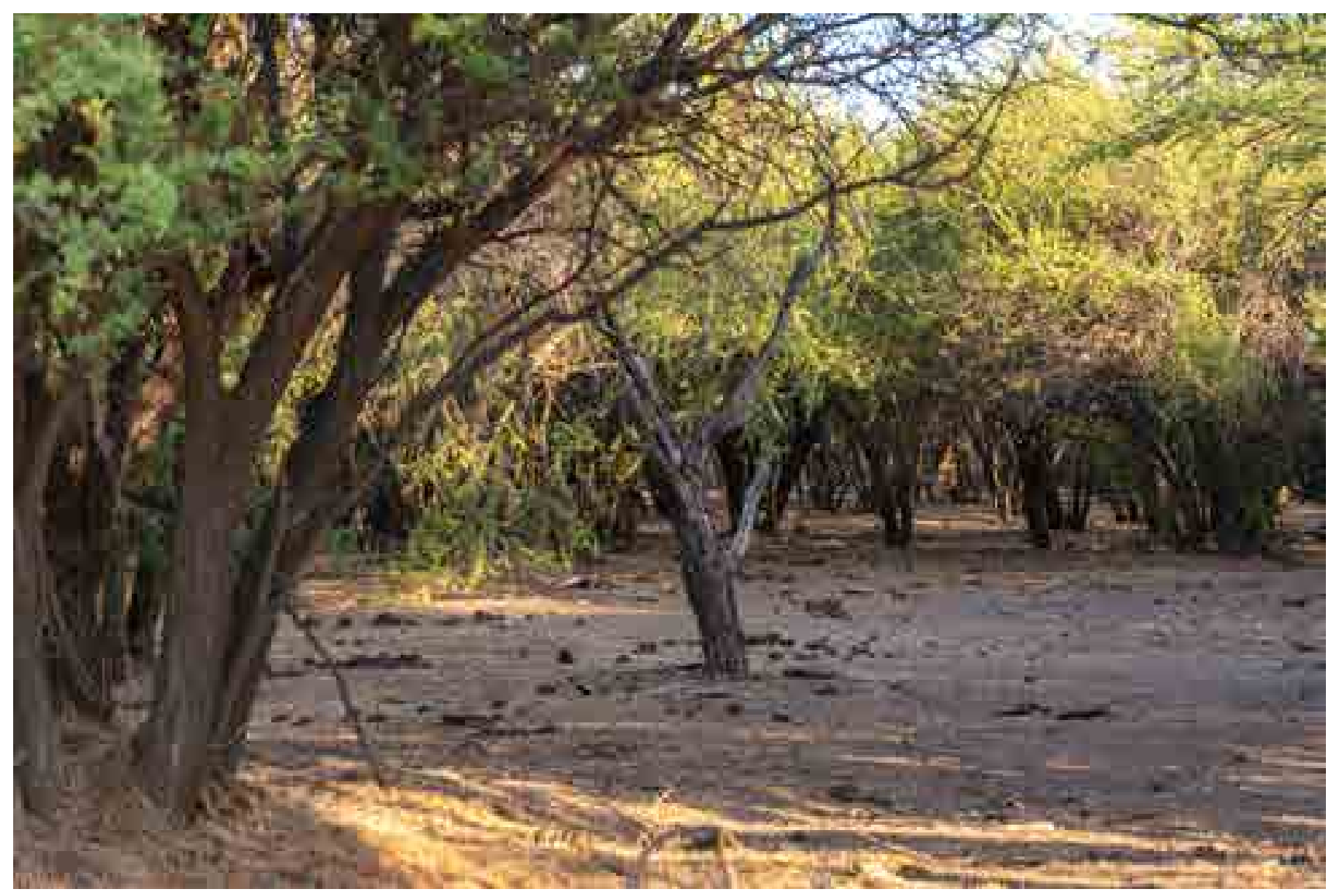

Figura 8.10. Vista del bosque de espinos (Acacia caven). Elaboración propia 


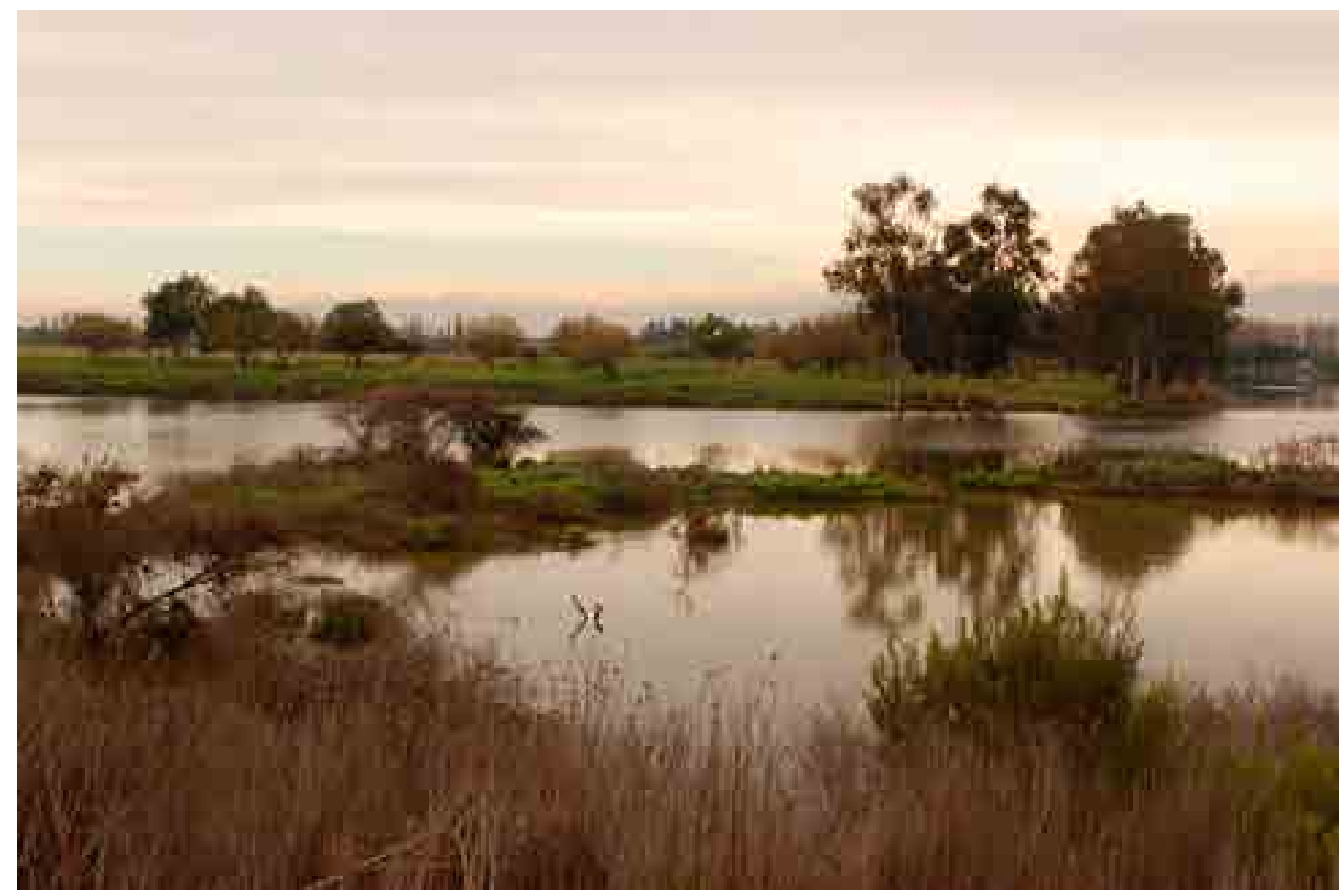

Figura 8.11. Vista de la ribera de la laguna. Se observan cañaverales característicos del humedal. Elaboración propia

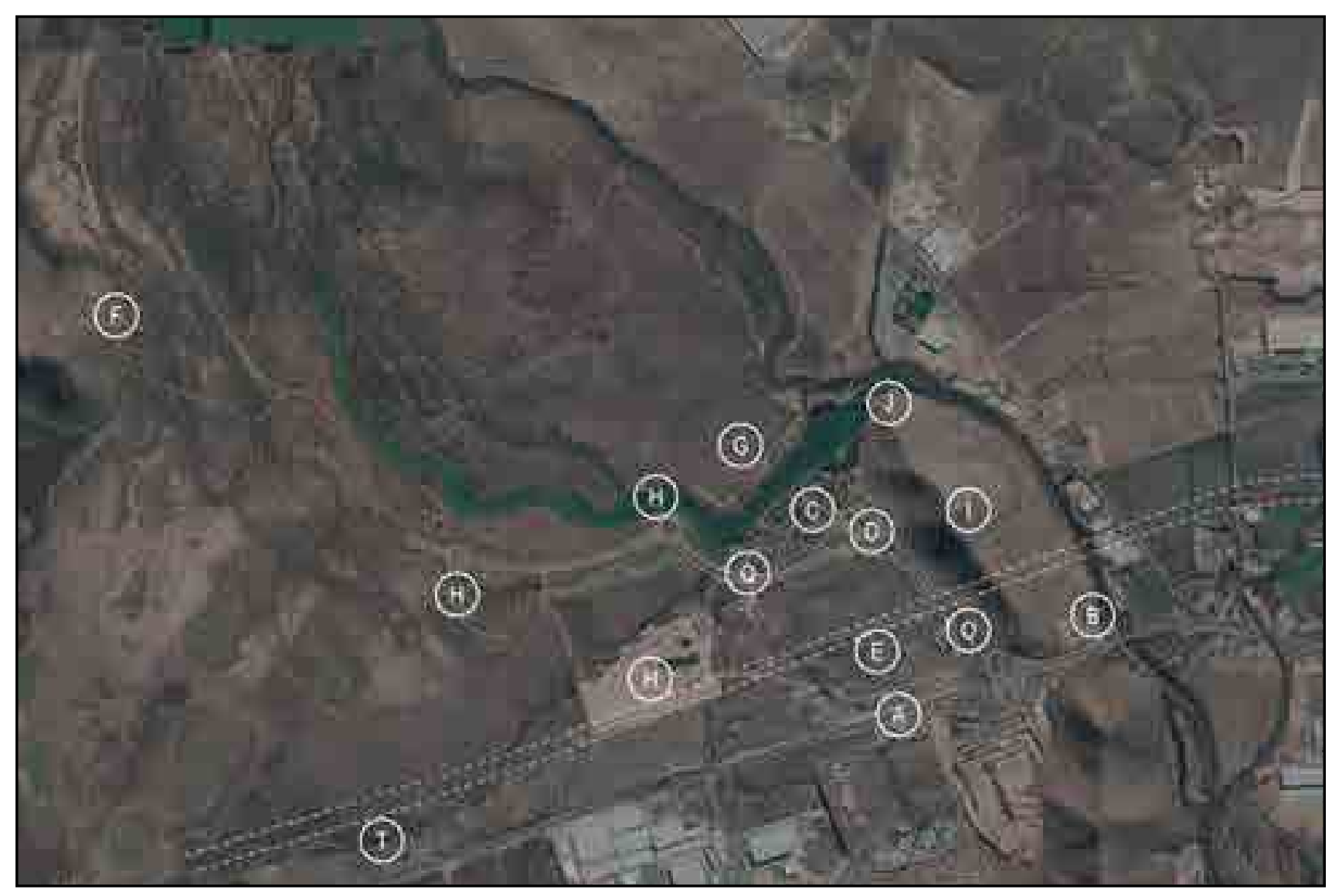

Figura 8.12. Planta de Componentes del paisaje. Se indican los hitos citados en el texto. Elaboración propia. 


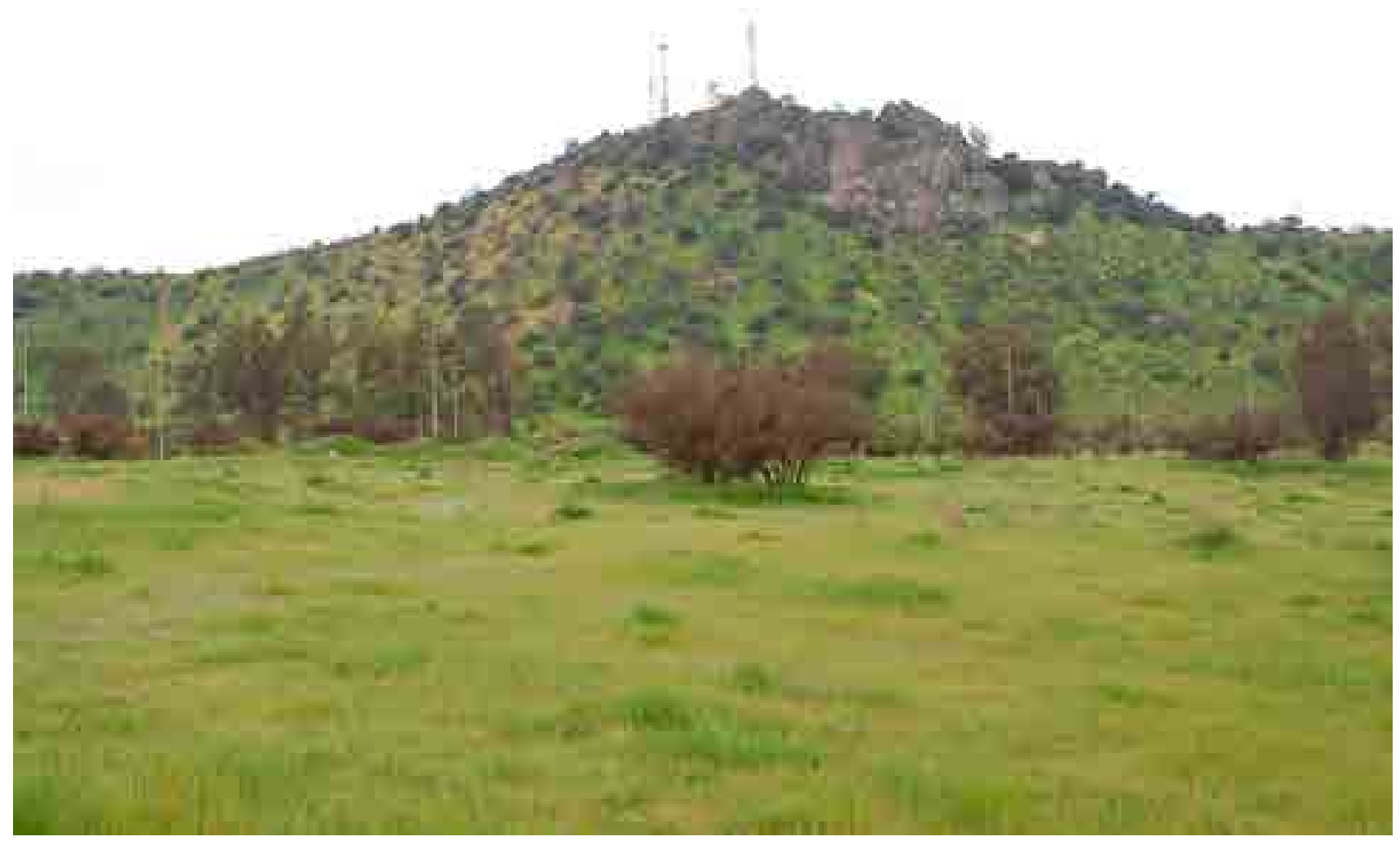

Figura 8.13. Vista desde la laguna hacia el cerro Amapola, con las antenas de telefonía celular en la cima. Elaboración propia 


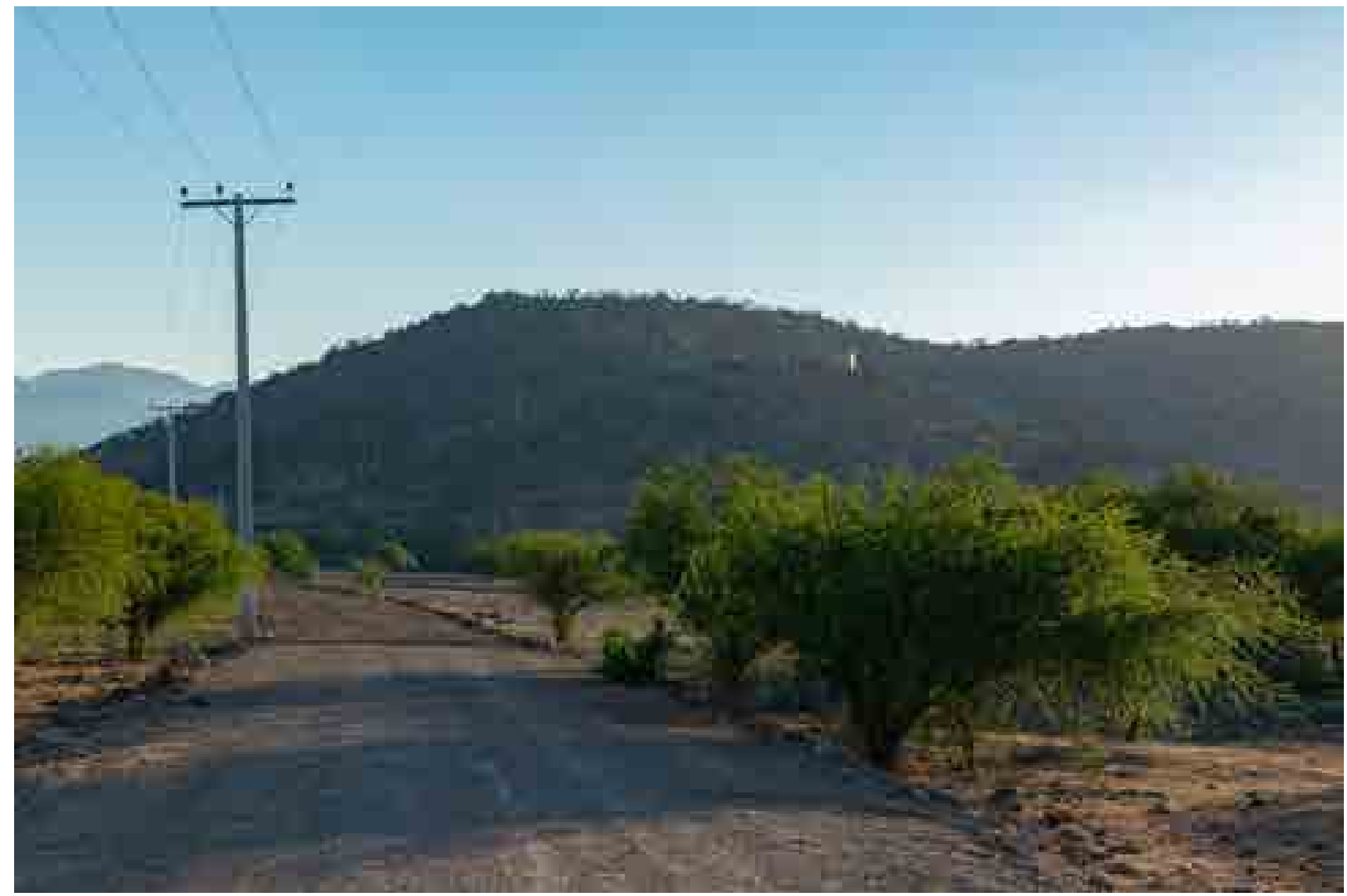

Figura 8.14. Vista del cerro Puntilla de Lo Vásquez. En el perfil se observan las matrices de agua potable y en la cima, el estanque. Elaboración propia 
electricidad a las instalaciones levantadas en el terreno. La mayor parte de ellas se encuentran cercanas a la laguna y al norte de ésta, asociadas a la planta de tratamiento de aguas y a una antigua casa de cuidador en una loma en el sector nor-oriente (J).

En general las construcciones existentes en el predio, no tienen valor estético ni histórico, salvo la media luna de rodeo, ejecutada en ladrillo formando un pequeño anfiteatro de 45 metros de diámetro, más unas galerías semicirculares de 11 metros.

Por último, en la zona sur-poniente del predio, se encuentra un sector destinado a competencias anuales de Jeep Fun Race. Se trata de una superficie de 20 hectáreas $(K)$ que fue una antigua cantera, por lo que los suelos están totalmente erosionados y han permanecido así, debido al uso. Como se trata de una depresión, cuyo fondo está compactado, cuando llueve, se transforma en una laguna.

\subsection{UNIDADES DE PAISAJE}

El entorno inmediato hace posible la observación de elementos visualmente atractivos a distancias entre 500 a $700 \mathrm{~m}$, lo que permite la identificación de unidades de paisaje en base a su homogeneidad y carácter, tanto en sus componentes paisajísticos como en la respuesta visual ante posibles actuaciones.

En consideración a los factores definitorios del paisaje y los aspectos visuales descritos, como también la aptitudes y limitaciones de los suelos, como de las condiciones climáticas que permiten el crecimiento de especies en el secano, se distinguen 11 zonas paisajísticas que se esquematizan en la Figura 8.15.

ZONA 1: la zona se encuentra en el sector nor-poniente del predio limitada por el estero Carén y el cerro Puntilla Lo Vásquez. Presenta una topografía plana, entre 462,10 y $462,80 \mathrm{~m}$ de altitud. Los espinos son de tamaño y densidad medias, y sin un ordenamiento perceptible. Los espinales son ralos y con poco contraste y colorido. Las praderas están deterioradas por el sobrepastoreo. Aun así, es una zona que presenta un grado menor de intervención antrópica.

ZONA 2: caracterizada por la Puntilla de Lo Vásquez, cuya cima se encuentra a 583,50 m de altitud, presenta afloramientos rocosos en la parte superior. La vegetación está representada por 9 especies leñosas, siendo la más típica la comunidad de espino-Huañil (ver Figura 7.16 y Tabla 7.4. sobre composición de flora). Desde 2006 existe un camino no pavimentado hasta la cumbre, donde se emplaza el estanque de agua, un volumen de $17 \mathrm{~m}$ de diámetro. Desde allí se puede observar todo el predio, comprender su extensión e identificar los principales hitos interiores y exteriores a él, teniendo como fondo lejano la cordillera de los Andes (Figura 8.16).

ZONA 3: Ubicada en el extremo sur-poniente entre los 460,10 y $461,20 \mathrm{~m}$ de altitud. Visibles desde la última rotonda, hacia el frente y la izquierda Las formaciones vegetacionales de esta zona son ralas, el suelo aparece desnudo y con costras de sal en un 70\%. Los espinales aparecen con mayor densidad y tamaño hacia el predio vecino. Los lugareños llaman a este sector "tierras muertas" (Figura 8.17).

ZONA 4: ubicada en el sector sur del predio, entre 460,20 y 461,20 m de altitud, entre el camino de ingreso 0 avenida de la universidad y el deslinde sur. El Portal de ingreso es un hito importante de referencia, si bien con bajo valor estético y simbólico. Es el sector de mayor intervención antrópica a nivel de suelos. En este sector se encuentra la pista de competiciones en Jeep, que ha aprovechado antiguas canteras de piedra pómez. En invierno, tras las lluvias este sector de inunda, creando una laguna de aproximadamente 3 hectáreas. Hacia la carretera, se instaló en el año 1997 una estación de servicios ${ }^{310}$ con algunos locales de comida rápida, dejando hacia el interior del predio la trastienda de servicios, lo que deteriora más aún la perspectiva de la zona. Junto al acceso, se encuentra la cancha de golf en tierra, que, si bien se presenta con un área despejada, presenta una superficie desnuda, surcada por torres de alta tensión (Figura 8.18).
310 Se trata de un contrato de arriendo suscrito con fecha 25 de julio de 1997 , renovado el 31 de agosto de 2007 por un plazo de 15 años, vale decir hasta el 31 de julnio de 2011. 


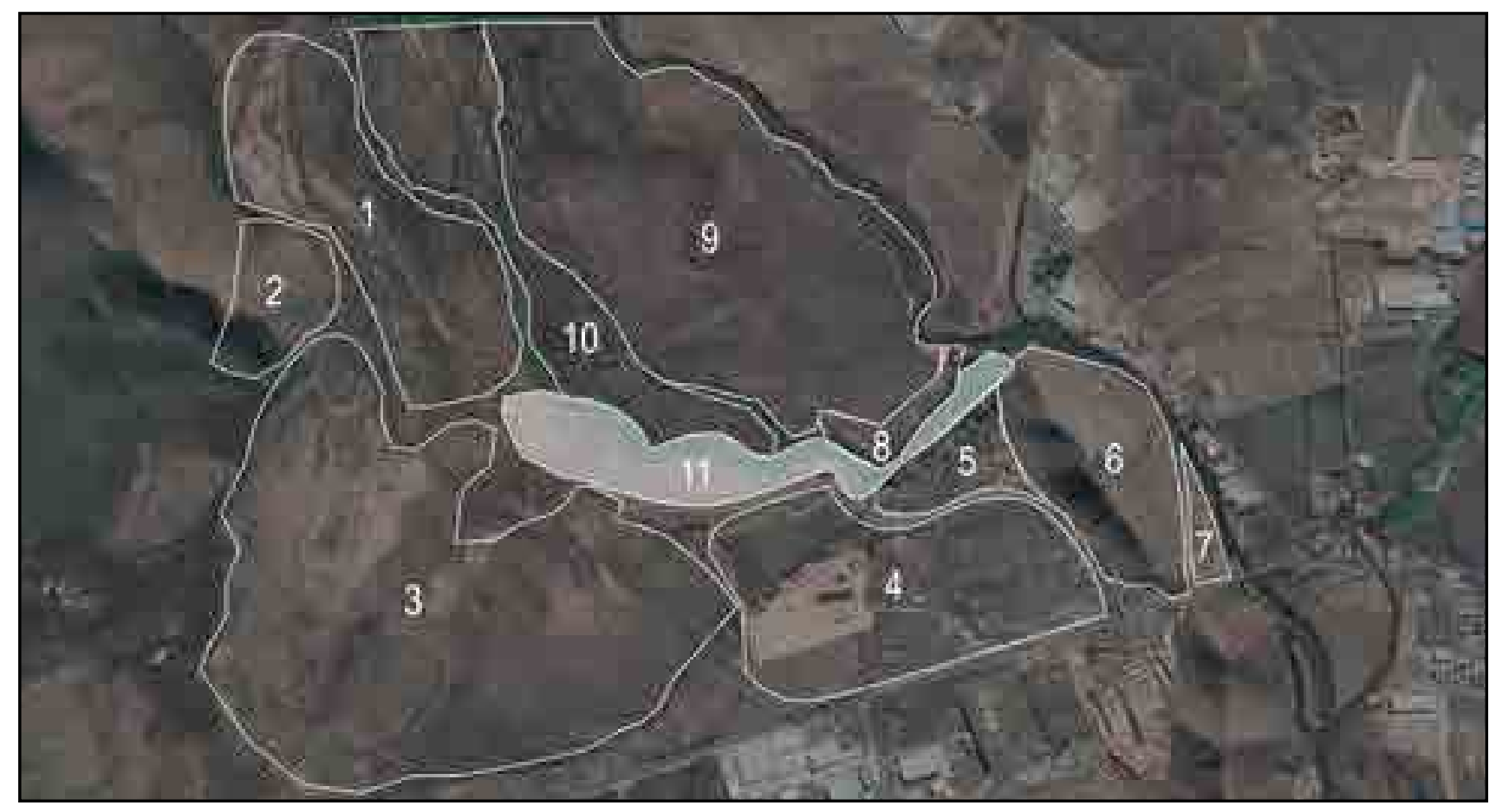

Figura 8.15. Planta del sitio donde se indican las unidades de paisaje. Elaboración propia.

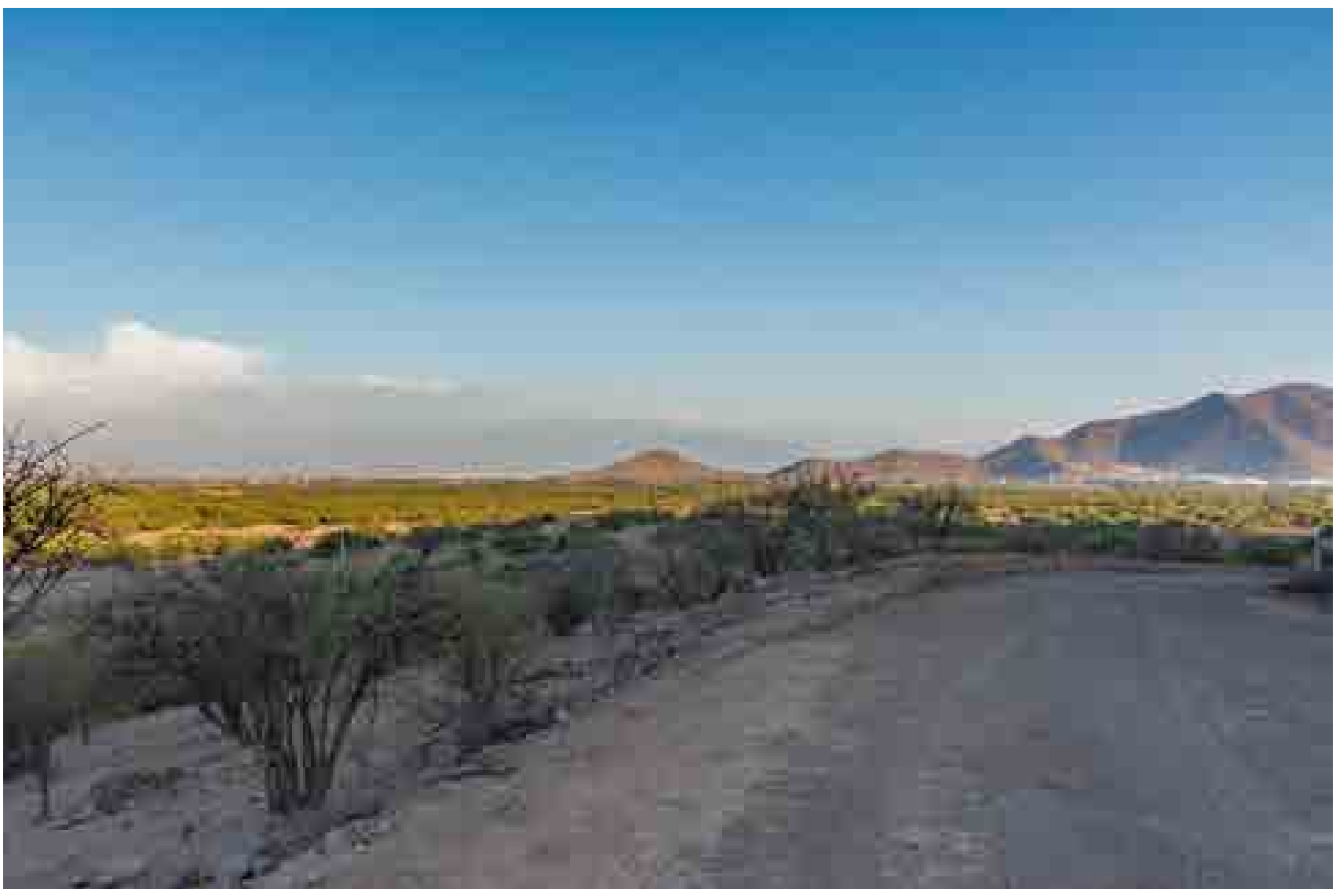

Figura 8.16. Vista desde el cerro Puntilla de Lo Vásquez hacia el oriente, con la cordillera como telón de fondo. Zona 2. Elaboración propia 


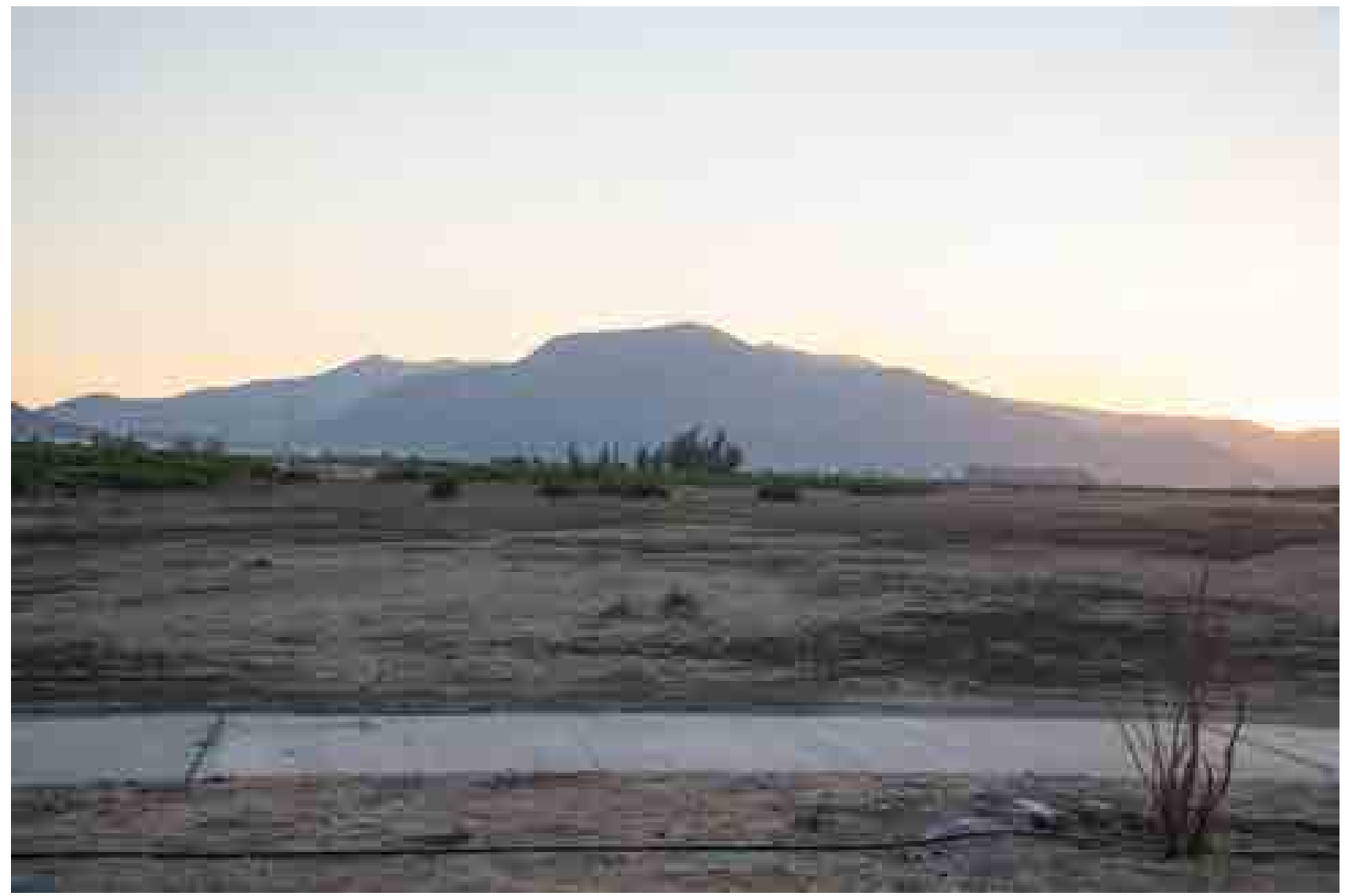

Figura 8.17. Vista de las "tierras muertas". Zona 3. Elaboración propia 
ZONA 5: Ubicada entre el camino de acceso 0 avenida de la universidad y la laguna. Es una superficie triangular entre los 461 y $475,5 \mathrm{~m}$ de altitud, donde se encuentran la mayor parte de las construcciones (galpones, bodegas, casas) siendo la media luna de rodeo, el único elemento de mayor calidad visual y material. Para los trabajadores del predio, esta es la "zona deportiva" ya que es usada por los visitantes habituales que practican remo y pesca ${ }^{311}$ en la mañana y vela en la tarde. Es un área fuertemente antropizada, con más vegetación que la anterior, pero con especies introducidas. Allí se encuentra un bosquecillo de eucaliptos, a mano derecha del camino, en un área de 2 hectáreas, sector cuyos suelos se encuentran muy deteriorados y secos (Figura 8.19.).

ZONA 6: Corresponde al cerro Amapola, que alcanza una altitud de 588, $50 \mathrm{~m}$. Es la altura mayor del predio, desde donde se obtiene una visión total del paisaje, incluyendo la cordillera de la Costa (que en el caso de la Puntilla Lo Vásquez, queda a la espalda del cerro). Desde este "cerro isla" con visión panorámica, puede comprenderse el relieve y su relación con los elementos geográficos externos al predio, por lo tanto, es un lugar apropiado para actividades educativas. En la parte alta se encuentran afloramientos rocosos de andesita y se exhiben pendientes de hasta un $40 \%$. Si bien la vegetación presenta señales de intervención antrópica por pastoreo de cabras y senderos de motocross, esta zona concentra la mayor variedad de especies vegetales del predio, lo que aumenta su interés (Figura 8.20.).

ZONA 7: Es una zona angosta que se encuentra entre el cerro Amapola y el estero Lampa, en el sector sur-oriente del predio, entre os 460 y $470 \mathrm{~m}$ de altitud. Esta zona es visible desde el cerro, pero de difícil acceso desde otras zonas del terreno, constituyéndose en una isla tanto funcional como perceptualmente. En ella están instaladas gran parte de las 34 familias que viven en el predio. La calidad de las construcciones es muy precaria y se encuentran próximas a la ribera poniente del estero, para suplir la falta de servicios de agua y alcantarillado. La ubicación de estas casas las expone a las crecidas del estero. Cerrando esta zona hacia la ruta 68 , se encuentra la vivienda y el taller de un picapedrero, que produce y vende hacia la carretera (Figura 8.21.).

ZONA 8: corresponde a la planicie al norte de la laguna Carén, ubicada entre 461,10 y 461,80m de altitud. En ella se encuentran áreas de picnic. En los bordes del agua se encuentra vegetación ornamental introducida. En ella la mayor parte de los suelos se encuentran desnudos y erosionados (Figura 8.22.).

ZONA 9: corresponde en su mayor extensión a una planicie ubicada entre los 461,40 y $461,80 \mathrm{~m}$ de altitud en el sector nororiente del predio, presentando tres lomas redondeadas con cimas a 469; 469,6; y 472,30 m de altitud desde donde se puede observar, cambiando levemente de altura el área con espinales y ubicar algunos algarrobos (Prosopis chilensis) aislados que destacan por su altura (Figura 8.23.).

ZONA 10: Corresponde a una superficie que se encuentra en el sector central del predio, entre los 460,20 y 462 m de altitud, entre el estero Carén y el curso de agua esporádico que recibe las aguas lluvias de la vertiente oriente del cerro Puntilla Lo Vásquez, a la derecha de la avenida de la universidad, entre esta y los cursos de agua. En ella se configura una isla alargada con mayor vegetación en los taludes de las márgenes de los cursos de agua y presencia de aves. Estas áreas presentan la mayor diversidad visual y ecológica de las zonas planas (Figura 8.24).

${ }^{311}$ Es habitual ver en las mañanas a pescadores de origen oriental en los bordes de la laguna.

ZONA 11 corresponde a la laguna en una visión próxima, especialmente desde el límite oriente. Desde allí el cuerpo de agua se despliega más allá del ángulo 

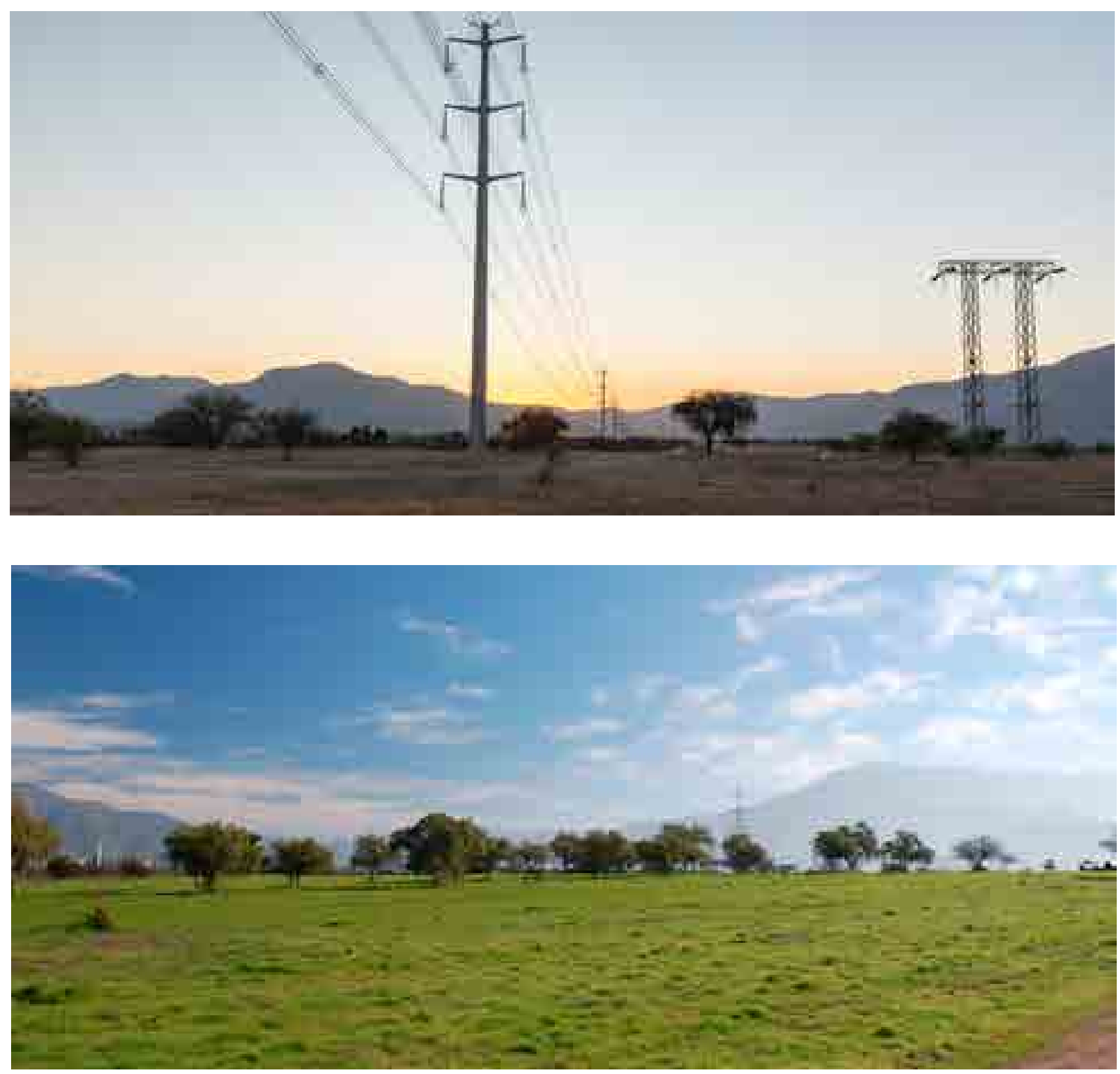

Figura 8.18. Vista desde la cancha de golf hacia el poniente. En verano (arriba) al inicio de la primavera (abajo). Zona 4. Elaboración propia 


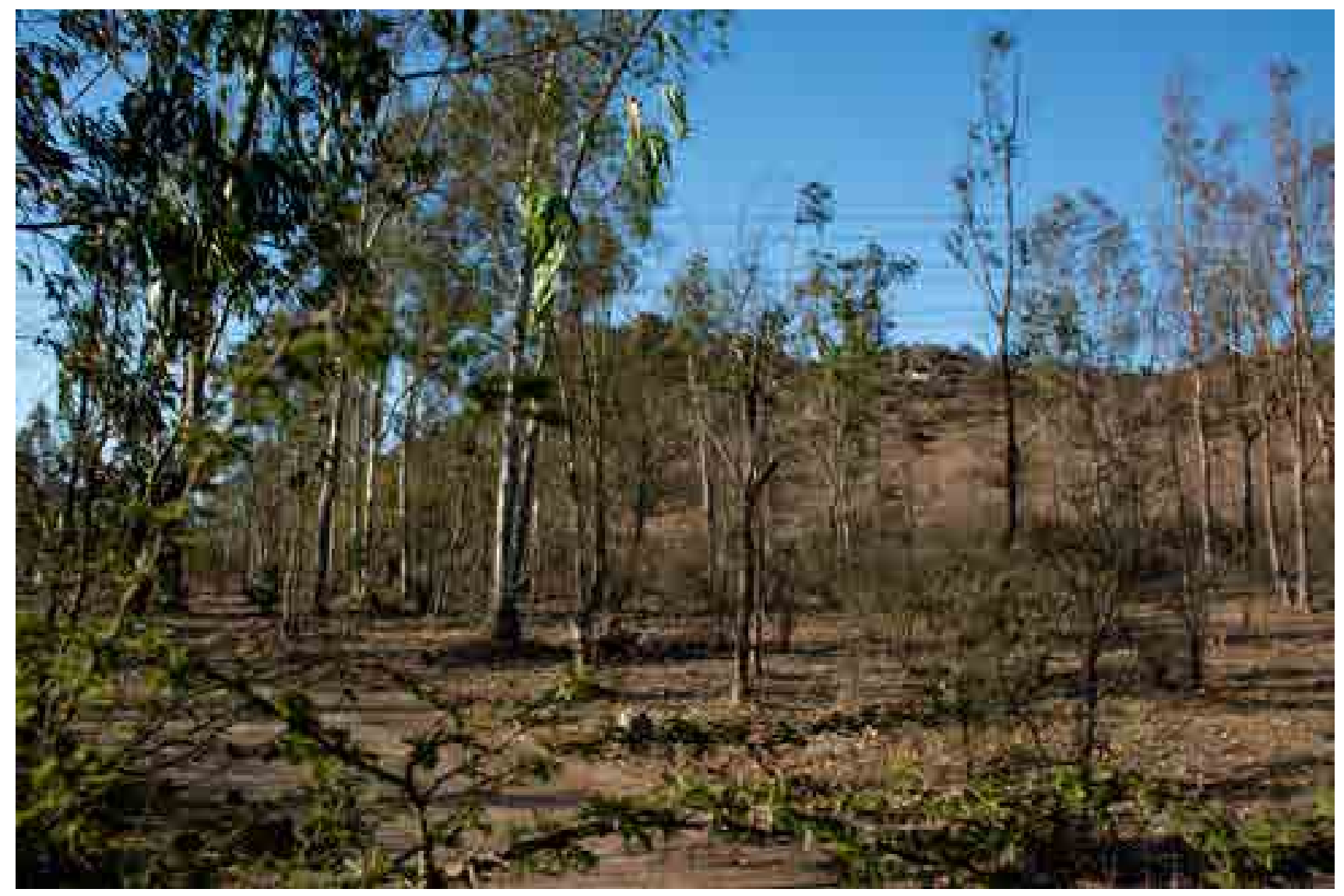

Figura 8.19. Vista del bosque de eucalip-

tus. Zona 5. Elaboración propia 


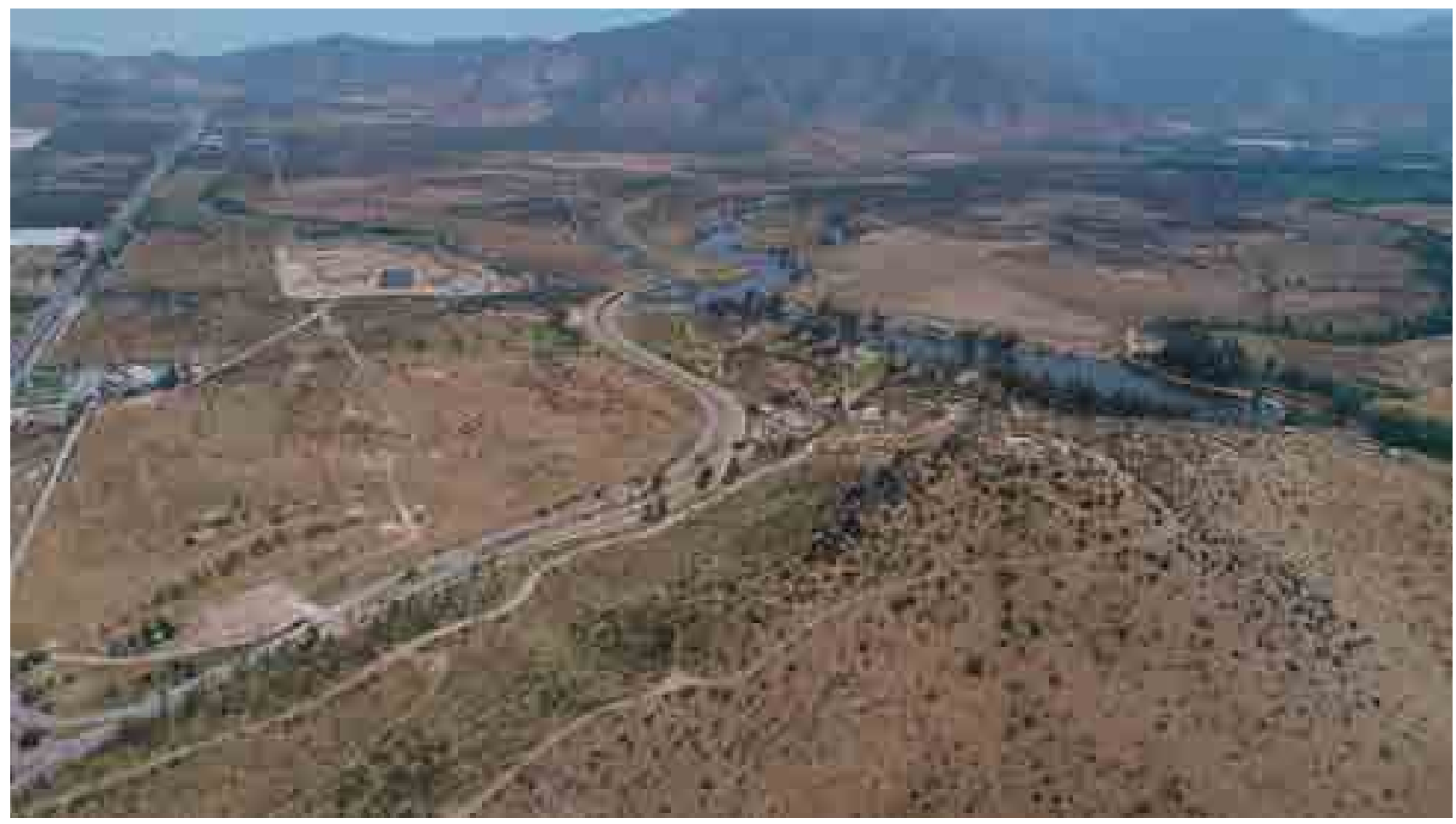

Figura 8.20. Vista panorámica desde la cumbre del cerro Amapolas. Zona 6. Elaboración propia

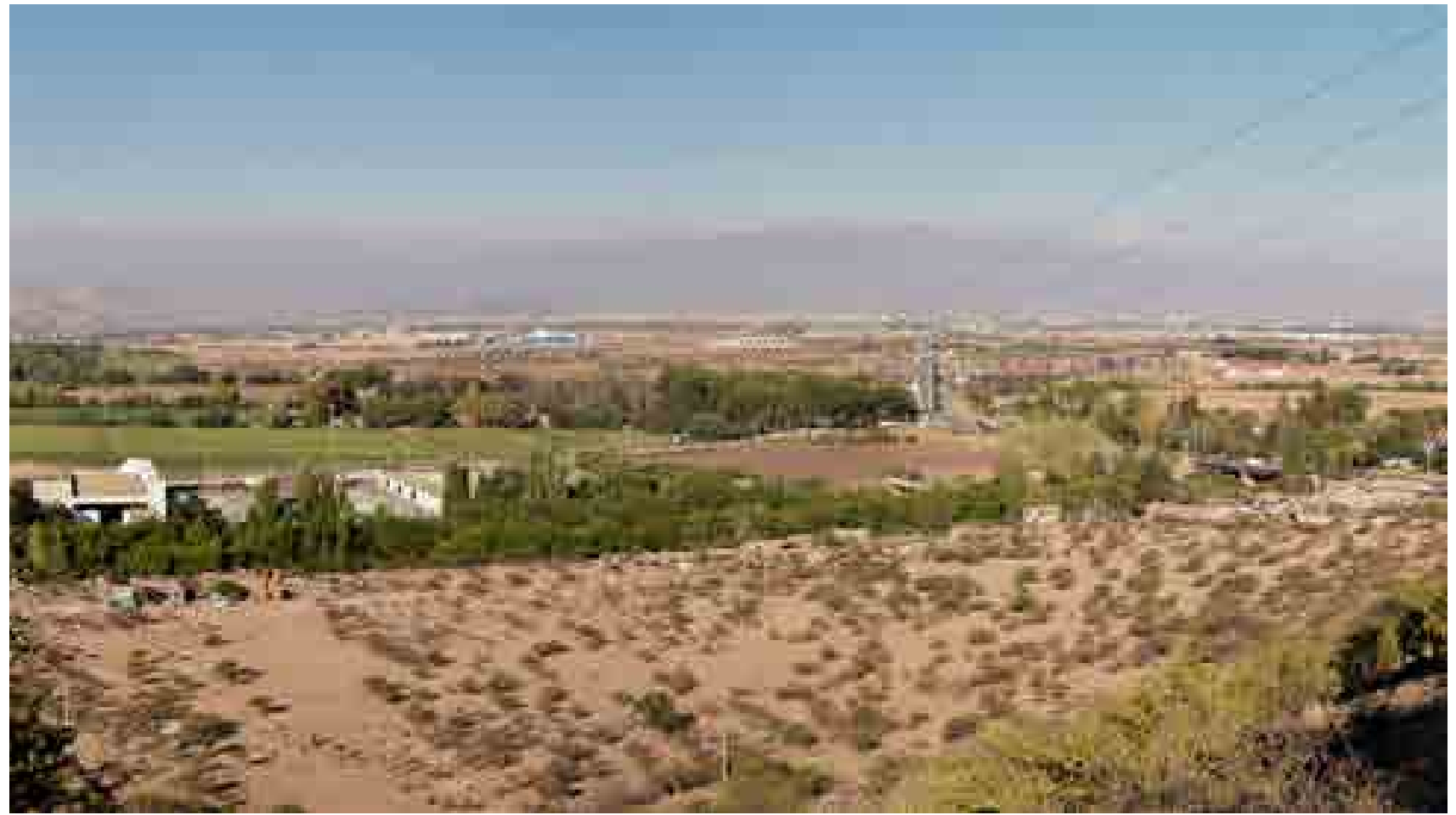

Figura 8.21. Vista del límite sur oriente del predio desde el cerro Ampolas. Es un sector aislado del resto del sitio por el cerro, donde habitan varias familias. Hacia la derecha de la imagen se aprecia la vivienda-taller del "picapedrero" que se abre sobre la Ruta 68. Zona 7. Elaboración propia 


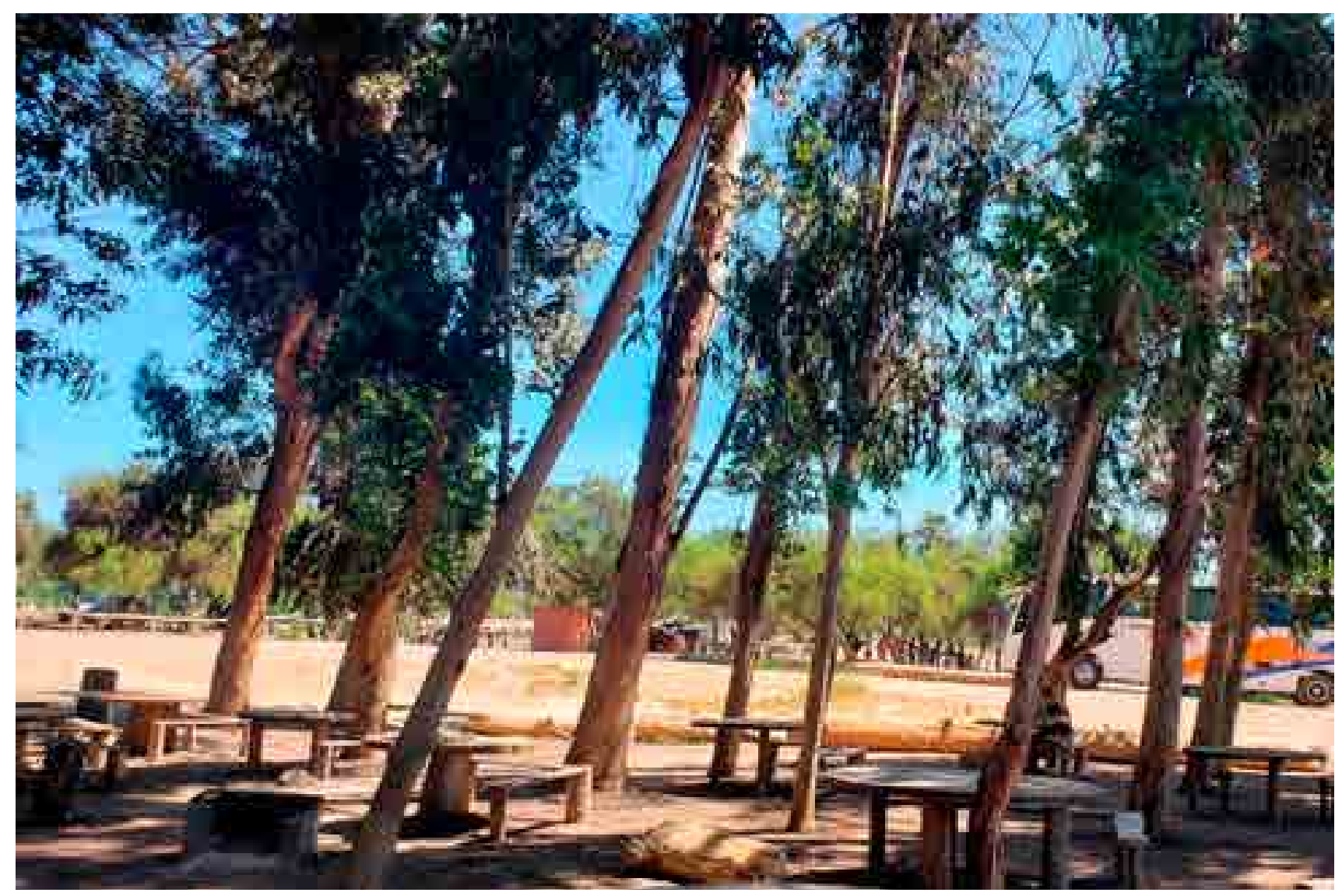

Figura 8.22. Vista de la zona de pic-nic.

Zona 8. Por Cristián Araujo (noviembre, 2019)

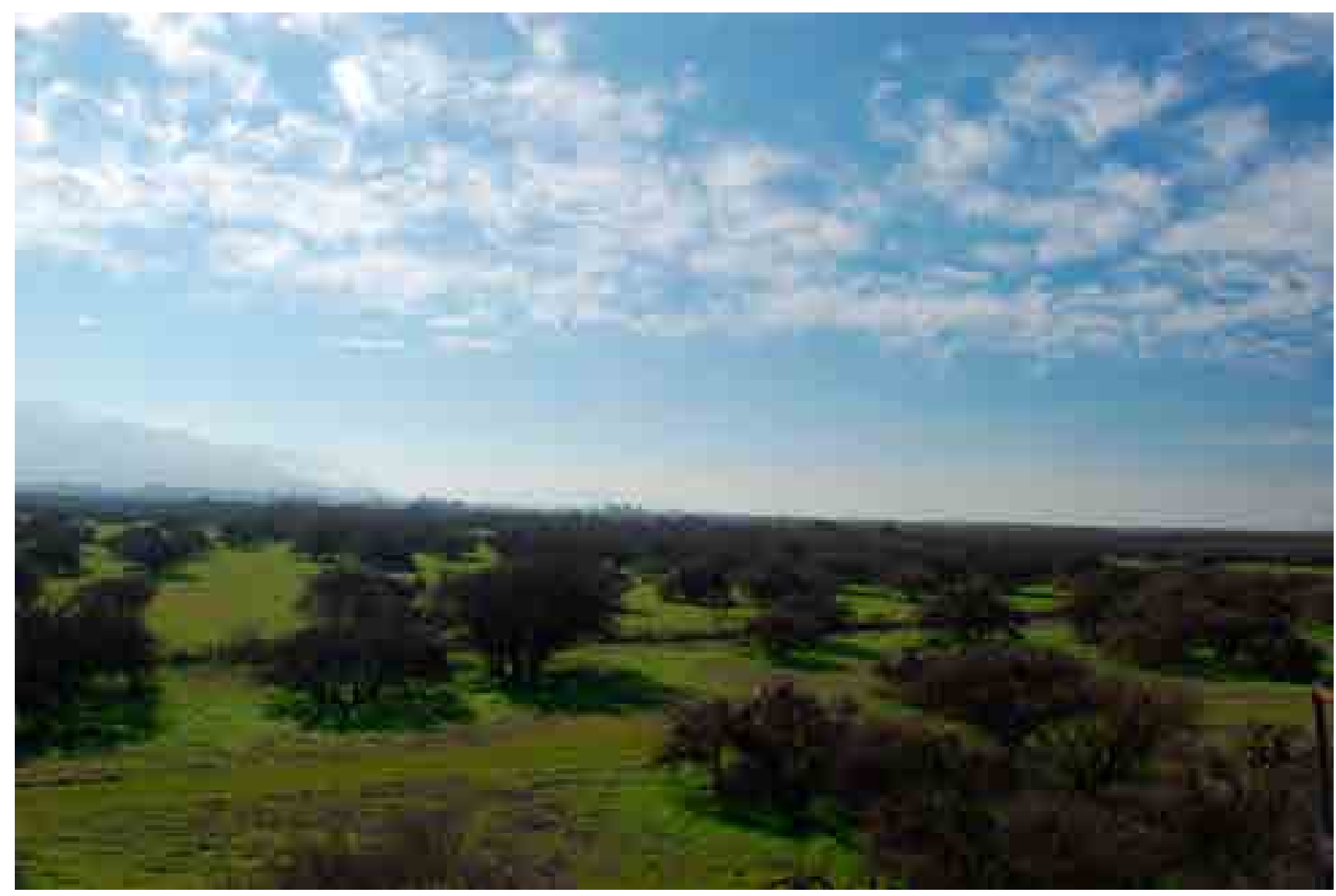

Figura 8.23. Vista de "las Iomas" sector nororiente de predio. Zona 9. Elaboración propia 


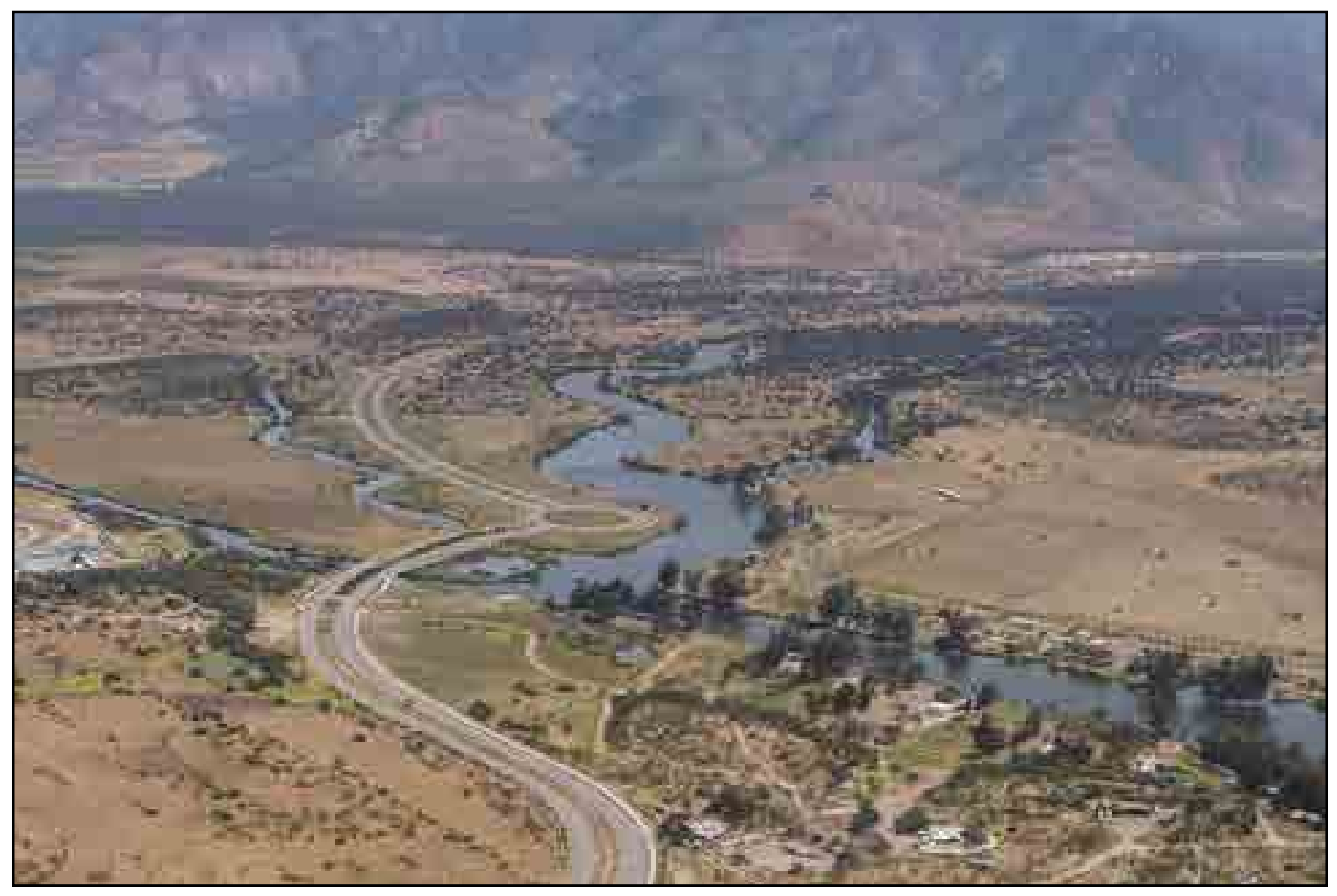

Figura 8.24. Vista de "la isla". Zona 10. Elaboración propia

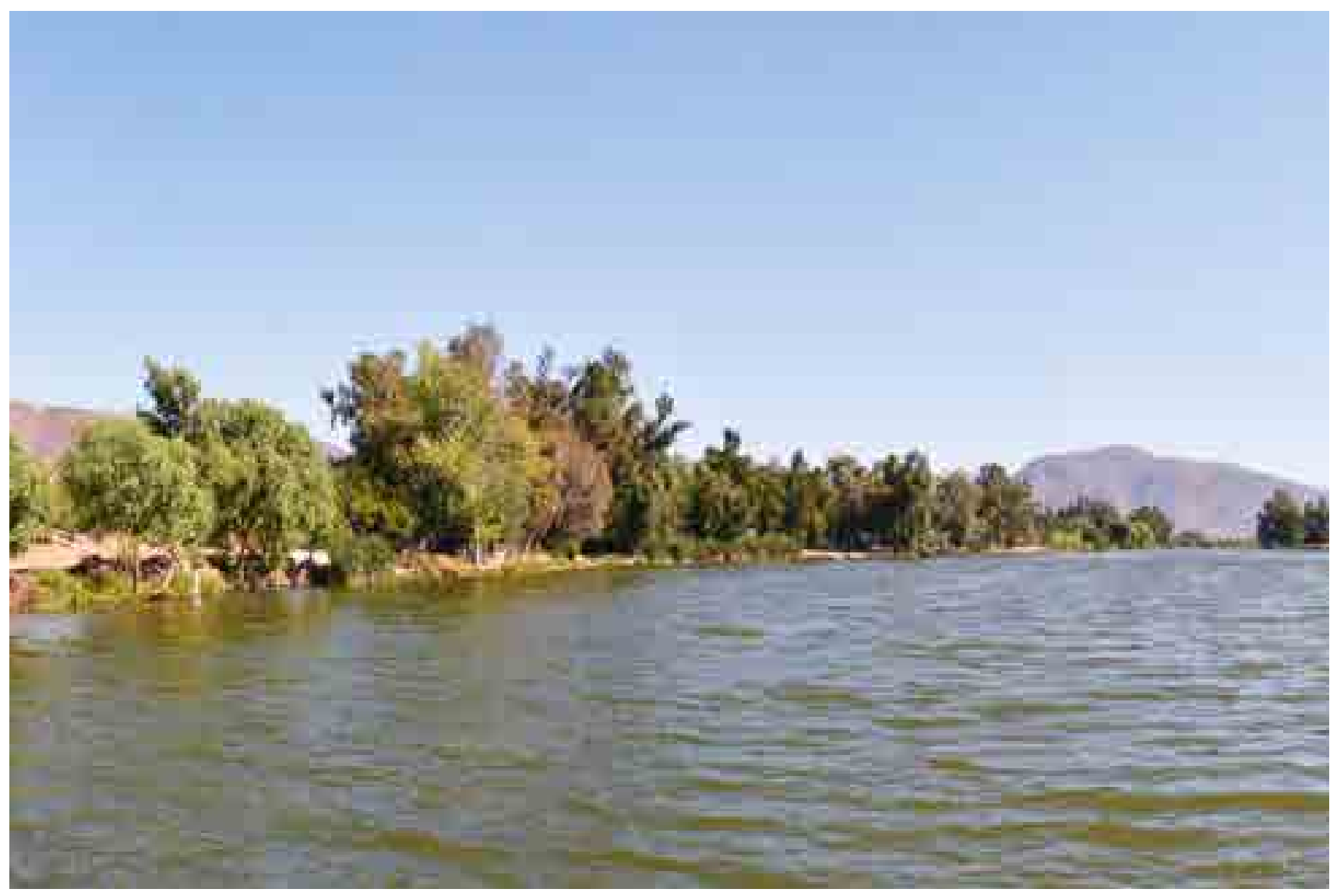

Figura 8.25. Vista de la laguna Carén. Zona 11. Elaboración propia 
de visión. Visualmente es la zona que posee más contrastes de color, sumado a efectos como el espejismo de los cielos sobre la superficie del agua, especialmente en las mañanas, cuando no hay viento y la laguna aparece como una placa quieta y brillante. En las tardes, cuando sale el viento, aparecen las olas, y la laguna se vuelve un plano rizado y en movimiento. Los bordes de la laguna están delineados por arbustos, y en el sector oriente, donde se encuentran los clubes de canotaje, se convierten en volúmenes verdes, donde los árboles que fortalecen el contraste y brindan un colorido más diverso al ocre predominante en el predio, especialmente al fin del otoño. Los suelos presentan a la vista una capa vegetal, casi permanentemente húmeda donde también se pueden observar insectos. El cuerpo de agua también tiene un efecto acústico, la sensación de estar en un interior, sin ruidos externos, sólo el eco de las aves y los sonidos próximos (Figura 8.25.).

\subsection{LEGIBILIDAD: CARÁCTER Y ESCALAS}

Dada la magnitud de terreno la legibilidad es un aspecto crucial, ya que no estamos perceptualmente condicionados para organizar los elementos del medioambiente a una escala tan vasta. Este fenómeno es abordado por Kevin Lynch, quien presenta como una de las nociones fundamentales de su investigación la "legibilidad del paisaje urbano", definiéndola como la "facilidad con que pueden reconocerse y organizarse sus partes en una pauta coherente" (1998, p. 59). Si bien, en nuestro caso, se trata de un espacio rural, sus consideraciones generales sobre la percepción son aplicables:

Nada se experimenta en sí mismo sino siempre en relación con sus contornos, con las secuencias de acontecimientos que llevan a ello y con el recuerdo de experiencias anteriores. Así establecemos vínculos con partes de la ciudad y su imagen está embebida de recuerdos y significados (Lynch, 1998, p. 9).

Es así, como este autor propone dividir la imagen ambiental en tres componentes: La "identidad", relacionada con la capacidad de identificar un objeto respecto a otros, la "estructura", referida a la relación entre objetos y de estos con el observador y el "significado" que trata sobre la relación práctica y emotiva del observador y el objeto (Lynch,1998, p. 17). Aclara, que, si bien esta división es funcional al análisis, en la realidad estos tres componentes aparecen simultáneamente. Lynch opta por trabajar fundamentalmente en identidad y estructura, bajo el supuesto que estas dimensiones facilitarán una representación clara, y que en conjunto son capaces de precisar y reforzar el significado del lugar.

necesitamos un medio que no sólo esté bien organizado, sino que asimismo sea poético y simbólico. El medio debe hablar de los individuos y su compleja sociedad, de sus aspiraciones y su tradición histórica, del marco natural y de las funciones y los movimientos complejos del mundo urbano. Pero la claridad de la estructura y la vividez de la identidad son los primeros pasos para el desarrollo de símbolos vigorosos (Lynch, 1998, p. 62).

La función clave de la Imagen ambiental sería la de facilitar la orientación y el movimiento, acciones que estarían en la base de cualquier asociación emotiva, actuando, además, como organizadora de las actividades en el espacio. La idea de una imagen continua, se lograría a través la articulación de elementos interdependientes, identificables por su forma y contexto. Como hemos visto en el capítulo 4, este autor propone para el ámbito urbano, cinco elementos: sendas, mojones, barrios, hitos y bordes. Los que, aplicados en la situación actual del predio, darían el siguiente esquema (Figura 8.26). 


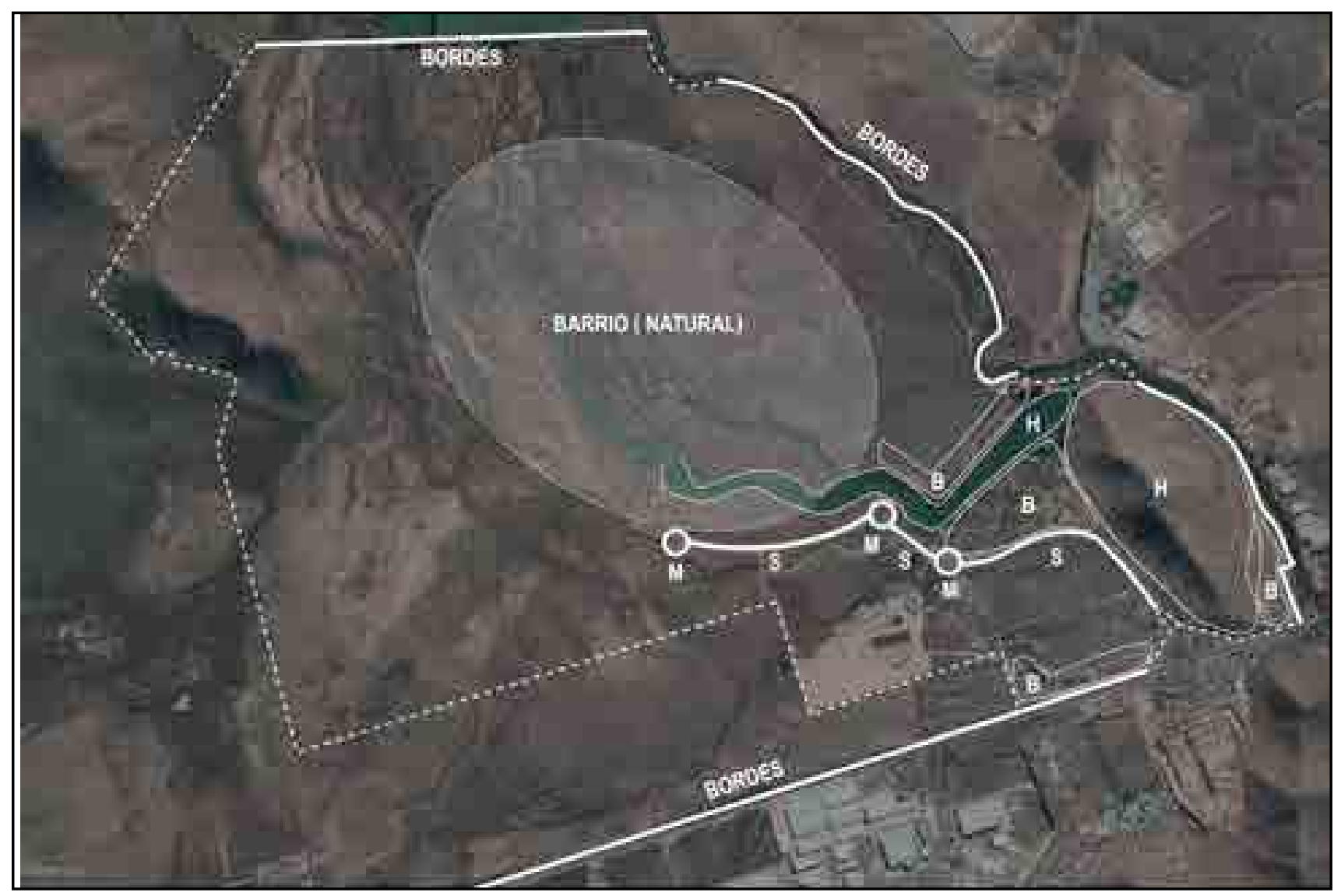

partir de la visión desde los cerros. Podemos corroborar que las zonas (barrios) son identificables tanto por su carácter como por sendas (transitables como visuales, en el caso de los cursos de agua) que ayudan a configurar sus límites 0 bordes. Las áreas ubicadas al norte (zona 1 y zona 8) no poseen "mojones" o elementos singulares que permitan la orientación a nivel de suelo. Sólo si se busca la referencia de hitos lejanos, como los cerros, es posible evitar la sensación de estar perdido. La falta de mojones también provoca que no se pueda estimar la distancia entre zonas.

Con respecto a los bordes, el único penetrable es en sur, por el acceso principal, sin embargo, los demás límites no tienen esa condición, sólo son deslindes, asunto que debe ser abordado en el proyecto, considerando la futura configuración de los predios vecinos.

Estas intervenciones deberían ser elaboradas siguiendo un "plan visual", como recomienda Lynch (1998, p. 142), que, considerando la forma actual que surge de este estudio, aplicará los mismos criterios para verificar la continuidad de la experiencia en el proyecto - para lograr una forma sensible- que controle lo vasto, incorporando, como plantea este autor, "una pauta compleja, continua y total [...], plástica para los hábitos de percepción de millares de ciudadanos, abierta para cambiar de función y significado, y receptiva para la formación de nuevas imágenes. Debe invitar a sus observadores a explorar el mundo" (Lynch, 1998, p. 146).

\subsection{CALIDAD VISUAL: BELLEZA Y SIGNIFICADO}

Si entramos en el difícil terreno de los significados, constatamos que los elementos materiales y sus representaciones no son suficientes para constituir paisaje. La dimensión estética: la experiencia de lo bello, lo sublime, lo pintoresco; es un fenómeno que el sujeto vive de acuerdo a valores propios, sentimientos y experiencias previas, difícilmente estandarizables. Uno de los mayores riesgos a este respecto, es imponer modelos de lo bello, externos al paisaje (real), recurrir a las "formulas probadas" bajo la visión del paisaje como objeto de consumo disponible para el mercado del turismo. Esta vía, compatible con la difusión del paisaje en los medios digitales, deriva en muchos casos, en Parques temáticos 0
Figura 8.26. Esquema con los elementos de Lynch aplicados al sitio de laguna Carén. Elaboración propia. 
en acciones de patrimonialización ${ }^{312}$ que sólo logran aislar el lugar de su contexto histórico y ecológico.

Perla Zusman nos advierte de este peligro citando a dos autores: "[los] paisajes definidos por Francesc Muñoz como en huelga y por Xerardo Estévez como sin-texto, parecerían interactuar poco con aquellos producidos en la vida cotidiana de las personas" (Zusman, 2009, p. 146). Esta reflexión, que tiene más carácter de exhortación que de análisis, nos obliga a recordar y registrar cuales son esos valores que hemos escuchado en los habitantes, como, por ejemplo, los que resuenan en los topónimos como Carén -siempre verde-, Pudahuel -y sus muchos posones-, "la nostalgia del campo", "lo abierto y amplio", "lo natural", deberían ser aquellos valores y cualidades que deberíamos preservar.

Si recurrimos al trabajo de Forman en Barcelona (2004), y consideramos que la calidad visual y estética, tiene importancia a largo plazo para una región, nos parece acertado rescatar que coincidentemente, "entre los recursos más valorados se cuentan: vistas panorámicas o perspectivas de extensas áreas, laderas y crestas sin desarrollo urbanístico" y seguir sus consejos, en cuanto "[...]En cada caso, siempre puede conjugarse un diseño apropiado con unas condiciones que favorezcan la fauna, el control de la erosión, las aguas limpias, y así sucesivamente"(Forman, 2004, p. 35).

\subsection{IMPORTANCIA Y FRAGILIDAD}

La calidad paisajística y visual, también la identidad del predio, está dada principalmente por la placa de agua, por las formaciones de cerros del terreno, por los lomajes a diversas alturas y por el fondo visual de los cerros del valle Lo Aguirre hacia el sur y el oeste y de la cordillera de Los Andes hacia el este.

De estos componentes, los cerros y los bordes de la laguna son los que presentan mayor fragilidad paisajística y visual. Los primeros, porque dada su altura, cualquier alteración o intervención es fácilmente percibida desde cualquier punto del predio y desde el exterior, requiriendo eventualmente una mayor inversión para mitigar el impacto visual de construcciones que se emplacen en ellos.

En cuanto a los bordes de la laguna, la fragilidad visual también está dada por su fácil percepción desde un amplio campo visual orientado hacia esos sectores. Si el proyecto quiere mantener el aspecto natural del predio, se debería reducir al mínimo las instalaciones en estos bordes.

Como hemos visto, existen tres zonas que, pese a la fuerte intervención antrópica, mantienen sistemas ecológicos más ricos, estos son los dos cerros y la laguna, incluidos los cursos de agua. Sin embargo, existe entre ellos una discontinuidad tanto ecológica como visual y funcional. Uno de los desafíos del proyecto, sería buscar el modo de conectar estas tres zonas, creando corredores que las conecten

${ }^{312}$ El concepto de paisaje ha sido incorporado como criterio de patrimonialización por parte de la UNESCO. Para este organismo internacional, el paisaje superaría las limitaciones de aquellos criterios que consideraban sólo objetos únicos y aislados (monumentos, sitios). La incorporación de la idea de paisaje dentro de dichos criterios busca dar cuenta de las relaciones entre los componentes naturales y culturales a lo largo del tiempo en los lugares. Cabe destacar que los procesos de patrimonialización de los paisajes, al igual que los procesos de patrimonialización en general, se han tornado en estrategias de legitimación (científico-cultural) para su transformación en atractivos turísticos (al respecto véase Bartoncello, Castro y Zusman, 2009)

Del mismo modo, podemos apreciar que las zonas más deterioradas y de menor calidad paisajística se encuentran hacia el sur, por lo que estas áreas serían las más apropiadas para incorporar funciones que requieran edificios. Esta es además la zona que ya está urbanizada, contando con todos los servicios básicos para emplazar allí las instalaciones necesarias para el proyecto. Esta recomendación es coherente con la que Forman (2004) expresa para el caso de Barcelona, a una escala mayor, por cierto:

Para la protección de los recursos naturales finitos, es importante la identificación de áreas potenciales para el crecimiento, la urbanización [...]en aquellos lugares en que los daños a los recursos naturales clave sean comparativamente bajos. Pequeños emplazamientos de actividad humana en su mayoría localizados cerca de las principales divisorias entre grandes usos del suelo (Forman, 2004, p. 36). 


\subsection{ALGUNAS RECOMENDACIONES DESDE EL PAISAJE}

El carácter de paisaje abierto y expuesto visualmente desde los puntos de altura de los alrededores, la actualmente deteriorada y limitada calidad de las intervenciones en contraste con la urbanización de alto estándar existente, las restricciones en la disponibilidad de aguas y las características del suelo deben ser consideradas en la planificación del uso que se puede dar a las distintas zonas, de tal modo de potenciar un mejoramiento ambiental global a partir del diseño de actividades adecuadas para cada una de ellas.

Así, por ejemplo, un plan de manejo de las áreas vegetacionales ya existentes, junto con nuevas plantaciones, podría enriquecer, tanto la cantidad como la calidad y variedad de la flora y la fauna nativa, tanto en los ambientes terrestres, como en los asociados a los cuerpos de agua, laguna y esteros.

El mejoramiento de la calidad de las aguas de los esteros y de la laguna es también necesaria para mejorar sus servicios ambientales y aumentar las actividades recreativas en ella.

Del mismo modo, el impacto visual y paisajístico que conlleve cada instalación o actividad dentro del predio, deben ser analizadas en el diseño de la totalidad de éste y considerar los efectos acumulativos de cada una de ellas.

Ante cualquier decisión de proyecto, junto a su calidad visual, debe verificarse si ésta responde a sus características ecológicas, a la historia que lo rodea y también a los riegos a los que está expuesto el sitio.

Si ampliamos la escala, vemos que el paisaje de los sectores aledaños (señalado en la descripción de los "Aspectos Visuales de los bordes y entorno") es variado. La imagen aérea presenta un lay out de los diversos paisajes, que incluye entre otros, las hijuelas productoras de hortalizas al norte del predio. Este encuentro entre actividades agrícolas y el parque, que claramente se visualiza desde esta perspectiva como un corte abrupto (Figura 8.27.), sugiere que este límite puede ser trabajado para conciliar el carácter rural, -el pattern de las hijuelas-, con el diseño propuesto, permitiendo que esta "mancha" penetre hacia el proyecto. Esta acción permitiría dar cabida a huertos familiares ${ }^{313}$, tan importantes en la vecina localidad de Noviciado. Su inclusión a una escala reducida en el proyecto, permitiría además reubicar a los actuales habitantes que ocupan las riberas del estero Lampa, sacarlos de una situación precaria y saldar al mismo tiempo, la deuda de tierras que quedaron pendientes con la Reforma Agraria (apartado 6.10, capítulo 6).

\subsection{A MODO DE CONCLUSIÓN}

Para finalizar, quisiera volver sobre la cita que abre este capítulo. Este fragmento que se encuentra en la introducción de la obra Tableau de la Geographie de la France (1908) del geógrafo Vidal de la Blanche, a quien hemos estudiado en el capitulo 4, expresa el sentido que esta sección tiene para la tesis. Al intentar la descripción de un territorio, quien escribe, revive una experiencia sensible que, aunque primaria (y a veces reiterativa) busca transmitir un sentido. El esfuerzo por ser "objetivo" asume que el paisaje es lo visible. En este ejercicio de escritura, el autor tiene la función de mediador entre la fisonomía y un lector; entre las características del territorio, las realidades objetivas que lo individualizan y lo identifican y un otro, que debe echar mano a sus experiencias pasadas, a su memoria e imaginación para construir una imagen. La narración es así un puente entre la memoria y la forma del paisaje.

Pero la realidad va más allá de la representación, y se presenta como un conjunto de signos que cuentan una historia, la que debe ser descifrada e interpretada. Lo humanizado, la historia que ha quedado plasmada en el territorio, sin envilecerlo, representa la postura ética de quien lo ha habitado sin rebasar los límites que la naturaleza le ha dictado. De este modo, la percepción es la puerta a un entendimiento más profundo, a la reflexión sobre el paisaje como efecto, como

${ }^{313}$ Los huertos familiares tienen importancia en la región y suministran una combinación de valores: producción de alimentos, interacciones sociales, y un vínculo con la naturaleza (suelo, agua, plantas, animales). (Forman, 2004) 
expresión evolutiva de un sistema de causas que también cambian en el tiempo. El observador-autor, queda así desenmascarado, porque la fisonomía también sugiere la transformación. En la mente del autor también está el proyecto.

Intenté revivir, en la parte descriptiva de este trabajo, una fisonomía que me pareció variada, amable y acogedora. Ojalá hubiera podido plasmar algo de las impresiones que he experimentado al recorrer en todas direcciones este territorio profundamente humanizado, pero no adulterado por las obras de la civilización. La mente es solicitada por la reflexión, pero es a la vista a veces risueña, a veces imponente, de estas campañas, estas montañas y estos mares que es constantemente devuelta como a una fuente de causas (Vidal de la Blanche, 1908, p. 2).

En la Figura 8.28 se indica en planta la posición de cada una de las fotografías de este capítulo.

Figura 8.27. Vista satelital del límite norte del predio, en su encuentro con las hijuelas de Noviciado. Se observa un corte abrupto (horizontal). Imagen capturada de Google Maps.

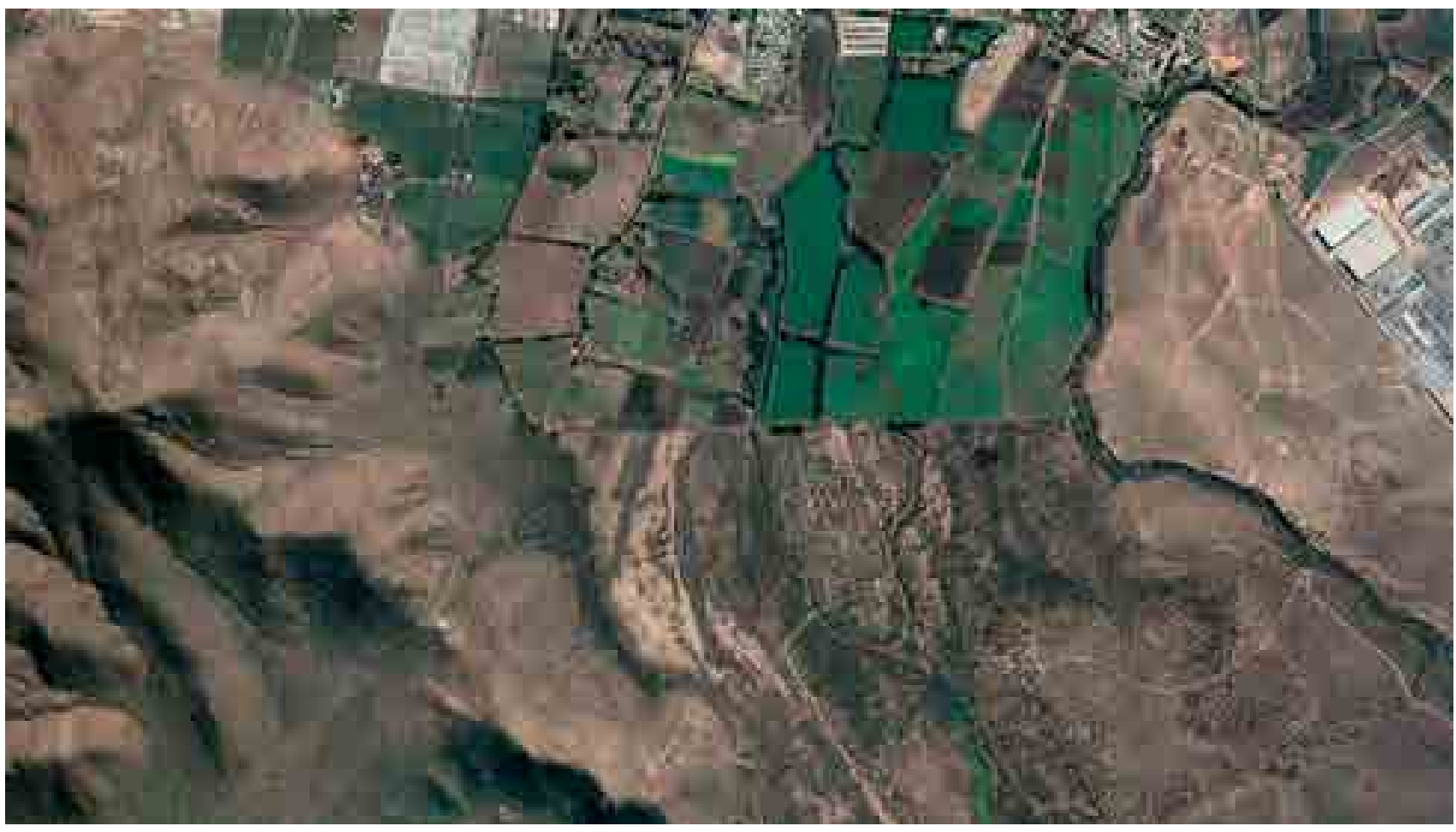




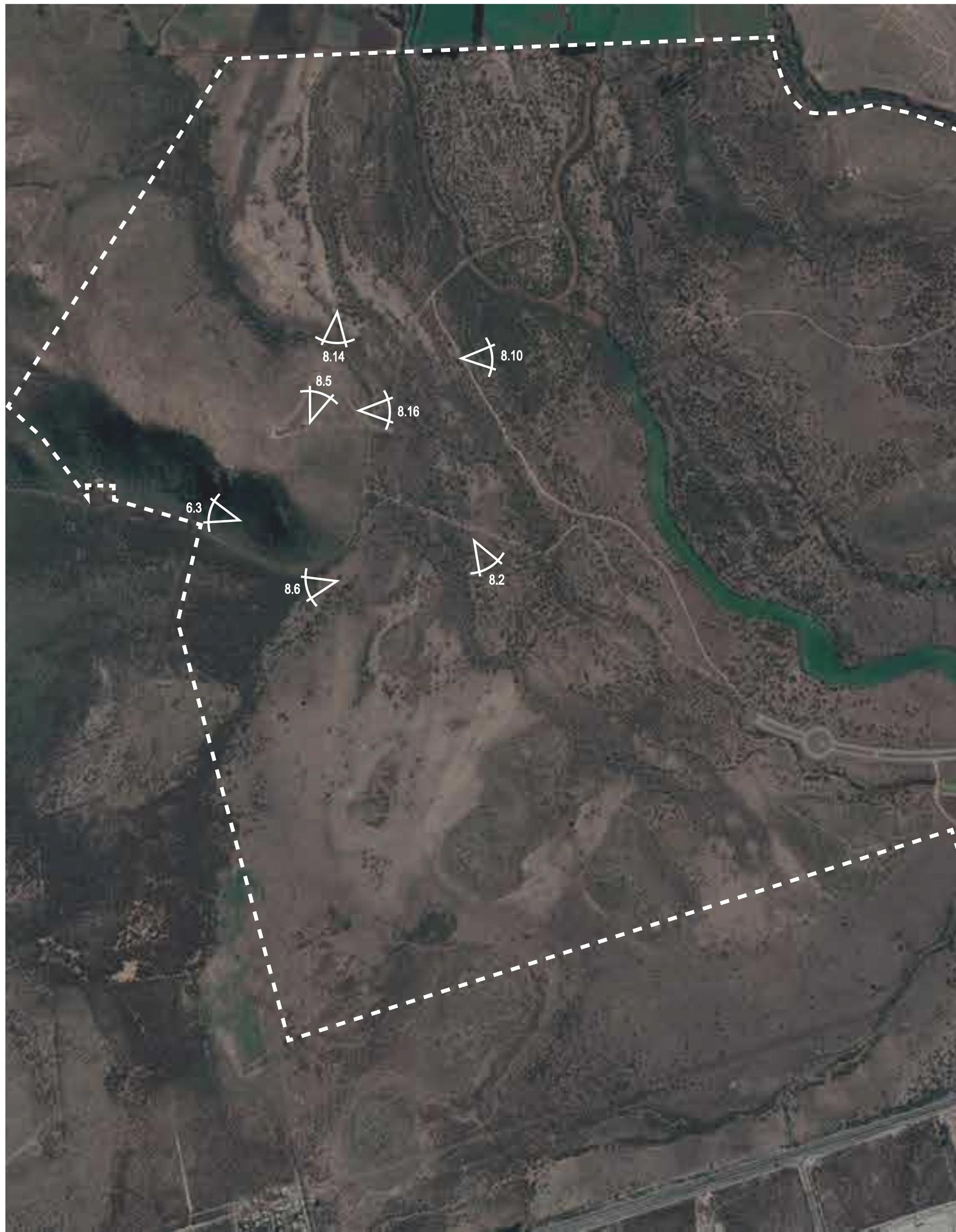




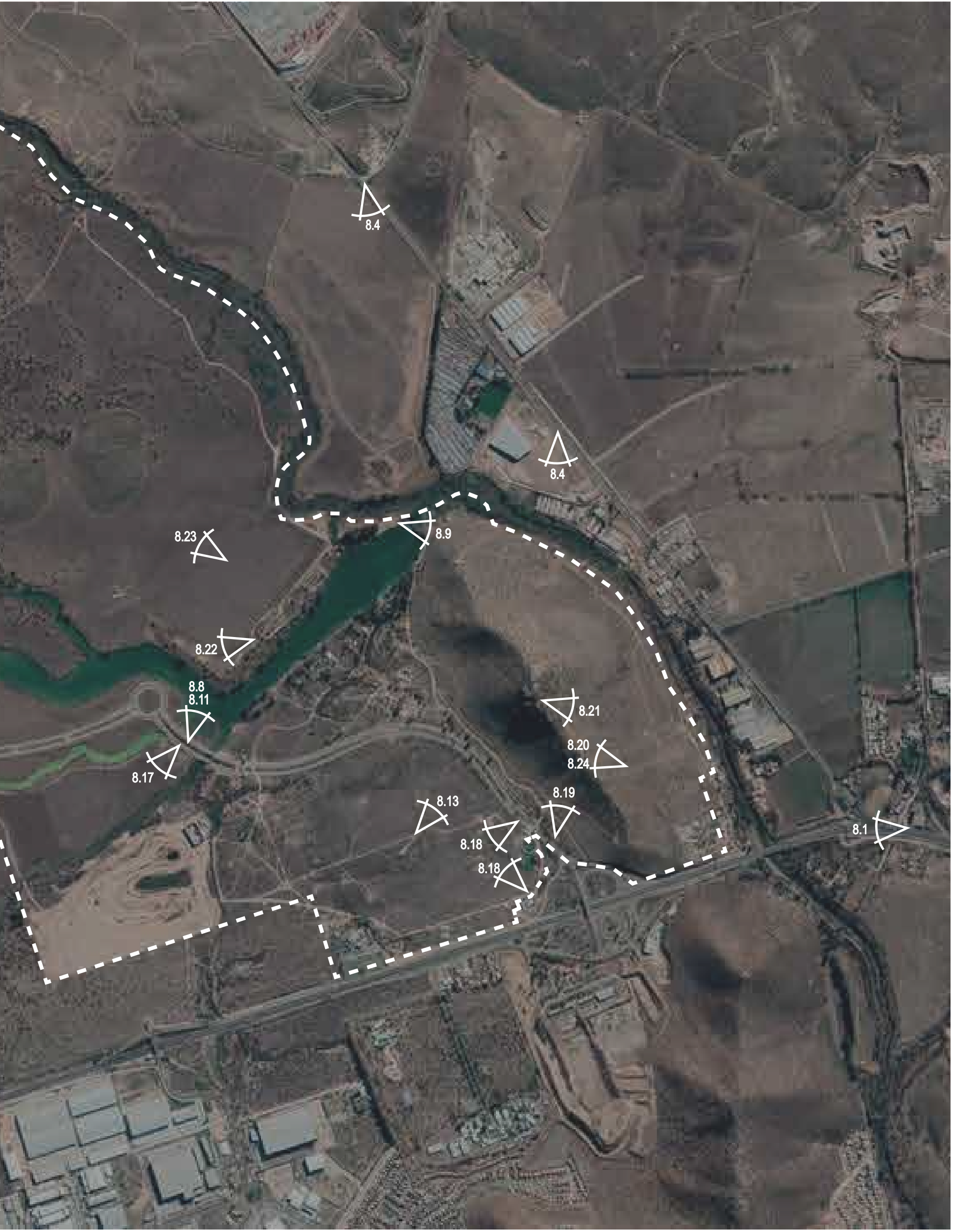




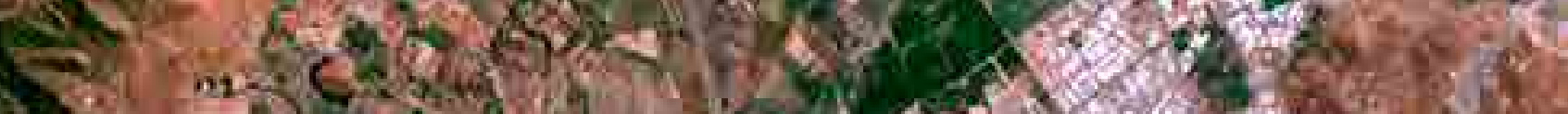

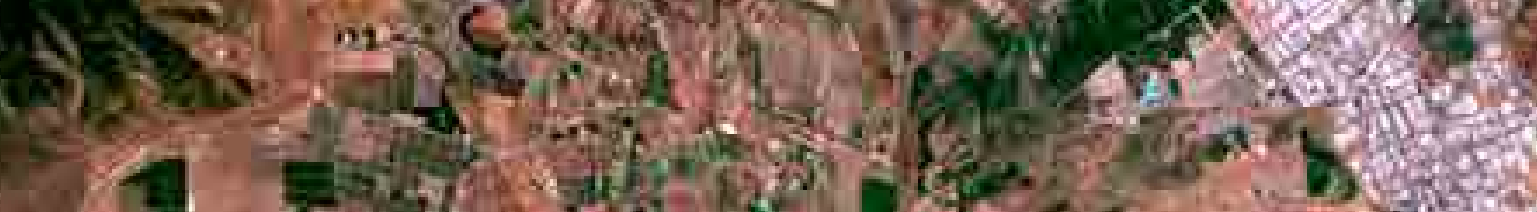

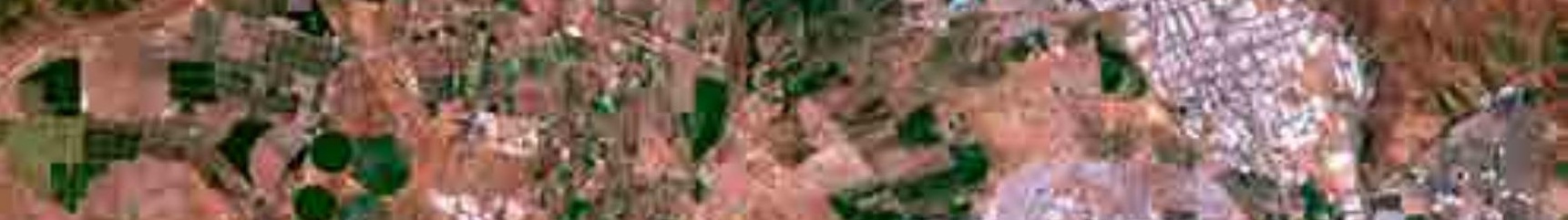

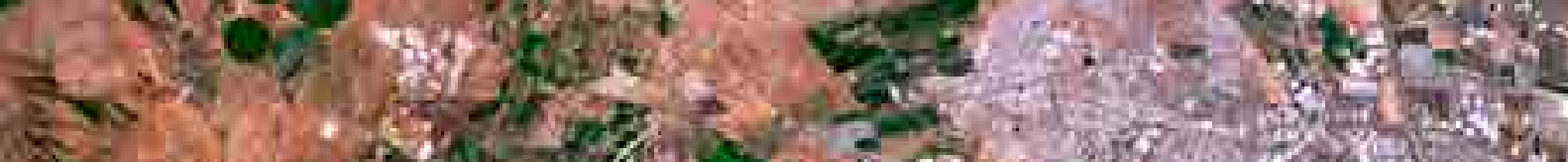

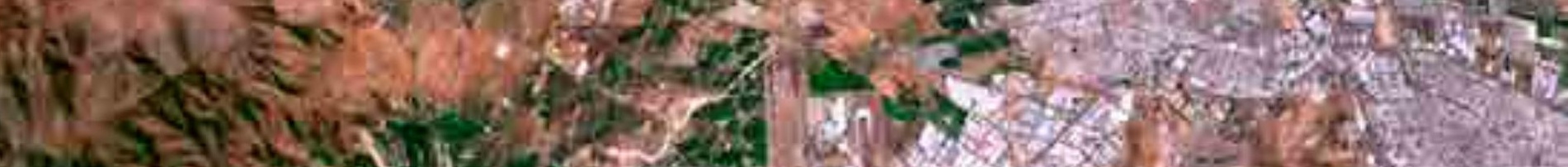
(4) T. S.

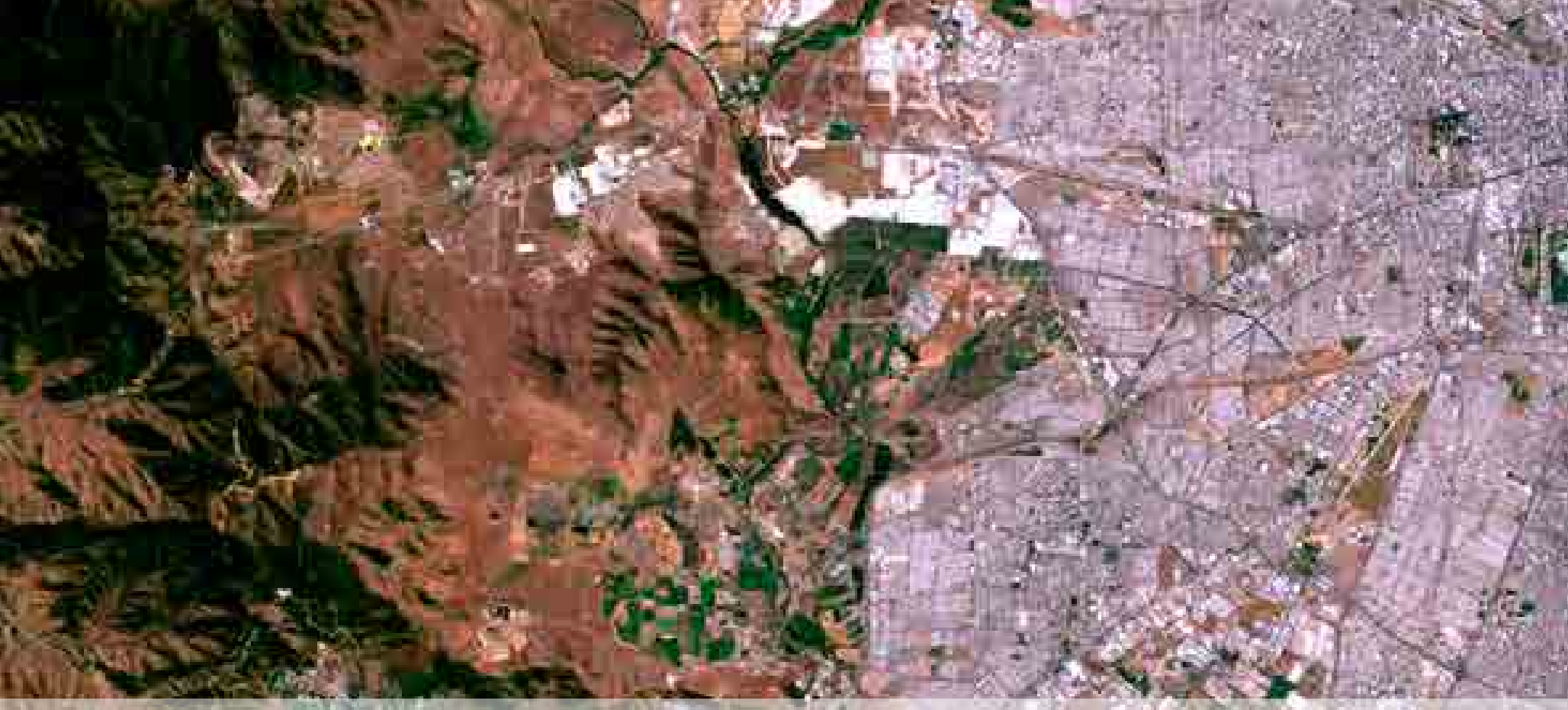

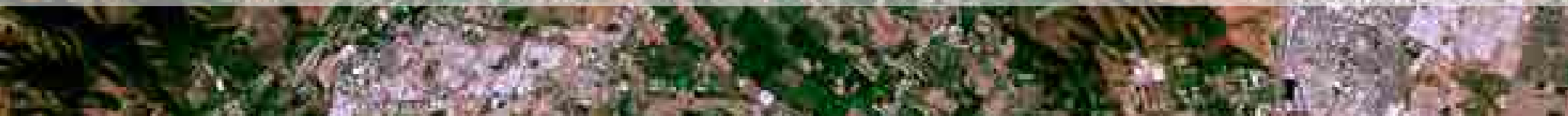

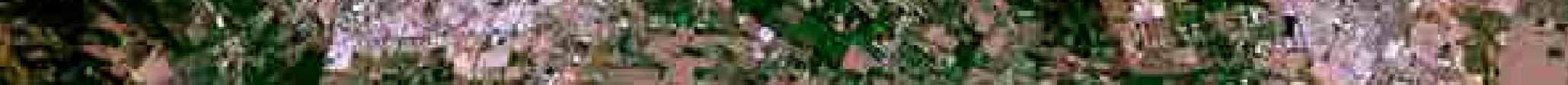

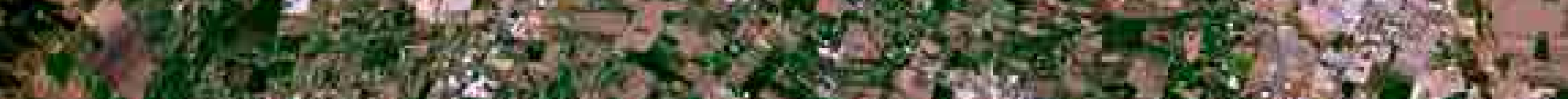

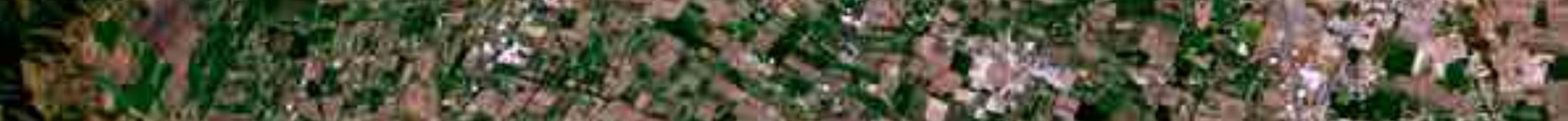

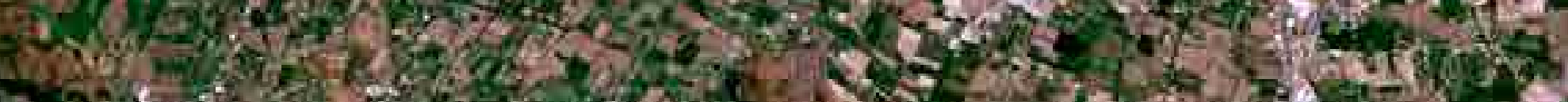

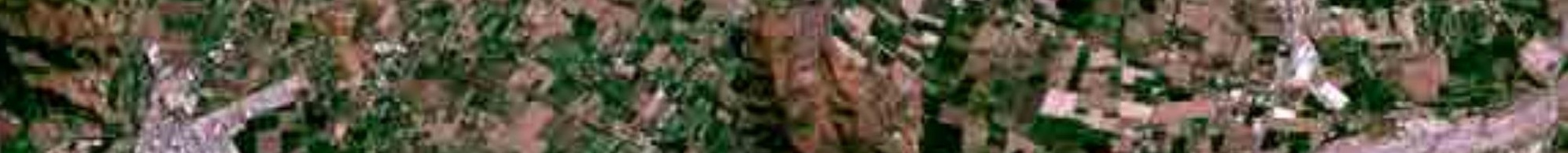
H. 



\section{MARCO NORMATIVO}

...hacia finales del siglo XIX, la expansión de la sociedad industrial dio lugar a una disciplina que se distinguió de las artes urbanas anteriores por su carácter reflexivo y crítico y su pretensión científica ${ }^{314}$ (Choay, 1965, p. 8).

\subsection{INTRODUCCIÓN: "PUESTA A TIERRA"}

La actuación en el territorio, exige como nos recuerda Françoise Choay, un trabajo reflexivo y crítico enmarcado dentro de la disciplina del urbanismo. Una disciplina que en su evolución ha creado instrumentos que ordenan y dan sentido a la relación entre la ciudad, en su constante expansión, y ese "otro" territorio que la rodea.

En este caso, resulta doblemente complejo comprender las posibilidades de desarrollo que este vasto predio posee. La normativa vigente ha experimentado en los últimos años una serie de cambios, que inducen a considerar "todo suelo como materia urbanizable" (Figueroa, 2011), por lo tanto, la interpretación de la norma requiere de un filtro ético autoimpuesto.

Recordemos que en el capítulo 2 ya nos habíamos referido a la dimensión ética del proyecto, aludiendo a aquellos imperativos que nos obligan a observar tanto los códigos que regulan el ejercicio profesional, como a las leyes, normas y ordenanzas que definen el marco de actuación en un territorio específico. Sin embargo, más allá de aquello que nos obliga, propusimos aplicar una ética dentro del proyecto, inspirada en la prudencia. La idea del Profesional Reflexivo de Donald Schön resitúa nuestro problema de investigación en relación a la práctica, a través del proyecto, cuando plantea que "la investigación es una actividad de los profesionales, desencadenada por los rasgos de la situación práctica, acometida en el acto e inmediatamente vinculada a la acción. El intercambio entre práctica e investigación es inmediato, la reflexión en la acción es su propia implementación" (Schön, 1998: 34).

El marco normativo será la materia de investigación en este capítulo, que, si bien es árido, representa un proceso de reflexión en la acción, un trabajo reflexivo respecto a la situación-problema concreta que se nos presenta. Teniendo en frente la normativa nos preguntamos primero ¿qué es lo que se puede hacer? para luego definir qué es lo que se debe hacer. Entender qué fuerzas actúan en el lugar y cómo el Estado, a través de sus normas y planes expresan lo que la ciudad y un lugar en específico quiere ser.

Para ello, pondremos en contexto la evolución de la normativa que impera en el territorio de la Región Metropolitana de Santiago, para luego analizar la reglamentación que rige el predio y plantear algunos escenarios bajo los cuales el parque de laguna Carén puede consolidarse, vale decir, los principios de posibilidad para un plan maestro en este vasto territorio signado por la incertidumbre, pero también con el potencial de ser un aporte a la ciudad.

\subsection{DESDE EL PLAN DE TRANSFORMACIÓN DE SANTIAGO AL PRMS-100}

En gran medida, la forma de Santiago y el control de su expansión obedecen al primer acto de planificación de inspiración científica, higienista y sobre todo estética del Plan de Transformación impulsado por Benjamín Vicuña Mackenna en su intendencia, que abarcó el breve período entre 1872 y 1875. La remodelación propuesta tenía la intención de convertir Santiago en la "París en América" (Martínez, 2007, p. 77), a través de un plan de hermoseamiento que contemplaba la creación de áreas verdes, la pavimentación y el alumbrado de las calles, la creación del parque Cousiño (que hemos revisado en el capítulo 5) y del cerro Santa Lucía. Junto a estas obras de modernización se trazaría el "camino de cintura", un anillo de circunvalación que definía lo urbano de lo rural, lo culto y lo salvaje, ya que como plantea Alfredo Palacios, esta demarcación "se convertiría en una especie de barrera, tanto social como sanitaria, ya que la plantación de árboles de gran altura sería una especie de tamiz contra las pestilencias, vicios y desordenes propios de la gente de clase popular y de los arrabales" (Palacios, 2010, p. 11).
314 Traducción propia de texto original de Françoise Choay: "vers la fin du XIXe siècle, l'expansion de la société industrielle donne naissance à une discipline qui se distingue des arts urbains antérieurs par son caractèreréflexif et critique et par sa prétention scientifique" (1965, p. 8). 
Haciendo gala de los avances en las técnicas de representación científica del territorio, el ingeniero francés Ernesto Ansart ${ }^{315}$, sellará el plan en 1875 en un plano que extrañamente tiene el norte hacia abajo (Figura 9.1). De este modo la cartografía científica, el estilo arquitectónico afrancesado, los parques y el ornato del espacio urbano, serán estrategias que el poder político usa para abrir un nuevo ámbito económico para las élites: la propia ciudad y su suelo. Mientras Ansart delineaba su plano, se realiza el censo de 1875 publicado bajo la dirección de Francisco Solano, y aparece el libro Geografia Física de la República de Chile de Armando Pissis. Tres novedades científicas de gran impacto en la época.

Es este impulso modernizador, el que inspirará una serie de reformas urbanas con motivo de la celebración del Centenario de la Independencia (1910). El discurso político republicano- liberal integrará gradualmente el tema de la ciudad, "la planificación urbana se presenta paulatinamente como un "método científico" y una racionalización disciplinaria que lentamente adquiere un status significativo como paradigma transformador del espacio urbano" (Fernández Domingo, 2014, p. 3) amparado por el poder del estado.

La transformación de aldea a ciudad, puso de manifiesto una tensión que se hará constante, entre un modelo compacto y otro que no tiene límites, a la par con el explosivo crecimiento demográfico (Tabla 9.1.).

Si en 1875 la ciudad tenía 129.807 habitantes, en poco más de 30 años ya alcanzaba 332.724 habitantes (1907), vale decir un $257 \%$ de crecimiento. El centenario se encuentra con una ciudad que hoy llamaríamos intermedia, similar a la Alicante (España) que tiene 336577 habitantes actualmente ${ }^{316}$. El plano de la

315 Junto con el ingeniero Ernesto Ansart, se formaron comités de trabajo integrados por técnicos, autoridades y miembros de las élites santiaguinas (Fernández Domingo, 2014, p. 4).

${ }^{316}$ Cifras oficiales de población resultantes de la revisión del Padrón municipal al 1 de enero de 2018. Disponible en línea en: https://es.wikipedia.org/wiki/Anexo:Capitales_de_provincia_de_Espa $\%$ C3\%B1a_por_poblaci\%C3\%B3n

Figura 9.1. Plano de Santiago de Ernesto Ansart que plasma el Plan de Transformación de Santiago impulsado por Benja-mín Vicuña Mackenna. Archivo Fotográfico de Carlos Maillet.

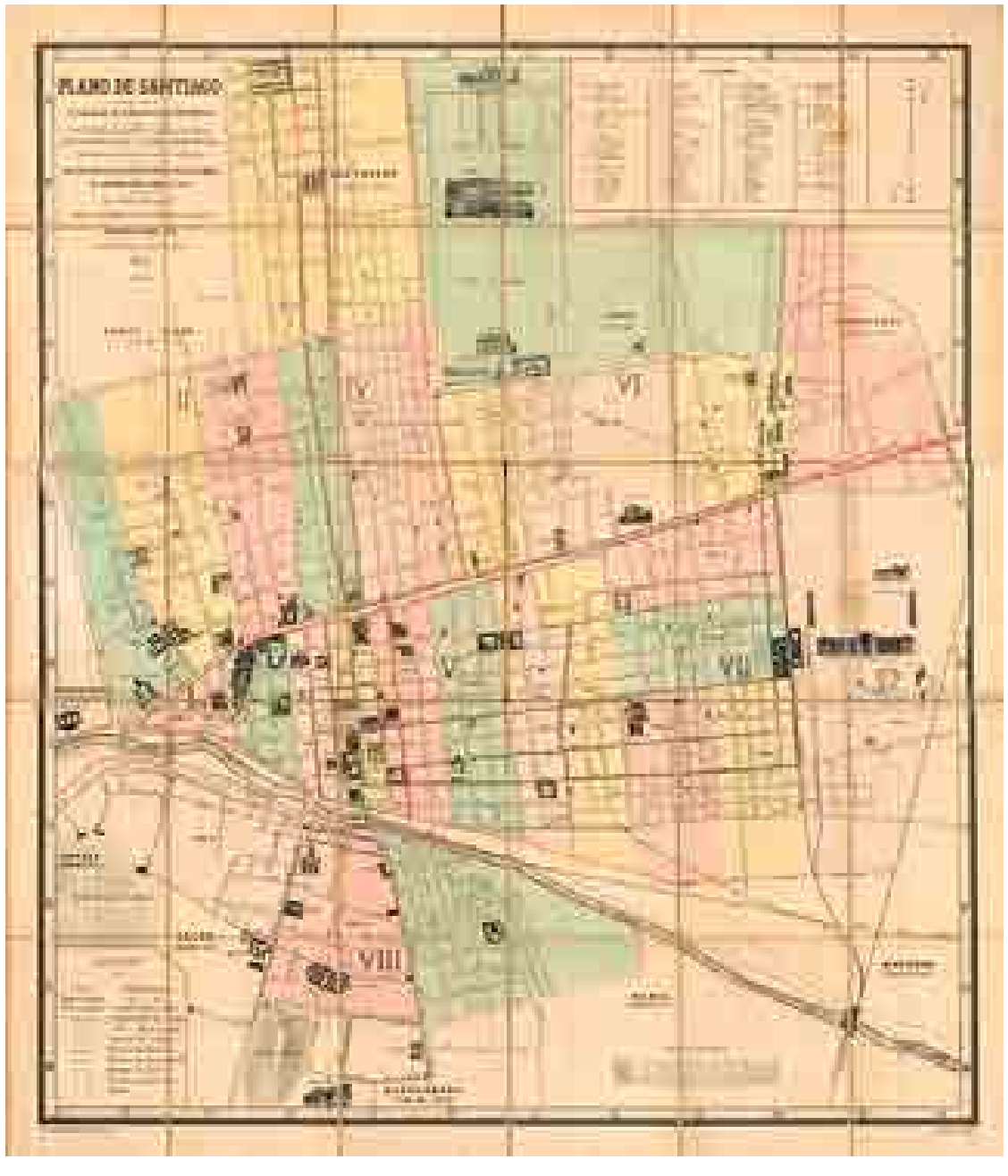




\begin{tabular}{|c|c|c|c|c|c|c|}
\hline A. & \multicolumn{2}{|c|}{ HABTRANTES } & 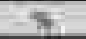 & POSLACIOU & MANCKA & MOEM \\
\hline CENSO & SANTUMO & Chile & & UABANA & UHENNA & wothing \\
\hline 3875 & $122 \mathrm{ag}$ & 2.084 tod & 6.29 & $30.8 \%$ & 10 & \\
\hline $190 \%$. & 312.724 & 3.231 .022 & $10.5 \mathrm{~N}$ & & 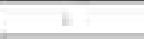 & \\
\hline 1920 & 507296 & 3.730 .235 & 13.65 & & $=$ & \\
\hline 1930 & 722.533 & 4.287 .455 & $16.6 \mathrm{~V}$ & & 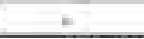 & \\
\hline 1910 & 952.072 & 5.023 .539 & $19.0 \mathrm{~N}$ & & 11.348 & PLAN BRUNNEA \\
\hline 1952 & 1.750409 & 5,932995 & 22.06 & & 15.570 & FUAN BAONNER \\
\hline 1960 & 1.507378 & 7.374 .115 & 25,97 & & 22830 & PKIS-1960 \\
\hline 1970 & 2.715 .216 & 8.880 .768 & $90.6 x$ & & $29 . A 80$ & PRis-1960 \\
\hline $10 \% 2$ & 3.694 .239 & 11.329736 & 32.65 & & 38364 & $054>01979$ \\
\hline 1992. & 4.311 .133 & 13.231 .803 & $32.6 \mathrm{~K}$ & & 49.347 & 0531-1485 \\
\hline 2002 & 6051185 & 15.116. 435 & $+0,1<$ & & 65. 1401 & pnows 190? \\
\hline 2011 & 2.007 .620 & $17,399.632$ & 4035 & & 173,272 & PRMT-100 \\
\hline 2017 & 7.112 .808 & 12.574 .003 & $20,5 \%$ & $87.8 \%$ & 133.506 & PAMS-100-2053 \\
\hline
\end{tabular}

ciudad de Santiago de 1910 (Figura 9.3.) muestra la extensión de la trama hasta los dos parques que hemos analizado: la Quinta Normal, a la izquierda de la imagen, y el Parque Cousiño en el límite inferior.

La década de 1930 el estado chileno emprende otro proceso de planificación que se hace cargo de las necesidades acuciosas de vivienda y ordenamiento. La población en el censo de 1930 había alcanzado los 712.533 habitantes, un poco menor a la población que actualmente tiene Valencia. Impulsado por un comité que se conforma en 1929, continuado con Karl Brünner ${ }^{317}$ que emite el Plan de urbanización para la Comuna de Santiago en 1934, seguido por Carlos Muñoz Maluschka que hace el estudio regulador de 1936, y finalmente, plasmado en el Plano oficial de la Urbanización dela Comuna de Santiago de 1939 de Roberto Humeres ${ }^{318}$ que se muestra en la Figura 9.3. (Rosas et al., 2015).

Si bien, Brünner entiende la ciudad como "un organismo sintético único" (Brünner, 1932, p. 85)., que concilia varias escalas, desde los grandes ejes urbanos a la acupuntura vial que se muestra valorizada en el plano, la evolución de la ciudad romperá los limites dispuestos en el Plan de 1939.

La expansión de la ciudad se produjo en evidentemente sobre los suelos agrícolas circundantes y en la segunda parte del siglo XX, especialmente hacia el oriente. Los sectores "altos" representarán mejores condiciones ambientales y de calidad de vida e, impensablemente también más riesgos (Ferrando, 2008).

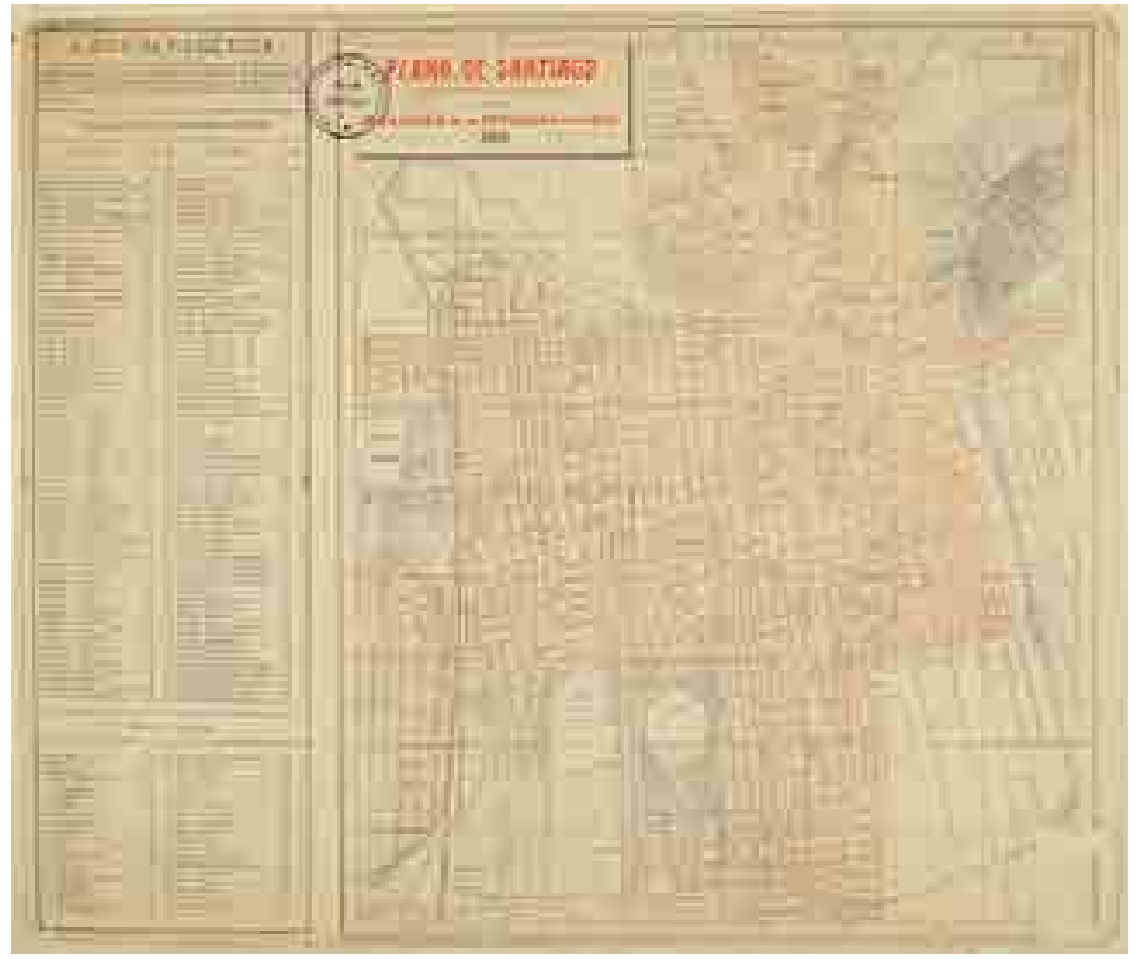

Tabla 9.1. Población de Santiago entre los censos de 1875 y 2017, extensión de la mancha urbana y normas asociadas.

Elaboración propia en base a los siguientes informes: a. para los años 1875-1952: XII Censo General de Población i Vivien-da: Levantado el 24 de abril de 1952(años 1875-1952); b. para el año 1960: Población del País (Censo 1960); c. para los años 1970 y 1982: Censos 1970-1982-Cifras comparativas; Para el año 1992: Resultados oficiales Censo de población 1992; para 2002: Censo2002_Resultados_v1; para 2012: Resultados comunales en Biblioteca del Congreso Nacional; para el año 2017 y cifras de población urbana: en información en línea del INE-Chile. http:// resultados.censo2017.cl/.

${ }^{317}$ Karl Brunner fue contratado por el estado chileno para realizar un estudio general de la ciudad de Santiago y dictar un seminario de Urbanismo en la Universidad de Chile. Su trabajo se desarrolló en dos estadías, una entre 1929-1932, y otra en 1934, año en que emite el Plan de Urbanización para la comuna de Santiago (Rosas et al. 2015).

${ }^{318}$ Arquitecto funcionario de la llustre Municipalidad de Santiago.

Figura 9.2. Plano de Santiago de 1910. En Colecciones Biblioteca Nacional de Chile, Archivo visual. 
Figura 9.3. Plano Oficial de Urbanización de la Comuna de Santiago - 1939. En Rosas et al., 2015, p. 8.

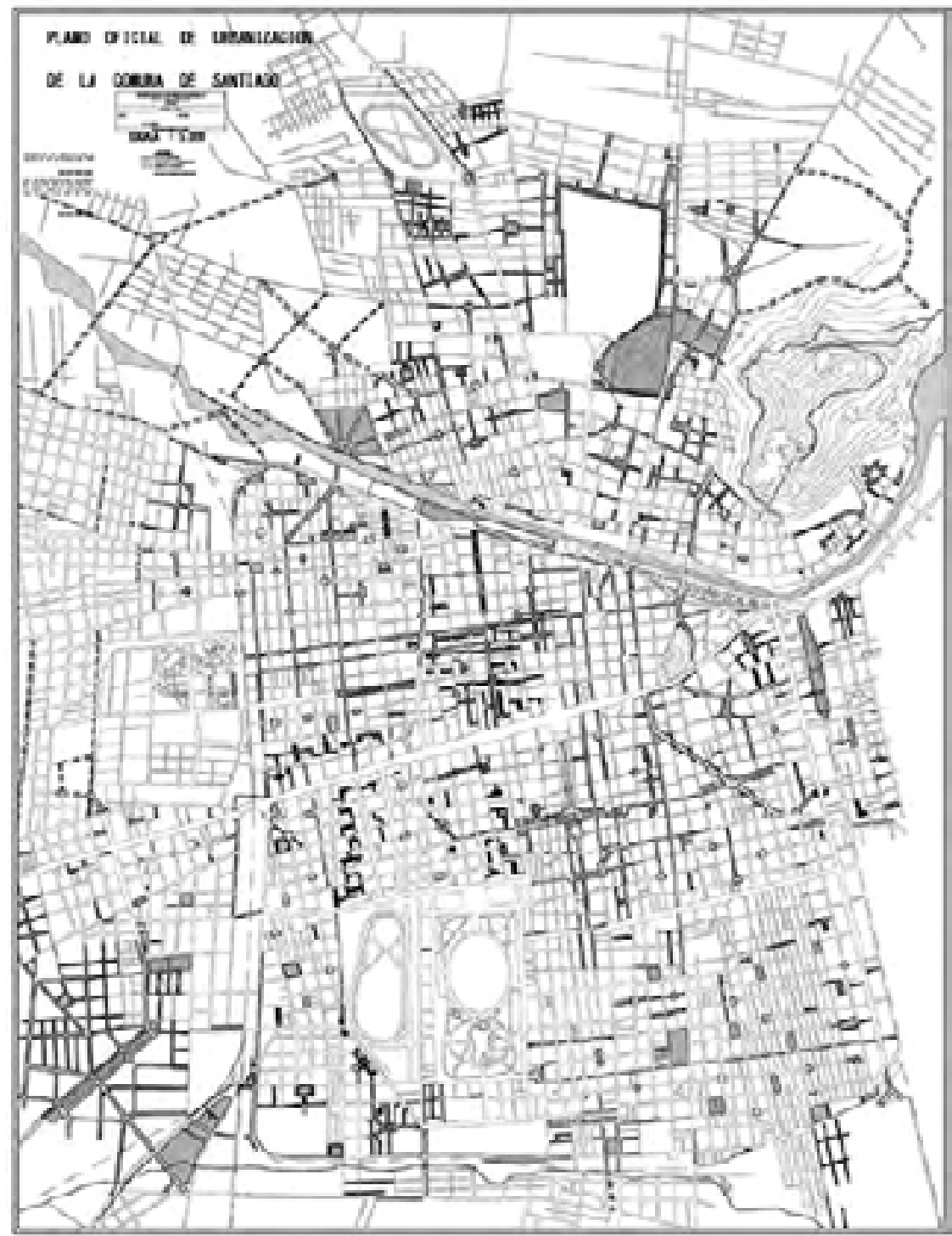

El instrumento que intentará controlar el crecimiento de la mancha urbana se gesta junto con la creación de la Corporación de Vivienda (CORVI) y el texto definitivo de la Ley de Construcciones Y Urbanización ${ }^{319}$ en 1953. Sin embargo, el Plan Regulador Intercomunal de Santiago (PRIS), demorará casi siete años en entrar en vigencia. EI PRIS de 1960 innova, ampliando la escala, para dar paso a la planificación urbano-regional.

Junto al Plano Intercomunal (Figura 9.4.) se traza el Plano Micro-Regional en 1964(Figura 9.5.), donde por primera vez vemos aparecer la zona donde se ubica Carén.

El PRIS de 1960 intenta regular la expansión de Santiago a través de un anillo periurbano que resguarda los servicios ambientales a escala metropolitana, tales como las grandes áreas verdes, las reservas naturales y el suelo agrícola; así como la zonificación de áreas industriales y de equipamiento (Gámez, 2003, p. 5). Puede observarse la valorización gráfica de vías troncales y secundarias de transporte, lo que demuestra la relevancia que empieza a cobrar la vialidad en la planificación, en coherencia con el aumento de población que la ciudad experimenta, sobrepasando en el decenio 1960-1970, los 2 millones de personas. De acuerdo al análisis que hace Vicente Gámez (2003) del PRIS y del Plan Micro-Regional, aparece por primera vez la regulación del paisaje natural de la periferia urbana:

Con la aprobación del Plan Regulador Intercomunal de Santiago (PRIS, 1960) se incorpora una incipiente noción de espacios abiertos, como recurso especial de uso del suelo a escala metropolitana: es así que se introducen conceptos
${ }^{319}$ Decreto con Fuerza de Ley 224: Fecha Publicación: 05-AGO-1953: Fecha Promulgación: 22-JUN-1953 


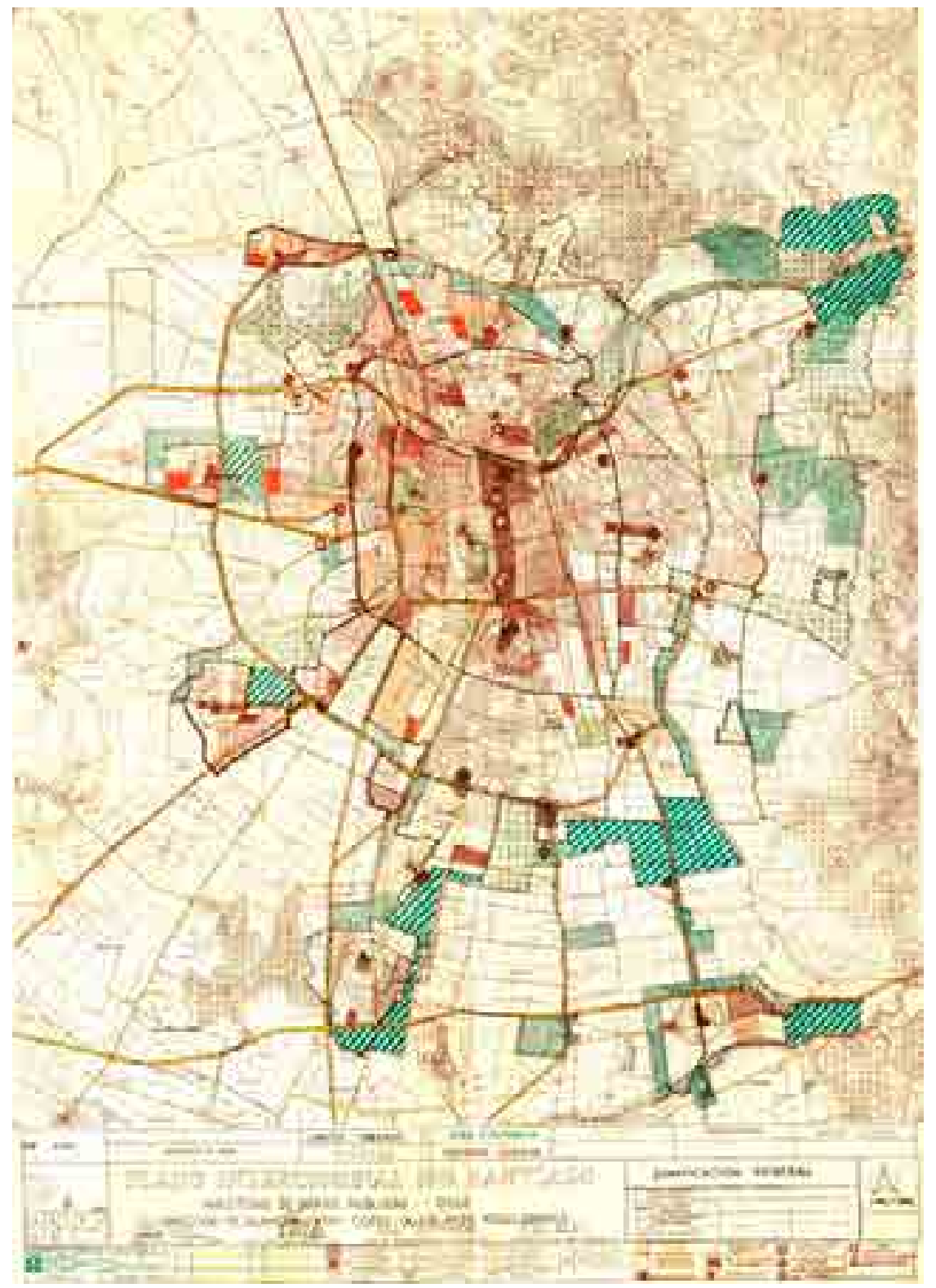

como los de "área suburbana" y "áreas verdes intercomunales", con contenidos básicos en el plan, de acuerdo a referentes teóricos e ideológicos de la práctica urbanística de esa época. Por otro lado, la propuesta paralela de un Plan Micro-regional para la cuenca de Santiago (1964), incorpora la noción de regulación del paisaje natural en la periferia amenazada por la expansión urbana y la influencia inmediata de la metrópolis en su cinturón agrícola, mediante categorías de uso del suelo que hacen referencia a los recursos agrícolas y naturales, las que sólo tendrán un valor indicativo, puesto que el "plan micro-regional" no llega a tener el status legal con que fue aprobado el Plan Intercomunal de Santiago (Gámez, 2003, p. 3).

Pese a la contención propuesta en el PRIS de 1960, la mancha urbana se triplicará respecto al Plan Brünner, pasando de 11.348 hectáreas en 1940 a 29.480 hectáreas en 1970. Este crecimiento explosivo es sincrónico con las migraciones campo-ciudad, especialmente en el período 1940-1960 (Hurtado, 1996).

Cabe destacar que, pese a la derrota del plan de 1960, la Ley de Construcciones y Urbanización de 1953, que regirá hasta 1976, defendía principios sociales y estéticos de la planificación territorial, lo que se expresa en los artículos siguientes: Artículo 8: Se entenderá por Plano Regulador Intercomunal a aquel que de acuerdo con el Plano Regional, organiza la vida colectiva en las comunas del país y en el cual se ordenan armónicamente las viviendas el trabajo, el esparcimiento, el transporte y la movilización.

Artículo 90: Se entenderá por Plano Regulador Comunal a aquel que de acuerdo con el Plano Regulador Intercomunal, ordena y da normas sobre obliga-
Figura 9.4. Plano Intercomunal de Santiago (1960). CHILE - MOP, Dir. Planeamiento, Depto. Planos Reguladores, firmado por Director Ing. J. Kelemen. Escala original 1:20.000. En Pavez, 2011, p. 64. 
ciones, prohibiciones y disposiciones del uso del suelo y de la edificación en la comuna, con el objeto de dar a la población las máximas condiciones de higiene, de seguridad, de comodidad y de estética. (DFL No224) ${ }^{320}$

Esta ley será derogada en $1976^{321}$ por la Ley General de Urbanismo y Construcciones que establece en su artículo $27^{\circ}$, un sentido muy distinto:

Se entenderá por Planificación Urbana, para los efectos de la presente ley, el proceso que se efectúa para orientar y regular el desarrollo de los centros urbanos en función de una política nacional, regional y comunal de desarrollo socio-económico. (DFL No 458, título II, Cap. I, artículo 27²)

De este modo, el desarrollo socioeconómico, será el motor de los siguientes actos de planificación a partir de la dictadura y la imposición del modelo neoliberal. Los terrenos rurales dentro de esta nueva racionalidad, serán considerados subordinados con respecto a las áreas urbanas, como espacios residuales y de reserva urbana (Jiménez, 2018, p. 40). Este espíritu se desprende de los artículos $34^{\circ}$ y $163^{\circ}$ de la misma ley (DFL No 458 ):

Artículo $34^{\circ}$ : Se entenderá por Planificación Urbana Intercomunal aquella que regula el desarrollo fisico de las áreas urbanas y rurales de diversas comunas que, por sus relaciones, se integran en una unidad urbana. (DFL №458)

Artículo $163^{\circ}$ : La vivienda económica podrá emplazarse en cualquier zona habitacional del área urbana. También podrá emplazarse en sectores rurales, siempre que ellas se destinen a habitaciones que complementen actividades

320 https://www.leychile.cl/Navegar?idNorma $=5107 \#$ franja0

321 Fecha Publicación: 13-ABR-1976. Fecha Promulgación: 18-DIC-1975

Figura 9.5. Plano Micro -Regional- región IVB-Santiago- Chile (1964). CHILE - M.O.P., Dir. Arquitectura, D. Urbanismo y Vivienda, S. Planes Intercomunales: Firmado por Director de Arquitectura Edwin Weil W. Reducción de escala original 1:100.000. En Pavez, 2011, p. 65.

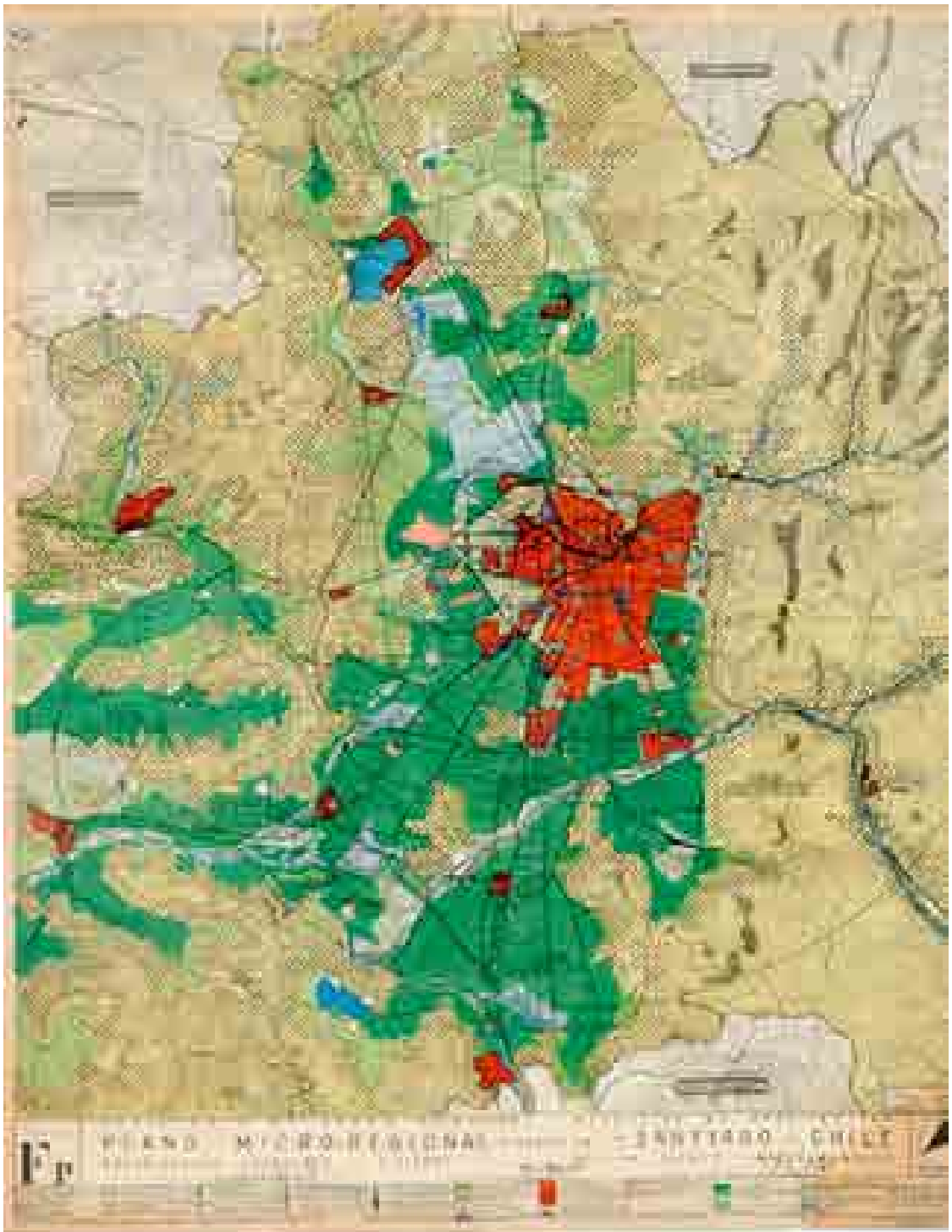


agrícolas, industriales, mineras o pesqueras, en cuyo caso se requerirá la autorización previa de la Secretaría Regional correspondiente del Ministerio de la Vivienda y Urbanismo.

Los propietarios de predios agrícolas requerirán solamente del respectivo permiso municipal para la construcción de su propia vivienda económica. (DFL No458).

La insipiente incorporación de criterios ecológicos a la planificación urbana, se anulará a partir de la nueva legislación, con la "desregulación total del uso del territorio, bajo una política basada en la libre operación del mercado inmobiliario" (Picón et al., 2017, p. 11). Esta desregulación se concreta con la Política Nacional de Desarrollo Urbano (PNDU) de 1979, que declara al suelo urbano como un bien no-escaso, por lo tanto, sometido al libre mercado, con la consiguiente expansión de la ciudad sobre suelos agrícolas. De este modo el Estado Planificador (19291979) se eclipsa, después de 50 años de acción en la ciudad (Ferrando, 2008, p. 5), formalizando la expansión que de modo irregular se había producido en las periferias de Santiago.

Tras la vuelta a la democracia en 1990, se hace el primer Catastro de Áreas Verdes del Área Intercomunal de Santiago (MINVU, 1992), que da como resultado un total de 2,16 $\mathrm{m}^{2}$ de áreas verdes públicas por habitante ${ }^{322}$ (CEC-PPR, 1992), y de $3,57 \mathrm{~m}^{2} /$ hab., si se suman las áreas privadas. Este estudio sirve de base al nuevo Plan Regulador Metropolitano de Santiago de 1994 (PRMS), que incorpora la reserva de áreas verdes públicas. Sin embargo, mantendrá la impronta neoliberal, considerando el suelo como un bien de consumo, al reemplazar el término sub-urbano por el de expansión urbana, limitada sólo por las áreas de "restricción":

Es así como desde 1994, el Plano Regulador Metropolitano de Santiago regulará la zona metropolitana con un horizonte de 30 años, que será modificado en 1997, al ampliar el área planificada, incluyendo las comunas de Colina, Lampa y Til Til; y luego en 2006 extendiéndose a todas las comunas de la Región Metropolitana. Pese a esta ampliación de los alcances de este instrumento, los límites urbanos de la ciudad de Santiago se mantuvieron, ocupando las zonas "potencialmente urbanizables". Como veremos más adelante, los agentes inmobiliarios usarán tres resquicios para urbanizar fuera de los límites. Este hecho, forzó a la autoridad a congelar todas las solicitudes de cambio de uso de suelo (Circular N41 del 6 de diciembre de 2006 la Seremi Metropolitana de Vivienda y Urbanismo), mientras se hacía una revisión del Plan Regulador conocida como el PRMS-100 ${ }^{323}$. Tras casi siete años de tramitación, una nueva versión del PRMS de 1994 (PRMS-100) se puso en vigencia en 2013224. El largo proceso se debió a que tanto la sociedad civil, como los organismos públicos hicieron ver sus distintos intereses, algunos de los cuales fueron acogidos, sin embargo, hasta el día de hoy subsiste una fuerte crítica ciudadana a la ampliación que proyecta (Figura 9.6.), así como una gran expectativa de los agentes inmobiliarios (Figura 9.7.). La síntesis del nuevo PRMS-100 del 2003, se muestra en la Figura 9.8.

En la memoria del PRMS-100 se incluye la siguiente evaluación respecto a la situación de áreas verdes, que se acompaña del plano en la Figura 9.9:

Carencia de Áreas Verdes: Según diversas encuestas consultadas, la principal aspiración de los habitantes de Santiago es contar con más parques y áreas verdes. Mientras los más prestigiosos estándares internacionales recomiendan un mínimo de $9 \mathrm{~m}^{2}$ de áreas verdes por habitante, el Gran Santiago apenas cuenta con $3,4 \mathrm{~m} 2$. Junto con aumentar la superficie construida es necesario mejorar su localización espacial ya que el déficit es mucho más alto en las comunas pobres, lo que incrementa el patrón de segregación socioespacial. (PRMS, 2008, p. 8)

Desde que Chile suscribió el convenio sobre la biodiversidad Biológica firmado y ratificado en 1994, ha ampliado la legislación ambiental a través de instrumentos

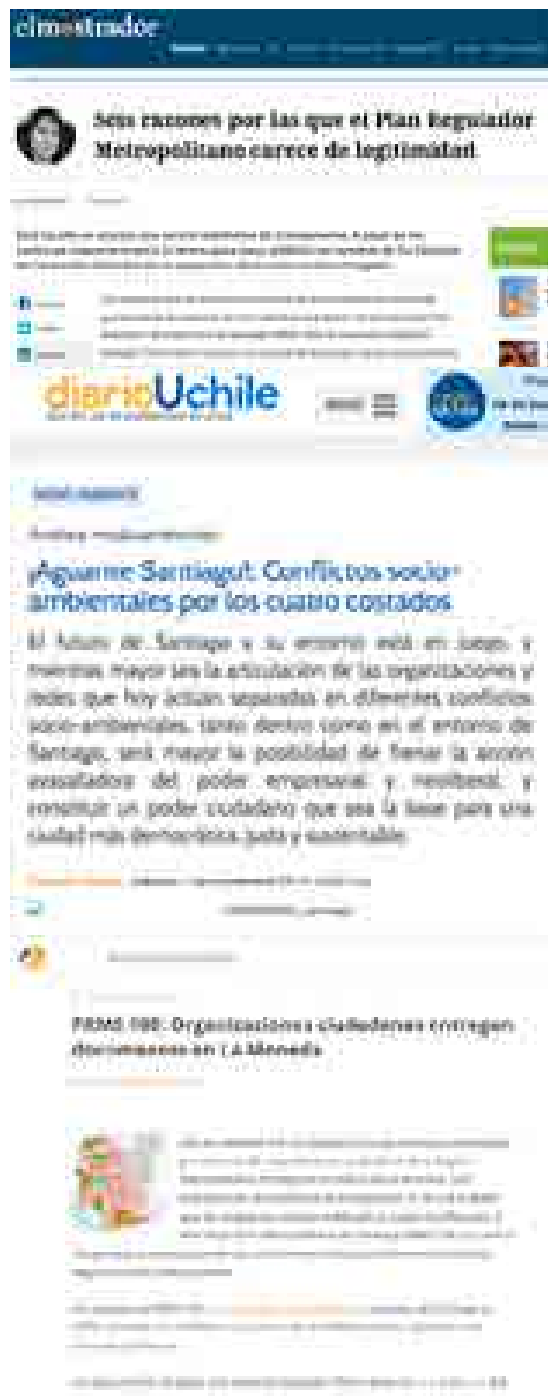

Figura 9.6. Recortes de prensa de los años 2011, 2012 y 2014, que expresan las críticas al nuevo Plan Regulador Metropo-litano de Santiago. En Plataforma Urbana (11 de enero, 2011); El Mostrador (9 de julio, 2012) y Diario UChile (1 de no-viembre, 2014).

322 Corresponden a área verde del Catastro de Áreas Verdes del Área Intercomunal de Santiago (CEC-PPR 1992). Se excluyen en el cálculo: aeródromo, suelos agrícolas, áridos, avenida parque, bandejón, cancha de fútbol, complejo deportivo, cementerio, cerro, construcción, hospital, preservación ecológica, protección, quebrada, regimiento, rotonda, sanitario y universidad.

${ }^{323}$ Las modificaciones de 1997 y 2006 no ampliaron el área urbanizable del Gran Santiago, pero si incorporaron y crearon nuevas áreas urbanas en el entorno de ésta, como las ZUDC en Colina, o las ampliaciones de las áreas urbanas de Peñaflor, Talagante, Buin y Paine entre otras. ${ }^{324}$ EI PRMS 100 fue aprobado el 26 de noviembre de 2013 
Figura 9.7. Artículo aparecido en el Diario El Pulso que anticipa el interés inmobiliario en el nuevo Plan Regulador Metropoli-tano de Santiago. En El Pulso 9 de noviembre, 2018.

\footnotetext{
${ }^{325}$ En este punto es importante mencionar el caso francés. En Francia, desde la Ley del Paisaje de 1993, la consideración del paisaje se registra en todos los niveles administrativos y debe figurar en todos los documentos de planificación urbana.
}

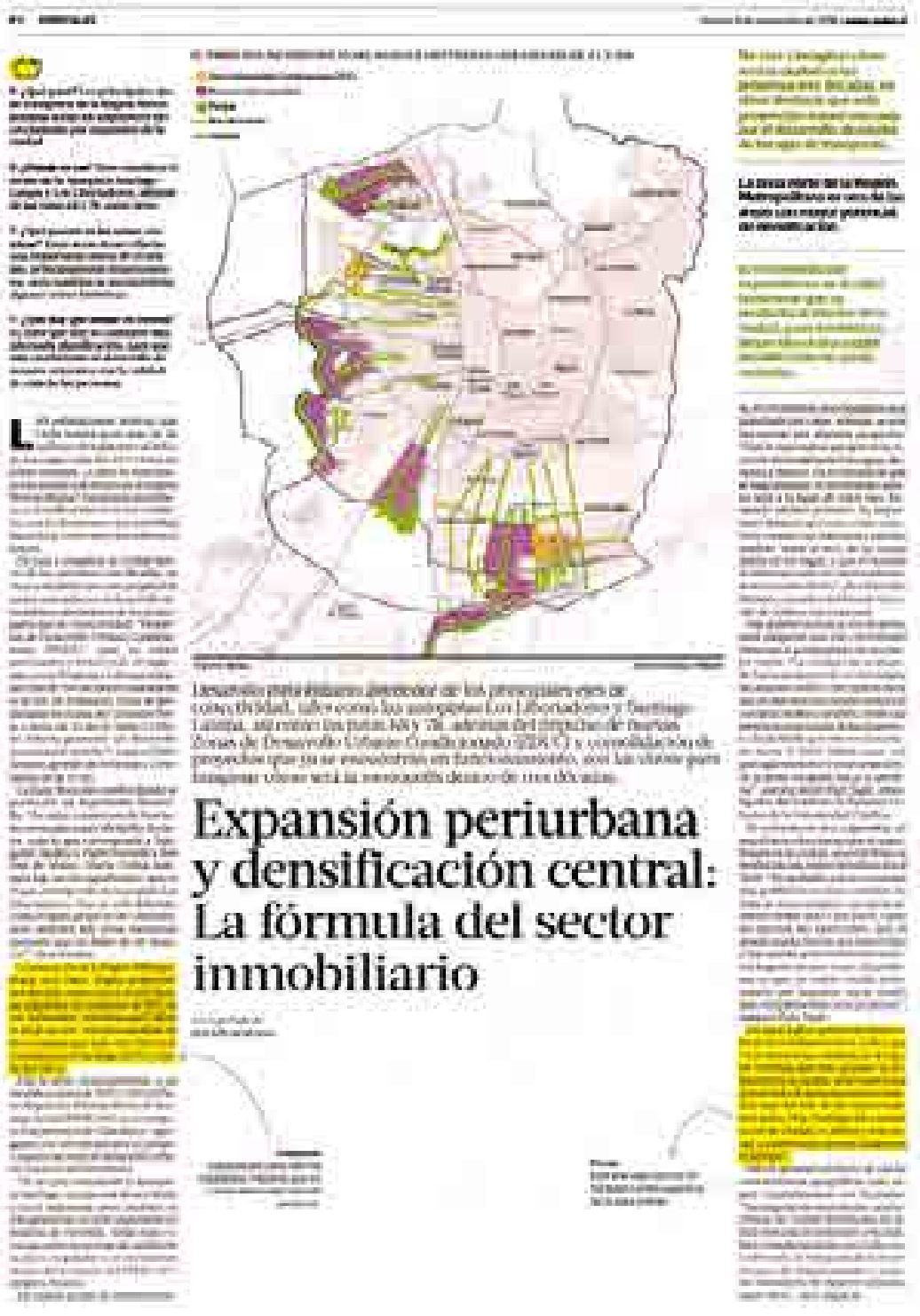

tales como: la Ley 19.300 Sobre Bases generales del medioambiente (1994); la Ley 19.473 de Caza (1996), la Ley 20.256 de Pesca Recreativa (2008); la Ley 20.283 sobre recuperación del Bosque Nativo (2008); la Estrategia Nacional de Conservación de la Biodiversidad a nivel nacional y a nivel regional; el Decreto 32 que Aprueba Reglamento para la Evaluación Ambiental Estratégica; el Plan de Ordenamiento Territorial Sustentable, la Política Regional de Áreas Verdes para la Región Metropolitana (2013), "que se superponen a los instrumentos definidos en la legislación urbana (Plan Regulador Metropolitano de Santiago), con una baja coherencia ${ }^{325}$ entre esos marcos regulatorios"(Picon et al., 2017, p. 13), y una falta de continuidad en programas estatales, como ha sucedido con el Programa de Parques Urbanos de 1993, y el Plan Elige Vivir tu Parque de 2013 que se extinguieron tras los cambios de gobiernos.

Sin embargo, las únicas menciones de la palabra paisaje se encuentran en dos modificaciones, la primera de 2002 (Artículo 5.2.4.4.) y la segunda de 2006 (Artículo 8.3.1.4.):

Artículo 5.2.4.4. Áreas Recreativas de Interés RES 6, Ecológico y Cultural.

$\left({ }^{*}\right)$ Se podrá explotar áreas para publicidad y propaganda, utilizando una materialidad natural o imitación, de manera de no degradar el medio ambiente y cuyas características propendan a mantener el paisaje [énfasis agregado] de parque de carácter natural, respetando las siguientes dimensiones para los letreros individuales: [...] (PRMS-100, RES-20-6, artículo 5.2.4.4., 2002) 


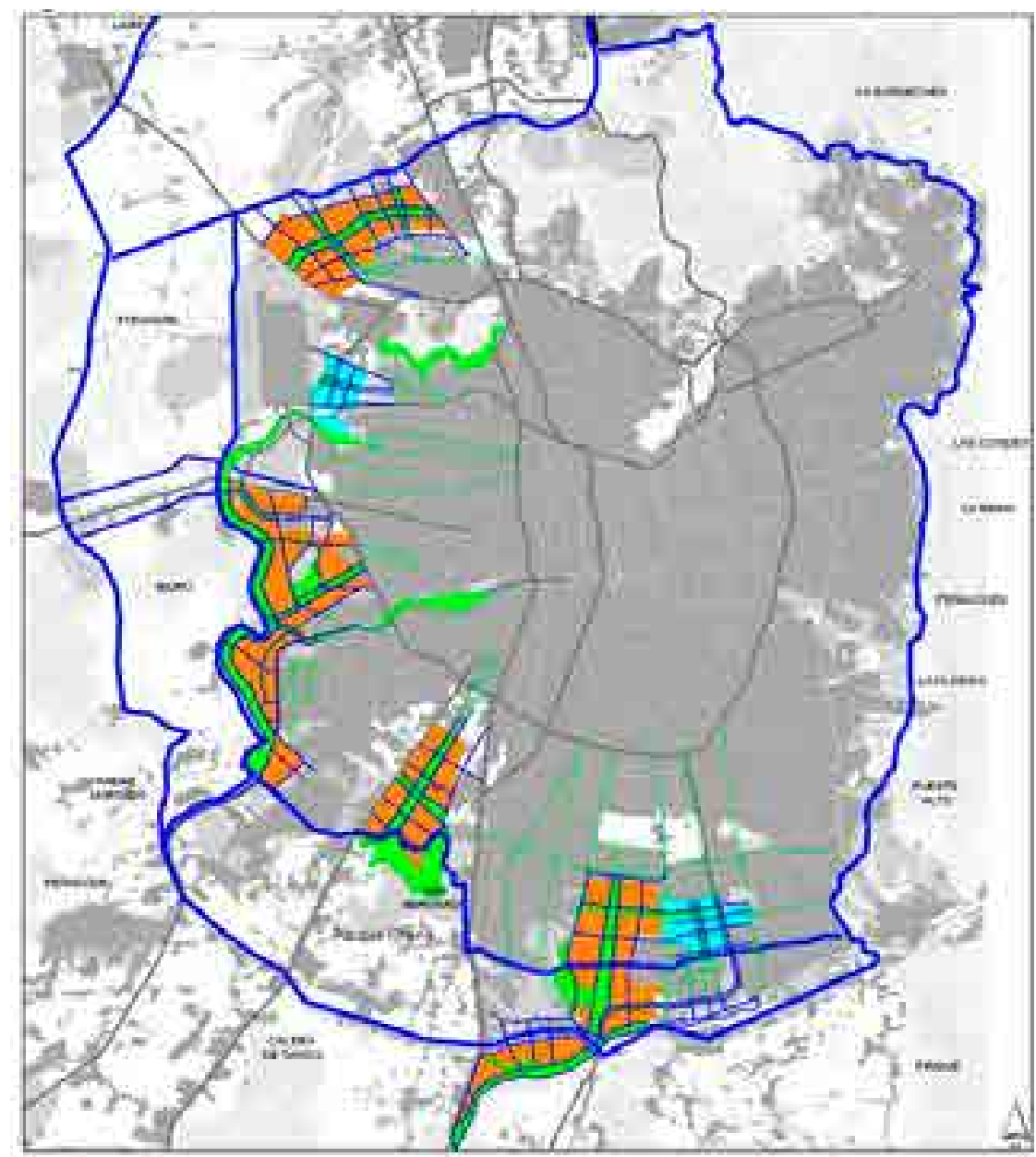

Art. 8.3.1.4. Áreas de Protección Prioritaria: Estas áreas presentan ecosistemas valiosos de importancia para la biodiversidad del país únicos, recursos genéticos, paisajes de gran belleza [énfasis agregado] y en general valores naturales o culturales que forman parte del patrimonio regional y nacional. Cumplen además, función de regulación climática, inmisión de contaminantes, corredores de ventilación, corredores biológicos y espacios de intercambio de fauna. (PRMS-100, RES-20-76, 2006)

Respecto al límite urbano, es importante destacar las acciones locales que las comunas periféricas emprenden. Ejemplo de ello, es el Plan de Desarrollo Comunal de Pudahuel que, sobrepasando lo indicado en el PRMS-100 considerará núcleos de desarrollo urbano, en la forma de ciudades satélite; un complejo logístico en torno al aeropuerto y paralelo a la ruta 68 ; y sin ir más lejos el propio sitio de Laguna Carén como un Parque Científico-Tecnológico y una ciudad universitaria.

Víctor Jiménez et al. en su artículo "Normalización del modelo neoliberal de expansión residencial más allá del límite urbano en Chile y España" de 2018, observa que el modelo chileno dota a los agentes inmobiliarios de las herramientas necesarias para la urbanización de prácticamente cualquier ámbito territorial (Jiménez et al., 2018, p. 42). Para ello se ha valido de tres resquicios que han posibilitado un desarrollo urbano disperso:

El primero consiste en el uso del Decreto No 420 que "Modifica Plan Intercomunal de Santiago y su Ordenanza" (1979) que además de incorporar el concepto de expansión urbana, que hemos comentado, en su Artículo $10^{\circ}$ determina una laxa tramitación:

Las subdivisiones y loteos que se originen en el área de expansión urbana sólo podrán ser aprobados por la Dirección de Obras Municipales respectiva, previo informe favorable de la Secretaría Ministerial de Vivienda y Urbanismo, Región Metropolitana, quien podrá consultar a los organismos competentes cuando lo estime indispensable (DL No 420, Artículo 10\%).
Figura 9.8. Síntesis del Plano Regulador Metropolitano de Santiago (PRMS-100) de 2013.

Detalla la ubicación de las vías troncales que serán exigidas al interior de las zonas de expansión condicionada y las zonas de reconversión industrial. En Memoria PRMS-100 (2008, p. 69) 
Figura 9.9. Áreas verdes del Plan Regulador Metropolitano de Santiago. En el PRMS-100 se propone incorporar 3.888 hectáreas de áreas verdes. Al sumar esta superficie con las áreas verdes actuales, el índice de $\mathrm{m} 2$ por habitante subiría de 3,4 (2006) a 8,31 m2/hab. en 2030. En Memoria PRMS-100 (2008, p. 64).

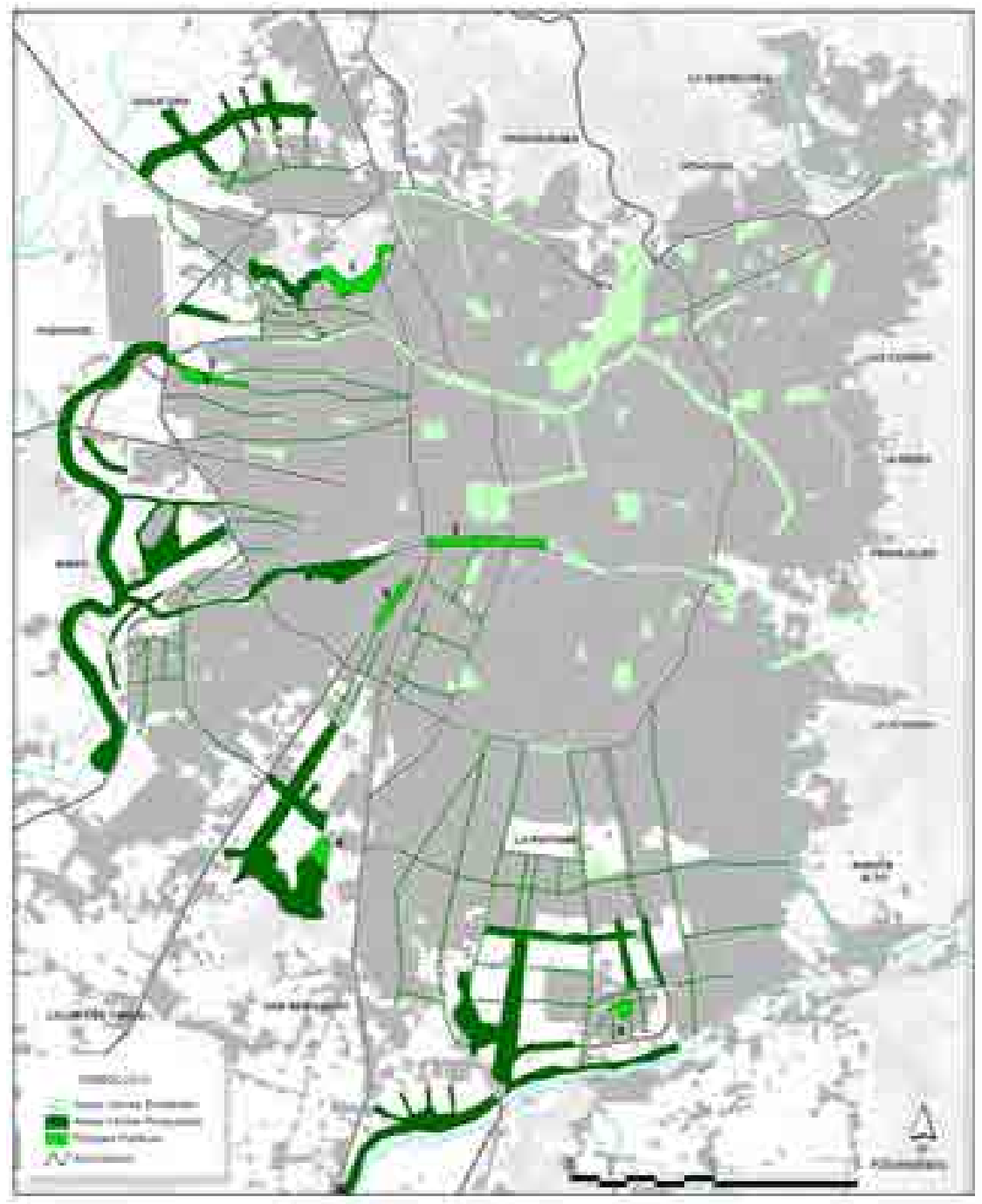

El segundo, es el Decreto $N^{0} 3.516$ de 1980, que permite urbanizar áreas rurales, condicionando una subdivisión mínima de media hectárea ${ }^{326}$. Este decreto, junto al Artículo N055 de la Ley General de Urbanismo y Construcciones que establece la posibilidad de construir viviendas para el propietario y construcciones necesarias para la "explotación agrícola", ha favorecido la creación de "parcelas de agrado", para propietarios que ficticiamente argumentan actividad campesina. El tercero, corresponde a una modificación del mismo artículo № 55 a través de la Ley 19.859 del 2003 (Art. Único No 1 D.0. 31.01.2003), que incluye la posibilidad de construir conjuntos habitacionales de vivienda social o de viviendas de hasta un valor de 1.000 UF (equivalente a 35.000 euros) sobre suelo rural:

Artículo 55.- Fuera de los límites urbanos establecidos en los Planes Reguladores no será permitido abrir calles, subdividir para formar poblaciones, ni levantar construcciones, salvo aquellas que fueren necesarias para la explotación agrícola del inmueble, o para las viviendas del propietario del mismo y sus trabajadores, o para la construcción de conjuntos habitacionales de viviendas sociales o de viviendas de hasta un valor de 1.000 unidades de fomento, que cuenten con los requisitos para obtener el subsidio del Estado.(Ley 19.859, 2003).

Estos tres instrumentos legales han propiciado la multiplicación de viviendas sobre suelo rural, para los sectores medios-altos con las ventajas de un bajo costo de terreno, libertad edificatoria y espacio libre. Para los sectores medios-bajos, se edificaron conjuntos de vivienda social, alejados de los centros urbanos, con problemas de locomoción y de servicios.

En este último caso, será el mismo estado, quien, a través de su política habitacional, subsidiará un insólito modelo de dispersión y segregación urbana que puede observarse en la Figura 9.10.
${ }^{326}$ Deroga de este modo la norma que exigía 20 hectáreas como mínimo. 
La memoria del PRMS (2008) justifica su acción sobre hechos consumados, aludiendo a la construcción de viviendas fuera del límite urbano:

Entre 1992 y 2002 el $73 \%$ del crecimiento total de viviendas (257.996 unidades) se concentró en 16 comunas ubicadas fuera del anillo de circunvalación de Américo Vespucio, como Puente Alto, Maipú, Las Condes, Quilicura y San Bernardo. Al interior de estas comunas se observan barrios donde el crecimiento se explica por la construcción masiva de viviendas sociales (Puente Alto sur, La Pintana o San Bernardo oriente) mientras que en otros, el desarrollo se debe a conjuntos de estratos medios y medio altos (ABC1 - C2), como ocurre en Peñalolén, Las Condes o Lo Barnechea (PRMS-100, 2008, p. 20).

Si volvemos a la Tabla 9.1. podemos observar que el potencial de expansión del PRMS-100 del 2013 a 133.506 ha es casi doce veces el área que proyectó Brünner para Santiago (11.348 ha), con la consiguiente pérdida de 122.158 ha de suelos agrícolas. Como vemos en la Figura 9.11, la evolución de la mancha urbana prácticamente ocupa todo el valle. Es por ello, que la disponibilidad de un terreno plano y vasto, contiguo a vías de transporte, -como Carén-, será codiciado.

Este efecto se ilustra en la Figura 9.12., que muestra un esquema del PRMS: a la izquierda, con las vías estructurantes; y a la derecha, el abanico de crecimiento de Santiago, que tiene al centro el terreno de Laguna Carén, franqueado al poniente por la PDUC Praderas. Cabe recordar, que el crecimiento de las últimas décadas hacia el oriente, sobre el pie de monte andino, (hacia la derecha de la figura) no ha considerado la amenaza geológica de la Falla de San Ramón (Universidad de Chile \& Universidad Católica de Chile, 2018, p. 17).

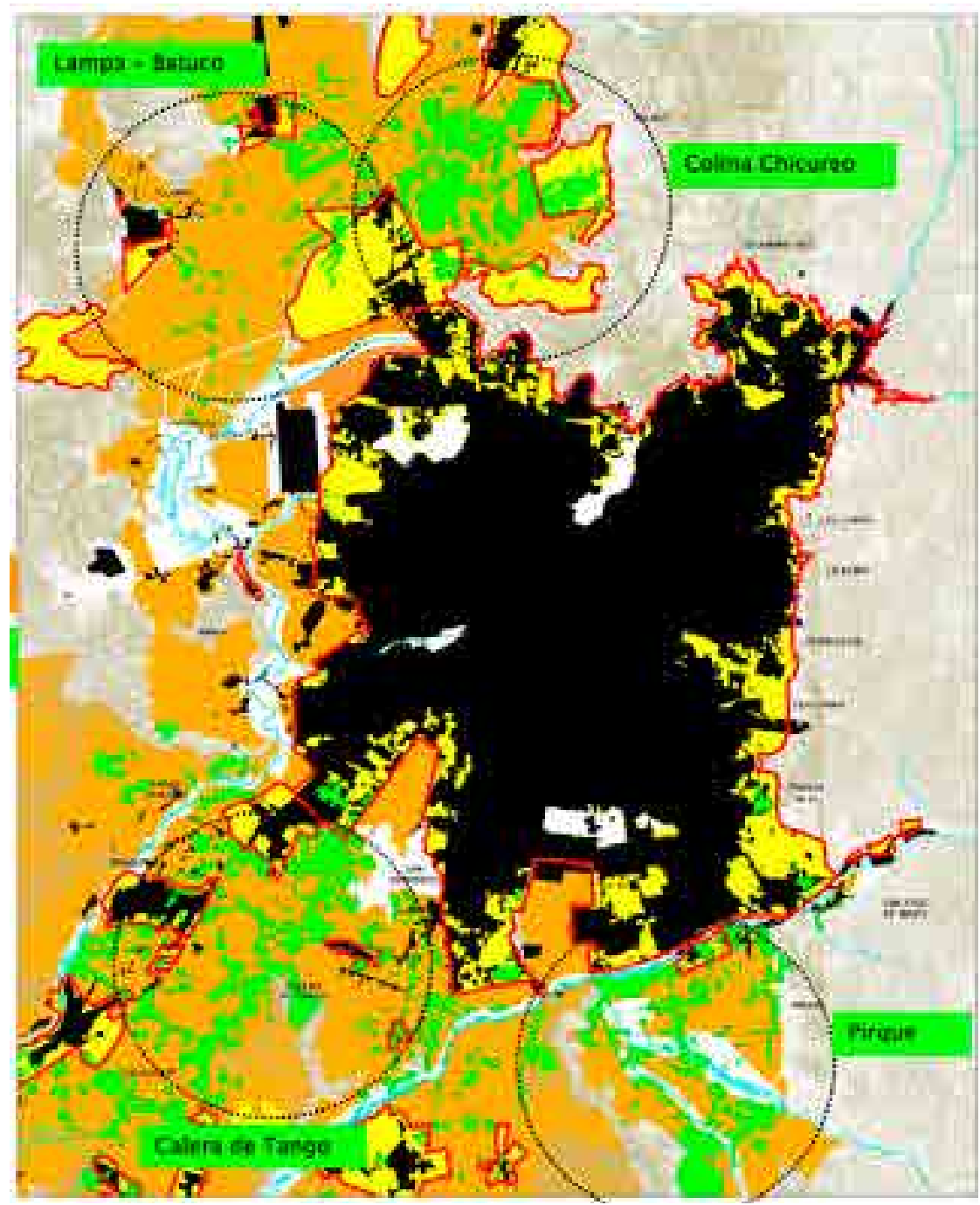

Figura 9.10. Distribución de Parcelas de Agrado fuera del límite urbano. En Memoria PRMS 100 (2008, p. 53). 
1960

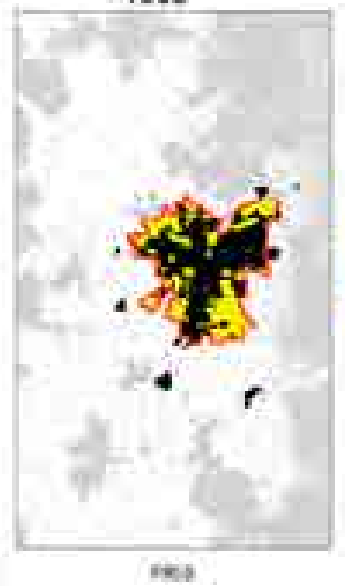

iss
1979

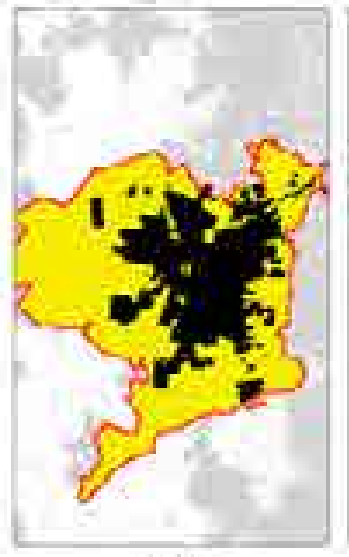

cenciev

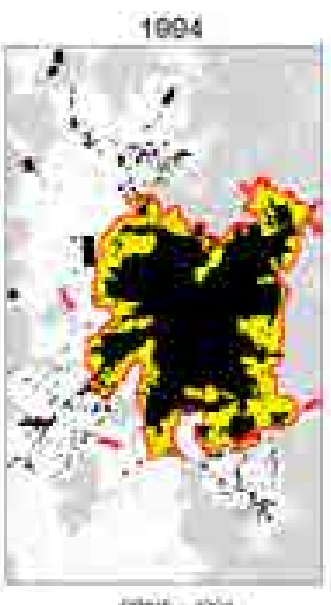

hers: tois
1997

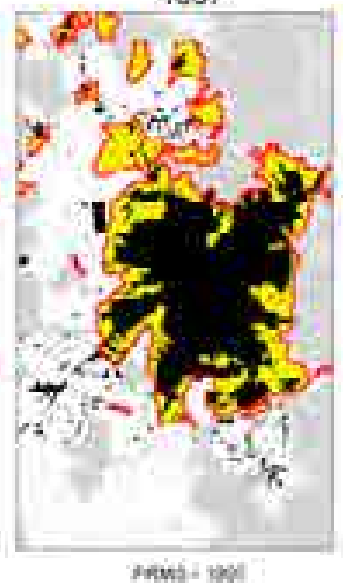

2003

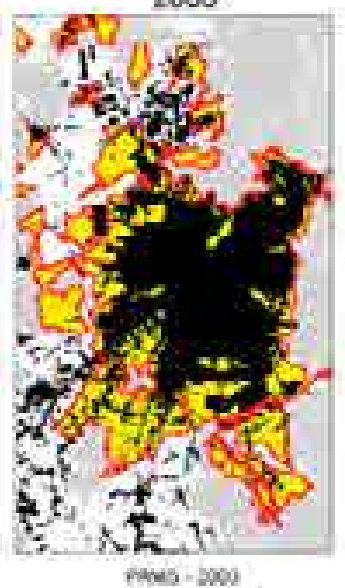

Figura 9.11. Evolución de la mancha urbana sobre el valle de Santiago entre 1960 y 2003. Por Iván Poduje (2006, p. 234).

\subsection{NORMATIVA URBANÍSTICA APLICABLE AL PREDIO DE LAGUNA CA- RÉN}

A continuación, se presentan las normas urbanísticas que se aplican al predio en estudio. Laguna Carén se ubica fuera del límite urbano, por lo que el Plan Regulador Comunal de Pudahuel no aplica. En consecuencia, la norma es dictada por el Plan Regulador Metropolitano de Santiago (PRMS-100). Si bien, este instrumento señala al predio de Carén como área verde (Figura 9.13), se muestra que esta condición no es plenamente aplicable, ya que está fuera del límite de regulación del plan y se muestra como "área verde no-construida" en el plano que se presenta en la Figura 9.14. Adicionalmente, se superponen tres áreas de riesgo sobre el predio.

De acuerdo a lo anterior:

9.3.1. El Plan Regulador Metropolitano de Santiago (PRMS) de 1994-2018 norma las áreas verdes y dentro de éstas, específicamente el predio de Laguna Carén.

Artículo 5.2 PRMS: Sistema Metropolitano de Áreas Verdes y Recreación Artículo 5.2.1. El Sistema Metropolitano de Áreas Verdes y Recreación está conformado por las Áreas Verdes de carácter público o privado y las vinculaciones o Avenidas Parque, que se consignan en el presente Plan. En este sistema se considerarán las áreas verdes de carácter metropolitano y aquellas de otros niveles que se le integren, de nivel vecinal y comunal. Este sistema se relaciona e integra con las áreas descritas en el Título $8^{\circ}$ de la presente Ordenanza, de Valor Natural y/o de Interés Silvoagropecuario y las de Riesgo para Asentamientos Humanos y todas aquellas áreas de carácter no edificable que en conjunto generan un nivel adecuado de saneamiento ambiental y de resguardo del bienestar de la comunidad [...].

Las condiciones técnico-urbanísticas para las instalaciones y edificaciones complementarias como asimismo las zonas de estacionamientos, serán determinadas en los proyectos específicos cuya aprobación efectuarán las Direcciones de Obras Municipales correspondientes, previo informe favorable de la Secretaría Ministerial Metropolitana de Vivienda y Urbanismo. (PRMS, Art. 5.2.)

Para mayor definición, el Artículo 5.2.2 del PRMS define Parque Laguna Carén como Parque Metropolitano, además de definir los usos que se permiten en estas áreas:

Artículo 5.2.2. Parques Metropolitanos Son las áreas verdes de uso público de carácter metropolitano que pueden acoger actividades relacionadas con lo recreacional, deportivo, de culto, cultural, científico, de esparcimiento y turismo al aire libre. Los usos antes mencionados deberán ser complementarios y compatibles con el carácter de área verde de uso público, su valor paisajístico o su equilibrio ecológico. Los Parques Metropolitanos son los siguientes:

Comuna Nombre

Providencia Parque Metropolitano

Vitacura San Cristóbal/Bosque Santiago 

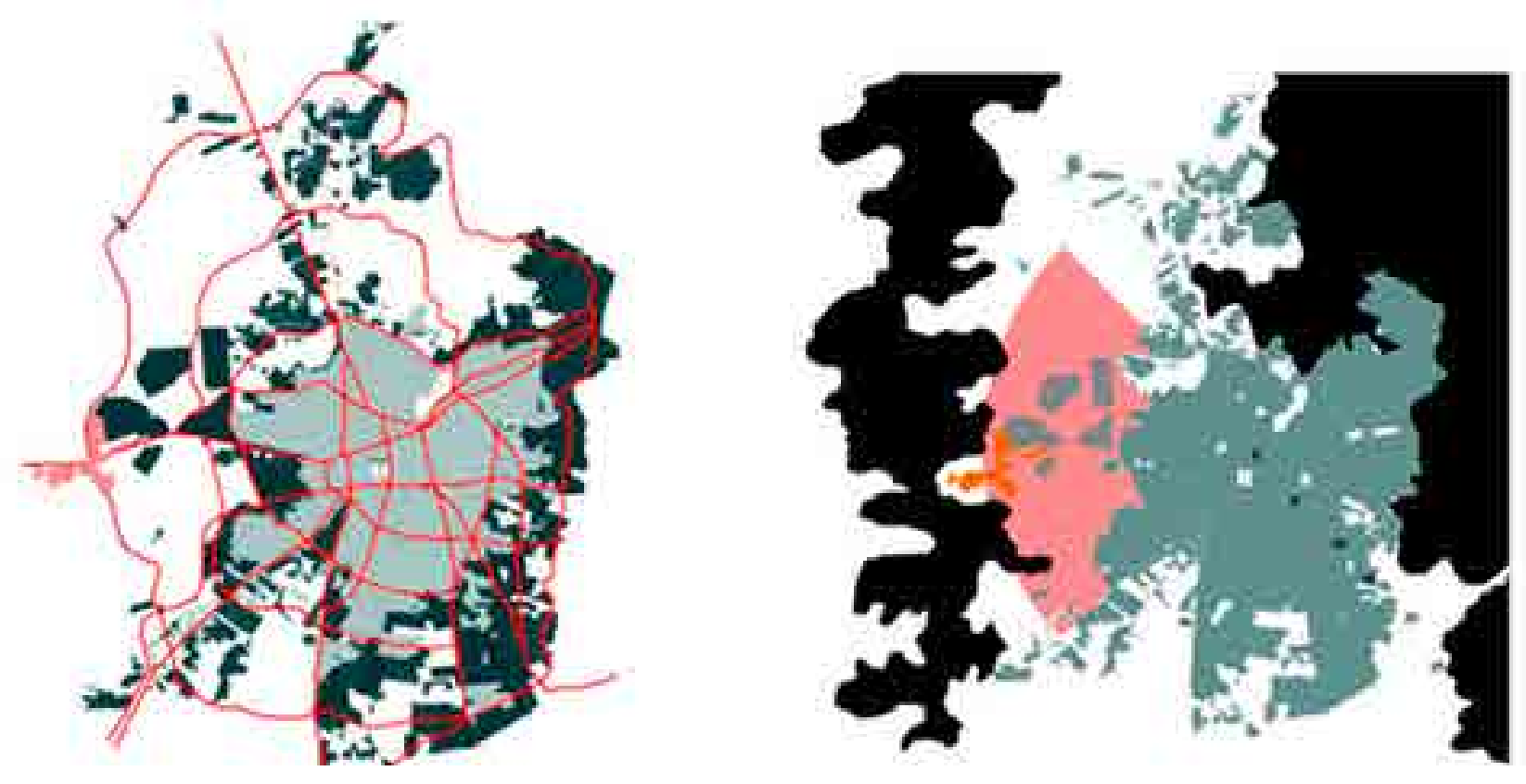

Figura 9.12. Mancha urbana de la ciudad de Santiago y su expansión. En gris, la extensión actual de la ciudad, en la imagen izquierda se sobreponen las vías estructurantes en rojo; a la derecha, se grafica el abanico de crecimiento al poniente, que tiene en su centro Carén. El Bosque S.A. (2005, p. 19).

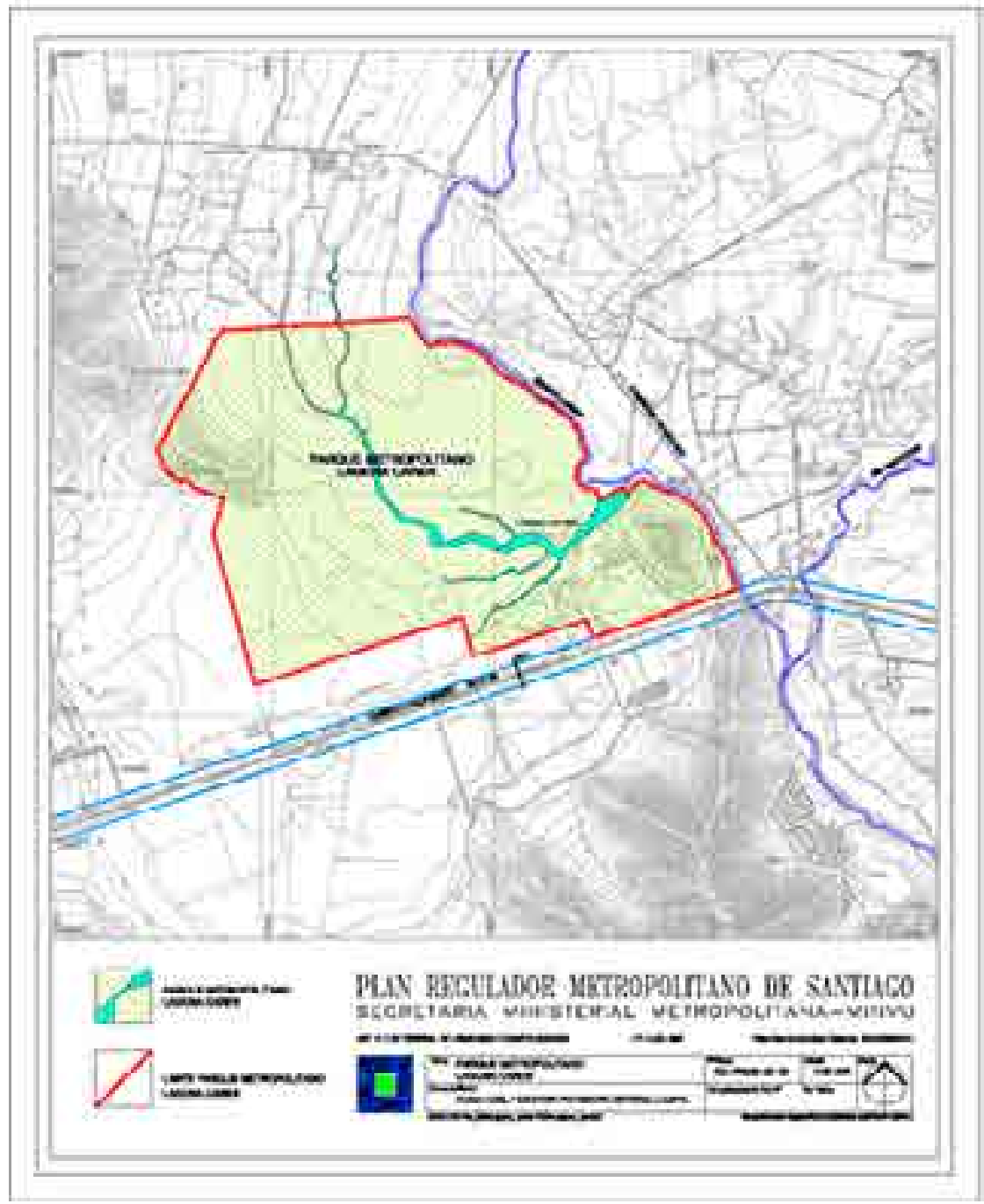

Figura 9.13. Plan Regulador Metropolitano de Santiago (1994). Lámina RM-PRMS 03-12, escala 1:25.000. Por Secretaría Regional Ministerial, Ministerio de Vivienda y Urbanismo (14 de mayo, 2003) 
Recoleta

Huechuraba

Pudahuel

Parque Laguna Carén [...]

La condición de parque supone restricciones en el porcentaje de uso de suelo, incluidos las áreas de estacionamientos, que en su conjunto pueden ocupar sólo el $1 \%$ de la superficie. Aplicado al sitio de Laguna Carén, esto correspondería a 10,22 ha, equivalente a $102.200 \mathrm{~m}^{2}$ de ocupación en superficie. La ocupación de suelo es diferente a la constructibilidad, para la cual no hay restricción:

Las instalaciones y/o edificaciones complementarias que puedan desarrollarse en estos parques no podrán sobrepasar, en su conjunto, el $1 \%$ de la superficie total del predio, incluidas las áreas de estacionamientos. (PRMS, Art.5.2.2)

Sin embargo, la definición de Laguna Carén como área verde es irregular ya que un Plan Regulador Intercomunal o Metropolitano no puede normar áreas verdes fuera del límite urbano, vale decir, fuera de su jurisdicción, como se detalla en punto $\mathrm{c}$ de este capítulo.

9.3.2. Consecuente a su supuesta condición de área verde, se aplica el Artículo 2.1.31 de la Ordenanza General de Urbanismo y Construcciones (OGUC), que permite la construcción en áreas verdes:

Figura 9.14. Situación de Carén en el Plan Regulador Metropolitano de Santiago PRMS-100. La lámina se titula Primer filtro sustentabilidad ambiental. En ella se incluye el predio de Carén como área verde no-construida (derecha) y área de ries-go+remoción en masa+inundación (izquierda, bajo). En PRMS-100 (2008, p. 51)

Riesgo+remoción en masa + Inundación

Restricción Aeropuerto

Proteccón ecologica

Rersyopes

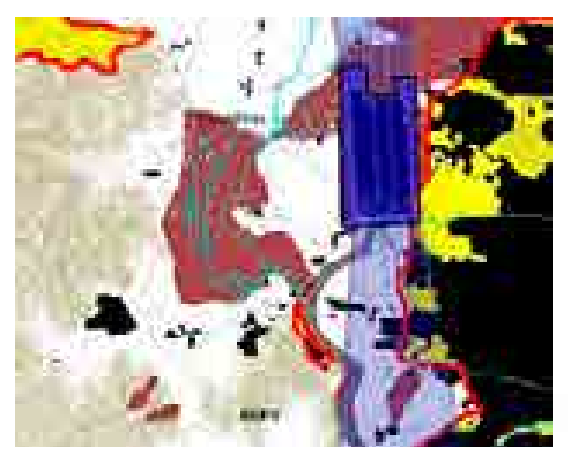

En las áreas verdes señaladas en el inciso anterior, que no se hubieren materializado como tales, se podrá autorizar la construcción de edificios de uso público o con destinos complementarios al área verde, siempre que el área destinada a estos usos no ocupe más del $20 \%$ de la superficie total del predio destinada a uso área verde en el Instrumento de Planificación Territorial. Se deberá incluir en dicho porcentaje la vialidad interna necesaria para estos usos, con excepción de la definida en el Instrumento de Planificación Territorial, si la hubiere; también las superficies destinadas a estacionamientos sobre el terreno

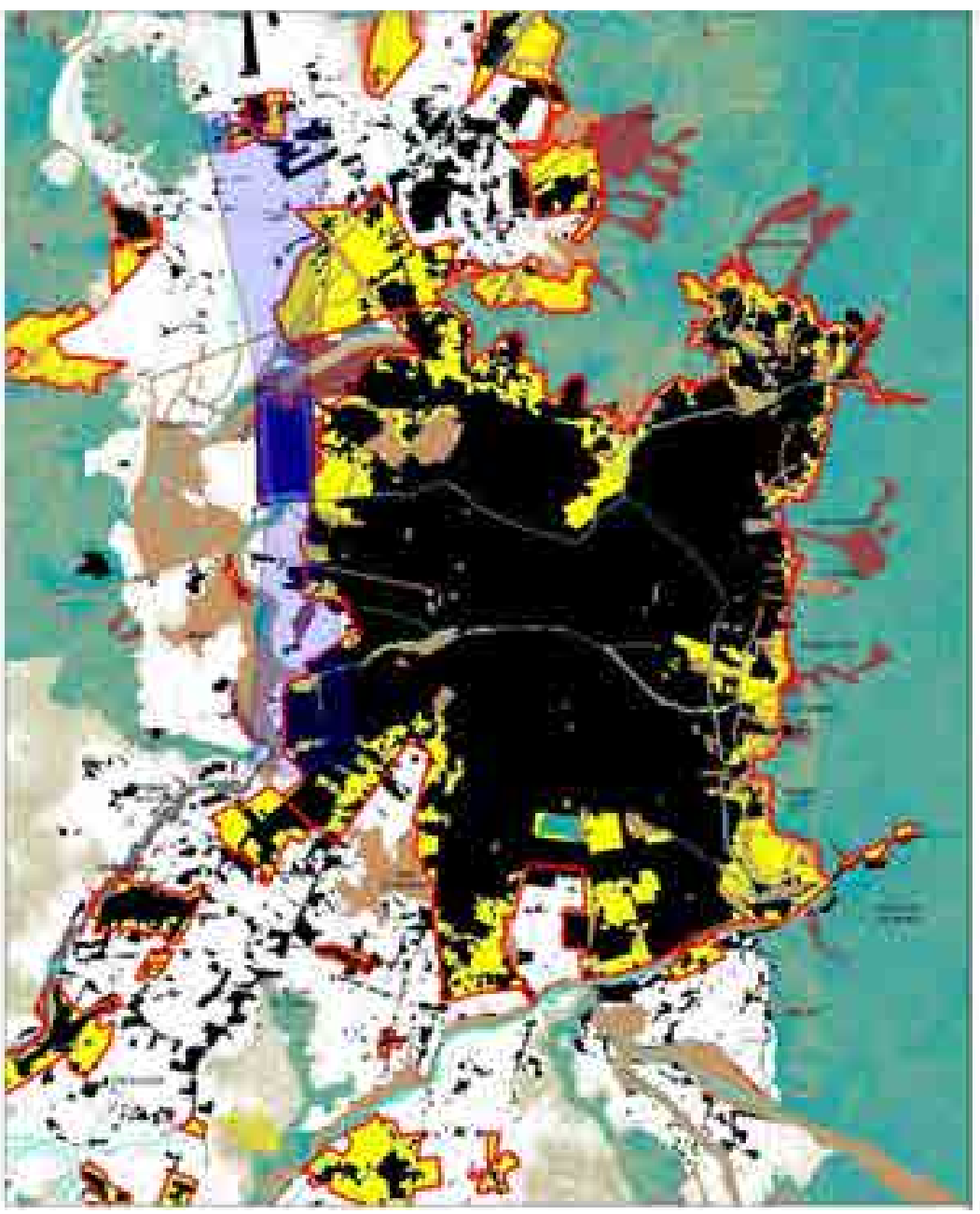


y cualquier otro porcentaje admitido previamente por el Instrumento de Planificación Territorial.

(...) En las áreas verdes a que se refiere este artículo, se entenderán siempre admitidos como destinos complementarios y compatibles los equipamientos Científico, Culto y Cultura, Deporte y Esparcimiento. (OGUC, Artículo 2.1.31.)

9.3.3. Sin embargo, mediante el Decreto Supremo 9 del 13 de abril de 2011 que modifica el artículo 2.1.7 de la OGUC, se diferencia los ámbitos de acción de este instrumento para áreas rurales y urbanas. Dentro de lo permitido en el área urbana está "g) La definición del uso de suelo de área verde de nivel intercomunal", sin embargo, no se menciona como posible para el área rural. Esta modificación se ve reflejada en la Circular 219 (año 2009) de la Dirección de Desarrollo Urbano (DDU) del Ministerio de Vivienda y Urbanismo (MINVU) que aclara los ámbitos de acción de los Planes Reguladores Intercomunales o Metropolitanos, en las áreas urbanas y rurales. En este documento se determina la definición de uso de suelo de área verde como norma urbanística que un Plan Regulador Intercomunal 0 Metropolitano puede regular en el área urbana, pero no se menciona como materia a regular para el área rural.

9.3.4. De todas formas, aun manteniendo su condición de área verde, el Artículo 59 de la Ley General de Urbanismo y Construcciones (LGUC) indica que los parques intercomunales tendrán una caducidad (si no están constituidos) de 5 años, si están en el área urbana y 10 años, si se encuentran en el área de extensión urbana desde su declaración, pudiendo prorrogarse por una vez por igual lapso. Sin embargo, por efecto de la Ley № 20791 publicada en octubre de 2014, queda sin efecto la caducidad sobre los parques no-consolidados. Es así como el Parque Laguna Carén revive, recuperando su condición de parque privado.

DISPOSICIONES TRANSITORIAS

\begin{abstract}
Artículo transitorio. - Declárase de utilidad pública los terrenos que hubieren sido destinados por un plan regulador o seccional a circulaciones, plazas y parques, incluidos sus ensanches, con anterioridad a las disposiciones de las leyes $\mathrm{N}^{\circ} 19.939$ y 20.331. Sin perjuicio de lo dispuesto en este inciso, respecto de los terrenos cuyas declaratorias hubieren caducado en virtud de las citadas leyes, deberá respetarse la aplicación de lo establecido en el artículo 116 de la Ley General de Urbanismo y Construcciones, cuyo texto fue fijado por el decreto con fuerza de ley $N^{\circ} 458$, de 1976, del Ministerio de Vivienda y Urbanismo, en lo referido a los anteproyectos aprobados y los permisos otorgados por la Dirección de Obras Municipales, los que no se verán afectados por la declaratoria de utilidad pública.(Ley № 20.791)
\end{abstract}

9.3.5. En este mismo sentido, en el PRMS-100 (1994-2018) se establece una excepción para los Parques no-consolidados:

Artículo 5.2.1.1. Recuperación de Áreas Verdes del Sistema Metropolitano de Áreas Verdes y Recreación.

Los Parques Metropolitanos, Parques Intercomunales y Áreas Verdes Complementarias, no consolidados, vale decir aquellos que nunca se hayan construido, podrán destinar en un solo paño, hasta el $20 \%$ de sus superficies originales respectivas a otros usos, de características urbanas compatibles con el entorno, condicionadas a un informe favorable de la Secretaría Regional Ministerial de Vivienda y Urbanismo, que será ratificado por el Consejo Regional previo al permiso que otorgue la Municipalidad respectiva, sin perjuicio del cumplimiento de las disposiciones contenidas en el D.F.L. № 458 (V. y U.) Ley General de Urbanismo y Construcciones y la ley № 19.300 sobre Bases Generales del Medio Ambiente.(PRMS, Artículo 5.2.1.1)

9.3.6. Adicionalmente, el PRMS de 1994 indica en su plano RM-PRM-92/1A la presencia de tres Áreas de Riesgo de Origen Natural (Artículo 8.2.1 del PRMS): Recurrentemente Inundables, De Riesgo Geofísico Asociados a Inundación Recurrente, y Afloramiento Potencial de Napa Freática (Figura 9.15.). 
Figura 9.15. Áreas de Riesgo según PRMS de 2004. Detalle del plano RMPRM-08-100. En URBE (2008, p. 13).

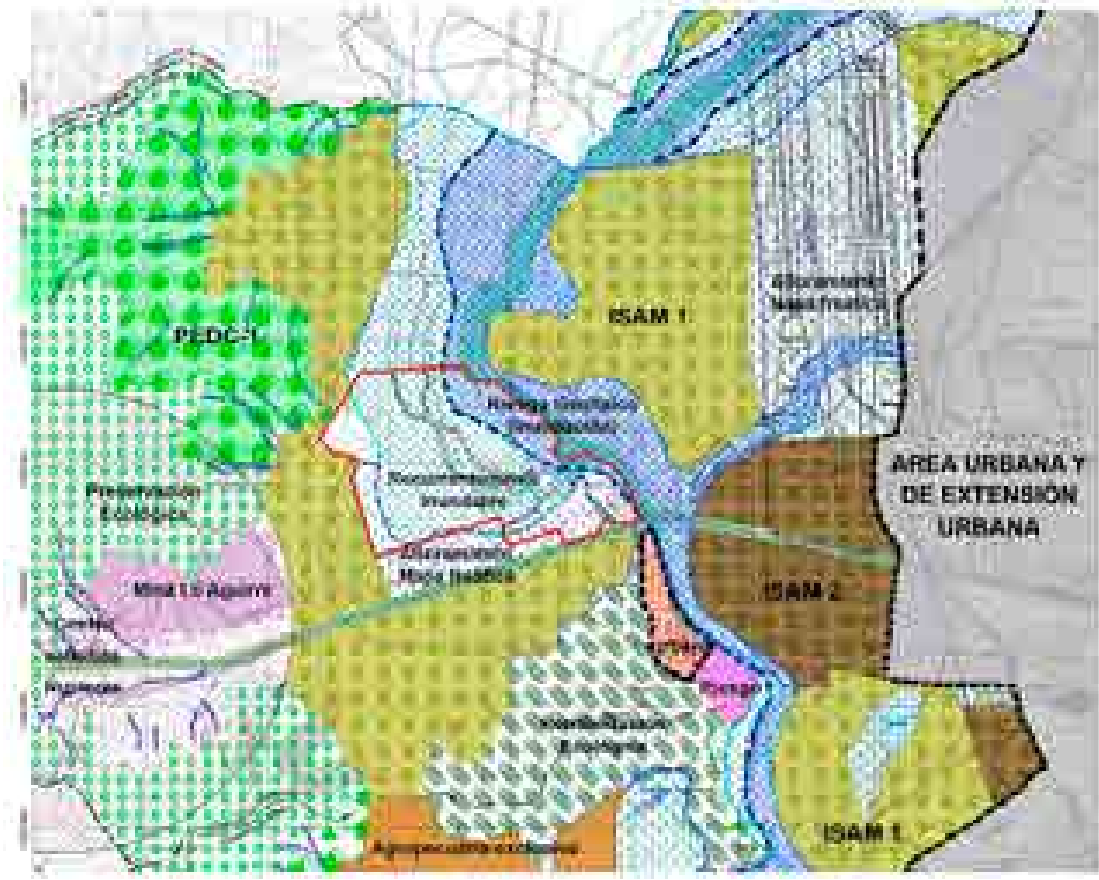

Dentro de las Áreas de Alto Riesgo Natural por Inundación (Artículo 8.2.1.1), se encuentran las áreas Recurrentemente Inundables, en las cuales:

Se permitirá sólo las instalaciones mínimas complementarias a las actividades al aire libre, por lo cual se prohíbe expresamente todo tipo de edificaciones y construcciones que impliquen la presencia prolongada de personas o la concentración de ellas sin posibilidad de evacuación expedita y/o que interfieran el libre curso de las aguas.

Los proyectos de urbanización, edificación y/o destinados al acondicionamiento y explotación de los terrenos emplazados en estas áreas, cualquiera sea su finalidad, deberán ser aprobados además por el Ministerio de Obras Públicas, en forma previa a su ejecución o iniciación.

Los propietarios de terrenos afectados por estas normas, podrán desarrollar estudios y proyectos específicos, debidamente aprobados por el Ministerio de Obras Públicas, en los cuales se determinen en detalle los límites del área inundable que afecte a su predio, como asimismo, las obras que deben realizarse para protegerlo.

Dentro de este mismo artículo, a continuación, se definen las condiciones para las áreas de Napas freáticas:

La autorización de obras de urbanización y/o edificación en estas áreas, deberá condicionarse al cumplimiento de lo siguiente:

- La napa freática no podrá tener una profundidad menor a $5 \mathrm{~m}$. en la época más desfavorable del año.

- La napa freática deberá estar a más de $3 \mathrm{~m}$. bajo el sello de fundación. Para verificar las condiciones señaladas en el inciso anterior, se deberán realizar sondajes y medir la profundidad del acuífero durante 3 días a lo menos. En caso de no cumplir tales condiciones en forma natural, la urbanización deberá considerar las obras de drenaje que resuelvan dicho aspecto. (PRMS, 8.2.1.).

\begin{tabular}{|c|c|c|c|c|c|c|}
\hline MoONo & \multirow[b]{2}{*}{ BAwO } & \multirow[b]{2}{*}{ EDucasion } & \multirow[b]{2}{*}{ seounsab } & \multirow[b]{2}{*}{ 2NEAS wERDES } & \multirow[b]{2}{*}{ seroktes } & \multirow[b]{2}{*}{ senveios } \\
\hline$\frac{N^{*}}{\text { navtasn }}$ & & & & & & \\
\hline 50 & $*$ & $=$ & +1 & REZA KECWAL & $=$ & $=$ \\
\hline 3000 & 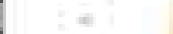 & BAscas & * & & AllTKENGH & $=i$ \\
\hline 5000 & $*$ & 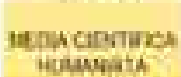 & . & & owour rutest & 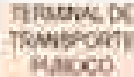 \\
\hline 10000 & -1 & $\begin{array}{l}\text { leph recus: } \\
\text { corverox }\end{array}$ & $\begin{array}{l}\text { orubessos } \\
\text { botirsoses }\end{array}$ & & gewns & \\
\hline 20000 & Hesastome? & & & $h=2 x$ & & $\begin{array}{l}\text { cclitap of } \\
\text { infhect }\end{array}$ \\
\hline 40000 & 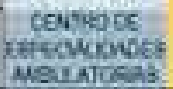 & & & & & \\
\hline
\end{tabular}

Tabla 9.2. Equipamiento exigido para los Proyectos de desarrollo Urbano Condicionado (PDUC). Elaboración propia sobre la base de lo establecido por el Plan Regulador Metropolitano de Santiago en el 2003. 
Luego, dentro de las áreas de Riesgo Geofísico Asociado a Eventos Naturales (Artículo 8.2.1.4., en la letra b. se considera "De Riesgo Geofísico Asociado a Inundación Recurrente. Corresponden a aquellas áreas próximas a los bordes de: cauces naturales permanentes, esteros y/o canales, con riesgo de erosión 0 socavamiento, producido por el aumento de volumen y velocidad del caudal de agua". Estas áreas se precisan en los siguientes planos:

RM-PRM-92 1.A., modificado parcialmente por el plano RM-PRM-08-100-láminas 1 de 4,2 de 4,3 de 4 y 4 de 4 y plano RM-PRM-95-CH.1. C.:

Listando a continuación los causes vulnerables, para luego indicar los usos permitidos:

Áreas asociadas al Río Mapocho, Río Maipo, Zanjón de la Aguada, Estero Las Cruces, Estero Lampa y ramales, Estero Colina y ramales, Estero Chacabuco, Estero Santa Margarita, Estero Til-Til, Estero Polpaico y Estero Carén [énfasis agregado].

En estas áreas sólo se permitirá el Equipamiento de Áreas Verdes, incorporándose éstas al Sistema Metropolitano de Parques, los que a su vez deben diseñarse de tal forma que la vegetación no afecte el cauce.

Para urbanizar las áreas cercanas a los causes, se considera la tramitación de una modificación al Plano Regulador Comunal

A su vez, en las áreas urbanizadas y urbanizables afectadas por este riesgo potencial, se podrá solicitar una modificación del destino de Equipamiento de Área Verde del área de riesgo establecida. Esto, a través de una modificación del Plan Regulador comunal, que implique un aumento de la ocupación del suelo, como asimismo de la densidad de población, la que deberá fundamentarse mediante estudios técnicos específicos, aprobados por organismos competentes, que contemplen las condiciones y obras necesarias para asegurar la minimización de los riesgos identificados para estas áreas. (PRMS, Artículo 8.2.1.)

9.3.7. Se tiene a la vista el Certificado Informaciones Previas $n^{\circ} 1331$ de 5 de septiembre de 2008, emitido por la Dirección de Obras de la Municipalidad de Pudahuel, que declara que la propiedad es rural, y que asigna las siguientes normas urbanísticas:

Zona: Excluida o Restringida al Desarrollo Urbano

Uso de Suelo: Riesgo de Origen Natural.

Superficie Predial Mínima: 10 ha;

Coeficiente de Constructibilidad: 0.01

Coeficiente (sic) de Ocupación de Suelo: 1 [Se asume que el Coeficiente de Ocupación de Suelo se refiere a Porcentaje de Ocupación de Suelo, y que el guarismo entregado es del $1 \%$ ].

\subsection{NORMATIVA APLICABLE PARA EL DESARROLLO DE UN PLAN MAES- TRO}

Con el objeto de tener claridad respecto a las condiciones del entorno, se resume a continuación las zonas normativas comparables. A su vez, se resumen las normas de Desarrollos Condicionados que podrían aplicarse complementariamente al uso Silvoagropecuario. Por último, se presenta el artículo 55, que permite el cambio de uso de suelo para sectores rurales.

\subsection{1. Áreas de Interés Silvoagropecuario}

Normadas en el artículo 8.3.2 del PRMS, son aquellas que tienen importancia desde el punto de vista productivo silvoagropecuario, para las cuales se asigna una subdivisión mínima de 4 ha. y una densidad máxima de 1 vivienda/predio.

Dentro de estas áreas se incluyen sectores con mayores posibilidades de desarrollo, denominadas ISAM (Interés Silvoagropecuario Mixto), definidas en el Artículo 8.3.2 del PRMS:

En ellas se permitirá una subdivisión predial mínima de 4 Há, con una vivienda por predio. Además, se podrá edificar en el mismo predio una vivienda para cuidador, siempre que esta cumpla con las características y condiciones definidas para las viviendas sociales en la Ordenanza General de Urbanismo y Construcciones. 
Adicionalmente se considera la construcción de viviendas para campesinos a solicitud del municipio:

Sin embargo, a petición del Municipio respectivo, se podrá emplazar conjuntos de viviendas sociales para campesinos en terrenos de hasta $100 \mathrm{~m} 2$ de superficie mínima, siempre que se cumpla con las exigencias siguientes:

- Contar con infraestructura suficiente.

- Informe favorable de la Secretaría Ministerial Metropolitana de Vivienda y Urbanismo y de los organismos, instituciones y servicios que correspondan.

Además, se permitirán las siguientes actividades:

- Desarrollos Urbanos Condicionados, conforme a lo señalado en el Artículo 8.3.2.4. de la presente Ordenanza.

- Desarrollos Industriales y/o Empresariales Condicionados, conforme a lo señalado en el Artículo 6.1.3.5., de la presente Ordenanza.

Las ISAM que se ubican cercanas al predio son las ISAM 1 e ISAM 2. La primera permite instalaciones de agroindustrias que procesen productos frescos, y extracción de minerales no metálicos aplicables a la construcción (principalmente pumacita). La ISAM 2 permite mayor intensidad de uso con la instalación de centros de distribución mayoristas y en general actividades complementarias a la vialidad y transporte.

\subsubsection{Proyectos de Desarrollo Urbano Condicionado (PDUC)}

Pudahuel posee un territorio con condiciones normativas que posibilitan desarrollos urbanos en suelos rurales a través del desarrollo de Estudios de Impactos Urbanos en áreas de interés silvo agropecuario (ISAM). Estos desarrollos son los denominados "Proyectos de Desarrollo Urbano Condicionado" (PDUC) istep En términos generales estos desarrollos permiten emprender proyectos inmobiliarios privados fuera del límite urbano de la ciudad, siempre que se cumplan ciertas normas o condiciones. Algunas de estas condiciones permiten incorporar nuevo suelo a la ciudad, pagando por los impactos sociales del desarrollo, apuntando principalmente a resguardar la calidad de éste, mitigar los impactos producidos e incentivar la inversión privada.

Una PDUC como característica general debe poseer una superficie mínima de 300 há con una densidad bruta promedio de 85 hab/ha, (con un rango de movilidad de15 hab./ha.). Al menos un 30\% de las viviendas debe ser subsidiada y además se debe destinar suelo para actividades productivas en al menos un $5 \%$ de la superficie urbanizable

El tipo de proyecto apunta a que los desarrollos paguen las externalidades urbanas que generen en las áreas de transporte, equipamiento, servicios e infraestructura.

Se describe a continuación la normativa que enmarca a la figura de las PDUC como una alternativa para el desarrollo del predio de laguna CarénisẸ: Esta figura está contemplada en el artículo 8.3.2.4 del PRMS desde 2003, la que permite el desarrollo de proyectos inmobiliarios en zonas de interés silvoagropecuario (por lo tanto, fuera del límite urbano), siempre y cuando se cumpla con la implementación de ciertas mitigaciones y provisión de superficies para equipamientos. Las condiciones de zonificación en rasgos generales son las siguientes:

- Superficie no inferior a 300 Há.

- Densidad bruta promedio de 85 Háb/Há con una tolerancia de $15 \mathrm{Hab} / \mathrm{Há}$.

- Un mínimo de 30\% de viviendas subsidiables, con una densidad bruta máxima de $400 \mathrm{Hab} / \mathrm{Há}$. Dentro de este porcentaje se debe incluir un $40 \%$ de vivienda social.

- Un 5\% mínimo de superficie para actividades productivas.

- Las condiciones de equipamiento se deben cumplir por etapas, según la siguiente tabla: 
La superficie por equipamiento se define según una tabla contenida en el mismo artículo. Las etapas a desarrollar y recibir por parte de la Dirección de Obras deben tener un mínimo de 3.000 habitantes.

A su vez, la PDUC debe contemplar un plan de mitigaciones que incluya:

- Por pérdida de suelo agrícola de clases I, II y III, se debe recuperar un equivalente al $150 \%$ de superficie en otro sector.

- Plan de restauración de hábitat de flora y fauna silvestre.

- Devolución al estado de inversión en fomento agropecuario, de haberse efectuada hasta hace 10 años en el sector.

- Garantizar funcionamiento de aguas de riego.

- Se debe considerar un plan de manejo de riesgos naturales y de actividades peligrosas.

- Se debe considerar un Estudio de Capacidad Vial y proponer un plan de inversiones en infraestructura vial para garantizar la conectividad con los centros urbanos cercanos.

La tramitación para desarrollar una PDUC se grafica en la Figura 9.16.

\subsubsection{Desarrollos Industriales y/o Empresariales Condicionados (DIEC)}

Esta figura se expresa en el Artículo 6.1.3.5 del PRMS, y plantean como conjuntos que pueden emplazarse en Área de Interés Silvoagropecuario (como las ISAM), cumpliendo con ciertas condiciones:

- 80 ha. mínimo, en un solo paño.

- Condiciones de arborización con diferentes tipos de especies.

- Los usos de suelo permitidos son: actividades productivas de carácter industrial, actividades de Servicio de carácter similar al industrial (Centros de distribución con comercio, Almacenamiento), actividades productivas de carácter agroindustrial, áreas verdes y espacio público, equipamiento de deporte, esparcimiento-recreación, científico, culto y cultura, comercio, servicios y social en todos sus niveles. Respecto de los equipamientos de salud y educación sólo se permitirá servicios de salud ambulatoria, jardines o guarderías infantiles, para satisfacer las demandas del propio proyecto, así como se permitirán establecimientos de formación técnico profesional. Se permite infraestructura complementaria a los usos de suelo permitidos.

- Se exigen superficies prediales mínimas para los lotes internos (entre 2.500 y $4.000 \mathrm{~m} 2$ ). Coeficiente de constructibilidad de 1.2.

La aprobación requiere de los informes favorables de la SEREMI MINVU (adecuación al sistema Intercomunal) y de Agricultura (inserción en el medio rural), así como de direcciones técnicas del MOP (aspectos hídricos, transporte, entre otros), y del asesor urbanístico de la comuna. El informe técnico final debe ser

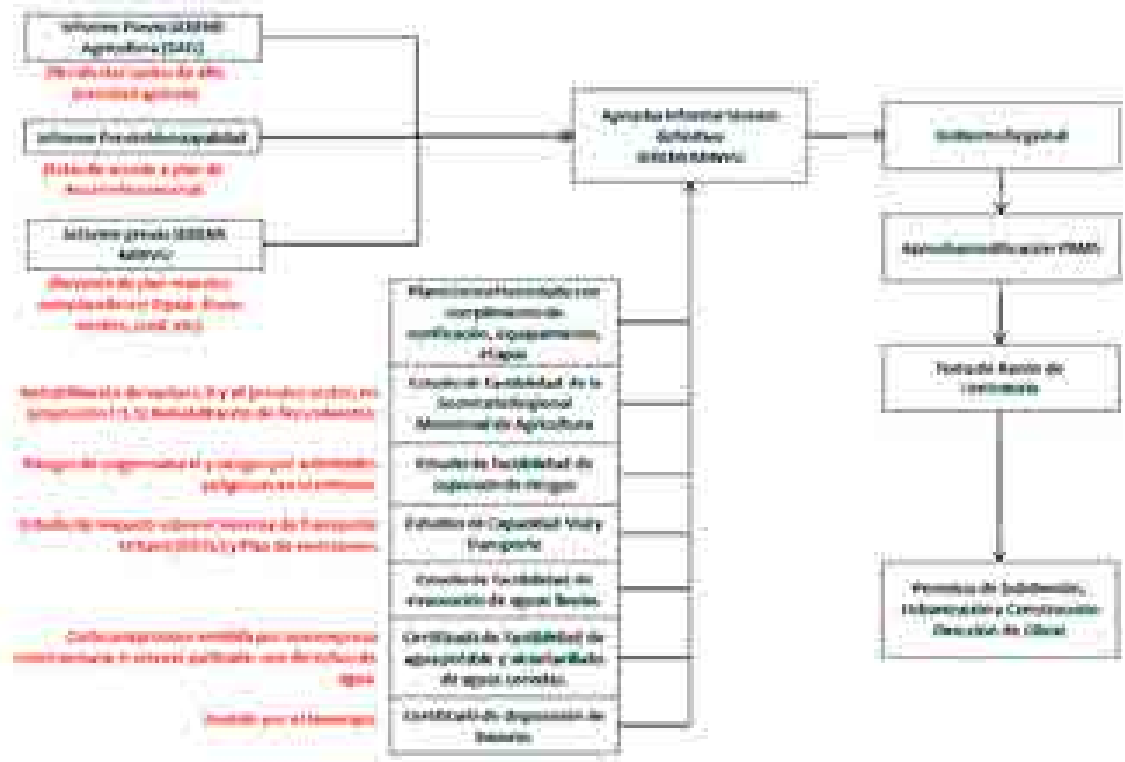

Figura 9.16. Esquema de la tramitación y condiciones para desarrollar un Proyecto de Desarrollo Urbano Condicionado (PDUC). Por Transsa (2014, p. 20). 
elaborado por la SEREMI MINVU teniendo todos los otros informes favorables, el cual luego debe ser remitido al Gobierno Regional para su tramitación.

Los estudios específicos que debe presentar son:

- Solución de Aguas Lluvias.

- Certificado de Factibilidad de Agua Potable y Alcantarillado, o una solución particular con derechos de aprovechamiento de aguas, sin afectar los usos rurales del entorno.

- Disposición de Residuos.

- Estudios de Impacto sobre el Sistema de Transporte Urbano (EISTU), presentado a la SEREMI de Transporte y Telecomunicaciones, lo que incluye la propuesta de obras de mitigación vial, a aprobar por este organismo.

- Estudio de suficiencia de equipamiento de salud y deporte.

- Estudios de Riesgos: Según los riesgos presentes en el predio, realizando los estudios y proyectos para mitigar los riesgos.

- Ingreso al Sistema de Evaluación de Impacto Ambiental (SEIA) de acuerdo a la ley 19.300 .

\subsubsection{El Artículo 55 de la LGUC permite urbanizar en áreas rurales en casos excepcionales.}

El citado artículo impide urbanizar fuera de los límites urbanos establecidos, salvo ciertas excepciones, entre las cuales se encuentran la formación de conjuntos de vivienda social, viviendas para industrias, balnearios, o dotar de equipamiento sectores rurales. Esto deberá contar con la autorización de la SEREMI de Agricultura y con el informe favorable de la SEREMI MINVU, buscando resguardar que no se originen nuevos núcleos urbanos al margen de la planificación urbana-regional.

\subsection{ESCENARIOS NORMATIVOS}

A partir del análisis de la normativa aplicable al predio, se puede concluir que el objetivo de la donación que hizo el Estado a la Universidad de Chile en el año 1994, no se puede cumplir. Vale decir, las normas y regulaciones que el mismo estado ha ordenado, incluyendo el PRMS-100 promulgado el 6 de octubre de 1994 (pocos meses después de la donación), impiden que, de los compromisos asumidos -que consistían en desarrollar una ciudad universitaria, un parque científico-tecnológico y un parque público-, sólo se puede cumplir parcialmente, ya que sólo se podría ejecutar el parque público.

Pese a este escenario, pocos meses después de asumir la dirección del proyecto, la Contraloría General de la República inició una investigación para verificar el avance del proyecto, con la posible pena de perder el predio por no haber concretado el proyecto.

A partir de estas circunstancias, y del marco normativo que hemos expuesto, se proponen distintas alternativas para hacer viable un Plan Maestro para Carén. Todos ellos tienen altos grados de incertidumbre, largos tiempos de tramitación y costos asociados difíciles de evaluar. A continuación, se presentan tres escenarios posibles:

\subsubsection{Escenario 1: Seguir con Plan Maestro de 2004 (Aplicación Artículo} 2.3.31):

Este escenario es el que hasta 2014 siguió la Fundación Valle Lo Aguirre, para proyectar el desarrollo del terreno, según el cual se aprovecha el $20 \%$ que es posible construir con usos complementarios al área verde.

La factibilidad de este escenario, se ha visto afectada por dos razones fundamentales, que se han definido en el último tiempo, la primera referida a las condiciones anómalas en que fue asignada su condición de Parque Intercomunal en el PRMS-94, ya que dicho Instrumento de Planificación Territorial no tiene la atribución de normar este uso de suelo fuera del límite urbano, situación que deja sin efectos la posibilidad de dar aplicación al Artículo 2.1.31 de la Ordenanza General de urbanismo y Construcción (OGUC) para los fines que autorizó en su momento la SEREMI MINVU a través del citado ORD N 2183 de 2004. 
Asimismo, debe tenerse en consideración el hecho que el año 2004 se modificó el Artículo 59 de la Ley General de Urbanismo y Construcciones (LGUC), dando una vigencia máxima a los Parques Intercomunales de cinco años, plazo que fue prorrogado por un año más, lo cual provocó que, de haber existido tal regulación, esta caducó, con todos sus efectos en febrero de 2010.

La única arista, que posibilita a la universidad (como propietario) seguir este camino es el visto bueno otorgado por el SEREMI MINVU en Julio de 2004 al Plan Maestro, en virtud del artículo 2.1.31. Sin embargo, este Ordinario no autoriza la materialización del proyecto, y solo autoriza el porcentaje de ocupación de suelo presentada en el Plan Maestro, lo cual se reafirma así cuando en el texto se indica, "La autorización de este proyecto solo acoge la ocupación de suelo que se grafica en el Plano PMLC-OS-01, por lo cual no inhibe en modo alguno las facultades municipales respecto a otorgamiento de permisos municipales que establece la legislación vigente (...)". (SEREMI-MINVU, 2004).

El conjunto de aprobaciones que tiene que obtener un proyecto de esta naturaleza, son vinculantes entre sí, pero no obligan necesariamente a la aprobación por parte de otro organismo que debe contar con la aprobación preliminar de la SEREMI, es decir, si el proyecto tiene el visto bueno por parte de la SEREMI MINVU, esto no obliga a la Dirección de Obras Municipales a autorizar las edificaciones. Por otra parte, debe tenerse en consideración que el predio, aun cuando cuenta con la aprobación de la SEREMI MINVU para efectos de lo señalado en el citado artículo 2.1.31, se encuentra emplazado fuera del límite urbano de la Región Metropolitana, vale decir en área rural, por lo que cualquier proyecto para fines distintos de la actividad agro-productiva requiere ser sancionado a través de la aplicación del Artículo 55 de la LGUC, que solicita ciertas condiciones excepcionales para la urbanización fuera de este límite. Por lo tanto, se vuelve inconducente evaluar este primer escenario como una alternativa factible, sin que previamente se resuelva la aplicación de la normativa ya señalada.

En consecuencia, continuar con Plan Maestro, que sancionó el año 2004 la SEREMI MINVU, -en lo que a autorizar el $20 \%$ de Ocupación de Suelo se refiere-, y en virtud de lo dispuesto en el Artículo 2.1.31 de la OGUC, requiere un particular dueño de un Área Verde no consolidada para poder edificar obras complementarias a la misma, por cuanto ello no autoriza edificar. Por otra parte, la condición de Parque Intercomunal se encontraba mal aplicada por el PRMS, y aunque así fuera considerada, dicha condición urbanística se encuentra caduca desde febrero de 2010. Sin perjuicio de lo anterior, debe reconocerse el derecho adquirido por el propietario del predio de la aprobación de la SEREMI.

\subsubsection{Escenario 2: Aplicación del Artículo 55 de la Ley General de Urbanis- mo y Construcciones:}

Esta segunda alternativa se refiere a un artículo que en su origen pretende proteger el espacio rural de la urbanización no planificada. Sin embargo, considera ciertas excepciones que son necesarias para el espacio rural y que tienen también un beneficio social, como es el caso de los villorrios rurales (vivienda social rural), y equipamiento complementario a los usos rurales (este fue el subterfugio para instalar, por ejemplo, la estación de servicio Shell en la ruta 68). De hecho, se insiste en resguardar que no se produzca un nuevo polo urbano fuera de la planificación urbana- regional.

De acuerdo a esto, el Plan Maestro proyectado para el predio no cumple con el espíritu de este artículo, toda vez que las construcciones proyectadas, dada su escala e impacto, no tienen por objeto dotar al espacio rural de equipamiento.

La interpretación de este artículo es importante, ya que la aprobación de un Plan Maestro de acuerdo a este artículo depende de más de un organismo. Se requiere del informe favorable de la Secretaría Regional del Ministerio de la Vivienda y Urbanismo y del Servicio Agrícola Ganadero (quien evalúa que la calidad del suelo no sea favorable para la agricultura), con los cuales la Dirección de Obras Municipales debe decidir su aprobación.

Todos estos organismos tienen la discrecionalidad de no aprobar el cambio de uso de suelo, si es que consideran que el proyecto no se ajusta al artículo 55. 
Es por estas razones, esta vía es poco factible, y, que de ser posible realizar algún avance por este medio, no permitiría un uso muy intensivo del suelo. Sin perjuicio de lo anterior, esta acción es la que el Ministerio de Agricultura ha denominado como Cambio de Uso de Suelo (CUS) para el área rural, proceso que debe tener en cuenta los siguientes alcances:

Normativa para Cambio de Uso de Suelo Rural (CUS):

La localización espacial de actividades con fines distintos al silvoagropecuario, que deban sentarse sobre el territorio rural, se determina mediante el procedimiento del Cambio de Uso del Suelo (CUS).

Aun cuando dicho concepto no se encuentra específicamente definido en un cuerpo legal, del Art. 55 del. D.F.L No 458 de 1975, se desprende que el cambio de uso del suelo se aplica en predios rústicos ubicados fuera de los límites urbanos, cuando se destine parte o la totalidad de la superficie de dichos predios, a fines no agrícolas, es decir, industriales, habitacionales, turísticos y/o de equipamiento comunitario.

No obstante lo anterior, el cambio de uso del suelo se encuentra citado en el texto del Art. 4 del D.S. No 718/77 del MINVU, que crea la Comisión Mixta Agricultura y Urbanismo, y el Art. 46 de la Ley No 18.755/89, Ley Orgánica del Servicio Agrícola y Ganadero, modificada por Ley No 19.283/94. En este contexto, el cambio de uso del suelo constituye un instrumento de gestión particularmente relevante en materia de ordenamiento del territorio rural.

La competencia del Ministerio de Agricultura, respecto del cambio de uso del suelo en el sector rural, se establece en la Ley General de Urbanismo y Construcciones, en lo dispuesto en los artículos 52, 53 y 55 del D.F.L. No 458 de 1975. Por otra parte, el D.S. No 211 de 1993, del Ministerio de Agricultura, aclara que el Servicio Agrícola mencionado en el inciso 4 del Art. 55, es la Secretaría Regional Ministerial de Agricultura y que ésta debe solicitar informe al SAG para resolver. Además, el Art. 46 de la Ley No 19.283 de 1994, Ley Orgánica del Servicio Agrícola y Ganadero, establece la participación del SAG en el trámite de cambio de uso del suelo al disponer que: "para autorizar un cambio de uso del suelo en el sector rural, de acuerdo al artículo 55 del DFL No 458/75, se requerirá informe previo del Servicio. Dicho informe deberá ser fundado y público, expedido por el Servicio dentro del plazo de 30 días, contados desde que haya sido requerido." (Ley No 19.283, 1994, Artículo 46).

Criterios Considerados en el Otorgamiento del Cambio de Uso del Suelo.

- Es política del Ministerio de Agricultura propender a la utilización del suelo rural, a través del cambio de uso del suelo, aplicando los siguientes criterios:

- Evitar la pérdida irreversible de los suelos agrícolas de mayor potencial productivo, regulando la instalación de actividades ajenas a la silvoagropecuaria, en sectores de elevada aptitud productiva, considerando que estos suelos constituyen un recurso natural básico, escaso y fundamental para la producción silvoagropecuaria.

- Para cumplir con este objetivo, se debe tender a conservar los suelos de las Clases I, II y III de capacidad de uso y otros de especial interés para la agricultura, favoreciendo la instalación de las actividades no agrícolas en los suelos de clases con menor potencial productivo.

- Proteger los ecosistemas de interés especial por su diversidad biológica y/o presencia de especies de flora y fauna amenazadas en el área de influencia del proyecto.

- Minimizar las externalidades que generen los proyectos 0 actividades industriales, mineras, habitacionales, turísticas, entre otros, que afecten el desarrollo agrícola del entorno. (Ley No 19.283, 1994, Artículo 46).

Procedimiento para la Autorización de Cambio de Uso del Suelo Inciso $3^{\circ}$, artículo 55, DFL No 458:

[...]cuando sea necesario subdividir y urbanizar terrenos rurales para complementar alguna actividad industrial con viviendas, dotar de equipamiento a algún sector rural, o habilitar un balneario o campamento turístico, o para la construcción de conjuntos habitacionales de viviendas sociales o de viviendas de 
hasta un valor de 1.000 unidades de fomento, que cuenten con los requisitos para obtener el subsidio del Estado, la autorización que otorgue la Secretaría Regional del Ministerio de Agricultura requerirá del informe previo favorable de la Secretaría Regional del Ministerio de la Vivienda y Urbanismo. Este informe señalará el grado de urbanización que deberá tener esa división predial, conforme a lo que establezca la Ordenanza General de Urbanismo y Construcciones.

Las solicitudes, con sus antecedentes, deben, ser dirigidas al SEREMI de Agricultura. No obstante, si la SEREMI de Agricultura por delegación así lo estableciera, los antecedentes podrán ser presentados en las Direcciones Regionales u Oficinas Sectoriales del Servicio Agrícola y Ganadero (SAG), con el propósito de agilizar la gestión y el trámite al usuario.

Para dar trámite a las solicitudes, el SEREMI de Agricultura utilizará el siguiente procedimiento:

- Solicitar informe a la SEREMI de Vivienda y Urbanismo, acerca si la subdivisión y urbanización solicitada origina o no un nuevo núcleo urbano al margen de la planificación urbano-regional. Junto con ello dicha autoridad deberá indicar el grado mínimo de urbanización que deberá tener la división.

- Tener a la vista informe técnico del SAG, el cual deberá ser emitido en un plazo máximo de 30 días.

- Solicitar un informe al Comité Mixto, si los informes de los SEREMI de Agricultura y Vivienda son contradictorios y alguna de dichas autoridades lo estimare conveniente. En caso de persistir la discrepancia, se podrá consultar a la Comisión Mixta.

- Emitir una resolución sobre la solicitud. En caso de autorizar, deberá contar con el informe favorable de la SEREMI del MINVU en que se señalen el grado mínimo de urbanización que deberá tener esa subdivisión predial.

- La resolución deberá ser entregada al requirente. Para otorgar la aprobación correspondiente la Dirección de Obras Municipales requerirá de la autorización de la SEREMI de Agricultura.

Inciso $4^{\circ}$, artículo 55, DFL № 458:

Igualmente, las construcciones industriales, de infraestructura, de equipamiento, turismo y poblaciones, fuera de los límites urbanos, requerirán, previamente a la aprobación correspondiente de la Dirección de Obras Municipales, del informe favorable de la Secretaría Regional del Ministerio de la Vivienda y Urbanismo y del Servicio Agrícola que correspondan. El mismo informe será exigible a las obras de infraestructura de transporte, sanitaria y energética que ejecute el Estado. (DFL N0458,1976).

Las solicitudes, con sus antecedentes, deben ser dirigidas al SEREMI de Agricultura y al SEREMI de Vivienda. No obstante, si la SEREMI de Agricultura por delegación así lo estableciera, los antecedentes podrán ser presentados en las Direcciones Regionales u Oficinas Sectoriales del Servicio Agrícola y Ganadero (SAG), con el propósito de agilizar la gestión y el trámite al usuario. Para dar trámite a las solicitudes, el SEREMI de Agricultura utilizará el siguiente procedimiento:

- Solicitar un informe a la Dirección Regional del SAG acorde lo establecido en el Art. 46 de la Ley No 19.283, el cual no tendrá el carácter de vinculante. Para la elaboración de este Informe, se deberá tener a la vista el Informe Técnico de terreno, según los antecedentes presentados en el Anexo No 1.

- Solicitar un informe al Comité Mixto, si los informes de los SEREMI de Agricultura y Vivienda son contradictorios y alguna de dichas autoridades lo estimare conveniente. En caso de persistir la discrepancia, se podrá consultar a la Comisión Mixta.

- Emitir un informe sobre la solicitud.

- El informe deberá ser entregado al usuario. Para otorgar la aprobación correspondiente la Dirección de Obras Municipales, requerirá de los informes favorables de la SEREMI de Agricultura y de Vivienda. 
Si al proyecto le corresponde someterse al Sistema de Evaluación de Impacto Ambiental, es decir, se encuentra incluido en la nómina de proyectos 0 actividades establecidas en el artículo 10 de la Ley № 19.300 y del artículo $3^{\circ}$ del D.S. No 30/97, una vez, que el expediente de solicitud ha ingresado a la SEREMI de Agricultura 0 al SAG, éstos deben admitir a trámite las aludidas solicitudes y avanzar en el procedimiento administrativo pertinente hasta antes de su resolución.

La resolución o el informe que emite el SEREMI de Agricultura, según sea el caso (Inciso $3^{\circ} \circ 4^{\circ}$ del Art. 55 del DFL No 458), deberá ser entregado al requirente cuando el proceso de Evaluación de Impacto Ambiental haya concluido, y se cuente con la Resolución de Calificación Ambiental favorable

\subsubsection{Escenario 3: Modificación de PRMS.}

Este escenario fue planteado por la empresa Transsa, especialista en tasaciones, para la aprobación de un Proyecto de Desarrollo Urbano Condicionado (PDUC). De acuerdo a las condiciones de usos que se le quieren asignar al predio, ésta sería una figura que se adapta mejor. Supone que el desarrollo tiene carácter industrial. Con los mismos requerimientos de Desarrollos Industriales y/o Empresariales Condicionados (DIEC), que tiene una condición similar a la de las PDUC, pero que no está enfocado a la vivienda como esta última.

Las condiciones que permite esta figura son bastante favorables para el desarrollo de equipamiento y de tipo productivas (almacenamiento y distribución). Tiene la restricción de permitir equipamiento de salud solo ambulatorio, lo cual de todas formas permite centros de consultas médicas.

Para aprobar esta figura se debe tener el informe favorable de cuatro organismos: SEREMI MINVU, Ministerio de Agricultura, MOP y Asesor Urbanista de la Municipalidad, para finalmente pasar al Gobierno Regional. El proceso de aprobación implica realizar los estudios detallados en la sección referida a esta figura en el capítulo de normativa posiblemente aplicable, así como también implementar las obras de mitigación necesarias.

Sin embargo, para el Predio Laguna Carén hay una incertidumbre respecto a su aplicabilidad, ya que el PRMS indica que esta figura se puede emplazar en Áreas de Interés Silvoagropecuario, y el predio no tiene esa condición. Ya que actualmente no es aplicable su condición de área verde, el predio se encuentra en un vacío normativo, sobre el cual sólo se aplicarían las Áreas de Riesgos preexistentes. En este sentido se tiene que pronunciar la Dirección de Desarrollo Urbano (DDU) para interpretar el PRMS y aplicar una norma coherente con el sector. En este camino, se considera que lo más coherente es aplicar la norma que se presenta en el entorno, es decir ISAM 1.

\subsubsection{Complemento a los 3 escenarios: Sistema de Evaluación Ambiental.}

Según la Ley 19.300: Bases Generales del Medio Ambiente:

Artículo 10. Los proyectos o actividades susceptibles de causar impacto ambiental, en cualquiera de sus fases, que deberán someterse al sistema de evaluación de impacto ambiental, son los siguientes:

a) Acueductos, embalses o tranques y sifones que deban someterse a la autorización establecida en el artículo 294 del Código de Aguas, presas, drenaje, desecación, dragado, defensa 0 alteración, significativos, de cuerpos o cursos naturales de aguas

b) Líneas de transmisión eléctrica de alto voltaje y sus subestaciones;

c) Centrales generadoras de energía mayores a $3 \mathrm{MW}$;

d) Reactores y establecimientos nucleares e instalaciones relacionadas;

e) Aeropuertos, terminales de buses, camiones y ferrocarriles, vías férreas, estaciones de servicio, autopistas y los caminos públicos que puedan afectar áreas protegidas;

f) Puertos, vías de navegación, astilleros y terminales marítimos;

g) Proyectos de desarrollo urbano o turístico, en zonas no comprendidas en alguno de los planes a que alude la letra siguiente; [énfasis agregado]

h) Planes regionales de desarrollo urbano, planes intercomunales, planes reguladores comunales, planes seccionales, proyectos industriales o inmobiliarios que los modifiquen o que se ejecuten en zonas declaradas latentes 0 saturadas;

i) Proyectos de desarrollo minero, incluidos los de carbón, petróleo y gas, com- 
prendiendo las prospecciones, explotaciones, plantas procesadoras y disposición de residuos y estériles, así como la extracción industrial de áridos, turba o greda;

j) Oleoductos, gasoductos, ductos mineros u otros análogos;

k) Instalaciones fabriles, tales como metalúrgicas, químicas, textiles, productoras de materiales para la construcción, de equipos y productos metálicos y curtiembres, de dimensiones industriales;

I) Agroindustrias, mataderos, planteles y establos de crianza, lechería y engorda de animales, de dimensiones industriales;

m) Proyectos de desarrollo o explotación forestales en suelos frágiles, en terrenos cubiertos de bosque nativo, industrias de celulosa, pasta de papel y papel, plantas astilladoras, elaboradoras de madera y aserraderos, todos de dimensiones industriales;

n) Proyectos de explotación intensiva, cultivo, y plantas procesadoras de recursos hidrbiológicos;

o) Producción, almacenamiento, transporte, disposición o reutilización habituales de sustancias tóxicas, explosivas, radioactivas, inflamables, corrosivas 0 reactivas;

p) Proyectos de saneamiento ambiental, tales como sistemas de alcantarillado y agua potable, plantas de tratamiento de aguas o de residuos sólidos de origen domiciliario, rellenos sanitarios, emisarios submarinos, sistemas de tratamiento y disposición de residuos industriales líquidos o sólidos;

q) Ejecución de obras, programas 0 actividades en parques nacionales, reservas nacionales, monumentos naturales, reservas de zonas vírgenes, santuarios de la naturaleza, parques marinos, reservas marinas o en cualesquiera otras áreas colocadas bajo protección oficial, en los casos en que la legislación respectiva lo permita,

r) Aplicación masiva de productos químicos en áreas urbanas o zonas rurales próximas a centros poblados 0 a cursos 0 masas de agua que puedan ser afectadas. (Ley 19.300, Artículo 10).

Por su parte, el Decreto Supremo DS 40; Reglamento del Sistema de Evaluación de Impacto Ambiental

Artículo 3.- Tipos de proyectos o actividades.

Los proyectos 0 actividades susceptibles de causar impacto ambiental, en cualesquiera de sus fases, que deberán someterse al Sistema de Evaluación de Impacto Ambiental, son los siguientes:

h) Proyectos industriales o inmobiliarios que se ejecuten en zonas declaradas latentes 0 saturadas.

h.1. Se entenderá por proyectos inmobiliarios aquellos loteos o conjuntos de viviendas que contemplen obras de edificación y/o urbanización, así como los proyectos destinados a equipamiento, y que presenten alguna de las siguientes características:

h.1.1. Que se emplacen en áreas de extensión urbana 0 en área rural, de acuerdo al instrumento de planificación correspondiente y requieran de sistemas propios de producción y distribución de agua potable y/o de recolección, tratamiento y disposición de aguas servidas;

h.1.2. Que den lugar a la incorporación al dominio nacional de uso público de vías expresas o troncales;

h.1.3. Que se emplacen en una superficie igual o superior a siete hectáreas (7 ha)

o consulten la construcción de trescientas (300) o más viviendas; o h.1.4. Que consulten la construcción de edificios de uso público con una capacidad para cinco mil (5.000) o más personas o con mil (1.000) o más estacionamientos.

Se exceptuarán dichos proyectos de su ingreso al Sistema de Evaluación de Impacto Ambiental en aquellas zonas declaradas latentes o saturadas, que cuenten con un Plan de Prevención o Descontaminación vigente, dictado de acuerdo al artículo 44 de la Ley y se permita el desarrollo de proyectos inmobiliarios en un Instrumento de Planificación Territorial aprobado ambientalmente conforme a la Ley.

El Decreto Supremo D.S. № 131 declara a la Región Metropolitana Zona Saturada y Latente

Decreto Supremo del Ministerio Secretaría General de la Presidencia, publicado en el Diario Oficial del $1^{\circ}$ de agosto de 1996 . Declara a la Región Metropolitana 
Zona Saturada por ozono (O3), material particulado respirable (PM10), partículas en suspensión (PTS), monóxido de carbono (CO) y Zona Latente por dióxido de nitrógeno (NO2).

De acuerdo a lo señalado en la Ley 19.300 en su artículo 43, el primer paso para el desarrollo de planes de descontaminación o de prevención es la declaración y delimitación de zonas saturadas y/o latentes.

Ahora bien, según el mismo cuerpo legal, es Zona Saturada aquella en que una o más normas de calidad ambiental se encuentran sobrepasadas y Zona Latente aquella en que la medición de la concentración de contaminantes en el aire, agua o suelo, se sitúa entre el $80 \%$ y el $100 \%$ de la respectiva norma de calidad ambiental.

En el año 1978 (Resolución Nº 1215/78 del Ministerio de Salud) se establecieron las normas primarias de calidad del aire para Partículas Totales en Suspensión (PTS), Dióxido de Azufre ( $\mathrm{SO}_{2}$ ), Monóxido de Carbono (CO), Ozono $\left(\mathrm{O}_{33}\right)$ y Dióxido de Nitrógeno $\left(\mathrm{NO}_{2}\right)$, y en el año 1992 se publicó la norma primaria de calidad del aire para PM 10 (D.S. No 185/92 del Ministerio de Minería). A partir de estas normas y sobre la base de los datos recopilados entre los años 1993 y 1995, en el año 1996 la Región Metropolitana fue declarada Zona Saturada por Ozono, MP 10 , PTS y CO, y Zona Latente por $\mathrm{NO}_{2}$.

\subsubsection{Síntesis y diagnóstico de los escenarios}

La evaluación de los escenarios propuestos dependerá de los intereses en juego: si se evalúa económicamente, el escenario de un Desarrollo Industrial y/o Empresarial Condicionado es el más propicio para asegurar un desarrollo a largo plazo, otorgando una mayor libertad en los usos del predio, más constructibilidad y por lo tanto una mejor rentabilidad.

El primer escenario (uso del $20 \%$ por área verde) tiene trabas en cuanto a la situación irregular como área verde, y se considera que el visto bueno otorgado por la SEREMI MINVU al Plan Maestro de 2004 es insuficiente ya que hay más instancias de aprobación que no fueron resueltas en su momento.

El segundo escenario (aplicación de Artículo 55 de la LGUC), tiene por objeto otro tipo de usos e intensidades a las previstas para este predio, y dado que la decisión de dar visto bueno y aprobación en las diferentes instancias es discrecional, fácilmente se puede negar la autorización por no cumplir con el espíritu de esta ley.

El tercer escenario se basa en una figura normativa que da mayores certezas respecto a un desarrollo en el tiempo, y que es coherente con la escala del proyecto. También existen antecedentes de su uso: el parque industrial ENEA, a unos $5 \mathrm{~km}$. de Laguna Carén, está tramitando una figura de este tipo. Este último proyecto desistió de su tramitación como PDUC dado los requerimientos que se exigían, para acogerse a un Desarrollo Industrial y/o Empresarial Condicionado, que tendría menores exigencias.

Sin perjuicio del escenario que se aborde, lo que, si resulta claro, es que cualquiera de ellos deberá someterse al Sistema de Evaluación Ambiental, y con ello quedar sujeto a la resolución que sobre el particular adopte la autoridad ambiental competente.

Como veremos en el desarrollo del Plan Maestro, también podemos asumir las dificultades normativas como variables de diseño. Considerar las restricciones en la ocupación de suelo como una posibilidad de ejercer la conciencia de límite. ¿es posible desarrollar un plan maestro viable con estas restricciones? ¿qué nos dice el sitio, incluidas sus normas y leyes, respecto a su uso?

Los planes urbanísticos y territoriales son instrumentos de proyecto del espacio en el que vivimos y actuamos. Son, por tanto, inevitablemente proyectos del paisaje del futuro (Busquets \& Cortina, 2009, p. 379). 


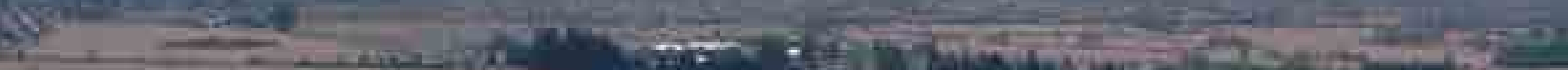

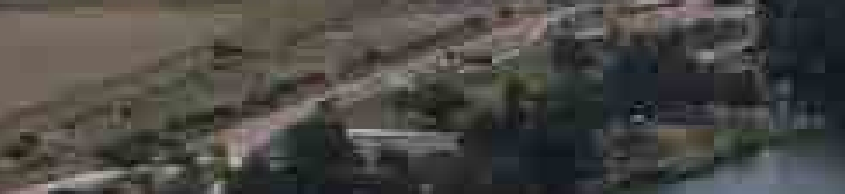

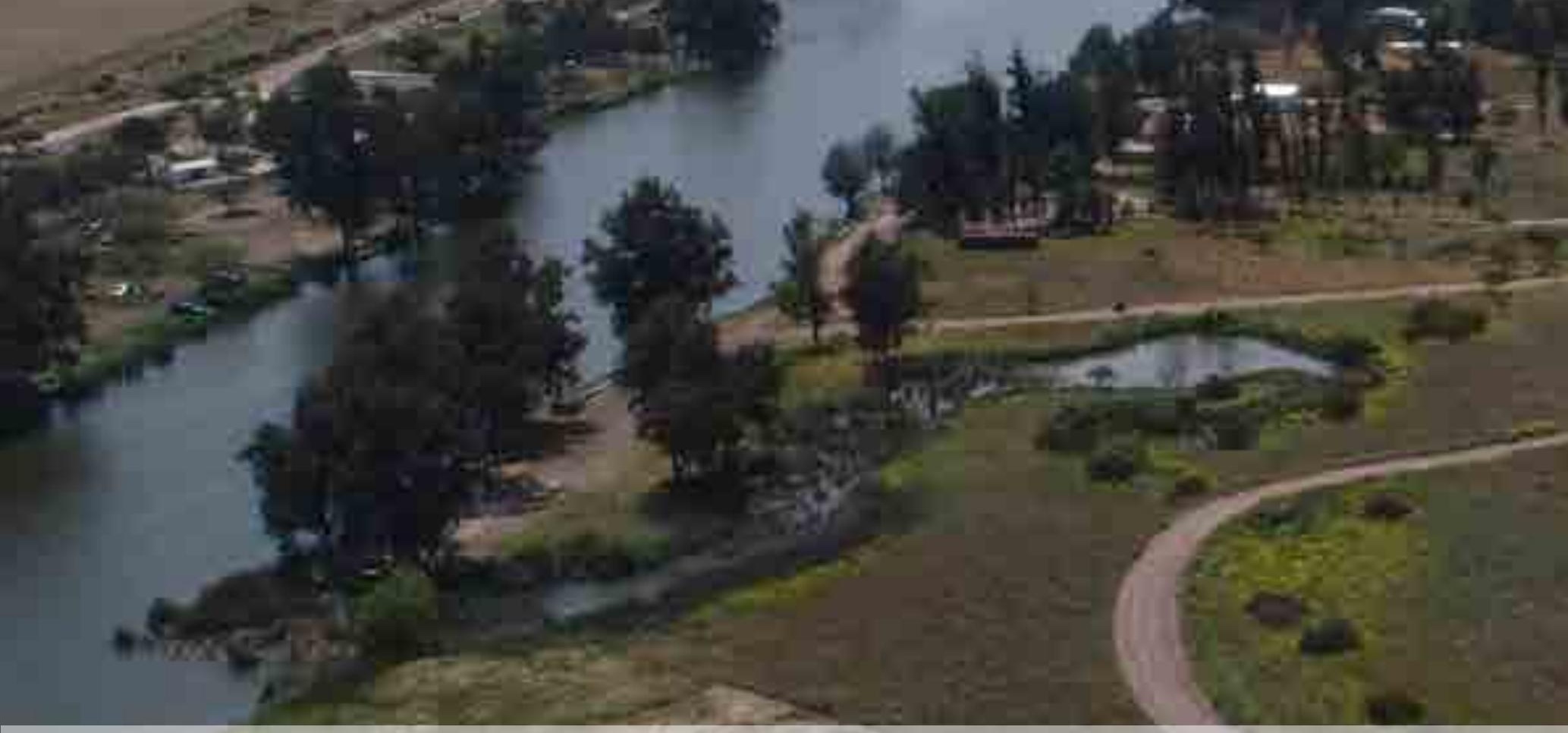

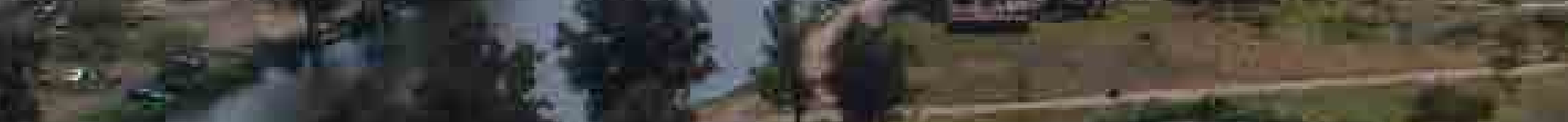

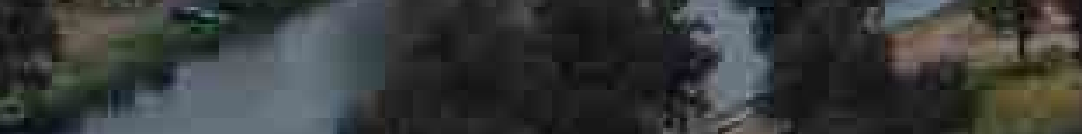




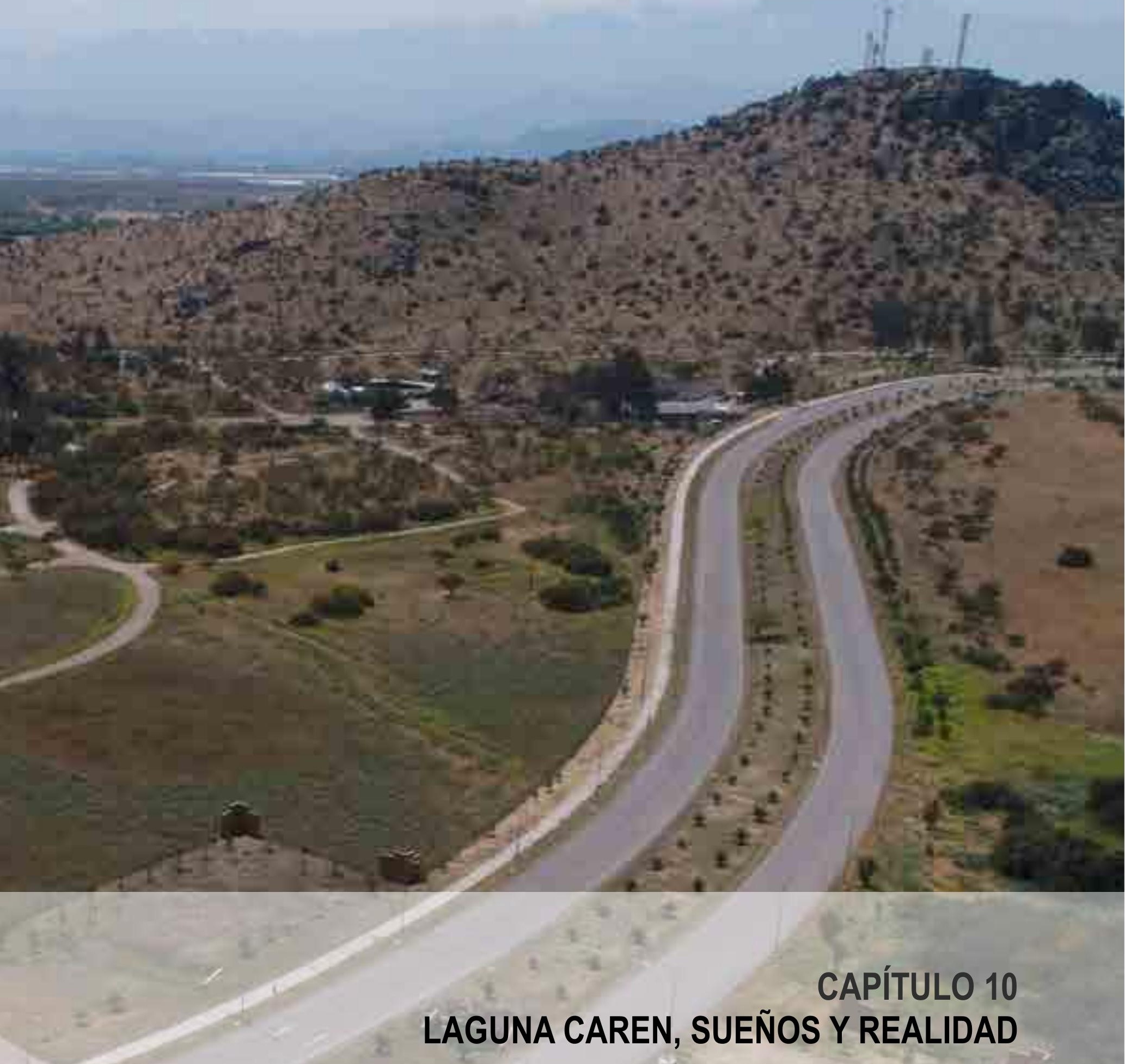




\title{
LAGUNA CAREN, SUEÑOS Y REALIDAD
}

\author{
Laguna Carén como proyección de las visiones de desarrollo en el \\ tiempo.
}

\subsection{INTRODUCCIÓN}

Así como en el capítulo pasado hemos hecho un trabajo hermenéutico, con fines comprensivos e interpretativos, analizado el complicado marco normativo que orienta ${ }^{327}$ el desarrollo de esta zona; en las páginas que siguen se propone un ejercicio de ética aplicada, en el que intentaremos reconocer en los proyectos de otros arquitectos, bajo qué criterios han problematizado el sitio y cómo han interpretado el marco de posibilidades para el desarrollo de un plan maestro.

Recordando lo señalado en el capítulo 2, diríamos que esta problematización será muy diferente si ésta se aborda desde el punto de vista estético, lógico 0 ético. Cada punto de partida determina la conducta del proyecto de acuerdo a un régimen específico. Lo importante sería entonces, determinar qué consecuencias tiene optar por una u otra postura.

Laguna Carén, pasa a ser en este capítulo, no sólo objeto de estudio, sino también objeto de proyecto. Las ideas (planes y proyectos) que analizaremos han quedado en el campo de la imaginación, de los sueños no realizados. Al repasarlos, como al hojear un álbum de familia, reconocemos rasgos comunes, gestos particulares, tensiones e intereses extraños. En ellos también pueden leerse posiciones ideológicas, conceptos de paisaje, ideas de ciudad y tras éstas, a sus artífices.

Como estudiamos en el capítulo 6 , este predio fue parte del fundo Lo Aguirre, que mantuvo su integridad, a partir del mayorazgo del mismo nombre que perduró hasta fines del siglo XIX. Esta hacienda estuvo dedicado principalmente a la ganadería. Luego se subdividió a causa de la presión que representó la explotación de la mina Lo Aguirre, los procesos de nacionalización del cobre y de la Reforma Agraria, sin llegar ésta última a completarse. Como hemos visto también, a partir del Plan Regulador Metropolitano de Santiago (PRMS) de 1994, este paño quedó señalado como Parque Metropolitano, como un órgano de la ciudad, pese a que al mismo tiempo quedó fuera del límite urbano, conservando hasta hoy su condición de zona rural. A partir de la interpretación de las normas y del compromiso de la universidad por llevar adelante un parque científico-tecnológico, una ciudad universitaria y un parque público en el predio, se han desarrollado, casi ininterrumpidamente, planes maestros, modificaciones y propuestas particulares, las que pueden calificarse como "sueños". Son sueños que han proyectado, por cierto, importantes profesionales. En la segunda parte de este capítulo, se describen los vestigios de esas ideas en el terreno, fundamentalmente plasmadas en la etapa 1 de urbanización, que técnicamente conocemos como "situación existente", la que se complementa con un análisis del desarrollo que tiene este valle como extensión de la ciudad. De este modo pasaremos de la meso-escala a la micro escala, para luego volver a mirar el sitio a macro-escala configurando asi "la realidad" desde la que proyectaremos el plan maestro.

\subsection{LOS SUEÑOS: PLANES MAESTROS ANTERIORES}

\subsubsection{Plan Maestro Parque Metropolitano, Año 1992 - Ilustre Municipalidad de Pudahuel}

Dos años antes de la aprobación del PRMS-1994, y anticipando la vocación y rol del predio en la comuna y la ciudad, la Municipalidad de Pudahuel, en 1992, desarrolló una propuesta para Carén denominada "Parque Metropolitano Laguna Carén" (Figura 10.1.). Este proyecto firmado por los arquitectos Camilo Ruíz Laulie y Alex W. Campbell, recogía la visión de la comuna sobre este lugar. El carácter del proyecto es el de un "Balneario", como lo fuera la Laguna Pudahuel 
hasta principios del siglo XX, formalizando algunas de las actividades que tienen lugar en distintas zonas del sitio, tales como:

- El grupo de aeromodelismo, que cuenta con 50 socios, dando cabida a distintas disciplinas como el vuelo a control remoto de aviones, planeadores y helicópteros, también botes a control remoto que tienes su espacio natural en la laguna

Los clubes de remo, canotaje, kayak y vela.

La zona de picnic que acoge, principalmente en los fines de semana, grupos familiares provenientes de toda la región Metropolitana.

Pese a la precariedad de las instalaciones actuales, Laguna Carén recibe anualmente un total de 48.282 personas (FVLA, 2017). Lo que representa una cantidad comparable con, por ejemplo, la Reserva Nacional Río Clarillo ${ }^{328}$ que tiene 13.185 ha y el año 2017 recibió 55.000 visitantes (Conaf, 2018).

La mayor afluencia de público general, -que actualmente paga por entrar-, se produce en las Fiestas Patrias (18 y 19 de septiembre). También desde el año 2016, se celebra en este lugar, la "Fiesta Mechona", acto que los estudiantes de la Universidad de Chile hacen anualmente como recepción a los nuevos alumnos (mechones). Esta fiesta, que normalmente se desarrolla como un paseo de una jornada, congrega a más de 3.000 personas.

De acuerdo al documento "Análisis y Diagnóstico, Condiciones Base para la Actualización del Plan Maestro del Predio Carén" (URBE, 2011), los fundamentos del Plan de 1992 fueron:

- Entregar un ambiente natural para el habitante de la ciudad, ante la necesidad de un ambiente que destense la agitada vida cotidiana de Santiago.

${ }^{328}$ La reserva Natural de Río Clarillo está ubicada al sudeste de Santiago, a $42 \mathrm{~km}$ de la Plaza de Armas en línea recta.

${ }^{329}$ El informe de la Fundación Atisba (2010), el Gran Santiago (área urbana de la Provincia de Santiago) registra un total de 2.392 hectáreas de áreas verdes, 10 que significa un promedio de $4 \mathrm{~m} 2 / \mathrm{hab}$. Si quisiéramos alcanzar la cifra recomendada por la OMS (9m2/hab) la ciudad debiera destinar nuevas 3.527 hectáreas de áreas verdes. Si adoptáramos el estándar de la ONU (16 m2/hab) la ciudad debiera cuadruplicar sus parques. En el caso de la comuna de Pudahuel, actualmente tiene 32 hectáreas de áreas verdes, con sólo un parque de más de 2 hectáreas (el Parque Santiago Amengual con 10 ha). Para superar su déficit y llegar a los $9 \mathrm{~m} 2 / \mathrm{hab}$ debiera incorporar 207 hectáreas de áreas verdes.

${ }^{330}$ Un caso destacable es el de la ciudad de Curitiba, en Brasil, que logró en 20 años, pasar de menos de $1 \mathrm{~m} 2 /$ hab. a los $51 \mathrm{~m} 2 /$ habitante que ostenta hoy.

${ }^{331}$ Este estudio explora la relación entre vínculos sociales, el espacio verde y la salud. Concluye, que menos espacios verdes en el entorno de vida de las personas, coincide con sentimientos de soledad y la percepción de falta de apoyo social.

- Falta de áreas verdes. Insuficiencia del Parque Metropolitano San Cristóbal para demanda de Santiago.

- Lejanía de otras soluciones, centros invernales, termas, costa, parques privados - Crear un parque de borde exterior cercano, siempre disponible.

- Predio Carén: tiene todas las características para ser este parque (URBE, 2011, p. 34).

Llama la atención que, pese a que este proyecto es una iniciativa comunal, no se alude a ninguna necesidad de Pudahuel, siendo que esta comuna es, dentro de la región, una de las cuatro con menos superficie de áreas verdes por habitante, equivalente a $1,3 \mathrm{~m}^{2}$ por persona ${ }^{329}$ (Atisba, 2010). La implementación de este parque al día de hoy, implicaría que la comuna de Pudahuel podría ostentar uno de los más altos estándares de área verde por habitante en el mundo, con 45,7 $\mathrm{m}^{2} /$ habitante, comparable con Washington, que tiene exactamente esa cifra ${ }^{330}$. Tampoco se realza la función social que este lugar podría tener para la comuna, otorgando oportunidades para una mayor integración de grupos que hoy se encuentran altamente segregados. Como destacan Jolanda Maas et al. (2009) las áreas verdes son un factor que refuerza el apego a la comunidad y entre los residentes, generando también beneficios en la salud de los habitantes ${ }^{331}$, especialmente para los niños, los ancianos y las personas más vulnerables económicamente (Maas et al., 2009, p. 595). Estas observaciones se hacen el 2019 sobre un plan realizado 27 años antes, lo que demuestra que la valoración de los parques, ha incluido factores que no se consideraban en las décadas pasadas. El diseño del Plan Maestro de 1992, interviene los cuerpos de agua e incorpora una serie de lagunas artificiales, en una suerte de red de pozones con islas temáticas que abarcan toda la extensión. Se introducen bosques, que encierran el estero Carén y una de las riveras de la laguna, modificando y ciertamente, borrando las unidades de paisaje existentes y los rastros de las capas históricas que perviven en el sitio. 


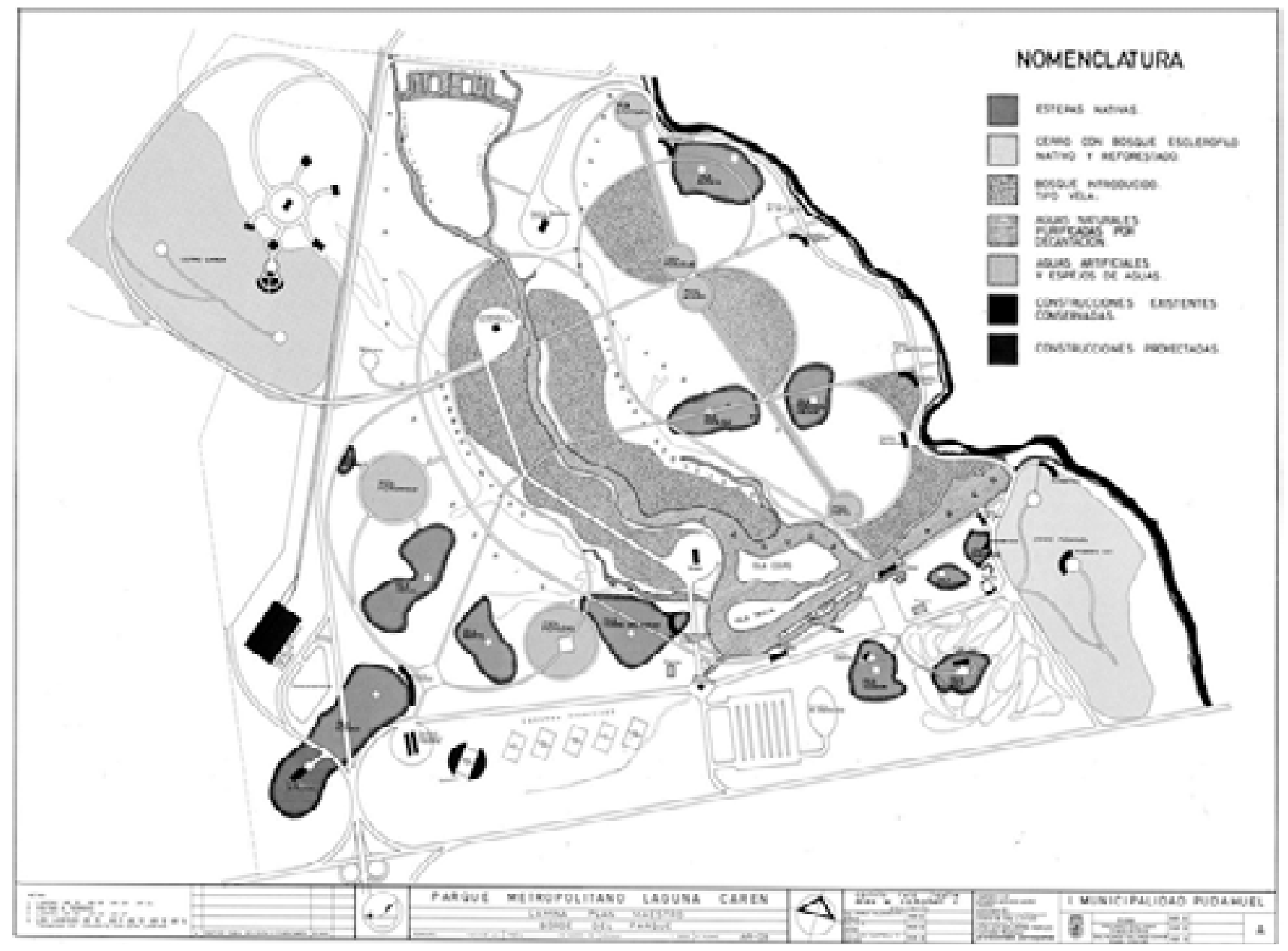

Tras el traspaso del predio Laguna Carén a la Universidad de Chile el año 1994, la universidad encomendó a la Fundación Valle Lo Aguirre ${ }^{332}$ la planificación territorial del predio, con el objetivo de cumplir con los compromisos de la donación, que consistía en el desarrollo de un parque científico tecnológico, una ciudad universitaria y un parque público de 200 ha en el plazo de cinco años.

\subsubsection{Plan Maestro MECSA, Año 1997}

En 1997, cuando la municipalidad de Pudahuel comienza la actualización de su Plan Regulador, y bajo el escenario de que este instrumento modificaría las condiciones de uso de suelo para el predio Carén, se desarrolló el primer Plan Maestro del Parque Científico Tecnológico por la Universidad de Chile. Este plan maestro fue desarrollado por el consorcio formado por MECSA de España del arquitecto Marcial Echeñique, ME\&P del Reino Unido e INECOM de Chile, y se basó en los lineamientos de la propuesta del Plan Regulador Comunal (PRC) en desarrollo.

El Plan Maestro (Figura 10.2.) acoge los tres componentes del programa que la universidad había comprometido al recibir la donación del predio, vale decir:

$\begin{array}{ll}\text { - } & \text { Parque Científico Tecnológico } \\ \text { - } & \text { Ciudad Universitaria } \\ & \text { Parque Público }\end{array}$

La propuesta de MECSA tiene un contundente estudio de base con dos grandes ejes argumentales para la planificación del predio: por una parte, la vialidad como elemento estructurante, y por otra, la fundamentación económica para el establecimiento de un parque tecnológico, analizando referentes internacionales, y elaborando un "estudio de mercado".
Figura 10.1. Plan Maestro "Parque Metropolitano Laguna Carén". Propuesta de la Ilustre Municipalidad de Pudahuel, 1992. En Archivo Fundación Valle Lo Aguirre
${ }^{332}$ Con fecha 9 de mayo de 1995, se dictó el D.S. $N^{\circ} 441$, del Ministerio de Justicia, que concedió personalidad jurídica y aprobó los estatutos de la "Fundación para la Administración y Desarrollo Tecnológico del Predio de la Universidad de Chile en el Valle Lo Aguirre" o "Fundación Valle Lo Aguirre", (FVLO), persona jurídica de derecho privado sin fines de lucro y con patrimonio propio, que tiene como objetivo y finalidad principal, el estudio, planificación, proposición, preparación, ejecución y posterior desarrollo de todo tipo de proyectos relativos al predio de propiedad de la Universidad. La Universidad aportó al patrimonio inicial de ésta, un derecho real de usufructo por el plazo de 30 años, sobre el referido predio. 
${ }^{333}$ Marcial Echeñique (1943-) Arquitecto de la Pontificia Universidad Católica de Chile. Master of Arts y Posdoctorado Catedrático ad Hominem de Estudios de Usos del Suelo y Transporte, Universidad de Cambridge. Professor of Land Use and Transport Studies, University of Cambridge. Fue decano de arquitectura de la Universidad de Cambridge UK (2004-2008), y Premio Nacional de Urbanismo del Reino Unido,

Figura 10.2. Plan Maestro MECSA, 1997. En Archivo Fundación Valle Lo Aguirre.
Cabe recordar que su autor, Marcial Echeñique ${ }^{333}$ es el gran artífice de las carreteras urbanas para el Gran Santiago, habiendo asesorado a los gobiernos de Allende, Aylwin, Frei, Lagos y Piñera. Para este arquitecto, el trasporte es un factor fundamental en la determinación de la forma de la ciudad. Desde esta idea, ha promovido un modelo de expansión urbana unificada por las redes tanto de transporte como de telecomunicaciones. El paradigma que subyace en esta propuesta es el de la ciudad sin límites.

El plan maestro pone en evidencia este criterio. En el plano de la estructura vial, claramente se observa el trazado de vías estructurantes (Figura 10.3.) en concordancia con la red urbana existente, pero sobre todo con la que estaba proyectada para el Gran Santiago, por el mismo Echeñique, que podemos observar en la Figura 10.4., sobre el nuevo PRMS-100. El modelo utilizado, MEPLAN, simula el mercado del suelo y el mercado de las infraestructuras y los relaciona entre sí. Como todo modelo de mercado, relaciona la demanda del suelo y construcciones generadas por la localización de las actividades productivas y residenciales, con la oferta inmobiliaria de cada área. Esta relación determina los precios de equilibrio que afectan tanto a los agentes demandantes (vivienda, locales comerciales, industrias, etc.) como a los oferentes (promotores inmobiliarios).

La demanda de transporte se genera a partir de los intercambios económicos y sociales entre las actividades, que se traducen en flujos físicos de carga y pasajeros. Esta demanda se relaciona con la oferta de infraestructuras, determinando los costos generalizados (precios) de uso de infraestructura, que incluyen los tiempos de viaje dados por la congestión en las redes. Este modelo, según la memoria del proyecto, fue calibrado primero para la macro-zona central y luego para la escala comunal en la región metropolitana. A partir de este estudio se llega al plan en el terreno (Figura 10.2.).

La propuesta plantea dos ejes principales, el primero corresponde a la vía de acceso desde la Ruta 68 y que continúa al norponiente bordeando a la Laguna Carén. El segundo eje cruza el predio en forma diagonal, desde el nororiente del predio, sector urbano de la comuna de Pudahuel, hacia el sur poniente del predio, hacia el sector del actual proyecto Praderas. El proyecto plantea organizar los programas del parque universitario y del parque tecnológico separados por

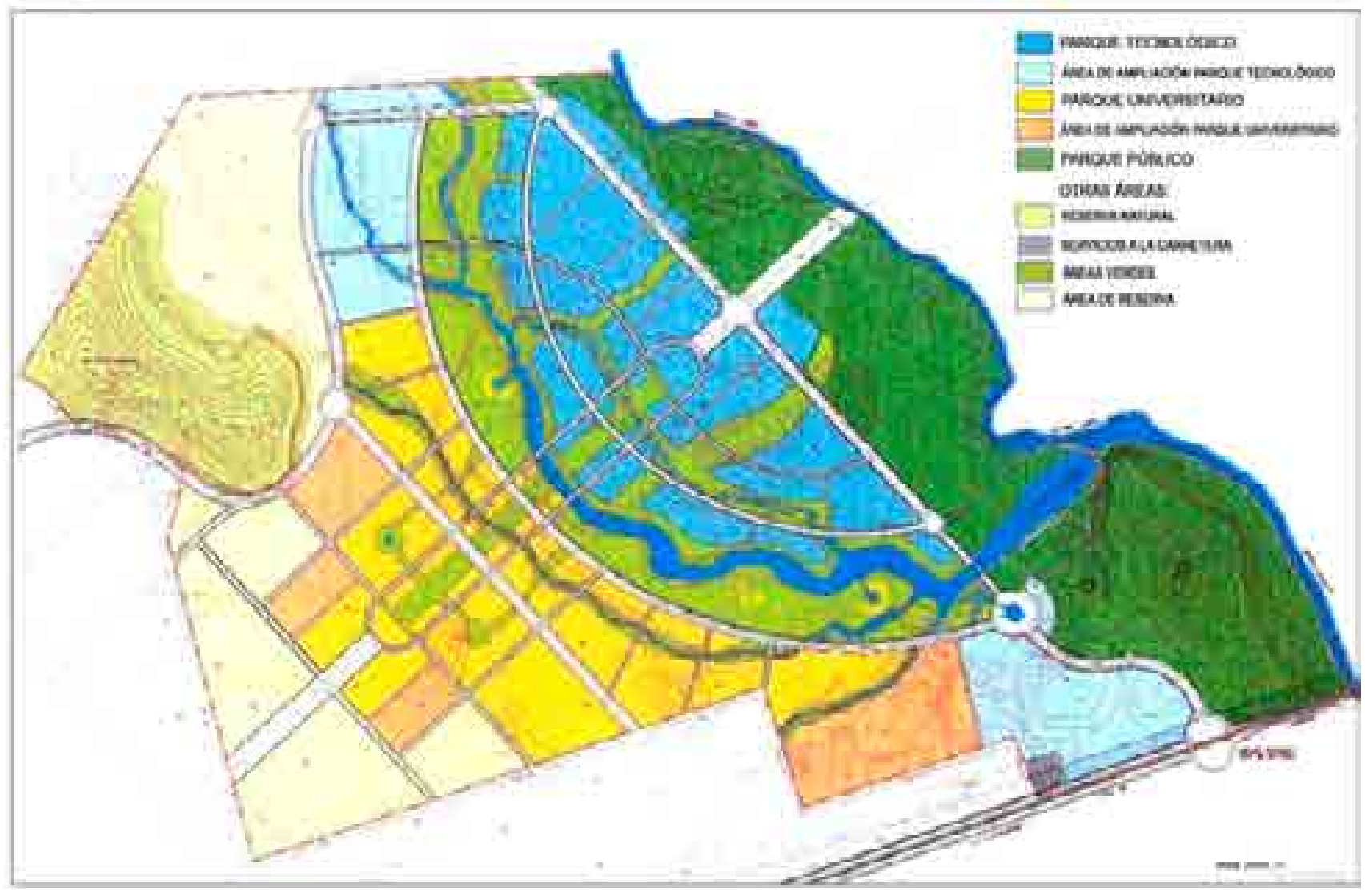




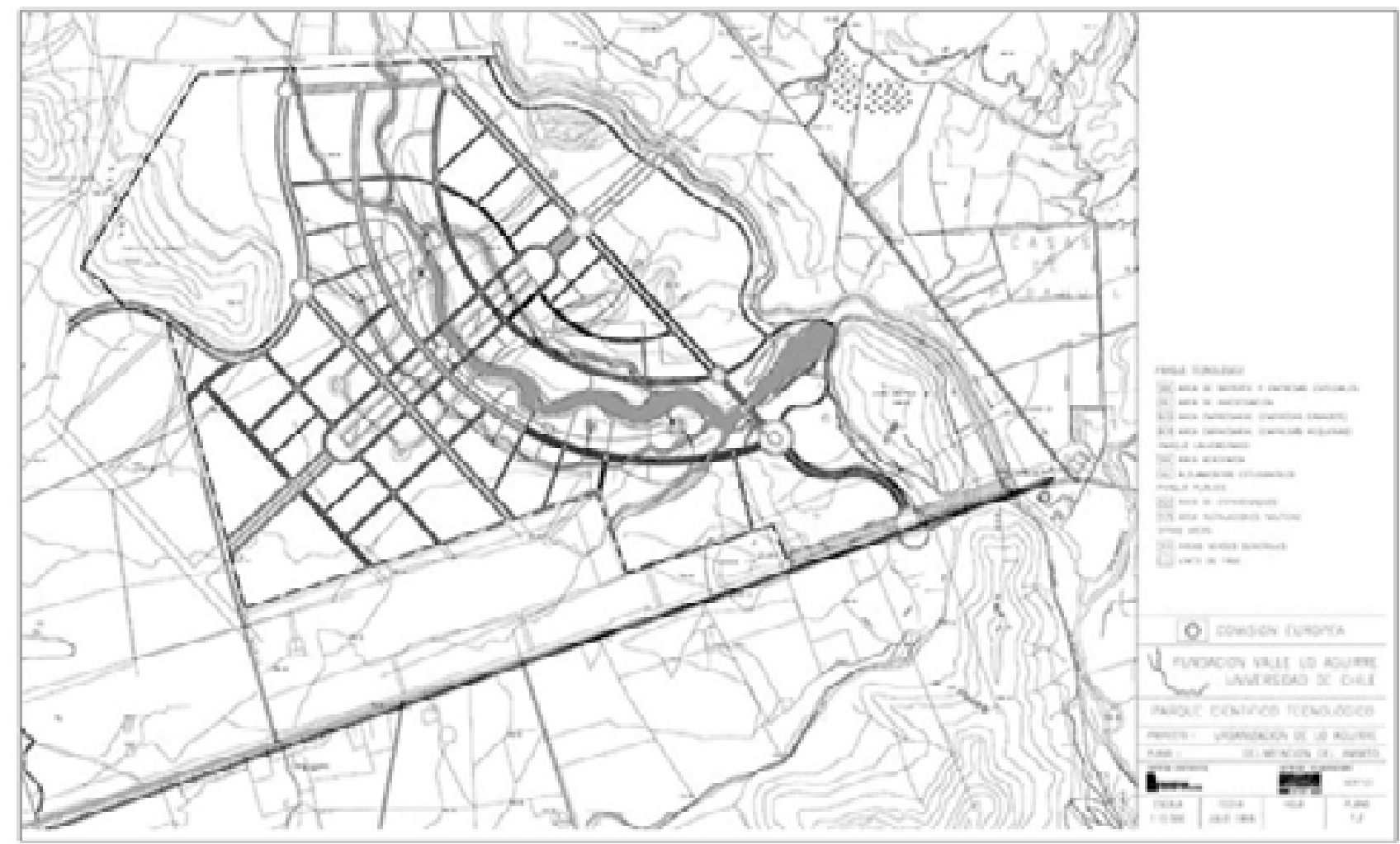

la laguna y su parque de borde, que también constituye un sistema de conexión de circuitos verdes entre ambos programas. Hacia el oriente del eje principal de acceso, se encuentra el parque científico-tecnológico y hacia el poniente se encuentra el parque universitario. El eje diagonal, une ambos programas atravesando la laguna con un sistema de par vial que conforma un parque-laguna. El parque público de 200 hectárea, compromiso adquirido por la Universidad de Chile, se ubica al costado poniente del Estero Lampa y reconoce las condiciones de mayores riesgos por inundaciones. La conformación de la centralidad del parque científico-tecnológico está ubicada a más de $1500 \mathrm{~m}$. al norte de la ruta 68 , lo que manifiesta una completa interioridad del proyecto y la expectativa de conectividades metropolitanas de largo plazo. Asimismo,

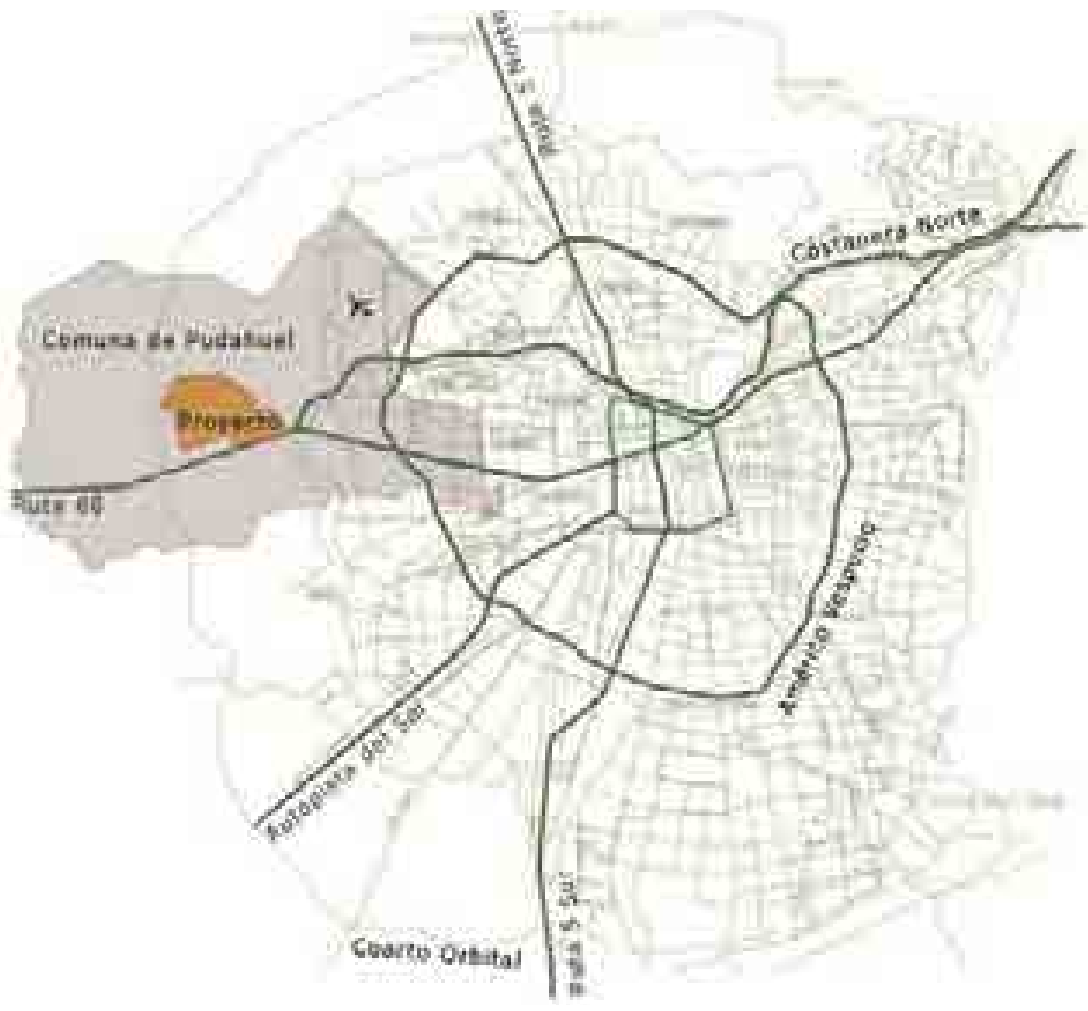

Figura 10.3. Estructura Vial del Plan Maestro MECSA, 1997. En Archivo Fundación Valle Lo Aguirre.
Figura 10.4. Estructura Vial del Plan Regulador Metropolitano de Santiago (PRMS100). En URBE (2011, p. 5). 
Frente las diferencias culturales entre el mundo académico y el empresarial, se propuso la localización del Parque Universitario y el Parque Tecnológico en riberas opuestas de la laguna creando un límite natural que las separara, pero a la vez permitiera su convivencia y cercanía. (MECSA, 1997).

La propuesta es por lo tanto segregada funcionalmente, aspecto que se mantiene en las modificaciones posteriores.

\subsubsection{Propuesta Plan Design Workshop, año 2002:}

En el año 2002, el proyecto de actualización del Plano Regulador Comunal (PRC) de Pudahuel se desechó y la Fundación Valle Lo Aguirre emprendió la actualización del Plan Maestro en base al nuevo escenario normativo. Ese mismo año, se elaboró una propuesta que rescataba los elementos estructurales del proyecto de MECSA, pero concentraba los usos de modo de consolidar el terreno utilizando el 20\% del predio, de acuerdo a la aplicación del artículo 2.1.31 de la Ordenanza General de Urbanismo y Construcción (OGUC), estrategia que daba factibilidad normativa al desarrollo del proyecto. Esta revisión y validación del Plan Maestro original, que resultó en la ejecución de un Plan Maestro ajustado (Figura 10.5.) y el Anteproyecto de Loteo de primera etapa, fue desarrollado por las consultoras chilenas AMCON Ingeniería Económica y Design Workshop Landscape Architects (DWLA).

La visión de las consultoras a cargo de la revisión y ajuste del plan maestro de 1997 , indican que centraron su propuesta en un enfoque que sustenta el desarrollo del futuro parque científico-tecnológico a partir de una visión para el proyecto, que responde al paisaje y su entorno, desde una perspectiva que califican como "Natural",

Figura 10.5. Plan Maestro Ajustado de Design Workshop Landscape Architects (DWLA) del año 2002. En Archivo Funda-ción Valle Lo Aguirre. poniendo en valor los atributos que el territorio entrega y concibiendo una propuesta de naturaleza respetuosa con el entorno, manteniendo en balance el ecosistema y apostando por un desarrollo que responda de manera adecuada a las contingencias regulatorias y a las expectativas que los distintos ámbitos de escenario nacional tienen de él (URBE, 2011, p. 36).

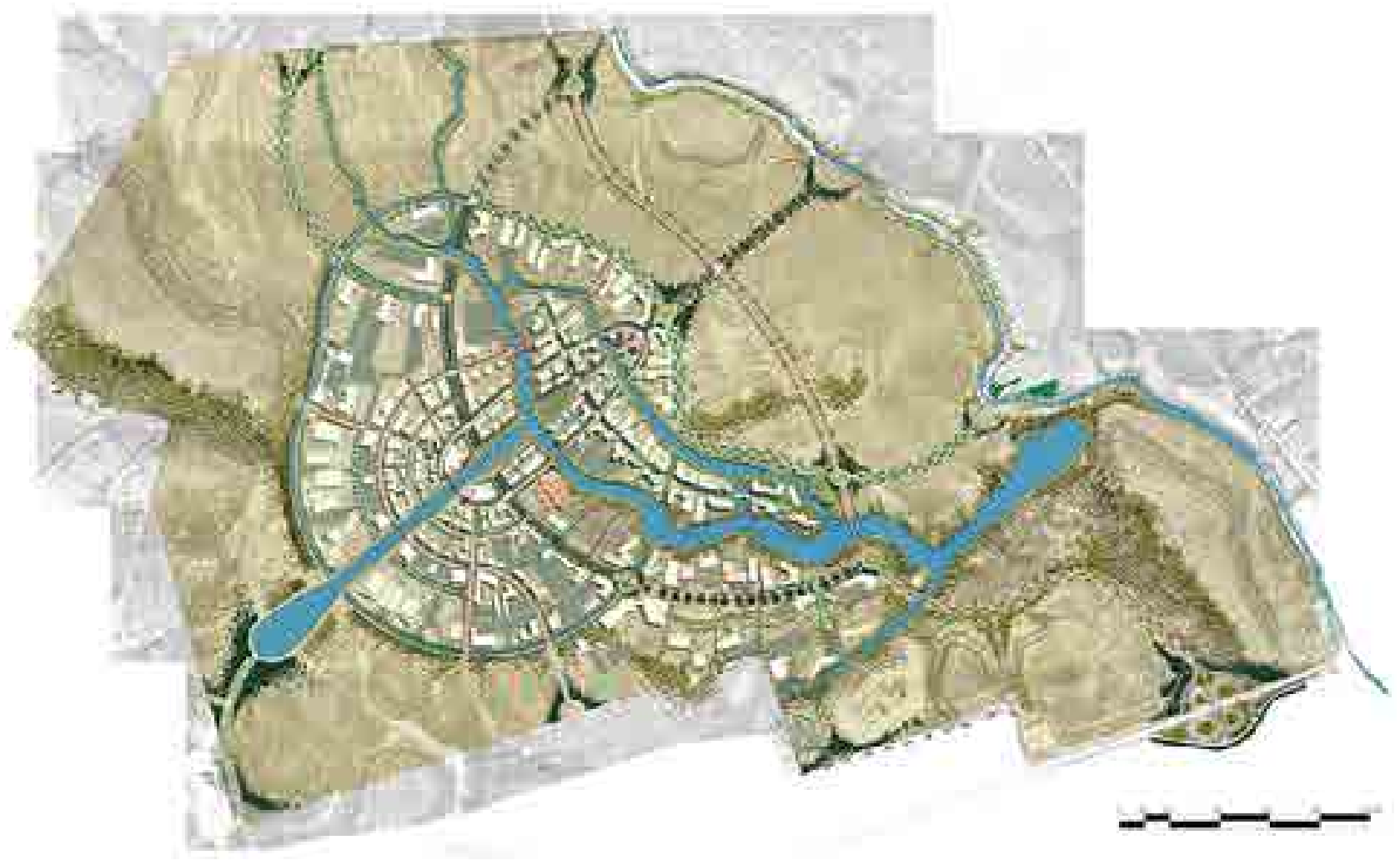


La propuesta evita distanciarse formalmente del plan original, incorporando un nuevo enfoque en la forma de distribuir, relacionar y jerarquizar los componentes del proyecto. Los elementos y/o conceptos que el proyecto desarrolla corresponden a los expuestos en la "Memoria explicativa del estudio del plan maestro" (2003) y que en síntesis son los siguientes:

Medio ambiente / atributos y restricciones del paisaje: "Puesta en valor de los atributos del paisaje"

Potenciar el sistema de áreas verdes y las áreas destinadas a Parque público: Adecuada propuesta de localización de áreas de programa" (ocupación del $20 \%$ del predio "parque")

Compromiso parque 200 hectáreas: el proyecto define zonas cercanas al acceso principal, desplazando la vialidad mayor al poniente y generando un segundo acceso (desde El Noviciado), que circunda el área recreativa.

Se plantea mejoramiento de las riberas de la laguna: crear cuerpos de agua reconocibles de mayor escala. Se proyecta también "espejo de agua" en sentido oriente poniente de 1.400 metros de largo por 80 metros de ancho, con un rol de eje ordenador del centro del proyecto y destinado a actividades náuticas y recreativas.

Integración de atributos y Sistemas naturales al programa: Integración de "laguna, vistas, geomorfología y paisaje", sistema de recorridos en el proyecto que permitan su reconocimiento total. Cursos de agua como elementos ordenadores de los espacios públicos y vinculación a edificación y otros programas.

Conectividad vial / interna y externa: Se organiza a partir de un sistema en cruz, más una vialidad circular que acompaña el curso de la laguna hacia el norte, más eje norte sur.

La escala, su importancia en los espacios y componentes programáticos: Dada la dimensión del predio versus la baja ocupación (20\%), la "distancia" se constituye en un tema crítico y fundamental. Variables a manejar: definición de macro lotes, dimensionamiento de vialidades, y la proporción entre los espacios abiertos y la concentración de usos (masa crítica).

[En esta] propuesta, se concentran actividades en torno al eje ordenador del espejo de agua, y la plaza de remate en su extremo oriente, localizando en esta zona los usos con mayor población potencial, [con el] objetivo de manejar la escala del proyecto para evitar la pérdida de las proporciones del espacio y la deshumanización de la propuesta. (p. 39)

Desde el punto de vista del programa, se propone la "Creación de vitalidades a través del balance programático" ( p. 36).

Pese a la argumentación expuesta, el diseño del paisaje se limita al acompañamiento verde de las vías y a la ocupación de los lotes que tienen mejor vista sobre el estero y la laguna, densificando el centro del predio -que es la zona más rica desde el punto de vista ecológico y visual-, y dejando los bordes como zonas de expansión. De este modo la legibilidad del conjunto se sigue produciendo a través de la estructura vial que conecta el interior con el exterior (Figura 10.6). La calidad espacial determina que el interior tenga un "grano más fino" que va haciéndose mayor hacia la periferia del terreno. Cabe señalar que cuando estamos hablando de grano fino, la subdivisión menor es de 1 ha aproximadamente, vale decir, el módulo pequeño es de una manzana, los intermedios de 4 y los grandes, de sobre 7 ha.

Desde el punto de vista de los límites, la fachada principal del proyecto hacia la Ruta 68 tiene asociada macrolotes destinados a "servicios de carretera", los demás deslindes no tienen propuesta alguna. El plan de Design Workshop (Figura 10.7.) mantiene también el criterio de segregación de actividades que se plantea en proyecto de MECSA. Las manzanas mejor ubicadas albergan la investigación, luego la empresa mediana, más afuera el área académica, el soporte de campus y el área empresarial. En el borde quedan el parque y las zonas deportivas 
Figura 10.6. Estructura vial del Plan Maestro Ajustado de DWLA desarrollado entre los años 2002-2004. En URBA (2011, p. 38)
Figura 10.7. Plan Maestro 2002-2004 de Design Worshop Landscape Architects. En Archivo Fundación Valle Lo Aguirre

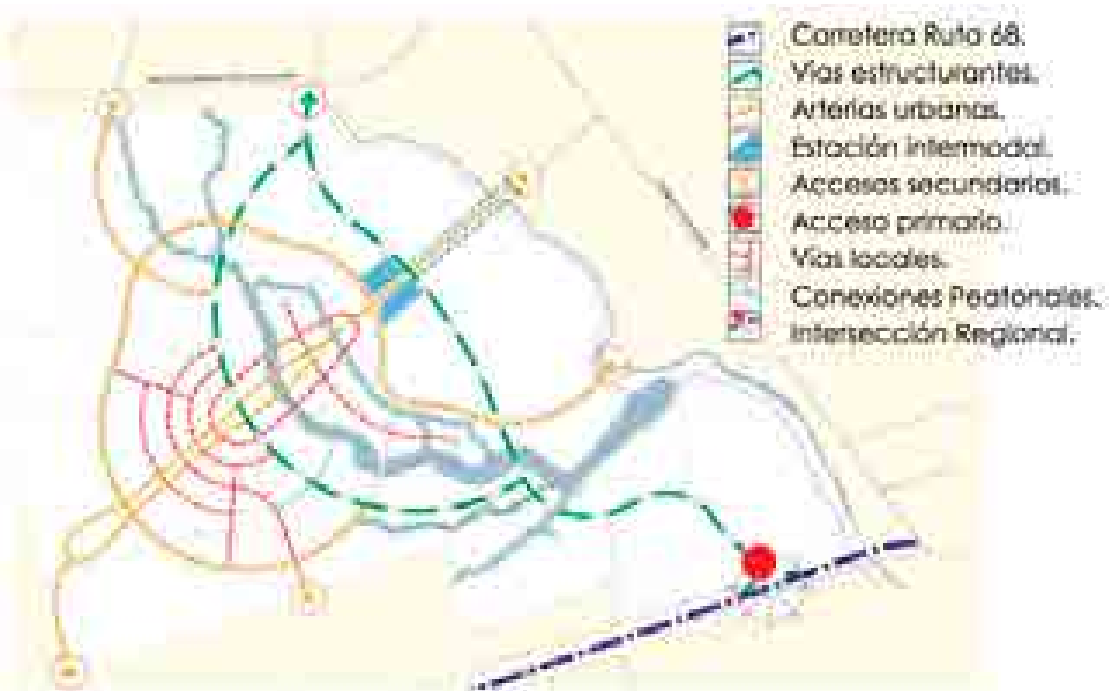

(vale decir lo más blando). Esta estructura espacial permite dividir el proyecto en etapas, iniciar el poblamiento desde el centro del terreno, dejando un perímetro más maleable.

En la propuesta de DWLA se tienen en consideración dos aspectos que condicionan el desarrollo futuro del proyecto a partir de las modificaciones del PRMS-100: en primer lugar, el desarrollo de Proyectos de Desarrollo Urbano Condicionado (PDUC) en el entorno inmediato, y, por otra parte, los trazados viales que se proyectan en el borde y atravesando el predio (Figura 10.8.).

Ambos aspectos son considerados favorables para el desarrollo del Parque científico-tecnológico y la ciudad universitaria, ya que auguran una masa crítica de habitantes en las inmediaciones y las posibilidades de conectividad urbana a través de corredores de transporte público. En la memoria de 2003, los proyectistas recomiendan "internalizar" la idea de que Carén tiene el potencial de transformarse en una nueva centralidad, integrada funcionalmente a su entorno inmediato y a la ciudad de Santiago, "lo que potencia su visibilidad y presencia en la imagen colectiva de los grandes equipamientos metropolitanos" (DWLA, 2003, p. 7).

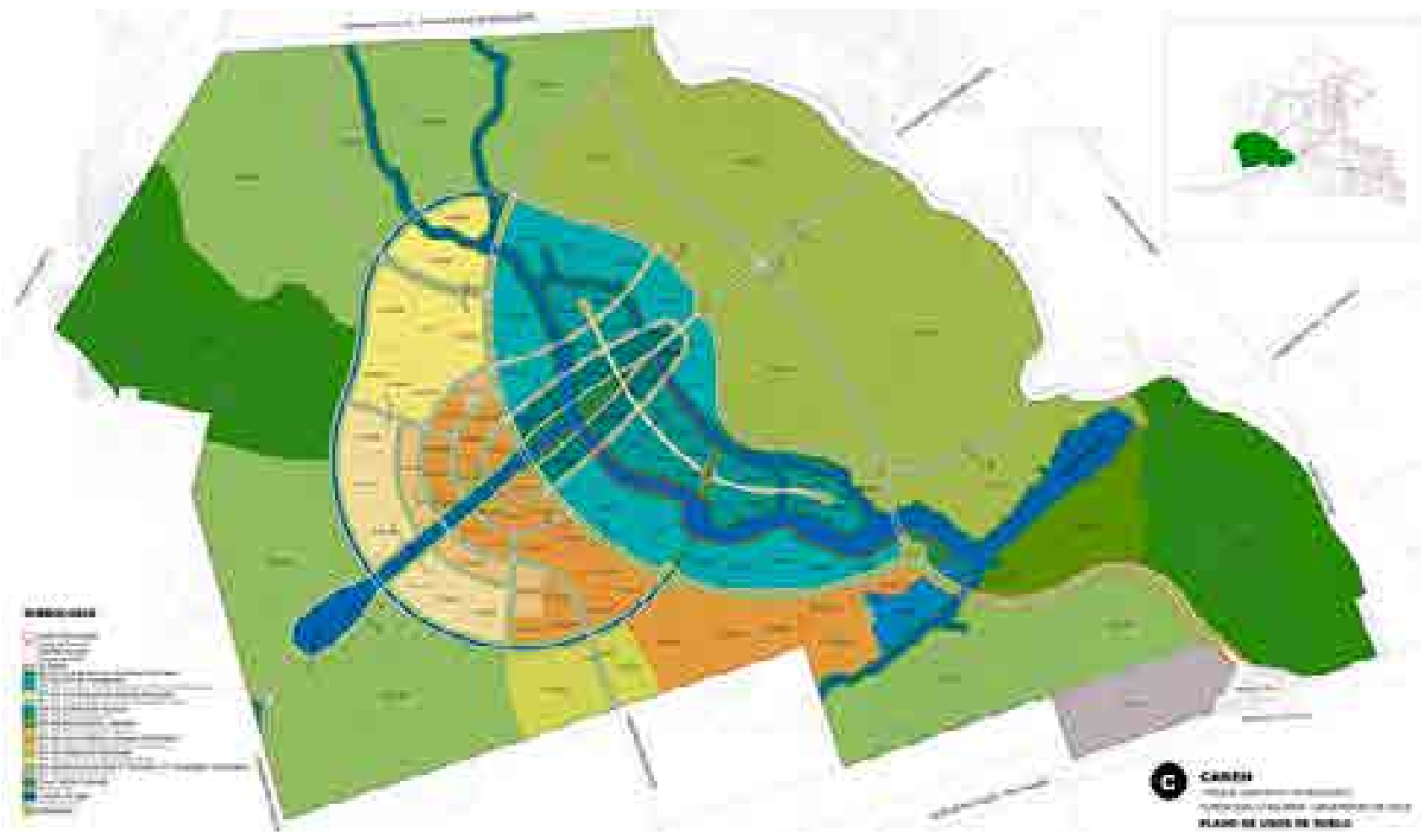


Es así como este tercer Pan Maestro define una primera etapa de 94,68 hectáreas con un horizonte de desarrollo estimado de 10 a 12 años. (Figura 10.9.).

Una de las grandes trabas que presentaba la ejecución del proyecto, consistía en la limitación al financiamiento por parte de la Universidad, que, en su calidad de institución pública, no podía optar a endeudamiento con plazo mayor a 4 años (correspondiente a la duración de los períodos presidenciales). Esta situación cambia el año 2001 , con la nueva Ley $N^{\circ} 19.767$, publicada en el Diario Oficial del 3 de noviembre de 2001, que, junto con ley $N^{\circ} 19.847$ (19 de diciembre de 2002) y la ley $N^{\circ} 19.908$ (3 de octubre de 2003), autorizan y regulan el endeudamiento de la Universidad de Chile, hasta por 20 millones de dólares americanos y con aval del Estado en las operaciones de crédito que se contraten, para la construcción del Parque Científico Tecnológico (PCT).

En este nuevo escenario, el Consejo Universitario ${ }^{334}$ aprueba, según se señala en la letra "a" del acuerdo №12 del 1 de abril de 2003, "La ejecución de la primera etapa del proyecto de construcción del Parque Científico Tecnológico". Este acto es ratificado el 16 de diciembre de 2003 por el mismo Consejo, quién aprueba la contratación del crédito y ratifica el acuerdo №12. Finalmente, a través del Decreto Universitario DU N ${ }^{\circ} 1671$ del 19 de enero de 2004 se autoriza la contratación de crédito por 20 millones de dólares americanos con el Banco de Chile, a 20 años de plazo, para financiar "la primera etapa del proyecto de construcción del Parque Científico Tecnológico". Ese mismo año, el 6 de septiembre, la Universidad encomienda a la Fundación la administración general del proyecto y la puesta en marcha de la primera etapa de construcción.

Como hemos visto en el capítulo 9, otro de los obstáculos del proyecto, que persiste hasta hoy, es la incertidumbre sobre las condiciones normativas aplicables al predio. Recordaremos que Laguna Carén fue declarado íntegramente como Parque Metropolitano por el Plan Regulador Metropolitano de Santiago (PRMS), en noviembre de 1994, con lo que fue afectado por una declaratoria de utilidad pública al considerarlo como área verde de uso público ${ }^{335}$ con un porcentaje de ocupación de suelo del $1 \%$.

Sin embargo, tras gestiones de la Fundación Valle Lo Aguirre, la Secretaría Regional Ministerial del Ministerio de la Vivienda y Urbanismo (SEREMI MINVU), con fecha 2 de julio de 2004 autorizó la ocupación de suelo del 20\% propuesta por el Plan Maestro graficado en el plano PMLC-OS-01 (Figura 10.10.). Lo anterior fue posible en virtud a la Modificación del Decreto $N^{\circ} 47$, de la Ordenanza General de Urbanismo y Construcciones, que reemplaza el Artículo 2.1.31 de la OGUC, con fecha 27 de febrero de 2003, cuando fue ministro Jaime Ravinet, correligionario de Patricio Rojas, vicepresidente de la Fundación (Figura 10.11.).

Con el aumento de la ocupación de suelo al 20\%, las autoridades universitarias estimaron que el valor terreno se habría incrementado en " 50 veces", como señala el documento "Minuta Parque Tecnológico Universidad De Chile y Fundación Valle Lo Aguirre" del año 2009, que revisa la evolución legal del proyecto, en especial este hito del año 2003.

Esta valorización del predio viene acompañada de nuevas dificultades para el financiamiento de las obras, como son, "la disminución de recursos disponibles, consecuencia de la caída en el tipo de cambio y al alza de los costos de obras" $(\mathrm{UCH}, 2009$, p. 15).

Los dos hechos señalados anteriormente se conjugan para definir una nueva modificación al proyecto. El Consejo Universitario aprueba (acuerdo $N^{\circ} 40$ de 12 de julio de 2005) una nueva estructura financiera y comercial contenida en el informe "Parque Científico Tecnológico Universidad de Chile, Modificaciones al Proyecto, Santiago, mayo 2005", que, en lo principal, autoriza lo siguiente:

a) Venta o comercialización de los terrenos denominados "fuera del proyecto", de acuerdo a las necesidades de caja del proyecto. Superficie por sobre 300 ha. para venta potencial, con restricciones de
${ }^{34}$ El Consejo Universitario es el órgano colegiado de carácter ejecutivo de la Universidad de Chile. Cumple su labor atendiendo las necesidades de la Universidad, ocupándose de su desarrollo, de acuerdo con las políticas y estrategias establecidas por el Senado Universitario. Está integrado por el Rector de la Universidad, quien lo preside, por el Prorrector, los Decanos de las distintas Facultades de la Universidad y dos representantes de la Presidencia de la República. Asisten a las sesiones, sólo con derecho a voz, un delegado de los académicos, uno de los estudiantes y uno del personal de colaboración, designados por las asociaciones de los respectivos estamentos.

${ }_{335}$ Con ello su valor de mercado como suelo potencialmente urbanizable cayó a su valor más bajo de la historia. En las áreas declaradas como parque metropolitano, solo se puede acoger actividades relacionas con lo recreacional, deportivo, de culto, cultural, científico y de esparcimiento al aire libre, es decir, los usos menos competitivos del mercado de suelo urbano. 


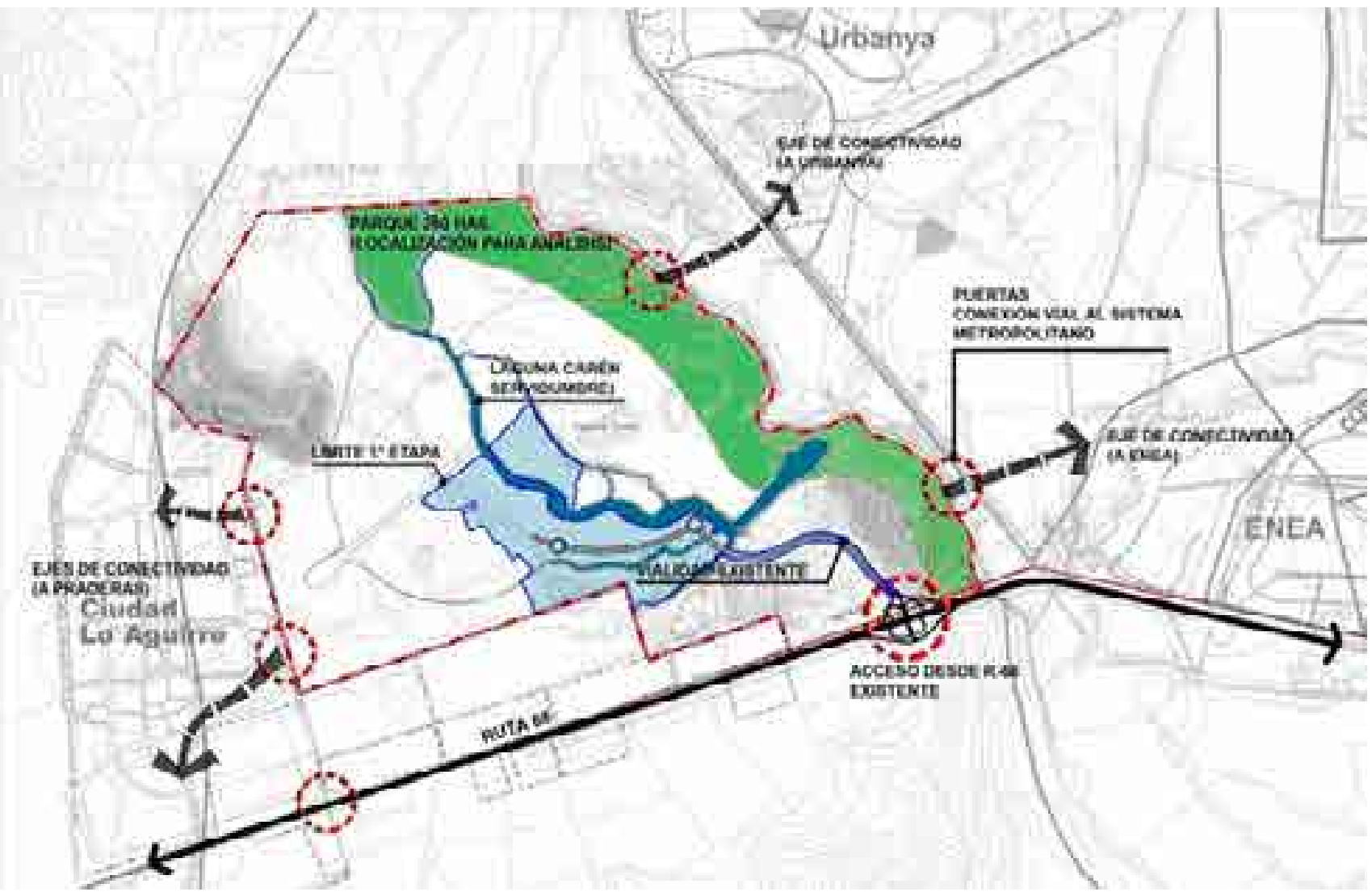

Figura 10.8. Esquema de condicionan-

tes externas del Plan Maestro de DWLA

(2002-2004). En URBE (2011, p. 46).

Figura 10.9. Plano de Uso de Suelos-Pri-

mera Etapa Plan Maestro DWLA (2004).

En Archivo Fundación Valle Lo Aguirre

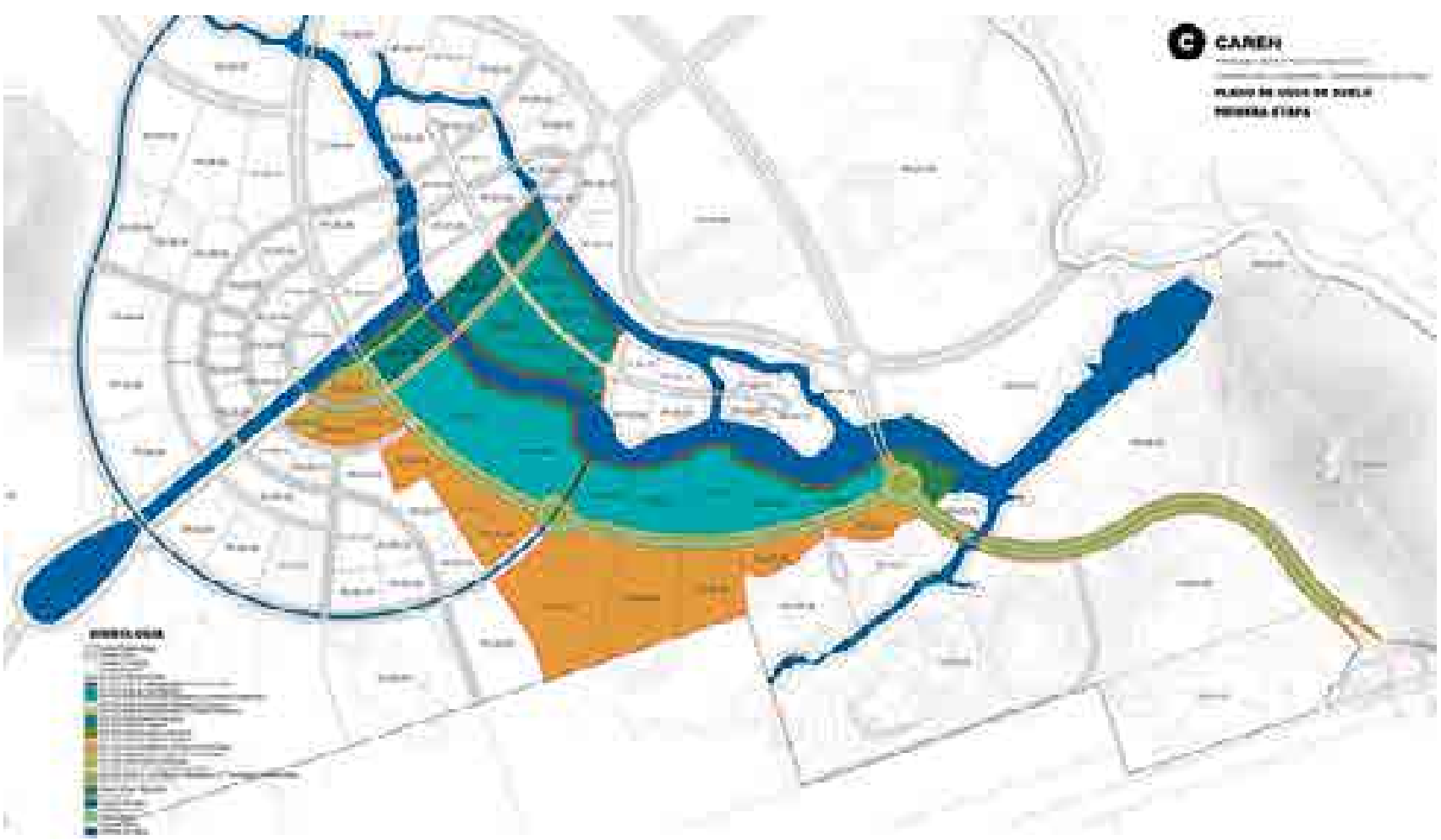



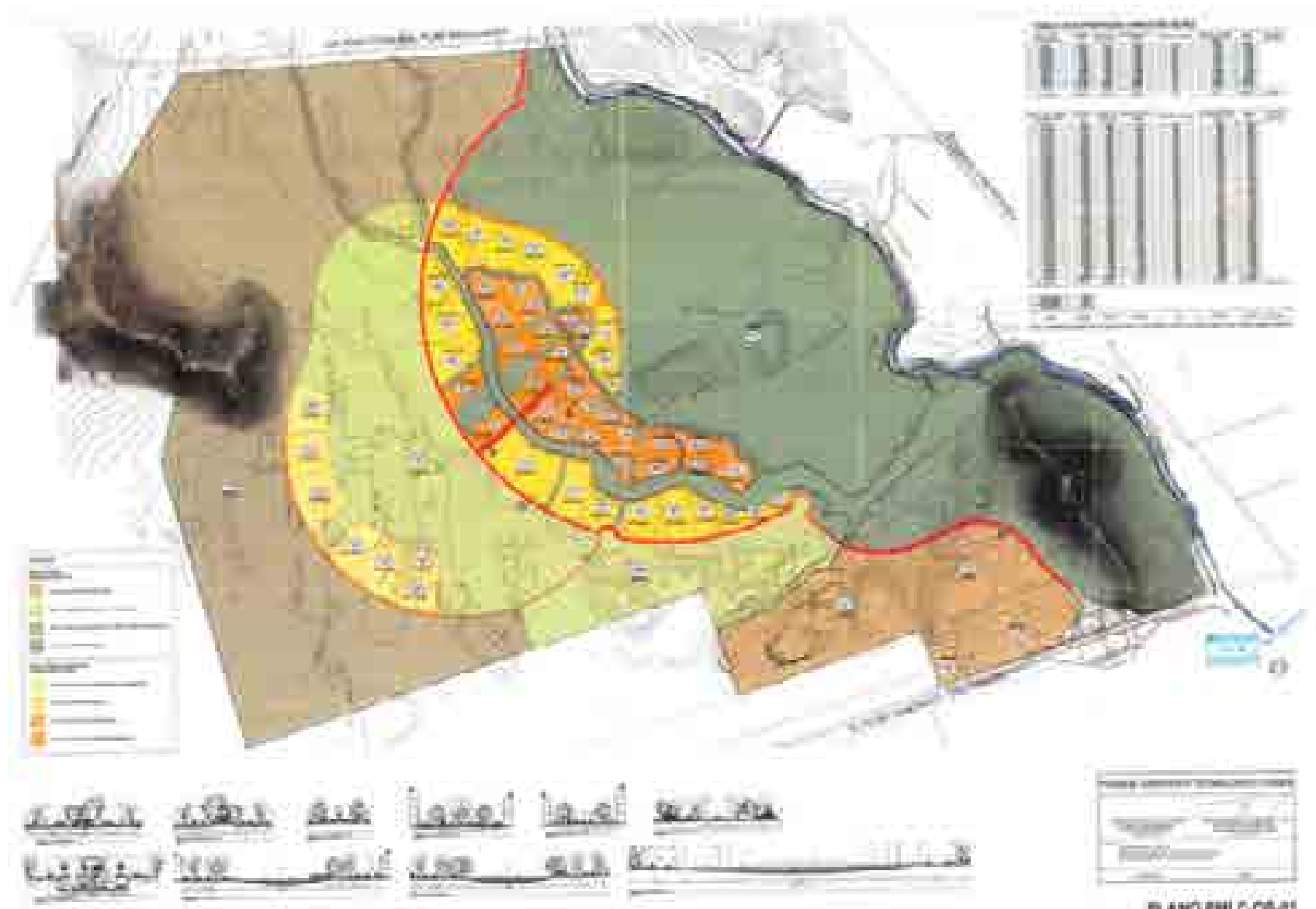

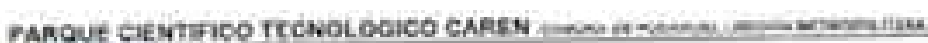

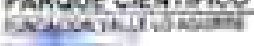

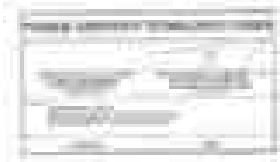

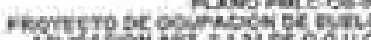
0 ing

Figura 10.10. Plano PMLC.OS-01. Proyecto de Ocupación de Suelo. Aplicación Art. 2.1.31. de la OGUC. Aprobado con fecha 2 de julio de 2004 (timbrado a la derecha del nudo vial de acceso). En Archivo Fundación Valle Lo Aguirre.

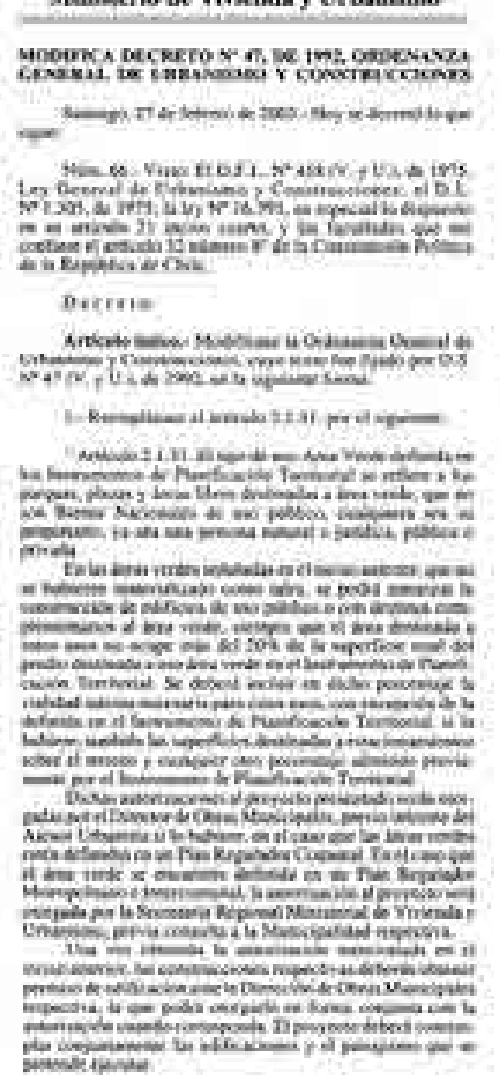

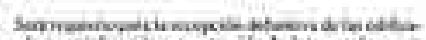

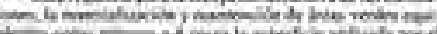

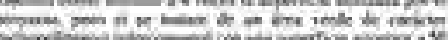

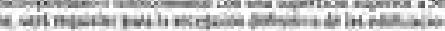

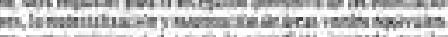

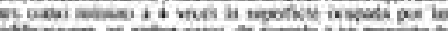

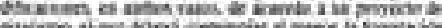

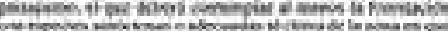

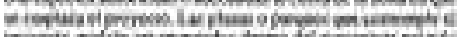

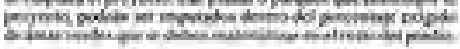

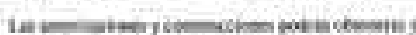

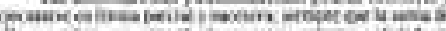

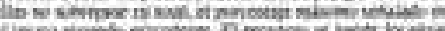

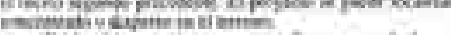

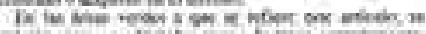
my

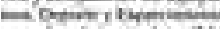

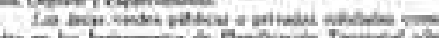

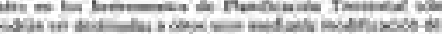

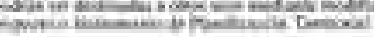

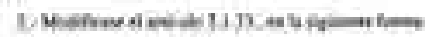

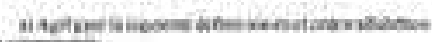
eximente

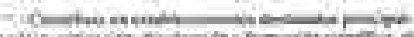

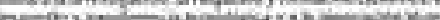
ise

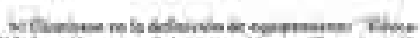
ras.

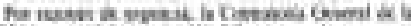

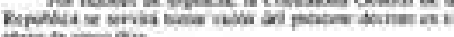
peivi fecenias

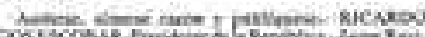

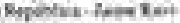

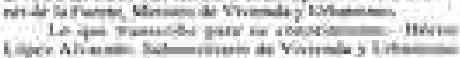

yecentats
Figura 10.11. Modificación del Decreto No 47, de la Ordenanza General de Urbanismo y Construcciones. Publicado en el Diario Oficial de la República de Chile N ${ }^{\circ}$ 37.524 del $1^{\circ}$ de abril de 2003. El decreto, fechado el 27 de febrero de 2003, está suscrito por el Presidente de la República, Ricardo Lagos y su Ministro de Vivienda y Urbanismo, Jaime Ravinet. En Archivo de la Dirección Jurídica, Universidad de Chile. 
precio mínimo.

b) Venta de la totalidad de los terrenos del parque tecnológico destinados a la instalación de empresas, servicios y soporte, entre otros, por una superficie neta de 37,8 ha $(\mathrm{UCH}, 2009$, p. 15).

Si bien las obras de urbanización de la llamada Fase 1-A se inician el 30 de junio de 2006, los antecedentes antes descritos explican por qué sólo se construyó la urbanización, dejando sin gastar parte de los dineros del préstamo, como también permite leer en los planos de arquitectura de esta etapa, la intención de "lotear", vale decir, urbanizar un terreno para poner en el mercado sus sitios (Figura 10.12.), dejando también grandes superficies disponibles.

En este contexto no es extraño el surgimiento de ofertas de negocios, entre los cuales cabe destacar la propuesta que desde el año $2008^{336}$ empieza a trabajar la empresa estadounidense Laguna Carén Investment LLC ${ }^{337}$.

\subsubsection{Laguna Carén Investment, año 2013}

El año 2013, la Universidad recibe la propuesta de empresa estadounidense Laguna Carén investment LLC, para un desarrollo inmobiliario denominado Pro-

336 Esta empresa contrata estudios en Chile a partir del año 2008, de acuerdo a las facturas enviadas a la autora por su representante en el país, años más tarde, cuando intentaron recuperar esta inversión vendiendo los estudios a la universidad.

${ }^{337}$ Empresa estadounidense Laguna Carén Investment LLC., domiciliada en el estado de Nevada y formalizada a partir del año 2007, según el siguiente registro disponible en línea: https://www.nevada-register. com/783641-laguna-caren-investment-IIc

Figura 10.12. Detalle del plano de la primera etapa de urbanización con subdivisión de lotes (2004). En Archivo Fundación Valle Lo Aguirre. yecto TRC (Tecnológico, Recreativo y Cultural) a desarrollar en 400 hectáreas dentro del predio, bajo el modelo de una Concesión a 99 años. Desde el punto de vista económico, esta oferta involucraba un monto inicial de 1 millón de UF (36 millones de euros) más un canon variable de $1 \%$ de los ingresos a partir del año 11 , con un piso de 25 mil UF anuales (equivalentes a 900.000 euros anuales).

La evaluación económica del proyecto realizada por la empresa TRANSSA en 2014, se inicia con la siguiente frase "No habiéndose concretado a la fecha este Plan Maestro, actualmente se está negociando la concesión de $400 \mathrm{Ha}$ del predio..." aludiendo a las cláusulas de una promesa para suscribir el contrato por 99 años (que en la práctica es una venta) para la construcción de: una Ciudad Hospitalaria de 38 ha, un área mixta de 267 ha, y un área parque de 95 ha. (Figura 10.13). Esta última, resguardando el área de mitigación que la normativa ambiental debería exigir a un proyecto de esta envergadura.

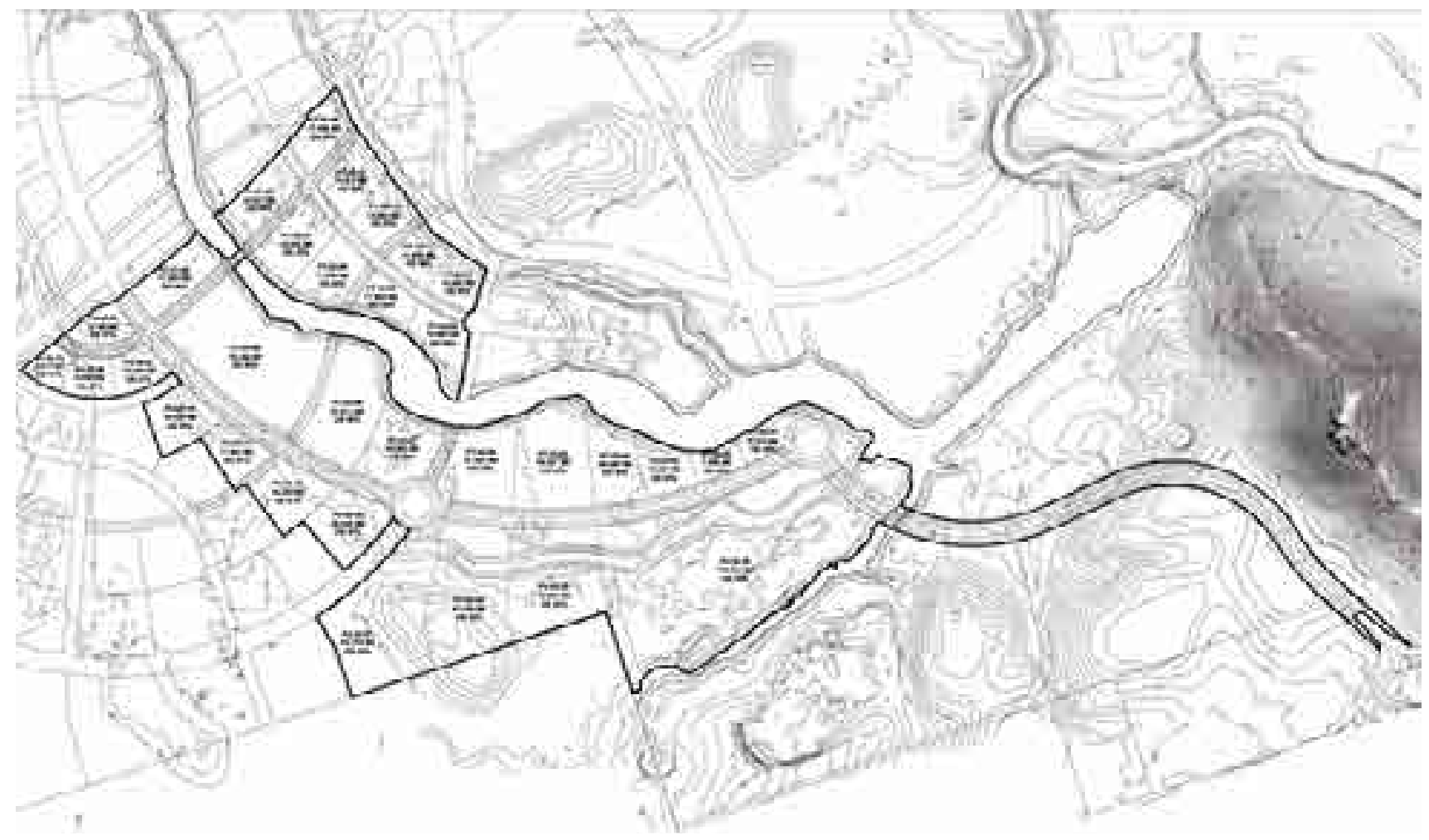




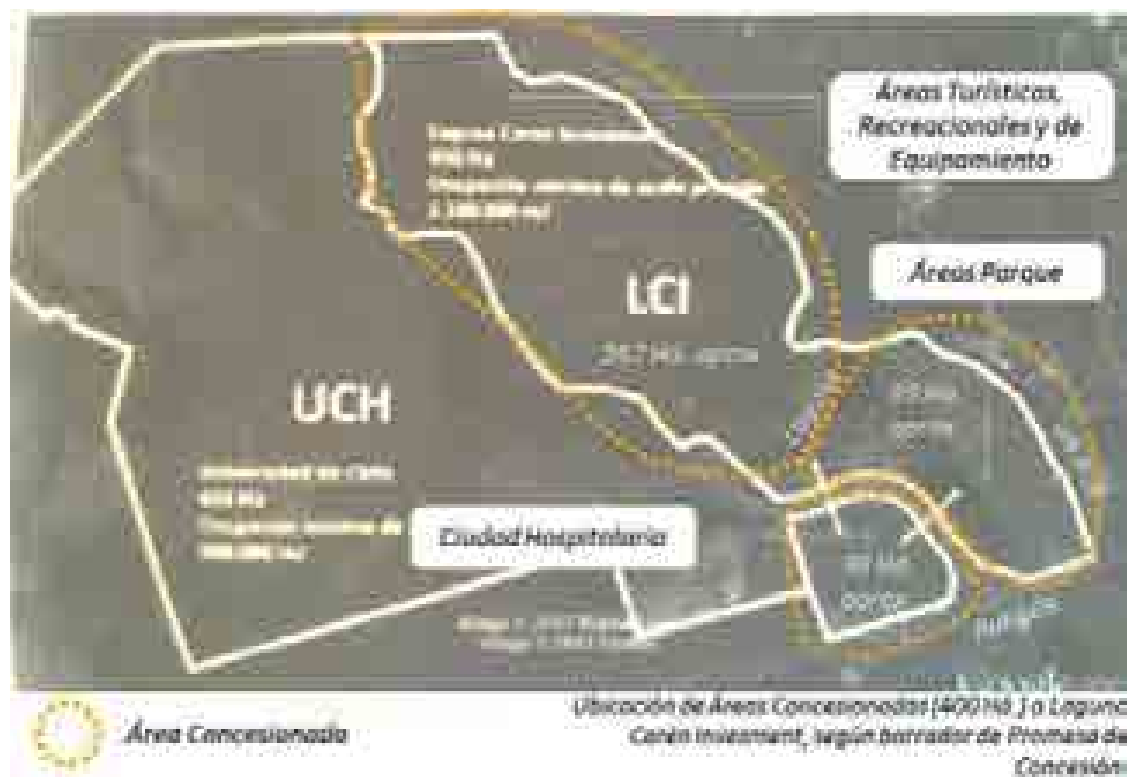

En el documento aludido ${ }^{338}$ también se señala que las áreas Turísticas Recreacionales y de equipamiento (Figura 10.14.), tendrán alta densidad de construcciones albergando "principalmente hoteles, retail, oficinas, viviendas de estudiantes y profesores, edificios institucionales, entre otros" (UCH, 2013, p. 5). Por último, también se define que "las partes acuerdan la exclusividad de la explotación de los usos asignados en el plan maestro a cada una" (UCH, 2013, p. 6). El estudio de valor, finalmente concluye que de esta oferta se obtiene un diferencial que hace "recomendable el contrato para la universidad" (TRANSSA, 2014, p. 36). Tras varios años de negociación, la rectoría del profesor Ennio Vivaldi desestima la propuesta.

\subsubsection{Estadio Club Universidad de Chile, año 2014}

La idea de emplazar el estadio del Club de futbol de la Universidad de Chile se anunció con espectacularidad en la prensa ${ }^{339}$ en el mes de abril de 2014 (The Clinic, 24 de abril, 2014). El proyecto de Azul Azul S.A. ${ }^{340}$ contemplaba la construcción de un estadio para 35 mil personas en el límite sur-oriente del predio Figura 10.15., ocupando un área de 24,06 ha en la franja ubicada entre el estero
Figura 10.13. Ubicación de Áreas Concesionadas (400 héctareas) propuestas por la empresa norteamericana Laguna Carén Investment. En Transsa, (2014, p. 14).

338 Promesa para Suscribir Contrato de Concesión Privada. Borrador con carácter reservado. (UCH, 2013).

339 http://www2.latercera.com/noticia/ los-detalles-del-nuevo-estadio-que-la-uconstruira-en-laguna-caren/ y en un video asociado al futbol chileno en: https://www. futbolchileno.com/universidad-de-chile-tiene-terreno-para-su-anhelado-estadio/

340 Azul Azul S.A. es una Sociedad Anónima Abierta, constituida por escritura pública del 15 de mayo de 2007.

La Sociedad tiene por objeto organizar, producir, comercializar y participar en actividades profesionales de entretención y esparcimiento de carácter deportivo, recreacional y en otras relacionadas o derivadas de éstas, así como en actividades formativas con contenido deportivo. En 2007 se hizo cargo del equipo de la Universidad de Chile, entonces en quiebra. La universidad sólo tiene representantes en el Directorio de Azul Azul.

Figura 10.14. Plano de Uso de Suelos para la Concesión propuesta por Laguna Carén Investment (2013). Gentileza de Andrés Sotomayor.

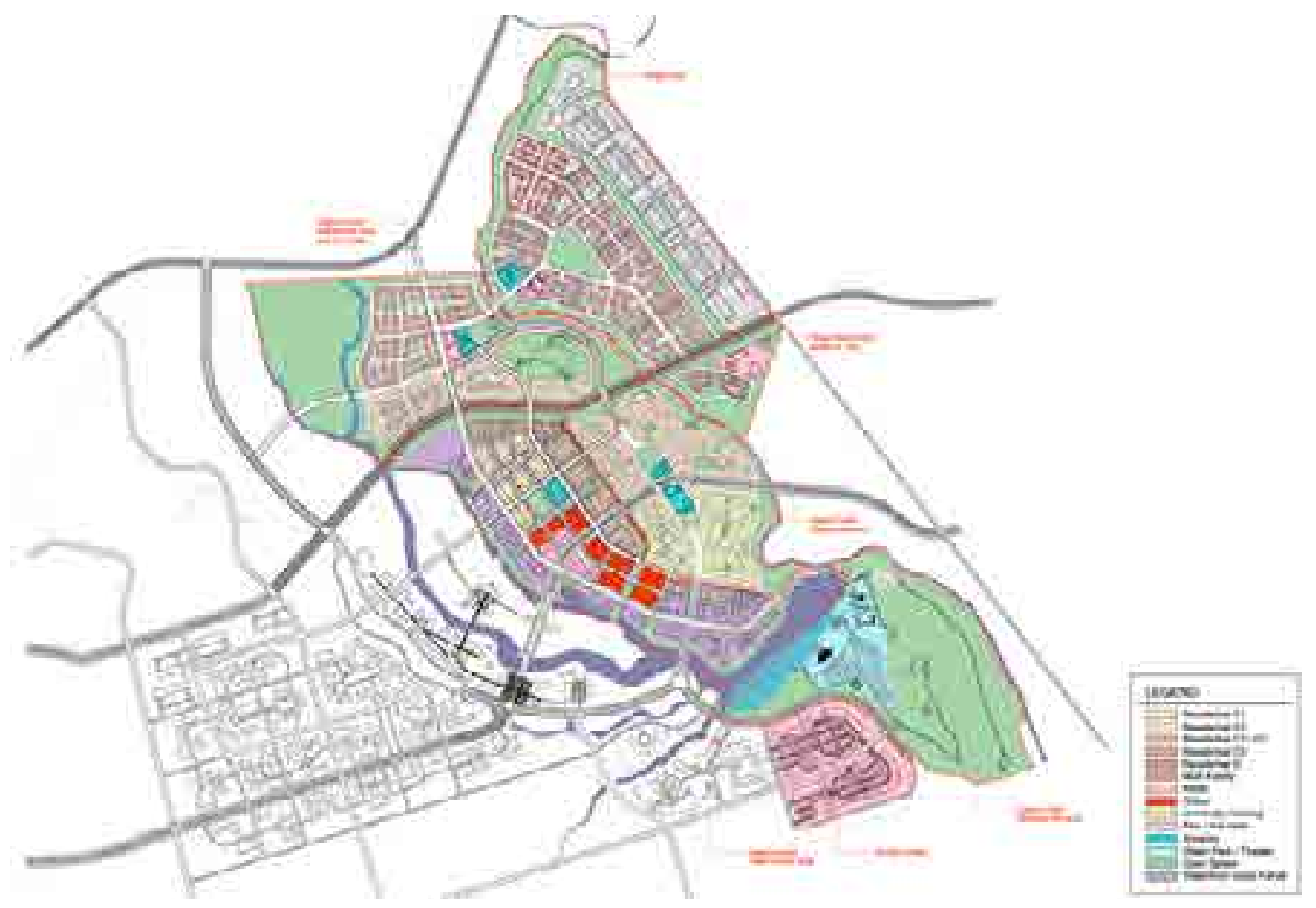


Figura 10.15. Maqueta electrónica del Proyecto para el Estadio de Club Universidad de Chile (2014). En Al Aire Libre (27 de agosto, 2014).
Figura 10.16. Plano de Emplazamiento y deslindes del proyecto Estadio Club de la Universidad de Chile (2014). En Olate (2014, p. 21).

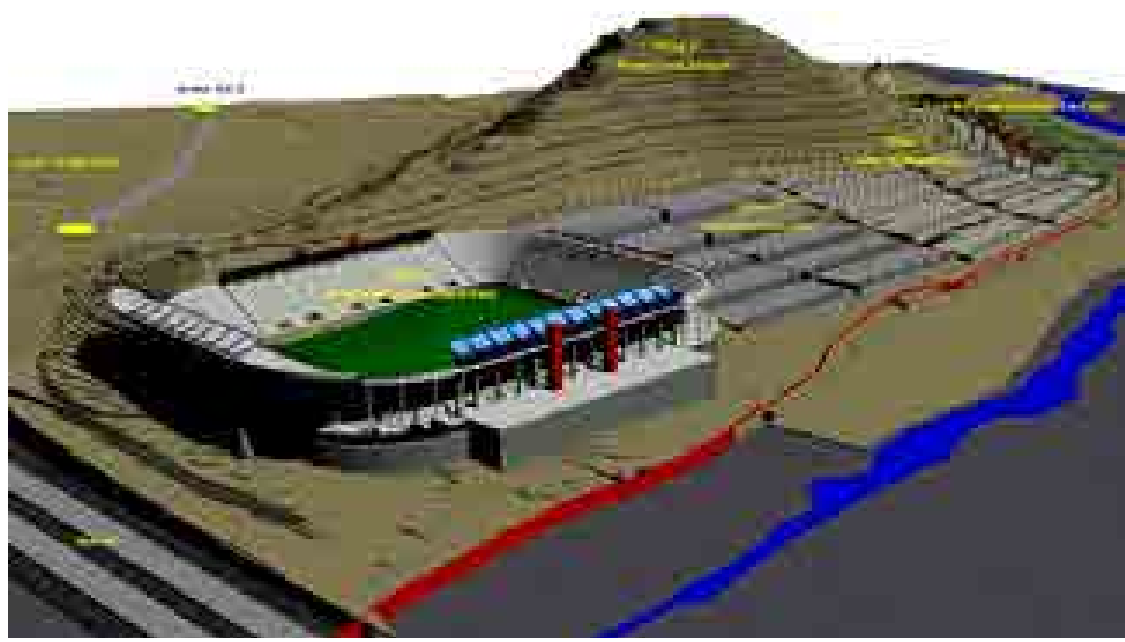

Lampa y el cerro Amapola (Figura 10.16). La inversión estimada, de 50 millones de dólares, contemplaba reforestar e intervenir naturalmente el cerro Amapola para crear un parque público de 28 hectáreas, incluyendo multicanchas, circuitos para trote, bicicleta y trekking, abierto a los vecinos de Pudahuel. Adicionalmente, Azul Azul ofrecía construir un club de campo para la comunidad universitaria. Como se comentó extensamente en los medios de comunicación, esta iniciativa hacia realidad el sueño de uno de los equipos más populares en Chile, de tener un estadio propio, luego de más de 60 años búsqueda.

Desde el punto de vista de la universidad, en el año 2014, el proyecto del estadio parecía ser un detonante de las futuras intervenciones y contaba con el apoyo tanto de la Municipalidad como de los vecinos que lo calificaban como "un aporte social" (Olate, 2014, p. 15).

Pese al entusiasmo inicial, en diciembre del mismo año y tras los estudios de factibilidad, esta ubicación se desechó. La evaluación realizada por consultores externos a la universidad señaló los siguientes problemas:

- El proyecto "consumía" el $40 \%$ de la ocupación del predio. Bajo el supuesto del $1 \%$ de ocupación de suelo, la superficie total sería 10,02 ha y la que requería el estadio 4,15 ha aproximadamente.

- Los altos costos y plazos iniciales para la realización de estudios de impacto ambiental e impacto vial.

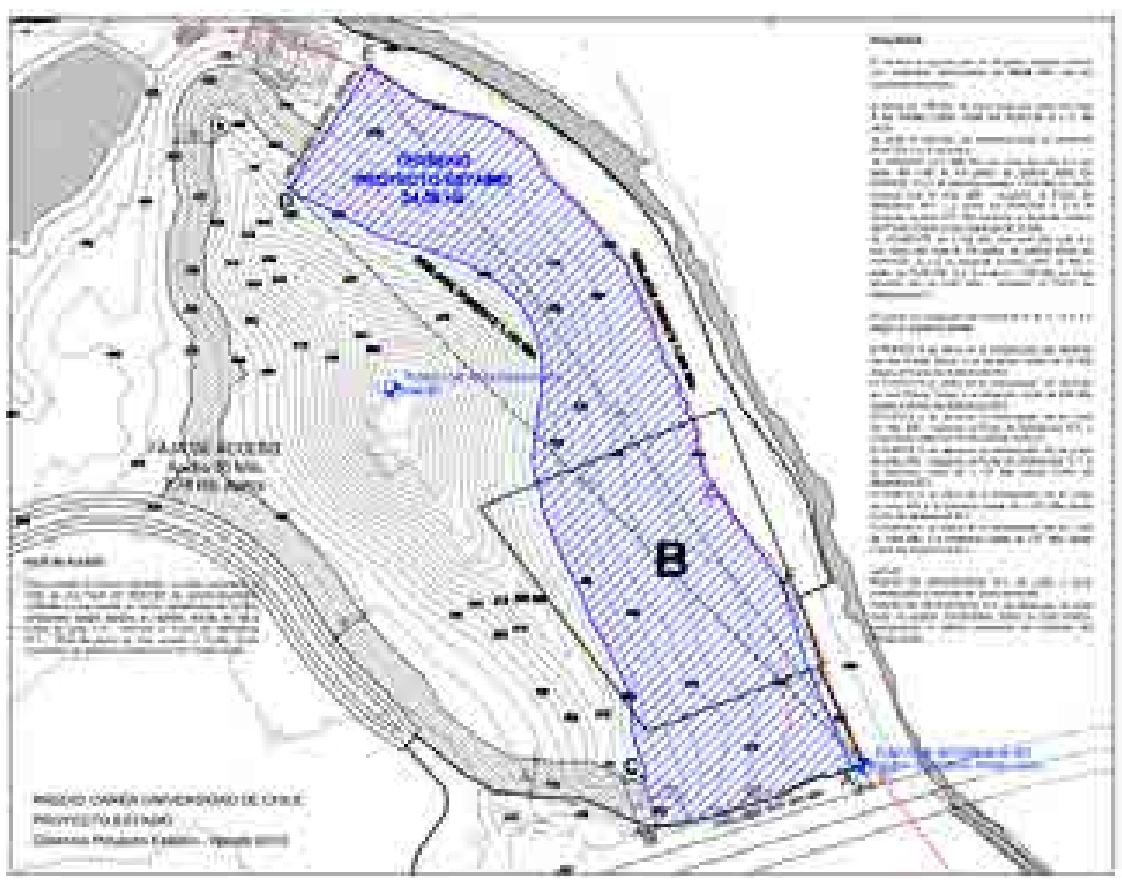


- Los altos costos de inversión en mitigaciones viales (si bien este costo es prácticamente obligado para cualquier emplazamiento de un estadio de esta magnitud).

- La dificultad para trasladar a las 21 familias que viven en esa área.

- La dificultad y costo adicional debido al emplazamiento de una Pertenencia Minera de Explotación, la misma que hemos descrito en el capítulo 6, caracterizando a sus habitantes como "picapedreros".

En la revisión de este caso, y pese a que no prosperó, el proyecto del estadio le permitió a la universidad relacionarse con la opinión pública y poner en discusión el destino de este gran terreno. Si bien el nombre de Universidad de Chile, se asocia a este predio desde hace más de 25 años, antes del estadio los comentarios en los medios tenían una connotación negativa (del tipo "caja negra") ${ }^{341}$, después del estadio, se menciona como un sueño que no prosperó. El humor ayudó a alivianar esta historia de intentos fallidos, como puede observarse en algunos artículos de prensa y tweets en redes sociales del año 2014 (Figuras 10.17. y 10.18).

Por último, si bien las instalaciones deportivas tan masivas son normalmente un elemento perturbador en el contexto, tanto por la volumetría asociada como por el impacto que implica la aglomeración de personas: el ruido, desgaste de suelos, vandalismo, etc. El sector propuesto, al otro lado del cerro Amapola, permitía que éste actuara como un biombo, protegiendo el resto del parque de la actividad del estadio.

Esta ubicación, por el contrario, tiene el inconveniente de ser una "esquina" muy visible del predio, lo que implica que, o puede ser leído como una unidad independiente del parque, fuera de él, que actúa por contraste, o bien, logra una identidad que destaque por sobre la del parque. En este último caso, podemos recordar la relación del Parque O'Higgins con el parque de diversiones Fantasilandia, ubicado en una de las esquinas del parque y que ha terminado por imponerse como referencia por sobre la imagen de éste.

De estos cinco proyectos y especialmente de los tres planes maestros aquí presentados, podemos interpretar distintas conductas respecto del proyecto. Podemos clasificar el proyecto de MECSA como un plan en el que predomina un punto de vista lógico, que entiende el proceso de diseño como la resolución de un sistema complejo dentro de otro mayor que es la ciudad al cual se acopla a través de la estructura vial. El plan maestro es la imagen de esta interrelación y el desarrollo en el tiempo dependerá de la capacidad de estas redes de movilizar fluidamente a los habitantes, sin consideraciones paisajísticas, salvo la forma de la avenida principal que sigue la curva del estero Carén. El primer plan del parque, actúa desde una visión en la que predomina el resultado estético, el proyecto se centra en la búsqueda de convertir el paisaje existente en un nuevo paisaje, con múltiples puntos focales. Este mismo punto de vista es el que guía el Plan de DWLA, que, si bien es radicalmente diferente por su programa, prioriza la conformación de un nuevo paisaje urbano, con los mismos criterios que la planificación inmobiliaria utiliza para los grandes condominios de vivienda que han surgido en Santiago en los últimos veinte años. Vale decir, una ocupación del territorio que la separa de su contexto, la protege de su entorno, creando un nuevo paisaje interior, que nuevamente es subdividido, segregando funciones. $\mathrm{Si}$ bien todos los planes utilizan la palabra paisaje, el concepto de paisaje aludido se refiere a la acepción más básica del término, como una "Parte de un territorio que puede ser observada desde un determinado lugar" (DRAE, 2014). Un panorama u horizonte invariable, sin considerar que es un territorio que hoy la población distingue y percibe, y "cuyo carácter, es el resultado de la acción e interacción de factores naturales y/o humanos", como recoge la definición del Convenio de Florencia $(2000$, p. 2).

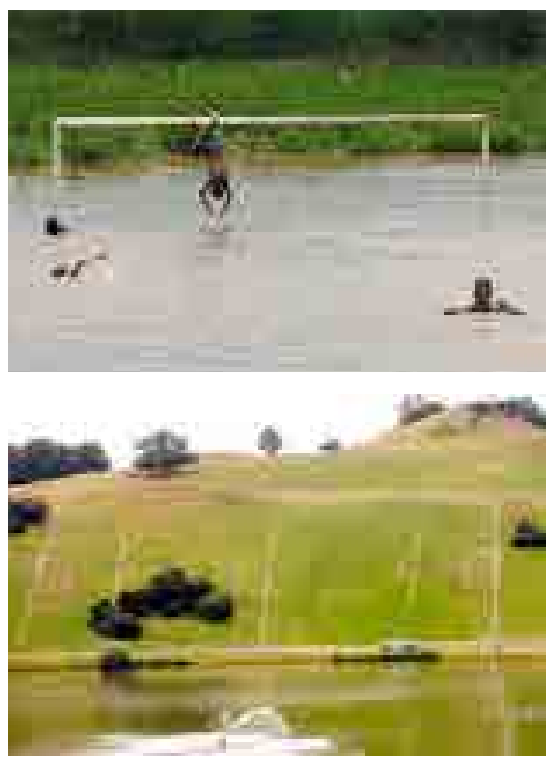

${ }^{341}$ Para comprender el sentido de la "caja negra" ver: http://ciperchile.cl/2014/05/13/ la-caja-negra-que-esconde-el-terreno-dela-universidad-de-chile-donde-azul-azulquiere-construir-su-estadio/ 


\subsection{LA REALIDAD: ESTADO ACTUAL DEL PREDIO, RESPECTO A LOS PLANES MAESTROS.}

Las obras que observamos hoy en el predio, surgen de la propuesta de DWLA (2002-2004), las que fueron ejecutadas a través de una Licitación Pública y adjudicadas a la empresa constructora ICAFAL Ingeniería y Construcción S.A., mediante Resolución № 826, de 2005 de la Universidad de Chile. La obra se denominó "Obras de Urbanización Fase 1-a para el Parque Científico Tecnológico de la Universidad de Chile" y comprometía un monto de $M \$ 5.749 .103$ en un contrato a suma alzada (Contraloría general de la República, 2015, p. 10). Como se observa en las imágenes siguientes (Figura 10.19.), las obras se concentran en la pavimentación y los servicios para urbanizar la zona que ya hemos revisado en la Figura 10.12.

La infraestructura construida en la primera etapa del proyecto, está diseña da para albergar 23.000 personas en $290.000 \mathrm{~m}^{2}$ de edificios (que no se construyeron) y considera las siguientes obras:

- Avenida Principal en doble calzada y calles

- Red de Alcantarillado de Aguas Servidas

- Recolección y Tratamiento de Aguas Servidas

- Producción y Almacenamiento de Agua Potable

- Red de Agua Potable y Grifos de Incendio

- Red de Riego

- Sistema de recolección de Aguas Lluvias.

- Red Eléctrica subterránea de Media Tensión

- Red Eléctrica de Baja Tensión (Alumbrado)

- Poliductos para distribución subterránea de Corrientes Débiles
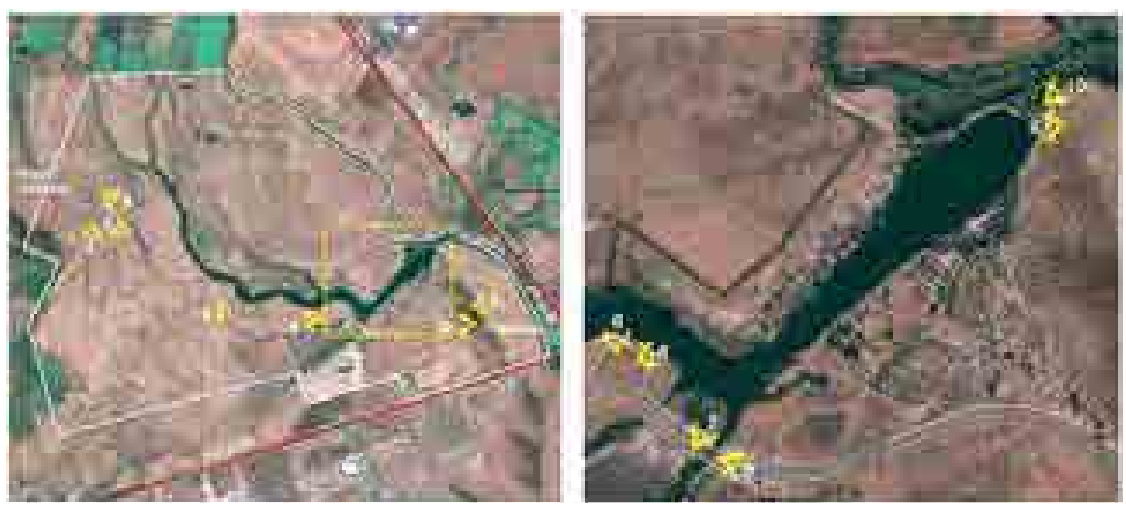

Figura 10.19.: Imágenes de la Urbanización e infraestructura de Servicios. Primera etapa ejecutada el año 2006. En URBE (2011).
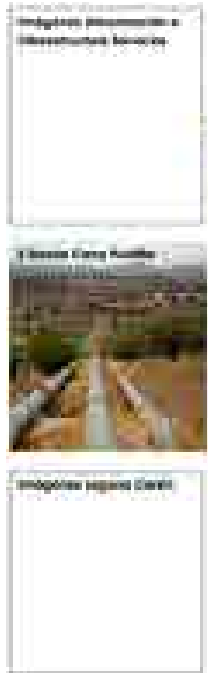
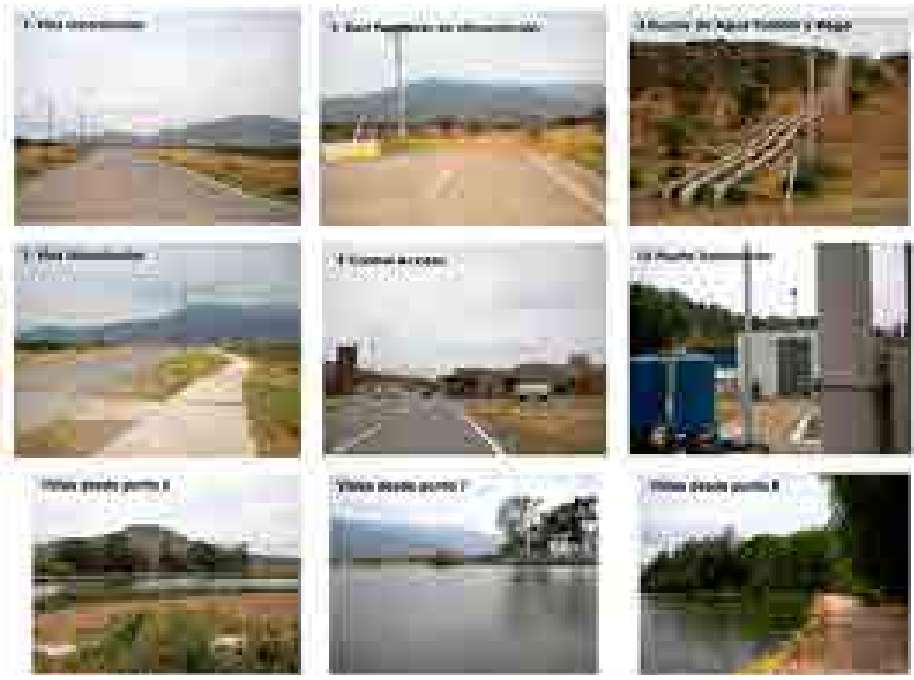


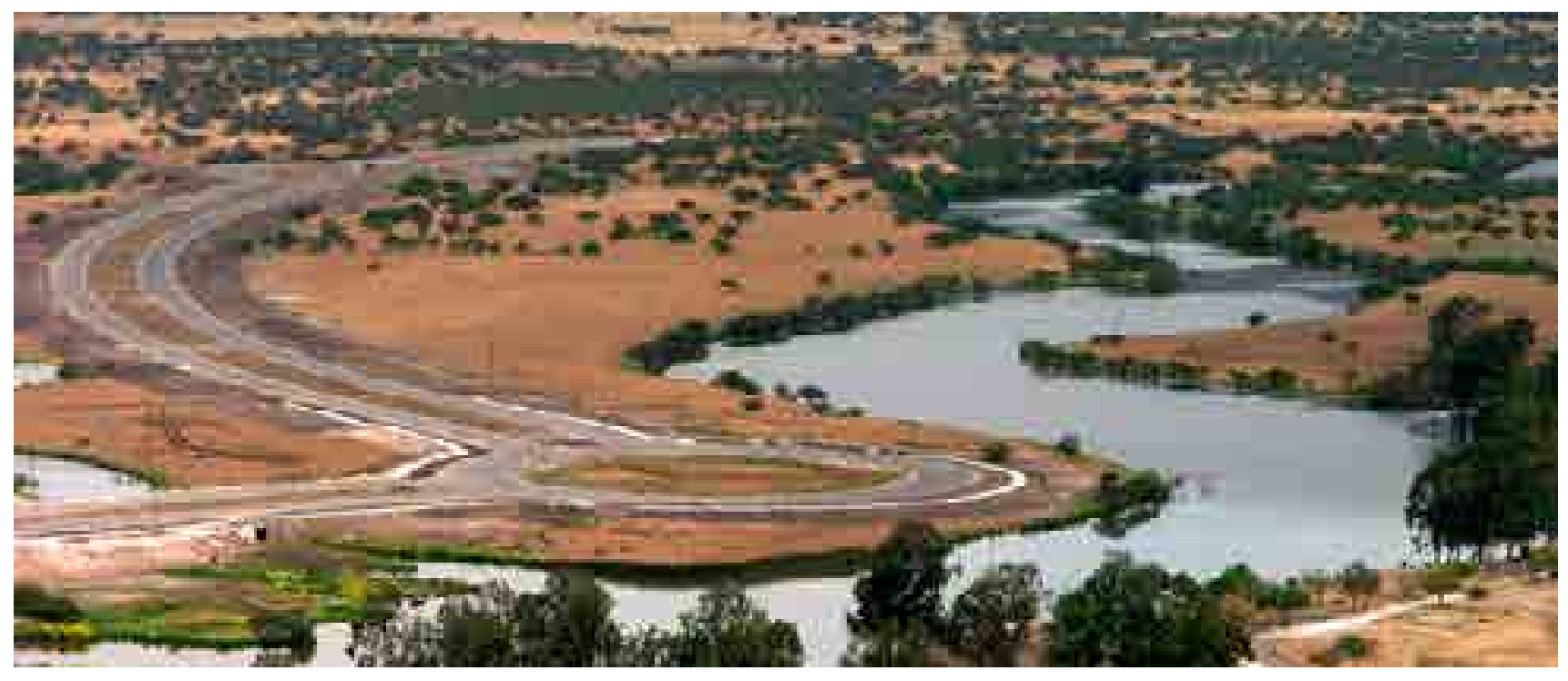

Figura 10.21. Vista de la vialidad principal desde el cerro Amapola. Desde la primera rotonda, al centro de la imagen, se obtiene una de las perspectivas más interesantes de la laguna.

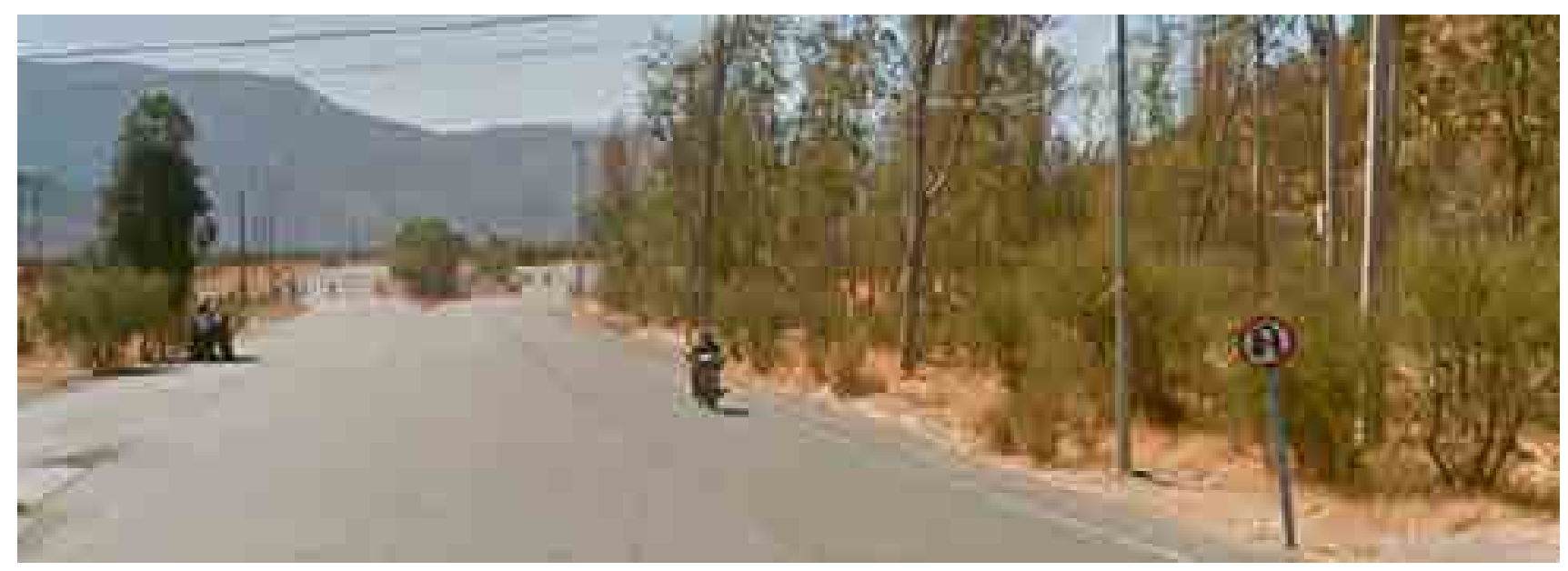

Figura 10.20. Vialidad de acceso al predio de Laguna Carén, vista desde la Ruta 68.

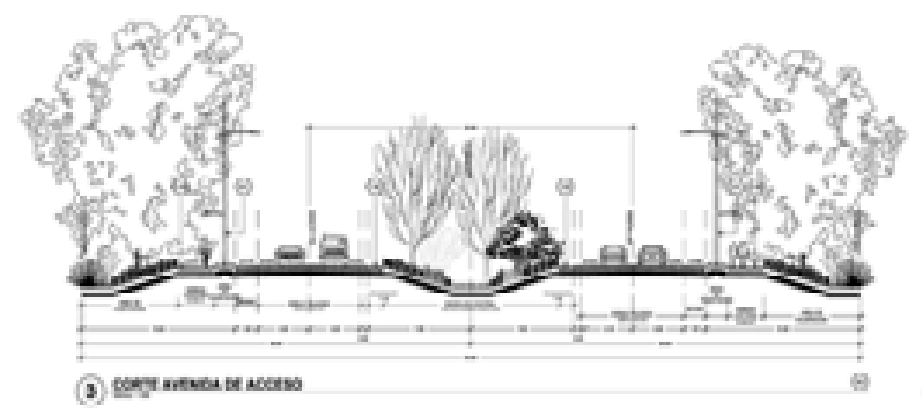

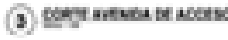

(6)

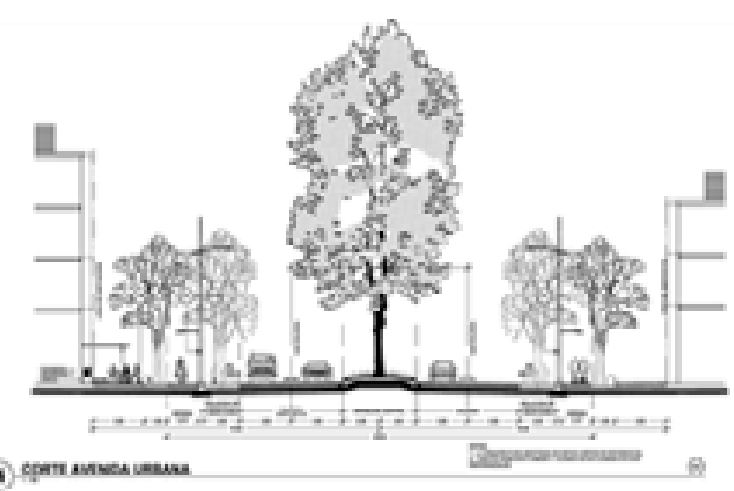

Figura 10.22. Detalle del Plano de Vialidad estructurante. Se aprecian dos secciones, correspondientes al primer y segundo tramo de la avenida de acceso. Planos digitales, gentileza de Andrés Sotomayor 


\subsubsection{Vialidad e infraestructura vial.}

A la fecha, se encuentra ejecutada toda vialidad proyectada como parte de una primera etapa del proyecto, la que está constituida por la vialidad estructurante, que incluye el acceso desde la ruta 68 y una avenida principal en doble pista.

La vialidad ejecutada se empalma con las obras ejecutadas por el Estado para la conexión del predio y su entorno con la Ruta 68 (trébol), que se desarrolla en una pista por sentido.

Como se muestra en la Figura 10.20., se trata de un primer tramo de aproximadamente $80 \mathrm{~m}$ de pavimento con dos calzadas (una pista por sentido), desde donde se genera una transición para el desarrollo de la vialidad contemplada en el desarrollo de la primera etapa del proyecto, la que se encuentra materializada en una vía estructurante de dos pistas por sentido que se prolonga por aproximadamente $4.000 \mathrm{~m}$.

El segundo tramo, corresponde a una vialidad de alto estándar por capacidad (doble pista por sentido) y especificaciones técnicas, tal como se observa en la siguiente imagen (Figura 10.21.) y en el plano donde se muestra el corte de la avenida (Figura 10.22.).

Existen dos puentes construidos que dan continuidad a la avenida que estructura la primera etapa del proyecto, dichas obras se encuentran en buenas condiciones técnicas y no requieren de reparaciones o mantenciones para su operación. Asimismo, cabe indicar que las señales para la operación vial se encuentran en buen estado y plenamente operativas.

La comunidad usuaria del Parque Carén, posee una imagen del predio como un lugar con infraestructura básica para actividades al aire libre, se visualiza como una "pampilla", dado que aún no implementa, a cabalidad, un sistema recreativo y mayor forestación de parques y áreas de sombra.

El punto donde mejor reconoce el proyecto, corresponde a la primera rotonda, después del ingreso por la Ruta 68, que enfrenta los atributos paisajísticos del cuerpo de agua. La actual portería, aún no configura una imagen de este lugar como parque.

\subsubsection{Alcantarillado y tratamiento de aguas servidas y disposición final de aguas tratadas.}

Con respecto al alcantarillado, este sistema se diferencia en tres grandes subsistemas, por una parte, la Red de alcantarillado, que es el sistema de recolecta y dispone las aguas servidas en la planta de tratamiento de las aguas servidas, que es para este efecto el segundo subsistema y finalmente y no menos importante, se debe mencionar el subsistema de disposición final de las aguas servidas tratadas.

\section{a. Subsistema de redes de Alcantarillado:}

Las redes de recolección de aguas servidas se encuentran operativas, sirviendo actualmente sólo a los baños existentes en la portería, que se conectan a la planta de tratamiento. Sin embargo, debido al tiempo transcurrido desde la construcción, las nuevas instalaciones deberán realizar pruebas que permitan corroborar su funcionamiento.

\section{b. Subsistema de Planta de Tratamiento de las Aguas Servidas:}

Este sistema (Figura 10.24.) se encuentra sin operación y con algunos elementos deteriorados, tales como el transformador que le entrega energía a la planta y el sistema de filtros externos. No es factible determinar el potencial daño interno que pueda tener la planta de tratamiento, dado que no ha sido usada. 

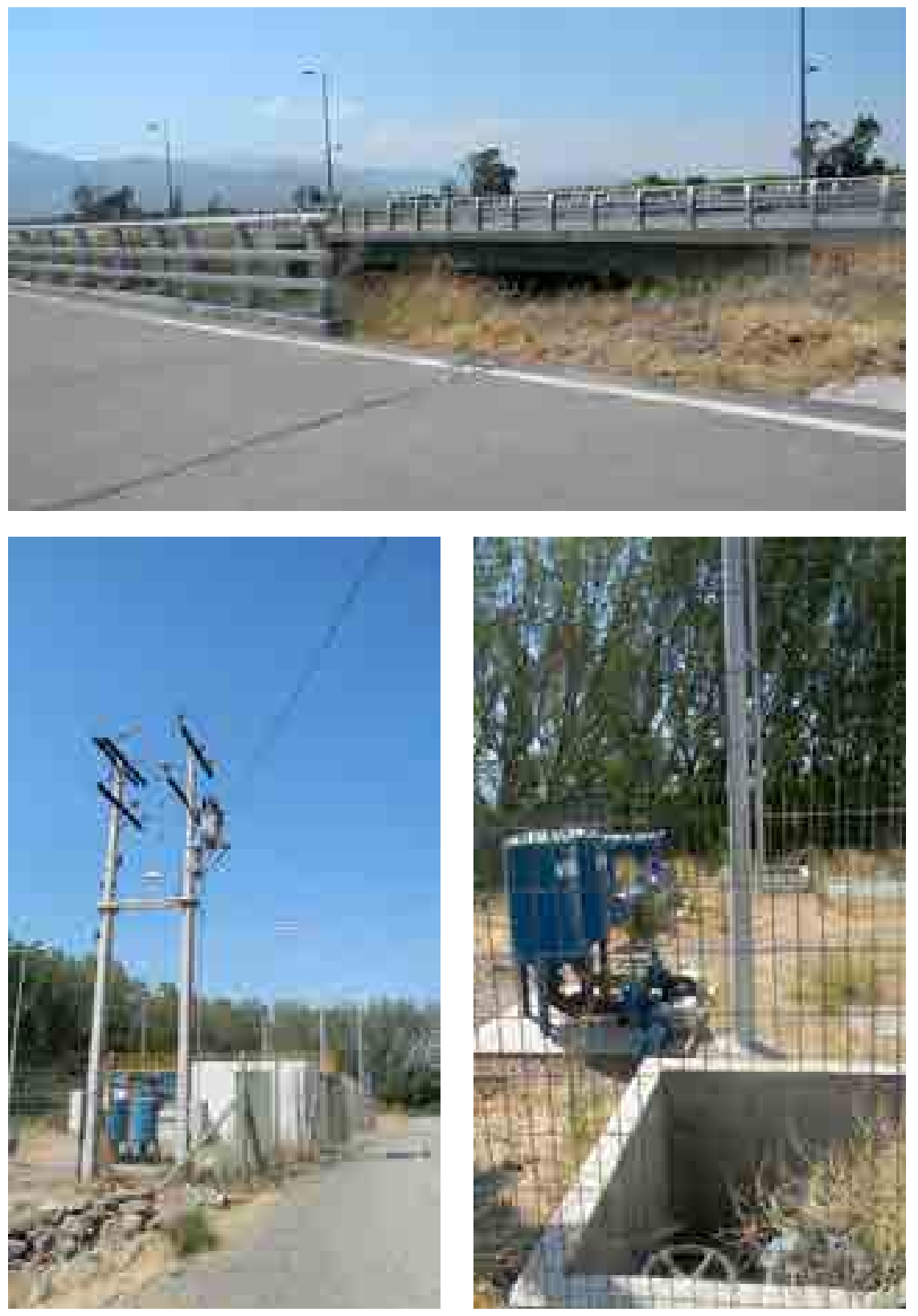

Figura 10.23.: Vista del puente sobre uno de los afluentes de la laguna.

Figura 10.24. Vista general y de detalle de la planta de Tratamiento de Aguas Servidas.
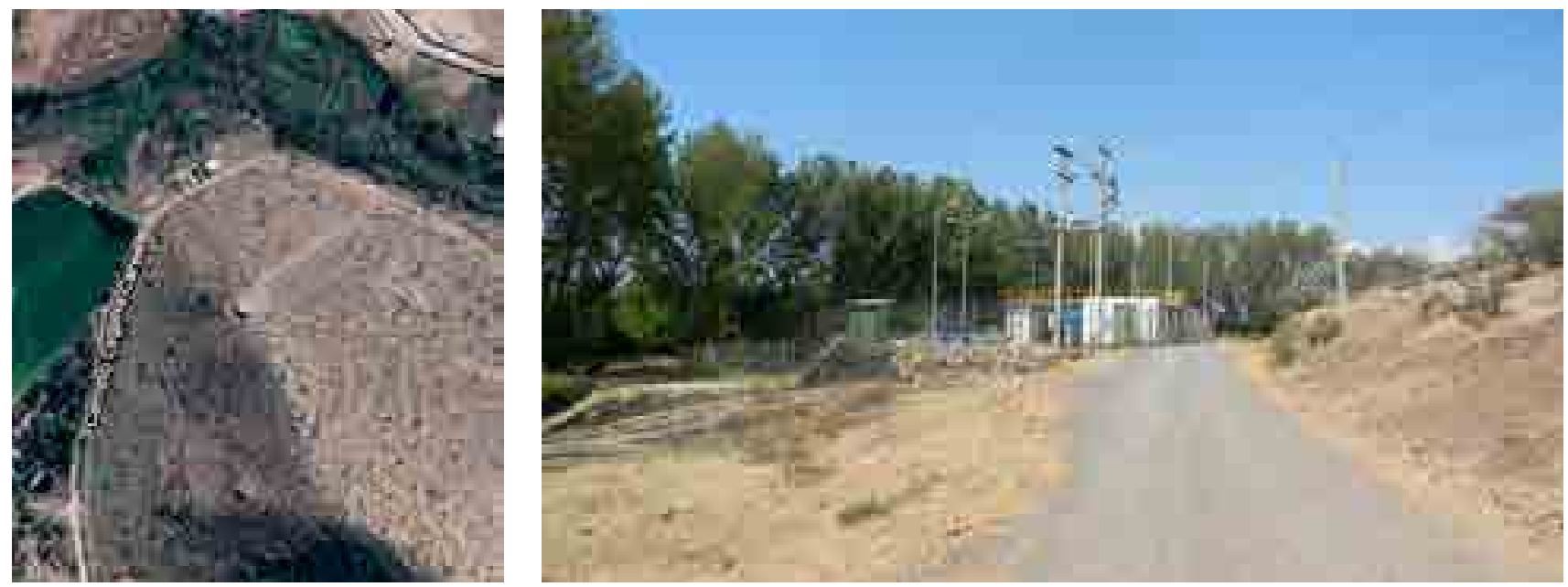

Figura 10.25. Planta de Tratamiento de Aguar Servidas, emplazado a los pies (norte) del cerro Amapola. En la vista satelital se observa el estanque sobre el cerro. Por la autora e imagen capturada desde Google Maps. 
Figura 10.26. Sistema de impulsión de las aguas tratadas a estanque para uso en el riego de las áreas verdes del proyecto. Cerro Amapolas, ladera norte.

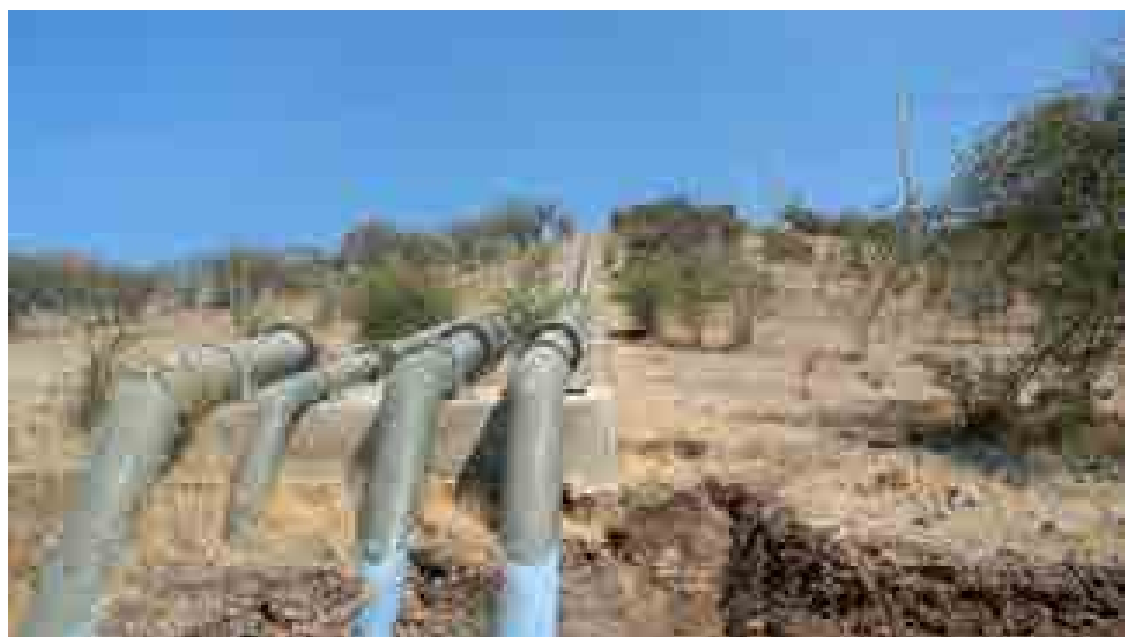

Cabe indicar que el proyecto original contempla dos sistemas para la disposición de las aguas servidas tratadas. Por una parte, un sistema de impulsión a estanques localizados en el cerro Amapola, donde se ubica la planta de tratamiento (Figura 10.25.). Desde allí, estas aguas servidas se aprovecharian en el sistema de riego de áreas verdes del proyecto. El segundo sistema contemplado, considera la disposición de las aguas tratadas al estero Lampa, tal como se indica en la Resolución de Calificación Ambiental otorgado a esta etapa por SEA (Sistema de Evaluación Ambiental chileno).

Respecto de este último sistema no es factible determinar en el estado en el cual se encuentra, dado que la Planta de Tratamiento no se encuentra en operación y por lo tanto no se ha impulsado agua tratada al estanque para su uso en el riego de las áreas verdes.

Como se observa en la Figura 10.26. la canalización se encuentra a la vista y en buenas condiciones.

\subsubsection{Agua Potable y sistema de grifos de incendio.}

En cuanto a las instalaciones, la propiedad tiene un estanque de 1.000 .000 de litros en el sector poniente, en altura, para dotar a futuro al proyecto. Además, en el sector norte existe un pozo de agua con planta de cloración y bombas impulsoras (35 lps), con un generador de respaldo. Ambas instalaciones están en funcionamiento y dotan al portal de acceso y otras construcciones. Hay una planta de tratamiento de aguas servidas en la base del cerro Amapolas (no está en funcionamiento), que se conecta a un estanque de 500.000 I ubicado en la ladera norte, que reúne agua para el sistema de riego del predio. Además, hay un estanque con bombas impulsoras en la segunda rotonda, al poniente del portal de acceso. Este sistema dota de riego por goteo a la zona urbanizada (vía de acceso).

Se puede apreciar que este sistema, junto a la vialidad, son los que se encuentran en plena operación y como los demás servicios, están sobre-dimensionados respecto al uso. Actualmente dota de agua a los baños existentes en la portería y está sujeto en un plan de mantención.

En la Figura 10.27. se puede observar el sistema de impulsión y almacenamiento de agua potable para su posterior distribución en el cerro Puntilla de Lo Vásquez. El estanque de agua (Figura 10.28.), tiene una capacidad de 1 millón de litros.

Se puede concluir que este sistema se encuentra plenamente operativo, por lo cual no requiere de la realización de obras o reparaciones, solamente se deberá considerar la realización de una mantención general previo a su puesta en operación. 

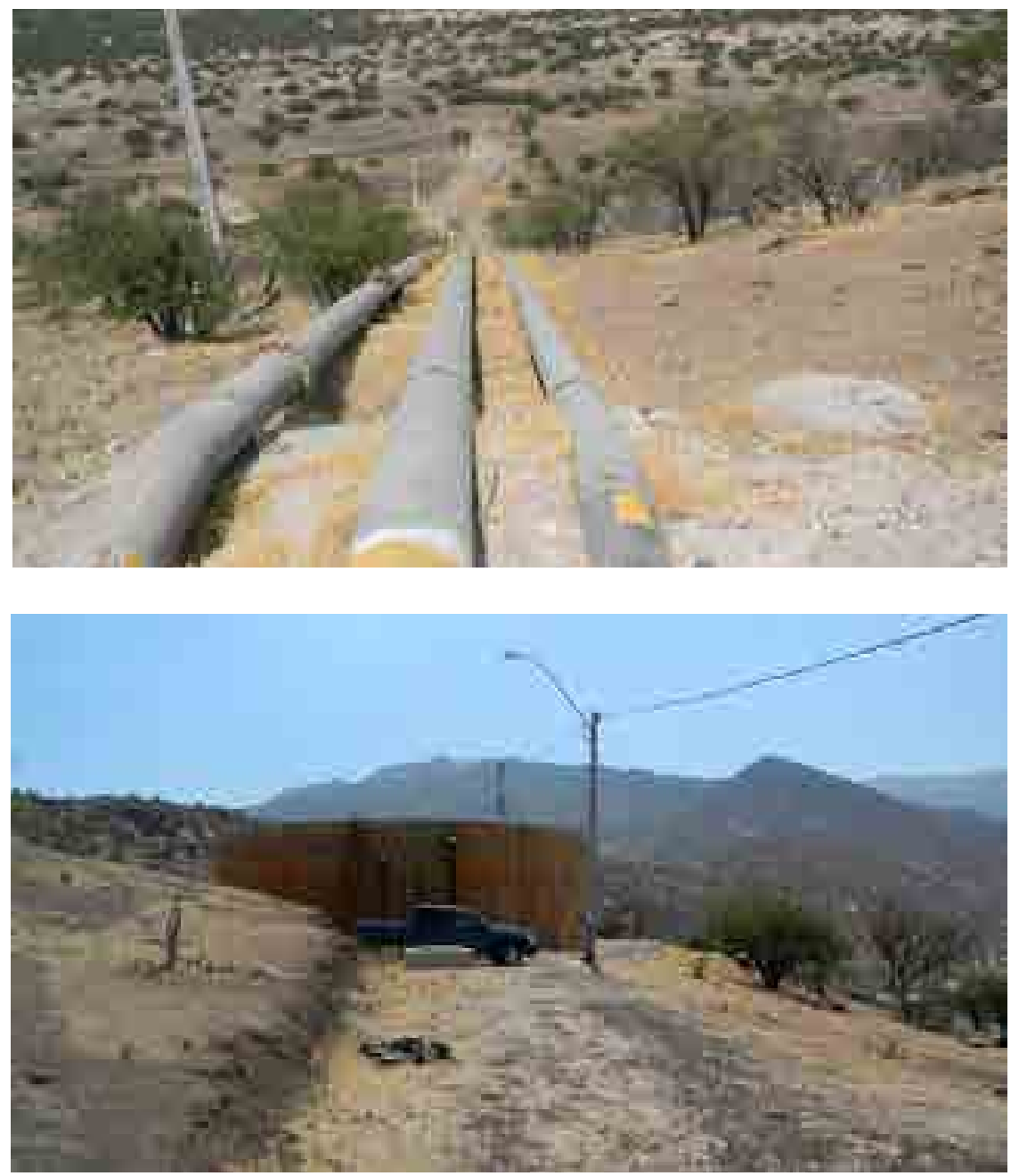

Con respecto al sistema de incendios, cabe aclarar que, dado que el sistema de agua potable se encuentra en perfectas condiciones, no debiera tener complicaciones para su puesta en operación, en terreno se observa que la infraestructura de incendios se encuentra en buenas condiciones, tanto en lo que respecta a los grifos instalados como al sistema de estanques considerados como sistema de emergencia.

\subsubsection{Sistema de recolección de aguas Iluvias.}

En general el sistema de recolección de las aguas lluvias se encuentra en buen estado, no se observa deterioro en el alcantarillado existente. En la Resolución de Calificación Ambiental (RCA) del proyecto, se indica que previo a la descarga de las aguas tratadas a la laguna, se debe habilitar un sistema de pre-tratamiento que permita el retiro de materiales que puedan generar algún tipo de contaminación en las aguas y su sistema natural. Este sistema de pre-tratamiento no está habilitado.

\subsection{SITUACIÓN DE LA LAGUNA.}

Según se señala en el Acta del Directorio de FVLA (2014), en febrero de 2011 uno de los clubes deportivos realizó, con conocimiento de la fundación, una denuncia sobre sospechas de descargas de aguas servidas no debidamente tratadas a la laguna.

En el mes de marzo de 2011, la Seremi de Salud realizó una visita a terreno, constatando "descargas de aguas tratadas, en el costado sur de la laguna, provenientes de zona habitacional Ciudad de Los Valles", "con presencia de olores molestos, aguas de tonalidades negruzcas y eutroficación de las aguas". En agosto del mismo año, la Seremi de Salud ordena un sumario sanitario a la empresa
Figura 10.27. Sistema de impulsión de agua potable a los estanques de almacenamiento, vista de la ladera oriente del Cerro Puntilla de Lo Vásquez.

Figura 10.28. Sistema de almacenamiento de agua potable en el Cerro Puntilla de Lo Vásquez. 
Servicios Sanitarios Lo Prado S.A. (SEPRA S.A.) la cual posee una Planta de Tratamiento de Aguas Servidas (PTAS) que sirve al conjunto habitacional Ciudad de Los Valles (Expediente N 1146-2011), en la cual ordena a SEPRA S.A. a:

realizar en forma inmediata la limpieza del sector de la Laguna Carén afectada por un foco de insalubridad provocado por la descarga de aguas tratadas provenientes de la planta de tratamientos de aguas servidas de propiedad de la sumariada, y que corresponden a las aguas servidas del complejo habitacional Ciudad de Los Valles, debiendo retirar los sedimentos depositados en ese sector de la laguna" e "implementar en un plazo de 15 días, contados desde la notificación de esta resolución, un plan de limpieza y mantención periódica y permanente del sector de la Laguna Carén, en el lugar donde llegan las aguas servidas y tratadas de la Ciudad de Los Valles" (Seremi Salud, 2011).

La Fundación inició, en agosto 2012, un proceso de diagnóstico y monitoreo de la Laguna Carén a cargo del CENMA ${ }^{342}$, institución que realizó 5 informes técnicos y un Informe de síntesis en febrero 2014, el cual indica que:

- $\quad$ Los datos obtenidos en el presente estudio llevan a la conclusión que la calidad del agua es regular, pero que dentro de la Laguna la calidad es heterogénea. Por otra parte, existe un sector específico, en el brazo sur de la Laguna Carén (estación LC-05), donde la calidad del agua es mala.

- $\quad$ Dado el resultado de la excedencia permanente de los niveles aceptables de Coliformes Fecales, hay una alta probabilidad que la causa sea el ingreso de aguas microbiológicamente contaminadas y, además, con una alta carga de materia orgánica muerta.

- $\quad$ Estos resultados pueden ser explicados por el ingreso a la Laguna, por los cauces naturales de aguas lluvias, de fugas de aguas servidas no tratadas, ya sea de industrias o de sistemas sanitarios deficientes, de una forma intermitente en días y horas variables, pero de forma recurrente. (CENMA, 2014).

A partir de esta situación, la FVLA ha iniciado un procedimiento de toma de muestras mensual y otras acciones administrativas.

En octubre de 2014, la Superintendencia de Servicio Sanitarios (Ord N ${ }^{\circ} 3760$ de oct 10,2014), manifiesta su incompetencia para conocer y sancionar los hechos denunciados efectuados por privados, puesto que sólo fiscaliza empresas sanitarias, además de señalar que, durante el año 2014, se realizaron 10 fiscalizaciones de la PTAS SEPRA S.A. Informa además, que los resultados de autocontrol de esta empresa, indican que se ha cumplido la norma de emisión y que se mantendrá una fiscalización permanente a la operación de SEPRA S.A.

Al respecto, según se establece en el acta mencionada, el Sr. Vicepresidente Ejecutivo indica que "lo anterior ratifica los monitoreos que se hacen diariamente en la laguna", y "que a la fecha se han terminado los olores, ha empezado a volver el color más natural de ésta y que no ha habido reclamos de los habitantes del sector" (FVLA, 2014).

\subsection{INSERCIÓN DEL PREDIO EN EL DESARROLLO DEL VALLE DE LO AGUIRRE}

Si volvemos desde la micro-escala que requiere el cuidado de la laguna, a la macro-escala, podemos observar cómo el sitio de Laguna Carén, emplazado en una zona rural, de pronto se ve inmerso en un proceso de transformación territorial más amplio, como consecuencia de una política de planificación errática.

De este modo, retomando el análisis normativo del capítulo anterior, podemos vislumbrar una realidad que sitúa el predio en medio de un área de crecimiento de la ciudad.

${ }^{342}$ Centro Nacional del Medioambiente de-

Desde los años 1960, ya se había identificado que el acceso poniente, desde la Ruta 68 se transformaría en una puerta a la ciudad, proveyendo servicios, que hoy se observan en la dinámica del nodo Vespucio/ Costanera Norte/Ruta 
68, con la instalación del conglomerado que forman el Aeropuerto Internacional Arturo Merino Benítez y el Parque de Negocios ENEA (AMB-ENEA).

Hubo otros indicios que dieronn pie a esta transformación, tales como el estudio y proyecto "Región Capital de Chile", premiado en 1987 por la Bienal de Arquitectura de Santiago (Munizaga et al.,1987) que identificaba el Valle Lo Aguirre como alternativa espacial para el crecimiento de Santiago, que, sin embargo, permaneció olvidado por algunas décadas.

Como vimos en el capítulo 9, a partir de 1979, se liberaron suelos rurales como zonas urbanizables, reconociendo los Usos de Suelo del PRIS tales como vivienda, industria, parques, agroindustrias y áreas de preservación natural, entregando un marco de desarrollo absolutamente viable para un modelo de crecimiento urbano poniente, que luego fue restringido por el PRMS de 1994.

El potencial del Valle Lo Aguirre - como un territorio de descentralización urbana vía creación de nuevas ciudades- atrajo en la década de 1990 la inversión privada, que silenciosamente, consiguió la aprobación de proyectos de loteo y edificación para Proyectos como Mina Lo Aguirre, Jardines de Lo Prado (AGSA) e Izarra de Lo Aguirre (de varios propietarios) (DOM-AU, I Municipalidad de Pudahuel, 2018)

Frente a la propuesta de reducción de área urbana de Santiago, formulada por el PRMS de 1994, la Municipalidad de Pudahuel manifestó su disconformidad al MINVU y presentó la propuesta de "Ciudad Compensada" (URBE, 1993) como modelo de desarrollo urbano descentralizado con autonomía de servicios y autosuficiente, diversa y mixta. Lo que en la última década ha tomado forma en el Plan de Desarrollo Comunal de Pudahuel (PLADECO), donde se declara una comuna aeroportuaria.

La estrategia del PRMS desestimó el crecimiento en el Valle Lo Aguirre y privilegió el desarrollo de Chacabuco (ZUDC 1993) en primer lugar y Talagante-Melipilla en segundo (2000).

Paralelamente en el 1994, el Plan Maestro para Transporte de Santiago (Echeñique-MOP) ratifica la $4^{\circ}$ Orbital del PRIS 60 que creará la conectividad entre el acceso norte de Santiago y la Ruta 78 , ratificando la centralidad potencial del Valle Lo Aguirre.

El Plan de Autopistas Concesionadas para Santiago (MOP 1998), licitando la Costanera Norte abre el territorio desde la Barnechea hasta el Rio Mapocho en Pudahuel y recientemente la expansión de dicha vía hasta la Autopista del Sol, que conecta Santiago con el puerto de San Antonio.

Serán los Tribunales de Justicia ${ }^{343}$, quienes, en contra de la autoridad planificadora, autoricen los seccionales de Izarra y de Jardines de Lo Aguirre (conocido hoy

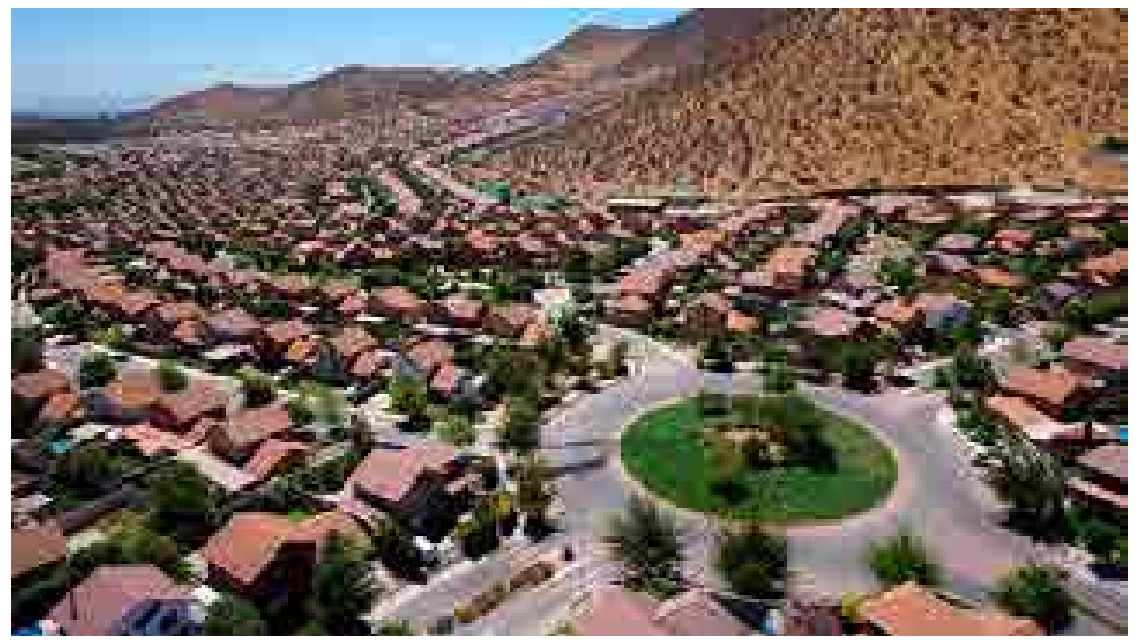

${ }^{343}$ En el caso de Ciudad de Los Valles, con la sentencia de agosto de 1996 de la Corte de Apelaciones de Santiago (Rol No $176-$ 1995); y respecto de Izarra de Lo Aguirre, a través de la sentencia de noviembre de 1999 de la Corte Suprema (Rol N 31731999).

Figura 10.29. Vista de Ciudad de Los Valles. En CIPER (31 de enero, 2019). 


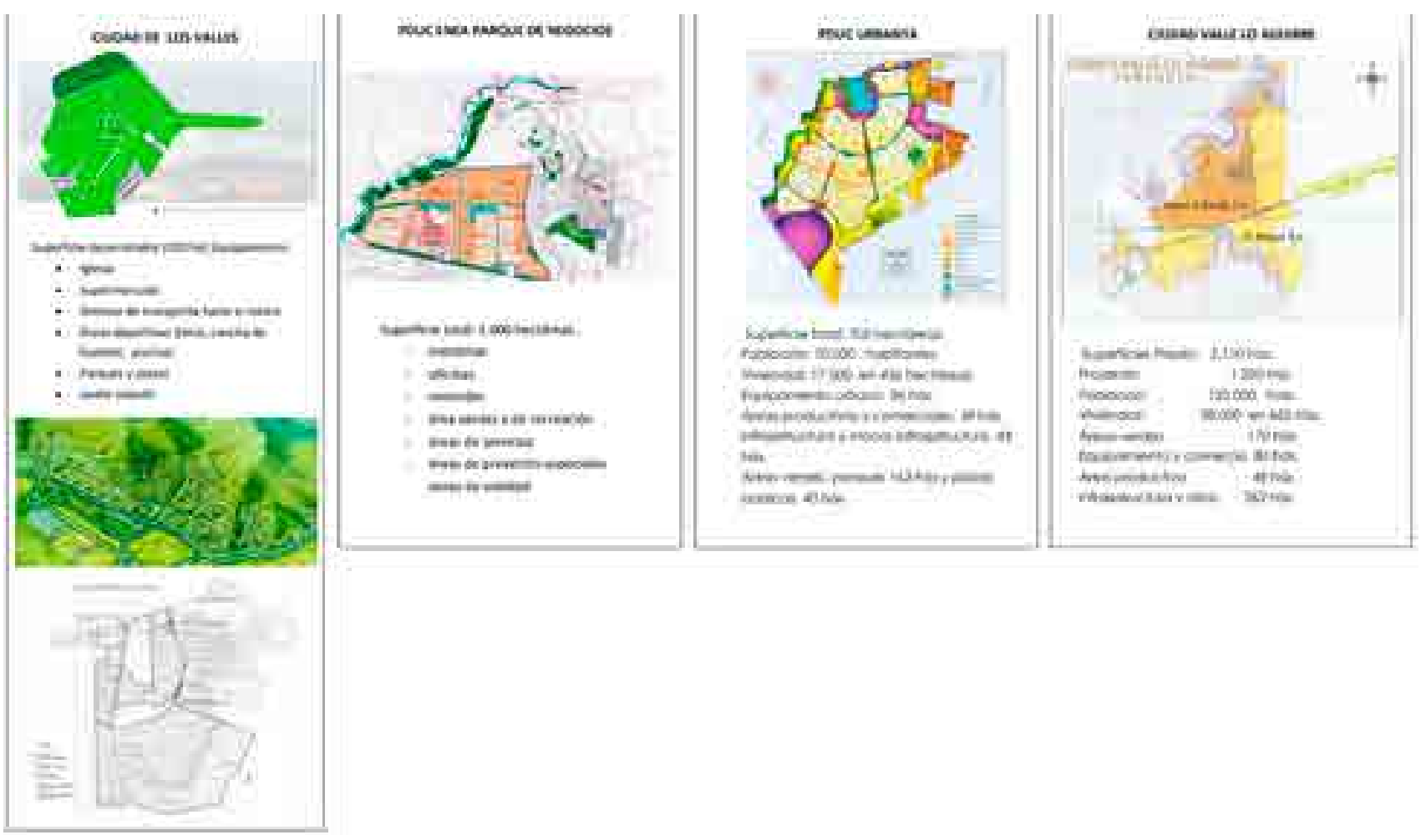

Figura 10.30. Proyectos de Desarrollo Urbano Condicionado que rodean el predio de Carén.En URBE (2011, p. 20).

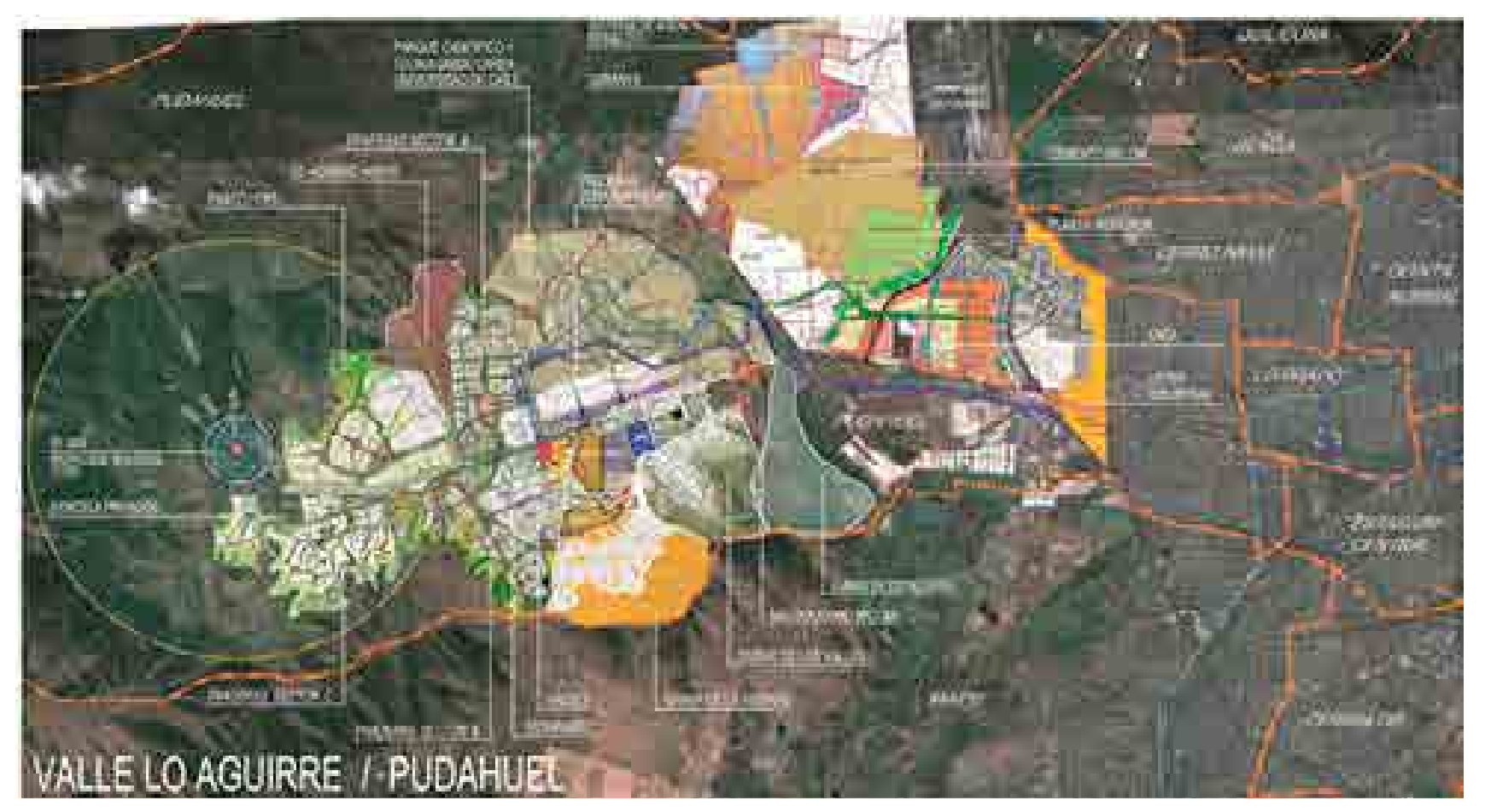

Figura 10.31. Desarrollos inmobiliarios en torno a Laguna Carén. En URBE, 2011, p.

19). 
como Ciudad de Los Valles). Ciudad de Los Valles ha construido 3.000 viviendas desde 2003, cubriendo gran parte del piedemonte que enfrenta el sitio de Carén, al otro lado de la carretera (Figura 10.29.).

En dicha coyuntura, se desarrolla el Seccional de la Ex Mina La Africana, reutilizando las zonas de campamento y creando el proyecto Lomas de Lo Aguirre, que expande y rentabiliza las inversiones en equipamiento y urbanización del predio disponible.

En la actualidad existen permisos de edificación residenciales pagados y vigentes en varios proyectos los cuales seguirán ejecutándose según los derechos adquiridos.

En forma paralela, la creación de la PDUC (ZUDC perfeccionadas) en el concepto de Desarrollos Urbanos Condicionados (PRMS 2005) vendrían a ratificar el destino urbano del territorio. Como se grafican en la Figura 10.30., las PDUC ${ }^{344}$ de Urbanya, ENEA, Ciudad de Los Valles y Praderas (Ciudad Valle Lo Aguirre), conformarán un continuum en el territorio, desde el Anillo Américo Vespucio hasta el Túnel Lo Prado (sumando sobre 6.000 hectáreas).

El fenómeno que observamos concierta una tendencia aparentemente irreversible de desarrollo urbano, sobre suelos rurales, que ya sea por la aprobación de nuevas PDUC 0 , la ejecución de los permisos vigentes se irá creando una nueva ciudad caracterizada por un modelo de crecimiento a partir de grandes emprendimientos privados, que dejan a Carén en el centro (Figura 10.31.).

Los soportes estratégicos de dicho desarrollo son:

- Corredor Autopistas Ruta 68.

- Autopista Américo Vespucio.

- Autopista Costanera Norte y su continuidad hasta Autopista del Sol

- Troncales R 68.-

- Ejes de transporte de mitigación formulados por las PDUCs de Praderas (nuestro vecino poniente), URBANYA y ENEA.

- Parque Empresarial ENEA.

- El nuevo Terminal Aeroportuario Nacional AMB.

- Carencia de restricciones ambientales relevantes.

- Baja calidad productiva agrícola de los suelos.

- La confluencia de agentes privados e institucionales con injerencia y voluntad de invertir y desarrollar el área.

En un territorio mayor, el Aeropuerto AMB (ex Pudahuel) y la disponibilidad de suelos adicionales en la zona (Hidronor y Cemento Melón) son un ancla fundamental en visualizar el "Cono Poniente de Pudahuel -Lo Aguirre" como un Sistema Mixto y Diversificado de actividades, Servicios y Vivienda.

Esta tendencia se ha visto ratificada por la creación del Parque empresarial ENEA, el Club de Golf Mapocho, el proyecto Lomas de Lo Aguirre, Ciudad de Los Valles, los centros de logística de UNIMARC y FASA; el Cementerio Canaán, entre otros desarrollos.

El sitio de Laguna Carén, han sido una promesa latente que conforma el centro del territorio del Valle Lo Aguirre que, inserto en el escenario antes descrito, no presenta dudas de la potencialidad y del ineludible rol aglutinador y complementario en la zona. También nos permite comprender las tensiones a las que está sometido.

Asumir un rol articulador del conjunto que hoy está en manos de los agentes inmobiliarios es el desafío mayor que presenta a esta escala el Plan Maestro para Carén. El Valle de Lo Aguirre se transformará en un sub-centro de la metrópoli con usos y destinos diversos, amenazada por la falta de coordinación entre agentes de desarrollo y una normativa contradictoria.
344 Aprobadas finalmente después de 13 años de tramitación, el 12 de enero de 2018. La publicación en el Diario Oficial está disponible en línea en: https:// www.diariooficial.interior.gob.cl/publicacio es/2018/03/07/42001/01/1362169.pdf

345 Se estima que las PDUC Ilegarán a albergar a 190.000 habitantes, los que, sumados a la población de Pudahuel, que, según el censo de 2017, llega a 230.293 personas, totaliza más de 420.000 habitantes. 
En este contexto, la conformación de una nueva centralidad sustentable que servirá una población residente que se proyecta alcanzará a $420.000^{345}$ habitantes, requiere de una visión y organización física, espacial y de usos que permitan un desarrollo autónomo del valle.

Para la universidad, se presenta la oportunidad excepcional de liderar la creación de un nuevo territorio con un destino no-inmobiliario, de conservación y restauración del valle y sus servicios ambientales. Junto con crear las condiciones de interacción con el marco de sustentabilidad ambiental, el proyecto debe ser capaz de sustentarse económicamente y ser un aporte a la sociedad, cumpliendo con el rol de creación de conocimiento, educación e innovación propio de una universidad pública.

A diferencia de los agentes inmobiliarios, la universidad puede pensar el uso de este territorio desde el paisaje y buscar en este diálogo con el lugar, el programa más adecuado y los límites de su acción, que serán los temas que trataremos en los próximos capítulos.

\section{DIARIO OFICIAL}

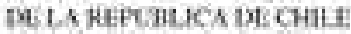

\begin{tabular}{|c|c|c|}
\hline \multicolumn{3}{|c|}{ 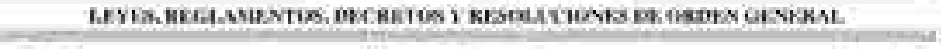 } \\
\hline - $20=$ & 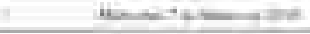 & $5-6=$ \\
\hline \multicolumn{3}{|c|}{ Normas Genrraiss } \\
\hline & Crisidies & \\
\hline
\end{tabular}

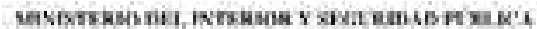

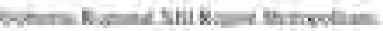

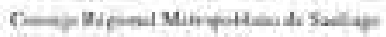

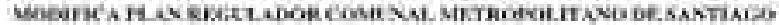

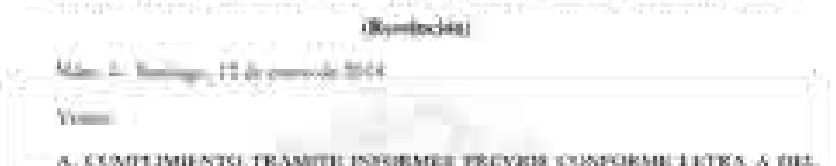
arintumistivgs

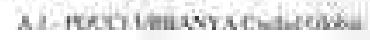

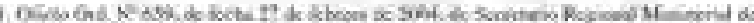

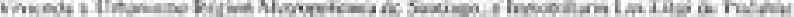

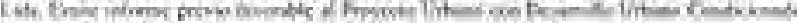

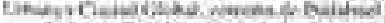

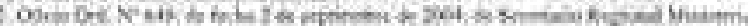

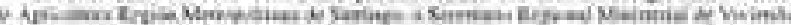

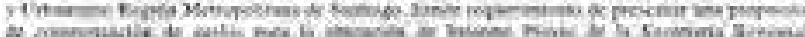

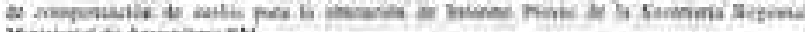

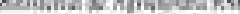

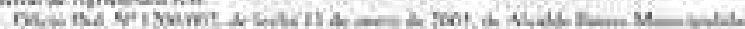

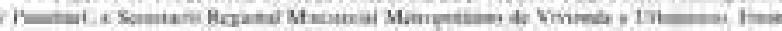

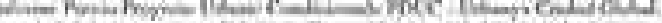

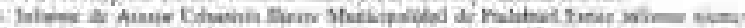

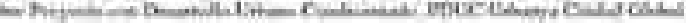

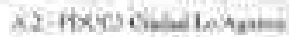

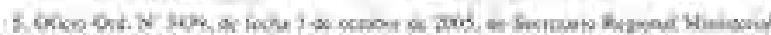

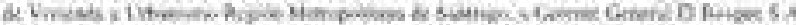

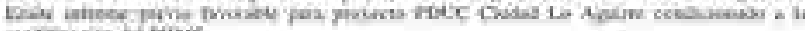

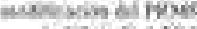

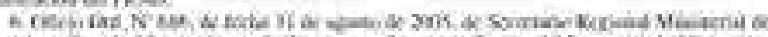

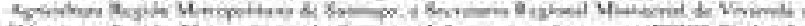

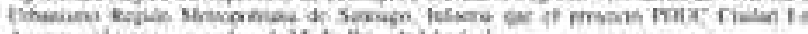

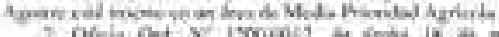

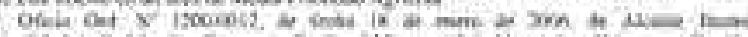

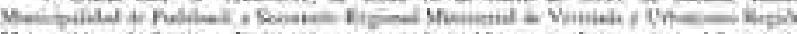

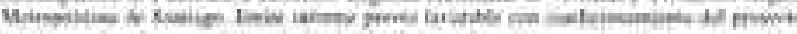

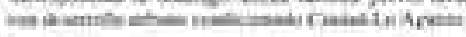




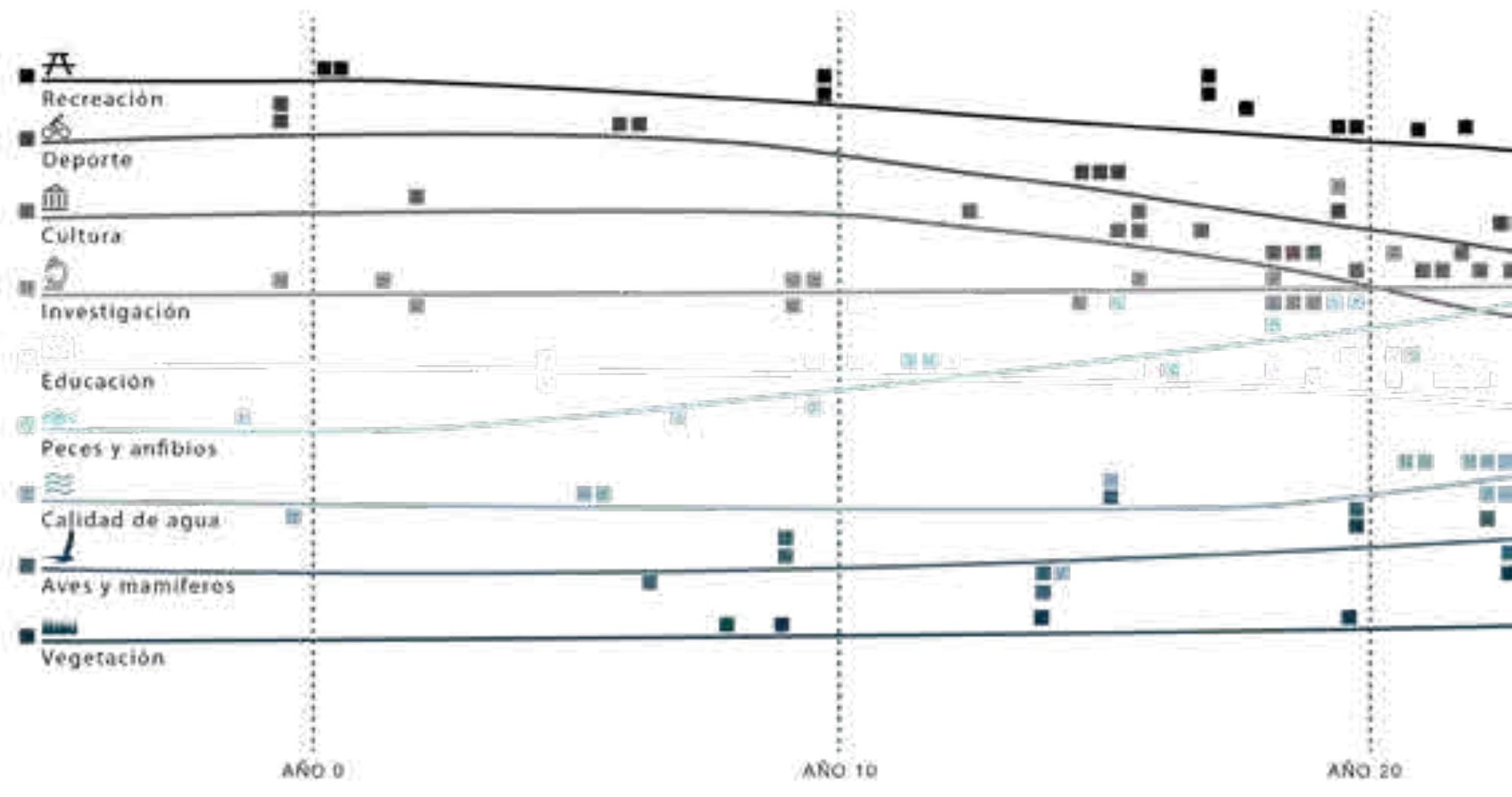

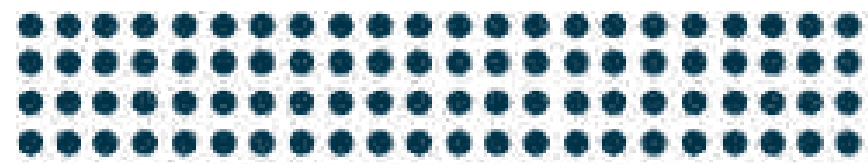

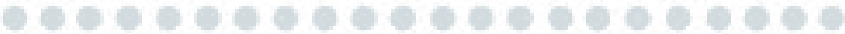

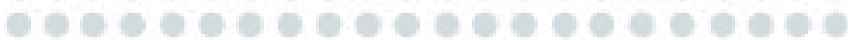

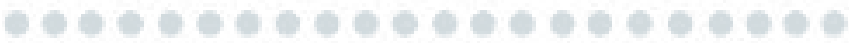

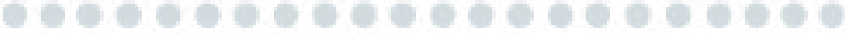

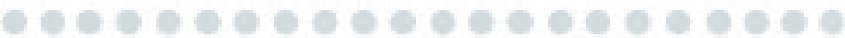

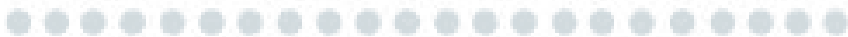

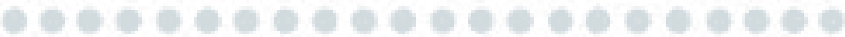

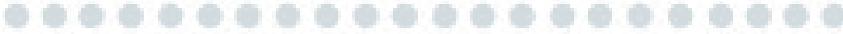

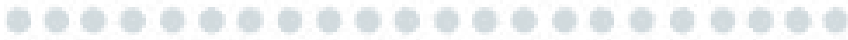

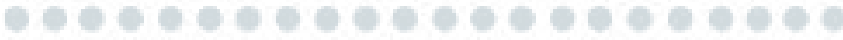

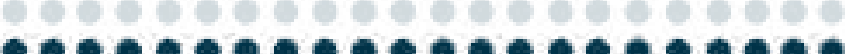
$\bullet \bullet \bullet \bullet \bullet \bullet \bullet \bullet \bullet \bullet \bullet \bullet \bullet \bullet \bullet \bullet \bullet \bullet \bullet \bullet$ $\bullet \bullet \bullet \bullet \bullet \bullet \bullet \bullet \bullet \bullet \bullet \bullet \bullet \bullet \bullet \bullet \bullet \bullet \bullet \bullet \bullet \bullet$ $\bullet \bullet \bullet \bullet \bullet \bullet \bullet \bullet \bullet \bullet \bullet \bullet \bullet \bullet \bullet \bullet \bullet \bullet \bullet$

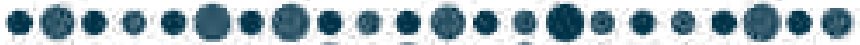

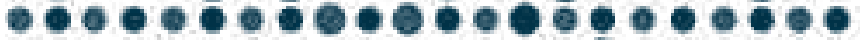

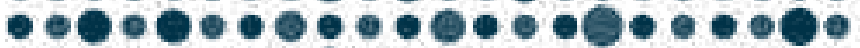

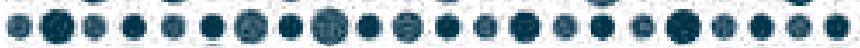

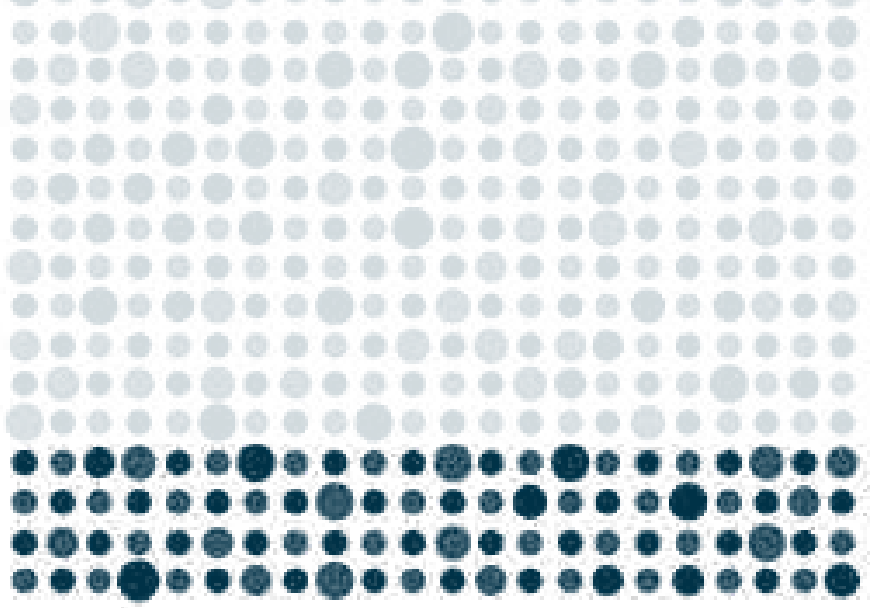




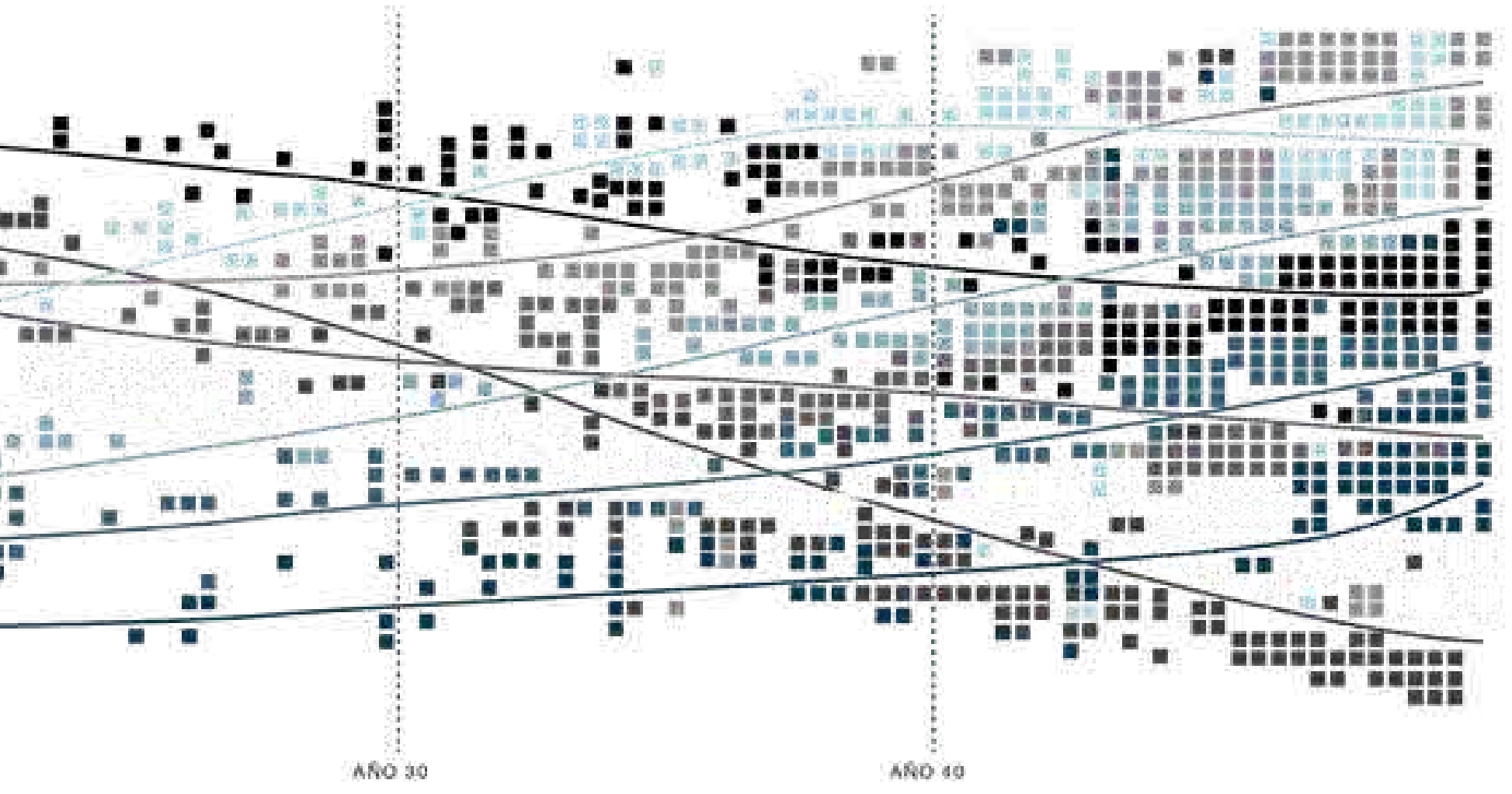

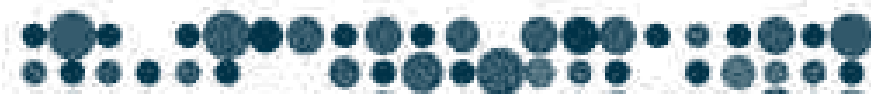

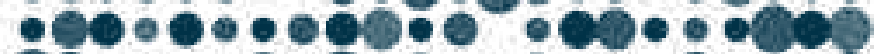

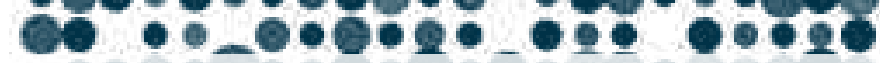
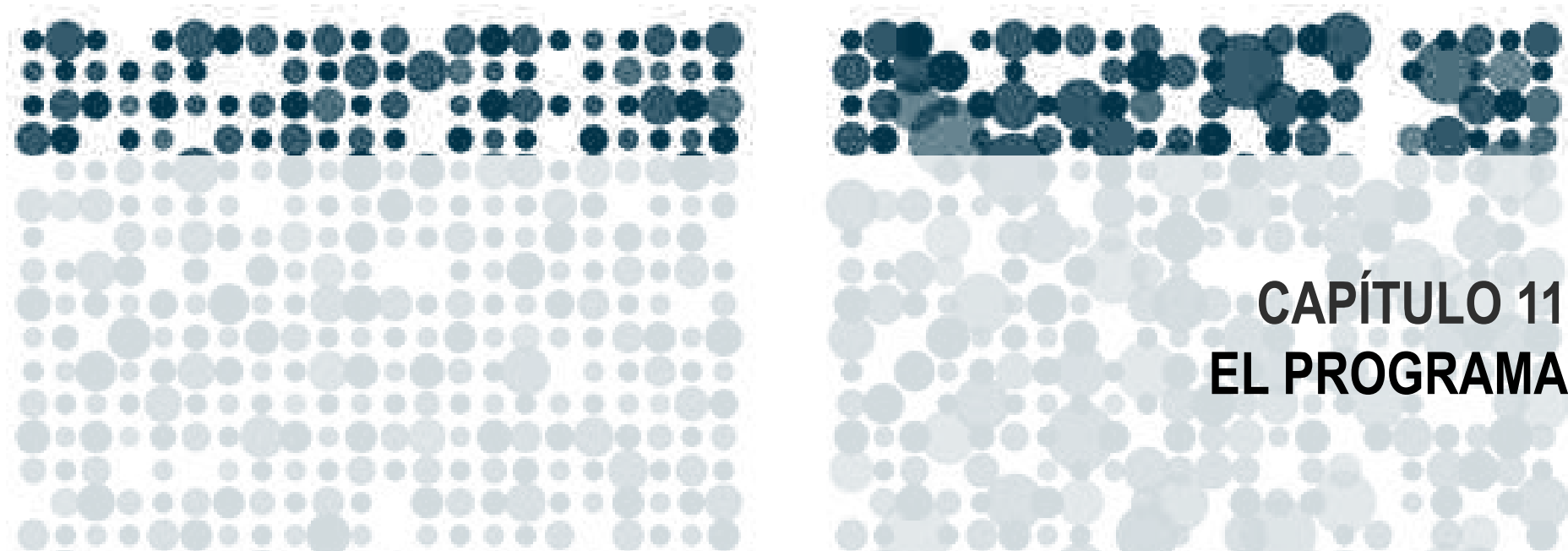

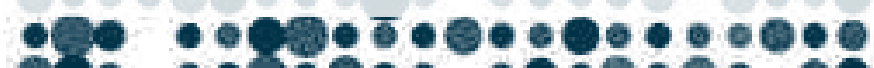

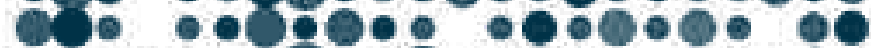

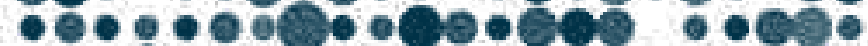

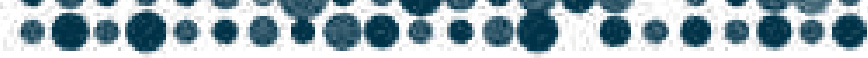

\section{CAPÍTULO 11 EL PROGRAMA}

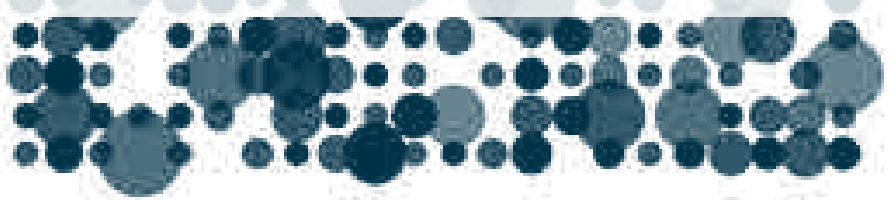




\section{EL PROGRAMA}

\section{¿UN PARQUE CIENTÍFICO-TECNOLOGICO EN CARÉN?}

\subsection{INTRODUCCION}

La Universidad de Chile al recibir la donación del predio Carén de parte del Estado, comprometió la creación de un parque científico-tecnológico (PCT), una ciudad universitaria y un parque público.

En esta revisión del proceso, en la que hemos priorizado el lugar como motivador del nuevo plan maestro, se ha postergado al mismo tiempo el programa, el "qué" del proyecto, que, en el proceso real, hace cinco años, partió con un trabajo colectivo para configurar primero, un proyecto académico ${ }^{346}$ que diera sustento a la intervención en el territorio.

Este capítulo explora y profundiza las preguntas que en ese momento fueron claves:

¿Cuál es la misión de la universidad y cómo esa misión se puede reforzar en este lugar?

¿qué entendemos por tercera misión, hoy, en Chile, en la Universidad de Chile? ¿Es un Parque Científico - Tecnológico el modelo pertinente?

Respecto a la idea de relocalizar a la universidad en Carén, vale decir el compromiso de la "Ciudad Universitaria", la evaluación fue, tras el estudio de las inversiones de los últimos diez años y la consulta a las 14 facultades y 4 Institutos, que no era viable pues, como el rector zanjó:

[...]en la actualidad las facultades han invertido sumas considerables en infraestructura en sus actuales sedes, para mejorar sus estándares de calidad, con lo cual están tendiendo a consolidar su localización física actual, a lo menos en el mediano plazo, ya que los proyectos de infraestructura y equipamiento que presentaron al programa de endeudamiento a 20 años, no consideran inversiones fuera de sus campus actuales (UCHILE, 2015, p. 16) ${ }^{347}$.

Por otra parte, el compromiso del "parque público" era incuestionable, pero había sido hasta el momento, un componente del programa, que, si bien no se discutía, tampoco se había problematizado. Bastaba con reservar el paño de 200 hectáreas en el lugar "menos apetecido". Refutar esta postura, e invertir la valoración de los elementos del programa, han sido las dos acciones que dieron el impulso definitivo ${ }^{348}$ al nuevo Plan Maestro. Planteamos que el parque podría llegar a ser lo más importante, si consideramos que el paisaje es la clave de interpretación del uso que podemos dar a este territorio, idea que ha inspirado, por otra parte, la realización de esta tesis. Si bien, el tema del parque público fue extensamente abordado en el capítulo 6, en rigor el parque científico tecnológico, no se ajusta a una evolución de la tipología del parque, sino más bien a un fenómeno que merece ser estudiado particularmente.

Es por ello, que hemos considerado necesario dedicar un capítulo a la revisión del concepto de "parque científico-tecnológico" y la relación que este modelo tiene, según varios autores (Bolton,1993;1996; Castells \& Hall,1994) que lo han estudiado desde los años 1990, con lo que suele señalarse como la tercera misión de la universidad.

\subsection{LA UNIVERSIDAD DE CHILE}

Es la institución de educación superior más antigua de Chile y una de las de mayor prestigio y tradición de Latinoamérica. En coherencia con sus estatutos, la presentación pública en la página web indica:

La Universidad de Chile es una institución de educación superior de carácter nacional y pública, que asume con compromiso y vocación de excelencia la formación de personas y la contribución al desarrollo espiritual y material de la Nación, construyendo liderazgo en el desarrollo innovador de las ciencias y las tecnologías, las humanidades y las artes, a través de sus funciones de docencia, creación y extensión, con especial énfasis en la investigación y el postgrado.
${ }^{346}$ Cabe destacar que los planes maestros realizados hasta 2015 y que hemos estudiado en el capítulo 10, no tenían en su fundamentación un proyecto académico de base, tampoco ninguna consulta a la comunidad universitaria.

${ }^{347}$ Este texto formó parte de la respuesta de la universidad a la Contraloría General de la República ante una investigación sobre el cumplimiento de los objetivos de la donación. La situación de las facultades ya había sido abordada por el Comité de Seguimiento de la Fundación Valle Lo Aguirre de fecha 10.06.2011.

${ }^{348}$ Ya que lograron entusiasmar a las autoridades y sumar tanto a la comunidad universitaria, como a los vecinos de la comuna de Pudahuel. 
En el ejercicio de dichas funciones promueve el ejercicio de una ciudadanía preparada, crítica, con conciencia social y responsabilidad ética, de acuerdo a los valores de tolerancia, pluralismo y equidad, independencia intelectual y libertad de pensamiento, así como también del respeto, promoción y preservación de la diversidad en todos los ámbitos de su quehacer (UCHILE, 2019).

Desde el punto de vista histórico, su origen se encuentra en la Universidad Real de San Felipe, creada en 1738, que inició la formación en cuatro áreas del conocimiento: leyes, teología, medicina y matemática. El proceso de Independencia, iniciado en 1811 impulsa la evolución hacia una universidad de carácter nacional que transitó desde Universidad del Estado de Chile, luego Universidad de la República de Chile, para finalmente adoptar el nombre actual de Universidad de Chile y consolidarse en 1842 con Andrés Bello como su primer rector. La ley que le da origen, define su rol de superintendencia de la educación en el país a todos los niveles, la promoción de la investigación y la divulgación científica y literaria como también el apoyo a las diversas funciones del Estado (UCHILE, 2018).

Junto a la formación de los profesionales que el país necesita, la universidad ha tenido un importante rol en el desarrollo Chile. A la tarea de estructurar un sistema de educación nacional, se sumaron en el siglo XX las de ampliar la atención primaria de salud, superar la desnutrición infantil, el apoyo al estado en la construcción de las obras públicas y del diseño de la matriz energética, como también, en los años 1960 el desarrollo productivo exportador, especialmente en las áreas de agricultura y minería. El desarrollo de la ingeniería sismo-resistente, es otra de las labores que han merecido el reconocimiento nacional e internacional de la universidad. Chile, uno de los países más sísmicos del mundo, posee también, junto a Japón, uno de los mejores desempeños ante estos eventos, basado en la investigación científica y tecnológica.

En el campo de las artes, en el seno de la universidad se crearon la orquesta Sinfónica de Chile, el Teatro Nacional, el Museo de Arte Popular Americano, el coro Sinfónico, el Ballet Nacional Chileno y el Museo de Arte Contemporáneo, instituciones que hoy operan en el Centro de Extensión Artístico y Cultural de la Universidad de Chile (CEAC).

La expansión de la universidad alcanzó a todas las regiones del país, proceso que fue desmembrado con la dictadura militar iniciada en 1973 y que se tradujo además en la desvinculación entre el Estado y la institución, rompiendo una larga tradición de colaboración que ha sido difícil de restaurar. La Ley General de Universidades promulgada en $1981^{349}$, junto con despojar a la Universidad de Chile de sus sedes regionales ${ }^{350}$ y del Instituto Pedagógico, inició la privatización de

${ }^{349}$ Actualmente, la Universidad se rige por el estatuto de 2006 que modifica el Decreto FL No 153 de 1981, dando lugar a una nueva institucionalidad: el Rector es la máxima autoridad unipersonal y representante legal, el Senado Universitario, órgano triestamental con funciones normativas y de lineamientos estratégicos; el Consejo Universitario, órgano colegiado de carácter ejecutivo; el Consejo de Evaluación, a cargo de la superintendencia de los procesos de evaluación, calificación y autoevaluación a nivel institucional e individual.

${ }_{350}$ Con esto se desarticulaba completamente la red de universidades públicas existentes hasta ese momento, regionalizándolas y dividiéndolas en un sinnúmero de universidades sin mayor vinculación entre sí y sin ningún poder político.

${ }^{351}$ Con la posibilidad de crear universidades privadas sin dependencia estatal.

Figura 11.1. La Universidad de Chile en cifras. Por UCHILE (6 de octubre, 2019). la educación superior ${ }^{351}$, terminando además con el derecho a la gratuidad de la educación universitaria y técnica. El financiamiento estatal de la universidad bajó con estas medidas a lo que es hoy, menos del $10 \%$ de su presupuesto.

Físicamente, la universidad tiene su Casa Central en el Barrio Cívico de Santia-

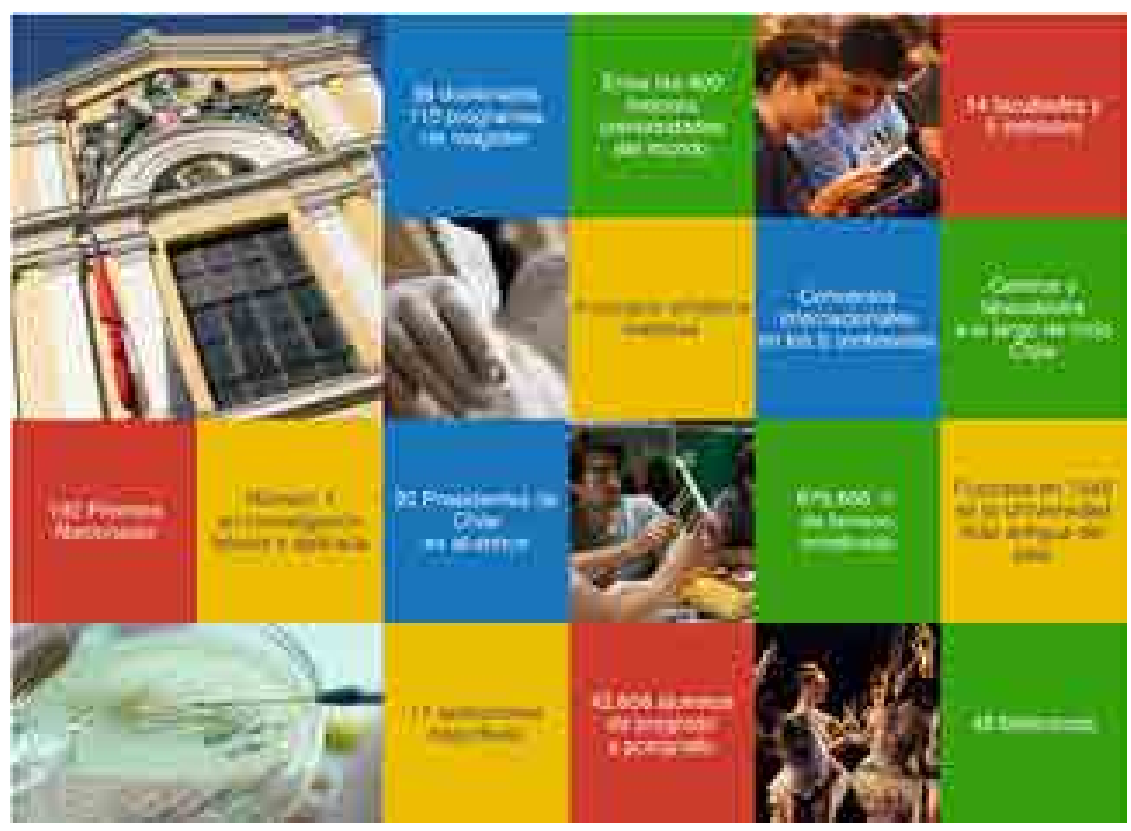


go, a pocos metros del palacio de gobierno y sus facultades están distribuidas en cinco campus emplazados en distintas zonas de la ciudad.

\subsection{LA TERCERA MISIÓN DE LA UNIVERSIDAD}

Las universidades públicas tienen una función ineludible con la sociedad porque han sido creadas por ella y normalmente, sustentadas por el estado, vale decir por todos los ciudadanos. Este rol ha cambiado a lo largo de la historia a partir de los modelos que han inspirado a estas instituciones, como también del contexto, que, en el caso de Chile, ha cambiado radicalmente. Lo anterior se traduce en una relación más o menos lejana con el estado y sus demandas, como también con la sociedad civil, cuyos cambios culturales aproximan o distancian el mundo de la academia al mundo "real"352.

Por otra parte, existe un cambio respecto a la concepción del conocimiento como un bien social. El neoliberalismo se ha convertido en un discurso hegemónico que también tiene, como nos ha señalado Harvey "efectos omnipresentes en las maneras de pensar y las prácticas político económicas hasta el punto de que ahora forma parte del sentido común con el que interpretamos, vivimos y comprendemos el mundo" (Harvey, 2008, p. 2), incluyendo el saber. Ya no es posible aplicar lo que Robert Merton (1977) llamó la "ética del desinterés" como modo de ser de la ciencia, donde ésta debe ser libremente ejercida y divulgada, y los científicos tienen como recompensa sólo el reconocimiento de sus pares, sin mediar interés económico en su trabajo. Por el contrario, en las sociedades contemporáneas la ciencia y la tecnología tienen valor de cambio, son entendidas como objetos económicos capaces de generar riqueza. Estos modelos económicos y de desarrollo, basados en el conocimiento sitúan a las universidades como agentes de lo que Henry Etzkowitz ha llamado el proceso de "capitalización del conocimiento" (Etzkowitz, 2009, p. 2), donde además del rol tradicional en docencia e investigación, estas instituciones han debido asumir la tarea de transferir los resultados del conocimiento científico y tecnológico al sistema productivo (representado por la industria), y a través de éste a la sociedad. Este proceso ha sido reforzado en el caso chileno con la disminución de los aportes estatales a las universidades públicas, por lo que los investigadores han debido buscar financiamiento externo para su trabajo. Este cambio cultural, como ha señalado Carmen Adán, "pone la motivación económica en el mismo plano que la motivación por el avance del conocimiento, transformando así el papel del científico y de la universidad en la sociedad" (Adán, 2012, p. 86).

Es en este contexto y desde el mundo anglosajón, que surge el concepto de tercera misión, congruente con ideas desarrolladas en la década de 1990 sobre la "universidad emprendedora" de Burton R. Clark (1997), y de la universidad como agente de la llamada "triple hélice" de Henry Etzowitz y Loet Leydesdorff (1997). Estos planteamientos fueron rápidamente incorporados por la Unión Europea en su plan de "La Europa del Conocimiento 2020" como por la OCDE-UN, globalizando el modelo. Para autores como Eduardo Bueno y Fernando Casani (2007), los principales ejes de esta tercera misión serían el emprendimiento, la innovación y el compromiso social, reconociendo tres enfoques:

1. Un primer enfoque, descrito por Martin y Etzkowitz (2000), considera todas las funciones (docencia, investigación, vinculación con el medio) que las universidades llevan a cabo con diferentes actores sociales con los que se relacionan. En especial, "la innovación que la sociedad reclama, actividades que están orientadas a satisfacer las necesidades del bienestar social y a cooperar con los objetivos públicos y privados de aquéllos" (Bueno \& Casari, 2007, p. 45).

2. Un segundo enfoque, que es una evolución del anterior, es representado por autores como Allan Gibb ${ }^{353}$ (1993) se enuncia como "la perspectiva social de su extensión y compromiso comunitario, es decir, como la función o papel que se relaciona con las necesidades sociales de su territorio o entorno de referencia, con una actuación tanto en dimensiones locales como regionales" (Bueno \& Casani, 2007, p.

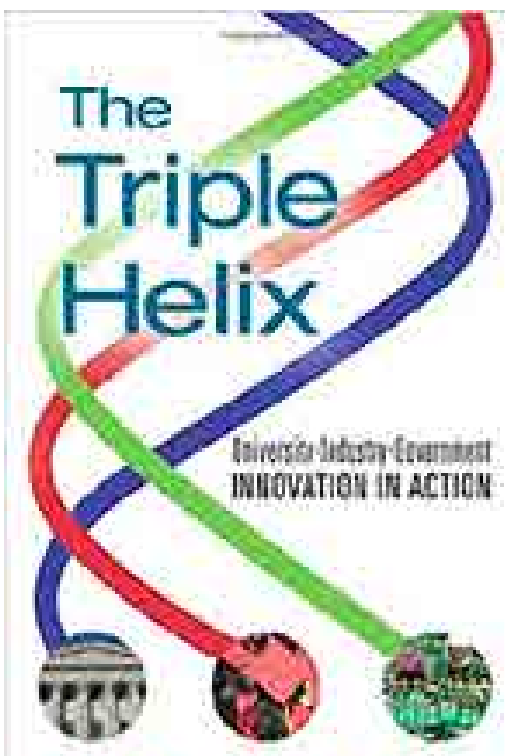

HENRY EIZXOWITZ

Figura 1.2. The Triple Helix: University-Industry-Government Innovation in Action de Henry Etzkovitz (2002). En el libro, el estado es el garante de las reglas de la sociedad; la Universidad quien genera y transmite el conocimiento y la empresa, los responsables de que el conocimiento genere productividad.

352 José Medina Echavarría, filósofo y sociólogo español, plantea que hay tres modelos: la universidad torre de marfil, en donde la institución investiga y enseña pero sin tener en cuenta las demandas y requerimientos sociales; la universidad militante, que sólo se justifica si trabaja en cuestiones de acción social directa, más allá de sus funciones específicas; y la universidad comprometida con su medio y con su tiempo, que está atenta a lo que pasa y trata de responder desde lo que puede y debe hacer, que es enseñar e investigar.(citado por Eduardo Sánchez Martínez, 2009). 
${ }^{353}$ El Profesor Arthur Allan Gibb, es el fundador y ex director del Small Business Center de Universidad de Durham, Inglaterra. Establecido en 1971 para proporcionar capacitación y educación a los empresarios, el Small Business Center fue la primera empresa social de este tipo en Europa. Gibb ha sido descrito en una publicación de la OCDE como "el decano de los académicos de desarrollo empresarial y de pequeñas empresas". En 2009, Gibb fue coautor de "Leading the Entrepreneurial University”, junto con G. Haskins, P. Hannon e I. Robertson, publicado la Universidad de Oxford. Actualizada en 2012, la publicación sirvió como el manual principal para el Programa de Líderes Universitarios Emprendedores (EULP), lanzado en la Universidad de Oxford en 2010. Las ideas derivadas de EULP y el manual condujeron a cambios para desarrollar la Universidad de Gales, Newport, como universidad emprendedora en 2012-13.

354 Traducción propia de la definición publicada en la página web de IASP:

A science park is an organisation managed by specialised professionals, whose main aim is to increase the wealth of its community by promoting the culture of innovation and the competitiveness of its associated businesses and knowledge-based institutions. To enable these goals to be met, a Science Park stimulates and manages the flow of knowledge and technology amongst universities, R\&D institutions, companies and markets; it facilitates the creation and growth of innovation-based companies through incubation and spin-off processes; and provides other value-added services together with high quality space and facilities.
45). A la función social, que vincula a la universidad con su entorno, se suma la posibilidad de ingresos adicionales, sin que éste sea "el objetivo principal, pero que, sin duda, facilita su desarrollo y mejora su imagen y responsabilidad corporativa con su sociedad" (2007, p. 45).

3. El tercer enfoque, es el que ha sido más influyente y está vinculado al trabajo de Burton Clark (1997) que propone el concepto de universidad emprendedora, capaz de comercializar los recursos universitarios. Este enfoque sin embargo, considera que el financiamiento de la docencia y la investigación siguen siendo básicamente públicos, pero adiciona nuevas fuentes de ingreso a través de la "asistencia técnica, los programas de formación continua y de postgrado y contratos de investigación, entre otras actividades, con corporaciones, fundaciones, empresas, clientes gubernamentales, asociaciones de antiguos alumnos, etc.[...], la cual configura un nuevo concepto de «capitalismo académico»"(Bueno y Casani, 2007, p. 45).

\subsection{LA TRIPLE HÉLICE}

Si bien los ejemplos que se toman como modelo fueron fundamentalmente acciones que buscaban la vinculación entre la universidad y la industria, como veremos más adelante, el estado ha tenido un papel fundamental en este nuevo paradigma. Este hecho es formalizado en el modelo de la triple hélice, que se basa en la transferencia de conocimientos desde la universidad hacia la empresa con el apoyo del estado (Etzkowitz, 2002/2009), donde el conocimiento se transforma en capital y, por lo tanto, el conjunto ciencia-tecnología pasa a ser una variable importante en el sistema económico, como medio para fomentar la innovación, el crecimiento y el bienestar social. La materialización de modelo, además de un cambio de cultura institucional, ha requerido de la creación de lugares que permitan el encuentro y coordinación de los actores involucrados en un clima que promueva la tan anhelada innovación. Es así como han surgido nuevas tipologías, entre las que se encuentran los centros de transferencia tecnológica, las incubadoras de proyectos y los parques científico-tecnológicos.

\subsection{EL PARQUE CIENTÍFICO TECNOLÓGICO (PCT)}

El concepto de "Science Park", desarrollado por la United Kingdom Science Park Association (UKSPA) y que es aceptado hoy internacionalmente por la International Association of Science Parks (IASP), se define como:

Un parque cientifico es una organización administrada por profesionales especializados, cuyo principal objetivo es aumentar la riqueza de su comunidad mediante la promoción de la cultura de la innovación y la competitividad de sus negocios asociados e instituciones basadas en el conocimiento.

Para que se cumplan estos objetivos, un Science Park estimula y gestiona el flujo de conocimiento y tecnología entre universidades, instituciones de I + D, empresas y mercados; facilita la creación y el crecimiento de empresas basadas en la innovación a través de procesos de incubación y spin-off; y proporciona otros servicios de valor agregado junto con espacios e instalaciones de alta calidad $^{354}$ (IASP, s.f.)

Las asociaciones mencionadas consideran que pueden incluirse bajo este término, iniciativas conocidas bajo otros nombres, tales como Parque Tecnológicos (Technology Park), Parque de Investigación (Research Park), Centro de Innovación (Innovation Center), High Techonology Development, Science Centre, Technopole o Technopolis, siempre que éstos respondan a los criterios anteriormente señalados (UKSPA, 1996; IASP, 2017).

Por su parte, la Organización para la Cooperación y Desarrollo Económico (OCDE), hace algunas distinciones que pueden ser útiles para precisar el programa del proyecto en Carén, diferenciando los parques científicos, de los parques tecnológicos, las Incubadoras y los centros de innovación, los que pueden sintetizarse del siguiente modo: 
Los Parques científicos o de investigación se pueden caracterizar como un conjunto complejo de actividades dentro de un área limitada del campus universitario donde investigadores, industria y capital de alto valor agregado son combinados por empresarios, incluido el personal académico y de investigación. En sintonía con la IASP, los parques científicos serían un acuerdo cooperativo formal con el propósito de promover el crecimiento de las empresas basadas en el conocimiento.

Su función principal es la transferencia de experiencia técnica y administrativa a la empresa. En algunos países, los parques también apuntan a atraer compañías existentes.

Los Parques tecnológicos: serán habitualmente, más grandes que los parques científicos, constituyendo una zona de actividad económica compuesta por universidades, centros de investigación, unidades industriales y terciarias, que realiza sus actividades basadas en investigación y desarrollo. Los parques tecnológicos suelen estar limitados en el área geográfica del país y mantienen enlaces de red con grandes empresas y la infraestructura pública de investigación a nivel nacional e internacional. En Japón y Francia, el modelo de Tecnopolis se ha llegado a entender como un área urbana. En los Estados Unidos, los parques tecnológicos difieren de esta connotación territorial, en la medida en que su principal objetivo es promover la sinergia entre los sectores de investigación e industriales de los alrededores y crear "centros de competencia" específicos (Coudivat y Giusti, 1991).

Las Incubadoras: si bien son más escurridizas, en la mayoría de los casos, se trata de una empresa basada en el conocimiento afiliada con una universidad, un parque científico o tecnológico o un centro de innovación. En algunos casos, la incubadora es una función integrada de un parque científico (Reino Unido) o centro de innovación y tecnología (Alemania), o puede ser una unidad distinta que opera dentro de la infraestructura basada en el conocimiento de una universidad o parque científico y tecnológico (Estados Unidos, Japón, Francia).

Los Centros de innovación: son similares a una incubadora de empresas, pero basadas en el conocimiento. La Asociación de Tecnología Alemana y Centros de Incubación de Empresas (ADT) define un centro de innovación como una empresa basada en la infraestructura para el establecimiento y crecimiento de las empresas. Los objetivos relacionados incluyen el desarrollo de la innovación en la región, la cooperación entre los investigadores y la industria; suministro de información y entrenamiento técnico y administrativo; y el fortalecimiento del desarrollo económico regional a través de redes regionales e internacionales para el intercambio de información y la cooperación entre empresas (OCD-GD,1997, p. 16).

Como veremos en los casos analizados, en todos ellos existe un terreno, vale decir un soporte físico, territorial, destinado a acoger actividades principalmente de base tecnológica donde confluyen empresas, orientadas al desarrollo (D) y universidades y/o centros de investigación que proveen conocimiento científico (I) con el objetivo de vincular las fuentes del progreso científico con la capacidad de gestión y la experiencia técnica de la industria para a través de esta relación sinérgica, aparezcan nuevos productos y servicios (innovación) que puedan ser de beneficio a la sociedad y produzcan riqueza.

Sin embargo, el surgimiento de estos parques tiene diversos orígenes y tiempos de maduración, aspectos que serán relevados en el análisis, observando cómo y quienes lo conciben y cuáles son sus motivaciones originales, que, si bien evolucionan en el tiempo, marcan el carácter del lugar. Podremos reconocer aquellos que surgen como un mecanismo para fomentar la relación entre la universidad y las empresas, o para potenciar el contacto entre los investigadores con la industria y la economía, otros han sido creados para revitalizar económicamente una región, o sencillamente para la creación de nuevos puestos de trabajo a partir de la creación de nuevas empresas. 


\subsection{LOS ORÍGENES}

Si bien en la actualidad esta tipología del PCT se ha difundido con muchas variantes, todos ellos, de uno u otro modo, tienen como referente a Silicon Valley, la iniciativa pionera de la Universidad de Stanford, que en 1951 creó un polo de alta tecnología electrónica que se extendió a este valle de California, cuna del hipismo; concentradora de talentos atraídos por dos grandes universidades (Stanford y Berkeley) y un clima benigno. Este fenómeno profusamente estudiado por el espectacular crecimiento económico y tecnológico generado, es el que tantos gobiernos e instituciones han querido reproducir, sin muchas veces considerar todas las variables que han influido en su éxito, obviando también los impactos negativos de sus célebres resultados. Es así como en la década de 1980 se produjo un inusitado auge en la creación de parques tecnológicos por todo el mundo. Es en este contexto que nace la iniciativa de la Universidad de Chile, que en el transcurso de primer gobierno después de la dictadura ${ }^{355}$, en un ambiente social de optimismo, logra en 1994 la transferencia del predio de Laguna Carén, para desarrollar el primer Parque Científico- Tecnológico en Chile.

Actualmente, de acuerdo con estimaciones de la IASP, existen en el mundo alrededor de 400 Parques Cientíicos y Tecnológicos (PCTs), desplegados en 77 países, en todos los continentes. Como se aprecia en la Figura 11.3., la mayor concentración de PCT se encuentra en los países más desarrollados, que al mismo tiempo exponen los mejores indicadores de inversión en ciencia y tecnología. El conjunto de estos parques agrupa aproximadamente a 142.000 empresas (IASP, s.f.) en su gran mayoría inscritas, en lo que se denomina la "economía del conocimiento". Vale decir, empresas de fuerte base tecnológica y con productos, procesos o servicios innovadores 0 , al menos, haciendo de la innovación una de sus prioridades.

El modelo de crecimiento de los diferentes parques y polos de desarrollo tecnológico del mundo, relevantes para este ejercicio, es tan variado como el número de ejemplos, y es consecuencia de su origen, localización y de las condiciones económicas y culturales del medio que las acoge. Pese a lo diverso, a continuación, se presenta una reseña de distintos ejemplos internacionales (algunos de los que siempre se nombran), que permite ilustrar características generales, patrones de crecimiento, condiciones contextuales, etc., que pueden servir de referencia para el proyecto Carén, incluso por oposición.

${ }^{355}$ El primer gobierno después de la dic-

\subsection{EL MODELO NORTEAMERICANO}

Silicon Valley y Highway 128, Boston, son ejemplos originados por iniciativas tadura militar estuvo encabezado por el presidente Patricio Aylwin (1918-2016), militante del Partido Demócrata Cristiano. Su mandato se enfocó a la consolidación interna de la democracia y la convivencia nacional: se restablecieron las instituciones democráticas, se enfatizó la importancia del respeto a los derechos humanos y se controló la tensión existente entre el nuevo gobierno y las Fuerzas Armadas.

Bajo su mandato también se dio a conocer el informe sobre detenidos desaparecidos y ejecutados políticos, se creó la Corporación Nacional de Desarrollo Indígena (CONADI) y se consolidó el modelo neoliberal impuesto en dictadura aplicando prudencia fiscal, una economía abierta, el crecimiento de la exportación y un sector privado fuerte. (MEMORIA CHILENA, 2018)

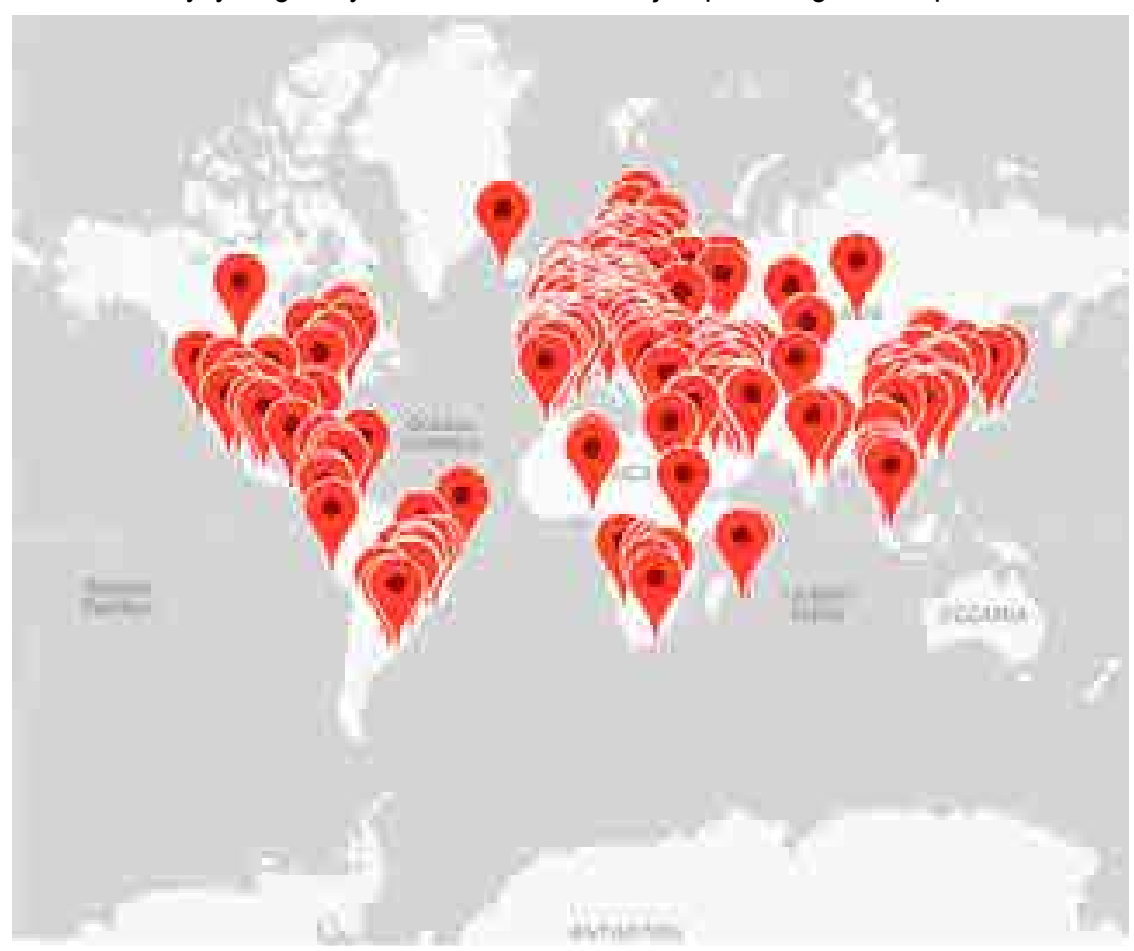


académicas, (Stanford y Berkeley en California y MIT y Harvard en la Costa Este), que crecieron y prosperaron en gran medida como resultado de las enormes sumas gastadas en EEUU durante la guerra fría, en el desarrollo de nuevos sistemas integrados de defensa y en el programa espacial de la NASA ${ }^{356}$. Esto se ve reflejado en su evolución, que sigue las oscilaciones del gasto nacional en esas áreas.

\subsubsection{Science Park Park de Stanford}

El Parque de investigación de Stanford iniciado en 1951, es el verdadero antecesor de todos los parques y polos tecnológicos del mundo, y en el que se inició el proceso de vinculación académico empresarial que transformó el desarrollo de nuevas tecnologías a escala comercial y demostró la importancia de la investigación de punta en ese proceso.

La Universidad de Stanford creada en 1891, fue una universidad pequeña hasta finales de la década de 1930, alcanzando notoriedad a partir de dos hechos: el ascenso de Herbert Hoover, egresado de esta institución, a la presidencia de los Estados Unidos (1929-1933) y de la creación del tubo Klystron ${ }^{357}$ (1937) en los laboratorios de Stanford. Debido a problemas financieros que la institución arrastraba desde la crisis de 1929, y que se agudizaron al finalizar la guerra (Stanford University, 2016, p. 10), la universidad arrienda terrenos que le habían sido legados por los fundadores en "The Valley of Hearts Delight" (el Valle Delicias del Corazón), una zona agrícola preindustrial a poco más de 3 kilómetros de la universidad. "El valle era próspero, convirtiéndose en el principal productor de fruta fresca, seca y enlatada, y el principal productor de ciruelas del país" (Pellow y Park, 2002, p. 46). El valor de este suelo, originalmente rural, era bajo, lo que llevó en la década de 1950, a que el rector y decano de la facultad de Ingeniería, Frederick Terman se asociara con la ciudad de Palo Alto para crear inicialmente el "Stanford Industrial Park" en 85 hectáreas (209 acres). La primera empresa que se instala allí, en 1953, es Varian Associates, a la que en 1956 se une Hewlett Packard (ambas tenían como cliente al gobierno norteamericano) con lo que se inicia el verdadero crecimiento del parque, que en 1960 llega a 40 empresas, en 1985 a 100 y en enero de 2018 a más de 150 compañías, en 140 edificios con $930.000 \mathrm{~m}^{2}$ construidos, en un parque que se ha ampliado hasta las actuales 283 hectáreas (700 acres), dando trabajo a 23.000 empleados (Chu, 2010). El Parque cambió de nombre en la década de 1970 a "Stanford Research Park", como se conoce hoy, resaltando el enfoque de cooperación entre la universidad y las empresas tecnológicas a partir de la investigación. La organización establece actualmente los siguientes principios en su misión:

Stanford Research Park es una comunidad de y para las personas que buscan inventar el futuro. Apoyamos a empresas innovadoras en sus actividades de investigación y desarrollo proporcionando instalaciones modernas en un hermoso paisaje natural, ofreciendo programas de transporte sostenible, forjando conexiones con el talento y los recursos de la Universidad de Stanford, y fomentando la colaboración. (Stanford Research Park, s.f.).

Estos principios, ya decantados con el tiempo, han servido de guía para la concepción de otros parques que buscan constituir una comunidad de colaboración para innovar e "inventar el futuro". El paisaje natural, el del valle de California, ha sido también un referente estético, sin muchas veces reparar en las diferentes condiciones de implantación en otras latitudes, con otros climas.

\subsubsection{Silicon Valley}

El Parque de Stanford sirvió como foco para el desarrollo del resto del valle, que hoy llamamos Silicon Valley ${ }^{358}$, posiblemente el referente más citado cuando se habla de parques científico-tecnológicos, pero también en la literatura acerca de la innovación. Este fenómeno no planificado, emergente, convirtió el "Valle de las Delicias del Corazón" en el mayor centro de alta tecnología del mundo que creció de 5.966 puestos de trabajo en empresas de alta tecnología en 1959, a 18.400 en 1965, 52.000 en 1970, 215.000 en 1985 (MECSA,1997, p. 20) a los 345.249 en 2017 , sobre una fuerza laboral total de 1.638 .698 empleos. Vale decir, el $25 \%$
${ }^{356}$ Este fenómeno es sincrónico con el auge de los "métodos de diseño", estudiado en capítulo 2.

${ }^{357}$ El tubo Klystron fue inventado en 1937 por los hermanos Russell y Sigurd Varian, quienes estudiaron y luego trabajaron en la Universidad de Stanford. Se trata de un generador de microondas de alta frecuencia que sirvió de base para el desarrollo de los radares en la Segunda Guerra Mundial. A partir de este invento se desarrollan una serie de avances tecnológicos de aplicación militar en dicha universidad.

${ }^{358}$ En 1971, el periodista Don Hoefler acuñó el término "Silicon Valley". 

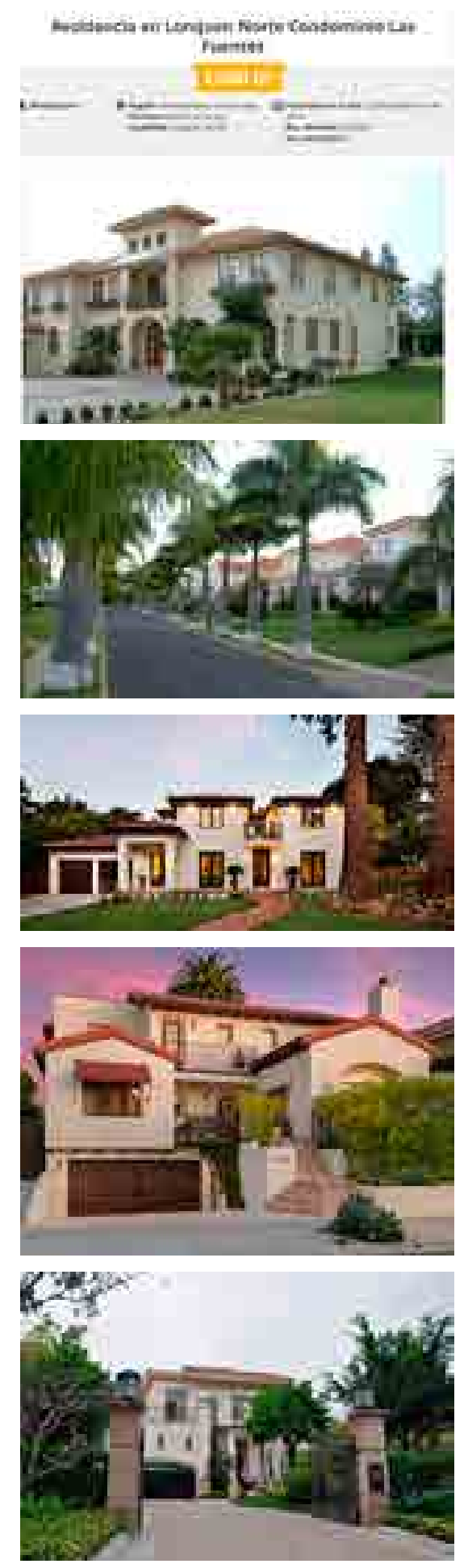

Figura 11.4.: Cinco imágenes publicitarias de distintos lugares del mundo que evocan la estética de Silicon Valley (desde arriba a abajo): el condominio Las Fuentes en Santiago (Clasificados.com, 22 de septiembre, 2014) ; Palm Meadows en Bangalore, India (Life Inside, 2019); Palo Alto (Zach Trailer, 2019); San Diego, California (Zillow, 2019); y una villa en Shenzhen, China (CW's Food \& Travel, 7 de marzo, 2011). de los trabajos son altamente calificados, también los mejor remunerados, con rentas promedio anuales de alrededor de US\$118.310 (Silicon Valley Indicators, 2018).

Este crecimiento, comparable con el producido un siglo antes por la fiebre del oro, tiene fuertes componentes de inmigración. De acuerdo al estudio de Glenda Matthews, la Ley de Inmigración y Nacionalidad de 1965 y otros factores como el éxodo masivo de balseros vietnamitas, dieron lugar a la llegada de un importante número de personas, -especialmente de asiáticos, latinos y portugueses- a Silicon Valley, donde contribuyeron tanto a la mano de obra de alta tecnología como a la de producción. La población asiático-estadounidense en el condado de Santa Clara aumentó de 43.000 en 1970 a 430.000 en 2000. Durante el mismo período, la población latina creció al $24 \%$ en el condado y al 30\% en San José. La población afroamericana se mantuvo estable, pero creció ligeramente a alrededor del 5\%. La expansión de la visa H-1B en 1990 también ha jugado un papel en este proceso (Matthews, 2003, p. 47-51) que incorpora la multiculturalidad y empeño propio de los inmigrantes, muchos de los cuales son altamente calificados, formados en sus respectivos países, por lo que la relación directa con las grandes universidades de la zona, en su rol de proveedoras de capital humano se relativiza.

De acuerdo a Margaret O'Mara, muchos de los parques tecnológicos que hoy surgen en el mundo, están liderados por inmigrantes que han regresado a sus países de origen, con la experiencia que le permite reproducir de mejor manera los logros que se esperan de estas empresas. Esto es especialmente relevante en las comunidades asiáticas, un gran número de las cuales llegaron al valle como estudiantes extranjeros y desempeñaron un papel importante en el florecimiento original del valle y en la exportación de su cultura a otros lugares. A medida que India y China liberalizaron sus economías, después de la década de 1980, los empresarios inmigrantes cruzaron el Pacífico desempeñando papeles decisivos en "los nuevos valles del silicio de Shanhai a Chennai" (O'Mara, 2011, p. 78), con la creación de clúster exitosos que tienen un poco de California.

En la búsqueda de elementos que ayuden a replicar el fenómeno de Silicon Valley, la arquitectura también ha jugado un papel importante, los edificios de la Universidad de Stanford, los de las misiones con sus techos rojos, junto al estilo Eichler con sus grandes garajes, amplitud y jardines bien cuidados, han alentado una estética "californiana" que hoy se asocia a los lugares donde ocurre la innovación, llevándola más allá de los nuevos valles del silicio, como ideal de suburbio próspero, con palmeras y techos rojos, como los que podemos observar (Figura 11.4.) en los condominios de Santiago (Chile), también en Bangalore (India) y en Shenzhen (China) ${ }^{359}$.

Un aspecto, débilmente abordado en la literatura sobre Silicon Valley es el de la equidad. A pesar de su riqueza, la región tiene altas tasas de pobreza, con cerca del 13,8\% de los residentes de San Francisco ${ }^{360}$ en esa condición (Haveman \& Massaro, 2015, p. 2). De acuerdo a cifras oficiales Silicon Valley Indicators, 2018) los trabajadores de Nivel 1 (altamente calificados y de sueldos altos) ganan aproximadamente $\$ 60,000$ anuales más que los trabajadores de nivel 2 (trabajadores de nivel medio, salario medio) y aproximadamente $\$ 90,000$ más que los trabajadores de Nivel 3 (trabajadores de baja calificación y bajo salario). Los altos ingresos de parte de la población, y la escasez de vivienda, a causa del aumento explosivo de población, ha hecho que el costo de la vida se eleve a niveles que dificultan la subsistencia de las familias con ingresos menores a US\$60.000 (Graglia, 2016). Las empresas tecnológicas no han sido capaces de distribuir la riqueza en la comunidad. Desde los años noventa, la creciente compensación de los altos cargos hizo que la brecha salarial aumentara descontroladamente. Pellow \& Park grafican esta situación con el ejemplo del "CEO de Hewlett-Packard que ganó US\$69,4 millones en 1999, mientras que en la misma empresa muchos trabajadores ganaban apenas US\$ 10.000 o menos" (Pellow \& Park, 2002, p. 86). Estas tensiones sociales se manifiestan en actos como los que el 


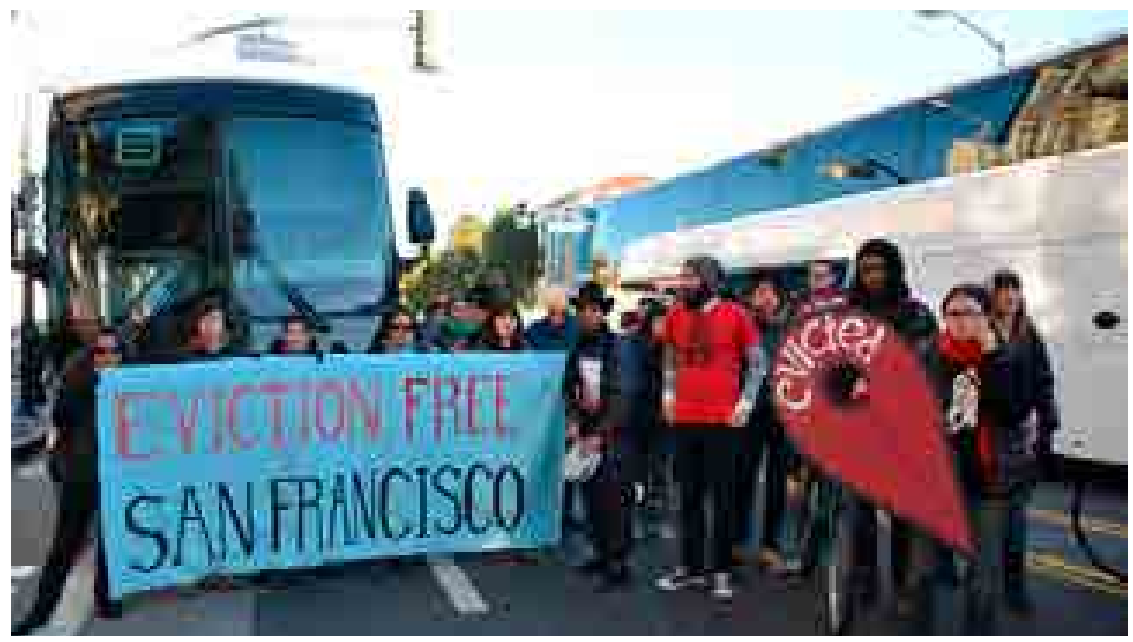

diario La Vanguardia relata en el artículo "Gentrificación en Silicon Valley: ¿por qué la gente tira piedras a los autobuses de Google?":

Con todo, al final San Francisco se ha convertido en el caldo de cultivo de un enfrentamiento: por una parte, los empleados de las mejores compañías de Silicon Valley, auténticos talentos de la tecnología que a una edad muy temprana ganan el sueldo suficiente para llevar un altísimo nivel de vida; por otra, los habitantes tradicionales de San Francisco, que, acostumbrados a una ciudad que se levantó sobre los cimientos del movimiento hippie, ahora sucumbe al capitalismo tecnológico más agresivo.(Otto, en Diario la Vanguardia, 5 de junio, 2016, s.p.)

Así como Silicon Valley ha sido reconocido como un ecosistema único para la creación de tecnología, varios autores, entre ellos O'Mara, consideran que desde el punto de vista urbano hay aspectos que hoy hacen crisis como resultado de la falta de planificación y polarización económica (y por lo tanto no deben "copiarse"). El transporte está saturado y depende del automóvil en un grado que reduce la calidad de vida y degrada la belleza natural que atrajo originalmente a las personas. "La burbuja de prosperidad económica de alta tecnología, también dejó fuera otros usos y otras personas y sirvió para disfrazar los aspectos menos atractivos y más contaminantes de su negocio" (O'Mara, 2011, p. 81).

La lección del caso que hemos estudiado, es que no se puede replicar un sistema complejo como el de Silicon Valley sin entender el contexto. Nace en un momento muy particular, la Guerra Fría, y en un lugar donde se combinaron el gasto militar nacional y la inversión en infraestructura suburbana, que atrajo nuevos flujos de dinero y a personas talentosas. A esta mezcla se suma la presencia de prestigiosas instituciones de investigación (entre las que se destaca la universidad de Stanford), el crecimiento sostenido del PIB (y sobretodo el porcentaje del PIB en ciencia y tecnología) y una cultura empresarial relajada, igualitaria, inusualmente tolerante al riesgo, que acogió a los soñadores e inmigrantes, y también un muy buen clima. Creció sin planificación, orgánicamente, con defectos, pero con espacio para "happy accidents and lucky breaks"(O'Mara, 2011, p. 79).

Así como muchos prohombres, hace casi 60 años, en 1960 Charles de Gaulle,
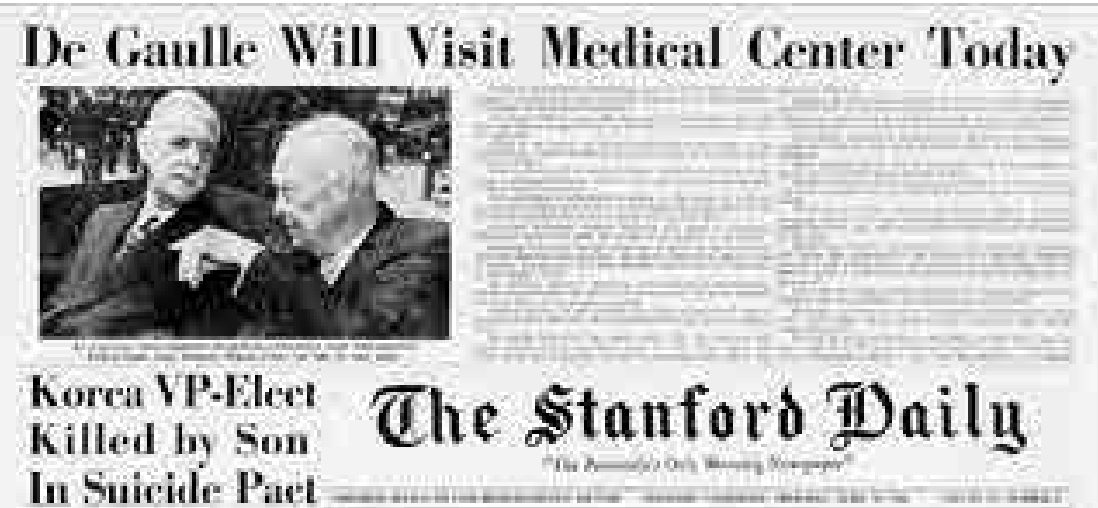

Figura 11.5.: Protesta en San Francisco (2016). En Carlos Otto (5 de junio, 2016) Reportaje en el diario electrónico La Vanguardia.
${ }^{359}$ O'Mara se refiere específicamente a Palm Meadows de Bangalore y Mission Hills de Shenzhen, que no solo evocan California en su nomenclatura sino también en la apariencia de sus casas, el diseño de sus calles y las comodidades ofrecidas a sus residentes. Los valles de silicio recientes no son los únicos lugares del mundo que ofrecen estos paisajes de riqueza, pero a menudo funcionaron como la vanguardia de este tipo de desarrollo, y reforzaron la poderosa conexión cultural entre el suburbio de California y la economía tecnológica.

${ }^{360}$ La tasa más alta la posee el área de Tenderloin, un barrio de San Francisco con un $50,6 \%$ de pobreza.

Figura 11.6. Registro de la visita del presidente francés Charles de Gaulle a California en 1960. En Archivo en línea de The Stanford Daily (28 de abril, 1960). 
visitó Estados Unidos y solicitó recorrer los parques de investigación que estaban apareciendo entre las granjas al sur de San Francisco (Figura 11.6.). Mientras recorría California, el mandatario francés notó la combinación original de la industria basada en la ciencia, la actividad de investigación universitaria y los tranquilos barrios suburbanos que formaban un ecosistema de innovación autónomo. En el último año de su presidencia, Francia había establecido su propia ciudad de alta tecnología, Sophia Antipolis, en la Costa Azul.

\subsection{EL MODELO PASA A EUROPA}

11.8.1. Sophia Antipolis es el primer parque científico tecnológico de Francia, y también de Europa. Fue establecido en 1969 en la Costa Azul, a $20 \mathrm{~km}$ del aeropuerto de Niza (Figura 11.7.), en un terreno de 2.400 hectáreas, idealmente ubicado entre el mar y la montaña. De esa superficie, dos tercios están reservados como espacios verdes y forestales (Figura 11.8.).

El parque está ubicado en la intersección de los municipios de Antibes, Biot, Mougins, Valbonne y Vallauris, en el corazón de un área de 1 millón de habitantes (Fundación Sophia Antipolis, 2018). Más allá de las influencias, este caso es un ejemplo de voluntarismo y liderazgo; de cómo el impulso sostenido de una persona puede lograr sacar un proyecto de esta envergadura adelante. Ese personaje es Pierre Laffitte (1925-), un científico y político nacido en Antibes, que el año 2001 relata así su realización:

En 1969, Sophia Antipolis era un nombre que tenía una ambición, la de construir en un matorral desierto, al norte de Antibes, una Ciudad Internacional de la Sabiduría, la Ciencia y la Tecnología.

Fue el símbolo del Renacimiento. La ambición de convertirse en Florencia del siglo XXI.

¿Cuáles fueron los objetivos entonces?

Crear un lugar donde el espíritu de innovación y empresa esté vinculado al Humanismo y la Convivencia. Un lugar donde el crecimiento económico respetaría la naturaleza y la calidad de vida. Un lugar donde la tecnología y la ecología, finalmente socios, serían el símbolo del desarrollo sostenible (Laffitte, 2001, p. 1).

El primer esbozo de esta idea, surgió de la imagen de un "Barrio Latino en el campo" lanzada por Laffitte en la prensa el año 1960, sin que tuviera ningún eco. Nueve años después convenció a sus colegas políticos de que esta zona, que no tenía tradición tecnológica, ni industrial|361; que Antibes, podía convertirse en un polo científico-tecnológico, sumando a centros de enseñanza e investigación, empresarios nacionales e internacionales y a los medios de comunicación local.

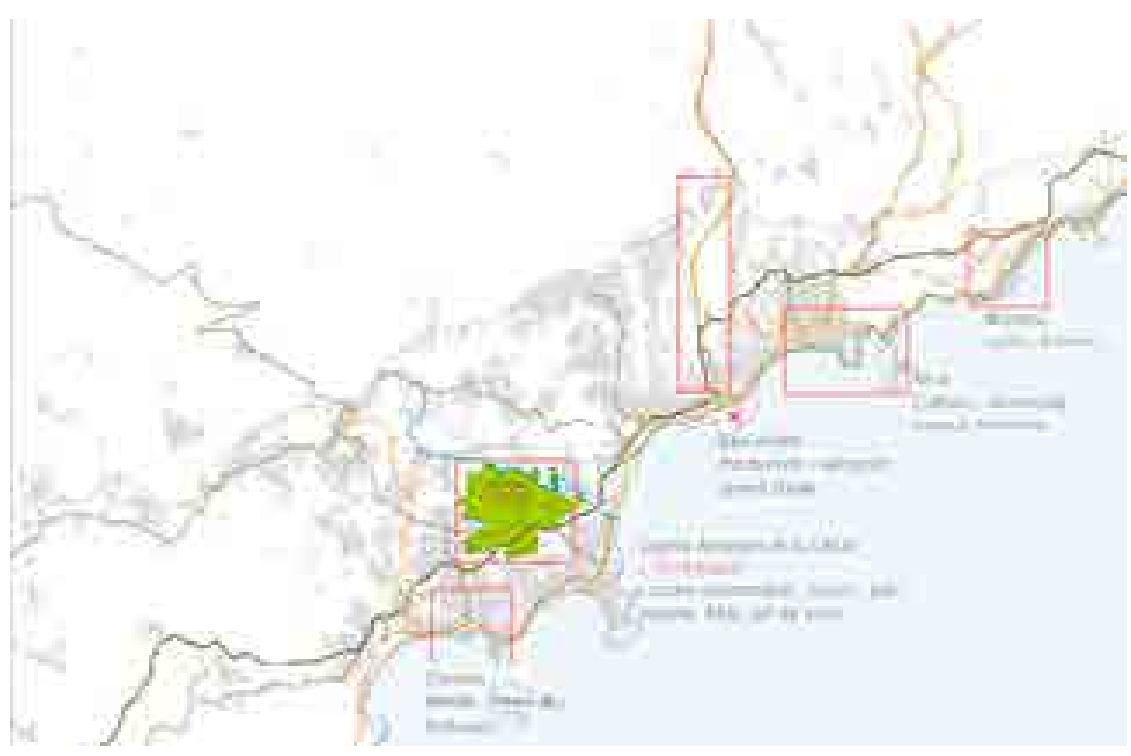




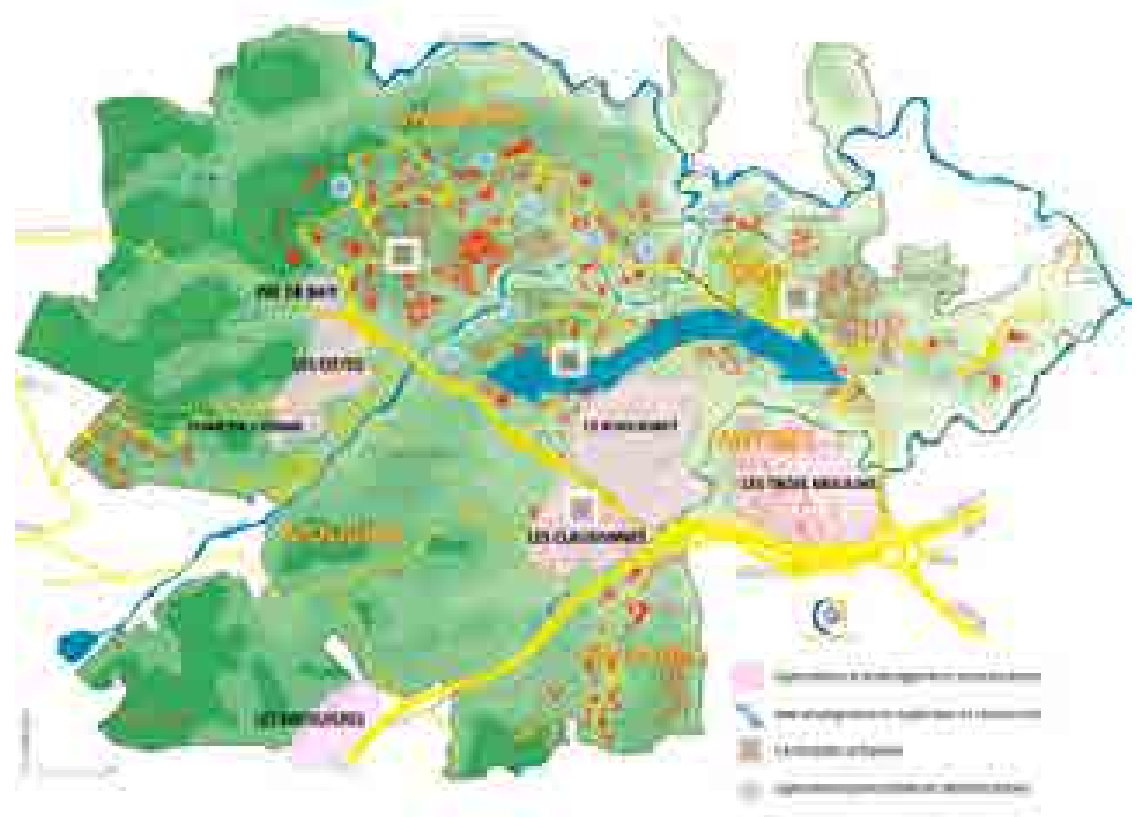

Este último agente es recalcado por Laffitte, lo que puede entenderse en relación al carácter del proyecto que, si bien pertenece a la categoría de los parques científicos tecnológicos, su fundación y sus primeros años al menos, planteaban un discurso épico, un relato que ponía al proyecto como una nueva Florencia del Mediterráneo y del mundo, incluyendo explícitamente otras áreas del conocimiento, como las artes, la filosofía y la literatura.

Estas acciones inaugurales, estuvieron guiadas por cuatro objetivos principales:

1- Establecer un vínculo fuerte y bilateral entre conocimiento y know-how. El conocimiento y su uso social deben reunir a científicos y empresarios. La investigación orientada cubre este concepto.

2- Facilitar los contactos entre personalidades de diferentes orígenes culturales: la fertilización cruzada simboliza este deseo de contactos amistosos.

3- La ciencia es global y la economía se convierte en eso. La apertura al mundo es una necesidad crucial, pero debe ser enriquecida por el respeto a la diversidad cultural.

4- Aceptar y anticipar la innovación, ya sea técnica, administrativa o jerárquica. Es una gimnasia a menudo difícil, pero necesaria. La prospección acostumbra a las mentes a cambiar. Al dirigir el cambio, es posible evitar descansos imprevistos y no preparados. (Laffitte, 2001, p. 2)

De estos objetivos surgen cuatro conceptos que animan y dan sentido a este acto fundacional: la investigación orientada, la fertilización cruzada, la apertura al mundo y la prospección, cada uno de ellos desarrollados en extenso por el mismo Laffitte en documentos del 1972, 2001 y 2011, principalmente.

El impulso inicial vino desde el estado, con el compromiso del entonces director del Centre National de la Recherche Scientifique (CNRS) de instalar centros de investigación; luego L'Oréal compra 10 hectáreas en 1970 y el Instituto Francés del Petróleo (IFP) construye el primer edificio. Paralelamente, se crea un Centro Internacional Comunicaciones Avanzadas dirigida por Maurice Papon, ex direc-
Figura 11.8. Plano general del territorio que abarca Sophia Antipolis con 2.400 ha. En Casa Infos (12 de marzo, 2011).
Figura 11.9. Vista general de Sophia Antipolis. Por Team Côte d'Azur (11 de mayo, 2016).

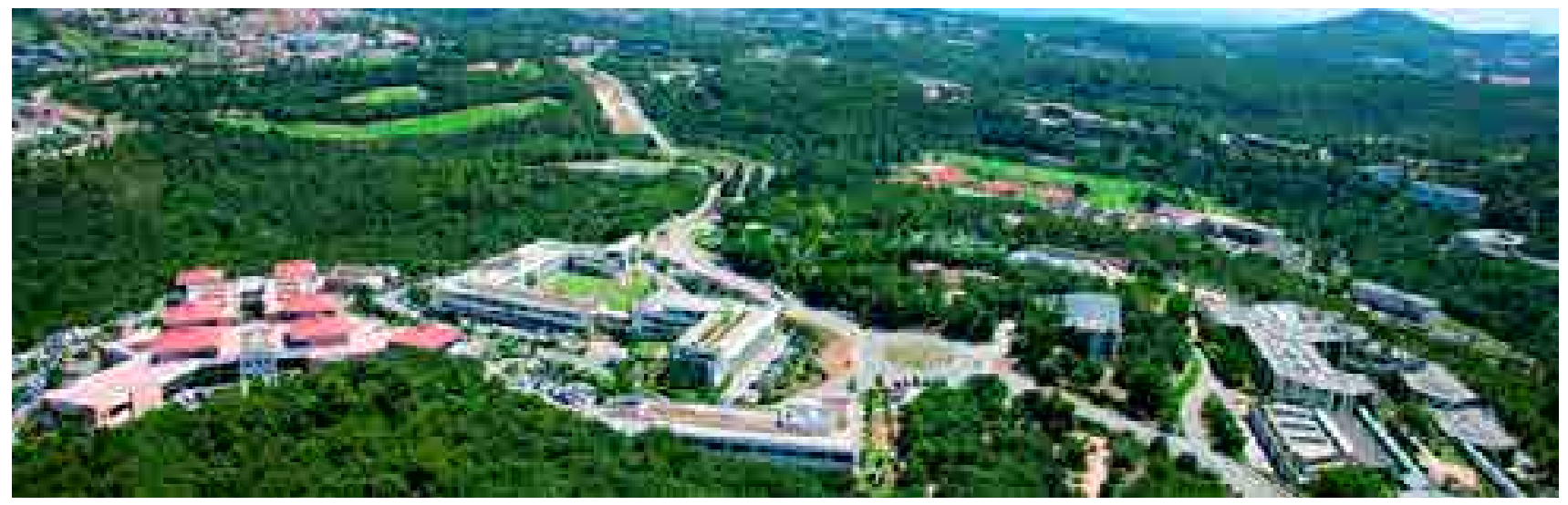


tor de IBM, para atraer a la industria, especialmente a través de la aplicación de Amadeus $\mathrm{CCI}$ un software de orientado a la aeronáutica comercial, lo que concreta la decisión de Air France en 1971, de radicar en ese lugar su oficina de reservas aéreas internacionales con más de 300 empleados. La decisión de la empresa, a su vez motiva la instalación de IBM, Texas Instrument y Digital en el Parque y da un rápido impulso al crecimiento de este núcleo. En 1982 el gobierno de Francois Mitterand promulga la legislación destinada a lograr la descentralización económica de Francia, lo que estimula la instalación de un número creciente de empresas internacionales y francesas. En 1995 Sophia Antipolis tenía 400 empresas con 10.278 empleos, los que al año 2017 ascienden a 2.230 empresas con más de 36.300 empleos, de los cuales, 4.000 corresponden a investigadores, a los que deben sumarse 5.000 estudiantes. Se afirma que la existencia de Sophia Antipolis ha sido responsable indirectamente del $10 \%$ de todos los empleos de la región (Plan de Déplacements Urbain, 2008).

El parque, es administrado por la Fundación Sophia Antipolis, desde 1984 asociada al Sindicato Mixto y la Comunidad Urbana del mismo nombre, como también a la Cámara de Comercio e Industria de Niza, la Región de Provece Alpes Côte d'Azur y el municipio de Mougins. Lo anterior, para asegurar el apoyo político en el tiempo y dar continuidad a lo logrado por Laffitte y Pierre Merli, el alcalde de Antibes a partir de 1971 y senador por la zona entre 1980 y 1988 del Partido Radical Valoisien; al que también pertenece el actual alcalde de Antibes, Jean Leotti (desde enero de 2002 a la fecha).

Pese a estos esfuerzos y al éxito del parque, en términos de cantidad y prestigio de las empresas instaladas allí, el espíritu fundacional se ha eclipsado. De acuerdo a entrevistas a usuarios en enero de 2018, la interacción entre instituciones es prácticamente nula. Una de las indicaciones de Laffitte era que se promovieran espacios comunes como los cafés, para estimular el sentido de comunidad y la comunicación, sin embargo, en la realidad, los protocolos de seguridad corporativos, no permiten que un empleado de una compañía cruce a otro edificio sin credencial, por lo que cada organización ha instalado sus propios servicios independientes. Por otra parte, la mayoría de los investigadores y docentes viven en Niza o en los pueblos cercanos, solo el $5 \%$ es un habitante de Sophia y un $85 \%$ de las personas utiliza el automóvil para ir al trabajo, con los consecuentes problemas de tráfico en las horas punta (Comunicación personal, 14 de febrero, 2018).

La solución de estos problemas a través del sistema de transporte público debido a la dispersión de los empleados en el gran terreno (Figura 11.10.). La configuración de Sophia en un sitio tan extendido, pero denso en superficie construida, y una estructura marcada por la ausencia de centralidad, han dificultado la solución de movilidad a través del transporte público o el uso compartido de los vehículos. Otro problema observado, ha sido la activación de la vida cultura proyectada, la que, por las razones expuestas, se extingue al término de la jornada laboral.

Figura 11.10. Plano de Sophia Antipolis donde se indica la distribución de personas en el parque. Por Plan de Déplacements Urbain (2008).

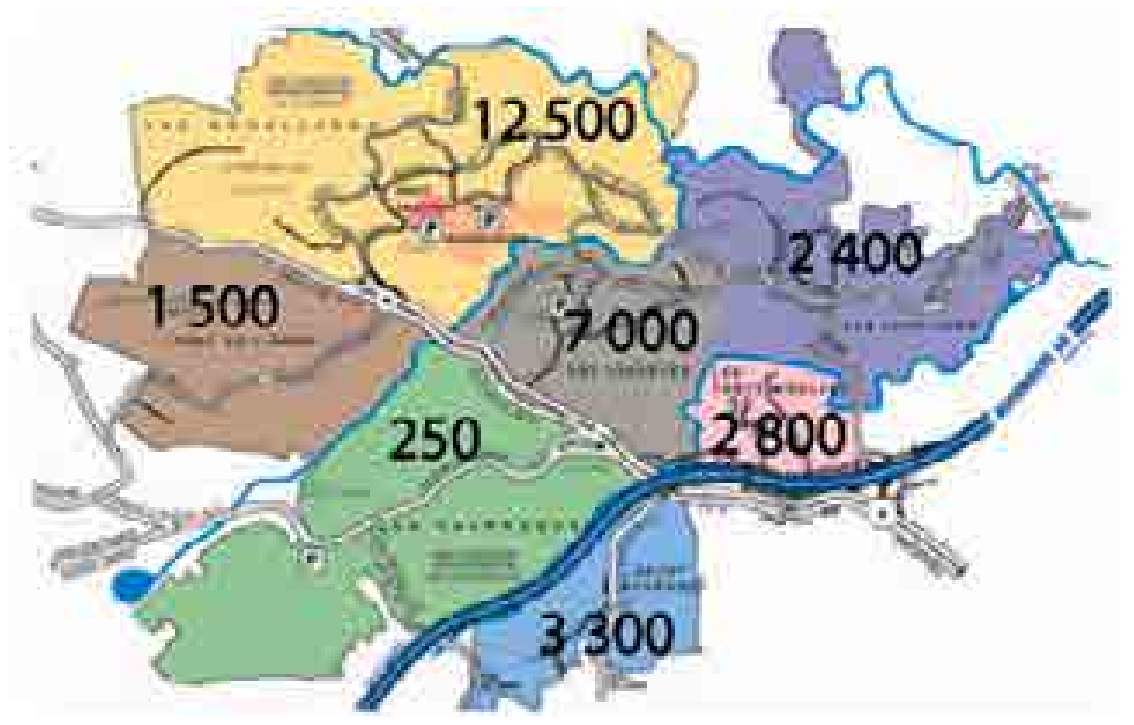


Finalmente, pese a los logros de este proyecto, en la realidad, es más bien una ciudad empresarial que un parque científico tecnológico, al menos si ello significa un lugar para que surjan ideas nuevas.

El modelo de Sophia Antipolis ha inspirado la tipología de los tecnopolos franceses que aparecen a finales de la década de 1970 y que toman, el concepto de "fertilización cruzada" acuñado por Laffitte como guía. Estas iniciativas son en general, lideradas por las ciudades o regiones que, en primera instancia buscan aprovechar el potencial universitario y de investigación para atraer empresas de alta tecnología, evolucionando luego, a soluciones que incorporan áreas residenciales, de servicios y equipamiento, que además de abrir nuevas fuentes de financiamiento y tener rendimientos sociales, son más populares y por lo tanto obtienen más apoyo político.

\subsubsection{Cambridge Science Park}

En Cambridge (Inglaterra) a mediados de la década de 1970, en parte bajo la presión del gobierno ${ }^{362}$ para asegurar que las actividades de las universidades fueran más relevantes al desarrollo económico del país, y en parte para reducir el éxodo de científicos e investigadores desalentados por los bajos salarios, la universidad decidió permitir la comercialización de trabajos de I+D realizado en sus laboratorios para beneficio de sus investigadores. De esta iniciativa resultó la creación de cientos de empresas en áreas de innovación tecnológica y alta tecnología en el área de Cambridge e indirectamente en la creación, por Trinity College, del Science Park, fuertemente influenciado por los modelos norteamericanos. Más allá del éxito económico y financiero, el parque terminó convirtiéndose en foco y símbolo del cambio estructural de la región, un proceso que permitió aprovechar el potencial intelectual, el conocimiento y el espíritu innovador de sus científicos e ingenieros, convirtiendo en 20 años a un área rural y sin industrias ${ }^{363}$, pero con una larga tradición científica, en un foco de innovación tecnológica a nivel internacional. Las tierras habían pertenecido al Trinity College desde su fundación por Enrique VIII en 1546 y estuvo dedicada a la agricultura hasta la segunda guerra mundial, hasta cuando fue requerida por el ejército norteamericano para preparar allí los vehículos y tanques que actuarían el día D. Después de la guerra el sitio quedó abandonado y en ruinas hasta 1970.

El crecimiento de Cambridge Science Park fue en sus comienzos relativamente lento, llegando a su madurez 15 años después de su fundación. "Una de las lecciones de la experiencia de Cambridge es que el evento que revolucionó y transformó a Cambridge tiene un período de gestación largo, que puede llevar entre 10 y 20 años" (MECSA, 1997, p. 22).

El patrón de crecimiento que se ha observado en este y otros proyectos, muestra la diversidad de tiempo que puede llevar el despegue de los parques tecnológicos, pero a su vez señala la fuerte influencia que puede tener en estos procesos, la localización de una empresa "clave" o "ancla", generalmente una multinacional de prestigio.

En Cambridge, con sólo 5,6 hectáreas desarrolladas en 1973, la primera empresa en instalarse fue Laser-Scan. Sin embargo, fue la decisión de NAPP, laboratorio canadiense de productos farmacéuticos innovadores, que montó en 1979 su laboratorio europeo y planta de producción de $20.000 \mathrm{~m}^{2}$, lo que detonó la ampliación del parque a 23, 4 hectáreas de desarrollo, resultado de la expansión de compañías existentes y la atracción de nuevas empresas. La evolución de Cambridge Science Park se puede seguir por el aumento de hectáreas desarrolladas en 45 años (Tabla 11.1.), totalizando en la actualidad en 61,50 hectáreas (152 acres) ${ }^{364}$, con $153.290 \mathrm{~m}^{2}$ construidos; 100 empresas operando, las que han creado más de 5.000 puestos de trabajo.

Desde sus inicios, el Cambridge Science Park definió su plan como "un entorno tipo parque de baja densidad". El diseño original de paisajismo se ha desarrollado
${ }^{362}$ El gobierno laborista británico, después de su elección en 1964, había instado a las universidades del Reino Unido a ampliar su contacto con el mundo de la investigación y el desarrollo tecnológico en el campo de la tecnología. Como respuesta, la Universidad de Cambridge establece bajo la presidencia de Sir Nevill Mott, un comité. El Comité Mott, en su informe publicado en 1969, recomendó una expansión de la "industria basada en la ciencia" cercana a Cambridge para aprovechar al máximo la concentración de conocimientos científicos, equipos y bibliotecas y para aumentar los aportes de la industria a la comunidad científica de Cambridge.

Trinity College acogíó estas ideas. La institución tenía un terreno disponible y se decidió a desarrollar un parque científico, siguiendo el modelo nacido en los años 50 en los Estados Unidos.

${ }^{363}$ La primera empresa de alta tecnología en Cambridge fue University Press, fundada en 1534 por Enrique VIII, que es la editorial más antigua del mundo. La tradición científica se remonta al menos a Isaac Newton. Si bien durante un tiempo no hubo grandes novedades, unos pocos siglos más tarde, el hijo de Charles Darwin, Horace, fundó la empresa Cambridge Scientific Instrument, dedicada a producir instrumentos científicos.

${ }^{364}$ Las superficies contabilizadas corresponden a la propiedad de Trinity College (152 acres), a los que se han sumado 21 acres contiguos de propiedad de Trinity Hall, con instalaciones dedicadas a la ingeniería genética. (Cambridge Science Park, 2018).

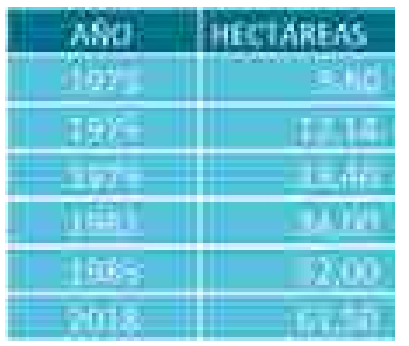

Tabla 11.1. Crecimiento de Cambridge Science Park entre 1973-2018. Elaboración propia a partir de datos de Cambridge Science Park (2018). 
con el objetivo de crear un entorno "pacífico y ambiental". Se han hecho grandes esfuerzos para ocultar los estacionamientos detrás de árboles, arbustos y setos, dándole continuidad al paisaje naturalizado, como se observa en la imagen aérea de la Figura 11.11.

En términos prácticos, el sitio de 61,5 hectáreas se beneficia de 8 hectáreas $(20$ acres) de paisajismo que brinda un área central de lagos, hábitats naturales, árboles maduros, arbustos y extensas áreas con césped, donde no se permite construir, constituyendo una suerte de área protegida dentro del predio (Cambridge Science Park, 2018).

Además, entre el $35 \%$ y el $40 \%$ de cada parcela de construcción se debe destinar a un proyecto de paisajismo particular que se extiende desde los espacios comunes hasta el borde mismo de los edificios.

Desde el punto de vista de la movilidad, el parque se encuentra a 4,3 millas (7 kilómetros) de Great St. Mary's, generalmente considerado como el punto central de la dispersa Universidad de Cambridge al que se comunica por un servicio de autobús regular y rutas ciclistas de gran uso.

El lento crecimiento inicial del Parque de Cambridge, sugiere un crecimiento exponencial que ha llegado a su meseta después del 2010. La razón de este fenómeno es que la sinergia entre empresas y universidad ha llevado tiempo en gestarse y madurar. Tuvieron un proceso de implantaciones productivas inicialmente lento, debido a la escasa participación de la empresa privada. En la década de los ochenta hubo una rápida proliferación de PCT en Inglaterra, por iniciativa de las universidades que se dedicaron a transformar conocimientos científicos y tecnológicos en riqueza económica. Actualmente la United Kingdom Science Park Association (UKSPA) reporta la existencia de más de 100 PCT, con un gran número de empresas afiliadas (UKSPA, 2019).

\subsubsection{El caso español.}

En España, existen actualmente 47 parques en funcionamiento y 33 en proceso de desarrollo, todos ellos adscritos a la APTE (Asociación de Parques Científicos y Tecnológicos de España).

El primer proyecto en la península ibérica fue el Parque Tecnológico BIZKAIA, conocido también como Zamudio, ubicado la provincia de Viscaya, País Vasco, a 7 km de Bilbao. Si bien tiene fecha de creación en 1985, empezó a funcionar en los años 1990. El parque tiene una superficie de 293,5 hectáreas y, según cifras de 2018, existen 266 empresas instaladas, lo que significa un grado de ocupación del $70 \%$ de los edificios construidos que suman $376.119 \mathrm{~m}^{2}$, con más de 10.000 empleos creados, de los cuales un 49,8\% corresponden a personal con títulos superiores. En su página web ${ }^{365}$ junto con destacar, que el $21,9 \%$ de su personal tiene menos de 30 años, el parque Bizkaia revela sus objetivos:

El Parque Tecnológico se crea con el objeto de estimular y promover la iniciativa y la inversión industrial, mediante la creación de una infraestructura que posibilite la implantación de empresas de alta tecnología, junto con actividades industriales y de servicios de alto contenido innovador, y, al mismo tiempo, potenciar la transferencia de tecnología y conocimiento entre la Universidad, los

\footnotetext{
365 https://parke.eus/bizkaia/es/quienes-so-
} mos/la-red-de-parques-en-cifras/

Figura 11.11.: Vista General del Cambridge Science Park en la actualidad. Cambridge Science Park (2019).

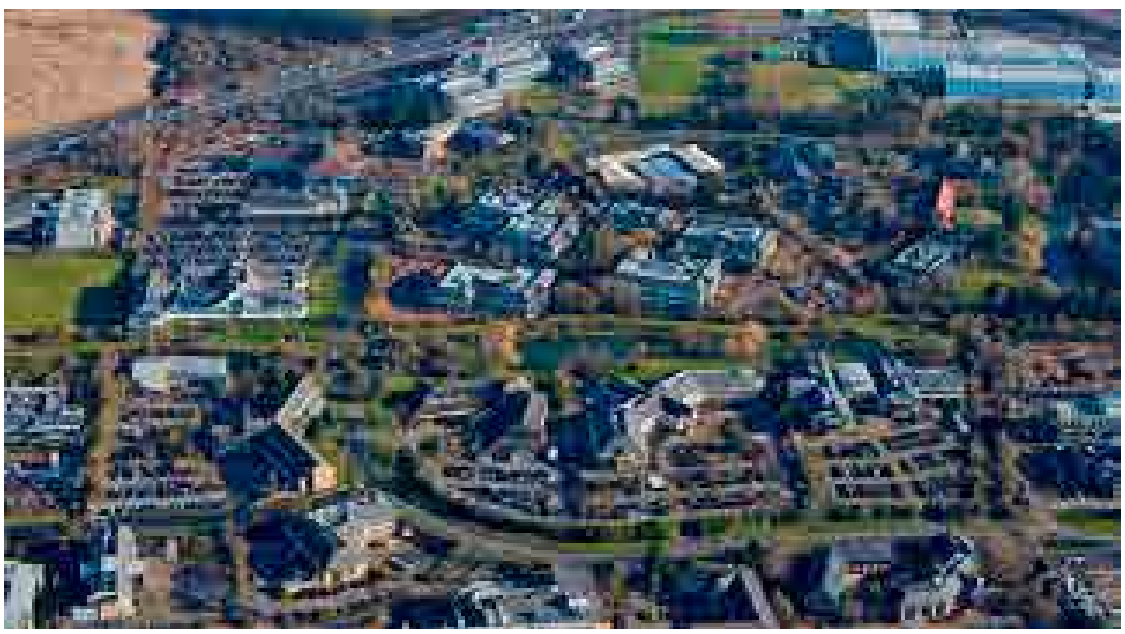


Centros Tecnológicos y las empresas (Bizkaia, 2018, s.p.).

A seiscientos kilómetros del parque Biskaia, está el Parc Tecnològic del Vallès (PTV), de Barcelona, ubicado en Cerdanyola del Vallès, que fue el primero en iniciar operaciones en el año 1989, cuando se finalizan las obras de la Primera fase de urbanización de 161 hectáreas y del edificio del Centre d'Empreses de Noves Tecnologies. En el año 2000 se suman 56 hectáreas al parque, llegando a las actuales $217 \mathrm{ha}$, con $25.645 \mathrm{~m}^{2}$ construidos, que albergan a 137 empresas (un $77 \%$ españolas y $23 \%$ extranjeras), dando trabajo a 2.991 personas (PTV, 2019). Esta iniciativa fue impulsada en 1987 por el CIDEM (Centre d'Innovació i de Desenvolupament Empresarial) de la Generalitat de Catalunya y el Consorci de la Zona Franca de Barcelona. Ambas entidades formaron la sociedad Parc Tecnològic del Vallès, S.A., como entidad gestora de un área tecnológica más amplia, llamada Cerdanyola, que tenía al PTV como primera etapa y muestra de los propósitos que alentaban al consorcio:

- Generar sinergias entre empresas e instituciones.

- Proporcionar servicios de calidad que mejoren la competitividad de las empresas.

○ Fomentar la proximidad de las empresas con las fuentes de conocimiento.

- Impulsar nuevos proyectos empresariales con contenido tecnológico (PTV, 2019, s.p.).

Si bien estos objetivos coinciden con los que hemos visto en las definiciones de la primera parte de este capítulo, en sus documentos e enfatizan los términos "comercialización de suelo empresarial", lo que es concordante con su constitución como Sociedad Anónima (de 16 accionistas), cuya actividad económica es "Alquiler de Bienes Inmobiliarios por cuenta propia" según el Directorio de empresas españolas (Informa - Directorio de Empresas, 2019). Lo que posiblemente ha dificultado la relación con las universidades, pese a su cercanía con la Universidad Autónoma de Barcelona (UAB). Sin embargo, se le reconoce ser pionero en servicios de primer nivel para empresas tecnológicas, instalándolo como un polo en el CIT (Catalonian Innovation Triangle), un corredor tecnológico que se desarrolla por el eje vial de la B-30 y que incluye el Parc de Recerca de la Universidad Autónoma de Barcelona, Esade-Creapolis y el Parc Alba. Como también su iniciativa de corredores verdes para enlazarse con el Parque Collserole. Otro aspecto interesante, es que, en su oferta de espacios, considera un edificio de $3.456 \mathrm{~m}^{2}$ destinado a las Pymes con espacios modulares, que permiten a las pequeñas empresas iniciar sus actividades arrendando espacios desde los 15 $\mathrm{m}^{2}$.

Estos dos ejemplos muestran la tendencia marcada por España en los parques tecnológicos, que son impulsados desde las regiones, desde arriba hacia abajo, planificados y con fuerte presencia del sector privado asociado a los municipios (ayuntamientos). Para la investigadora Carmen Adán "los PCT, en esta primera etapa, son instrumentos de la política industrial que persiguen la atracción de sectores estratégicos propios de la nueva economía [...] alejado de la universidad, a pesar de ser parte de su origen" (Adán, 2012, p. 87). A estos parques, que podrían encasillarse en una primera generación, se suman otros en prácticamente la mitad de las regiones autónomas.

Con la apertura en 1993 del PCT Cartuja 93, se abre una segunda generación de proyectos

Con un mayor peso del papel de la ciencia y tecnología y mayor conexión con instituciones educacionales. Este parque se funda en el recinto de la Exposición Universal de Sevilla (Expo'92) convirtiendo el parque ferial en un espacio de conexión entre "universidad, ciencia y empresa", que tiene como lema "Innova, coopera, crece" (PCT Cartuja, 2019). A diferencia de los dos casos anteriores de España, este es un parque urbano, que se encuentra a pocos minutos del centro de la ciudad de Sevilla y con expedita comunicación al aeropuerto y la estación de ferrocarriles. Emplazada sobre 203 hectáreas, la Cartuja posee 91 edificios, 56 de los cuales fueron heredados de la muestra ferial. Operan en el parque 459 empresas e instituciones científicas, tecnológicas y educacionales, que generan 
más de 17.000 empleos directos. En este caso, se contemplan siete centros de educación ${ }^{366}$ dentro del parque (La Cartuja, 2019).

La gestión del parque pertenece a la sociedad anónima "Parque Científico y Tecnológico Cartuja, S. A." dependiente de la Consejería de Economía y Conocimiento de la Junta de Andalucía.

Un importante estudio sobre el impacto de los PCT en el sur de Europa ${ }^{367}$ elaborado por Achilleas Tsamis (2009) en su tesis de PhD, sugiere que los primeros proyectos en la zona se originaron como un negocio, conectados con las políticas industriales regionales, y en una segunda ola, después de 1992, "parece tener una conexión más grande y directa con la ciencia" (Tsamis, 2009, p. 105). En sus conclusiones plantea que el rol de los PCT, están lejos de haber creado entornos de innovación, quedando principalmente como proveedores de infraestructura de alto estándar. "No son ni polos de crecimiento que difunden el conocimiento de la tecnología y apoyan el crecimiento económico, ni juegan ningún papel crítico en la transferencia de tecnología, redes y creación de sinergias para la innovación en la región" (Tsamis, 2009, p. 374). Las razones de este fenómeno son múltiples, pero este autor enfatiza la falta de vínculos entre los agentes internos y el entorno externo del parque, a los que suma una débil base tecnológica, una cultura empresarial que no tolera el riego y que no tiene tradición cooperativa, sumado a una baja demanda y valoración de la innovación externa, por lo que estos parques han derivado en parques empresariales o bien, en especulaciones inmobiliarias con un bajo impacto económico y social (Tsamis, 2009, p. 383).

La tercera generación de parques estaría representada por el Parque Científico de Barcelona (PCB) inaugurado en 1997, siendo el primero promovido por una universidad en España, donde la Universidad de Barcelona asume el rol de "universidad emprendedora", que como vimos, estuvo en el origen de los PCT. Junto al liderazgo de la universidad, este nuevo modelo se emplaza en la ciudad, contigua a las distintas facultades, como se observa en la Figura 11.12., y con una orientación específica, las ciencias de la vida. Esto explica su oferta de espacios ligada a la biomedicina, biotecnología, nano-bioingeniería y la química farmacéutica, con laboratorios montados o espacios para habilitarlos como tales, gestión de residuos e incluso servicios especializados, como lavandería de ropa de laboratorio, además de oficinas y servicios de apoyo. Esto se refleja en su misión que declara:

Potenciar la investigación, la transferencia de conocimiento y la innovación del sector público y privado, mediante una gestión inteligente de los espacios, la oferta tecnológica y de las relaciones y diálogo de la comunidad PCB (PCB, 2018).

${ }^{366}$ Escuela Técnica Superior de Ingenieros de la Universidad de Sevilla; Facultad de Comunicación de la Universidad de Sevilla; Universidad Internacional de Andalucía; Escuela de Organización Industrial de Andalucía, ESIC, CEADE.33; Universidad Oberta de Cataluña

${ }^{367}$ En su estudio considera Portugal, España, Italia y Grecia.

Figura 11.12. Emplazamiento del Parque Científico de Barcelona en la ciudad. En Portal PCV (s.f., contacte).

"Esta oferta, que se centraliza en el Edificio Clúster, consta de potentes infraestructuras y servicios especializados que ocupan una superficie de $5.000 \mathrm{~m}^{2}$ y que cuentan con técnicos altamente especializados" (PCB, 2018). La superficie total

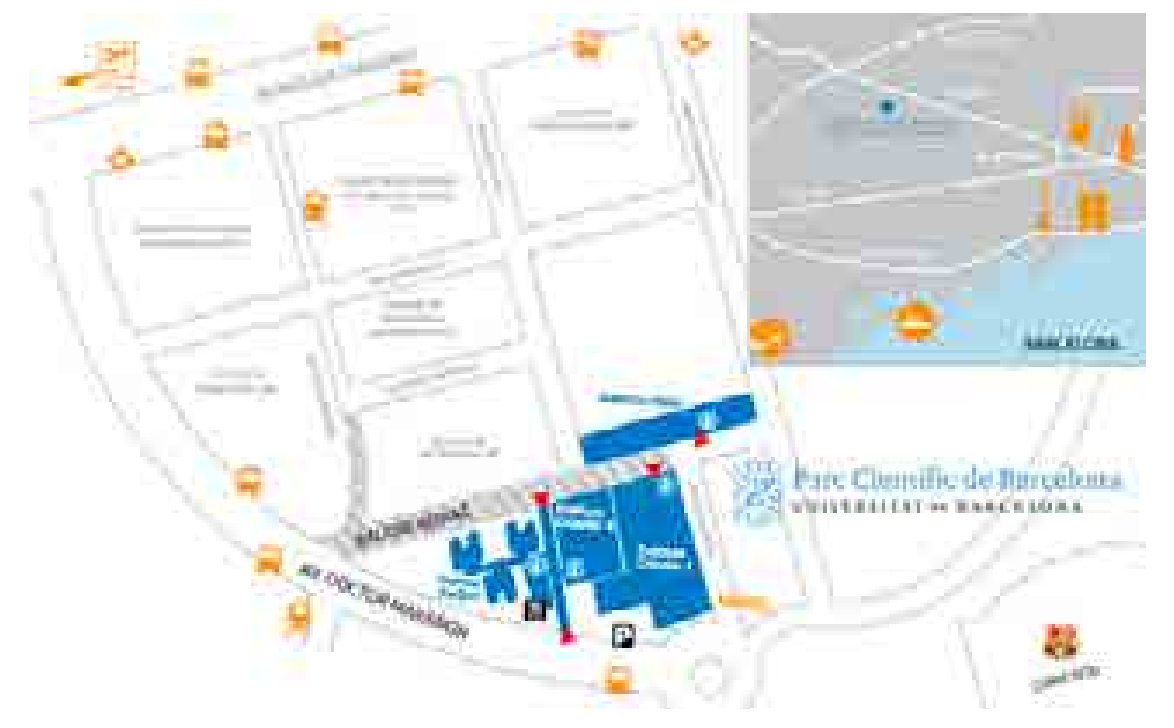


construida alcanza a $100.000 \mathrm{~m}^{2}$, de los cuales un $37 \%$ corresponde a laboratorios, $15 \%$ a oficinas, $38 \%$ a servicios y $10 \%$ a servicios científicos, donde se ubican tres institutos de investigación y cerca de 100 empresas y entidades sin fines de lucro, con 2.800 investigadores. El PCB también realiza actividades de divulgación de la cultura científica y fomento a nuevas vocaciones con una participación anual de alrededor de 5.000 personas a estos eventos (PCB, 2018).

De acuerdo al estudio de Carmen Adán, con este proyecto, los PCT se incorporan a la política de innovación del Estado Español, que inicia el 2000 un plan de apoyo público, que ha favorecido la creación de nuevos parques. Este plan consideró el otorgamiento de créditos sin interés, destinados a la creación de infraestructura física y científico-tecnológica en los parques, para luego en el 2001 ampliar estos beneficios a los órganos gestores y a las instituciones instaladas en ellos. La misma autora, citando a Castells (1997) y Krugman (2009), señala que "a partir de los años noventa, las transformaciones sociales y económicas de las sociedades basadas en el conocimiento afloran el papel de los territorios y las regiones como variable endógena del sistema económico" (Adán, 2012, p. 87). En una suerte de ecosistemas de investigación e innovación, los PCTs se despliegan en los territorios buscando ser instrumentos de no sólo del desarrollo económico, sino que también social de la zona donde se implantan, caracterizando así, lo que algunos autores han llamado la tercera generación. En esta evolución, las funciones del parque se integran a la ciudad o región, incluyendo elementos identitarios y la cultura emprendedora, si existe. Adán, citando a John Allen $^{368}$ (2007) define las características de estos nuevos parques, los que sintetiza en los siguientes puntos:

- Son actores globales con rutas locales, es decir, el PCT define la imagen y la marca de la ciudad en la que se ubica y la proyecta hacia el exterior. Las empresas situadas en PCT de tercera generación no tienen fronteras en los mercados e incrementan su presencia en el mercado internacional.

- L L L PCT son parte de la comunidad donde se ubican y de su entorno.

- Es necesaria una gestión profesional de gran calidad para gestionar la diversidad que incluye un parque y para proporcionar un negocio saneado y atractivo a la inversión.

- $\quad$ EI PCT es un elemento esencial de las actividades de la universidad.

- $\quad$ EI PCT forma parte de una multiplicidad de redes.

- Está centrado en las necesidades de las entidades que están ubicadas en el PCT. El entorno físico es importante, pero también el apoyo a las empresas situadas en el parque. (Adán, 2012, p. 87)

No es casual que entre los ejemplos de este modelo se encuentren el corredor de Manchester, donde Allen fue director. Otro de los ejemplos citados por Adán corresponde al distrito de Barcelona, el "Manchester catalán", con el proyecto 22@Barcelona (Figura 11.13.), que busca expandirse en los distintos barrios de la ciudad, en un agresivo programa de renovación urbana que tiene como hito la torre Agbar de Jean Nouvel y Fermín Vázquez. Actualmente, sobre las 115 manzanas (200 ha) existen más de 8.300 empresas instaladas y según cifras oficiales, se han creado 95.000 puestos de trabajo. El barrio tiene un potencial de

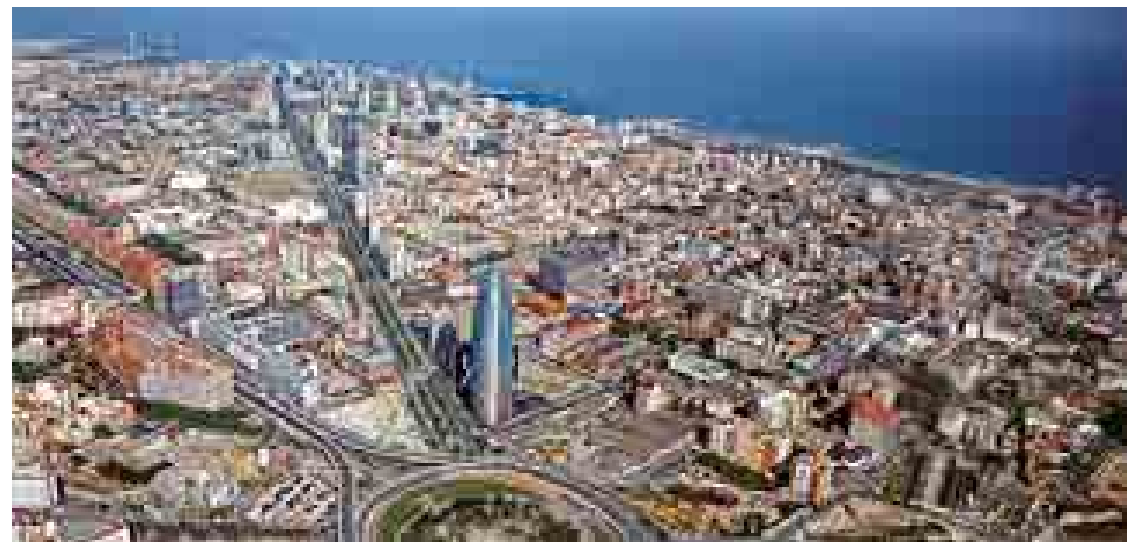

368 John Allen estudió Química en King's College, Londres y fue profesor universitario de Bioquímica durante unos 20 años, con alrededor de 100 publicaciones. Fue miembro de la Royal Society of Chemistry. En 1985, se convirtió en el director ejecutivo de Newtech en el norte de Gales, que apoyó el desarrollo de más de 200 PYME y ayudó a crear unos 1.700 puestos de trabajo en 10 años. Entre 1993 y 2000, fue director ejecutivo del Manchester Science Park.

Figura 11.13. Vista aérea del Proyecto 22@Barcelona, con la torre Agbar al centro. Por Diario El País, 3 de julio, 2018). 


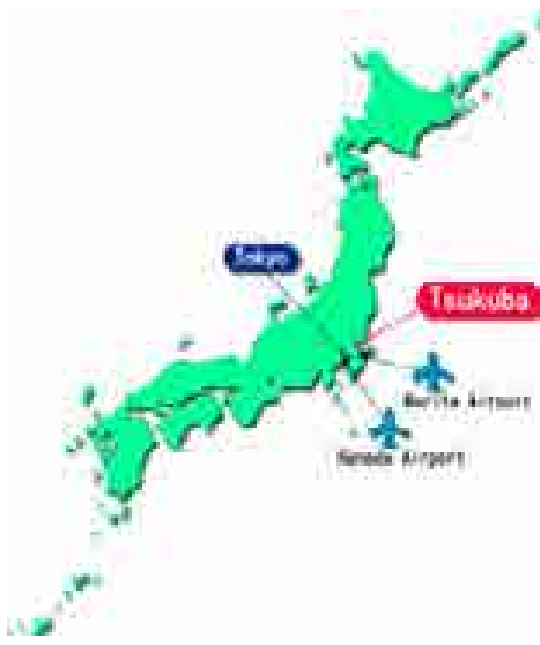

Figura 11.14. Mapa de ubicación ciudad de Tsukuba. En The International Centre for Water Hazard and Risk Management [ICHARM] (s.f.).
${ }^{369}$ El monte Tsukuba alberga el santuario de la montaña Tsukuba, el tercer santuario sintoísta más antiguo de Japón. La montaña tiene 877 metros de alto, y se puede subir a pie. El santuario tiene varios festivales durante todo el año.

${ }^{370}$ Comunicaciones personales entre el 18 y el 27 de julio de 2015.

Figura 11.15. Vista general del Valle de Tsukuba (2017). Por Tsukuba Global Innovation Promotion Agency (TGIPA).
$800.000 \mathrm{~m}^{2}$ de oficinas, con valores de arriendo que van entre 11 y 21 euros por $\mathrm{m}^{2}$ (Diario El País, 3 de julio, 2018).

La cuarta etapa o generación de PCTs es la propuesto por Angle Technology (UKSPA, 2003) y que se suma, a las etapas estudiadas por Allen. Ésta consiste en la diversificación. Los ejemplos más claros de este modelo se encuentran en Asia, donde junto a las ciudades tecnológicas como Tsukuba, se han iniciado operaciones en múltiples sitios y servicios en red, para apoyar el crecimiento de las empresas que ya están formadas en el parque, y ayudar a multiplicarse, es el caso de Hsinchu Science Park en Taiwán.

\subsection{PARQUES Y CIUDADES DE LA CIENCIA EN ASIA \\ 11.9.1. Tsukuba Science City}

El caso de Tsukuba, ha sido cercano para el proyecto en Laguna Carén debido a que esta ciudad ha prestado asistencia técnica al proyecto, a través de dos visitas de expertos a Santiago en el marco de la colaboración entre la Universidad de Tsukuba y la Universidad de Chile.

La ciudad de las Ciencias de Tsukuba se inicia como "proyecto nacional" en 1963, cuando el gobierno japonés, ante la saturación de Tokio, decide crear una ciudad donde reubicar los centros de investigación fuera de la metrópoli, en una ciudad planificada. El primer instituto de investigación se instaló en 1968 y en 1973 se estableció la Universidad de Tsukuba. Para 1980 la ciudad albergaba 40 institutos de investigación y contaba con una población de 127.401 habitantes. En 1985, Tsukuba fue sede de la Feria Mundial, lo que la dio a conocer internacionalmente. La ciudad se encuentra a $60 \mathrm{~km}$ del centro de Tokio (Figura 11.14.), a $45 \mathrm{~min}$. en tren rápido (inaugurado en 2005) y 56 min. en el tren local. La superficie planificada abarca 284.000 hectáreas en el valle Ibaraki, una tradicional zona rural dominado por el monte Tsukuba ${ }^{369}$ al norte y el lago Kasumigaura, el segundo más grande de Japón, al este; ofreciendo un entorno natural rico en vegetación y referencias naturales (Figura 11.15.).

Desde el punto de vista científico-tecnológico se han establecido en la ciudad el consorcio de institutos de estudio de nanotecnología y el centro nacional de robótica, ambos financiados con el gobierno central. Recientemente, Tsukuba fue nominada como una de las cuatro "Zonas Estratégicas Internacionales" que promueven la vida y la innovación ecológica, como componentes de las ciencias de la vida y la tecnología.

De acuerdo a los estándares japoneses (1,6\% en Japón) la población de Tsukuba es muy diversa, ya que de los 221.500 habitantes (2015), 8.500 son extranjeros $(3,8 \%)$ representantes de 90 países. También es una de las ciudades más jóvenes en términos de promedio de edad y una de las más educadas. De los 20.000 investigadores residentes, 5.000 tienen grado de doctor. La propia universidad, que tiene 2.000 estudiantes extranjeros.

En la actualidad existen más de 200 organizaciones privadas y 60 organizaciones públicas de investigación, con un fuerte apoyo del estado, que invierte casi el $50 \%$ de los fondos de investigación en esta ciudad.

En las reuniones ${ }^{370}$ con Akihiko Yahata y Ohsawa Yoshiaki, ambos de la Universidad de Tsukuba expusieron lo que a su juicio eran elementos clave en el diseño de un gran parque científico-tecnológico, que pueden sintetizarse en:

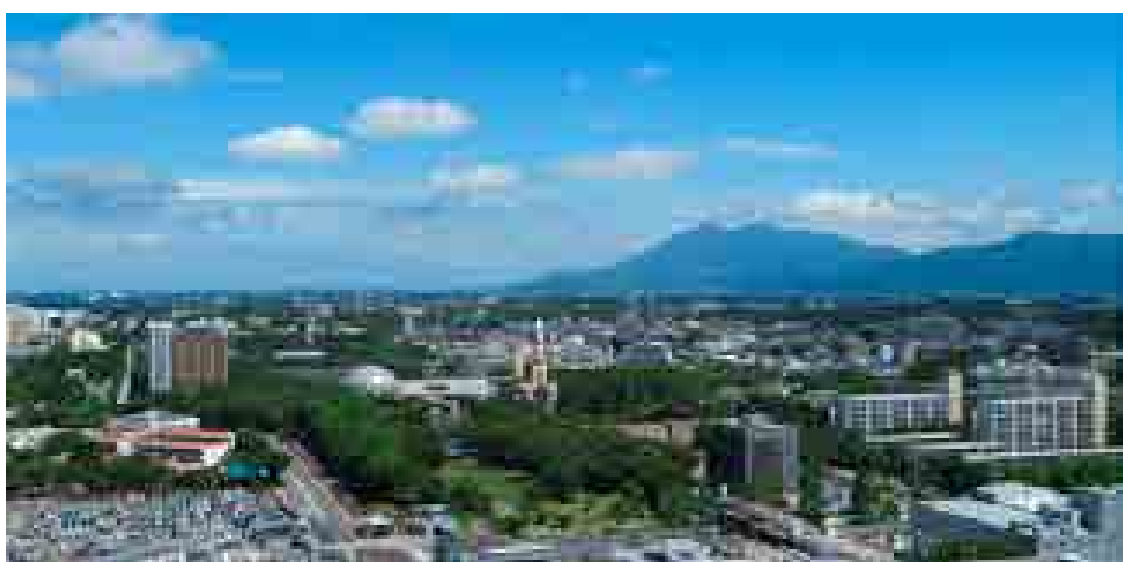


- Un ordenamiento racional a partir de la vialidad, con una cuadrícula diseñada por los ingenieros de tránsito, lo que defendían, comparando el orden y eficiencia del transporte público de Tsukuba con el ordenamiento orgánico y peatonal de Lovain-la-Neuve, la ciudad que usaron de referente para, por oposición, diseñar la suya (Figuras 11.16. y 11.17.)

- $\quad$ Lograr que el proyecto tenga prioridad nacional. Los grandes proyectos requieren de largos procesos que solo el estado puede solventar.

- Lograr un sistema de transporte público que comunique expeditamente el terreno, el centro de la ciudad y el aeropuerto. Para Tsukuba fue fundamental la apertura de Tsukuba Express, el tren rápido.

También advirtieron acerca de los problemas que Tsukuba tiene:

- $\quad$ El mantenimiento y la dirección de infraestructura ya que después de 50 años y al haberse construido al mismo tiempo, también simultáneamente han caducado, representando su renovación, grandes sumas de dinero. Por lo que recomiendan un desarrollo por etapas.

- La falta de control sobre la estética y mantenimiento de los edificios. Lo anterior debido a que en la primera etapa vendieron lotes. Actualmente, sólo arriendan y recomiendan que la universidad no pierda la propiedad, construya y arriende los edificios, para tener control sobre ellos.

- La conciencia ciudadana: incluyendo los estudiantes, no hay habitantes que permanezcan por períodos largos, por lo tanto, no hay ciudadanos, no hay una identidad que los caracterice y tampoco interés en participar en las decisiones urbanas.

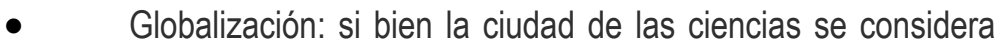
globalizada, los habitantes tienen una resistencia cultural a lo externo. (Comunicación personal con Akihiko Yahata y Ohsawa Yoshiaki, 18 - 27 de julio de 2015).

\subsubsection{Hsinchu Science Park.}

El Parque Tecnológico de Hsinchu (HSP), instalado en diciembre de 1980 es el primero de su tipo en Taiwan y hoy, uno de los más exitosos, ya que se ha convertido en referente para los proveedores de equipos y componentes electrónicos e informáticos del mundo. Fue fundado por Kwoh-Ting Li, antiguo Ministro de Finanzas de la República de China. Inspirado por Silicon Valley en Estados Unidos, y apoyado por Frederick Terman (el decano de Stanford y creador de "Stanford Industrial Park").

En este parque están localizados centros tecnológicos públicos y privados como Acer, uno de los mayores productores de computadores del mundo (Ministry of Science and Technology, 2019).

Este caso es también una iniciativa del estado, que, con el fin de promover la investigación y el desarrollo industrial, ha establecido parques científicos, como zonas económicas de renta y servicios con incentivos fiscales y préstamos con tasas especiales para atraer inversionistas internos y extranjeros.

Ubicado en el condado Hsinchu, el HSP posee 653 ha $\left(6,5 \mathrm{~km}^{2}\right)$ y 435 edificios (de los cuales 429 están ocupados). Alberga principalmente empresas de semiconductores y optoelectrónica. Las 393 compañías presentes, emplean a 130.670 personas. De éstas, 3.960 son doctores, 44.623 Máster y $42.208 \mathrm{Ba}-$ chilleres, lo que dota a HSP de recursos humanos excepcionales "que actúan dentro de un sistema con reglas claras, con estatutos bien definidos" (Ministry of Science and Technology, 2019, Introduction).

A partir de esta iniciativa, el HSP se ha expandido a seis campus satélites ${ }^{371}$ alcanzando una superficie total de desarrollo de 1.342 hectáreas (poco más de las 1.022 que tiene Carén), con 430 empresas instaladas, que emplean a más de 130.000 personas. Este conglomerado corresponde a la sección superior de la Figura 11.19., donde se puede observar la expansión de parques científicos
371 En la actualidad, el HSP cubre seis ubicaciones: los parques Hsinchu, Jhunan, Tongluo, Longtan y Yilan, y el Parque Científico Biomédico Hsinchu, que abarca un área total de casi 1.400 hectáreas.

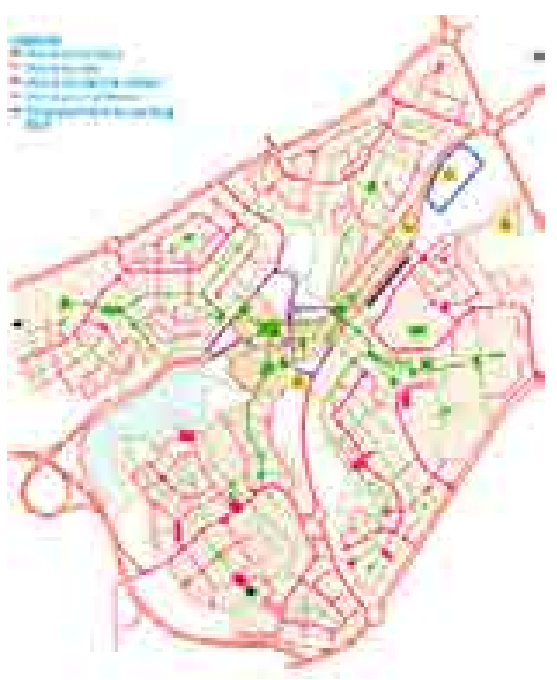

Figura 11.16. Plan general de Louvain-la-Neuve. Referente, por oposición, para la planificación de Tsukuba. En Laconte, P. (2011, p. 31).

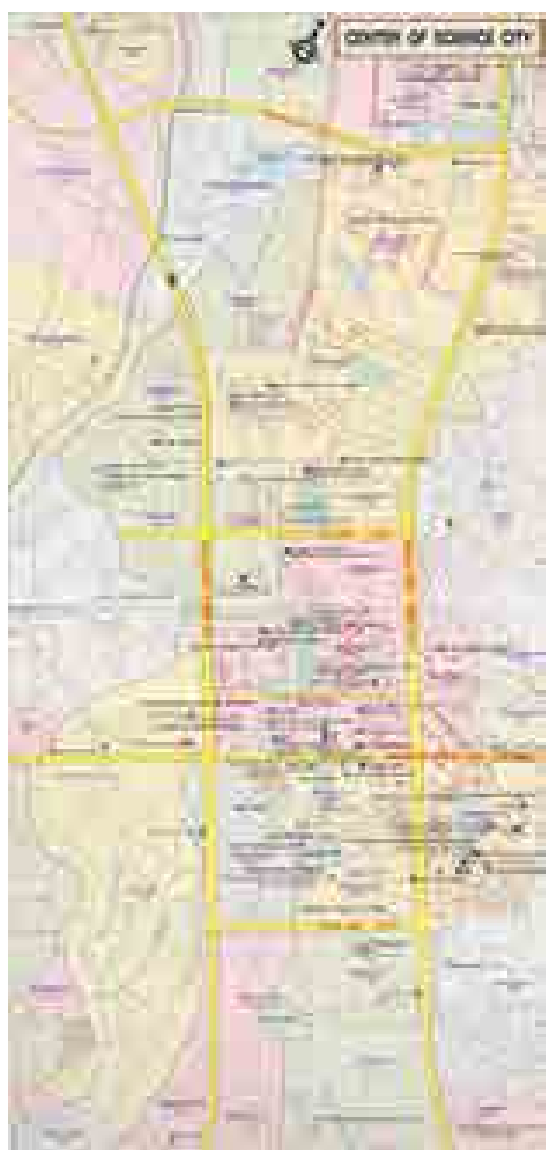

Figura 11.17. Planta general de la Ciudad de Tsukuba, cuyo trazado responde a criterios de transporte eficiente. En Alien Times (2008). 


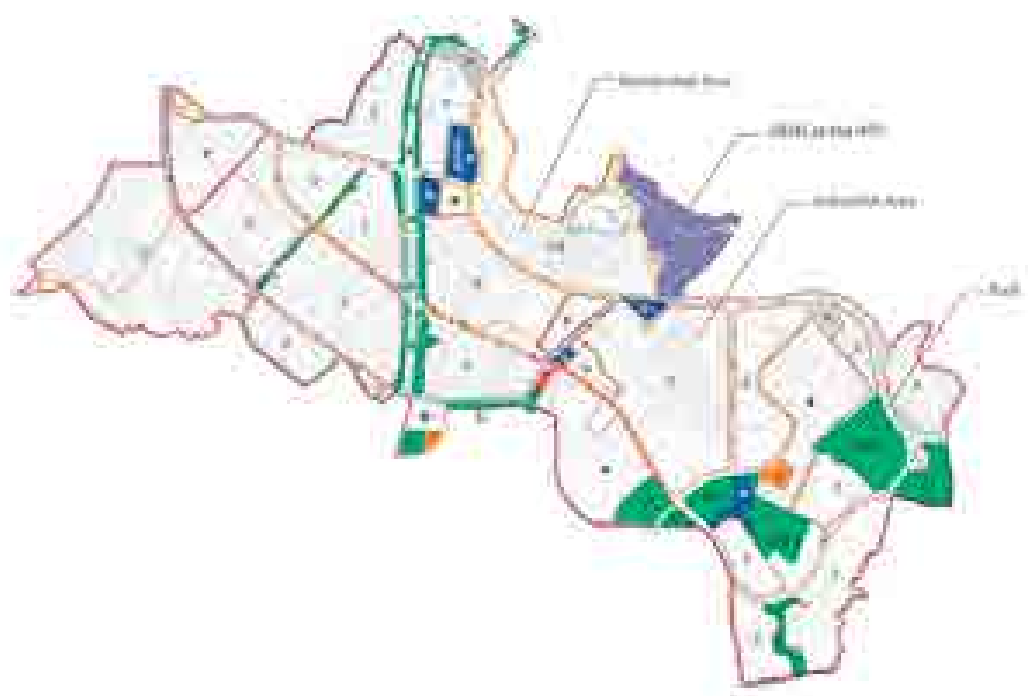

hacia el centro y el sur de Taiwan, con un total general de 4.632 hectáreas en el país.

Tanto Taiwán Semiconductor Manufacturing Company y United Microelectronics Corporation, el primer y segundo mayor fabricante de chips en el mundo, como Microtek Intenacional, especializada en equipos para impresión con el $12 \%$ en el mercado mundial en escáners tienen su sede en el parque. Se considera que más del $70 \%$ de los productos de la industria global de tecnologías de la Información están involucrados en el Parque Científico Hsinchu. Opera también en este sitio, el Instituto de Investigación de Tecnología Industrial (ITRI) que es la organización de investigación sin fines de lucro más grande de Taiwán y que ha estado trabajando en el desarrollo de las industrias tradicionales de Taiwán. Es así como el parque ha sido capaz de establecer un vínculo con la tradición textil local, a una escala menor, pero con un posible impacto social importante.

Una vez alcanzada su madurez, el HSP puede ser visto como ejemplo de cuarta generación, que se multiplica y aprovecha su know-how, para replicar la experiencia en otras zonas, con una voluntad clara de aportar al progreso local. Prueba de ello, en su memoria declara que además de estimular la I + D, parte de los beneficios de su operación se destinan al cultivo de talentos, para aumentar "la prosperidad de las comunidades locales" y "mejorar la conciencia cultural de la nación", vale decir, crear una identidad tecnológica asociada con ser ciudadano de Taiwán (Ministry of Science and Technology, 2019, Introduction).

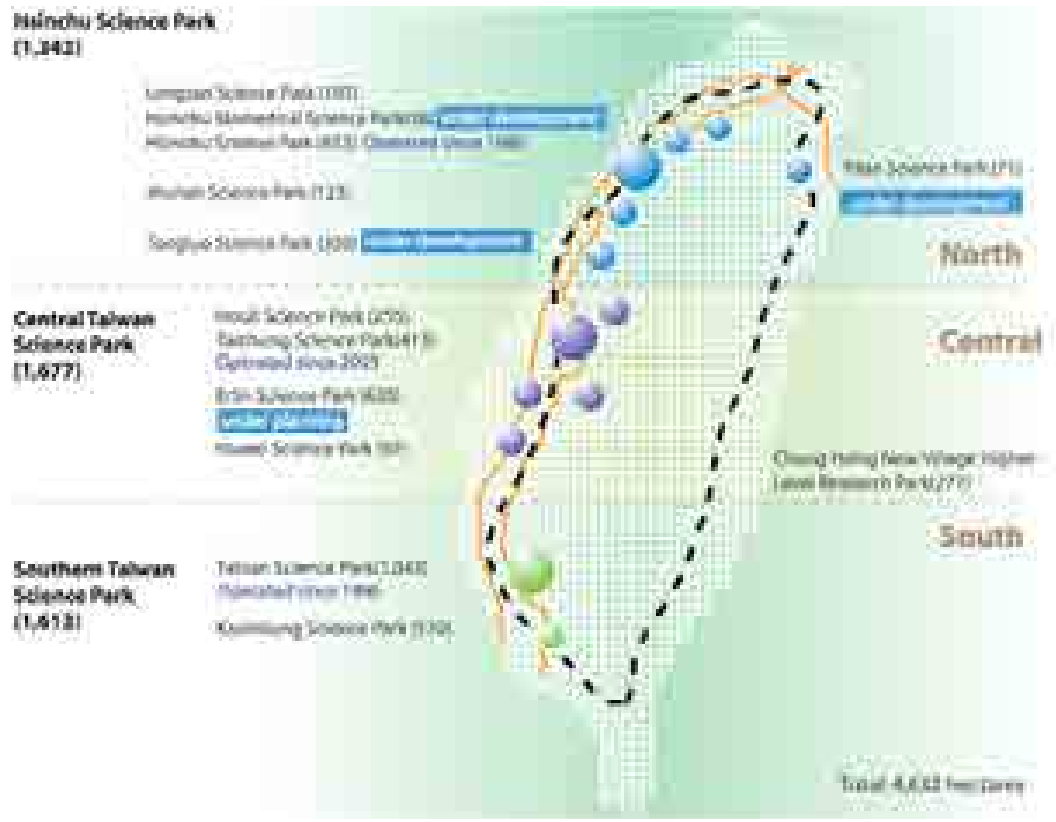




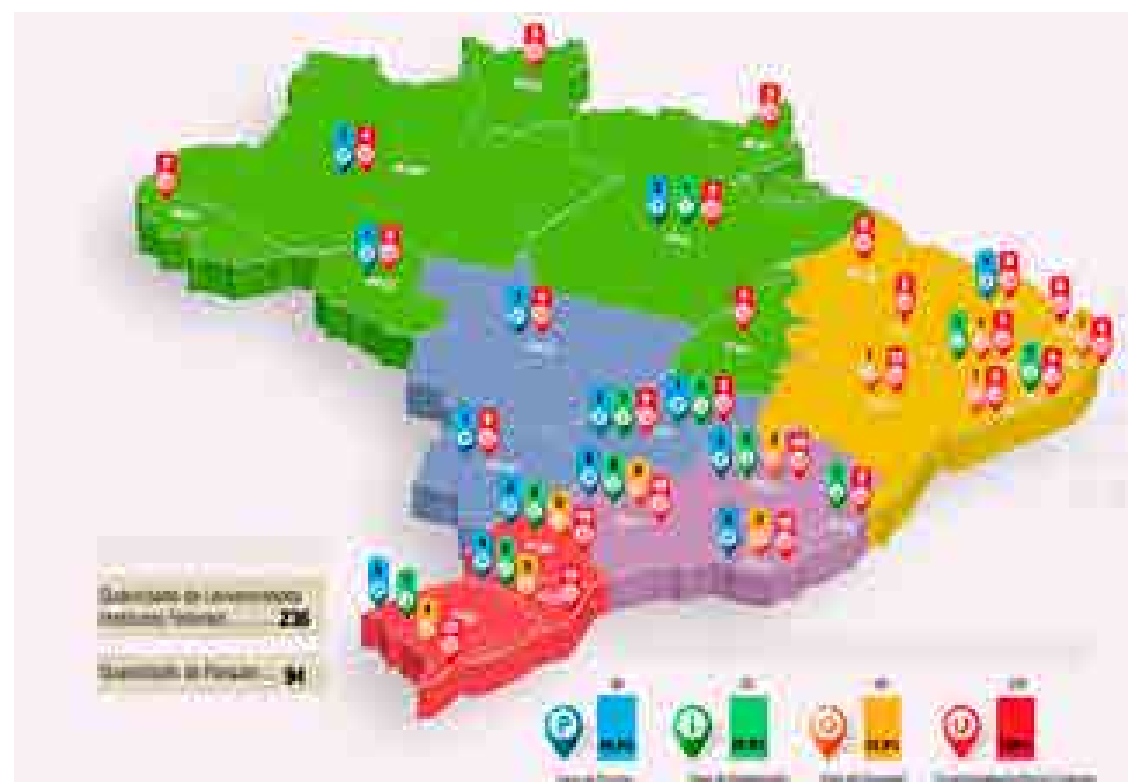

En los reportes anuales del HSP se dedica un apartado especial al paisajismo, "para mantener la HSP como un entorno de inversión deseable" (Yen, 2009, 47). Para ello, la administración del parque se ocupa del mantenimiento de árboles y setos, la siembra, la limpieza ambiental y el dragado de los drenajes para todas las áreas públicas. La gestión paisajística de las empresas residentes para sus edificios, es evaluada anualmente desde el punto de vista ecológico y estético, por la administración del parque (que contrata a expertos y becarios para esta tarea). Desde el año 2009, se realiza también un concurso anual para premiar el "embellecimiento del medio" (Yen, 2009, p. 26).

\subsection{LATINOAMÉRICA}

Podemos asimilar el fenómeno de los parques tecnológicos en Latinoamérica a lo ocurrido en el sur de Europa, vale decir, a las iniciativas impulsadas por los estados centrales o federados como parte de las políticas de ciencia y tecnología, que en el caso americano han estado apoyados por entidades internacionales como el BID y el Banco Mundial.

El proceso se inicia lentamente en los años 1980, con Brasil y México. Las dos mayores economías de la región, se ponen a la cabeza en los noventa, pero en la práctica es en la primera década del siglo XXI, cuando el proceso de creación de parques científicos crece y se diversifica. Si bien en el estudio patrocinado por el BID en el 2012, indica que casi todos los países latinoamericanos declaran Parques Científicos y Tecnológicos, al profundizar en el estado de desarrollo y en el tamaño, sólo Brasil muestra ejemplos interesantes, los que pueden sintetizarse en las siguientes cifras que se desprenden del "Estudo de Projetos de Alta Complexidade - Indicadores de Parques Tecnológicos", desarrollado por el Ministerio de Ciencia Tecnología e Innovación (MCTI) con el apoyo de la Universidad de Brasilia el año 2014: de los 94 PCT registrados, sólo 28 están en operación, otros 28 en implementación y 32 en proyecto; con solo 10 de los 94 , creados antes del año 2000. Del total, como se muestra en la Figura 11.20., el 40\% está concentrado en la zona sur, vale decir la región con tradición industrial. A partir de los 28 PCT que están en operación, se contabiliza un total de 32.237 puestos de trabajo creados, 29.909 de ellos en las empresas, 531 en la gestión de los parques y 1.797 correspondientes a los institutos o centros de innovación. Del total, el 13\% del personal contratado, tienen título de máster o doctor.

Tras el liderazgo de Brasil está el hecho de que es la sexta mayor economía del mundo, con un territorio inmenso (el quinto en tamaño) y una población de más de 200 millones de habitantes. A estas condiciones se suma un esfuerzo de más de 60 años $^{372}$, que ha puesto a este país en el № 14 del ranking de producción científica en el mundo (Scimago, 2016). Pese a esto, el país sigue dependiendo de tecnología desarrollada fuera de sus fronteras, sin lograr el "desarrollo de productos procesos y servicios innovadores" (MCTI, 2014, p. 5). Es en este contexto
Figura 11.20. Distribución de Parques Científico-Tecnológicos y universidades en Brasil. En Ministério da Ciência, Tecnolo-gia e Inovação (MCTI, 2014, p. 22). 
372 Primero con la creación del Consejo Nacional de Desarrollo Científico y Tecnológico (CNPq) en 1951; la Financiadora de Estudios y Proyectos (FINEP), en 1967 y el Ministerio de Ciencia, Tecnología e Innovación en 1985.

373 El informe registra 384 incubadoras, que al 2011 habían creado más de 5.000 empresas.

374 Este enfoque didáctico aplicado a la educación financiera, tiene como fundamento que los individuos no pueden tomar decisiones acertadas o eficientes con la poca información que poseen sobre los instrumentos financieros y el mercado en general. El grupo más vulnerable son los jóvenes, tienen más riesgo de caer en la pobreza y son los que reportan actitudes y comportamientos financieros más inadecuados a la hora de tomar decisiones. Así muchos países, incluido Chile, han comenzado a medir este fenómeno para lograr diseñar e implementar estrategias eficientes con el objetivo mejorar la situación de la inclusión y educación financiera.

Figura 11.21. Plan Maestro del Parque Científico y Tecnológico del Bío-Bío. En (PACYT, s.f., el parque). y sobre la base de este desarrollo, que surge el Programa Brasileño de Parques Tecnológicos de 1984, que busca potenciar la transferencia tecnológica en todas las regiones, ubicándolos "en áreas cercanas a las universidades y centros de investigación, para la implementación de una infraestructura de laboratorio y de servicios y para el apoyo a las empresas en el proceso de desarrollo tecnológico e innovación" (MCTI, 2014, p. 13).

Entre los aprendizajes que destaca el estudio, se identificó que el rol del gobierno federal fue esencial para la implementación de los parques científicos y tecnológicos, ya que las inversiones iniciales se suelen realizar con recursos federales, dada la gran incertidumbre en esta fase de desarrollo. Frente al impulso inicial del estado, una vez en operación, los recursos asignados por la iniciativa privada son ampliamente superiores a las inversiones realizadas con recursos fiscales, demostrando que las empresas invierten en ellos una vez establecidos. Por último, más que los parques mismos, "son las incubadoras de empresas las que concentran los ambientes de innovación, con fuerte impacto económico"373(MCTI, 2014, p.12)

Este último punto es reforzado por Etzkowitz, Webster, Gebhardt y Cantisano (2000) quiénes junto con criticar el modelo académico tradicional latinoamericano que opera junto al estado de "arriba hacia abajo", reconoce logros en las incubadoras que operan de "abajo hacia arriba", poniendo como ejemplo a COPPELEC, perteneciente a la escuela de ingeniería de la Universidad Federal de Río de Janeiro, que ha desarrollado un programa para organizar cooperativas. En vez de enfocarse en emprendimientos de alta tecnología, el programa busca residentes con orientación empresarial en favelas de vecindarios pobres, con poca educación formal y les proporciona capacitación básica para pequeñas empresas. Los grupos formulan proyectos, desarrollan liderazgos y prueban sus ideas a pequeña escala, pero producen innovación e impacto local junto con una experiencia de gestión social del conocimiento en los estudiantes. Esta experiencia remite a otra dentro de la Universidad de Chile, particularmente en la Facultad de Economía, que, dentro de la formación de economistas e ingenieros comerciales, plantea el modelo de aprendizaje \& servicio ${ }^{374}$, ofreciendo a la comunidad, servicios de economía familiar y apoyo a las pequeñas y medianas empresas (Pymes), en el territorio donde se emplaza la escuela.

Volviendo a los parques científico-tecnológicos, después de Brasil, México según datos de 2012, tiene 21 parques operativos, Argentina cinco, pero de tamaño menor; Colombia también tiene cinco; Venezuela, dos; Uruguay, uno; Panamá, uno: La ciudad del Saber, que será la que analizaremos con más profundidad y en el caso de Chile, si bien aparecen dos: El Parque Biotecnológico de Nuñoa, en Santiago, ligado a la Universidad Andrés Bello, y del Parque Científico y Tecnológico e Industrial de Quillota, en la provincia de Valparaíso, en ambos casos corresponden a iniciativas privadas, pequeños en extensión y número de empresas, sin que ninguno de ellos este asociado a IASP ni reconocido por otros organismos internacionales. Sin embargo, cabe mencionar una iniciativa de la

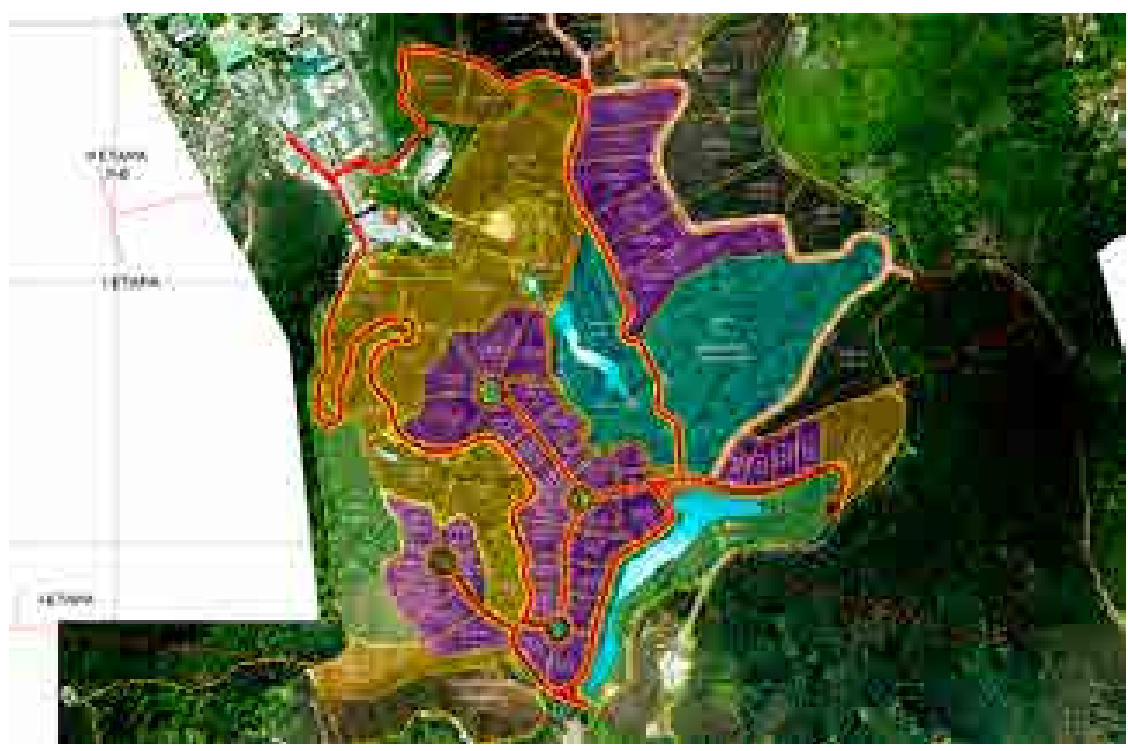


Corporación de Fomento de la Producción (CORFO) que en 1997 instaló el Parque Industrial y Empresarial de Curauma (Región de Valparaíso) y que después de 20 años muestra sólo el edificio principal, aislado y con escasa evidencia de su ocupación en la actualidad.

En la fase de proyecto, se encuentra el Parque Científico y Tecnológico de Biobío (PACyT-Biobío), emplazado junto al campus de la Universidad de Concepción, sobre un terreno de 91 hectáreas, de las que se destinarán 24 para los edificios y 67 para áreas verdes, incluyendo un bosque nativo (Figuras 11.21. y 11.22.). En mayo de 2019 se iniciaron las obras de urbanización de la primera etapa, financiadas por el Gobierno Regional. En la información web ${ }^{375}$ señala que se inspira en el modelo anglosajón y espera en 10 años tener instaladas 40 empresas, generando 2.000 puestos de trabajo. Para su administración, se ha creado una entidad sin fines de lucro, la Corporación PACyT.

Un referente Latinoamericano exitoso es La Ciudad del Saber en Panamá, con cuyo presidente la autora sostuvo una comunicación personal ${ }^{376}$, con motivo de la " $1{ }^{\circ}$ Conferencia Iberoamericana de Ciudades del Conocimiento, Innovadoras Y Emprendedoras" realizada en Pachuca, México, los días 20 y 21 de octubre de 2015.

La Ciudad del Saber (CDS) ${ }^{377}$, se declara un parque científico, tecnológico y empresarial. Está ubicado a orillas del Canal de Panamá, en un terreno de 120 hectáreas, ocupado por las antiguas instalaciones de la base militar estadounidense de Clayton $^{378}$. El sitio fue entregado por el Estado panameño a la Fundación Ciudad del Saber, en 1999379. Constituyéndose en una suerte de "zona franca" para las instituciones que allí se emplazan.

El estado exigía que se iniciar operaciones en el primer año y que el parque fuera sustentable al año 10, objetivo que fue alcanzado al sexto año (comunicación personal con Jorge Arosemena, Presidente Ejecutivo de la Fundación Ciudad del Saber, 2015). Desde su origen, el proyecto se plantea como misión "Ser una ciudad sostenible modelo que facilita la gestión del conocimiento, la innovación, la cultura y el desarrollo humano para Panamá y el mundo" (FCDS, 2016, p. 4), aprovechando su enclave estratégico y función logística, que han hecho de la ciudad, históricamente un punto de encuentro.

En la CDS se permiten, además de las actividades e instituciones científicas y tecnológicas, otras de desarrollo humano y culturales, ampliando el espectro habitual de los PCT. Se ubican en ella, por ejemplo, la UNICEF, la Cruz Roja Internacional, la oficina regional del Programa de las Naciones Unidas para el Desarrollo de América Latina y el Caribe, el Programa Mundial de Alimentos y Plan International, y a sede de la Organización Mundial de la Región Interamericana del Movimiento Scout.

También se han integrado nueve entidades educativas ${ }^{380}$, entre las que destaca, la Escuela de Arquitectura y Diseño de América Latina y el Caribe, Isthmus (que además fue la primera en instalarse), con una novedosa estructura académica

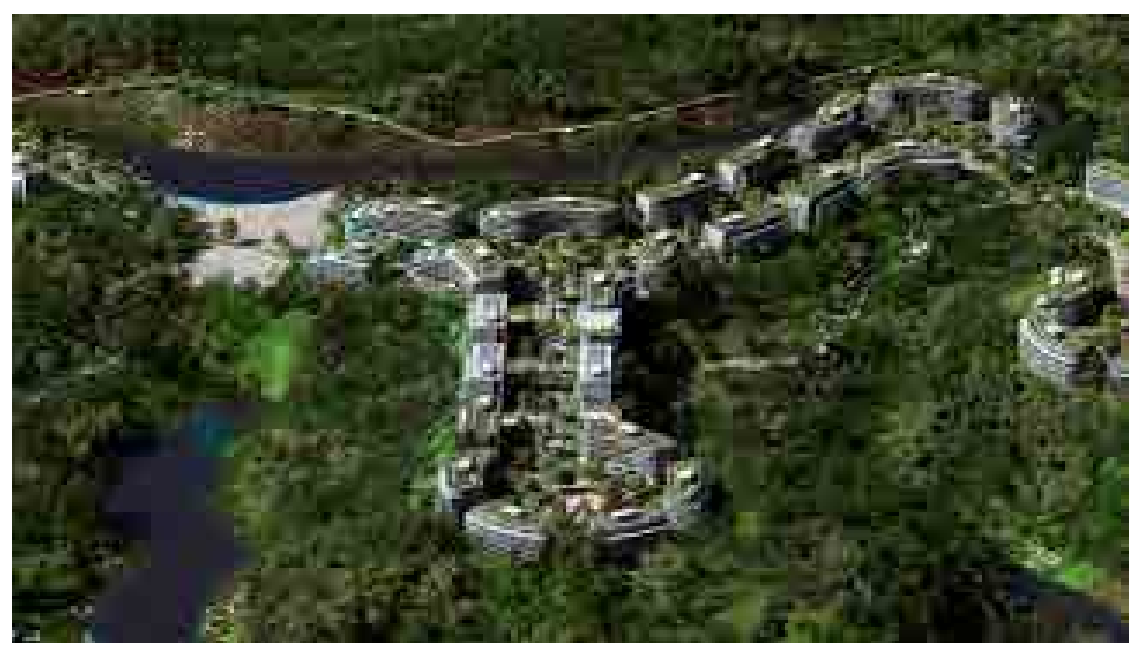

375 http://sabes.cl/2017/03/01/asi-sera-parque-cientifico-tecnologico-pacyt-concepcion/

${ }^{376}$ Informe de Viaje en Anexos.

$377 \mathrm{http}: / /$ ciudaddelsaber.org/es

378 La construcción del Fuerte Clayton (1922) responde a la época en que los norteamericanos deciden establecerse de forma permanente en la Zona del Canal y a la creciente preocupación de procurar una mejor defensa a la vía interoceánica. Es por ello que la gran mayoría de las edificaciones son de mampostería y su diseño fue planificado como una ciudad autosuficiente con hospitales, escuelas, viviendas, bunkers, iglesias, campos de juego, comercios, hotel, etc. Durante la Segunda Guerra Mundial, el fuerte Clayton sirvió como cuartel de la fuerza móvil de Panamá y del Comando de Seguridad. Las instalaciones se convirtieron en los cuarteles del componente del Ejército del Comando Sur a partir de los tratados del canal.

379 Las instalaciones actuales en Fort Clayton fueron entregadas oficialmente a la Fundación Ciudad del Saber (FCDS) por la presidenta Mireya Moscoso en noviembre de 1999, durante la etapa final de la implementación de los Tratados Torrijos-Carter.

Figura 11.22. Maqueta electrónica del proyecto Parque Científico y Tecnológico del Bío-Bío. En Universidad de Concepción (10 de junio, 2019). 
en pre y postgrado.

Lo que hemos llamado "zona franca" implica una serie de incentivos fiscales para las instituciones instaladas en el CDS, como son la exoneración del impuesto a la renta, de los impuestos de exportación, de inmuebles y de transferencias al extranjero; de manera que las empresas que producen bienes o servicios tecnológicos en la CDS no pagan impuestos directos ni de licencia. También existen incentivos laborales que permiten contratar el personal extranjero con facilidades migratorias, concediendo visas especiales a empleados de empresas afiliadas, incluidos sus cónyuges e hijos dependientes.

Otro elemento diferenciador de Ciudad del Saber es que también ofrece posibilidades de vivienda, así como de los servicios propios de un barrio, con espacios recreativos, culturales e institucionales, los que son utilizados diariamente por más de 5.000 personas. A todos ellos se suman, las personas que visitan el Campus y las que asisten a eventos, conferencias y actos culturales. Esto recuerda el sueño de Laffitte para Sophia Antipolis.

Otro de los residentes clave en la CDS es el Instituto de Tecnología e Innovación (ITI), una entidad dependiente de la Autoridad Nacional para la Innovación Gubernamental (AIG) que tiene como misión la capacitación de los funcionarios públicos en las áreas de Tecnología de Información y Comunicaciones (TIC) con el propósito de asistir en el proceso de modernización del Estado. Asimismo, como parte del convenio bilateral entre los gobiernos de Panamá y Corea, se creó el Centro de Acceso de Información Panamá- Corea (CAIC), con el propósito de apoyar el desarrollo de las Tecnologías de Información y Telecomunicaciones en el país.

Del total de 1.296 edificios que tenía originalmente el fuerte Clayton, fueron entregados a Ciudad del saber 243. Esto constituye una superficie edificada de $172.078 \mathrm{~m}^{2}$ de edificios existentes, más 255.764 edificios nuevos proyectados en el Plan Maestro (Figura 11.23.), con normas de edificación que establecen una altura máxima excepcional de ocho pisos, siendo la altura promedio de dos (SUMA, 2009)

En reunión con autoridades ${ }^{381}$ de Ciudad del Saber, éstos destacan que, en su experiencia, ha sido clave que la gestión esté a cargo de una fundación sin fines de lucro, que pueda actuar con flexibilidad, rapidez e independencia de los vaivenes políticos, pero al mismo tiempo, contar con apoyo del estado. Nos enfatizan que Ciudad del Saber es considerado un proyecto del Estado de Panamá.

Recomiendan también, la incorporación de otras actividades como las artísticas, culturales y deportivas, que vitalizan la vida cotidiana del parque.

Desde el punto de vista del Plan Maestro, si bien la CDS se emplaza sobre edificios preexistentes y de valor patrimonial, ha sido necesario establecer y revisar criterios de diseño tanto para la restauración, rehabilitación, reparación y edificación de nuevos edificios, así como establecer una normativa urbana.

\subsection{OTRAS EXPERIENCIAS DE INTERÉS.}

380 Balboa Academy, ILISA (escuela de idiomas), el programa internacional de McGill University, la Universidad de Pennsylvania, Florida State University, Saint Louis University, lowa State University, SIT Study Abroad (School for International Training) y Isthmus University (Arquitectura).

381 Jorge Arosemena, Presidente Ejecutivo y Guillermo Castro, Vicepresidente de Investigación y Formación.

Figura 11.23. Ciudad del Saber, Panamá. Por SUMA (2009, p.9).

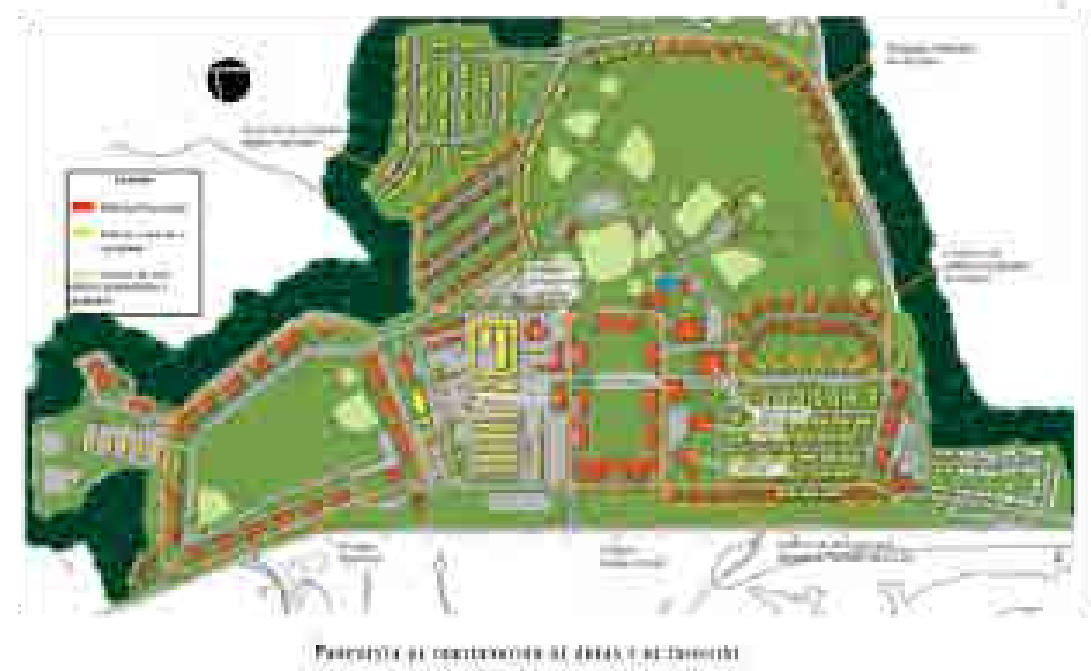


En el marco de la " $1{ }^{\circ}$ Conferencia Iberoamericana de Ciudades del Conocimiento, Innovadoras y Emprendedoras", ya mencionada, se dieron a conocer dos casos que presentan aspectos interesantes, desde el punto de vista del programa:

11.11.1. Skolkovo Innovation Center (SkIC), también conocido como Russian Silicon Valley, se define como "un área de negocios de tecnología" (Skolkovo Fundation, 2019) de 460 hectáreas planeada en Skolkovo ${ }^{382}$, a 16 km de Moscú. El proyecto fue formalmente iniciado el 28 de septiembre de 2010, por el entonces presidente Dmitri Medvédev, que en esa fecha firmó la ley "Sobre el Centro de Innovación de Skolkovo", que dio origen a la entidad sin fines de lucro, gestora del proyecto, la Fundación Skolkovo.

El objetivo general de la Fundación es "crear un ecosistema sostenible de iniciativa empresarial e innovación, engendrando una cultura de puesta en marcha y fomentando el capitalismo de riesgo" (Skolkovo Fundation, 2019) que incluye cinco áreas de desarrollo: Tecnologías de la Información, Energía, Tecnologías Nucleares, Biomedicina y Tecnologías Espaciales. Estas áreas se asientan sobre una sólida tradición rusa en ciencia y tecnología, la que sin embargo debe superar la falta de espíritu emprendedor de su pasado soviético, la intervención del estado en las patentes y la visión regionalista de sus empresas. La creación de una nueva comunidad urbana busca distanciarse de las antiguas ciudades satélites soviéticas, al ofrecer espacios de calidad con una "vibrante mezcla de usos" (Skolkovo Fundation, 2019).

Para acelerar la implementación, en 2011, la Fundación llamó a un concurso para el plan maestro conceptual, que atrajo a importantes firmas internacionales (Sanaa, OMA, Boeri, entre otras) y que fue adjudicado a la empresa francesa AREP junto al arquitecto paisajista Michel Devigne. Los elementos principales del programa son la universidad y un parque tecnológico, incluyendo un centro de congresos, edificios de oficinas, laboratorios, vivienda, un colegio, gimnasios y tiendas (Figura 11.24.).

El esquema urbano se desarrolla alrededor de la idea de cinco distritos compactos, como islas urbanas, integrados con el paisaje. Cada uno de los cinco Distritos tiene una forma singular, un programa específico y está diseñado por un arquitecto diferente (Herzog \& de Meuron; Valode \& Pistre; Kasuyo Sejima; Davis Chipperfield; Sergey Choban; Gensler y Bernaskoni), lo que le da un carácter y un ambiente específico.

La oficina de Herzog \& de Meuron recibió el encargo de diseñar la Universidad de Skolkovo, un proyecto que, requirió la elaboración de un plan maestro propio junto con el trabajo de desarrollo arquitectónico. Este plan maestro y el estudio conceptual se completaron a finales de 2011. En la memoria del proyecto, Herzog $\&$ de Meuron se preguntan ¿Cuál es la visión arquitectónica adecuada para una nueva universidad para Moscú, para Rusia, para el mundo entero?, abordando la intención política y económica del encargo, así como la aspiración científica que lo inspira. Se enfrentan a una institución recién fundada que empieza de cero, de
382 Skolkovo era, antes de 2011, una localidad cubierta por praderas y bosques, atravesada por autopistas y salpicada de zonas industriales abandonadas de la época soviética.

Figura 11.24. Vista panorámica del Centro de Innovación de Skolkovo proyectada al 2020. En Skolkovo Innovation Center (2019).

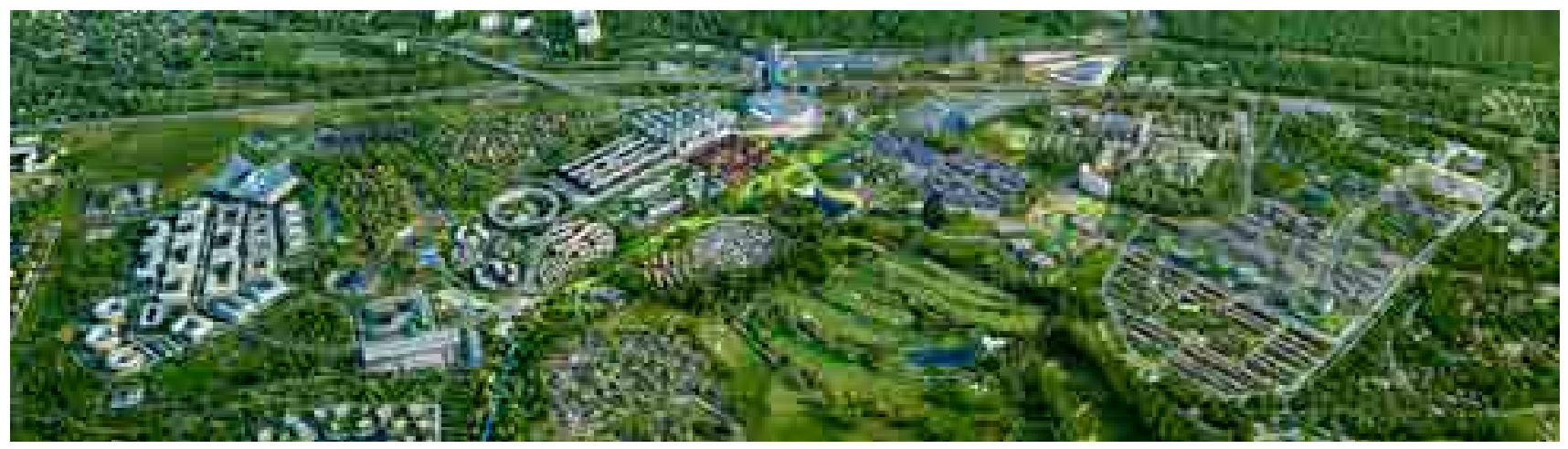


El denominador común entre los ejemplares globales es que la universidad está integrada en la vida urbana. Nunca está completamente aislado [...] Otra característica común de todos los modelos exitosos es un núcleo, una pieza central distintiva que puede ser ampliada y mejorada. El "organismo" urbano resultante conserva su carácter único y distintivo incluso después de muchos años. (Herzog \& De Meuron, 2012).

El proyecto plantea un esquema basado en tres formas circulares de diferentes tamaños (Figura 11.25.). El interior de estas formas circulares se completa con un sistema lineal de patios y volúmenes de edificios que albergan los laboratorios y oficinas de los cinco departamentos (coincidentes con las cinco áreas de desarrollo del centro).

Próximo a la universidad se despliega un distrito residencial destinado a albergar a estudiantes, profesores y nuevos residentes. Para esta zona, la oficina Herzog \& de Meuron, invitó a participar a jóvenes arquitectos locales e internacionales. En la Figura 11.26. se muestra el conjunto de las primeras 90 viviendas proyectadas por la firma francesa Bechu + Associés en 2017. Las casas de entre $125 \mathrm{y}$ $155 \mathrm{~m}^{2}$, son de madera, levantadas a $80 \mathrm{~cm}$ del nivel de piso.

El proyecto de paisaje fue encomendado a la firma $\mathrm{AECOM}^{383}$, que proyectó las áreas que amarran y unifican las parcelas de desarrollo (Figura 11.27.).

El sitio se dividió en ocho unidades de paisaje, que buscan ampliar las actividades de experimentación, ensayo e innovación: La Cinta Ecológica; El Valle de la Experimentación; La Gran Estepa; La gran Llanura; EI Valle Tecno; Los Campos del Placer; El Parque de los Niños; y El vivero de plantas.

En su memoria, AECOM describe así la propuesta:

[...] es una morfología dendrítica que une todas las partes del sitio a través del relieve y el movimiento del agua a través del sitio. La forma del terreno mejorada también sirve para un propósito funcional, administrando el agua y mitigando las vistas de la infraestructura, absorbiendo el exceso de materiales generados por los movimientos de tierra, y proporcionando características de juego o hábitat. El diseño paisajístico de AECOM ofrece un nivel de creatividad e innovación en el diseño del entorno exterior acorde con las aspiraciones de un Centro de Innovación como Skolkovo. (Skolkovo Fundation, 2019).

La propuesta de paisaje refuerza la producción de ambientes variados, libres y que buscan estimular la creatividad a través de tres estrategias: acentuar la topografía existente, el carácter distintivo de cada zona asociada a su uso, y la gestión del agua en todo el sitio, como recurso y como experiencia.

${ }^{383}$ AECOM Design + Planning, es una oficina multinacional estadounidense.

Figura 11.25. Edificio para Skolkovo Institute of Science and Technology. Es el primero de 3 edificios que forman la Univer-sidad. Superficie: 133.979 m2. El diámetro en planta es de $280 \mathrm{~m}$. proyectado por Herzog \& de Meuron + ARUP + Vogt landschaftsarchitekten. Fue inaugurado en septiembre de 2018. Por Iwan Baan @ ( $(16$ de noviembre, 2018).
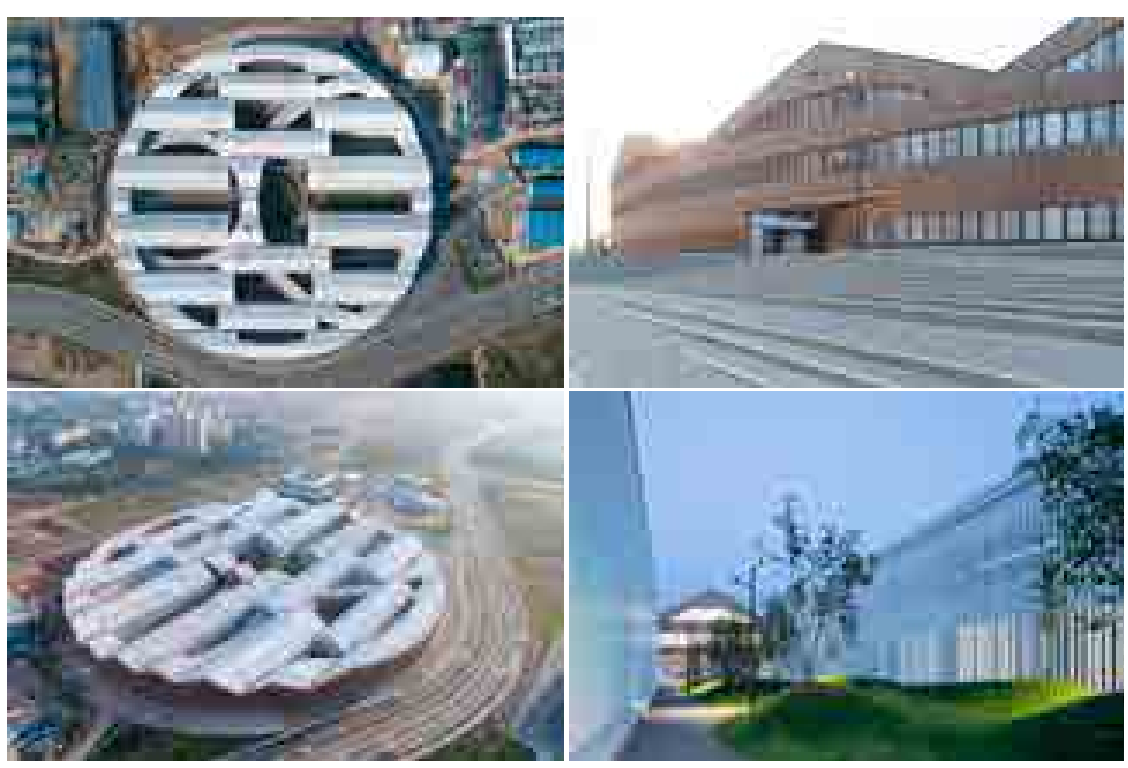


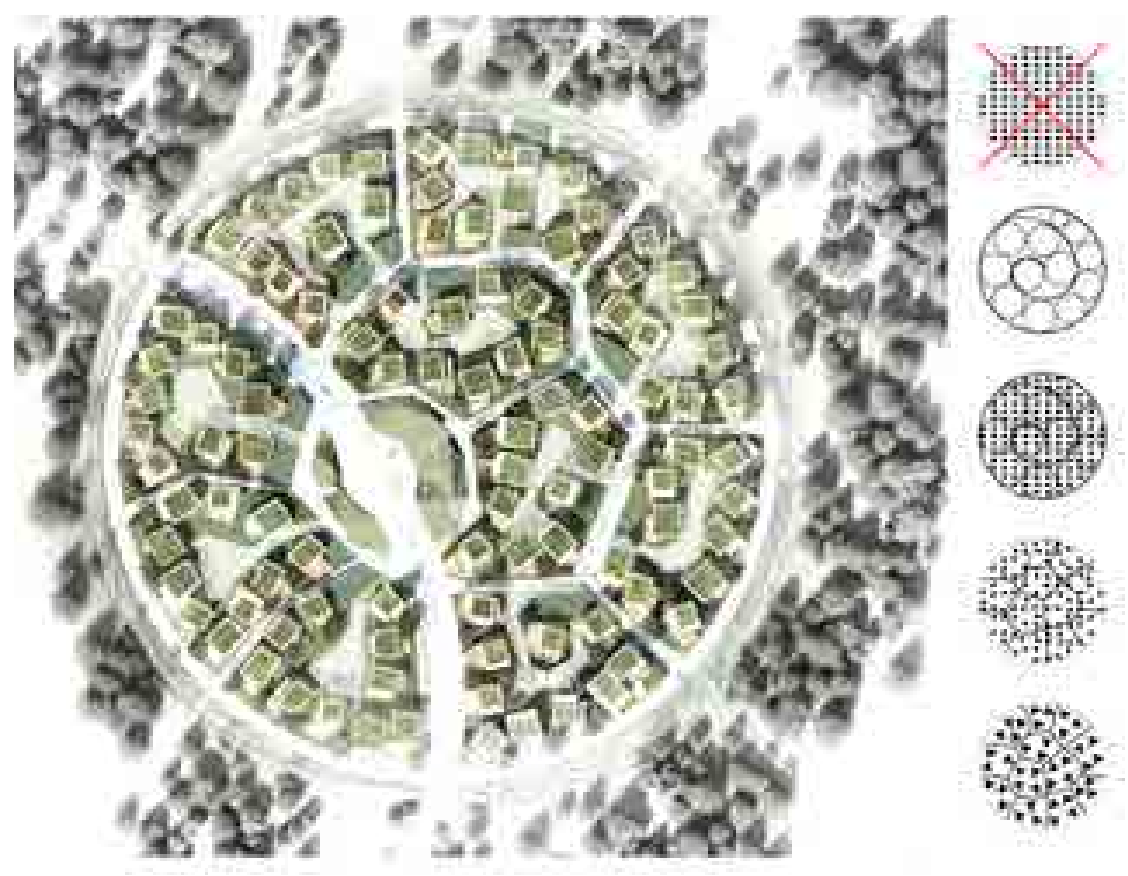

La extensión de SkIC es 460 ha, vale decir, cabe 2, veces en Carén. Se proyecta que Skolkovo tendrá una población permanente de 21.000 personas. Los empleados, incluidos los que viajan diariamente desde Moscú y las regiones circundantes, comprenderán aproximadamente 31.000 personas.

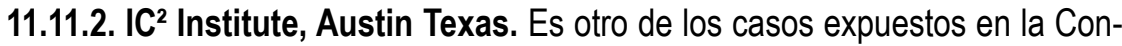
ferencia de Pachuca, que, pese a que no se trata de un Parque Científico Tecnológico, representa una experiencia interesante desde el punto de vista del programa y la gestión del conocimiento desde la universidad. La Universidad de Texas "estableció el Instituto IC² en 1977 para investigar la teoría y la práctica de la creación de riqueza empresarial" (IC 2 , 2019). El fundador del IC ${ }^{2}$, George Kozmetsky, propuso crear un espacio de colaboración entre la universidad, el gobierno y el sector privado, para resolver problemas no estructurados, sobre la base de tres elementos: una incubadora de empresas, la creación de programas de postgrado centrados en la innovación y el intercambio de buenas prácticas. Desde 2018, se promueve especialmente la acción sobre zonas rurales o ciudades pequeñas y aisladas, "explorando nuevas formas para que las empresas, el gobierno y el mundo académico trabajen juntos en este tema" $\left(I^{2}, 2019\right)$.

En la Conferencia de Pachuca, se expuso el programa de Master en Ciencias y Comercialización de Tecnología. En 2014 los estudiantes del Master generaron 14 nuevas empresas como producto de las tesis desarrolladas (Barba, 2015). A partir de la experiencia acumulada en el postgrado, se han diseñado programas adecuados a distintos contextos regionales, como una oferta internacional de servicios. En la exposición, se relató la evolución de esta iniciativa ubicada en una región de Texas, que hasta los años 1980, estaba caracterizada por la vida rural. A partir de 1998 se posiciona como número 1 en desarrollo de negocios y 5 en creatividad. El año 2009, en plena crisis, la ciudad de Austin se mantiene activa gracias a la acción de la Universidad de Texas y su vínculo con otras universidades en el mundo.

El IC Institute ha investigado las mejores prácticas en más de 40 países y ha desplegado programas proporcionando educación y capacitación, creando capacidad e infraestructura física y ayudando activamente al crecimiento de las empresas local e internacionalmente $\left(\mathrm{IC}^{2}, 2019\right)$ Este caso exitoso, sin embargo, no tiene ninguna expresión territorial. En la página web de $\mathrm{IC}^{2}$ y en los documentos públicos no aparecen imágenes, ni planos del lugar físico que alberga el instituto,
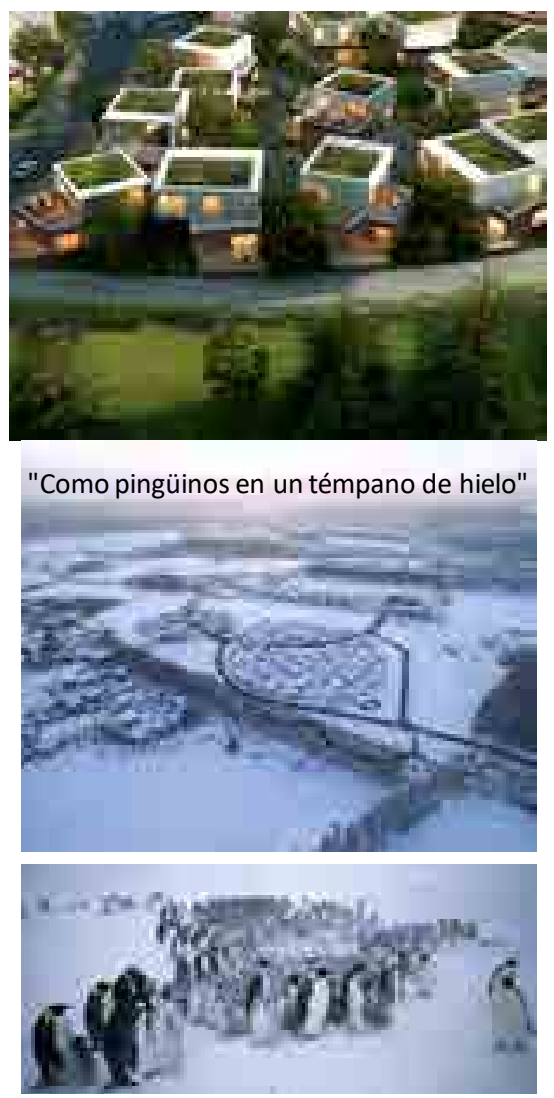

Figura 11.26. Sector habitacional Ilamado Distrito 11. Se trata de 90 viviendas de entre 125-155 m2 (17.000, m2 totales) proyectadas por la firma francesa $A A A B \mid-$ Bechu Associés. Fue inaugurado el 2017. Por Alexander Patelin (c) Alexander Pete-lin \& David Tipling (2017).

Figura 11.27. Vista aérea del Centro de Innovación de Skolkovo con la propuesta paisajística. Por AECOM (C) (13 de sep-tiembre, 2012).

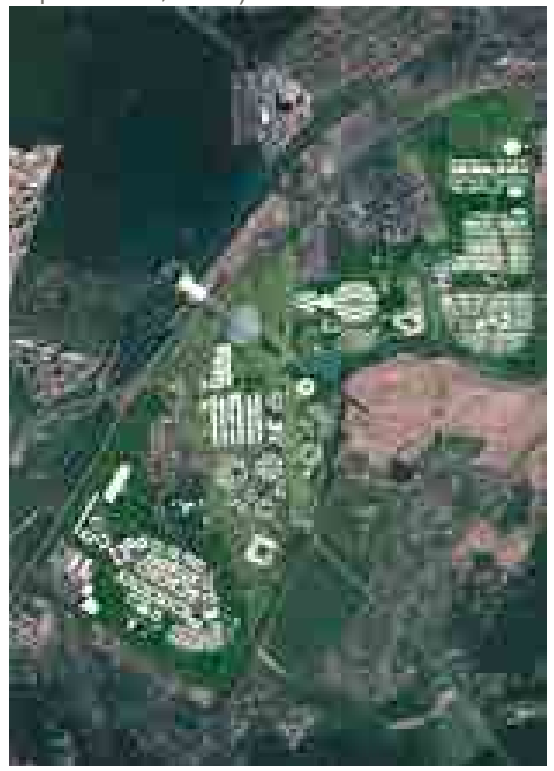




\subsection{EVALUANDO EL ÉXITO DE LOS PARQUES CIENTÍFICOS}

En octubre de 2010, Manchester Science Parks organizó un taller junto a la Asociación Internacional de Parques Científicos (IASP) titulado "Measuring the success of science parks" (Evaluando el éxito de los parques cientíicos).

Al taller, se convocaron cuatro grupos de interés, a los que se les consultó acerca de qué es "éxito para un parque científico". Estaban representadas las universidades, la ciudad a través de la agencia de desarrollo regional, las empresas y los inversionistas. Justyna Dabrowska (2011) resume así los resultados del encuentro:

- $\quad$ Para los rectores y vicerrectores, el parque debe ser un catalizador para el cambio cultural en la universidad actual, como conector en innovación, convirtiendo la universidad en un actor clave en la economía del conocimiento, siendo el parque, el que hace tangible el éxito de la universidad. También mejora las posibilidades de empleo de los graduados, retroalimenta el currículum, da relevancia a la investigación y, por último, genera recursos para que la institución los reinvierta en investigación, reforzando el papel de las universidades en la región a la que pertenecen.

- $\quad$ Para la ciudad, el parque es un generador de empleos de calidad, las empresas retienen el talento, el parque mejora la sostenibilidad económica, atrae visitas a la región y tiene un impacto positivo en la imagen de la zona/ ciudad donde se implanta.

- $\quad$ Para las empresas el éxito está relacionado con la disponibilidad de espacio gestionado y flexible que les permite despreocuparse de los problemas de infraestructura y concentrarse en su tarea. Estar en el parque otorga credibilidad a las empresas con poca historia; tienen impacto positivo en su imagen; es un lugar inteligente donde se puede tener acceso a redes y donde se pueden compartir ideas, problemas e incluso recursos humanos.

- $\quad$ Por último, para los inversionistas, es una inversión segura, con rendimiento a largo plazo y con posibilidad de recibir recursos estatales e internacionales. (Dabrowska, 2011).

Llama la atención en estos resultados, la nula valoración al lugar, salvo como un espacio sin problemas domésticos, sin menciones al valor paisajístico o ambiental. Aspectos que sí son profusamente divulgados en las páginas web y elementos promocionales de los parques. Se puede observar también cómo los elementos valorados son intangibles -como el acceso a redes o la imagen- frente al supuesto de parque como lugar físico de proximidad, vale decir tangible. Esto nos sugiere que los parques pueden ser entidades más abiertas y relacionadas con el entorno, como también integradas al paisaje, como algo más vital dentro de los procesos de innovación y comunicación entre las personas. $Y$ consecuente con la idea de red, más interconectado con el lugar, la geografía física y humana que le da origen, abarcando múltiples escalas.

\subsection{VISIÓN CRÍTICA DESDE LATINOAMÉRICA}

El primer estudio comparativo sobre la viabilidad y el impacto económico de los PCT, en Latinoamérica fue desarrollado por el cientista social Andrés Rodríguez-Pose (2012). En su informe indica que, pese al aparente dinamismo en la creación de parques en la región, su verdadero impacto es muy bajo, argumentando que además de la escasa tradición empresarial en los 8 paises estudiados $^{384}$, sólo cuatro poseen universidades situadas entre las 500 mejores del ranking de Shanghai, siete de ellas son brasileras, dos chilenas, una mexicana y una argentina, once en total; la misma cantidad que, por ejemplo, tiene España (Rodriguez,2012:31). A esto podríamos agregar un indicador que también revela condiciones para el éxito de los PCT: el porcentaje del PIB destinado a Ciencia y Tecnología, que, a juicio de la autora, es determinante en la creación de condicio- 
Coincidiendo con Rodríguez-Pose, en los países emergentes como Chile, se deben adoptar estrategias más realistas, que partan por mejorar paso a paso, conscientes de la incertidumbre y de lo alejadas que son las condiciones contextuales, de las que presentan los países desarrollados. Lo anterior para evitar que en vez de que estos lugares sean dinamizadores de las economías locales, se transformen en enclaves empresariales desvinculados del territorio.

Las universidades de América Latina han buscado la vinculación con el mundo productivo como una forma de sobrevivir física y académicamente en un contexto de restricciones presupuestarias impuestas por el estado, que, en todos los casos vistos, son un actor fundamental en el proceso de implantación de los PCT. Por otra parte, dentro de nuestra cultura, el empresariado no busca la innovación y el conocimiento en las universidades, sino más bien al contrario, son las universidades las que deben salir a convencer acerca de lo que saben y de cómo aquello puede ser útil para las empresas.

Por otra parte, como han observado Etzkowitz, Webster, Gebhardt y Cantisano (2000), las estructuras académicas en Latinoamérica siguen siendo muy rígidas, pese a los esfuerzos para reconfigurar los sistemas de innovación nacionales y regionales y promover la reestructuración de las universidades para hacerlas más receptivas a las necesidades de los empleadores ${ }^{385}$. Sin embargo, algunas políticas en educación superior han tenido un resultado inesperado:

El enfoque tradicional en la educación de pregrado, principalmente impartido por profesores a tiempo parcial, ha sido desplazado por un profesor de tiempo completo con mayores competencias en investigación [...]. Una consecuencia involuntaria, ha sido el debilitamiento de la integración tradicional de la academia al medio profesional, a través del modelo del profesor-profesional, [con experiencia en el medio externo]" (Etzkowitz et al., 2000, p. 324).

En la Universidad de Chile, por ejemplo, los llamados a concurso por cargos de profesor exigen la posesión del grado de doctor y progresivamente se han disminuido el porcentaje de profesores a tiempo parcial. Lo anterior en consonancia con los estándares internacionales y sus indicadores.

\subsection{LA SITUACIÓN DE CHILE}

Junto a los factores señalados antes, Chile presenta niveles de desigualdad críticos que también dificultan el tránsito a la tan anhelada economía del conocimiento. La Organización para la Cooperación y el Desarrollo Económico ${ }^{386}$ (OCDE) en su Estudio Económico de Chile 2015, critica la alta desigualdad de ingreso, riqueza y educación.

Los estudios señalan que el $10 \%$ más rico, gana 26,5 más que el $10 \%$ más pobre (mientras que el promedio OCDE es de 9,5 veces), que la desigualdad medida por el coeficiente de Gini es de 0,55 , mientras que el promedio OCDE se mueve entre 0,4 a 0,3. Las pensiones están también entre las más bajas respecto a los países miembros, con una tasa de reemplazo del $60 \%$, mientras el promedio OCDE es del $80 \%$. El trabajo precario prevalece, con un $30 \%$ con contratos a plazo fijo (12\% el promedio OCDE). Y lo que con miras al futuro se presenta más crítico: que el $45 \%$ de los estudiantes no alcanza el nivel mínimo de habilidades (el promedio OCDE es $21 \%$ ) con una fuerte desigualdad en el acceso a la educación superior (con un $35 \%$ para el quintil más pobre, contra el $90 \%$ para el quintil más rico). Lo que deja anclado el desarrollo a una economía del "sudor" y no de la "Inspiración" (en referencia al progreso intelectual) usando los términos que Lau \& Park (2003) ha aplicado en su análisis del crecimiento económico chino ${ }^{387}$. Chile es un país pequeño, si no en territorio, en población, esto constituye una ventaja a nivel de implementación de políticas públicas, pero una desventaja respecto al desarrollo tecnológico. Lo que industriales y economistas (p.e., Eyzaguirre et al., 2005) señalan, es que necesariamente debemos desarrollar economías abiertas, ya que el consumo interno no justifica desarrollos, sino más bien la compra de tecnología, manteniendo la dependencia de la producción de materias

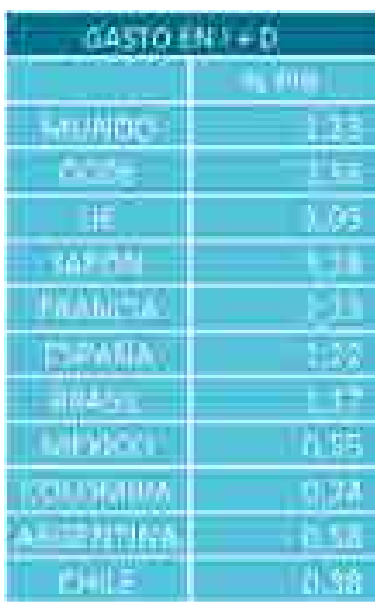

Tabla 11.2. Gasto en Investigación y Desarrollo expresado como porcentaje del Producto Interno Bruto (PIB) de cada país. En el informe de 2017 todos los países han bajado menos Rusia. Chile bajo al 0,36\% del PIB. Elaboración propia a partir de datos de OCDE (2015).

384 Brasil, México, Argentina, Perú, Colombia, Chile, Uruguay y Venezuela

${ }^{385}$ En el caso chileno, los procesos de acreditación de carreras, incluyen la consulta a empleadores y su resultado es evaluado como parte de los criterios de calidad.

${ }^{386}$ Fundada en 1961, tras el Plan MarshaII, a la salida de la II Guerra Mundial. La Organización para la Cooperación y el Desarrollo Económicos (OCDE) agrupa a 35 países miembros y su misión es promover políticas que mejoren el bienestar económico y social de las personas alrededor del mundo:

La OCDE ofrece un foro donde los gobiernos puedan trabajar conjuntamente para compartir experiencias y buscar soluciones a los problemas comunes. Trabajamos para entender que es lo que conduce al cambio económico, social y ambiental. Medimos la productividad y los flujos globales del comercio e inversión. Analizamos y comparamos datos para realizar pronósticos de tendencias. Fijamos estándares internacionales dentro de un amplio rango de temas de políticas públicas. https:/l www.oecd.org/centrodemexico/laocde/ ${ }^{387}$ Laurence Lau descubrió que el rápido crecimiento de la economía China entre 1965 y 1995 se debió en gran medida al vertiginoso aumento de las inversiones de capital, siendo la aportación por parte del progreso tecnológico casi anecdótico. 
primas, sin valor agregado y con poco espacio para el aprendizaje científico-tecnológico. Salvo que se apueste por un trabajo en red, como lo han hecho los países nórdicos.

Un análisis similar, es el que realiza Judith Sutz (1996) para Uruguay, concluyendo que la idea de las incubadoras puede ser un medio más a la escala de los recursos y problemas que los países menos desarrollados tenemos.

Esta postura es coincidente incluso, con lo observado por William Bolton en el proceso Cambridge, al plantear que "La experiencia de Cambridge mostró que era posible desarrollar un clima y un mecanismo de apoyo al crecimiento de empresas simplemente a través de una incubadora, sin tener que recurrir a alguna etapa previa de formación de empresas." (Bolton, 1992, p. 9) En el caso de Cambridge, esto se debió a que ya había suficiente actividad de innovación informal antes de iniciar las empresas. En el caso latinoamericano nos encontramos, con la situación contraria, sin un contexto cultural propicio; por lo que el parque en sí mismo no va a generar actividades de transferencia tecnológica sin un mecanismo a una escala menor, y desde abajo hacia arriba, como son las incubadoras.

\subsection{5. ¿UN PARQUE CIENTÍFICO Y TECNOLÓGICO EN CARÉN?}

Como hemos visto, el modelo del parque tecnológico se debe entender en contexto. Chile en la década de 1990 vivió la euforia de la vuelta a la democracia, Silicon Valley no solo era un ejemplo que mostraba los beneficios del modelo neoliberal, sino que también simbolizaba el progreso en un ambiente de libertad. Las posibilidades que ofrece la designación PCT también están cargadas ideológicamente, si es científico, la hegemonía la tiene la universidad y sus investigadores, si es tecnológico, la tiene la empresa o la industria.

Cabe también preguntarse si es la única posibilidad de orientar la tercera misión de la universidad es rentabilizar el conocimiento, si no cabe, postergar el lucro y poner la vinculación con el medio, el progreso material y espiritual de la comunidad como objetivos.

Repensando la triple hélice universidad-empresa-estado, parece evidente después del recorrido que hemos hecho, incorporar a la ciudadanía como una cuarta aspa y también el territorio como una quinta, que deberíamos precisar como paisaje, ya que trasciende lo funcional, incorporando la experiencia sensible y la identidad asociada a un lugar.

De este modo la tercera misión de la universidad debería ser localizada, desde el territorio y desde el paisaje, vale decir, que confluyan en ella aspectos humanos $^{388}$ y medioambientales.

Desde este punto de vista, la memoria del primer plan maestro de la universidad realizado por MECSA y descrito en el capítulo 10 parece anacrónica en sus objetivos al plantear que:

El objetivo de este entorno es fomentar la interrelación activa entre el mundo universitario, científico-tecnológico, y el mundo empresarial. Este entorno dará cabida a instituciones dedicadas a la docencia superior, compatibles [énfasis agregado] con la esencia fundamental del proyecto (facultades universidades, cursos de pregrado y posgrado, conferencias, jornadas y seminarios, cursillos, cursos "a medida" de empresas).

...por ello el criterio usado en definir que dependencias de la universidad y en qué orden de prioridad se trasladan al Polo de Lo Aguirre está directamente vinculado con la necesidad de asegurar ese medio innovador y en armonizar los objetivos académicos de I+D con las necesidades empresariales [énfasis agregado].

[...]Por ello, es para beneficio de la universidad y de las empresas que sus facultades, centros de investigación e institutos "clave" [énfasis agregado], estén íntimamente relacionados con el parque". (MECSA, 1997, p. 11).

${ }^{388}$ culturales, sociales, institucionales, económicos, etc.

En esta propuesta, sólo tendrían cabida las disciplinas "compatibles", aquellas que armonizaran con las necesidades de la empresa, sólo las "clave". Cabe preguntarse ¿Por qué han quedado fuera las otras áreas del conocimiento? ¿no hay conocimiento en el arte, en el diseño, en las ciencias sociales, en la co- 
municación, que sean necesarios a la sociedad?, incluso a las empresas. Por ejemplo, los temas que hoy nos aquejan como las inmigraciones, el acceso de las minorías, la ética en cuestiones científicas, la probidad o si se deben recibir donaciones sin conocer el donante, son problemas que trascienden la ciencia y la tecnología.

Que justamente la innovación, tan buscada, se da en un ambiente de libertad, de riesgo. En medios diversos con capacidad crítica y entrenamiento creativo. Esto lleva a preguntarnos también acerca de nuestro rol como proyectistas y sobre cómo el proyecto (el diseño) promueve esta nueva postura ¿Es entonces apropiado que el plan maestro esté totalmente definido?, ¿no deberíamos, consecuentemente, diseñar un proceso abierto más que un resultado?

\subsection{EL PENSAMIENTO DE DISEÑO COMO HERRAMIENTA EN EL PRO-} CESO.

En la experiencia del Proyecto Académico para Carén se dio naturalmente, por fuerza y por falta de recursos, que el equipo de arquitectos participara también en la formulación de los primeros proyectos de I+D para el parque. Se pusieron a disposición de esta tarea las competencias propias del oficio, haciendo uso de las herramientas del pensamiento de diseño (sin mucha conciencia de ello).

El primer requerimiento externo parte de la convocatoria que hizo la CORFO, que llamó a concurso por proyectos asociativos en áreas definidas: alimentación, minería, energía y construcción sustentable.

El equipo de proyecto previamente había hecho un levantamiento de todos los grupos de investigación de la Universidad de Chile, entre los que se contaban algunos pequeños hasta los proyectos Milenio, Fondecyt, Fondef, etc., que ya contaban con apoyo del estado. Tras el levantamiento de más de 400 grupos, éstos se ordenaron por temas y luego por "problemas" de relevancia nacional, de los que emergieron las primeras iniciativas propuestas, las que expondremos en el próximo capítulo como parte del proyecto.

¿Qué descubrimos? Que muchos de estos grupos trabajaban sobre el mismo problema, pero, sin embargo, o no se conocían o bien eran equipos en competencia. Cabe señalar, que, en la política de ciencia y tecnología en Chile, como en muchos otros países occidentales, el financiamiento se logra a través de procesos competitivos, por lo que se desincentiva el trabajo de colaboración. Encontramos también, que temas tan relevantes para Chile como son los riesgos socio-naturales, riesgos a secas o emergencias, estaban presentes en innumerables grupos interdisciplinarios donde no sólo había científicos e ingenieros, sino también geógrafos, psicólogos, sociólogos, profesionales de la salud, diseñadores, entre otros.

Este ejemplo nos reveló que el proyecto Carén ofrecía la posibilidad de repensar la misión de la universidad e incluso su estructura disciplinar, pero sin violentarla, proponiendo un proceso, donde este nuevo emplazamiento permitiría alojar aquellas iniciativas transversales, tensionando y atrayendo a la antigua estructura. En ese momento la declaración del rector que citamos al inicio del capítulo, cobró más sentido. No sería necesario ni obligar, ni convencer a ninguna facultad que dejara su actual sede, el tiempo y los acontecimientos actuarían como atractor para que la universidad disciplinar transitara hacia una estructura de universidad más abierta y transversal.

\subsection{LA TRANSDISCIPLINARIEDAD}

La universidad actual está enfrentada a una producción de información sin precedentes, que plantea nuevos desafíos tanto para los procesos de enseñanza-aprendizaje, como para su evaluación; para la investigación y la vinculación con el medio.

Si bien el acceso a la información ya no es un problema, si lo es convertir los datos en conocimiento, vale decir, que la tarea fundamental consiste en siste- 
matizar e interpretar, con una creciente conciencia de la complejidad que ofrece la realidad que pretendemos conocer, enseñar, diseñar y transformar. La problematización de la realidad, asume esta complejidad, pero la formación tradicional disciplinar, nos obliga a fragmentarla y simplificarla para su análisis, síntesis y generalización.

En la realidad de la Universidad de Chile y de la universidad latinoamericana en general, el abordaje de problemas transdisciplinarios se da a nivel de postgrado y como hemos visto en el ejemplo antes citado, en la investigación de problemas complejos como los riesgos socio-naturales, el envejecimiento, el cambio climático, los problemas urbanos, etc.

Si bien la transdisciplinariedad ha sido abordada por autores como Edgard Morin y en esta tesis, aplicada al proyecto por Findeli (ver Capítulo 2), podemos situar un hito importante para su aplicación en la enseñanza, en el Congreso de Arrábida de 1994, que luego se plasma en el Manifiesto de Basarab Nicolescu de 1996 y a la Declaración Mundial sobre la Educación Superior en el Siglo XXI de la UNESCO (1998) que en el artículo 5 señala:

a) [...]Deberían fomentarse y reforzarse la innovación, la interdisciplinariedad y la transdisciplinariedad en los programas, fundando las orientaciones a largo plazo en los objetivos y necesidades sociales y culturales. [...]c) Se debería incrementar la investigación en todas las disciplinas, comprendidas las ciencias sociales y humanas, las ciencias de la educación (incluida la investigación sobre la educación superior), la ingeniería, las ciencias naturales, las matemáticas, la informática y las artes, en el marco de políticas nacionales, regionales e internacionales de investigación y desarrollo.

Por su parte, la Carta de Arrábida parte por definir "la existencia de diferentes niveles de realidad, regidos por diferentes lógicas" (Nicolescu, 1996, p. 121) para luego aclarar que:

[...] la transdiciplinariedad es complementaria al enfoque disciplinario; hace emerger de la confrontación de las disciplinas nuevos datos que las articulan entre sí, y nos ofrece una nueva visión de la naturaleza y de la realidad. La transdisciplinariedad no busca el dominio de muchas disciplinas, sino la apertura de todas las disciplinas a aquellos que las atraviesan y las trascienden ( $p$. 121, artículo 3),

Desde esta perspectiva, "Una educación auténtica no puede privilegiar la abstracción en el conocimiento. Debe enseñar a contextualizar, concretar y globalizar [...] reevalúa el rol de la intuición, del imaginario, de la sensibilidad y del cuerpo en la transmisión de los conocimientos" (p. 122, artículo 11), para proponer una economía fundada sobre la base de su servicio al ser humano y no a la inversa ( $p, 123$, artículo 12), y una ética tolerante, donde el "saber compartido debería conducir a una comprensión compartida, fundada sobre el respeto absoluto de las alteridades unidas por la vida común sobre una sola y misma Tierra" (p. 123, artículo 13). Estos principios son coincidentes con los propuestos en el desarrollo de esta tesis desde la conceptualización del proyecto y su relación con la investigación, como también en la conceptualización del paisaje como estrategia de abordaje de la complejidad que encierra el territorio, más allá de su existencia material, sobre la experiencia sensorial y dimensión cultural que en el subyace, reivindicando el rol de "la intuición, del imaginario, de la sensibilidad y del cuerpo en la transmisión de los conocimientos", parafraseando a Nicolescu (1996).

Más allá de la recomendación de la UNESCO para la puesta en práctica de la transdiciplinariedad de la reforma de universidades, el proyecto académico Laguna Carén pretende investigar "problemas" más que "temas" como sostiene Karl Popper (1963), a fin de poder abordar la complejidad, asumiendo un modo transdisciplinar.

Gibbons, Limoges, Nowotny, Schwartzman, Scott, y Trow. (1997) Ilaman modo 2, para diferenciarlo con el modo 1, disciplinar. Así según estos autores:

El modo 1 se basa en la disciplina y conlleva una distinción entre lo que es fundamental y lo que es aplicado; eso implica a su vez una distinción operativa entre un núcleo teórico y otros ámbitos de conocimiento, tales como las cien- 
cias de la ingeniería, en las que las comprensiones teóricas se traducen en aplicaciones. En contraste con ello, la producción de conocimiento en el modo 2 es transdisciplinar. Se caracteriza por un flujo constante, de un lado a otro, entre lo fundamental y lo aplicado, entre lo teórico y lo práctico. Típicamente, el descubrimiento se produce en contextos en los que el conocimiento se desarrolla para ser utilizado, y así se hace, mientras que los resultados (que habrían sido tradicionalmente caracterizados como aplicados) alimentan nuevos progresos teóricos.

[...]El modo 2 se caracteriza por un alejamiento de la búsqueda de principios fundamentales, para avanzar hacia modos de investigación orientados hacia resultados contextualizados. Además, el propio proceso experimental viene guiado cada vez más por los principios de diseño [...] (Gibbons et al., 1997, p.3)

Principios de diseño o pensamiento de diseño, que como hemos visto han permitido sortear la etapa construcción del proyecto académico y colaborar en la formulación de las primeras iniciativas que se instalarán en el Parque.

En la lógica transdisciplinar, la universidad puede eludir el rol de gerente del PCT de Carén y convertirse en un gestor social del proyecto que incluya, por un lado, el amplio espectro de disciplinas presentes en la universidad (también en otras universidades), por otro el estado en todas las escalas de actuación (central, municipal, regional), los ciudadanos y ciudadanas, las empresas e instituciones sin fines de lucro y el territorio donde se implanta.

Este campo de desarrollo para la universidad como gestor social, amplia los alcances de lo que hoy entendemos por emprendimiento a campos que van más allá de la creación de empresas, incluyendo la acción política ${ }^{389}$, lo que concierne directamente al ambiente de formación de los estudiantes.

La universidad puede así contribuir a la producción y difusión del conocimiento, como también procurar la emergencia de la innovación científico-tecnológica desde abajo hacia arriba, promoviendo un desarrollo económico, social y cultural de la región que incorpore el territorio en su dimensión medioambiental y paisajística, con el fin de:

mejorar la calidad de vida y fortalecer los valores democráticos en el conjunto de la sociedad, articulando el conocimiento universal con los saberes producidos por la comunidad para poder resolver problemas sociales y nacionales en una agenda compartida con la nación. (Jaramillo, 2010, p. 64).

Desde De Gaulle en 1961, hasta los rectores de la Universidad de Chile han tenido en Silicon Valley un lugar de inspiración, "la mayor creación legal de riqueza en la historia del planeta" según (Lewis, 2000, p. 30 citando a John Doerr) ${ }^{390}$. Un modelo estético, empresarial y de innovación que ha regado el mundo de valles con colinas, vegetación, palmeras y techos rojos, sin lograr replicar el fenómeno, ya que como nos revelan Castells \& Hall, "la propia existencia del Silicon Valley ha cambiado para siempre la división espacial del trabajo en la investigación y producción de alta tecnología impidiendo, irónicamente, la imitación directa de su propia experiencia" (Castells \& Hall, 1994, p. 57).

El proyecto Carén, que posiblemente siga siendo calificado como un Parque Científico y Tecnológico, seguramente será miembro de IASP, pero como una alternativa a los modelos hegemónicos, proponiendo una ecología de la innovación, que, como un sistema natural evolucione en el tiempo a partir de una incubadora de proyectos (no necesariamente de empresas), a la que hemos llamado edificio vínculo.

\footnotetext{
${ }^{389}$ Burton Clark sostenía que gran parte de los políticos, había tenido sus primeras experiencias como dirigentes universitarios (Clark, 1983, p. 225).

390 Traducción propia del inglés: "The greatest legal creation of wealth in the history of the planet".
} 


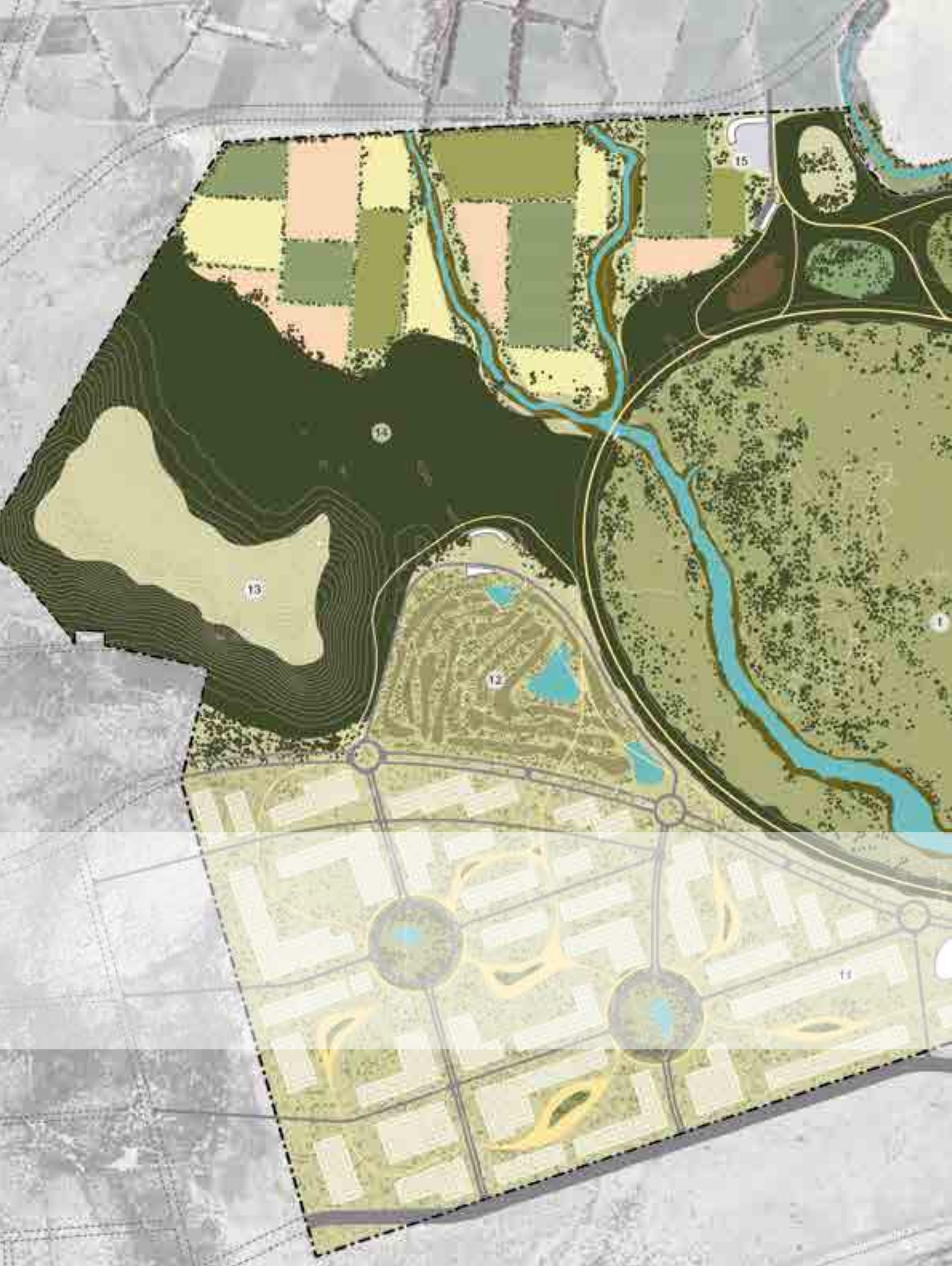

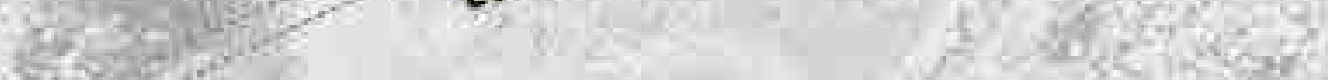





\section{FUNDAR: UN PLAN MAESTRO PARA LA- GUNA CARÉN}

\begin{abstract}
Me gustaría que hubiera lugares estables, inmóviles, intangibles, intocados y casi intocables, inmutables, arraigados; lugares que fueran referencias, puntos de partida, Principios: mi país natal, la cuna de mi familia, la casa donde habría nacido, el árbol que habría visto crecer (que mi padre habría plantado el día de mi nacimiento), el desván de mi infancia lleno de recuerdo sin tactos...

Tales lugares no existen, y como no existen el espacio se vuelve pregunta, deja de ser evidencia, deja de estar incorporado, deja de estar apropiado. El espacio es una duda: continuamente necesito marcarlo, designarlo; nunca es mío, nunca me es dado, tengo que conquistarlo. (Perec, 2001, p. 139)
\end{abstract}

\subsection{INTRODUCCIÓN}

El paisaje de Laguna Carén tiene algo de ese deseo de Perec, de encontrar ese lugar intocado, un lugar que ha quedado suspendido en el tiempo y que pese a su existencia se vuelve una pregunta. Este largo recorrido de indagación sobre el lugar para descubrir las capas que revelan su identidad, es la experiencia "paisajera" que, en este capítulo, da un paso más, y entrega una respuesta a través del proyecto.

Aparecerá la necesidad de marcar el lugar, de recordar sus nombres y también de re-nombrarlo. El acto proyectual será entendido más como crianza que como una conquista, vale asumiremos un rol que se parece más al de un jardinero que al de un urbanista.

La etapa que se describe en este capítulo se inicia en 2014, cuando el doctor Ennio Vivaldi asume como rector de la Universidad de Chile y decide retomar el desafío de llevar adelante un proyecto desde la universidad en el predio de Laguna Carén. Para ello, el 4 noviembre de ese año, crea la Comisión Proyecto Académico y Territorial Laguna Carén ${ }^{391}$, que sesiona por primera vez el 12 de noviembre de 2014, para luego anunciar públicamente esta iniciativa en el contexto de la celebración de los 172 años de la universidad:

La Universidad de Chile refleja y proyecta tanto la identidad y la diversidad cultural del pueblo chileno como la historia y el futuro de la nación chilena.

... [el Proyecto Académico Laguna Carén] será una instancia interdisciplinaria, interinstitucional y una gran base operativa para la internacionalización.

La idea es combinar universidad, investigación aplicada, emprendimiento y una nueva concepción de extensión.

[...] Este proyecto académico, para cuyo estudio se ha configurado ya un grupo de trabajo, se centrará al interior de la Universidad bajo la responsabilidad de Rectoría. (Vivaldi, 19 de noviembre, 2014, pp. 2-3) 392

Estas palabras son un llamado a reforzar y proyectar el rol republicano que ha jugado la Universidad de Chile en la historia de la nación, hacia los desafíos que se presentan en el contexto actual y futuro, haciendo un acto fundacional para la universidad y el país.

La primera tarea fue formular un proyecto académico que, diera sustento a la intervención en este territorio, el que se inició con la revisión del modelo de parque científico-tecnológico, que fue el destino pensado hace más de 20 años. Como hemos analizado extensamente en el Capítulo 11, este modelo, ha sido el de mayor profusión en los países desarrollados, sin embargo, casi siete décadas ${ }^{393}$ después de la creación de los primeros parques tecnológicos, éstos muestran resultados disimiles, especialmente en los países en vías de desarrollo, y requieren ser revisados a la luz de los nuevos desafíos de la sociedad, sobre todo en lo referido a la relación universidad, empresa, sector público, incorporando necesariamente a la ciudadanía y considerando la sostenibilidad social, económica y
391 La Comisión estuvo constituida por las siguientes personas: el Rector Ennio Vivaldi, Patricio Aceituno, Ignacio Agüero, Pilar Barba, Francisco Brugnoli, Andrés Couve, Juan Carlos Letelier, Pía Lombardo, Enrique Manzur, Eduardo Muñoz, Sergio Olavarrieta, Verónica Retamal, Javier Ruiz del Solar, Juan Sabbagh, Eduardo Vera y Andrés Weitraub, representando todas las áreas de conocimiento de la universidad. Luego se creó un grupo de trabajo que sesionó semanalmente y estuvo conformado por: Juan Carlos Letelier, Eduardo Vera, Eduardo Muñoz, Giorgio Solimano, Flavio Salazar y Pilar Barba. El equipo de proyecto estuvo formado por Francisco Allard, Fernando Bravo y Pilar Barba. El acta de la primera sesión se encuentra en el anexo 1. 392 Discurso del Rector Ennio Vivaldi con motivo de la celebración de los 172 años de la Universidad de Chile.

393 Son 68 años (2019) si consideramos la iniciativa pionera de la Universidad de Stanford que en 1951 creó un polo de alta tecnología que se extendió a este valle de California, dando paso a Silicon Valley en las décadas posteriores. 
medioambiental como ejes fundamentales de su quehacer. Nuestra propuesta es ampliar el modelo de la triple hélice a uno con cinco componentes, agregando la comunidad y el paisaje como sujetos activos dentro del proyecto.

En este capítulo se recogen los análisis realizados en los apartados anteriores y los aspectos teóricos desarrollados en la primera parte, tanto en lo referido al concepto de proyecto-investigación como al de "paisaje" poniendo en práctica lo que Christophe Girot llama "fundar": ese acto que se basa en tomar lo que aprendido en los pasos anteriores y formular una respuesta basada en esa información.

[...] el acto de fundar es siempre una reacción a algo que ya estaba allí. La solución puede ser tan efímera como un escenario, o puede tener lugar gradualmente durante un período prolongado de tiempo.

La fundación también puede entenderse como traer algo nuevo a un lugar, algo que puede cambiar y redirigir un sitio en particular. Los ejemplos van desde la colocación de un nuevo objeto, hasta el encuadre de algún nuevo punto de visión [o] simplemente cambiar el uso de un lugar en particular. Cada acto de fundación corresponde, en la jerga arqueológica, a una época: un período determinado en la historia en el que una relación cultural con el paisaje evoluciona y cambia. (Girot, 1999, p. 64)

La narrativa que se presenta al describir las decisiones de diseño es deudora del Enfoque por ecosistemas descrito por la Secretaría del Convenio sobre la Diversidad Biológica (2011), que considera la interconexión entre todos los componentes de un ecosistema -incluyendo los seres humanos-, y tiene como objetivo la conservación de la biodiversidad y el uso sostenible y equitativo de los recursos. Este enfoque, si bien tiene base científica, es consciente de que el conocimiento en estas áreas es insuficiente, por lo cual está abierta a los saberes de las comunidades locales y de las instituciones. Lo anterior, hace fundamental que la gestión del proyecto considere la articulación social y política junto con la técnica.

Por otra parte, debido a que trabajamos con procesos que se dan en el tiempo y que muchas veces son impredecibles, el proyecto debe ser flexible. Vale decir no solo hablamos de un enfoque por ecosistemas, sino de un enfoque que además debe ser adaptativo.

De este modo, la resiliencia ${ }^{394}$ del parque como ecosistema, estará dada por establecer qué partes del paisaje tendrán prioridad para la conservación y restauración, para compatibilizarlos con las otras prioridades no-ecológicas del proyecto, especialmente las que impliquen construcciones nuevas, vale decir, un cambio de uso de suelo (al menos desde el punto de vista ecológico).

${ }^{394}$ Hemos hablado Resiliencia en el Capítulo 5 como una de las características que deben tener los grandes parques y que puede definirse en su acepción más general, como la capacidad de recuperarse o adaptarse al cambio que puede percibirse como «bueno» o «malo». En el contexto de la tesis, este sería un atributo positivo, tanto de carácter (como en una persona) y de comportamiento (como en un material). Como concepto ecológico, la resiliencia es la capacidad de un sistema de experimentar perturbaciones (como una inundación, una epidemia o un incendio) y luego regresar a un estado estable reconocible.

En una definición ecológica menos tradicional y más útil, la resiliencia sería la capacidad de un sistema para ajustarse frente a condiciones desafiantes.

Para ello se han definido estrategias a múltiples escalas, que en este texto se sintetizan en tres: macro-escala para el predio dentro de la región; meso-escala para el sitio mismo y micro-escala para las intervenciones puntuales o zonas, particularmente para la primera etapa. De este modo, se toman decisiones teniendo en consideración los cambios de uso de suelos a nivel comunal, otros proyectos de interés ambiental, la proximidad con otras áreas naturales, y las condiciones propias del sitio, dando especial atención a la laguna y el humedal asociado.

Los valores estético-perceptuales sintetizados en las unidades de paisaje del $\mathrm{Ca}$ pítulo 8 , serán una importante pauta para la toma de decisiones, la jerarquización de elementos y los criterios de diseño descritos.

Por último, esta versión del "enfoque adaptativo" propuesto en la tesis reconoce que los procesos naturales de un ecosistema son tan importantes como los procesos sociales que se dan en el territorio. En esta perspectiva, la gestión del proyecto bajo el enfoque adaptativo requiere que los involucrados estén abiertos a la experimentación, probando algunas soluciones y evaluando si éstas se ajustan a 
los objetivos tanto ecológicos como sociales, vale decir, si son apropiadas. Por lo tanto, es necesario que el plan sea realista en sus expectativas, esté abierto a la experimentación y la evaluación, y sea comunicable.

Estas características, a juicio de la autora, permitirán despertar un interés colectivo en el proceso de restauración ecológica propuesto, para que además de ser aceptados por la comunidad, ésta se comprometa con su cuidado (como mantenimiento, conservación o uso sostenible) a largo plazo.

El proceso emprendido por el proyecto ha requerido y seguirá requiriendo de la resolución de conflictos derivados de distintas visiones acerca de la naturaleza, del rol de la universidad, de la innovación y del emprendimiento, por lo que el desafío mayor, sincrónico al diseño, será lograr una visión común, es decir una construcción social del mismo, expresada en una narrativa compartida.

\subsection{ANTECEDENTES}

Recordando lo que ya hemos analizado bajo diversos puntos de vista, el proyecto se emplaza en el predio de 1.022 ha cedido por el Estado a la Universidad en 1994. Está ubicado en la Comuna de Pudahuel, a orillas de la ruta 68 , a $20 \mathrm{~km}$ del centro de Santiago y próximo al aeropuerto internacional, ofreciendo condiciones inigualables para su desarrollo. Éstas se sintetizan en la Figura 12.1, donde además están indicados los 5 campus que hoy tiene la universidad dispersos en la ciudad, y su casa central, próxima al palacio de La Moneda. Este vasto terreno está emplazado en uno de los 35 hotspot de biodiversidad mundial, posee el segundo mayor cuerpo de agua de la región, la Laguna Carén, rodeada de un paisaje de amplias perspectivas, en el que predomina la sabana de Acacia caven. La cercanía a la cordillera de la costa (al poniente) actúa como un biombo climático y ayuda a encausar los vientos que ventilan el valle (ver Capítulo 7), otorgando un rol importante en la descontaminación de Santiago. Desde el punto de vista urbano, el predio está fuera de los límites urbanos, pero en un área de expansión, que como hemos visto en los capítulos 9 y 10, plantea dificultades normativas en un contexto de cambio, rodeado de tres Proyectos de Desarrollo Condicionado (PDUC) que se proyecta, atraerán entre 160 y 190 mil nuevos habitantes a la zona. Ver Figura 12.2.

\subsection{EL PROYECTO ACADÉMICO}

[...] la mayor potencialidad que ofrece el proyecto de Carén, es servir de infraestructura para la integración multidisciplinaria del más alto nivel, para buscar soluciones nuevas o plantear problemas nuevos. Es la puerta a la transdisciplinaridad que, según un cierto consenso ya universal, marcará la forma de organizar la investigación, la innovación, el diseño de políticas de transferencia tecnológica y el impulso a los emprendimientos en el marco de las transformaciones que habrán de llevar a cabo las universidades. (Vivaldi, 19 de noviembre, 2014, p. 2)

En el discurso del rector, se asume la necesidad de hacer transformaciones a las instituciones de educación superior en su conjunto. Las universidades, y la Universidad de Chile en especial, presentan una arquitectura institucional que no

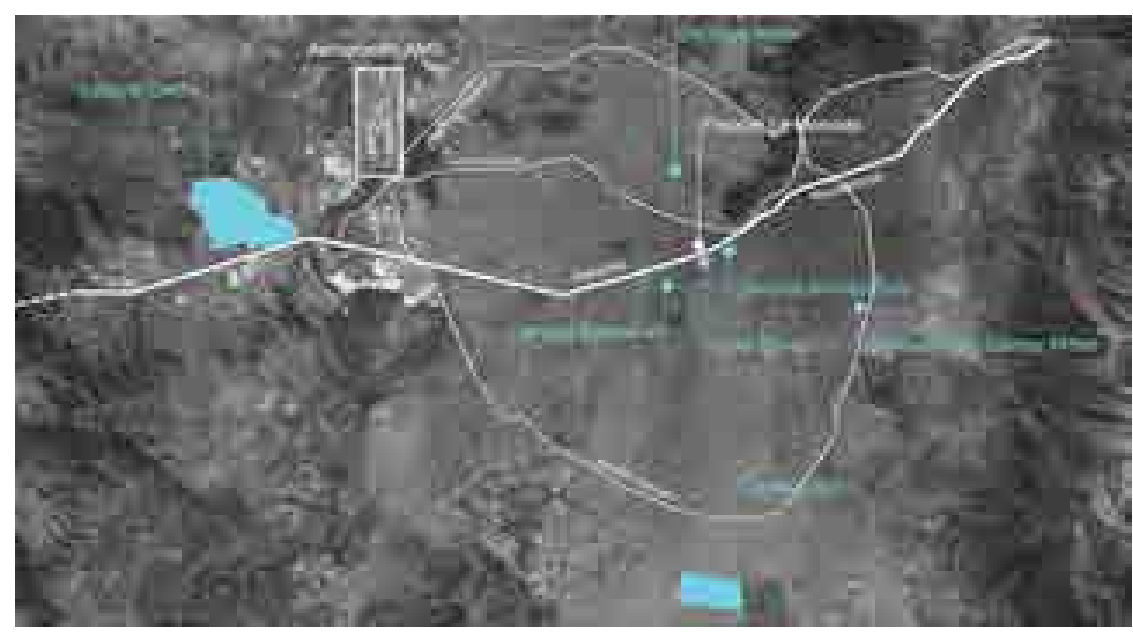

Figura 12.1. Plano de emplazamiento del predio Laguna Carén, respecto a la ciudad de Santiago, donde se indican las vías principales y los campus de la Universidad de Chile. Elaboración propia en asociación con Allard y Bravo. 
395 Slogan propuesto por Sergio Bitar, tras la presentación del Plan Maestro propuesto por la autora en el Consejo Universitario de 08 de septiembre de 2015 donde el Sr. Bitar participaba como representante de la Presidencia de la República (2015-2018). Sergio Bitar es un importante político chileno, a los 33 años fue Ministro de Minería del gobierno de Salvador Allende, también fue Ministro de Educación en el gobierno de Ricardo Lagos y de Obras Públicas en el primer gobierno de Michelle Bachelet, también Senador de la república en el período 1994-2002. Estuvo detenido en campos de concentración y luego exiliado durante la dictadura militar.

Figura 12.2. Se muestra el terreno de Laguna Carén, rodeado de los proyectos de desarrollo Condicionado (PDUC) de Urbania, Ciudad de Los Valles y Enea, junto a Lomas de Lo Aguirre (existente) y la ubicación del aeropuerto internacional AMB. En la franja inferior se indican las características más relevantes del sitio.

Elaboración propia en asociación con Allard y Bravo. facilita innovación y la transferencia tecnológica, ya sea por las características de sus estatutos, por una cultura renuente al cambio y debido los procesos históricos que la han alejado del estado.

Por otra parte, la investigación y desarrollo a nivel internacional, ha evolucionado de un orden meramente disciplinar a la estructuración en torno a problemas, cuyo enfrentamiento sólo puede provenir desde la conjunción de distintas miradas. En la actualidad, los mayores polos de desarrollo científico, a nivel internacional, tienen un carácter inter o transdisciplinar. En contraste, a nivel nacional, existe una gran deuda con la generación de proyectos y programas asociativos.

Pensamos que la respuesta, desde la Universidad, debiera estar enfocada a la generación de estructuras institucionales de asociatividad y vinculación.

Teniendo en consideración estas condiciones y bajo el slogan "Un proyecto que despierta la imaginación de Chile" ${ }^{395}$, se propone que Carén sea ese espacio de la universidad, donde se puedan desarrollar la transdisciplinariedad, la interinstitucionalidad y la internacionalización de la Universidad de Chile.

Entendiendo la transdisciplinariedad y convergencia como condición necesaria para enfrentar la complejidad de los problemas de la sociedad y ciencia contemporánea, planteando un territorio abierto a la colaboración y fecundación de ideas, especialidades y conocimiento para construir soluciones y respuestas innovadoras.

Asimismo, la Interacción con el medio considera la tecnología como un bien cultural que requiere de la interacción con la comunidad y la convergencia de las ciencias, las artes, las ciencias sociales, las humanidades, en la producción de bienes y servicios que mejoren la calidad de vida de las personas y los ecosistemas donde se implantan. La visión de la tecnología limitada a su interacción con la industria, según la autora, ha sido uno de los motivos del fracaso de los planes maestros anteriores, que no han contado con el apoyo de la comunidad universitaria, por presentarse como una visión reduccionista del rol de la universidad, que deja fuera otros campos del saber.

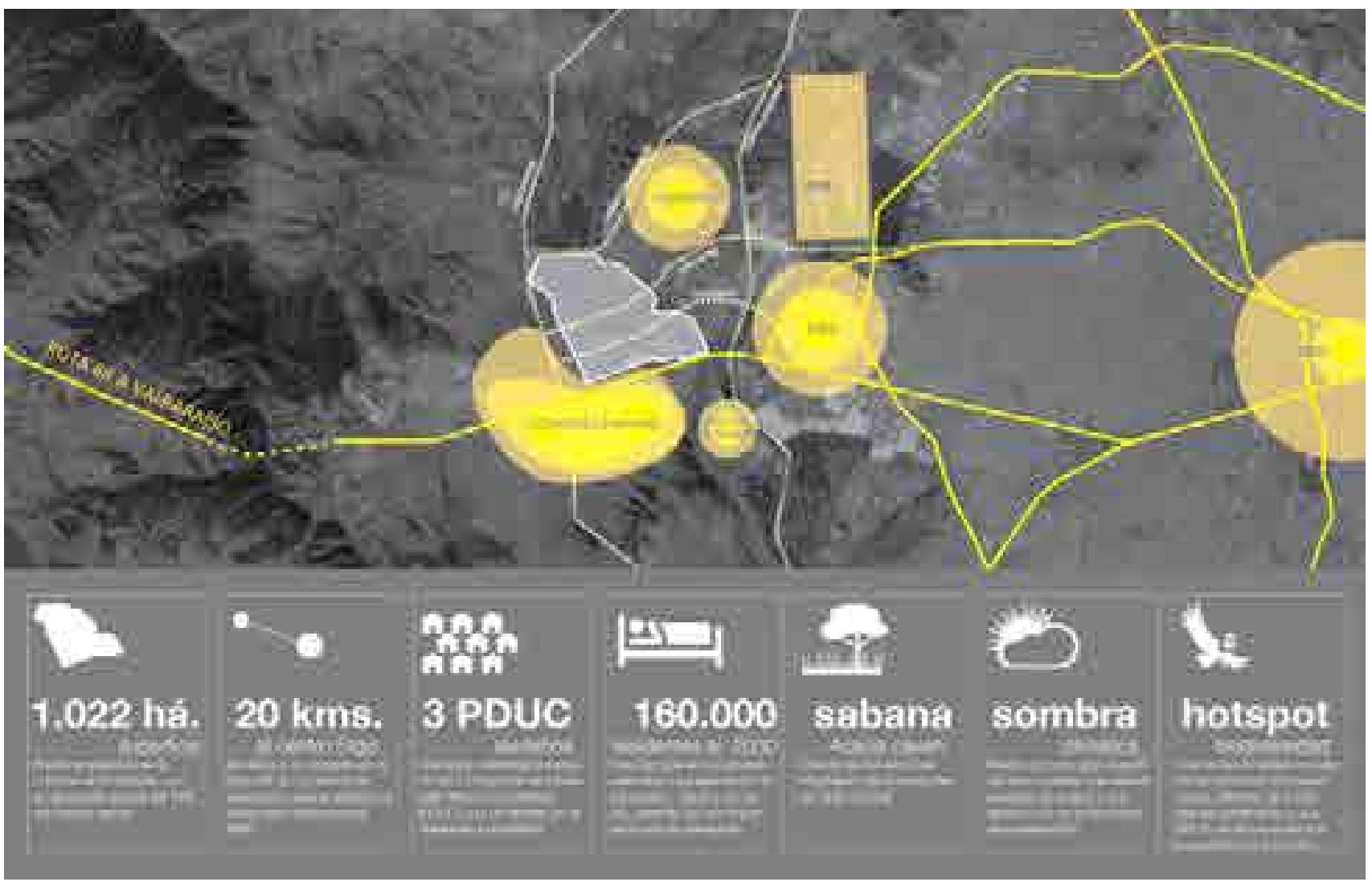


Alternativamente, se plantea una concepción integrada de la tecnología, energía, biología, arte y sociedad, para entregar a la comunidad un proyecto humanizado, en que la tecnología esté al servicio de las personas y que, de una manera transdisciplinar, genere la soluciones que nuestra época requiere.

Desde esta perspectiva, el proyecto puede contribuir a la construcción de un nuevo pensamiento sobre el desarrollo económico de Chile, esta proyección al desarrollo nacional permite que la universidad junto al Estado, anticipen y orienten un movimiento desde economías limitadas a la explotación de recursos naturales y tareas extractivas hacia economías basadas en el conocimiento, en un momento, además, en que se advierten expectativas políticas y sociales crecientes.

Es una oportunidad también para aportar a la regionalización ${ }^{396}$, desde el ámbito universitario, articulando al conjunto de universidades estatales, y convocando al resto del sistema universitario y a empresas nacionales interesadas en promover el desarrollo científico, tecnológico y cultural del país.

Por último, la Internacionalización aparece como plataforma y puente para el conocimiento y la generación de valor compartido mediante la colaboración e innovación con instituciones académicas, estatales y privadas internacionales, que ya han manifestado su interés en el proyecto. Los conceptos anteriores se sintetizan en la Figura 12.3.

De esta manera, el proyecto ha sido pensado como una ecología de la innovación y conocimiento, una plataforma de colaboración entre el mundo civil, el mundo académico, el mundo público y el privado con el fin de promover el desarrollo sustentable, la innovación y creación de conocimiento de vanguardia al servicio del país con el fin de resolver problemas nacionales de importancia estratégica, transferibles a soluciones globales.

Como se grafica en la Figura 12.4, en primer lugar, se propone la generación de una plataforma de colaboración que permita el aprendizaje directo por medio de la experimentación; siendo un lugar que genere innovación mediante investigaciones integradas y en el que exista una comunicación transversal que permita una amplia difusión.

En segundo lugar, se propone este lugar como un espacio sustentable y transdisciplinar, concebido como un proyecto diverso, de excelencia y abierto a toda la comunidad académica, donde se pueda ejercitar el análisis y la síntesis crea-

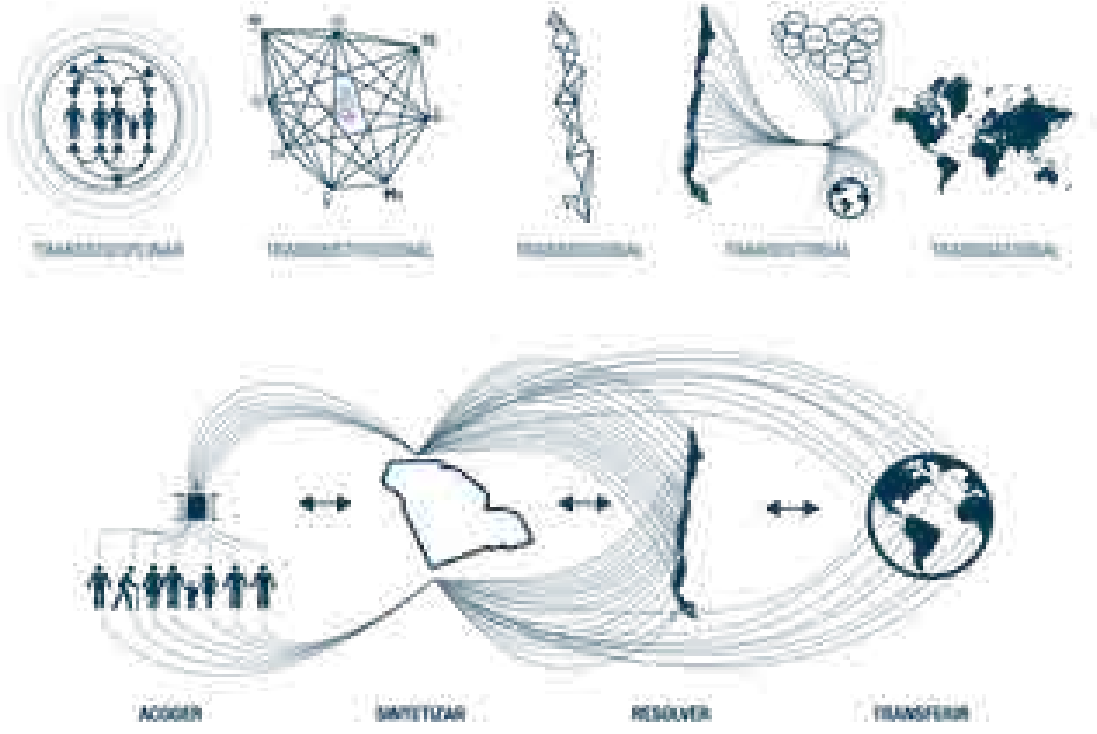

396 El Rector Vivaldi fue elegido en marzo de 2015 Presidente del Consorcio de Universidades del Estado (CUECH), instalando los conceptos de "reconstrucción del Estado chileno" y "restauración del sistema de las universidades estatales", para "Instalar una idea solidaria como país, que se plantea tareas comunes" (Vivaldi citado por Jiménez, 2015, s.p.)

Figura 12.3. Infografía con los conceptos principales del Proyecto Académico para Laguna Carén. Elaboración propia en asociación con Allard y Bravo. 
Figura 12.4. Infografía con los principios construidos colectivamente para el Proyecto Académico para Laguna Carén. Ela-boración propia en asociación con Allard y Bravo.
${ }^{397}$ La autora fue parte de las distintas comisiones formadas por el Rector Vivaldi para el proyecto Laguna Carén.

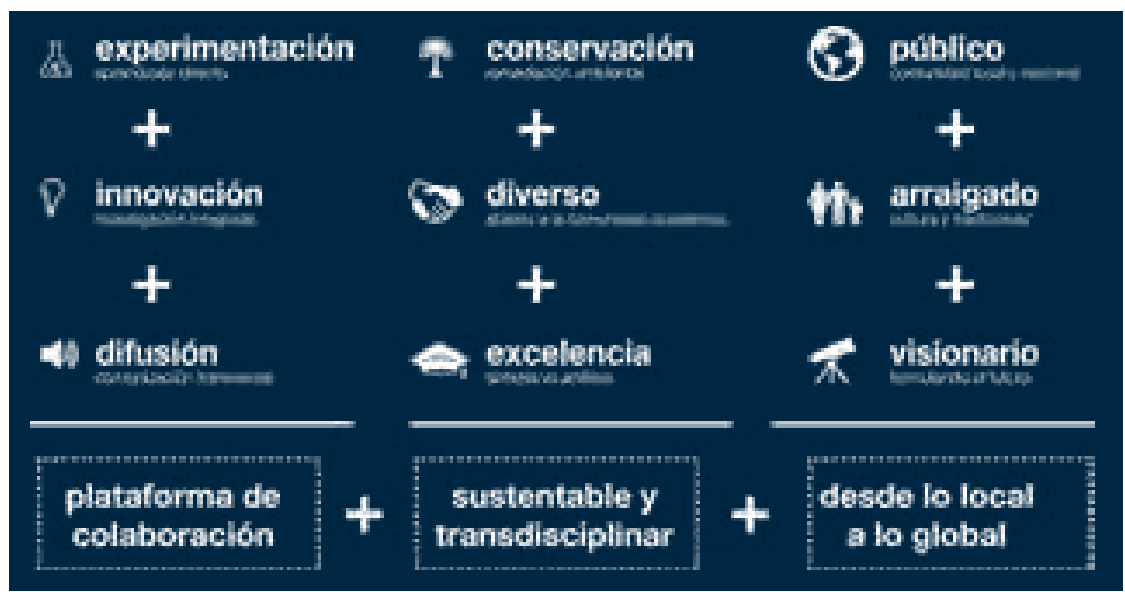

tiva. Se entiende la excelencia como característica situada, integrada al paisaje, en un entorno de conservación y remediación medio ambiental.

Finalmente, se propone un desarrollo que va desde lo local a lo global, con un enfoque público, de comunidad local y nacional que se encuentra arraigado a las culturas y tradiciones, pero con una fuerte componente especulativa que pretende vislumbrar y formular el futuro.

Expuesto lo anterior, se construye la visión para el Proyecto Académico Laguna Carén elaborado el año 2015, que concibe el proyecto como:

Una plataforma donde el conocimiento, las ciencias naturales y sociales, la tecnología y el arte, se integran para resolver de una manera transdisciplinar las demandas que enfrentará Chile y el mundo, proyectando junto a otros, el saber generado en el país para resolver problemas nacionales y globales (Barba, 2015, p. 1)

Se espera que este proyecto en Laguna Carén se convierta en un crisol, donde la comunidad académica de la Universidad de Chile integre y sea capaz de comunicar las problemáticas y soluciones concretas tanto para el país como el mundo.

Esta perspectiva obliga a replantearse el concepto de Parque Científico-Tecnológico, originalmente comprometido, orientando el proyecto en este enfoque más transdisciplinar, vinculando el quehacer universitario, en primer lugar, con las instituciones del estado -con lo público-, lo que sin duda atraerá iniciativas privadas, tanto empresariales como sin fines de lucro.

En paralelo al trabajo de la Comisión ${ }^{397}$ que elaboró la conceptualización del Proyecto Académico para Laguna Carén, el equipo de proyecto trabajó con la Vicerrectoría de Investigación y Desarrollo, en un levantamiento de las fortalezas internas que la universidad tenía, para luego cruzarlas con los temas-país más importantes (por ejemplo, los que tenían comisiones presidenciales). De este ejercicio surgió la siguiente infografía (Figura 12.5), que resume los más de 400 grupos de investigadores que existen en la universidad, organizados por temas. Como hemos comentado, en tópicos como los riesgos socio-naturales, había más de una decena de grupos, que muchas veces desconocían de la existencia de los otros o bien eran competencia a la hora de postular a recursos para investigación.

A partir de este trabajo, se organizaron una serie de reuniones, en las que se convocaron temáticamente a los investigadores, para luego invitar a las entidades públicas relacionadas.

Esta acción de vinculación académica desembocó en la postulación de varios proyectos para fondos de la Corporación de Fomento de la Producción (CORFO) con la participación del equipo de proyecto en la formulación de cada uno de 
ellos. El resultado de esta gestión ha permitido la conformación de varios centros, en los que la Universidad de Chile se ha asociado con otras universidades chilenas y centros de investigación, instituciones del estado, empresas y entidades internacionales, cumpliendo así los objetivos enunciados en el proyecto académico.

Del mismo modo, cada uno de estos proyectos tiene una componente de vinculación con el medio social, una impronta medioambiental y fondos destinados a infraestructura, comprometidos en Laguna Carén.

Paralelamente, se han desarrollado, junto al Grupo de Investigación Científica en Morfología Evolutiva Integrativa, liderado por los Doctores Germán Manríquez (Universidad de Chile), René Bobe (universidad de Oxford) y Dr. Kornelius Kupczik (Sociedad Max Planck), el proyecto Darwin en Chile. Este proyecto museográfico ha sido pensado en dos etapas: la primera como una sala-museo integrada al edificio vínculo (la incubadora de proyectos de Carén) y la segunda como un museo autónomo. La sala-museo se ha pensado como una aproximación biográfica e íntima al joven Darwin en su paso por Chile a través de su correspondencia y dibujos. En el museo, además de lo anterior se propone un recorrido de aborda tres ópticas; la antropológica, la biológica y la geológica (terremotos y evolución a escala planetaria), para luego presentar la teoría de la evolución de El origen de las especies y las visiones actuales respecto a ella. Se adjunta presentación del Proyecto Darwin en Chile en Anexo 2.

\subsection{EL PLAN MAESTRO 2015}

El primer bosquejo de Plan Maestro fue realizado como una respuesta urgente ante la investigación que la Contraloría General de la República ${ }^{398}$ hizo al proceso de sesión del predio de Laguna Carén. Este proceso que tenía como riesgo hacer valer el artículo 87 del decreto de transferencia (ver Anexo 3), en la que se indicaba que, de no cumplirse los compromisos adquiridos, "el Fisco recuperará el dominio", "cancelándose asimismo la inscripción de dominio de la entidad beneficiaria" (Contraloría General de la República, 2015, p. 4).
${ }^{398}$ En el Preinforme de Investigación Especial $\mathrm{N}^{\circ} 4$, remitido mediante el Oficio $\mathrm{N}^{\circ}$ 033152, de 27.04.2015, relativo al estado de cumplimiento del Decreto $N^{\circ} 350$, de 1994, del Ministerio de Bienes Nacionales señala que

[...] cabe manifestar que la Universidad de Chile incumplió la condición de la señalada letra b), puesto que, según se desprende de los documentos analizados, durante el transcurso de los cinco años definidos en el aludido decreto $N^{\circ} 350$, de 1994, no se materializó en el predio antes individualizado, la "Ciudad Universitaria" y el "Parque Tecnológico" para el cual fue transferido.
Figura 12.5. Infografía que resume el trabajo de levantamiento de información de los grupos de investigación que operaban dentro de la Universidad de Chile. Esta información fue cruzada con los "temas país" enunciados en los distintas Comisiones Presidenciales. Elaboración propia en asociación con Allard y Bravo.

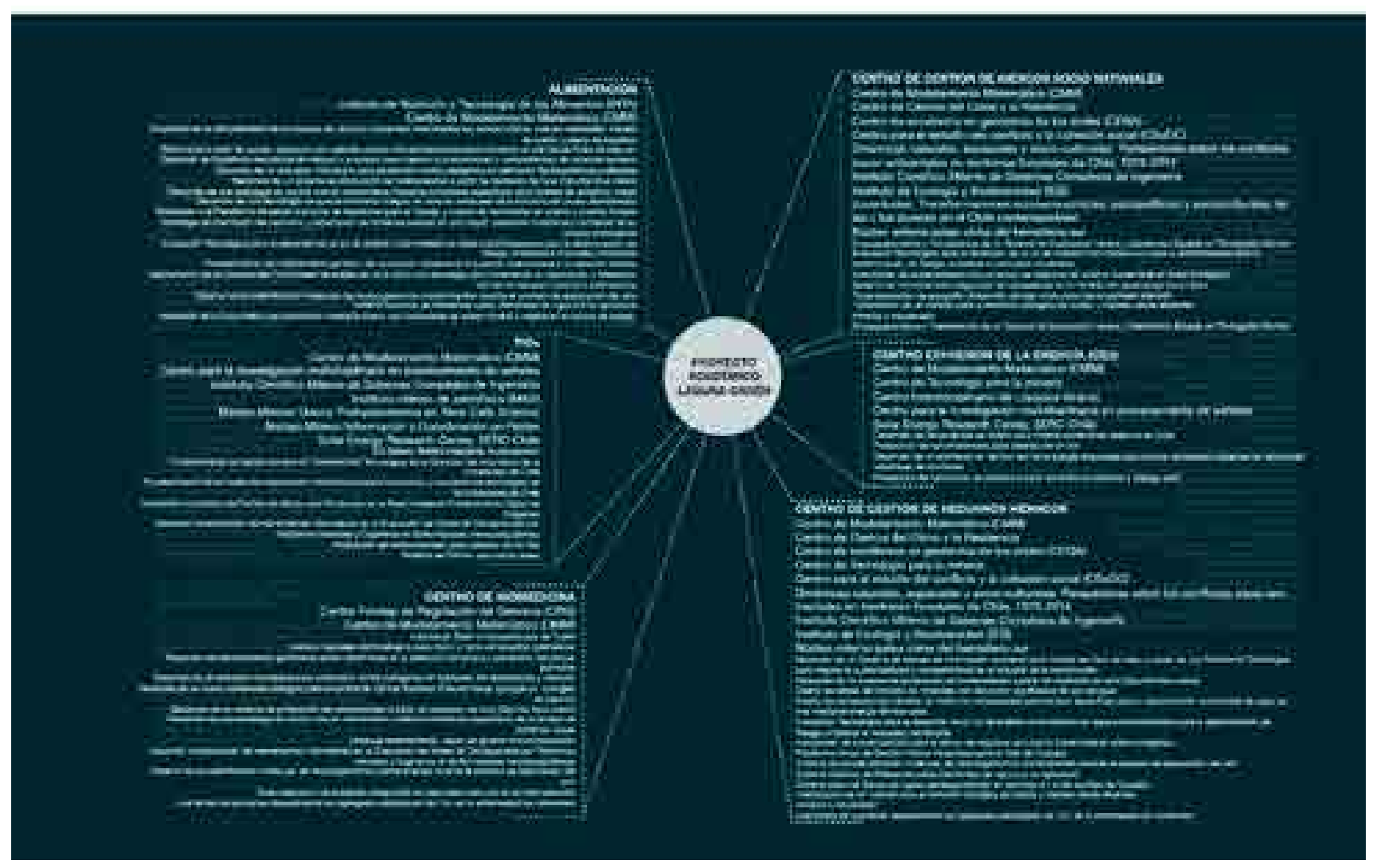


En la respuesta, se exponían los argumentos legales, se daba cuenta de la ejecución de la urbanización y se presentaba el Proyecto Académico aún en discusión, junto a una primera propuesta. En ella, como se puede ver en la Figura 12.6, se planteaba un esquema muy básico.

El proyecto, desarrollado a nivel conceptual, declaraba que se empalmaba con la urbanización de cerca 94 ha ya ejecutada, actualizando el Plan Maestro existente (el del 2004) a las realidades y desafíos actuales. Redefiniéndose, a partir de las condiciones académicas y territoriales, buscaba configurar un sistema que incitara la generación, interacción e innovación del conocimiento, junto con remediar y poner en valor el patrimonio medioambiental del lugar. De este modo, se conservan las áreas de mayor interés biótico, consolidando un parque central (la sabana de Acacia caven) que atraviesa el predio en su totalidad en el sentido de los flujos de agua, localizando en este lugar los edificios y proyectos científicos de la Universidad de Chile.

Acompañando al parque central, en la zona de acceso, se proponía una zona de agrícola experimental; una zona entorno a la laguna, de carácter público recreativo; una zona de museos (Museo de los terremotos, Museo Darwin en Chile y Museo de Arte Contemporáneo-experimental) y equipamiento. También se dejaban en reserva 30 ha para la instalación de un Centro de Convenciones Metropolitano (proyecto liderado por el Gobierno Regional) y 4 megalotes para desarrollo futuro.

Como acción inicial, detonante, se propuso la construcción del Proyecto Vínculo, edificio que actuaría como la piedra fundacional del Proyecto Académico Laguna

Figura 12.6. Planta (arriba) e imagen a vuelo de pájaro del Plan Maestro de 2015. Elaboración propia en asociación con Allard y Bravo.

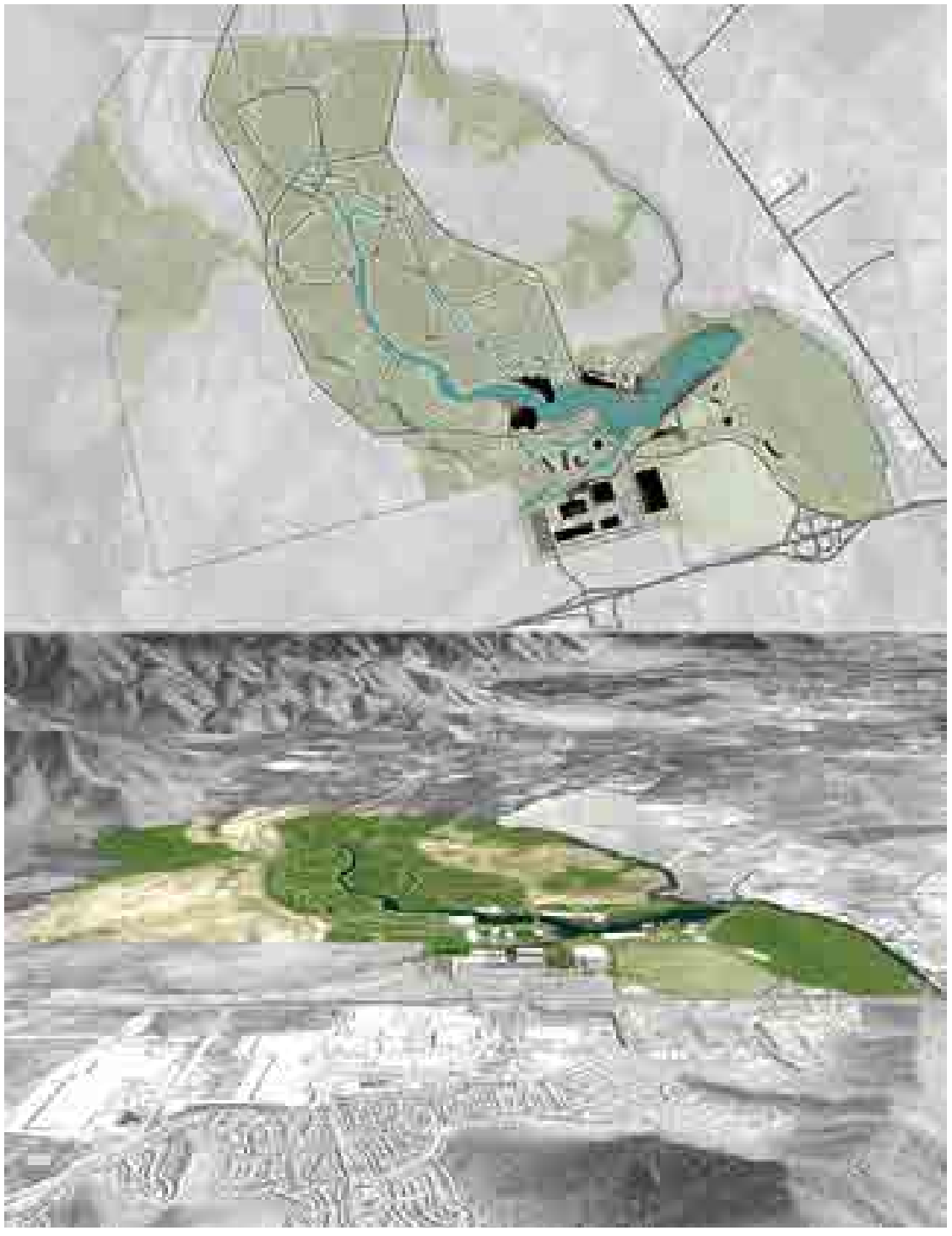




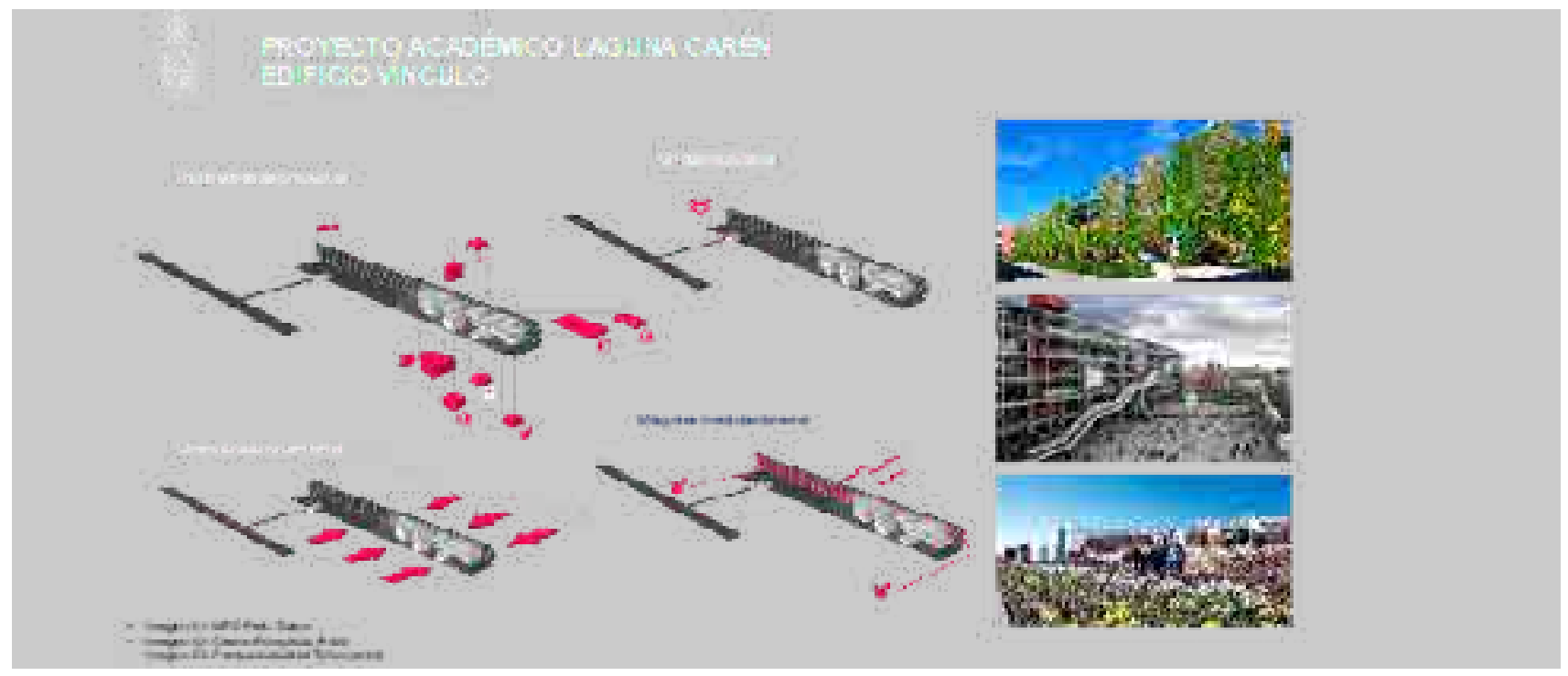

Carén y sería la incubadora del resto de los proyectos que se desarrollaran en el predio (Figura 12.7). Se trataba de una súper estructura operativa que permitía ir habilitando los diversos recintos para las primeras iniciativas del proyecto tanto internas de la universidad como de otras instituciones (universidades regionales, entidades públicas y privadas)

De esta manera, el edificio cumpliría una serie de funciones en relación con los objetivos del Proyecto Académico Laguna Carén, y además funcionaría como:

[...] un artefacto que impulsaba el desarrollo de nuevos proyectos de investigación aplicada, reuniendo a la comunidad universitaria con el medio, vinculando así el quehacer académico con las realidades sociales junto con generar un proceso medioambiental que mejore las condiciones ecológicas del entorno. (Barba, 2015, p. 2)

Este plan, bastante utópico, reproducía las lógicas del parque Quinta Normal, que hemos estudiado en el Capítulo 5. Vale decir, ampliando la escala, proponía un parque central de 550 ha, en el que se emplazarían los edificios de los distintos proyectos diseminados una vez que hubieran madurado en el "edificio vínculo": portal de acceso, incubadora, elemento fundacional y máquina medioambiental del proyecto. Se proponía una estructura vial mínima que continuaba la existente y rodeaba este parque central, dejando fuera de él, cuatro macro lotes de crecimiento futuro. Tomar como referente la Quinta Normal, permitía no sólo ilustrar una estrategia de intervención -incluso una estética-, sino también una intención pionera integrar intereses científicos, productivos y sociales a través de un parque público. Recordemos que la Quinta Normal fue creada como un jardín de aclimatamiento y un centro de formación y experimentación agrícola, que fue clave para el desarrollo de la agricultura a partir del siglo XIX en Chile. Claudio Gay su promotor, pretendía también que fuera un paseo público donde se encontrarán hacendados, campesinos y los habitantes de la ciudad para ver la naturaleza de un modo renovado (ver Capítulo 5).

Si bien, el proceso legal, después de dos largos años de negociaciones, consolidó la propiedad en manos de la universidad, paralelamente el equipo de proyecto analizó críticamente la propuesta junto a otros especialistas, la comunidad y autoridades, incluyendo las observaciones del Ministerio de Bienes Nacionales (el donante formal), que veían con desconfianza las zonas en reserva, por la fuerte presión inmobiliaria que concurre a esta zona y a las intrigas que habían rodeado la gestión de la fundación que tiene a su cargo el predio.

Efectivamente, este esquema conceptual, era poco resiliente. Dejaba fuera, casi la mitad de la superficie, expuesta a deterioro y también a la tentación de lotear, dejando que los desarrollos inmobiliarios que lo rodean pudieran crecer sobre
Figura 12.7. Esquema y referentes del edificio Vínculo, incluida en la presentación del Plan Maestro de 2015. 
él. Desde el punto de vista ecológico, si bien protegía el área de mayor valor, también la aislaba, contraviniendo la idea de conectarla a redes ecológicas más amplias.

El esquema de implantación, de baja densidad y desperdigado, si bien podría garantizar la mantención de la suma de los paños, dificultaría la relación entre las personas e instituciones allí instaladas. Un efecto que hemos analizado en el caso de Sophia Antípolis, que hoy está siendo reestudiado como estructura, ya que como recordaremos, la falta de centralidad y dispersión de los edificios y actividades ha traído problemas de transporte, vitalidad y sobre todo de contacto entre los habitantes del parque francés. La escala de laguna Carén, lo vasto en este plan es un defecto, a diferencia de lo que ocurre en la Quina Normal, donde, si bien los edificios se encuentran dispersos, la distancia entre ellos permite cierta tensión visual y funcional. En estas condiciones, difícilmente podría surgir una identidad asociada al lugar, pues por su ordenamiento, no permitiría ser intuitivamente leído (descifrado), por lo tanto, no cumpliría tampoco con la legibilidad necesaria para construir una imagen mental de la totalidad del parque.

\subsection{PLAN MAESTRO 2016}

La revisión del primer bosquejo, integra como primer criterio asumir, como lo determina el Plan Regulador Metropolitano de Santiago y el espíritu del Primer Plan Maestro de 1992 de la Comuna, que todo el terreno es un parque y respeta una identidad ya instalada en el imaginario colectivo.

El segundo criterio, discutido con ecólogos y geógrafos de la universidad, es que hoy un parque no puede considerarse como un santuario de la naturaleza, diferente y separado de su contexto territorial, sino más bien debemos considerarlo como un nodo dentro de redes ecológicas más amplias que necesitan involucrar todo el territorio. Ya no pueden ser consideradas, como ha planteado Roberto Gambino, para los parques italianos y norteamericanos, áreas especiales concebidas para el disfrute público, ya que siempre son territorios habitados y paisajes culturales, donde el uso público debe conciliarse con el equilibrio ecológico, cultural y económico (Gambino, 1997).

Esta idea, como hemos visto en el Capítulo 5, se plantea como una evolución del parque tradicional, que era concebido paradojalmente, como fortaleza, una isla separada de sus comunidades naturales y humanas. Los parques urbanos de Frederick Law Olmsted eran refugios, como el Central Park de Nueva York, claramente separados del resto de la ciudad, en una interioridad que permite, incluso hoy, olvidar que se está en el centro de una próspera metrópoli. Sin embargo, Olmsted no creía que un parque individual fuera completo en sí mismo. Preveía sistemas de parques que incluían parkways como el elemento organizador de las ciudades. En esta línea de pensamiento, recordamos lo que Lewis Mumford advierte:

La planificación de parques [...], no puede detenerse en los límites de los parques: su mayor necesidad es infundir sus estándares de espacio, belleza y orden en todos los demás aspectos de los desarrollos de la ciudad. El sistema de parques es, por lo tanto, la punta de lanza de la planificación urbana integral399. (Mumford, 1938, p. 45)

12.5.1 Macroescala: El parque pensado así, a escala geográfica (macroescala), puede seguir estrategias tales como: vincularse con las políticas ambientales más amplias aplicadas en el sistema regional, ser un nodo en las redes ecoló-

399 Traducción propia del texto en inglés:

Park planning, in other words, cannot possibly stop at the edges of the Parks: its greatest need is to infuse its standards of space and beauty and order into every other aspect of the city's developments. The park system is thus the very spearhead of comprehensive urban planning. gicas a través de su coordinación con otros proyectos en la región y también, al menos intentar, ser el marco para paisajes naturales y culturales completos.

Lo primero, se logra consolidando el paño completo como un parque, lo que incorpora las 1.022 ha como áreas verdes al Plan de la Región, que tiene un déficit de 2.720 ha (Poduje, 2011), para lograr el estándar de $9 \mathrm{~m}^{2}$ por habitante para el Gran Santiago. Esto significa, aportar con más del $37 \%$ de las necesidades de 
la ciudad, en una de las zonas con menor índice de espacios verdes, tal como se aprecia en la Figura 12.8. Contrarrestando la distribución inequitativa que hoy tiene Santiago.

De acuerdo a lo hemos expuesto en el capítulo sobre normativa, el valle de Lo Aguirre, donde se emplaza Laguna Carén, también tiene un rol en el Plan de Descontaminación de Santiago, por lo que el aumento de masa vegetal y el resguardo de la laguna como superficie de evaporación son acciones que ayudan a mejorar las condiciones de ventilación de la ciudad (recordemos que los vientos predominantes son sur-este), lo que debe ser reforzado con una baja densidad de edificación tanto en el plano como en la altura.

Por último, esta zona tiene restricciones por "riesgos de inundación" y "afloramiento de napas freáticas", que, si bien a través de estudios más acuciosos y algunas obras civiles puede levantarse como impedimento, el plan maestro del parque ha considerado ésta, como una condición de diseño del paisaje. Un gran parque permite ofrecer un área de infiltración, para las zonas urbanas que están río arriba, y las rurales ubicadas al norte, y así evitar inundaciones. Con la consolidación de este parque, el mejoramiento de la laguna y el humedal asociado se paliará en gran medida el riesgo de inundación en zonas aledañas, actuando el parque como depósito retenedor para almacenar temporalmente el volumen de agua de lluvia acumulado, cumpliendo al mismo tiempo como área recreativa para el ocio y esparcimiento de los ciudadanos, dotándolo de unas características formales y paisajísticas singulares.

Lo segundo, relacionado con redes ecológicas, se logra engarzando el proyecto a otras iniciativas que hoy se encuentran en diferentes niveles de desarrollo.

Es así como el Plan maestro se ha coordinado con los siguientes proyectos:

12.5.1.1. Santiago Cerros Islas: se trata de una iniciativa liderada por la Fundación Cerros Islas que desde 2011, promueve la incorporación de 26 cerros ubicados en la Región Metropolitana, en un plan para consolidarlos como espacios recreativos de uso público integrados al sistema metropolitano de áreas verdes (Cerros Isla, s.f.). Estos cerros, entre los que se encuentra el cerro Amapola, del predio de la Universidad de Chile, constituyen terrenos no edificados, distribuidos en el valle de Santiago y que, al ser recuperados, pueden ayudar a paliar el déficit de áreas verdes y potenciar la biodiversidad. Como vemos en su distribución en la Figura 12.9, éstos se encuentran en su mayoría, en las comunas con menos recursos, por lo que su forestación los transforma en un recurso clave para mejo-
Figura 12.8. Catastro de áreas verdes consolidadas de Gran Santiago. En (izq.) Fundación Cerros Islas (s.f.) y (der.) Da-niela Paz (3 de abril, 2014).
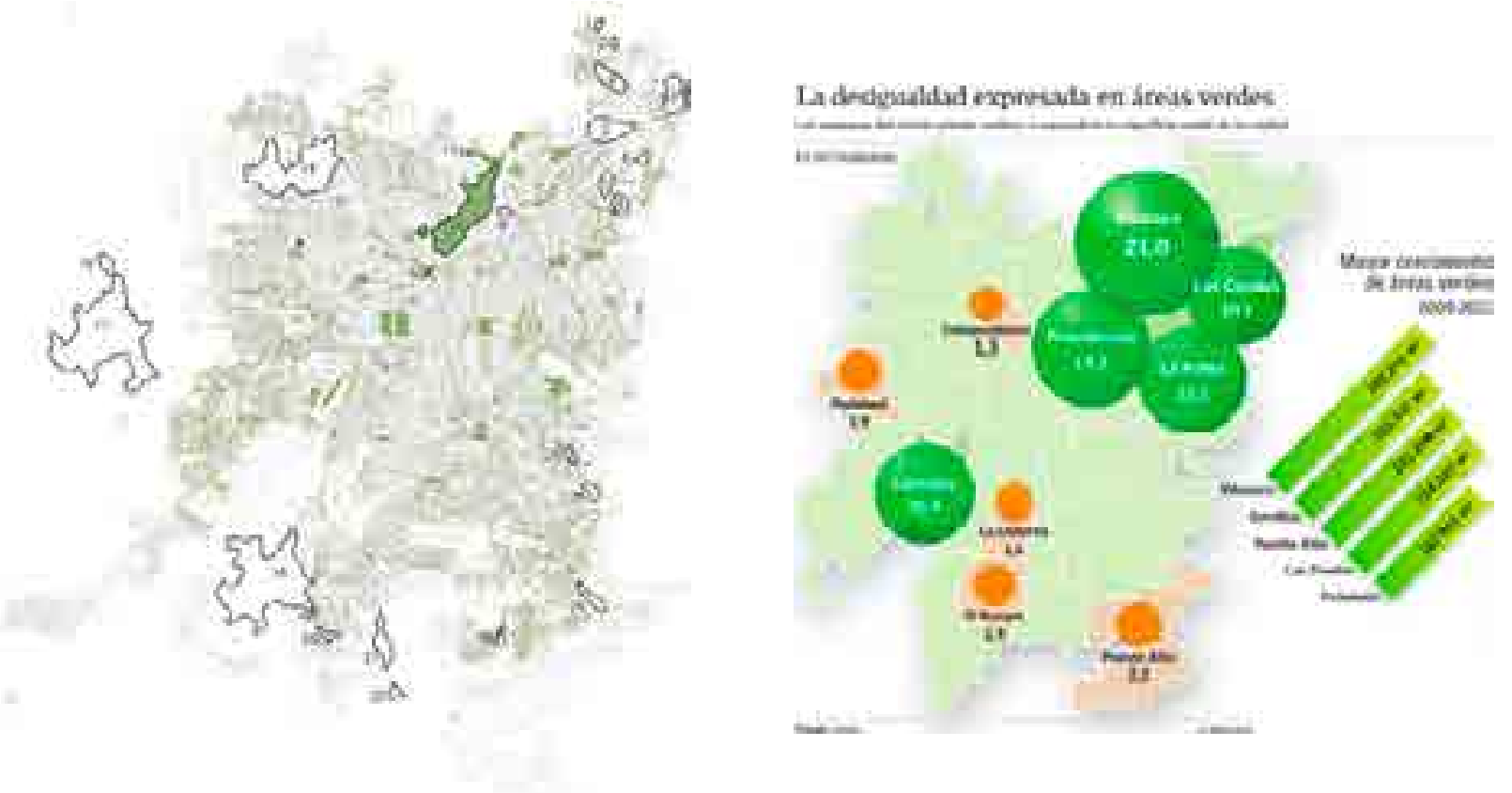


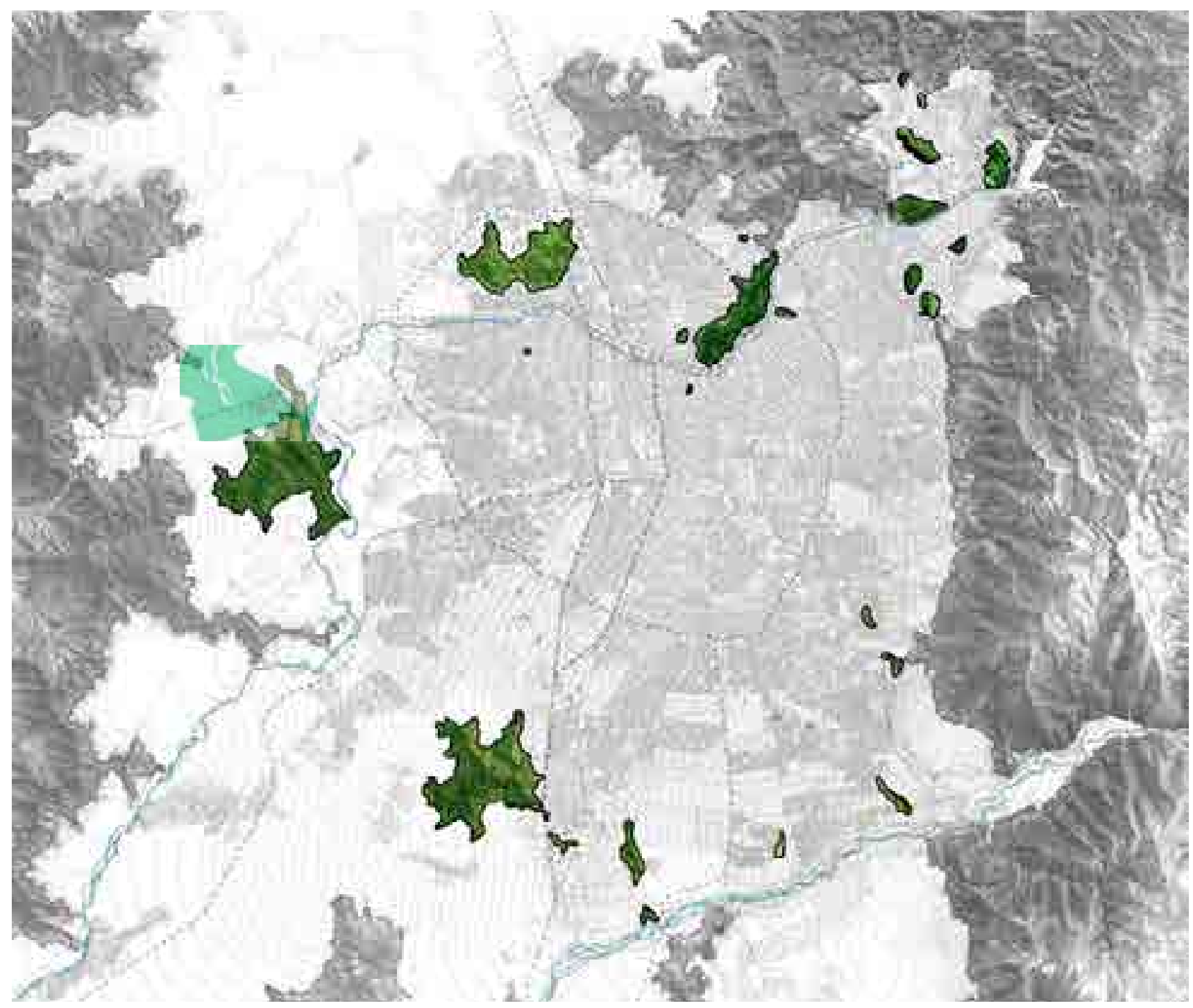

Figura 12.9. Plano del valle de Santiago con la ubicación de los cerros isla, entre ellos el cerro Amapola, en el predio de Laguna Carén. Imagen capturada de la página web Cerros Isla e intervenida por la autora.

\footnotetext{
400 MAPOCHO 42K nace al alero de una investigación aplicada en la Escuela de Arquitectura de la Universidad Católica el año 2009 recogiendo los planteamientos del arquitecto Mario Pérez de Arce, Premio Nacional de Arquitectura, quien propuso la visión del paisaje del río Mapocho como un Sistema de Parques integrados.
}

rar la distribución de estas áreas en la ciudad y "promover principios de equidad en los procesos de desarrollo urbano" (Picon \& Ruiz, 2017, p. 17).

Con fecha 25 de septiembre de 2015 la Universidad de Chile suscribió una Carta de intenciones con la Fundación Cerros Isla, con el objetivo de incorporar el cerro Amapola como el primer cerro que se asocia al proyecto. El cerro Amapola con sus 70 ha, se incorpora así al plan de medidas de compensación ambiental, para que empresas que requieren hacer mitigaciones, financien el desarrollo de nuevas áreas verdes que incluyen zonas de esparcimiento y recreación, senderos interpretativos de la flora nativa, áreas de conservación de especies adaptadas al cambio climático, senderos educativos y el diseño del equipamiento necesario para velar por la seguridad y recorridos dentro del Cerro Amapola, cuyo diseño se aborda más adelante.

\subsubsection{Mapocho $42 \mathrm{~K}^{400}$}

Este proyecto surge en 2009, como un ejercicio académico en la Universidad Católica de Chile, logrando incorporarse al programa gubernamental Legado Bicentenario en agosto del año 2012 y a los planes reguladores comunales para su ejecución. La idea propuesta consiste en la recuperación de las riberas del río Mapocho, para estructurar un corredor verde (greenway) ${ }^{401}$ que atraviesa el valle de oriente a poniente. Sus autores, Sandra Iturriaga, Juan Ignacio Baixas, Francisco Croxatto, Paulina Ibieta y Francisco Quintana la describen así:

Esta propuesta considera recuperar la potencialidad que presentan las riberas del río Mapocho -principalmente la ribera sur- en cuanto a su capacidad de conformar un espacio público de escala metropolitana y una columna vertebral 
en sentido oriente-poniente, que permitiría unir a través de un paseo público diversos estratos sociales y topográficos de la ciudad a lo largo de once comunas. (Iturriaga et al, 2013, p. 85)

El proyecto aprovecha que el río, en su paso por la ciudad cruza 11 comunas $^{402}$, de diferentes estratos sociales, dando no solo continuidad ecológica, sino también social a la tan segregada ciudad de Santiago.

Las riberas del río Mapocho fueron históricamente, espacios abandonados y deteriorados, ya que el río fue por mucho tiempo un límite y también un receptor de basura y aguas servidas. Esta situación se ha revertido gracias al Plan de Depuración de Aguas Residuales de la Cuenca de Santiago ${ }^{403}$, que entre el año 2001 y 2010 logró descontaminar el 100\% de las aguas residuales de la capital ${ }^{404}$, lo que ha permitido recuperar el cauce como un elemento paisajístico.

El diseño de este corredor no motorizado, permite el deporte, el paseo y también el traslado de sus peatones, personas con movilidad reducida y ciclistas en un desarrollo de 42 kilómetros que se inician en la Plaza San Enrique, comuna de Barnechea, en la precordillera, hasta las localidades rurales de la cuenca del río en la comuna de Pudahuel, donde se encuentra el predio de Laguna Carén que actuaría como remate de estos 42 kilómetros y como nodo de una posible extensión de este largo borde-río.

La articulación con este proyecto, a través del trabajo conjunto con el equipo de la Universidad Católica, permitirá habilitar un acceso peatonal (no motorizado) que hoy no existe para llegar a Carén, conectando este parque con el resto de la ciudad, en una continuidad que presta beneficios sociales y ecológicos.

Las obras de Mapocho 42K se iniciaron en el 2014 en la comuna de Cerro Navia, a las que se han sumado tramos en las comunas de Providencia, Las Condes (LC en la Figura) y Santiago.
401 La Declaración de Lille define greenways del siguiente modo: Son vías de comunicación autónomas reservadas a los desplazamientos no motorizados, desarrolladas en un marco de desarrollo integrado que valore el medio ambiente y la calidad de vida, cumpliendo las condiciones suficientes de anchura, pendiente y calidad superficial para garantizar una utilización en convivencia y seguridad a todos los usuarios de cualquier capacidad física. En este sentido, la utilización de los caminos de servicio de canales y de las vías ferroviarias abandonadas constituyen un soporte privilegiado para el desarrollo de Vías Verdes. (Asociación Europea de Vías Verdes, 12 de septiembre, 2000).

402 El proyecto consolida un recorrido por las ocho comunas de la ribera sur. Sin embargo, el río Mapocho atraviesa once comunas por ambas riberas que quedan incorporadas en su tramo urbano y 16 comunas hasta el encuentro con el río Maipo en una extensión total de $97 \mathrm{~km}$.

${ }^{403}$ Llevada adelante después de la privatización de estos recursos por la empresa Aguas Andina S.A., subsidiaria de AGBAR

Figura 12.10. Proyecto Mapocho 42K. Ubicación en el valle (arriba) y trayecto por ocho de las once comunas que la ciudad de Santiago (abajo). Imagen recuperada de la página web de Mapocho 42K (s.f.).
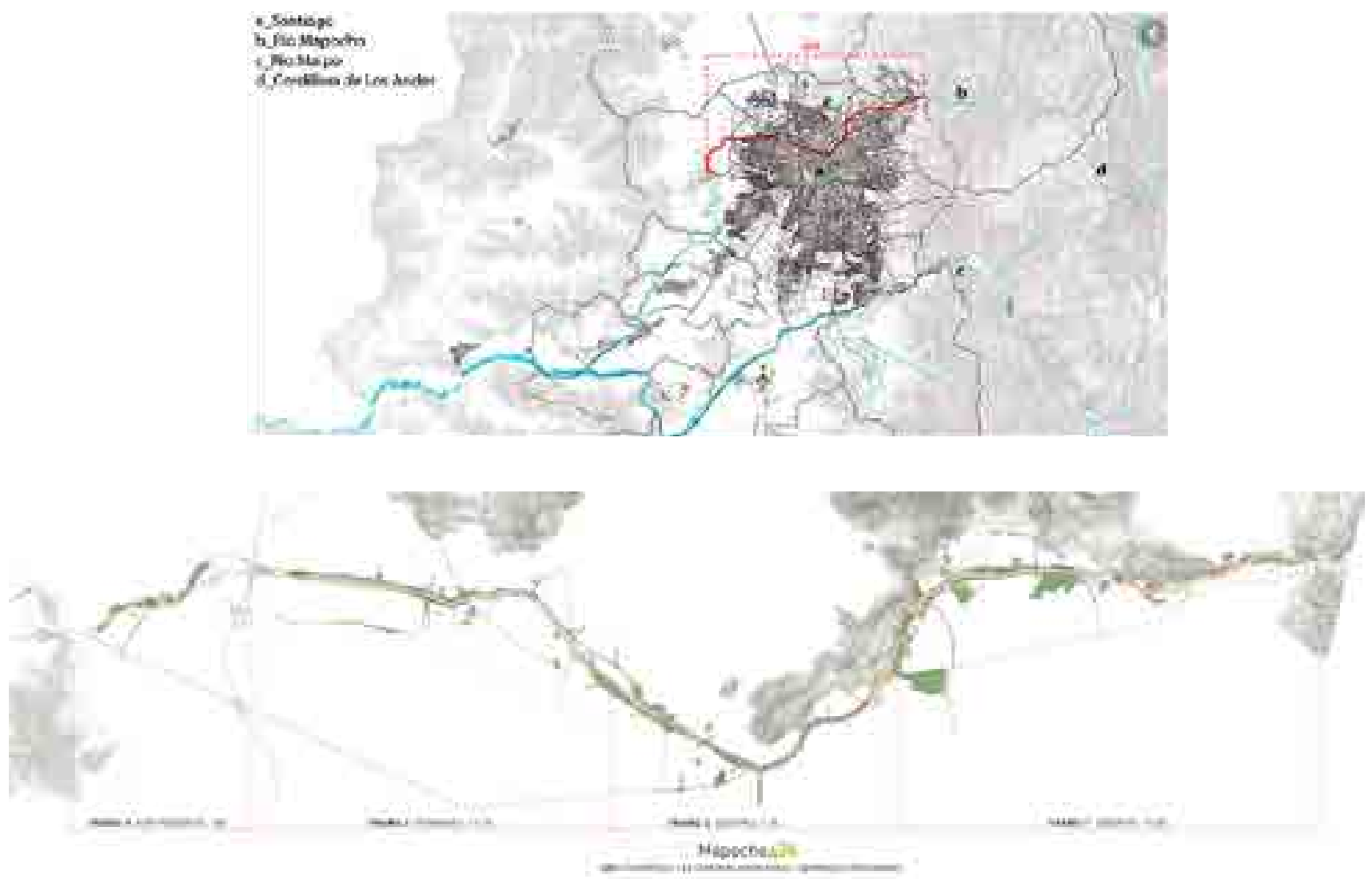
12.5.1.3. Plan Quiero Santiago Verde: Este plan fue incluido en la Cuenta Pública 2007 del Gobierno Regional y ha tenido algunos altibajos con cada cambio de gobierno (ver Zúñiga, 2008). Recientemente (2017) se publicó una propuesta semejante de la Fundación San Carlos de Maipo y de ATISBA ${ }^{405}$.

En la Figura 12.11 se muestra el plan de 2007 compuesto por tres anillos concéntricos. El más externo está demarcado por dos Reservas de la Biósfera, La Campana - Peñuelas y Bosques Mediterráneos de Montaña y el Santuario de la Naturaleza Yerba Loca entre otros sitios que cuentan con declaratoria o están en proyecto. A estos se suman 1.100 ha recientemente declaradas Santuario de la Naturaleza en Quebrada de la Plata, la que forma parte de la Estación Experimental Germán Greve Silva de la Facultad de Ciencias Agronómicas de la Universidad de Chile, ubicadas en la comuna de Maipú y el parque Laguna Carén de 1.022 ha, incluido el cerro Amapola en la Comuna de Pudahuel.

El anillo intermedio está conformado por cerros islas como Cerro Lo Aguirre, Cerros de Renca, Cerro Chena, Cerro Manquehue y Cerro San Cristóbal, dejando dentro del anillo interno las plazas y parques urbanos (Pozo, 13 de marzo, 2009).

${ }^{404}$ La descontaminación de las aguas ha permitiendo también que miles de hectáreas destinadas al cultivo agrícola sean regadas con agua limpia, disminuyendo de esta manera el riesgo de enfermedades y entregando una mejor calidad de vida a la población. Especialmente importante para las zonas aguas abajo, como es el caso de Pudahuel, en particular para la localidad de Noviciado

405 Atisba es una oficina de urbanismo independiente liderada por el arquitecto y urbanista Iván Poduje Capdeville, que tiene 20 años de experiencia desarrollando proyectos en más de 60 ciudades de Chile y Latinoamérica. Sus estudios se encuentran en la siguiente página web: http:// www.atisba.cl/

${ }^{406}$ La Convención fue aprobada en Chile como Ley de la República en septiembre de 1980 y promulgada como tal a través del DS N 771 de 1981, del Ministerio de Relaciones Exteriores. A noviembre de 2005, Chile cuenta con nueve humedales de importancia internacional (Sitios Ramsar), cubriendo un total de 160.154 ha. El documento fue elaborado inicialmente en febrero de 2000, por representantes de servicios públicos, académicos, instituciones privadas y ONG y revisado para su versión final por CONAMA - CONAF en octubre de 2005. El documento establece como Objetivo General Promover la conservación de los humedales prioritarios de Chile y de sus funciones y beneficios en un marco de desarrollo sustentable (CONAMA (2005).

Figura 12.11. Proyecto Quiero Santiago Verde (2007). En Santiago Del Pozo Donoso (20 de septiembre, 2012).

De acuerdo al plan original,

el anillo interno tiene un potencial de crecimiento de 640 ha de parques y plazas, lo que significa un aporte de $1,07 \mathrm{~m}^{2}$ de áreas verdes por habitante. El anillo intermedio significa un aporte de 6.400 nuevas ha al interior de la ciudad, lo que implica un incremento de $11 \mathrm{~m}^{2}$ de áreas verdes por habitante. El anillo externo representa más de 10 mil hectáreas bajo algún sistema de protección. (Pozo, 13 de marzo, 2009, s.p.)

Por su parte, el proyecto de la Fundación San Carlos de Maipo y Atisba apunta a establecer una red de parques y barrios integrados 26 comunas asociado a ejes fluviales en $233 \mathrm{~km}$, compuesta de 63 tramos y 22 nodos de transporte (Herrera, 4 de junio, 2017). Este cinturón verde, al estar estructurado por los cursos de agua, es más extenso en la dimensión norte-sur y coincide en uno de sus nodos con Laguna Carén, como se aprecia en la Figura 12.12, a partir de su continuidad con los esteros las Cruces y Lampa.

12.5.1.4. Estrategia Nacional para la Conservación y Uso Racional de los Humedales en Chile: el nuevo plan maestro se hace parte de esta iniciativa regional de diciembre $2005^{406}$, que a su vez es parte de la "Estrategia Nacional de Biodiversidad" aprobada a fines del 2003, en estos documentos se establece que "Ios humedales constituyen espacios donde se concentra biodiversidad y

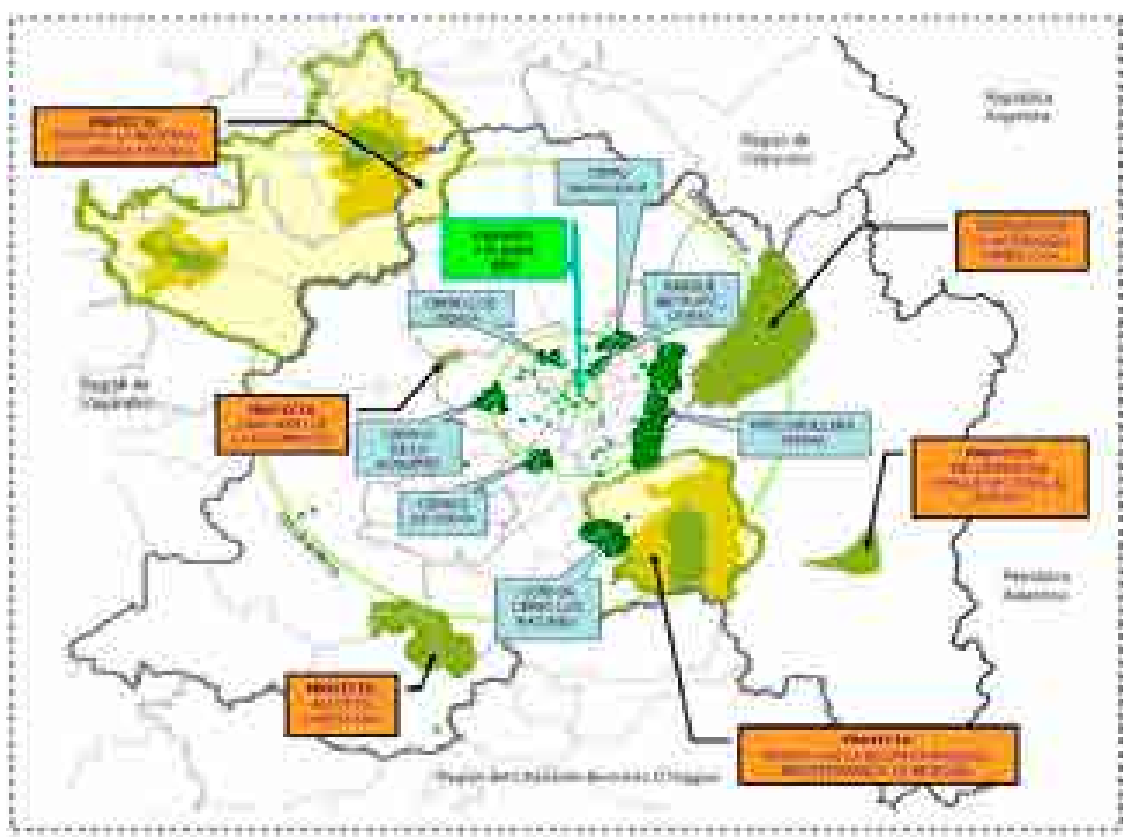




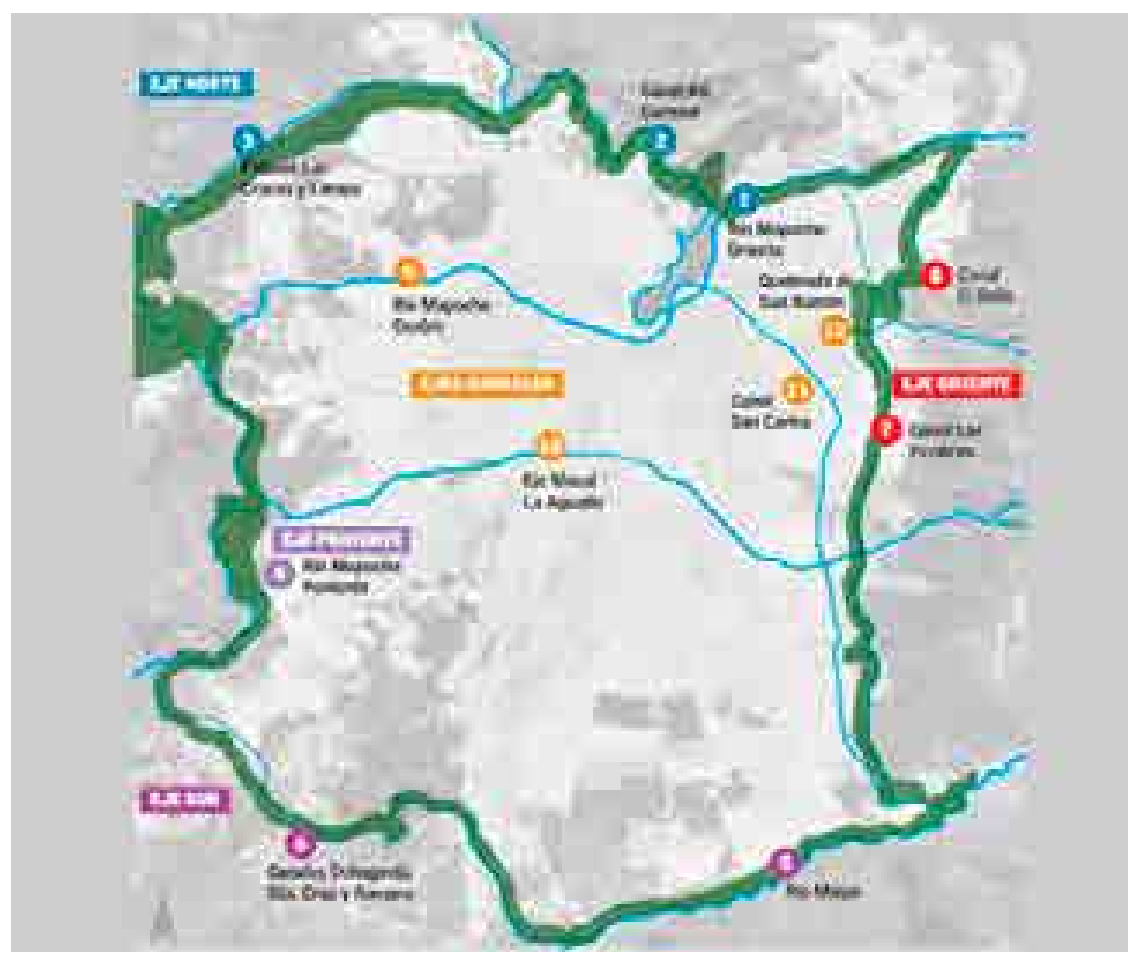

son determinantes en el funcionamiento de los ecosistemas y por ende la vida humana" (CONAMA, 2005, p. 7).

Como hemos visto en el Capítulo 7, durante los últimos 100 años se ha perdido un $64 \%$ del total de humedales y un $66 \%$ de las especies asociadas a éstos (Marta, 2 de junio, 2015), debido a la expansión tanto de la ciudad como de las actividades agrícolas, el impacto del cambio climático y la contaminación.

En el caso de Chile, la diversidad de climas ha originado una gran variedad de ambientes acuáticos, entre los que se encuentran los estudiados por Ricardo Figueroa y su equipo en la eco-región mediterránea de la zona central, donde sus lagos, lagunas y tranques registran hábitats que albergan "flora y fauna terrestre y acuática de interés, con alta diversidad de especies, además de corresponder a un punto importante en la ruta de migración de aves a lo largo de la costa chilena" (Figueroa, Suarez; Andreu, Ruiz \& Vidal-Abarca, 2009, p. 77).

A esta escala, la importancia de Laguna Carén, debe entenderse como parte de una red de humedales y lagunas, tanto naturales como artificiales, que conectan los cuerpos de agua ubicados en los valles transversales con los costeros y a través de ellos hacia la región austral y el hemisferio norte. Al conformarse una red, las aves acuáticas tienen la posibilidad de complementar sus necesidades de alimentación y refugio.

Investigadores como Zhijun Ma, Yinting Cai, Bo Li \& Jiakuan Chen (2009), reconocen que los humedales artificiales pueden proporcionar hábitats alternativos o complementarios para las aves acuáticas en todas las etapas de su vida y, en consecuencia, pueden mitigar las influencias adversas de la pérdida y la degradación de los humedales naturales. Como vimos en el Capítulo 7, la ubicación de Laguna Carén es clave, respecto a los humedales de la zona central, ya que actúa como nodo. En consecuencia, es importante incorporar la restauración tanto de la laguna como del humedal dentro del plan maestro ${ }^{407}$.

En síntesis, podríamos afirmar que el primer objetivo a macro escala ha sido fijar un uso de la tierra relativamente fijo, y una idea-imagen (el parque) capaz de dar una forma identificable a una comunidad.

Si bien "el parque" (genéricamente) aún tiene una imagen separada o marginada, incluso a pesar de los esfuerzos por expandirlos para abarcar entornos urbanos
Figura 12.12. Propuesta Anillo Verde (2017). En Herrera (4 de junio, 2017).
${ }^{407}$ Al incorporar esta problemática dentro del plan maestro, se asume el compromiso con los siguientes puntos de la Estrategia Nacional para la Conservación y Uso Racional de los Humedales en Chile, publicado en diciembre, 2005:

5.3. Priorizar los humedales que serán objeto de planificación y manejo, tanto respecto de los sitios Ramsar como de otros humedales públicos y privados. Es imperativo desarrollar planes de manejo para aquellos humedales considerados como prioritarios, destacando, su importancia científica, ecológica, recreativa, cultural y económica y detallando las acciones de conservación y las necesidades de restauración que se requieran; y 5.5 Identificar y proponer la designación de nuevos sitios Ramsar.

(CONAMA- CONAF, 2005, pp. 21-22) 
completos, posee funciones de integración social, ecológica, política, histórica y estética. Lo anterior nos llevaría a pensar utópicamente, en la posibilidad de que este parque promueva una nueva visión para la vida urbana, donde la misma ciudad puede ser contemplada como una obra de arte, el "parque sin límites" del que nos habla Paul Marshall Bray (1988). Para Santiago, es la posibilidad de resituarse en el valle, reconocer su geografía, recuperar la visión de sus montañas (hoy ocultas por el smog) y entregar una gran superficie verde a sus habitantes. Esta sería la versión positiva, pero sabemos que los parques no garantizan por sí mismo, automáticamente, una ordenación territorial democrática. Para lograrlo, las decisiones no pueden seguir tomándose sin considerar el territorio en el que se implantan, como se ha hecho con muchos parques públicos (y en prácticamente todos los parques industriales y científico-tecnológicos). Cualquier intervención de esta magnitud, generará un nuevo contexto socioeconómico sometido a las tensiones propias de la relación entre protección ecológica y desarrollo económi$\mathrm{co}$, que se hace más crítico si consideramos los parques como áreas sin límites definidos (por lo tanto, más difíciles de manejar). De hecho, según documenta Pablo Alonso, "la mayor parte de los parques en el mundo se enfrenta a amenazas que provienen del exterior de sus límites, cuestión imposible de resolver mediante una gestión unilateral" (Alonso, 2014, p. 233). El futuro de este parque y su integridad ecológica dependerán, por lo tanto, de la capacidad de establecer acuerdos duraderos entre la comunidad interna y la comunidad local, para poder superar los conflictos entre el parque y las tierras adyacentes, a través del reconocimiento de intereses compartidos con los vecinos y la ciudad.

Podríamos decir también, que esta primera operación consiste en salvaguardar la unicidad del predio bajo el concepto de parque, como una tipología paisajística que actúa en oposición a la de "territorio" como objeto, como conjunto de morfologías naturales y artificiales, que se puede catastrar y dividir. El "paisaje" entendido como obra y bien colectivo, es indivisible, difuso en su titularidad y eventualmente subjetivo. Por lo tanto, el derecho al paisaje aquí defendido constituye una facultad común más que individual de los habitantes y sobre todo de los ciudadanos, de transformar este paisaje y al mismo tiempo transformarse a sí mismos (incluyendo al arquitecto). La idea de paisaje puesta a prueba aquí nos ayuda a comprender que no estamos ante un componente o un nuevo aspecto del medioambiente sino frente a una perspectiva, una nueva actitud de la cultura que modifica y se apropia de la naturaleza para cuidarla. Es pertinente recordar aquí la precisión que hace Juan Morel en términos jurídicos, cuando plantea que "el paisaje es la manera como el hombre ha llegado a ver la naturaleza, no en su utilidad ${ }^{408}[\ldots]$, sino en su estética" $(2015$, p. 83).

\subsubsection{La meso escala, la escala del predio: el parque Laguna Carén}

Conceptualmente, el Plan maestro considera que actuamos sobre un territorio con valor patrimonial, lo que representa un desafío. El de ser capaces de conciliar un ecosistema de innovación transdisciplinar articulado desde la Universidad de Chile, en un entorno estratégico y de gran valor ecológico.

Se trata de consolidar un parque único, a escala regional y nacional, donde se ha considerado cultivar la investigación y desarrollo, los deportes y la recreación, la conservación y la educación ambiental. Lo que Matthias Groß, H. Hoffmann-Riem \& W. Krohn (2005) llamarían un "experimento real" (Realexperimente). Esto significa pensar el proyecto y los procesos ecológicos que materialmente se dan en el terreno dentro de las lógicas de la sociedad del conocimiento, donde el territorio es un componente de lo que se estudia.

El análisis que hemos realizado en los capítulos precedentes se vuelca así en una planificación cuidadosa pero flexible y abierta a la incertidumbre. De este modo el parque pasa a ser un laboratorio real, en el que se buscan nuevos conocimientos y se aplican conocimientos ya probados, en un proceso de aprendizaje continuo y recursivo. Pensamos que, de este modo, la experiencia del proyecto 
de Carén, si bien es un caso particular, puede contribuir, como lo haría un experimento de laboratorio, replicable y generalizable, en la generación de conocimiento que tiene como variable las incertezas del futuro. De este modo, el plan maestro sería consonante con el espíritu del proyecto académico y con la visión que hemos planteado de la sociedad del conocimiento.

Formalmente, el Plan Maestro se basa en una serie de operaciones arquitectónicas y de urbanismo del paisaje, que tienen como telón de fondo el proyecto académico con su impronta transdisciplinar, que se hace cargo de la complejidad de los problemas actuales.

Como hemos planteado en el Capítulo 2, la mayor dificultad de esta etapa radica cómo lograr que el conocimiento producido por las disciplinas científicas orientadas a lo analítico se transforme, para que pueda participar e integrarse a la acción, a una acción que encuentre su sentido en la satisfacción del usuario final. Recordemos que Findeli et al. llaman a esta operación "pragmatización" (2008, p. 81) de la teoría o del conocimiento, y correspondería al momento transdisciplinar. También, cabe recordar que hemos privilegiado el registro ético del modelo, que incorpora tanto los aspectos antropológicos como ecológicos, poniendo nuestra prioridad en los actores, antes que el proceso 0 el producto, para poder responder las preguntas de investigación que nos planteamos al inicio de este trabajo: ¿cuál es el proyecto del paisaje con el que los destinatarios se pueden identificar? Y por lo tanto ¿Cuál es el proyecto de paisaje que puede ser validado socialmente? ¿cuál es el proyecto que puede preservar las condiciones ecológicas y paisajísticas de un territorio en disputa? ¿qué elementos del proyecto se definen como plan y cuales son una estrategia? y finalmente, ¿cómo un proyecto trabaja con la incertidumbre, con el cambio y con un tiempo que excede el horizonte mismo de quién lo proyecta?

12.5.2.1 Conservando el valor del paisaje local para las generaciones futuras: Como hemos visto en el Capítulo 7, Laguna Carén es un importante y frágil ecosistema del Valle Central, cuyas características locales pueden resumirse en la siguiente matriz ambiental ecológica (Figura 12.14). Es el lugar donde la napa freática que irriga la cuenca de Santiago aflora en plena pradera Acacia caven, creando lagunas y humedales que ofrecen condiciones únicas tanto para especies endógenas como las aves migratorias.
Figura 12.13. Vista general del Plan Maestro 2016 para Laguna Carén. Elaboración propia en asociación con Allard y Bravo.

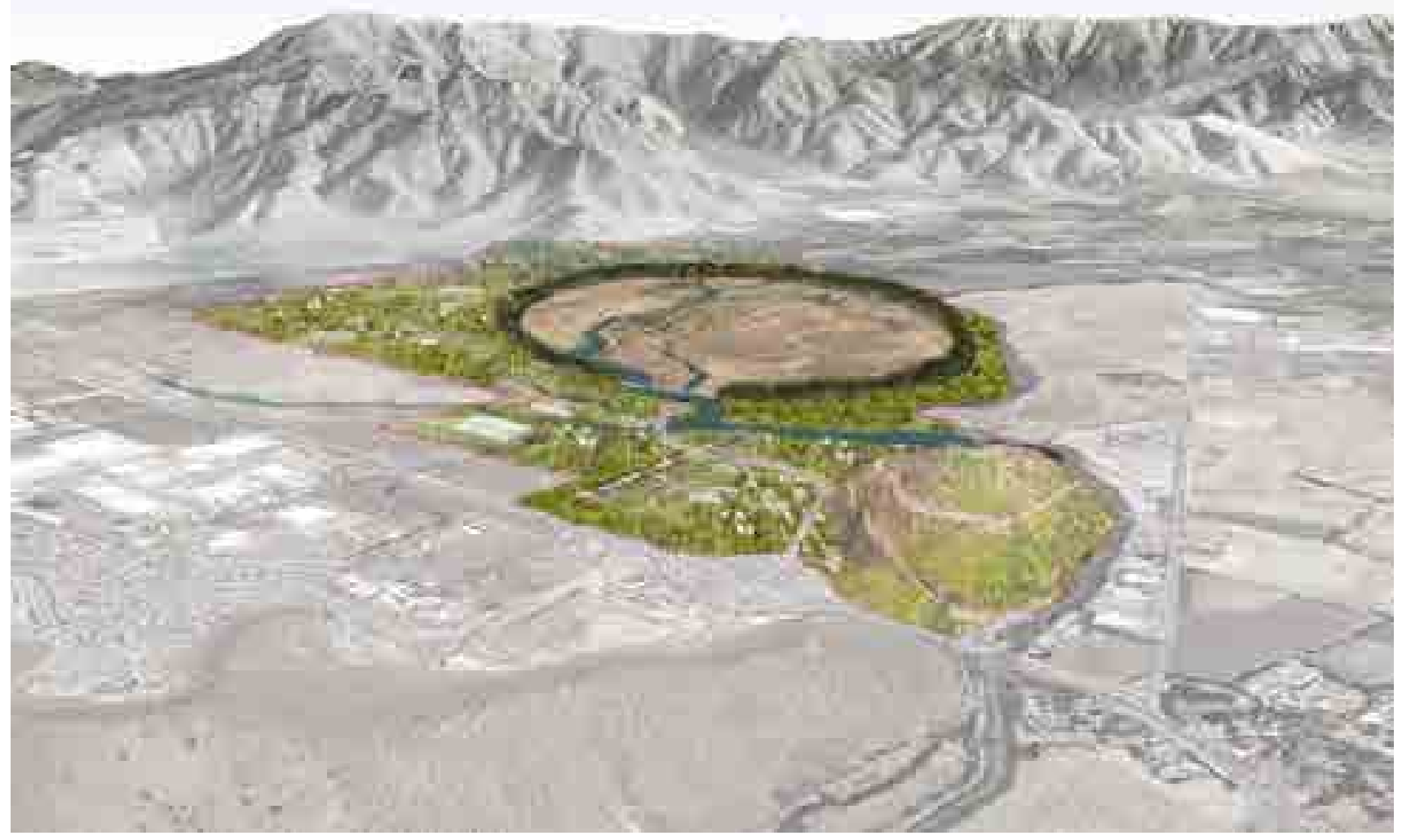




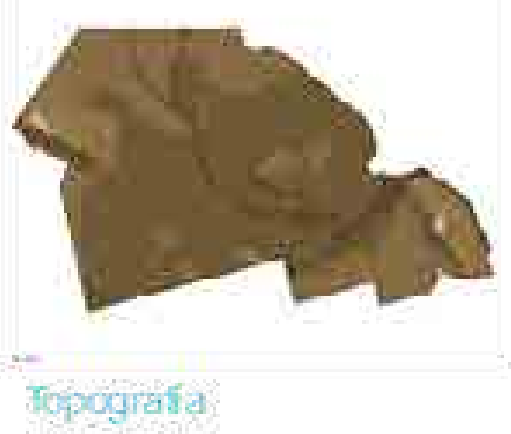

Figura 12.14. Matriz Ambiental Ecológica. Elaboración propia en asociación con Allard y Bravo.

\begin{abstract}
${ }^{409}$ De acuerdo al objetivo de "dejar actuar la naturaleza" declarado por el proyecto, cabe relacionar el artículo 2 letra p) de la Ley $N^{0} 19.300$, que define la Preservación de la Naturaleza, como el conjunto de políticas, planes, programas, normas y acciones, a asegurar la mantención de las condiciones que hacen posible la evolución y el desarrollo de las especies y de los ecosistemas del país. En este sentido, ésta sería un "Área de Preservación" de 400 ha.
\end{abstract}

Figura 12.15. Matriz ambiental (izquierda), matriz programática (centro) y matriz vial (derecha). Elaboración propia en asociación con Allard y Bravo.

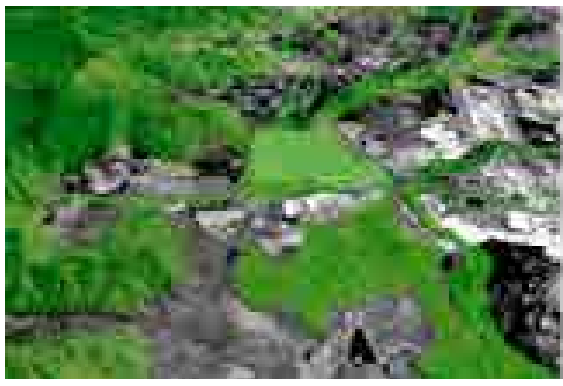

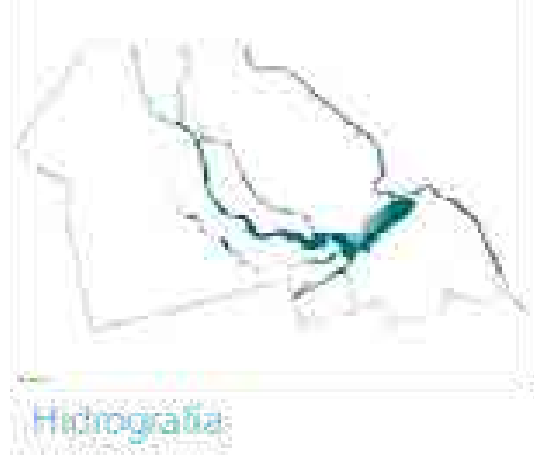

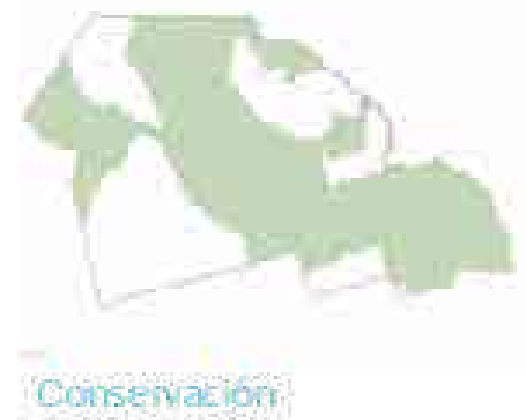

Esta rica biodiversidad se ha visto mermada por presiones antrópicas y especies invasoras. El proyecto pretende revertir esta situación y poner en valor este paisaje único en Chile a través de la definición de tres áreas que surgen de la yuxtaposición de la matriz ambiental y las unidades de paisaje estudiadas en el Capítulo 8, y de una interpretación de la normativa. En la Figura 12.15 se incorporan la matriz ambiental, la programática y la vial de esta macrozona.

La primera operación ha sido definir un centro, representado por un área de conservación ${ }^{409}$ de 400 ha, correspondiente a una sabana destinada a la recuperación por sucesión natural del bosque esclerófilo de Acacia caven, rodeado de un anillo que actuaría como buffer de resguardo (Figura 12.16). El perímetro de este anillo de 7 kilómetros lineales de extensión y más de $40 \mathrm{~m}$ de ancho, contempla un bosque esclerófilo de reforestación con 250.000 árboles nativos (quillayes, espinos, boldos y peumos entre otras especies del Valle Central), en el que desarrollarán paseos, ciclovías, senderos deportivos, avistamiento de aves, miradores panorámicos, una ruta botánica, étnica y geológica; un centro de información ambiental y servicios (las Figuras 12.17 y 12.18 corresponden a imágenes objetivo de esta zona). El anillo toma su forma (elíptica) del trazado de las vías preexistentes por el sur y las prolonga para contener los cursos de agua y llegar lo más próximo posible a los pies del cerro Puntilla de Lo Vásquez, una de las áreas con más diversidad ecológica.

La interacción entre el Anillo y la pradera cumple una serie de funciones ambientales entre las que se pueden destacar la ventilación de la cuenca, aprovechando los vientos provenientes del suroeste y la protección de la laguna y sus afluentes. Se espera que, en el paisaje árido propio de la pradera, se generare un proceso de sucesión natural que a largo plazo debería crecer para formar un bosque nativo más diverso.

El anillo formado por el nuevo bosque esclerófilo también rodea, restaura, recupera y pone en valor la laguna, que hoy sufre altos niveles de eutrificación ${ }^{410}$. La restauración ecológica de la laguna se abordará a esta escala por medio del trabajo de sus humedales y bordes. Se ha puesto énfasis en la conservación de las aves acuáticas y la restauración de sus hábitats, ya que además de su valor per se, son excelentes indicadores de la calidad del medio, acusando visiblemente cualquier perturbación.

Desde el punto de vista simbólico, tanto el anillo como el gran vacío servirán de referente a escala geográfica, ya que por su forma y composición será reconoci-
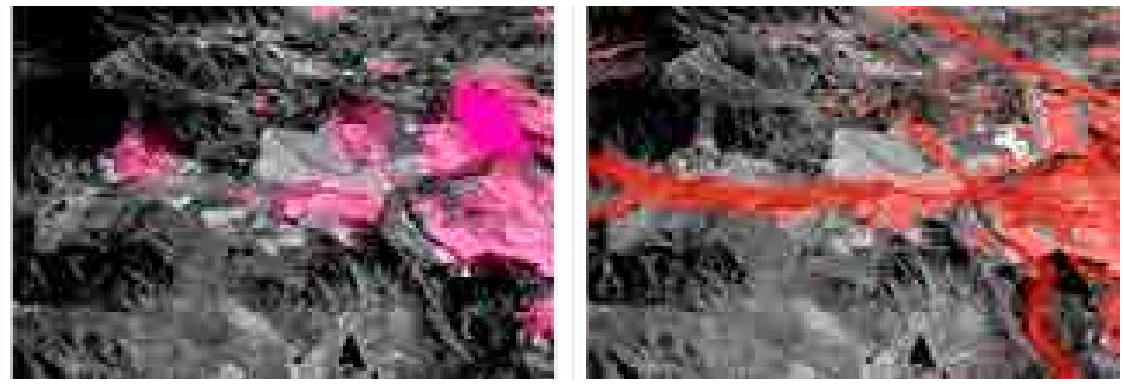


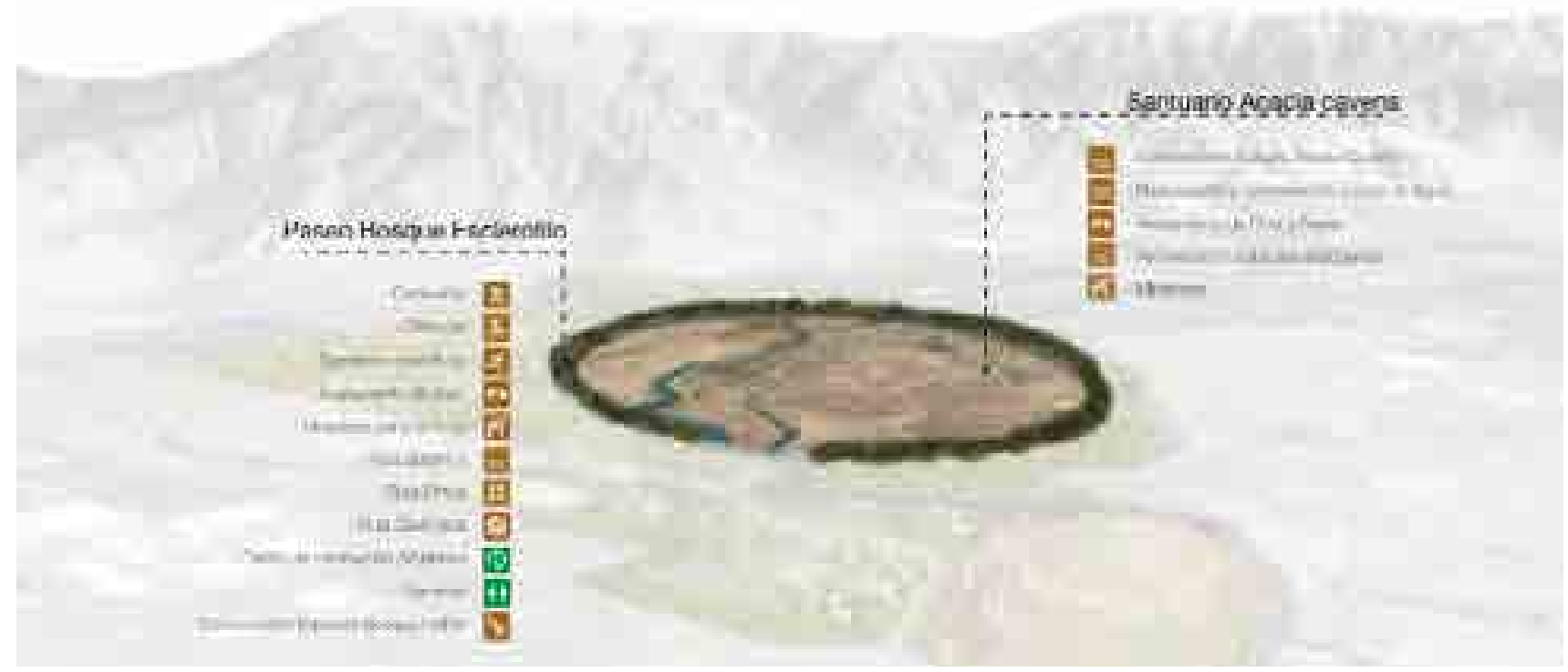

Figura 12.16. Área de Conservación. Elaboración propia en asociación con Allard y Bravo.

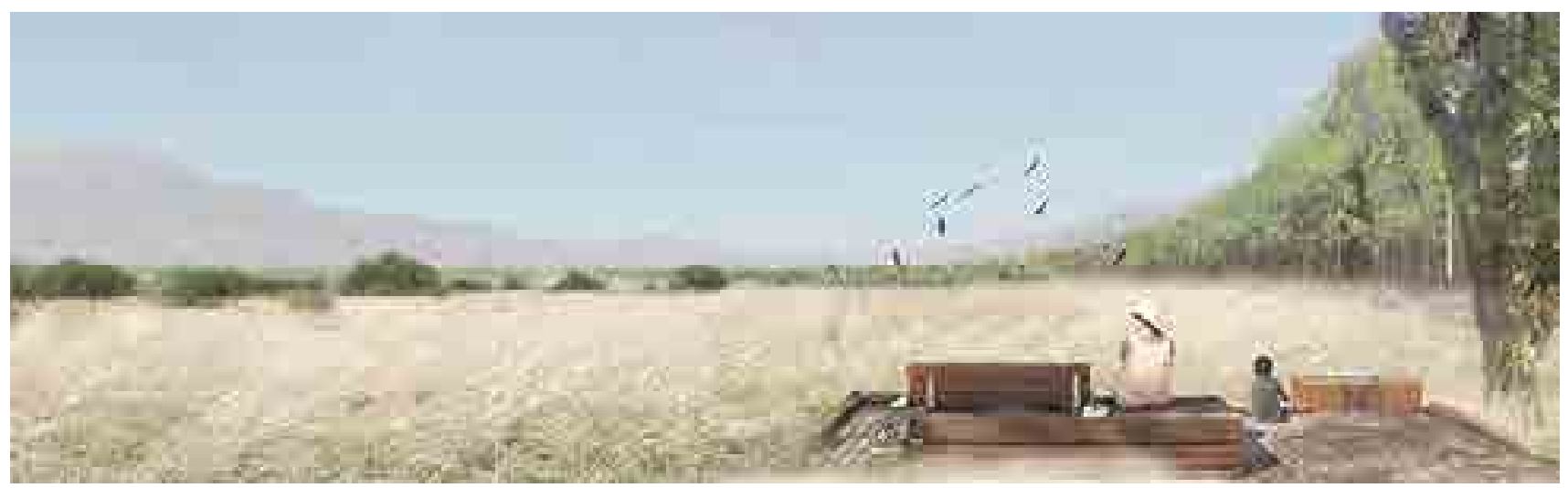

Figura 12.17. Imagen objetivo Área de conservación. Elaboración propia en asociación con Allard y Bravo.

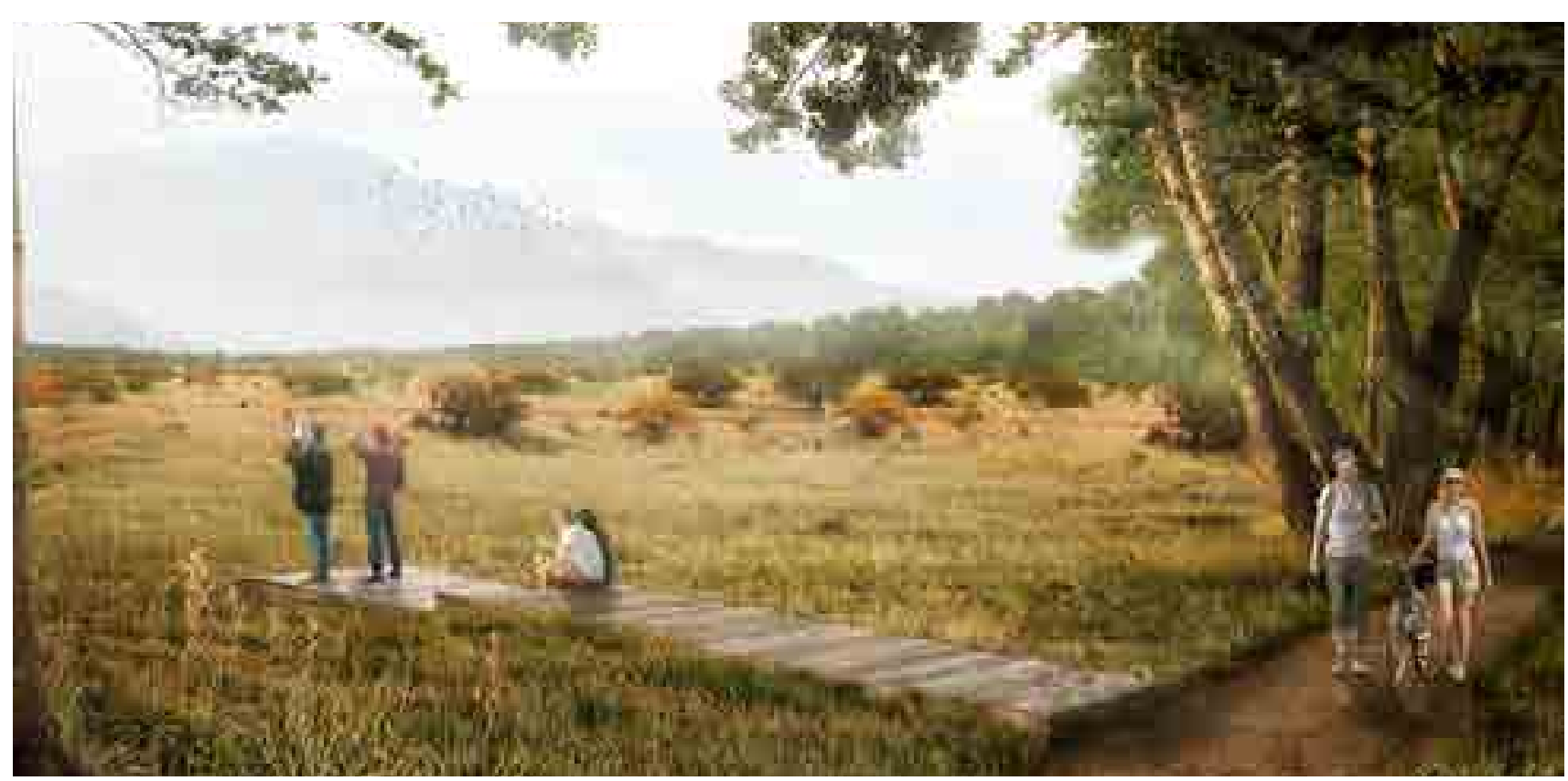

Figura 12.18. Imagen objetivo Área de conservación. Elaboración propia en asociación con Allard y Bravo. 
ble desde el aire.

La segunda estrategia, es la consolidación de un parque público de 200 ha, que como recordaremos es un compromiso establecido en el Decreto de Transferencia. Se incluyen en él programas recreativos, culturales y deportivos de uso ciudadano de carácter intercomunal y metropolitano, en los lugares que espontáneamente hoy se usan como zonas de paseo, de deportes náuticos y de picnic.

Esta zona abraza el anillo de conservación desde el norponiente al nororiente, como se muestra en la Figura 12.19 amarrando los cerros Amapola y Puntilla Lo Vásquez, dos hitos, que como hemos visto en los Capítulos 7 y 8 son importantes como puntos de referencia, como lugares desde donde observar el paisaje y también las áreas con la mayor diversidad de especies vegetales. Así el parque actúa también como corredor ecológico al interior del predio, vinculando elementos que sin el proyecto están fragmentados y por lo tanto fragilizados.

Otra función de este parque será la de articular el proyecto con la zona agrícola de Noviciado, ubicada en el límite norte del predio. La propuesta contempla desarrollar un programa de agricultura familiar campesina en un sector dentro del parque, con el apoyo de la Facultad de Agronomía. Este programa sería un "experimento real" de reasentamiento campesino en un parque, con rendimientos tanto estéticos como sociales. La idea es trabajar con las familias que ya viven en el terreno y con los vecinos de Noviciado para construir en conjunto un modelo que sirva como ejemplo de soberanía alimentaria dentro de una política medioambiental y paisajística coherente con el proyecto general. Recordemos también que de acuerdo a lo investigado (ver en el Capítulo 6, y anexo 3 con el registro de familias allegadas en el terreno) este sería un modo de compensar

${ }^{410}$ El término Eutrificación o eutroficación, describe:

el proceso natural y/o antropogénico que consiste en el enriquecimiento de las aguas con nutrientes, a un ritmo tal que no puede ser compensado por la mineralización total, de manera que la descomposición del exceso de materia orgánica produce una disminución del oxigeno en las aguas profundas. Sus efectos pueden interferir de modo importante con los distintos usos que el hombre puede hacer de los recursos acuáticos (abastecimiento de agua potable, riego, recreación, etc.) como en la vida de animales asociados a la laguna. Las masas de agua eutróficas tiene un alto nivel de productividad y de biomasa en todos los niveles tróficos; proliferan las algas, tienen aguas profundas pobres en oxígeno y un crecimiento intenso de las plantas acuáticas. En contraste, los cuerpos de agua oligotróficos, poseen concentraciones bajas de nutrientes, poseen mayor diversidad en las comunidades de plantas y animales, un bajo nivel de productividad primaria y de biomasa y una buena calidad del agua para distintos usos. (Conicet, s.f.)

${ }^{411}$ En esta tarea ha colaborado la Facultad de Ciencias Forestales y de la Conservación de la Naturaleza. La profesora Paulette Naulin Gyslin junto a sus estudiantes, ha realizado varias campañas desde el año 2016 con el fin de recolectar semillas del terreno. Agraria.

El parque público es el elemento principal de vinculación funcional y ecológica con otros proyectos que actualmente se desarrollan en la región: es la puerta de entrada e interfase para el proyecto $42 \mathrm{~K}$, con el cual se une a los pies del cerro Amapola. Que al mismo tiempo es una de las primeras áreas a intervenir, sumándose al proyecto Santiago Cerros isla.

Tanto para el parque público como para el anillo de conservación se establecerá un "banco de proyectos" que actuará como repositorio de los aportes y mitigaciones que por ley deben hacer los proyectos industriales, logísticos y habitacionales que se desarrollen en la Región Metropolitana. La idea es forestar dividiendo el diseño en secciones de distinto tamaño, a las que las empresas podrán postular cuando requieran hacer mitigaciones ambientales, quedando abierta a aquellas instituciones que quieran hacerlo de manera voluntaria. Para esto, desde la etapa de análisis, hemos iniciado un plan de recolección de semillas ${ }^{411}$ en el terreno, de manera de cultivar luego, especies que respondan a la genética del lugar y por lo tanto estén más adaptadas al ecosistema existente.

La tercera zona corresponde a un área de desarrollo de 422 ha, según se muestra en la Figura 12.21. La estrategia asociada a esta zona consiste en concentrar los edificios de la universidad en este sector en lo que hemos llamado "ecotonos de innovación", formado por sistema de parches ambientales con infraestructura destinada al desarrollo de investigación y producción, entretejido con la creación de lugares para la ciudadanía y la restauración ambiental.

Esta estrategia toma la zona más antropizada y deteriorada del terreno y al mismo tiempo la que ya posee servicios e infraestructura vial de buen nivel para casi 100 ha, las que determinarían la primera etapa de intervención.

Es también la zona que está más vulnerable a los cambios que contexto sufrirá en los próximos años, como son: la construcción de la PDUC Praderas (hacia el poniente), la construcción de una zona logística hacia la carretera (en parte del 


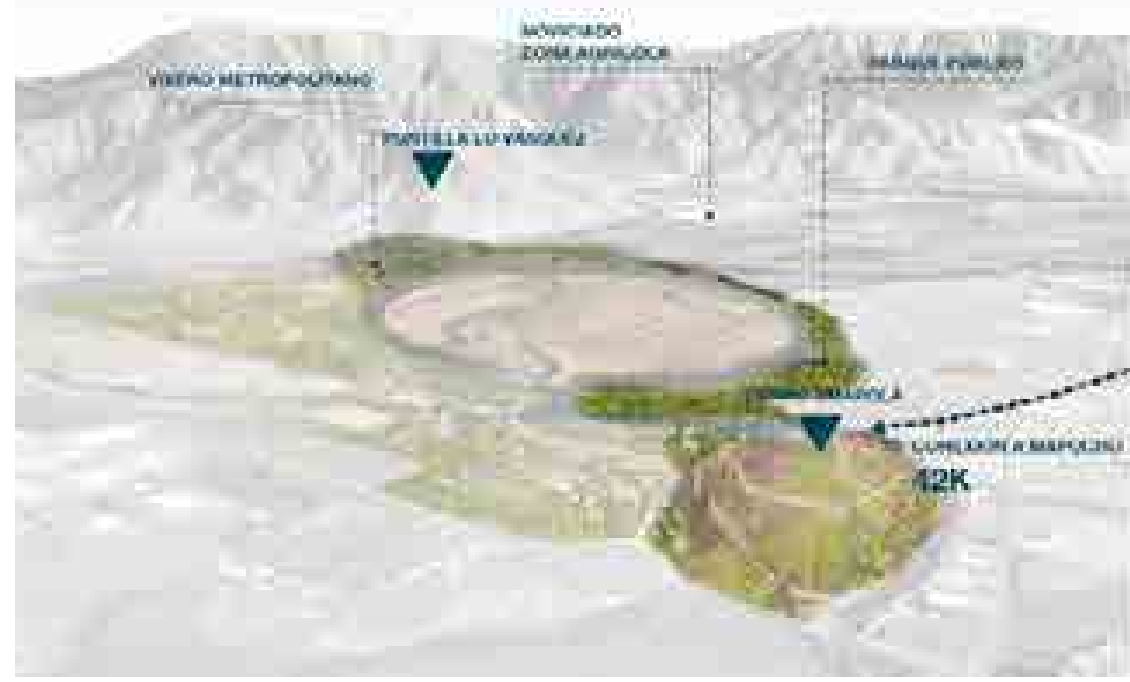

menec nibuto:

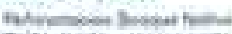

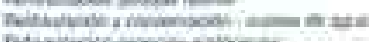

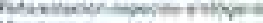

Puindeints

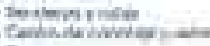

tritisios

sovelisi ion

bow ibse

tovents

\section{reveto Merimorocriwid}

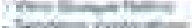

inosiontionses

Mowisevinge

20.

Nevevire

Sencen

Figura 12.19. Parque Público. Elaboración propia en asociación con Allard y Bravo.

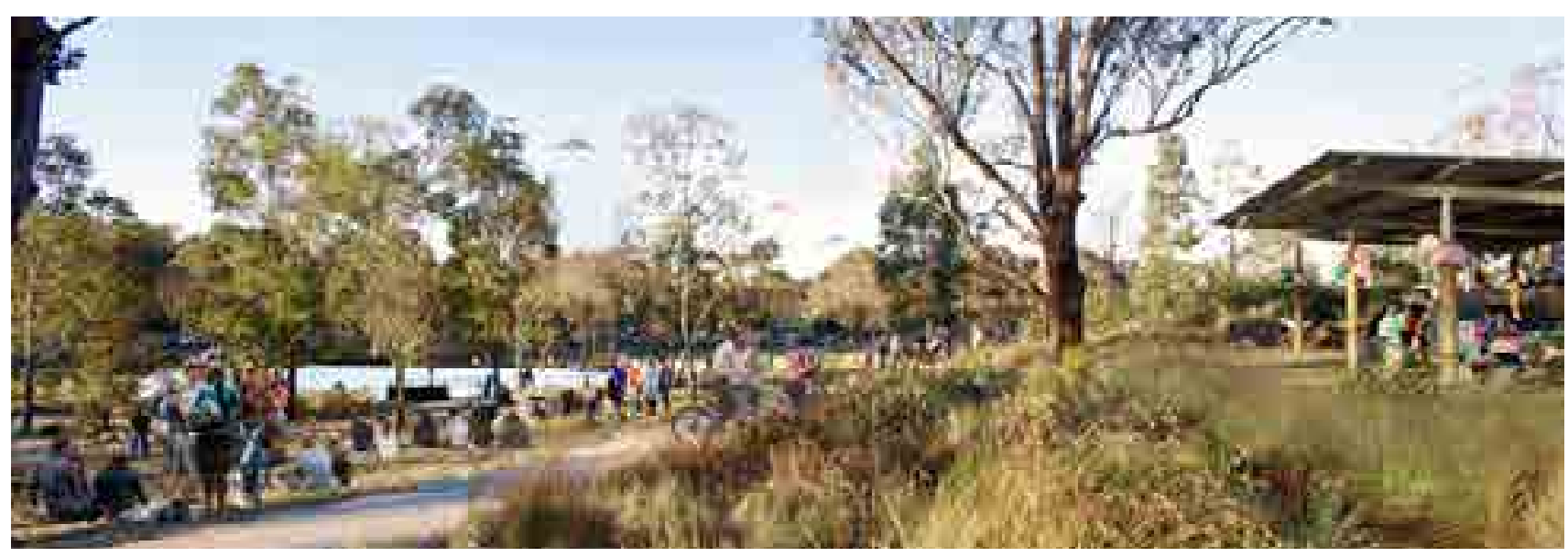

Figura 12.20. Imagen objetivo del parque público en la proximidad a la laguna. Elaboración propia en asociación con Allard y Bravo.

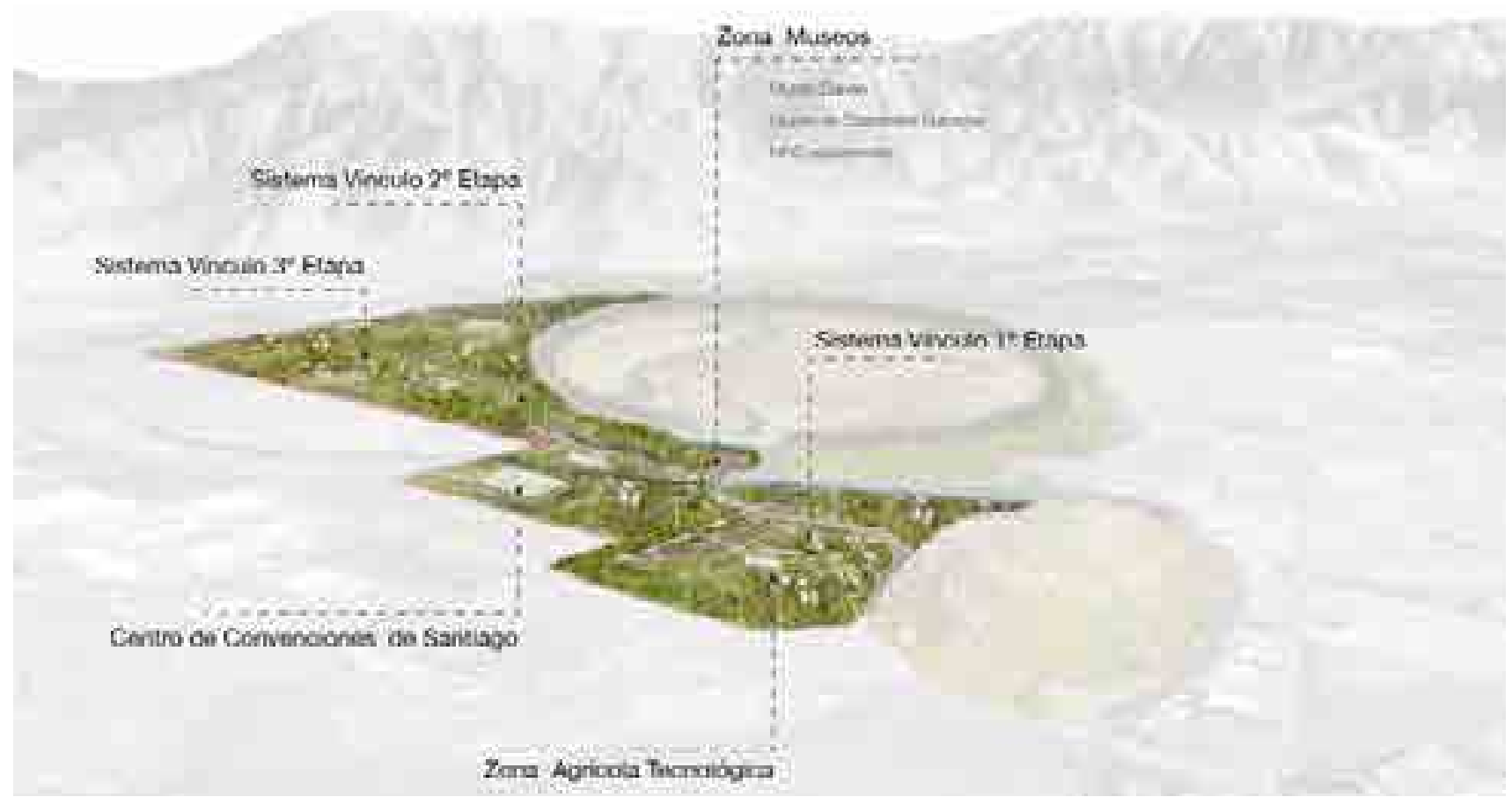

Figura 12.21. Área de desarrollo: Ecotono de innovación. Elaboración propia en asociación con Allard y Bravo. 

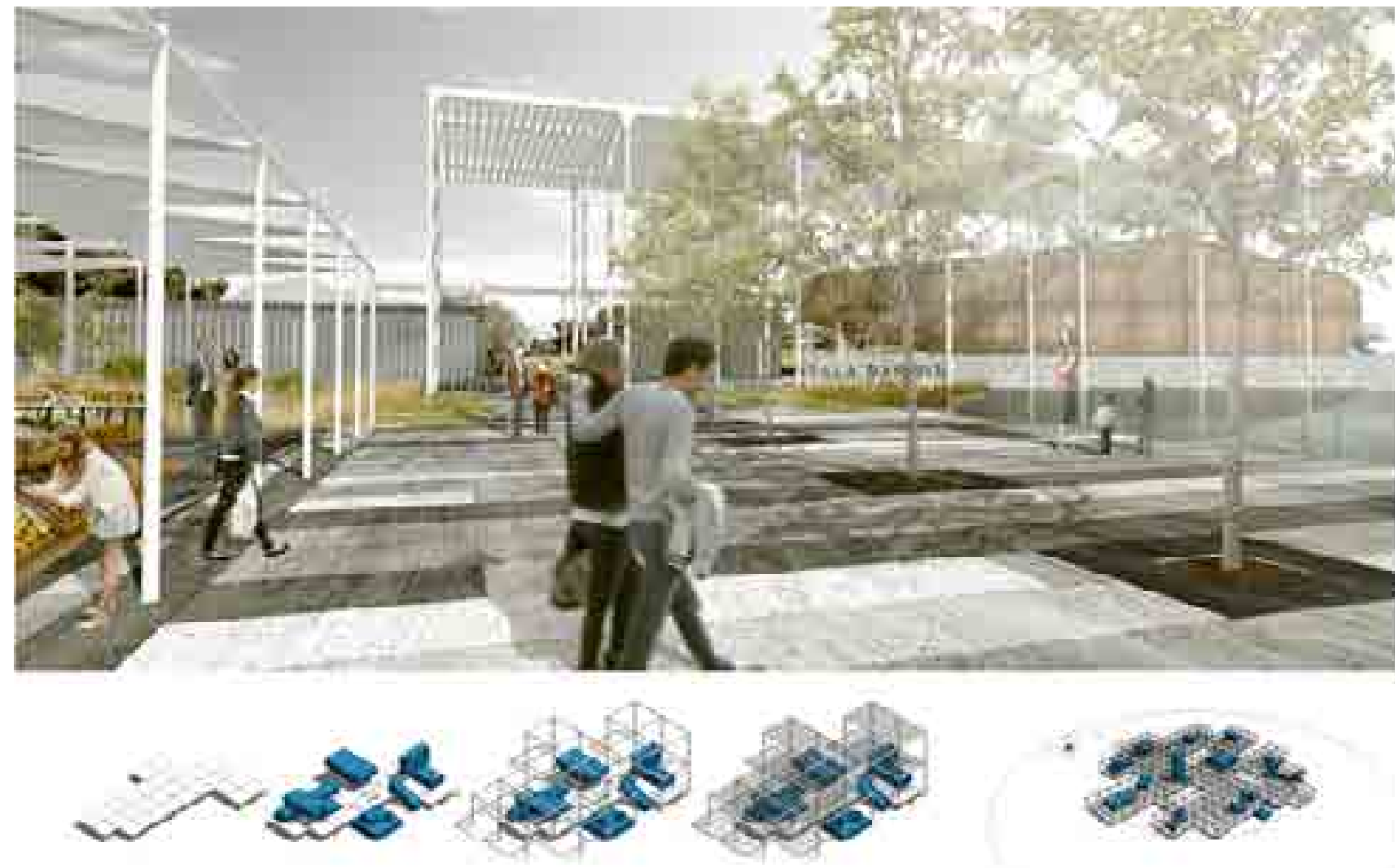

Figura 12.22. Imagen objetivo del Área de desarrollo. En la franja inferior se muestra el esquema de crecimiento propuesto. Elaboración propia en asociación con Allard y Bravo. 
límite sur, también como parte del proyecto Praderas) y la ampliación de la ruta 68, prevista para el 2023. Esta área es también cruzada por dos líneas de alta tensión, que dejan una franja de exclusión de $60 \mathrm{~m}$ de ancho, por el largo del terreno en sentido oriente-poniente.

Estas condiciones adversas y la cercanía a la ruta 68, tiene la ventaja de facilitar el acceso con fibra óptica de alta velocidad al terreno. La conectividad digital a alta velocidad es una condición crítica para el proyecto, ya que permitiría convertir Carén en un nodo de la Red Fotónica Nacional ${ }^{412}$. Hemos llamado a este componente del proyecto "plataforma logístico-digital" y es la permitirá, la conectividad con las regiones y otros países, la operación en tiempo real de equipos e instrumental a distancia, aplicables a medicina, astronomía, emergencias y minería; diversas aplicaciones en educación y manejo de grandes bases de datos.

\section{Un Plan para la laguna y su humedal:}

Gran parte del valor ecológico y paisajístico de este predio está relacionado con la presencia de la Laguna Carén. Lo hemos visto en su historia y mitos, también en la persistencia del nombre, que, pese a los distintos destinos pensados para este territorio, se ha mantenido.

Entre las funciones más importantes que la laguna tiene, es el almacenaje de agua (Figura 12.23). La calidad de este recurso está directamente relacionada con la capacidad de retener, remover y acumular compuestos, para lo cual, más que la laguna en sí misma, debe considerarse ésta en conjunto con sus afluentes como un humedal.

El tamaño del humedal determinará también el volumen de agua y el desarrollo de una flora y fauna diversa, especialmente de aves acuáticas.

Por lo anterior, resulta fundamental restaurar las funciones hídricas del humedal, que de acuerdo a experiencias como las recogidas por Olivia Fox en su tesis sobre el humedal de Batuco debieran considerar las siguientes acciones:

- $\quad$ Recuperar la periodicidad y amplitud de las inundaciones controlando
- $\quad$ las entradas y salidas de agua
- $\quad$ Aumentar la capacidad hidráulica
- $\quad$ Cotas de inundación
- $\quad$ Mejovisión de agua la calidad de las aguas $(2011$, p. 26$)$

Podríamos decir que estas recomendaciones se dividen en cantidad y calidad de las aguas. La cantidad, puede verse afectada por la disminución de precipitaciones, la alteración de los afluentes y el consumo excesivo del recurso. La cantidad, en el caso de Carén puede verse afectada tanto por razones externas como internas. Entre ellas las que el propio proyecto puede provocar con el plan de reforestación, ya que estos procesos requieren de mucha agua en los primeros tres años para el crecimiento de árboles (incluso los nativos), razón por la cual, es necesaria la implementación del plan maestro, incluida la reforestación, en etapas.

Siguiendo las recomendaciones de Fox, los proyectos de restauración de humedales pueden recurrir al uso de aguas provenientes de plantas de tratamiento, aguas lluvias y aguas grises si previamente son tratadas a través de procesos de fito-remediación y filtros verdes (Fox, 2011, p. 26). Por lo tanto, la calidad del agua requerirá intervenir la flora del humedal, mejorando la cubierta vegetal que también evita la erosión y favorece el hábitat de la fauna, que encuentra alimento y refugio en los bordes de la laguna.

El Plan Maestro considera la limpieza e incorporación de especies nativas en los bordes inundables de los afluentes de la laguna con un ancho promedio del doble del que tiene la superficie de agua, para acercarse a las proporciones que
412 Esta iniciativa ha sido liderada por el profesor Eduardo Vera, del Centro de Modelamiento Matemática, con la asesoría de la Universidad Tsukuba. Más ampliamente, La red fotónica busca unir los puntos donde se encuentran los clústers de las universidades y conectar el país, desde Arica a Punta Arenas. El año 2018 se iniciará la construcción del último tramo que une la zona austral con más de 3.000 kilómetros de cable submarino. Esta infraestructura hoy sólo está disponible en el clúster de universidades de la Región Metropolitana. 


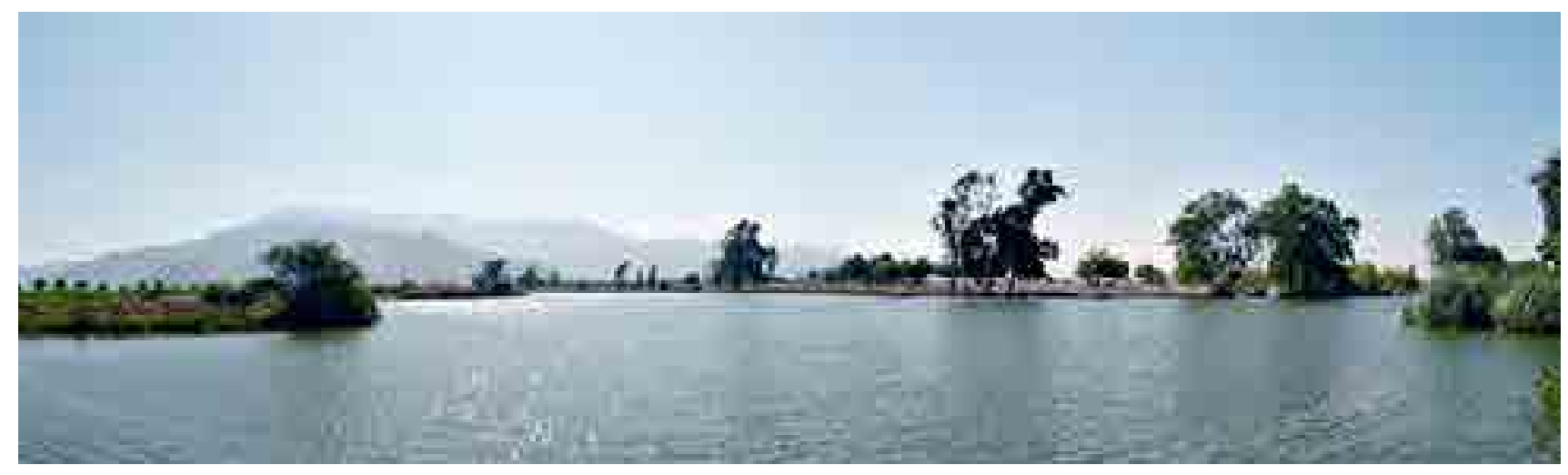

Figura 12.23. Laguna Carén. Elaboración propia.

\section{NORMA VIGENTE}

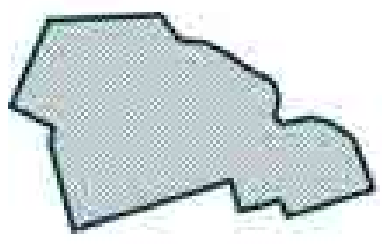

Decreto D.S. N 350 BBNW

-Traspaso Reserva Cora A

- Comcromiso parque zoona

\section{PRMS}

Pacque thatrejolmano

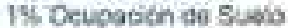

- Usos permitidos:

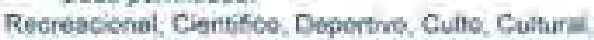

Etparcimiento. Turamo, Comercio Compiementario

\section{Descontaminacion}

Qecrefo N1E98 SEGPRES

Plan Prevención Descontaminadoon Athinsterika RM

Ler 19.300

Art 5.2.7.7 PRus 100: Acots verdeb no cocisolidadas. $20 \%$ Dcupacion de sueto para otros usos si se compansu àrea.

\section{PROPUESTA}

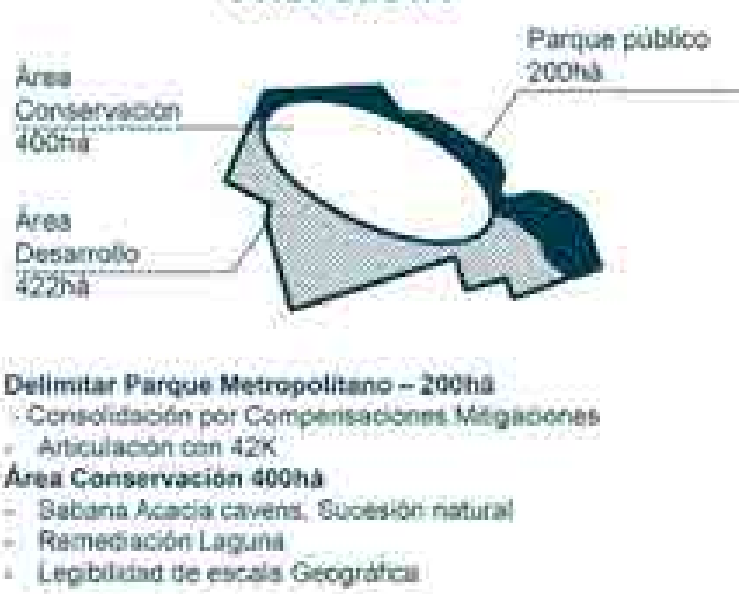

Oportunidad

Art.2 f.3t-OGUC: En aress verdes qua no se hubieren muterishizado

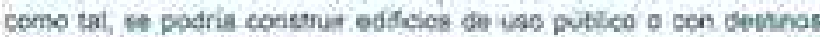

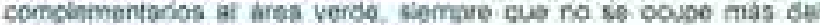
$20 \%$ de la woerficie tobal det predo

\section{interpretacion Usos de Suelo}

- 800 ha de Pargue Metropotians a Areas Recreacionafes de Intoress Ecoldgico Cuinurai

4. Deupacian de suble is.

- Consantibsoad del 0.5

- Usos Permitiós.

Avea Verde, Recreacion, Deperte, Culfira Cientifico, Espancimienth

Contro Eventos, Ressoranmi. Hospodaies.

Figura 12.24. Síntesis normativa. Elaboración propia en asociación con Allard y Bravo. 
establece el "Protocolo de recuperación y rehabilitación ecológica de humedales en centros urbanos" (Van der Hammen, T., Stiles, F., Rosselli, L., Chisacá, M., Camargo, G., Guillot, G., Useche, Y., \& Rivera, D., 2008, p. 134) con una proporción de 3/7 entre espejo de agua y borde inundable tratado, el que podría considerarse que se extiende, en el caso de Carén, hasta el anillo de amortiguación (buffer) proyectado como área de restauración ecológica.

Más allá de la función ecológica del humedal, coincidimos con lo señalado por Oscar Cid (2005) sobre el potencial educativo de los humedales, incorporando sus principales criterios de valoración en el discurso sobre Laguna Carén:

- Constituyen "aulas abiertas" donde se pueden observar, conocer y estudiar conceptos, fenómenos y procesos muy singulares. Permiten leer e interpretar las relaciones que una comunidad establece con su medio.

- Los humedales son auténticos "laboratorios de biodiversidad" que nos permiten conocer procesos ecológicos de forma muy intuitiva.

- Los humedales constituyen también "laboratorios sociales" donde la relación ancestral de los habitantes y sus alrededores con el humedal ha sufrido cambios profundos como consecuencia de los nuevos estilos de vida en nuestro contexto socioeconómico.

- El análisis de los usos actuales y pasados del humedal nos proporciona informaciones relevantes sobre la sostenibilidad, y también de la insostenibilidad, de estos territorios.

- La gestión del humedal se determina, la mayor parte de los casos, lejos del humedal. El análisis de las problemáticas ambientales de un humedal resulta, en muchas ocasiones, un ejercicio insustituible para comprender las relaciones entre las políticas ambientales globales y las realidades locales, así como para comprender los alcances y limitaciones de la planificación de la conservación.

- Desde el punto de vista metodológico, el estudio de los humedales y los paisajes del agua exigen desarrollar planteamientos interdisciplinares que contribuyen a la comprensión de la noción de complejidad e interdependencia.

- La subjetividad de la percepción y los sentimientos, las valoraciones y actitudes personales condicionan la lectura que hacemos del paisaje e influyen en nuestra relación vital con el mismo.

- Los paisajes del agua, como los otros paisajes, tienen carácter global, integrador, dinámico y permiten ser tratados desde distintos puntos de vista. Actúan como vertebradores de procesos de aprendizaje, constituyen por sí mismos un objeto de estudio desencadenante de investigaciones, moviliza conceptos, técnicas de trabajo y valores.

- Las actividades educativas en los humedales permiten evaluar y poner de manifiesto los cambios de valoración y de preferencias de las personas que participan en las actividades ambientales.

- Los humedales provocan emociones, estimulan sensaciones y movilizan sentimientos. Permiten un trabajo basado en la percepción sensorial y, por tanto, adaptable a cualquier edad.

(Cid, 2005, pp. 2-3).

\section{Interpretación normativa}

Desde el punto de vista normativo, este plan hace la siguiente interpretación resumida en la Figura 12.24, y que en síntesis define lo siguiente: Se considera el sitio completo como Parque Metropolitano, de acuerdo al PRMS de 1994. Se concentra la ocupación de suelo del $1 \%$ en el área de desarrollo de la universidad (zona 3), lo que significa $102.200 \mathrm{~m}^{2}$ de superficie a nivel de piso, con una constructibilidad de tres veces ese valor, llegando a $306.600 \mathrm{~m}^{2}$, que es justamente el doble de la superficie edificada que, por ejemplo, tiene Cambridge Science Park. Por su parte, Sophia Antípolis con 2.400 ha de terreno tiene 1,1 millones de $\mathrm{m}^{2}$ edificados; Ciudad del Saber $172.078 \mathrm{~m}^{2}$ de edificios patrimoniales y 255.764 de edificios nuevos (total $427.842 \mathrm{~m}^{2}$ totales), pero, considerando alturas de hasta 8 pisos, lo que contraviene lo que hemos establecido como máximo para Carén. Bajo estas condiciones el proyecto es viable, considerando un crecimiento en etapas, como un proceso evolutivo que debe ser evaluado constantemente. Incluso a futuro se podría solicitar un aumento de ocupación de suelo para esta misma zona.

Debemos reconocer, que, dentro de experiencia, que viabilizar el proyecto desde 
el punto de vista normativo ha significado proporcionalmente muchas horas de gestión, por parte del equipo de proyecto.

\subsubsection{La micro-escala y la primera etapa de intervención.}

La primera etapa está representada por las primeras iniciativas que la universidad ha logrado levantar en período 2014-2018 a partir de los principios enunciados en el proyecto académico. El desafío ha sido determinar como a través de acciones mínimas, producir un efecto fundacional. Por lo tanto, más que la implementación de un plan maestro, esta primera etapa es una suerte de acupuntura arquitectónico-paisajista, que considera las siguientes zonas y componentes (Figura 12.25):

Pabellón de Acceso: En el ingreso principal al parque se emplaza una plaza semicubierta, que funciona como un espacio de encuentro, orientación, congregación y referencia que a su vez actuará como punto de partida de una red de circulaciones peatonales que conectarán con los otros nodos de esta red de espacios (Figura 12.26). Esta primera obra ya ejecutada, fue inaugurada con fecha 9 de enero de 2018, por la Presidenta de la República ${ }^{413}$.

Sistema vínculo: se trata de algo más que un edificio. Es una matriz estructural de marcos de acero que se despliegan cautelosamente sobre el territorio como una plataforma y cubierta para albergar los primeros espacios de innovación, investigación, trabajo y divulgación del Plan Maestro Laguna Carén.

Este sistema surge de una interpretación de los requerimientos y restricciones del lugar y de los procesos de innovación y vinculación con el medio que se promueven en el proyecto académico.

El tipo de suelo de Carén, principalmente constituido por cenizas volcánicas pumicíticas y roca madre muy profunda, requiere de soluciones de fundación mediante sistemas puntuales, lo que hace menos dañino el proceso constructivo, favorece las condiciones ambientales y continuidad ecológica de la flora y fauna que crecen a ras de suelo, si la estructura se levanta. Al subir las estructuras se crea un piso noble o tarima de $4 \mathrm{~m}$ sobre el nivel natural del suelo, que alberga todos los servicios y redes necesarios para activar los programas, espacios y laboratorios de investigación. Previniendo también el riesgo de inundación.

Este espacio de servicios además permite generar estacionamientos cubiertos, reduciendo la huella ecológica del conjunto.

La estructura del Sistema Vínculo se proyecta hasta los $16 \mathrm{~m}$ de altura, en módulos regulares, que son coronados por un parrón de paneles solares, aprovechando las excelentes condiciones de radiación solar existentes en el lugar.

Este diseño facilita la experimentación e implementación de los más avanzados sistemas de climatización pasivos y de eficiencia energética. De esta manera se espera que la huella de carbono del complejo sea mínima, y promueva el desarrollo de actividades y proyectos que tengan como meta llegar a cero emisiones.

La geometría simple y la esbeltez de los marcos de acero son una reminiscencia de los parrones chilenos. Como hemos visto en el Capítulo 4, estos espacios intermedios de la arquitectura tradicional son justamente los que se ajustan al cambio de estaciones, otorgando sombra en verano y dejando pasar el sol en invierno. Son también los espacios para el encuentro y la conversación. El color blanco y la regularidad dada por la modulación actúan por contraste con el paisaje natural, en una acción leve, sutil y consiente de la fragilidad del territorio en que se emplaza (Figura 12.27).

El programa y espacios que albergará el Sistema Vínculo se organizan en forma adaptable y modular, bajo el concepto de plug-in, o como libros en una biblioteca. 


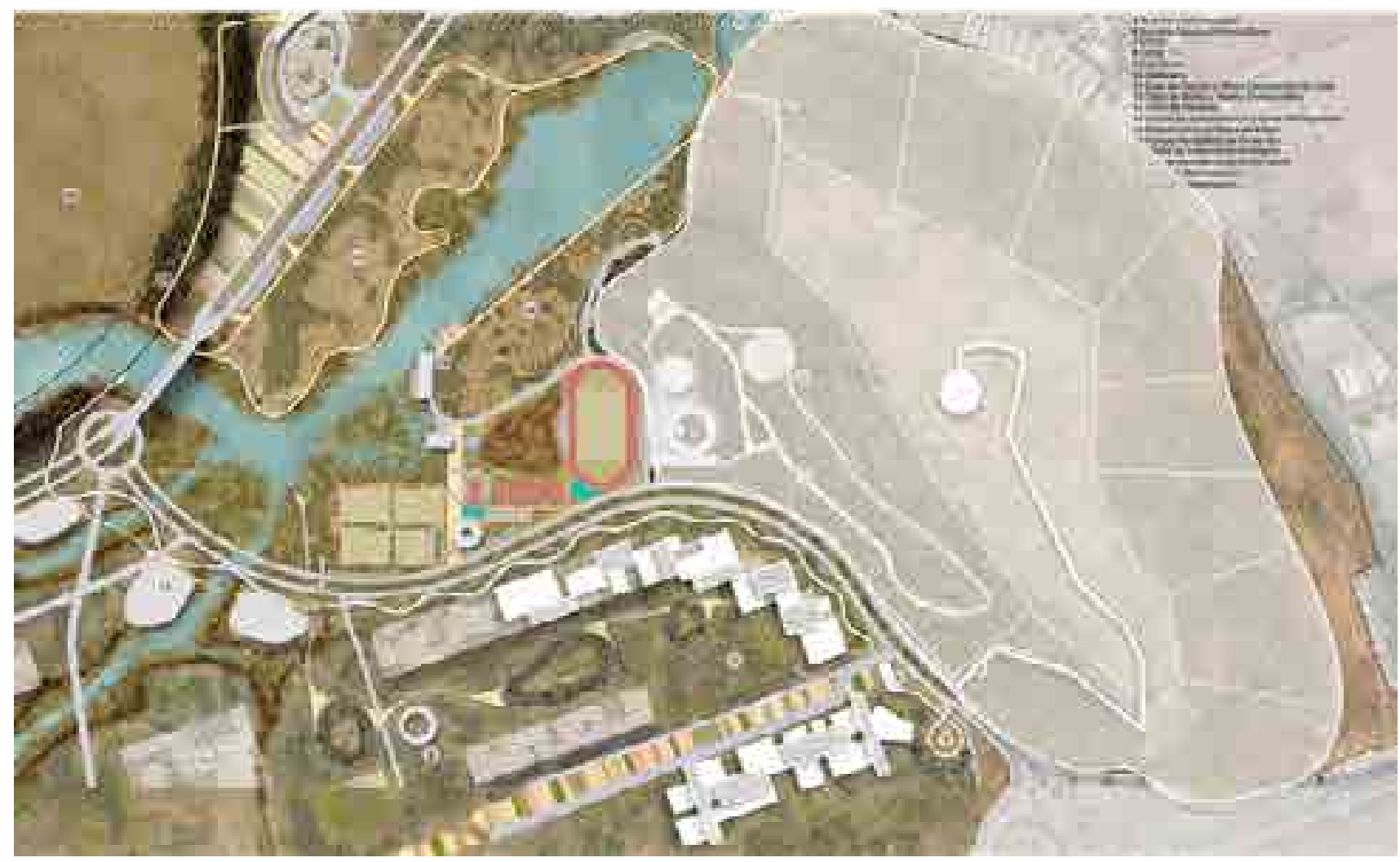

Figura 12.25. Primera etapa Plan Maestro Laguna Carén. Elaboración propia en asociación con Allard y Bravo.
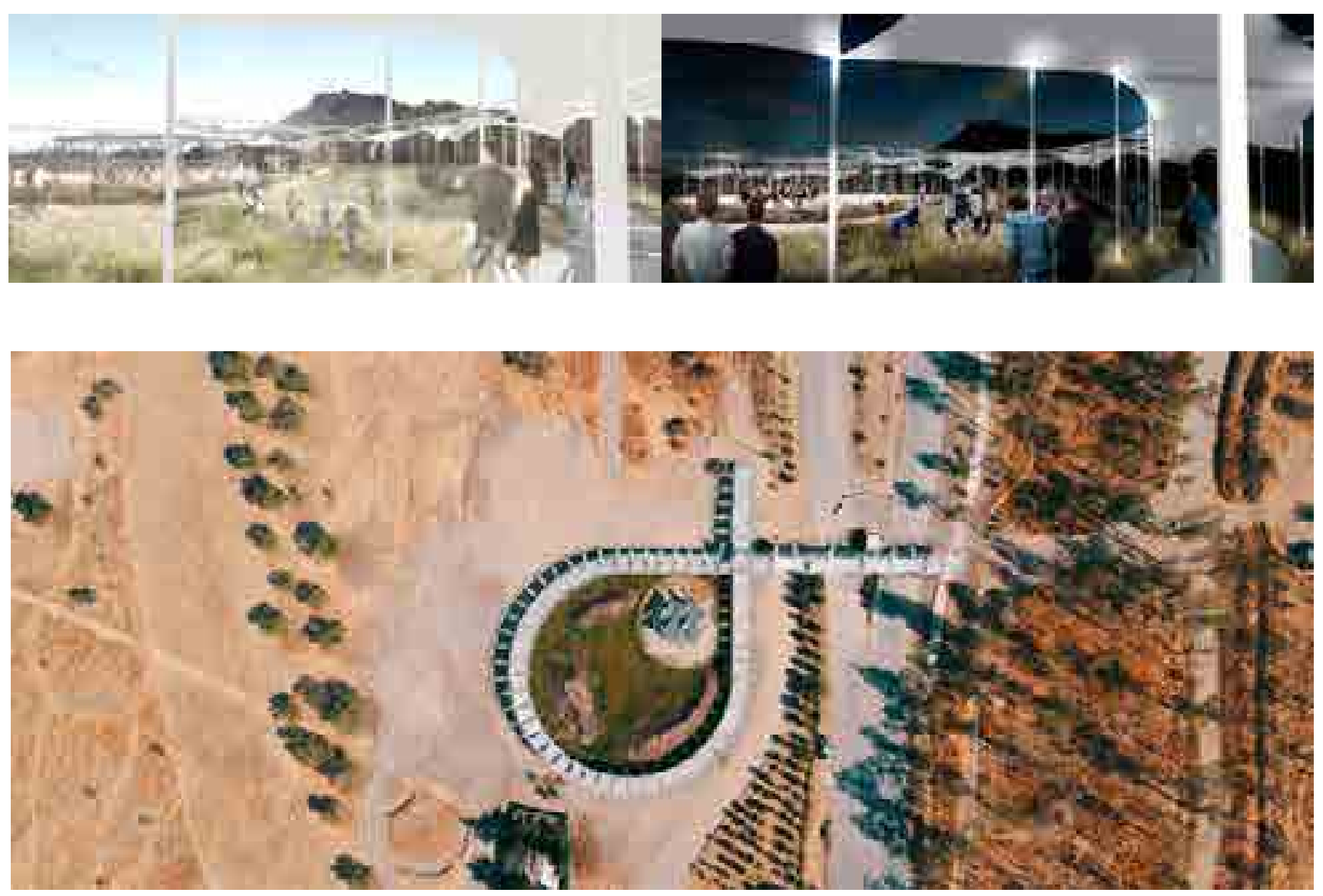

Figura 12.26. Portal de Acceso. Imágenes objetivo diurna (superior izquierda) y nocturna (superior derecha). La imagen inferior corresponde a una vista aérea (dron) del portal ejecutado en diciembre de 2018. 
bilidad y adaptabilidad en el tiempo. La movilidad horizontal y vertical a lo largo del Sistema Vínculo se dará por medio de los espacios intermedios, patios, corredores y jardines.

Algunos programas y recintos de mayor escala como Auditorios y Halls llegarán al suelo de manera de resolver sus solicitaciones sísmicas y el acceso de servicio junto con permitir el amplio acceso a la comunidad.

En el primer nivel aparece la tarima técnica o entresuelo, sobre la cual se desarrollarán los programas de carácter semipúblico como cafeterías, espacios de trabajo conjunto, salas de clases y extensión (Figura 12.28).

En el segundo nivel se ubicarán espacios semiprivados como salas de estudio y trabajo grupal, prototipado rápido y fab-labs.

En el tercer nivel se proponen los espacios más privados como oficinas, laboratorios especializados, y dependencias administrativas.

Este primer edificio, será una síntesis del potencial que tendrá a futuro el Sistema Vínculo, poniendo a disposición de la comunidad una infraestructura compartida de calidad, con laboratorios, espacios de trabajo compartido (co-work), un auditorio para 500 personas, salas de clases y salas multiusos, cafeterías y la primera sala de exposiciones, que se inaugurará con una muestra sobre las expediciones de Charles Darwin en Chile, como anticipo del Museo que se construirá a futuro. Dentro de lo que hemos analizado en el Capítulo 11, este edificio se asimila a la tipología de la incubadora, en este caso, de proyectos de toda índole, no solo científico-tecnológicos sino también artísticos y comunitarios.

Humedales: Se propone la intervención de la ribera norte de la laguna con humedales artificiales para operar como bío-filtros de las aguas, junto con generar un búfer para restringir el acceso indiscriminado del público a las zonas con aguas profundas. Esta intervención es parte del proyecto general de humedales que permitirá mejorar las condiciones ecológicas del sistema hídrico y al mismo tiempo regenerar el hábitat de las aves migratorias. En paralelo, en el extremo oriente del parque, dadas las características de escurrimiento del terreno, se ubica la planta de tratamiento de aguas servidas, diseñada en base a sistemas naturales de humedales y biodigestores permitiendo la recuperación de aguas grises para riego. Incluyéndose también dentro de las actividades de educación ambiental para el público general.

Arboretum: A los pies del cerro Amapola se propone un jardín botánico, dedicado primordialmente a árboles y otras plantas leñosas. Con la ayuda de la Facultad de Ciencias Forestales y de Conservación de la Naturaleza, se trabaja en el cultivo de una colección de árboles disponibles para su estudio científico, lo que considera la implementación de un centro de educación ambiental, una zona de exposiciones y vivero. Esta primera etapa del parque considera un programa educacional que es un modelo experiencial para padres e hijos escolares y preescolares, basado en un ejercicio de relación y contacto directo con la naturaleza, estableciendo vínculos de apego con el territorio y su riqueza desde la primera infancia (Figura 12.29.).

Se ha proyectado también la rehabilitación de las instalaciones de la medialuna existente, adecuándola como un espacio para eventos culturales y sociales.

\section{Cerro Amapola:}

Desde el Parque Público se desarrolla un camino-paseo que asciende rodeando el cerro Amapola hasta llegar a la cumbre desde donde se pueden contemplar 


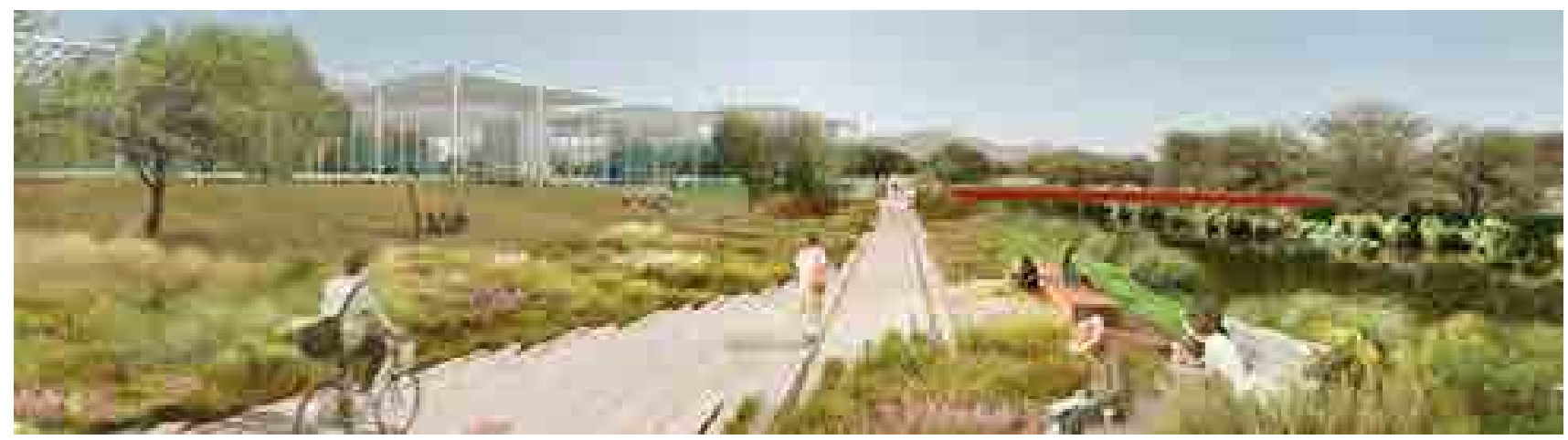

Figura 12.27. Imagen objetivo del sistema vínculo. Elaboración propia en asociación con Allard y Bravo.

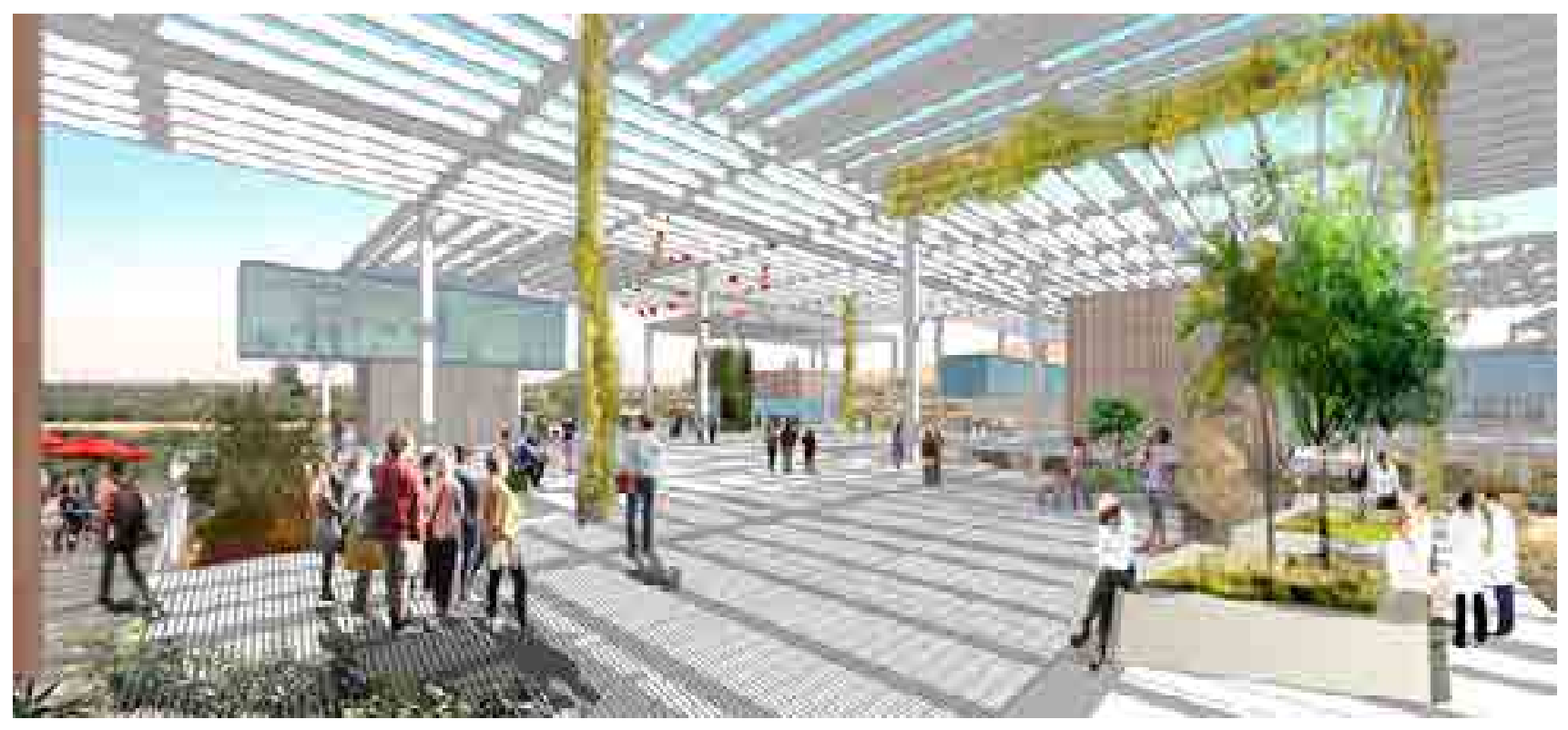

Figura 12.28. Imagen objetivo del sistema vínculo para la creación de espacios públicos. Reminiscencia de los parrones de la arquitectura tradicional chilena. Elaboración propia en asociación con Allard y Bravo.

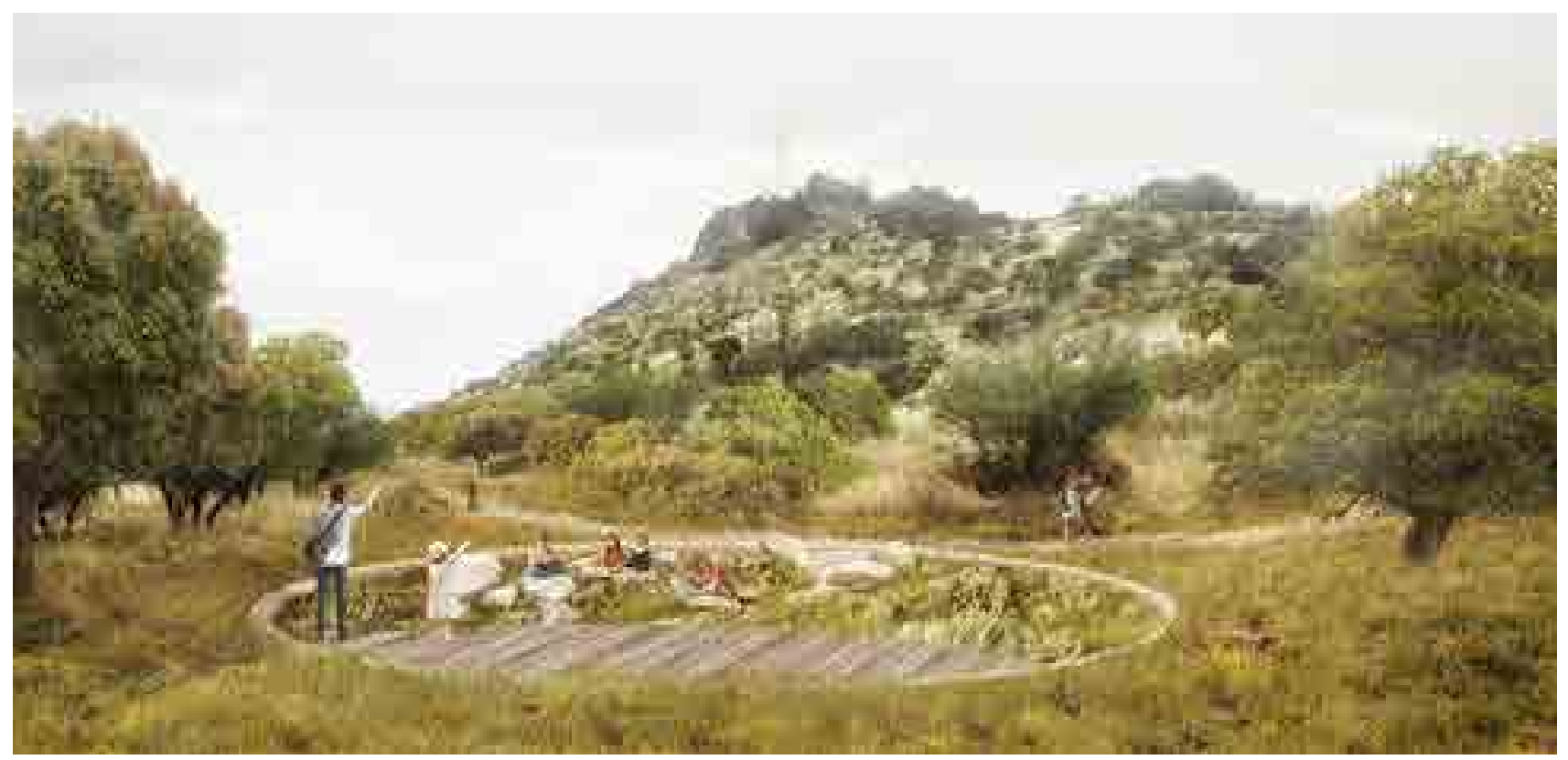

Figura 12. 29. Imagen objetivo del parque público, a los pies del cerro Amapola. Elaboración propia en asociación con Allard y Bravo. 
ambas cordilleras y el valle de Santiago. En la cumbre, se propone la construcción de una torre escultural para relocalizar las cinco antenas de telecomunicaciones existentes, cuya base estará rodeada por un mirador panorámico (Figura 12.30). Además de eliminar el desorden producido por el enjambre de instalaciones en la cumbre del cerro, este elemento único, con una sutil iluminación, podría transformarse en un hito a escala regional, un punto que actúa como signo de la conectividad global del Parque Laguna Carén, marcando el acceso a Santiago desde la Ruta 68 y desde las aeronaves en su descenso nocturno a Santiago (Figura 12.31).

\section{Club de campo y remo}

Ubicado en el sector suroriente de la laguna Carén, y a distancia prudente de las áreas de conservación y remediación del humedal se emplazará el Club de Campo de la Universidad de Chile (Figura 12.32).

Este centro deportivo y social responde a un anhelo tanto de la comunidad académica y funcionarios de la Universidad, así como los vecinos de las comunas de Pudahuel y el sector poniente de la capital, entregando equipamiento para la recreación y el deporte.

El complejo contempla un edificio gimnasio abierto a la comunidad universitaria y local junto a 1 cancha de fútbol de tamaño oficial con pista de atletismo, 7 canchas de futbolito, 5 canchas de tenis con un court central, así como canchas de tenis y squash en conjunto con una pista de entrenamiento de 1,5 kilómetros con estaciones de ejercitación multifuncional y calistenia, permitiendo el desarrollo integral de actividades deportivas (Figura 12.33).

Complementario a las instalaciones deportivas se propone una Casa Club aledaña a una zona con humedales, permitiendo vistas hacia la laguna y el ecosistema local, con servicios de restaurant, salones de reunión y equipamiento de apoyo. La edificación se abre hacia una terraza y jardines de esparcimiento con una piscina recreativa con zona de baños y juegos de agua para niños.

En la ribera Sur de la laguna se propone la construcción de un paseo costanera apoyado por una zona de parque recreativo que incorpora infraestructura para picnic y celebraciones familiares.

Como remate del malecón, se instalará el Club de Remo de la Universidad, con muelles, embarcadero y servicio de cafetería. Como no está permitido bañarse en la laguna, se propone además una serie de piscinas flotantes desarrolladas con tecnologías bionaturales.

Huertos Experimentales: Aprovechando la faja de seguridad del tendido de Alta Tensión ubicado al sur de parque, se propone una zona de huertos experimentales, donde se pueda explorar en forma controlada, cultivos avanzados para zonas áridas junto con investigación aplicada al desarrollo de permacultura y cultivos en zonas urbanas (Figura 12.34.).

Como hemos señalado en la descripción del proyecto Académico, junto con el desarrollo del Plan Maestro, el equipo de arquitectos ${ }^{414}$ trabajó en la formulación de una serie de proyectos de investigación aplicada, algunos de los cuales han sido ganadores de fondos públicos para su ejecución (ver presentación en Anexo 2). Estos proyectos, son por lo tanto los primeros habitantes del Parque Laguna Carén, quienes, de acuerdo a las condiciones presupuestarias construirán sus edificios propios o bien ocuparán el edificio Vínculo en su etapa de incubación: 


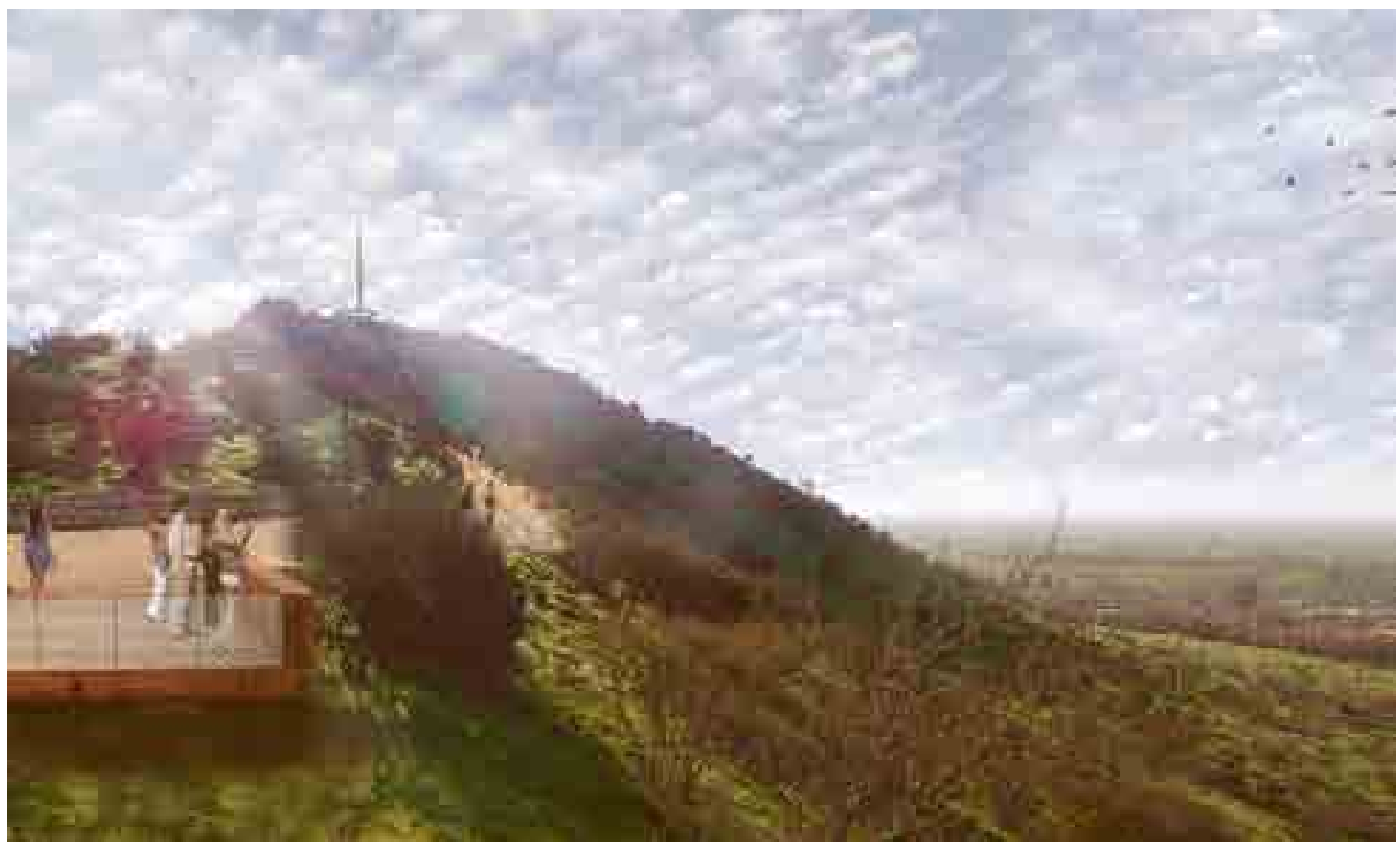

Figura 12.30. Imagen objetivo paseo cerro Amapolas. En primer plano, uno de los miradores a la Cordillera de Los Andes, al fondo la torre que concentra las antenas existentes. Elaboración propia en asociación con Allard y Bravo.

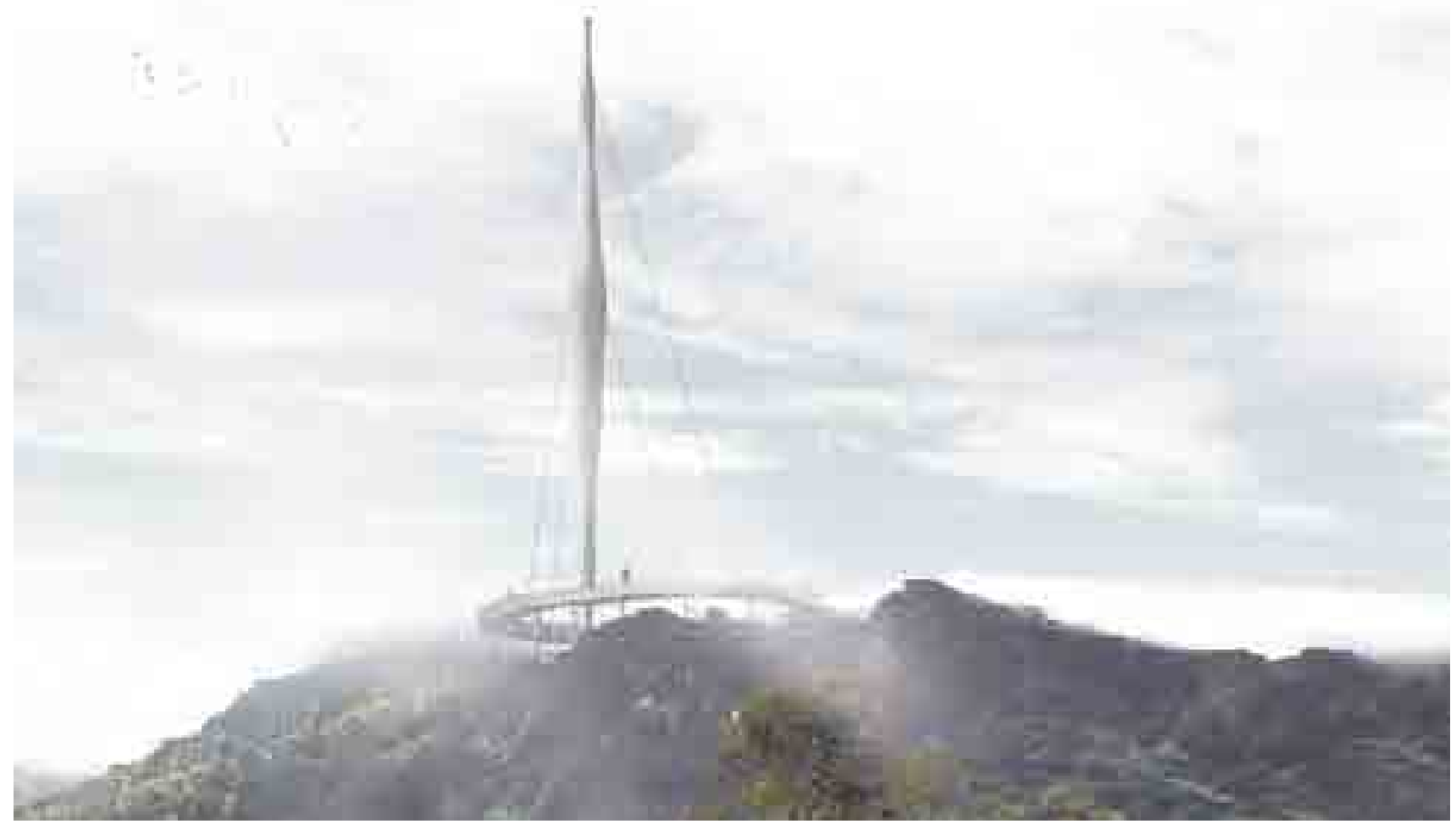

Figura 12.31. Imagen objetivo de la torre-mirador en la cumbre del cerro Amapola. Elaboración propia en asociación con Allard y Bravo. 


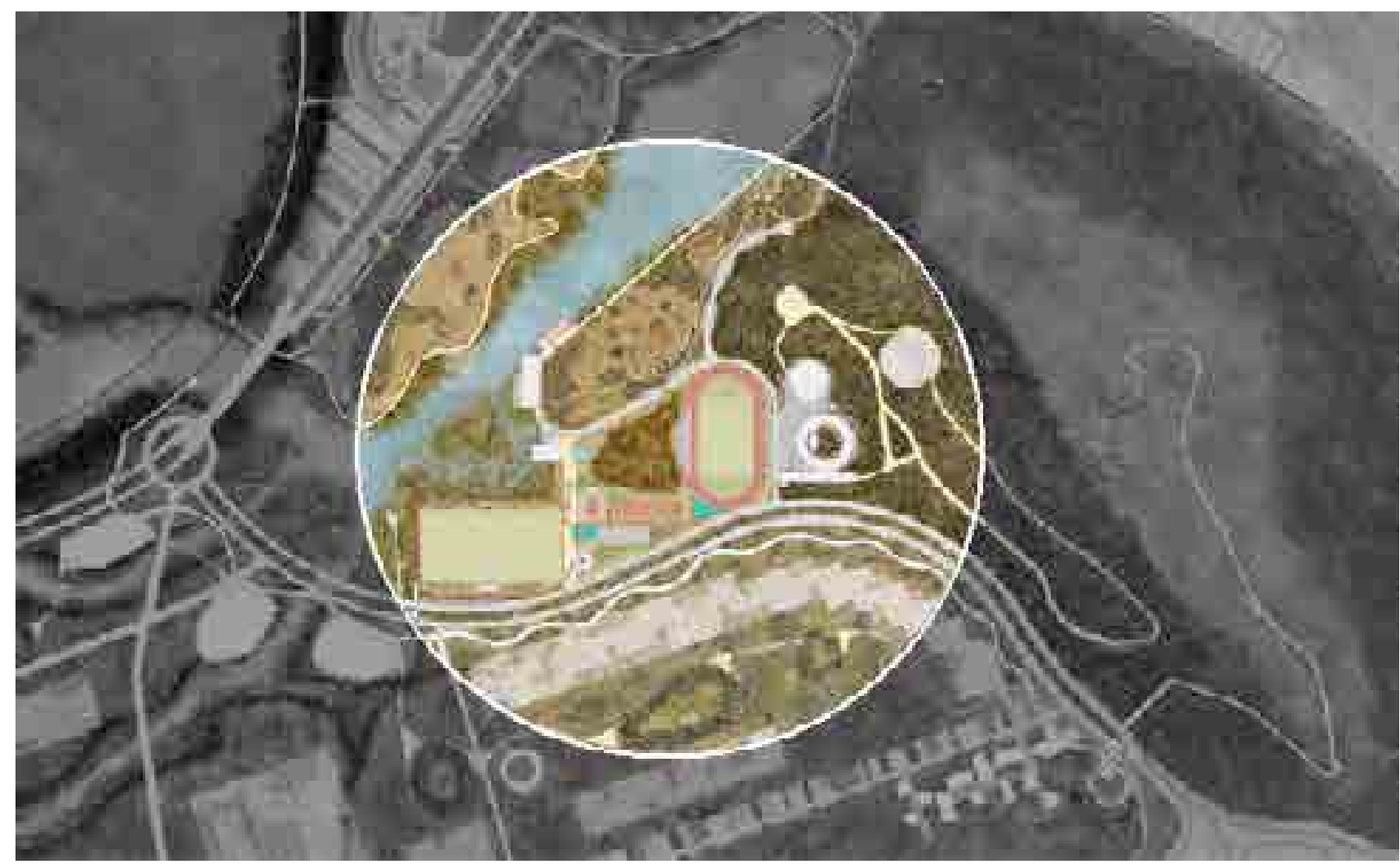

Figura 12. 32. Planta del sector que alberga el Club de Campo de la universidad. Elaboración propia en asociación con Allard y Bravo.

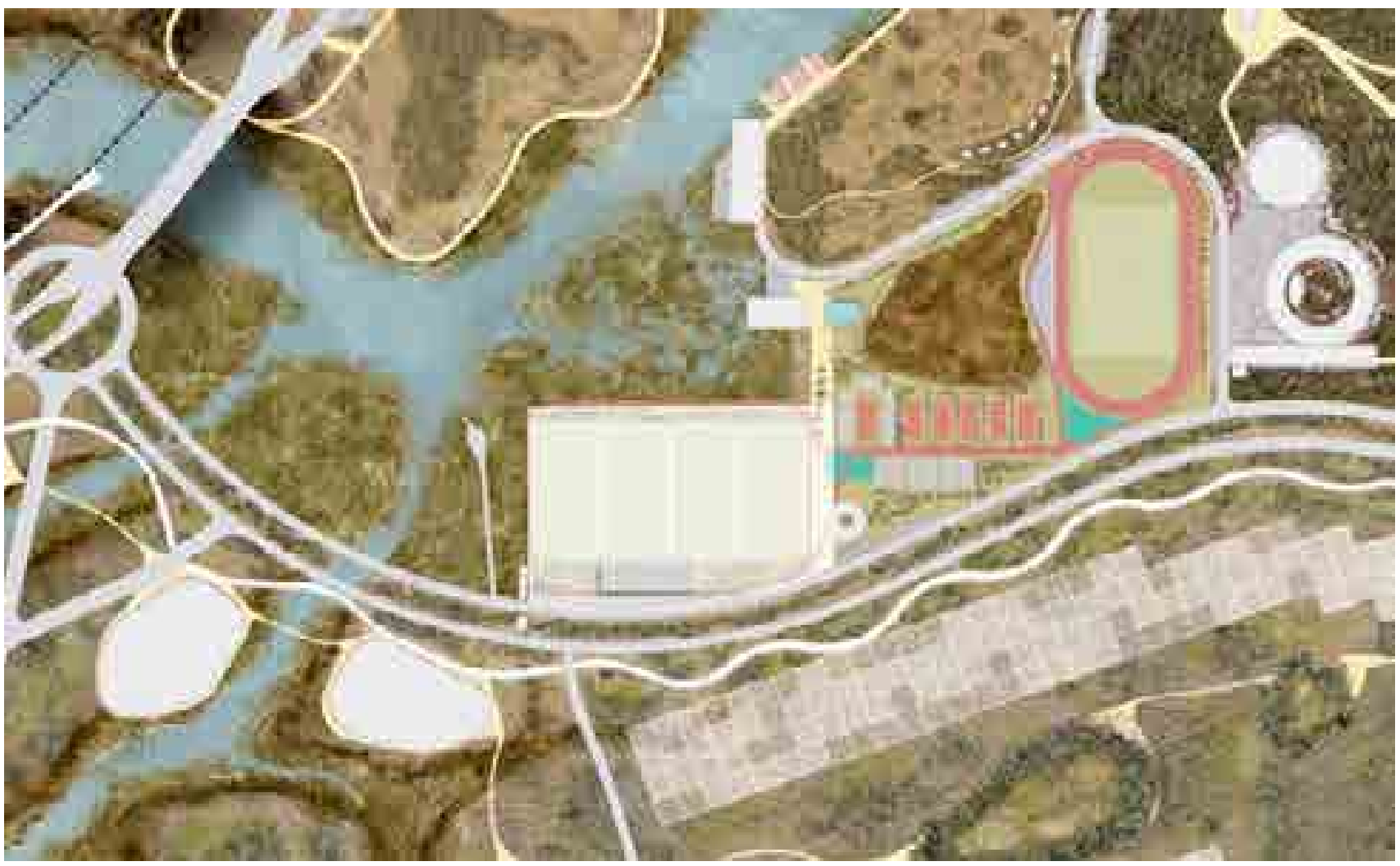

Figura 12.33. Detalle de la planta del sector que alberga el Club de Campo. En ella se observan las canchas, gimnasio y equipamiento de apoyo. Elaboración propia en asociación con Allard y Bravo. 


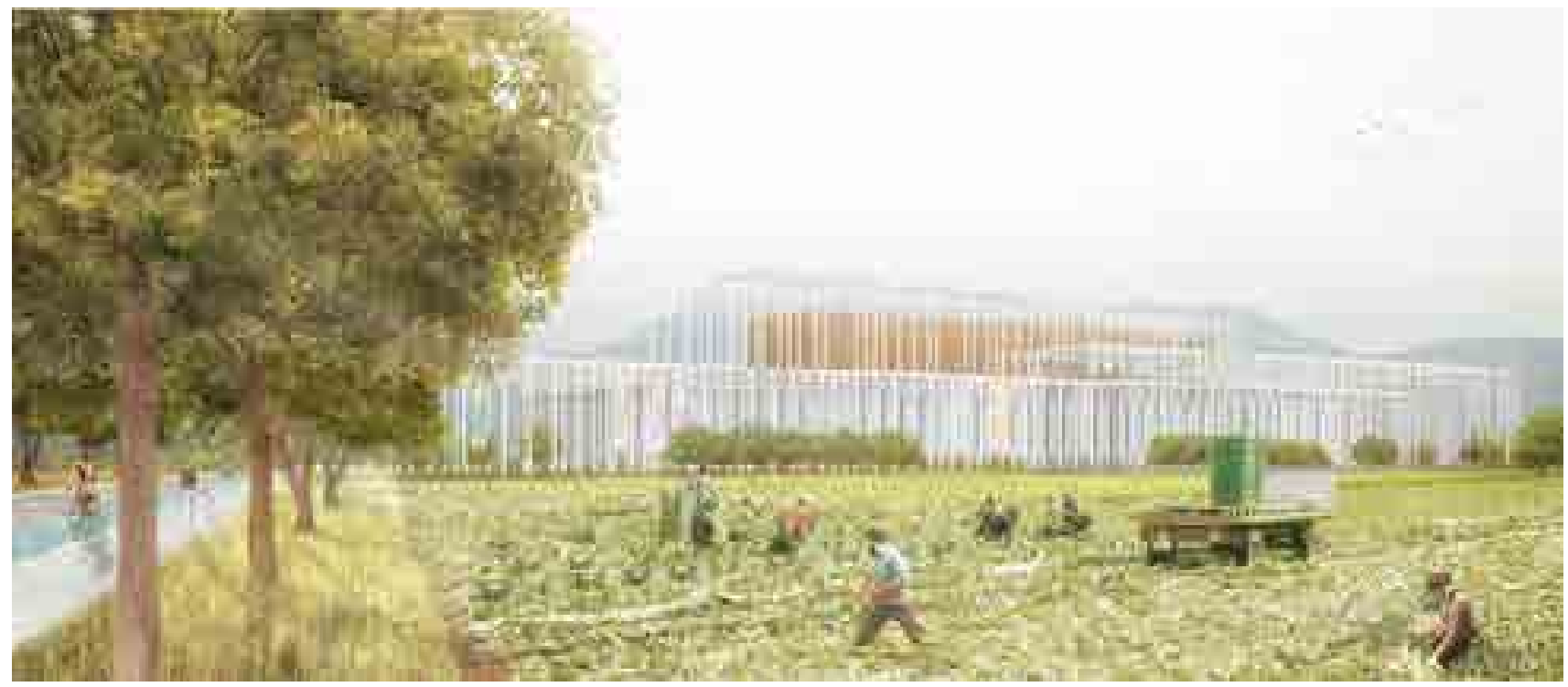

contará con una superficie de más de $1.000 \mathrm{~m}^{2}$, será pionera en el desarrollo de ingredientes saludables, alimentos procesados y empaques, con miras a duplicar las exportaciones chilenas del sector al 2025. Cuenta con un subsidio de $\$ 9.700$ millones de la Corporación de Fomento de la Producción (CORFO) para 10 años de ejecución (En la Figura 12.35, se muestra el emplazamiento del edificio CeTA).
Figura 12.34. Imagen objetivo de la zona de huertos experimentales. Elaboración propia en asociación con Allard y Bravo.

\section{Centro Tecnológico para la Innovación en Productividad y Sustentabilidad} en la Construcción (CTeC): El proyecto coordina a siete universidades nacionales ${ }^{416}$ y una red internacional de tres centros tecnológicos, el Ministerio de la Vivienda y Urbanismo y la Corporación de Desarrollo Tecnológico, la Ruta Solar y el Instituto de la Construcción. El centro ofrecerá estaciones experimentales a la industria de la construcción, las que permitirán a las empresas interactuar con la investigación académica para mejorar tanto la productividad como la sustentabilidad de las soluciones, especialmente en la vivienda social. Cuenta con un subsidio de $\$ 9.700$ millones de la Corporación de Fomento de la Producción (CORFO) para 10 años de ejecución.

Hub de Transferencia Tecnológica: La iniciativa busca potenciar los procesos de transferencia tecnológica de las universidades y centros de investigación ${ }^{417}$, teniendo en perspectiva el impacto internacional. Para ello, se crea una estructura asociativa de siete universidades y tres institutos de investigación cofinanciado por CORFO por cinco años.

Germán Rehren (Universidad Austral de Chile), considera que:

"la instalación del Hub responde a la necesidad de acelerar y profesionalizar los procesos, que permiten poner los resultados y productos de investigación al servicio del medio social y productivo. Espero que el impacto se mida en cómo las soluciones que provienen de nuestras universidades e instituciones contribuyen a impulsar la economía a nivel local y nacional, influyendo directamente en el mejoramiento de la calidad de vida de las personas". (citado por Comunicaciones VID, 6 de julio, 2016)

Este Hub que opera desde 2016, será uno de los primeros habitantes del "edificio vínculo".

\section{Observatorio Nacional de Riesgos Socionaturales}

Este proyecto trabajado estrechamente con el Ministerio del Interior, busca disponer de capacidad científica-tecnológica para identificar a tiempo escenarios de riesgo, contribuyendo con observaciones y conocimientos para detectarlos y caracterizarlos anticipadamente. Esta es una prioridad irrenunciable del estado,

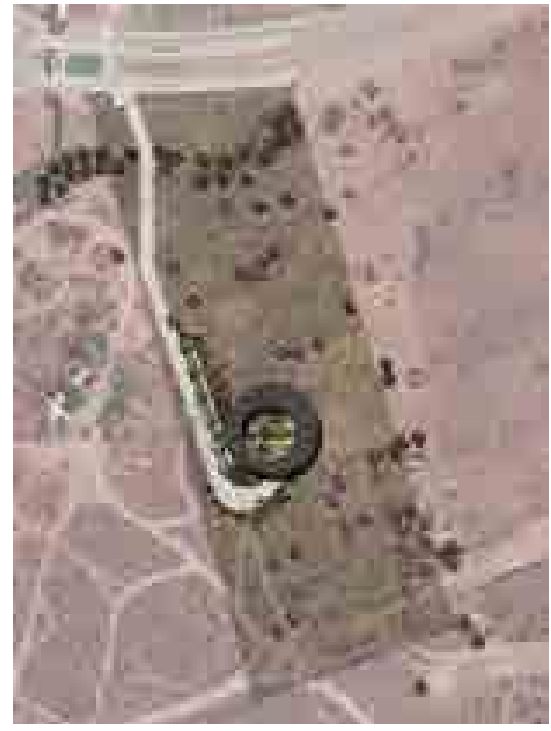

Figura 12.35 Emplazamiento edificio CeTA. Elaboración propia en asociación con Allard y Bravo. 
que debe promover la integración de las capacidades instaladas, propiciando data interoperable, fortaleciendo el sistema de monitoreo y alerta temprana y las capacidades de I+D destinadas tanto a la caracterización como a la toma de decisiones. De acuerdo a lo expuesto por la autora ante en Consejo Universitario el año 2016.

La propuesta es situar en Carén una plataforma interinstitucional e interdisciplinaria que potencie el conocimiento científico y tecnológico para la reducción del riesgo de desastres, mediante la implementación e integración de redes de observación y procesamiento de fenómenos asociados, con la investigación, la innovación, la conectividad y transferencia del conocimiento hacia los distintos sectores de la sociedad, permitiendo el fortalecimiento del Sistema Nacional de Protección Civil y la generación de políticas públicas a largo plazo. (Barba, 17 de mayo, 2016, p. 18)

Tomando experiencias internacionales, especialmente de Japón, junto a este centro, de investigación y operaciones, se propone la creación de un museo interactivo de los terremotos y riesgos socio naturales, con el objetivo de integrar la investigación producida en la academia, la gestión de desastres por parte del estado y la respuesta que la sociedad tiene ante estos eventos.

\section{Red Transdisciplinaria Envejecimiento}

Este proyecto busca que la Universidad de Chile contribuya significativamente, en diálogo con la comunidad, a la generación de conocimiento transdisciplinario sobre el envejecimiento, abarcando individuos, instituciones, sus relaciones, conductas y los contextos en que las personas mayores viven, aportando fundamentos científicos para la formulación y evaluación de políticas públicas en este ámbito y para el diseño de intervenciones de cambio en la sociedad que ayuden a integrar a las personas mayores y contribuyan en forma más efectiva a mejorar su calidad de vida. Si bien esta iniciativa aún no cuenta con financiamiento externo, se ha propuesto una institucionalidad académica de largo plazo al interior de la Universidad de Chile, que coordine e integre el trabajo transdisciplinario de investigación, formación y diseño de acciones pertinentes que contribuya de forma permanente al país en este campo.

Para ello se ha potenciado la investigación y la docencia de pregrado y postgrado en el ámbito del envejecimiento, desde una mirada transdisciplinaria, para con-

${ }^{415}$ En esta iniciativa se asocian la Universidad de Chile, la Pontificia Universidad Católica de Chile, la Universidad de Talca y la Universidad de la Frontera de Temuco. 416 Universidad de Chile, Universidad de Antofagasta, Universidad de La Serena, Universidad de Santiago, Universidad Tecnológica de Chile, Universidad de Concepción y Universidad de la Frontera, junto a tres centros tecnológicos de clase: Building Research Establishment (BRE), de Inglaterra, Tecnalia y Eurecat, ambos de España, en conjunto con el Ministerio de Vivienda y Urbanismo, la Corporación de Desarrollo Tecnológico (CDT), SCX, La Ruta Solar y el Instituto de la Construcción. 417 Universidad de Chile, el Instituto de Neurociencia Biomédica, el Instituto de Investigación Agropecuaria, la Universidad Católica del Maule, la Universidad de Talca, el Centro de Estudios de Alimentos Procesados, la Universidad del Biobío, la Universidad Católica de Temuco, la Universidad de Los Lagos y la Universidad Austral de Chile. tribuir a la formación de científicos y profesionales de alto nivel en este campo.

\section{Centro Nacional de Vacunas e Inmunobiológicos}

Es un proyecto liderado por el Instituto Milenio de Inmunología e Inmunoterapia (IMII) asociado al Instituto de salud Pública de la Universidad de Chile, al Ministerio de Salud y varias empresas farmacéuticas, que busca fortalecer las capacidades nacionales, tanto en el ámbito público como privado, de abastecer a la población chilena de vacunas e inmuno-biológicos, con el fin de proteger a la ciudadanía frente a enfermedades infecciosas e instalar las capacidades para responder a epidemias de manera autónoma.

Chile según Kalergis (2015), gasta anualmente 25 mil millones de pesos en vacunas compradas en el extranjero, por lo que este centro cubre necesidades que son estratégicas para el país.

Centro de Convenciones y Ferial de la Región Metropolitana: Se reserva un terreno hacia la Ruta 68 para emplazar el futuro Centro de Convenciones y Ferial de la Región Metropolitana, respondiendo a una solicitud del Gobierno Regional. Este espacio consolidaría a Santiago como el principal centro de negocios y servicios a nivel sudamericano, gracias a la cercanía con el aeropuerto internacional y su conectividad. La ubicación de este sector de 30 ha se ha definido de manera que puede habilitarse como una unidad autónoma con acceso independiente y en una segunda línea de fachada, sin afectar así a la imagen unitaria del parque 
desde la Ruta 68 (Figura 12.35). Uno de los problemas que representa la materialización de este centro de convenciones es que, por la naturaleza de sus funciones, requiere de grandes superficies, las que se estiman en $100.000 \mathrm{~m}^{2}$, más estacionamientos, lo que consumiría gran parte del porcentaje de ocupación de suelos permitido (1\%). La masividad de los eventos que en este tipo de recintos convoca, exigiría también de medidas de mitigación vial que el parque en su plan actual no requiere, pero que lo beneficiarían, sobre todo si un proyecto así atrae la construcción de una estación de Metro cercana.

\subsection{GESTIÓN Y PROBLEMAS EMERGENTES:}

En la Figura 12.36 se muestra el esquema de trabajo con entidades externas, realizado en el transcurso del proyecto para lograr los siguientes objetivos:

1. Viabilizar el proyecto con el área de desarrollo universitario, en consideración a las restricciones normativas y a las múltiples interpretaciones que de ella se pueden hacer. El interés del Gobierno Regional de emplazar en Carén un Centro de Convenciones Nacional, permitió que el equipo de proyecto pudiera convocar a los Secretarios Regionales Ministeriales (SEREMI) a una mesa de trabajo semanal para resolver qué estrategia usar para la aprobación del proyecto con y sin Centro de Convenciones, vale decir ciñéndose al $1 \%$ o al $20 \%$ de ocupación de suelo.

2. Viabilizar el proyecto en términos medioambientales y Sociales. De estas mesas bilaterales, la más importante ha sido la formada con la llustre Municipalidad de Pudahuel, que ha dado su apoyo político y técnico al proyecto, siendo también puente con la comunidad.

La mesa con la Dirección de Aeropuertos tuvo la finalidad de dilucidar los efectos de la restauración ecológica de la laguna, con el consecuente aumento de aves acuáticas y migratorias en la zona del aeropuerto internacional, en consideración a que unos de los problemas de seguridad que tienen las naves, es el peligro de accidentes por colisión de aves en las turbinas. Tras el análisis de especialistas, se despejó esta interrogante, ya que como muestra la Figura 12.37 el predio de laguna Carén está fuera del radio de peligro. Incluso, la posibilidad de atraer aves beneficia el área del aeropuerto, ya que las alejaría de la zona de seguridad.

A partir del trabajo con el Servicio de Evaluación Ambiental, surgió la idea de crear un banco de proyectos de remediación ambiental. A partir de esta posibilidad, se entablaron conversaciones con la empresa Hidronor y Bodegas San Francisco, con quienes se establecieron los primeros convenios de reforestación para el predio.

3. Garantizar la integridad del predio y del parque ante proyectos viales. En la mesa bilateral con el Proyecto Praderas se evidenció que los trazados viales (troncales) exigidos al proyecto Ciudad de Lo Aguirre, cruzaban el predio de la universidad, en doble vía y a $2 \mathrm{~m}$ sobre la cota de terreno, como muestra elocuentemente las Figuras 12.38 y 12.39 tras varios meses de trabajo en conjunto con el ministerio de Obras Públicas, la dirección de Vialidad y los gerentes de Praderas, se logró modificar el trazado como lo muestra la Figura 12.40.

4. Crear lazos con empresas instaladas en la zona a través de la participación y exposición del proyecto en la Corporación de Desarrollo Sustentable de Pudahuel, a la que están afiliadas las principales compañías.

\subsection{A MODO DE CIERRE}

Revisando este capítulo y los anteriores, podemos encontrar en ellos los distintos intereses de los que Habermas habla, cuando se refiere a las motivaciones del conocimiento (Capítulo 2). Así, en este mismo capítulo retomamos la investigación histórico-hermenéutica con objetivos comprensivos e interpretativos; en el 


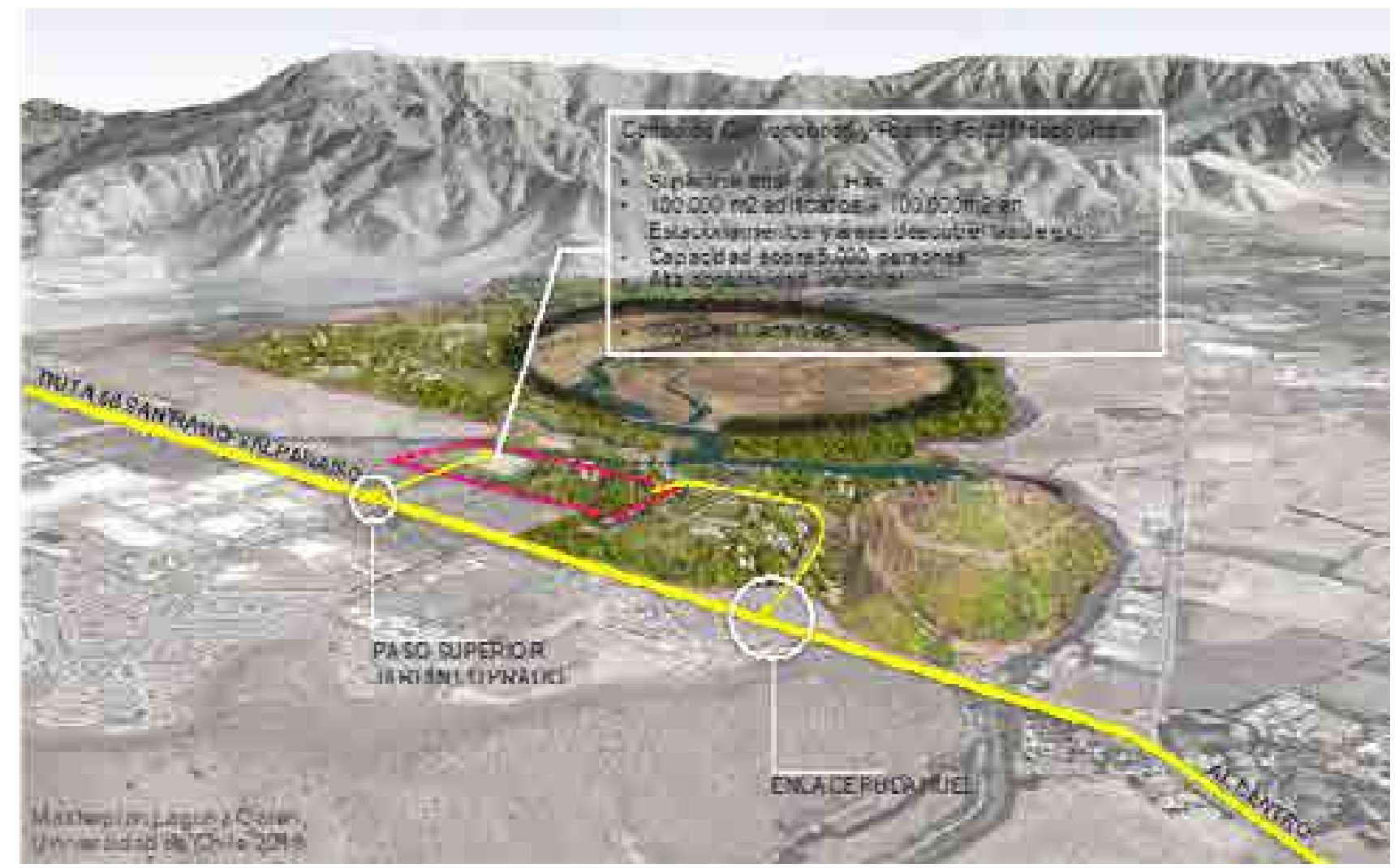

Figura 12. 35. Vista a vuelo de pájaro del emplazamiento para el Centro de Convenciones y Recinto Ferial metropolitano. Elaboración propia en asociación con Allard y Bravo para la presentación de 2016 ante el Consejo Universitario.

Figura 12.36. Esquema de trabajo con entidades externas. Elaboración propia.

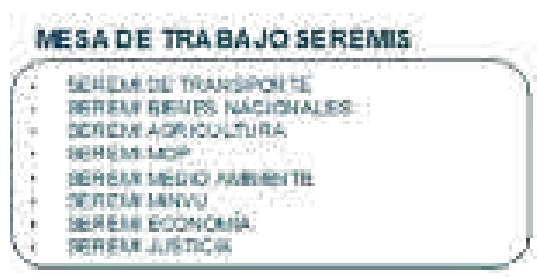

\section{MESAS BILATERALES S, PÛBLICOS}

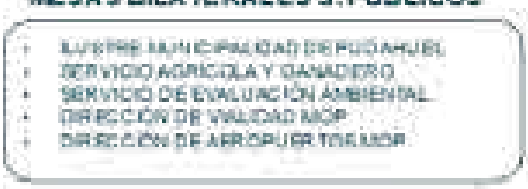

MESAS BILATERALES PRNADOS

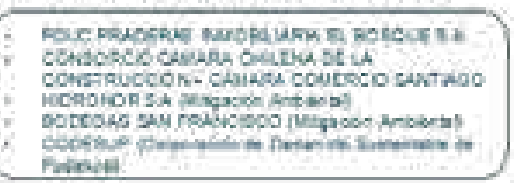

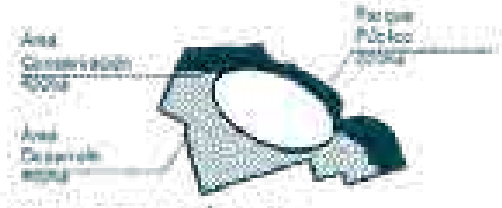

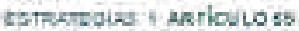
C. Are so deiask Nitik os $\mathrm{kg}$.

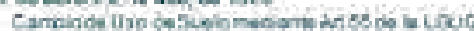
SREFIIINWI

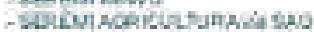

Esmategtas 2 sa

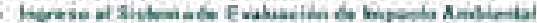

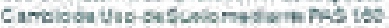

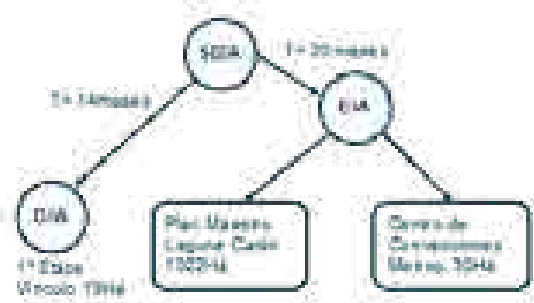

Figura 12.37. Mapa del valle Lo Aguirre donde se estudió la relación entre el predio Carén y el Aeropuerto Internacional AMB. Elaboración propia en asociación con Allard y Bravo sobre imagen capturada de Google Earth.

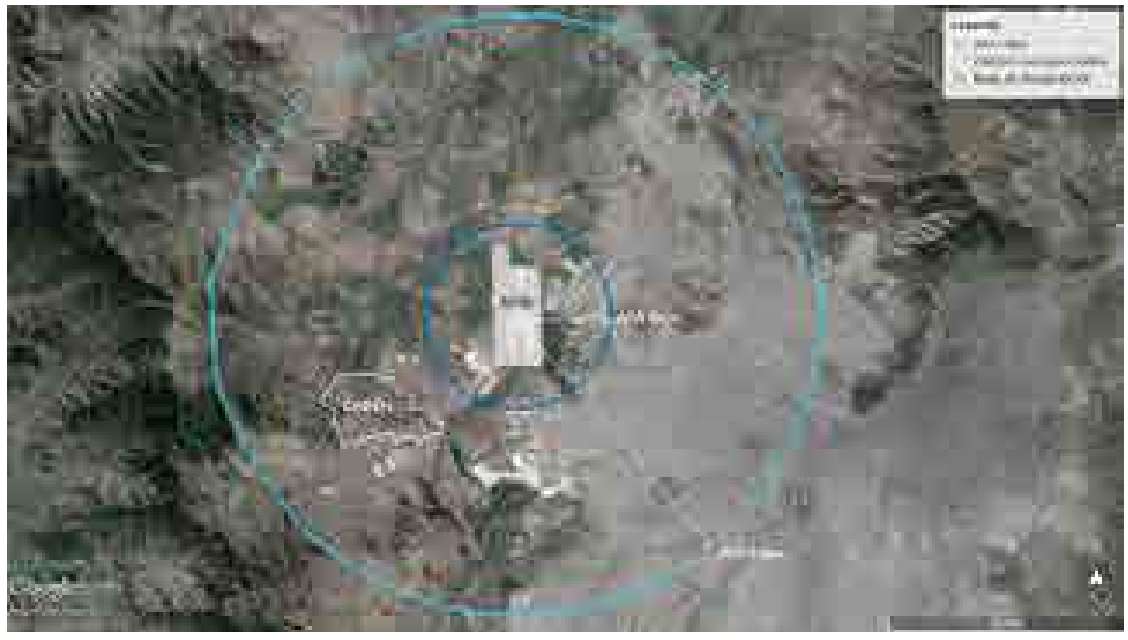




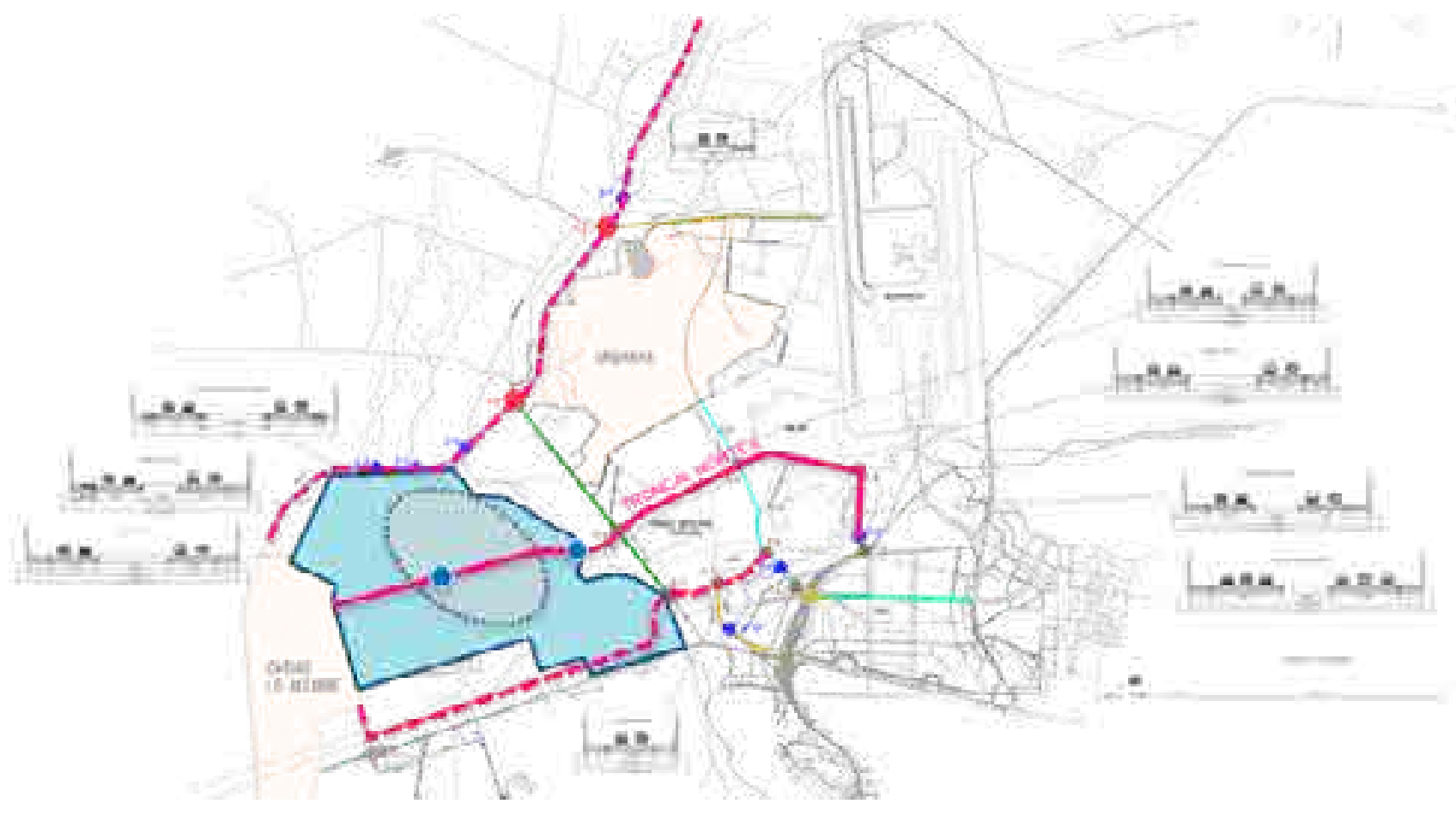

Figura 12.38. Propuesta de vialidad de la ZODUC Ciudad de Lo Aguirre (Praderas) donde se destaca el trazado vial. La Troncal Norte II cruza por el centro del predio de Carén, cortando el área de conservación. Plano Proyecto Praderas, inter-venido por la autora.

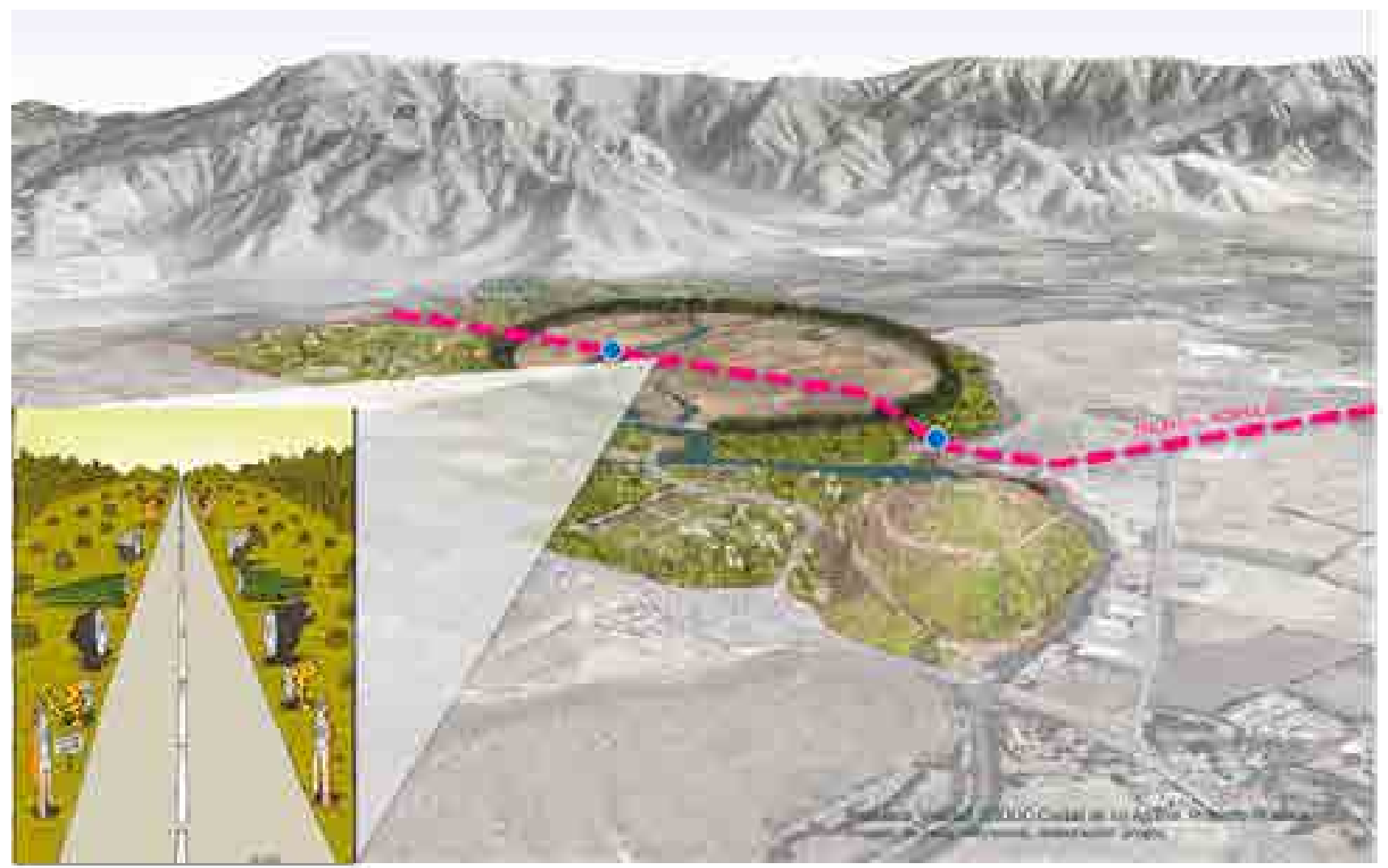

Figura 12.39. Trazado vial de la propuesta original de Praderas sobrepuesta al plan maestro. Elaboración propia en asocia-ción con Allard y Bravo. 


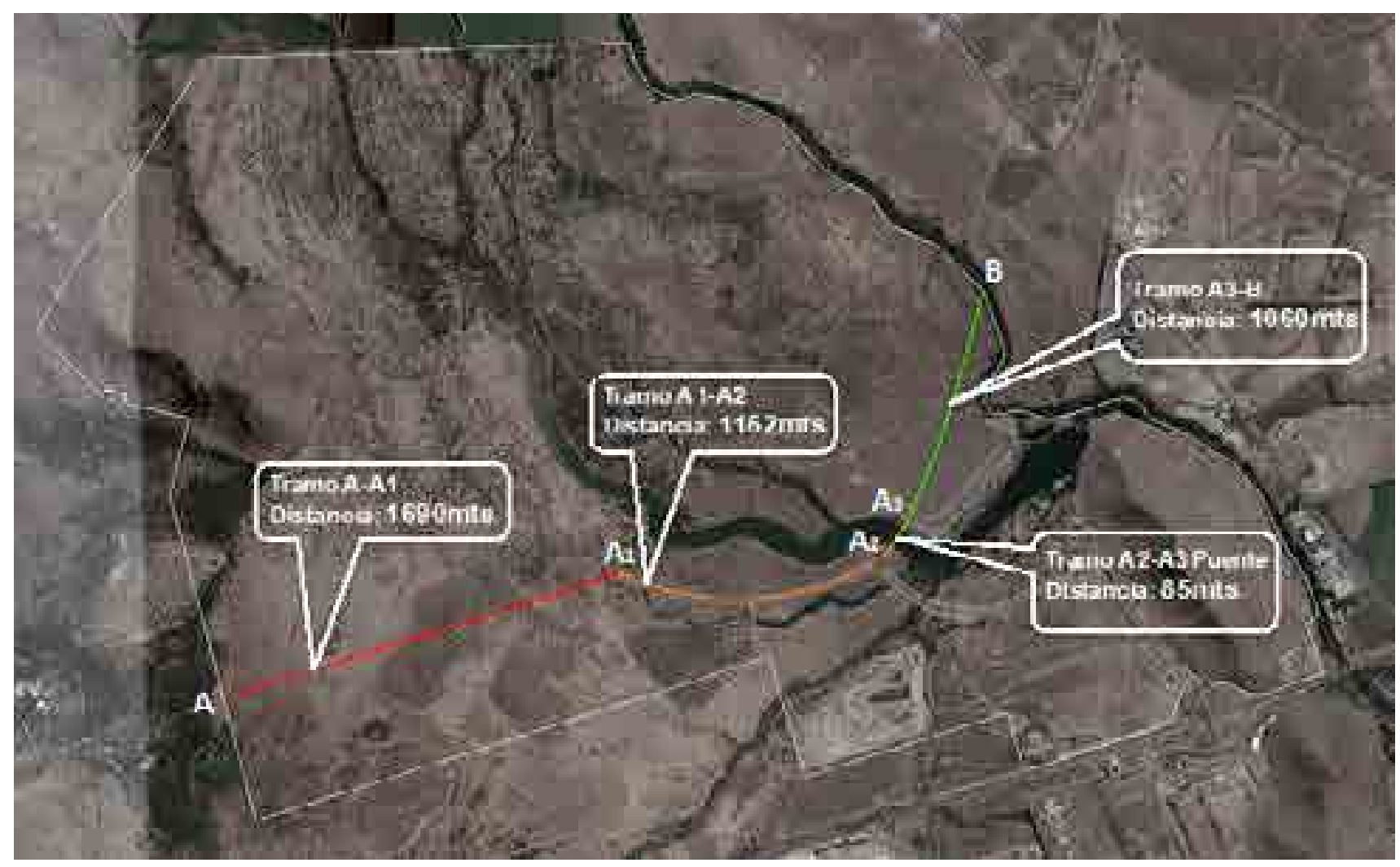

Figura 12.40. Propuesta de la autora para resolver el trazado vial de Praderas a través del predio Carén, utilizando la viali-dad ejecutada en la etapa I de urbanización. Elaboración propia en asociación con Allard y Bravo sobre imagen de Google Earth. plan maestro se plasma la investigación técnico-instrumental con fines explicativos y predictivos, y tal vez, corresponde profundizar aquí en la crítica (y autocrítica), que como este autor señala, tiene como motivación la búsqueda de emancipación.

Lo primero que podemos reconocer, es que los proyectos de esta magnitud no son ni deben ser personales. Son empresas colectivas, donde las sensibilidades, conocimientos y experiencias de vida se ponen al servicio de una causa que se considera justa e importante.

Los proyectos vastos exigen no sólo de competencias técnicas, sino sobre todo de la capacidad de orquestar voluntades, crear lazos de confianza, de saber escuchar y comunicar adecuadamente.

Los grandes proyectos requieren de apoyo político, una visión clara, porfía y una ética intachable.

Si repasamos los planteamientos a macro-escala del Plan maestro podemos afirmar que la consolidación del predio de laguna Carén como un parque, un gran parque, trae importantes beneficios:

Desde el punto de vista medioambiental, asegura que esta zona seguirá aportando ventilación al valle y con una mayor forestación, aumentará su capacidad de captar material particulado, en favor del plan de descontaminación de Santiago.

En la medida que se constituyan los corredores verdes externos e internos se protegerá a las especies vegetales y animales, especialmente las aves acuáticas.

Habrá reducción de ruido a través del manejo de masas vegetales, que actuarán como barrera que absorbe, desvía y refracta el eco de la carretera, de los aviones y el rumor de fondo de la ciudad para las zonas aledañas.

Desde el punto de vista social, la consolidación de un gran parque en la zona poniente de Santiago, significa compensar a comunas con las densidades más bajas de áreas verdes, mejorando de este modo la auto-imagen colectiva, la percepción de seguridad y la calidad de vida de los barrios cercanos. El proyecto puede considerarse desde este punto de vista, la respuesta a una demanda 
ciudadana, ya que como hemos visto, las áreas verdes constituyen una de las principales exigencias de la comunidad a nivel regional y municipal. A ellas se sumarán los nuevos programas de la universidad, que permitirán la realización de actividades artístico-culturales, deportivas, de recreación y de comunicación social.

Está previsto que las siguientes etapas de diseño, la participación ciudadana tenga un papel más importante, lo que contribuirá a la apropiación del parque por parte de los habitantes. Esta es una deuda importante del proyecto, que aún puede ser subsanada.

Cabe destacar también la contribución de un parque de esta naturaleza y magnitud para la educación, lo que está apoyado por una serie de dispositivos para la observación de flora y fauna, de la geografía y de la belleza del paisaje.

La restauración a la escala del paisaje de Laguna Carén, no implica sólo la protección de las funciones ecológicas, sino también la recomposición e integración de las unidades de paisaje que hoy se encuentran fragmentadas. Restituir la matriz de paisaje de la cual son parte, considera acciones de jardinería y arquitectura del paisaje que consideran tanto, procesos de sucesión natural (o primaria) como dirigida (o secundaria). El área central de sucesión natural es ejemplo de la primera dinámica y el anillo de conservación de la dirigida o secundaria.

La restauración de la laguna y la consolidación del humedal son también objetivos irrenunciables.

Tal vez el acto más importante y controvertido es la creación del vacío central. Controvertido porque contraviene la lógica del "mayor rendimiento", al renunciar a prácticamente al $40 \%$ de la superficie. Pero con ventajas performativas, ya que, desde el punto de vista ecológico, como diría Richard Forman, es una "forma óptima", una "nave espacial", de "núcleo redondeado, límites curvilíneos y dedos para dispersión de especies" (Dramstad, Olson \& Forman, 1996, p. 32). También podríamos argumentar, que, a través de esta gran zona, logramos conformar un centro, un lugar de referencia que permite comprender la dimensión espacial en la experiencia del parque. Podemos recordar aquí a Norberg-Schulz (1971), cuando nos dice que centro, dirección, transición y área, tienen implicaciones sobre la legibilidad del espacio. La idea de conformar un centro, como recurso para lograr la integridad en la obra, es también expuesta por Alexander, quién utiliza específicamente el término centro ${ }^{418}$ para aludir, no solo a una cuestión geométrica, sino también a una "entidad psicológica que es percibida como un todo en el campo visual" (Alexander, 1993, p. 88). Este autor, en The timeless way of building (1979), explica la cualidad de "integridad" del centro, con una imagen que parece venir de Carén:

Compare los arboles a lo largo de un lago silvestre y soplado por el viento, y en un cauce erosionado. Estos árboles y ramas están hechas de tal manera, que cuando corre el viento todo se inclina, y todas las fuerzas del sistema, incluso las fuerzas violentas del viento, se mantienen en equilibrio, no hacen daño, no hay violencia. La forma flexionada de los árboles los hace autosustentables ${ }^{419}$. (Alexander, 1979, p. 30)

Lo íntegro (whole) capta parte de este significado, ya que, como nuestra sabana de espinos, "está libre de contradicciones internas" o "fuerzas que actúan para desmembrarlo" (Alexander,1979, p. 30).

La curva cerrada recuerda también la forma que adoptan los ritos ancestrales mapuche. La elipse es la figuración del movimiento de la tierra (mapu) que se plasma en la planta de la ruka, la vivienda arcaica de los primeros habitantes de este territorio (Figura 12.41).
${ }^{418}$ Los centros de Alexander no son simplemente principios abstractos, sino que pretenden ser parte fundamental de un intento más profundo y complejo de unificar la geometría, la experiencia humana y la forma espacial y la función.

${ }^{419}$ Traducción propia desde el texto en inglés:

Compare the trees along a wild and windblown lake, with an eroded gully. These trees and branches are so made that when the wind blows they all bend, and all the forces in the system, even the violent forces of the wind, are still in balance, they do no harm, they do no violence. The configuration of the bending trees makes them self-maintaining. 
${ }^{420}$ Richard Weller, es catedrático (chair) y David Gerard Gouverneur Malakoff, Profesor Asociado de práctica (Associate Professor of Practice) del Departamento de Arquitectura del Paisaje de la Universidad de Pensilvania. Visitaron Chile y sostuvieron reuniones con el equipo de proyecto y el grupo de especialistas asesores del plan maestro Laguna Carén. Las reuniones se efectuaron en la Facultad de Arquitectura y Urbanismo y en la Casa Central de la Universidad de Chile, los días 9 y 10 de agosto de 2016.

Figura 12.41. Referentes de la forma elíptica del área central del plan maestro: la ruca mapuche, la cestería y los ritos que describen este ordenamiento espacial. Vista, corte y planta de la ruca mapuche. En José Tomás Franco (4 de febrero, 2014).
Una crítica que podría hacerse a este anillo, es de ser una figura con demasiada pregnancia, sospechosamente análoga a lo que Robert Solom alude respecto a las formas que utiliza OMA, cuando advierte que éstas funcionan "con la inmediatez gráfica de los logotipos" (Solomon, 2004, p. 87) observación que no podríamos refutar, por cuanto hemos pensado que el anillo será una imagen distinguible incluso desde el cielo, cuando los aviones surquen el espacio aéreo al aproximarse o despegar de Santiago.

Una de las debilidades del plan a micro-escala, está en la decisión de tratar el área de desarrollo como ecotonos, a través de parches ambientales y no de una subdivisión predial convencional. Esta estrategia tiene la ventaja de que establece un modo de crecimiento gradual, análogo a una mitosis celular, equilibrando la proporción entre espacios construidos y libres (Figura 12.42.).

La solución propuesta recuerda la arquitectura evolutiva, y si nos remontamos un poco más atrás en el tiempo, a las utopías metabolistas de los sesenta. Las estructuras del sistema vínculo hace un giño a la Ciudad Agrícola de Kurokawa de 1960, que buscaba resolver la contradicción de ciudad-campo mediante una grilla de concreto de 500 x 500 m elevada 4 m sobre el suelo rural mediante pilotes, con posiblemente, los mismos problemas que tendría la solución propuesta, vale decir la dificultad de que la vegetación prospere a nivel de suelo, debido a la falta de luz solar, pese a que se han considerado pisos metálicos que dejan espacio para el paso del sol.

En una visita de los profesores Richard Weller y David Gouverneur de la Universidad de Pensilvania ${ }^{420}$, a quienes expusimos el plan maestro, también plantearon dudas acerca de la conveniencia del tipo de crecimiento propuesto en base a parches ambientales. Estos especialistas recomendaban, la construcción continua en el borde de los ejes viales y el aprovechamiento más "comercial" de las vistas a la laguna.

Por último, quisiera ilustrar las dificultades que enfrentamos al plantear un ordenamiento distinto al loteo convencional: Hace poco más de un año, me reuní con un joven arquitecto, a quién se le había encomendado el anteproyecto de uno de los Centros financiados por CORFO (el edificio para el proyecto CeTA). El joven arquitecto, nos había solicitado, que le entregáramos "el plano de su terreno". En la reunión le explicamos que la intención del proyecto era no lotear, y que, por lo tanto, lo invitábamos a desarrollar una solución en conjunto, articulada con el edificio vínculo, como parte de la grilla propuesta. El joven arquitecto, reiteró que lo que necesitaba, era que le entregáramos un plano donde se especificaran las coordenadas de los cuatro vértices de un rectángulo. Pese a que volvimos a explicarle la estrategia propuesta, y pareció comprenderla, algunas horas después de la reunión, recibí un correo en el que insistía en "el rectángulo", sin el cual no podría dibujar y por lo tanto cobrar sus honorarios. Esa tarde, le envié un plano con coordenadas.

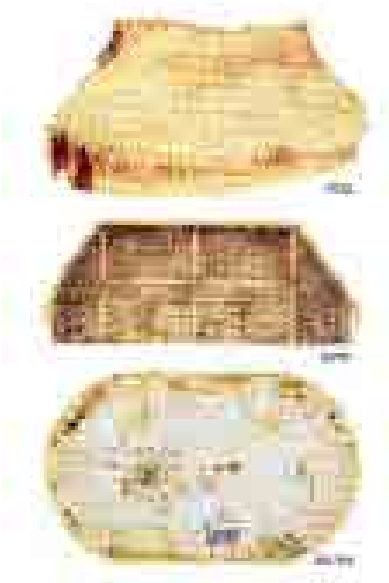

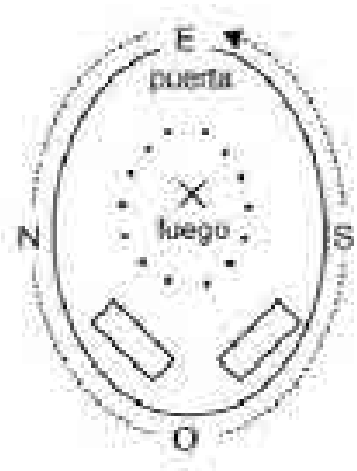




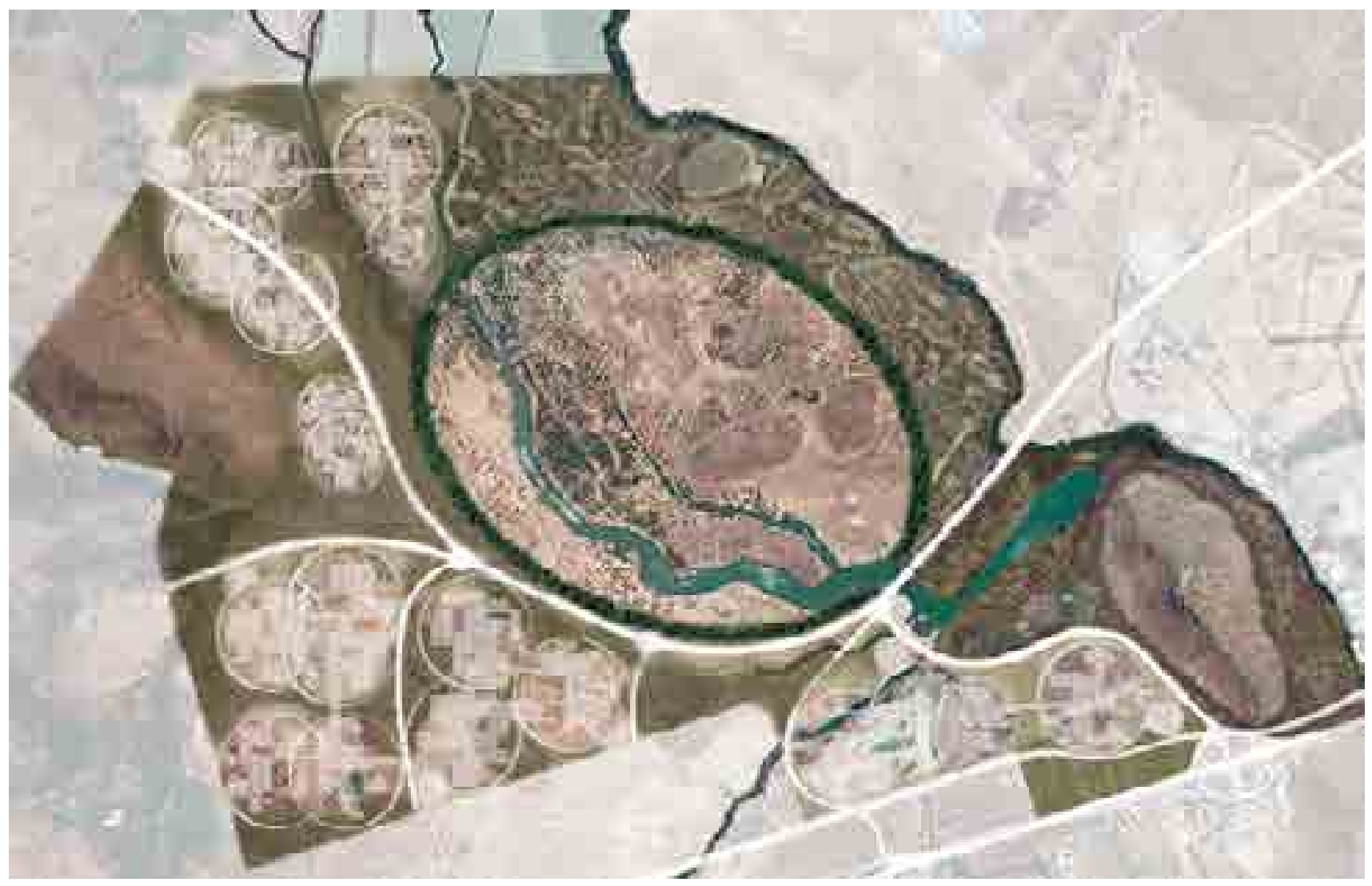

Como hemos planteado al inicio de este capítulo, este ha sido un proyecto abierto a la experimentación, lo que compromete una continua revisión y evaluación de las soluciones adoptadas. La gestión adaptativa propuesta para conciliar el proyecto ecológico y el proyecto arquitectónico tiene ese riego y también esa riqueza. Otorgando la posibilidad de repensar y de escribir.

Escribir: tratar de retener algo meticulosamente, de conseguir que algo sobreviva: arrancar unas migajas precisas al vacío que se excava continuamente, dejar en alguna parte un surco, un rastro, una marca o algunos signos. (Perec, 2001, p. 140)

Figura 12.42.: Planta esquemática del plan maestro, donde se grafica el crecimiento a través de parches ambientales (círcu-los). Elaboración propia en asociación con Allard y Bravo. 
(4)

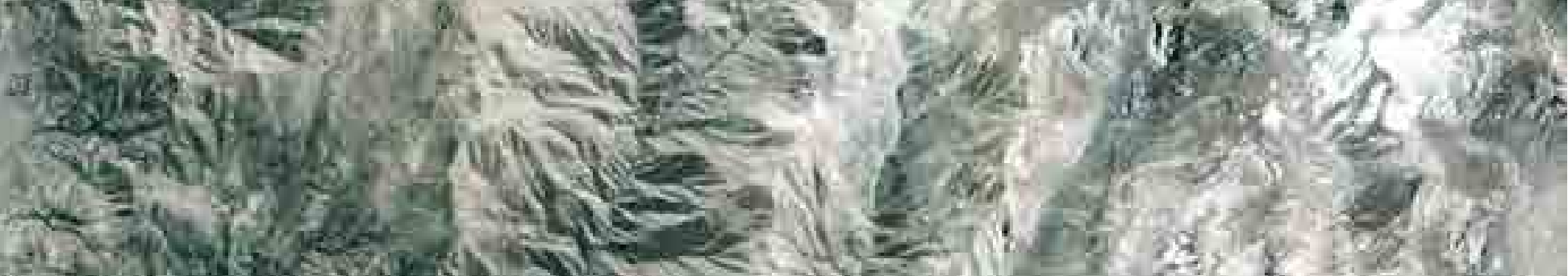

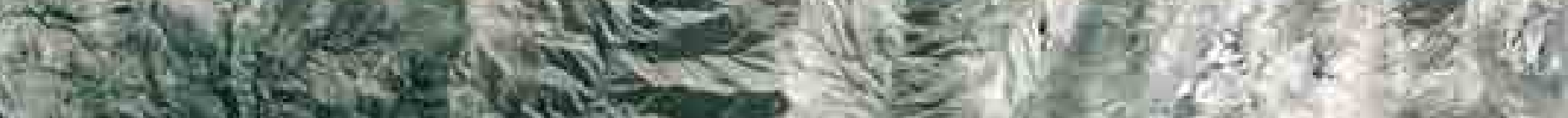

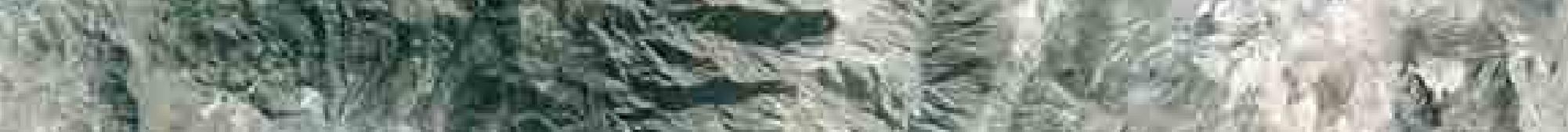

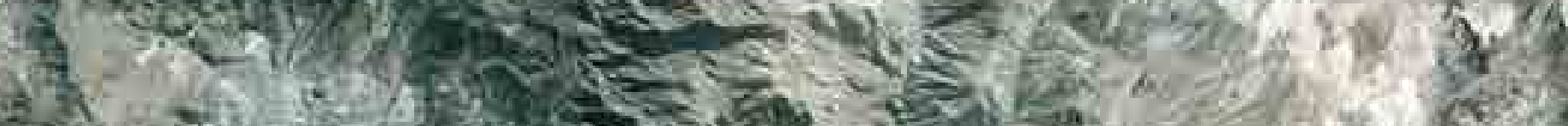

If

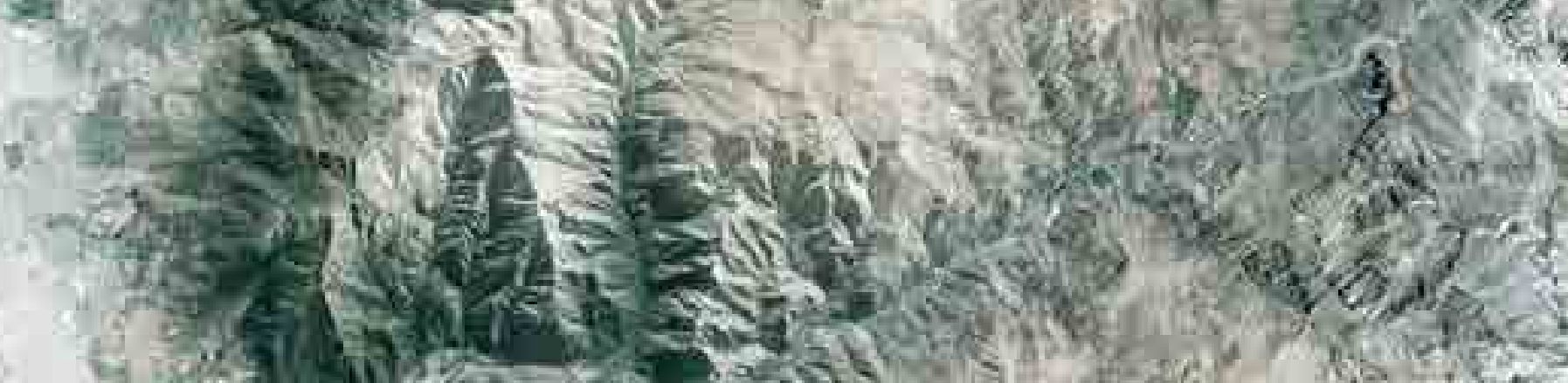




\section{CONCLUSIONES}

La arquitectura del paisaje como disciplina está en una posición única para integrar los resultados de los estudios ecológicos de la estructura espacial del paisaje con las preocupaciones sociales, culturales y estéticas en el diseño de los paisajes a muchas escalas espaciales ${ }^{421}$. (Collinge, 1996, p. 72)

El momento de las conclusiones es difícil, significa tomar la decisión de detenerse, de parar esta carrera que a veces me ha parecido que no tendrá fin. Pese a la acumulación de notas, archivos y dibujos que están incluidos en el texto, aún me parece que faltan cosas, reviso mi cuaderno de apuntes y debo aceptar que algunas queden allí.

La hipótesis que orientó este trabajo plantea lo siguiente:

La arquitectura del paisaje representa una racionalidad multiescalar, que permite el desarrollo de métodos de análisis y estrategias operativas para la transformación del territorio desde un pensamiento ecológico, que integra los elementos naturales (bióticos y abióticos), sociales, culturales, estéticos y económicos. En esta racionalidad, el proyecto se convierte en un dispositivo dinámico en el tiempo, abierto y flexible, que incorpora la incertidumbre y la participación de múltiples actores.

El recorrido, descrito a través de los capítulos precedentes ha tenido la intención de, por una parte, establecer las bases teóricas de un tipo de intervención en el territorio desde el paisaje, particularmente desde la arquitectura del paisaje, y por otra probar si esos hallazgos se pueden aplicar en la resolución de problemas reales, en este caso en el Proyecto Laguna Carén.

La tarea, en una dimensión más profunda, ha sido transformar mi propia racionalidad de arquitecto educada en los fragores de la posmodernidad latinoamericana, aquella marcada por las dictaduras y el advenimiento sin freno del neoliberalismo, por una que he llamado multiescalar, como característica de una arquitectura desde el paisaje.

Por lo tanto, los capítulos, más que informar, dan cuenta de distintos momentos de duda y por lo tanto de búsqueda un nuevo conocimiento, que pudiera iluminar las decisiones que en la realidad (la del proyecto) tenía que tomar.

En el proceso, me di cuenta de que el único modo de hacerlo, era produciendo un distanciamiento del proyecto o más bien, del rol que como arquitecto tenía en él. Sólo de ese modo, esta indagación teórica y práctica, ha podido liberarse de las demandas propias del ejercicio profesional -que normalmente están llenas de contradicciones-y volver a observar tanto el problema como la solución, críticamente. De este modo, mi contribución es totalmente desinteresada, circunstancia necesaria para una producción de estatus científico (aún, si mis competencias de investigadora son incipientes).

Para ser consecuente con la lógica propuesta (multiescalar) resumiré las conclusiones a distintas escalas, integrado una visión crítica del rol del arquitecto en cada una de ellas.

Desde la macro-escala, la primera indicación viene dada por el tamaño del terreno.

- Lo vasto, exige ampliar la escala de análisis a la escala geográfica. La comprensión de los fenómenos locales requiere del desciframiento del origen geológico, hidrológico, edológico y climático del lugar. El paisaje que observamos, el relieve, el suelo, la brisa y el agua, se han formado en el tiempo por eventos a veces lentos y otros violentos.

- Lo vasto, involucra a muchas personas. Existe una escala ciudadana, que tiene opinión y se siente afectada. Ampliar la escala implica interac-

${ }^{421}$ Traducción propia del inglés:

Landscape architecture as a discipline is uniquely situated to integrate results of ecological studies of landscape spatial structure with social, cultural, and aesthetic concerns into the design of landscapes at many spatial scales. 
tuar con muchos actores, con diversos intereses, muchas veces contrapuestos y distintos grados de poder.

- Lo vasto exige de una gestión política, ética y sostenida en el tiempo. Requiere de gran perseverancia y firmeza.

- Lo vasto necesita conocer la historia, hay también una macro-escala temporal, que ha dejado su huella en el paisaje. Estas capas tienen un mensaje latente para el arquitecto, que debe aprender a leer con la ayuda de quienes han habitado el lugar y de quienes lo han estudiado. Los grandes proyectos son de largo aliento, sus resultados posiblemente no serán evaluados por quienes lo ejecutaron.

- La macro-escala requiere del trabajo multidisciplinar. Los límites de la multidisciplinariedad estarán dados por el tiempo y los recursos económicos. Una de las tareas más difíciles es sintonizar los lenguajes y lograr visiones comunes.

- La actuación a macro escala es transdisciplinar, es una síntesis.

- Los proyectos a gran escala deben considerar los demás proyectos e intentar vincularse en lo medioambiental, social, económico y político.

- Lo vasto siempre tendrá efectos y se verá afectado por la ciudad.

- Lo vasto es caro. La variable económica debe ser incorporada desde el principio, para co-construir los principios que guiarán el proyecto, sus etapas y sus límites.

- Lo vasto requiere conciencia de límite. Extender los límites e incorporar la complejidad, pero también establecer cuáles son los aspectos no negociables.

- Por último, los grandes proyectos requieren generosidad y paciencia. Generosidad para anteponer el bien común a los intereses personales y paciencia para enfrentar las presiones.

Desde la meso-escala es importante definir estrategias y luego un plan en el tiempo.

- Debemos conocer los planes y proyectos anteriores al nuestro y descifrar de ellos la identidad y las imágenes que la comunidad se ha formado.

- Debemos considerar los habitantes actuales y futuros

- Las estrategias de zonificación deben considerar las unidades de paisaje, que incluyen los aspectos ecológicos, estéticos, culturales y los usos.

- El plan debe lograr la legibilidad del proyecto como un todo. Definir un centro (real o virtual) y una estructura que permita la orientación, el recorrido y la contemplación.

- El plan debe considerar un guion, un relato compartido que ponga en valor el paisaje y le dé sentido. En esta narración deben incorporarse los elementos de todas las escalas. Las partes deben poder ser nombradas e identificadas.

- Debe encontrarse una alternativa a la subdivisión convencional, al loteo. La fragmentación habitual de los grandes paños para efectos administrativos o de gestión, tienen el riesgo de convertirse en muros, vallas y cierres, que destruyen la idea de unidad y continuidad.

- El programa debe ser pensado a partir del paisaje y sus objetivos. Los usos y su magnitud pueden fragmentar el sitio. Por ejemplo, la instalación de un centro de distribución internacional, tiene una escala y condiciones de funcionamiento y seguridad incompatibles. Un programa de este tipo, significa la aparición de un volumen grande, cerrado y resguardado, posiblemente vallado.

- Los espacios habitables deben estar a una distancia accesible e inclusiva (por ejemplo, en silla de ruedas), que hemos considerado como máxima de $500 \mathrm{~m}$. El espacio debe provocar el encuentro y propiciar la formación de una comunidad.

- Las especies vegetales utilizadas deben ser nativas, adaptadas a la disponibilidad de recursos hídricos de la zona e idealmente cultivadas a partir de la recolección de semillas del lugar. La elección de especies 
debe cuidar no introducir aquellas de características pirófilas, para evitar incendios. La reforestación debe realizarse en etapas para no estresar las napas subterráneas y afectar de ese modo la disponibilidad de agua.

- Las aguas deben ser tratadas y recuperadas.

- Todos los programas deben tener una parte orientada a la vinculación con el medio, de manera que en su espíritu se relacione con la comunidad y ésta lo cuide.

- La arquitectura debe ser de calidad, sin competir con el paisaje. El parque no se puede convertir en un muestrario de arquitecturas de moda. Se tiene que encontrar una estética apropiada.

- La gestión ecológica adaptativa propuesta en el plan maestro debe permear las actividades del parque. El parque debe estar abierto a la experimentación y evaluación de sus acciones.

- Se debe crear una gobernanza flexible y ágil concordante con el plan maestro y convencida de las prioridades no-comerciales del proyecto.

- Debe evaluarse continuamente la carga de uso propuesta, para no sobrecargar de actividades y no exceder la capacidad del sitio.

- Debe evaluarse la calidad del agua de la laguna y priorizar la consolidación de los humedales.

- El parque debe ser un laboratorio para abordar riesgos socio-naturales $\tan$ frecuentes en Chile (terremotos, aluviones, inundaciones). Con registro en investigación.

- El parque debe ser un aula abierta, para la educación ecológica e histórica.

Pensar la micro-escala ha implicado una inmersión en la percepción y la calidad de los hábitats humanos, animales y vegetales. Para ello, como diseñadores hemos cerrado muchas veces el computador, para caminar como una práctica reflexiva dentro del proceso de diseño, que nos permite probar, nosotros mismos, la experiencia que proyectamos para los futuros habitantes.

- Hacer lo mínimo para lograr lo mejor posible. Pensamos, como Georges Descombes (1999) que más importante que lo que agregamos en un sitio, es lo que tomamos de él, y que puede convertirse en un camino para lograr experiencias más profundas y reflexivas. Esto no es posible si todo se nos presenta a primera vista. El diseño debe ser sugerente y plantear más preguntas que respuestas, de una manera sutil y significativa.

- Debemos asumir el riesgo de comenzar a diseñar proyectos que generen más preguntas que respuestas y creen lugares que intensifiquen lo que hay y lo que no vemos.

- Proyectar pensando en el cuerpo, en las distancias, en los descansos. Siguiendo a Lynch (1998), definir sutilmente, los hitos, sendas, nodos, barrios y límites que permitan que el habitante construya su imagen del lugar.

- Crear y recrear espacios de observación panorámica y de perspectivas amplias en la secuencia de espacios del recorrido.

- Así como los edificios deben crear las condiciones para el encuentro, también el plan debe considerar la posibilidad de observación solitaria y porque no decir melancólica, como preámbulo a experiencias más sublimes y reflexivas.

- Privilegiar pavimentos que permitan la absorción de aguas lluvias, permeables.

- Proteger los suelos, a través de sendas, tipo pasarela.

- Activar la vegetación de suculentas y cubre suelos nativos para dar variedad visual y ecológica.

- Cuidar y observar las aves acuáticas, con interés estético, naturalista y medioambiental, ya que son buenas indicadoras de la calidad ambiental, especialmente de las aguas.

- Usar materiales cuya textura enriquezca la percepción espacial. 
- Definir espacios de observación geológica, hidrológica, arqueológica y ecológica de acuerdo a los hallazgos detectados en el lugar (piedras tacita, afloramiento de roca y capas geológicas a la vista, cortes de suelo para observación de pumicita.

El análisis y diseño multiescalar que hemos expuesto, permiten transitar desde lo vasto a lo íntimo, con la participación de todos los sentidos, para lograr la inscripción el cuerpo en el lugar.

Hemos usado en varias oportunidades la analogía del laboratorio y del parque como un "experimento real". Pensar en Carén como un gran parque, ha exigido adoptar un enfoque de diseño basado en procesos. La complejidad de la tarea nos ha llevado a definir estrategias de diseño que buscan conciliar las variables ecológicas con el potencial estético y poético del sitio, para, de este modo, crear lugares memorables, espacios social y culturalmente reconocibles.

Como plantea Anita Berrizbeitia (2007), crear lugares memorables debería ser un objetivo y un valor fundamental para la disciplina, "pese al énfasis en las cuestiones relacionadas con los aspectos ecológicos en la práctica reciente" (p. 179). Para ello, la noción de lugar debe concebirse ampliamente, haciéndose cargo de la complejidad, al incorporar la historia social y natural del lugar, los procesos ecológicos, los usos, las costumbres, la experiencia perceptual y la ciudad de la que somos parte. Esta autora nos enseña que, para los grandes parques, el paisaje ha dejado de ser una escena inerte, para "transformarse en un proceso históricamente contingente, en continuo estado de formación" (p. 179). Como hemos visto en el capítulo precedente, más que un plan o diseño cerrado, parece ser más apropiado hablar de estrategias de diseño, que permitan distintas formas de organización, instaurando procesos dinámicos en el sitio. Algunos procesos serán abiertos, dejando la posibilidad de que acontecimientos inesperados se desplieguen, como también que el parque se vincule más allá de sus límites, mientras que otros serán cerrados, preservando los elementos característicos del lugar. Para ello, la definición e interpretación de las unidades de paisaje serán el fundamento de las estrategias de diseño. La creatividad de este trabajo será menos un invento, que un ejercicio hermenéutico, que implica descifrar "la superficie del terreno sobre la que se graba la memoria de sus transformaciones, se convierte en el mapa y en la crónica del lugar" (Marot, 2006, p. 126), para descubrir el programa apropiado para el sitio en particular.

\subsection{SOBRE LA TRASFORMACIÓN DEL PAISAJE}

En el pensamiento a escala geográfica, reconocemos que este territorio forma parte de una conurbación urbana. Sabemos que, desde la década de 2000 , la población que vive en ciudades es mayoritaria (en el caso de Chile $87,6 \%$ según Knoema, 2018), lo que Steiner ha llamado "el primer siglo urbano" (Steiner, 2009 , p. 14). El rápido ritmo de la urbanización ha puesto a los ecosistemas bajo la influencia de las ciudades y los entornos construidos. El desarrollo sostenible se presenta como una respuesta, aunque algunos autores, tales como Marcuse (1998), la consideran insuficiente y prefieren afirmar la necesidad de un verdadero "punto de inflexión ecológico" (Reimer, 2010), que exige pensar el espacio urbano en forma estratégica. Este punto de inflexión se refleja hoy en el surgimiento de nuevas teorías y prácticas profesionales en la planificación urbana. También da un nuevo rol a los paisajistas, cuyo campo de especialización tradicionalmente se encuentra en la interfaz entre la arquitectura y las ciencias naturales. Las implicaciones teóricas de este cambio ecológico se expresan en los discursos de paisaje, teniendo, como hemos visto en el capítulo 4, a Charles Waldheim como uno de los principales exponentes de lo que se ha dado en llamar Urbanismo del Paisaje (Landscape Urbanism) desde principios de la década de 2000. Este propone "un realineamiento disciplinario en el que el paisaje reemplaza el papel tradicional de la arquitectura como el componente básico del proyecto urbano" (Waldheim, 2006, p. 101). La experiencia aquí relatada, permite 
afirmar que un diseño desde la noción paisaje, vinculado a las ciencias ecológicas, es capaz de ofrecer un modo de abordar el proyecto de ordenación territorial (plan maestro) desde la arquitectura y que esta racionalidad es aplicable a los problemas de la ciudad.

La situación crítica medioambiental puede verse así, como una oportunidad para innovar, superando las soluciones convencionales de arquitectura sustentable, que han legitimado la carencia de valores estéticos a través de soluciones tecnocráticas y muchas veces, aparentemente ecológicas.

A macro-escala también podemos aventurar, que más allá del diseño, una racionalidad multiescalar orientada por el paisaje, exige revisar conceptos como el desarrollo sustentable (que ciertamente es una contradicción). Esto es posible en un país como Chile, con un territorio extenso y diverso y una población no tan numerosa (17 millones de personas). Aún a esta escala se pueden diseñar alternativas de progreso social y equidad en equilibrio con el medioambiente. Esto requiere de un cambio cultural profundo. La historia económica de Chile ha estado orientada por la explotación de los recursos naturales, especialmente la minería. La cultura minera es la cultura del campamento, de lo transitorio, de lo que se explota y se deja. Pensamos que esta propuesta desde el paisaje puede ser un modelo que la Universidad de Chile ofrece al país para experimentar nuevas soluciones tanto en lo que respecta al ordenamiento territorial como en la gestión más global de cuestiones sociales, económicas, ecológicas y políticas.

Si bien los modelos de transformación del paisaje han sido inspiradores, no podemos dejar de observar críticamente la hegemonía norteamericana en la arquitectura y el urbanismo del paisaje. En este sentido, podemos coincidir en la mirada crítica que hacen lan Thompson (2012) y Anaïs Leger-Smith (2013). Representando la tradición inglesa y francesa del paisaje, estos autores observan que este movimiento estadounidense es sobre todo un discurso profesional de naturaleza descriptiva y operativa. Como conocimiento explícito, describe y clasifica las prácticas de paisaje, y sirve como referencia en la profesión. Este discurso profesional emana de la práctica, proviene de la argumentación del proyecto y legitima la experiencia del paisaje. Los problemas a los que se enfrentan los paisajes en Europa, son mucho más complejos y en ellos intervienen muchas más partes interesadas. Por ello, el uso de las métricas y modelación ecológica del paisaje, tan características de la escuela norteamericana, han tenido menos éxito en Europa, donde el valor del patrimonio y los significados sociales y simbólicos exigen un enfoque más holístico. En este contexto, la caracterización del paisaje requeriría de otras representaciones y narraciones que contemplen aspectos culturales y estéticos.

El éxito de la visión norteamericana, se debe a que explota el punto de inflexión ecológico actual, promoviendo a los profesionales del paisaje en la planificación urbana. También es un discurso sobre la colaboración con otras profesiones expresado en sus textos como multidisciplinariedad, siendo que en rigor se trata de multi-profesión (ver Capítulo 2). Debemos coincidir con Mohsen Mostafavi en que hoy "cada disciplina individual tiene un valor limitado para responder al rango y la diversidad de los problemas urbanos contemporáneos" (Mostafavi, 2011, p. 15). Actuar en Santiago, como en otras metrópolis densamente pobladas hace evidente la dificultad de actuar bajo las lógicas clásicas de arquitectos o urbanistas. Tal vez esta es una oportunidad de revisar estos límites disciplinarios y al difuminarlos recobrar el rol y el prestigio profesional de los arquitectos, junto a la capacidad de trabajar con otras disciplinas.

"Landscape Urbanism" también es un discurso pedagógico, o como lo hemos denominado, una escuela de pensamiento, que hace operativa la ecología a través del proyecto de paisaje y transmite este modelo a los futuros paisajistas. Debemos reconocer, la gran capacidad que han tenido Waldheim, Mostafavi y Corner para publicar y divulgar en Latinoamérica su modelo. Sin ir más lejos, en octubre 
de 2014 y con mucho éxito, se lanzó en Chile ${ }^{422}$ el libro Urbanismo Ecológico en el marco de un ciclo de conferencias de Mohsen Mostafavi, Gareth Doherty, Charles Waldheim y Diane Davis, donde se expusieron los principios filosóficos de este modelo, ilustrado con numerosos proyectos.

La contribución de esta perspectiva, asumida desde el sur del mundo, es que ofrece evidencias, que nos han permitido ver cómo la injusticia y la inequidad urbanas están directamente relacionadas con la calidad y cantidad de infraestructuras y paisajes en la ciudad. Como argumenta Mostafavi, un urbanismo alternativo puede crear nuevos imaginarios que consideren "la fragilidad del planeta y sus recursos como una oportunidad para innovaciones de diseño especulativas, más que como una forma de legitimación técnica para promover soluciones convencionales" (Mostafavi, 2011, p. 17).

\subsection{SOBRE LA RELACIÓN ENTRE PROYECTO E INVESTIGACIÓN}

Hace sólo unos días, mientras terminaba de redactar el último capítulo, encontré el interesante artículo Forty years of Landscape Research de Vera Vicenzotti, Anna Jorgensen, Mattias Qviström \& Simon Swaffield (2016), que comunica una investigación ${ }^{423}$ relativa a la revista británica Landscape Research y sus cuarenta años de publicaciones (desde su creación en 1976 a 2016). La revisión de este artículo, nos permite retomar uno de los temas emergentes de esta tesis, la relación entre proyecto e investigación, particularmente en proyectos de paisaje.

Esta importante revista internacional, se inició modestamente como un compendio de investigación para académicos y profesionales, lo que se mantiene como espíritu hasta hoy, que es producida como revista académica por un importante editor comercial, manteniendo la propiedad intelectual y comité editorial (LDG) para el cual, la relación entre teoría y práctica sigue siendo una preocupación central.

La revista se concibe como multidisciplinaria, ya que en ella que se aborda un tema común (el paisaje o Landscape), a partir del conocimiento de bases disciplinarias especificas.

Los inicios fueron marcados por temas de interés local, un ejemplo de ello es el Peak District del Reino Unido que ha sido discutido en todas las épocas. En los primeros años se desarrollan informes y planes de distintos parques, para poco a poco ir introduciendo generalizaciones de interés internacional, haciendo más explícitos los métodos y teorías.

Los temas principales en las décadas de 1970 y 1980 fueron los parques y la historia que, si bien se han mantenido con la ampliación de la revista, también se ha expandido temáticamente. Solo en la segunda mitad de la década de 1980 se empieza a analizar el concepto "paisaje" como tal, incorporando nuevas perspectivas teóricas sobre cómo entender los paisajes.

Si en los primeros años, los artículos sólo resumían brevemente los resultados de las investigaciones, para el 2005, el requisito de una justificación contextual y

${ }^{422}$ El simposio Ecological Urbanism reunió en Santiago de Chile a arquitectos latinoamericanos junto a destacados académicos de la Escuela de Arquitectura de la Universidad de Harvard (Harvard GSD), incluyendo a su Decano, Mohsen Mostafavi; el director del programa de Landscape Architecture, Charles Waldheim; Gareth Doherty, Lecturer in Landscape Architecture, y a Diane Davis, profesora de Urbanismo y Desarrollo de Harvard GSD.

${ }^{423}$ La investigación revisa 788 papers publicados entre 1976 y 2014. metodológica explícita es más evidente.

Como hemos visto en el Capítulo 2, en los noventa aparece un interés emergente en los discursos conceptuales, representaciones e ideologías del paisaje dentro de las humanidades y las ciencias sociales. Según Vicenzotti et al., "este giro cultural se desarrolló aún más con la introducción de un enfoque crítico que comenzó a explorar las posiciones ideológicas detrás de las diferentes interpretaciones del paisaje" (2016, p. 394). Este enfoque, representado especialmente por Cosgrove (1990), expandió los estudios de paisaje hacia la geografía y campos afines de las humanidades y las ciencias sociales.

También fue a partir de finales de la década de 1990 en adelante que la revista 
capturó más ampliamente la amplitud del campo, tanto en lo que respecta a los temas estudiados como a las conceptualizaciones del paisaje. Esto se ilustra con el tema transversal de los estudios de paisaje de carreteras. Con innumerables artículos (más de 17) que las analizan de distintos puntos de vista ${ }^{424}$.

Otra observación interesante del estudio, es que en los múltiples estudios sobre el Peak District, pocos se refieren a artículos publicados anteriormente. Esto sugiere que el proceso de aprendizaje mutuo y acumulativo que caracteriza a una comunidad de investigadores no está bien establecido.

El análisis revela que el alcance temático de la revista es amplio, pero se centra en la planificación del paisaje y la ecología, la historia del paisaje y la cultura, y, cada vez más, en las dimensiones sociales y antropológicas del paisaje. Sin embargo, también detectan una disminución en los artículos sobre temas centrados en la práctica.

Otra característica destacada, es que los autores principales son actualmente, casi en su totalidad, investigadores académicos, lo que plantea preguntas sobre la pertinencia de la investigación para los profesionales, tanto en la utilidad de esta investigación para la práctica como respecto al interés de los propios profesionales en participar en investigaciones y publicar. Respecto a la metodología, las publicaciones se caracterizan por un creciente énfasis en la interpretación y la modelación, con foco en el diagnóstico y la evaluación como estrategias de investigación. Al mismo tiempo, hay muy pocos informes de experimentación, investigación-acción o investigación de diseño. Lo que sí encontramos en las publicaciones norteamericanas ${ }^{425}$.

El artículo es prácticamente una imagen especular de lo que hemos observado en los temas de tesis de doctorados en arquitectura, discutidos en el Capítulo 2. Tanto la evolución de los temas de tesis en el tiempo (desde 2008 a la fecha en Chile); la falta de investigación con base en la práctica; y la escasez aprendizaje acumulativo, son características muy propias de la investigación en arquitectura, que difícilmente reconoce que el trabajo se funda en el de otros, buscando de este modo una supuesta originalidad.

El énfasis interdisciplinario, parece ser un elemento central en la investigación en paisaje, como lo muestra este estudio de la revista y también, pero en grado menor, el ejemplo de la tesis de doctorado catastradas en Chile. Ésta está dada, más que en la diversidad de disciplinas de los investigadores, en estrategias de investigación amplias y diversas. Podríamos hablar de investigaciones híbridas con énfasis en lo interpretativo.

Reconocemos en el análisis que hace Vicenzotti et al., tres discursos que forman parte de esta tesis, y que pueden reconocerse en los distintos capítulos como puntos de vista complementarios: una preocupación empírica por entender el paisaje como un lugar cotidiano en el que las personas viven, trabajan y se recrean; una perspectiva ampliamente interpretativa sobre el paisaje como un fenómeno cultural y socialmente significativo; y un enfoque de diagnóstico y evaluación sobre la acción e intervención del paisaje. Estos tres discursos son todos activos y en crecimiento. No son mutuamente excluyentes, de hecho, están fuertemente interrelacionados ya que reflejan diferentes imperativos para la formación del conocimiento, un conocimiento necesario para el proyecto.

La reflexión sobre proyecto-investigación o de investigación a través del proyecto, es una de las contribuciones de esta tesis. Especialmente relevante en Chile, ya que como hemos visto, la investigación en arquitectura es aún incipiente, concentrándose fundamentalmente en el doctorado de la Universidad Católica, que está acreditado y el de la Universidad del Biobío más pequeño y recientemente acreditado (2019). Hace menos de dos años, el 16 de noviembre de 2017, se realizó el lanzamiento oficial del Doctorado en Territorio, Espacio y Sociedad (D_TES), el primer programa de doctorado de la Facultad de Arquitectura y Ur-
${ }^{424}$ La investigación del paisaje es quizás única al aceptar tal variedad, y sin embargo todos estos aspectos contribuyen a una mejor comprensión del fenómeno de la carretera como paisaje.

425 Las investigaciones norteamericanas ponen, en general, mucho énfasis en la exposición del proyecto, tal vez demasiado, lindando con el marketing. 
banismo de la Universidad de Chile, que comenzó a dictarse desde el año 2018. Este será sin duda, un espacio en el que la autora de esta tesis ${ }^{426}$, podrá ampliar esta línea de investigación.

\subsection{TEMAS ABIERTOS}

Las conclusiones son también una instancia de revisión crítica del proceso de investigación. La estructura original de la tesis contemplaba cinco capítulos, que fueron abriéndose en nuevos temas. Podemos incluso considerar que hay más de una tesis anidada en los doce capitulos que hemos presentado. En ellos, la conceptualización de la racionalidad multiescalar, y el problema de la escala han quedado implícitos a lo largo del texto. Sin embargo, su profundización podría haber dado pie a un nuevo capítulo, incluso tiene el potencial, por sí mismo, de ser el tema de otra tesis. De hecho, actualmente trabajo en un artículo titulado "notas sobre la escala en la arquitectura", que indaga sobre el concepto de escala. A partir de la relación de tamaño entre dos realidades, emerge el problema de la representación, que pone en evidencia el pensamiento racional en tanto espejo de la naturaleza. La escala nos enfrenta a la dificultad de encontrar un modo de representación precisa de la realidad que nos permita pensarla y transformarla.

Si bien en esta tesis, hemos usado medios de configuración gráfica como herramientas de conocimiento e invención, hemos analizado y proyectado considerando distintas escalas, el objetivo ha sido demostrar que la arquitectura se enriquece mirada desde supuestos paisajísticos. Sin embargo, quedaría por desentrañar cuál es la racionalidad subyacente cuando hablamos de experiencia 0 percepción multiescalar, cuando pensamos operando a diversas escalas.

Un segundo tema que queda abierto para seguir investigando es la historia del paisaje en Chile. Si bien tanto en el Capítulo 3, sobre paisaje e identidad; en el 4 sobre la transformación del paisaje y en el 5 , sobre los grandes parques, hemos incluido y entretejido visiones sobre el paisaje en Chile, la reflexión ha estado orientada a descubrir aquellos aspectos identitarios que ligan el paisaje con la cultura chilena. A partir de la búsqueda de fuentes documentales, hemos descubierto muchas e interesantes referencias en crónicas, literatura, poesía y pintura sobre paisaje, sin embargo, no existe un texto que sistematice el tema del paisaje en Chile, tampoco un trabajo teórico que conceptualice rasgos propios. Podemos decir, que no hay un discurso intelectualmente autónomo, sino por el contrario, nuestro discurso sigue estando colonizado por los referentes europeos o norteamericanos.

Un tercer tema es paisaje y género, que surge de la coyuntura acontecida el año 2018, con los movimientos sociales a nivel global sobre equidad de género. La autora $^{427}$ ha investigado en esta temática junto a su hija (estudiante de arquitectura) y la doctora Claudia Alarcón (experta en género). Nuestro trabajo examina como la teoría de género pueda dar luces sobre nuevos modos de entender la relación entre arquitectura y paisaje. Proponemos revisar la teoría relacional a través del trabajo de Raewyn Connell (2013) que entiende el género como una estructura social en el espacio de múltiples relaciones (masculinas, femeninas y entre géneros); y confrontarla con la reflexión teórica contemporánea sobre paisaje, especialmente aquella que lo descifra como un palimpsesto. El objetivo es ofrecer un acercamiento alternativo a las teorías contemporáneas en arquitectura $y$ género.

${ }^{426}$ La autora de esta tesis pertenece al Departamento de Arquitectura de la Facultad de Arquitectura y Urbanismo de la Universidad de Chile

${ }^{427}$ La autora fue creadora y directora en 2019 de la Oficina de Equidad de Género de la recién creada Universidad Regional de O'Higgins.

Un cuarto tema es la relación entre proyecto e investigación, que, si bien ha sido extensamente abordado en esta tesis, que tiene potencial para un mayor desarroIlo. Como se ha mencionado, la autora ha participado en varios encuentros nacionales e internacionales con ponencias que reflexionan acerca de esta temática. $A$ partir de estas experiencias, se han establecido contactos con el grupo de trabajo de la Dra. Margitta Buchert de la Universidad de Hannover, el profesor Jürgen Weidinger de la Universidad de Berlín, el Dr. Alejandro Ferraz-Leite y Valentina 
Odella del Grupo de Investigación Teoría de la Arquitectura de la Universidad de la República de Uruguay. Como hemos dicho, la investigación en arquitectura es aún insipiente en Chile, y con muy poca vinculación con el proyecto, lo que ofrece un fértil campo de trabajo. En el mes de septiembre de 2018, la autora fue elegida directora del Departamento de Arquitectura de la Universidad de Chile, posición desde la cual ha impulsado la creación de grupos de trabajo que reúnen profesores que están en la práctica profesional con académicos investigadores, motivando esta línea de investigación.

Un quinto tema abierto en esta tesis es la vinculación entre arquitectura y geografía. La búsqueda de una base científica para comprender el paisaje, hizo patente la riqueza y tradición que posee esta disciplina. El encuentro con el profesor José Araya, al inicio del proyecto, fue clave para descubrir dimensiones del territorio que habitualmente permanecen ocultas para los arquitectos, tales como la geomorfología y los suelos. Del mismo modo, el trabajo con el Dr. Hugo Romero ${ }^{428}$ especialista en segregación socio-ambiental, ha ampliado la reflexión sobre el paisaje, para entenderlo como un sistema, que hace patente los conflictos socio territoriales que el modelo capitalista genera. Junto al Profesor Romero, el año 2018 trabajamos en el proyecto Resiliencia urbana y sustentabilidad ante el cambio climático en Latinoamérica: teoría y práctica, que fue expuesto en el Congreso Intersecciones ese mismo año. Actualmente desarrollamos una investigación que busca definir estándares de altura de edificación para zonas periurbanas. En ambos trabajos, el caso de estudio ha sido laguna Carén.

Por último, desde el año 2019, el rector de la Universidad de Chile me ha solicitado la asesoría para impulsar nuevamente el proyecto en Laguna Carén. En esta nueva etapa, mis opiniones y decisiones se fundan en la experiencia y la investigación sobre esa experiencia, plasmada a lo largo de esta tesis. Las intuiciones han sido reemplazadas por evidencias.

La defensa de este vasto territorio y de su paisaje como un bien común y como un derecho será la tarea profesional y el trabajo intelectual que asumiré. Cuando hablamos del paisaje como bien común, pensamos en una entidad difícil de privatizar, ya que se trata de una construcción social que se origina en la percepción de un espacio geográfico determinado. Un espacio subjetivo, que sin embargo está en tensión con el territorio que lo sustenta, y que sí está sujeto a un régimen de propiedad, de normas y de gestión política y administrativa.

Más que objeto entonces, el paisaje, puede ser considerado un sujeto con contenido ético, porque simboliza, transmite y conserva valores propios de una comunidad. Por lo tanto, como planeta Martín Checa-Artasu (2018) "proteger un paisaje sirve para salvaguardar, compartir y difundir ciertos valores ligados a la preservación de un determinado medioambiente y de un determinado marco cultural y social" (p. 9).

En el paisaje convergen naturaleza y cultura, sin embargo, su existencia es perecedera, pues depende del cultivo de una mirada compartida por una comunidad. El proyecto de paisaje tiene entonces el compromiso de despertar la atención sobre el mundo que nos rodea -educar y educarnos-, para hacer propios y amados los espacios de vida. Sólo así los territorios podrán hacer frente a las fuerzas del mercado, que lo ven como un recurso, vulnerando la frágil armonía entre hombres, mujeres y naturaleza.

\subsection{OTROS HALLAZGOS}

En la investigación documental realizada se han hecho dos hallazgos que me parece importante relevar: el primero, corresponde al lugar que le cabe en la historia de los parques públicos, a la Quinta Normal de Agricultura. La Quinta, inaugurada en 1841, fue el primer parque público construido en Chile y sería uno de los primeros de su especie en el mundo, al menos anterior a Birkenhead en 
Inglaterra, inaugurado en 1847 , y considerado por varios autores, como el primer parque público de la historia. Recordemos que se han definido en esta categoría, a aquellos que han sido creados y financiados por el estado para uso y goce de la ciudadanía. La omisión de este parque en la historia de los parques occidentales se debe a que Latinoamérica, y especialmente Chile, debido a su aislamiento geográfico, son considerados territorios culturalmente periféricos, colonias que han quedado fuera de la historia.

Otro hallazgo de esta investigación es que la primera mención de la palabra paisaje para el territorio chileno, fue Landscape, en inglés, por una mujer: la viajera inglesa María Graham, como consta en su diario de viaje de $1822^{429}$. Si bien, es un descubrimiento menor, dio pie a un intercambio epistolar muy interesante con la biógrafa de Graham, la historiadora Regina Akel, con quién planeamos escribir un artículo el año 2020.

\subsection{SOBRE LA ESCRITURA}

Para finalizar quisiera recordar a dos autores que han estado silenciosamente presentes a lo largo de este proceso de reflexión y escritura. El primero Karl Popper, que marcó por muchos años mi visión acerca de la relación entre ciencia y arquitectura, especialmente en la concepción de los campos disciplinares y su idea de la falsación como método de aproximación a la verdad, siempre huidiza. Popper en la conferencia de Tanner (1978) propone una imagen del universo representado por tres mundos: el universo físico, que contiene al segundo, el de los organismos vivos, donde aparece la experiencia consciente como producto emergente de la evolución y que a su vez produce el tercer mundo, el de los productos de la mente humana.

Estos tres mundos se interconectan y retroalimentan continuamente y dependen el uno de los otros. Para Popper, nuestras mentes son las creadoras del tercer mundo, pero también creadas por él. Así, la idea que tenemos de nosotros mismos depende de las teorías del mundo, que están ubicadas en el tercer espacio. Allí se conjugan nuestra identidad, la idea del yo, del espacio y del tiempo.

En este modelo, todo aprendizaje se entiende como un acto creativo, que produce un efecto de retroalimentación. El trabajo: proyectar o investigar también están en una relación de retroalimentación, que tiene algo de racional y también de imaginación e intuición, lo que los hace falibles, como todo producto humano. Popper nos señala una estrategia para lidiar con nuestra falibilidad y también los valores que la sustentan, cuando afirma:

La intuición debe ser controlada a través de la crítica racional, que es el producto más importante del lenguaje humano. Este control a través de la crítica es el aspecto racional del crecimiento del conocimiento y de nuestro crecimiento personal. Es una de las tres cosas más importantes que nos hacen humanos. Los otros dos son la compasión y la conciencia de nuestra falibilidad. (1978, p. 167).

${ }^{429}$ El diario de María Graham se publica en Londres el año 1824; el mismo año, Peter Schmidtmeyer (1772-1829) publica su libro Travel into Chile. Over the Andes in the years 1820 and 1821. En el texto de Graham se menciona siete veces la palabra Landscape y en el de Schmidtmeyer seis.
La conciencia de nuestra falibilidad, vale decir la humildad, es otro valor que debiéramos cultivar como arquitectos.

El otro autor es Georges Perec, cuyas narraciones he recordado en distintos momentos de esta tesis. Sus palabras nos vuelven a atar a la tierra, para recuperar el sentido de las cosas y recordar que somos responsables.

[...] el mundo, no ya como un recorrido que hay que volver a hacer sin parar, no como una carrera sin fin, un desafío que siempre hay que aceptar, no como el único pretexto de una acumulación desesperante, ni como ilusión de una conquista, sino como recuperación de un sentido, percepción de una escritura terrestre, de una geografía de la que habíamos olvidado que somos autores. (2001, p. 120) 
NOTA:

Parte de los contenidos de los capítulos 5, 12 y de las Conclusiones han sido publicadas por la autora en:

Barba-Buscaglia, P. (2019). Paisaje y ciudad: plan maestro parque Laguna Carén (Chile). Revista Ciudad y Territorio. Estudios territoriales, LI (201), 643 - 650.

Barba, P.; Allard, F. \& Bravo, F. (2019). Diseñar lo Vasto. Un Plan maestro para Laguna Carén (Santiago de Chile). En Planur-e, 13. Recuperado de 


\section{BIBLIOGRAFÍA}

Adán, C. (2012). El ABC de los parques científicos. Seminarios de la Fundación Española de Reumatología, 13(3), 85-94.

Adrià, M. (2013). Postales Chilenas. En Blanca montaña. Arquitectura en Chile (pp. 13-25). Santiago, Chile: Puro Chile.

Adriá, M. (2010). Blanca Montaña. Arquitectura reciente en Chile/White Mountain. Recent architecture in Chile (pp. 337339). Ediciones Puro Chile.

Addison, J. (1712). Pleasures Of Imagination. Spectator. (411).

AECOM ๑ (13 de septiembre, 2012). Vista aérea del Centro de Innovación de Skolkovo con la propuesta paisajística. [ilustración]. Recuperada de

https://worldlandscapearchitect.com/skolkovo-innovation-centre-moscow-russia-aecom/

AERES. (2014). Rapport d'activité 2014 de l'Agence d'évaluation de la recherche et de l'enseignement supérieur. Versailles-Marseille, Francia: HCERES. Recuperado de https://www.hceres.fr/sites/default/files/media/downloads/RAP_2014_ 22122014VD.pdf

Agence TER. (2014). Ubicación de Sophia Antipolis, respecto a la Costa Azul a 20 km del aeropuerto de Niza. Recuperado de https://agenceter.com/projets/antibes-sophia-antipolis/\#

Aicher, O. (2001). El Mundo como proyecto. Barcelona, España: Editorial Gustavo Gili.

Ajepbah. (24 de mayo, 2015). Festwiese im Hamburger Stadtpark in Hamburg-Winterhude, im Hintergund das Planetarium. [fotografía]. Recuperada de https://commons.wikimedia.org/wiki/File:Stadtpark_(Hamburg-Winterhude).Festwiese.4.22023.ajb.jpg

Akel, R. (2011). María Graham: Una biografía literaria. Santiago, Chile: Editorial Universitaria.

Al aire libre. (27 de agosto, 2014). Maqueta electrónica del Proyecto para el Estadio de Club Universidad de Chile. [imagen web]. Recuperado de

https://www.alairelibre.cl/noticias/deportes/futbol/universidad-de-chile/la-u-suma-una-nueva-complicacion-en-la-construccion-de-su-estadio/2014-08-27/074306.html

Alberti, L. (1991). De re aedificatoria (2nd Ed.). Madrid, España: Akal.

Alberti, M. (2008). Advances in urban ecology. New York, EE.UU.: Springer Science.

Alberti, T., \& Prado, J. L. (2008). Presencia de Stegomastodon (Gomphotheriidae, Proboscidea) en el Pleistoceno Superior de la zona costera de Santa Clara del Mar (Argentina). Estudios Geológicos, 64(2), 175-185.

Aldunate, C. y Rodríguez, H. (eds.). (2010). Santiago de Chile. Catorce mil años. Santiago, Chile: Banco Santander y 
Museo Chileno de Arte Precolombino.

Alegría, F. (1990). Creadores del mundo hispánico. Santiago, Chile: Editorial Andrés Bello.

Alexander, Ch. (1971). La estructura del medio ambiente. Barcelona, España: Tusquets.

Alexander, Ch. (1971). The State of the art in design methods. Design methods group, 5(3), 3-7.

Alexander, Ch. (1973). Notes on the synthesis of Form ( ${ }^{\text {nd }}$ Ed.). Cambridge, EE.UU.: Harvard University Press. Recuperado de https://monoskop.org/images//fff/Alexander_Christopher_Notes_on_the_Synthesis_of_Form.pdf

Alexander, Ch. (1976). Ensayo sobre la sintesis de la forma. Buenos Aires, Argentina: Ediciones Infinito. Biblioteca de Diseño y Artes Visuales. Recuperado de_https:/les.scribd.com/document/258659655/Christopher-Alexander-Ensayo-Sobre-La-Sintesis-de-La-Forma

Alexander, Ch. (1977). A Pattern Lenguage. Towns. Buildings. Construction. Nueva York, EE.UU.: Oxford University Press. Inc.

Alexander, Ch. (1979). The Timeless Ways of Buildings. Nueva York, EE.UU.: Oxford University Press.

Alexander, Ch. (1980). Un lenguaje de patrones. Barcelona, España: Editorial Gustavo Gili.

Alexander, Ch. (1993). A foreshadowing of 21st century art: The color and geometry of very early Turkish carpets. Nueva York, EE.UU.: Oxford University Press. Recuperado de https://archive.org/stream/AForeshadowingOf21stCenturyArt/A+Foreshadowing+of+21st+Century+Art_djvu.txt

Alexander, Ch., Ishikawa, S., \& Silverstein, M. (1977). A pattern language: Towns, buildings, construction. Berkeley, EEUU.: The Center for Environmental Structure.

Alexander, Ch.; Silverstein, M.; Angel, S. \& Ishikawa, S. (1978). Urbanismo y participación. El caso de la Universidad de Oregón. Barcelona, España: Editorial Gustavo Gili.

Alien Times. (2008). Planta general de la Ciudad de Tsukuba, cuyo trazado responde a criterios de transporte eficiente. [mapa]. Recuperado de http://www.alientimes.org/pmwiki/images/maps/tsukuba1.jpg

Allen, J. (2007). Third generation science parks. [web]. Manchester, Inglaterra: Manchester science parks. Recuperado de https://stanforddailyarchive.com/cgi-bin/stanford?a=d\&d=stanford19600428-01.2.2\#

Allen, S. (2001). Mat urbanism: The thick 2-D, en SARKIS, H. Case: Le Corbusier's Venice Hospital and the Mat building revival (pp. 118-126). Münich, Alemania: Prestel.

Almaldla. (18 de enero, 2007). Taj Mahal, India. [Fotografia]. Recuperada de https://es.wikipedia.org/wiki/Taj_Mahal 
Alonso, P. (2014). La transición al pos-productivismo: parques patrimoniales, parques culturales y ordenación territorial. EURE (Santiago), 40(119), 217-238. https://dx.doi.org/10.4067/S0250-71612014000100010

Alphand, A. (1867). Exposition Universelle de 1867 - Plan. En Les promenades de Paris. París, Francia: J. Rotschild. Bibliothèque de l'Institut National d'Histoire de l'Art. [Grabados]. Recuperado de https://www.atlasofplaces.com/cartography/ les-promenades-de-paris/

Alphand, A. (1867/1873). Les Promenades de Paris. Planches. París, Francia: Rothschild Éditeurs. Bibliothèque Nationale de France. Recuperado de https://www.atlasofplaces.com/cartography/les-promenades-de-paris/

Álvarez Munárriz, L. (2011). La categoría de paisaje cultural. Revista de Antropología Iberoamericana, 6(1), 57-80.

Ampuero, G., \& Rivera, M. (1971). Las manifestaciones rupestres y arqueológicas del Valle de El Encanto (Ovalle, Chile). Boletín del Museo Arqueológico de La Serena, (14), 71-103.

Amunátegui, D. (1903). Mayorazgos y títulos de Castilla. Santiago, Chile: Imprenta litografía y encuadernación Barcelona. Recuperado de_http://www.memoriachilena.cl/archivos2/pdfs/MC0018273.pdf

ANDALUÉ. (2016). Propuesta estudios ambientales. Proyecto académico Laguna Carén. Informe Técnico.

ANPROTEC. (s.f.). Asociación Nacional de Entidades Promotoras de Emprendimientos Innovadores. Recuperado de http://anprotec.org.br/site[m1] /.

Arancibia, S. (2015). La representación del cuerpo en el abate Juan Ignacio Molina. (Tesis Pregrado de licenciatura, Facultad de Filosofía y Humanidades, Universidad de Chile, Chile). Recuperado de http://repositorio.uchile.cl/handle/2250/130578

Araujo, C. (noviembre, 2019). Zona de pícnic a orillas de la laguna Carén. [Fotografía]. Recuperada de https://n9.cl/f412

Araya, B., Bernal, M., Schlatter, R., \& Salaberry, M. (1995). Lista patrón de las aves chilenas (3ra Ed.). Santiago, Chile: Editorial Universitaria.

Archer, B. (1981). A view of the nature of the design research. Design, science, method. 36-39. Recuperado de https:// catedrammo.files.wordpress.com/2010/01/archer_bruce_1981_design_science_method.pdf

Argán, G.C. (1973). El Concepto del espacio arquitectónico desde el Barroco a nuestros días. (L. Rainis trad.) Curso dictado en el Instituto Universitario de historia de la Arquitectura en la ciudad de Tucumán, el año 1961. Buenos Aires, Argentina: Ediciones Nueva Visión.

Arica Hoy. (30 de octubre, 2014). Cultivos en Arica. [Fotografía]. Recuperado de http://www.aricahoy.cl/2014/10/mejoraran-agricultura-local/

Aristóteles. (1994). Ética a Nicómaco. (M. Araujo \& J. Marías). Madrid, España: Centro de Estudios Constitucionales. 
Ariza, E. (2013). El ser, estar y actuar andino y la crisis ambiental. Tendencias \& retos, 18 (2), 93-110.

Arnaldo, J. (2008). Goethe: El paisaje como imagen. Johann Wolfgang von Goethe. Paisajes. Madrid, España: Circulo de Bellas Artes.

Arriola, A. (Ed.) (1993). Moving beyond Darwin. En Modern Park Design: Recent Trends. 36-45. Amsterdam, Países Bajos: Thoth.

Arteche, P. (2012). El camino de Valparaíso a Santiago. Trazados y rutas coloniales. Ensayo inédito. Recuperado de https://wiki.ead.pucv.cl/El_camino_de_Valpara\%C3\%ADso_a_Santiago._Trazados_y_rutas_coloniales.

Ascher, F. (2004). Los nuevos principios del urbanismo: el fin de las ciudades no está a la orden del día. Madrid, España: Alianza.

Asociación Europea de Vías Verdes. (12 de septiembre, 2000). Declaración de Lille. Lille, Francia. Recuperado de https:// www.aevv-egwa.org/es/vias-verdes-2/

Atelier Castro Denissof \& Associés @ ( (10 de octubre, 2014). Un projet de ville-parc à La Courneuve, au nord de Paris. Le Moniteur [Planta]. Recuperado de

https://www.lemoniteur.fr/article/un-projet-de-ville-parc-a-la-courneuve-au-nord-de-paris.1467019\#zoom

ATISBA. (2011). La Brecha Verde: Distribución espacial de las áreas verdes en el Gran Santiago. Santiago, Chile: Atisba Estudios y Proyectos Urbanos Ltda. Recuperado de http://www.atisba.cl/wp-content/uploads/2017/04/Atisba-Monitor-Areas-Verdes.pdf

Augusta, F. J. (1906). Diccionario Araucano-Español y Español-Araucano. Santiago, Chile: Imprenta Universitaria.

Austrich, R. (2003). Frederick Law Olmsted y el Emerald Necklace de Boston. Revista Urbano, 6 (8), 93-99. Recuperado de_http://revistas.ubiobio.cl/index.php/RU/article/download/567/530/

Avilés, L. (2000). Relaciones horizontales y miradas penetrantes: discurso y visión en Petrarca y Gracián. En F. Sevilla \& C. Alvar (Coord.), Actas del XIII Congreso de la Asociación Internacional de Hispanistas. Madrid, España: Centro Virtual Cervantes.

Avocat, C. (1984). Essai de mise au point d'une méthode d'étude des paysages en Lire le paysage, lire les paysages. Actas del coloquio realizado el 24 y 25 noviembre de 1983 en la Université de Saint-Etienne, 11-23. Paris, Francia: C.I.E.R.E.C.

AQUIAYSEN. (3 de febrero, 2017). Roces a fuego en Coyhaique. [Fotografía]. Recuperado de https://aquiaysen.wordpress.com/2017/02/03/fuego-en-la-patagonia-de-aysen-en-los-inicios-de-1900-el-incendio-forestalmas-grande-de-la-historia-de-chile/comment-page-1/

Baan, I. ( (16 de noviembre, 2018). Edificio para Skolkovo Institute of Science and Technology. [Fotografías]. Recuperadas de https://www.archdaily.com/905951/skolkovo-institute-of-science-and-technology-herzog-and-de-meuron 
Bachelard, G. (1957/2000). La poética del espacio. Traducido por Ernestina de Champourcin. Buenos Aires, Argentina: Fondo de Cultura Económica.

Baczko, B. (1984). Los imaginarios sociales: Memorias y esperanzas colectivas (2nd Ed.). Buenos Aires, Argentina: Nueva Visión. Recuperado de_https://imaginariosyrepresentaciones.files.wordpress.com/2015/09/baczko-bronislaw-los-imaginarios-sociales.pdf

Baeza, F. (1959) El Parque Cousiño, (Seminario de Historia de la Arquitectura) Departamento de Historia, Facultad de Arquitectura y Urbanismo. Santiago: Universidad de Chile.

Bailey, R. G. (2002). Ecoregion-Based design for sustainability. New York, EE.UU.: Springer-Verlag New York Inc.

Ballent, A. (2005). Las huellas de la política: vivienda, ciudad, peronismo en Buenos Aires, 1943-1955. Bernal, Argentina: Universidad Nacional de Quilmes.

Bann, S. (1974). The Tradition of Constructivism. Nueva York, EE.UU.: The Viking Press.

Barba, P. (2015). Memoria Proyecto Académico Laguna Carén. Informe Interno Rectoría. Santiago, Chile: Universidad de Chile.

Barba, P. (17 de mayo, 2016). Laguna Carén. Presentación que incluye proyectos de investigación aplicada que se instalarían en Carén. Consejo Universitario. Santiago, Chile: Universidad de Chile.

Barlow Rogers, E. (1972). Frederick Law Olmsted's New York. Nueva York, EE.UU.: Praeger. Digitizing sponsor: Metropolitan New York Library Council. Recuperado de https://archive.org/details/frederick00roge

Barlow Rogers, E. (2001). Landscape Design: A Cultural and Architectural History. Nueva York, EE.UU.: Abrams Books.

Bateson, G. (1987). Steps to an ecology of mind. Northvale, New Jersey, Londres: Jason Aronson Inc.

Bateson, G. (1998). Pasos hacia una ecología de la mente. Nueva York, EE.UU.: Chandler Publishing Company.

Bateson, M. C. (1972). Our Own Metaphor. A Personal Account of a Conference on the Effects of Conscious Purpose on Human Adaptation. Nueva York, EE.UU.: Alfred A. Knopf. Basado en la conferencia organizada por el antropólogo Gregory Bateson en Austria el año 1968. La autora, hija de Bateson transcribe e interpreta lo observado en esa ocasión.

Bauman, Z. (2003). Utopia with no Topos. History of the Human Sciences, 16(1), 11-25. Recuperado de https://doi. org/10.1177/0952695103016001003

Bauman, Z. (2004). La sociedad sitiada. México: Fondo de Cultura Económica.

Bayazit, N. (2004). Investigating design: A review of forty years of Design Research. Design isssues, 20(1), 16-29. 
Becher, B., Becher, H. \& Smithson, R. (2002). Field Trips. Bernd and Hilla Becher, Robert Smithson. Catálogo de la exposición en el museo de Arte contemporáneo de Serralves. Oporto, Portugal: Fundação de Serralves/Hopefulmonster.

Beer, S. (1972). Brain of the firm. Londres, Inglaterra: Allen Lane The Penguin Press.

Benavides, A. (1961). La arquitectura en el Virreinato del Perú y en la Capitanía General de Chile. Santiago, Chile: Editorial Andrés Bello.

Benévolo, L. (1994). La captura del infinito. Madrid, España: Celeste.

Bengoa, J. (1990). Historia social de la agricultura chilena, Tomo II, Haciendas y Campesinos. Santiago, Chile: Editorial Sur.

Bengoa, J. (2015). Historia rural de Chile central. Tomo I: La construcción del Valle Central de Chile. Santiago, Chile: LOM Ediciones.

Bengoa, J. (2015). Historia rural de Chile central. Tomo Il: Crisis y ruptura del poder hacendal. Santiago, Chile: LOM Ediciones.

Berque, A. (2000). Médiance de milieux en paysages. París, Francia: Belin.

Berque, A. (2009). El pensamiento paisajero. Madrid, España: Biblioteca Nueva.

Berman, M. (1989). Todo lo sólido se desvanece en el aire. La experiencia de la modernidad. (Tercera edición castellana). Buenos Aires: Siglo XXI Editores.

Berrizbeitia, A. (2007). Re-placing Process. Nueva York, EE.UU.: Princeton Architectural Press.

Bertalanffly, K.L. von. (1989). Teoría General de los Sistemas (séptima reimpresión) Trad. Juan Almela. México DF, México: Fondo de Cultura Económica. Título original: (10 ed. 1968) General System Theory. Nueva York, EE.UU.: George Braziller.

Bertoncello, R., Castro, H., y Zusman, P. (2003). Turismo y patrimonio: Una relación puesta en cuestión. En R. BertonceIlo, C. Alessandri, A. Fani (Ed.), Procesos territoriales en Argentina y Brasil (pp. 277-292). Buenos Aires, Argentina: IGFFyl-UBA.

Besse, J. M. (2001). Cartographier, construire, inventer. Notes pour une épistémologie de la démarche de projet. Les Carnets du paysage, 7, 126-145. Recuperado de https://dpearea.files.wordpress.com/2012/12/2001-besse-cartographie-projet.pdf

Besse, J. M. (2009). Mapping, constructing, inventing: on the notion of project and its 
Epistemology. En Le Goût du monde. Exercices de paysage. Actes Sud/ ENSP (pp. 149-188). Arles,

Francia.

Besse, J. M. (2010). La sombra de las cosas. Sobre paisaje y geografía. Madrid, España: Biblioteca Nueva.

Bibar, G. de. (1558/1966). Crónica y relación copiosa y verdadera de los Reynos de Chile. Transcripción Paleográfica de I.A. Leonard según el manuscrito original. Santiago, Chile: Editorial Universitaria.

BID. (2014). Indicadores. Banco Interamericano de Desarrollo. Recuperado de https://datos.bancomundial.org/indicador/ GB.XPD.RSDV.GD.ZS?view=map\&year=2014

Blaeu, J. (1704). Hortus et Palatium Atestinorum Tyburi. [grabado]. En Nouveau theathre d'Italie. Amsterdam, Países Bajos: Pierre Mortier. Lámina LXI. Recuperado de http://www.pierotrincia.it/en/3063/Villa-d-Este-Tivoli-Hortus-et-PalatiumAtestinorum-Tyburi---Joan-Blaeu---Pierre-Mortier.html

Boettinger, H. (2001). Reseña Histórico Urbanista de la Comuna de Pudahuel. Santiago, Chile: I. Municipalidad de Pudahuel, Dirección de Obras.

Bolton, W. (1992). New mechanisms to link university-enterprise: The Incubator as a technological development factor. Ponencia en la Conferencia University infrastructure to improve linkages with industry. Veracruz, México.

Bolton, W. K. (1996). Technological development \& globalisation: The importance of incubators and science parks for the generation of new interprises. Revista Produçào, 6(2), 213-224. Recuperado de http://www.scielo.br/scielo.php?script=sci_arttext\&pid=S0103-65131996000200005\&lng=en\&tlng=en

Bondy Ecologie. (20 de mayo, 2015). Parc de la Courneuve en Danger. [Afiches]. [blog]. Recuperado de http://bondyecologie.blogspot.com/2015/05/pique-nique-citoyen-contre-le-projet-de.html

Bonsiepe, G. (1978). Teoría y práctica del Diseño Industrial. Barcelona: Gustavo Gilli, S.A.

Bonsiepe, G. (2004). Dos textos recientes: Proyectar hoy Diseño | Globalización | Autonomía. La Plata, Argentina: Nodal.

Bonsiepe, G. (2007). The uneasy relationship between design and design research. En Z. Ralf Michel-(Ed.), Design Research Now: essays and selected projects. Basel - Boston - Berlín: Birkhäuser.

Bonsiepe, G. (2012). Diseño y crisis. Valencia, España: Campgràfic.

Borobio, M., \& García, M. (2012). El paisaje como medio para la planificación territorial. Revista ciudades 15 (1), 115-132. Valladolid, España: Editado por el Instituto Universitario de Urbanística de la Universidad de Valladolid.

Boutinet, J. P. (1990/2015). Anthropologie du projet. (3ra. Ed.). París, Francia: Presses Universitaires de France. 
Boullée, E. L. (1784) Projet de cénotaphe à Isaac Newton - Vue en coupe. [Fotografía del grabado original]. Recuperada de https://commons. wikimedia.org/w/index.php?curid $=625800$

Boullée, E. L. (1985). Arquitectura. Ensayo sobre el arte. (Carlos Fuentes trad.). Barcelona, España: Editorial Gustavo Gili.

Brantz, D. \& Dümpelmann, S. (Eds.). (2011). Greening the City: Urban landscapes in the twentieth century. Berlin, Alemania: Technische Universitat Berlin.

Bray, P. M. (1988). Possibility of parks unbounded. Environment. Braypapers. Waterloo, Canadá: University of Waterloo. Recuperado de_http://www.braypapers.com/parks-and-other-articles/possibility-of-parks-unbounded-environment-may-1988/

Brenner, N. (2016). La explosión de lo urbano. Santiago de Chile: Pontificia Universidad Católica de Chile, ARQ Ediciones.

Brettell, R. \& Friis-Hansen, D. (1996). Richard Long: Circles Cycles Mud Stones. Catálogo de la Exhibición. Houston, EE.UU.: Contemporary Arts Museum.

Brown, E. (1988). Espíritu de la época y espíritu del lugar. México D.F., México: Editorial Gustavo Gili. Recuperado de http://ebrowne.cl/wp-content/uploads/2014/11/1986_espiritu_epoca.pdf.

Bronowski, J. (1987) El Ascenso del Hombre. Wilmington, Delaware, EE.UU.: Addison-Wesley lberoamericana, S.A.

Brüggen, J. (1950). Fundamentos de la geología de Chile. Santiago, Chile: Instituto Geográfico Militar.

Buchanan, R. (2001). Design research and the new learning. Design Issues, 17(4), 3-23. Recuperado de http://doi. org/10.1162/07479360152681056

Buchert, M. (ed.) (2014). Reflexives Entwerfen, Reflexive Design. Berlin, Alemania: jovis Verlag.

Bueno, E. \& Casani, F. (2007). La tercera misión de la universidad. Enfoques e indicadores básicos para su evaluación. Economía Industrial, (366), 43-59. Recuperado de http://www.minetad.gob.es/Publicaciones/Publicacionesperiodicas/Economialndustrial/RevistaEconomialndustrial/366/43.pdf

Bulnes, M. (1849). Discurso del Presidente de la República en 1849. En Documentos Parlamentarios, Tomo IV: Discursos de Apertura en las Sesiones del Congreso i Memorias Ministeriales correspondientes al segundo quinquenio de la Administración Bulnes (1847-1851). Santiago, Chile: Imprenta del Ferrocarril.

Bulnes, M. (1851). Exposición que el General Don Manuel Bulnes dirige a la Nación Chilena. En Documentos Parlamentarios, Tomo IV: Discursos de Apertura en las Sesiones del Congreso i Memorias Ministeriales correspondientes al segundo quinquenio de la Administración Bulnes (1847-1851). Santiago, Chile: Imprenta del Ferrocarril.

Burckhardt, J. (1952). La cultura del renacimiento en Italia. Buenos Aires, Argentina: Losada. 
Bustamante, P. \& Rojas, R. (2015). Tawantinsuyu, Alianza Multicultural Precolombina. Presentación en el IV Congreso de la Internacional del Conocimiento. Simposio No37. Riobamba, Ecuador.

Busquets, J., Cortina, A. (Ed.). (2009). Gestión del paisaje. Manual de protección, gestión y ordenación del paisaje. Barcelona, España: Ariel.

Cabrera, C. (2016). Ética y modernidad en el discurso de Gui Bonsiepe. (Tesis de Maestría, Universidad Jorge Tadeo Lozado, Colombia). Recuperado de_http://expeditiorepositorio.utadeo.edu.co/handle/20.500.12010/1780

Calderón, A. (2001). Memorial de Valparaíso. Santiago, Chile: RIL Editores.

Cambridge Science Park. (2018). 48 years of history \& 700 years of Heritage. [sitio web]. Recuperado de https://www. cambridgesciencepark.co.uk/about-park/past/

Cambridge Science Park. (2019). Vista General del Cambridge Science Park en la actualidad. [Fotografía]. Recuperado de https://www.cambridgesciencepark.co.uk/about-park/present/

Cárdenas, I. de (2009). El "Manifiesto Verde" de Leberecht Migge. Cuaderno de Notas, 0(12), 119-134.

Careri, F. (2014). Walkscapes. El andar como práctica estética. Barcelona, España: Editorial Gustavo Gili.

Carrasco-Lagos, P., Moren, R.A., Tala, Ch., Ibarra-Vidal, H. \& Duarte, M. (2016). Vertebrados En Peligro de la Región Metropolitana de Santiago, Chile. Santiago, Chile: Seremi del Medio Ambiente Región Metropolitana de Santiago, Universidad Santo Tomás, Ministerio del Medio Ambiente, Exp Ediciones al Conocimiento, Instituto de Ecología y Biodiversidad (IEB-Chile) y Minera Florida. Pp. 52.

Carter, W. y Aguirre, L. (1965). Structural geology of Aconcagua province and its relationship to the central valley Graben, Chile. Geological Society of America Bulletin, 76, 651-664.

Cartier-Bresson, J., Destremau, B., \& Lautier, B. (2009). Les mots du développement: trajectoires et pouvoirs. Introduction. Revue Tiers Monde, 4 (200),725-734. DOI 10.3917/rtm.200.0725

Casa Infos. (12 de marzo, 2011). Plano general del territorio que abarca Sophia Antipolis con 2.400 ha. Por Communauté d'Agglomération Sophia Antipolis. Recuperado de

https://casa-infos.agglo-casa.fr/sites/files/images/pages/Sophia_centrevie_carte_1000.jpg

CASEN. (2013). Nueva Metodología de Medición de la Pobreza por Ingresos y Multidimensional. Serie Documentos metodológicos № 28. Versión revisada: 26 de enero de 2015. Santiago, Chile: Observatorio Social - Ministerio de Desarrollo Social. Recuperado de http://observatorio.ministeriodesarrollosocial.gob.cl/documentos/Nueva_Metodologia_de_Medicion_de_Pobreza.pdf

Castells, M. \& Hall, P. (1994). Tecnópolis del mundo. La formación de los complejos industriales del siglo XXI. Madrid, España: Alianza Editorial. 
Castillo, E. (Ed.). (2009). Conversaciones informales I. Luis Izquierdo/Germán del Sol. Santiago, Chile: Editorial ARQ.

Castillo Espinoza, E. (2010). Artesanos, artistas, artífices. La Escuela de Artes Aplicadas de la Universidad de Chile. Santiago, Chile: Ocho Libros; Pie de Texto.

Castro Jorquera, C. (18 de agosto, 2014). Richard Long: «Mi Trabajo Es Sobre Las Ideas De Libertad. Hago Arte Casi De La Nada». Entrevista. Artishock. Recuperado de http://artishockrevista.com/2014/08/18/richard-long-trabajo-las-ideas-libertad-hago-arte-casi-la-nada/

CELADE - División de Población de la CEPAL \& Naciones Unidas, Departamento de Asuntos Económicos y Sociales, División de Población (2019). World Population Prospects. Recuperado de https://www.cepal.org/es/temas/proyecciones-demograficas/estimaciones-proyecciones-poblacion-total-urbana-rural-economicamente-activa

Central Park Conservancy. (7 de septiembre, 2017). How Geology Influenced Central Park's Design. Jessica Sain-Baird. [fotografía]. Recuperada de

https://www.centralparknyc.org/blog/geology-influenced-design

CEPAL. (1966). El edificio de las Naciones Unidas en Santiago de Chile. Santiago, Chile: Naciones Unidas.

Cerros Isla. (2018). Fundación Cerros Isla. Recuperado de http://www.santiagocerrosisla.cl/

Cerros Isla (s.f.). Fundamento. Recuperado de https://www.santiagocerrosisla.cl/fundamento

Cervantes, M. (2012). El ingenioso hidalgo don Quijote de la Mancha. Tomo I, Cap. VI. Madrid, España: Alba Libros SL.

Chambers, W. (1772). A dissertation on oriental gardening. Londres, Inglaterra: Editado por W. Griffin, The Royal Academy. Recuperado de https://archive.org/details/gri_dissertation00cham/page/n13

Chazarra, A. (2017). Epicuro: el filósofo de los placeres moderados. Revista digital Entreletras. Recuperado de https:/l www.entreletras.eu/index.php/ensayo/471-epicuro-el-filosofo-de-los-placeres-moderados.html

Charton de Treville, E. (1845). 18 de septiembre en el Campo de Marte. [fotografía] Recuperada de https://es.wikipedia. org/wiki/Archivo:Charton,_Ernest_18_de_septiembre_en_el_Campo_de_Marte,_1845_f2.jpg

Checa-Artasu, M. (2018). El paisaje como bien común y como un derecho, Algunas reflexiones. Biblio3W, Revista Bibliográfica de Geografía y Ciencias Sociales, (XXIII), 1.251, 1-20.

Chermayeff, S., \& Alexander, Ch. (1963). Community and Privacy. Nueva York, EE.UU.: Doubleday \& Co. Inc.

Chermayeff, S., Alexander, Ch. (1968). Comunidad y Privacidad. Buenos Aires, Argentina: Editorial Nueva Visión. (Rubén Masera trad.). 
Chilexplora.com (2019). Vista panorámica desde Parque Metropolitano. [fotografía] Recuperada de https://chilexplora. com/chilexplora/panorama/entornos/metropolitana/parquemetrodedia/tour.html

Chiuminatto, P. (2016). Paisajes, materia y olvido. $8^{\circ}$ Coloquio El patrimonio: ¿Bien común o de mercado?. Valdivia, Chile: Consejo Nacional de la Cultura y las Artes.

Choay, F. (1996). Le régle et le modéle. Sur la théorie de l'architecture et de l'urbanisme. París, Francia: Éditions du Seuil.

Choay, F. (2000). L'Utopie et le statut philosophique de l'espace édifié. En Lyman Tower Sargent y R. Schaer (Eds.), Utopie. La quête de la société idéale en Occident. París, Francia: Bibliothèque Nationale de France/Fayard.

Cid, G. (2009). Un icono funcional: La invención del roto como símbolo nacional, 1870-1888. En G. Cid y A. San Francisco. Nación y nacionalismo en Chile - Siglo XIX. Santiago, Chile: Centro de Estudios Bicentenario.

Cid, Ó. (2005). Los Humedales: Espacios Educativos. Los humedales, un patrimonio ambiental para el futuro. Oleiros, España: Universidad Internacional Menéndez y Pelayo. Recuperado de_http://www.mapama.gob.es/es/ceneam/articulos-de-opinion/2005_04cid_tcm7-53055.pdf

CIPER. (31 de enero, 2019). Vista de Ciudad de Los Valles. [fotografía] Recuperada de https://ciperchile.cl/2019/01/31/proyectos-inmobiliarios-en-pudahuel-las-irregularidades-de-ciudad-de-los-valles-e-izarra-de-lo-aguirre/

CIREN. (1996). Capacidad de uso de suelo. Geoportal del Ministerio de Agricultura. Recuperado de http://ide.minagri.gob. cl/geoweb/

Clasificados.com (22 de septiembre, 2014). Aviso publicitario de vivienda en Santiago, Chile. [imagen web]. Recuperada de http://cl.clasificados.com/residencia-en-lonquen-norte-condominio-las-fuentes-723920

Clark, B. (1997). Creando universidades emprendedoras en Europa. Revista Valenciana d'Estudis Autonòmics, (21), 373392.

Clément, G. (2017). El jardín en movimiento. Barcelona, España: Editorial Gustavo Gili.

Clément, G. (2018). Manifiesto del Tercer Paisaje. Barcelona, España: Editorial Gustavo Gili.

CMU. (2019). Doctor of Professional Practice (DPP). En [Página web] Carnegie Mellon University. Recuperado de https:// soa.cmu.edu/dpp

Collinge, S. K. (1996). Ecological consequences of habitat fragmentation: Implications for landscape architecture and planning. Landscape and Urban Planning 36, 59-77.

Collot, M. (1984). L'horizon du paysage. En Ch. Avocat. (Ed.), Lire le paysage, lire les paysages. Paris, Francia : C.I.E.R.E.C. 
Colonna, F. (1499). Hypnerotomachia poliphili. Venecia, Italia: Aldus manutius. Recuperado de https://archive.org/details/ A336080

Comisión Chilena de Energía Nuclear (CCHEN). (1989). 25 años 1964-1989. Santiago, Chile: Comisión Chilena de Energía Nuclear.

Comisión Económica para América Latina (CEPAL) \& El Caribe/Programa de las Naciones Unidas para el Desarrollo (PNUMA). (2002). Financiamiento para el desarrollo sostenible en América Latina y el Caribe, de Monterrey a Johannesburgo (LC/ G.2146 [CONF.90/4]). Santiago, Chile: CEPAL.

Comisión Nacional del Medio Ambiente (CONAMA). (s.f.). Inventario Nacional de los Humedales de Chile. [visor web]. Recuperado de https://gis.mma.gob.cl/portal/apps/webappviewer/index.html?id=19ff876d63ed4a53aef1a57e39370474

Comisión Nacional del Medio Ambiente (CONAMA). (2005). Estrategia Nacional para la Conservación y Uso Racional de los Humedales en Chile. Recuperado de https://www.ramsar.org/sites/default/files/documents/library/chile_estrategia_nacional_2005.pdf

Comisión Nacional del Medio Ambiente (CONAMA). (2008). Biodiversidad de Chile, patrimonio y desafíos. Santiago, Chile: Ocho Libros Editores.

Comisión Nacional del Medio Ambiente (CONAMA), Corporación Nacional Forestal (CONAF). (2005). Estrategia Nacional para la Conservación y Uso Racional de los Humedales en Chile. Santiago, Chile: Comisión Nacional del Medioambiente. Recuperado de https://www.ramsar.org/sites/default/files/documents/library/chile_estrategia_nacional_2005.pdf

Conicet (s.f.). Eutrofización. En Enciclopedia/términos [en línea]. Mendoza, Argentina: Conicet. Recuperado de https:// www.mendoza.conicet.gov.ar/portal/enciclopedia/terminos/Eutrofizac.htm

Conklin, J. (2005). Dialogue Mapping: Building Shared Understanding of Wicked Problems. Nueva York, EE.UU.: John Wiley \& Sons, Inc.

Connell, R. (2013). Género, Salud y Teoría: Conceptualizando el tema en perspectiva mundial y local. Nómadas (Bogotá, Colombia), (30), 63-77. Universidad Central.

Conseil départemental de la Seine-Saint-Denis. (2016). Plan du parc Georges-Valbon. [plano para visitantes en formato digital]. Recuperado de https://es.calameo.com/read/0006349240426ce1f1567

Consejo de Europa. (2000). Convenio Europeo del paisaje. Florencia, Italia: BOE 31, Edición en español. Recuperado de http://otv.jccm.es/uploads/tx_cotv/Convenio_Europeo_Paisaje.pdf

Consejo Nacional de la Cultura y las Artes (2016). Coloquios Patrimoniales. Santiago, Chile: Gobierno de Chile. Recuperado de https://coloquiospatrimoniales.cultura.gob.cl/opinal

Contraloría General de la República (CGR). (2015). Preinforme de Investigación Especial №4, remitido mediante el Oficio $\mathrm{N}^{\circ}$ 033152, de 27.04.2015, relativo al estado de cumplimiento del Decreto $\mathrm{N}^{\circ} 350$, de 1994, del Ministerio de Bienes Nacionales. 
Cooper, M. \& Henriquez, C. (2010). Planificación territorial y crecimiento urbano: Desarticulaciones y desafíos de la sostenibilidad urbano-regional en Santiago metropolitano. Scripta Nova. Revista Electrónica de Geografía y Ciencias Sociales, 331(14). Recuperado de http://www.ub.es/geocrit/sn/sn-331/sn-331-14.htm.

Corboz, A. (1998). II territorio come palinsesto. En P. Viganò \& B. Secchi (Eds.), Ordine sparso: Sa-ggi sull'arte, il metodo, la città e il territorio, 177-191. Milán: Franco Angeli.

Cornejo, L. (2010). Arqueología de cazadores recolectores en Chile central: Una síntesis de lo avanzado, las limitaciones y las aspiraciones. Revista Werken, 13, 69-83.

Corner, J. (1999). Recovering landscape as a critical cultural practice. Introduction. J. Corner (Ed.). Nueva York, EE.UU.: Princeton Architectural Press.

Corner, J. (2004). Not unlike life itself. Harvard Design Magazine, 21, 32-34. Recuperado de http://www.harvarddesignmagazine.org/issues/21/not-unlike-life-itself-landscape-strategy-now

Corner, J. (2006). Terra fluxus. The Landscape urbanism reader. Nueva York, EE.UU.: Princeton Architectural Press.

Corporación Nacional Forestal (CONAF). (1988). Libro Rojo de los vertebrados terrestres de Chile. Actas del simposio. Santiago, Chile: Corporación Nacional Forestal, Ministerio de Agricultura.

Cormier, L. (2011). Les trames vertes: Entre discours et matérialités, quelles réalités? (Tesis Doctoral, Université d'Angers, Angers). Recuperado de https://tel.archivesouvertes.fr/file/index/docid/640049/filename/Doctorat_Cormier_Laure_trames_ vertes_entre_discours_et_materialites_quelles_realites.pdf

Cortina, A. C. (2009). Gestión del paisaje. Manual de protección, gestión y ordenación del paisaje. Barcelona, España: Editorial Ariel, colección Patrimonio.

Cosgrove, D. (1990). Landscape studies in geography and cognate fields of the humanities and social sciences. Landscape Research, 15(3), 1-6. Recuperado de http://dx.doi.org/10.1080/01426399008706316

Coste, A. (2008). Quel sens en architecture pour le polysémique de modéle. En A. Coste et M.-A. Creps. Séminaire Doctoral: Espace Matiéres Société. (pp. 73-86). Grenoble, Francia: École Nationales Supérieure d'Architecture de Grenoble.

Coudivat, Y., \& Giusti, J. (1991). Atlas International das Technopoles. París, Francia: DATAR, Ministère de la Ville et de Laménagement da Territoire.

Council of Europe. (2000). European Landscape Convention. Recuperado de https://www.coe.int/en/web/conventions/ full-list/-/conventions/rms/0900001680080621

Cranz, G. (1982). The Politics of Park design: A history of urban parks in America. Cambridge, MA, EE.UU.: MIT Press.

Cranz, G. (2000). Changing Roles of Urban Parks. San Francisco, EE.UU.: SPUR Newsletter. 
Cross, N. (Ed.). (1984). Developments in design methodology. (p. 317). Chichester, Inglaterra: Wiley.

Cross, N. (2001). Designedly ways of knowing: Design discipline versus design science. Design Issues, 17(3).

Cross, N. (2007). Designedly Ways of Knowing. Basel-Boston-Berlin: Birkhäuser.

Cross, N. (2007). From a Design Science to a Design Discipline: Understanding Designedly Ways of Knowing and Thinking. En M. Ralf (Ed.), Design Research Now. 41-54. Basel, Suiza: Birkhäuser. Board of International Research in Design

Cross, N. (2007). Forty years of design research. Design Studies, 28(1), 1-4.

Cubillos, A. (2011). El desarrollo nuclear en Chile: Las perspectivas favorables y críticas. En A. Cubillos \& F. Estenssoro (Eds.), Energía y medio ambiente. Una ecuación difícil para América Latina: los desafíos del crecimiento y desarrollo en el contexto del cambio climático (pp. 149-179). Santiago, Chile: IDEA-USACH.

CW's Food \& Travel. (7 de marzo, 2011). Aviso publicitario de vivienda en Shenzhen, China. [imagen web]. Recuperada de http://cwfoodtravel.blogspot.com/2011/03/shenzhen-dongguang-2010-villas-at.html

Czerniak, J., Hargreaves, G., \& Beardsley, J. (2007). Large parks. New York, EE.UU.: Princeton Architectural Press.

D’Argenville, D. (1709). La théorie et la practique du jardinage. Recuperado de https://gallica.bnf.fr/ark:/12148/bp-

t6k85672b.pdf

Dabrowska, J. (2011). Measuring the success of science parks: Performance monitoring and evaluation. Artículo presentado en la XXVIII IASP World Conference on Science and Technology Parks, Inglaterra. Recuperado de http://www.pmf. sc.gov.br/arquivos/arquivos/pdf/08_07_2011_16.28.06.346a693b4baaca30ad620164d8186c1d.pdf

Daly, H. (1995). On Wilfred Baeckerman's critique of sustainable development. Environnemental Values, 4(1), 49-55. Recuperado de http://www.jstor.org/stable/30301392

Danus, H. (2014). Crónicas mineras de medio siglo (1950-2000). Santiago, Chile: RIL Editores.

Dardel, E. (2013). El hombre y la tierra: Naturaleza de la realidad geográfica. Madrid, España: Editorial Biblioteca Nueva, S.L.

Decreto Fuerza de Ley № 458. Diario Oficial. Decretado en 1976, actualizado el 15 de febrero del 2018.

Decreto N.106. Reglamento Administrativo de la Quinta Normal de Agricultura del Ministerio del Interior. Diario oficial de la República de Chile, 1842. Santiago, Chile.

Decreto Supremo 40. Aprueba el Reglamento del Sistema de Evaluación de Impacto Ambiental promulgado el 2012, y que entró en vigencia el año 2014. Santiago, Chile. 
Deensel. (23 de enero, 2018). Santuario de la Inmaculada Concepción, Cerro San Cristóbal. [fotografía]. Recuperada de https://es.wikipedia.org/wiki/Parque_Metropolitano_de_Santiago\#/media/Archivo:Santuario_de_la_Inmaculada_Concepci\%C3\%B3n,_Cerro_San_Crist\%C3\%B3bal_(25059260397).jpg

Delso, D. (11 de febrero, 2016). Cerros Pintados, Pampa del Tamarugal, Chile. [Fotografía]. Recuperada de https:/les.wikipedia.org/wiki/Archivo:Cerros_Pintados,_Pampa_del_Tamarugal,_Chile,_2016-02-11,_DD_97.jpg

Descola, P. (2005). Par-delà nature et culture. Paris, Francia: Gallimard. Recuperado de https://archive.org/details/PhilippeDescolaParDelNatureEtCultureGallimard2005

Desvigne, M. (2009). Introduction. En G. A. Tiberghien (ed.), Intermediate Natures: The landscapes of Michel Desvigne. (pp. 11-13). Basel Suiza: Birkhäuser.

Descombes, G. (1999). Shifting Sites: The Swiss way, Geneva. En J. Corner (Ed.), Recovering landscape: Essays in contemporary landscape architecture. Nueva York, EE.UU.: Princeton Architectural Press.

DGAC. (2013). Anuario Climatológico. Santiago, Chile: Dirección General de Aeronáutica Civil Recuperado de http://geonode.meteochile.gob.cl/documents/70/download.

Diario El País. (3 de julio, 2018). El distrito 22@ se consolida como el gran polo empresarial de Barcelona. [Fotografía]. Recuperada de https://cincodias.elpais.com/cincodias/2018/07/02/companias/1530551689_894437.html

Diener, P. (2007). Lo pintoresco como categoría estética en el arte de viajeros. Apuntes para la obra de Rugen-das. Revista Historia, 40(2), 185-309. Recuperado de https://dx.doi.org/10.4067/S0717-71942007000200002.

Disponzio, J. J. (2002). Jean-Marie Morel and the Invention of Landscape Architecture. En H. Dixon \& M. Conan (Eds.), Tradition and Innovation in French Garden Art. Philadelphia, EE.UU.: University of Pennsylvania Press.

Domeyko, I. (1978). Mis viajes: Memoria de un exiliado. Santiago, Chile: Ediciones de la Universidad de Chile.

Donadieu, P., \& Périgord, M. (2005). Clés pour le paysage. París, Francia: Ophrys.

Downing, A.J. (1841). A Treatise on the Theory and Practice of Landscape Gardening. Nueva York - Londres: Wiley and Putnam. Recuperado de https://archive.org/details/treatiseontheory41down/page/n7

Dramstad, W. E., Olson, J. D., \& Forman, R. T. T. (1996). Landscape ecology principals in landscape architecture and land-use planning. Cambridge, MA -Washington, D.C. EE.UU.: Harvard University Graduate School of Design and Island Pre.

Durand, J. N. L. (1805). Précis des leçons d'architecture données à l'École polytechnique, Volumen 2. París, Francia : Por el autor. Colección University Mayland. Digitalizado por Lyrasis Members and Sloan Foundation. Recuperado de https:// archive.org/details/prcisdesleon02dura 
Durand, J. N. L. (1981). Compendio de lecciones de arquitectura. Madrid, España: Editorial Pronaos.

Edwards Bello, J. (1973). Mitópolis. Santiago, Chile: Editorial Nascimento.

El Agricultor, Periódico bimestre publicado por la Sociedad Chilena de Agricultura (1838-1849) Tomos I a III (octubre de 1838 a diciembre de 1843, nos 1-40), Santiago, Chile: Imprenta de La Opinión; Tomos IV a X (enero de 1844 a julio de 1846, nos 41-59) y sin numeración de tomo (agosto de 1846 a febrero de 1849, nos 60-78), Santiago, Chile: Imprenta de los Tribunales.

El Bosque S.A. (EBSA). (2005). Praderas. una nueva comunidad mirando al futuro. [Blochure]. Santiago, Chile: El Bosque S.A.

Eliash, H., \& Laborde, M. (2003). Arquitectura y paisaje. Santiago, Chile: Editorial de la Facultad de Arquitectura y Urbanismo de la Universidad de Chile.

El Mercurio (EMOL). (5 de febrero, 2005). Hoy se conmemoran 38 años de la muerte de Violeta Parra. Recuperado de https://www.emol.com/noticias/magazine/2005/02/05/171961/hoy-se-conmemoran-38-anos-de-la-muerte-de-violeta-parra. $h \mathrm{tml}$

Ercilla, A. (1569/2006). La Araucana. México: Editorial Porrúa. Recuperado de_http://www.memoriachilena.cl/602/w3-article-3286.html\#documentos

Español, I. (2010). El paisaje como nuevo paradigma de la sostenibilidad. Revista Fabrikart: arte, tecnología, industria, sociedad (9), 104-115. Recuperado de_http://www.ehu.eus/ojs/index.php/Fabrikart/article/view/4887/4759.

Espinoza, G., \& Hajek, E. (1988). Riesgos climáticos: Evidencias en Chile central. En E. R. Fuentes \& S. Prenafeta (Eds.), Ecología del paisaje en Chile central. Estudios sobre sus espacios montañosos (pp. 31-41). Santiago, Chile: Editorial U. Católica. Recuperado de https://ecolyma.cl/documentos/riesgos_climat_evid_chile_central_1988.pdf

Etzkowitz, H. (2009). La triple hélice: Universidad, industria y gobierno implicaciones para las políticas y la evaluación. Estocolmo, Suecia: SISTER.

Etzkowitz, H., \& Leydesdorff, L. (1997). Universities and the global knowledge economy. A triple of a triple helix of university-Industry-government relations. Londres, Inglaterra: Pinter.

Etzkowitz, H., Websterb, A., Gebhardt, C., \& Cantisano, B. (2000). The future of the university and the university of the future: evolution of ivory tower to entre-preneurial paradigm. Research Policy, 29(2), 313-330.

EXPLORA: Las 7 tesis (2002). Catálogo de la exposición bajo la dirección artística de Guillermo Tejeda. Santiago, Chile: Ograma S.A.

Eyzaguirre, N., Marcel, M., Rodríguez, J., \& Tokman, M. (2005). Hacia la economía del conocimiento: el camino para crecer con equidad en el largo plazo. Estudios Públicos (97), 5-57.

Farr, W. (1839). Letter to the Registrar General. En First annual report of the Registrar General. Londres, Inglaterra: 
Fein, A. (1972). Frederick Law Olmsted and the American Environmental Tradition. Nueva York, EE.UU.: George Braziller Inc.

Feliú, G. (1959). Alejandro de Humboldt. América a través de su correspondencia. Anales de la Universidad de Chile, número extraordinario (9-11). Santiago, Chile.

Feliú, G. (1965). Conversaciones históricas de Claudio Gay con algunos testigos y actores de la Independencia de Chile 1808-1826. Santiago, Chile: Editorial Andrés Bello.

Fernandes, D. (25 de febrero, 2018). Pasarelas en Caleta Tortel. [Fotografía]. Recuperado de: https://www.plataformaarquitectura.cl/cl/02-6267/plataforma-en-viaje-pasarelas-en-caleta-tortel

Field Operations. (2008). Master Plan Report. Shelby Frams Park. Memphis, EE.UU.: Shelby Farms Park Conservancy.

Figueroa, R., Suarez, M. L., Andreu, A., Ruiz, V., \& Vidal-Abarca, M. R. (2009). Caracterización ecológica de humedales de la zona semiárida en Chile Central. Gayana (Concepción), 73(1), 76-94. Recuperado de https://dx.doi.org/10.4067/ S0717-65382009000100011

Filleron, J. C. (2008). « Paysage », pérennité du sens et diversité des pratiques. Actes Semiotiques. Recuperado de http:// epublications.unilim.fr/revues/as/1265

Findeli, A. (1998). La recherche en design. Questions épistémologiques et méthodologiques. Journal of Design and Innovation Research, I (1), 3-12.

Findeli, A. (2003). La recherche en design, questions épistémologiques et méthodologiques. En Jollant-Kneebone, F. (dir.), La critique en design. Contribution à une anthologie. Nîmes, Francia: Editions Jacqueline Chambon

Findeli, A. (2010). Searching for design research questions: Some conceptual clarifications. En A. Chow, W. Jonas, \& G. Joost (Eds.), Questions, hypotheses and conjetures. Berlin, Alemania: Design Research Network en Berlin. Recuperado de http://projekt.unimes.fr/files/2014/04/Findeli.2010.DRN_.Design_research_questions.pdf

Findeli, A., \& Bousbaci, R. (2005). L'éclipse de l'objet dans les théories du projet en design. The Design Journal, 8, 35-49. doi:10.2752/146069205789331574

Findeli, A., Brouillet, D., Martin, S., Moineau, C., \& Tarrago, R. (2008). Research through design and transdisciplinarity: A Tentative contribution to the methodology of design research. Artículo presentado en Swiss design network symposium 2008, Mount Gurten. Berna, Suiza. Recuperado de https://www.researchgate.net/publication/235700599_Research_ Through_Design_and_Transdisciplinarity_A_Tentative_Contribution_to_the_Methodology_of_Design_Research

Findeli, A., \& Coste, A. (2007). De la recherche-création à la recherche-projet: un cadre théorique et méthodologique pour la recherche architecturale. Revista Lieux communs, (10), 139-161. 
Flores, S., \& Saavedra, J. (1978). El Valparaíso de O'Higgins en la observación de los viajeros. Revista Chilena de Historia y Geografía, (146), 181-211.

Flusser, V. (2014). Gesture. Minneapolis, London: University of Minnesota Press. Recuperado de https://jpgenrgb.files. wordpress.com/2017/07/338252667-flusser-gestures.pdf.

Forman, R.T.T. (1986). Mosaico territorial para la región metropolitana de Barcelona. Barcelona, España: Editorial Gustavo Gili.

Forman, R., \& Godron, M. (1986). Landscape Ecology. Nueva York, EE.UU.: John Wiley and Sons.

Forman, R.T.T.(1995). Land Mosaics. The ecology of landscape and regions. Cambridge, Inglaterra: Cambridge University Press.

Foucault, M. (1968). Las palabras y las cosas, Una arqueología de las ciencias humanas. (Elsa Cecilia Frost trad.). Buenos Aires, Argentina: Editorial Siglo XXI.

Fox, O. (2011). Proyecto de restauración ecológica del humedal laguna de Batuco. (Tesis de Magíster en Asentamientos Humanos y Medio Ambiente, Pontificia Universidad Católica de Chile, Región Metropolitana de Santiago, Chile). Recuperado de http://www.estudiosurbanos.uc.cl/?tesis=pre_humedal-laguna-de-batuco-propuesta-de-restauracion-ecologica-del-humedal-laguna-de-batuco-rm-de-santiago-chile.

Franceschi, C. (1997). Du mot paysage et de ses équivalents dans cinq langues européennes. Les enjeux du paysage, $75,77-83$.

Franco, J. T. (4 de febrero, 2014). Vista, corte y planta de la ruca mapuche. [ilustración]. Recuperada de https://www.plataformaarquitectura.cl/cl/02-333115/arquitectura-vernacula-la-ruca-araucana-en-el-sur-de-chile/ 52f11791e8e44e611100006e-arquitectura-vernacula-la-ruca-araucana-en-el-sur-de-chile-foto

Fraser, M. (Ed.). (2013). Introducción. En Design Research in Architecture: an overview. Farnham, Inglaterra: Ashgate Publishing, Ltd.

Frases suicidas (9 de septiembre, 2018). Señalización de Carén en la Ruta 68. [Fotografía]. Recuperada de https://n9.cl/ m8i3

Frassinetti, D. \& Alberdi, M. (2005). Presencia del género Stegomastodon entre los restos fósiles de mastodontes de Chile (Gomphotheriidae), Pleistoceno Superior. Estudios Geológicos, 61, 101-107. ISSN: 0367-0449

Friends of Battersea Park. (s.f.). The Park. [Plano]. Recuperado de https://www.friendsofbatterseapark.org/the-park

Fuentes, P. (2012). Orientaciones para una política regional de infraestructura verde: Región Metropolitana de Santiago. [Diapositivas en Power Point]. Recuperado de https://es.scribd.com/document/375142627/Santiago-Verde 
Fundación Martin Bodmer (23 de abril, 2017). Paisaje, Johann Wolfgang von Goethe. Dibujo en tinta marrón y acuarela sobre papel beige, hacia 1788, con la inscripción en el reverso "Handzeichnung meines Grossvater Johann Wolfgang von Goethe. Dresde 18 de septiembre de 1836. Wolfgang Maximilian von Goethe". Colección Fundación Martin Bodmer. Recuperado de https://www.fykmag.com/goethe-et-la-france-a-la-fondation-martin-bodmer-cologny/

Gabler, F. (8 de octubre, 2017). Poesía y paisaje: Zurita exhibe su último sueño. Diario La Tercera. Recuperado de http://culto.latercera.com/2017/10/08/poesia-paisaje-zurita-exhibe-ultimo-sueno/

Gravis, A. (7 de abril, 2016). Birkenhead Park Map. [Plano]. Recuperado de https://commons.wikimedia.org/wiki/File:Birkenhead_Park_Map.jpg

Gajardo Tobar, R. (1958/1959). Investigaciones acerca de las "Piedras con Tacitas" en la Zona Central de Chile. Anales de Arqueología y Etnología t. XIV y XV: 163-204.

Gajardo, R. (1983). Sistema básico de clasificación de la vegetación nativa chilena. Santiago, Chile: Ministerio de Agricultura- Corporación Nacional Forestal - Universidad de Chile.

Gajardo, R. (1994). La vegetación natural de Chile. Clasificación y distribución geográfica. Santiago, Chile: Editorial Universitaria.

Gallardo, V. (2012). Rugendas, artista viajero y su aporte a la construcción de la representación indígena en Tiempo histórico. Revista de la Escuela de Historia, (4), 67-86.

Gambino, R. (1997). Conservare Innovare: paesaggio, ambiente, territorio. Turín, Italia: UTET.

Gana, P., Wall, R., \& Gutierrez, A. (Cartografo). (1996). Mapa geológico del área Valparaíso-Curacaví, Regiones de Valparaíso y Metropolitana.

Gannon, M. (2013). Lost in Central Park? Rocks Guide the Way. Recuperado de https://www.livescience.com/39189-lostin-central-park-rocks-guide-the-way.html

Garcés, M. (2002). Tomando su sitio: el movimiento de pobladores de Santiago, 1957-1970. Santiago, Chile: LOM ediciones.

García Santa Cecilia, C. (23 de enero, 1987). Nicanor Parra: "Me considero fundamentalmente un alfabetizador ecologista" El escritor chileno lee sus 'ecopoemas' en Madrid. Diario El País. Recuperado de http://elpais.com/diario/1987/01/23/ cultura/538354811_850215.html

García Valdés, J. (2011). Lugar y Resiliencia Comunitaria: Estudio desde la Problemática Ambiental en Comunidades Rurales de Pudahuel. Espacios, 1(2), 177-206. Recuperado de http://www.revistaespacios.cl/?p=4017

García, A., Campos, J. J., Villalobos, R., Jiménez, F., \& Solórzano, R. (2005). Enfoques de manejo de recursos naturales a escala de paisaje: convergencia hacia un enfoque ecosistémico. Turrialba, Costa Rica: CATIE. 
García, P. (1994). La vivienda popular chilena entre los siglos XVI y XIX. Revista de Ciencias Sociales, 39(6), 149-217.

Gaston, K. J. (Ed.). (2010). Urban ecology. Oxford, Inglaterra: Oxford University Press.

Gay, C. (1841). Proyecto de un Jardin de Aclimatación para Santiago. El Agricultor, Periódico bimestral, II (15). Sociedad Chilena de Agricultura.

Gay, C. (1862). Historia Física y Política de Chile. Agricultura. Tomo I. París, Francia: en la casa del autor; Santiago, Chile: Museo de Historia natural de Santiago. Recuperado de http://www.memoriachilena.cl/archivos2/pdfs/MC0002687.pdf

Gendrat-Claudel, A. (2007). Le paysage," fenêtre ouverte" sur le roman: le cas de l'Italie romantique. París, Francia: Presses Paris Sorbonne.

Gentina, J. C., \& Acevedo, F. (2016). Copper bioleaching in Chile. Minerals, 6(1), 23.

Georgescu-Roegen, N., Naredo, J. M., \& Grinevald, J. (1996). La ley de la entropía y el proceso económico. Madrid, España: Fundación Argentaria.

Geuze, A. (1993). Moving beyond Darwin. En A. Arriola (Ed.), Modern Park Design: Recent Trends. (pp. 36-45). Amsterdam, Países Bajos: Thoth.

Gibb, A. A. (1993). No Enterprise culture and education: understanding enterprise education and its links with small business, entrepreneurship and wider educational goals. International Small Business Journal, 11(3), 11-34.

Gibbons, M., Limoges, C., Nowotny, H., Schwartzman, S., Scott, P., \& Trow, M. (1997). La nueva producción del conocimiento. La dinámica de la ciencia y la investigación en las sociedades contemporáneas. Barcelona, España: Ediciones Pomares.

Girot, C. (1999). Four trace concepts in landscape architecture. En J. Corner (Ed.), Recovering landscape: essays in contemporary landscape architecture (pp. 59-68). Nueva York, EE.UU.: Princeton Architectural Press.

Girot, C. (2013). Topology-A New Measure Of Quality In Landscape Architecture. Copenhague, Dinamarca: Copenhagen Landscape Lectures. Recuperado de https://girot.arch.ethz.ch/research/a-new-measure-of-quality-in-landscape-architecture-topology

Glanville, R. (1999). Researching design and designing research. Design Issues, 15(2), 80-91.

Goethe, J. W. V. (1891). Viaje a Italia. Madrid, España: Librería de la Viuda Hernando. Recuperado de http://www.tribuna-ram.com/2010/10/goethe-viaje-italiapdf.html

Goethe, J. W. V. (2017). Viaje a Italia. Barcelona, España: Ediciones B. S.A.

Google. (abril, 2012). [Street view, Los Maitenes Pudahuel en Google maps]. Recuperado el 12 de Diciembre, 2019. 
Gonzáles, C. (17 de mayo, 2017). ¿Qué piensa la élite de la energía nuclear? La Tercera. Recuperado de https://www. latercera.com/noticia/piensa-la-elite-la-energia-nuclear/ (6)

González, A, Calvo, F. \& Marchán, S. (1999). Escritos de arte de vanguardia, 1900/1945 (No. 147). Ediciones Akal.

González de León, I. y Núñez Valdés, J. (2018). Mujeres pioneras de la arquitectura española. En Investigación y género. Reflexiones desde la investigación para avanzar en igualdad : VII Congreso Universitario Internacional Investigación y Género (264-282), Sevilla, España: SIEMUS (Seminario Interdisciplinar de Estudios de las Mujeres de la Universidad de Sevilla).

Gore RM. (2005). Programa de Ordenamiento territorial. OTAS.

Gorelik, A. (1998). La grilla y el parque: espacio público y cultura urbana en Buenos Aires, 1887-1936. Bernal, Argentina: Universidad Nacional de Quilmes.

Gorelik, A. (2003). Ciudad, Modernidad, Modernización. Universitas Humanística, 11-27.

Gothein, M. L. S. (1928/2002). A history of garden art. Cambridge, Inglaterra: Cambridge University Press.

Gracia, F. de (2009) Entre el paisaje y la arquitectura, apuntes sobre la razón constructiva. Madrid, España: Editorial Nerea.

Graglia, D. (2016). Silicon Valley es de los ricos: familias pobres dejan San Francisco, San José y Oakland. UNIVISION ON LINE. [Consultado en línea el 5 de febrero de 2018]. Recuperado de https://www.univision.com/noticias/desde-silicon-valley/silicon-valley-es-de-los-ricos-familias-pobres-dejan-san-francisco-san-jose-y-oakland

Graham, M. (1916). Diario de su residencia en Chile (1822) y de su viaje al Brasil (1823). (J. Concha, Trad.). Madrid, España: Editorial América.

Graham, M. (1824). Journal of a residence in Chile during the year 1822 and a voyage from Chile to Brazil in 1823. Londres, Inglaterra: Longman, Hurst, Rees, Orme, Brown, and Green, and John Murray.

Gravis, A. (7 de abril, 2016). Birkenhead Park Map. [Plano]. Recuperado de https://commons.wikimedia.org/wiki/File:Birkenhead_Park_Map.jpg

Grimal, P. (2019). Les jardins: Les Dossiers d'Universalis. Francia: Encyclopaedia Universalis

Gropius, W. (1962). Is There a Science of Design?. Scope of Total Architecture (Nueva York), 24, 30-43. Collier Books.

Groß, M., Hoffmann-Riem, H., \& Krohn, W. (2005). Realexperimente. Ökologische Gestaltungsprozesse in der Wissensgesellschaft. Bielefeld, Alemania: transcript Verlag.

Gtres (1 de agosto, 2016). Mono con cola de espiral, Líneas de Nazca, Perú. [Fotografía]. Recuperada de https://www. 
nationalgeographic.com.es/historia/actualidad/descubren-un-nuevo-geoglifo-en-el-desierto-de-nazca_10306/5

Guasch, A. M. (2000). El arte último del siglo XX: del posminimalismo a lo multicultural. Madrid, España: Alianza Forma.

Gutiérrez, J. R., Meserve, P. L., Jaksic, F. M., Contreras, L. C., Herrera, S., \& Vásquez, H. (1993). Structure and dynamics of vegetation in a Chilean arid thornscrub community. Acta Oecologica. International Journal of Ecology, 14(2), 271-285.

Habermas, J. (1982). Conocimiento e Interés. Madrid, España: Taurus.

Haigh, S. (1917). Viaje a Chile en la época de la Independencia. Santiago, Chile: Imprenta Universitaria. Recuperado de http://www.memoriachilena.cl/archivos2/pdfs/mc0007493.pdf

Hall, B. (1906). Estracto de un diario de viaje a Chile, Perú i Méjico en los años de 1820, 1821, 1822. (Trad. por F. Gana, Ed.). Santiago, Chile: Imprenta Universitaria.

Hanson, B. (2005). Book Three: a vision of a living world/ Review. The Structurist: Regenerating Art and Architecture in Nature's Landscape, 45, 34-38.

Harris Diez, R. (2011). El paisaje de los dioses: los santuarios griegos de la época clásica y su entorno natural. Aisthesis, (49), 67-83. https://dx.doi.org/10.4067/S0718-71812011000100004

Harvey, D. (2008). El neoliberalismo como destrucción creativa. Apuntes Del CENES, 27(45).

Haveman, J., \& Massaro, R. (2015). Poverty in the San Francisco bay area. Silicon Valley Institute for Regional Studies.

Henderson, J. (7 de abril, 2013). 66th Street transverse. [fotografía]. Recuperada de

https://commons.wikimedia.org/wiki/File:CP_Transverse_Rd_1_west_arches_cloudy_early_spring_jeh.jpg

Henríquez, L. (7 de septiembre, 2016). Roca Sagrada de Machu Picchu. [Fotografía]. Recuperado de http://www.conexionflorida.com/kueka-piedra-sagrada-ultima-parte/

Herbarium (26 de diciembre, 2013) Dibujo de Goethe incluido en su libro "Zur Morphologie" (1790)

Recuperado de https://herbarium.cc/category/goethe-2/

Herman, P. (2010). La Universidad de Chile y el Parque Laguna Carén. Dario La Nación. Recuperado de http://www.defendamoslaciudad.cl/index.php/columnas/item/2858-la-universidad-de-chile-y-el-parque-laguna-caren

Hermosilla, N., \& Ramírez, J. (1982). La Prehistoria de Chile Central: la localidad de Las Cenizas. Santiago, Chile: Universidad de Chile. 
Herrera, J. (4 de junio, 2017). Anillo Verde: Propuesta de Atisba y fundación San Carlos de Maipo. El Mercurio, Nacional, C12. Recuperado de http://impresa.elmercurio.com/mermobileiphone//Pages/NewsDetailMobile.aspx?dt=2017-06-04\&PaginalD=12\&Supplementld=0\&Body|D=3\&|sNPHR=0\&Anchor=

Hervé, F., \& Thiele, R. (1987). Estado de conocimiento de las megafallas en Chile y su significado tectónico. Comunicaciones. Universidad de Chile, 38, 67-91.

Hoffmann, A. (1983). El árbol urbano en Chile. Santiago, Chile: Ediciones Fundación Claudio Gay.

Holling, C.S. (1973). Resilience and Stability of Ecological Systems. Review of Ecology and Systematics, 4, 1-23. Recuperado de https://www.jstor.org/stable/2096802?origin=JSTOR-pdf\&seq=1

Hospita Chuquicamata [weblog] (28 de julio, 2003). Hospital Roy H. Glover de Chuquicamata. [Fotografía]. Recuperado de https://hospitaldechuquicamata.wordpress.com/imagenes-de-despedida-hop/

Humboldt, A. von. (1826). Viage á las regiones equinocciales del nuevo continente. (2nd ed.). Paris, Francia: En casa de Rosa. Recuperado de http://cdigital.dgb.uanl.mx/la/108f0018319_C/1080018319_T1/1080018319_MA.PDF

Humboldt, A. von. (1878). Ventas de las cordilleras y monumentos de los pueblos indígenas de América. Madrid, España: Imprenta y librería Gaspar.

Humboldt, A. von. (1875). Cosmos. Ensayo de una descripción física del mundo. (E. Perie ed.). Bélgica: Biblioteca Hispano-Sur-Americana.

Humboldt, A. von. (2011). Cosmos. Ensayo de una descripción física del mundo. Madrid-Santiago, Chile: Libros de la Catarata, Consejo Superior de Investigaciones Científicas y Dirección de Bibliotecas, Archivos y Museos.

Huppatz, D. (2015). Revisiting Herbert Simon's "science of design." Design Issues, 31(2), 29-40. Recuperado de https:// www.mitpressjournals.org/doi/abs/10.1162/DESI_a_00320

IASP. (s.f.). Internacional Association of Science Parks. Recuperado de http://www.iasp.ws

Ilustre Municipalidad de Pudahuel (IPM). (2012). Plan de Desarrollo Comunal de Pudahuel 2011-2015. Santiago, Chile: Municipalidad de Pudahuel.

Ilustre Municipalidad de Pudahuel (IPM). (2017). Plan de Desarrollo Comunal de Pudahuel 2016-2019. Resumen ejecutivo. Santiago, Chile: Municipalidad de Pudahuel. Recuperado de https://www.mpudahuel.cl/sitio/index.php/pladeco/file

INFOGRAMAX. (10 de abril, 2014). Doce terremotos más grandes de Chile. [infografía]. Recuperado de https://infogramax.wordpress.com/2014/04/10/los-doce-terremotos-mas-grandes-de-chile-infografia/

Informa - Directorio de Empresas. (2019). Parc Tecnologic Del Valles, Sa. Recuperado de https://www.informa.es/directorio-empresas/Empresa_PARC-TECNOLOGIC-VALLES.html 
Instituto Chileno de arquitectos paisajistas. (15 de enero, 2019) Piscina Antilén. [Fotografía]. Recuperado de http:/lichap. cl/2019/01/15/reconocimiento-a-carlos-calico-martner/

International Association of Science Parks (IASP) (s.f.). Definitions. Recuperado de https://www.iasp.ws/our-industry/definitions

International Association of Science Parks (IASP) (2019). Infografía que muestra los países miembros de IASP. [Infografía]. Recuperado de https://www.iasp.ws/our-members/directory

Iriarte, S. (2003). Mapa de Vulnerabilidad a la contaminación de los acuíferos de la cuenca de Santiago. Carta Geológica de Chile (Vol. 4). Santiago, Chile.

Isfahan (5 de diciembre, 2010). Garden carpet [fotografía]. Recuperado de https://commons.wikimedia.org/wiki/File:Isfahan_Garden_carpet.jpg

ISTOCK (13 de noviembre, 2019). Machu Picchu. [Fotografía]. Recuperada de: https://viajes.nationalgeographic.com. es/a/cusco-a-machu-picchu_9427/1

Iturriaga, S.; Baixas, J.; Croxatto, F.; Ibieta, P. \& Quintana, F. (2013). Mapocho 42K, Santiago, Chile. Equipo Mapocho 42k, 2013. ARQ, 85, 82-87. https://dx.doi.org/10.4067/S0717-69962013000300012

Jackson, D., \& Thomas, C. (1994). Actas del $2^{\circ}$ Taller de Arqueología de Chile Central. En El Arcaico de la Comuna de Lampa, Chile Central. Santiago, Chile. Recuperado de http://www.arqueologia.cl/actas2/jacksonythomas.pdf

Jacob, C. (1984). Logiques du paysage dans les textes géographiques grecs: quelques propositions méthodologiques. En Ch. Avocat (dir.), Lire le paysage, lire les paysages (pp. 159-178). Saint-Etienne, Francia: C.I.E.R.E.C.

James Corner Field Operations. (s.f.). Woodland Discovery Playground. [fotografía]. En Word Architects [web]. Recuperada de https://www.world-architects.com/en/james-corner-field-operations-new-york/project/shelby-farms-park\#image-4

Jantsch, E. (1970). Inter- and Transdisciplinary University: A systems approach to education and innovation. Policy Sciences, 1, 403-428. Recuperado de https://doi.org/10.1007/BF00145222

Jaramillo, A. (2010). Transdisciplina, Ética y Compromiso Social. El caso de la Universidad Nacional de Lanús. En A. Saegh, D. Ezcurra, F. Comparato. (Comp.), La Educación Superior: Tensiones y debates en torno a una transformación necesaria (pp. 159-174). Villa María, Argentina: Eduvim.

Jencks, C. (1977/1981). El lenguaje de la Arquitectura Posmoderna. (R. Pérdigo y A. Kerrigan, trad.). (2da ed.) Barcelona, España: Editorial Gustavo Gili.

Jenofonte. (1999). Anábasis. (C. Varias, Ed.). Madrid, España: Cátedra de Letras Universales.

Jiménez, C. (2015). Ennio Vivaldi, es el nuevo Presidente de las Universidades Estatales. En Consorcio de Universidades del Estado de Chile. Santiago, Chile. Recuperado de http://uestatales.cl/cue/?q=node/4275 
Jiménez, V., Hidalgo, R., Campesino, A., \& Alvarado, V. (2018). Normalización del modelo neoliberal de expansión residencial más allá del límite urbano en Chile y España. EURE, 44(132), 27-46.

Jocelyn-Holt, A. (2004). Historia General de Chile. Tomo III. Amos, Señores y Patricios. Santiago, Chile: Editorial sudamericana.

Jocelyn-Holt, A. (2013). Ramón Subercaseaux Vicuña, "Criollo entre Mundos". Anales de Literatura Chilena (19), 89-111.

Johnston, S. (1919). Diario de un Tipógrafo Yanqui en Chile y Perú durante la Guerra de la Independencia. Madrid, España: Editorial América.

Jonckbloet, W.J.A. (trad.). (1867). Guillaume d'Orange, Le Marquis au Court Nez. Chanson de geste du XII siècle. Amsterdam, Holanda: P.N. Van Kampen. Recuperado de https://archive.org/details/guillaumedorang03joncgoog

Jones, C. J. (1977). How my Thoughts about Design Methods Have Changed during the Years. Design Methods and Theories, 11(1), 48-62.

Kalergis, A. (17 de noviembre, 2015). Científicos chilenos proyectan crear un centro nacional de elaboración de antídotos. El Mostrador. Recuperado de http://www.elmostrador.cl/cultura/2015/11/17/cientificos-chilenos-proyectan-crear-un-centro-nacional-de-elaboracion-de-antidotos/

Karzulovic, J. (1960). Características de los depósitos de cenizas volcánicas de Chile Central. Santiago, Chile: Informaciones Geográficas.

Knoema. (2018). Chile - población urbana (\% del total). Atlas mundial de datos. Recuperado de https://knoema.es/atlas/ Chile/Poblaci\%C3\%B3n-urbana-percent-del-total

Kluckert, E. (2000). Grandes Jardines de Europa. Desde la antigüedad hasta nuestro días. Colonia, Alemania: H.F. ULLMANN.

Komara, A. (2004). Concrete and the Engineered Picturesque - The Parc des Buttes Chaumont (Paris, 1867). Journal of Architectural Education, 58(1), 5-12.

Komara, A. (2009). Measure and Map: Alphand's Contours of Construction at the Parc des Buttes Chaumont, Paris 1867. Landscape Journal, 28, 22-39.

Koolhaas, R. (1978). Delirious New York: A Retroactive Manifesto for New York. New York, EE.UU.: Oxford University Press.

Koskinen, I., Zimmerman, J., Binder, T., Redstrom, J., \& Wensveen, S. (2011). Design research through practice: From the lab, field, and showroom. San Francisco, EE.UU.: Morgan Kaufmann Publishers Inc. 
Kusch, A., Cárcamo, J., \& Gómez, H. (2008). Aves acuáticas en el humedal urbano de tres puentes, Punta Arenas (53 S), Chile austral. Anales Del Instituto de La Patagonia, 36(2), 4-51.

Laconte, P. (2011). Louvain-la-Neuve Comment une université a-t-elle pu concevoir et réaliser une ville "désirable»? Que faire pour qu'elle le soit encore davantage? Revista Les Cahiers nouveaux 80, 28 - 32. Bruselas, Bélgica: Mardaga. Recuperado de https://ffue.org/archive/PDF/CahiersNouveaux-LLN-1211.pdf

Lacoste, Y. (1977). À quoi sert le paysage? Qu'est-ce que un beau paysage?. Hérodote, 7, 3-41.

Laffitte, P. (1991). Naissance d'une Ville ? Sophia Antipolis. Niza, Francia: Fundación Sophia Antipolis. Recuperado de http://sophia-antipolis.org/images/fsa/communication/naissance-1-ville.pdf

Laffitte, P. (2001). Le Modele Sophipolitain. Niza, Francia: Fundación Sophia Antípolis.

Lafont de Lurcy, G. (1911). Viaje a Chile. Santiago, Chile: Imprenta Universitaria. Recuperado de www.memoriachilena.cl/ archivos2/pdfs/MC0033173.pdf

Lago, T. (2000). La viajera ilustrada. Vida de maría Graham. (D. Oses, Ed.). Santiago, Chile: Editorial Planeta.

Lagos Garay, G. (2004). Gregory Bateson: un pensamiento (complejo) para pensar la complejidad. Un intento de lectura/ escritura terapéutica. Polis. Revista Latinoamericana, 9.

Lane, C. (3 de julio, 2019). The concert will be held in Birkenhead Park [fotografía]. En Liverpool Echo [web] Royal Liverpool Philharmonic Orchestra to play open air concert at Birkenhead Park. Recuperado de

https://www.liverpoolecho.co.uk/whats-on/whats-on-news/royal-liverpool-philharmonic-orchestra-play-16524406

La Tercera (20 de marzo, 2018). Árboles en Santiago. [Infografía]. Recuperado de https://www.latercera.com/tendencias/ noticia/86-los-arboles-santiago-corresponde-especies-exoticas/105361/

Latour, B. (1999). Politiques de la nature. Comment faire entrer les sciences en démocratie. París, Francia: Éditions la Découverte. Recuperado de http://journals.openedition.org/questionsdecommunication/6525

Laugier, M.A. (1999). Ensayo sobre la Arquitectura. (L. Maure, Ed.). España: Ediciones Akal.

Lavquen, A. (24 de octubre, 2003). Entrevista a Raúl Zurita: Un poeta vale por cien novelistas. Punto Final 555.

Le Corbusier (1923/1929). Vers une architecture. (Nouvelle édition revue et augmentée). París, Francia: G. Crès. Facsímil digitalizado por Bibliothèque nationale de France. Recuperado de https://gallica.bnf.fr/ark:/12148/bpt6k9600362d. textelmage

Le Corbusier (1933). La Ville Radieuse. París, Francia: Éditions de L'Architecture d'Aujourd'hui.

Le Corbusier. (1939). La Carretera. Paris, Francia. Recuperado de https://ddooss.org/textos/documentos/la-carretera 
Le Dantec, Jean-Pierre (1996). Jardins et paysages, Textes: essentiels. París, Francia: Larousse.

Leblanc, F. (1898). Vista del Museo de Historia Natural desde la laguna. Parque Quinta Normal. Santiago, Chile. [fotografía]. Colección Biblioteca Nacional. Recuperado de http://www.plataformaurbana.cl/archive/2012/07/20/archivo-fotografico-parque-quinta-normal/

Lefebvre, H. (1968). La vie quotidienne dans le monde moderne (Collection). París, Francia: Gallimard.

Lefebvre, H. (1972). La Revolución Urbana. Madrid, España: Alianza Editorial.

Lefebvre, H. (1974). La production de l'espace. París, Francia: Anthropos.

Lefebvre, H. (2013). La Producción del Espacio. Madrid, España: Capitán Swing Libros S.I.

Leger-Smith, A. (2013). Analyse interprétative du discours du Landscape Urbanism et impact sur le développement des pratiques des paysagistes dans le contexte français. Revista Projet de Paysage, 9. Recuperado de http://www.projetsdepaysage.fr/editpdf.php?texte $=819$

León Echaíz, R. (2017). Historia de Santiago. Santiago, Chile: Nueve Noventa Ediciones.

Leroux, J. B. (s.f.). Vue aérienne du parc de la Courneuve. [fotografía]. Colección L’Agence Photo [web]. Recuperada de https://www.photo.rmn.fr/archive/11-551548-2C6NU0WDZ6WB.html

Letelier, S. (2008). La escala urbana: evolución del pensamiento disciplinar para un relato identitario del territorio y del deseo. Revista de Urbanismo, 19.

Lewis, M. (2000). The new new thing: a Silicon Valley story. New York, EE.UU.: W.W. Norton \& Company.

Ley N¹9.283. Diario Oficial de la República de Chile. Promulgada el 16 de diciembre de 1993; Publicada el 5 de enero de 1994. Santiago, Chile. Recuperado de https://www.bcn.cl/historiadelaley/nc/historia-de-la-ley/6942/

Ley № 19.300. Diario Oficial de la República de Chile. Promulgada el 1 de marzo de 1994; Publicada el 9 de marzo de 1994; última versión del 15 de julio de 2019. Santiago, Chile. Recuperado de https://www.leychile.cl/Navegar?idNor$\mathrm{ma}=30667$

Life Inside. (2019). Aviso publicitario de vivienda en Palm Meadows Bangalore, India. [imagen web]. Recuperada de http:// lifeinside.co.in/portfolio/palm-meadows/

Lindholm, G. (2012). Visible gestures. En Urban landscape perspectives in planning. Planning Theory. 11.

Lipovetsky, G. (2016). De la ligereza. Barcelona, España: Editorial Anagrama. 
Lira, R. (2004). Patrimonio Urbano. Urbano, 7(10). Recuperado de http://revistas.ubiobio.cl/index.php/RU/article/ view/517/480

Lobera, P. M. de (1970). Crónica del reino de Chile. (B. De Escobar \& J. U. Echeverría, Eds.). Santiago, Chile: Editorial Universitaria.

London County Council (1913). Housing of the working classes in London. Notes on the action taken between the years 1855 and 1912 for the better housing of the working classes in London, with special reference to the action taken by the London County Council between the years 1889 and 1912. Londres, Inglaterra: London County Council by Odhams Limited. Recuperado de

https://archive.org/details/housingofworking00londrich/page/n4

López Von Vriessen, C. (2005). El Palin o Chueca. Estudio etnográfico de un juego tradicional Mapuche. En U. Castro, F. Amador, \& J. M. Álamo (Eds.), Juegos Tradicionales: Universal Cultural del siglo XXI (pp. 149-161). Las Palmas de Gran Canaria, España: Cabildo Insular de Fuerteventura y ACCEDEL.

Luna, J.R. (22 de octubre, 2017). Painted garden, Villa di Livia, Rome, fresco. [Fotografía]. Recuperada de https:/jjohnroeluna.tumblr.com/post/166655687063

Luzán, J. (26 de enero, 2008). Lo más real de Goethe. Diario El País. Recuperado de http://elpais.com/diario/2008/01/26/ babelia/1201305972_850215.html

Lynch, K. (1998). La imagen de la ciudad. Barcelona, España: Editorial Gustavo Gili.

Lyotard, J.-F. (1988). Scapeland. Écrire le paysage. Revue Des Sciences Humaines, 209, 39-48.

Ma, Z., Cai, Y., Li, B., \& Chen, J. (2010). Managing wetland habitats for waterbirds: an international perspective. Wetlands, 30(1), 15-27.

Maas, J., Van Dillen, S. M., Verheij, R. A., \& Groenewegen, P. P. (2009). Social contacts as a possible mechanism behind the relation between green space and health. Health \& Place, 15(2), 586-589.

Maass, I. (1981). Peoples parks in Germany -City and culture in the open air. Lotus International, 30(1), 123-128.

Machupicchu Travel (s.f.). Templo de las Tres ventanas. [Fotografía]. Recuperada de https://www.machupicchu.com.pe/ el-templo-de-las-tres-ventanas-en-machu-picchu

Maderuelo, J. (2006). El paisaje: Génesis de un concepto. Madrid, España: Abada.

Magnaghi, A. (2011). El Proyecto Local: hacia una conciencia del lugar. Barcelona, España: Universidad Politécnica de Cataluña. 
Magrini, C., \& López, S. (2015). VALPARAISO H30. Humedad y restauración ecológica: estrategias para un ordenamiento territorial desde sus factores de riesgo. Revista AUS, 19. Recuperado de http://ausrevista.cl/index.php/es/n-actual/leer-articulos/26-revista-n-19/200-valparaiso-h30-humedad-y-restauracio-n-ecolo-gica-estrategias-para-un-ordenamiento-territorial-desde-sus-factores-de-riesgo

Maldonado, T. (1970). Design, Nature and Revolution. New York, EE.UU.: Harper and Row.

Mallol i Esquefa, M. (2008). Diseño y realidad. Revista Kepes. Grupo de Estudios En Diseño Visual, 5(4), 73-106.

Mann, G. (1978). Los pequeños mamíferos de Chile: marsupiales, quirópteros, edentados y roedores. Concepción, Chile: Universidad de Concepción.

Manthorne K. (21 de julio, 2017). Extracto de la carta de Maria Graham a William Hooker, 11 de abril de 1824. Archivos del Real Jardín Botánico, Kew. [web] Recuperado de https://www.coleccioncisneros.org/editorial/cite-site-sights/female-eyes-south-america-maria-graham

Manuel Jerez, E. de (2007). Participar para recuperar la Polis. En: J. Encina; J. M. López Medina; R. Alcón \& M. Á. Ávila. La ciudad a escala humana. Sevilla, España: Atrapasueños.

Mapocho 42K (s.f). Propuesta. Recuperado de https://www.mapocho42k.cl/propuesta

Mapuche (9 de agosto, 2017). Rehue. [Fotografía]. Recuperado de Mapuche [blog] http://mapucheancestral.blogspot. com/2017/08/el-rehue-descubriendo-sus-secretos.html

Marceca, M. L. (1981). Reservoir, circulation, residue - J. C. A. Alphand, technological beauty and the green city. Lotus International, 30, 56-79.

Marcuse, P. (1998). Sustainability is not enough. Environment and Urbanization, 10(2), 103-111. Recuperado de http:// journals.sagepub.com/doi/abs/10.1177/095624789801000201

Marileo, A. (1995). Mundo Mapuche. En L. Citarella (Ed.), Medicinas y Culturas en la Araucanía. Santiago, Chile: Editorial sudamericana.

Marín, L., \& Barriga, D. (2005). Presentación General de los Grandes Territorios de la Comuna de Pudahuel. Santiago, Chile: Corporación para el Desarrollo Sustentable de Pudahuel.

Marion Singer, M.O. (2000). Bajo la sombra de la gran ceiba: la cosmovisión de los lacandone. Desacatos, 5, 45-56.

Marot, S. (1999). The Reclaiming of Sites. En J. Corner (Ed.), Recovering Landscape. Essays in Contemporary Landscape Architecture (pp. 45-57). Nueva York: Priceton Architectural Press.

Marot, S. (2006). Suburbanismo y el arte de la memoria. Barcelona, España: Editorial Gustavo Gili. 
Marta (2 de junio, 2015). El 64\% de los humedales ha desaparecido del mundo en 100 años. Entrevista a Christopher Briggs, Secretario General de la XII reunión de la Conferencia de las Partes de la Convención de Ramsar sobre Humedales (COP12) de 2016, realizada en Punta del Este. En EFEverde.com, la plataforma global de noticias y periodismo ambiental de la Agencia EFE. Recuperado de http://www.efeverde.com/noticias/humedales-64-perdidos-100-anos-convenio-ramsarl

Martinet, J. (1984). Le paysage: signifiant et signifié. En Lire le paysage, lires les paysages (pp. 61-68). Saint-Etienne, Francia: Centre Interdisciplinaire d'Étude et de Recherche sur l'Expression Contemporaine.

Martínez, R. (1973). El Parque de los Cuatro Nombres. Revista de Planificación - Vivienda Ciudad Región, (8), 29-46. Santiago, Chile: Universidad de Chile.

Martínez, J. L. (1990). Hernán Cortés. México: Fondo de Cultura Económica.

Massaro, R. (2015). Poverty in the San Francisco Bay Area. Research Brief. San José CA, EE.UU.: Silicon Valley Institute for Regional Studies-Joint Venture Silicon Valley. Recuperado de https://jointventure.org/images/stories/pdf/poverty-brief-2015-03.pdf

Massone, M. (1978). Los tipos cerámicos del Complejo Cultural Aconcagua. Santiago, Chile: Universidad de Chile.

Massone, M., \& Sánchez, R. (1995). Cultura Aconcagua. Santiago, Chile: Ediciones de la Dirección de Bibliotecas, Archivos y Museos.

Matos Moctezuma, E. (2014). Vida, pasión y muerte de Tenochtitlan. México DF, México: Fondo de Cultura Económica.

Matthews, G. (2003). Silicon Valley, women, and the California dream: Gender, class, and opportunity in the twentieth century. California, EE.UU.: Stanford University Press.

Mattos, C. A. de (2001). Movimientos del capital y expansión metropolitana en las economías emergentes Latinoamericanas. Revista de Estudios Regionales, 15-43. Recuperado de http://www.redalyc.org/articulo.oa?id=75506001

Maturana, H., \& Varela, F. (1980). Autopoiesis and Cognition. The Realization of the Living. Dordrecht, Países Bajos: Springer Sciences.

Maturana, H., \& Varela, F. (1984). El árbol del conocimiento. Santiago, Chile: Editorial Universitaria.

Maturana, H., \& Varela, F. (2003). De máquinas y seres vivos, autopoiesis de la organización de lo vivo. Buenos Aires, Argentina: Lúmen.

Mazel, I., \& Tomasi, L. (2017). Approche du projet dans la recherche doctorale en architecture. Recuperado de https://hal. archives-ouvertes.fr/hal-01155262

McHang, I. (1969/2000). Proyectar con la naturaleza, 712. (P. Fernández, M.

San Miguel, A. Centeno y R. Fernández trad. Castellano.) Barcelona, España: Editorial Gustavo Gili. 
MCTI. (2014). Estudo de Projetos de Alta Complexidade - Indicadores de Parques Tecnológicos. Centro de Apoio ao Desenvolvimento Tecnológico. Brasilia, Brasil: Ministério da Ciência, Tecnologia e Inovação.

MECSA. (1997). Estudio de Factibilidad Construcción Polo de Desarrollo Científico Tecnológico en el Valle Lo Aguirre. Santiago, Chile: INECON Ltda. Chile-Marcial Echeñique y Compañía S.A.

Menéndez Pelayo, M. (1948). Historia de la poesía hispanoamericana. Madrid, España: CSIC.

Merleau-Ponty, M. (1964). Le visible et l' invisible. París, Francia: Gallimard. Recuperado de https://monoskop.org/images/c/c6/Merleau_Ponty_Maurice_Le_Visible_et_L_Invisible_1979_2001.pdf.

Merton, R. K. (1977). La sociología de la ciencia. Investigaciones teóricas y empíricas. Madrid, España: Alianza Editorial.

Michelis, M. di (1991). The Green Revolution: Leberecht Migge and the Reform of the garden in Modernist Germany. En M. Mosser \& G. Teyssot (Eds.), The Architecture of Western Gardens. Cambridge Massachusetts, EE.UU.: MIT Press.

Milani, R. (2015). El arte del paisaje. (F. López Silvestre, Ed.). Madrid, España: Biblioteca Nueva.

Millennium Ecosystem Assessment. (2005). Ecosystems and Human Well-Being: Scenarios. Washington DC., EE.UU.: World Resources Institute.

Miller, S. C. (2009). Seeing Central Park: The Official Guide to the World's Greatest Urban Park. New York, EE.UU.: Abrams.

Miller, S., \& Rottmann, J. (1976). Guía para el reconocimiento de mamíferos chilenos. Serie expedición a Chile. Santiago, Chile: Editorial Gabriela Mistral.

Ministerio de Vivienda y Urbanismo (MINVU). (1992). Modifica Decreto N 47, De 1992, Ordenanza General De Urbanismo Y Construcciones En El Sentido De Adecuar Diversas Disposiciones Sobre Planificación Y Normas Técnicas. Artículo 2.1.31. Santiago, Chile. Recuperado de http://bcn.cl/20974

Ministerio de Obras Públicas (MOP). (2019). Concesión interconexión vial Santiago-Valparaíso-Viña del Mar. Informe mensual enero 2019. Santiago, Chile.

Ministerio del Medio Ambiente. (2011). Las Áreas Protegidas de Chile. Santiago, Chile.

Ministerio de Energía. (2019). Explorador de Energía Eólica. Santiago, Chile. Recuperado de http://walker.dgf.uchile.cl/ Explorador/Eolico2/

Ministry of Science and Technology. (2019). Hsinchu Science Park. [web]. Recuperado de http://www.sipa.gov.tw/english/

Miranda, M.A. (1977). El «Cosmos»: Entre La Crisis De La llustración Y El Romanticismo Alemán. En el "cosmos" de 
Humboldt. Revista GEO Crítica año 2 (11). Cuadernos críticos de geografía humana. Barcelona, España: Universidad de Barcelona. Recuperado de http://www.ub.edu/geocrit/geo11.htm

Mistral, G. (1992). Antología mayor. Santiago, Chile: Editorial Lord Cochrane.

Mistral, G. (2013). Algunos rasgos de la geografía humana de Chile. En L. Vargas-Saavedra (Ed.), Caminando se aprende: prosas inéditas. Santiago, Chile: Lúmen.

Molina, J. I. (1788). Compendio de la historia geográfica, natural y civil del Reyno de Chile. Madrid, España: Antonio de Sancha. Recuperado de http://www.memoriachilena.cl/602/w3-article-8028.htm

Molinelli, G. (1859). El Campo de Marte. Óleo sobre tela Colección Museo Nacional de Bellas Artes. [fotografía] Recuperada de https://www.artistasvisualeschilenos.cl/658/w3-article-39804.html

Mollet, C. (1652). Theatre des plans et iardinages. Paris, Francia: C. de Sercy

Montealegre, P. (2010). Jardín para el pueblo: el imaginario de la Unidad Popular en el parque O'Higgins. Santiago, Chile: Pontificia Universidad Católica de Chile.

Montealegre, P. (2013). El ajardinamiento del geórgico. $A R Q, 83,30-35$. Recuperado de https://dx.doi.org/10.4067/ S0717-69962013000100005

Montealegre, P. (2016). El Estado como agente de la expansión del suelo urbano: Santiago, siglo XIX. ARQ, 93, 52-61. Recuperado de https://dx.doi.org/10.4067/S0717-69962016000200007

Montealegre, P. (2017). La figuración de un jardín público Urbanismo y agricultura en la construcción del Santiago moderno (1838-1875). Santiago, Chile: Pontificia Universidad Católica de Chile. Recuperado de https://www.academia. edu/40047778/La_figuración_de_un_jardín_público_Urbanismo_y_agricultura_en_la_construcción_del_Santiago_moderno_1838-1875_

Montes, H. (1974). Para leer a Neruda. Santiago, Chile: Francisco de Aguirre.

Montes, H., \& Rodríguez, M. (1970). Nicanor Parra y la poesía de lo cotidiano. Santiago, Chile: Zig-Zag.

Moore, G. (2005). The structure and content of Doctoral Programs in Architecture.

En Gülsün Sağlamer ; Fatma Erkök (Ed.). Doctoral Education in Architecture: Challenges and Opportunities (pp. 31-

54). Cambridge, Inglaterra: Cambridge Scholars Publishing.

Moran Alonso, N. \& Fernández Casadevante, J. L. (2013). Entrevista a Alberto Magnaghi. Revista Papeles de Relaciones Ecosociales y Cambio Global, 54, 143-153.

Morel, J. C. (2015). El derecho al disfrute del paisaje: alcance, límites y técnicas para su protección en el ordenamiento argentino. Alicante, España: Universidad de Alicante. 
Moreno, O. (2006). El paisaje como proyecto de territorio: Hacia un modelo de recuperacion ambiental e integración social desde la agricultura urbana. Estrategias de intervención en el espacio periurbano de Berazategui. (Tesis de Magister, Universidad Nacional de la Plata, Argentina).

Moreno, O. (2007). Paisaje: plataforma de comprensión y gestión de las dinámicas del ambiente y del territorio. Recuperado de http://repositorio.uchile.cl/handle/2250/118055

Morin, E. (2005). Introducción al pensamiento complejo (5th ed.). Barcelona, España: Gedisa.

Morin, E., \& Nicolescu, B. (1994). Carta de la transdisciplinariedad. Convento de Arrábida. Revista Nueva Época, 4(6), 14.

Moscow Institute of Physics and Technology - MIPT. (2019). Skolkovo [web].

Mostafavi, M. (2011). Why ecological urbanism? Why now? En M. Mostafavi \& G. Doherty (Eds.), Ecological Urbanism. Boston, EE.UU.: Harvard Graduate School of Design \& Lars Müller.

Mostafavi, M. \& Najle, C. (eds.) (2003). Landscape urbanism: a manual for the machinic landscape. Londres, Inglaterra: Architectural Association.

Moulian, R. (2009). Ailla \& Rewe. La mediación ritual de la sociedad mapuche williche. Revista Austral de Ciencias Sociales, 17, 57-74.

Moullart-Sanson, P. (1724). Carte du Paradis terrestre selon Moyse. Bibliothèque Nationale de France, Departement Cartes et Plans, GE D-13530. [detalle del mapa]. Recuperado de https://gallica.bnf.fr/ark:/12148/btv1b8490536w/f1.item. zoom

Mumford, L. (1938). Whither Honolulu?. A memorandum report on park and city planning. New York, EE.UU.

Mumford, L. (1968). The Urban prospect. New York, EE.UU.: Harcourt, Brace and World.

Mumford, L. (1969). Perspectivas urbanas. Buenos Aires, Argentina - Barcelona, España: Emecé.

Mumford, L. (2012). La ciudad en la historia. La Rioja, España: Pepitas de Calabaza.

Museo Nacional de Bellas Artes (s.f.). El huaso y la Lavandera, óleo sobre tela de Mauricio Rugendas (1835). [Fotografía]. Recuperada de https://commons.wikimedia.org/wiki/File:ElHuasoYLaLavandera.jpg

Museo Nacional del Prado (s.f.). Paisaje con San Jerónimo, Joachim Patinir. 1516 - 1517. Óleo sobre tabla, 74 x $91 \mathrm{~cm}$. Recuperado de https://www.museodelprado.es/coleccion/obra-de-arte/paisaje-con-san-jeronimo/116e5d91-b895-48cf-9cf1-3bd5bf17f983

Museo Nacional del Prado (s.f.). El triunfo de la Muerte (1562 - 1563). Óleo sobre tabla, 117 x $162 \mathrm{~cm}$ de Pieter Bruegel el Viejo. [Fotografía]. Recuperada de https://www.museodelprado.es/coleccion/obra-de-arte/el-triunfo-de-la-muerte/d3d- 
Myers, N., Mittermeier, R.M., Mittermeier C.G., Fonseca, G.A.B da. (2000). Biodiversity hotspots for conservation priorities. Nature. (403), 853-858. Recuperado de https://www.nature.com/articles/35002501

Naranjo, R. (1998). Una taberna llamada Chile. Entrevista a Raúl Ruiz. Revista Paula, 779. Recuperado de http://www. ccplm.cl/sitio/wp-content/uploads/2016/06/ENTREVISTAS_RR_RP.pdf

NASA. (24 de octubre, 2014). Satellite image of Santiago. [fotografía satelital]. Recuperada de

https://es.wikipedia.org/wiki/Archivo:Satellite_image_of_Santiago,_Chile_-_October_24,_2014.jpg

Nassauer, J. (2012). Landscape as medium and method for synthesis in urban ecological design. Landscape and Urban Planning, 106, 221-229.

Neruda, P. (1945). Alturas de Machu Pichu. Recuperado de https://www.neruda.uchile.cl/obra/cantogeneral.htm

Neruda, P. (1954). Algo sobre mi poesía y mi vida. Aurora, (1), 10-21. Santiago, Chile.

Neruda, P. (1979). Nosotros, los indios. En Para nacer he nacido. México DF, México: Seix Barral.

Neruda, P. (1980). Memorial de Isla Negra. Barcelona, España: Seix Barral, S.A.

Neruda, P. (1981). Canto General. Caracas, Venezuela: Biblioteca de Ayacucho.

Neruda, P. (2005). Odas Elementales. Santiago, Chile: Pehuen Editores.

Neruda, P. (2011). El poeta se despide de los pájaros. En Arte de pájaros. Buenos Aires, Argentina: Losada.

Nicholson, J. (29 de julio, 2007). Castle Howard. [Fotografía]. Recuperada de https://upload.wikimedia.org/wikipedia/commons/9/9d/Castle_Howard_01.jpg

Nicolau, J. M., Rey, J. M., \& Espigares, T. (2007). Restauración de ecosistemas mediterráneos en España: Conclusiones de un simposio. En J. Rey, T. Espigares, \& J. Nicolau (Eds.), Restauración de ecosistemas mediterráneos, Asociación de ecología terrestre (pp. 3-10). Madrid, España: Universidad Alcalá de Henares.

Nicolescu, B. (2004). La Transdisciplinariedad. Manifiesto. Recuperado de http://www.ceuarkos.com/manifiesto.pdf

Nicolin, P. (1981). Great thinking machines. Volumen 1. Lotus International, 30, 2-9.

Nietzsche, F. (2002). Consideraciones Intempestivas 1873-1876. Buenos Aires, Argentina: Alianza Editorial. 
Nietzsche, F. (1882/2002). La gaya ciencia. Madrid, España: Edaf.

Noble, K. A. (1994). Changing doctoral degrees: an international perspective (Society for Research into Higher Education). Milton Keynes, Inglaterra: Open University Press

Nogué, J. (2007). La construcción social del paisaje. Madrid, España: Biblioteca Nueva.

Nogué, J., \& San Eugenio, J. (2009). Pensamiento Geográfico versus teoría de la comunicación. Hacia un modelo de análisis comunicativo del paisaje. Documents d'anàlisi Geográfica, 55, 27-55.

Norberg-Schulz, C. (1971). Existence, Space, and Architecture. New York, EE.UU.: Praeger.

Norman, D. (2001). Applying the Behavioural, Cognitive, and Social Sciences to Products. Recuperado de http://www.jnd. org/dn.mss/applying_the_be.htmlffindeli

Nueva Pudahuel S.A. (NPSA). (2010). Plan de Cierre Mina Lo Aguirre. Recuperado de http://www.smp.cl/plandecierre.php

Nueva Pudahuel S.A.(NPSA). (2010). Regularización de cierres de faenas mineras. Presentación de la Sociedad Minera Pudahuel (SMP) Recuperado de

https://www.sonami.cl/v2/wp-content/uploads/2016/03/05.-Regulacion-de-Cierres-de-Faenas-Mineras.pdf

O’Mara, M. (2011). Silicon Valleys: Here, there, and everywhere. Boom: A Journal of California, 1(2), 75-81.

OCDE. (2015). Estudios económicos de la OCDE CHILE. Visión General. Recuperado de https://www.oecd.org/eco/surveys/Chile-2015-vision-general.pdf

OCDE/CHILE (2018). [web]. Recuperado de http://www.oecd.org/chile/

OCDE/GD. (1997). Technology Incubators: Nurturing Small Firms Organisation for Economic Co-Operation and Development. París, Francia. Recuperado de http://www.oecd.org/officialdocuments/publicdisplaydocumentpdf/?cote=OCDE/ GD(97)202\&docLanguage=En

Odum, E.P. (1972). Ecología. México D.F., México: Nueva Editorial Interamericana S.A.

Odum, E., \& Barrett, G. (2005). Fundamentals of ecology (5th ed.). Belmont, California, EE.UU.: Thomson Brooks/Cole.

OECD. (2019). Main Science and Technology Indicators. OECD Pubihing,(1), 11. Recuperado de https://doi.org/10.1787/ g2g9fb0e-en. https://read.oecd-ilibrary.org/science-and-technology/main-science-and-technology-indicators/volume-2019/ issue-1_g2g9fb0e-en\#page11 
OECD. (s.f.). Organization for economic co-operation and development. Glossary of Statistical terms. Recuperado de http://stats.oecd.org/glossary/index.htm

Olate, J. P. (2014). Informe Interno Proyecto Estadio Club Universidad de Chile. Documento Interno. Santiago, Chile.

Olmsted, F.L. (1858). Document N 5. Board of Commissioners of the Central Park. Recuperado de

https://www.nycgovparks.org/pagefiles/48/Board\%20of\%20Commissioners $\% 20$ of $\% 20$ the $\% 20$ Central\%20Park\%20-\%20

Documents\%20-\%20April\%2030\%201859_2.pdf

Olmsted, F. L. (1870). Public Parks and the Enlargememnt of Towns. En American Social Science Association Lowell Institute. Boston, EE.UU. Recuperado de https://www.fandm.edu/david-schuyler/ams280/public-parks-and-the-enlargement-oftowns

Olmsted, F. L., \& Kimball, T. (1928). Frederick Law Olmsted, Landscape Architect, 1822-1903. Nueva York, EE.UU.: G.P. Putnam. Recuperado de https://archive.org/details/fredericklawolms00olm

Olson, R. (21 de septiembre, 2018). Isla de Pascua. [Fotografía]. Recuperado de https://www.nationalgeographic.com.es/ historia/grandes-reportajes/si-los-moais-hablaran_6272/1

ONU. (1997). Glossary of Environment Statistics, Studies in Methods, Series F, No. 67. Nueva York, EE.UU.

Oppenheim, D. (1968). Annual Rings. [Collage de 101,6 x 76,2cm]. The MET Collection. @ Dennis Oppenheim Estate. Recuperado de https://www.metmuseum.org/art/collection/search/282758

Orrego Luco, L. (1984). Memorias del tiempo viejo. Santiago, Chile: Ediciones de la Universidad de Chile.

Ossa, B. (2016). Intervención visual y sonora en el paso bajo nivel de General Velásquez en la Comuna de Renca, Chile. [Render]. Recuperado de http://artishockrevista.com/2016/01/27/benjamin-ossa-gana-concurso-arte-publico-rencal

Otto, C. (5 de junio, 2016). Gentrificación en Silicon Valley: ¿por qué la gente tira piedras a los autobuses de Google? Reportaje en el Diario digital La Vanguardia. Recuperado de http://www.lavanguardia.com/tecnologia/20160604/402278819582/silicon-valley-enfrentamientos-autobuses-google.html

Ovalle, A. (1646). Historica relación del Reyno de Chile y de las Misiones y Ministerios que exercita en la Compañia de Jesús. Roma, Italia. Recuperado de /whttp://ww.memoriachilena.cl/602/w3-article-8380.html

Ovalle, C., \& Avendaño, J. (1984). Utilización silvopastoral del espinal. Influencia del espino (Acacia caven (Mol) sobre la productividad de la pradera natural. Agricultura Técnica, 44, 353-362.

PACYT. (s.f., el parque). Plan Maestro del Parque Científico y Tecnológico del Bío-Bío. [mapa]. Recuperado de https:/l www.pacyt.cl/el-parque/ 
Pallasmaa, J. (2005). Encounters. Helsinki,Finlandia: Rakennustieto.

Pallasmaa, J. (2016). Habitar. Barcelona, España: Editorial Gustavo Gili.

Palmarola, H. (2002). Diseño Industrial Estatal en Chile 1968 -1973. Santiago, Chile: Conferencia presentada en el ciclo "Testimonio de la Modernidad". Extensión FADEU.Recuperada de http://www.guibonsiepe.com/pdffiles/timeline_design_ chile.pdf

Paquot, T. (2016). Le Paysage. París, Francia: Éditions La Decouverte.

Pareyson, L. (2007). Aesthetics. Theory of Formativity. París, Francia: Rue D'Ulm.

Parque Metropolitano de Santiago (PARQUEMET). (2016). 100 años 100 historias. Santiago, Chile: ParqueMet. [fotografía]. Recuperado de https://catalogo.minvu.cl/cgi-bin/koha/opac-detail.pl?biblionumber=24770

Parra, N. (1969). Obra Gruesa. Santiago, Chile: Editorial Universitaria. Recuperado de http://www.memoriachilena.cl/archivos2/pdfs/MC0014335.pdf

Patelin, A.(proyecto) \& Tipling, D. (pingüinos) @ (2017). Sector habitacional llamado Distrito 11 de AAAB|Bechu Associés. [Fotografías]. Recuperadas de https://www.bechuetassocies.com/fr/projet/skolkovo-innovation-center-district-11

Paulsen, A. (2013). Alexander von Humboldt. Cosmos. Ensayo de una descripción física del mundo. Revista de Geografía Norte Grande, 54, 269-272. Recuperado de https://dx.doi.org/10.4067/S0718-34022013000100015

Pavez Reyes, M. I. (2011). Marcha a pie urbana y regional y movilidad en los modelos de ciudad para Santiago, Chile. Revista INVI, 26(71), 57-85. Recuperado de https://dx.doi.org/10.4067/S0718-83582011000100003

Paz, D. (3 de abril, 2014). La desigualdad expresada en áreas verdes. [infografía]. Recuperada de https://wiki.ead.pucv.cl/ Archivo:Danur2.jpg

PCB. (2018). [web] Parc Científic de Barcelona. Barcelona, España. http://www.pcb.ub.edu/

PCT Cartuja. (2018). El parque y su sociedad gestora. [sitio web]. Recuperado de https://www.pctcartuja.es/

Péguy, Ch. (1961). Oeuvres en Prose 1909-1914. París, Francia: Bibliothéque de la Pléiade.

Péguy, Ch. (1900). Zangwill. En Oeuvres en Prose 1909-1914 (pp. 185-272) .París, Francia: Bibliothéque de la Pléiade.

Peirce, Ch. (1931/1958). Sanders Collected Papers, 1-8. (C. Hartshorne \& C. Peirce, Eds.). Cambridge, EE.UU.: Harvard University Press. Recuperado de https://colorysemiotica.files.wordpress.com/2014/08/peirce-collectedpapers.pdf 
Peliowski, A. (2016). La conquista de la naturaleza: el imaginario arquitectónico de Alonso de Ovalle en el siglo XVII. $A R Q, 94,98-107$. Recuperado de https://dx.doi.org/10.4067/S0717-69962016000300098

Pellow, D. N., \& Sun-Hee Park, L. (2002). The Silicon Valley of Dreams: Environmental Injustice, Immigrant Workers, and the High-tech Global Economy. Nueva York, EE.UU.: New York UP, Pellow Print.

Peña, H. (1983). Estudio de previsión de crecidas: río Mapocho. Santiago, Chile: Dirección General de Aguas. MOP.

Peralta, M. (1994). Conservación y degradación de los suelos en Chile. En Perfil Ambiental de Chile. Santiago, Chile: Comisión Nacional del medioambiente CONAMA.

Perec, G. (2001). Especies de Espacios. (J. Camarero trad.). Barcelona, España: Editorial Montecinos.

Pérez, F., Aravena, A., \& Quintanilla, J. (1999). Los Hechos de la Arquitectura. Santiago, Chile: Editorial ARQ.

Pérez Rosales, V. (1859). Ensayo sobre Chile. Santiago: Imprenta del Ferrocarril.

Periégesis. (s.f.). En Wikipedia. Recuperado de https://es.wikipedia.org/wiki/Peri\%C3\%A9gesis

Perrault, C. (1673). Les Dix livres d'architecture de Vitruve corrigez et traduits nouvellement en françois, avec des notes et des figures. Con grabados de Sébastien Leclerc. París, Francia: Jean-Baptiste Coignard. Digitalizado por Getty Research Institute. Recuperado de https://archive.org/details/gri_33125008503100/page/n317

Petrarca, F. (2011). Subida al Monte Ventoso. Barcelona, España: Editorial Centellas.

Picon, A. (2002). Building Technologies, Imagination and Utopia. New Sheets, 64, 27-34.

Picon, C. \& Ruiz, F. (2017). Los cerros isla: una oportunidad para mejorar la calidad de vida de la ciudad. En Cerros Isla de Santiago, Construyendo un nuevo imaginario de ciudad a partir de su geografía. pp. 14-40. Santiago, Chile: Ediciones $A R Q$.

Pina, R. (2004). El Proyecto de Arquitectura. El rigor científico como instrumento poético. (Tesis de doctorado, Universidad Politécnica de Madrid UPM, Madrid, España). Recuperado de https://issuu.com/maurobrunelli/docs/rafael_pina_lupianez-1-443

Pinaud, H. (2009). Astronomía Mapuche. Recuperado de http://cecitecastronomiachile.blogspot.com/2009/02/astronomia-mapuche.html

Pozo, S. del (13 de marzo, 2009). Plan Santiago verde. Gestión del Árbol Urbano [blog]. Recuperado de http://arboriculturaurbana.blogspot.com/2009/03/plan-santiago-verde.html

Plan de Déplacements Urbain. (2008). Plano de Sophia Antipolis donde se indica la distribución de personas en el parque. [Plano]. Recuperado de http://www.pdu-casa.fr/mobilite_salaries.html 
Planella, M. T., Santander, G., \& McRostie, V. (2010). Estudio morfo-tecnológico y análisis de microfósiles en bloques con piedras tacitas en Chile Central. En S. Rojas \& C. Belmar (Eds.), De las muchas historias entre las plantas y las gentes. Oxford, Inglaterra: BAR South American Series.

Planella, M. T., Santander, G., \& McRostie, V. (2017). Aportes a la discusión sobre piedras tacitas en Chile Central. Intersecciones En Antropología, 18(1), 5-17. Recuperado de http://www.scielo.org.ar/scielo.php?script=sci_arttext\&pi$d=S 1850-373 \times 2017000100001 \&$ Ing=es\&tlng=es

Plataforma Arquitectura (18 de octubre, 2016). Plaza Mirador Pablo Neruda de Carlos Martner, Humberto Eliash, Sebastián Lambiasi, Tomás Westenenk. [fotografía]. Recuperada de <https://www.plataformaarquitectura.cl/cl/797506/ plaza-mirador-pablo-neruda-carlos-martner-plus-humberto-eliash-plus-sebastian-lambiasi-plus-tomas-westenenk> ISSN 0719-8914

Platón. (1872). Obras completas (de Azcárate, Vol. 9). Madrid, España. Recuperado de http://www.filosofia.org/cla/pla/ img/azf09261.pdf

Pliscoff, P., \& Luebert, F. (2006). Sinopsis bioclimática y vegetacional de Chile. Santiago, Chile: Editorial Universitaria.

Poduje, I. (2006). El globo y el acordeón: planificación urbana en Santiago, 1960-2004. En A. Galetovic. (Ed.), Santiago: Dónde estamos y hacia dónde vamos, pp. 231-276. Santiago, Chile: Centro de Estudios Públicos (CEP).

Poeppig, E. (1960). Un testigo en la alborada de Chile (1826-1829). Santiago, Chile: Zig-Zag. Recuperado de http://www. memoriachilena.cl/archivos2/pdfs/MC0012326.pdf

Polanski, J. (1962). Estratigrafía, neotectónica y geomorfología del pleistoceno pedemontano entre los ríos Diamante y Mendoza. Provincia de Mendoza. Revista de La Asociación Geológica Argentina, 17(3-4), 127-349.

Pollack, L. (2002). Sublime matters: Fresh Kills. Praxis: Journal of Writing and Building, 4, 58-63.

Pope, A. (1731). An epistle to the Right Honourable Richard, Earl of Burlington : occasion'd by his publishing Palladio's designs of the baths, arches, theatres, \&c. of ancient Rome. Londres, Inglaterra: L. Gilliver. Recuperado de https://archive. org/details/gri_33125008438711/page/n7

Popper, K. (1978). Three Worlds: The Tanner Lecture on Human Values. Michigan, EE.UU.: University of Michigan. Recuperado de https://tannerlectures.utah.edu/_documents/a-to-z/p/popper80.pdf

Popper, K. (1994). Conjeturas y Refutaciones. Barcelona, España: Paidós.

Portal PCV. (s.f., contacte). Emplazamiento del Parque Científico de Barcelona en la ciudad. [mapa]. Recuperado de http://www.pcb.ub.edu/portal/es/contacte

Pozo, S. del (20 de septiembre, 2012). Ley del árbol urbano para Chile. Recuperado de http://leydelarbol.blogspot. com/2012/09/cerros-islas-cerros-parques.html

Proctor, R. (1919). Narración del viaje por la Cordillera de los Andes. Buenos Aires, Argentina: Imprenta de la Nación. 
PTV. (2019). Parc Tecnològic del Vallès. Barcelona, España. Recuperado de http://www.ptv.es

Public Walks. (1834). The Westminster review, Vol. XX, 496-513. Report of the Select Committee on Public Walks (1833). Londres, Inglaterra. Recuperado de https://play.google.com/books/reader?id=ZCM6AQAAMAAJ\&hl=es\&pg=GBS.PA508

Quezada, J. (2004). Neruda y su Canto general. Algunas referencias elementales. Alforja, Revista de Poesía, 28, 59-62.

Radovic, I. (2005). Experiencia de la Reforma Agraria Chilena. Santiago, Chile: Fundación OCAC CEME - Centro de Estudios Miguel Enríquez - Archivo Chile. Recuperado de http://archivochile.com/Historia_de_Chile/ranquil/HCHranq0010.pdf

Ramón, A. de (1985). Estudio de una periferia urbana: Santiago de Chile 1850-1900. Revista Historia, 199-289.

Ramón, A. de (2000). Santiago de Chile (1541-1991) Historia de una Sociedad Urbana. Santiago: Editorial Sudamericana.

Ramón, A. de (2007). Santiago de Chile (1541-1991). Historia de una Sociedad Urbana. Santiago, Chile: Editorial Catalonia.

Reed, C., \& Lister, N.-M. (2014). Ecology and Design: Parallel Genealogies. Places Journal. Recuperado de https://doi. org/10.22269/140414

Reimer, M. H. (2010). Unsettling eco-scapes: aesthetic performances for sustainable futures. Journal of Landscape Architecture, 1, 24-37. Recuperado de https://doi.org/10.1080/18626033.2010.9723428

Reyes, F. (2017). Materiales de mi canto. Extractos de entrevistas a Violeta Parra. Santiago, Chile: Alquimia Ediciones.

Reyes, S., \& Figueroa, I. M. (2010). Distribución, superficie y accesibilidad de las áreas verdes en Santiago de Chile. EURE - Revista de Estudios Urbanos Regionales, 36(109), 89-110. Recuperado de https://scielo.conicyt.cl/pdf/eure/ v36n109/art04.pdf

Rittel, H. (1971). Some principles for the design of an educational system for design. Journal of Architectural Education, $25,(1 / 2)$.

Rittel, H. (1972). Second generation Design Methods. En N. Cross (Ed.), Engineering design methods: strategies for product design (pp. 317-327). Chichester, Inglaterra: John Wiley \& Sons.

Rittel, H., \& Webber, M. (1973). Dilemmas in a General Theory of Planning. Policy Sciences, 4, 155-169. Amsterdam, Países Bajos: Elsevier Scientific Publishing Company.

Robic, M.-C. (2004). Géographicité. Revista Electrónica Hypergeo. Recuperado de http://www.hypergeo.eu/spip.php?article19\# 
Rodríguez, J. (1998). La Ciencia del Paisaje a la luz del paradigma ambiental. Revista Trimestral Geonotas, 2. Brasil: Universidad Estatal de Maringá.

Rodriguez-Pose, A. (2012). Análisis de la situación actual de los parques Cientificos y Tecnológicos en América Latina. Washington DC, EE.UU.: BID. Recuperado de https://publications.iadb.org/bitstream/handle/11319/3132/Los parques científicos y tecnológicos en América Latina \%282\%29.pdf?sequence=1\&isAllowed=y

Roger, A. (2007). Breve tratado del paisaje. Madrid, España: Bibilioteca Nueva.

Rojas, A. (2012). Memorias de Las Barrancas y Lo Prado. Santiago, Chile: Departamento de Cultura Municipalidad de Lo Prado.

Rojas, R. (2015). Raúl Zurita: el humilde más ambicioso. En Revista Anfibia. San Martín, Argentina: Universidad Nacional de San Martín. Recuperado de http://revistaanfibia.com/cronica/raul-zurita-humilde-mas-ambicioso/

Romero, H., Salgado, M., \& Fuentes, C. (2009). Segregación Socio-Ambiental en espacios intraurbanos de la ciudad de Santiago de Chile. Recuperado de http://www.repositorio.uchile.cl/handle/2250/118161

Rosales, D. de (1877). Historia General en el Reyno de Chile. Flandes Indiano. (B. Vicuña Mackenna, Ed.). Valparaíso: Imprenta de El Mercurio. Recuperado de http://www.memoriachilena.cl/archivos2/pdfs/MC0005271.pdf

Rosenzweig, R., \& Blackmar, E. (1992). The Park and the People: a History of Central Park. Ithaca, EE.UU.: Cornell University Press.

Rosas, J., Hidalgo, G., Strabucchi, W., \& Bannen, P. (2015). El Plano Oficial de Urbanización de la Comuna de Santiago de 1939: Trazas comunes entre la ciudad moderna y la ciudad preexistente. $A R Q$ (Santiago), (91), 82-93. https://dx.doi. org/10.4067/S0717-69962015000300013

Roth, L.M. (1993). Entender la arquitectura, sus elementos, historia y significado. Barcelona, España: Editorial Gustavo Gili.

Rousseau, J. J. (1762/2019). Emilio o la educación. Madrid, España: Editorial Verbum.

Rugendas, M. (1837). El Presidente Prieto llegando a la Pampilla. Óleo sobre tela. [fotografía]. Recuperada de https:// es.wikipedia.org/wiki/Archivo:Llegada_del_Presidente_Prieto_a_la_Pampilla.PNG

Ruschenberger, W. S. (1834). Three years in the Pacific; including nothes of Brasil, Chile, Bolivia and Peru. By an officer of the United States Navy. Filadelfia, EE.UU.: Carey, Lea and Blanchard. Recuperado de https://www.biodiversitylibrary. org/item/174124\#page/7/mode/1up. Digitalizado desde: Smithsonian Libraries

Ruskin, J. (1950). Sésamo y lirios. Buenos Aires, Argentina: Espasa-Calpe.

Ruskin, J. (2015). Las siete lámparas de la arquitectura. Madrid, España: Editorial Biblok Book Export. 
Sada de Carlos, L. (1856). Plano y proyecto de un establecimiento de agricultura y Botánica en la Quinta Normal de Yungay. [Plano]. En el Boletín mensual El mensajero de la Agricultura Tomo I, octubre de 1856. Santiago, Chile: Imprenta chilena. Recuperado de http://www.bibliotecanacionaldigital.gob.cl/visor/BND:122062

Saffie, N. (2014). Más de 150 expositores rescatan el aporte de los naturalistas en Chile. UC News. Recuperado de https://www.uc.cl/la-universidad/noticias/13860-mas-de-150-expositores-rescatan-el-aporte-de-los-naturalistas-en-chile

Sagredo Baeza, R. (2013). Chile en el cosmos de Humboldt: Conocimiento y saber local para la ciencia universal. Revista de Geografía Norte Grande, 54, 155-177. Recuperado de http://www.scielo.cl/scielo.php?script=sci_arttext\&pi$d=S 0718-34022013000100009 \&$ Ing=es\&nrm=iso\%3E

Salazar, G. (2000). Labradores, peones y proletarios. Santiago, Chile: LOM ediciones.

Sánchez, C. (2011). Aventura del cuerpo. El pensamiento cinematográfico de Raúl Ruiz. Santiago, Chile: Ocholibros.

Sánchez Martínez, E. (2009). La universidad debe formar buenos ciudadanos. En UP Educación, 1. Buenos Aires, Argentina: Universidad de Palermo. Recuperado de https://www.palermo.edu/cienciassociales/publicaciones/pdf/UPEDUC-N1.pdf

Sanhueza, C. (2006). Chilenos en Alemania y alemanes en Chile. Viaje y nación en el siglo XIX. Santiago, Chile: LOM ediciones.

SANTIAGOOFF. (2019). Parque Quinta Normal. [fotografía]. Recuperada de https://santiagooff.com/lugar/parque-quinta-normal/parque-quinta-normal-3-web/

Saric, N., Kreft, C., \& Huete, C. (2003). Geología del yacimiento Lo Aguirre, Chile. Revista geológica de Chile, 30(2), 317331. Recuperado de https://dx.doi.org/10.4067/S0716-02082003000200010

Sarlo, B. (2001). Prólogo. En Williams, R. (Ed.). El campo y la ciudad. Buenos Aires, Argentina: Paidós. Recuperado de http://frrq.cvg.utn.edu.ar/pluginfile.php/8705/mod_resource/content/1/Williams $\% 20$ Raymond. $\% 20$ El\%20Campo\%20y $\% 20$ La\%20Ciudad.pdf

Sarmiento, D. F. (1841). Un viaje a Valparaíso. Diario El Mercurio de Valparaíso, 7 de septiembre de 1841. En D. F. Sarmiento, A. Belin Sarmiento, L. Montt. (Eds.), Obras de D.F. Sarmiento. Santiago, Chile: Imprenta Gutenberg. Recuperado de https://es.scribd.com/document/273765190/OBRAS-COMPLETAS-DE-SARMIENTO-Tomo-I

Sarmiento, D. F., Belin Sarmiento, A., Montt, L. (Eds.) (1887). Obras de D.F. Sarmiento. Santiago, Chile: Imprenta Gutenberg. Recuperado de https://es.scribd.com/document/273765190/OBRAS-COMPLETAS-DE-SARMIENTO-Tomo-I

Savin, A. (2 de julio, 2013). Acrópolis de Atenas, vista desde el monte Philopappos. [Fotografía]. Recuperada de https:// es.wikipedia.org/wiki/Acr\%C3\%B3polis_de_Atenas\#/media/Archivo:Attica_06-13_Athens_50_View_from_Philopappos_-Acropolis_Hill.jpg 
Scarpa, L. (1981). Quantifying parkland. The standards of happiness in Socialdemocratic Berlin. LOTUS International, 30(1), 118-122.

Schlatter, J., Grez, R. \& Gerding, V. (2003). Manual para el reconocimiento de suelos. (3a ed.). Valdivia, Chile: Facultad de Ciencias Forestales, Universidad Austral de Chile.

Schlatter, R. et al. (1999). Costas del centro y sur de Chile. En Canevari, P. et al. Los humedales de América del Sur. Una agenda para la conservación de la biodiversidad y las políticas de desarrollo. Wageningen, Países Bajos: Wetlands International. Recuperado de http://lac.wetlands.org/Publicaciones/tabid/396/Page/3/Default.aspx

Schmidtmeyer, P. (1824). Travels into Chile over the Andes in the years 1820 and 1821. Londres, Inglaterra: Longman, Hurst, Rees. Recuperado de http://www.memoriachilena.cl/602/w3-article-10336.html

Schön, D. (1983). The Reflective Practitioner: How Professionals Think in Action. Nueva York, EE.UU.: Basic Books.

Schön, D. (1998). El profesional reflexivo. Cómo piensan los profesionales cuando actúan. Barcelona, España: Editorial Paidós.

Schumacher, F. (1910). Entwurf für den Stadtpark Hamburg- Winterhude. [Plano de Planta]. En Die Gartenkunst 12.1910. Würzburg, Alemania: Stürtz. Colección Universitätsbibliothek Heidelberg. Recuperado de https://digi.ub.uni-heidelberg.de/ diglit/gartenkunst1910

SEA. (s.f.). Análisis Territorial para la Evaluación. Geoportal del Ministerio del Medio

Ambiente. Recuperado de http://sig.sea.gob.cl/analisisTerritorialExterno/

Secretaría del Convenio sobre la Diversidad Biológica. (2011). Convenio sobre Diversidad Biológica. Recuperado de https://www.cbd.int/undb/media/factsheets/undb-factsheets-es-web.pdf

Segawa, H. (2004). Alamedas e passeios na América Colonial. Anais: Seminário de História da Cidade e do Urbanismo, 8.

Semper, G. \& Semper, M.; Semper, H. (1884). Kleine Schriften. Stuttgart, Alemania: Spemann. Digitalizado por ETH-Bibliothek Zürich. Recuperado de https://www.e-rara.ch/zut/content/pageview/3586617

Sennett, R. (1997). Carne y Piedra. El cuerpo y la ciudad en la civilización occidental. Madrid, España: Alianza Editorial.

Serlio, S. (1551). Regole generali di architettura di Sabastiano Serlio Bolognese : sopra le cinque maniere de gliedifici, cioe, thoscano, dorico, ionico, corinthio, e composito ; con gli essempi de l'antiquita, che per la maggior parte concordano con la dottrina di Vitruuio. Venecia, Italia: Pietro de Nicolini da Sabbio, ad instantia di Marchione Sessa. Recuperado de https://archive.org/details/regolegeneralidi00serl/page/n137

SERNAGEOMIN. (1999). Área Santiago, Mapa Geológico (11).

SERNAGEOMIN. (2004). Geología para el ordenamiento territorial de la Región Metropolitana de Santiago (24). 
Serra, M. T., Torres, J., \& Grez, I. (2002). Breve historia de la introducción en Chile del álamo [Populus nigra L. var. italica (Moench.) Koehne] y el desarrollo de ejemplares siempreverdes. Chloris Chilensis, 5(2). Recuperado de http://www.chlorischile.cl

Servicio Nacional de Información Ambiental. (SINIA). (2018). Cuarto Reporte del Estado del Medio Ambiente. Recuperado de https://sinia.mma.gob.cl/wp-content/uploads/2019/01/Cuarto-reporte-del-medio-ambiente-compressed.pdf

Servicio de Evaluación Ambiental. (2015). Guía para la Descripción de los Componentes Suelo, Flora y Fauna de Ecosistemas Terrestres. Recuperado de http://www.sea.gob.cl/sites/defaultffiles/imce/archivos/2016/01/15/guia_ecosistemas_terrestres.pdf

Sevilla-Buitrago, Á. (2014). Central Park y la producción del espacio público: el uso de la ciudad y la regulación del comportamiento urbano en la historia. EURE (Santiago), 40 (121), 55-74. https://dx.doi.org/10.4067/S025071612014000300003

Shapiro, G. F. (2015). The promenades of Paris. Alphand and the urbanization of garden art, 1852-1871. (Tesis de doctorado, University of Pennsylvania, EE.UU.). Recuperado de https://repository.upenn.edu/dissertations/AAI3743590/

Silicon Valley Indicators. (2018). Consultado el 02 de febrero de 2018. Recuperado de http://siliconvalleyindicators.org/ data/economy/employment/employment-percent-of-total-employment-by-tier-silicon-valley/

Silvestri, G. \& Aliata, F. (2001). El paisaje como cifra de armonía: relaciones entre cultura y naturaleza a través de la mirada paisajística. Buenos Aires, Argentina: Ediciones Nueva Visión.

Simeone, A., Oviedo, E., Bernal, M., \& Flores Morales, M. (2008). Las aves del Humedal de Mantagua: Riqueza de especies, amenazas y necesidades de conservación. Boletín Chileno de Ornitología 14(1), 22-35.

Simo, M. (1999). 100 Years of Landscape Architecture: Some Patterns of a Century. Washington, DC, EE.UU.: ASLA Press.

Simon, H. (1996). The sciences of the Artificial. Londres, Inglaterra: MIT Press (3a ed.). Recuperado de https://monoskop. org/images/9/9c/Simon_Herbert_A_The_Sciences_of_the_Artificial_3rd_ed.pdf

Simonetti, J., Nuñez, H. \& Yañez, J. (1982). Falco sparverius L.:rapaz generalista en Chile central (aves: Falconidae). Boletín del Museo Nacional de Historia Natural, 39: 119-124. Recuperado de http://publicaciones.mnhn.gob.cl/668/articles-64188_archivo_01.pdf

Sin Salud. (15 de octubre, 2009). Edificio sede de la CEPAL en Santiago, Chile. [Fotografía]. Recuperada de https://www. flickr.com/photos/sinsalud/4050157570/

Skolkovo Innovation Center (2019). Vista panorámica del Centro de Innovación de Skolkovo proyectada al 2020. [imagen web]. Recuperada de 
Smithson, R. (1967). The Monument of Passaic. Artforum, December 1967, 52-57. Recuperado de

http://pdf-objects.com/files/Essay_Robert-Smithson-A-Tour-of-the-Monuments-of-Passaic.pdf

Snep, R., \& Opdam, P. (2010). Integrating nature values in urban planning and design. En K.J Gaston. (Ed.), Urban ecology, (261-286). Cambridge, Inglaterra: Cambridge University Press.

Sol, G. del (2009). Conversaciones informales. E. Castillo. (Ed.). Santiago, Chile: Editorial ARQ.

Sol, G del (2019). Germán del Sol - Arquitecto [web]. Recuperado de http://www.germandelsol.cl/. (4)

Solomon, R. (2004). 12 Reasons to Get Back into Shape. En Koolhaas y OMA-AMO. (Eds.). Content, 86-87. Colonia, Alemania: Tashen.

Stanford. (2016). Stanford University Investment Report. Stanford CA, EE.UU.: Stanford Management Company. Recuperado de

http://www.smc.stanford.edu/sites/default/files/site_files/Report\%20from\%20SMC\%202016.pdf

Stanford Research Park. (s.f.). Página web del parque. Recuperado de https://stanfordresearchpark.com/about

Stehberg, R. \& Sotomayor, G. (2012). Mapocho Incaico. Boletín del Museo Nacional de Historia Natural, 61, 85-149. Recuperado de http://www.mnhn.cl/613/articles-49204_archivo_01.pdf

Steiner, F. R. (2009). Nature and the city: changes for the first urban century in the United States. Ciudades: Revista del Instituto Universitario de Urbanística de la Universidad de Valladolid, 12, 13-31.

Stern, C., Amini, H., Charrier, R., Godoy, E., Herve, F., \& Varela, J. (1984). Petrochemistry and age of rhyolitic pyroclastic flows which occur along the drainage valleys of the río Maipo and río Cachapoal (Chile) and the río Yaucha and río Papagayos (Argentina). Revista Geológica de Chile, 23, 39-52.

Straus, E. (1935/2000). Du sens des sens. Grenoble, (Tines, G., \& Le-Grand, J.P., Trad.). Francia: Millon.

SUMA [arquitectos y planificadores urbanos]. (2009). Plan Maestro Ciudad del Saber. Panamá. Recuperado de http://static.gestorsutil.com/CDS_web/plan_maestro/cdsplanmaestro09.pdf

Sutz, J. (1996). Universidad, producción, gobierno: Encuentros y desencuentros. Montevideo, Uruguay: Centro de informaciones y Estudios del Uruguay (CIESU).

Swaffield, S. (2002). Theory in landscape architecture. Philadelphia, EE.UU.: University of Pennsylvania Press.

Tarapuez, E. ; Osorio, H. y Parra, R. (2012). Burton Clark y su concepción acerca de la universidad emprendedora. Revista Tendencias de la Facultad de Ciencias Económicas y Administrativas. XIII (2) 103-118. 
Tarroja, A. (2009). La dimensión social del paisaje. En J. Busquet, A. Cortina (Eds.), Gestión del paisaje. Manual de protección, gestión y ordenación del paisaje. 239-252. Barcelona, España: Editorial Ariel.

Tate, A. (2001). Great City Parks. Nueva York, EE.UU.: Taylor \& Francis.

Tate, A. (2015). Great City Parks. (2da. Ed.). Nueva York, EE.UU.: Routledge.

Team Côte d'Azur. (11 de mayo, 2016). Vista general de Sophia Antipolis. [Fotografía]. Recuperada de http://www.investincotedazur.com/en/sophia-antipolis/

Tejeda, G. (2002). Explora. Las 7 tesis. Catálogo de la Exposición en la sala de Arte de Fundación Telefónica. Santiago,Chile: Ograma S.A.

Tempe, W. (1908). Sir William Temple upon the gardens of Epicurus, with other XVIlth century garden essays. Londres, Inglaterra: Chatto and Windus. Recuperado de https://archive.org/details/sirwilliamtempl00tempuoft/page/52

Teyssot, G. (1981). Grandi macchine pensanti. Editorial. Lotus International, (30), 2-10.

The Bartlett School of Architecture (s.f.). Architectural Design MPhil/PhD. Recuperado de https://n9.cl/td49

The Clinic. (24 de abril, 2014). Imágenes alusivas a la instalación del Estadio del Club Universidad de Chile en Laguna Carén. [imágenes web]. Recuperadas de https://www.theclinic.cl/2014/04/24/los-mejores-webeos-por-el-estadio-de-la-uen-laguna-caren/

The International Centre for Water Hazard and Risk Management (ICHARM) bajo el auspicio de UNESCO (s.f.). Tsukuba City in Japan. [Mapa]. Recuperado de http://www.icharm.pwri.go.jp/access/index.html

The New York Times. (31 de enero, 1997). A Village Dies, A Park Is Born. Por Douglas Martin.Nueva York, EE.UU. Recuperado de https://www.nytimes.com/1997/01/31/arts/a-village-dies-a-park-is-born.html

The Royal Parks. (2019). The Royal Parks. [fotografías]. Recuperado de https://www.royalparks.org.uk/.

The Times. (7 de septiembre, 1847). Part of a letter from George Alston. Recuperado de https://www.victorianlondon.org/ entertainment/victoriapark.htm

The Stanford Daily. (28 de abril, 1960). Registro de la visita del presidente francés Charles de Gaulle a California en 1960. [recorte de diario]. Recuperado del Archivo en línea de The Stanford Daily en https://stanforddailyarchive.com/cgi-bin/ stanford?a=d\&d=stanford19600428-01.2.2\#

Thompson, I. H. (2012). Ten tenets and six questions for landscape urbanism. Landscape Research, 37(1), 7-26.

Thwaites, K., \& Simkins, I. (2005). Experiential landscape place: Exploring experiential potential in neighbourhood settings. Urban Design International, 10(1), 11-22. Recuperado de http://dx.doi.org/10.1057/palgrave.udi.9000134 
Travel+Leisure. (2 de mayo, 2013). World's Most Beautiful City Parks. [captura parcial del sitio web]. Recuperado de https://www.travelandleisure.com/slideshows/worlds-most-beautiful-city-parks

Troncoso, C; Lara, L; Silva, C; Castuccio, Á. (2015). Facies Piroclásticas de la Ignimbrita Pudahuel: implicancias en su emplazamiento. En Actas XIV Congreso Geológico Chileno. 102-105.

Troncoso, A., Pino, M., \& Belmar, C. (2017). Piedras tácitas, prácticas socio-espaciales, comunidades y paisaje en la cuenca hidrográfica del río Limarí (norte semiárido, Chile). En C. Belmar, L. Contreras, \& O. Reyes. (Eds), Actualizaciones en el estudio de las piedras tácitas: Nuevas perspectivas. Serie Monográfica de la Sociedad Chilena de arqueología $N^{\circ} 6$. Santiago, Chile: Anglo American y CEHP Arqueólogos. Recuperado de https://es.scribd.com/document/357796226/ Actualizaciones-en-el-estudio-de-piedras-tacitas-Nuevas-Perspectivas-67-PIEDRAS-TACITAS-PRACTICAS-SOCIO-ESPACIALES-COMUNIDADES-Y-PAISAJE-EN-LA

Tsamis, A. (2009). Science and technology parks in the less favored regions of Europe: An evaluation of their performance and the parameters of success. (Tesis doctoral, London School of Economics, Inglaterra). Recuperado de http://etheses. Ise.ac.uk/2543/1/U615492.pdf

Tsukuba Global Innovation Promotion Agency (TGIPA). (2017). Vista general del Valle de Tsukuba. [Fotografía]. Recuperada de http://tsukuba-gi.jp/en/high-level-forum-2017/

Tuan, Y. (1974/2007). Topofilia. Un estudio de las percepciones, actitudes y valores sobre el entorno. Nueva Jersey, EE.UU.: Prentice-Hall Inc. Recuperado de https://es.scribd.com/doc/102293451/Fu-Tuan-Yi-Topofilia

Turner, T. (1996). City and Landscape. London, Inglaterra: E\&F Spon.

Turri, E. (1998). Il paesaggio come teatro. Padua, Italia: Marsilio.

Universidad Central (UCENTRAL). (s.f.). Arquitectura del Paisaje. En Facultad de Ingeniería y Arquitectura [web]. Recuperado de http://www.ucentral.cl/prontus_ucentral2012/site/edic/base/port/f_arquitectura_paisaje.html

Universidad de Chile (UCH). (2013). Promesa para Suscribir Contrato de Concesión Privada. Borrador con carácter reservado. Santiago, Chile.

Universidad de Chile (UCH). (2018). WEB Institucional de la Universidad de Chile. Recuperado de http://www.uchile.cl/

Universidad de Chile (UCH). (2009). Minuta Parque Tecnológico Universidad de Chile y Fundación Valle Lo Aguirre. Documento en formato digital, emitido por la asesora legal de rectoría, con carácter reservado. Santiago, Chile.

Universidad de Chile (UCH). (2013). Promesa para Suscribir Contrato de Concesión Privada. Borrador con carácter reservado. Santiago, Chile.

Universidad de Chile (UCH) (6 de octubre, 2019). La Universidad de Chile en cifras. [Infografía]. Recuperado de http:/l www.uchile.cl/hechosYCifras 
Universidad de Concepción. (10 de junio, 2019). Maqueta electrónica del proyecto Parque Científico y Tecnológico del Bío-Bío. [render]. Recuperado de

https://www.udec.cl/panoramaweb2016/content/parque-cient\%C3\%ADfico-y-tecnol\%C3\%B3gico-pacyt-informaci\%C3\%B3n-para-la-comunidad-universitaria-0

UKSPA. (2003). United Kingdom Science Park Association. Evaluation of the past \& future economic contribution of the UK Science Park Movement. Technology 44. Recuperado de http://www.ukspa.org.uk/ContentFiles/UKSPAEvaluation-Executive Summary.pdf

UKSPA. (2018). [web] United Kingdom Science Park Association. Recuperado de www.ukspa.org.uk.

UKSPA. (2019). Our Members. United Kingdom Science Park Association. Recuperado de http://www.ukspa.org.uk/members/ourmembers?member_type=Associate\%20Member

UNESCO (1972). Convención sobre la protección del patrimonio mundial, cultural y natural. La Conferencia General de la Organización de las Naciones Unidas para la Educación, la Ciencia y la Cultura (París), $17^{a}$. Ratificada por Chile por el D.S. 259/80 del Ministerio de Relaciones Exteriores.

UNESCO. (1998). Declaración mundial sobre la educación superior en el siglo XXI: Visión y acción. Recuperado de http:// www.unesco.org/education/educprog/wche/declaration_spa.htm

UNESCO. (2005). Directrices Prácticas para la aplicación de la Convención del Patrimonio Mundial. París, Francia: Centro del Patrimonio Mundial. Recuperado de https://whc.unesco.org/archive/opguide05-es.pdf

Universidad de Chile \& Universidad Católica de Chile. (2017). Actualización del balance hídrico nacional. Informe final. Solicitado por la Dirección General de Aguas, Ministerio de Obras Públicas, Gobierno de Chile. Santiago, Chile. Recuperado de http://documentos.dga.cl/REH5796v1.pdf

University of Hong Kong. (2019). History. Faculty of Architecture, The University of Hong Kong. Recuperado de https:// www.arch.hku.hk/about/history/

Uña, O. (2014). Aportaciones a la teoría de la comunicación y a la teoría de los objetos desde las Odas de Neruda. Revista Internacional de Sociología, 72(3), 517-539.

URBE. (2011). Análisis y Diagnóstico, Condiciones base para la actualización del Plan Maestro del Predio Carén. Informe técnico realizado por Urbe Arquitectos Ltda para la Fundación Valle Lo Aguirre.

Valdés, G. (1985). El poder económico de los Jesuitas en Chile. 1593- 1767. Santiago, Chile: Pucará.

Valadez, L. (2 de enero, 2013). De Barrancas a Pudahuel [Blog]. Revista de Estudios Culturales Urbanos: Bifurcaciones. Recuperado de http://www.bifurcaciones.cl/2013/01/de-barrancas-a-pudahuel/

Valdivia, P. de (1992). Carta al Emperador Carlos V, La Serena 4 de septiembre de 1545. En Cartas de relación de la conquista de Chile / Pedro de Valdivia. Santiago, Chile: Editorial Universitaria. Recuperado de http://www.memoriachilena. cl/602/w3-article-98403.html 
Valero Juan, E.M. (2010). Reconstruyendo el camino de Ercilla... Bello, Mistral y Neruda. Alicante, España: Biblioteca Virtual Miguel de Cervantes. Recuperado de http://www.cervantesvirtual.com/obra-visor/reconstruyendo-el-camino-de-ercilla-bello-mistral-y-neruda/html/de5782a9-9461-4b94-a601-22754e87a611_3.html

Vancouver, G. (1902). Viaje a Valparaíso / Santiago. Santiago, Chile: Imprenta Mejía.

Van der Hammen, T., Stiles, F., Rosselli, L., Chisacá, M., Camargo, G., Guillot, G., Useche, Y., \& Rivera, D. (2008). Protocolo de recuperación y rehabilitación ecológica de humedales en centros urbanos. Bogotá, Colombia: Secretaría Distrital de Ambiente.

Vaseli, D. (2004). Architecture in the age of divided representation: The question of creativity in the shadow of production. Massachusetts, EE.UU.: Boston MIT Press.

Vásquez, A., \& Salgado, M. (2009). Desigualdades socioeconómicas y distribución inequitativa de los riesgos ambientales en las comunas de Peñalolén y San Pedro de la Paz: Una perspectiva de justicia ambiental. Revista de Geografía Norte Grande, 43, 95-110. Recuperado de https://dx.doi.org/10.4067/S0718-34022009000200006

Vaux, C., \& Olmstead, F.L. (1968). Modified Greensward Plan. En Thirteenth Annual Report of the Board of Commissioners of the Central Park. [fotografía]. Por Geographicus Rare Antique Maps. Recuperado de https://commons.wikimedia. org/w/index.php?curid $=14686084$

Venier, A. (1981). Milk, meadow, water, brick - Story of the Hamburg Stadtpark. Venecia, Italia: LOTUS International 30.

Verhoeven, P. (s.f.). Siedlungen der Berliner Moderne. [fotografía]. Recuperada de https://www.pinterest.com/ $\operatorname{pin} / 567101778064459558 /$

Vial, S. (2015). Qu'est-ce que la recherche en design? Introduction aux sciences du design. Sciences du Design, 1(1), 22-36. Recuperado de

http://www.cairn.info/revue-sciences-du-design-2015-1-page-22.htm

Vicenzotti, V., Jorgensen, A., Qviström, M., \& Swaffield, S. (2016). Forty years of Landscape Research. Landscape Research, 41(4), 388-407. doi: 10.1080/01426397.2016.1156070.

Vicuña Mackenna, B. (1926). Historia crítica y social de la ciudad de Santiago, 1541-1868 (Tomo II). Santiago, Chile: Editorial Nacimiento.

Vicuña Mackenna, B. (1936). Obras completas. Páginas de mi diario durante tres años de viaje 1853-18541855. Santiago, Chile: Universidad de Chile.

Vicuña Mackenna, B. (1856). La Agricultura de Chile : Memoria presentada a la Sociedad de Agricultura en su sesion del 6 de setiembre de 1856 con el objeto de constituirla bajo nuevas bases i de reinstalarla de un modo solemne con ocasión de las festividades del 18 de setiembre. Santiago, Chile: Imprenta Chilena.

Vicuña Mackenna, B. (1876). Transformación de Santiago, Notas e indicaciones. Santiago, Chile: Imprenta de la Librería del Mercurio. 
Vidal de La Blanche, P. (1908). Tableau de la geographie de la France. París, Francia: Librairie Hachette \& Cie. Recuperado de https://fr.wikisource.org/wiki/Page:Vidal_de_la_Blache_-_Tableau_de_la_geographie_de_la_France,_1908.djvu/18

Vilina, Y., Cofré, H., Pizarro, C. (2006). Reporte final, aves acuáticas en Chile. Waterbird Conservation for the Americas.

Villari, S. (1990). J.N.L. Durand (1760-1834): Art and Science of Architecture. Nueva York, EE.UU.: Rizzoli

Viollet-le-Duc, E. (1854/1868). Dictionnaire raisonné de l'architecture française du XIe au XVle siècle, Tomo 1. París, Francia: Édition BANCE - MOREL. Recuperado de https://fr.wikisource.org/wiki/Dictionnaire_raisonn\%C3\%A9_ de_1\%E2\%80\%99architecture_fran\%C3\%A7aise_du_Xle_au_XVle_si\%C3\%A8cle/Index_Tome_1

Viollet-le-Duc, E. (2004). Historia de una casa. Madrid, España: Abada Editores.

Vitruvio, M. (1992). Los diez libros de la arquitectura. (J. Ortiz, Trad.). Madrid, España: Akal.

Vivaldi, E. (19 de noviembre, 2014). Discurso del Rector Ennio Vivaldi con motivo de la celebración de los 172 años de la Universidad de Chile. Recuperado de http://www.uchile.cl/portal/presentacion/rectoria/107474/discurso-del-rector-en-el172-aniversario-de-la-universidad-de-chile

Vrba, J. \& Zaporozec, A. (Eds.). (1994). Guidebook on mapping groundwater vulnerability. IAH. Vol. 16. Hannover, Alemania: Verlag Heinz Heise.

VV.AA. (1989). Sophia Antipolis 1969-1989. Niza, Francia: Fundación Sophia Antipolis. Recuperado de http://sophia-antipolis.org/images/fsa/communication/20-ans-sophia/20ans-sophia.pdf

Yáñez, D. (2015). Los Otros Caval. Diario The Clinic. Recuperado de http://www.theclinic.cl/2015/04/05/negocios-redondos-de-especulacion-inmobiliaria-los-otros-caval/

Waldheim, C. (2002). Landscape urbanism: A genealogy. Praxis: Journal of Writing and Building (4), 10-17.

Waldheim, C. (2006). Introduction: A reference manifesto. En The landscape urbanism reader (pp. 13-19). Nueva York, EEUU.: Princeton Architectural Press.

Waldheim, C. (2006). Landscape as Urbanism. En The landscape urbanism reader. Nueva York, EEUU.: Princeton Architectural Press.

Waldheim, C. (Ed.). (2006). The landscape urbanism reader. Nueva York, EEUU.: Princeton Architectural Press.

Waldheim, C. (2014). Introduction: landscape as architecture. Studies in the History of Gardens \& Designed Landscapes: An International Quarterly, 34(3), 187-191, Recuperado de http://dx.doi.org/10.1080/14601176.2014.893140

Waldheim, C. (2016). Landscape as urbanism. Nueva York, EEUU.: Princeton Architectural Press. 
Warnken, C. (2010). Santiago después de la Lluvia. En C. Aldunate, y H. Rodríguez (eds.), Santiago de Chile. Catorce mil años. Santiago, Chile: Banco Santander y Museo Chileno de Arte Precolombino.

Warnken, C. \& Pfeiffer, E. (Ed.). (2016). Violeta Parra. Poesía. Valparaíso, Chile: Editorial UV - Universidad de Valparaíso.

Weidinger, J. (ed.). (2015). Designing Knowledge. Berlín, Alemania: Universitätsverlag der TU Berlin.

Wenborne, G. (29 de octubre, 2014). Termas de Puritama. [Fotografía]. Recuperado de: https://www.plataformaarquitectura.cl/cl/756386/termas-de-puritama-german-del-sol/545054c4e58ece63a800016c-puritama-thermal-bath-german-del-sol-photo?next_project=no

Wenborne, G. (24 de diciembre, 2014). Termas Geométricas. [Fotografía]. Recuperada de: https://www.plataformaarquitectura.cl/search/cl/all?q=termas\%20geom\%C3\%A9tricas

Werle, M. A. \& Restrepo, C. E. (2012). La cuestión del colorido en la pintura: Hegel frente a Goethe y Diderot. Estudios de Filosofia, 45, 123-148. Recuperado de http://www.scielo.org.co/scielo.php?script=sci_arttext\&pi$\mathrm{d}=\mathrm{S} 012136282012000100007 \&$ Ing=en\&thng=es

Winchester, L. (2006). Desafíos para el desarrollo sostenible de las ciudades en América Latina y El Caribe. Revista EURE - Revista de Estudios Urbano Regionales, 30(96). Recuperado de http://www.eure.cl/index.php/eure/article/ view/1305

Wright, K. R., \& Valencia, A. (2009). Machu Picchu, maravilla de la ingeniería civil. Lima, Perú: Universidad Nacional de Ingeniería.

Wulf, A. (2017). La invención de la naturaleza. El nuevo mundo de Alexander Von Humboldt. Santiago, Chile: Taurus.

Yáñez, D. (5 de abril, 2015). Los otros Caval. Diario The Clinic. Recuperado de https://www.theclinic.cl/2015/04/05/negocios-redondos-de-especulacion-inmobiliaria-los-otros-caval/

Yen, R. (2009). Hsinchu Science Park Annual Report 2009. Hsinchu, Taiwan: Science Park Administration.

Yukievich, S. (2005). Introducción general. En Obras Completas de Neruda I (pp. 11-81). Barcelona, España: RBA-Círculo de Lectores.

Zach Trailer. (2019). Aviso publicitario de vivienda en Palo Alto, California. [imagen web]. Recuperada de http://www.zachtrailer.com/

Zapf, M. (2014). Hamburger Stadtpark 1914-2014. Mathias Buller (Ed.). Hamburgo, Alemania: Bezirksamt Hamburg-Nord. [fotografía]. Recuperado de https://www.hamburg.de/contentblob/4338980/e26918491317f092fa14c237beb8efbe/data/ hamburger-stadtpark-1914-2014.pdf

Zillow. (2019). Aviso publicitario de vivienda en San Diego, California. [imagen web]. Recuperada de 
Zoido, F. (2009). El convenio europeo del paisaje. En J. Busquets, A. Cortina (Ed.). Gestión del paisaje. Manual de protección, gestión y ordenación del paisaje (pp. 299-315). Barcelona, España: Ariel.

Zúñiga, V. (2007). Pudahuel. En el camino de la memoria. Santiago, Chile: Ilustre Municipalidad de Pudahuel.

Zúñiga, V. (21 de diciembre de 2008). Acusan que programa "Santiago Verde" no ha cumplido sus objetivos. El Mercurio. Recuperado de http://buscador.emol.com/noticias/Santiago+Verde

Zurita, R. (1982). Anteparaíso. Santiago, Chile: Editores Asociados. Recuperado de http://www.memoriachilena.gob. cl/archivos2/pdfs/MC0011215.pdf

Zurita, R. (1982). La vida nueva. [Fotografía]. Recuperada de https://gatopardo.com/arte-y-cultura/raul-zurita/

Zurita, R. (1989). El amor de Chile. Santiago, Chile: Editorial Los Andes.

Zurita, R. (1993). Ni pena ni miedo. [Fotografía]. Recuperada de http://viajedelasletras.blogspot.com/2014/11/raul-zurita-raul-zurita-es-un-poeta.html

Zurita, R. (30 de julio, 2016). Discurso de agradecimiento Premio Iberoamericano de Poesía Pablo Neruda 2016. Recuperado de http://www.vallejoandcompany.com/discurso-de-agradecimiento-de-raul-zurita-premio-pablo-neruda-2016/.

Zusman, P. (2009). La construcción social del paisaje (Reseña). Revista de Geografía Norte Grande, 44, 143-147. Recuperado de https://dx.doi.org/10.4067/S0718-34022009000300008 
